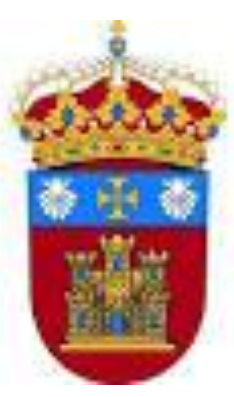

UNIVERSIDAD DE BURGOS

FACULTAD DE EDUCACIÓN

DEPARTAMENTO DE CIENCIAS DE LA EDUCACIÓN

Programa de Doctorado:

Pedagogía política curricular y social

TESIS DOCTORAL

\title{
LA EDITORIAL BURGALESA HIJOS DE SANTIAGO RODRÍGUEZ (1891-1936): ANÁLISIS DE LOS LIBROS ESCOLARES
}

DOCTORANDA:

$\mathrm{M}^{\mathrm{a}}$ PILAR ALONSO CASTRO

DIRECTOR:

Dr. D. PABLO CELADA PERANDONES

BURGOS 2015 



\section{LA EDITORIAL BURGALESA}

HIJOS DE SANTIAGO RODRÍGUEZ (1891-1936): ANÁLISIS DE LOS LIBROS ESCOLARES 

A mi hermano Nico, a Ana y Carlos, mis hijos. 



\section{Índice}

RESUMEN

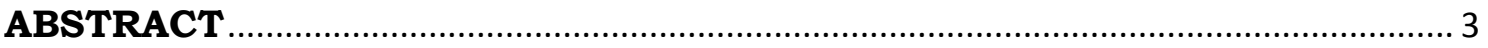

SIGLAS

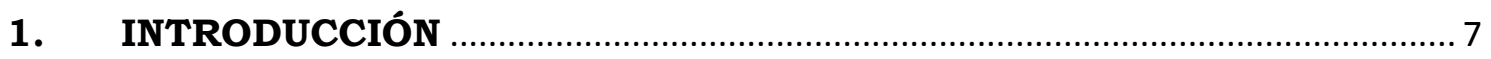

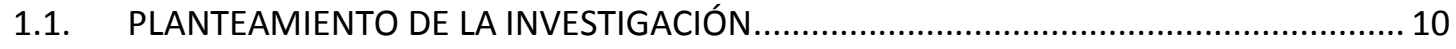

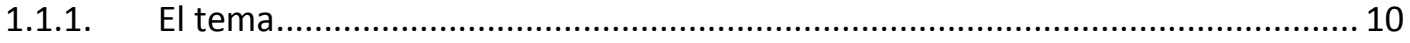

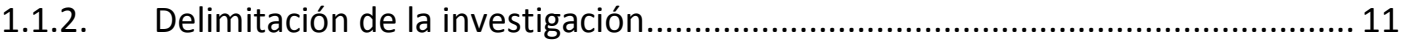

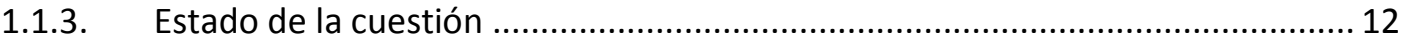

1.1.4. Objetivos e interés científico....................................................................... 13

1.1.5. Diseño metodológico: el método histórico-educativo....................................... 15

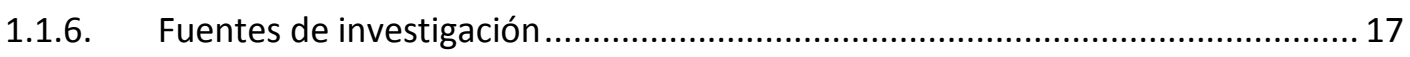

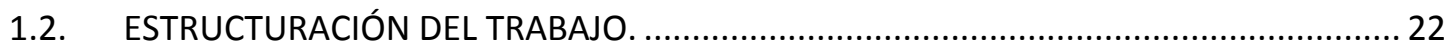

PRIMERA PARTE. RAÍCES Y DESARROLLO DE LA EDITORIAL

BURGALESA HIJOS DE SANTIAGO RODRÍGUEZ ………………………….... 25

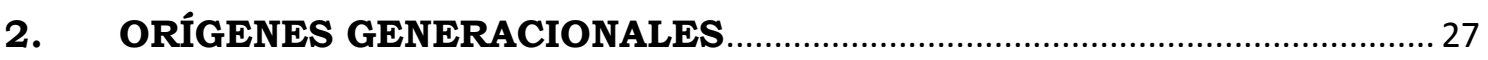

2.1. LA SAGA PATERNA EN UNA VILLA CERCANA A BURGOS: ISAR .................................. 27

2.1.1. La familia Rodríguez en el Catastro del Marqués de la Ensenada ....................... 29

2.1.2. La familia Rodríguez entre los siglos XVIII y XIX ................................................ 38

2.1.3. La familia Rodríguez en los comienzos del siglo XIX ........................................ 43

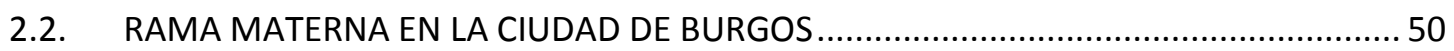

\section{SANTIAGO RODRÍGUEZ ALONSO (1829-1891): FUNDADOR DE LA}

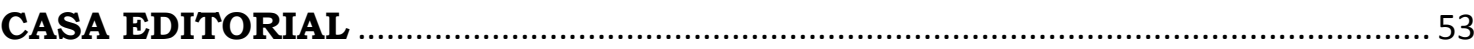

3.1. NACIMIENTO Y JUVENTUD EN UNA ÉPOCA DE CAMBIOS ......................................... 54

3.2. UNA ILUSIÓN EMPRESARIAL JUNTO AL PROYECTO DE VIDA FAMILIAR .......................69

3.2.1. El entorno familiar de Santiago Rodríguez Alonso ..............................................69

3.2.2. Fundación de la librería y comienzos de la Casa Editorial..................................... 80

3.2.3. Librerías en Burgos en la época de Santiago Rodríguez...................................... 86

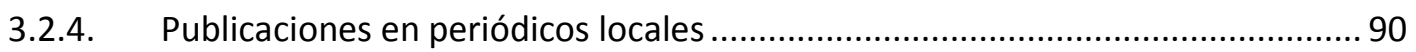

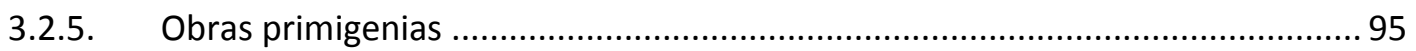

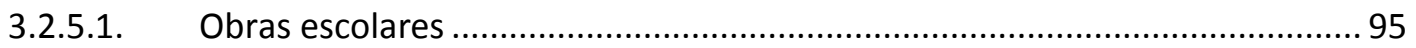

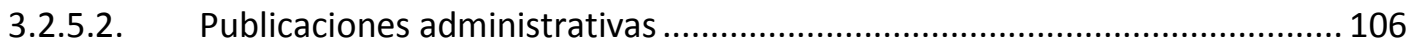

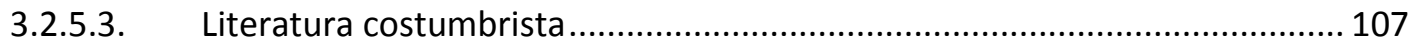

3.2.5.4. Certámenes pedagógicos y literarios ......................................................... 107

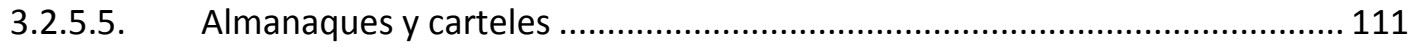

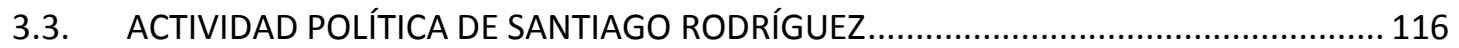


3.4. EL LEGADO PERSONAL Y TESTAMENTARIO A LA MUERTE DE D. SANTIAGO RODRÍGUEZ

4. MARIANO RODRÍGUEZ MIGUEL (1860-1925). EDITORIAL HIJOS DE SANTIAGO RODRÍGUEZ

4.1. MARIANO RODRÍGUEZ MIGUEL (1860-1825): UNA VIDA DEDICADA A LA VIDA CULTURAL Y LITERARIA TRASPASANDO FRONTERAS.

4.2. ASOCIACIONES Y SOCIEDADES DONDE MARIANO RODRÍGUEZ MIGUEL PARTICIPÓ

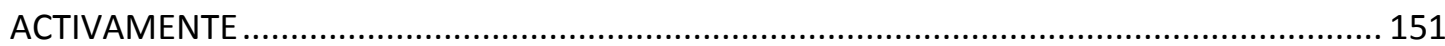

4.2.1. Cámara de Comercio e Industria de Burgos.................................................... 151

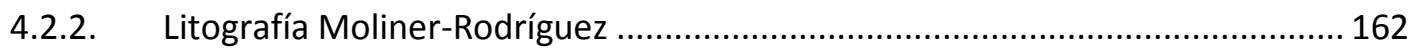

4.2.3. Sociedad Anónima "Automóviles de Burgos" ................................................... 164

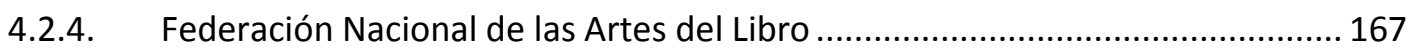

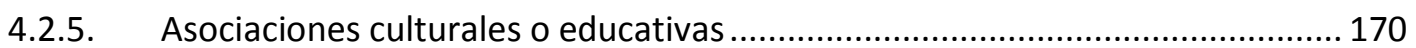

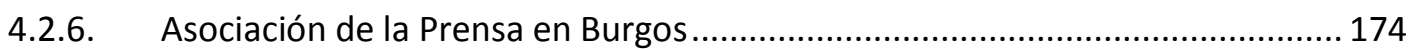

4.2.7. Otras sociedades burgalesas vinculadas con Mariano Rodríguez...................... 177

4.3. ACTIVIDAD POLÍTICA DE MARIANO RODRÍGUEZ (1899-1903) ................................. 182

4.4. EVOLUCIÓN, MEDIOS Y PROCLAMAS EDITORIALES DE ACUERDO A LOS NUEVOS TIEMPOS

SEGUNDA PARTE. CATALOGACIÓN Y ANÁLISIS DE LOS LIBROS ESCOLARES EDITADOS EN HIJOS DE SANTIAGO RODRÍGUEZ ................... 215

5. CATALOGACIÓN DE LA PRODUCCIÓN EDITORIAL (1891-1936) ...... 217

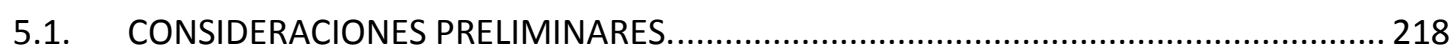

5.2. LISTADO ALFABÉTICO DE LAS OBRAS DE LA EDITORIAL EN LAS PRINCIPALES BIBLIOTECAS NACIONALES E INTERNACIONALES............................................................... 223

5.3. LIBROS DE LA EDITORIAL QUE NO APARECEN EN LAS BIBLIOTECAS............................339

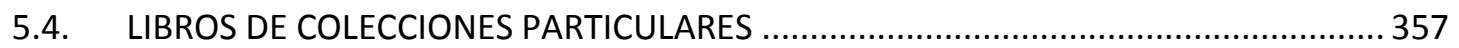

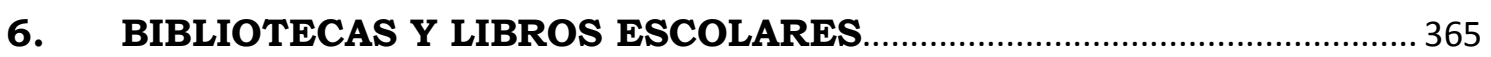

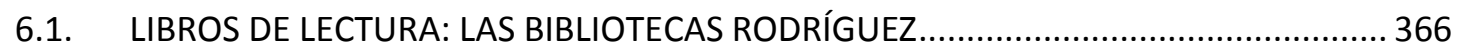

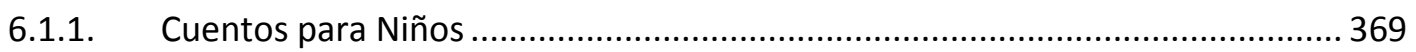

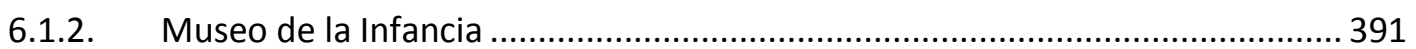

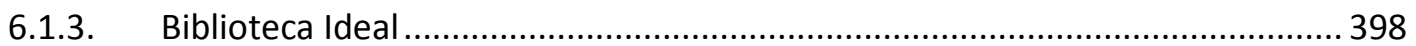

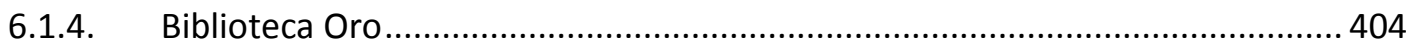

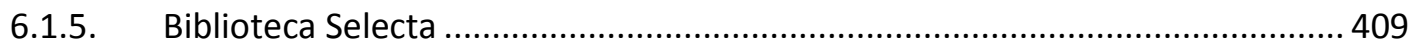

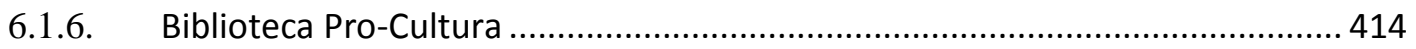

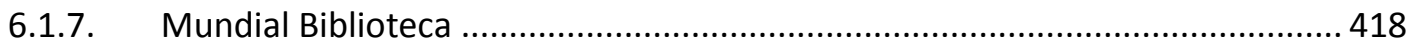

6.1.8. Biblioteca Enciclopédica Hispano-Americana ................................................. 424

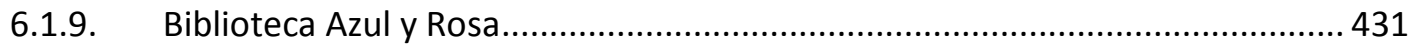

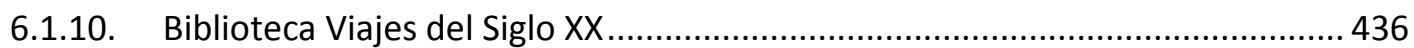


6.1.11. Biblioteca Popular de Medicina e Higiene. ................................................... 437

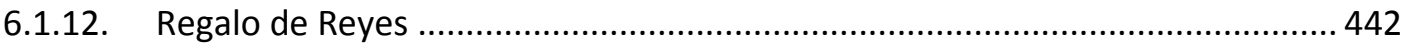

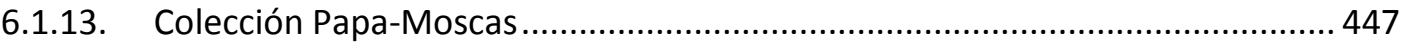

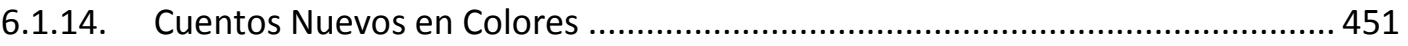

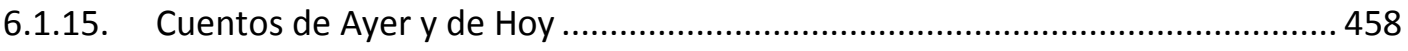

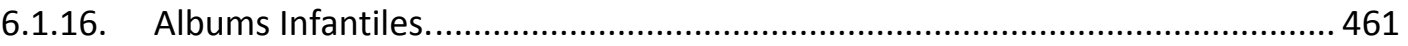

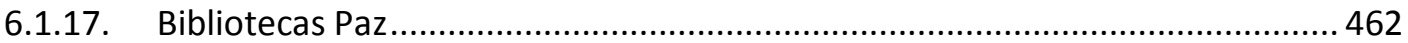

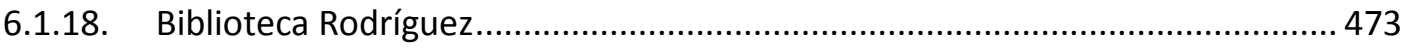

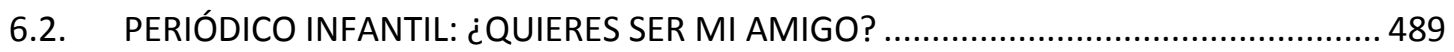

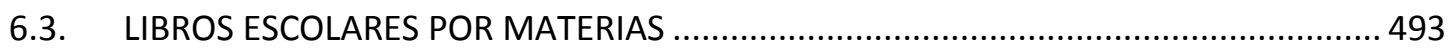

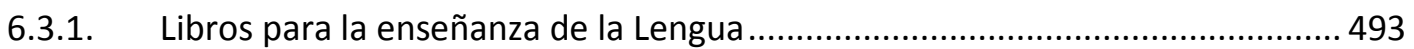

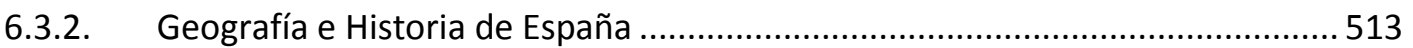

6.3.3. Agricultura, Física, Química e Historia Natural ............................................... 519

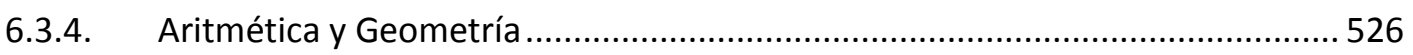

6.3.5. Urbanidad, Economía, Fisiología e Higiene ......................................................5 536

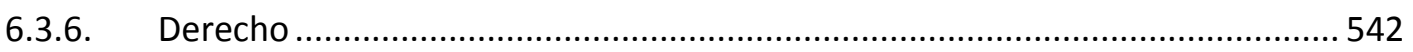

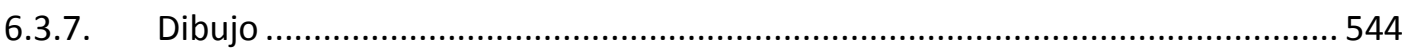

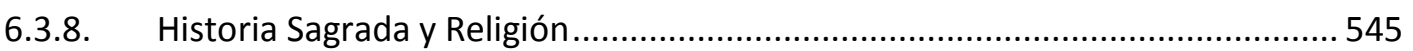

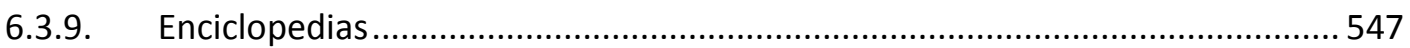

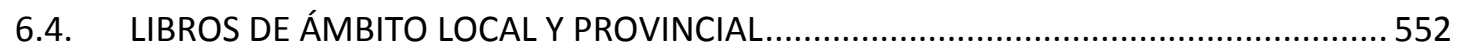

6.4.1. Libros acerca del conjunto histórico y artístico................................................... 553

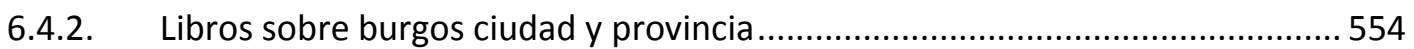

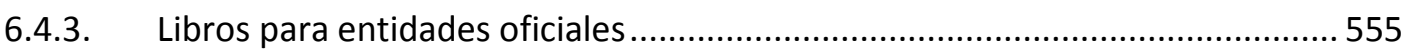

7. BALANCE DE LA INVESTIGACIÓN Y CONCLUSIONES …........................ 557

8. FUENTES DOCUMENTALES Y ELECTRÓNICAS …................................... 573

8.1. CENTROS DE DOCUMENTACIÓN: ARCHIVOS Y BIBLIOTECAS................................... 573

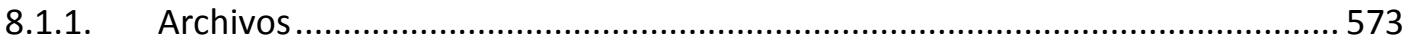

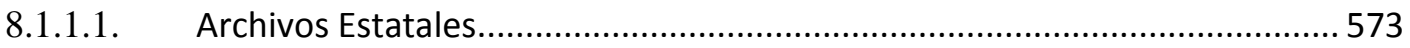

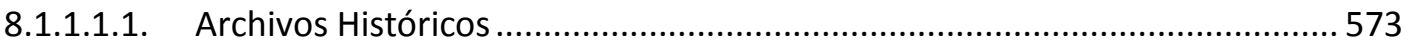

8.1.1.1.2. Archivos Provinciales y Municipales........................................................... 575

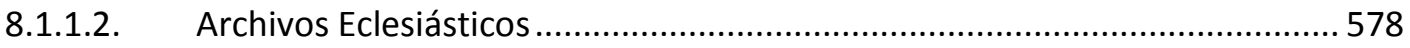

8.1.1.3. Archivos de organismos oficiales ............................................................... 579

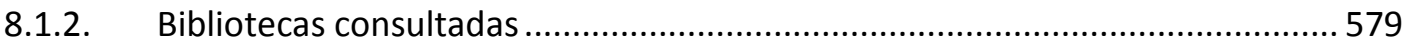

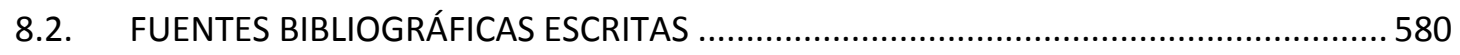

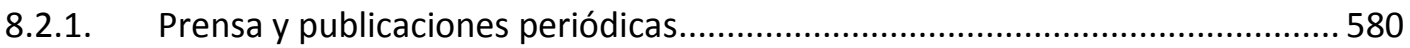

8.2.2. Publicaciones escritas de la editorial Hijos de Santiago Rodríguez..................... 580 


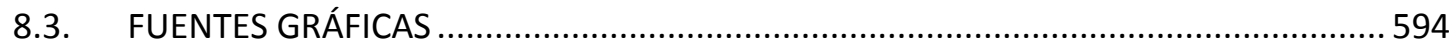

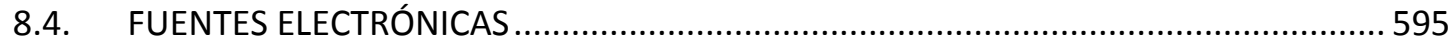

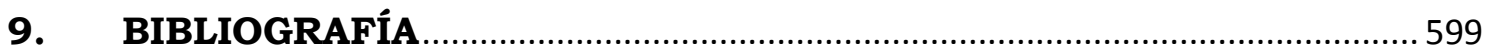

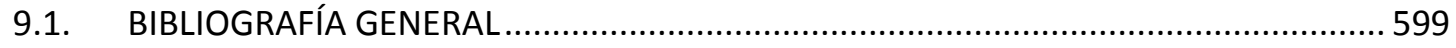

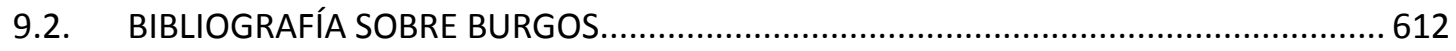

ANEXOS

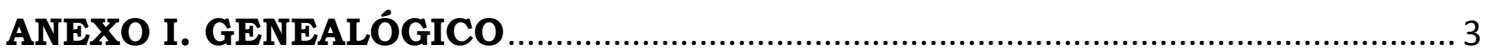

1.1. ÁRBOL GENEALÓGICO: FAMILIA DE D. SANTIAGO RODRÍGUEZ ALONSO ...................... 3

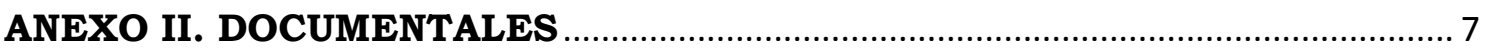

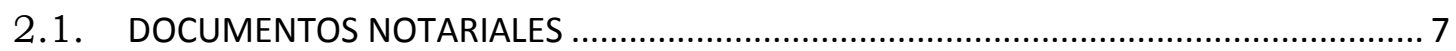

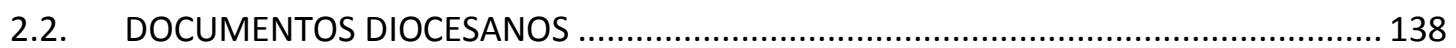

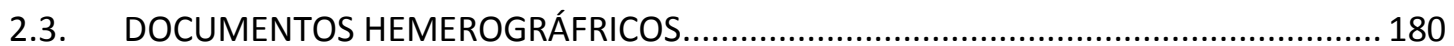

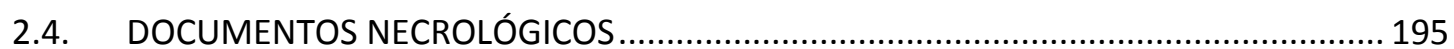

2.5. INVENTARIO DE LA LIBRERÍA E IMPRENTA DE SANTIAGO RODRÍGUEZ EN 1891...... 201

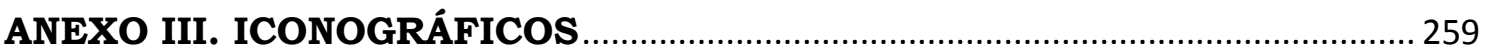

3.1. EVARISTO BARRIO (ZARAGOZA, 1841-BURGOS 1924) ............................................ 259

3.2. ISIDRO GIL GABILONDO (AZCOITIA, GUIPUZCOA, 1840-BURGOS 1917).................... 304

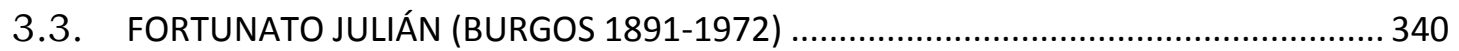

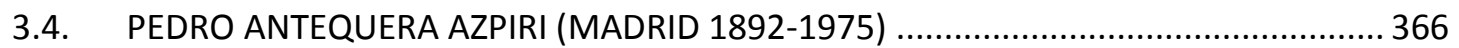

3.5. ENRIQUE MARTÍNEZ DE TEJADA Y ECHEVARRÍA -ECHEA- (1884-1959).................... 399

3.6. FRANCISCO LÓPEZ RUBIO (MOTRIL, 1895 - MADRID, 1965)..................................... 406 


\section{Índice de figuras}

Fig. 2-1: Información de Julián Rodríguez Torre en el Catastro Marqués de la Ensenada......... 31

Fig. 2-2: Carta de la Marquesa de Aguilar dirigida a Julián Rodríguez García. ......................... 33

Fig. 2-3: Información de Francisco Rodríguez Torre en el Catastro Marqués de la Ensenada.. 34

Fig. 2-4: Información del notario Miguel de la Torre Andrés................................................. 36

Fig. 2-5: Portada del libro de contabilidad de la villa de Isar correspondiente al año 1760 ...... 36

Fig. 2-6: Información de la entrada como vecino de Isar ......................................................... 42

Fig. 2-7: Guías de la Real Hacienda de España de 1816 y 1817. Partido de Aranda. Burgos.

Antolín Rodríguez, veredero de la administración en Rentas estancadas y papel sellado........... 46

Fig. 2-8: Certificado y acta literal de bautismo de Mariano Cecilio Rodríguez Alonso, hijo de

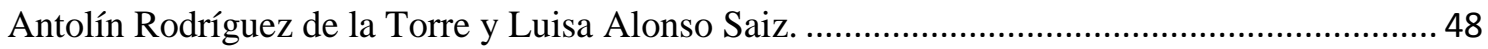

Fig. 3-1: Dibujo de Fortunato Julián sobre Santiago Rodríguez Alonso. .................................. 53

Fig. 3-2: Certificado de la partida de bautismo de Santiago Pascual Rodríguez Alonso. Archivo

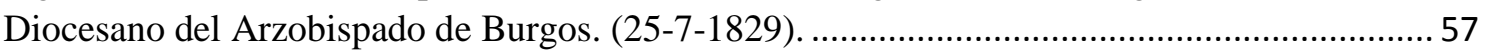

Fig. 3-3: Acta literal de bautismo de Santiago Pascual Rodríguez Alonso.................................. 58

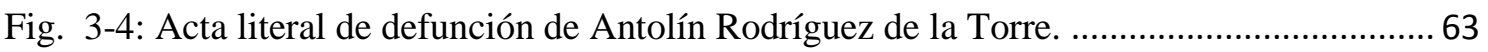

Fig. 3-5: Acta literal de defunción de Mariano Rodríguez Alonso. ............................................ 71

Fig. 3-6: Acta literal de defunción de Luisa Alonso Saiz. ......................................................... 72

Fig. 3-7: Acta literal de matrimonio de Santiago Rodríguez Alonso con Irene de Miguel

Campo. Archivo Diocesano del Arzobispado de Burgos (27-2-1858)...................................... 75

Fig. 3-8: Acta literal de matrimonio de Mariano Rodríguez Miguel con Luisa Escudero y

Torres. Archivo Diocesano del Arzobispado de Burgos (4-8-1886)........................................ 78

Fig. 3-9: Tarjeta de presentación de la Imprenta y Librería de Santiago Rodríguez Alonso.

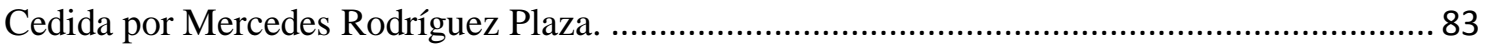

Fig. 3-10: Cubierta de la obra Compendio de Aritmética. 29a edición........................................ 96

Fig. 3-11: Cubierta y contracubierta de la obra El Previsor en la edición de 1889 de la Imprenta

y Librería de Santiago Rodríguez. Imágenes cedidas por Mercedes Rodríguez Plaza. .............. 99

Fig. 3-12: Cubierta del libro Apuntes para una Guía de Burgos. ........................................... 101

Fig. 3-13: Cubierta original del Catecismo de Higiene y Economía Domésticas. Imprenta de

Santiago Rodríguez Alonso. $3^{\text {a }}$ edición. Imagen cedida por Mercedes Rodríguez Plaza. ......... 103

Fig. 3-14: Cubierta del Certamen Pedagógico celebrado en Burgos en 1888, impreso en la

Imprenta y Librería de Santiago Rodríguez Alonso. Imagen cedida por Mercedes Rodríguez

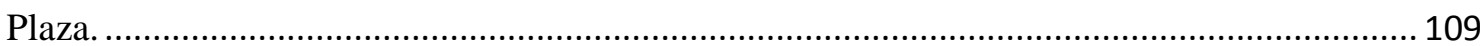

Fig. 3-15: Cubierta del Certamen Pedagógico celebrado en Burgos en 1889, impreso en la Imprenta y Librería de Santiago Rodríguez Alonso. Imagen cedida por Mercedes Rodríguez

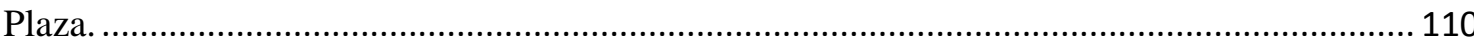

Fig. 3-16: Programa de las corridas de toros en las fiestas de San Pedro y San Pablo de Burgos

los días 29 y 30 de junio de 1883. Imágenes cedidas por Mercedes Rodríguez Plaza............... 112

Fig. 3-17: Trabajos de la Imprenta de Santiago Rodríguez Alonso para diversas asociaciones y

comerciantes de Burgos. Imágenes cedidas por Mercedes Rodríguez Plaza............................. 113

Fig. 3-18: Tarjetas de presentación de la Imprenta de Santiago Rodríguez Alonso. ................. 114

Fig. 3-19: Tarjetas diversas de felicitación y de representación de la Imprenta y Librería.

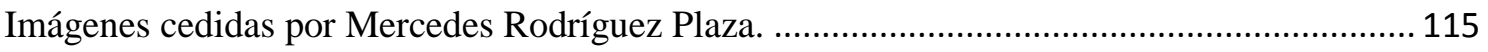

Fig. 3-20: Tarjeta para los representantes de la Imprenta y Librería de Santiago Rodríguez

Alonso. Imagen cedida por Mercedes Rodríguez Plaza............................................................ 115

Fig. 3-21: Tarjeta de felicitación del personal de la Casa Editorial a D. Santiago Rodríguez en

su 60 cumpleaños. Imagen cedida por Mercedes Rodríguez Plaza. 
Fig. 3-22: Propaganda sobre la Imprenta y Librería de Santiago Rodríguez Alonso, donde se detalla los artículos más importantes de su comercio.

Fig. 3-23: Tarjeta de propaganda de la recién creada empresa editorial Hijos de Santiago

Rodríguez, donde se detalla su actividad. Burgos. 1891. 139

Fig. 4-1: Retrato de Mariano Rodríguez Miguel (1860-1925) realizado por Fortunato Julián. Imagen cedida por Lucas Rodríguez Plaza.

Fig. 4-2: Tarjeta de felicitación de los dependientes de la Casa editorial de Santiago Rodríguez Alonso con motivo del matrimonio del hijo y gerente de la Casa, el día 4 de agosto de 1886. Tarjeta cedida por Mercedes Rodríguez Plaza. 144 Fig. 4-3: Tarjeta-entrada de socio de honor impresa en la editorial Hijos de Santiago Rodríguez con motivo del V Congreso Católico Nacional realizado en Burgos el 30 de agosto de 1899. Tarjeta cedida por Mercedes Rodríguez Plaza.

Fig. 4-4: Cubierta y contracubierta del Catálogo de la librería de Hijos de Santiago Rodríguez.

Burgos 1908. En la contraportada se pueden distinguir el lema, emblema y principales medallas obtenidas en diversas Exposiciones. 191

Fig. 4-5: Contracubierta del libro Higiene y Economía Doméstica. ......................................... 198

Fig. 4-6: Contracubierta Catecismo histórico o Compendio de la Historia Sagrada y de la

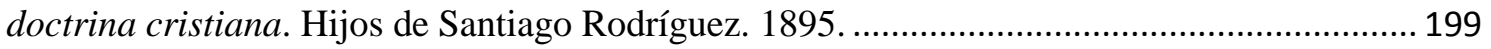

Fig. 4-7: Contracubierta de la Biblioteca Cuentos para Niños............................................ 200

Fig. 4-8: Contracubierta del libro Telémaco de la Biblioteca Hispano-Americana. ................. 201

Fig. 4-9: Contracubierta de los libros de la Biblioteca Enciclopédica Hispano-Americana,

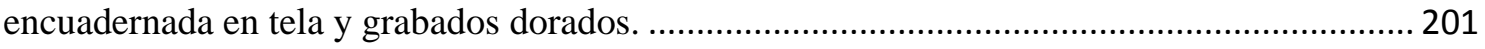

Fig. 4-10: Cubierta y contracubierta del Catálogo General publicado con motivo de la Exposición Iberoamericana de Sevilla y la Exposición Internacional de Barcelona. ................ 202 Fig. 4-11: Propaganda en las últimas páginas del libro Para aprender a leer. Grado primero.

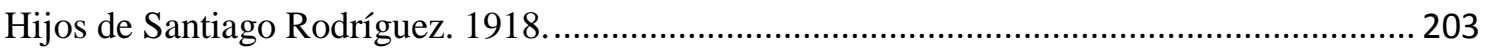

Fig. 4-12: Páginas finales del libro Viejas Memorias. Leyendas y Tradiciones........................ 204

Fig. 4-13: Contracubierta del libro Catón Metódico por Seijas. ................................................ 205

Fig. 4-14: Papeleta de propaganda para sorteo de LOTES RODRÍGUEZ. .............................. 205

Fig. 4-15: En las Bibliotecas Paz en Mi Libro de Año Nuevo presenta el resultado del sorteo de

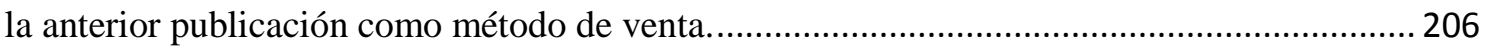

Fig. 4-16: Imágenes en las guardas del libro Cartas a Leonardo ........................................... 206 Fig. 4-17: Publicidad que encontramos en numerosos libros para simbolizar que la lectura que presenta la Casa Editorial es para todo el público infantil y juvenil. ........................................... 207 Fig. 4-18: Modelos distintivos de propaganda reflejados en los libros de la Casa Editorial Hijos

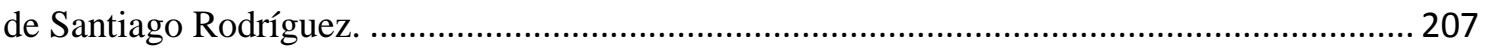
Fig. 4-19: Propaganda de las Bibliotecas Rodríguez con pequeños logotipos, frases sugerentes y utilizando la figura del pequeño y travieso Rodriguete y niños y niñas de todas las edades, así como monumentos de diversas partes del mundo como sugerente para incitar a leer. .............. 208 Fig. 4-20: Propaganda editorial en el periódico de Burgos Guasa Viva para animar a la compra de libros del día 6 de enero, festividad de los Reyes Magos. 210 Fig. 4-21: En la Biblioteca Paz "Rodriguete" nace como símbolo de propaganda para animar a los niños a la lectura. Los dibujos están realizados por Fortunato Julián................................... 211 Fig. 5-1: Portada de Catálogos de la editorial Hijos de Santiago Rodríguez. Ejemplares de la Biblioteca de la Diputación Provincial de Burgos y de la Biblioteca Pública de Valladolid.... 217 Fig. 6-1: Fotografía de la calle Laín Calvo. Librería Hijos de Santiago Rodríguez. Archivo Municipal de Burgos. 
Fig. 6-2: Contraportadas de la casas litográficas burgalesas de A. Moliner y de la hija de Braulio Fournier para la Biblioteca Cuentos para Niños. Hijos de Santiago Rodríguez.

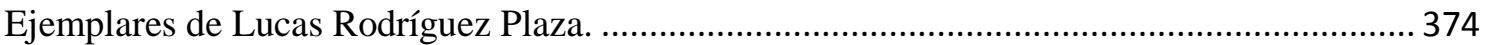

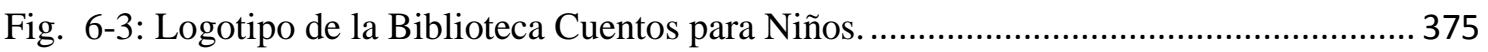

Fig. 6-4: Cubierta de Evaristo Barrio para el cuento Pedro el avaricioso ................................. 377

Fig. 6-5: Cubierta de Evaristo Barrio para el cuento La madre pequeñita................................ 379

Fig. 6-6: Cubierta de Evaristo Barrio y Fortunato Julián en distintas reediciones del cuento La

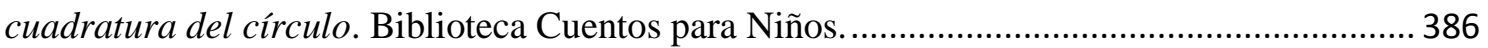

Fig. 6-7: Cubierta del cuento El abrigo escocés de Rosa de Eguilaz....................................... 387

Fig. 6-8: Cubierta y portada del cuento El miedo de la Biblioteca Cuentos para Niños........... 389

Fig. 6-9: Cubierta y portada del cuento El capricho de Susú de la Biblioteca Cuentos para

Niños. Hijos de Santiago Rodríguez. Imágenes cedidas por Lucas Rodríguez Plaza................ 390

Fig. 6-10: Cubierta de El abandonado de la Biblioteca Museo de la Infancia. ........................ 393

Fig. 6-11: Cubierta de cuento Al borde del abismo. Biblioteca Cuentos para Niños................ 394

Fig. 6-12: Cubierta de El limpiabotas de la Biblioteca Museo de la Infancia........................... 395

Fig. 6-13: Cubierta de Evaristo Barrio de Las mariposas. Biblioteca Museo de la Infancia.

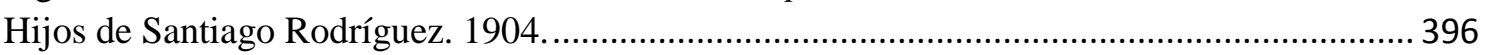

Fig. 6-14: Cubierta a color de Evaristo Barrio en El músico callejero. ...................................... 398

Fig. 6-15: Cubierta de la obra Casa de muñecas por Carmen de Santiago-Fuentes. Biblioteca

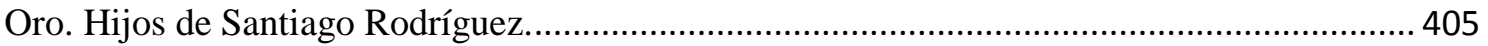

Fig. 6-16: Contraportada del libro Casa de muñecas de la Biblioteca Oro................................. 406

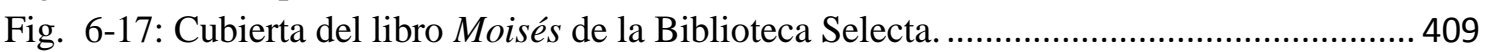

Fig. 6-18: Contracubierta de la Biblioteca Selecta.................................................................. 410

Fig. 6-19: Cubierta del libro Ferrús o el ermitaño del abrojo escrito por Mariana Álvarez Bollo

Carretero. Biblioteca Selecta. Hijos de Santiago Rodríguez................................................... 411

Fig. 6-20: Cubierta de Evaristo Barrio de la obra Jesucristo sembrando el bien escrita por Mariano Rodríguez Miguel. Biblioteca Selecta. Hijos de Santiago Rodríguez. ....................... 413

Fig. 6-21: Contracubierta de los libros de la Biblioteca Pro-Cultura........................................... 415

Fig. 6-22: Pompas de jabón de Rafael Marcos Blanco Belmonte. ….............................................. 418

Fig. 6-23: Historias de Don Quijote de Martín Domínguez Berrueta...................................... 420

Fig. 6-24: Acuarela ilustrada de Evaristo Barrio de la obra Historias de la Historia escrito por

Martín Domínguez Berrueta. Hijos de Santiago Rodríguez................................................. 421

Fig. 6-25: Cubierta del libro Historias de Gil Blas escrito por Ángel Menoyo Portalés. ......... 422

Fig. 6-26: Logotipo de Pedro Antequera Azpiri para la Biblioteca Enciclopédica Hispano-

Americana. Hijos de Santiago Rodríguez. ......................................................................... 424

Fig. 6-27: Cubiertas ilustradas de Los grandes inventos y Alma y corazón de la Biblioteca

Enciclopédica Hispano-Americana. Hijos de Santiago Rodríguez.......................................... 427

Fig. 6-28: Cubierta de Antequera Azpiri de la obra de Quo Vadis? Biblioteca Enciclopédica

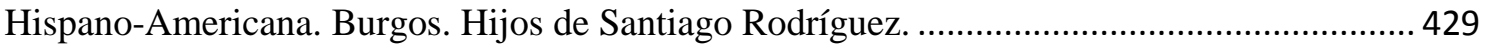

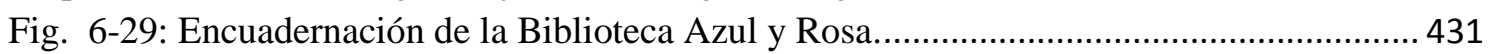

Fig. 6-30: Cubierta de la obra El hijo del capitán Nemo. Biblioteca Azul y Rosa.................... 432

Fig. 6-31: Cubierta de la obra Vidas que quedan realizada por Evaristo Barrio....................... 434

Fig. 6-32: Cubierta del libro ¿Quiere usted criar bien a sus hijos? Biblioteca Popular de

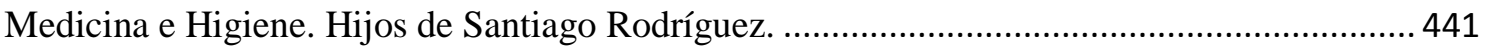

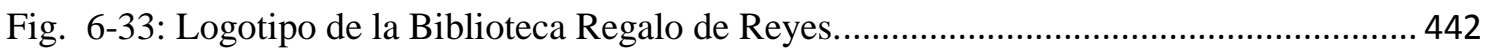

Fig. 6-34: Cubierta del cuento Gasparín ilustrado por Antequera Azpiri................................. 443

Fig. 6-35: Ilustración interior a color de Antequera Azpiri del cuento Gasparín..................... 444

Fig. 6-36: Cubierta del cuento Un amigo ilustrado por Antequera Azpiri............................... 445

Fig. 6-37: Contracubierta de la Colección Papa-Moscas. ........................................................... 447 
Fig. 6-38: Patachín Patachán. Consejas del Papa-Moscas. Ilustrado por Antequera Azpiri.

Colección Papa-Moscas. Hijos de Santiago Rodríguez. .......................................................... 448

Fig. 6-39: Cubierta y portada del libro Rinconete y Cortadillo. Biblioteca Papa-Moscas....... 449

Fig. 6-40: Ilustración interior del libro Rinconete y Cortadillo...................................................450

Fig. 6-41: Propaganda de la Biblioteca Cuentos Nuevos en Colores......................................... 451

Fig. 6-42: Logotipo de la Colección Cuentos Nuevos en Colores. ............................................ 452

Fig. 6-43: Cubierta a color del cuento Mikolán y Cía por Antequera Azpiri............................ 453

Fig. 6-44: Cubierta del cuento La larva y el águila de Antequera Azpiri................................ 455

Fig. 6-45: Ilustraciones interiores del cuento La larva y el águila de Antequera Azpiri.......... 457

Fig. 6-46: Cubierta de Lee estos cuentos ilustrado por Fortunato Julián. .................................. 458

Fig. 6-47: Cubiertas de los dos primeros libros de Bibliotecas Paz, ilustrados por Fortunato

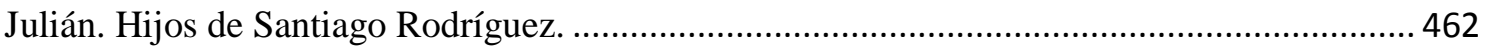

Fig. 6-48: Guardas ilustradas con el logotipo de Bibliotecas Paz, ilustradas por Fortunato

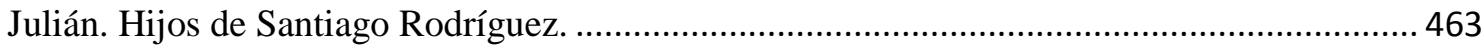

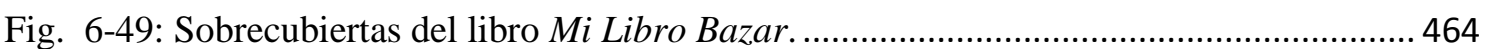

Fig. 6-50: Cubierta y contracubierta de Mi Libro de Estampas y cuentos. Bibliotecas Paz..... 465

Fig. 6-51: Cubierta y contracubierta de Mi Libro Bazar. Bibliotecas Paz. .............................. 466

Fig. 6-52: Historieta muda "Un buen golpe” de Francisco López Rubio en Mi Libro de Año

Nuevo. Bibliotecas Paz. Hijos de Santiago Rodríguez............................................................ 469

Fig. 6-53: Historieta muda "El último recurso" de Francisco López Rubio en Mi Libro de Año

Nuevo. Bibliotecas Paz. Hijos de Santiago Rodríguez.......................................................... 470

Fig. 6-54: Historietas cómicas de Emilio Ferrer en Mi Libro Bazar............................................ 471

Fig. 6-55: Logotipo de la colección Biblioteca Rodríguez. ..................................................... 474

Fig. 6-56: Cubierta del libro Los tres sorianitos de Pedro Antequera Azpiri. .......................... 476

Fig. 6-57: Cubierta y portada de Cuentos de Pototo, ilustradas por Francisco López Rubio.

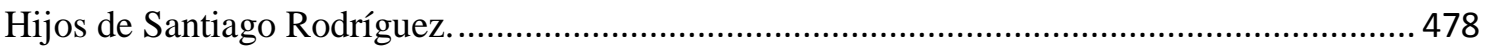

Fig. 6-58: Cubierta y portada de El pájaro en la nieve de Armando Palacio Valdés................ 481

Fig. 6-59: Cubierta y contracubierta de Contando Cuentos de Angélica Palma ilustrado por

Pedro Antequera Azpiri. Hijos de Santiago Rodríguez........................................................... 483

Fig. 6-60: Ilustración en blanco y negro sobre el lugar y personaje que narra los cuentos del

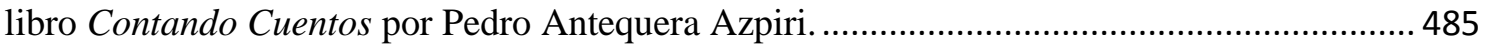

Fig. 6-61: Ilustraciones interiores de Rosario de Velasco en Cuentos a mis nietos................... 488

Fig. 6-62: Primera plana del Semanario infantil ilustrado ¿Quieres ser mi amigo? ................. 490

Fig. 6-63: Cubierta del Catón metódico de Seijas. La ilustración es de Fortunato Julián, donde

observamos la figura femenina en primer plano y mayor que la masculina. ............................ 494

Fig. 6-64: Cubierta del libro El primer vuelo para la enseñanza simultánea de la lectura y

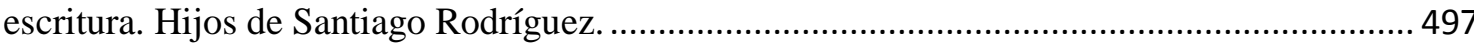

Fig. 6-65: Portada y contraportada del Compendio de Ortografía Castellana de Anselmo Salvá.

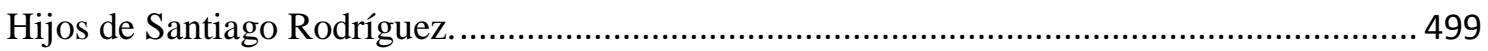

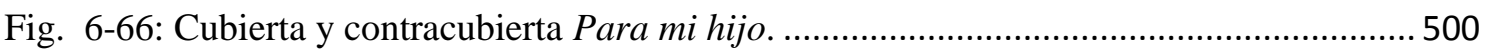

Fig. 6-67: Cubierta de Evaristo Barrio en Lectura Morales .................................................... 502

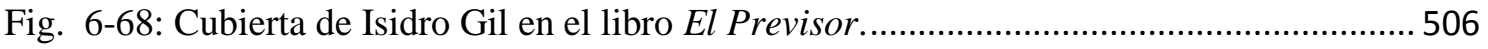

Fig. 6-69: Cubierta de Evaristo Barrio de la obra El Ciudadano................................................5 508

Fig. 6-70: Cubierta de Evaristo Barrio de La Escuela y la Patria. ............................................. 510

Fig. 6-71: Cubierta del libro Geografía para niños de José Osés Larumbe............................... 516

Fig. 6-72: Cubierta de la obra Historia de España, escrita por Anselmo Salvá......................... 517

Fig. 6-73: Cubierta de Evaristo Barrio del libro En el campo............................................... 522

Fig. 6-74: Cubierta de Evaristo Barrio de Páginas sobre ciencias físicas y naturales. Grado superior. Hijos de Santiago Rodríguez. Ejemplar de la Biblioteca del CEINCE...................... 523 
Fig. 6-75: Cubierta de Compendio de Aritmética ..................................................................... 527

Fig. 6-76: Cubierta del libro Nuevas lecciones de Geometría................................................ 534

Fig. 6-77: Cubierta y contracubierta de Higiene y Economía Doméstica................................ 539

Fig. 6-78: Cubierta ilustrada por Evaristo Barrio de la obra Fisiología e Higiene. .................. 541

Fig. 6-79: Cubierta de Evaristo Barrio de la obra Nociones de derecho....................................543

Fig. 6-80: Cubierta del método Dibujarás y pintarás de Pedro Antequera Azpiri. .................. 544

Fig. 6-81: Cubierta y contracubierta de Tesoro Escolar. ...................................................... 548 

CUADRO I: RELACIÓN DE TÍTULOS DE LA BIBLIOTECA CUENTOS PARA NIÑOS, CON EL AUTOR, ILUSTRADOR Y CATÁLOGOS EDITORIALES... 371 CUADRO II: RELACIÓN DE LA BIBLIOTECA MUSEO DE LA INFANCIA CON LA BIBLIOTECA CUENTOS PARA NIÑOS Y LOS CATÁLOGOS DE LA EDITORIAL HIJOS DE SANTIAGO RODRÍGUEZ. 397

CUADRO III: RELACIÓN DE LOS TÍTULOS DE LA BIBLIOTECA IDEAL CON LOS CATÁLOGOS HIJOS DE SANTIAGO RODRÍGUEZ. 401

CUADRO IV: RELACIÓN DE LOS CUENTOS PUBLICADOS EN LAS BIBLIOTECAS CUENTOS PARA NIÑOS, MUSEO DE LA INFANCIA Y BIBLIOTECA IDEAL. 401 CUADRO V: RELACIÓN DE TÍTULOS DE LA BIBLIOTECA ORO EN LOS CATÁLOGOS DE LA EDITORIAL HIJOS DE SANTIAGO RODRÍGUEZ. 408 CUADRO VI: RELACIÓN DE LOS TÍTULOS DE LA BIBLIOTECA SELECTA EN LOS CATÁLOGOS DE LA EDITORIAL HIJOS DE SANTIAGO RODRÍGUEZ. 413 CUADRO VII: RELACIÓN DE LOS TÍTULOS DE LA BIBLIOTECA PRO-CULTURA EN LOS CATÁLOGOS DE LA EDITORIAL HIJOS DE SANTIAGO RODRÍGUEZ... CUADRO VIII: RELACIÓN DE TÍTULOS DE LA MUNDIAL BIBLIOTECA EN LOS CATÁLOGOS DE LA EDITORIAL HIJOS DE SANTIAGO RODRÍGUEZ. 423 CUADRO IX: RELACIÓN DE TÍTULOS DE LA BIBLIOTECA ENCICLOPÉDICA HISPANO-AMERICANA EN LOS CATÁLOGOS DE LA EDITORIAL HIJOS DE SANTIAGO RODRÍGUEZ. 430 CUADRO X: RELACIÓN DE TÍTULOS DE LA BIBLIOTECA AZUL Y ROSA EN LOS CATÁLOGOS DE LA EDITORIAL HIJOS DE SANTIAGO RODRÍGUEZ. 435 CUADRO XI: RELACIÓN DE LOS TÍTULOS DE LA BIBLIOTECA MEDICINA E HIGIENE EN LOS CATÁLOGOS DE LA EDITORIAL HIJOS DE SANTIAGO RODRÍGUEZ.

CUADRO XII: RELACIÓN DE LOS TÍTULOS DE LA BIBLIOTECA REGALO DE REYES EN LOS CATÁLOGOS DE LA EDITORIAL HIJOS DE SANTIAGO RODRÍGUEZ. ......... 446 CUADRO XIII: RELACIÓN DE TÍTULOS DE LA BIBLIOTECA COLECCIÓN PAPAMOSCAS EN LOS CATÁLOGOS DE LA EDITORIAL HIJOS DE SANTIAGO RODRÍGUEZ.

CUADRO XIV: RELACIÓN DE TÍTULOS DE LA BIBLIOTECA CUENTOS NUEVOS EN COLORES EN LOS CATÁLOGOS DE LA EDITORIAL HIJOS DE SANTIAGO RODRÍGUEZ.

CUADRO XV: RELACIÓN DE TÍTULOS DE LA BIBLIOTECA PAZ EN LOS

CATÁLOGOS DE LA EDITORIAL HIJOS DE SANTIAGO RODRÍGUEZ. 472

CUADRO XVI: RELACIÓN DE LOS TÍTULOS DE LA BIBLIOTECA RODRÍGUEZ EN LOS CATÁLOGOS DE LA EDITORIAL HIJOS DE SANTIAGO RODRÍGUEZ. 487 

Esta investigación analiza, desde una perspectiva histórico-educativa, la evolución y el contexto educativo de la editorial burgalesa Hijos de Santiago Rodríguez, desde sus orígenes hasta la Guerra Civil Española.

En la primera parte, se señalan los protagonistas principales con los matices, genialidades y aportaciones personales, políticas, culturales y comerciales que configuraron una editorial influyente y destacada.

$\mathrm{Su}$ fundador, Santiago Rodríguez Alonso (1829-1891), hombre autodidacta, de semblante liberal, abierto y preocupado por la educación, abre una librería en Burgos, en 1850. Durante la Restauración amplía su negocio, con una imprenta especializada en textos de $1^{\mathrm{a}}$ enseñanza, que se expande a los mercados nacionales e hispanoamericanos. Como marca empresarial configura los motivos que aluden a la infancia, al progreso y a la civilización, recogidos en su lema La escuela redime y civiliza; y a la sabiduría, con el icono de Minerva. A su muerte, en 1891, se constituye la editorial Hijos de Santiago Rodríguez a cargo de su hijo Mariano Rodríguez Miguel (1860-1925). Activo y fiel continuador de la obra de su padre, invierte en mayores y mejores medios, amplia toda la producción escolar y se convierte en un ejemplo paradigmático de la evolución editorial en el conjunto del panorama nacional. Sin olvidar la importante aportación de escritores e ilustradores que hicieron posible la creación de libros de una extraordinaria calidad literaria y artística, más allá de ideas políticas y de pensamiento.

En la segunda parte, se presenta y despliega una catalogación de sus obras como base para el posterior estudio de las Bibliotecas Rodríguez y de los libros escolares. Observamos y destacamos un objetivo principal: contribuir a la erradicación del analfabetismo al facilitar el acceso a la lectura. Además, la editorial fomenta la cultura literaria en niños y jóvenes de clases medias y bajas, con precios populares. Sorprende, en este mismo sentido, el esfuerzo por actualizar la escuela incluyendo en los textos los nuevos cambios educativos. Muchos de sus libros escolares son reconocidos y aprobados como libros de texto para las escuelas. Y, sin duda, no se debe olvidar el gran legado aportado a la literatura infantil de su época, con sus 18 Bibliotecas, en poco más de 40 años (1894-1935). 
PALABRAS CLAVE: Santiago Rodríguez Alonso, Mariano Rodríguez Miguel, Hijos de Santiago Rodríguez, libros escolares, Bibliotecas Rodríguez, editorial. 
This doctoral research analyses, from a historical educative perspective, the evolution and educational context of the publishing house Hijos de Santiago Rodriguez settled in Burgos, from its origins until the Spanish Civil War.

In the first part, the main characters are outlined with their singularities, genialities and personal contributions in the politics, cultural and commercials fields that configure an influential and prominent publishing house.

The founder, Santiago Rodríguez Alonso (1829-1891), was a self taught person with an open and liberal mind. Worried about education, he decided to set up a bookshop in his town Burgos in 1850. During the Restauración, he expanded business buying printing equipment specialized in first teaching textbooks; thanks to that operation he spread his products to national and international markets. As a trademark, he captured the essence of certain topics as childhood, progress and civilization, wisely assembled in his slogan: School redimes and civilizes. He also adopted the icon of Minerva, the goodness of wisdom, for his business. He died in 1891 and his son and heir, Mariano Rodríguez Miguel (1860-1925), incorporated the publishing house Hijos de Santiago Rodríguez. He was an active and loyal family business keeper: he invested in bigger and better facilities increased the scholar production and he became in a paradigmatic example of the publisher evolution in the national context. In addition, it is crucial do not forget, the vital contribution of writers and illustrators who made possible the creation of excellent quality textbooks, beyond political ideas and thoughts.

In the second part, an extensive cataloging of works is presented as a base for the following study of the Bibliotecas Rodríguez and textbooks. It is observed and highlighted a main goal: the contribution to the illiteracy eradication due to the promotion of reading. Besides, the publisher encouraged the literacy culture in children and teenagers of all conditions thanks to its affordable prizes. Furthermore, the continue effort to update the school is reflected in the new educational changes that they included in their school materials, which most of them, are recognized and proved as official textbooks for schools. Moreover, it has not been forgotten the huge legacy in children literature with 18 Bibliotecas published in a period of over 40 years (1894-1935). 
KEY WORDS: Santiago Rodríguez Alonso, Mariano Rodríguez Miguel, Hijos de Santiago Rodríguez, textbooks, Bibliotecas Rodríguez, Publishing House. 
ADPBU: Archivo de la Diputación Provincial de Burgos.

AHPBU: Archivo Histórico Provincial de Burgos.

AHPS: Archivo Histórico Provincial de Segovia.

ADBU: Archivo Diocesano de Burgos.

AMBu: Archivo Municipal de Burgos.

AMI.: Archivo Municipal de Isar, Burgos.

ACCBU: Archivo de la Cámara de Comercio e Industria de Burgos.

CATÁlOGO 1908: Catálogo Ilustrado de la editorial Hijos de Santiago Rodríguez del año 1908.

CATÁlOGO 1917: Catálogo General Ilustrado de la editorial Hijos de Santiago Rodríguez del año 1917.

CATÁlOGO 1925: Catálogo Recuerdo 1850-1925 de la editorial Hijos de Santiago Rodríguez del año 1925.

CATÁloGo 1929: Catálogo General publicado con motivo de la Exposición Iberoamericana en Sevilla y de la Exposición Internacional en Barcelona del año 1929.

CEINCE: Centro Internacional de la Cultura Escolar.

UNED: Universidad Nacional de Educación a Distancia.

IES: Instituto de Educación Secundaria. 

Comenzar una tesis supone realizar, en primer lugar, una reflexión de vivencias personales que cobran sentido, en nuestro caso, con paso del tiempo. Las expectativas y el interés por conocer producen, paulatinamente, una decantación del tema y su tratamiento.

Al echar la vista atrás, observamos que una primera aproximación comenzó al finalizar los estudios de Tercer Ciclo y decidir qué tema elegir para el proyecto de Investigación y la obtención del diploma de Estudios Avanzados en la Universidad de Burgos (Facultad de Humanidades y Educación - Departamento de Ciencias de la Educación).

Entre las posibilidades de investigación planteadas, las propuestas que despertaban mayor interés, y coincidencia con mi tutor, eran las editoriales escolares que vivieron entre siglos -XIX y XX-, impulsoras de proyectos de regeneración y modernización.

Destacan las referencias a Calleja, Hernando, Bastinos, ampliamente valoradas. Sin embargo, observamos la carencia de estudios suficientes sobre Santiago Rodríguez. Así, fue imponiéndose la idea de estudiar las editoriales como importantes agentes del cambio educativo y social en España. ${ }^{1}$ Entre ellas destacamos, por afecto y proximidad, Santiago Rodríguez pues los recuerdos escolares y personales que sus libros nos aportan, y los escasos o insuficientes estudios sobre ella, despertaron nuestra curiosidad por conocer sus avatares y valorar su incidencia histórico-educativa. Todo ello nos movió iniciar y profundizar en esta investigación.

Por ello, la editorial burgalesa Hijos de Santiago Rodríguez nos surgió de forma casi espontánea, con más fuerza, ya que, en mi infancia y juventud, sus libros escolares formaron parte de mi quehacer diario.

Además, el hecho constatable de un mayor interés de la investigación histórica, en estas últimas décadas, por "desenterrar de la memoria" a aquellas personas que han marcado hitos histórico-educativos, e hicieron posible una labor de modernización de la sociedad española, me dirigen a buscar información sobre la figura fundacional de la editorial.

En este sentido, presentamos la Suficiencia Investigadora bajo el título Santiago Rodríguez Alonso: Perfil de un impresor con proyección editorial, un conjunto de datos inéditos y novedosos que nos hablan de su figura y obra.

\footnotetext{
${ }^{1}$ Es a mediados del siglo XIX con la aplicación de la ley Moyano de 1857, cuando se constituye un sistema educativo bajo los principios de gratuidad relativa para la enseñanza primaria, uniformidad, centralidad y libertad de enseñanza limitada. A partir de dicha ley fueron surgiendo nuevas editoriales, principalmente en Madrid y Barcelona.
} 
En un contexto más amplio, sabemos que, mediado el siglo XIX, con la aplicación de la ley Moyano (1857) se constituye un sistema educativo para la enseñanza primaria, bajo los principios de gratuidad relativa, uniformidad, centralidad y libertad de enseñanza relativa. Paralelamente a su desarrollo, existía la imperiosa necesidad de textos, que fueron aportados por las nuevas editoriales surgidas en Madrid y Barcelona, principalmente.

Todo ello nos lleva, en principio, a plantearnos varios interrogantes. Afloran numerosas preguntas, que nos llevan a seguir indagando, sin pensar en una Tesis Doctoral. La búsqueda y la posterior relación de los datos recogidos nos despierta la curiosidad y el interés para seguir rellenando las grandes lagunas que surgieron de las mismas.

Posteriormente, estas ideas tomaron forma e intención con la participación, los días 19 y 20 de noviembre de 2007, en un "Coloquio sobre los primeros editores escolares", en Berlanga de Duero, en el Centro Internacional de la Cultura Escolar $[\mathrm{CEINCE}],{ }^{2}$ donde presentamos la ponencia "Líneas de trabajo en torno a la editorial Santiago Rodríguez e hijos", en coautoría con nuestro director, Pablo Celada.

En este encuentro tomamos como referencia los ejemplos afines de dos editoriales propuestas que nos sirvieron para afianzar la línea de investigación a seguir. Sobre la Editorial Hernando, Jean François Botrel, profesor de la Universidad de Rennes, Francia, hizo un exhaustivo balance historiográfico; de la Casa Calleja, los investigadores Julio Ruiz Berrio, de feliz memoria, Carmen Colmenar y Myriam Carreño, profesores de la Universidad Complutense de Madrid, presentaron un amplio análisis de la aportación, de la casa editora, a la sociedad de su época.

Al año siguiente, en julio de 2008, tuve la oportunidad de disfrutar una beca del CEINCE para realizar una estancia de investigación y poder acceder a los fondos recopilados de la editorial Hijos de Santiago Rodríguez. Además, pude contar con la impagable tutorización, asesoramiento y cercanía del profesor D. Agustín Escolano.

Allí, en honor a la verdad, se comienza a dar forma y perfilar la importancia y el interés en el estudio de las dos etapas iniciales de la editorial dirigidas por Santiago Rodríguez Alonso, fundador de la casa editorial, y Mariano Rodríguez, continuador y artífice de importantes renovaciones y cambios técnicos. Del primero, llama la atención la apertura de una librería, su especialización en libros escolares de $1^{a}$ enseñanza, desde la que proyecta su imprenta, al igual que muchos editores de su época, sin que hubiera antecedentes familiares en el sector. Del segundo, destaca que no se conformó en seguir las huellas de su padre, como algunas

\footnotetext{
${ }^{2}$ Su director actual es el doctor D. Agustín Escolano Benito, catedrático jubilado de la Universidad de Valladolid.
} 
imprentas burgalesas, sino que la amplió con la incorporación de nuevos medios técnicos. Además, creó las llamadas Bibliotecas Rodríguez, a la vez que continuó con impresión de libros escolares de $1^{a}$ enseñanza, con actualizaciones pedagógicas y artísticas, equiparándolos a la altura de las ediciones extranjeras.

En suma, estos planteamientos pretenden lograr un mayor reconocimiento de estos hombres ilustres de mi tierra que no han sido suficientemente conocidos y/o reconocidos. Valorar su labor, preservar su memoria y reconocer la influencia histórico-educativa supone que su obra no sea olvidada o arrinconada por el tiempo, ni por la indiferencia, que ha conducido a un desconocimiento de su gran legado que, en buena medida, pretendemos recuperar. 


\subsection{PLANTEAMIENTO DE LA INVESTIGACIÓN}

Teniendo en cuenta el tipo de investigación en ciencias educativas realizada, es necesario abordar algunos aspectos que resultan fundamentales para su elaboración, tales como el tema de estudio, su delimitación, los objetivos e interés científico, al igual que la metodología, sus fuentes y estructuración.

\subsubsection{El tema}

La elección del tema para esta investigación, titulada La editorial Hijos de Santiago Rodríguez (1891-1935): Análisis de los libros escolares, pretende ahondar en el conocimiento de la editorial burgalesa y situar su importancia en el conjunto de las génesis editoriales españolas.

Por ello, se pretende delimitar dos líneas fundamentales de estudio centradas, por una parte, en las personas que dirigieron la editorial hasta poco antes de los inicios de la guerra civil española $y$, de otra, incidir en la organización de una primera catalogación, lo más exhaustiva posible, para un posterior análisis de los libros escolares, publicados en la época y encontrados en las distintas bibliotecas públicas.

Trataremos de recoger toda la información dispersa aunque concentrada, principalmente en los diversos archivos de instituciones burgalesas, para unificar todos los datos biográficos y todas las obras editadas, en un mismo texto escrito. Así, esto puede ser un punto de partida que facilite estudios posteriores.

Un elemento a nuestro favor radica en que es un tema inédito en investigación educativa, ya que solo se han publicado pinceladas de la misma en diversos libros y publicaciones locales de la ciudad. Es relevante, y a su vez sorprendente, que hasta ahora no se hayan publicado más estudios sobre la misma pues todas las editoriales con cierto renombre y prestigio -Hernando, Calleja, Calpe, Bastinos, Espasa y un largo etcétera-, disponen de publicaciones e investigaciones donde se atiende a toda su historia: sus orígenes, creadores, producciones, trayectoria, colaboraciones, sus medios técnicos, etc. Y, a nuestro modo de ver, Hijos de Santiago Rodríguez necesita, también, un estudio no menor. 


\subsubsection{Delimitación de la investigación}

Como punto de partida, y al objeto de conocer los orígenes sociales, culturales y económicos de la figura fundacional, ha sido necesario remontarse al período comprendido desde finales del siglo XVIII hasta mediados del XIX. Situamos a la persona, la biografía y el contexto, del que surgió una empresa innovadora.

La investigación avanza con la fundación de la librería, en torno a 1850, los comienzos editoriales en las últimas décadas del siglo y la continuidad de la misma, después de la muerte de Santiago Rodríguez, en 1891. La nueva empresa Hijos de Santiago Rodríguez es dirigida por su hijo Mariano Rodríguez Miguel, hasta su muerte en 1925. Prosiguió, a su vez, su hijo Pascual Rodríguez Escudero, hombre introvertido y enfermizo -del que no se conservan datos biográficos relevantes- hasta su muerte en 1935.

Más allá de los límites de esta investigación, su hermano Lucas Rodríguez Escudero se convierte en propietario único al comprar, a sus 5 hermanos y tías, todas las acciones de la empresa, con el aval de su suegro José Martín Cobos Varona, según nos cuenta uno de sus nietos, Lucas Rodríguez Plaza.

Aunque la actividad editorial tiene una mayor amplitud en el tiempo (1850-1989), la hemos delimitado hasta la Guerra Civil española por estimarla como la época de mayor auge y esplendor editorial.

Nos interesa estudiar los cambios que se produjeron con el desmantelamiento del Antiguo Régimen, la influencia de los ideales de libertad promulgados en la Revolución Francesa y los cambios producidos por la Revolución Industrial que conformaron una línea cultural y política liberal, progresista y moderada, eje fundamental en la editorial, interrumpida con la llegada del Franquismo. Y dejamos una puerta abierta a la investigación de la última etapa editorial que complemente la presente.

La delimitación geográfica de este estudio se centra en Burgos, ciudad donde nació el proyecto editorial que traspasó los límites locales en su propagación comercial a otras ciudades españolas, iberoamericanas e internacionales.

Desde sus inicios, la imprenta y librería de Santiago Rodríguez Alonso se publicita como una casa que surte a las principales librerías de España y América. Se especializa en publicaciones para la enseñanza primaria, libros de texto y de literatura infantil, con ejemplares de gran interés pedagógico y literario. 


\subsubsection{Estado de la cuestión}

En la revisión documental realizada sobre la editorial, no se ha encontrado ningún estudio monográfico. Sin embargo, sí existe un estudio de la evolución didáctica de los libros de Historia de España, en la casa de Hijos de Santiago Rodríguez, ${ }^{3}$ y otros datos sobre la figura del fundador de la editorial, en el trabajo para la obtención del Diploma de Estudios Avanzados del Departamento de Ciencias de la Educación de la Universidad de Burgos. ${ }^{4}$

En publicaciones de carácter local aparecen informaciones relacionadas con la editorial al hablar de las industrias burgalesas, así como de los personajes destacados más ilustres. ${ }^{5}$ Las investigaciones sobre otras editoriales españolas de la época hacen alusión a nuestra editorial en un plano de colaboración y situación cronológica.

Agustín Escolano, en la Historia Ilustrada del libro escolar en España, señala la importancia e interés seguida por la línea editorial que se evidencia en la elección de su lema "La escuela redime y civiliza" y se materializa en sus obras. ${ }^{6}$

Ante la necesidad de dignificar el papel de una editorial que tanto aportó al panorama educativo, cultural y de progreso de la época, consideramos importante la recogida de datos dispersos, unificándolos, para un mayor conocimiento e inicio de nuestra investigación.

\footnotetext{
${ }^{3}$ ARNÁN LOMBARTE, F. Cien años de evolución didáctica de una editorial: Los libros de Historia de España de Hijos de Santiago Rodríguez de Burgos. Barcelona: Universidad de Barcelona, Tesis doctoral, Microficha 1060/1991.

${ }^{4}$ ALONSO CASTRO, M. P. Santiago Rodríguez Alonso: Perfil de un impresor con proyección editorial. Universidad de Burgos, 2004, trabajo inédito para la obtención del Diploma de Estudios Avanzados del Departamento de Ciencias de la Educación.

${ }^{5}$ MONJE MATÉ, C. La industria del libro en Burgos durante el siglo XX. En: L.S. IGLESIAS ROUCO, coord. Protagonistas burgaleses del siglo XX. Burgos: Diario de Burgos, 2002, v. I, pp.145-150.

${ }^{6}$ ESCOLANO BENITO, A., dir. Historia Ilustrada del libro escolar en España. Del Antiguo Régimen a la Segunda República. Madrid: Fundación Germán Sánchez Ruipérez, 650 p. 1997.
} 


\subsubsection{Objetivos e interés científico}

Una vez enunciada la justificación y delimitación del tema de estudio, cuáles fueron los móviles que lo motivaron, su ubicación y finalidad, procede referirse a los objetivos e intereses científicos, que jalonan la tesis.

Varios son los objetivos fundamentales que, desde el principio, se pretenden alcanzar en esta investigación:

- Conocer la evolución de la Editorial Hijos de Santiago Rodríguez, desde sus orígenes hasta la Guerra Civil española, rescatando de la memoria a las personas más influyentes que la dirigieron en las distintas épocas: Santiago Rodríguez Alonso y Mariano Rodríguez Miguel, realzando en ambos su talante intelectual, político y cultural.

Es prioritario tratar de situar y organizar los aspectos biográficos más importantes de su fundador, Santiago Rodríguez. A través de ellos, se descubren sus relaciones familiares y sociales que le ayudaron a inaugurar una pequeña librería, en pleno centro de Burgos, y le empujaron en la aventura editorial. Abordamos, también, otras facetas de su vida, de su pensamiento en el ámbito político, cultural y educativo, en una ciudad conservadora confrontada con los avances del progreso.

La influencia paterna, en su hijo Mariano Rodríguez Miguel, nos lleva a valorar como un hecho natural el nacimiento de una nueva empresa, Hijos de Santiago Rodríguez. Comprobaremos cómo padre e hijo atravesaron por similares avatares, ampliando su arco de acción en diversas asociaciones burgalesas y nacionales. Fiel al pensamiento de su padre, configura los iconos, símbolos y lemas, señas de identidad de la editorial

- Realizar una catalogación de los libros de la editorial registrados en las diversas bibliotecas nacionales e internacionales, reconociendo dichas obras en los diversos Catálogos que la propia editorial distribuía como promoción y propaganda.

Al no disponer de la Casa Editorial de ningún fondo documental de los libros publicados en la misma fue necesario elaborar un Catálogo de libros registrados en las diversas bibliotecas españolas y extranjeras. En esta catalogación expondremos las principales señas identificativas de: autor (en algunos casos desconocido), título, descripción, edición, colección, bibliotecas en las que se encuentra y si fue publicitado en los Catálogos estudiados de 1908, 1917, 1925 y 1929. 
- Analizar las principales obras señaladas por la propia Editorial como Bibliotecas Rodríguez en diferentes aspectos como son el contenido, autor e ilustrador, precio y otras peculiaridades, así como los libros en las diversas materias de estudio dentro de la enseñanza primaria.

Seleccionamos todas las obras, separando para una mejor clarificación los textos de lectura, señalados por la editorial como Bibliotecas Rodríguez, y los libros escolares por materias.

Como curiosidad, se presenta un semanario infantil editado a finales del siglo XIX de corto recorrido y libros significativos en el ámbito local y provincial.

- Contribuir a la Historia de la Educación sobre cómo se ha configurado nuestro entramado escolar, el estilo y metodologías educativas, sus lenguajes e iconos propagandísticos, a través de uno de los editores escolares más relevante.

De cada grupo se hace un análisis de los textos, estudiando su adecuación de contenidos, su didáctica, los valores transmitidos, las ilustraciones y el nivel de actualización a los métodos más ampliamente aceptados, que nos aproximan a la realidad escolar del momento.

Por supuesto, para ello necesitamos alcanzar unos objetivos secundarios que nos permitan avanzar hacia los fundamentales de forma gradual.

Así pues, consideramos importante forjar una personalidad investigadora que nos permita obtener el Grado de Doctor y culminar el Tercer Ciclo, como parte de un enriquecimiento personal que contribuya a un mejor desarrollo social y educativo. 


\subsubsection{Diseño metodológico: el método histórico- educativo}

El método es todo aquello que diseñamos para llegar a la finalidad propuesta. Por ello es importante elegir, como afirma Bunge, dentro del método científico que comparten todas las ciencias, aquellas tácticas ${ }^{7}$ que nos sirven para resolver los problemas concretos. ${ }^{8}$

Según López Yepes, el método puede ser entendido, en sentido amplio, como método general de una ciencia de cualquier rama del saber, y en sentido estricto, también aplicable para la ejecución de un trabajo de investigación. ${ }^{9}$

Al adaptarlo a la Historia, siguiendo a Best, diremos que la investigación histórica es la aplicación del método científico en la investigación de los problemas históricos. ${ }^{10}$

La Historia de la Educación, integrada en el ámbito de las ciencias históricas, utiliza el método histórico como han puesto de manifiesto investigadores españoles de la talla de Escolano, ${ }^{11}$ Galino, ${ }^{12}$ Negrín y Soto, ${ }^{13}$ Ruiz Berrio ${ }^{14}$ y Tiana, ${ }^{15}$ entre otros, nombrando alguno de los autores más conocidos. En este sentido, el método histórico se apellida histórico-educativo.

La finalidad de esta investigación es dar a conocer la importancia de la editorial burgalesa en una etapa fundamental de la edición escolar en España y adoptamos el método histórico educativo, que la dirigirá.

\footnotetext{
7 CARDOSO, C. F. C. Introducción al trabajo de investigación histórica: Conocimiento, método e historia. Barcelona: Crítica, 1989, p. 47.

${ }^{8}$ BUNGE, M. La investigación científica. Su estrategia y su filosofía. Barcelona: Ariel, 1976, p. 32.

${ }^{9}$ LÓPEZ YEPES, J. La aventura de la investigación científica. Guía del investigador y del director de investigación. Madrid: Síntesis, 1995, p. 35.

${ }^{10}$ BEST, J. W. Cómo investigar en educación. Madrid: Morata, 1972, p. 48.

${ }^{11}$ ESCOLANO BENITO, A., coord. Introducción a la Historia de la Educación. Diccionario de Ciencias de la Educación. Historia de la Educación. I. De la Antigüedad a la Ilustración. Madrid: Anaya, 1984, t. I, p. XI-XLIII; La investigación en Historia de la Educación en España. Revista de Ciencias de la Educación, 1993, 155, pp. 321-349; La investigación en Historia de la Educación en España: tradiciones y nuevas tendencias. En: A. NÓVOA; J. RUIZ BERRIO, eds. A História da Educaçao em España e Portugal. Investigaçoes e actividades. Lisboa: Sociedade Portuguesa de Ciências da Educaçao-SEDHE, 1993, pp. 65-83.

${ }^{12}$ GALINO, M. A. Pedagogía e historia. Enciclopedia de la Nueva Educación. Madrid: Apis, 1968.

13 NEGRÍN FAJARDO, O; SOTO ARANGO, D. E. La metodología de la investigación históricoeducativa. Madrid: UNED, 1993.

${ }^{14}$ RUIZ BERRIO, J. El método histórico en la investigación histórico-educativa. Revista Española de Pedagogía, 1976, 134, pp. 449-475; GABRIEL, N. de; VIÑAO, A., eds. La investigación históricoeducativa. Tendencias actuales. Barcelona: Ronsel, 1997, pp. 131-202.

15 TIANA FERRER, A. La investigación histórico-educativa actual. Enfoques y métodos. Madrid: UNED, 1988.
} 
Entre las fases que este método debe abordar se encuentran: ${ }^{16}$

- Heurística: nos centramos en la localización y clasificación de las fuentes. ${ }^{17}$

- Hermenéutica: momento en el que se procede a una crítica externa de las fuentes localizadas, para constatar si son válidas. Posteriormente se continúa con una crítica interna, en la que se procede a la comprensión y correcta interpretación de los resultados.

- Construcción histórico educativa, de formación.

También se ha recurrido a la utilización de otros métodos, como el comparativo. De alguna manera, según Arostegui, ${ }^{18}$ el método histórico es siempre comparativo porque investigar la historia es siempre distinguir "las composiciones sociales en unos momentos respecto de otros". En este trabajo nos hemos servido de este método para valorar y/o comparar la editorial Hijos de Santiago Rodríguez con otras editoriales nacionales. Un procedimiento es la elaboración y contraste de listados de libros, según contenidos afines.

Hemos utilizado otras metodologías para el análisis de contenido, el estilo, vocabulario e iconografía presente en los libros escolares de la editorial.

No siempre ha sido fácil poder servirse de dichos métodos ya que en muchas ocasiones hay un vacío documental que impide poder comparar o cuantificar con datos fiables su producción editorial, el número de publicaciones o ejemplares realizados, para así poder establecer relaciones con otras editoriales de su nivel y época.

\footnotetext{
${ }^{16}$ GABRIEL, N. de; VIÑAO FRAGO, A. La investigación histórico-pedagógica: tendencias actuales. Op. cit., pp. 161-163.

${ }^{17}$ BIZQUERRA, R. Métodos de investigación educativa. Barcelona: CEAC, 1989, p. 144. Señala la importancia de las fuentes en los trabajos de investigación.

${ }^{18}$ AROSTEGUI, J. La investigación histórica. Teoría y método. Barcelona: Crítica, 1995, pp. 274-275. 


\subsubsection{Fuentes de investigación}

Planteado el tema de investigación, fijado su interés científico, señalados los objetivos y la metodología a seguir en los apartados anteriores, sólo nos queda proceder a la localización de las fuentes oportunas.

La cuestión de las fuentes es central en todo trabajo histórico. En este sentido, García Garrido manifestaba que los historiadores de la educación desarrollan su labor no sólo en las bibliotecas sino entre archivos y legajos, para descubrir todas las huellas que han ido dejando ayuntamientos, entidades eclesiásticas, personas particulares e instituciones diversas. ${ }^{19} \mathrm{De}$ ahí la necesidad de dar detalles de los archivos de donde han surgido las fuentes histórico-educativas, como lo describen autores conocidos como Eco, ${ }^{20}$ Cardoso, Carreras, ${ }^{21}$ y Tiana, por referir solo algunos.

Ante la duda de cómo proceder en la exploración de los diferentes archivos, y otras fuentes consultadas, hemos decidido seguir un orden cronológico ya que todas las fuentes atesoran riqueza informativa, por muy pequeña que pudiera parecer.

La primera fuente informativa que intenté recabar fue la de los herederos actuales. Algunos de ellos están a cargo de una parte de la empresa familiar, como es la librería burgalesa Hijos de Santiago Rodríguez, continuadora de la saga en la $7^{\mathrm{a}}$ generación y considerada la librería más antigua de España. Desgraciadamente, no han conservado documentos importantes relativos a la fundación, a los años iniciales, y posterior asentamiento empresarial de la editorial.

Al no contar con las referencias más básicas, acudí al Archivo Diocesano del Arzobispado de Burgos -ADBU- para recabar la información esencial y poder establecer una pequeña genealogía familiar.

En la búsqueda en el Archivo Diocesano del Arzobispado de Burgos, y entre numerosos legajos, no encontramos todos los datos ya que muchos libros de nacimientos, matrimonios y defunciones siguen en poder de las parroquias actuales. Tuve que acudir y consultar, en los libros parroquiales correspondientes a las parroquias de San Gil, San Lesmes y S. Lorenzo,

\footnotetext{
${ }^{19}$ GARCÍA GARRIDO, J. L. Sistemas Educativos de Hoy. Madrid: Dykinson, 1987, p. 81.

${ }^{20} \mathrm{ECO}$, U. Cómo se hace una tesis. Técnicas y procedimientos de estudio, investigación y escritura. Barcelona: Gedisa, 2011, p. 71.

${ }^{21}$ CARRERAS PANCHÓN, A., coord. Guía para la elaboración de un trabajo científico. Bilbao: Cita, Publicaciones y Documentación, 1994, p. 263.
} 
para conseguir el resto de los datos familiares que oportunamente me facilitaron, de forma fácil y accesible.

Con la información extraída de los libros del Archivo Diocesano y de las parroquias de San Lesmes, San Gil y San Lorenzo, en Burgos, logré una primera aproximación a la familia Rodríguez, fundadores de la editorial. A partir de los datos encontrados, el trabajo me remitió y se diversificó entre varios archivos burgaleses y de Segovia.

La búsqueda, en el Archivo Diocesano de Segovia, se ha centrado en los libros de la parroquia de Santa María la Mayor, en Ayllón, donde se rastreaba el nacimiento de un hermano de Santiago Rodríguez. Esta acción nos condujo al Archivo Histórico Provincial de Segovia y a la consulta, en su Sección de Protocolos, donde pudimos obtener documentos valiosos sobre la actividad desarrollada por el padre de Santiago Rodríguez entre los años 1817-1821.

Conocidas las raíces del fundador, radicadas en la villa burgalesa de Isar, era preciso buscar si existían datos en su Ayuntamiento que pudieran darnos algunas pistas. En su momento, el alcalde nos facilitó el acceso a todos los documentos, muy amablemente, entre los que se encontraban los Libros de Pechía de 1760, 1789, 1794.

Buscando los testamentos que aportaban las partidas de defunción, aclarado el notario y la fecha del registro realizado, consulté el Archivo Histórico Provincial de Burgos -AHPBU-. Pude comprobar la fuente, la amplitud de documentos relacionados con la actividad personal, profesional y económica de la Editorial a través de la sección de "Protocolos Notariales" y "Enseñanza", donde se describían poderes, testamentos, alquileres, diversas rentas, apoderamientos, inventarios de bienes, fianzas, préstamos, reclamaciones, subastas, escritura de sociedades, venta de derechos de cesión intelectual, permutas, centros educativos, etc.

La información anterior se ha visto completada con la consulta de documentos, en el Archivo Municipal de Burgos - $\mathrm{AMBu}$-, sobre recursos gráficos, estadísticos, con censos de población, Libros de Actas del Ayuntamiento, documentos sobre propietarios y renteros, sobre elecciones, Padrones municipales, contribuciones y alojamientos.

El Catastro del Marqués de la Ensenada, guardado en el Archivo de la Diputación Provincial de Burgos -ADPBU- ha sido una fuente importante, germinal, en la búsqueda de información de la familia Rodríguez en la villa de Isar. Incluso, en el mismo archivo, se hizo un rastreo importante que nos aportó información, detallada y exhaustiva, de la participación política de Santiago Rodríguez en la Diputación Provincial. 
La Cámara de Comercio de Burgos -ACCBU- posee una abundante documentación, desde los inicios de su andadura, lo cual ha permitido conocer la actividad desarrollada por Mariano Rodríguez Miguel, en la misma, así como otros datos relacionados con su empresa editorial. Los testimonios escritos quedan reflejados en los Libros de Actas de las sesiones, en los años 1887-1896; 1896-1906; 1906-1912, en los Libros de Correspondencia y Censo, de los años 1890-1907, e igualmente en los Libros de contribuyentes, de los años 1912, 1914 y 1921-22.

En el Archivo de la Diputación Provincial de Burgos y en el Archivo Municipal, en sus respectivas secciones de Biblioteca, se ha consultado todos los libros editados por la editorial. Asimismo, estos manuales escolares se han examinado en diversas bibliotecas públicas de Burgos, Valladolid, Vitoria, Pamplona y Madrid. Y, sin duda, la Biblioteca Nacional de España es el depósito de numerosos libros inéditos de la Casa estudiada.

Otro lugar de referencia obligada al hablar de manuales escolares son los fondos del CEINCE, en Berlanga de Duero, Soria. Su biblioteca dispone de un amplio volumen de libros, de los principales editores escolares, y una importante colección de la editorial "Hijos de Santiago Rodríguez", objeto en estudio.

Para conocer los libros editados en la imprenta y librería de Santiago Rodríguez Alonso hemos acudido a una obra inédita de Domingo Hergueta Martín sobre la imprenta en Burgos y su provincia. ${ }^{22}$

Hemos rastreado los manuales escolares de la editorial, en los catálogos virtuales, por medio de los buscadores en red de las bibliotecas públicas y universidades, tanto nacionales como internacionales. Las visitas han sido efectuadas en el Catálogo Colectivo del Patrimonio Bibliográfico, perteneciente al Ministerio de Educación, Cultura y Deporte; la Biblioteca Digital Hispánica, dependiente de la Biblioteca Nacional de España; la Biblioteca Digital de Castilla y León; REBIUM, de la Red de Bibliotecas universitarias; y, en la Online Computer Library Center, buscador de carácter internacional.

Una de las dificultades para clasificar el libro escolar, de final del siglo XIX y principios del XX, es el desconocimiento de la fecha de edición,

22 HERGUETA MARTíN, D. La imprenta en Burgos y su provincia (1475-1920), Ejemplar mecanografiado. Copia digital. Valladolid: Junta de Castilla y León. Conserjería de Cultura y Turismo, 2009-2010, 4 v. 
exacta o aproximada. Para una mejor estructuración y ordenación cronológica se han utilizado algunos Catálogos editoriales encontrados en bibliotecas públicas, o de colecciones particulares, como es el caso del Catálogo de la Librería de Hijos de Santiago Rodríguez de 1908.

El resto de los Catálogos que han servido de fuente imprescindible son:

- Catálogo General Ilustrado. Imprenta, Librería y Casa Editorial de los Hijos de Santiago Rodríguez. Burgos. 1917.

- Catálogo Recuerdo. 1850-1925. Edición publicado con ocasión del LXXV aniversario de la fundación de la Casa.

- Catálogo General publicado con motivo de la Exposición Iberoamericana de Sevilla y de la Exposición Internacional de Barcelona. 1929.

La lectura de los libros editados -como principal fuente de estudio-, nos ha permitido realizar el análisis necesario para este tipo de investigación.

Otras fuentes primarias, fundamentales para la investigación, han sido las hemereográficas puesto que en la prensa de la época se hacía eco y comentario puntual de la vida social. La digitalización de sus documentos ha facilitado esta labor, en algunas ocasiones. El vaciado sistemático de publicaciones como El Papa-Moscas, Diario de Burgos, El Pueblo, Guasa Viva, La Verdad, La Voz de Castilla, Tierra Hidalga, La Fidelidad Castellana, Crónica de Burgos, El Noticiero Mercantil, El Heraldo de Castilla, La Brújula, nos ha permitido asociar lugares y personalidades que de otra forma hubiesen sido solamente cábalas y suposiciones.

No obstante, hay vacíos documentales importantes que podrán ser posteriormente estudiados con una mayor búsqueda en otros Archivos españoles o por documentos que quedan en manos de particulares, aunque parezcan escasos. Según admiten los descendientes, la falta de documentos pudo ser debido a algún incendio o quizá a la dispersión de documentos, al cierre de la editorial. Estas circunstancias nos permiten suponer o sospechar, y abrigar la esperanza, de que puedan aflorar posteriormente.

En cuanto a las fuentes secundarias, se han utilizado varias publicaciones bibliográficas nacionales, y sobre todo de carácter local, que han ayudado a contextualizar esta investigación y reconstruir, de alguna manera, el escenario en el que se desenvolvió la editorial. 
Para conocer los libros, aprobados para ser utilizados en las escuelas hemos utilizado las obras de José Luis Villalaín, investigador del Proyecto MANES. $^{23}$

Las fuentes iconográficas, a pesar de la dificultad de su acceso, han resultado de gran interés ya que a través de la imagen se suscitan todo un conjunto de estímulos que difícilmente se pueden expresar con palabras. A lo largo de todo el trabajo hemos incluido numerosas fotografías de personajes, tarjetas, documentos notariales y partidas de nacimientos, defunción y matrimonio, así como fotografías de los principales libros escolares en estudio. Nos tomamos esta licencia porque no cabe duda que las imágenes descansan el texto, suscitan nuestra atención y completan una visión próxima de los objetos editoriales.

También en la web hay información de estudios relativos a editoriales, autores e ilustradores que trabajaron para la editorial. Algunos son más conocidos, no por su relevancia, y fueron difundidos porque al gobierno de postguerra le interesó ensalzar determinadas figuras, mientras que otros permanecieron en el anonimato. En estos últimos años van saliendo publicaciones que les rescatan del olvido.

Finalmente, los documentos encontrados son, en principio, poco sospechosos de falsedad y altamente fidedignos dado que, en algunos casos, se citan varias fuentes para certificar datos importantes, toda vez que avalan la autenticidad y veracidad de la información.

${ }^{23}$ VILLALAÍN BENITO, J. L. Manuales escolares en España. Tomo II. Libros de texto autorizados y censurados (1833-1874). Madrid: UNED, Serie Proyecto MANES, 1999; Manuales escolares en España. Tomo III, Libros de texto autorizados y censurados (1874-1939). Madrid: UNED, Serie Proyecto MANES, 2002. 


\subsection{ESTRUCTURACIÓN DEL TRABAJO.}

Seguimos una estructura en capítulos, introductoria y de presentación, con el primer capítulo donde se perfilan las bases conceptuales y metodológicas que preceden a la exposición.

Su articulación consta de dos partes bien diferenciadas. En la primera, se explican las raíces y las biografías de los editores, de las distintas épocas, y la formación de la editorial desde su fundador hasta los años previos a la Guerra Civil. La segunda, nace de una catalogación de los libros de la editorial, que servirá de base a un estudio más pormenorizado en los capítulos siguientes.

El segundo capítulo narra el contexto histórico de finales del siglo XVIII y principios del siglo XIX, donde asoman los protagonistas que preceden al fundador de la Casa Editorial para conocer su situación social, política y cultural que llevó a Santiago Rodríguez Alonso a situar la imprenta y librería como un ideal de civilización y de cambio. Sus antecesores eran miembros importantes de la sociedad del Antiguo Régimen en un pueblo pequeño de la provincia de Burgos, Isar. Las transformaciones sociales posteriores configuraron un posicionamiento hacia una sociedad reformada a través de la cultura.

El tercer capítulo se centra en la figura del fundador, Santiago Rodríguez Alonso que vivió de 1829 a 1891 en la capital burgalesa. Su infancia y adolescencia estuvo ligada a una creciente inestabilidad política y militar coincidiendo con la primera guerra carlista. Vivió en Madrid, en unos años de estabilidad oligárquica, durante la mayoría de edad de Isabel II. Su vuelta a Burgos le permitió involucrarse en toda una serie de acontecimientos clave de este final de siglo: la revolución democrática septembrina (1868) y la Restauración (1874). En este contexto histórico, de su biografía emerge el talante liberal, abierto y de visión futura que forjaría una empresa editorial, en igualdad a otras editoriales, como lo fueron Hernando o Calleja. A nivel personal, formó a su hijo en el mismo ideal de regeneración cultural y política a través de la educación.

En este capítulo se han incluido las obras editadas por la imprenta y librería de Santiago Rodríguez Alonso. Su compilación es insuficiente al no disponer de referencias en Catálogos, ni de la propia editorial. Se han recogido sólo una mínima parte, aquellas referenciadas por el trabajo de Domingo Hergueta y encontradas en algunas bibliotecas. 
El cuarto capítulo se centra en el sucesor del fundador, e hijo del mismo, Mariano Rodríguez Miguel, 1860-1925. Marcada su vida por dos revoluciones, la política y la industrial, su visión abierta y activa aporta a la empresa una nueva línea de cambio, de regeneración social y cultural. Con él nace una editorial, "Hijos de Santiago Rodríguez", que se perpetuará hasta casi finales del siglo XX. Este capítulo incluye con los datos encontrados una pequeña biografía de su gerente, Mariano Rodríguez, a través de su vida familiar y de las asociaciones en las que estuvo implicado. Se hace hincapié en los cambios realizados en la empresa, la dotación de mejores y mayores medios, los cambios sucesivos de locales y la continuación de autores e ilustradores en la edición de sus libros. Además, se incorporan otros autores o ilustradores de acuerdo con las nuevas innovaciones pedagógicas, metodológicas, modernistas y de vanguardia del primer tercio del siglo XX.

Los capítulos quinto y sexto se centran en el estudio de los libros de la editorial Hijos de Santiago Rodríguez. En el capítulo quinto se realiza una catalogación de las obras en las que, además del título, se señala el autor o autores, descripción, edición, colección, bibliotecas y Catálogos de la editorial donde se pueden encontrar estos libros escolares. En el sexto capítulo se ha seguido un orden para colocar, en primer lugar, los textos de lectura llamados por la editorial "Bibliotecas" como lo más novedoso frente a lo que se editaba con anterioridad. Abarca un tiempo amplio desde 1894 hasta 1933, lo cual permite ver la evolución y los cambios adoptados. En segundo lugar, se constata un intento de realización de un periódico infantil, surgido de un interés por llevar a los niños a descubrir el gusto por la lectura, e interactuar con el mismo, al promover la realización de trabajos para concursos mensuales. Además nos recuerda los inicios de Santiago Rodríguez en la impresión de periódicos locales y el comienzo de varias publicaciones de semanarios infantiles a partir de la Restauración.

También continuamos analizando los libros escolares de las distintas áreas. Las tradicionales se centran en "leer, escribir y contar". Se estudian los textos para la enseñanza de la aritmética y geometría, y se observan los cambios efectuados, en los manuales escolares, debido a la evolución didáctica y pedagógica.

Otros textos son los que se refieren a la geografía y la historia, especialmente los que incluían conocimientos de las ciencias físiconaturales, destacados por los ilustrados y enciclopedistas.

Acerca de la Fisiología e Higiene y sobre Derecho encontramos un conjunto de libros que posteriormente formarán parte del currículo escolar. 
Respecto a la formación religiosa observamos que se centraba en el aprendizaje memorístico de las principales oraciones del cristianismo, y sobre la instrucción en Historia Sagrada, desarrollado por la lectura de libros religiosos y piadosos, junto con láminas con historias.

Llama la atención el no encontrar libros de urbanidad como tales, sino como un apéndice de la Fisiología. Sin embargo, en los libros de lectura se comprueba que incluyen lecciones de buenas formas, cortesía, presencia, apariencia y finos modales.

También edita un método de dibujo para escolares, formado por siete cuadernillos, en un supuesto aprendizaje gradual y con multitud de dibujos para reproducir, como modelos de copia.

Finalmente, se detalla el balance de la investigación y las conclusiones generales en el capítulo séptimo, incluyendo las posibles líneas de investigación, donde se resume y concreta la génesis de la editorial, la riqueza y variedad de libros escolares editados. Seguidamente, se detallan las diversas fuentes utilizadas en esta Tesis y las diferentes referencias bibliográficas.

Por último, en la sección de Anexos se incluyen textos e ilustraciones inéditas, con documentos editoriales y de textos desconocidos, así como parte de la transcripción del inventario, que el fundador Santiago Rodríguez Alonso legó a sus hijos y a la Casa Editorial, el árbol genealógico familiar, y una necrología del fundador, escrita cinco años más tarde.

De la misma manera, existe un índice de las imágenes impostadas en el desarrollo de la tesis, al objeto de ilustrar, corroborar y afianzar la exposición. En determinados casos, son aportaciones de fotografías y de documentos inéditos que enriquecen el texto y visualizan su comprensión. 
PRIMERA PARTE. RAÍCES Y DESARROLLO

DE LA EDITORIAL BURGALESA HIJOS DE SANTIAGO RODRÍGUEZ 



\section{ORÍGENES GENERACIONALES}

\subsection{LA SAGA PATERNA EN UNA VILLA CERCANA A BURGOS: ISAR}

La génesis de la historia familiar que se narra transcurre durante dos siglos que fueron claves para la historiografía local y nacional.

España había dejado de ser una gran potencia europea y era un país atrasado económica y socialmente. La llegada de los Borbones, a comienzos del siglo XVIII, supuso la implantación de un modelo de monarquía absoluta, ante los recelos de la mayor parte de las potencias europeas. Se emprendió un amplio programa de reformas encaminadas a reforzar el poder de los monarcas, debido a la influencia de la Ilustración, los cuales se apoyaron en el movimiento cultural conocido como Ilustración.

Asimismo, se impulsaron cambios políticos procedentes de la baja nobleza que dependían del favor del monarca. Estas reformas se centraron en el Gobierno, en la Administración, en el control sobre la Iglesia y en la economía, aunque chocaron frontalmente con los privilegios de diferentes estamentos e instituciones del Antiguo Régimen: la alta nobleza y gran parte del clero, que lo percibieron como amenazas contra sus intereses. No será hasta comienzos del siglo XIX, a partir de 1834, cuando se configure una nueva sociedad liberal.

A escala provincial, los límites territoriales de Burgos eran más amplios que los actuales e incluían importantes zonas de Cantabria, Palencia y La Rioja, antes de la reforma de Javier de Burgos en 1833.

El poder en la provincia se centraba en el Corregidor, representante directo del rey en la capital. Éste precisaba de un agente en Madrid para conseguir todas las necesidades y peticiones para la Ciudad. El resto de los municipios dependía de la capital de la provincia.

Los orígenes paternos del fundador de la Casa Editorial Hijos de Santiago Rodríguez se remontan a Isar, pueblo ubicado en la provincia de Burgos, a unos 20 kilómetros de la capital, en la comarca del OdraPisuerga, en el eje del Camino de Santiago. Las localidades que rodean a dicha población son: Villanueva de Argaño por el norte, la villa de Hornillos del Camino por el sur, Las Quintanillas por el este y Yudego por el oeste.

Rafael Sánchez Domingo, en su libro Historia de Isar. Cámara de los Manrique, ${ }^{24}$ nos explica que Isar fue señorío de los Manrique desde el

${ }^{24}$ SÁNCHEZ DOMINGO, R. Historia de Isar. Cámara de los Manrique. Burgos: Diputación de Burgos, 2012. 
primer tercio del siglo XV y que estaba unido al condado de Castañeda y al marquesado de Aguilar. En él, nos describe los diferentes pleitos que por razones jurisdiccionales, tanto de instituciones monásticas como de los concejos de Yudego, Hornillos del Camino e Isar, llegaban hasta la Real Chancillería de Valladolid para pedir justicia contra los abusos del Marqués. $^{25}$

En uno de estos pleitos, interpuesto contra la entonces marquesa de Aguilar en 1692, Mateo Rodríguez ejercía como procurador general de la villa con carta de poder que los vecinos de Isar le otorgaron para personarse ante la Real Chancillería e impedir que la marquesa pudiese "residenciar" en dicha villa. ${ }^{26}$

Nos hemos remontado en la genealogía familiar hasta esta fecha, comenzando con la persona de Mateo Rodríguez, comprobando que en 1716 -año del nacimiento del futuro rey Carlos III- se le arrienda el molino de Cubo y de Suso durante cuatro años, en 38 fanegas anuales de trigo alaga y cebada blanca. ${ }^{27}$ Esto nos indica la situación excepcional de la que gozaban los estamentos del poder -en concreto de Mateo Rodríguez-, en el momento de arrendar tierras y otras posesiones, la mayoría de las cuales en manos del marqués y de los monasterios que existían alrededor de la villa. Deducimos que la situación de la familia Rodríguez era de privilegio dentro del Antiguo Régimen.

Aunque no se encuentran datos en el Archivo Diocesano de Burgos sobre todos los parentescos familiares, por no existir libros de nacimientos entre 1666 y 1719, -así como de casados y finados entre 1666 y 1751- se puede ver en el Anexo del árbol genealógico familiar ${ }^{28}$ que los matrimonios de los hijos de Mateo Rodríguez fueron convenidos con miembros de la clase social acomodada de la villa: el regidor, el notario o poseedores de numerosas fincas como más adelante se indicará con los datos extraídos del Catastro del Marqués de la Ensenada.

\footnotetext{
${ }^{25}$ Ibídem, pp. 91-97.

${ }^{26}$ Ibídem, pp. 98-109. El término "residenciar" se refiere a un procedimiento de control sobre la actuación de los que detentan oficios públicos. En este pleito aunque fue favorable a la marquesa de Aguilar en su derecho a nombrar juez de residencia, en la apelación se mantuvieron los derechos de los vecinos de la villa, en el control de los pesos y medidas bajo pena de 50.000 maravedíes si no se cumplía.

${ }^{27}$ Ibídem, p. 183.

${ }^{28}$ Vid. Anexo 1.1. Árbol genealógico: Familia de D. Santiago Rodríguez Alonso.
} 


\subsubsection{La familia Rodriguez en el Catastro del Marqués de la Ensenada}

Los Gobiernos de los Borbones llevaron a cabo una serie de reformas fiscales, con objeto de incrementar sus ingresos y solucionar el problema del déficit estatal, creando un impuesto único para todos los estamentos de Castilla. Para tal fin, se elaboró un censo -conocido como el Catastro de Ensenada- sobre los recursos y riquezas existentes. Fue elaborado entre los años 1750 y 1753 para la recaudación de impuestos procedentes tanto de vasallos como de instituciones laicas, nobles o eclesiásticas. La oposición de los privilegiados y la caída en desgracia del Marqués de Ensenada impidieron la puesta en práctica del mismo. Actualmente el Catastro nos da una valiosa información sobre la realidad de las poblaciones.

El primer paso para realizar ese catastro era una carta que el rey enviaba a la población, siendo el alcalde el encargado de anunciar mediante un pregón la orden del monarca y la fecha de llegada del intendente responsable del censo. Luego, esta información se exponía en un bando que debía colocarse en un lugar público. Desde la promulgación de ese bando, vecinos y forasteros disponían de un plazo de tiempo determinado para entregar sus declaraciones de rentas, derechos y cargas, llamadas "memoriales" o "relaciones".

Se presentaba una encuesta de 40 preguntas que debían ser contestadas en todas las ciudades y pueblos, siendo el alcalde y los regidores locales los que debían elegir a algunos miembros de la villa para actuar como peritos y registrar la valiosa información. Los elegidos para ello solían ser vecinos con cultura y ascendiente social y familiar. Cuando llegaba el equipo responsable para la realización del Catastro, el Intendente mandaba citar al alcalde, regidores, peritos y cura párroco, en un día, hora y lugar determinados, y se procedía al interrogatorio mientras el escribano recogía las respuestas literales. Además, éste debía ocuparse de preparar dos relaciones completas del vecindario -una de las familias de legos y otra de los eclesiásticos- en las que se consignaban los datos de cada vecino con todas sus pertenencias y cargas, así como los miembros que componían cada familia. El documento resultante fue llamado Respuestas Generales. Una vez contrastados todos los datos, se procedía a pasar toda la información a un libro en limpio. Por último, el interesado lo firmaba o, en caso de no saber escribir, lo hacían otras personas designadas por él. ${ }^{29}$

\footnotetext{
${ }^{29}$ CAMARERO BULLÓN, C. Burgos y el Catastro de Ensenada. Burgos: Caja de Ahorros Municipal de Burgos, 1989, pp. 185-218.
} 
En este documento se registran, desde el comienzo del interrogatorio, a varios antepasados de la familia Rodríguez junto al notario Miguel de la Torre Andrés, con parentescos anteriores y posteriores.

En las siguientes líneas se realizará un pequeño, y a veces complicado, boceto biográfico de estos personajes, parentescos, posesiones e influencias. Podemos observar estos datos en el anexo genealógico.

El interrogatorio comenzó el 22 de julio de 1751, a la seis de la mañana, donde se señalan todas las personas citadas para responder a las preguntas.

En la villa de Isar y su casa de concejo principal, a veintidós días del mes de julio de mil setecientos y cincuenta y uno, siendo como a la hora citada de las seis de la mañana, el Señor Don Bartolomé Fernández de Humada juez subdelegado para la operación de única contribución, hallándose presentes y congregados en dicha casa especial y nominadamente el señor don Joseph de Lodoso cura beneficiado más antiguo de esta villa; Francisco Rodríguez, Pedro Calzada y Francisco Yudego, alcalde pedáneo y regidores de esta, y demás que manifestaron componer su Ayuntamiento, cuyos nombres y apellidos se omiten por excusar prolijidad, y concurrido así bien Julián Rodríguez, Matías González, Joseph de la Torre, Mateo García igualmente vecinos de esta referida villa y de dicho ayuntamiento, personas nombradas para responder a las preguntas que insertas en el interrogatorio que queda echa mención de quien es y cada uno, ynsolidun dicho señor juez subdelegado por ante mí el infrascrito escribano, tomo y recibo juramento por Dios nuestro Señor y a una señal de cruz y habiéndolos echo bien y cumplidamente, hicieran cumplir con lo que este a su cargo, en cuya inteligencia pasan a dar respuestas. ${ }^{30}$

El Catastro señala a Julián Rodríguez García, hijo de Mateo Rodríguez, como persona cualificada para dar información sobre la villa. Estaba casado con Magdalena de la Torre ${ }^{31}$ siendo alcalde su primogénito Francisco Rodríguez de la Torre. La familia forma parte de la oligarquía de la población aunque es difícil precisar si también participa en otras instituciones, como en el caso de Mateo Rodríguez.

Julián Rodríguez García, según el catastro, es labrador de labranza entera, de 60 años y casado. Vive con su hijo de cuarenta años y su hija menor. Tiene dos criados, uno de veinte años al que paga 15 ducados, y otro de diecisiete que recibe 10 ducados. Éstos y su hijo cultivan toda su hacienda y la de renta. ${ }^{32}$

$\mathrm{Su}$ mujer Magdalena de la Torre posee por herencia algunas fincas personales. Gracias a los datos aportados por el Archivo Diocesano

\footnotetext{
${ }^{30}$ Archivo de la Diputación Provincial de Burgos [en adelante ADPBU]. Catastro de la Ensenada. Villa de Isar. Respuestas Generales y Libros Mayores de lo raíz y personales de ambos estados. Sig. 942, f. $10-10 \mathrm{v}$.

${ }^{31}$ Vid. Anexo 1.1. Árbol Genealógico: Familia de D. Santiago Rodríguez Alonso.

Magdalena de la Torre era hermana del notario Miguel de la Torre Andrés. No existen documentos en el Archivo Diocesano sobre su matrimonio, pero sí nos consta donde están inscritos como abuelos paternos.

${ }^{32}$ ADPBU. Catastro de la Ensenada. Villa de Isar. Relación de lo personal. Sig. 942, f. 6. Vid. Fig. 1.
} 
sabemos que muere el 21 de enero de 1754, haciendo testamento ante su hermano Miguel de la Torre Díez, ${ }^{33}$ y su marido Julián Rodríguez García, el 19 de septiembre de $1773 .{ }^{34}$ Según consta en la partida de defunción tiene un único hijo varón, Francisco Rodríguez de la Torre, y un nieto, Andrés, de su hijo Santiago, ya fallecido. ${ }^{10}$ Sus hijas son Juliana, Josefa y Juana; las dos últimas casadas en Isar, con Manuel González y Manuel Yudego, ${ }^{35}$ respectivamente, miembros importantes de la villa. ${ }^{36}$

Julián Rodríguez García es titular de posesiones de vínculo, ${ }^{37}$ y su hacienda era una de las más señaladas de la población, con más de 47 posesiones incluido el ganado, viñedo y colmenas, además de numerosas fincas de las que era rentero.

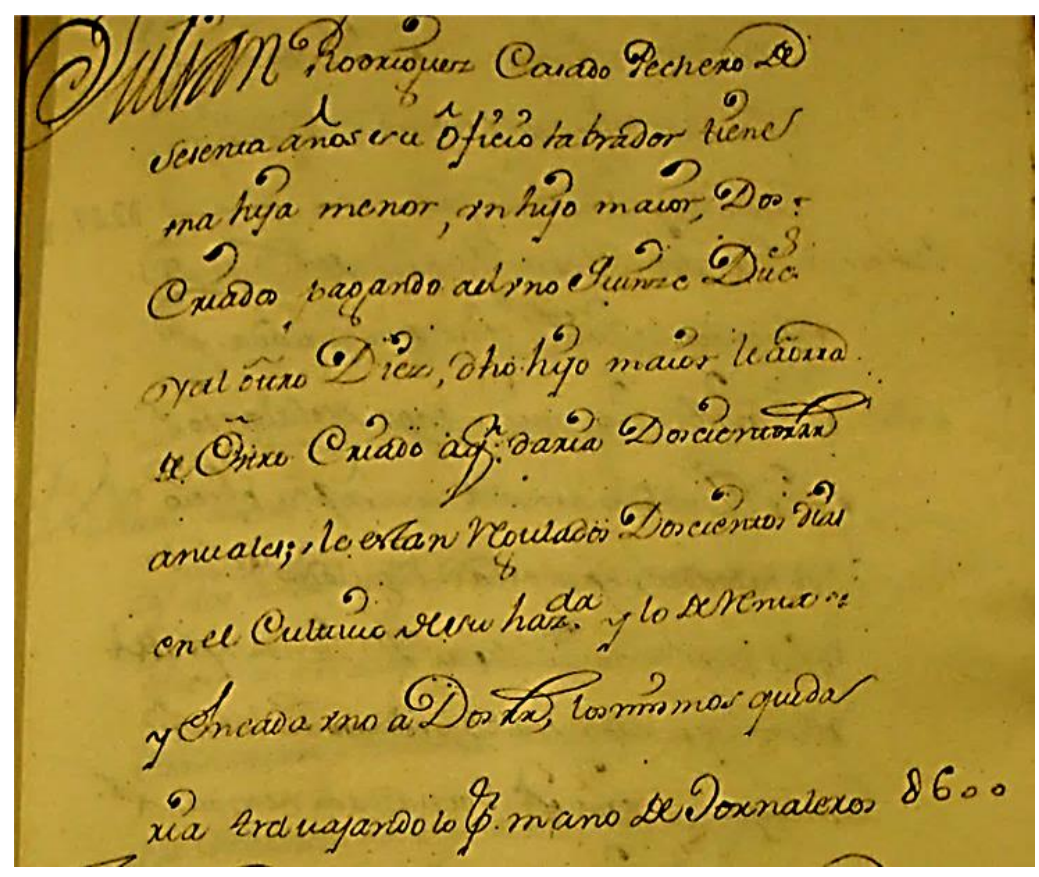

Fig. 2-1: Información de Julián Rodríguez Torre en el Catastro Marqués de la Ensenada.

\footnotetext{
${ }^{33}$ Archivo Diocesano de Burgos. [en adelante ADBU]. Parroquia de San Martín de Isar. $2^{o}$ Libro de difuntos 1751-1919, tomo $3^{\circ}$ (1751-1852), f. 6.

${ }^{34}$ Ibídem, f. 53. [...] hizo testamento ante Miguel de la Torre, escribano, el 24 de septiembre de 1777[...] Deja hijos legítimos Francisco Rodríguez, Juliana, Josefa, Juana, sus herederos y por Santiago hijo ya difunto, Andrés Rodríguez, nieto.

${ }^{35}$ En el Archivo Diocesano de Burgos no se conservan libros de casados de dichos años, pero se tienen referencias por el nacimiento de sus hijos.

${ }^{36}$ Manuel González es hijo de Manuel González, labrador de media labranza y tejedor de paños, y a quien se le adjudica una de las rentas más importantes de Isar. Manuel Yudego, hijo de Francisco Yudego, es regidor y labrador. El hecho de tener una criada para ayuda de la casa a quien paga 58 reales anuales, cuando sólo diez personas en la villa disponen de este tipo de servicio, la mayoría de ellas mayores o viudos, indica la posición social y de solvencia económica de la familia. Vid. ADPBU. Catastro de la Ensenada. Villa de Isar. Libro de lo personal seglar. Sig. 942, f. 1-16.

${ }^{37}$ Archivo Municipal de Isar [en adelante AMI]. Libro de pecho de la villa de Isar correspondiente al año 1760, f. $29 \mathrm{v}-32$.
} 
Cultiva más de treinta tierras, con una suma aproximada de unas 35 fanegas, ${ }^{38}$ en su mayor parte de secano, casi todas de $3^{\mathrm{a}}$ calidad y muy pocas de $1^{\mathrm{a}}$ y $2^{\mathrm{a}}{ }^{39}$ Además debemos añadir un prado de una fanega y dos huertas, con un total de media fanega, para el consumo de la casa y alimento de los animales.

Sin embargo lleva en renta fincas de diversas personas, conventos y algunas del marqués de Aguilar, la mayoría de $1^{\mathrm{a}}$ y $2^{\mathrm{a}}$ calidad. Entre las primeras, cultiva fincas de Fernando Ángulo de Zumel a quien paga de renta 37 fanegas de pan mediado de trigo y cebada por 16 fanegas de tierra de primera calidad, otras 10 fanegas de segunda calidad y dos fanegas de tercera calidad. ${ }^{40}$ Dispone también en renta propiedades de D. Pedro Alonso de Hormaza con un total de 4 fanegas de tierra de $1^{\text {a }}$ y $2^{\mathrm{a}}$ calidad $^{41}$ y, de D. Francisco López de Castrillo de Murcia, con un total de tres tierras de una fanega cada una, de $1^{\mathrm{a}}$ calidad, y otra de una fanega y media de $2^{\mathrm{a}}$ calidad. ${ }^{42}$

Además, pertenecientes al Convento de San Agustín de Burgos, cultiva 4 fanegas y ocho celemines de tierra de primera calidad, 3 fanegas y 10 celemines de segunda calidad y dos fanegas y 3 celemines de tercera calidad, junto a viñedos de dos obreros y medio de segunda calidad, ${ }^{43}$ por las que paga 5 fanegas de pan mediado de trigo y cebada.

Reunidas todas las rentas de Julián Rodríguez alcanza la cifra de más de 40 fanegas que, junto a su patrimonio personal, sobrepasa 80 fanegas. ${ }^{44}$

Por lo que se refiere a las viñas, sumando todas ellas, en la villa podría tener unas trescientas sesenta y un obrero de viñas, ${ }^{45}$ unas cincuenta y nueve de $1^{\mathrm{a}}$ calidad, ciento sesenta y siete de $2^{\mathrm{a}}$ y 135 de $3^{\mathrm{a}}$. Cada obrero de viña produce cuatro cántaras de vino en las de $1^{\mathrm{a}}$ calidad, 3 en las de $2^{\mathrm{a}}$ calidad y una en la de $3^{\mathrm{a}}$ calidad. Cada cántara de vino se costeaba a tres reales.

La explotación vinícola de Julián Rodríguez García ascendía a unos 600 litros de vino extraídos de sus tierras que podía guardar en una bodega llamada Los Corrales. ${ }^{46}$

\footnotetext{
${ }^{38}$ Es difícil conocer la superficie real ya que en esta época cada zona mantenía diferencias importantes en su conversión.

${ }^{39}$ ADPBU. Catastro de la Ensenada. Villa de Isar. Libro mayor de lo raíz seglar. Sig. 942, f. 179-188v. (Hemos sumado todas las posesiones que declara en el Catastro).

${ }^{40}$ ADPBU. Catastro de la Ensenada. Villa de Isar. Memoriales de ambos estados. Sig. 943, f. 167-170v.

${ }^{41}$ Ibídem, f. 408.

${ }^{42}$ Ibídem, f. 138-138v.

${ }^{43}$ ADPBU. Catastro de la Ensenada. Villa de Isar. Libro mayor de lo raíz eclesiástico. Sig. 942, f. $37-$ 40v.

${ }^{44}$ MORENO PEÑA, J.L. Gran propiedad rústica en Burgos. Burgos: Caja de Ahorros Municipal de Burgos, 1992, p. 47. El autor señala que la superficie por propietario, no llegaba a alcanzar las 6 hectáreas y en más de 165 municipios, no llega a las 3,35 hectáreas.

${ }^{45}$ La superficie de viñas se mide por obreros, cada uno corresponde a un número de cepas, siendo diferente en las distintas poblaciones.

${ }^{46}$ ADPBU. Catastro de la Ensenada. Villa de Isar. Libro mayor de lo raíz seglar. Sig. 942, f. 186v-187.
} 
Dispone de pocos animales, dos pares de bueyes para la labranza, y una pollina para su abastecimiento personal 7 ovejas y dos pies de colmenas.

Posee varios inmuebles: una casa en la que vivía, en el barrio de Arriba junto a otra de Miguel de la Torre y Gabriel López, cura beneficiado de la villa; otra casa en el barrio de Abajo, con dos corrales con memoria [hipoteca] de 26 reales que se pagaban a los curas beneficiados de la villa; así como otra casa en el barrio de Abajo, más pequeña y que formaba parte del vínculo junto a una tenada. ${ }^{47}$

Cuenta con dos hipotecas: una de 50 ducados, que pagaba 16 reales y medio a las Monjas de Palacios de Benaver -la hipoteca era sobre sus casas, corrales, huerta, bodega y tenada-, y otra de 20 ducados, que costea a 6 reales y 20 maravedíes a los curas de Villanueva de Argaño. ${ }^{48}$

Muestra del papel principal de Julián Rodríguez García es la inclusión en el Catastro de una carta girada por la marquesa de Aguilar desde Madrid (Figura 2-2) como contestación a otra u otras que éste escribió con anterioridad a aquella donde se pedía se le devolviese un escrito sobre el inventario de sus posesiones.

En inteligencia de todo cuanto me participas en tu carta de 8 del presente, te prevengo que me devuelvas el testimonio en relación de las pertenencias de estas mis villas a mi casa; porque aquí dispondré se acuda cuanto antes a la Junta de esta comisión de única Real Contribución con el privilegio original, para la saca de la copia autorizada, que parece es bastante.

Dios te guarde muchos años. ${ }^{49}$

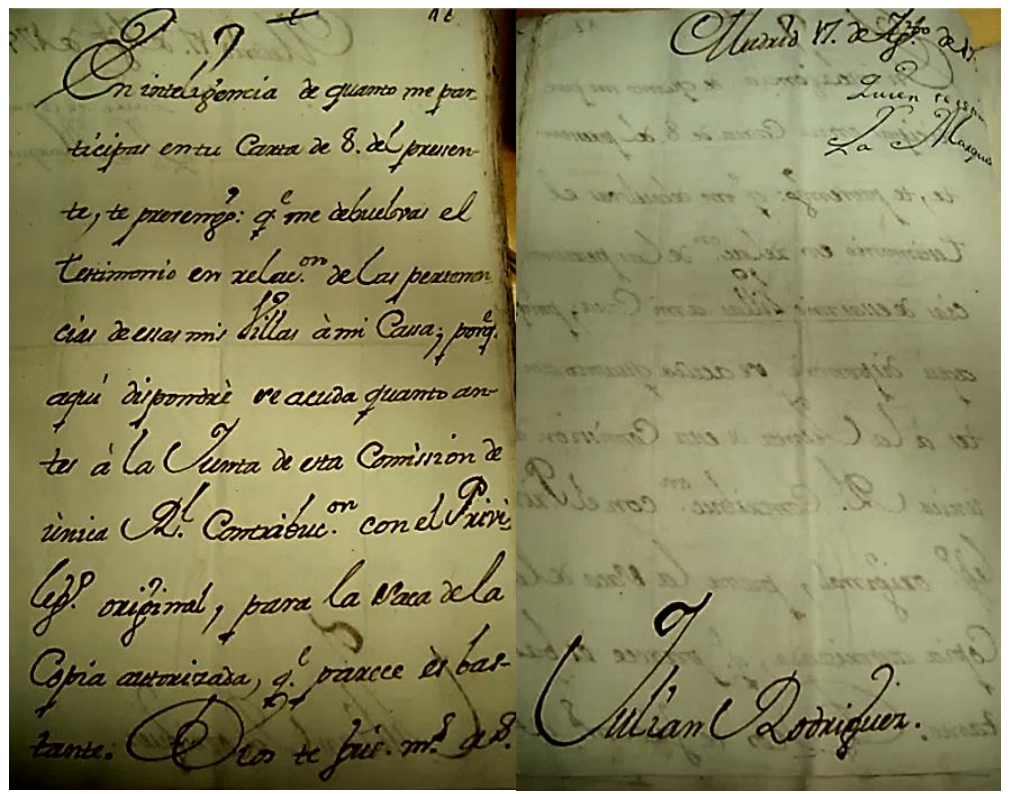

Fig. 2-2: Carta de la Marquesa de Aguilar dirigida a Julián Rodríguez García.

\footnotetext{
${ }^{47}$ Ibídem, f. 187.

48 Ibídem, f. 188-188v.

${ }^{49}$ ADPBU. Catastro de la Ensenada. Villa de Isar. Respuestas generales. Sig. 942. f. 42-42v.
} 
Su hijo Francisco Rodríguez de la Torre es alcalde de la villa, se casa en primeras nupcias con Manuela López, sobreviviendo varios hijos: Gabriel, Catalina, Rosa, Eugenia y Julián (religioso); y en segundas nupcias, con Ángela García nacieron: Joseph, Francisca, Julián, Juan y Santiago.

Por los escritos del Catastro conocemos que, a los 38 años, no sabe leer ni escribir, ya que los documentos testimoniales siempre los firma su padre Julián Rodríguez. ${ }^{50}$ Sin embargo es el único en la villa de Isar que tiene un criado para la labranza, pagándole de salario 150 reales anuales. ${ }^{51}$ (Figura 2-3).

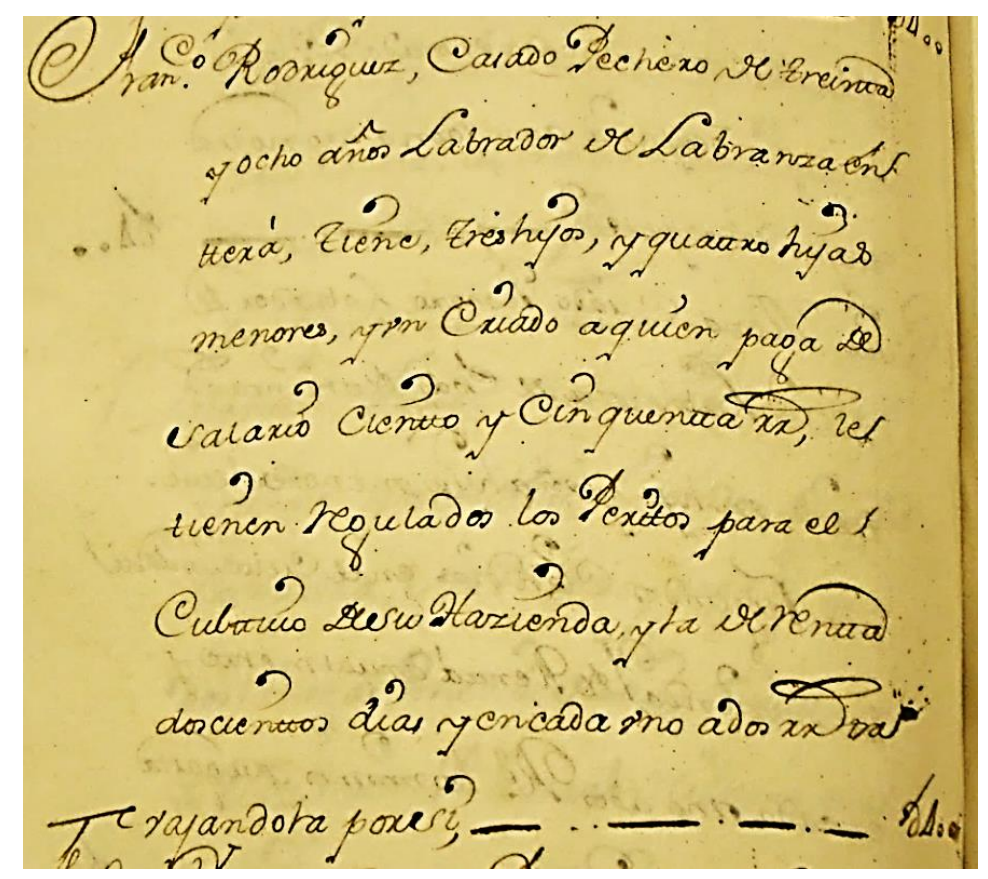

Fig. 2-3: Información de Francisco Rodríguez Torre en el Catastro Marqués de la Ensenada.

Disfruta de numerosas propiedades pero muy pocas de $1^{\mathrm{a}}$ y $2^{\mathrm{a}}$ calidad, siendo las más numerosas de $3^{\mathrm{a}}$. De $1^{\mathrm{a}}$ calidad tienen una hipoteca con un censo de seiscientos sesenta y siete reales al Cabildo de la villa, junto con otra tierra y un prado de media fanega con un rédito de 20 reales anuales al Convento de Palacios de Benaver. Otra huerta de 3 celemines tiene hipoteca a favor de Santa María La Mayor de Burgos. Sumadas todas alcanzan, aproximadamente, un total de tierra de cultivo en unas 50 fanegas. ${ }^{52}$

\footnotetext{
${ }^{50}$ ADPBU. Catastro de la Ensenada. Villa de Isar. Memoriales de ambos estados. Sig. 943, f. 115-123v. Es la relación de sus bienes que fueron firmados por su padre y no firma ningún documento dentro del Catastro como alcalde.

${ }^{51}$ ADPBU. Catastro de la Ensenada. Villa de Isar. Libro de lo personal seglar. Sig. 942, f. 3v. Vid. Figura 3.

${ }^{52}$ ADPBU. Catastro de la Ensenada. Villa de Isar. Libro mayor de lo raíz seglar. Sig. 942, f. 106v a $115 \mathrm{v}$.
} 
En renta tiene numerosas fincas, todas de $1^{\mathrm{a}}$ calidad, de la Cofradía Nuestra Señora de la $\mathrm{O}$ desglosadas en 6 fincas, cuya renta era de 4 fanegas y media de trigo, que le quedan de utilidad 77 reales, pagando 2 celemines a la cofradía por la cera gastada el día de la Expectación y lo restante se distribuye por igual entre el Cabildo eclesiástico de la villa y el de Villanueva de Argaño. ${ }^{53}$

De Fernando Ángulo de Zumel cultiva una era pequeña y dispone de un corral que paga de renta 8 celemines de pan mediado de trigo y cebada. Y del marqués de Aguilar tiene unas 16 fanegas de primera calidad por los que paga de renta 28 fanegas de pan mediado. ${ }^{54}$

Para uso personal dispone de viñedos de $1^{\mathrm{a}}$ y $2^{\mathrm{a}}$ calidad, de unos 7 obreros de viña, con un total de unos 400 litros de vino. ${ }^{55}$ Además cuenta con 42 cabezas de ganado, junto con una pollina y 3 bueyes de labranza y en una de las fincas 9 pies de colmenas. ${ }^{56}$

Otro protagonista principal de la familia Rodríguez será Miguel de la Torre Andrés, ${ }^{57}$ casado con María Díez de la Lastra, de Sargentes de Lora, que en la época del Catastro tenía 60 años. Era labrador y notario, con un hijo, Joaquín de la Torre, y una hija, Ana ${ }^{58}$ ambos menores, dentro de la villa. En la ciudad de Burgos su hijo mayor, Miguel, se preparaba para el mismo oficio que su padre, ya que en febrero de 1752 se le nombra escribano ${ }^{59}$ Miguel, casado en primeras nupcias con Francisca Zelada, se traslada a Isar como notario. Su mujer fallece en 1766, casi un año antes que su padre. ${ }^{60}$ Se casa en segundas nupcias con Águeda Lodoso, ${ }^{61}$ vecina de Isar, de cuya unión nacerá una única hija, Eusebia de la Torre. ${ }^{62}$

Según el Catastro, Miguel de la Torre Andrés tenía varios criados, uno para la labranza a quien pagaba 170 reales y 17 maravedíes, una criada para

\footnotetext{
${ }^{53}$ ADPBU. Catastro de la Ensenada. Villa de Isar. Libro mayor de lo raíz eclesiástica. Sig. 942, f. 183v185.

${ }^{54} \mathrm{ADPBU}$. Catastro de la Ensenada. Villa de Isar. Memoriales de ambos estados. Sig. 943, f. 351-351v.

${ }^{55}$ ADPBU. Catastro de la Ensenada. Villa de Isar. Libro mayor de lo raíz seglar. Sig. 942, f. 112v-113v.

${ }^{56}$ Ibídem, f. 115.

${ }^{57}$ Vid. Anexo 1.1. Árbol genealógico: Familia de D. Santiago Rodríguez Alonso.

${ }^{58}$ Ana de la Torre Díez, nace en 1732, y vive soltera en compañía de sus padres, fallece muy joven el 26 de marzo de 1755. Ver: ADBU. Parroquia de San Martín de Isar, $2^{\circ}$ Libro de difuntos 1751-1919, tomo $3^{\circ}$ (1751-1852), f. 10.

${ }^{59}$ Archivo Histórico Provincial de Burgos [en adelante AHPBU]. Sección Protocolos. Caja 7135, 7 de febrero de 1752.

${ }^{60}$ Ibídem, f. 45-46. Ambos mueren en fechas muy próximas: María Díez de la Lastra el 1 de noviembre de 1766 y Miguel de la Torre Andrés el 14 de febrero de 1767.

${ }^{61}$ Águeda Lodoso era hija de Tomás de Lodoso, labrador de 51 años en el momento del Catastro y emparentado con Joseph Lodoso, cura beneficiado de Isar -administrador perpetuo de una obra pía que fundó en la villa Julián de Lodoso-, y que junto con el alcalde de la misma reparten 24 fanegas de trigo, recogidas de las fincas que formaban parte de la obra, entre los labradores pobres, siendo preferidos sus parientes. Su hermano Mateo Lodoso era cura medio racionero que vivía con su tío Joseph Lodoso.

${ }^{62}$ ADBU. Parroquia de San Martín de Isar. $1^{\circ}$ Libro de bautizados 1.719-1.773, 14 de agosto de 1769. Vid. Anexo 2.2.2. Acta literal de bautismo de Eusebia de la Torre Lodoso. Ver en: ADPBU. Catastro de la Ensenada. Villa de Isar. Libros Mayor de lo raíz eclesiástico. Sig. 942, f. 193v.
} 
la casa a quien pagaba 71 reales y una pastora a la que pagaba 66 reales. (Figura 2-4). Por su cargo de notario, se le aplica una contribución de 250 reales. ${ }^{63}$

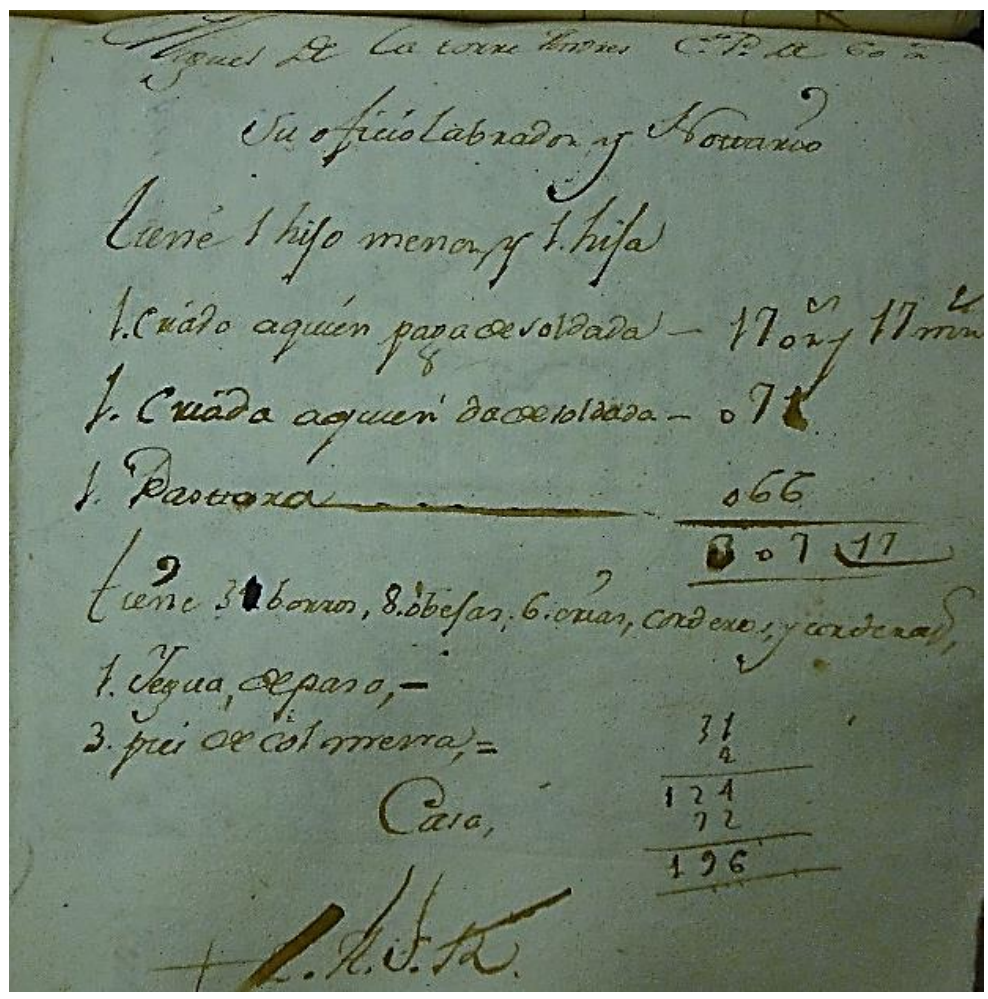

Fig. 2-4: Información del notario Miguel de la Torre Andrés.

Después del Catastro del Marqués de la Ensenada la familia mantiene su ascendencia social y económica registrada en el Ayuntamiento de la villa de Isar en Libros de Concejo de los siglos XVII a XIX. A través de ellos conocemos la actividad económica y administrativa de los vecinos de la villa: sus tierras, sus censos, los remates de oficios etc.

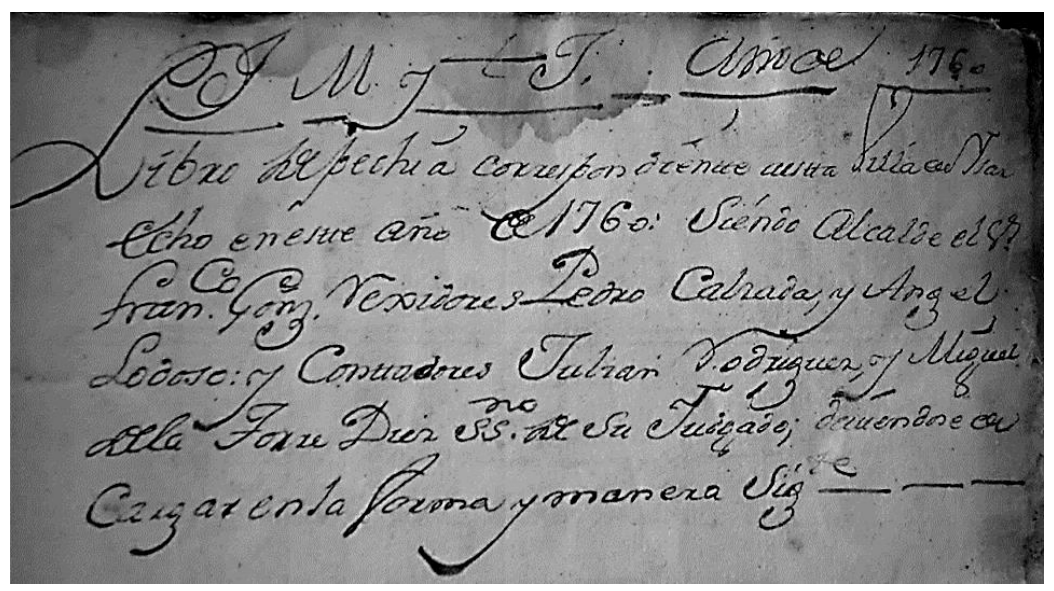

Fig. 2-5: Portada del libro de contabilidad de la villa de Isar correspondiente al año 1760 .

\footnotetext{
${ }^{63}$ ADPBU. Catastro de la Ensenada. Villa de Isar. Libro de lo personal. Sig. 942, f. 9.
} 
En 1760, en el libro de pechía (contabilidad) de esta villa, figura Francisco González en calidad de alcalde, como regidores Pedro Calzada y Ángel Lodoso, y como contadores Julián Rodríguez y Miguel de la Torre Díez, escribano de su juzgado.

Este libro aporta datos que no están presentes en el Catastro de Ensenada. Aparecen a nombre de Julián Rodríguez García unos bienes registrados como vinculados consistentes en un arca para pan, tres bueyes de labranza, una casa en el Barrio de Abajo con sus corrales y tierra detrás de ella, un prado, 8 tierras de buena calidad y 9 viñedos. ${ }^{64}$

Su hijo Francisco Rodríguez Torre había aumentado considerablemente los bienes comparándolos con los aparecidos en el Catastro; unos por herencia de sus tíos Juan Rodríguez y Catalina Cañizar -arca, dos bueyes, pollina, casa con bodega, pajar, dos huertas, 5 viñedos, un prado, 23 fincas de secano-, o de su madre Magdalena de la Torre -dos viñedos y cinco tierras de secano-; y bienes adquiridos en sus dos matrimonios. ${ }^{65}$

De su primer matrimonio con Manuela López adquiere bienes como una vaca de labranza, quince fincas, una fanega y media de monte, siete viñedos, una tenada en el Barrio de Arriba y una huerta. ${ }^{66}$ A la muerte de Manuela, se casa con Ángela García de cuyo matrimonio nacen Joseph, Francisca, Julián, ${ }^{67}$ Juan y Santiago. De este segundo matrimonio obtuvo numerosos bienes como señalan los libros de contabilidad de la villa: 16 pies de colmenas, 14 árboles, un tonel y una tina, una casa en el barrio de Abajo, 25 tierras, un viñedo, una era, una tierra de monte, 2 bueyes de labranza y un pedazo de huerta añadido a una anterior. ${ }^{68}$

Por último, Miguel de la Torre Díez, titular de la escribanía que ostentó su padre Miguel de la Torre Andrés, muestra que, además de la escribanía, tiene varias propiedades -arca para pan, un tonel, una tenada, huerta, la casa donde vive, otra en el Barrio de Abajo con su bodega y jaraíz, así como pajares, ocho tierras y diez viñedos- y compra numerosas tierras a Magdalena López natural de Villanueva. ${ }^{69}$

Las propiedades de su padre las cultiva Joaquín de la Torre Díez ya que en censo del Marqués de la Ensenada ponía que éste último era quien lo pagaba. ${ }^{70}$ Éste hace las funciones de secretario y registrador a la muerte de su hermano Miguel. ${ }^{71}$

\footnotetext{
${ }^{64}$ AMI. Libro de pecho de la villa de Isar correspondiente al año 1760 , f. $23 \mathrm{v}$.

${ }^{65}$ Ibídem, f. 19-23.

${ }^{66}$ Ibídem, f. 20-21v.

${ }^{67}$ ADBU. Parroquia de San Martín de Isar. $1^{\circ}$ Libro de bautizados 1719-1773, 4 de julio de 1769 . Vid. Anexo 2.2.1. Acta literal de bautismo de Julián Rodríguez García.

${ }^{68}$ AMI. Libro de pecho de la villa de Isar correspondiente al año 1760 , f. $21 \mathrm{v}-23$.

69 Ibídem, f. 32v-36.

70 Ibidem, f. 36v-37.

${ }^{71}$ Hay numerosos datos, pero citaré el que hiciera su cuñada: Águeda Lodoso, viuda de Miguel de la Torre Díez murió el 28 de diciembre de 1802. Hizo testamento ante Joaquín de la Torre, fiel de fechas en esta dicha villa. Sus herederos, los nietos que se expresan en la cláusula.
} 


\subsubsection{La familia Rodriguez entre los siglos XVIII y XIX}

Hay un vacío documental familiar, después del Catastro del Marqués de la Ensenada y en años posteriores, tanto en el Archivo Diocesano como en el Archivo de Isar.

La familia mantuvo y conservó en sus descendientes sus esferas de poder en el municipio, hecho que se repetía en la mayoría de las poblaciones rurales en el Antiguo Régimen.

Las medidas reformadoras de los Borbones para mejorar los organismos del Estado obtuvieron pocos resultados en los municipios que seguían bajo el poder de oligarquías locales donde, con amplísimas atribuciones, recaudaban sus propios arbitrios, administraban una gran cantidad de tierras comunales y mediaban a su favor en muchos tributos estatales.

El pueblo llano puso muchas esperanzas en la sucesión de Carlos IV a la muerte de su padre Carlos III en 1788, pero pronto se esfumaron. Su atonía y la propia abulia con la que el monarca gobernó dejó de nuevo en el poder a validos y a Manuel de Godoy como primer ministro.

La política de éste oscilará entre el inicial enfrentamiento con Francia, cuando tuvo lugar la Revolución Francesa, seis meses después de subir al trono Carlos IV, y una posterior alianza con la llegada del régimen republicano posicionándose contra el Reino Unido lo que provocó el aislamiento con el resto de Europa.

El enfrentamiento con la Francia revolucionaria fue presentado como una cruzada contra los enemigos de la monarquía y de la Iglesia, pero el ejército no estaba bien preparado y sufrió una estrepitosa derrota.

Las tropas españolas se distribuyeron en tres ejércitos, llevando todo el peso de las operaciones el de Cataluña, con 32.000 hombres, mientras que el de Aragón vigilaba los pasos del Pirineo Central, con 5.000 soldados, y el de Navarra y Guipúzcoa, con 18.000 hombres, centraba sus operaciones sobre Bayona. Este último ejército transitará por la provincia de Burgos y deberá resolver todos sus alojamientos. ${ }^{72}$

Aunque en un primer momento los ejércitos españoles traspasaron las fronteras, el recurso a la movilización del ejército francés le permitió contar con una mayor superioridad y ganar la contienda y obligó a una paz con Francia.

\footnotetext{
${ }^{72}$ CASTRILleJO IBÁÑEZ F. La crisis del Antiguo Régimen en Burgos. En: J. M. PALOMARES IBAÑEZ, dir. Historia de Burgos. IV Edad Contemporánea (1). Burgos: Caja de Burgos, 2002, pp. 23128.
} 
Las deudas heredadas del reinado de Carlos III y las nuevas guerras contra los británicos, junto con los recursos de las Indias que no llegaban a causa del bloqueo naval, pusieron a la corona al borde de la bancarrota.

Pero no sólo fueron lamentables los problemas financieros sino más aún los de carácter político ya que la firma de la paz con Francia obligó a una alianza que desembocó en la invasión de la Península por parte del ejército napoleónico.

Poco o nada influye el devenir de estos acontecimientos en la familia Rodríguez. Anotamos la muerte de Julián Rodríguez García (1773), la de su hijo Francisco Rodríguez Torre (1787), al igual que los dos notarios con vinculaciones familiares: Miguel de la Torre Andrés (1767) y su hijo Miguel de la Torre Diez (1785). Sólo cabe resaltar la fecha de 1787, siendo Gabriel Rodríguez López hijo primogénito de Francisco Rodríguez de la Torre, alcalde de la villa de Isar, reclama el mayorazgo que había disfrutado su abuelo y su padre:

Gabriel Rodríguez vecino de esta villa...digo que Francisco Rodríguez mi difunto padre vecino de esta villa falleció el nueve de este mes, quien en el tiempo que vivió, poseyó y gozó con el nombre de vínculo, o mayorazgo, una casa en el casco de esta villa, barrio bajero, con otro, bajo corral y demás pertenencias; un prado segadero y otros efectos; raíces de que se compone la fundación de dicho vínculo, el que también poseyó Julián Rodríguez, mi abuelo, como a mí me corresponde como a hijo varón mayor del recordado Francisco ... la posesión del recordado vínculo y sus predios.

[...] En la villa de Isar a 18 de agosto de 1787 el Sr. Julián Saldaña teniente de Alcalde y juez ordinario en ella y delante del notario...hizo actos de Real y verdadera posesión...y en la que dicho señor Juez le amparaba y amparó... y lo firmo siendo testigos los mismos Jacinto Lodoso, Manuel González y Josef Pampliega. (Firmado: Julián Saldaña, Gabriel Rodríguez y el notario Manuel García Puente). ${ }^{73}$

Ante el notario Manuel García Puente comparecen, el 18 de agosto de 1787, Joseph Rodríguez -hijo mayor del segundo matrimonio de Julián Rodríguez-, para ser tutor y administrador de los bienes y rentas de sus hermanos menores, Juan y Santiago, y como fiador, su cuñado Mariano Yudego -marido de Rosa Rodríguez.

En la villa de Isar a dieciocho de agosto de 1787, ante mí el escribano de su Majestad, vecino de Sasamón y que el Ayuntamiento, concejo y vecinos de ella, apareció Josef Rodríguez y dijo que por cuanto en la tarde de ese día se le ha dado recado de orden del señor Julián Saldaña, teniente de alcalde mayor en el que por no poder ejercer en este asunto el señor Gabriel Rodríguez su hermano, que lo es en propiedad, para que compareciese a la judicial presencia, para encargarse de cuidador de las personas y bienes de Juan y Santiago Rodríguez García, sus dos

\footnotetext{
${ }^{73}$ AHPBU. Sección Protocolos. Caja 10015, 18 de agosto de 1787.
} 
hermanos, mayores de catorce años y menores de veinticinco hijos que quedaron de Francisco Rodríguez y Ángela García sus difuntos padres, vecinos que fueron de ella; y no hallándose con causa legítima que le impida la aceptación del encargo de cuidador, ...recibió juramento y bajo de él ofreció administrar, regir y gobernar con toda justificación y pureza las personas y bienes de sus dos consabidos hermanos: Juan y Santiago, a quieres educará, arrendará sus bienes, cobrará sus rentas y seguirá sus pleitos siendo justo y hará todo los demás... hasta la edad cumplida y para cumplirlo bien dio por su fiador a Mariano Yudego su cuñado y convecino quien estando presente lo aceptó...Así y al cumplimiento de todo ello obligaron sus personas y bienes, muebles y raíces habidos y por haber...siendo testigos Jacinto Lodoso, Manuel González y Manuel Rodríguez vecino de esta villa y la de Grijalva...(Firman: Julián Saldaña, Josef Rodríguez, Mariano Yudego, testigo: Manuel Rodríguez y el notario Manuel García Puente). ${ }^{74}$

Ese mismo día, en otro documento -fechado el 18 de agosto de 1787comparece Jacinto Lodoso ante el notario Manuel García Puente para ser tutor y administrador de los bienes y rentas de Julián Rodríguez García, al ser menor de 21 años.

En la villa de Isar a dieciocho de agosto de 1.787 ante mí el notario de su Majestad, vecino de Sasamón y del Ayuntamiento, concejo y vecinos...para que compareciese Jacinto Lodoso y aceptase de cuidador de la persona y bienes de Julián Rodríguez García, menor de veinticinco, hijo legítimo de Francisco Rodríguez y Ángela García difuntos vecinos de esta villa, y al no hallarse con causa legítima que le conste le impida de la aceptación y encargo de tal cuidador...tomó juramento... ofreció administrar, regir y gobernar con toda justificación y pureza la persona y bienes del declarado Julián Rodríguez a quien documentaría, arrendaría sus bienes, cobraría sus rentas y seguirá sus pleitos siendo justos...hasta la edad cumplida...y dio por su fiador a D. Mariano Yudego...siendo testigos Manuel González, Josef Pampliega y Manuel Rodríguez...( Firman: Julián Saldaña, Jacinto Lodoso, Mariano Yudego, testigo: Manuel Rodríguez y el notario Manuel García Puente). ${ }^{75}$

Dos meses más tarde, Julián Rodríguez García, hijo de Francisco Rodríguez de la Torre, se casa con Eusebia de la Torre, ${ }^{76}$ hija única del notario Miguel de la Torre Díez, ya fallecido, siendo posible que Jacinto Lodoso ejerciese de tutor de Eusebia, haciéndose cargo de Julián ante un inminente matrimonio que se realiza con 18 años de $\operatorname{edad}^{77}$ y que cuatro años más tarde forma parte como regidor en el gobierno del municipio.

Podemos contrastar su nivel económico y social con el Libro de contabilidad correspondiente al año 1794 que en su portada nos dice:

\footnotetext{
${ }^{74}$ Ibídem, 18 de agosto de 1787.

${ }^{75}$ Ibídem. 18 de agosto de 1787.

${ }^{76}$ ADBU. Parroquia de San Martín de Isar. $1^{\circ}$ Libro de bautizados 1.719-1.773, 14 de agosto de 1769. Vid. Anexo 2.2.2. Acta literal de bautismo en Isar de Eusebia de la Torre Lodoso.

77 ADBU. Parroquia de San Martín de Isar. Libro de casados, tomo $3^{\circ}$ (1751-1851), 14 de octubre de 1787. Vid. Anexo 2.2.3. Acta literal de matrimonio de Julián Rodríguez García y Eusebia de la Torre Lodoso.
} 
Libro de pecho para el gobierno de los vecinos para con sus haciendas hecho en el año 1794 siendo de justicias el Sr. Tomás López, Francisco García, Julián Rodríguez, alcalde y regidores y contadores Gabriel Rodríguez y Pablo López y su fiel de fechas Joaquín de la Torre. ${ }^{78}$

Para este año se recoge la obligación tributaria -llamada cabeza- de los vecinos de la familia Rodríguez. Algunos de ellos pagan las rentas más elevadas de la villa. Gabriel Rodríguez López, contador de la villa, paga tres mil setecientos treinta y tres reales $^{79}$ tras la rebaja de dos mil doscientos setenta y dos reales establecida en los documentos del Ayuntamiento consultados. Su hermano, Julián Rodríguez García, abona cuatro mil setenta y nueve reales y Joseph Rodríguez García seis mil quinientos ochenta y siete reales. ${ }^{80}$

Este libro también contiene el registro de entrada de nuevos vecinos y las rentas de tierras que les corresponde pagar al marquesado de Aguilar, cuando por fallecimiento quedan libres.

Julián Rodríguez García, con 18 años, firma como nuevo vecino de la villa de Isar (Figura 2-6). Tres días después se celebra su boda con Eusebia de la Torre; ambos nacidos en verano de 1769.

En la villa de Isar y su casa del Ayuntamiento a once días del mes de octubre de mil setecientos ochenta y siete entró nuevo vecino Julián Rodríguez hijo legítimo de Francisco Rodríguez y de Ángela García difuntos vecinos que fueron de esta villa quien se obligó a llevar todas las cargas como todos los demás vecinos sin excepción alguna y a contribuir con cinco fanegas de pan por mitad trigo y cebada siempre que por su derecho le corresponda la renta de las repartidas propias del marquesado de Aguilar y para que conste lo firmo junto con el fiel de fechas dicho día, mes y años. ${ }^{81}$

\footnotetext{
${ }^{78}$ AMI. Libro de pecho de la villa de Isar correspondiente al año 1794.

${ }^{79}$ Ibídem, f. 8 y ss.

${ }^{80}$ Ibídem, f. 23-24.

${ }^{81}$ Ibídem, 11 de octubre de 1787. Vid. Figura 2-6.

Este libro contiene la entrada de nuevos vecinos y las rentas que eran traspasadas pertenecientes al marqués de Aguilar, cuando alguno por fallecimiento las dejaba.
} 


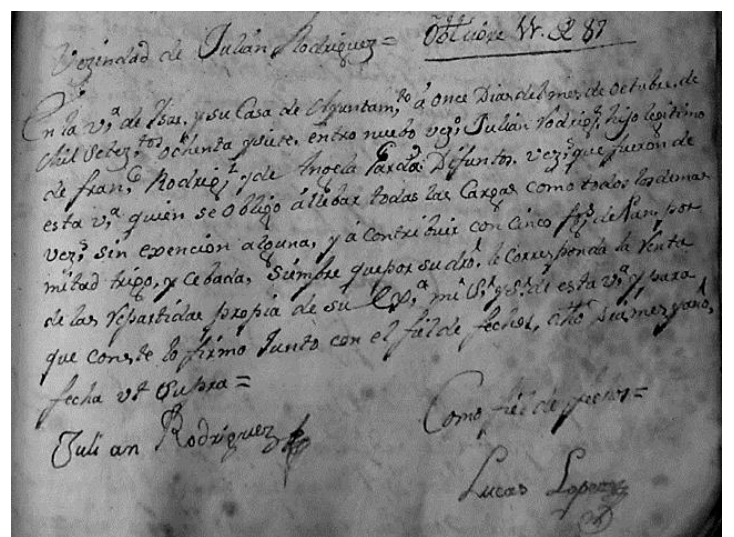

Fig. 2-6: Información de la entrada como vecino de Isar a Julián Rodríguez García con 18 años. 11 de octubre de 1787.

El 17 de junio de 1790 se le adjudica la renta de censo perpetuo que la villa tenía a favor del Marqués de Aguilar, a cargo de pagar cinco fanegas de pan mediado de trigo y cebada.

En la villa de Isar y su casa de Ayuntamiento a diecisiete de junio de mil setecientos noventa se le adjudicó la renta... a Julián Rodríguez quien se obligó a pagar cinco fanegas de pan mediado para el día de San Miguel de septiembre de cada un año limpio y seco y le fio Joseph Rodríguez su hermano quienes lo firmaron junto con el fiel de fechas dicho día, mes y año. ${ }^{82}$

El 20 de octubre de 1790 entra como vecino su hermano Juan Rodríguez, y el dieciséis de marzo de 1793 se le adjudica la renta de las propiedades del Marqués de Aguilar siendo su fiador, su hermano, Julián Rodríguez García. ${ }^{83}$ Lo mismo sucede con su hermano Santiago Rodríguez, que entra como nuevo vecino el 29 de octubre de 1794, al casarse con Isidora García y firma como rentero en 1798, siendo su fiador su suegro Ángel García. ${ }^{84}$

Julián Rodríguez García, aun siendo el tercer hijo de un segundo matrimonio de Francisco Rodríguez, sabe leer y escribir, forma parte del concejo como regidor, posee muchas fincas personales y se casa con la única hija del notario de la villa. De su primer matrimonio tiene cuatro hijos: Antolín, Felipe, María y Andrés. ${ }^{85}$ Antolín nació el uno de septiembre de 1789; y como se relatará más adelante, es el único que sale de la villa, mientras que el resto de sus hermanos permanecen en la misma como labradores. Felipe se casa con Gertrudis López, María con Alejandro López y Andrés con Brígida Revilla. ${ }^{86}$

\footnotetext{
${ }^{82}$ Ibídem, 17-6-1790.

83 Ibídem, 16-3-1793.

${ }^{84}$ Ibídem, 29-10-1794.

${ }^{85}$ ADBU. Parroquia de San Martín de Isar. $2^{\circ}$ Libro de difuntos 1751-1919, tomo $3^{\circ}$ (1751-1852), 1 de agosto de 1832, f. 228. Julián Rodríguez [...] dejó como herederos a Antolín, Andrés, María y Felipe de su primer matrimonio.

${ }^{86}$ Vid. Anexo 1.1. Árbol genealógico: Familia de D. Santiago Rodríguez Alonso.
} 


\subsubsection{La familia Rodriguez en los comienzos del siglo XIX}

En España comienza un período entre guerras durante el primer tercio del siglo XIX, iniciado con la guerra de la Independencia y continuado con los comienzos de las guerras de emancipación de las repúblicas hispanoamericanas que llegan a su fin con las guerras carlistas.

Durante ese tiempo, en España al igual que otros países europeos se produce el paso del Antiguo Régimen, basado en la monarquía absoluta, a un nuevo régimen liberal. ${ }^{87}$

La ineficacia de la política social y económica del rey Carlos IV, con Manuel de Godoy al frente, condujo a un acercamiento a Francia a través de una serie de acuerdos y pactos. Propició el bloqueo marítimo inglés, que perjudicó el comercio y las comunicaciones con América, y llevó a la Hacienda Pública a una situación de bancarrota.

Los motines por la carestía y las subidas del precio del pan fueron constantes, lo cual deterioró el nivel de vida de los grupos sociales más populares. El Motín de Aranjuez, en marzo de 1808, tuvo consecuencias importantes: hizo caer en desgracia a Godoy, fue encarcelado, y Carlos IV abdicó en su hijo Fernando, cuyos partidarios habían financiado y organizado la revuelta. El nuevo rey Fernando VII ratificó la política con Francia y permitió la entrada de las tropas napoleónicas.

Ante esta nueva situación, Napoleón decidió cambiar de planes. Si su primera intención había sido implicar a España en su política contra Portugal y Reino Unido, tras los sucesos de marzo decidió instaurar una monarquía poniendo al frente de ella a un miembro de su propia familia, como había hecho en otros lugares de Europa.

Pronto se desencadenó la guerra provocada por el descontento contra las tropas francesas que cada vez actuaban más como invasores. Las maniobras políticas de Napoleón para sustituir la legítima monarquía de Fernando VII por José Bonaparte hicieron el resto en el levantamiento insurreccional general.

En el inicio de la contienda armada se crearon las Juntas de Defensa que dirigían la sublevación. Burgos y su provincia se convirtieron en un lugar militar estratégico en el paso de las tropas francesas hacia Portugal y provocó un escenario insostenible para la ciudad ya que en sus inmediaciones llegaron a establecerse más de 30.000 hombres y 4.000 jinetes. Sólo en la ciudad se llegaron a contabilizar más de 3.000 de los primeros y 1.000 de los segundos. ${ }^{88}$

\footnotetext{
${ }^{87}$ PALACIO ATARD, V. Nosotros, los españoles. Una breve historia de España. Barcelona: Editorial Planeta, 1991, pp. 173-192.

${ }^{88}$ CASTRILLEJO IBÁÑEZ F. La crisis del Antiguo Régimen en Burgos. Op. cit., p. 42.
} 
A ello debemos añadir la aparición de numerosas plagas, -la de langosta, la del "tabardillo pintado"-, que unido a las sequías crearon una fuerte crisis de subsistencia en toda la zona. ${ }^{89}$ Durante los cinco años que duró la contienda los burgaleses sufrieron las consecuencias de la guerra provocadas por los franceses ante las exigencias de toda clase de alimentos, -de buena calidad-, equipos, arreglos, cuidados de los caballos etc., sin olvidar la destrucción de casas, caminos, iglesias, castillo y calles. Tras el abandono de la ciudad por las tropas francesas se mantuvo la misma situación con la entrada de las tropas españolas.

No todo fue negativo, mientras se luchaba contra la invasión francesa, se diseñó la Constitución de 1812 en Cádiz y se proclaman las ideas del liberalismo con el que se inició el desmantelamiento de la sociedad estamental y la supresión de privilegios.

Napoleón liberó a Fernando VII, tras el Tratado de Valençay. Comienza su reinado volviendo a restaurar el absolutismo, en mayo de 1814, y anulando los valores progresistas promulgados por la Constitución de Cádiz.

Este es el contexto social y político que acontece en la infancia y juventud de Antolín Rodríguez de la Torre. Al ser el primogénito de una familia acomodada nos hace pensar que tuvo una instrucción cualificada en Burgos, posiblemente en el oficio de su abuelo -notario- o semejante. No es posible afirmarlo con rotundidad al no encontrar datos debido, posiblemente, a la situación caótica inherente a todo conflicto.

La muerte de su madre, muy joven, el 20 de noviembre de 1802, y de su abuela materna, Águeda Lodoso, al mes siguiente, ${ }^{90}$ así como los acontecimientos bélicos de la época, truncarían las aspiraciones de una completa formación.

Su padre, Julián Rodríguez García se casa en segundas nupcias con Petra González, de cuyo matrimonio tuvo varios hijos: Pedro, Romualdo, Benita y Manuela,${ }^{91}$ pero su posición social y económica disminuye hasta quedar reducido a la mendicidad.

Conocemos este hecho porque el 25 de febrero de 1817 el administrador del conde de Oñate presentó demanda de despojo contra los vecinos y justicias de la villa de Isar por haber sembrado una era contigua al palacio, propiedad del marqués de Montealegre y conde de Oñate que llevaba en renta Julián Rodríguez y Bárbara López, su cuñada, quienes sembraron y recogieron su fruto durante los últimos años hasta que los

\footnotetext{
${ }^{89}$ SANCHEZ DIANA, J. M. Burgos en la guerra de la independencia: la ciudad y los guerrilleros. Hispania, 1970, 30, (116), pp. 515-569.

${ }^{90}$ ADBU. Parroquia de San Martín de Isar. $2^{\circ}$ Libro de difuntos 1751-1919, tomo $3^{\circ}$ (1751-1852), f. 135 y 143.

${ }^{91}$ Ibídem, f. 228, 1 de agosto de 1832. Julián Rodríguez [...] y Pedro, Manuela, Romualdo y Benita de su segundo matrimonio.
} 
vecinos lo requisaron para el concejo. Se dictó sentencia dando razón al conde y, en su nombre, a los renteros. ${ }^{92}$

La sentencia se recurrió en 1818, saliendo favorable a los vecinos de Isar y condenado Julián Rodríguez a pagar todas las costas, multas y apercibimientos por ese hecho, a pesar de expresar que lo realizó por razones de pura necesidad.

[...] que dicha tierra común se encontraba en inmemorial posesión de un egido concejil al término que llaman Los Puentes, de cabida de fanega y media, que había servido de pasto para los ganados, y para tender las ropas de lavar, por hallarse contiguo al río y cauce del molino, se había propasado a romperle en el marzo de 1814, Julián Rodríguez colono del conde por el interés que podía resultarle, con pretexto de ser de la propiedad de este, causando el mayor atentado despojo al común y como entonces se hallaba este casi reducido a la mendicidad de resultas de la guerra, no se había hecho oposición alguna hasta que en el año 1816 se trató por la Justicia de sembrarlo de cebada, lo que había dado margen al recurso del apoderado del Conde, fundado en una posesión ajena de verdad, pues si trilló allí las mieses hace pocos años José Rodríguez y en algunos después de su fallecimiento, su viuda Bárbara, ha sido únicamente por la condescendencia y al modo que lo han ejecutado los demás vecinos en las eras del común, sin que por esto se atribuyesen posesión ni propiedad en ello que el mismo José Rodríguez había empezado hacía 14 años a romper dicho egido, en lo que luego cesó por haberle requerido judicialmente, haciéndole ver que por una posesión inmemorial era de la propiedad del común, lo que se comprobaba con no haberse puesto por del pertenecido Conde en la operación de única contribución. Y por tanto pidió se recibiere información sobre la certeza de lo expuesto, certificándose del libro del Catastro y resultando lo bastante se defiriese al reintegro o manutención en posesión condenando a Julián Rodríguez en todas las costas, multas y apercibimientos por el violento despojo que causó. ${ }^{93}$

En tiempos de guerra y posguerra nada sabemos de Antolín Rodríguez de la Torre, ni de sus destinos y trabajos posteriores. Ahora bien, algunos protocolos de Ayllón le citan y refieren como un hombre conocedor de leyes que se mueve bien en pleitos ante los tribunales, lo cual nos hace entrever una formación en este sentido.

Los datos que lo avalan se encuentran en Ayllón, localidad de la actual Segovia pero que en 1817 pertenecía al partido de Aranda, en Burgos. Cinco años permanece en esta ciudad como veredero en la administración de rentas estancadas de la Hacienda Pública. ${ }^{94}$

Durante el año anterior -1816-, no ejercía en dicho puesto ya que lo hacía D. José González ${ }^{95}$ y sí figura, tanto en un año como en otro, D.

\footnotetext{
${ }^{92}$ SANCHEZ DOMINGO, R. Op. cit., p. 110.

93 Ibídem, pp. 111-112.

${ }^{94}$ Archivo Histórico Provincial de Segovia [en adelante AHPS]. Sección de Protocolos. Notario Pío González 1817-1821.

${ }^{95}$ ATANASIO XARAMILLO, G. Guía o estado general de la Real Hacienda de España. Año de 1816. Madrid: Imprenta de la Compañía, p. 12. Corresponde a la segunda parte que contiene todo lo perteneciente a las provincias.
} 
Baltasar Crespo como observamos en las guías de la Real Hacienda de España de 1816 y 1817 (Figura 2-7). ${ }^{96}$
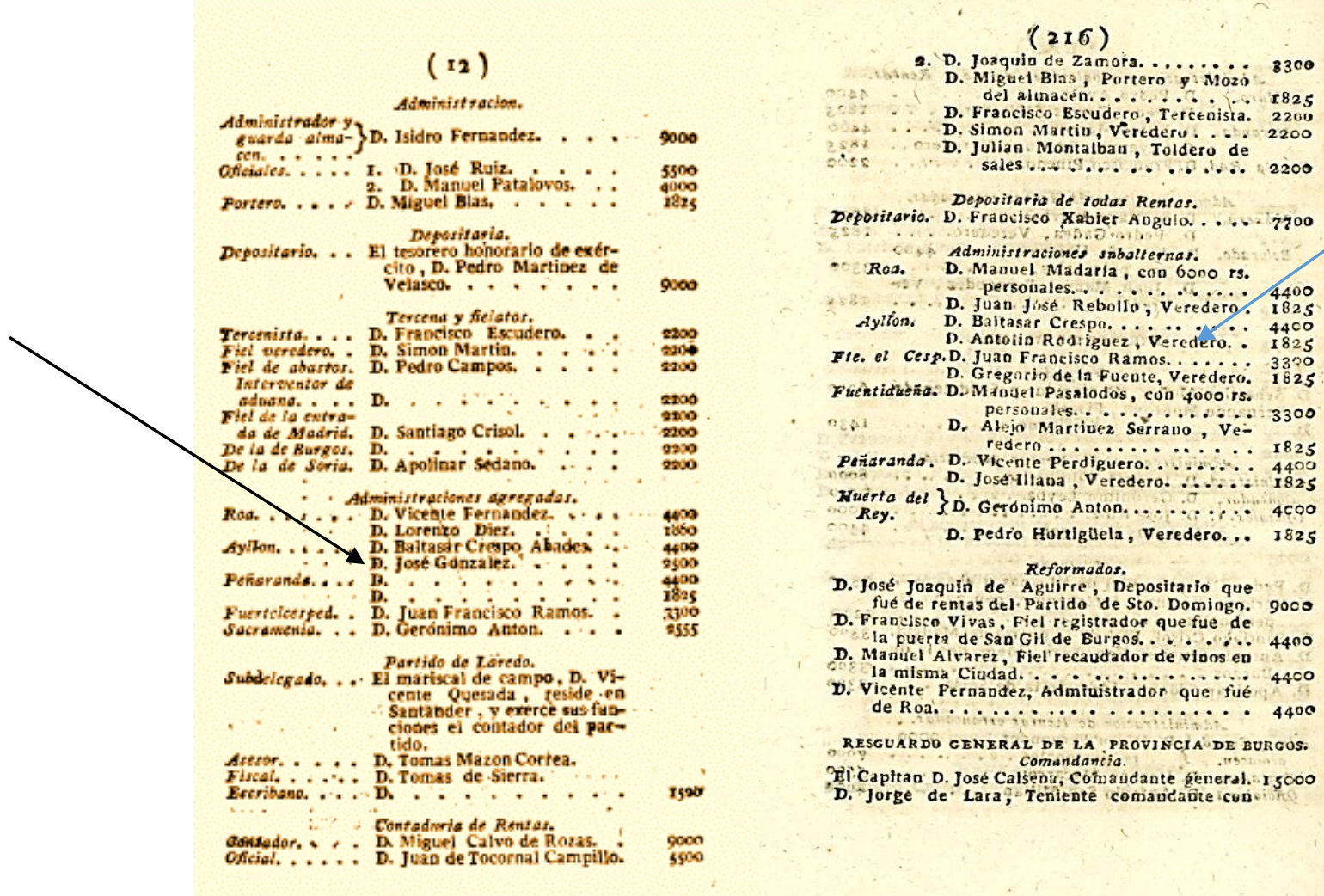

Fig. 2-7: Guías de la Real Hacienda de España de 1816 y 1817. Partido de Aranda. Burgos. Antolín Rodríguez, veredero de la administración en Rentas estancadas y papel sellado.

En el Archivo Histórico de Segovia nos encontramos diversos documentos que confirman lo anterior. Aparece desde 1817 firmando como testigo, ${ }^{97}$ o bien el vicario eclesiástico y abad del Cabildo de la villa de Ayllón deposita en él su confianza y le da poder amplio y general para que pueda cobrar todo lo que le deben diferentes personas, concejos y comunidades:

En la villa de Ayllón a diecinueve de febrero de mil ochocientos diecisiete ante mí el escribano y testigos que aquí se expresaron pareció D. Andrés Díaz Muñoz, presbítero vicario eclesiástico y abad del Cabildo eclesiástico de esta misma villa y dijo que así en ella como en los pueblos de su jurisdicción y otros de fuera de ella le están debiendo diferentes personas, concejos y comunidades crecidas cantidades de granos, réditos y diversos empréstitos que lo tienen hechos y que por otros motivos como capellán y poseedor que lo es ... cuya cobranza le precisa hacer para subvenir al cumplimiento de sus cargas y obligaciones, la cual no puede practicar

96 SEÑÁN Y VELÁZQUEZ J. Guía general del estado de la Real Hacienda de España. Año de 1817. Madrid: Imprenta de Vega y Compañía, p. 216.

${ }^{97}$ AHPS. Sección de Protocolos. Caja 8833, 16 febrero 1817, f. 63. 
por sí a causa de sus ocupaciones en el desempeño de su ministerio y por lo mismo teniendo como tiene entera satisfacción y confianza en Don Antolín Rodríguez. domiciliado en esta villa, desde luego en la vía y por forma que más haya lugar en derecho otorga, que le da y confiere todo su poder cumplido y que lo requiere y es necesario más puede y debe valer amplio general y sin limitación alguna... ${ }^{98}$

Antolín Rodríguez de la Torre se casa en la iglesia de S. Lorenzo de Burgos, el día 16 de abril de 1817, ${ }^{99}$ con Luisa Alonso Saiz, hija de Juan Alonso y Manuela Saiz, vecinos de Burgos.

Dos meses más tarde firman ambos ante el notario de Ayllón D. Pío González García una escritura de fianza a favor de la Real Hacienda por la suma de 3.000 reales poniendo las fincas personales de Antolín en Isar como fianza de la misma para el destino de veredero de la Administración de Rentas Estancadas de Ayllón, y de los pueblos de su partido, para así surtir de tabacos y recaudar para la Hacienda.

En la villa de Ayllón a 14 de junio de 1817 ante mí el Escribano del número y testigos que al final se presentarán aparecieron D. Antolín Rodríguez y $D^{a}$ Luisa Alonso su mujer vecinos de ella y precedido la venia y licencia que para estos casos el derecho impone que ha sido pedida, concedida y aceptada.... de cuya petición, concesión y aceptación yo el infrascripto doy fe dijeron que hallándose empleado el referido D. Antolín en el destino de veredero de la Administración de Rentas Estancadas de esta villa y pueblos de su partido, para surtir de tabacos a los mismos y recaudar sus productos... y para cumplir puntualmente con lo mandado en el Real Reglamento expedido en el particular y demás órdenes que se le han comunicado... que la fianza a favor de la Real Hacienda hasta la suma de tres mil reales de vellón siendo en fincas para la responsabilidad de dicho su destino[...] Ante... la villa de Isar pueblo de su natural he solicitado, se le recibiere información para acreditar que las fincas señaladas para la fianza eran suyas y le corresponden por legítima ...que su valor es de tres mil reales las cuales justifica en la citada información... por el administrador principal de las mismas rentas del Partido de Aranda de Duero. ${ }^{100}$

Hay dos documentos relevantes en la citada ciudad durante su estancia hasta finales de 1821. En el primero, Bernabé Mateo vecino de Fuentelcésped, funcionario en el abastecimiento de vinos de la oficina pública le da poder amplio y general a Antolín para que pleitee al no aplicársele una rebaja ya estipulada en subasta. ${ }^{101}$ En un segundo documento, fechado el 31 de marzo de 1821, Isidro Vicente y Francisco Benito dan un poder amplio y general, sin limitación alguna, a D. Antolín

\footnotetext{
98 Ibídem, 19 de febrero de 1817, f. 69.

99 ADBU. Parroquia de San Lorenzo de Burgos. Libro de casados del 28 de octubre de 1.795 a 5 de marzo de 1.827, 16 de abril de 1817.

${ }^{100}$ AHPS. Sección Protocolos. Caja 8833, 14 de junio de 1817, f. 252-253. Vid. Anexo 2.1.1. Escritura de fianza a favor de la Real Hacienda otorgada por D. Antolín Rodríguez y D a Luisa Alonso en Ayllón -Segovia- el 14 de junio de 1817.

101 AHPS. Sección Protocolos. Caja 8835, 2 de agosto de 1819, f. 209. Vid. Anexo 2.1.2. Poder de D. Bernabé Mateo a D. Antolín Rodríguez. en Ayllón -Segovia- el 2 de agosto de 1819.
} 
Rodríguez de la Torre para que comparezca ante el Sr. Juez de $1^{\mathrm{a}}$ instancia de esta villa y su partido, y demás Tribunales competentes, con objeto de la defensa de sus patrocinados. Ante unos hechos acaecidos en una noche en la que resultaron heridas dos personas, gestiona la libertad y absolución de los cargos que se les imputa y demanda se les abone los gastos, daños y perjuicios que han tenido. ${ }^{102}$

Durante su estancia en Ayllón nace su primer hijo Mariano Rodríguez Alonso, el 22 de noviembre de 1819 (Figura 2-8). ${ }^{103}$
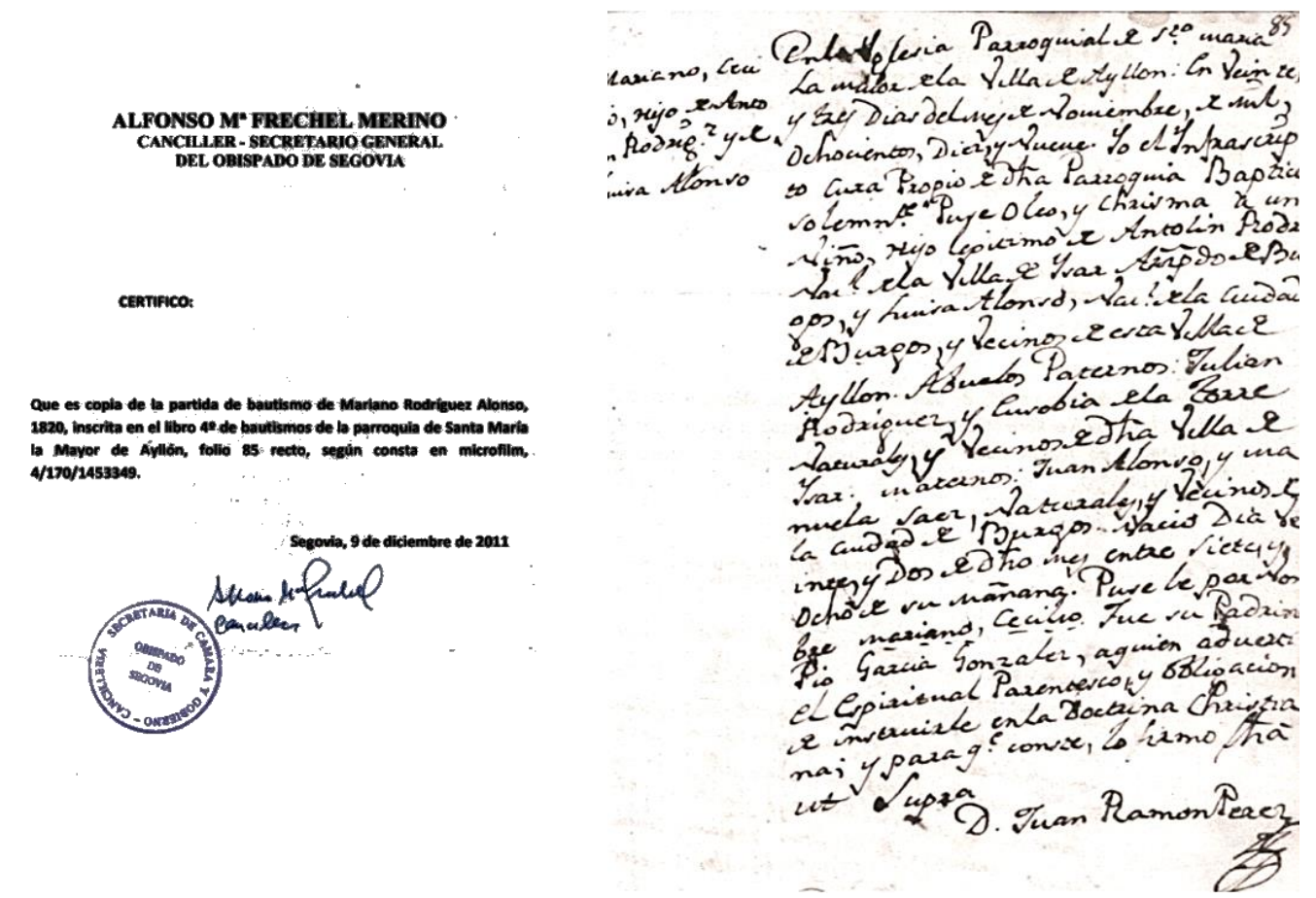

Fig. 2-8: Certificado y acta literal de bautismo de Mariano Cecilio Rodríguez Alonso, hijo de Antolín Rodríguez de la Torre y Luisa Alonso Saiz.

Archivo Diocesano de Segovia.

Poco tiempo después, el 1 de enero de 1820, el teniente coronel Rafael de Riego proclamaba la Constitución en Cabezas de San Juan y, el 7 de marzo, Fernando VII se verá obligado a aceptarla aunque en la ciudad de Burgos apenas tuvo repercusiones prácticas porque todavía estaba preocupada por restaurar los destrozos causados durante la Guerra de la Independencia.

En un ambiente de tensión entre realistas y liberales se producirá en junio de este año, la llamada "Conjura de Burgos" donde los realistas, junto

\footnotetext{
102 Ibídem, 31 de marzo de 1821, f. 161-162. Vid. Anexo 2.1.3. Poder otorgado por Isidro Vicente y Francisco Benito vecinos de Fuentearmegil a Don Antolín Rodríguez y a D. Francisco Navas vecinos de la villa de Ayllón -Segovia- para presentarse ante el Sr. Juez de $1^{a}$ instancia y realizar gestiones pertinentes.

${ }^{103}$ Archivo Diocesano de Segovia. Parroquia Santa Ma La Mayor de Ayllón. Libro $4^{o}$ de bautismos, 22 de noviembre de 1819 , f. 85 r.
} 
con antiguos cortesanos refugiados, urdieron un plan para atraer a Fernando VII a Burgos y abolir la constitución liberal. La intentona no llegó a materializarse aunque alentó un movimiento guerrillero que enfrentó a dos antiguos luchadores: el Cura Merino que encabezaba la guerrilla realista y El Empecinado, general del Gobierno liberal.

En Madrid, las Cortes denunciaron a los párrocos de Burgos por apoyar a los guerrilleros. En esa denuncia había una base real: las medidas tomadas, desde el poder central contra la Iglesia, propiciaron que algunos curas participasen ayudando a los guerrilleros.

Se iniciaba así el período conocido como Trienio Liberal (1820-1823), una etapa en la que se pudieron aplicar las reformas aprobadas por las Cortes de Cádiz como con la supresión del tribunal de la Inquisición, la abolición del régimen señorial, la desamortización aplicada a la supresión de mayorazgos y una reforma eclesiástica para reducir el número de monasterios y órdenes religiosas.

Los liberales se dividieron en dos grupos cada vez más definidos: los moderados, líderes históricos del liberalismo español, y los exaltados, más tarde llamados progresistas, partidarios de reformas más radicales. Los primeros gobiernos del Trienio liberal, hasta agosto de 1822, estuvieron en manos de moderados. Tras las segundas elecciones las nuevas Cortes, presididas por Riego, demandaban mayores reformas. Mientras tanto el rey aprovechó el descontento de militares afines, del clero y muchos campesinos perjudicados por la revolución liberal, junto con sectores que veían con añoranza el Antiguo Régimen, para negociar en secreto con la Santa Alianza la invasión de España.

En 1823 la Santa Alianza decide en el Congreso de Verona acudir en ayuda de Fernando VII, apoyado por los "Cien Mil Hijos de San Luis", y restaurar en el poder al rey Borbón dando comienzo una nueva década absolutista. 


\subsection{RAMA MATERNA EN LA CIUDAD DE BURGOS}

Luisa Alonso Saiz, madre de Santiago Rodríguez, nace en Burgos, el mismo año que su marido Antolín Rodríguez, un 23 de agosto de 1789, siendo la cuarta hija de una familia numerosa, especialmente de mujeres. Sus padres fueron Juan Alonso y Manuela Saiz, él natural de Burgos y ella de Medina de Pomar. ${ }^{104}$ Del matrimonio sobreviven ocho hijos: Ramona, ${ }^{105}$ Mariano, ${ }^{106}$ Bonifacia, ${ }^{107}$ Luisa, Josefa, ${ }^{108}$ María, ${ }^{109}$ Felipa,${ }^{10}$ y Carmen..${ }^{11}$

Juan Alonso era tabernero, su vivienda y establecimiento estaba situado en el centro de la ciudad, en la calle del Mercado número 16. La casa pertenecía al mayorazgo de los Moneda, y fue alquilada con una renta de mil cien reales, en el año 1811, siendo su fiador Lucas García, su yerno. ${ }^{112}$

Fueron años difíciles de lucha por su negocio en la venta libre de vinos, como consta en una protesta junto con otros taberneros de la ciudad, sobre el libre uso en su compra y venta. Algunos comerciantes, entre los que se encuentran Juan Alonso, Manuel Ordoñez y Juan Ojeda, dieron poder a D. Hilario Páramo, de Madrid, para que en nombre suyo demanden al Supremo Consejo de Hacienda. Exigen el libre uso de compra y venta de toda clase de vinos al haber pagado los derechos establecidos, impidiéndoselo el Caballero Intendente de la ciudad y provincia. ${ }^{113}$

Los dos hijos mayores de Juan Alonso, Ramona y Mariano, son comerciantes y maestros herreros. Ambos permanecen solteros al igual que sus hermanas Josefa y María. Bonifacia Alonso se casa con Lucas García, maestro de obra prima, dedicado a la construcción junto a su hermano Julián García. Tuvieron una hija: Aquilina García Alonso. ${ }^{114}$ El resto de sus hermanas, Felipa y Carmen se emparentaron con militares. Felipa Alonso se casa con Pascual Luengo Cabañero, teniente de la Quinta Compañía del Primer Batallón de Soria y natural de Hoz de la Vieja de Teruel, actuando como padrino de Santiago Rodríguez Alonso. ${ }^{115}$

En un documento, fechado el 8 de mayo de 1840, Pascual Luengo se encargaba del suministro de pobres de la Cárcel de la ciudad. ${ }^{116}$ Vivían en la calle del Mercado, número 12. Su única hija, Manuela, se casó con Manuel Espí, $2^{\circ}$ mariscal veterinario del Regimiento de Farnesio y $4^{\circ}$ de

\footnotetext{
${ }^{104}$ ADBU. Parroquia San Lorenzo de Burgos. $2^{\circ}$ Libro de bautizados 1755-1802, f. 152.

105 Ibídem, 29 de marzo de 1782 f. 301.

${ }^{106}$ Ibídem, 8 de julio de 1785, f. 46.

${ }^{107}$ Ibídem, 14 de mayo de 1787 , f. $94 \mathrm{v}$.

${ }^{108}$ Ibídem, 19 de marzo de 1792, f. 227.

${ }^{109}$ Ibídem, 9 de septiembre de 1796, f. 94.

${ }^{110}$ Ibídem, 23 de agosto de 1799, f. 1.86.

${ }^{111}$ Ibídem, 15 de julio de 1801, f. 241v.

112 AHPBU. Sección de Protocolos. Caja 7253, 2 de enero de 1.811.

113 AHPBU. Sección de Protocolos. Caja 7348, 8 de marzo de 1817, f. 86.

${ }^{114}$ Archivo Municipal de Burgos [en adelante AMBu]. Sig. 12-265. Censo de población 1821.

115 ADBU. Parroquia de San Lesmes de Burgos, $3^{\circ}$ Libro de bautizados 1785-1835, tomo $10^{\circ}$, f. 197.

${ }^{116}$ AHPBU. Sección de Protocolos. Caja 7480, 8 de mayo de 1840.
} 
Caballería. Ambos murieron muy jóvenes y dejaron tres hijos pequeños: Ricardo, $\mathrm{M}^{\mathrm{a}}$ Carmen y Emilia. Santiago Rodríguez ejerció de albacea testamentario ${ }^{117}$ y Ricardo Espí convive durante un tiempo en la casa familiar de Santiago, estudiando en el instituto de San Gil en Burgos. Carmen Alonso se casa con Francisco Écija, sargento del $1^{\circ}$ batallón Ligero de Baylén, sin descendientes.

Conocemos que Juan Alonso fue un próspero comerciante ya que al casarse sus hijas les dio como dote 200 ducados. Sin embargo, al morir anciano $^{118}$ sólo deja deudas de las que se encarga su hijo Mariano.

117 AHPBU. Sección de Protocolos. Caja 8172, 25 de diciembre de 1865, f. 467-468.

118 ADBU. Parroquia de San Lorenzo de Burgos, $8^{\circ}$ Libro de difuntos abril 1836 a 1849, 11 de abril de 1836. 

3. SANTIAGO RODRÍGUEZ ALONSO (1829-1891): FUNDADOR DE LA CASA EDITORIAL

\section{SANTIAGO RODRÍGUEZ ALONSO (1829-1891): FUNDADOR DE LA CASA EDITORIAL}

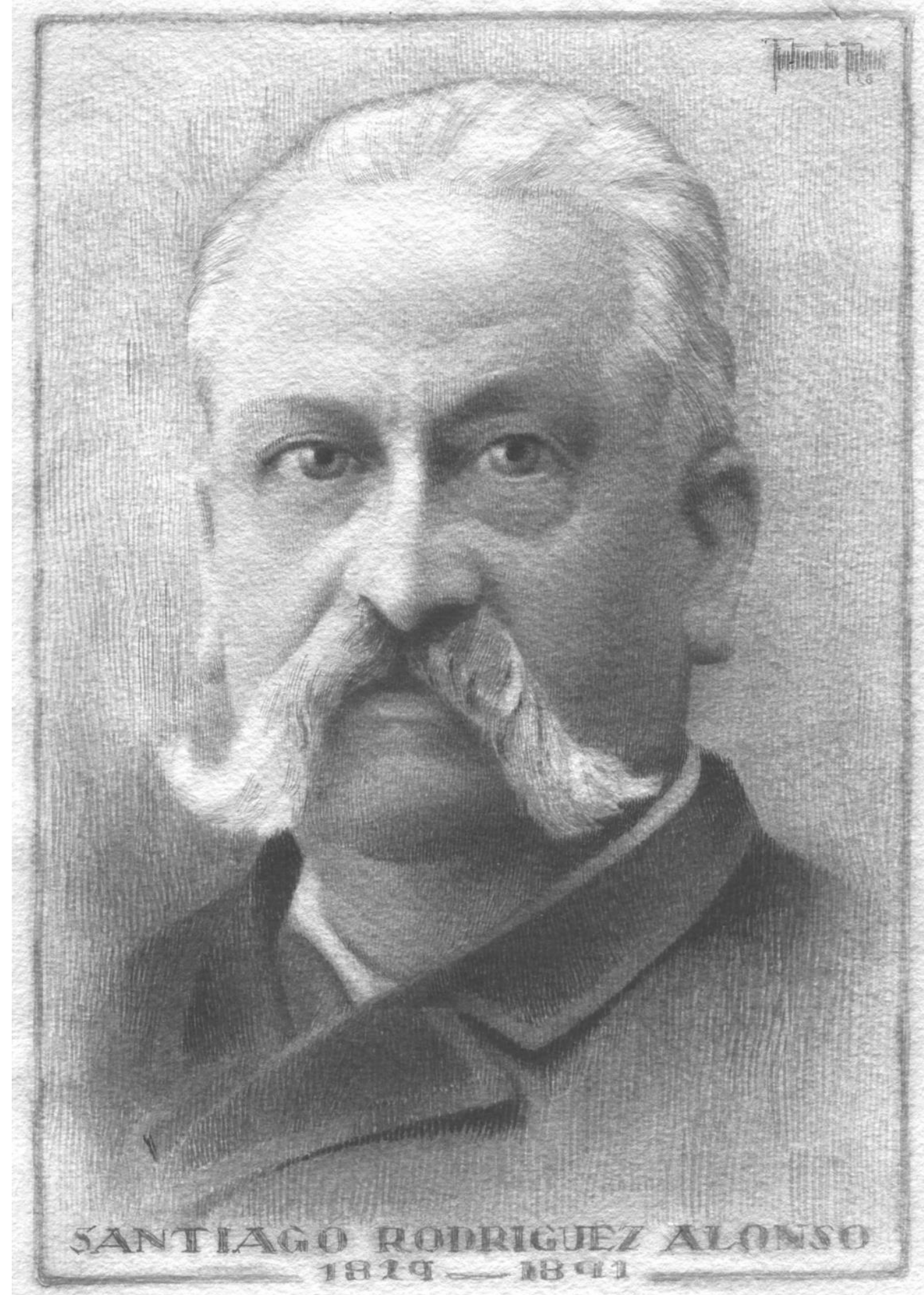

Fig. 3-1: Dibujo de Fortunato Julián sobre Santiago Rodríguez Alonso. 


\subsection{NACIMIENTO Y JUVENTUD EN UNA ÉPOCA DE CAMBIOS}

Durante el sexenio absolutista de Fernando VII la vida cotidiana en Burgos estaba marcada por la rutina. Sus habitantes trataban de dinamizar el comercio, mejorar las estructuras urbanas y los alojamientos de los soldados, limpiar las calles y esguevas, así como participar en las diversas ceremonias religiosas, de duelo o regocijo, del entorno del monarca y satisfacer las exigencias tributarias de la ciudad.

El paso a la etapa constitucional, durante el Trienio Liberal en Burgos (1820-1823), ocasionó nuevos temores entre la población ante la posibilidad de una nueva confrontación bélica. ${ }^{119}$

Fue en este contexto histórico cuando Antolín Rodríguez de la Torre regresa a Burgos, hacia principios de 1822, dejando su puesto de veredero de rentas estancadas. Este hecho lo conocemos por el cambio de titularidad en su función pública y por el nacimiento en Burgos de su segundo hijo, Francisco, entre el 6 y el 7 de enero del citado año ${ }^{120}$ y creemos que pudo residir en el paseo del Espolón en el número 46. ${ }^{121}$

Otro hecho que confirma esta datación la encontramos en el censo de población de Burgos en 1821. Su nombre no figura en el mismo, y tampoco en el expediente del Ayuntamiento sobre propietarios y renteros de casas. Sin embargo su suegro Juan Alonso vive y comercia en la calle del Mercado $^{122}$ número 16 y señala en la misma vivienda a un hijo miliciano y a sus hijas, con excepción de Bonifacia Alonso y Luisa Alonso, ya casadas.

En la misma zona habitan miembros destacados de la reciente burguesía comercial como Florentín Izquierdo, -recaudador de la contribución de la ciudad-, su hermano Julián y su madre Manuela Laredo, ${ }^{123}$ posiblemente familiares de Juliana Izquierdo, casada con un hermano de Juan Alonso.

Manuela Laredo era viuda, comerciante y propietaria de tres casas: una en la Plaza del Mercado Menor, número 4, -actual Plaza Mayor- donde vivía con su hijo Julián Izquierdo, también comerciante, y con su nuera, Gregoria Mendivil; otra, en la calle Juego de la Pelota que la tenía arrendada a su hermana, Catalina Laredo, tintorera y viuda; y la tercera en

\footnotetext{
${ }^{119}$ CASTRILLEJO IBÁÑEZ F. Op. cit., pp. 108-120.

${ }^{120}$ ADBU. Parroquia de San Lesmes de Burgos, $3^{\circ}$ Libro de bautizados $1785-1835$, tomo $10^{\circ}$, f. 1 . Vid. Anexos 2.2.4. Acta literal de bautismo en la parroquia San Lesmes de Burgos de Francisco Rodríguez Alonso, nacido entre el 6 y 7 de enero de 1822.

${ }^{121}$ AMBu. Sig.12-244. En este documento aparece como Antonio Rodríguez, en vez de Antolín. Nos hace pensar en una posible errata ya que no encontramos ningún Antolín en registros municipales.

${ }^{122}$ Hacía referencia a una calle que estaba situada entre la plaza del Mercado Mayor, actual Plaza Mayor y la plaza del Mercado Menor, hoy Plaza de la Libertad y Plaza Santo Domingo de Guzmán unidas antiguamente al no existir los Soportales de Antón. Actualmente esta calle del Mercado la conocemos como calle Entremercados.

${ }^{123}$ AMBu. Sig. C2-3-9/11. Propietarios y renteros de Burgos. Año 1821; Sig. 12-265. Censo de población 1821.
} 
la calle La Paloma número 16, arrendada a su hermano Pedro Laredo, médico, por un valor de 1.000 reales. Esta misma casa la ocupará posteriormente Antolín Rodríguez, una década más tarde.

Se la arrienda a Antolín Rodríguez, cuando muere su hermano Pedro Laredo, lo cual nos está indicando sus posibles vínculos familiares ya que todas sus viviendas fueron ocupadas por miembros de su familia. Es difícil conocer a qué se dedica en todos estos años, salvo que fue funcionario de las puertas de la ciudad, aunque sin precisar en qué años exactamente.

Dos documentos nos hablan de la profesión de funcionario de la Administración de Hacienda en las puertas de Burgos, lo que nos permite suponer que se trasladó a Burgos cuando dejó el puesto de veredero en Ayllón.

El primero, es una carta de D. Eugenio María Pérez, gentilhombre de Boca de S.M. y administrador de puertas en arriendo de la ciudad, certificando que la lista presentada de 17 personas cumple la normativa para votar en las Elecciones a Diputados de 1839. En la lista aparece Antolín Rodríguez. ${ }^{124}$

El segundo, presentado ante el notario Emeterio González, el 16 de marzo de 1855 cuando ya había muerto Antolín, su mujer Luisa Alonso da poder a su hijo Dámaso Rodríguez Alonso para que cobre de la Administración principal de Hacienda la pensión que le correspondía como viuda de empleado en las puertas de la ciudad.

Poder de $D^{a}$ Luisa Alonso, viuda vecina de esta ciudad a favor de su hijo D. Dámaso Rodríguez, soltero residente en ella para cobrar cantidad menor de 5.000 reales.

En la ciudad de Burgos a dieciséis de marzo de mil ochocientos cincuenta y cinco ante mí el Escribano de su número y testigos que se expresarán pareció $D^{a}$ Luisa Alonso, viuda, vecina de la misma a quien doy fe conozco y dijo que confiere el poder necesario en derecho a su hijo D. Dámaso Rodríguez, soltero residente en ella, para que cobre de la Administración principal de Hacienda de esta dicha ciudad la pensión que tiene como viuda de D. Antolín Rodríguez, empleado que fue en las puertas de la misma capital, importante una suma menor de 5.000 reales otorgando al efecto las conducentes cartas de pago que tendrán la misma validez. que si se expidiera por la Sra otorgante, pues el poder que para lo dicho se requiere y demás incidentes o dependiente en cualquiera manera, ese mismo da al nominado D. Dámaso Rodríguez sin restricción con cláusula impresa de relevación en forma, obligando al cumplimiento de cuanto se hiciere en virtud de este poder sus bienes en general presentes y futuros conforme a derecho. Lo otorga así y firmo siendo testigos D. Fermín Aranzana Pérez, D. Julián Martínez Medina y D. Gregorio Guinea vecinos y residentes en esta ciudad. ${ }^{125}$

\footnotetext{
${ }^{124}$ AMBu. Sig. 10-60. Expediente de elección de Diputados a Cortes y propuesta de Senadores, 24 de julio de 1839 .

${ }^{125}$ AHPBU. Sección de Protocolos. Caja 7679, 16 de marzo de 1855. Anexo: 2.1.10. Poder notarial de Da Luisa Alonso a favor de su hijo D. Dámaso Rodríguez para que cobre la pensión de su madre, como viuda de empleado de las puertas de la ciudad.
} 
Posiblemente su relación con Florentín Izquierdo le ayudó a integrarse social y económicamente a Antolín, unido a sus hábiles cualidades de gestor y administrador. ${ }^{126}$

$\mathrm{Su}$ familia política deposita en él toda la confianza. Lo podemos observar en un poder que su mujer Luisa Alonso le da para que venda una casa en Zamora a petición de su tía Carmen Alonso. ${ }^{127}$

Quedan dudas acerca de si trabajó con su cuñado Lucas García en la construcción o como su ayudante o administrador, lo cierto es que aparece en una contribución por oficios, de obra prima, en $1836 .{ }^{128}$

Nacen el resto de los hijos que sobreviven, Ramona, ${ }^{129}$ Santiago, ${ }^{130} \mathrm{y}$ Dámaso. ${ }^{131}$

\footnotetext{
${ }^{126}$ AMBu. Sig. C2-5-15/2. Contribución al derecho de puertas.

${ }_{127}$ AHPBU. Sección de Protocolos. Caja 7284, 4 de marzo de 1823.

${ }^{128}$ AMBu. Sig. LI-98-5. Contribución por oficios.

${ }^{129}$ ADBU. Parroquia de San Lesmes de Burgos. $3^{\circ}$ Libro de bautizados 1785-1835, tomo $10^{\circ}, 4$ de agosto de 1827, f. 135. Vid. Anexo 2.2.5. Acta literal de bautismo en la parroquia San Lesmes de Burgos de Ramona Rodríguez Alonso, nacida el 4 de agosto de 1827.

${ }^{130} \mathrm{Ibídem}, 25$ de julio de 1829, f. 197. Vid. Figura 10 y 11.

${ }^{131}$ Ibídem, 11 de diciembre de 1831. Vid. Anexo 2.2.6. Acta literal de bautismo en la parroquia San Lesmes en Burgos de Dámaso Rodríguez Alonso, nacido el 11 de diciembre de 1831.
} 
ARZOBISPADO DE BURGOS

CERTIFICACION EN EXTRACTO DE PARTIDA DE BAUTISMO

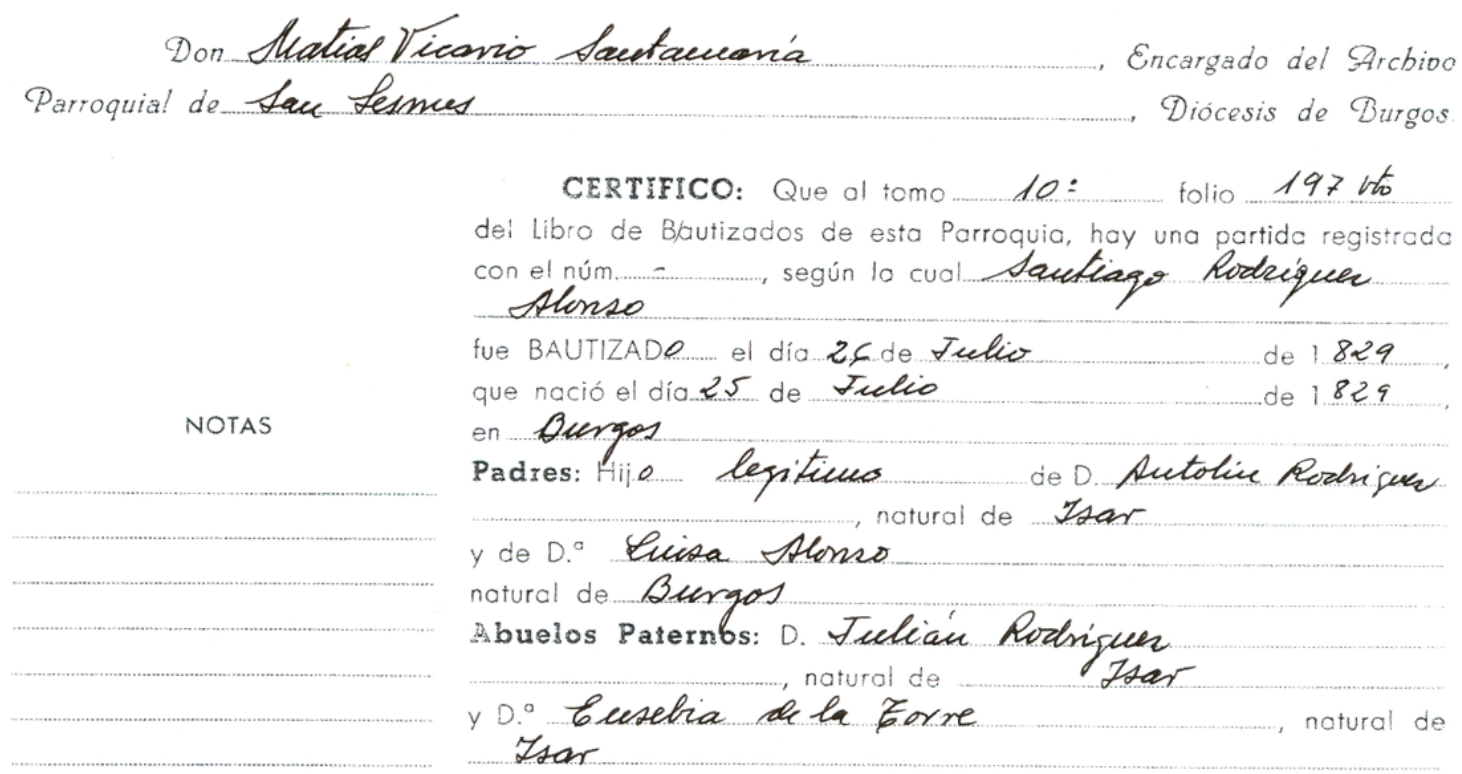

Abuelos Maternos: D. Tean Alonso y D. Shanuela Saes Burjos

Padrinos: D. Pascual Luengo

D. - Carmen Almso

Miristro: D. Tuan Autorio Ruis

Y para que conste, a los efectos a que hubiere lugar on derecho, expido la presente certificación en Burgas 13 de abril de EL ENCARGADO DELARCHIVO (sello)

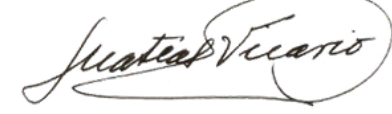

Fig. 3-2: Certificado de la partida de bautismo de Santiago Pascual Rodríguez Alonso. Archivo Diocesano del Arzobispado de Burgos. (25-7-1829). 
LA EDITORIAL BURGALESA HIJOS DE SANTIAGO RODRÍGUEZ (1891-1936): ANÁLISIS DE LOS LIBROS ESCOLARES

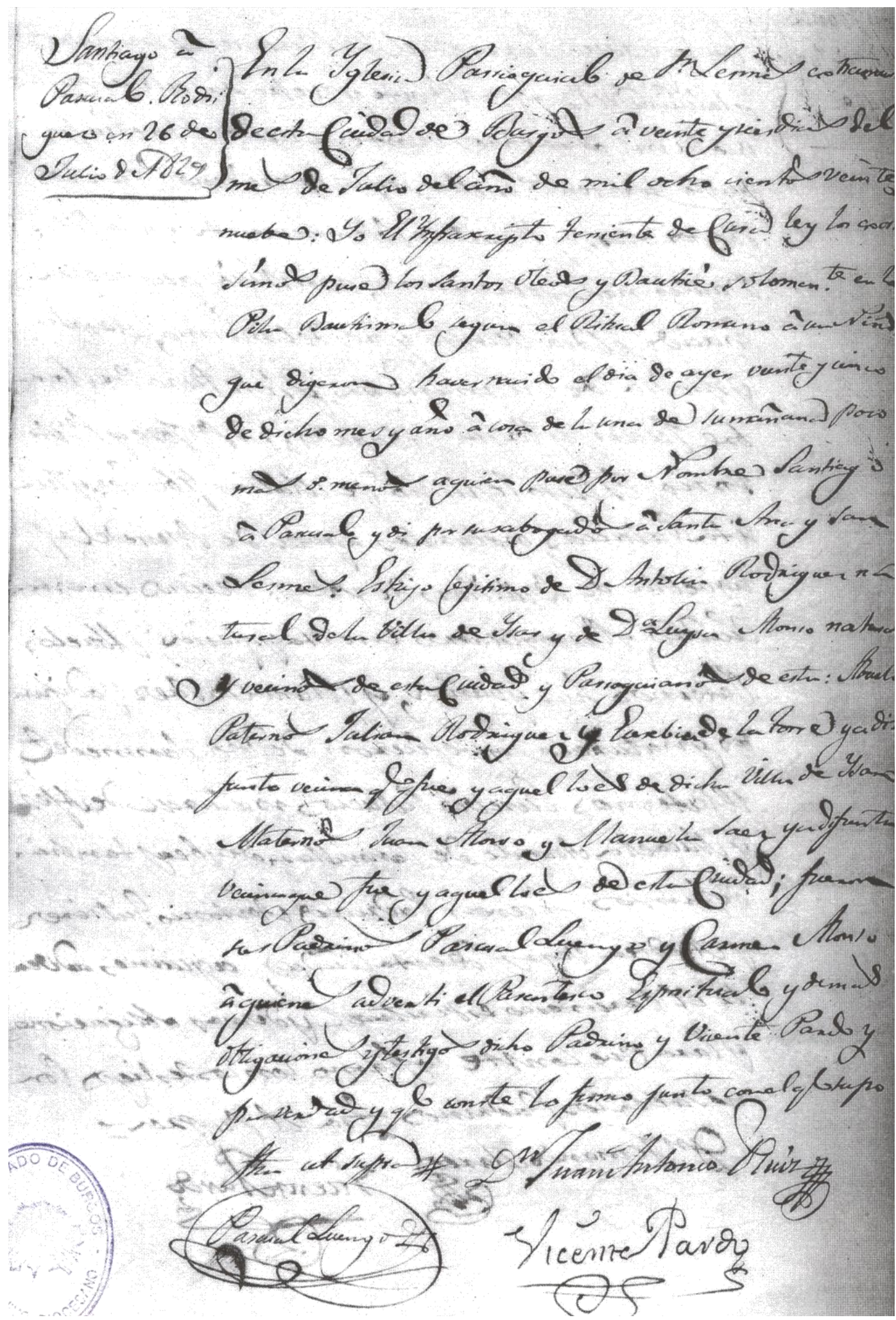

Fig. 3-3: Acta literal de bautismo de Santiago Pascual Rodríguez Alonso. Archivo Diocesano del Arzobispado de Burgos. (25-7-1829). 
En el conjunto de la Nación, la imposibilidad de seguir gobernando con instituciones del Antiguo Régimen obligó a crear otras, entre las que se encontraban el Consejo de Ministros con un Ministerio de Fomento que proyectará una política de moderada liberalización económica.

En el seno realista, un grupo de exaltados se convirtieron en carlistas a causa de la sucesión de Fernando VII que había hecho publicar la Pragmática Sanción, con el nacimiento de Isabel, fruto del cuarto matrimonio del rey. Su muerte, en septiembre de 1833 se desencadena la guerra sucesoria.

Si bien en el conjunto del país fueron unos años convulsos, para Burgos se iniciaba un período de lenta recuperación. La muerte del rey no despertó demasiados pesares y se aceptó la sucesión de Isabel II. Sin embargo nada más morir el rey, se produjo la constitución de todas las Juntas carlistas, entre las cuales la de Burgos fue la más activa.

Otro de los hechos notorios, a principios de la era isabelina, será la formación de la nueva provincia de Burgos debido a la reorganización territorial efectuada por Javier de Burgos en 1833. Surge así la actual provincia subdividida en doce partidos judiciales. Como consecuencia de esta reforma se crea la Audiencia Territorial, la Diputación Provincial, con sus BOPB, y más tarde la Capitanía General. Esta última supone la llegada de funcionarios, empleados y militares, que darán auge a la industria y al comercio.

También esta década de los años 30 es importante para Antolín. Mantiene en renta dos viviendas. Una, en la calle La Paloma $\mathrm{n}^{\circ} 16$ de Manuela Laredo, desde el 20 de abril de 1831, alquilada por tres años a un precio de mil ciento cuarenta reales cada año, no incluyendo una oficina que queda para uso de Manuela o la persona que la represente; otra en la Calle Puerta Alta no $30,1^{\circ}$. 132

Sépase por esta pública escritura de arrendamiento, vienen como nosotros $D$. Antolín Rodríguez y $D^{a}$ Luisa Alonso marido y mujer legítimos vecinos de esta ciudad de Burgos, premisa entre nosotros la venia licencia y consentimiento marital que se requiere que de haber sido pedida, concedida y otorgada en toda forma legal yo el notario doy fe y de ella usando otorgamos: que tomamos en renta y arrendamiento de $D^{a}$ Manuela Laredo, convecina una casa que la pertenece con el número diez y seis por tiempo y espacio de tres años que empezamos a correr y contarse desde el día 24 de junio del año corriente y de ser fin en otro tal día del que vendrá de mil ochocientos treinta y cuatro por la renta en cada uno de mil

${ }^{132}$ AMBu. Sig. C-44/11. Listado general de 16 a 54 años. Año 1836. En este listado se menciona la ubicación de cada una de las familias residentes en la ciudad. 
ciento cuarenta reales vellon en moneda sonante y contante usual y corriente y no en otra especie papel moneda creada y crearse pueda. ${ }^{133}$

El posible motivo de la pertenencia de ambas viviendas la encontramos el 7 de diciembre de 1832 cuando se realiza una escritura pública, ante el notario D. Agustín de Espinosa, en la que Antolín Rodríguez se convierte en apoderado del Marquesado de la Rambla. Puso como aval de este apoderamiento tres fincas heredadas de la villa de Isar.

Sépase para esta pública escritura de obligación y fianza en forma como nosotros D. Antolín Rodríguez y $D^{a}$ Luisa, marido y mujer legítimos, vecinos de esta ciudad de Burgos y para lo que se diga la venia licencia y consentimiento que de uno a otro y de otra a otro, se requiera, pedido, concedido y otorgado en toda forma legal de que yo el presente escribano certifico y de él usando otorgamos que nos obligamos a administrar, regir y gobernar, todos los bienes, fincas rusticas y urbanas que en esta ciudad y fuera de ella posee la Excma. Sra. Marquesa viuda de la Rambla, vecina de la ciudad de Úbeda, como madre tutora y curadora de su menor hijo D. Bernardo de Orozco, actual marqués del mismo título, cuyo encargo confió al Sr. coronel D. Lorenzo Fernández, teniente coronel mayor, del regimiento de Caballería, quinto de la Albuera que guarnece al presente en esta ciudad de Burgos con la cláusula de que le pudiese sustituir en quien fuera de su agrado caso de tener que salir de esta capital, según qué caso así, pues aparece en el citado poder fechado y otorgado para dicha excelentísima señora, en citada ciudad de Úbeda, a veinte de noviembre del corriente año, fidelidad de Bonifacio de la Quadra escribano público y del número de aquella ciudad y como que el Señor D. Lorenzo Fernández no puede contar con ninguna seguridad de permanencia en esta capital por el servicio que está prestando a vs.....en la milicia, le ha sustituido en este día y testimonio del presente escribano para los mismos fines y efectos que le ha sido conferido las resultas y poniéndole en ejecución por la aceptación hecha de su encargo, obligamos todos nuestros bienes, créditos y acciones presentes y futuras a administrar, regir y gobernar bien y fielmente todos los predios rústicos y urbanos que en esta ciudad y fuera de ella pertenecen a v.e. en el concepto que responde por su Marquesado de la Rambla percibir sus rentas, dar cuenta con pago de ellas, como y cuando se le ordene, ayudando de los mejores aumentos y requerimientos del Estado, para su ejecución y costas y el más exacto cumplimiento además de la obligación que en general tenemos hechos de todos nuestros bienes, créditos y acciones presentes y futuras... ${ }^{134}$

Habita en la misma casa al morir Manuela Laredo, siendo su hijo D. Florentín Izquierdo el que se la arrienda, el 8 de mayo de 1833, por seis

\footnotetext{
${ }^{133}$ AHPBU. Sección de Protocolos. Caja 7358, 20 de abril de 1.831. Vid. Anexo 2.1.4. Arrendamiento de una casa a D. Antolín Rodríguez y consorte a favor de $\mathrm{D}^{\mathrm{a}}$ Manuela Laredo, en Burgos el 20 de abril de 1831.

134 AHPBU. Sección de Protocolos. Caja 7359, 7 de diciembre de 1831. Vid. Anexo 2.1.6. Escritura de fianza D. Antolín Rodríguez Alonso y su consorte vecinos de esta ciudad a favor de la Excelentísima Sra. Marquesa viuda de la Rambla, por su apoderamiento el 7 de diciembre de 1831.
} 
años y una nueva renta de mil doscientas cincuenta reales, si bien en este nuevo contrato se incluía toda la casa. ${ }^{135}$

Antolín arrienda a diversos agricultores las tierras de la Marquesa; se puede apreciar por varios testigos ante el notario D. Agustín Espinosa. Un ejemplo de ello fue el documento registrado el 9 de diciembre de 1832:

Arrendamiento Francisco Lomillo y Francisca Tobar su mujer como principales y Antonio Franco y Ciriaco Mayoral todos vecinos del lugar de Villalvilla a favor de la Excma. Señora Marquesa de la Rambla y como su apoderado de D. Antolín Rodríguez vecino de esta ciudad.

Sépase por esta pública escritura... que tomamos y recibimos en renta y arrendamiento de la Excma. Señora Marquesa de la Rambla y como su apoderado y administrador D. Antolín Rodríguez vecino de esta ciudad a saber una casa y veinte y tres fanegas de heredades que hasta aquí hemos labrado y traído en arriendo pertenecientes a su E.A. que por sernos notorias y bien conocidas que no se individualizan por tiempo y espacio de nueve años que empezaron a correr $y$ contarse en primero de marzo del año próximo pasado y la renta en cada uno de ellos de treinta y siete fanegas de pan mediado, paja y cebada blanca de buena calidad... en esta ciudad la casa y poder del administrador que es o fuere de su AS por nuestra cuenta y de la misma ha de ser el pago de derecho de puertas... ${ }^{136}$

Además este documento añade que deberá abonar el pago completo, sin descuento, incluso cuando se perdiera la cosecha por niebla, hielo, langosta u otro imprevisto y con la obligación de tener bien trabajadas las tierras, no pudiendo subarrendarlas.

Antolín aparece como testigo en varios protocolos durante los años 1831-34. Entre ellos cabe resaltar que fue testigo en el testamento de Florentín Izquierdo. ${ }^{137}$

Son años difíciles donde Antolín Rodríguez de la Torre, como funcionario y apoderado, sale adelante ante las dificultades y miserias que mantiene la ciudad.

$Y$, con todo, fue tal la magnitud del infortunio burgalés, de 1833 a 1837, sobre su ya desastrada economía anterior, que pocos pueblos lo soportaron en circunstancias más dificultosas: con la ruinosa decadencia de su agricultura, la nulidad de su comercio y la pobreza general de todas sus clases, al extremo, de que el Ayuntamiento constitucional, en memorial dirigido a la reina gobernadora, el 3X-1837 afirmaba que a Burgos "ya no le faltaba más que ser devorada. ${ }^{138}$

\footnotetext{
135 AHPBU. Sección de Protocolos. Caja 7358 y Caja 7360, 20 de abril de 1831 y 13 de mayo de 1833 respectivamente. Vid. Anexo 2.1.5. Arrendamiento de una casa a D. Antolín Rodríguez y consorte a favor de D. Florentín Izquierdo, en Burgos el 8 de mayo de 1833.

${ }^{136}$ AHPBU. Sección de Protocolos. Caja 7359, 9 de diciembre de 1832.

${ }^{137}$ AHPBU. Sección de Protocolos. Caja 7361, 17 de enero y 5 de agosto de 1834.

138 ALBERDI ELOLA, L. Breverías burgalesas. Burgos: Ayuntamiento de Burgos, Imprenta Aldecoa, 1969, p. 131.
} 
En el expediente de contribución del subsidio de comercio e industria del año 1837 aparece un tal Antonio Rodríguez, que suponemos se refiere a Antolín Rodríguez, viviendo en la calle La Paloma con un pago de 40 reales. ${ }^{139}$ Lo mismo constatamos en el expediente de contribución extraordinaria de guerra y empréstito forzoso de los años 1837-38 de 81 reales. ${ }^{140}$

En los libros de contribución tanto Ramona Alonso como su hermano Mariano, sus hermanas, su cuñado Lucas y Antonio Rodríguez pagaban distintas cantidades por sus oficios. ${ }^{141}$

De los datos señalados anteriormente es difícil contrastar que Antonio Rodríguez sea Antolín Rodríguez. Sin embargo, podemos afirmar que seguía residiendo en la calle La Paloma número 16. De esta coincidencia deducimos que posiblemente sean la misma persona.

Aparece con su propio nombre en el alojamiento en su casa de un subteniente del Depósitos de Quintos de Asturias, ${ }^{142}$-1837-, en el pago del arriendo de las tierras del Marqués de la Rambla, del año $1837,{ }^{143}$ y en la contribución de Paja y utensilios del Ayuntamiento, en 1839, pagando 23 reales, poniendo como concepto "por la Rambla", aludiendo a su apoderamiento.

La familia Rodríguez disfrutaba de una buena posición económica y social, en la década de los años 40, ya que sus dos hijos mayores cursaron estudios superiores: Mariano, la carrera de abogado, y Francisco, su segundo hijo, estudia en el recién creado Instituto Superior de Burgos. ${ }^{144}$

Francisco Rodríguez se matriculó el 21 de diciembre de 1840 en la asignatura de Aritmética y Álgebra para ganar el primer año de Matemáticas puras. Examinado en junio, obtiene sobresaliente. ${ }^{145}$ No

\footnotetext{
${ }^{139}$ AMBu. Sig. LI-98-8. Contribución del subsidio del comercio e Industria del año 1837.

${ }^{140}$ AMBu. Sig. LI-98-2. Contribución extraordinaria de guerra y empréstito forzoso de los años 1837-38. Del resto de su familia política podemos observar en los documentos del Archivo municipal que pagan distintas cantidades: Su suegro Juan Alonso paga 700 reales en la contribución extraordinaria de guerra y lo mismo su cuñado Lucas García. AMBu. Sig. LI-669-2. Índice de los contribuyentes a la extraordinaria de guerra con los nombres y número que cada uno tiene en su cuenta respectiva.

${ }^{141}$ AMBu. Sig. LI-98-3. En el libro de contribución de 1837, Ramona y hermanas pagan 60 reales; en el libro de contribución por oficios; Sig. LI-98-5, Lucas García y Antonio Rodríguez, pagan respectivamente 60 y 40 reales. En la contribución de pagos especiales Sig. LI-98-9, aparecen Ramona y hermanas que pagan 6 reales, Antonio Rodríguez también aparece aunque no se puede ver lo que aporta por el mal estado del documento.

${ }^{142}$ AMBu. Sig. LI-669-1837-1. Alojamientos de soldados.

143 AHPBU. Sección de Protocolos. Caja 7384, 1 de septiembre de 1838.

${ }^{144}$ AHPBU. Sección Enseñanza. Sig. 593/3. Instituto Literario Superior de Burgos. Libro de matrículas $\mathrm{n}^{\circ}$ 1. Vid. ALBARELLOS, J. Efemérides burgalesas. Burgos: Talleres Gráficos Diario de Burgos, 1980, p. 8-9. Informa que se creó dicho Instituto en octubre de 1840 a propuesta de la Junta de Gobierno de la Provincia por medio de su vocal Antonio Collantes. Secundó la propuesta la Corporación Municipal gracias a diversas rentas procedentes de obras pías y fundaciones. La inauguración se realizó el 10 de enero de 1841 e impartían conocimientos no sólo de bachillerato, sino otros más elevados que la hacían parecer una verdadera Universidad.

${ }^{145}$ AHPBU. Sección Enseñanza. Sig. 593/3. Instituto Literario Superior de Burgos. Libro de matrículas $n^{\circ}$ 1 , matrícula $\mathrm{n}^{\circ} 42$.
} 
volvió a matricularse en años sucesivos pero sabemos que sacó la oposición para una plaza en las Oficinas de la Contabilidad de la Hacienda Pública, cuyo destino le llevó a Navarra.

La familia mantiene la casa de calle Puerta Alta número 30, arrendada el 26 de octubre de 1841 por el Marqués de la Rosa. El contrato estipula tres años de alquiler, pagando al mes la cantidad de mil trescientos sesenta reales. Sus fiadores fueron sus cuñados Mariano Alonso y Ramona Alonso. ${ }^{146}$

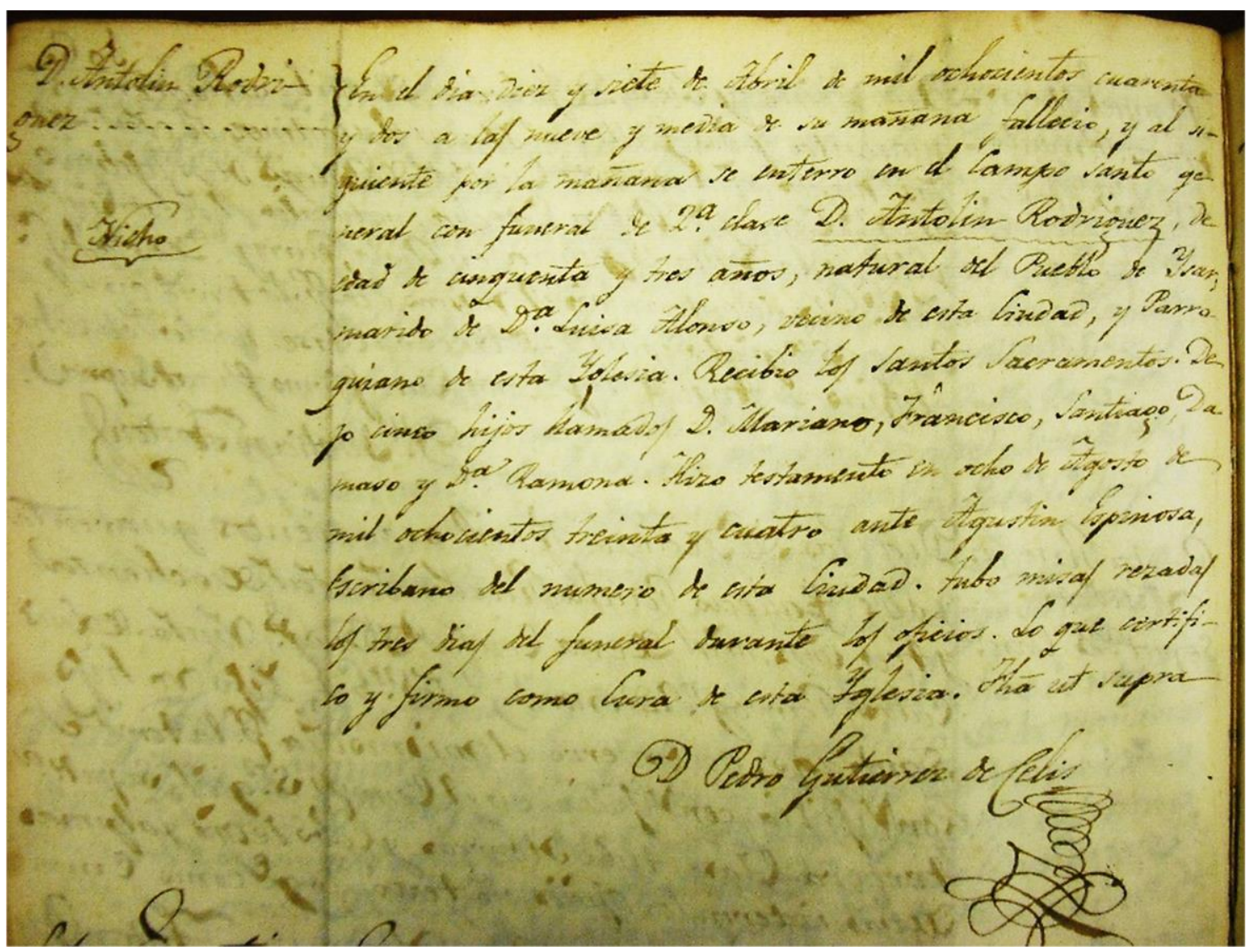

Fig. 3-4: Acta literal de defunción de Antolín Rodríguez de la Torre. Archivo Diocesano del Arzobispado de Burgos (17-4-1842).

Antolín Rodríguez de la Torre muere el 17 de abril de $1842,{ }^{147}$ su funeral se oficia en la parroquia de San Gil. (Figura 3-4). Dispuso testamento ante el notario Agustín Espinosa el 8 de agosto de 1834.

[...]Mandamos usando de las facultades que la ley nos dispensa a nuestro hijo menor D. Dámaso Rodríguez Alonso el remanente del quinto, de todos aquellos bienes, créditos y acciones y si este falleciere antes de tomar estado o llegase a tomarle quedando constituidas en la menor edad nuestra hija Ramona Rodríguez

\footnotetext{
${ }_{146}$ AHPBU. Sección de Protocolos. Caja 7459, 26 de octubre de 1841.

147 ADBU. Parroquia de San Gil de Burgos. $5^{\circ}$ Libro de difuntos. Del 13 de diciembre de 1827 al 30 de enero de 1852, 17 de abril de 1842 .
} 
Alonso queremos que recaiga en esta, y por lo tanto y desde ahora y para entonces esto, le legamos otro quinto y remanente de nuestros bienes, créditos y acciones como en que nuestro hijo y su hermano el susodicho Dámaso y que nos encomiende a Dios.

En uso de la misma ley yo el susodicho D. Antolín Rodríguez nombro por Protectora, casadora y legitima administradora de las personas y bienes de mis hijos menores a su madre la susodicha Luisa Alonso en forma de finanzas y en su defecto a nuestro hermano D. Mariano Alonso y a este y a D. Julián López vecinos de esta ciudad para testamentarios y contadores con todas las facultades que para el mejor desempeño de este encargo necesite $[\ldots]^{148}$

En los meses anteriores a su fallecimiento firma como fiador en una escritura de obligación de D. Ángel Martín, cirujano de Isar, a favor de Juan Pérez, por 2.600 reales de vellón y 13 fanegas de trigo, cancelada el 12 de octubre de $1843 .{ }^{149}$ También como apoderado de la Marquesa de la Rambla arrienda sus tierras a vecinos de Villatoro:

Asciclo y Petra Ortega y José y Micaela García, vecinos de esta ciudad y moradores del barrio de Villatoro... otorgamos que tomamos y recibimos el arrendamiento, los primeros nombrados por el fallecimiento de Petra Ortega, para nosotros los enunciados José y Micaela García al Sr. Marqués y su administrador D. Antolín Rodríguez las heredades que al Sr. Marqués le corresponden en términos del Barrio de nuestra morada y una era de trillar de San Pedro de la Fuente por 9 años y por renta de 27 fanegas de pan mediado, mitad alaga y cebada blanca, pura, seca y limpia para el 29 de septiembre, día de San Miguel.[...] $]^{150}$

El 30 de marzo de 1842 firma una escritura, ante el notario D. Agustín Espinosa, de arrendamiento de las tierras del marqués de Rambla, por espacio de nueve años, a Simón Toribio, vecino de Burgos. El precio y renta de cada año es de 34 fanegas de pan mediado por mitad de trigo y cebada, siendo por cuenta de los renteros la contribución al clero. ${ }^{151}$

Después de la muerte de Antolín Rodríguez de la Torre, su hijo Mariano Rodríguez Alonso ejerce de abogado, con despacho en Burgos, y mantiene el apoderamiento del marqués de la Rambla. ${ }^{152} \mathrm{Su}$ madre, Luisa Alonso, adquiere un papel relevante al convertirse en administradora de todos los bienes de la familia, lo cual nos hace pensar que viviendo Antolín ejercería funciones similares. Durante el año 1843 contamos con varias escrituras que lo avalan: presta dinero a cambio de unas hipotecas que, en caso de impago, revierten e incrementan el patrimonio familiar.

\footnotetext{
148 AHPBU. Sección Protocolos. Caja 7361, 8 de agosto de 1834. Vid. Anexo 2.1.7. Testamento de D. Antolín Rodríguez y D $\mathrm{D}^{\mathrm{a}}$ Luisa Alonso su mujer, en Burgos el 8 de agosto de 1834.

149 AHPBU. Sección Protocolos. Caja 7369, 11 de febrero de 1842.

150 Ibídem, 24 de marzo de 1842.

${ }^{151}$ Ibídem, 30 de marzo de 1842.

152 AHPBU. Sección Protocolos. Caja 7678, 17 de octubre de 1853. Vid. Anexo 2.1.9. Mariano

Rodríguez Alonso, apoderado del Sr. marqués de la Rambla, 1853.
} 
A modo de ejemplo, explicitamos algunos casos:

23 de enero de 1843: Obligación de D. Manuel y D. Esteban de la Peña, padre e hijo de Quintanilla Somuñó, el segundo de Muñó... por tres mil reales...por un año ... hipotecando varias fincas... ${ }^{153}$

4 de marzo de 1843: Obligación de D. Bonifacio Hernando y $D^{a}$ Jerónima Rioseras, su mujer, vecinos de esta ciudad... a pagar 8.800 reales sin interés...dentro de un año... hipotecando dos casas, una en el Hospital de los Ciegos(fábrica de S. Gil) y otra en Santa Clara... ${ }^{154}$

3 de mayo de 1843: Obligación de Manuel Calleja, vecino de Villaveta, como principal y Ruperto Navarro como fiador, vecino de esta ciudad por 4.500 reales, sin interés y por un año". Cancelada con la firma del licenciado D. Mariano Rodríguez Alonso el dos de junio de $1.852 .{ }^{155}$

20 de junio de 1843: Obligación de Ruperto Navarro por 1.400 reales, por tres meses, sin interés. ${ }^{156}$.

4 de octubre de 1843: Obligación de José Prieto, vecino de Quintanadueñas a pagar 1.000 reales a $D^{a}$ Luisa. ${ }^{157}$ Mariano Rodríguez Alonso firmó su cancelación en 12 de diciembre de 1843.

El tercer hermano, Santiago Rodríguez Alonso figura fundacional de la editorial, siguió sus estudios de segunda enseñanza y obtuvo el grado de Bachiller en Artes, en 1844, según referencia de Carmen Monje. ${ }^{158}$ El libro de Valero de Tornos España fin de siglo, escrito en 1896, señala su formación en Madrid de 1846 a 1850:

...pero en vez de seguir una carrera científica o literaria, abandonó las aulas y emprendió con fe y entusiasmo su vida industrial, para la que manifestaba inteligencia y dotes poco comunes, realizando bien pronto las ideas y empresas que su pensamiento le indicara.

Después de haber adquirido en Madrid durante los años 1846 al 50 los conocimientos y práctica indispensables, regresó a Burgos y fundó su librería y hoy casa editorial de primer orden y de gran importancia. ${ }^{159}$

Poco o nada conocemos de esos años de la familia Rodríguez hasta 1849. En esta fecha a Santiago Rodríguez le toca la suerte de soldado, por siete años, en el sorteo de quintos. Era una época convulsa, de crisis y revueltas, en la que enviar a un hijo al servicio militar significaba que pudiera volver herido, lisiado o muerto. Ante esta perspectiva, las familias que podían permitírselo hacían lo necesario para evitarlo, pagando a otra

\footnotetext{
${ }^{153}$ AHPBU. Sección Protocolos. Caja 7394, 23 de enero de 1843.

${ }^{154}$ Ibídem, 4 de marzo de 1843.

155 Ibídem, 3 mayo de 1843.

${ }^{156}$ Ibídem, 20 de junio de 1843.

157 Ibídem, 4 de octubre de 1843.

158 MONJE MATE, M. C. La industria del libro en Burgos durante el siglo XX. En: L. S. IGLESIAS ROUCO, coord. Protagonistas burgaleses del siglo XX. Burgos: Diario de Burgos-Universidad de Burgos, 2000, v. I, pp. 145-150.

${ }^{159}$ VALERO DE TORNOS, J. España fin de siglo. Madrid: Romero Impresor, 1896, t. 2, p. 108.
} 
persona para ahorrarles este trance. La redención por una cantidad no estaba permitida, sino únicamente la sustitución, hasta 1851.

Su hermano mayor, Mariano Rodríguez Alonso, compra la suerte del soldado a un vecino de Villalmanzo, Lorenzo Medina, por la suma de seis mil reales:

En la ciudad de Burgos a veintiséis de febrero de mil ochocientos cuarenta y nueve ante mí el escribano de su número y testigos que se expresarán, Lorenzo Medina, soltero natural de Villalmanzo usando el consentimiento que para formalizar este instrumento obtuvo de su padre Francisco, vecino de dicho pueblo que se halla presente dijo: que tiene convenido con D. Mariano Rodríguez vecino de esta ciudad el sustituir la suerte de soldado que a D. Santiago Rodríguez, hermano del D. Mariano le ha cabido en el último sorteo, celebrado en esta capital, con calidad de que el indicado D. Mariano le ha de satisfacer y satisfará seis mil reales en metálico, de esta forma; los mil de presente tan luego como ingrese en caja a razón de setecientos catorce con diez maravedíes, en cada uno de ellos, pero si antes de finalizar los siete años, muriese el Lorenzo, si se inutilizare, entonces el D. Mariano entregará inmediatamente y en una sola partida la cantidad que adeudare, de los seis mil reales mencionados, ya sea al Lorenzo o a su legítimo representante y tan luego como aquel sea licenciado por haber servido los siete años en la milicia o por cualquier otra razón se dará el D. Mariano, además de los reales citados un vestido completo de paisano, conjunto de chaqueta, chaleco y pantalón, camisa, sombrero y zapatos, aquella de paño pardo... ${ }^{160}$

La escritura deja patente el nivel social al señalar, con el tratamiento de don, a Mariano y Santiago Rodríguez frente al sustituto registrado simplemente como Lorenzo. La escritura se cancela el 8 de enero de 1855 al haber recibido Lorenzo Medina la licencia absoluta junto a los 6.000 reales y vestido.

Esta situación nos ilustra la influencia social de la familia, pues muy pocas tenían la solvencia económica para poder hacer frente a un pago tan elevado, según la oferta y la demanda del momento. Disponen de liquidez pero no de bienes materiales para hipotecar tal como preveía la Ley para el caso de deserción. En marzo de este año, D. Victoriano García, sale como fiador en caso de deserción del quinto sustituto de Santiago Rodríguez. En la fianza se señalaba una casa a su nombre en la calle San Juan número 7, en carta remitida al Alcalde de la ciudad D. Timoteo Arnaiz.

Victoriano García, vecino de la misma dijo que habiendo cabido la suerte de soldado en el reemplazo de este año y por esta ciudad a D. Santiago Rodríguez, soltero, hijo de D. Antolín, ya difunto, y de $D^{a}$ Luisa Alonso de la misma vecindad tiene por conveniente ser fiador para el sustituto que quiere presentar por si desertara en la cantidad que marca la Ley para cuya fianza designa una casa de su pertenencia sita en la calle San Juan número siete, con los surqueros siguientes: regañón casa de D. Fermín Aranzana, sub y mediodía calle pública, solano casa de D. José Tejada y cierzo con el jardín adyacente a la misma casa y el parque de

${ }^{160}$ AHPBU. Sección de Protocolos. Caja 7673, 26 de febrero de 1849. Vid. Anexo 2.1.8. Sustitución en la suerte de soldado de D. Santiago Rodríguez Alonso, el 26 de febrero de 1849. 
Artillería cuya finca vale más de cuarenta mil reales. En cuya atención se sirva admitirme la información de testigos que ofrezco a tenor de los particulares expuestos y hecha en la parte que baste y tomada razón en el oficio de hipoteca en donde resultara no estar gravada, ni hipotecada a pago de ninguna especie, se me entreguen las diligencias a los fines convenientes. Es justicia que pido, juro. Burgos marzo uno del año del sello... ${ }^{161}$

Los testigos fueron D. Higinio Carrera, de 52 años; D. Ángel Rincón, de 28 años; y Faustino La Peira, de 35 años; y el fiador, D. Victoriano García. Se presentaron en casa del Sr. Alcalde, a las diez de la mañana del primer día de marzo, después de la notificación a D. Francisco López Talaya, regidor provincial síndico de esta capital, para que ratificasen la declaración anterior.

Ese mismo año Mariano Rodríguez se convierte en apoderado de $\mathrm{D}^{\mathrm{a}}$ María Amalia Zamora de la Mota, viuda de D. Juan Modesto de la Mota, ministro jubilado del Supremo Territorial de Guerra y Marina.

La señora $D^{a}$ María Amalia Zamora de la Mota, viuda y vecina de esta ciudad a favor del licenciado D. Mariano Rodríguez Alonso vecino de la misma.

[...] viuda de D. Juan Modesto de la Mota, ministro jubilado que fue del Supremo Territorial de Guerra y Marina... poder especial... para que represente en todo y por todo la persona, acciones y derechos... y a su nombre siga y administre los predios rústicos y urbanos que le son debidos de esta provincia percibiendo aquellas que no estén encomendadas a su familia... perciba el importe de su asignación de viudedad y el de las mensualidades atrasadas y que vayan venciendo $[\ldots]^{162}$

Durante el reinado de Isabel II, los gobiernos liberales llevaron a cabo, progresivamente, el desmantelamiento del Antiguo Régimen, al principio ejecutado por los monárquicos reformistas y, finalmente, por un Gobierno liberal autoritario.

Las provincias, como Burgos en esta nueva situación política, tomaron un mayor protagonismo y autonomía de las autoridades centrales, buscando una representación directa de los órganos municipales y provinciales. ${ }^{163}$

En Burgos una pequeña clase media acomodada, con aspiraciones a ascender en la pirámide social, como en el caso de Antolín Rodríguez de la Torre, estaba formada por personas liberales que ejercen una actividad profesional o tenían un empleo público. A muchos de sus coetáneos se les reconoce el ascenso por la obtención de propiedades inmuebles. Sin

\footnotetext{
161 Ibídem, 5 de marzo de 1849.

162 Ibídem, 24 de octubre de 1849.

163 SAMANIEGO BONEU, M. Burgos en la etapa isabelina y en el sexenio revolucionario En: J. M. PALOMARES IBAÑEZ, dir. Historia de Burgos. IV Edad Contemporánea (1). Burgos: Caja de Burgos, 2002, pp. 133-222.
} 
LA EDITORIAL BURGALESA HIJOS DE SANTIAGO RODRÍGUEZ (1891-1936):

ANÁLISIS DE LOS LIBROS ESCOLARES

embargo, Antolín Rodríguez lo centró en dar una formación completa a sus hijos, lo que será para Santiago Rodríguez un hito fundamental en su vida. 


\subsection{UNA ILUSIÓN EMPRESARIAL JUNTO AL PROYECTO DE VIDA FAMILIAR}

\subsubsection{El entorno familiar de Santiago Rodriguez Alonso}

A partir de 1849 el clima político español se fue deteriorando como consecuencia del autoritarismo del gobierno. Esta situación impulsó el levantamiento de progresistas, del recién creado Partido Demócrata y de algunos sectores del moderantismo defraudados por el poder. El alzamiento, que contó con el apoyo popular y de distintos jefes militares, obligó a Isabel II a deshacerse de los moderados y entregar el poder al general Espartero. De nuevo se convocaron unas nuevas elecciones que fueron ganadas por los unionistas de O’Donnell y por los progresistas que gobernarían conjuntamente durante dos años.

Este Bienio progresista (1854-1856) no estuvo exento de numerosos conflictos. La epidemia de cólera, las malas cosechas y la subida del trigo hicieron que Espartero presentase su dimisión en 1856, tras lo cual la reina encargó a O’Donnell la formación de un nuevo gobierno que se materializó con la vuelta de Narváez y los moderados, hasta 1858.

Durante estos años la familia Rodríguez despliega una fuerte actividad. El hermano mayor, Mariano, sigue ejerciendo como abogado; su hermano Francisco, funcionario, oficial de $3^{a}$ de Hacienda en Navarra muere joven, el 16 de septiembre de 1850; ${ }^{164}$ Santiago Rodríguez Alonso inaugura su librería, aunque no disponemos de ningún dato en esos primeros años y su madre gestiona su patrimonio con la realización de préstamos con interés o hipotecarios.

En estos años nos constan numerosas escrituras de obligación de su madre Luisa Alonso y de su hermano Mariano Rodríguez. Un dato a destacar es la firma de su madre en muchas obligaciones de Mariano Rodríguez. Esto nos hace pensar que su hijo dio un poder notarial para su representación, como aparece en una venta judicial realizada por D. Policarpo Casado y otros curiales de esta Audiencia Territorial en favor de D. Félix Sanz, vecino de Castrillo de la Reina, por dos tierras sitas en su término municipal, por 440 reales de vellón.

En la ciudad de Burgos a treinta de diciembre de mil ochocientos cincuenta y cuatro, comparecieron ante mí el infrascripto escribano de S.M. del número de la misma y testigos que se dirán los Sres. D. Policarpo Casado, licenciado, Don

\footnotetext{
${ }^{164}$ Su madre Luisa Alonso solicita la liquidación como heredera de los bienes de su hijo, dando poder a D. Juan José Egozme, jefe de la contabilidad de Hacienda en Navarra. Ver: AHPBU. Sección Protocolos. Caja 7674, 5 de octubre de 1850 .
} 
Manuel Andrés, $D^{a}$ Luisa Alonso, viuda, madre de D. Mariano Rodríguez Alonso, D. Lorenzo García Esteban, Don Benigno González de Castro, D. Eustaquio Pedrero, D. Luis de León, Don Ángel Revilla y D. Pedro Saiz, todos de esta vecindad a quienes doy fe conozco y dijeron: que en la causa criminal formada en el Juzgado de Salas y ejecutada en esta Excma. Audiencia Territorial contra Narciso Villa y Eladio Gómez, vecinos de Castrillo La Reina sobre la muerte de Ignacio García de igual vecindad intervinieron en los respectivos conceptos de abogados, procuradores, escribano, relator, tasador, portero y alguacil y habiendo sido condenado los reos al pago de costas librada la correspondientes certificación por el pago... ${ }^{165}$

En otras ocasiones, Luisa Alonso y su hijo prestan dinero sin interés, pero con hipoteca de bienes. Durante 1851 realizan tres préstamos de 6.489 , 6.600 y 4.000 reales cada uno, inscritos ante el notario Emeterio González; el primero a principios de año, y los otros dos en el mes de noviembre. En el año de 1852 encontramos un mayor número de préstamos con cantidades menores, aunque su importe final de 16.510 reales no dista excesivamente del correspondiente al año anterior. Lo mismo ocurre con los años 1853, con 12 préstamos con un total de 11.386 reales y en 1854 con el mismo número de préstamos y un total de 18.165 reales. Durante el siguiente año sólo se realizan 3 préstamos, con un total de 8.890 reales. El último año del que constan documentos, 1856, ascienden a 24 préstamos con importes más bajos y con un total de 15.615 reales. ${ }^{166}$

La mayoría de los préstamos son a favor de Mariano Rodríguez Alonso, otros a favor de Luisa Alonso y algunos se inscriben como de ambos. Se realizan a personas de la provincia, principalmente de zonas cercanas a la ciudad:

Obligación de Fernando y Blas Martínez de Atapuerca como principal y fiador a pagar a D. Mariano Rodríguez. Alonso o a su Sra. Madre D ${ }^{a}$ Luisa Alonso viuda para el ocho de septiembre del propio año setecientos setenta reales sin interés. ${ }^{167}$

Luisa Alonso arrienda las fincas familiares en Isar en el año 1853 y nueve años siguientes, por un precio de 20 reales y libres de contribución. ${ }^{168}$ Es una mujer con recursos que toma la iniciativa y no duda en utilizar todos los medios disponibles para reclamar las cantidades que se le deben. Como ejemplo de ello da poder a su convecino Marcos López y a D. Julián Tomé, procurador del juzgado de $1^{\mathrm{a}}$ instancia de Castrojeriz, para que en la Alcaldía de Villamedianilla demanden a juicio verbal a Victoria

\footnotetext{
165 AHPBU. Sección Protocolos. Caja 7718, 30 de diciembre de 1854.

${ }^{166}$ Ver en: AHPBU dentro de la sección de protocolos los correspondientes a dichos años con el notario

D. Emeterio González.

${ }^{167}$ AHPBU. Sección Protocolos. Caja 7679, 9 de enero de 1854

168 AHPBU. Sección Protocolos. Caja 7676, 7 de noviembre de 1852.
} 
Palacios, vecina de la misma, en reclamación de 330 reales que se le adeuda desde el 4 de diciembre de $1854 .{ }^{169}$

Por esas mismas fechas, Santiago Rodríguez Alonso presta 2.120 reales a varios vecinos de Isar, algunos de ellos familiares lejanos, con obligación hipotecaria para pagar al año siguiente. ${ }^{170}$ Esto nos hace pensar en la buena marcha de la librería a pocos años de su inauguración.

En 1855 Mariano Rodríguez Alonso deja de ser apoderado del marqués de la Rambla, bien por el mayor número de trabajo como abogado o por los comienzos de su enfermedad. El nuevo desempeño lo realiza D. Manuel Argomaniz. ${ }^{171}$

Durante el año 1857 existen diversas escrituras para alargar el plazo de algunos préstamos, la mayoría ratificaciones. ${ }^{172}$ Sólo nos encontramos un préstamo, el siete de marzo de 1857, a Juan López y Ángela Merino, marido y mujer, vecinos de Cavia, a devolver a Mariano Rodríguez Alonso la cantidad de 550 reales, sin intereses. ${ }^{173}$ Hemos de suponer que la actividad de Mariano Rodríguez Alonso se vio mermada, ya que muere el 6 de junio de dicho año. ${ }^{174}$ (Figura 3-5).

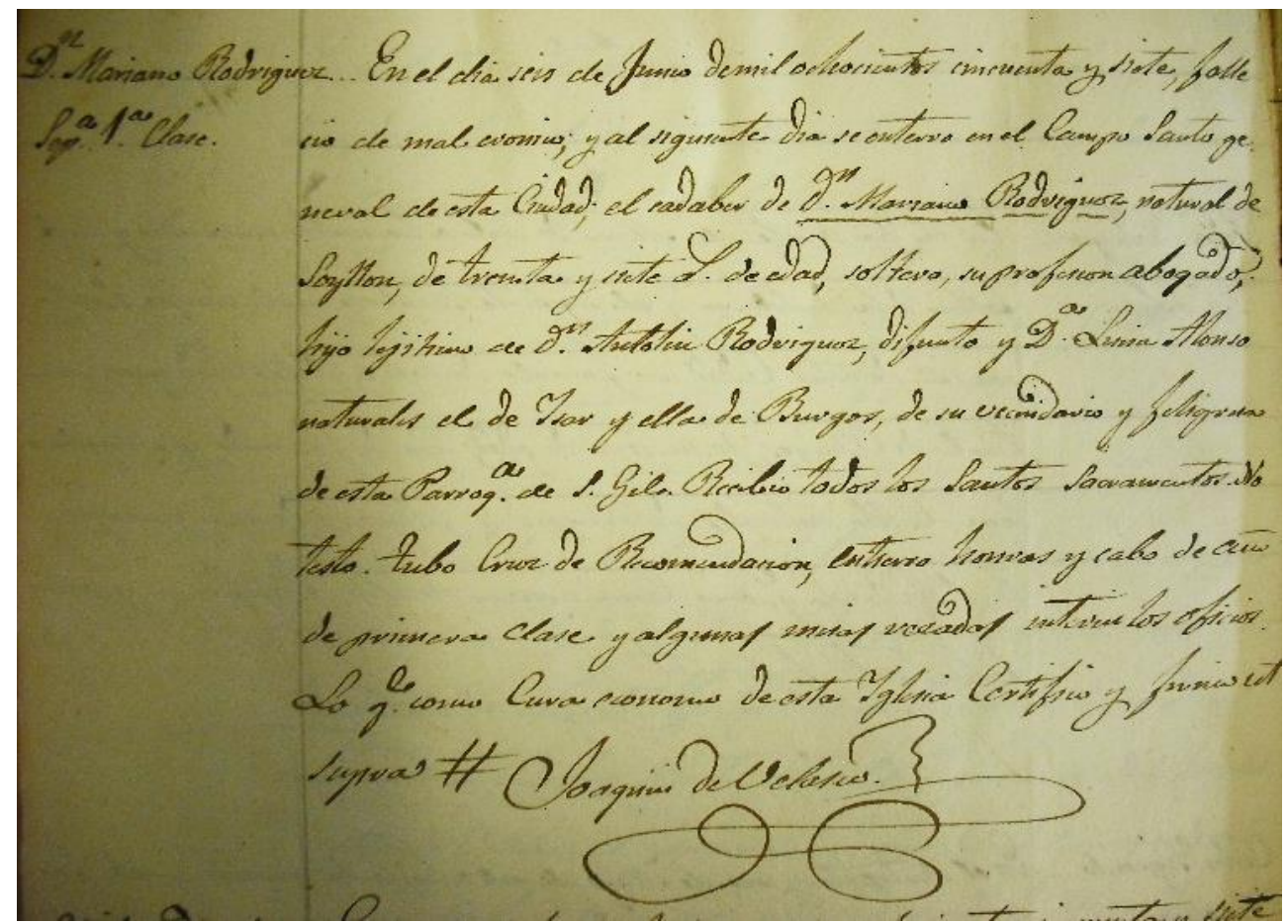

Fig. 3-5: Acta literal de defunción de Mariano Rodríguez Alonso.

Archivo Diocesano del Arzobispado de Burgos. (6-6-1857).

\footnotetext{
${ }^{169}$ AHPBU. Sección Protocolos. Caja 7683, 18 de enero de 1856.

${ }^{170}$ AHPBU. Sección Protocolos. Caja 7679, 28 de diciembre de 1854.

171 AHPBU. Sección Protocolos. Caja 7529, 28 abril de 1855.

172 AHPBU. Sección Protocolos. Caja 7686, 3, 13, 16, 25 y 26 de enero, 9 de febrero y 6 de marzo de 1857.

173 AHPBU. Sección Protocolos. Caja 7686, 7 de marzo de 1857.

${ }^{174}$ ADBU. Parroquia de San Gil de Burgos, Libro $5^{\circ}$ de finados, $13^{\circ}$ del 31 de diciembre de 1827 al 30 de enero de 1852, 6 de junio de 1857.
} 
A la muerte de Mariano Rodríguez, Luisa Alonso se hizo cargo de todos los pagos que le deben, acostumbrada a realizar este tipo de gestiones que ya desempeñaba desde su viudedad. En el año 1858 sólo constan escrituras con poderes para que diversas personas pudieran enjuiciar y litigar sobre las deudas debidas a su hijo Mariano Rodríguez Alonso. ${ }^{175}$

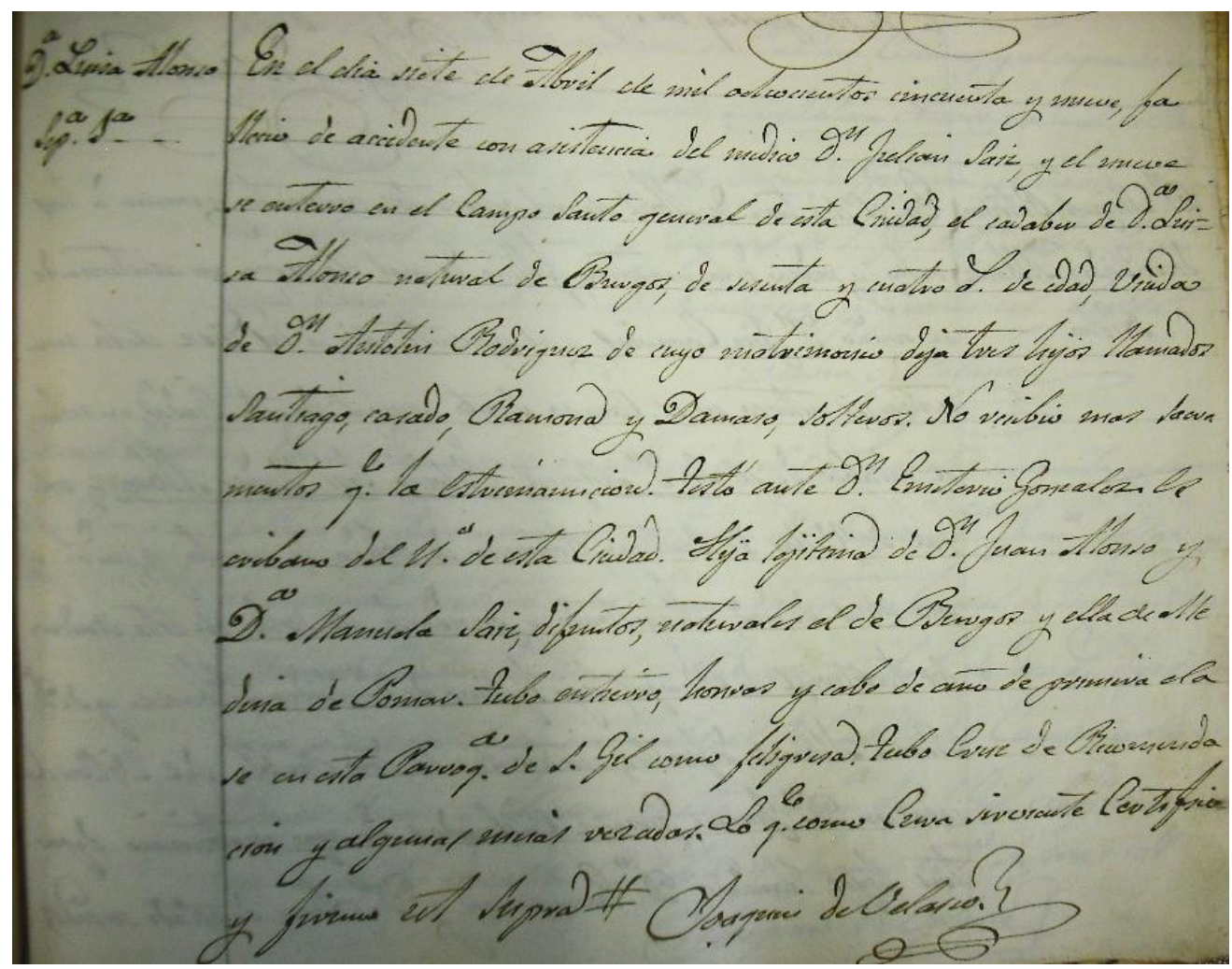

Fig. 3-6: Acta literal de defunción de Luisa Alonso Saiz. Archivo Diocesano del Arzobispado de Burgos (7-4-1859).

Su madre muere el 7 de abril de 1859 (Figura 3-6). En el testamento especifica que Santiago tiene adelantados seis mil quinientos reales y que, de los veinticuatro mil que dejó su hijo Mariano Rodríguez Alonso, corresponde a Ramona Rodríguez Alonso un tercio por vía de mejora. Del resto de sus bienes dejaba el tercio y quinto para protegerla en el futuro por su situación de soltería. Lo demás lo disponía por partes iguales a sus tres hijos: Ramona, Santiago y Dámaso.

En la ciudad de Burgos a diez y ocho de octubre de mil ochocientos cincuenta y ocho, ante mí el Escribano de su número y testigos que se expresarán, $D^{a}$ Luisa Alonso viuda y vecina de ella, dijo que es hija legítima de D. Juan y $D^{a}$ Manuela Saiz difuntos vecinos que fueron de esta población...Declara haber estado casada en primeras y únicas nupcias con D. Antolín Rodríguez en cuyo matrimonio procrearon diferentes hijos de los cuales viven hoy $D^{a}$ Ramona, D. Santiago y $D$. Dámaso Rodríguez y Alonso; éste y la $D^{a}$ Ramona solteros mayores de edad y el D.

175 AHPBU. Sección Protocolos. Caja 7689, 29 de abril, 1 de mayo, 6 de septiembre de 1858. 
Santiago casado, quien tiene recibidos por cuenta a su haber seis mil quinientos reales según consta de recibo sin que los otros dos hayan recibido cosa alguna...

Cumplido y pagado que sea este su testamento del remanente de todos sus bienes derechos y acciones nombre e instituye por los únicos y universales herederos a sus nominados hijos $D^{a}$ Ramona, D. Santiago y D. Dámaso Rodríguez Alonso para que les hagan y hereden por iguales partes con la bendición de Dios y la suya.

También declara que al fallecer su otro hijo D. Mariano Rodríguez Alonso dejó por caudal suyo propio veinte y cuatro mil reales, disponiendo que el tercio de ellos lo percibieron por vía de mejora su hermana $D^{a}$ Ramona y sin embargo de que su disposición no fue escrita y en este extremo solo afectaba los derechos de legitima que como a madre correspondían a los testadores según las leyes, quiere y es su voluntad que sea respetada la dicha mejora deduciéndose después de su muerte los ocho mil reales que sobra sobre los veinte y cuatro mil citados reconoce pertenecer a su referida hija $D^{a}$ Ramona a quien sin perjuicio de la anterior declaración mejora en el tercio y quinto de sus bienes para proteger en la situación de infortunio en que pudiera quedar, rogándole que se recuerde de su anciana madre en sus oraciones... ${ }^{176}$

Su hermana Ramona ingresó en el Monasterio de las religiosas de San José de Burgos, ${ }^{177}$ el 31 de marzo de 1862, con una dote de 15.000 reales y en un documento ante el notario D. Valentín Díaz Güemes expresa su renuncia a todos los bienes y pertenencias actuales, desde ese momento hasta su profesión, ${ }^{178}$ a favor de sus dos hermanos Santiago y Dámaso Rodríguez por partes iguales.

Su hermano Dámaso residía en Burgos, según el Padrón del Vecindario en 1858 y 1859 , en Huerto del Rey 20, $2^{\circ}$ piso, y como oficio pone empleado. Los siguientes años reside en Alicante y la relación con su hermano Santiago se deteriora hasta tal punto de litigar contra él para reclamar el pago de unas cantidades adeudadas, hecho que se suscribe en un poder del 11 de marzo de 1868 a D. José Ortega, procurador de Alicante.

En el inventario de los deudores, a la muerte de Santiago Rodríguez, aparece Dámaso Rodríguez con una deuda de 1.104 pesetas. Al no poner un segundo apellido no se puede saber su autoría.

En la ciudad de Burgos a once de marzo de 1868 ante mi Fernando Monterrubio vecino de esta ciudad y Notario de su colegio, presentes los testigos que nombraré, comparece Don Santiago Rodríguez Alonso de treinta y ocho años de edad, del comercio, vecino de esta ciudad de cuyo conocimiento, profesión y vecindad doy fe y asegurando hallarse en el pleno uso de los derechos civiles y con

\footnotetext{
${ }^{176}$ AHPBU. Sección Protocolos. Caja 7690, 18 de octubre de 1858. Vid. Anexo 2.1.11. Testamento de D ${ }^{\mathrm{a}}$ Luisa Alonso.

${ }^{177}$ La comunidad de religiosas recibe a Ramona como religiosa de coro, voz y voto bajo las reglas y estatutos de este convento, prometiendo que le serán guardadas las consideraciones y preeminencias correspondientes.

178 AHPBU. Sección Protocolos. Caja 8277, 31 de marzo de 1862. Vid. Anexo 2.1.12. Recepción de la novicia D ${ }^{\mathrm{a}}$ Ramona Alonso en la comunidad de Religiosas de San José de Burgos.
} 
la capacidad legal para otorgar este instrumento dice: que su hermano Don Dámaso, empleado y residente en Alicante, le es en deber cierta cantidad procedente de entregas en metálico que le ha hecho y pagos también en metálico hechos por cuenta suya para cuya cobranza ha deliberado autorizar una persona de su confianza mediante no serle posible verificarlo por sí propio y al efecto .... Otorga: que da y confiere todo su poder cumplido... a Don José Ortega procurador del juzgado y vecino de Alicante...reclame a Don Dámaso Rodríguez Alonso las cantidades que es en deber al Señor otorgante para lo cual le comunicará las noticias y antecedentes precisos por medio de la correspondencia particular y si por los medios de armonía no pudiese conseguir la cobranza la demandará por el juicio o juicios que procede con arreglo a derecho proveyéndose en su uso del certificado o certificados que fueren menester ante el Tribunal que pueden ocurrir el Señor otorgante en aquella capital y su partido autoriza al expresado procurador Don José Ortega Miralles con toda su amplitud celebrando al efecto juicios de conciliación y verbales, presentando escritos, pedimentos y documentos que tenga por convenientes haciendo pruebas justificaciones de toda clase oyendo las providencias que se dicten de las cuales consentirá las favorables... ${ }^{179}$

Aunque parte de sus parientes desaparecen, Santiago forma su propia familia al casarse con Irene Miguel Campo en $1858^{180}$ (Figura 3-7). Se conocen desde niños ya que los padres eran vecinos al residir en la Calle Alta $\mathrm{n}^{\circ} 28$ y n $^{\circ} 30$. $^{181}$

Sus padres fueron Miguel de Miguel Francés, catedrático de Latín y Lengua en el colegio de San Gil, ${ }^{182}$ y Andrea Campo. Tuvieron cinco hijas de las cuales cuatro contrajeron matrimonio. Eustaquia estaba casada con Antonio Sivelo, nacido en La Coruña y vecino de Valladolid, fue Comisario de Guerra y vivió algún tiempo en la calle Huerto del Rey no 16; su hermana Carolina, casada con Bartolomé Doés y Sentí; y Adelaida con José Molet y LLuch, de Vitoria, empleado y vecino de Vich en Barcelona; Irene, con Santiago Rodríguez; y Elisa, la menor, permaneció soltera para ayudar a sus padres en su ancianidad y posteriormente cuidará a la familia Rodríguez, cuando su hermana Irene muere joven, y formará parte de la misma hasta su fallecimiento.

\footnotetext{
179 AHPBU. Sección Protocolos. Caja 7752, 11 de marzo de 1868. Vid. Anexo 2.1.13. Poder de D. Santiago Rodríguez a D. José Ortega, procurador de Alicante, para litigar contra su hermano D. Dámaso Rodríguez, por deudas.

${ }^{180}$ ADBU. Parroquia de San Gil de Burgos, $14^{\circ}$ Libro de Casados 1852-1875, 27 de febrero de 1858. Al igual que el resto de sus hermanas recibe una dote que se especifica en un documento notarial. Vid. AHPB. Sección de Protocolos. Caja 7548/1, 20 de junio de 1875.

${ }^{181}$ AMBu. Sig. C-44/11. Listado general de 16 a 54 años. Año 1836.

${ }^{182}$ AHPBU. Sección de Enseñanza. Sig. 617/3. Colegio San Gil de Burgos. Libro de Bachilleres no 370, cursos 1861-1865.
} 


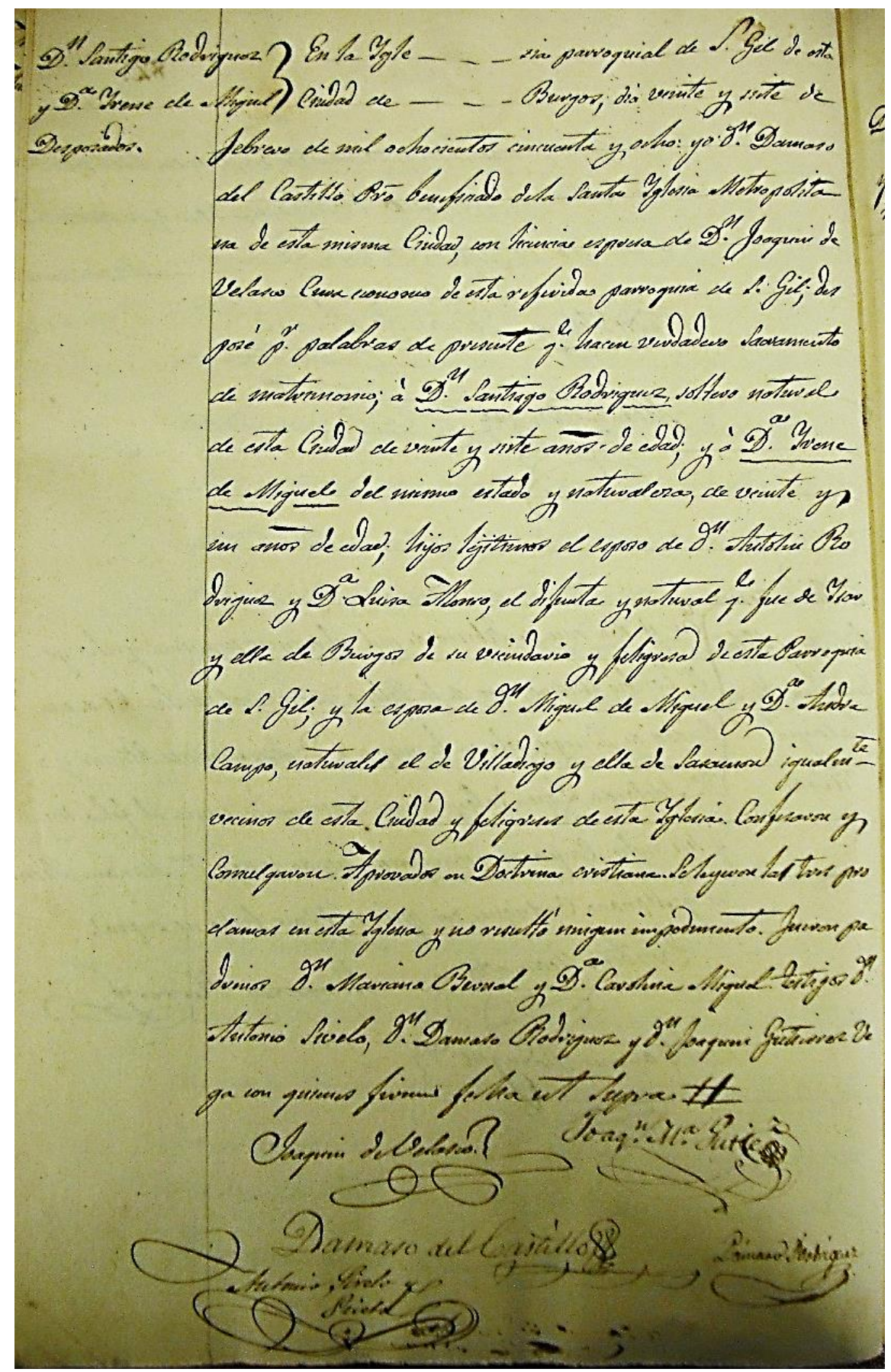

Fig. 3-7: Acta literal de matrimonio de Santiago Rodríguez Alonso con Irene de Miguel Campo. Archivo Diocesano del Arzobispado de Burgos (27-2-1858).

En el primer padrón del Vecindario de 1859 Santiago Rodríguez aparece en dos viviendas, en la calle Pescaderías número $6,1^{\circ}$ y en la Calle Huerto del Rey número 9, $1^{\circ}$; en esta segunda dirección figura Santiago Rodríguez como encuadernador. ${ }^{183}$ En ambas direcciones el núcleo familiar está formado por él mismo, su esposa Irene Miguel y una hija, Luisa, de un año, con la ayuda de una criada.

\footnotetext{
${ }^{183}$ AMBu. Padrones del vecindario. PA-2. Padrón del Ayuntamiento de Burgos, 1859.
} 
En este entorno van naciendo todos sus hijos: Luisa Rodríguez Miguel, ${ }^{184}$ Mariano Rodríguez Miguel, ${ }^{185} \mathrm{M}^{\mathrm{a}}$ del Pilar, ${ }^{186}$ Francisco, ${ }^{187}$ y $\mathrm{M}^{\mathrm{a}}$ de la Gloria. ${ }^{188}$

La situación en España con la muerte de Narváez y O’Donnell, en 1867 y 1868, las dos figuras centrales en la alternancia en los Gobiernos de España, junto a dos años de malas cosechas de 1866 y 1867, produjeron una enorme carestía que desembocó en la revolución Septembrina o La Gloriosa. Comenzó en Cádiz dirigida por los generales Prim y Serrano, a los que se unió el almirante Topete. La insurrección, liderada por los demócratas, tuvo un gran apoyo popular y se organizaron juntas revolucionarias en las ciudades.

Isabel II huyó a Francia y se formó un Gobierno provisional que convocó elecciones a Cortes Constituyentes en enero de 1869 para la elaboración de una nueva Constitución.

Para ocupar la corona el candidato elegido fue Amadeo de Saboya aunque abdicó en febrero de 1873; el establecimiento de la I República se convirtió en una salida pactada entre algunos partidos. Un nuevo pronunciamiento militar del general Martínez Campos, en diciembre de 1874 restauró la monarquía en la persona de Alfonso XII, hijo de Isabel II siendo su artífice político Antonio Cánovas del Castillo.

Santiago Rodríguez forma parte como regidor del Ayuntamiento de Burgos en esos años clave de 1865-66, 1869-1871 y 1873.

En el Padrón de Burgos de los años 1869-70 sigue viviendo en Huerto del Rey $\mathrm{n}^{\circ}$ 9, muy cerca de su comercio, donde consta la profesión de librero. Aparece su esposa Irene y sus hijos: Luisa, de 10 años, Mariano de 9 años, $M^{a}$ del Pilar con dos años, Francisco con 1 año, junto con Ricardo Espí Luengo, de 13 años, nieto de su tía Felipa Alonso. Completan su residencia dos sirvientas: Manuela Asenjo, de 23 años, y Desusa López, de

\footnotetext{
${ }_{184}$ ADBU. Parroquia de San Gil, Libro de bautizados, principios de noviembre de 1860 a 1 de enero de 1864, 28 de noviembre de 1858. Vid. Anexo 2.2.7. Acta literal de bautismo en la Iglesia parroquial San Gil en Burgos de Luisa Rodríguez Miguel.

${ }^{185}$ No se ha encontrado en el Archivo Diocesano el acta de bautismo de Mariano Rodríguez Miguel en ninguna de las parroquias cercanas a su vivienda. Un año antes nació otro niño que le pusieron el mismo nombre por lo que hemos de entender que falleció. En todos los documentos oficiales como en el Padrón de la ciudad y en las tarjetas de felicitación de la empresa a Mariano se reconoce la fecha de 8 de diciembre de 1860.

${ }^{186}$ ADBU. Parroquia de San Gil, Libro de bautizados, 6 de enero de 1864 a 23 de febrero de 1868, 17 de octubre de 1867. Vid. Anexo 2.2.9. Acta literal de bautismo en la Iglesia parroquial San Gil en Burgos de María del Pilar Rodríguez Miguel.

187 ADBU. Parroquia de San Gil, Libro de bautizados, del 25 de noviembre de 1868 a septiembre de 1872, 10 de septiembre de 1868. Vid. Anexo 2.2.10. Acta literal de bautismo en la Iglesia parroquial San Gil en Burgos de Francisco Rodríguez Miguel.

${ }^{188}$ Ibídem, 10 de enero de 1872. Vid. Anexo 2.2.11. Acta literal de bautismo en la Iglesia parroquial San Gil en Burgos de María de la Gloria Rodríguez Miguel.
} 
22 años; así como Nemesia, que está casada y es ama de cría, de 23 años. También figura Isidoro Lozano como dependiente de 23 años. ${ }^{189}$

A la muerte de Irene Miguel, el 10 de julio de $1874,{ }^{190}$ Santiago Rodríguez abandona su actividad en el Ayuntamiento y se centra más en su familia, en los círculos culturales y en su librería, con la creación e inversión en la imprenta. En esos años sus hijos mayores tienen 16 años, Luisa, 14 años, Mariano, los medianos 6 y 5 años, $M^{a}$ Pilar y Francisco, y la pequeña $\mathrm{M}^{\mathrm{a}}$ de la Gloria 2 años y medio.

Los padres de Irene Miguel con su hermana soltera, Elisa de 20 años, y el presbítero D. Dámaso del Castillo de 59 años, sacerdote perteneciente a la Catedral de la ciudad, ${ }^{191}$ viven muy cerca, en Huerto del Rey 24 , con la ayuda de una criada y un criado,

En los tres años siguientes fallecen los padres de Elisa y el sacerdote Dámaso del Castillo, ${ }^{192}$ por lo que ésta se traslada a la casa familiar de Santiago Rodríguez, hasta su ancianidad y muerte en 1930.

La primera que sale del núcleo familiar es Luisa Rodríguez Miguel al casarse con D. Valentín Jalón Gallo ${ }^{193}$ nacido el 14 de febrero de 1854, en Gumiel de Izán, en el seno de una familia influyente y acomodada. Ejerce como Secretario de la Audiencia Territorial de Burgos, cargo que desempeñó durante 36 años. Vive como propietario en la calle Almirante Bonifaz número $11,2^{\circ}$ hasta su fallecimiento, el 5 de mayo de 1918. Fue, desde su fundación, Presidente del Círculo Católico de Obreros. Su hermana, $\mathrm{D}^{\mathrm{a}}$ Marta Jalón, se casa con uno de los alcaldes constitucionales burgaleses más importante y querido de la época, D. Juan José Arroyo Ontoria. Luisa, al igual que su esposo, estaba entregada a actividades religiosas y caritativas. Realizaba acciones de apostolado en la Asociación de "Esclavas de Nuestra Señora de los Dolores", en la parroquia de San Gil, donde, desde su constitución en 1878 y con su director D. Fernando Linage, aparece como tesorera ${ }^{194}$ y vocal de la Junta de Protección a la Infancia. ${ }^{195}$

\footnotetext{
${ }^{189}$ AMBu. Padrones del Vecindario. PA-8, 1869-70.

${ }^{190}$ ADBU. Parroquia de San Gil de Burgos. $7^{\circ}$ Libro de difuntos 1867-1874, 10 de julio de 1874, f. 282.

191 AMBu. Padrones del Vecindario. PA-8, 1869-70. Los padres de la fallecida Irene Miguel Campo viven muy cerca de la casa de Santiago Rodríguez, en c/ Huerto del Rey $24,3^{\circ}$.

192 Miguel de Miguel el 12 de marzo de 1876, su mujer Andrea el 11 de junio de 1877 según la testamentaría con un legado de 1.921,25 pts. a favor de Elisa y aunque es menor que el que recibieron sus hermanas al casarse se conforma. Ver: AHPBU. Sección de Protocolos. Caja 7553, 21 de marzo de 1880. El sacerdote Dámaso del Castillo muere el 16 de enero de 1878, según se desprende de la testamentaría en la que lega por los cuidados recibidos a Elisa de Miguel 2.928 pts. Ver: AHPBU. Sección de Protocolos. Caja 7901, 29 de noviembre de 1878.

${ }^{193}$ Se decía que poseía una cuantiosa fortuna aunque la mayor parte de su tiempo y su dinero lo dedicó, junto al padre Salaverri (jesuita oriundo de Lugo que impulsó sindicatos católicos, constructoras benéficas, obras educativas y Cajas de Ahorros) a la obra social del Círculo Católico de Obreros de Burgos.

${ }^{194}$ EBRO, M. C. Memorias de una burgalesa (1885-1931). Burgos: Instituto Municipal de Cultura, 2004, p. 136.

${ }^{195}$ El Papa-Moscas. Año XXXVIII, no 1983, 20 de junio de 1915, p. 3.
} 
Aunque tienen varios hijos sólo sobrevive una hija, Teresa, que nace el 15 de octubre de 1885 y que posteriormente se casa con D. Fidel Dávila, ${ }^{196}$ siendo éste, a la muerte de su suegro, comandante del Estado Mayor y, posteriormente, ministro de guerra en la época Franquista.

Mariano Rodríguez se casa con Luisa Escudero ${ }^{197}$ el 4 de agosto de 1886. Se instalan en el mismo edificio en el que vivió su padre y, a su muerte, continuaron habitando sus hermanos y su tía. ${ }^{198}$

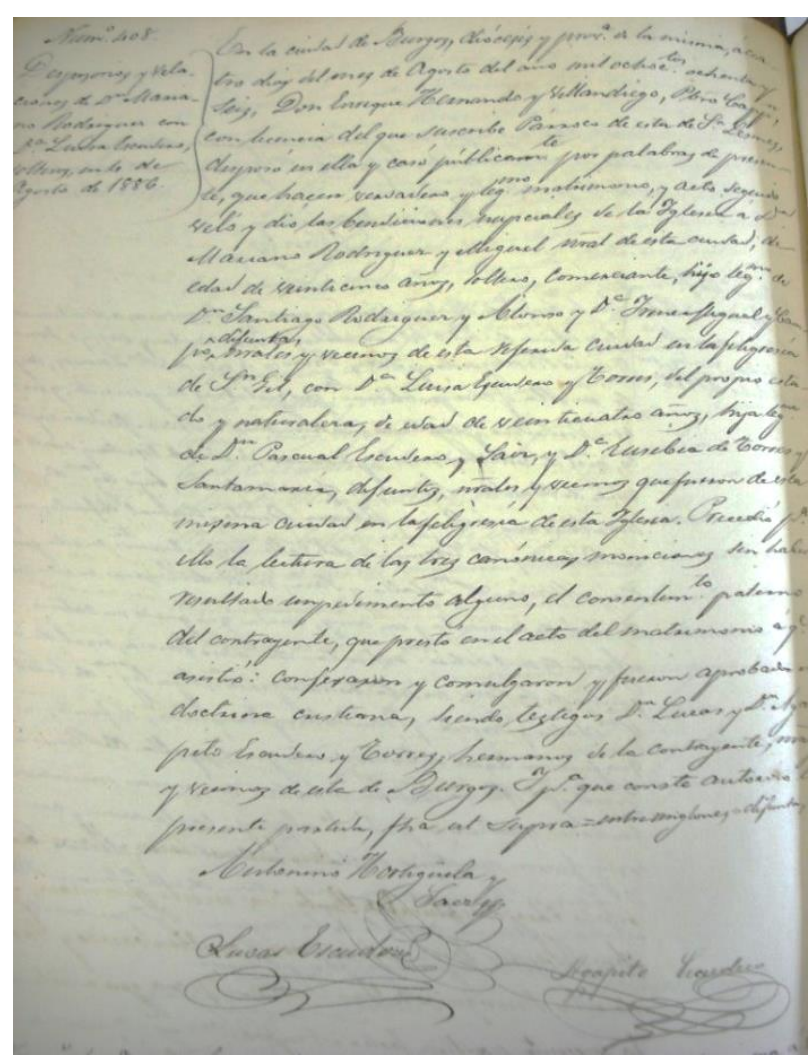

Fig. 3-8: Acta literal de matrimonio de Mariano Rodríguez Miguel con Luisa Escudero y Torres. Archivo Diocesano del Arzobispado de Burgos (4-8-1886).

En el censo del año 1890 Santiago Rodríguez vivía en la calle Laín Calvo $\mathrm{n}^{\mathrm{o}}$ 12, en el edificio de su negocio familiar, junto a sus hijos solteros: $\mathrm{M}^{\mathrm{a}}$ del Pilar, de 23 años; Francisco, de 22 años; y $\mathrm{M}^{\mathrm{a}}$ de la Gloria de 18 años. También reside su cuñada Elisa de Miguel, de 41 años; y dos sirvientas: Brígida Ibeas de Braceras de 26 años, y 8 años en la ciudad, y María Mena Ruiz de 23 años, de Quintanilla del Monte. Paga una contribución de 400 pts. ${ }^{199}$ según dicho censo.

\footnotetext{
${ }^{196}$ Parroquia de San Lesmes de Burgos. Libro de casados no 11 de 1902 a 1914, 4 de agosto de 1910.

197 ADBU. Parroquia de San Lesmes, 9 Libro de casados, 1873-1902; El Papa-Moscas. Año VIII, nº 400, 11 de octubre 1885, p. 2.

198 AMBu. Padrones del Ayuntamiento. PA- 82, 1894. Comprobamos que vivía en la misma calle y número, Laín Calvo 12, Mariano Rodríguez en el principal, y el resto de sus hermanos vivía en el entresuelo. En el mismo edificio tenían el negocio familiar de imprenta y librería.

${ }^{199}$ AMBu. Padrones del Vecindario. PA-36 y 37, Laín Calvo 12, 1º 1890.
} 
Muere meses después, el 9 de abril de 1891, a los 61 años y su funeral tuvo lugar en la parroquia de San Gil. La partida de defunción nos relata:

D. Santiago Rodríguez viudo de $D^{a}$ Irene Miguel.

En la ciudad de Burgos a 10 días del mes de abril del año 1891 yo el licenciado D. Tiburcio Peña, cura canónico de la Iglesia parroquial de San Gil Abad de la misma, mandé dar sepultura en el cementerio público de ella al cadáver de D. Santiago Rodríguez Alonso, natural y vecino de Burgos, feligresía de San Gil de sesenta y dos años de edad de estado viudo de $D^{a}$ Irene Miguel vecina que fue también de esta ciudad e hijo legítimo de D. Antolín Rodríguez y $D^{a}$ Luisa Alonso naturales el primero de Isar y la segunda de Burgos.

Murió el día anterior de una lesión de corazón a las 8 y 10 minutos bajo testamento que otorgó ante D. Fernando Monterrubio, notario público de esta ciudad. Deja cinco hijos llamados Luisa, Mariano, $M^{a}$ Pilar, Francisco y $M^{a}$ de la Gloria. Recibió los Santos Sacramentos de la Penitencia, Sagrado Viático y Extremaunción se le hizo entierro de $1^{a}$ clase con Cruz de Recomendación y acompañamiento del Cabildo hasta el cementerio con asistencia además del Cabildo de la parroquia de S. Esteban. Tuvo dos días de honras y misas de letra abierta. $^{200}$

200 Parroquia de San Gil de Burgos. $9^{\circ}$ Libro de difuntos 1889 a 1900, f. 45, 9 de abril de 1891. Vid. Anexo 2.2.15. Acta literal de defunción en la Iglesia parroquial de San Gil en Burgos de D. Santiago Rodríguez Alonso. 


\subsubsection{Fundación de la libreria y comienzos de la Casa Editorial}

Aunque no hay un registro escrito que nos indique el inicio de la casa mercantil, varias fuentes la datan en 1850. Sus propios hijos lo conmemoran en el Catálogo Recuerdo de su $75^{\circ}$ aniversario, en $1925 .^{201}$

Domingo Hergueta Martín, al hablar de las imprentas que hubo en Burgos durante el siglo XIX, la señala como "imprenta y librería que se funda en 1850 para la venta de libros". ${ }^{202} \mathrm{M}^{\mathrm{a}}$ Cruz Ebro en su libro de Memorias de una burgalesa data su fundación en $1850 .{ }^{203}$

La única fuente que lo sitúa en 1846 es el Diario de Burgos, en un artículo publicado en 1902 sobre las industrias burgalesas, aunque es del todo improbable ya que en ese año Santiago Rodríguez tendría 17 años, y permanecía en Madrid, lo cual nos hace pensar más en la primera fecha. ${ }^{204}$

Hemos de suponer que comienza su actividad con los 6.500 reales que en el testamento de su madre ponía como adelantados, como parte de su herencia. Fue una primera inversión para la compra del material necesario y el alquiler de la parte baja de un edificio en la calle Laín Calvo, llamado del Paso, en la esquina del Pasaje de la Flora. Este local, en adelante y en todos los escritos de la época, nos lo situará en la calle Laín Calvo, Pasaje de la Flora $\mathrm{n}^{\circ} 12$. Quizá, también pudiera ser la parte de la fianza que pagó su hermano al comprar la suerte de soldado que correspondía a los 6.000 reales más todo el vestuario a la salida del servicio para el sustituto.

Lo que resulta evidente es que su formación e ilusión en el proyecto de mejorar la sociedad burgalesa influyeron de forma muy positiva en el inicio de esta actividad, especialmente en la educación, como nos confirma la necrológica realizada en homenaje a su figura:

Desde el primer momento manifestó tal estimación por la enseñanza, por la educación y por el Magisterio, que no se dio momento de reposo hasta ver en su establecimiento todo cuanto de más notable más nuevo y más útil existía entonces para dicho ramo. Libros, menaje, aparatos de todo ofreció a los dignos maestros de la provincia.

Como no podía menos de suceder, desde el cariño que el señor Rodríguez profesaba a todo lo que con la enseñanza se relacionara, era uno de los propagandistas más activos de las nuevas ideas pedagógicas de su tiempo. ${ }^{205}$

\footnotetext{
${ }^{201}$ HIJOS DE SANTIAGO RODRÍGUEZ. Catálogo Recuerdo 1850-1925 [en adelante: CATÁLOGO 1925]. Burgos: Hijos de Santiago Rodríguez, 1925, 164 p.

${ }^{202}$ HERGUETA MARTÍN, D. La imprenta en Burgos y su provincia (1475-1920). Valladolid: Junta de Castilla y León. Conserjería de Cultura y Turismo, 2009-2010, T. IV, pp. 497-498. Ejemplar mecanografiado. Copia digital.

${ }^{203}$ EBRO, M. C. Op cit., p. 67.

${ }^{204}$ Diario de Burgos. Las industrias burgalesas, 11 de julio de 1902, p. 1. Vid. Anexo 2.3.2. Las imprentas burgalesas. Hijos de Santiago Rodríguez. Diario de Burgos.

${ }^{205}$ VALERO DE TORNOS, J. Op. cit., p. 108.
} 
La localización de su establecimiento es muy importante, basta recordar que las principales escuelas de educación primaria se situaban en sus alrededores, en las zonas céntricas de la ciudad y más concretamente entre la Plaza Mayor, calle Cantarranas, Paloma, Huerto del Rey, Laín Calvo. ${ }^{206}$ La mayoría son de carácter privado, con más de 1.200 alumnos/as y otras municipales, 4 en la primera mitad de siglo y 8 en 1867.

Con el nuevo Plan Pidal sobre las Enseñanzas Medias se crearon Institutos de Segunda Enseñanza, uno por cada provincia. En Burgos se decidió que se instalara en el viejo colegio de San Nicolás. Hasta 1849 no pudo estar operativo y es, durante el curso 49-50, cuando se abre el nuevo Instituto de Segunda Enseñanza Cardenal López de Mendoza. Aunque alejado de la zona céntrica, la mayoría de los alumnos que accedían al Instituto forman parte de la clase media y alta que residen en la zona centro, lugar donde realizan sus compras.

El primer dato encontrado sobre la librería nos la proporciona Luis Alberdi Elola en su libro Breverías Burgalesas:

En la sesión del Regimiento de Burgos, de 14-11-1856, se aprobaron las cuentas presentadas por Santiago Rodríguez, de encuadernaciones y papel de adorno para la Secretaría de la Corporación, por importe de 308 reales. ${ }^{207}$

Domingo Hergueta, al hablar de la publicación Caput Castellae, pone como punto de suscripción la librería y encuadernación de S. Rodríguez Alonso. ${ }^{208}$ En el Padrón del Vecindario de 1859, en el apartado del oficio u ocupación, lo sitúa como librero y encuadernador. En el Padrón del Vecindario de los años siguientes $(1860,1865,1869-70)$ aparece Santiago Rodríguez como librero.

En cuanto a los medios técnicos para la imprenta, Domingo Hergueta escribe que:

[...] hasta el año 1874, no adquirió la primera máquina tipográfica para tarjetas, anuncios, prospectos, etc., y, hasta el 12 de diciembre de 1879, no inauguró la máquina Bremmer para imprimir que trajo de Londres. ${ }^{209}$

Este primer dato sobre maquinaria adquirida en 1874, no podemos contrastarlo con ninguna otra fuente donde comparar y verificar este hecho; lo único reseñable, aunque no aparece la fecha, lo refiere $\mathrm{M}^{\mathrm{a}}$ Cruz Ebro cuando, al hablar de la imprenta librería de D. Santiago Rodríguez, nos

\footnotetext{
${ }^{206}$ SANTAMARTA REGUERA, J. La enseñanza primaria en Burgos (1875-1931). Burgos: Universidad de Burgos, 2000, p. 78.

${ }^{207}$ ALBERDI ELOLA, L. Breverías burgalesas. Burgos: Publicaciones del Excmo. Ayuntamiento de Burgos, Imprenta de Ediciones Aldecoa S.A., 1969. "Son artículos sobre temas locales, publicados en "La Voz de Castilla", del 25 de julio de 1967 al 26 de febrero de 1969.

${ }^{208}$ HERGUETA MARTÍN, D. Op. cit., T. IV, pp. 175-178. Habla de los encuadernadores de la ciudad: Rufino San Gonzalo en Huerto del Rey, 2 (es la más antigua); Jesús Pereda, en Laín Calvo 59, y Enrique Martínez en Laín Calvo 12 (es la más moderna).

${ }^{209}$ Ibídem, p. 64
} 
expone que trabaja con una pequeña "Minerva" de mano para imprimir tarjetas; la autora no sitúa la fecha, como sí lo hace Domingo Hergueta.

El 12 de diciembre de 1879 inaugura la máquina impresora Bremen importada de Londres. La prensa local, en el periódico El Papa-Moscas del día $14,2^{\circ}$ domingo de diciembre, explica que D. Santiago Rodríguez Alonso invita a un numeroso público, y entre ellos a la prensa, donde elabora un cartel a la vista de todos:

El viernes por la noche tuvimos el gusto de asistir, previa y galantemente invitados por el Sr. Rodríguez Alonso, al estreno de la máquina de imprimir que ha traído de Londres y que pone al servicio del público. Es de forma esbelta, bien construida y alcanza las últimas innovaciones conocidas. El papel se coloca con facilidad y economía de tiempo y tiene la ventaja de poderla parar cuando conviene, en todo o en parte, y en el momento que se desea.

A nuestra vista se hizo un cartel concebido en los siguientes términos:

SANTIAGO RODRIGUEZ Y ALONSO

SALUDA

A SUS COMPANEEROS DE INDUSTRIA

$Y$

DEDICA

EL PRIMER TRABAJO TIPOGRÁFICO DE SU

MÁQUIMA BREMMER

A LA CIUDAD DE BURGOS

$Y$ EN SU REPRESENTACIÓN A LA

PRENSA LOCAL

Felicitamos al Sr. Rodríguez, y le deseamos felices resultados, a la par que agradecemos su galantería para con la Prensa. ${ }^{210}$

El periódico Crónica de Burgos también describe la crónica anterior:

Por causas independientes de nuestra voluntad nos fue imposible asistir en la noche del viernes último el ensayo de la nueva y hermosa máquina inglesa, que acaba de montar en su imprenta el acreditado industrial Santiago Rodríguez. Alonso.

En la primera impresión que se hizo saludó el Sr. Rodríguez a sus compañeros de industria y a la prensa local, por lo cual así como por la galante invitación para que dicho acto recibimos, damos las gracias al nuevo impresor y le deseamos buena suerte. ${ }^{211}$

Fueron unos años -entre 1879 y 1890- muy importantes para la impresión y el comercio de libros, ganando terreno a las imprentas que hasta entonces habían tenido un mayor relieve en la ciudad. Se afianza y centra su trabajo en distintas publicaciones de prensa, en publicaciones para la enseñanza elemental y para diversas instituciones.

${ }^{210}$ El Papa-Moscas. Año II, no 94, 14-12-1879, p. 3. Vid. Anexo 2.3.1. Inauguración del estreno de maquinaria tipográfica en la librería e imprenta de Santiago Rodríguez Alonso.

${ }^{211}$ Crónica de Burgos. Año I, nº 205, 18 de diciembre de 1879, p. 1-2. 
En la propaganda de la Casa se puede comprobar cómo se especializa en libros para la primera enseñanza (Figura 3-9).

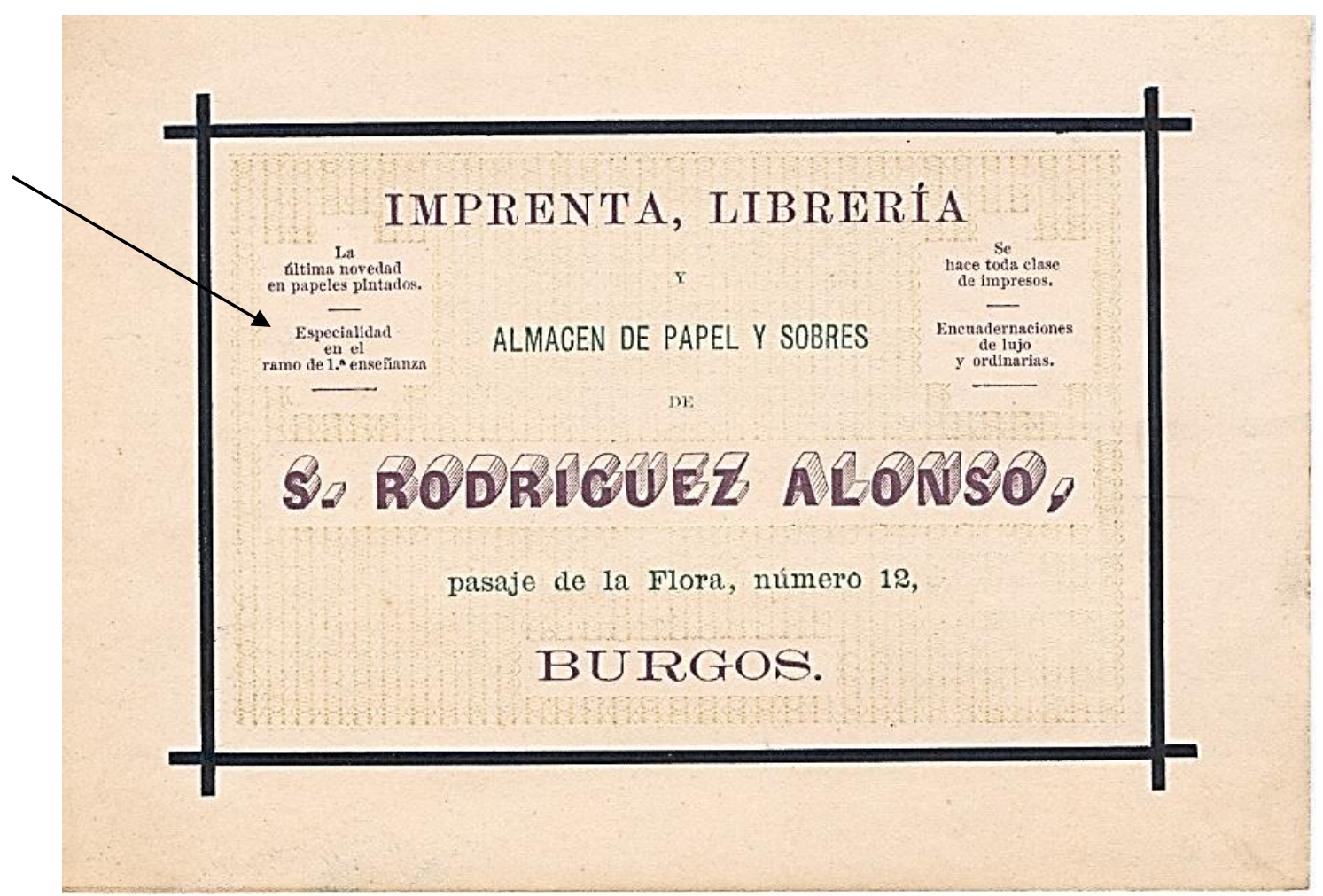

Fig. 3-9: Tarjeta de presentación de la Imprenta y Librería de Santiago Rodríguez Alonso. Cedida por Mercedes Rodríguez Plaza.

En diciembre de 1884, cuando Santiago Rodríguez Alonso alcanza 55 años deja un poder en el que autoriza a su hijo Mariano Rodríguez Miguel para que le represente en todos los asuntos de su comercio.

En la ciudad de Burgos a diecinueve de diciembre de mil ochocientos ochenta y cuatro ante mí D. Fernando Monterrubio vecino de la misma y notario de su Colegio presentes los testigos que nombraré comparecen: Don Santiago Rodríguez Alonso de cincuenta y cinco años de edad, viudo, comerciante y vecino de esta ciudad, según cédula personal que me exhibe y expedida con fecha dieciséis del presente mes y número trescientos sesenta y cuatro de séptima clase, el cual tiene a mi juicio la capacidad legal necesaria para celebrar este instrumento y dice: que con el fin de que los asuntos y negocios comerciales de su casa no sufran entorpecimiento ni alteración alguna y mereciéndole una ilimitada confianza su hijo Mariano ha resuelto autorizarle para que represente en toda clase de actos que pudieran ocurrirle y en que el Sr. otorgante tenga un interés directo o indirecto o se precise su intervención por cualquier concepto y a efectos con la más solemne forma de derecho otorga: que autoriza con el poder más amplio especial o general que por derecho se requiera al expresado su hijo Don Mariano Rodríguez Miguel, soltero, mayor de edad y que vive en su compañía para que le represente en todos los asuntos de su casa comercial del mismo modo que podía hacerlo por sí propio el Sr. otorgante si éste se hallare enfermo o ausente aunque no fuera de la población, de modo que podrá hacer compras, ventas o intervenir en todos los negocios del comercio con inclusión de los giros de letras, pagarés y otros efectos 
públicos, aceptar, endosar o pagar los mismos documentos, otorgar contratos públicos y privados, ejecutar en fin todos cuantos actos y diligencias requieran la marcha regular y acostumbrada de la casa en términos de que por falta de algún particular imprevisto se le ponga obstáculo alguno en el ejercicio de este cometido porque al efecto erige desde ahora a su citado hijo D. Mariano en su misma personalidad y aprueba y ratifica cuantos actos ejercite a nombre del Sr. otorgante; y si por cualquier caso o motivo fuera necesario parecen en juicio, le autoriza también para que dé respuesta en todos los actos de conciliación con avenencia o sin ella y en los juicios verbales y en actos de todas las clases, así civiles como criminales de jurisdicción voluntaria y gubernativa que pueda ocurrirle en los Tribunales de justicia y en las Oficinas del Estado, la provincia o el municipio, pudiendo en su virtud presentar instancias escritas y documentos, hacer pruebas, oír providencias y practicar cuantas diligencias judiciales o extrajudiciales sean necesarias sin reserva ni restricción alguna, pues el poder general o especial que para todo lo referido se requiera y demás que sea una incidencia o dependencia de ello, ese mismo da y confiere a su citado hijos D. Mariano Rodríguez. Miguel con la mayor amplitud y facultades $[\ldots]^{212}$

Mariano tiene 24 años y vemos como ya lleva las riendas del comercio, de la imprenta y librería.

El local original de Laín Calvo se queda pequeño, y busca ampliar el negocio en un nuevo establecimiento del Paseo de los Cubos. Lo inaugura invitando a diversas personas y a sus compañeros de prensa, según nos informa El Papa-Moscas, el miércoles 21 de septiembre de 1887. El nuevo local es muy amplio y espacioso permitiendo una mayor comodidad para la instalación de máquinas accesorias y cajas con tipos. Lo más señalado es la nueva compra de una máquina Marinoni, de grandes dimensiones, con gran velocidad y simplicidad en su mecanismo. ${ }^{213}$

Como nota curiosa, en el Ayuntamiento quedó registrada una denuncia junto con otros 11 vecinos sobre situaciones indecorosas que sucedían a la vista de éstos por culpa de un cantero que dejaba grandes piedras donde podían esconderse individuos para otras actuaciones. ${ }^{214}$ Esta acusación tuvo lugar el 14 de febrero, meses antes de la inauguración de su nuevo local.

Además de la compra de nuevas máquinas y accesorios, coloca anuncios en prensa para contratar a nuevos aprendices y a un cajista. ${ }^{215}$

La ampliación en Los Cubos deja un mayor espacio en el emplazamiento de la librería y, con su habilidad mercantil, no duda en vender papeles pintados para decorar habitaciones ${ }^{216}$ o la apertura de una

${ }^{212}$ AHPBU. Sección de Protocolos. Caja 7808, 19 de diciembre de 1884. Vid. Anexo 2.1.14. Poder de D. Santiago Rodríguez Alonso a su hijo Mariano Rodríguez Miguel para que le represente en todos los asuntos de la Casa.

${ }^{213}$ El Papa-Moscas. Año X. no 503, 2 octubre 1887, p. 2.

214 AMBu. Sig. 22-81, 14 de febrero de 1887.

${ }^{215}$ El Papa-Moscas. Año V, no 235, 13 agosto 1882 p. 1; Año VI, no 260, 4 febrero 1883, p.4; Año IX, no 448, 12 septiembre 1886, p.1.

${ }^{216}$ El Papa-Moscas. Año X, no 486, 5 junio de 1887, p.3. 
Expendeduría especial de tabacos de Filipinas. ${ }^{217}$ Vende todo tipo de papel de estraza en tamaño folio y doble folio, o bolsas timbradas con el anuncio que se desease, en todos los tamaños y con precios económicos. ${ }^{218}$

Santiago Rodríguez formó a numerosos aprendices. Sabemos que inició en el oficio de la imprenta a un joven llamado Hermenegildo Ortega que en 1900 se establece por su cuenta en Pradoluengo. ${ }^{219}$

Todos estos esfuerzos, en los últimos años de su vida, descubren el talante emprendedor y luchador para disponer de todos los nuevos avances técnicos en la impresión de los libros escolares. Esto nos hace pensar también que sus hijos apoyasen los proyectos e ilusiones de su padre pues encontramos publicidad de la nueva entidad Hijos de Santiago Rodríguez a los dos meses de su fallecimiento.

\footnotetext{
${ }^{217}$ El Papa-Moscas. Año XI, no 524, 26 febrero 1888, p.3.

${ }^{218}$ El Papa-Moscas. Año XII, nº 594, 12 mayo 1889, p.3.

${ }^{219}$ Fue la primera imprenta fundada en dicha villa y contaba con una Minerva de pedal y una guillotina donde elaboró varias obras junto con la impresión del periódico El Pradoluengo. En 1911 compró el taller de imprenta a José Sainz de Santo Domingo de la Calzada en Burgos, vendiendo la de Pradoluengo a Eusebio Martínez Echevarría. Conocemos este hecho por las crónicas que Domingo Hergueta nos explica en: HERGUETA MARTÍN, D. Op. cit., T. IV, p. 516.
} 


\subsubsection{Librerias en Burgos en la época de Santiago Rodriguez}

En Burgos, en el momento que Santiago Rodríguez inaugura su librería, existen distintas imprentas que llevaban funcionando varios años y editaban diversas publicaciones, eminentemente para uso local, ya sea de tipo administrativo, eclesiástico, judicial o militar.

La imprenta de Ramón Villanueva era una de las más antiguas, constituida a finales del siglo XVIII, situada en sus inicios en la calle Lencería, lugar predilecto de los impresores burgaleses y libreros, se traslada posteriormente a los Soportales de Antón. Su hijo Sergio Villanueva la ubica en la Plaza Mayor, $\mathrm{n}^{\circ}$ 2, de 1844 a 1855. Tuvo litografía y su viuda sigue con la misma desde 1868 a 1892.220

Durante este largo período de tiempo realizan diversas publicaciones, gran parte en periódicos locales:

- Boletín de la Provincia (1847 y 1850).

- El Cruzado (1844-1846).

- Revista Religiosa, Científica y Literaria de Castilla (1848-1849).

- Revista de los Tribunales y de la Administración (1850-56).

- Boletín Jurídico (1853).

- Fígaro (1879-80).

- El Heraldo de Castilla (1880-81).

- Boletín del Círculo de Obreros (1883-1887).

La mayoría de estas publicaciones fueron de índole religiosa; otras, sobre instituciones administrativas y de los Tribunales de justicia. ${ }^{221}$

Por otra parte, como señala Domingo Hergueta publica varias obras:

- Guía del Viajero en Burgos de Vicente García y García. ${ }^{222}$

- Apuntes sobre Burgos de Eduardo Augusto de Besson. ${ }^{223}$

En la última etapa, la viuda de Sergio Villanueva edita algunas obras relacionadas con la enseñanza: ${ }^{224}$ algún manual sobre lengua castellana,

\footnotetext{
${ }^{220}$ HERGUETA MARTÍN, D. Op. cit., T. IV, pp. 485-486.

${ }^{221}$ PÉREZ MANRIQUE, J. C. Prensa periódica en Burgos durante el siglo XIX. Burgos: Imprenta Editorial Aldecoa, 1996, pp. 49-53, 59-60, 61-64, 68-73, 77-79, 136-138, 146-148, 167-169.

${ }^{222}$ HERGUETA MARTÍN, D. Op. cit. T. III, p. 74. Encontramos en Burgos la obra Guía del viajero de Burgos de Vicente García en varias bibliotecas: una en la biblioteca pública de Valladolid, la $1^{\mathrm{a}}$ edición de 1862, y otros libros de la $2^{a}$ edición de 1867, se encuentran en la biblioteca pública de Aranda de Duero y en la biblioteca de Santo Domingo de Silos. El establecimiento tipográfico es de Blas González López.

${ }^{223}$ Ibídem, T. III, p. 44.
} 
lecciones de aritmética, ${ }^{225}$ cartillas silábicas ${ }^{226}$ y diversos estudios sobre la enseñanza de sordomudos en Burgos, entre otras muchas.

La imprenta de Timoteo Arnaiz se sitúa en la Plaza del Mercado ${ }^{\circ}$ 42, desde 1820, -actualmente formada por dos plazas: Libertad y Sto. Domingo de Guzmán- y compite fuertemente con la imprenta de Villanueva. Su titular fue uno de los alcaldes de la nueva burguesía y emprendedor de grandes proyectos de mejora en la ciudad, no exentos de beneficios personales.

Desde el 21 de septiembre de 1833 hasta el 30 de enero de 1844 se hizo con la impresión, venta y reparto del Boletín Oficial de la Provincia. Más adelante traslada sus talleres a la misma Plaza del Mercado en el número 17, donde imprime sus obras, hasta 1889.

Las publicaciones en periódicos locales ${ }^{227}$ más importantes fueron:

- Castilla (1844).

- El Amigo de la Provincia (1855).

- El Civilizador (1856-1862).

- El Fomento (1859-60).

- Álbum de la Academia de Ciencias, Artes y Bellas Letras en Burgos (1863-?).

- El Caballero de la Triste Figura (1868).

- Círculo de Moratín y El Papa-Moscas (1879).

- El Diablo Cojuelo (1880).

- Revista Burgalesa (1880-81).

- El Sereno (1882-89).

Imprime numerosas obras ya que formaba parte de varias sociedades, fue alcalde de la ciudad y tenía un gran interés por la enseñanza. Se rodea de colaboradores importantes, profesores, cronistas y abogados, como José Martínez Rives, Eduardo A. de Besson, Pascual Polo, Antonio Buitrago y Romero, Agustín García Nieto, etc.

La imprenta de Pascual Polo y Palacios en sus inicios tenía un local de la Catedral, alquilado desde 1835. Logró montar su propia imprenta en 1847, en la calle de la Paloma ${ }^{\circ} 35$. Hacia el año 1857 se traslada a la calle del Arco del Pilar $n^{\circ}$ 10. Su propietario Pascual Polo fue un gran literato y

\footnotetext{
${ }^{224}$ Ibídem, T. III, p. 84. Edita: Estudios teórico-prácticos sobre la enseñanza de sordomudos y de ciegos de Antonio Hernández Martínez, primer maestro de sordomudos en el colegio del Distrito Universitario de Valladolid, en Burgos. 1870.

${ }^{225}$ Ibídem, T. III, p. 117. Tratado auxiliar de aritmética decimal teórico práctica de Félix Esteban, profesor de instrucción primaria y superior. $2^{\mathrm{a}}$ edición. 1880.

${ }^{226}$ Ibídem, T. III, p. 136. Cartilla silábica teórico-práctica de Francisco Martín Aparicio. 1885.

${ }^{227}$ PÉREZ MANRIQUE, J. C. Op. cit. p. 60, 80-82, 87-90, 96-98, 100-103, 111, 123-133, 144, 153-154.
} 
humanista, y uno de los impresores más importantes de Burgos. A su muerte, en 1878, se encarga de la imprenta su hijo D. Pedro Polo Gómez. Imprime el Boletín Eclesiástico, así como numerosos trabajos para distintas entidades eclesiásticas.

Otras publicaciones de periódicos locales ${ }^{228}$ fueron los siguientes:

- El Boletín de la Provincia. (1844).

- El Mensual Farmacéutico. (1842-43).

- El Civilizador. (1866).

- Crónica de Burgos. (1878).

- Crónica Judicial de Burgos. (1880).

- El Sereno. (1882-91?).

También imprime en 1869 El Castellano Viejo, publicación de aspiraciones carlistas e identificado con el nuevo periodismo católico.

La mayoría de las imprentas se dedican mayoritariamente a trabajos de tipo religioso como la imprenta de Anselmo Revilla que, además de imprimir el Boletín Eclesiástico, publica muchos trabajos encomendados por la Archidiócesis: novenas, oraciones, devocionarios, manuales de doctrina cristiana. Con el nacimiento del nuevo Instituto de $2^{\mathrm{a}}$ enseñanza comienza a editar obras vinculadas con la educación como Programas de Historia de España, Programas de Geología agrícola, Curso de Retórica y Poética, Programa de segundo grado de Latín y Castellano.

La imprenta de Anselmo Cariñena comienza también en 1850, pero su labor editorial fue muy escasa. Publicó: ${ }^{229}$

- El Boletín de la Provincia durante los años, 1851, 1853 y 1858.

- El Papa-Moscas y El Secretariado en 1888.

- La Lealtad Burgalesa entre 1889-91.

Pocos datos más se conocen; Mariano Rodríguez Miguel la compró en $1913 .^{230}$

La imprenta y librería de Calixto Ávila tuvo su sede en la Plaza Mayor $n^{\circ} 41$. Publica el periódico local El Papa-Moscas durante su primera etapa, de 1866 a 1870.

\footnotetext{
${ }^{228}$ Ibídem, pp. 49-55, 81-82, 117-121, 149-151, 159-160.

${ }^{229}$ Ibídem, pp. 49-53, 123-133, 180-181, 182-183.

${ }^{230}$ HERGUETA MARTÍN, D. Op. cit., T. IV, p. 492.
} 
La imprenta de Gregorio Casañal sólo duró desde el año 1848 hasta 1850 y se la cita como del Boletín Oficial por haberse encargado de su publicación.

Hasta 1850 el Boletín de la Provincia se cedía por contrato anual a la imprenta que mejor puja realizaba en la subasta, hasta la creación ese año de la imprenta de la Diputación Provincial cuyo fin era imprimir el Boletín Oficial.

La litografía de Fournier hermanos, fundada en 1857, se especializa en trabajos litográficos: catálogos, invitaciones, obligaciones para sociedades, y sobre todo confección de naipes.

Existen otras imprentas, pero el número e importancia de sus publicaciones es pequeña o bien se iniciaron a finales del XIX o principios del siglo XX. 


\subsubsection{Publicaciones en periódicos locales}

Santiago Rodríguez imprime varias publicaciones de periódicos locales, como son: El Sereno, La Brújula, Cartas Burgalesas, Almanaque de la Ilustración, El Papa-Moscas, La Imparcialidad y El Anunciador Burgalés.

El Sereno es un periódico ilustrado que sale los domingos y días festivos. Según nos cuenta Domingo Hergueta comienza con un primer número el 5 de noviembre de 1882. Su director, D. Manuel Guerra lo dirige hasta 1884, en que le sucede D. Salvador Sancho. Después de un período de suspensión, desde el 14 de septiembre de 1884 hasta el 6 de mayo de 1888 , inicia su andadura en una segunda época bajo la dirección de D. Gregorio Gutiérrez y Martínez hasta su cierre definitivo el 29 de marzo de 1891. Tuvo numerosos colaboradores entre los que se destacaron: Fermín Gil, Juan Albarellos, Emeterio Gallo y notables ilustradores como lo fueron D. Evaristo Barrio y D. Isidro Gil.

Durante los años de publicación, los ejemplares se imprimieron en Santiago Rodríguez, Pedro Polo, Cariñena y Timoteo Arnaiz, desconociendo el momento exacto de la publicación en cada una de ellas. ${ }^{231}$

$\mathrm{Y}$ aunque no se define como conservador, lo cierto es que otro periódico La Brújula así lo declara: "El Sereno, periódico que no es conservador aunque lo parece... "232

La Brújula, periódico de tirada semanal en sus inicios, comienza saliendo los miércoles, desde noviembre de 1890, y continúa de forma bisemanal desde enero de 1891 hasta que interrumpe sus trabajos a finales de junio de 1891. Nace como órgano de expresión del Partido Liberal Fusionista de la provincia de Burgos, ya que la prensa del partido estaba pobremente representada, defendiendo la política del Sr. Sagasta, en la facción de Acosta.

Este periódico se imprime en la imprenta de Santiago Rodríguez y en la de Fernández y Santamaría. Las suscripciones se realizan en esta imprenta y en la de Ávila.

En la imprenta de Santiago Rodríguez se imprimen los 10 primeros números y éste coloca en la sección de anuncios una reproducción de sus tarjetas de propaganda, hasta mayo de 1891, después de su fallecimiento. En el último número publicado, el 27 de junio, aparece en el periódico publicidad como Hijos de Santiago Rodríguez.

Hace un homenaje a su recuerdo escribiendo unas emotivas palabras:

231 Ibídem, T. IV, p. 215.

${ }^{232}$ La Brújula, Año I, no 4, 3 de diciembre de 1890, p. 1. 
El jueves por la noche falleció a consecuencia de una afección al corazón, nuestro querido amigo el acreditado industrial de esta localidad Don Santiago Rodríguez Alonso.

$\mathrm{Su}$ muerte ha sido muy sentida en la población, donde podemos asegurar que tenía tantos amigos como conocidos y ni un solo enemigo, porque a lo agradable de su trato unía su laboriosidad y una honradez que le habían granjeado las simpatías de cuantos le trataron.

Enviamos a su apreciable familia el más sentido pésame. ${ }^{233}$

En la imprenta de Santiago Rodríguez se imprimen en su totalidad los 24 números del periódico dominical y semanal Cartas Burgalesas. Se publicaba los domingos, desde el 16 de noviembre de 1890 hasta el 26 de abril de 1891. Su director fue Andrés Ruiz Cobos que escribía bajo el seudónimo de Pedro Claridades. Se rodea de numerosos colaboradores: Isidro Gil, Evaristo Barrio, Jacinto Ontañón, Juan Albarellos, José de la Serna, Manuel Escolar, Gregorio Gutiérrez y el propio hijo de Santiago, Mariano Rodríguez. Éste último escribió un artículo titulado "Empeños". La suscripción se realizaba en la librería de Santiago Rodríguez y se califica a este periódico como semanario independiente. ${ }^{234}$

Santiago Rodríguez elabora el Almanaque de la Ilustración, redactado e ilustrado por los mejores escritores y artistas y encuadernado con una preciosa cubierta al cromo, con un precio de 8 reales. ${ }^{235}$

El Papa-Moscas fue fundado por el librero Calixto Ávila y dirigido por Cesáreo Hernando en su primera época, de 1866 a 1870. En la segunda de 1878 a 1920, su editor era Jacinto Ontañón, colaborador de la primera etapa que lo resucita dándole un carácter satírico.

El Papa-Moscas fue un periódico independiente que trató de defender los intereses de las clases medias contribuyentes. Políticamente es abierto, sin ser órgano de ningún partido político, y se mueve dentro del liberalismo criticando por igual a los gobiernos liberales y a los conservadores, aunque a éstos últimos con mayor dureza. Se basa en la defensa de los intereses económicos de Castilla; en cuanto al aspecto religioso es respetuoso, sin muestras de anticlericalismo. ${ }^{236}$

La suscripción se hacía en 1879 en la imprenta de Timoteo Arnaiz y en las librerías de Ávila y Santiago Rodríguez En 1881 se amplió la suscripción en la propia administración del periódico, en la calle Llana de Afuera, $\mathrm{n}^{\circ} 4,2^{\circ}$, en la farmacia Barriocanal de la calle del Cid, $\mathrm{n}^{\circ} 17$ y en la librería de Ávila, y Herce. A partir de 1882 se suscribía en todas las librerías de Burgos.

\footnotetext{
${ }^{233}$ La Brújula. Año II, $\mathrm{n}^{\circ} 35,11$ de abril de 1891, p.2.

${ }^{234}$ HERGUETA MARTÍN, D. Op. cit., T. IV, pp. 236-237.

${ }^{235}$ El Papa-Moscas. Año II, $\mathrm{n}^{\circ} 144,145$ y $146,3^{\circ}, 4^{\circ}$ y $1^{\circ}$ domingo de noviembre y diciembre de 1880.

${ }^{236}$ PÉREZ MANRIQUE, J. C. Op. cit., pp. 130-132.
} 
Se imprime en 1880 en la imprenta de Santiago Rodríguez Alonso, Pasaje de la Flora y a partir de $1^{\circ}$ de enero de 1881, y quedó encargado de la Sección de anuncios del periódico.

A consecuencia de contrato hecho con el señor D. Santiago Rodríguez, queda este encargado desde $1^{\circ}$ de enero próximo de la Sección de anuncios de este periódico, lo que se pone en conocimiento de los señores anunciantes.

Los que tienen contrato hecho con este periódico, pueden pasar por casa de dicho señor a tratar las renovaciones. ${ }^{237}$

En Burgos existían publicaciones para los maestros de la ciudad y provincia como La Guía del Maestro. En un principio, comenzó a partir de 1869, bajo la dirección de Julián Vega -hermano del catedrático de Burgos, Rafael Vega- que contrata colaboradores como Marcelino Goya, catedrático del Instituto de Burgos, y Agustín Ruiz Yanguas, maestro de primera enseñanza. Cuando su director se marchó destinado a Panamá siguió Antonio Álvarez Carretero. ${ }^{238}$ Se trataba de una Revista o periódico sostenido por docentes que desarrollaban sus actividades en distintos centros de la capital y que pretendía la mejora del magisterio. ${ }^{239}$ Desconocemos su duración pero si sabemos que en 1874 el profesor Antonio Álvarez Carretero funda La Imparcialidad, periódico que será el órgano de representación de las Asociaciones de Maestros de la provincia.

En octubre de 1882 aparece otro periódico con el título de $E l$ Magisterio Burgalés, redactado por los Sres. Díaz Rabago y Santos Monje.

El Papa-Moscas, en mayo de 1885, nos habla de las malas relaciones de ambas publicaciones: "La Imparcialidad anda a la graña con El Magisterio..."

Según Hergueta, en mayo de 1888, El Magisterio se refunde con La Imparcialidad. La nueva publicación conserva su título y como subtítulo "Revista de Primera Enseñanza". Sigue de director Antonio Álvarez Carretero, aunque no sabemos hasta cuándo perduró. Pero este dato contrasta con una noticia aparecida en el periódico El Papa-Moscas sobre los Certámenes Pedagógicos que organizaba el periódico La Imparcialidad donde nos dice que, en abril de 1888, uno de los premios era patrocinado por Santiago Rodríguez Alonso, dueño y propietario de dicha publicación. ${ }^{240}$

También Anselmo Salvá nos da algunos datos en la primera obra que escribió: Burgos a vuela pluma:

\footnotetext{
${ }^{237}$ El Papa-Moscas. Año II, no 149, 26 de diciembre de 1880, p. 4.

${ }^{238}$ HERGUETA MARTÍN, D. Op. cit., T IV, pp. 167-168.

${ }^{239}$ PÉREZ MANRIQUE, J. C. Op. cit., p. 109.

${ }^{240}$ El Papa-Moscas. Año XI, no 532, 22 de abril de 1888, p. 3.
} 
...hay periódicos buenos de instrucción primaria, entre ellos La Imparcialidad, el que D. Santiago Rodríguez ha sabido dar vida independiente y próspera, y hay, de vez en cuando, fiestas, certámenes pedagógicos. ${ }^{241}$

Juan Valero de Tornos nos explica en 1896 las motivaciones de Santiago Rodríguez para hacerse cargo de esta publicación:

Deseoso de servir más cumplidamente a los intereses de la enseñanza, adquirió la propiedad de la revista profesional La Imparcialidad, que ya de antiguo se publicaba en la ciudad del Cid, haciendo notables mejoras en la misma y estableciendo una inteligente y estudiosa redacción que publica los más interesantes trabajos pedagógicos, a la vez que sostiene las campañas más enérgicas en favor del bienestar moral y material de los maestros. En gran parte se le debe que sea ésta la única provincia de España que tiene satisfechas todas las atenciones de enseñanza. ${ }^{242}$

Hergueta asegura que en 1890 estaba bajo la dirección de Mariano Rodríguez Miguel y como propietario su padre D. Santiago Rodríguez

En la Ilustración del Profesorado Hispano Americano” acreditado periódico que publica en Madrid, hemos visto un buen retrato de nuestro infortunado amigo D. Santiago Rodríguez Alonso, director propietario que fue del colega local La Imparcialidad. $^{243}$

Ya en septiembre de 1892, Mariano Rodríguez es el propietario, después de la defunción del padre:

Por iniciativa del Sr. Rodríguez (D. Mariano) propietario de La Imparcialidad, el viernes se celebró una misa en la capilla del cementerio por el alma del periodista sevillano D. Lorenzo Leal y Ramírez Arias, como triste recuerdo de la prensa burgalesa, el infortunado compañero que falleció en el choque de trenes el 23 de septiembre del año pasado. ¡Rogad a Dios por él! $!^{244}$

Domingo Hergueta relata que Mariano Rodríguez cuenta con 4 colaboradores y dos empleados en la administración. La tirada es de 700 ejemplares, cuenta con 672 suscriptores y una entrega al año de 33.600 números. $^{245}$

Alberdi Elola en su libro Breverías burgalesas nos informa que se fundó en 1873.

"La Imparcialidad", "revista de primera enseñanza”, se dio a luz en 1873 y subsistía en 1889. Se publicaba cinco días al mes; era propiedad de Santiago

\footnotetext{
${ }^{241}$ SALVÁ PÉREZ, A. Burgos a vuela pluma. Burgos: Imprenta de la Revista de Provincias, 1889.

${ }^{242}$ VALERO DE TORNOS, J. Op. cit., v. 2, p. 108.

${ }^{243}$ El Papa-Moscas. Año XIV, no 700, 24 de mayo de 1891 p. 3.

${ }^{244}$ El Papa-Moscas. Año XV, no 770, 25 de septiembre de 1892, p. 3.

${ }^{245}$ HERGUETA MARTÍN, D. Op. cit., T. IV, pp. 172-173.
} 
Rodríguez Alonso y colaboraban en la misma Salvá, Díaz de Rábago y M. Añibarro. ${ }^{246}$

Otra publicación, El Anunciador Burgalés, con una tirada de más de 4.000 ejemplares, la comienza a publicar Santiago Rodríguez Alonso en cada feria de S. Pedro. Contiene una buena colección de anuncios del comercio burgalés y el programa de las ferias.

Este año ha aumentado en páginas El Anunciador Burgalés que publica por ferias en esta capital el Sr. Rodríguez Alonso, a quien agradecemos los ejemplares que nos ha remitido. Dicho señor se propone aumentar progresivamente el tamaño y la edición que ya es numerosa. ${ }^{247}$

Se reparte gratis desde 1878 .

A LOS INDUSTRIALES Y COMERCIANTES. Los señores que quieran insertar algún anuncio en el libro que con el título del ANUNCIADOR BURGALÉS se publicará como en años anteriores con objeto de repartirle en los días de ferias, pueden dirigirse a la Librería e Imprenta de Santiago Rodríguez Alonso. Pasaje de la Flora, donde se admiten dichos anuncios a los precios siguientes: Plana, 26 rs. $=$ Media, 14 rs. $=$ Cuarto, 8 rs. Tirada, 4.000 ejemplares. ${ }^{248}$

Se desconoce los años que se publica pero en 1882 en El Papa-Moscas recordaba que se acercan las ferias de San Pedro y San Pablo en Burgos y que podían mandar los modelos de los anuncios de todos los que lo deseasen. Con el título Anunciador Burgalés se venía publicando desde hacía cuatro años. Informaba que los precios y condiciones seguían siendo las mismas, con mejoras en la impresión y ampliación de la tirada a 4.000 ejemplares. ${ }^{249}$

\footnotetext{
${ }^{246}$ ALBERDI ELOLA, L. Op. cit., pp. 44-45.

${ }^{247}$ El Papa-Moscas. Año II, no 69, 4ª semana de junio de 1879.

${ }^{248}$ El Papa-Moscas. Año III, no 116, 117, 118 y 119, 16 de mayo al 21 de junio de 1880.

${ }^{249}$ El Papa-Moscas. Año V, no 222, 14 mayo de 1882, p. 1.
} 


\subsubsection{Obras primigenias}

Para conocer las obras publicadas en la imprenta de Santiago Rodríguez se ha utilizado un rastreo por las diferentes bibliotecas públicas de España, en periódicos locales y en la obra inédita mecanografiada, documento de gran riqueza informativa, de Domingo Hergueta: Imprenta de Burgos y su provincia (1475-1920).

\subsubsection{Obras escolares}

\section{MATEMÁTICAS}

\section{- Lecciones de Aritmética.}

Autor: D. Adrián Larrea Martínez.

Esta obra fue aprobada por Real Orden de 13 de abril de 1883 para su uso en las escuelas de primera enseñanza.

Burgos 1882. ${ }^{250}$

- Sistema métrico y decimal.

Autor: D. Cástor Palacios, maestro superior de primera enseñanza.

El libro contiene el sistema monetario actual, reducción de unas medidas a otras y equivalencias de precios de las unidades del sistema antiguo con las actuales.

Impreso en tamaño $8^{\circ}$, con 31 páginas. ${ }^{251}$

Burgos 1884.

- Tablas de reducción de las pesas y medidas de Burgos a las del sistema métrico decimal. ${ }^{252}$

Autores: Antonio Álvarez Carretero y Agustín Ruiz Yanguas.

Burgos 1883.

Existe una reedición en $1887 . .^{253}$

- Compendio de Aritmética.

Autores: D. Jorge García de Medrano y D. Clemente Fernández.

Fue aprobado para servir de texto en las escuelas, por Real Orden de 6 noviembre de $1852,{ }^{254}$ y de 5 de mayo de 1879.255

${ }^{250}$ VILLALAÍN BENITO, J. L. Op. cit., T. III, p. 80.

Menciona que la obra fue editada en Burgos y Domingo Hergueta la describe como obra de la Imprenta y librería de S. Rodríguez Alonso. HERGUETA MARTÍN, D. Op. cit., T. III, p. 122.

${ }^{251}$ HERGUETA MARTÍN, D. Op. cit., T. III, p. 136.

${ }^{252}$ El Papa-Moscas. Año VI, no 286, 5 agosto 1883, p.2. Explica que contiene las reducciones de varas a metros, arrobas a kilogramos, kilos de aceite y vino a litros, reducción de monedas y precios y una explicación de las unidades principales del sistema métrico. Se vende a 20 céntimos de peseta.

${ }^{253}$ El Papa-Moscas. Año X, no 488, 19 de junio de 1887, p. 3. 
Burgos 1888.

Edición: $29^{a}$ edición corregida y aumentada. ${ }^{256}$

Impreso en tamaño $15 \mathrm{~cm}$, de 38 páginas (Figura 3-10).

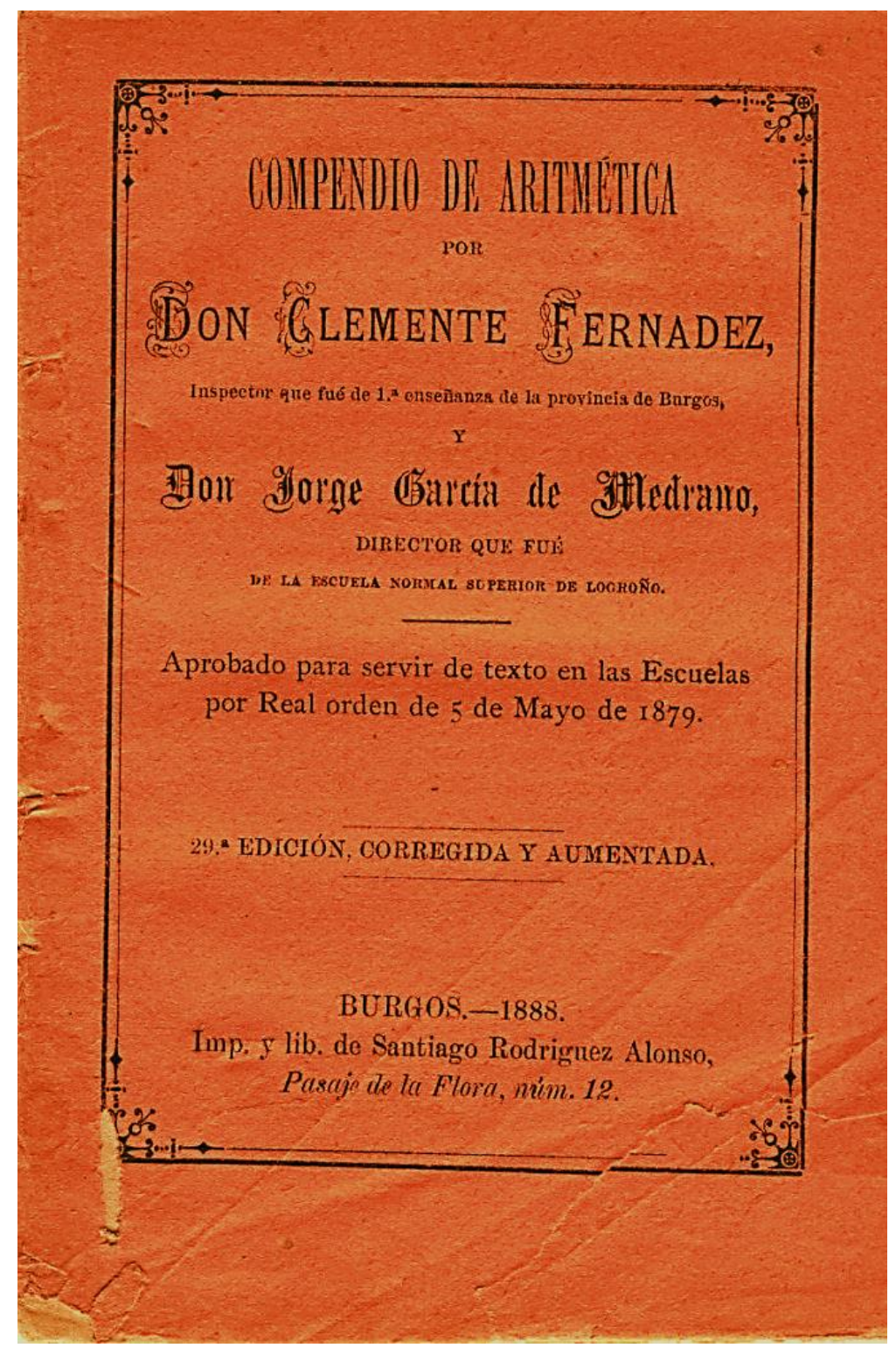

Fig. 3-10: Cubierta de la obra Compendio de Aritmética. $29^{a}$ edición. Imprenta y librería de Santiago Rodríguez Alonso. 1888.

\footnotetext{
${ }^{254}$ VILLALAÍN BENITO, J. L. Op. cit. T. II, p. 238.

${ }^{255}$ Ibídem, p. 44.

${ }^{256}$ De la edición realizada en la Imprenta y librería Santiago Rodríguez se conservan varios ejemplares en las Bibliotecas Públicas de Castilla y León. La impresión más antigua data de 1888 siendo su $29^{\mathrm{a}}$ edición. Se encuentra en la Biblioteca Pública de Valladolid en la sección Estudios Castellanos y Leoneses, con la signatura G-F 15383, de la Imprenta y librería Santiago Rodríguez Alonso. Domingo Hergueta nos habla de una $30^{\mathrm{a}}$ edición de 1890 en el T. III en las páginas 158-159. El resto de las ediciones pertenecen a la editorial Hijos de Santiago Rodríguez de Burgos, impresas en 1903, 1907 y 1912, de las que se conservan en la Biblioteca Pública de Burgos y en la Biblioteca de la Diputación de Burgos.
} 
D. Jorge García de Medrano fue director de la Escuela Normal Superior de Logroño, e inspector de Instrucción Primaria de Navarra. D. Clemente Fernández fue director de la Escuela Normal de la Provincia de Logroño e inspector de Primera Enseñanza en la Provincia de Logroño y de Burgos. Estos autores publicaron otra obra ampliada de la anterior, bajo el título Nociones generales de aritmética teórico-práctica impresa en 1849, -su primera edición- en la Imprenta de Domingo Ruiz de Logroño. ${ }^{257}$ La obra estaba destinada a la enseñanza de los niños que concurrían a la Escuela Normal de la provincia de Logroño y acomodada a todas las escuelas elementales de instrucción primaria. Formaba parte de las obras aprobadas para servir de texto en las escuelas de primera enseñanza. Fue premiada con diploma de $1^{\mathrm{a}}$ clase en la Exposición logroñesa de $1880 .{ }^{258}$

\section{LENGUAJE}

- Lecciones de ortografía y prosodia castellanas.

Autor: D. Adrián Larrea Martínez.

Burgos 1882.

Fue aprobada como texto para las escuelas de primera enseñanza según Real orden de 19 de marzo de $1886 .{ }^{259}$ Domingo Hergueta menciona como editora de la obra a la imprenta de Santiago Rodríguez. ${ }^{260}$

Se conserva la $2^{a}$ edición de 1883 , con 48 páginas en la Biblioteca Pública de La Rioja y la $4^{\text {a }}$ edición de 1889 , con el mismo número de páginas, en la Biblioteca Eclesiástica de la Abadía de Santo Domingo de Silos en Burgos. Ambos ejemplares aparecen como editadas en la imprenta de Timoteo Arnáiz.

- Compendio de Prosodia y Ortografía castellanas para uso de las Escuelas de instrucción primaria.

Autor: D. Víctor Giménez de V. y Mingo (maestro de la Escuela pública de niños de Villahoz).

Burgos 1882.

La obra fue premiada en la Exposición Pedagógica Nacional de Madrid. Se vendía a 2 reales ejemplar y 20 la docena, en Villahoz, en la casa del autor; en Burgos, en la imprenta y librería del Sr. Rodríguez Alonso; en Lerma, en la librería de Cobos Caballero; en Villarcayo y Pampliega en las

\footnotetext{
257 Ver: Biblioteca Digital Hispánica.

${ }^{258}$ En el prólogo de la obra expone la buena acogida de la obra, aprobada para texto en las escuelas y premiada con diploma en la Exposición de Logroño. Ver: FERNÁNDEZ, C., GARCÍA DE MEDRANO, J. Nociones generales de aritmética teórico-práctica. Burgos: Hijos de Santiago Rodríguez, 24ª edición, [19--], prólogo.

${ }^{259}$ VILLALAÍN BENITO, J. L. Op. cit., T. III, p. 148.

${ }^{260}$ HERGUETA MARTÍN, D. Op. cit., T. III, p. 122.
} 
casas de dos compañeros suyos, el profesor D. Manuel Palacios y D. Leoncio Grijalvo, respectivamente. ${ }^{261}$

No se puede asegurar si fue realizada en la imprenta del Sr. Rodríguez ya que no disponemos de ningún ejemplar pero, de todos los lugares citados, es el único lugar de venta con imprenta.

- El progreso: silabario teórico-práctico. ${ }^{262}$

Autor: D. Víctor Giménez de V. y Mingo.

Burgos 1884. $1^{\mathrm{a}}$ edición. Tamaño: 24 p.; $16 \mathrm{~cm}$.

Fue aprobada como texto de primera enseñanza, según Real Orden de 20 de diciembre de 1886.

- Método ingenioso para poder enseñar los tiempos del verbo gramatical. ${ }^{263}$

Se desconoce el autor/a. Burgos 1884.

- Tratado de la oración gramatical.

Autora: Sor María Candelas (religiosa del Convento de San Juan de Burgos). ${ }^{264}$

Burgos 1885.

- El Previsor. Breve reseña de las principales artes, oficios, profesiones y carreras de España. ${ }^{265}$

Autor: D. Antonio Álvarez Carretero.

Burgos 1887.

Esta obra forma parte de los textos aprobados por Real Orden de 8 de junio de 1880 como libro de lectura en las escuelas de adultos. Según se recoge en la obra de José Luis Villalaín ${ }^{266}$ estaba impresa en Burgos, en 1874. Se desconoce la imprenta burgalesa, pues en esa fecha Santiago Rodríguez sólo contaba con una pequeña máquina tipográfica para tarjetas, e impresiones semejantes.

Con este título hay un ejemplar, la $2^{\mathrm{a}}$ edición de 1881, depositada en la Biblioteca Eclesiástica de San Pedro de Cardeña de Burgos, de 249 páginas, ilustrada y con un tamaño de $16 \mathrm{~cm}$. Domingo Hergueta la

\footnotetext{
${ }^{261}$ El Papa-Moscas. Año V, no 237, 27 de agosto de 1882, p. 3.

262 Existe un ejemplar en la biblioteca pública de Burgos. Fondo local. BU 3904 (9) y citada en: HERGUETA MARTÍN, D. Op. cit., T. III, p. 131.

${ }^{263}$ HERGUETA MARTÍN, D. Op. cit., T. III, p. 133.

264 Ibídem, T.III, p. 137.

265 Ibídem, T. III, p. 141. Hergueta pone como título: El Porvenir. Breve reseña de las principales artes, oficios, profesiones y carreras de España con el mismo autor, lo que induce a pensar en un error en la transcripción. En la p. 163, la edición del libro es de 1891, con el título El Previsor, perteneciendo a la editorial Hijos de Santiago Rodríguez, impreso en $8^{\circ}$, con 241 páginas, más 6 de índices y armiños. Contiene una breve reseña de las principales artes, oficios profesionales y las carreras en España.

266 VILLALAÍN BENITO, J. L. Op. cit., T. III, p. 52.
} 
describe como edición de la Imprenta y librería de Santiago Rodríguez Alonso en 1887. Mercedes Rodríguez Plaza conserva la portada y contraportada de la edición de 1889 (Figura 3-11). Las ediciones posteriores pertenecen a la editorial Hijos de Santiago Rodríguez. Más adelante realiza nuevas ediciones, corregidas y aumentadas por Ángel Bueno.
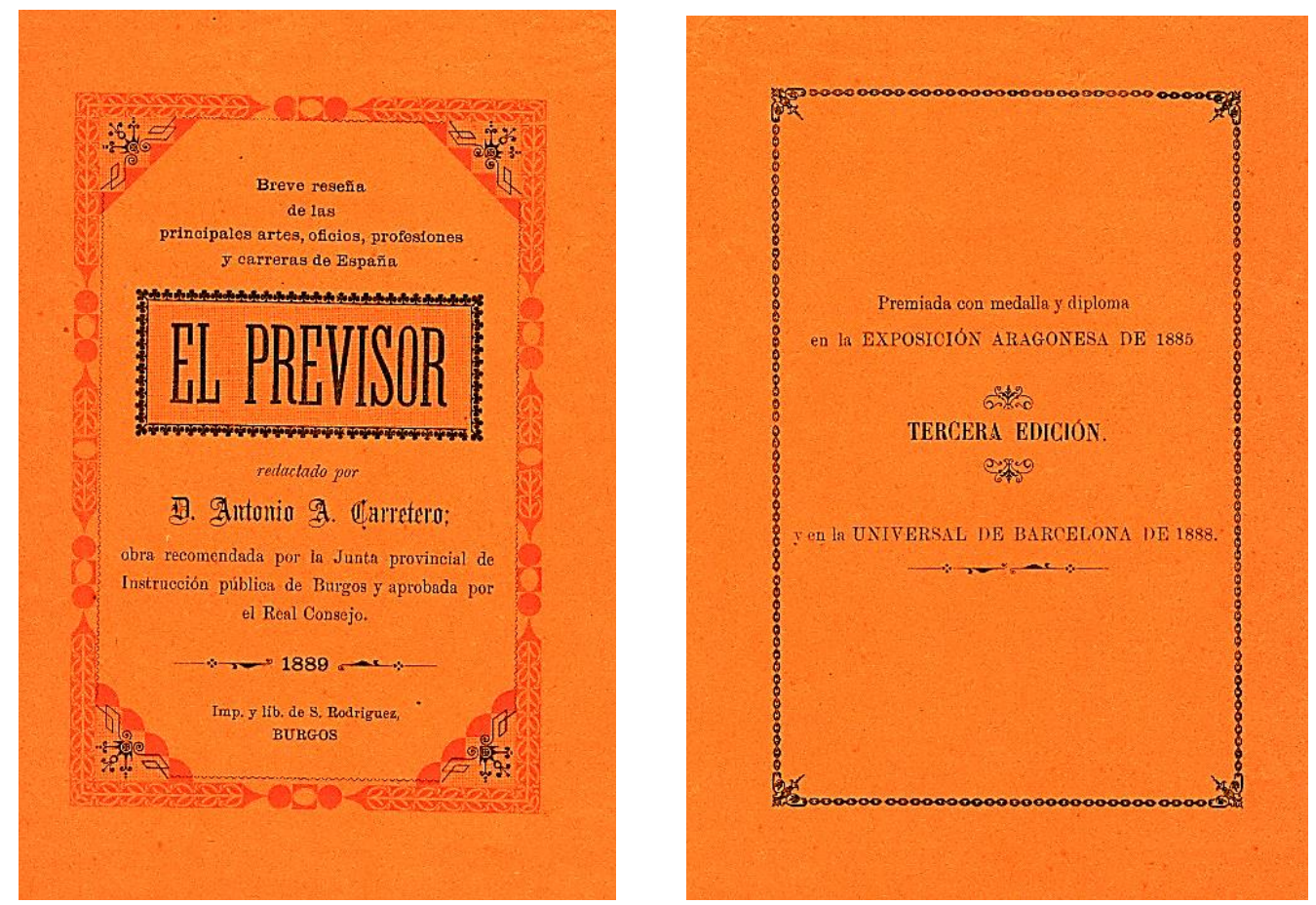

Fig. 3-11: Cubierta y contracubierta de la obra El Previsor en la edición de 1889 de la Imprenta y Librería de Santiago Rodríguez. Imágenes cedidas por Mercedes Rodríguez Plaza.

- Lecturas morales para instrucción de los niños de ambos sexos.

Autor: Mateo Bustamante y Junquera

Burgos, 1880.

Este texto fue aprobado por Real Orden de 28 de marzo de 1882 para su uso en las escuelas de primera enseñanza según señala Villalaín, haciendo referencia a un libro editado en Burgos en su tercera edición, en 1880. ${ }^{267}$

Los ejemplares encontrados son posteriores y se imprimieron en la casa editorial Hijos de Santiago Rodríguez, ${ }^{268}$ en el final de siglo XIX o primeros años del XX, por lo que se podría pensar que ya su padre lo imprimiese en esos años. Esta obra se siguió editando más allá del periodo estudiado por esta Tesis Doctoral.

\footnotetext{
${ }^{267}$ VILLALAÍN BENITO, J. L. Op. cit., T. III, p. 63.
}

${ }^{268}$ HERGUETA MARTÍN, D. Op. cit., T. III, p. 239. 


\section{GEOGRAFÍA E HISTORIA}

- Programa razonado de Geografía.

Autor: D. José Martínez Rives.

Impreso en $4^{\circ}$ menor, con 549 páginas más 7 de apéndice.

Burgos 1882.

Éste es el título que nos pone Hergueta. ${ }^{269}$ La obra se encuentra en la Biblioteca Eclesiástica de Santo Domingo de Silos como Elementos de geografía, del mismo autor y con el mismo número de páginas y apéndices, aunque en dicha obra no se dispone de información sobre el editor.

- Monografía histórico-arqueológica del Palacio de los Condestables de Castilla más comúnmente conocido por Casa del Cordón.

Autor: D. Leocadio Cantón Salazar (1848-1888).

Burgos 1884.

Impreso en $4^{\circ}$, de 82 páginas, más 6 sin foliar. ${ }^{270}$

D. Leocadio Cantón Salazar es miembro de las Real Academia de la Historia y de Bellas Artes de Madrid y de la Asociación del Museo Histórico de Arlén. Disponemos de varios ejemplares en las bibliotecas de la región, de la imprenta de Santiago Rodríguez. ${ }^{271}$

La obra se publicita en El Papa-Moscas añadiendo que se vende en las librerías de Santiago Rodríguez Alonso y de Calixto Ávila, al precio de 8 reales el ejemplar. ${ }^{272}$

- Apuntes para una guía de Burgos: La Catedral, la Cartuja, el Real Monasterio de las Huelgas y el Hospital del Rey. ${ }^{273}$

Autor: Leocadio Cantón Salazar, de las Reales Academias de la Historia y de Bellas Artes de Madrid, y de las asociaciones del Museo Histórico de Arlén.

Están revisados por Julio García de Quevedo.

Impreso en $8^{\circ}$, tiene 95 páginas.

Burgos 1888. (Figura 3 - 12).

\footnotetext{
${ }^{269}$ Ibídem, p. 122.

${ }^{270}$ Ibídem, p. 131.

${ }^{271}$ Se dispone de varios ejemplares en distintas bibliotecas: en Valladolid, en la Biblioteca central. Sig. G13162, cuyo texto lo podemos ver digitalizado y en la Biblioteca Pública de Burgos. Sig. BU-283.

${ }^{272}$ El Papa-Moscas. Año VII, no 333, 29 junio 1884, p. 3; HERGUETA MARTíN, D. Op. cit., T. III, p. 145.

${ }^{273}$ Se dispone de tres ejemplares en Burgos: uno en la Biblioteca Pública, en la Biblioteca de la Diputación y en la Biblioteca del Archivo Municipal; HERGUETA MARTÍN, D. Op. cit., T. III, p. 145. 


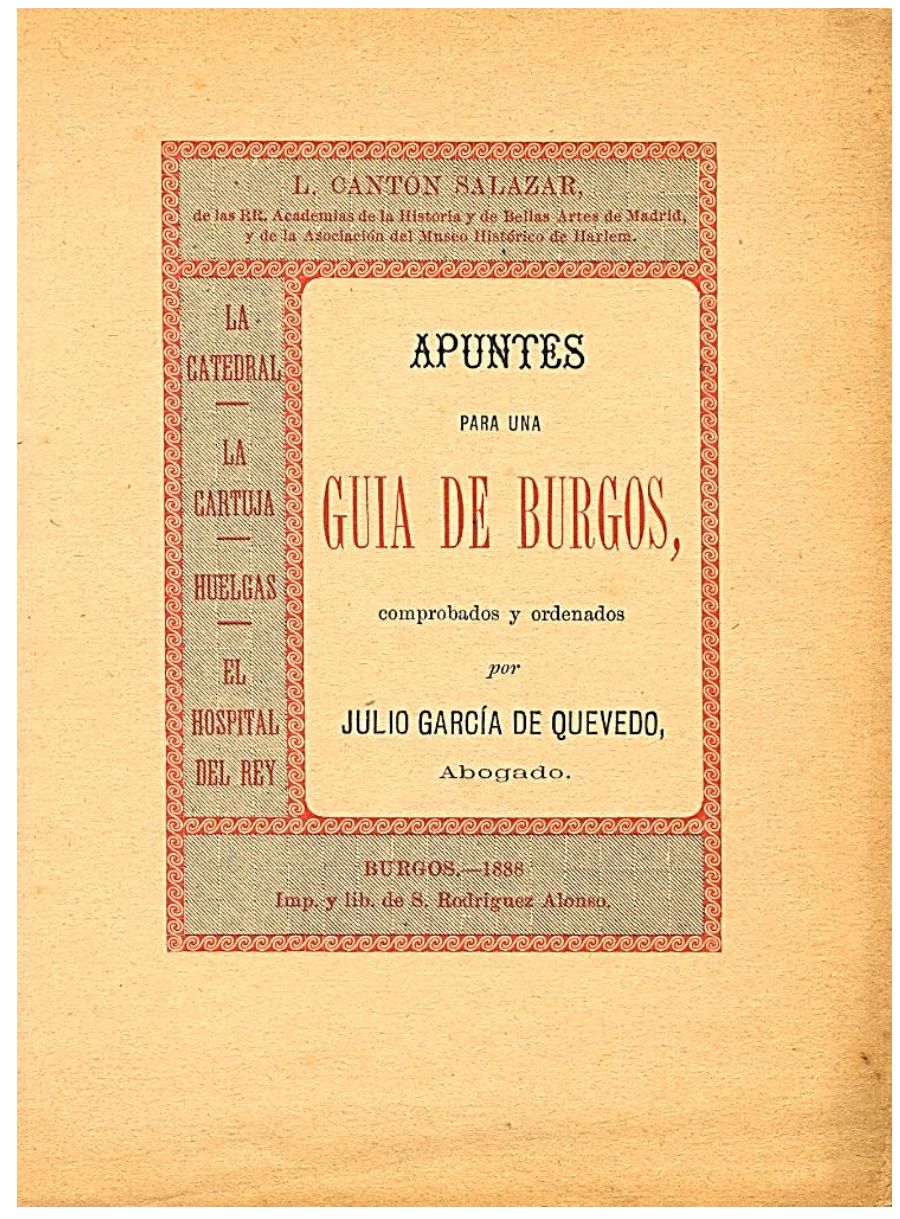

Fig. 3-12: Cubierta del libro Apuntes para una Guía de Burgos. Imprenta y Librería de Santiago Rodríguez Alonso. 1888. Imagen cedida por Mercedes Rodríguez Plaza.

- Burgos a vuela pluma. ${ }^{274}$

Autor: D. Anselmo Salvá (1849-1922).

Impreso en $8^{\circ}$ mayor, de 162 páginas. Administración de Santiago Rodríguez. Imprenta de la Revista de las Provincias. 1889.

- Programa de las lecciones de Historia Universal. Libros de texto.

Autor: D. José Martínez Rives.

El compendio es de Fernando Díaz Carona y el Atlas de Geografía e Historia de Manuel Morelo.

Tamaño: 36 p.; $20 \mathrm{~cm}$.

Burgos 1889.

En la Biblioteca Pública de Burgos podemos obtener esta publicación. ${ }^{275}$

${ }^{274}$ HERGUETA MARTÍN, D. Op. cit., T III, p. 151.Se encuentra un ejemplar en la Biblioteca Pública de Burgos. Sig. BU-404 y en la Biblioteca Digital Hispánica.

${ }^{275}$ Ibídem, p. 154. Se encuentra un ejemplar en la Biblioteca Pública de Burgos. Fondo local. Sig. BU $3936(20)$. 
- Programa de las lecciones de la asignatura de Historia de España. ${ }^{276}$ Autor: José Martínez Rives

Compendio del texto de Alejandro Gómez Ramera y el atlas de Juan Artero.

Tamaño: 26 p.; $21 \mathrm{~cm}$.

Burgos 1889.

D. José Martínez Rives fue un prestigioso hombre de letras y director durante varios años del Instituto de $2^{\mathrm{a}}$ Enseñanza.

- Las Cortes en 1392 en Burgos.

Autor: Anselmo Salvá Pérez, archivero municipal burgalés. Perteneció a la Academia de Historia, a la que se unió en noviembre de 1891.277

Obra publicada por Hijos de Rodríguez Alonso; salió a la luz muy poco tiempo después de la muerte de Santiago Rodríguez.

Anselmo Salvá siguió publicando libros de historia de España para niños y niñas, y otros libros, en la imprenta de Hijos de Santiago Rodríguez, lo cual nos da idea de continuidad dado por su fundador.

\section{HIGIENE Y ECONOMÍA DOMÉSTICA}

- Catecismo de higiene y economía domésticas: precedido de unas nociones de fisiología.

Autor: Antonio Álvarez Carretero.

Tamaño: 164 páginas, ilustrado y de $16 \mathrm{~cm}$.

Tenemos dos ediciones: la $2^{\mathrm{a}}$, de 1884 , y la $3^{\mathrm{a}}$, de 1889 , de la imprenta y librería de Santiago Rodríguez. ${ }^{278}$

Se cuenta con un ejemplar de la $2^{\mathrm{a}}$ edición en la Biblioteca Eclesiástica de la Abadía de Santo Domingo de Silos y dos ejemplares de la $3^{\text {a }}$ edición en la misma biblioteca, y en la Biblioteca Pública de Burgos.

El Papa-Moscas publicita la venta de la segunda edición de esta obra y la recomienda a las señoras encargadas de la enseñanza y jóvenes que aspiran a tan honroso título. ${ }^{279}$

En el mismo periódico se relata:

\footnotetext{
${ }^{276}$ De esta obra hay un ejemplar en la Biblioteca Pública de Burgos, Sig. BU 3972 (2) y la cita Domingo Hergueta en el tomo III en la página 154.

${ }^{277}$ El Papa-Moscas. Año XIV. N ${ }^{\circ} 724,8$ de noviembre de 1891. p. 1 y 2; HERGUETA MARTÍN, D. $O p$. cit., T. III, p. 162.

${ }^{278}$ HERGUETA MARTÍN, D. Op. cit., T. III, p. 152.

${ }^{279}$ El Papa-Moscas. Año VII, n 327,18 mayo 1884, p. 3. 
Nuestro querido amigo y compañero en la prensa Sr. Álvarez Carretero, nos ha regalado el Catecismo de higiene y Economía domésticas, de que es autor y acaba de publicar, cuya atención le agradecemos íntimamente.

Es un libro muy útil, que no dudamos en recomendar a nuestros lectores, y que pueden adquirir por la ínfima cantidad de 3 reales en casa del Sr. Rodríguez Alonso.

Las diversas materias que encierra obrita tan curiosa, no son para explicadas en los pequeños límites de un suelto; es necesario leerla para comprender su utilidad.

Así se lo deseamos. ${ }^{280}$

Sin duda, se refiere a la edición realizada en la Imprenta de Cariñena, en 1879, de la que tenemos un ejemplar, coincidente con los editados en la imprenta de Santiago Rodríguez depositado en la Biblioteca de la Diputación de Burgos.

Hergueta describe esta misma obra y aunque pone como edición a la imprenta de Carmona, y es de suponer se refiera a la imprenta de Cariñena, no consta como tal. Esta obra fue aprobada por Real Orden, de 12 de mayo de 1888 para que sirviese de texto en las escuelas de primera enseñanza. ${ }^{281}$

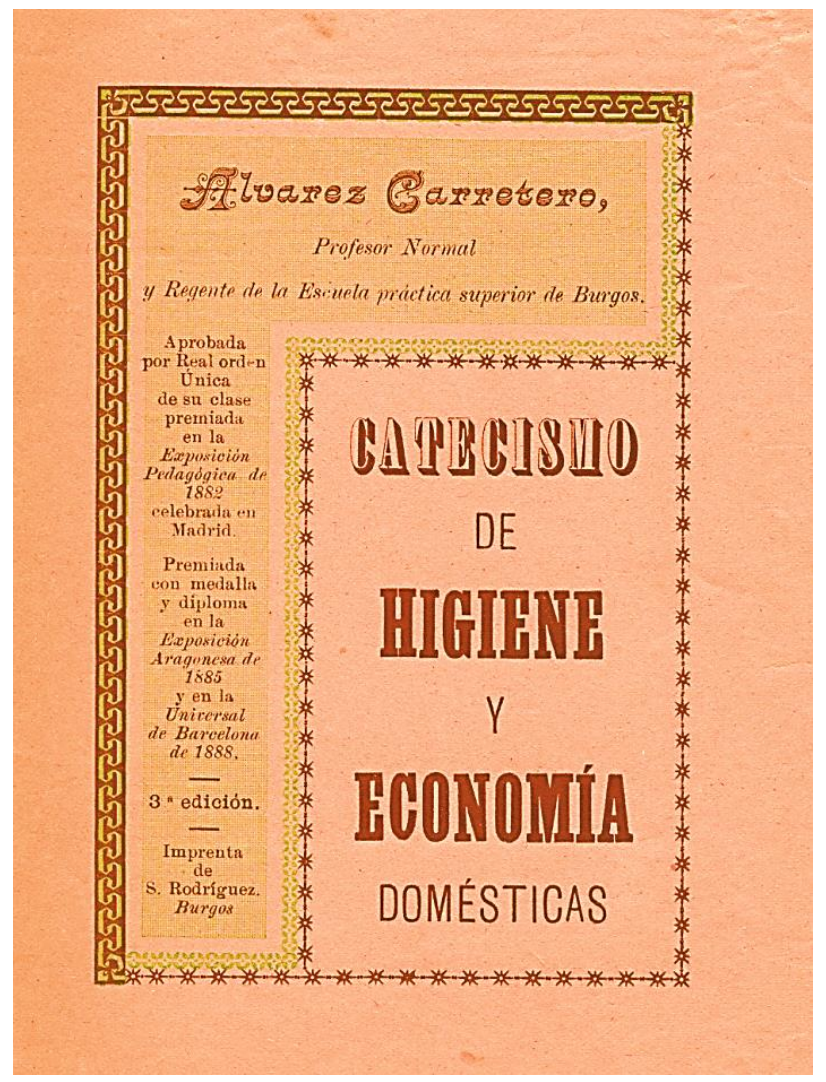

Fig. 3-13: Cubierta original del Catecismo de Higiene y Economía Domésticas. Imprenta de Santiago Rodríguez Alonso. $3^{\text {a }}$ edición. Imagen cedida por Mercedes Rodríguez Plaza.

${ }^{280}$ El Papa-Moscas. Año III, no 122, 21 de junio de 1880.

${ }^{281}$ VILLALAÍN BENITO, J. L. Op. cit., T. III, p. 165. 
Su hija, Mariana Álvarez Bollo Carretero, a petición de Santiago Rodríguez, cita en el prólogo del libro Resumen del Catecismo de Higiene y Economía doméstica que adapta la obra de su padre. Se imprime en 1890 como texto de lectura obligatoria en todas las Escuelas Normales de Maestras. El nombre en acróstico [D.A.A.C.] que aparece en su título hace referencia al padre de la propia autora, verdadero artífice del texto, y se presenta resumido por Mariana Álvarez Bollo Carretero. El éxito inmediato que obtuvo este manual de higiene y economía propició sucesivas reediciones a lo largo del último decenio del siglo XIX y el primero de la centuria siguiente de tal modo que, en 1906, la obra alcanzaba ya su séptima edición. ${ }^{282}$

En la Biblioteca Pública Municipal de Castilla y León, en Burgos, localizamos un ejemplar del título, autora y edición ya descritos, con ilustraciones de Isidro Gil, coincidiendo con Domingo Hergueta. ${ }^{283}$

La prensa local lo recoge con unas bellas palabras:

D. Santiago Rodríguez, conocido editor, impresor y librero ha editado un librito, escrito por doña Mariana Álvarez Carretero, que se titula "Resumen del Catecismo de Higiene y Economía doméstica de D. A. A. C.'

Es un extracto que aquella señorita ha hecho de una obra de su señor padre, y que resulta agradable y útil, sobre todo para las niñas de las escuelas.

Está ilustrado con unas viñetitas muy monas, mиy apropiadas, de muy buen gusto, y de una corrección y gentileza de dibujo que denuncian el lápiz de nuestro insigne artista Isidro Gil.

Además, tiene la obrita una cubierta, también de Gil, y al cromo, liadísima; de modo que el tal libro hasta por el forro gusta e interesa, y visto el forro dan ganas de leer lo que hay dentro.

Con que a leerla, hijas mías, vosotras que tenéis la dicha de hallaros en la edad de ir a la escuela.

$Y$ yo entretanto a felicitar, como felicito, a la autora, a Gil y a Rodríguez. ${ }^{284}$

\section{DE CARÁCTER PEDAGÓGICO}

- Prontuario de Pedagogía.

Autor: Antonio Álvarez Carretero.

Hergueta nos habla de esta publicación sin especificar la fecha. En la Biblioteca Pública de Burgos se encuentra un ejemplar de 1877 con el título Prontuario de Pedagogía: dedicado a los aspirantes a maestros incompletos, maestras elementales y jóvenes opositores, impreso en la imprenta de Cariñena, en Burgos. ${ }^{285}$

\footnotetext{
${ }^{282}$ En la Biblioteca Pública de Burgos hay un ejemplar con la sig. BU 3904.

${ }^{283}$ HERGUETA MARTÍN, D. Op. cit., T. III, pp. 160-161.

${ }^{284}$ El Papa-Moscas. Año XIII, no 645, 4 de mayo 1890, p. 2.

${ }^{285}$ En la Biblioteca Pública de Burgos, en su fondo local se conserva un ejemplar con la sig. BU 4373
} (13). 
Ya en junio de 1880 el periódico El Papa-Moscas, al hablar de otra publicación del Sr. Álvarez Carretero, escribe:

Acreedor se ha hecho el Sr. Álvarez Carretero a las distinciones que el público le dispensa por sus desvelos a favor de la enseñanza, y no dudamos que esta última obrita tenga el mismo éxito que el Previsor, el Prontuario de Pedagogía y el Lustro Escolar. ${ }^{286}$

No se cuenta con ningún otro ejemplar hasta 1894, impreso por Hijos de Santiago Rodríguez. ${ }^{287}$ Se señala que está conforme al Programa Oficial de oposiciones y la prensa local se hace eco unos meses más tarde.

Hemos recibido un ejemplar elegantemente encuadernado de la obra "Prontuario de Pedagogía" escrito por el que fue nuestro querido amigo D. Antonio Álvarez Carretero, Maestro Normal y Regente que fue de la Normal Superior de Burgos.

Ningún encomio necesita la obra, por lo mismo que es tan conocida, y más que nada lo prueba el ser de cuarta edición que de la misma se publica, habiéndose esta corregido y aumentado, conforme al programa oficial de oposiciones y con el último decreto sobre provisión de plazas. ${ }^{288}$

Fue una obra premiada con sendas medallas de bronce en la Exposición nacional de Zaragoza, en 1885, y en la Exposición Universal de Barcelona de 1888. Lo cual nos hace entender que existían ediciones en esos años ya que la Casa Editorial recoge como propios los citados premios.

- Necesidad de la enseñanza religiosa en las escuelas primarias, dada por el mismo maestro. 289

Autor: Agustín Ruiz Yanguas.

Tamaño: XII p.; $24 \mathrm{~cm}$.

Burgos 1884.

- Guía administrativa de la Primera Enseñanza: dedicada a la muy ilustre Junta Provincial de Instrucción Pública. ${ }^{290}$

Autores: D. Martín Santa María González y Marcelino Bonifaz Fernández Baeza.

En Burgos 1884.

- Conferencias pedagógicas de Burgos.

Por D. Agustín Ruiz Yanguas.

\footnotetext{
${ }^{286}$ El Papa-Moscas. Año III. No 122, 21 de junio de 1880.

${ }^{287}$ En la Biblioteca Pública de Burgos, en su fondo local se conserva un ejemplar con la sig. BU 4968.

${ }^{288}$ El Papa-Moscas. Año XVIII, nº 898, 10 de marzo de 1895, p. 2.

${ }^{289}$ AMBu. Sección Biblioteca. Depósito. BI-1031.

${ }^{290}$ HERGUETA MARTíN, D. Op. cit., T. III, p. 131. Encontramos un ejemplar en la Biblioteca Pública de Burgos en el fondo local con la sig. 4864.
} 
La editorial imprime la conferencia pedagógica celebrada en Burgos el 25 de agosto de $1890 .{ }^{291}$

RELIGIOSOS

- Festividades de la Iglesia compendiadas. ${ }^{292}$

Autor: P. Croisset [sj.] compendiadas por Antonio Moral.

Burgos 1888. (En la obra de Hergueta figura 1868, pero por los datos aportados es imposible dicha fecha y sí 1888).

D. Antonio Moral siguió publicando este libro y otros, después de la muerte de Santiago Rodríguez, con la nueva editorial Hijos de Santiago Rodríguez.

Esta publicación forma parte del listado de obras de texto para las escuelas de enseñanza primaria propuesta en dictamen por el Consejo de Instrucción Pública a propuesta de la Dirección General. ${ }^{293}$

\subsubsection{Publicaciones administrativas}

- Estatuto del Código de Procuradores de los Tribunales de Burgos. En tamaño $4^{\circ}$ de 54 páginas. Burgos $1880 .{ }^{294}$

- Memoria leída en Junta General de accionistas de la Sucursal del Banco de España en Burgos, el 21 de febrero de $1886 .{ }^{295}$

- Memoria leída por la Junta General de accionista de la Sucursal del Banco de España en Burgos el 19 de febrero de 1888. ${ }^{296}$

- Diccionario de contabilidad municipal por León Villén y Negro. Burgos 1889. ${ }^{297}$

- Memoria relativa a un proyecto de conducción de aguas a Burgos y creación de una sociedad anónima para la realización de las obras y explotación del servicio en sus diversas aplicaciones.

\footnotetext{
${ }^{291}$ Ibídem, p. 160. En la Biblioteca Pública de Burgos se conserva en su fondo local varios ejemplares con las referencias BU 1747 (22) y en AMBu. Sección Biblioteca. Depósito, BI-1006.

${ }^{292}$ Se la cita en: HERGUETA MARTÍN, D. T. III, p. 147 y se conserva un ejemplar en la Biblioteca Nacional de España, en la sede de Recoletos con la sig. 1/587224.

${ }^{293}$ VILLALAÍN BENITO, J. L. Op. cit., T. III, p. 172.

${ }^{294}$ HERGUETA MARTÍN, D. Op. cit., T. III, p. 115.

${ }^{295}$ Ibídem, p. 139. Se conserva un ejemplar en la Biblioteca Pública de Burgos en el fondo local con la sig. BU-R 10390

296 Ibídem, p. 147.

${ }^{297}$ Ibídem, p. 153. Además de la referencia de Domingo Hergueta se conservan ejemplares en: AMBu. Sección Biblioteca. Depósito. BI-1121-2; BI-11667 y en la Biblioteca Pública de Burgos en el fondo local, con la sig. BU 8292 y en la Biblioteca Marqués de Piedras Albas, en Ávila, con la sig. PA 46/51305131
} 
Impreso en $4^{\circ}$, de 47 páginas. Burgos $1889 .{ }^{298}$

\subsubsection{Literatura costumbrista}

Se tiene noticia de la edición del libro de Manuel Matoses, Del Montón, por un artículo de prensa del año $1887 .{ }^{299}$ Santiago Rodríguez edita una primera edición en mayo, y en octubre una segunda, al precio de 2 pesetas.

Manuel Matoses fue un periodista y escritor costumbrista, compañero de Clarín en La Ilustración Española y Americana, al que dedicó el prólogo del libro. Fue colaborador desde los inicios del periódico El Globo, de 1879 hasta 1893, escribiendo y adquiriendo, bajo el pseudónimo de Andrés Corzuelo una gran notoriedad gracias a sus críticas jocosas en la sección Dimes y diretes. Del Montón es una obra donde crítica y censura los comportamientos sociales de su generación. ${ }^{300}$

\subsubsection{Certámenes pedagógicos y literarios}

A partir de 1873 se estableció solemnizar con funciones oficiales y particulares la época de Ferias. En el último cuarto de siglo se ofrecen grandes festejos con iluminaciones en la Plaza Mayor, Arco Santa María, Espolón, Teatro Principal, puentes de San Pablo y Santa María y fuegos artificiales así como otras actividades de tipo cultural y literario con compañías de ópera y zarzuela, la realización de Certámenes Pedagógicos, y Fiesta de la Enseñanza, junto con Exposiciones Didácticas de Bellas Artes y de labores del "bello sexo". ${ }^{301}$

Los Certámenes Pedagógicos estaban promocionados por el periódico La Imparcialidad: revista profesional de Primera Enseñanza.

En el año 1880 El Heraldo de Castilla ${ }^{302}$ señala cinco categorías, con cinco premios y títulos diferentes, que corrían a cargo de diferentes personalidades. El director de La Imparcialidad, bajo la dirección de Mariano Rodríguez, se encargaba de subvencionar el tercer y quinto premio, y los diplomas. El premio más valioso era un ejemplar del Ingenioso Hidalgo D. Quijote de la Mancha de Miguel de Cervantes, edición de lujo con láminas y viñetas para el ganador de la segunda categoría. Estaba patrocinado por Santiago Rodríguez Alonso bajo el título

\footnotetext{
${ }^{298}$ Ibídem, p. 155. Se encuentra un ejemplar en la Biblioteca Pública de Burgos en el fondo local con sig. BU 3991(14), en la Biblioteca de la Diputación Provincial de Burgos en la sala de investigadores, sig. F2159 y en la Biblioteca Pública de San Sebastián.

${ }^{299}$ El Papa-Moscas. Año X, no 484 y 506, 22 de mayo y 23 de octubre de 1887.

300 RUBIO CREMADES, E: Del montón. Retratos de sujetos que se ven en todas partes de Manuel Matoses [en línea]. Universidad de Alicante. Disponible en: http://dfelg.ua.es/romanticismo_espa\%C3\%B1ol_e_hispanoamericano/articulos/enrique/del_monton.pdf ${ }^{301}$ ALBERDI ELOLA, L. Op. cit., p. 190.

${ }^{302}$ El Heraldo de Castilla. Año I, no 29, 7 julio de 1880, p.2.
} 
Reglas de conducta que debe observar el maestro de Primera Enseñanza, a fin de captarse las simpatías de las gentes y el amor de los niños.

El Jurado estaba formado por el Presidente y secretario de la Junta provincial de Instrucción pública; el director del Instituto Provincial de segunda Enseñanza; el director de la Escuela Normal de Maestros; un profesor de la misma escuela; el inspector de primera enseñanza; un maestro con escuela pública en la provincia; y los directores de los periódicos que publicaban en Burgos. Resultó ganador D. Víctor Giménez de V. y Mingo; Santiago Rodríguez lo editaría en 1884 con 26 páginas. ${ }^{303}$

En el Certamen Pedagógico del año 1888 (Figura 3-14) El PapaMoscas nos informa del título del quinto tema: ¿Debe el Maestro formar el corazón y desenvolver el entendimiento de los niños, o bastará que les enseñe a leer, escribir etc. para llenar cumplidamente su misión? Aclara que era un premio promovido por Santiago Rodríguez Alonso, propietario del periódico de La Imparcialidad, con un regalo consistente en un ejemplar de la obra de dos tomos titulada "Vida de Nuestro Señor Jesucristo", impresa e ilustrada con grabados en acero y lujosamente encuadernada. Santiago Rodríguez también costea todos los programas oficiales para anunciar el certamen. ${ }^{304}$

${ }^{303}$ HERGUETA MARTÍN, D. Op. cit., T. III, pp. 133-134.

${ }^{304}$ El Papa-Moscas. Año XI, no 532, 22 de abril de 1888. p. 3. 


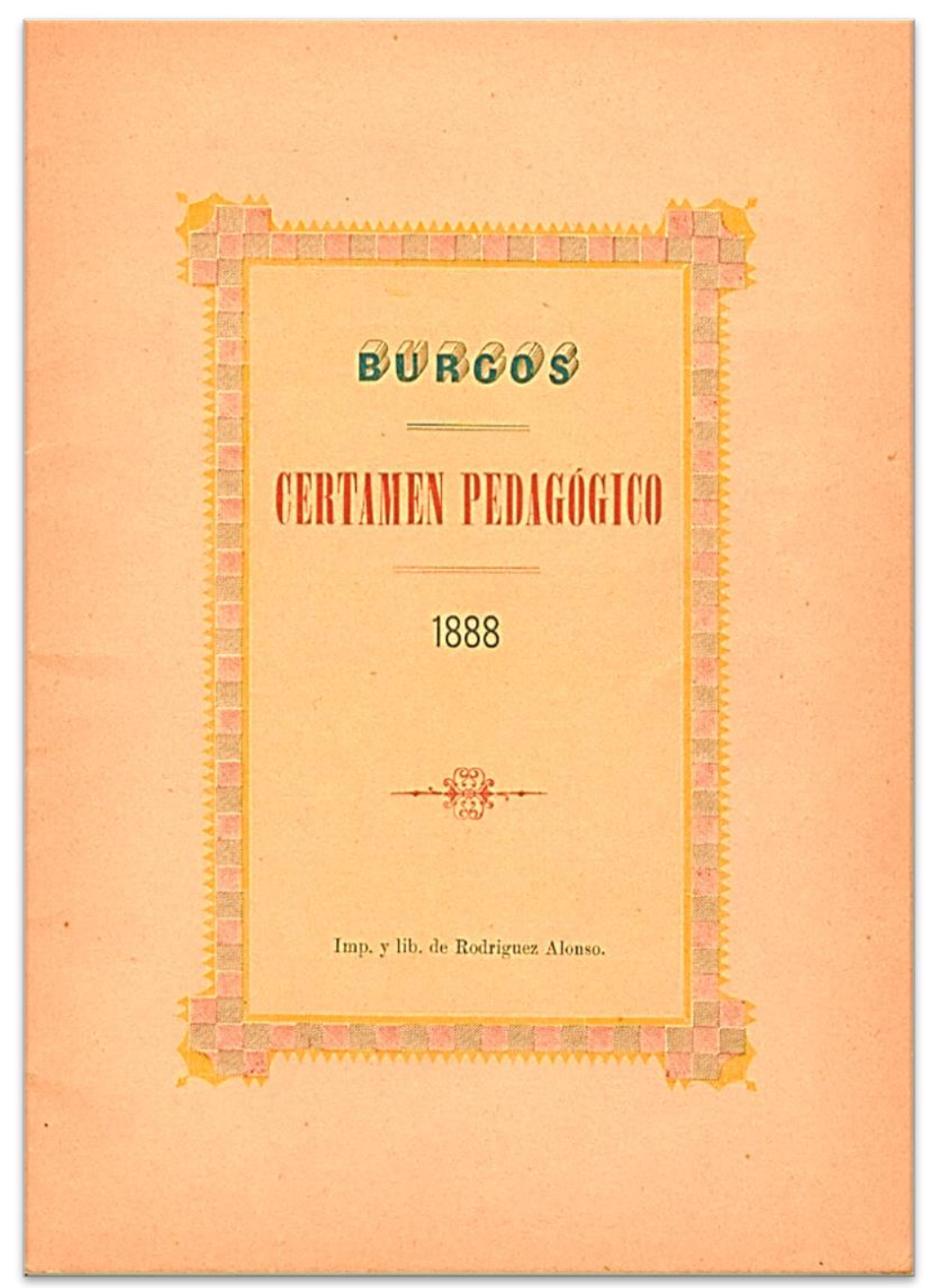

Fig. 3-14: Cubierta del Certamen Pedagógico celebrado en Burgos en 1888, impreso en la Imprenta y Librería de Santiago Rodríguez Alonso. Imagen cedida por Mercedes Rodríguez Plaza.

En el Certamen Pedagógico y literario de las Ferias y Fiestas de San Pedro y San Pablo de 1889 (figura 3-15) ganó uno de los premios D. Agustín Ruiz Yanguas, maestro superior de Primera Enseñanza, con el título Fin religioso y social de la instrucción primaria: medios para su consecución. Esta obra fue editada con 37 páginas, de $23 \mathrm{~cm}$ de tamaño, en la imprenta de Santiago Rodríguez. ${ }^{305}$ Lo recuerda El Papa-Moscas comentando sus bondades, no sólo del autor sino también debido a su buena impresión en la imprenta de Santiago Rodríguez, con su dedicatoria hacia el pueblo de Burgos y a la prensa local. ${ }^{306}$

\footnotetext{
${ }^{305}$ HERGUETA MARTÍN, D. Op. cit., T. III, p. 153. Se conservan ejemplares en la Biblioteca Pública de Burgos en su fondo local, con la sig. BU 1916 (7) y en: AMBu. Sección Biblioteca. Depósito. BI-1034. ${ }^{306}$ El Papa-Moscas. Año XII, no 601, 1 septiembre 1889, p. 3.
} 
LA EDITORIAL BURGALESA HIJOS DE SANTIAGO RODRÍGUEZ (1891-1936): ANÁLISIS DE LOS LIBROS ESCOLARES

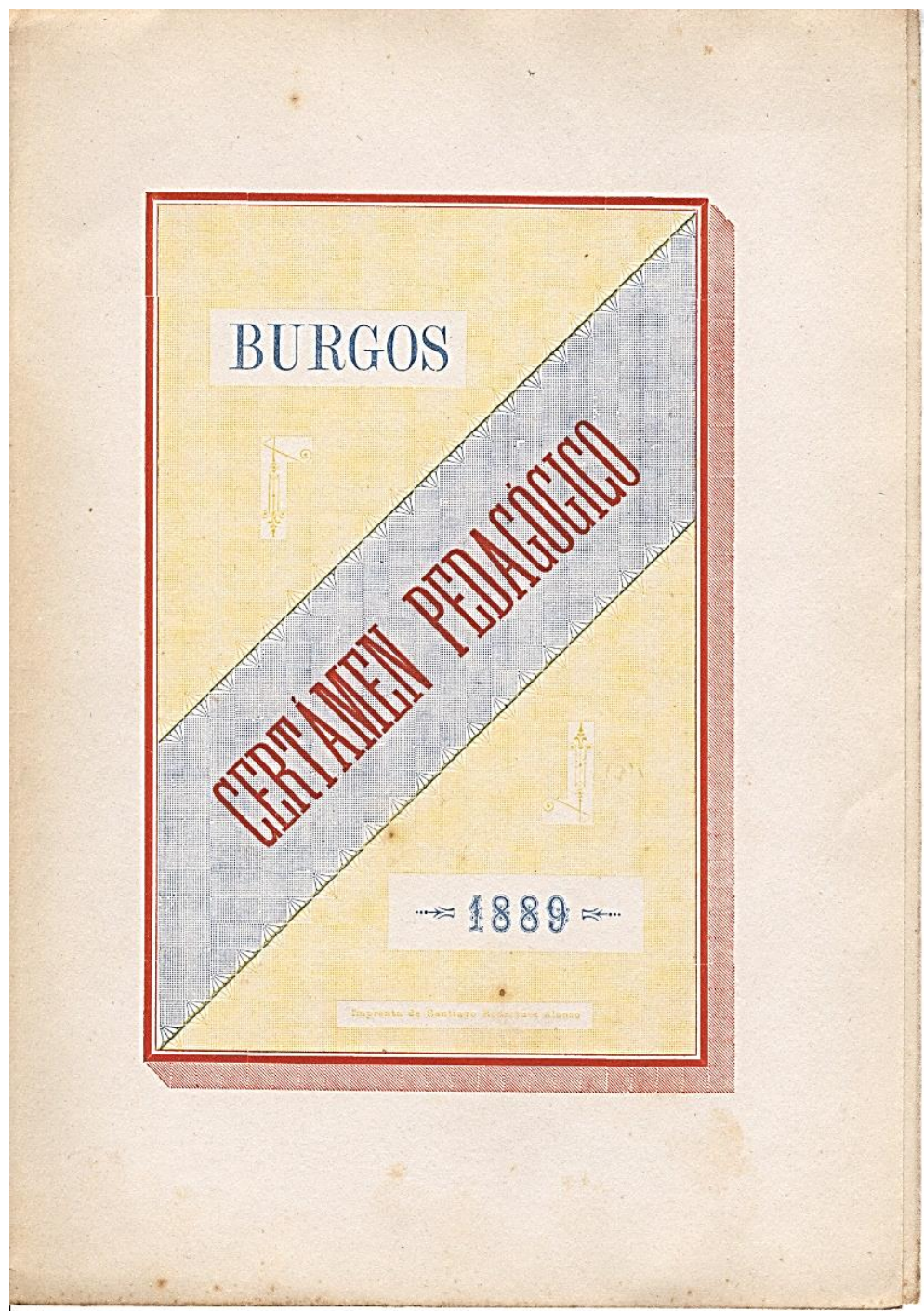

Fig. 3-15: Cubierta del Certamen Pedagógico celebrado en Burgos en 1889, impreso en la Imprenta y Librería de Santiago Rodríguez Alonso. Imagen cedida por Mercedes Rodríguez Plaza. 


\subsubsection{Almanaques y carteles}

Santiago Rodríguez elaboró sus propios Almanaques, llamados de la Ilustración y que recomienda Martinillo en el Papa-Moscas.

Ayer tuvimos el gusto de ver el precioso Almanaque de la Ilustración para 1881 que ha puesto a la venta el Sr. Rodríguez Alonso. Martinillo, que es amante de todo lo bueno, recomienda a sus lectores desfiguren un duro y se hagan con el citado Almanaque, que vale solo 8 reales. ${ }^{307}$

El periódico El Papa-Moscas, no duda en dedicarles unos versos en varias ocasiones:

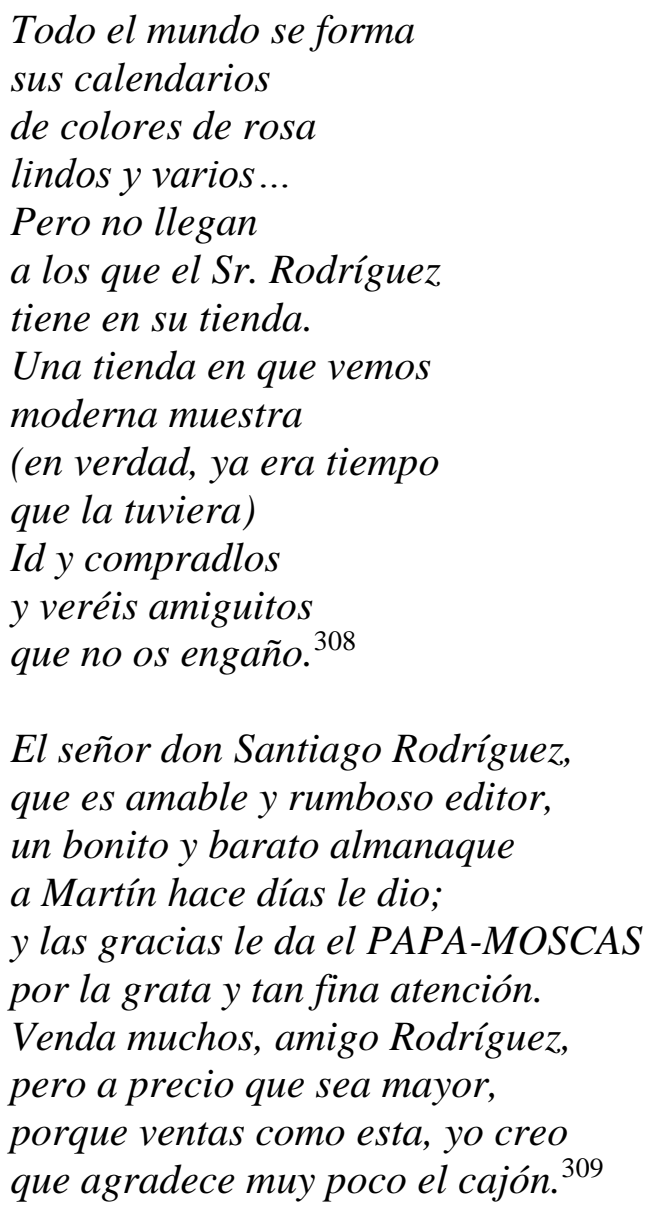

Imprime los carteles para las corridas de toros de las Ferias de Burgos del año 1883, (figura 3-16). El Papa-Moscas describe el alto nivel de su imprenta en 1883 por la buena combinación de caracteres y sus siete tintas

\footnotetext{
${ }^{307}$ El Papa-Moscas. Año III, no 143, 2 de noviembre de 1880.

${ }^{308}$ El Papa-Moscas. Año II, no 89, noviembre 1879, p. 3.

${ }^{309}$ El Papa-Moscas. Año VI, no 302, 25 noviembre 1883, p. 3.
} 
LA EDITORIAL BURGALESA HIJOS DE SANTIAGO RODRÍGUEZ (1891-1936): ANÁLISIS DE LOS LIBROS ESCOLARES

diferentes. Felicita al Sr. Rodríguez por su buen gusto, añadiendo que no duda de que acudirá mucha gente aunque solo sea por ver los carteles. ${ }^{310}$
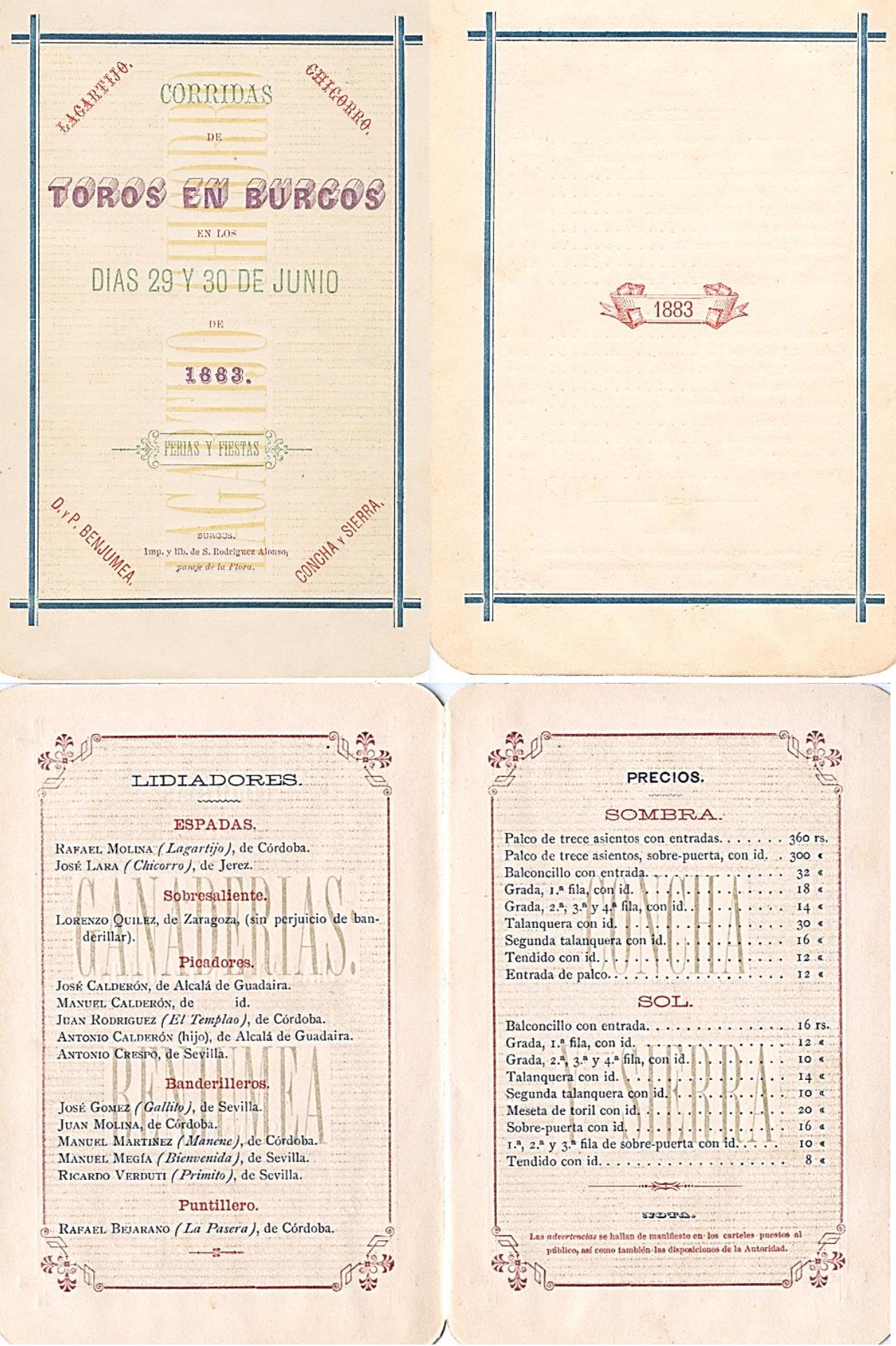

Fig. 3-16: Programa de las corridas de toros en las fiestas de San Pedro y San Pablo de Burgos los días 29 y 30 de junio de 1883. Imágenes cedidas por Mercedes Rodríguez Plaza.

\footnotetext{
${ }^{310}$ El Papa-Moscas. Año VI, no 277, 3 junio de 1883, p. 3 y no 279, 17 junio 1883, p. 3.
} 
Se dedica a hacer impresiones de lujo y económicas, en todo tipo de trabajos comerciales, ${ }^{311}$ como consta en algunos ejemplos reproducidos en las figuras 3-17, 3-18, 3-19, 3-20.
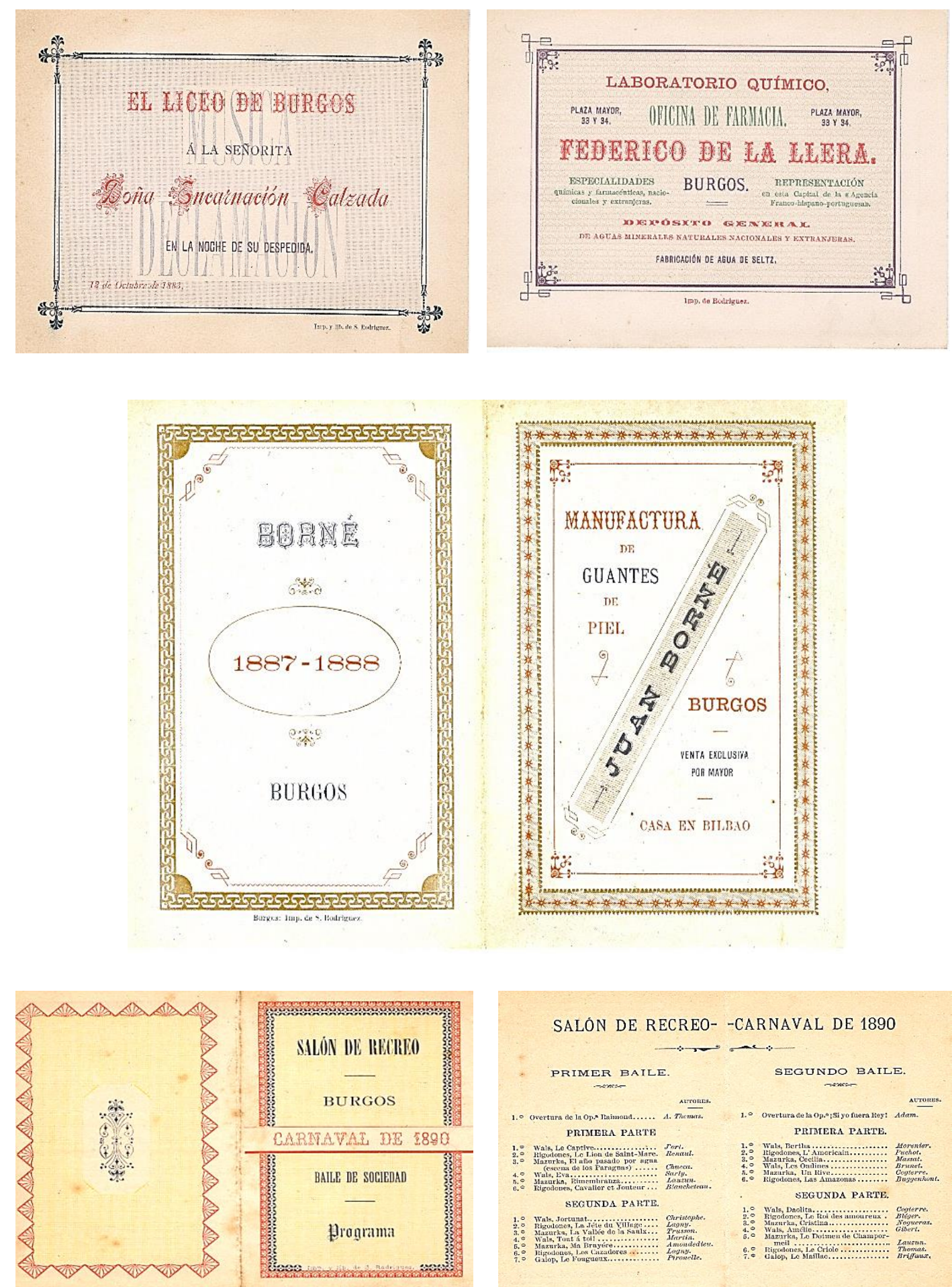

Fig. 3-17: Trabajos de la Imprenta de Santiago Rodríguez Alonso para diversas asociaciones y comerciantes de Burgos. Imágenes cedidas por Mercedes Rodríguez Plaza.

${ }^{311}$ El Papa-Moscas. Año III, no 134, $2^{\circ}$ domingo de septiembre de 1880. 
LA EDITORIAL BURGALESA HIJOS DE SANTIAGO RODRÍGUEZ (1891-1936): ANÁLISIS DE LOS LIBROS ESCOLARES

Imprime tarjetas con propaganda de su imprenta.
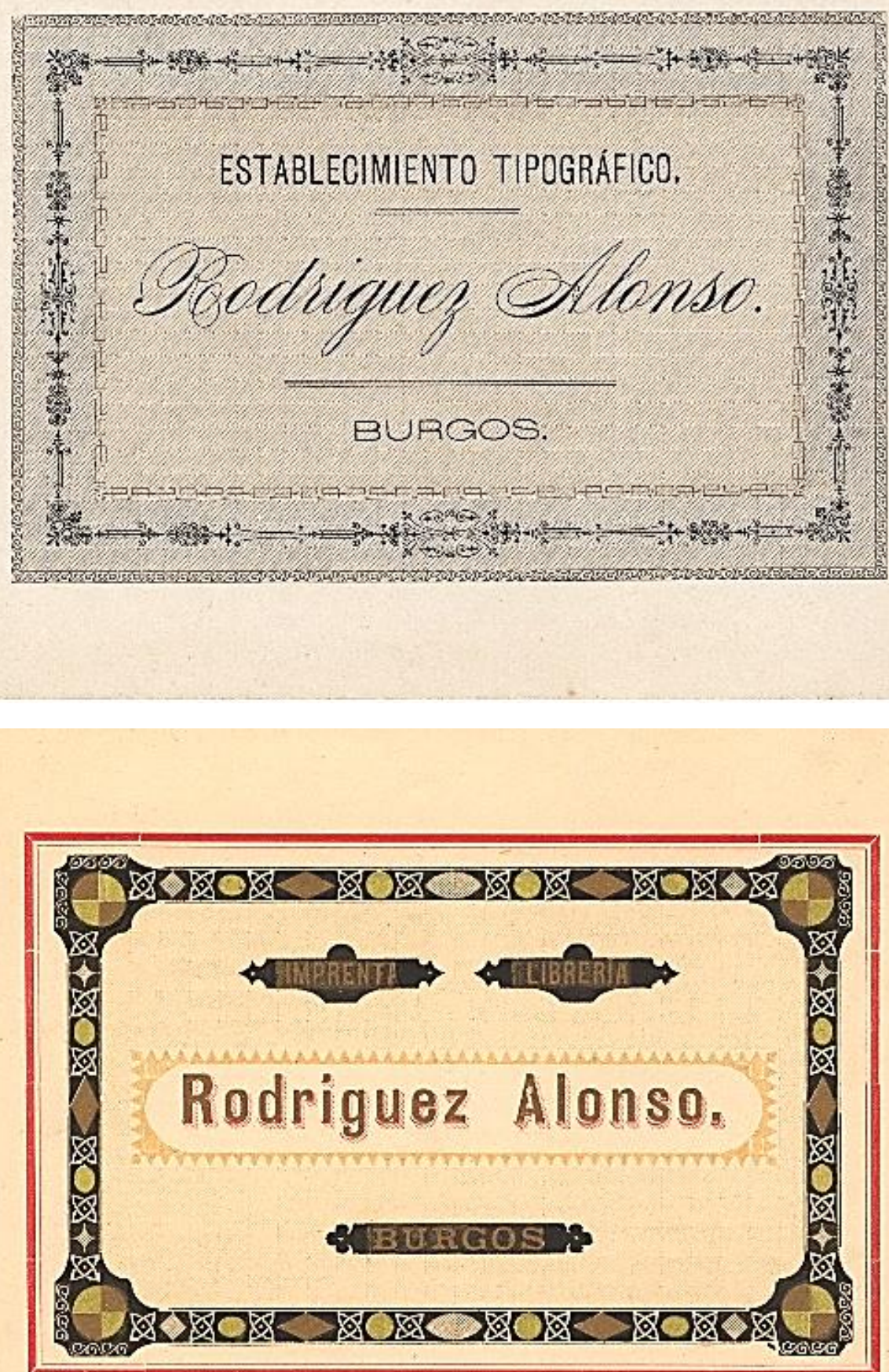

Fig. 3-18: Tarjetas de presentación de la Imprenta de Santiago Rodríguez Alonso. Imágenes cedidas por Mercedes Rodríguez Plaza. 
Sus empleados le felicitan con tarjetas realizadas en su propia imprenta y que sirven para propaganda de la misma.

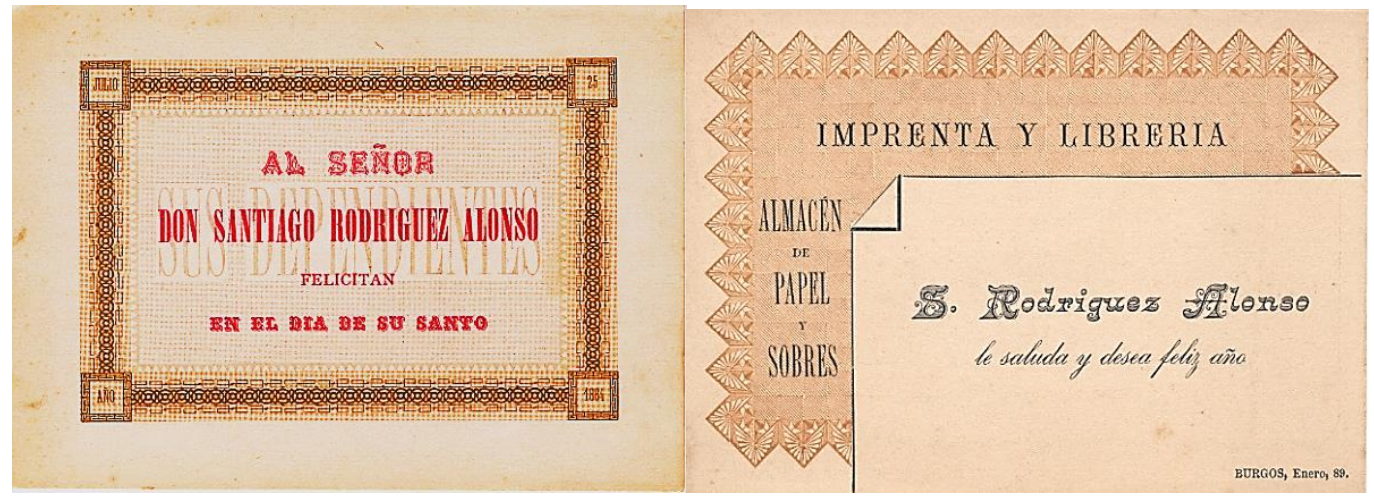

Fig. 3-19: Tarjetas diversas de felicitación y de representación de la Imprenta y Librería. Imágenes cedidas por Mercedes Rodríguez Plaza.

Imprime postales para los representantes de su empresa, a imitación de las grandes Casas editoriales, lo cual da a entender el proceso de expansión de la imprenta (Figura 3-20).

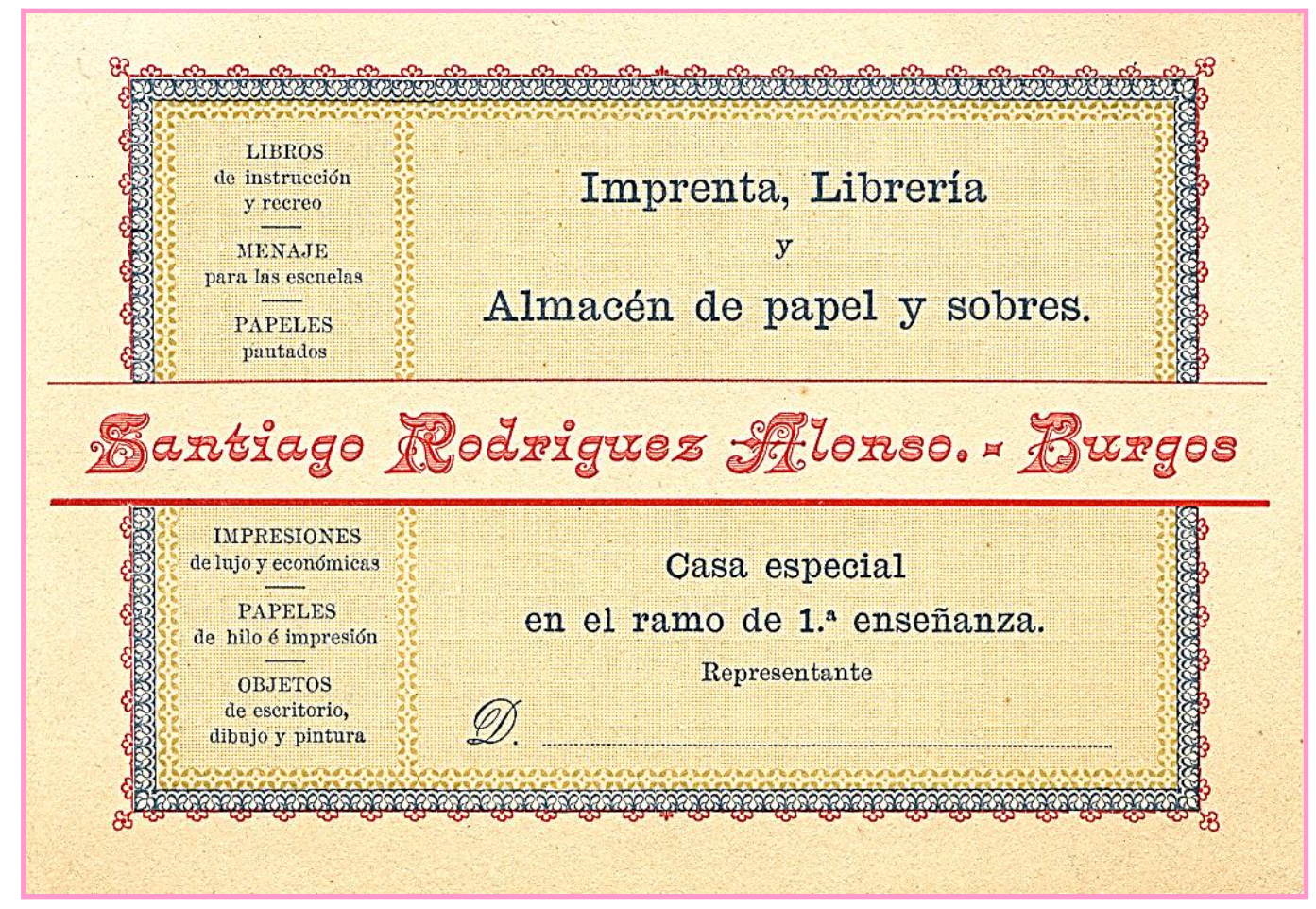

Fig. 3-20: Tarjeta para los representantes de la Imprenta y Librería de Santiago Rodríguez Alonso. Imagen cedida por Mercedes Rodríguez Plaza. 


\subsection{ACTIVIDAD POLÍTICA DE SANTIAGO RODRÍGUEZ}

$\mathrm{Su}$ carácter abierto e inquieto por mejorar y transformar la nueva sociedad liberal, anterior a la Gloriosa, hizo que se presentase en las elecciones municipales, siendo regidor durante unos mandatos claves de la historia española, de 1865 a 1866, de 1869 a 1871 y en 1973.

¿Por qué y cómo llega Santiago Rodríguez a ser regidor en estas épocas concretas? Santiago Rodríguez aparece en la lista de los electores y elegibles para cargos municipales en el bienio de 1865-66, con el número 244, pagando de contribución industrial 762 reales por su comercio en Laín Calvo 12. También figura en las listas para las elecciones de Diputados a Cortes, y Provinciales por Burgos donde por el mismo comercio y en la misma calle satisface una contribución de 60 escudos. ${ }^{312}$

Durante los años 1865 y 1866 fue elegido alcalde Bartolomé Goyri y como tenientes de alcalde Bonifacio Gil Rojas, Manuel Villanueva Arribas, Modesto Gómez Marrodán y Braulio Gallardo. El resto de los regidores de los distintos distritos de la ciudad fueron: Antolín Díez, Ramón de Diego, Francisco Hernando, Ildefonso Miegimolle, Crisanto Espiga, Pascual Escudero, Anselmo Revilla, Juan Ibeas, Víctores Redondo, Eugenio Albarellos, Victoriano Calvo, Julián Gutiérrez, Saturnino Gutiérrez, Anselmo Carranza, Juan Cruz Gómez Lorente, José Arroyo Revuelta y Santiago Rodríguez Alonso. ${ }^{313}$ La mayoría de ellos forman parte de la clase media industrial y comercial de Burgos, inicio de una emergente burguesía.

En la constitución de las diversas comisiones del nuevo ayuntamiento, Santiago Rodríguez forma parte de las de Personajes, Paseos y Arbolado, y Abastos. $^{314} \mathrm{Su}$ participación en estos años es de plena colaboración y sintonía con la mayoría, y desde la comisión de Paseos y Arbolado ayuda en la recaudación para la Hacienda municipal, con graves problemas económicos, poniendo a la venta al precio de 3 reales todos los árboles existentes en el vivero, sin distinción de clases, ya que no eran necesarios en ese momento para los paseos o sitios públicos. ${ }^{315}$

\footnotetext{
312 A título comparativo conocemos que los mayores contribuyentes fueron en estas fechas: Francisco Javier Arnaiz con 2.230,479 escudos, siguiéndole Pascual Escudero Sainz con 1.072,50 escudos. Ver: AMBu. Sig. 10-35 Elecciones municipales. Año 1864 y sig. 10-494. Elecciones a Diputados a Cortes y Provinciales. Lista electoral ultimada el 15 mayo de 1864.

${ }^{313}$ AMBu. Actas del Ayuntamiento. LA-501, 2 de enero de 1865

${ }^{314}$ Ibídem, 2 de enero de 1865.

315 Ibídem, 13 de enero de 1865.
} 
Desde la Comisión de Abastos propone, junto con sus compañeros en la comisión, un lugar más oportuno para el mercado de cerda: la margen izquierda del río Arlanzón, más arriba del sitio que ocupaban las carretas de madera. $^{316}$ Los acuerdos mayores se concentran en el apartado sobre presupuestos, consumos y Hacienda.

En las siguientes elecciones -diciembre de 1866- se reúne una nueva Corporación cuyo alcalde será Primitivo Nevares y Jalón, con los tenientes de alcalde Manuel Villanueva Arribas, Modesto Gómez Marrodán, Saturnino Gutiérrez y Venancio Fuentes. Salen elegidos como concejales: Timoteo Arnaiz, José Arroyo Revuelta, Braulio Gallardo, Raimundo Velez, Bartolomé Goyri, Santiago Moral, Domingo Rico y Gil, Modesto López de la Riva, Martín Plaza, Hilario Miguel, Victoriano Calvo, Juan Manzanedo, Pío de la Morena, Juan Cruz Gómez Lorente y Víctores Redondo. ${ }^{317}$

Repiten más de la tercera parte de regidores: Manuel Villanueva, Modesto Gómez Marrodán, Braulio Gallardo, Víctores Redondo, Victoriano Calvo, Saturnino Gutiérrez, Juan Cruz Gómez Lorente y José Arroyo Revuelta.

En la ciudad, durante los años 1866 y 1867, y en toda la región castellana se suceden años de malas cosechas que generan una fuerte crisis de subsistencia y son el detonante de protestas regionalistas que se manifestaron en las calles y sólo un profundo cambio podía solucionar.

Durante esta etapa del reinado de Isabel II se conjugaron una recesión económica internacional, que afectó a la industria y a la banca española, y un avance del conservadurismo que condujo a la revolución de la Gloriosa.

La revolución, instaurada en Cádiz, se fue reproduciendo en otras provincias españolas. El éxito de los sublevados permitió la inmediata formación de Juntas revolucionarias.

En la ciudad de Burgos el pronunciamiento se produce en la madrugada del 29 al 30 de septiembre de 1868, cuando se confirma su triunfo en Madrid. Se forma la Junta Revolucionaria, nombrando al nuevo Ayuntamiento, en una especie de reconversión de los representantes políticos hacia posiciones de acuerdo al espíritu revolucionario de $\mathrm{La}$ Gloriosa.

Algunos hechos nos hacen entender la falta de postulados revolucionarios en el nuevo Ayuntamiento como fue la lentitud en la organización de los Voluntarios de la Libertad, la negativa a armar a la población ante la llegada de las tropas leales a la reina, la rebaja de

\footnotetext{
${ }^{316}$ Ibídem, 10 febrero de 1865.

${ }^{317}$ AMBu. Actas del Ayuntamiento. LA-502, 31 diciembre 1866.
} 
impuestos al consumo y otras medidas tendentes a mitigar la situación de los labradores y empleados. ${ }^{318}$ Este nuevo Ayuntamiento estaba formado por Emilio Gómez de la Vega, Joaquín Badals, Valentín Fernández, Antonio Gil, José Casans, Casimiro Barrera, Luciano Manzano, Fernando Monterrubio, Antonio Martínez Acosta, Gregorio Díez, Juan Díaz, Baldomero Martínez de Velasco, Eduardo Augusto de Bessón, León de la Colina, Lorenzo García Martínez, Próspero Gallardo, Victoriano Zumárraga, Justo Casabal, Emilio de San Pedro, Antonio Dancausa y Bartolomé Goyri. ${ }^{319}$

Las Juntas dejan a un lado la parte radical y revolucionaria para expresar la necesidad de acuerdos. La lista definitiva de la Junta burgalesa, en fecha inmediata a la Revolución, estaba formada por Eusebio de Salazar y Mazarredo, José María Villalobos, Julián González, Agustín Moreno, Félix Moradillo, Manuel Izquierdo, Julián de la Llera, Zacarías Casabal, Pedro Marrón, Santiago Rodríguez, Tomás Arribas, Martín Barrera, Francisco Arquiaga, Gregorio Martín, Felipe Corral, Pedro María Ángulo, José Soto de Vega y Cayetano Lerena Bustillo. ${ }^{320}$ Y ninguno de ellos participa como regidor en el nuevo Ayuntamiento de la Gloriosa.

Esta Junta tenía un carácter unionista, de talante liberal y conservador. El Bando de la Junta de 3 de octubre expresa que sea el conducto de las Cortes quien convierta a España en una monarquía verdaderamente liberal, hecho que prueba la falta de republicanos en sus filas pues se hubiesen opuesto a esta proclama. Frente a otras provincias españolas, Burgos no adopta medidas para ayudar a las clases trabajadoras y se muestra bastante temerosa respecto al clero. ${ }^{321}$

A principios de octubre de 1868 se forma un gobierno provisional presidido por el General Serrano. Las provincias, una vez que las Juntas locales y provinciales se constituyeron en Ayuntamientos y Diputaciones, convocan elecciones municipales mediante sufragio restringido en vez del sufragio universal masculino.

En Burgos se presenta una lista de los electores, según la contribución que cada uno aporta, para cargos municipales y por orden alfabético, separando la contribución territorial de la industrial.

En el listado de los electores para cargos municipales se detalla la contribución que cada uno satisface. Santiago Rodríguez paga únicamente

\footnotetext{
${ }^{318}$ SAMANIEGO BONEU, M. Burgos en la etapa isabelina y en el sexenio revolucionario. En: J. M. PALOMARES IBÁÑEZ. Op. cit., pp. 222-225.

${ }^{319}$ AMBu. Actas del Ayuntamiento. LA-504, 30 septiembre de 1868.

${ }^{320}$ SERRANO GARCÍA, R. La revolución de 1868 en la ciudad de Burgos. La actuación de la Junta revolucionaria y de la corporación municipal. En: Actas del Congreso de Historia de Burgos. Valladolid: Consejería de Educación y Cultura, Junta de Castilla y León, 1985, p. 613.

${ }^{321}$ Ibídem, p. 615.
} 
por contribución industrial 75,79 reales, ${ }^{322}$ por su comercio de librería, al igual que otras librerías de la época como Anselmo Cariñena, Anselmo Revilla, Isidro Herce, Juan Arnaiz, Julián Fournier, Pascual Polo y Sergio Villanueva.

Santiago Rodríguez sale elegido en estas elecciones municipales y forma parte como regidor en los años 1869 a 1871. En la nueva Alcaldía por votación se nombra como alcalde $1^{\circ}$ Emilio Gómez de la Vega; alcalde $2^{\circ}$ Fernando Monterrubio; alcalde $3^{\circ}$ Cándido Fernández de Castro; alcalde $4^{\circ}$ Ambrosio Hervias; alcalde $5^{\circ}$ Joaquín Badals; alcalde $6^{\circ}$ Emilio de San Pedro; y como Regidor representante y regidor interventor Federico Fernández Izquierdo y Próspero Gallardo respectivamente. El resto de regidores fueron los siguientes: Donato López, Valentín Lorente, Ramón Conde, Juan Díaz, Eustaquio Pedrero, Hilario Morquecho, Luciano Manzano, Lorenzo García Martínez, Santiago Valdivielso Bonis, Andrés Riveras, Rufino Almendres, Luis Carabias, Lucas Villangómez, Eduardo Arnaiz y Santiago Rodríguez. ${ }^{323}$ Como se puede comprobar siguen más de un tercio de los regidores propuestos en septiembre del 68.

Cada uno de los tenientes de alcalde se encarga de la administración de los cinco barrios en los que Burgos estaba distribuido, con más de 1.000 vecinos cada uno; a estos había que añadir los barrios rurales. Una comisión de los regidores, -entre los que se encontraba Santiago Rodríguez- propuso al Alcalde la decisión de elegir, entre una terna de vecinos, al alcalde de cada barrio. ${ }^{324}$

Pocos días después, el 22 de enero, la situación se va tensando entre las instituciones, especialmente en el sector eclesiástico. Manifestaba su queja, al propio Ayuntamiento, en una instancia de la Universidad de los curas beneficiados y coadjutores de la ciudad para que interpusiera su influencia ante el gobierno $^{325}$ que el decreto del primero de enero de 1869 la incautación de los bienes de Archivos, Bibliotecas y colecciones que trataban de ciencia, arte y literatura. Las autoridades trataron de evitar enfrentamientos pero, días después e instigado por el clero, tuvo lugar el asesinato del Gobernador civil y presidente de la Diputación, D. Isidoro Gutiérrez de Castro, a las puertas de la Catedral.

\footnotetext{
${ }^{322}$ El mayor contribuyente es Francisco Javier Arnaiz del Olmo que paga 2.783,978 reales, la mayor parte por contribución territorial; y siguen D. Policarpo Casado Lostan (Laín Calvo 22); 1.632,895 reales, Territorial: 1.270. Industria: 360; D. Pascual Escudero Sainz con 1.286,875 reales, 1000 por contribución territorial y 286,875 reales por industria. Los demás ya se sitúan en menos de 600 reales. Vid. AMBu. Sig. 10-193. Lista de los electores por contribución para cargos municipales, por orden alfabético y señalando la contribución que paga cada uno.

${ }^{323} \mathrm{AMBu}$. Actas del Ayuntamiento. LA-505, 1 de enero 1869.

${ }^{324}$ Ibídem, 1 de enero de 1869.

${ }^{325}$ Ibídem, 22 de enero de 1869.
} 
La reacción ante tal suceso fue la promulgación de dos bandos, uno del Ayuntamiento y otro de la Diputación, insistiendo en señalar la importancia de la Constitución como ley de libertad en el orden.

El ayuntamiento imprime dos mil ejemplares del bando y los distribuye entre las distintas corporaciones, funcionarios y diversos particulares. Señala el "horrendo crimen" y que, en nombre de la religión se había infiltrado el veneno del fanatismo, pues lejos de robar, lo que se pretendía era la fiel conservación y la formación de un inventario para impedir la desaparición de tales bienes. Insiste en que algunos trataban de presentar el espíritu liberal contrario al principio religioso, siendo esto falso. ${ }^{326}$

Durante ese mandato podemos conocer las posturas de los distintos regidores a través de algunas de sus intervenciones. En una de ellas se discute sobre la adopción del distintivo de los concejales, de la faja tricolor, que otras ciudades ya habían adoptado. A favor de la aprobación estuvieron Rodríguez, Carabias, Gonzalo y Riveras. Los demás regidores, Almendres, Gallardo, Manzano, Arnaiz, Villangomez, Izquierdo, San Pedro, Badals, Hervias, Monterrubio y el señor Presidente, ${ }^{327}$ optaron por su aplazamiento. Esto nos hace pensar en un talante más liberal del Sr. Rodríguez que el resto de sus compañeros, más conservadores.

Santiago Rodríguez participa en la Comisión de Festejos que ha de preparar las funciones de la promulgación de la Constitución de 1869. 328

Las decisiones del Ayuntamiento durante el sexenio revolucionario se enmarcan en su posicionamiento de política económica: proteccionismo y contención fiscal. Por ello los temas recurrentes durante el año 1870 fueron conseguir la Capitanía General suprimida, los ferrocarriles en su eje norte y este-oeste, y la bajada de los impuestos.

En este periodo, Santiago Rodríguez suministra diversos materiales para las escuelas municipales que regentan Gregorio Martínez Villanueva, Feliciano Hortigüela, Manuel González de la Puente ${ }^{329}$ y también proporciona diversos efectos de escritorio y encuadernaciones para la Secretaría del Ayuntamiento. ${ }^{330} \mathrm{Al}$ año siguiente, en 1871, se aprueba en sesión municipal las cuentas de la comisión de Instrucción Pública sobre

\footnotetext{
${ }^{326}$ Ibídem, 27 de agosto de 1869.

${ }^{327}$ Ibídem, 2 de abril de 1869.

${ }^{328}$ Ibídem, 2 de junio de 1869.

${ }^{329}$ AMBu. Actas del Ayuntamiento. LA-506, 4 de julio de 1870. Hay varios pagos a D. Santiago

Rodríguez Alonso a las escuelas públicas que regenta D. Gregorio Martínez Villanueva.

Aprobadas las cuentas de la Comisión de Instrucción Pública por efectos suministrados por D. Santiago Rodríguez para las escuelas públicas que regentan D. Gregorio Martínez Villanueva, D. Manuel

González de la Puente y D. Feliciano Hortigüela e importando veinte y tres escudos doscientas milésimas",

${ }^{330}$ Ibídem, 15 julio de 1870. "Aprueba la cuenta de efectos de escritorio y encuadernaciones hechas por

D. Santiago Rodríguez para la Secretaría e importando veinte y tres escudos cien milésimas.
} 
los efectos suministrados por Santiago Rodríguez para las escuelas municipales que regentan los maestros citados y la escuela de Marcos Saiz por valor de 422 reales. Asimismo, de la Comisión de Secretaría, los gastos por materiales y encuadernaciones, por valor de 450 reales. ${ }^{331} \mathrm{~A}$ finales de 1871 se aprueba el pago de materiales para la Secretaría del Ayuntamiento por valor de 527,75 reales a la librería de Santiago Rodríguez.

En otra sesión la comisión de Secretaría acuerda el pago del importe de 1.012,50 reales por la cuenta de papel colocado en la Audiencia y suministrado por D. Santiago Rodríguez.

El 16 enero de 1871, en sesión del Ayuntamiento se lee una comunicación de la Excma. Diputación de la Provincia informando de forma semioficial de la posibilidad de que S.M. el Rey se detuviese una noche en la ciudad a su paso para recibir a S.M. la reina madre. Se nombra una comisión para preparar la visita, con Santiago Rodríguez Alonso junto con los capitulares Badals, Manzano, Arnaiz, y los diputados provinciales Jorge de la Riva y Antonio Martínez Acosta.

Otra de sus intervenciones destacada en el pleno del Ayuntamiento en ese año de 1871 fue la resolución de una nueva plaza de maestro. Se presentaron tres personas y Agustín Ruiz Yanguas sale elegido por trece votos. Se cubre otra plaza, con 7 votos a favor, para Antonio Álvarez Carretero, maestro de primera enseñanza superior, en la regencia de la Escuela agregada a la Normal de Maestros de la ciudad. ${ }^{332}$ En estas votaciones Santiago Rodríguez apoya al candidato elegido. Ambos fueron autores de varios libros editados por Santiago Rodríguez y siguieron colaborando con Hijos de Santiago Rodríguez.

En las elecciones de diciembre de 1871 Santiago Rodríguez no sale elegido como concejal del Ayuntamiento.

El primero de febrero de 1872 se reunieron la anterior corporación: D. Emilio Gómez de la Vega, D. Fernando Monterrubio, D. Antonio Hervias, D. Joaquín Badals, D. Emilio de San Pedro y D. Luis Carabias, alcaldes $1^{\circ}, 2^{\circ}, 3^{\circ}, 4^{o}, 5^{\circ}$ y $6^{o}$, populares, y los regidores: D. Cándido Fernández de Castro, D. Rafael Benito, D. Santiago Valdivielso Bonis, D. Lucas Villangomez, D. Eduardo Arnaiz, D. Eustaquio Pedrero, D. Santiago Rodríguez, D. Donato López y D. Juan Díaz, con los del Ayuntamiento entrante: D. Lucio Puente, D. Miguel Moral, D. Nicanor Diez. Salazar, D. Saturnino Delgado, D. Nicolás Espinosa, D. José Casans, D. Calisto Martínez, D. Ildefonso Miegimolle, D. Eusebio Andris, D. Ángel Revilla, D. Ramon Serrano, D. José Vilardell, D. Rafael García y D. Mariano Villanueva.

Colocados en su lugar se retiraron los concejales salientes que no han sido reelegidos: D. Fernando Monterrubio, D. Lucas Villangómez, D. Santiago Rodríguez y D. Donato López. ${ }^{333}$

\footnotetext{
${ }^{331}$ AMBu. Actas del Ayuntamiento. LA-507, 9 de enero de 1871.

${ }^{332}$ Idem, 9 de enero de 1871.

${ }^{333}$ AMBu. Actas del Ayuntamiento. LA- 508, 1 de febrero de 1872.
} 
El ayuntamiento sigue emitiendo diversos pagos a Santiago por papel y encuadernación, según consta en algunas Actas del Ayuntamiento.

Con fecha 29 de abril se producen 10 vacantes en el ayuntamiento: por el fallecimiento de Cándido Fernández de Castro, Ambrosio Hervias, Eduardo Arnaiz y Ángel Revilla; por traslado de residencia, Joaquín Badals y Luis Carabias; y por la renuncia de Emilio Gómez de la Vega, Emilio San Pedro, Juan Díaz y José Vilardell, acorde con la situación convulsa de la Nación. Les sustituyen los que han ejercido anteriormente por elección popular, según el orden de votos obtenidos en las Elecciones de 1868. Así, retoma su cargo Santiago Rodríguez Alonso ${ }^{334}$ junto con Valentín Lorente, Luciano Manzano, Lucas Villangómez, Próspero Gallardo, Rufino Almendres, Donato López, Federico Fernández Izquierdo, Andrés Riveras y Tomás Gonzalo.

En la sesión del nuevo ayuntamiento se forman las distintas comisiones. Santiago Rodríguez forma parte de muchas de ellas: Visita de Personajes, Beneficencia, Caminos, Paseos y Arbolado, y Presupuesto. ${ }^{335}$ En la misma sesión se nombra la comisión de fiestas para dicho año formando parte de ella nuestro protagonista, junto con Gallardo, Rafael Benito y Bonis.

En las elecciones del 19 de julio de $1873,{ }^{336}$ por el primer colegio electoral, salen elegidos: Santiago Diez y Díaz, Federico Fernández Izquierdo, Próspero Gallardo, Santiago Rodríguez Alonso y Pascual Moliner, de un total de 25 concejales.

El alcalde fue Federico Fernández Izquierdo, acompañados por los tenientes de alcalde, Lucio de la Puente, Rafael Benito, Ildefonso Miegimolle, Miguel Moral y Ramón Serrano y regidores Andrés Riveras, Nicanor Diez Salazar, Saturnino Delgado, Santiago Valdivielso Bonis, José Casans, Calixto Martínez, Rafael García, Mariano Villanueva, Luciano Manzano, Próspero Gallardo, Santiago Rodríguez, Rufino Almendres, Andrés Riveras y Tomás Gonzalo. ${ }^{337}$

En esta nueva legislatura, en la sesión del 29 de agosto de 1873, también se encargan de la comisión de Personajes, junto con el Alcalde, Julio García de Quevedo y Francisco Aparicio. Sigue formando parte de las comisiones de Beneficencia, Hacienda, Paseos y Arbolado, Presupuestos, deja la comisión de Caminos y pasa a la Comisión de Teatro junto a Próspero Gallardo, Pascual Moliner y Ángel Iradier.

En enero de 1874 el general Pavía asestó el golpe final a la I República. A consecuencia de ello el Capitán General de Burgos comunica a todos los

\footnotetext{
${ }^{334}$ AMBu. Actas del Ayuntamiento. LA-509, 29 de abril de 1873.

${ }^{335}$ Ibídem, 9 de mayo de 1873.

${ }^{336}$ AMBu. Sig. 10-53.

${ }^{337}$ AMBu. Actas del Ayuntamiento. LA-509, 24 de agosto de 1873.
} 
concejales su cese en el cargo y nombra alcalde a José Soto Vega, conde de Encinas; y de tenientes de alcaldes a Antonio Martínez Acosta, Emilio San Pedro, Primitivo Nevares, Victoriano Zumárraga y Lucio de la Puente; de regidores a José Arroyo Revuelta, Eustaquio Pedrero, Claudio Bajo, Antonio Martínez, Cosme Díez, Pedro Calleja, Tomás Arribas, Nicolás Espinosa, José Casans, Jacinto de Ceano Vivas, Jacinto Sevilla, Calixto Martínez Vadillo, Pascual Escudero, Lucas de Carranza Díaz, Eugenio Ceballos, Julián Gallo y Eladio Escudero. ${ }^{338}$

De todas maneras sigue sus pasos en la política como diputado provincial, reconocido en las Actas de la Diputación de 1874 en sesión ordinaria del 3 de noviembre, nombrado por el distrito de BurgosSedano. ${ }^{339}$

Así bien, quedó enterada la Corporación del oficio del Sr. Gobernador nombrando diputados provinciales a los señores D. Santiago Rodríguez Alonso, D. Carlos Mallaina, D. Eulogio González Montero, D. Lorenzo López Casas, D. Gregorio Pineda, D. Cipriano Santana y D. Pascual Moral. ${ }^{340}$

Después de revisar todas las actas de las sesiones ordinarias de la Diputación no se ha encontrado ninguna otra participación en las mismas, ni los trabajos realizados en su distrito. El vacío documental de las elecciones de dichos años dificulta conocer el tiempo que llevó a cabo tal acreditación.

La muerte de su mujer, en julio del mismo año y desengaños políticos hacen que Santiago Rodríguez se retire de la política. Se centra en sus hijos, en el desarrollo de su librería y en la creación de una imprenta.

Por otro lado, tal como señala Juan Valero Tornos y el Diario de Burgos a Santiago Rodríguez se le concedió en julio de 1874 la cruz de Carlos III, rechazándola pues dijo que no quería más honores y recompensas que los que su trabajo le proporcionara. ${ }^{341}$

Se puede elucubrar que quizá sus ideas, más próximas a principios más liberales que monárquicos, le indicaran una contradicción con sus principios y optó en consecuencia negando su concesión.

\footnotetext{
${ }^{338}$ AMBu. Actas del Ayuntamiento. LA- 510, 24 enero de 1874.

339 VALERO DE TORNOS, J. Op. cit., p. 109.

${ }^{340}$ ADPBU. Fondo Diputación, ADP-28, p. 107.

${ }^{341}$ VALERO DE TORNOS, J. Op. cit., p. 109.
} 


\subsection{EL LEGADO PERSONAL Y TESTAMENTARIO A LA MUERTE DE D. SANTIAGO RODRÍGUEZ}

En la obra de Juan Valero de Tornos, España en fin de siglo, se rinde un recuerdo a su figura, su carácter y forma de ser, recordando su defensa de la enseñanza y las nuevas ideas pedagógicas. Le describe como hombre respetado, con gran iniciativa y seriedad en los negocios.

En un artículo del Diario de Burgos se refleja su carácter, así como su actividad comercial.

...Activo, laborioso, trabajador, fundó su establecimiento de librería hacia mediados del siglo pasado. Era un buen tipo de castellano viejo, del genuino burgalés.

Su físico parecía exigir la cota de malla y el casco de los escuderos del Cid, pero su aspecto de guerrero era desmentido por su simpática mirada y agradabilísimo trato; alegre, dicharachero, amigo y comilitón de los buenos burgaleses Lorencito Rincón, Sarachu Marrón, Los Roscones, Los Cármenes y tantos otros que recuerdo con gusto, porque con su alegría y graciosas bromas animaban a este querido Burgos, que si de algo peca es de serio y tristón.

Santiago Rodríguez, gran trabajador, sin temor a competencias, con tantos y tan buenos impresores, fue extendiendo su modesta librería; empezó por hacer tarjetas, más tarde, a su industria de librero y almacenista de papel y objetos de escritorio, añadió editar obras de primera enseñanza, a cuya especialidad tenía gran cariño.

A este fin y compró una máquina "Bremen", de gran tamaño; lanzado ya en este camino, ensanchó su esfera de acción y llegó a figurar un burgalés entre los editores españoles.

Por sus iniciativas y seriedad en los negocios, su nombre fue respetado en el comercio y consiguió ser premiado con diploma y medallas en las Exposiciones de 1882, 1885 y en las de Barcelona de 1888.

He tenido el placer de dedicar este recuerdo a la memoria del buen Santiago, no sólo por afecto, sino porque creo que en Burgos se padece la enfermedad del olvido para con sus hijos, y creo también que ya es hora de que todos, y aprovechando todas las ocasiones, vayamos haciendo justicia a los que poco a poco, en silencio y con modestia, hacen culto, simpático y agradable el nombre de Burgos, y poco a poco también contribuyen a que nuestra ciudad sea conocida y respetada. ${ }^{342}$

Los principales periódicos de la ciudad ensalzan el carácter abierto, su constante trabajo y preocupación por hacer de su librería no sólo un lugar donde se podía encontrar todos los artículos y novedades sino un lugar de encuentro cultural de literatos y personas afines a la educación.

Era popular en la ciudad, pues nos llama la atención que el anuncio de la fábrica de chocolate "La Pureza", del Pasaje de la Flora, se recuerda por su situación frente a la librería de Rodríguez. ${ }^{343}$

\footnotetext{
${ }^{342}$ Diario de Burgos. Expositores burgaleses. 1 de diciembre de 1908, p. 1. Vid. Anexo 2.3.6.

${ }^{343}$ El Papa-Moscas. Año V, no 216, 2 de abril de 1882, p. 4.
} 
Aceptaba de buen grado el inconveniente de no poner el rótulo en su librería e imprenta debido a las reformas de la calle Laín Calvo, después de más de dos años y medio. ${ }^{344}$

Ante un negocio de camisería en el Paseo del Espolón de Florentina Sainz de Lozano, cerrado con motivo de las obras en su edificio, Santiago deja que todos los pedidos e información se realicen a través de la librería. $^{345}$

Utiliza sus escaparates, no sólo para anunciar sus artículos, sino que también para visualizar trabajos cerámicos del cuñado de su hijo, Nazario Escudero, ${ }^{346}$ lo que nos hace estimar las buenas relaciones con su familia política.

La cercanía de los empleados de Santiago Rodríguez la descubrimos al imprimir cada año una tarjeta de felicitación por su cumpleaños, al igual que a su hijo y socio de la casa editorial ${ }^{347}$ (Figura 3-21).

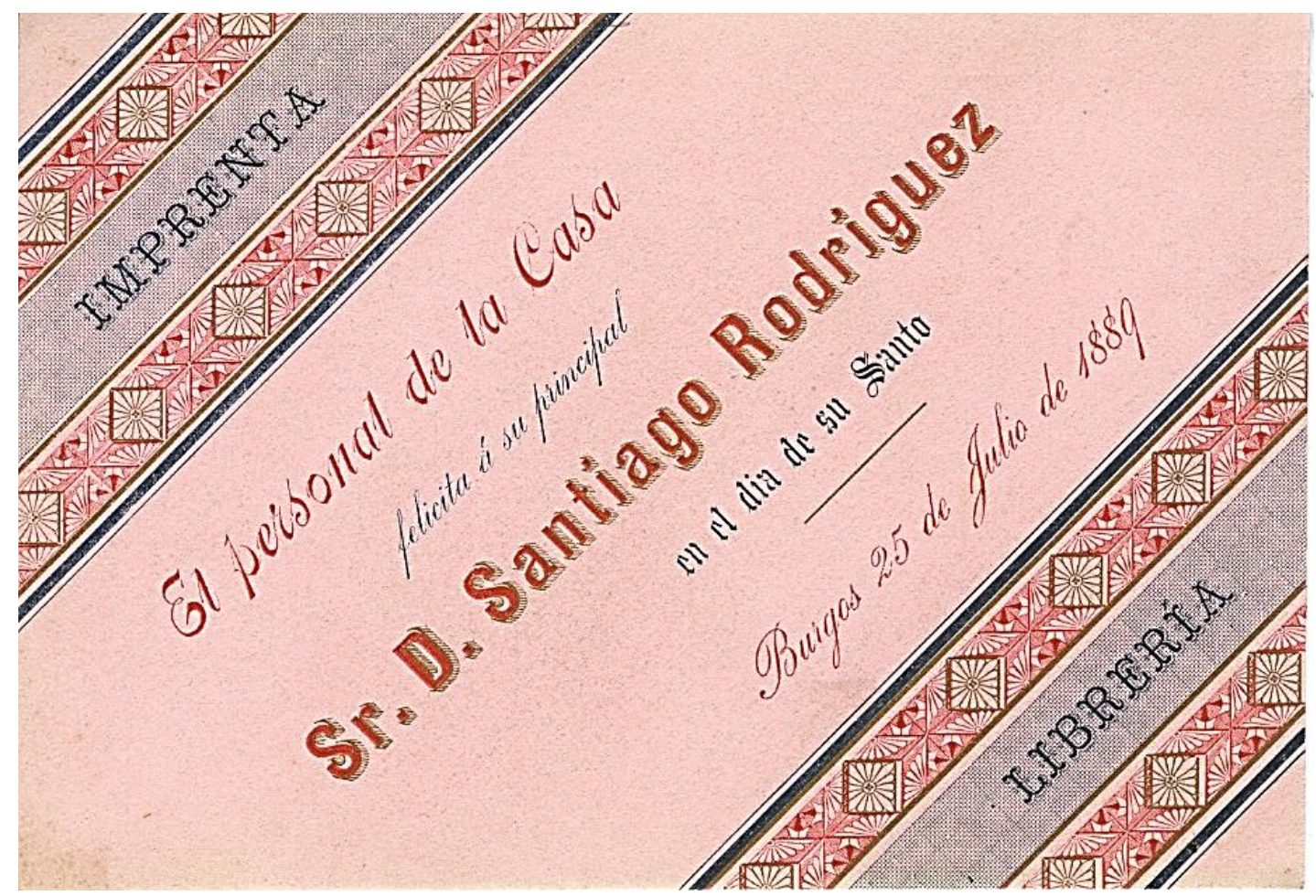

Fig. 3-21: Tarjeta de felicitación del personal de la Casa Editorial a D. Santiago Rodríguez en su 60 cumpleaños. Imagen cedida por Mercedes Rodríguez Plaza.

Un sello distintivo de la librería Santiago Rodríguez fue dotarla de todos los materiales y libros que se publicaban en España de tal forma que cualquier obra se podía conseguir de forma rápida.

\footnotetext{
${ }^{344}$ El Papa-Moscas. Año II, no 83, $4^{\mathrm{a}}$ semana de septiembre de 1879, p. 3.

${ }^{345}$ El Papa-Moscas. Año II, $\mathrm{n}^{\circ}$ 63, segunda semana de mayo de 1879, p. 4.

${ }^{346}$ El Papa-Moscas. Año XIV, no 689, 8 de marzo de 1891, p. 3.

${ }^{347}$ Mercedes Rodríguez Plaza conserva algunas de estas tarjetas de felicitación de los años 1884, 1885, 1886, 1887, 1889, 1890.
} 
Cuenta con todos los libros escolares necesarios para cada curso, se especializa en primera enseñanza, ${ }^{348}$ y se anuncia en los periódicos locales y nacionales. ${ }^{349}$ También tiene libros comerciales, libros religiosos, devocionarios variados, novedades literarias, ${ }^{350}$ agendas, calendarios, artículos de encuadernación, tintas, papel de hilo, estampas, cuadernos rayados y todas las novedades en objetos de escritorio y cromos. (Figura 322).

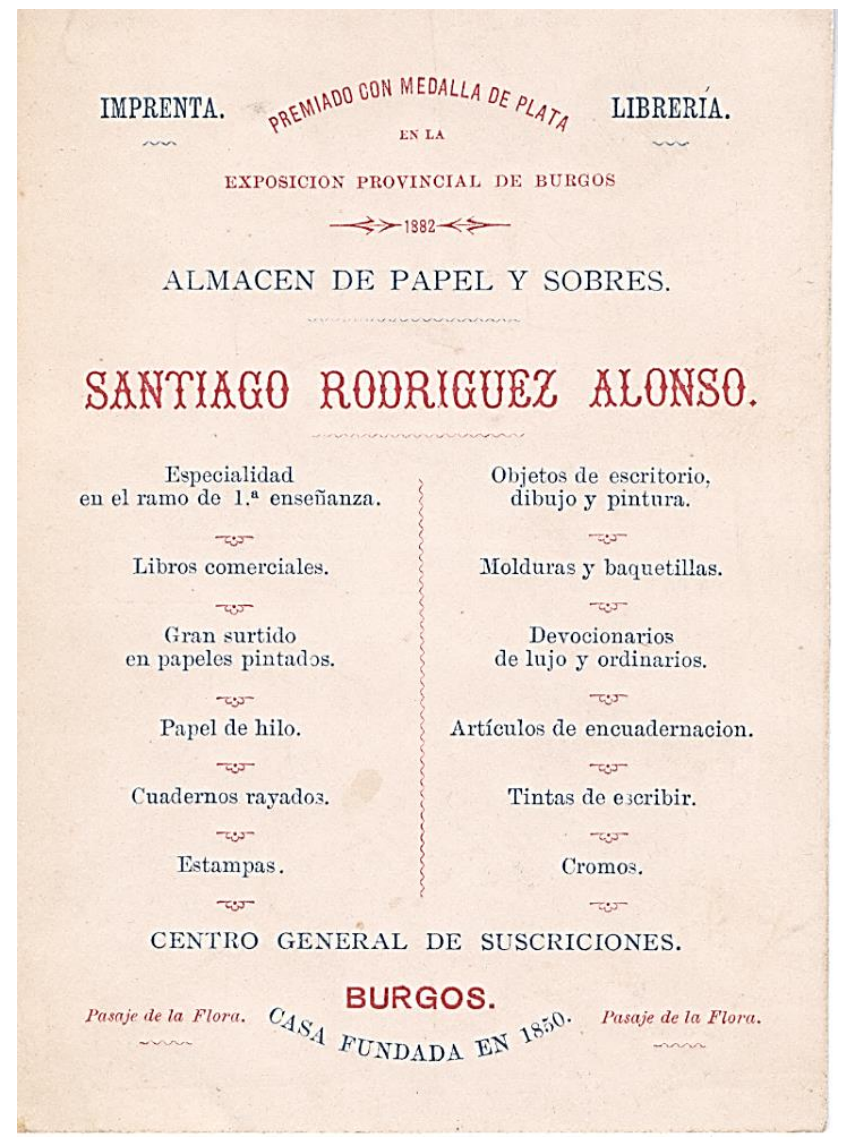

Fig. 3-22: Propaganda sobre la Imprenta y Librería de Santiago Rodríguez Alonso, donde se detalla los artículos más importantes de su comercio.

Imagen cedida por Mercedes Rodríguez Plaza.

Como premio a esta labor fue galardonado en varias Exposiciones. La primera medalla obtenida fue en la Exposición Provincial de Burgos en 1882, donde consigue la medalla de plata por la impresión y mención honorífica por encuadernación. ${ }^{351}$ Instala una escuela modelo y obtuvo el premio de honor. ${ }^{352}$ No duda de la calidad de sus trabajos, presentándose a

\footnotetext{
${ }^{348}$ El Papa-Moscas. Año II, no 83, $4^{\circ}$ domingo de octubre 1879, p.4. Al año siguiente el 17 de octubre de 1880 se publicita que en la librería de S. Rodríguez Alonso se venden toda clase de libros de texto ${ }^{349}$ El Papa-Moscas. Año III, no 102 y 103, $1^{\circ}$ y $2^{\circ}$ domingo de febrero de 1880, p.1. Se vende en la imprenta y librería de S. Rodríguez Alonso el París-Murcia en castellano, con los mismos grabados que en francés.

${ }^{350}$ El Papa-Moscas. Año IV, $\mathrm{n}^{\circ} 155,6$ de febrero de 1881, p. 4.

${ }^{351}$ El Papa-Moscas. Año V, no 230, 9 de julio 1882, p. 3.

${ }^{352}$ VALERO DE TORNOS, J. Op. cit., p. 109.
} 
Exposiciones en otras ciudades como la Nacional en Zaragoza o la Internacional en Barcelona, donde obtuvo medalla de bronce. ${ }^{353}$ En ambas ganó importantes premios siendo medalla de bronce en Zaragoza por varias obras de enseñanza, y obteniendo otras 6 en la Universal de Barcelona de $1888 .{ }^{354}$ Fue delegado por algunas editoriales españolas, Nueva Biblioteca Universal, acreditado en un artículo en prensa. ${ }^{355}$

Participa de la vida de la ciudad, formando parte de asociaciones culturales, y colabora con las fiestas. Realiza donativos para aliviar la pobreza o para paliar situaciones de desastres naturales en distintos puntos de España. ${ }^{356}$

Encabeza las listas, junto con otros editores, en la creación de una Sociedad de Socorros Mutuos para atender a los enfermos de sus respectivas profesiones como cajistas, prensistas, libreros, litógrafos de la ciudad. Para formar parte de esta Sociedad, según los Estatutos, se pagaba una pequeña cuota de entrada, variable en función de la edad de la persona, y 25 céntimos de peseta semanalmente. El socio enfermo tenía derecho a percibir ocho reales diarios durante dos meses. ${ }^{357}$

Es socio, desde los inicios en enero de 1876, de La Liga de Contribuyentes de Burgos cuyo objetivo era la defensa de los intereses de los contribuyentes y de las clases productoras. Se dedica al estudio crítico de los Presupuestos del Estado y de todas las leyes, decretos y disposiciones que se publican para velar por sus intereses al plantear una mejora del sistema administrativo, para promover una regeneración de la Hacienda $^{358}$ y pedir proteccionismo y facilidades para la venta de sus productos.

En El Papa-Moscas se relata el encuentro diario que mantenía el catedrático de Derecho civil de la Universidad de Valladolid, D. Julián Arribas, con varios amigos, en la librería Hijos de Santiago Rodríguez todas las tardes de 5 a $7 .{ }^{359}$ La noticia es de septiembre de 1891, pocos meses después del fallecimiento de Santiago Rodríguez, por lo que entendemos que estas reuniones se sucedían con anterioridad.

De esta semblanza se desprende cómo su actividad comercial, social y familiar fueron los ejes conductores de su vida. Se preocupa por las dificultades que le ocasiona la compañía de ferrocarriles en el envío de sus

\footnotetext{
${ }^{353}$ El Papa-Moscas. Año XI, no 529, 1 de abril de 1888. Nos informa de todos los expositores de Burgos que concurren a Barcelona, “...Santiago Rodríguez, libros de primera y segunda enseñanza. Adrián Larrea, libros de pedagogía, aritmética, ortografía y prosodia”.

${ }^{354}$ VALERO DE TORNOS, J. Op. cit., p. 109.

${ }^{355}$ El Papa-Moscas. Año VIII, no 400, 11 de octubre de 1885, p. 2.

${ }^{356}$ El Papa-Moscas. Año VII, no 362 y 398, 18 de enero y 27 septiembre de 1885.

357 El Heraldo de Castilla. Año I, no 77, 22 de diciembre de 1880. La sociedad la inician: Santiago Rodríguez, Fournier, Joaquín y Juan Ramón Villanueva, Juan Santamaría.

${ }^{358}$ Reglamento Liga de Contribuyentes de Burgos. Burgos: Imprenta de Timoteo Arnaiz, 1876. p. 5.

${ }^{359}$ El Papa-Moscas. Año XIV, no 717, 20 de septiembre de 1891, p. 2.
} 
pedidos y autoriza a una sociedad madrileña para que gestione todas las diligencias necesarias en dicha mejora.

[...]Don Santiago Rodríguez. Alonso de cincuenta y siete años... autoriza a los Sres. Foreada y Compañía, sociedad constitutiva de la villa de Madrid... para que haga gestiones cerca de la Compañía de Ferro-carriles cuantas reclamaciones tenga que hacer al Sr. otorgante por razón de retrasos, averías u otras causas que le ocurran con motivo de los envíos o remesas de géneros o por cualquier otro concepto... utilizando todos los medios y derechos que

conceden las leyes de Ferro-carriles para lo cual presentará instancias pidiendo rectificación de talones y demás diligencias que se requieran a fin de conseguir las consiguientes indemnizaciones de los prejuicios y demás intereses que se le originen y sean procedente $[\ldots]^{360}$

Asiste a numerosas subastas de venta de papel en diferentes instituciones, como consta el 31 de marzo de 1890 donde autoriza a Blas Serrano, vecino de la ciudad de La Coruña, para que tomase parte en la subasta de papel para el servicio de la Diputación Provincial de La Coruña, encomendándole que, en su nombre, forme parte de dicha subasta presentando la correspondiente proposición, previo al Depósito y demás requisitos necesarios, y le autoriza para que le represente en cualquier otra subasta o asunto mercantil que le pueda convenir, comunicándoselo por correspondencia particular. ${ }^{361}$

El 7 de junio de 1890 se constituye una sociedad anónima para el establecimiento y explotación del servicio telefónico público en Burgos. La componían 28 personas de la ciudad, la mayoría comerciantes, abogados, médicos, farmacéuticos, periodistas y agentes de negocios.

La Sociedad se forma como una compañía anónima por acciones y tiene por objeto el establecimiento y explotación del servicio telefónico público en la ciudad. La Compañía se denominará "Empresa del servicio telefónico de Burgos", con una comisión ejecutiva y unos estatutos, con un capital social de 30.000 pesetas que representan a ciento veinte acciones de doscientas cincuenta pesetas cada una. El periódico El Papa-Moscas describe esta sociedad en la que cada abonado aporta de 90 a 100 pesetas anuales. $^{362}$

Santiago Rodríguez compra tres acciones, sólo superado por 9 personas: Manuel Rico, Carlos Marín, 20 acciones cada uno; Federico Fernández (abogado), Víctor Diez Montero (comerciante), Francisco Aparicio Mendoza (industrial), Juan José Gómez Zamora (comerciante), con 5 acciones cada uno; Juan José Redondo Santaolalla (comerciante), Hilarión

\footnotetext{
${ }^{360}$ AHPBU. Sección de Protocolos. Caja 8928, 11 de agosto de 1888

361 AHPBU. Sección de Protocolos. Caja 8939, 31 de marzo de 1890.

${ }^{362}$ El Papa-Moscas. Año XII, no 595, 19 mayo 1889, p. 2.
} 
Ruiz Casaviella (abogado) e Isidro Alfaro Moreno (propietario), con 4 acciones cada uno. ${ }^{363}$

En otro orden de cosas algunas voces discordantes manifiestan ciertas críticas hacia la gestión del periódico La Imparcialidad. Eduardo Espinosa dirige una carta a D. Jacinto Ontañón, director de El Papa-Moscas, donde denuncia el monopolio informativo de Rodríguez y comparsa. Argumenta que el periódico sólo defiende las aspiraciones del librero y no la libertad de la profesión, aludiendo como ejemplo su silencio, ante una situación injusta contra un maestro de Cebrecos. ${ }^{364}$

Respecto al testamento, Santiago Rodríguez instituye como herederos a sus cinco hijos, expresando lo siguiente:

En la ciudad de Burgos a las cinco de la tarde del día seis de abril de mil ochocientos noventa y uno, ante mi Fernando Monterrubio, vecino de la misma y Notario de su colegio presentes los testigos que comparece Don Santiago Rodríguez Alonso, de sesenta años de edad, viudo, comerciante, natural y vecino de esta ciudad, según cédula personal que me exhibe expedida en ella con fecha once de agosto última y número cuarenta, de séptima clase, hijo de Don Antolín y $D^{a}$ Luisa, difuntos, vecinos que fueron de esta ciudad, el cual hallándose algo delicado de salud pero en su juicio con capacidad legal necesaria para testar dice:

...Declara haber estado casado legítimamente en primeras y únicas nupcias con $D^{a}$ Irene Miguel y Campo, de cuyo matrimonio tiene cinco hijos llamados $D^{a}$ Luisa, D. Mariano, $D^{a}$ María del Pilar, D. Francisco y $D^{a}$ María de la Gloria de los cuales los dos últimos son menores de edad en cuya virtud nombra por tutor de los mismos a D. Valentín Jalón y Gallo por el D. Francisco y a D. Mariano hijo del testador para $D^{a}$ María de la Gloria relevada de toda fianza por merecerles ambos la misma e ilimitada confianza.

Es su expresa voluntad que teniendo recibidas algunas cantidades sus hijos casados $D^{a}$ Luisa, D. Mariano se iguale con los mismos a los otros tres adjudicándoles en su oportunidad la suma equivalente según aparecerá de los apuntes que el testador lleva en sus libros.

Lega y manda la cantidad de dos mil pesetas a su hermana política $D^{a}$ Elisa Miguel y Campos que vive en su compañía y la recomienda muy particularmente a sus hijos para que la atiendan y no la abandonen durante sus días por sus especiales circunstancias.

Instituye y nombra por sus únicos y universales herederos de todos sus bienes, acciones y derechos presentes y futuros a sus referidos cinco hijos: $D^{a}$ Luisa, $D$. Mariano, $D^{a}$ María del Pilar, D. Francisco y $D^{a}$ María de la Gloria Rodríguez y Miguel por iguales partes para que los hayan y hereden con la bendición de Dios y la suya.

Declara que sus dos hijos D. Mariano y D. Francisco aunque no se hallan en sociedad con el otorgante, trabajan e intervienen en todos los asuntos de la casa por un estipendio que les tiene asignado el Señor otorgante y que les tiene

363 AHPBU. Sección Protocolos. Caja 8932, 7 de junio de 1889.

${ }^{364}$ El Papa-Moscas. Año XIII, no 664, 14 septiembre 1890, p. 3. 
satisfechos constantemente hasta el día sin atraso de ningún género lo que manifiesta para que se tenga presente en su oportunidad.

Para cumplir y pagar este su testamento y lo en él contenido nombra por sus albaceas testamentarios y contadores a sus dos hijos legítimo y político respectivamente D. Mariano Rodríguez y D. Valentín Jalón y a su convecino D. Agapito Escudero Torres, a los tres juntos y a cada uno in solidum con todas las facultades más amplias para que luego de su fallecimiento y sin intervención alguna judicial cumplan todo cuanto deja dispuesto prorrogándose el término... ${ }^{365}$

El 21 de junio de 1891 se realiza una reunión de Consejo de familia para la tutela de los dos hijos menores, Francisco y María de la Gloria, donde literalmente se dice:

Don Nicolás Rey Redondo presidente del Consejo de familia de los menores D. Francisco y $D^{a}$ María de la Gloria Rodríguez Miguel.

Certifico que por dicho Consejo se ha celebrado reunión en la que se ha acordado lo que resulta del acta que literalmente copiado dice:

En la ciudad de Burgos a veinte de Junio de mil ochocientos noventa y uno se reunió previo recado de su presidente el consejo de familia de los menores $D$. Francisco y $D^{a}$ María de la Gloria Rodríguez Miguel asistiendo formalmente los vocales D. Juan Gómez Zamora, D. Jose de..., D. Leonardo Rodríguez y D. Francisco Esteban y con presencia de los tutores D. Valentín Jalón y D. Mariano Rodríguez Miguel. El Sr. presidente dijo que el consejo estaba convocado para deliberar acerca de la pensión alimenticia que debía señalarse a dichos menores y por votos manifiesta el Consejo se realizó en vista del inventario de bienes y demás que dispone el artículo doscientos sesenta y ocho del Código civil que los productos de los bienes se corresponden a $D^{a}$ María de la Gloria se destinen anualmente mil trescientos cuarenta y dos pesetas para alimentos de la misma. Respecto al señor D. Francisco el consejo acordó también por manutención que el cargo de tutor que respecto al mismo desempeña $D$. Valentín se entienda con la asignación de frutos por alimentos teniendo para ello en consideración la proximidad que el menor se halla a su mayoría de edad y el género del comercio a que en brevedad se va a dedicar. Por el tutor D. Valentín se pidió al consejo autorización para que el menor D. Francisco pueda continuar al comercio a que su padre se dedicó y por el otro tutor D. Mariano se pidió autorización para que la menor D. María de la Gloria pueda imponer su capital en el comercio de su finado padre que correrá a cargo de los hermanos D. Mariano y D. Francisco y el consejo comprendiendo que ambas peticiones eran favorables a los intereses de los menores concedió por unanimidad de votos las citadas autorizaciones a los tutores según se prevé el artículo doscientos sesenta y nueve del Código.

Por la presente y después de haberse enterado de las bases que han de regir la sociedad mercantil e industrial que ha de formarse y con esto dio por terminado el acto: Nicolás Rey, Juan Gómez Zamora, José de Melle y Leonardo Rodríguez, Francisco Esteban, Mariano Rodríguez Miguel, Valentín Jalón y para que conste a los efectos oportunos y a petición de los tutores D. Valentín Jalón y D. Mariano

365 AHPBU. Sección Protocolos. Caja 7897, 6 de abril de 1891. Vid. Anexo 2.1.15. Testamento de D. Santiago Rodríguez Alonso. 
Rodríguez expide la presente que firma a Burgos a veinte y uno de junio de mil ochocientos noventa y uno. ${ }^{366}$

A su muerte se promueve la Sociedad constituida el 23 de junio de 1891 bajo el nombre de "Hijos de Santiago Rodríguez"

En la ciudad de Burgos a veinte y tres de Junio de mil ochocientos noventa y uno, ante mí Fernando Monterrubio, vecino de la misma y Notario de su colegio, presentes los testigos que nombraré comparecen: Don Mariano, Don Francisco, Doña María del Pilar y Doña María de la Gloria Rodríguez Miguel, hermanos, de edad, respectivamente de treinta y uno, veinte y dos, veinte y uno y diez y siete años, casado el primero y solteros los demás, comerciantes los dos varones...y Don Valentín Jalón y Gallo de treinta y seis años, casado, Secretario de Sala y propietario y vecino de esta ciudad... éste último como legítimo representante de su esposa Doña Luisa Rodríguez Miguel... han resuelto fundar una sociedad y empresa industrial y de comercio que teniendo por objeto la continuación del que su Señor padre giraba, comprenda las bases meditadas y discutidas que consideran han de contribuir al interés de todos; y en consecuencia otorgan la presente escritura de fundación de la sociedad regular colectiva solamente por los dos hermanos Don Mariano y Don Francisco Rodríguez Miguel...

La compañía mercantil e industrial regular colectiva que se constituye tendrá su domicilio en esta ciudad y girará bajo la razón social "Hijos de Santiago Rodríguez" y se dedicará al comercio de librería, papelería y objetos de escritorio, y a la industria de imprenta, reputándose continuadora del establecimiento expresado "Santiago Rodríguez Alonso. ${ }^{367}$

En la escritura de la nueva sociedad se ponen las bases de la compañía mercantil donde los dos socios, Mariano y Francisco, aportan diez mil pesetas como gestores y administradores de la compañía; el uso de la firma social fue encomendada a Mariano Rodríguez Miguel, y faculta a Francisco Rodríguez para las gestiones que se requieran en casos de ausencia, enfermedad u otro impedimento de Mariano.

Se concretan los sueldos de ambos: Mariano Rodríguez dispone de cuatro mil pesetas anuales y Francisco 1.000 pts. anuales; y para gastos particulares 1.200 pts. cada uno.

$\mathrm{M}^{\mathrm{a}}$ del Pilar, María de la Gloria, y Valentín Jalón y Gallo en representación de su esposa Luisa Rodríguez, dejan a título de imposición de la Sociedad los bienes, derechos y acciones del establecimiento mercantil e industrial de su padre. Todos los meses se entregará a cada uno de los tres imponentes la cantidad de cien pesetas como adelanto de las utilidades que les pudieran corresponder y si hubiere pérdidas se disminuirá dicha cantidad; lo mismo ocurrirá con los dos socios de la Sociedad. La duración de la Compañía será de diez años contando a partir de esta fecha.

\footnotetext{
${ }^{366}$ AHPBU. Sección Protocolos. Caja 9898, 23 de junio de 1891.

${ }^{367}$ Ídem, 23 de junio de 1891. Vid. Anexo 2.1.16. Escritura de Sociedad Hijos de Santiago Rodríguez.
} 
Y si alguno falleciese, los herederos adquirirán los mismos derechos y obligaciones.

Los tres impositores podrían retirar, cuando lo tengan por conveniente, la imposición que hacen en la sociedad en cuyo caso se haría inventario y se entregaría a cada uno que lo solicitase, el valor en metálico a que ascienda la quinta parte del haber de la sociedad "Hijos de Santiago Rodríguez". En el mes de junio se hará el balance general para presentar a todos los socios. Como condición se impone que ninguno de los socios podrá ceder, donar, vender ni permutar su participación en la sociedad a persona extraña a ésta.

Terminado el inventario el 20 de mayo de 1891 se puede comprobar que su legado es muy superior, en calidad y cantidad, a lo que podríamos pensar. En el activo en caja hay 2.500 pts., el resto del capital se reparte entre almacén, tienda e imprenta.

En el almacén se puede observar una larga lista de libros, algunos impresos en su imprenta, de otras editoriales y multitud de material escolar, papelería, artículos para trabajos manuales, carnets, orlas, diplomas y papeles pintados.

De los libros publicados en su imprenta se pueden apreciar 3.000 ejemplares que figuran en el inventario, ${ }^{368}$ junto a 10.000 cubiertas al cromo, "Higiene por Carretero", a 1 real la unidad. Esta simplificación en el título nos hace especular que podría referirse al libro Catecismo de Higiene y Economía domésticas: precedido de unas nociones de Fisiología cuya $3^{\text {a }}$ edición data de 1889, o bien al Resumen del Catecismo de Higiene y Economía doméstica refundido por su hija Mariana Álvarez Bollo Carretero en 1890. La misma duda nos surge con otros 1.018 ejemplares que se citan en el mismo inventario como "Higienes por Carretero", a cartoné, por un precio de 1,50 reales unidad.

También de Antonio Álvarez Carretero se encuentran ejemplares de la obra Prontuario de Pedagogía: 81 de ellos a un precio de 1 real, 16 en rústica a dos reales y 100 en cartoné a 3 reales.

Otra obra de la que se hicieron grandes tiradas, con 6.000 ejemplares en el almacén, es Tablas de reducción de las pesas y medidas de Burgos a las del sistema métrico decimal, con ediciones en 1883 y 1887, a un precio de 0,1 real la unidad. A un menor precio 0,04 y 0,06 reales la unidad de la misma obra con un número de 736 ó 1.900 obras respectivamente.

Santiago Rodríguez disponía de libros de aritmética y geometría de diversas editoriales de la época (Hernando, Paluzíe, Bastinos) y de diversos autores de la segunda mitad del siglo XIX como Torrecilla, ${ }^{369}$ Cardín, ${ }^{370}$ Escosura, ${ }^{371}$ Tejada, ${ }^{372}$ Vallín, ${ }^{373}$ Córtazar, ${ }^{374}$ Yeves, ${ }^{375}$ y Morate. ${ }^{376}$

\footnotetext{
${ }^{368}$ AHPB. Sección Protocolos. Caja 9898, 20 mayo de 1891. Vid. Anexo 2.4.1. Inventario de la Librería e Imprenta a la muerte de Santiago Rodríguez Alonso.

369 TORRECILLA, G. Elementos de Aritmética. Madrid: Imprenta de la Viuda de Burgos, 1854.
} 
El número de ejemplares no es muy elevado a excepción de los 103 ejemplares de Geometría de Yeves y los 92 de Morate.

Se citan como ejemplares en rama 200 ediciones impresas, plegadas pero sin encuadernar de la obra Amigo de los niños con un precio de 0,40 reales por ejemplar. Podemos pensar que se trata de la obra El Amigo de los niños del Abate Sabatier, traducida por Juan de Escoiquiz del que se conservan ejemplares en Hijos de Santiago Rodríguez, en 1895, como nueva edición ilustrada. Hecho que ilustra su existencia en la imprenta de Santiago Rodríguez Alonso. Con el mismo título Amigo de los niños 800 ejemplares en rústica a 0,33 reales unidad, 500 ejemplares en cartulina a 0,46 reales la unidad y otros 500 ejemplares en cartoné a 0,70 reales la unidad. Esto nos hace suponer que era una publicación ya consolidada en el tiempo. Además, encontramos esta obra editada por otras imprentas como la de Saturnino Calleja ${ }^{377}$ o la librería de Pascual M. Villalba de Valencia, en 1893, como nueva edición corregida y traducida por F. José de Toro.

En el almacén había 1.000 ejemplares de Historia de la Instrucción Pública en España y otros 100 en pasta. El título guarda cierta similitud con Historia de la instrucción pública en España y Portugal de Vicente de la Puente, impresa en Madrid en la Imprenta y Estereotipia de Rivadeneyra.

Otra obra, con un número importante de ejemplares en rama, es Geografía, por Rives, con un total de 175 ejemplares a 10 reales la unidad, por lo que se puede referir a la obra que Hergueta pone como Programa razonado de Geografía, citado en obras primigenias, de 549 páginas y 7 hojas de apéndice, diferente de los 274 ejemplares bajo el título Programa Geografía Rives con un precio de 1 real por unidad.

Quedan 117 ejemplares editados en la imprenta de Santiago Rodríguez Alonso como Programa de las lecciones de la asignatura de Historia de España y 53 ejemplares de Programa de las lecciones de Historia Universal. Libros de texto, ambos al precio de 1 real la unidad.

\footnotetext{
370 FERNÁNDEZ Y CARDÍN, J.M. Elementos de matemáticas. Madrid: Imprenta Alejandro Gómez Fuentenebro, 1876. Es una obra de texto para la segunda enseñanza.

371 ÁlVAREZ DE ESCOSURA, S. Elementos de Aritmética. Madrid: Sucesores de Hernando, s/a. (El autor era profesor Normal de primera enseñanza).

372 TEJADA, M. Aritmética al alcance de los niños. Barcelona: Librería de Juan y Antonio Bastinos, 1881.

373 VALLÍN Y BUSTILLO, A. F. Aritmética para niños. Se encuentran ejemplares de diversas imprentas Véase: En Madrid: Imprenta del Colegio de Sordo-Mudos y de ciegos (1854); Imprenta de Santiago Aguado (1865), Librería de Hernando (1878); y en París en la Librería de Garnier Hermanos, 1882. Es una obra dedicada para la enseñanza primaria.

374 CÓRTAZAR, D. y J. Tratado de Aritmética. Diversas imprentas publicaron ejemplares: Madrid: Imprenta de Manuel Tello, 1877; Madrid: Imprenta de Hernando, 1879.

375 YEVES, C. Programa de primera enseñanza. Aritmética. En diversas imprentas madrileñas: Imprenta de Alejandro Gómez Fuentenebro, 1872, posteriormente en Sucesores de Hernando.

${ }^{376}$ SÁNCHEZ-MORATE y MARTÍNEZ, J. F. Nuevo compendio de aritmética práctica: con el sistema métrico decimal y un método sencillo para resolver las cuestiones de la regla de tres, sin el auxilio de las proporciones. Madrid: Librería de Francisco F. Vila, 1867.

377 REYRE, J. (Abate Sabatier). Traducido por Juan de Escoiquiz. El amigo de los niños. Madrid: Saturnino Calleja (imp. de M. M. de los Ríos), 1884.
} 
El resto de las obras más conocidas son 150 ejemplares de Elementos de Geografía, de Juan Francisco Sánchez-Morate y 100 de Prontuario de $H^{a}$ de España, de Ángel $\mathrm{M}^{\mathrm{a}}$ Terradillos, realizadas en la imprenta de Viuda de Hernando y Cía. Otras sobre Historia de España se mencionan por su autor como Flórez, Guillén, ${ }^{378}$ Sanz, González Alfaro, Yeves, mientras que otras lo hacen por su impresor como Historia de España Calleja, Historia de España Paluzíe y los Atlas de Geografía de Paluzíe.

Se encuentran otros 320 ejemplares de La Guía general de Burgos, escrita por Antonio Buitrago y Romero. Editada por la imprenta de Aribau, en 1876, da pie a pensar Santiago Rodríguez pudo ser su representante en Burgos.

Entre las obras del inventario relacionadas con el aprendizaje de la lengua, especialmente lectura, nos encontramos Catón metódico de los niños de José González Seijas; ${ }^{379}$ se puede deducir que la obra se publicaba por Santiago Rodríguez. Hay un total de 2.360 ejemplares encuadernados en papel o cartulina con unos precios que oscilaban entre $0,20,0,28$ y 0,50 reales la unidad.

Las obras dedicadas al aprendizaje de la lectura eran muy numerosas. Encontramos Método para aprender a leer de Naharro, Silabarios y Catones de Flórez, Pampliega, Serrano, González, San Antonio, García, Hernando, San Casiano y Paluzíe. Algunos de éstos fueron publicados en Hijos de Santiago Rodríguez como el Libro Primero o Silabario de San Antonio, Abecedario y Silabario de Antonio de la Iglesia Serrano, Catón Cristiano de San Casiano. Son citados en el Catálogo de 1908 pero que no se puede asegurar que como tales fuesen editados por Santiago Rodríguez. Lo mismo ocurre con las obras de Eduardo Augusto de Bessón, con 141ejemplares de la obra Método Nuevo para el aprendizaje de la lectura de niños y adultos, en cartoné, a un precio de 0,50 reales por unidad u otros 141 ejemplares del Libro Segundo de Bessón. ${ }^{380}$

El inventario recoge también un extenso surtido de libros de Fábulas, de Samaniego, Iriarte, Regúlez, Miguel, Raeza y Calleja. El elevado número de Fábulas de Samaniego que aparece en el almacén, -1.000 ejemplares-, refleja que ya eran editadas en la Imprenta y Librería de Santiago Rodríguez Alonso. Su precio era de 0,76 reales la unidad, en cartoné, muy por debajo del resto de los ejemplares de otras editoriales;

\footnotetext{
${ }^{378}$ GUILLÉN DE LA TORRE, M. Compendio de Historia de España. Madrid: Imprenta de Pascual Conesa, 1878. Se hace referencia al libro en la obra de: GARCÍA PUCHOL, J. Los textos escolares de $H^{a}$ en la enseñanza española (1808-1908). Análisis de su estructura y contenido. Barcelona: Universidad de Barcelona. 1993. p. 271.

${ }^{379}$ En el Catálogo de 1908 de la editorial Hijos de Santiago Rodríguez publicita esta obra como edición Rodríguez, con un tamaño de 15,5 x $11 \mathrm{~cm}$ y 16 páginas, encuadernado en pasta, con tapas al cromo por un precio de 0,3 pts. y 3 pts. la docena.

380 En el mismo Catálogo de 1908 esta obra la titula El Primer Libro de la Escuela, y la describe como complemento del Método Nuevo para conseguir leer con fluidez. Tienen las dos obras la misma descripción y el precio es mayor en éste, 0,5 pts. la unidad y 5,5 pts. la docena.
} 
excepto las Fábulas de Calleja que las vendía a un precio de 0,80 reales la unidad. ${ }^{381}$

Otras obras depositadas en el almacén corresponden a varias obras de Juanito de Parravacini, recopilada por varias editoriales como Hernando, Valle, Rosado y Torrente y todas editadas en cartoné.

Existían cuadernos de lectura de Joaquín Avendaño y Mariano Carderera, ortografías de Salazar, gramáticas de Paluzíe y Morate..$^{382}$ También se encontraban ejemplares de escritura y lectura de Paluzíe $\left(2^{\circ}\right.$ y $3^{\circ}$ cuaderno).

Encontramos 42 ejemplares de Lecturas morales de Mateo Bustamante y 138 ejemplares de la obra Festividades de la Iglesia de Antonio Moral, ${ }^{383}$ que ya los editó Santiago Rodríguez en 1880 y 1888, respectivamente.

También existen más de 500 ejemplares del libro Obligaciones del Hombre de Escoiquiz, sobre la de educación moral. Esta obra la encontramos publicada por las principales imprentas de la época. ${ }^{384}$

Además, se hallan numerosas obras de tipo religioso: Iris del cristiano, Lirio Celestial, Kempis, Oficio Divino, Domingos de San Luis, Hora Divina, Visitas al Sto. Sacramento, Camino recto, Devocionarios, Manual de Sacristanes, Manera de catequizar a los nuevos fieles, Ancoras de Salvación, Semana Santa...

De los numerosos ejemplares de catecismos y de religión para escolares realizados por su editor, encontramos "Catecismos Paluzíe", con más de 500 ejemplares, o los 14 "Catecismos Calleja". Con referencias de autor están "Obras de misericordia Gómez", "Obras de misericordia Torrecilla", o "Catecismos Claret", "Religión y Moral Flórez", "Historia Sagrada Calonge", "Manuscrito, religión y moral Valle", "Historia Sagrada de Rosado". La mayor parte de los catecismos son de Ripalda, con 1.000 ejemplares, del Abad Claudio Fleury, con unos 350 ejemplares, y del mismo autor, Diálogo del Catecismo Histórico e Historia Sagrada con unos 200 ejemplares. Hemos de señalar que si bien es cierto que la mayoría de las imprentas de la época tenían impresiones de estas obras no nos consta ningún ejemplar impreso de Santiago Rodríguez.

\footnotetext{
${ }^{381}$ En el Catálogo de 1908 aparece publicidad sobre Fábulas literarias por Samaniego, edición especial de la casa, y Fábulas literarias de Iriarte, como nueva edición aumentada por algunas fábulas póstumas del autor. Ambas tienen la misma descripción física de 16 x 11,8 cm, encuadernadas en pasta y cubiertas al cromo. Tiene el mismo precio para ambas de 0,5 pts. la unidad y 4,50 la docena.

${ }^{382}$ En el inventario no especifica el título, sólo habla de Gramática de Morate. Se puede pensar en la obra de: SÁNCHEZ-MORATE, J. F. y CARPERA Y TRIGUEROS, A. Nuevo compendio de la Gramática de la Lengua Española: para uso de los niños. Madrid: Sucesores de Hernando.

${ }^{383}$ MORAL, A. Festividades de la Iglesia. Burgos: Imprenta y librería de Santiago Rodríguez Alonso, $1888,156 \mathrm{p}$.

${ }^{384}$ En el Catálogo de 1908 aparece dicha obra como publicación de la editorial. Teniendo en cuenta el número elevado de ejemplares y su bajo precio, 0,2 reales la unidad, pensamos que fue editada por la imprenta de Santiago Rodríguez Alonso.
} 
De todas las obras de diversas editoriales se observa por el inventario que las de precio más bajo son las que se publicitan como tales, y corresponden a Calleja y Santiago Rodríguez.

Las obras registradas en "Tienda" alcanzan un número menor de ejemplares. Encontramos muchas de las obras anteriormente comentadas, y otras de literatura y libros de texto para escuelas e institutos.

La suma total del inventario de almacén y tienda ascendía a $246.998,82$ reales $(61.749,71 \mathrm{pts}$.$) .$

El apartado de "Imprenta" asciende a un total de 115.192 reales $(28.798$ pts.). Incluye, en maquinaria de imprenta, como una Minerva de 1.000 pts., una Bremen de 6.750 pts. y una Marinoni de 5.000 pts., junto con maquinaria para cortar, prensar trepar y encuadernar, unido a todo un conjunto de tipos, rayas, cajas, galeras, galerines y resmas de papel de varios tamaños y calidad.

Si la comparamos con la mejor editorial de Madrid, casa Hernando, en 1896, que trabajaba con una máquina Marinoni simple de cilindro, valorada en 2.800 pts., y con dos máquinas sistema Fort Bolm, valoradas en 5.500 pts. cada una, ${ }^{385}$ se observa que Santiago Rodríguez Alonso, a su muerte en 1891 había dejado un legado mayor en maquinaria de imprenta, que el de la Casa Hernando, cinco años antes.

En el inventario también anota los saldos deudores y los acreedores. La mayor parte de los deudores tienen deudas menores caso de pequeños comerciantes, libreros, etc. No así las deudas con entidades como la Diputación de Salamanca por un valor de 254 pts., el Salón de Recreo de Burgos, con una importante deuda de 2.089,31 pts., o la Diputación de León por 100 pts.

Entre los deudores encontramos a Roca Bren con un importe de $1.499,13$ pts., que bien pudiera ser Manuel Roca Bren, catedrático de Agricultura Elemental en Londres durante los años 1882-1892. ${ }^{386}$ También pone como deudor a Dámaso Rodríguez, por 1.104 pts.; aunque no se puede saber si se refiere a su hermano contra el que en su día litigó por asuntos económicos.

Los mayores deudores fueron: Yarto Jiménez con un total de 1.474,16 pts., comerciante de Burgos; León Velasco por 2.089,31 pts. del que se desconoce su procedencia y empleo; Juan Esplá, librero e impresor de

\footnotetext{
385 BOTREL, J-F. Libros, prensa y lectura en la España del siglo XIX. Madrid: Fundación Germán Sánchez Ruipérez, Ediciones Pirámide, S.A., 1993, p.215. Hace referencia a la Escritura de Constitución de la Compañía mercantil Hernando y Cía el 1-07-1896, pp. 419-420.

${ }^{386}$ En la página del IES Práxedes, en la sección Apuntes para la Historia, en la sección de "personas y personajes" van ampliando el número de personas y personajes importantes en la educación. Nos describe a Manuel Roca Bren como catedrático numerario de agricultura, natural de Londres y que después de 1892 pide permuta de su plaza. Ver: www.iessagasta.edurioja.org/elsagasta/archivo/personas_v.htm\#roca.
} 
Alicante por un total de 918,54 pts. ${ }^{387}$ Galo Barrutia, impresor de Vitoria, que regentaba la Imprenta la Ilustración por un total de 2.165,74 pts.; ${ }^{388}$ Darío Rahola, vecino de Gerona, a quien había enviado numeroso material y que le debía dos letras de distintas cantidades por un total de 267,26 pts. ${ }^{389}$ y Buenaventura González, vecino del comercio de Torrelavega, por un importe de 511,55 pts., suma que después fue liquidado en parte rebajándose a un total de 256,39 pts., en abril de 1892.390

Pequeños deudores, con quienes trabajaba asiduamente, fueron Eduardo A. Bessón por 500 pts. o Antonio Álvarez Carretero por 175 pts.

Simbólicas cantidades son las deudas de editoriales con las que trabaja habitualmente como Antonio J. Bastinos por 2,08 pts. y J. M. Paez por 92,21 pts.

En sección aparte anota a maestros deudores, sin especificar quienes, por un importe de 2.086 pts. junto a deudores del periódico $\mathrm{La}$ Imparcialidad, por 200 pts. Otras cuentas a cobrar ascendían a un total de $8.627,51$ pts.

En el apartado de los saldos deudores aporta una rica información sobre personas y empresas con las que trabajaba.

La deuda más importante era a Fernández Villa Hermanos, banqueros de Burgos por un valor de 12.413,65 pts.

Señala otras editoriales, como:

- Espasa y Compañía, creada en Barcelona en 1869 por Manuel Salvat y Pau y Josep Espasa. En 1881, este último llega a un acuerdo con su cuñado Manuel Salvat para constituir España y Compañía. Y en la primera mitad de siglo XX, Salvat Editores, S.A son líderes del sector hasta la guerra civil.

- Montaner y Simón, fundada en Barcelona en 1861, se convirtió en una de las más importantes de España por su producción, calidad y exportación a América.

- Sucesores de J.M. Fabre, editor e impresor de Barcelona especializado en obras científicas y artísticas.

- Viuda e hijos de J. Subirana, impresores barceloneses especializados en obras de temática religiosa, teología y filosofía, así como en obras de ficción.

- L. Turgis et Fils, grabador y editor de París, especialista en el comercio de la estampa.

- Saturnino Calleja, fundador de la editorial Calleja en Madrid.

- Viuda de Hernando, libreros e impresores con obras de carácter pedagógico y didáctico en Madrid.

\footnotetext{
387 AHPBU. Sección Protocolos. Caja 9900, 9 diciembre 1891.

${ }^{388}$ Ibídem, 5 de diciembre 1891. La cuenta fue finalmente embargada el 24 de enero de 1894.

${ }^{389}$ AHPBU. Sección Protocolos. Caja 8937, 18 de julio de 1890.

390 AHPBU. Sección Protocolos. Caja 10752, 4 de abril de 1892.
} 
- Faustino Paluzíe editor de Barcelona muy relevante en el campo de los libros educativos y material de enseñanza para niños.

- Juan Gili, editor de Barcelona.

- Saenz de Jubera Hermanos, editores que nacieron al final del siglo en Madrid como empresa familiar al igual que Calleja, Casa Hernando y sucesores de Rivadeneyra.

- A. Bethencourt e Hijos, impresores y libreros en Curazao, Venezuela.

- Hachette y compañía, librería de París.

- Garnier Hermanos, editorial fundada en París en 1833.

Otros adeudados fueron Schomburg Caballero y compañía, empresa madrileña dedicada a maquinaria y material para la industria con especialidad para la imprenta, litografía y encuadernación.

Por las deudas, podemos saber que trabajaba con varias industrias papeleras como Arza y Compañía con un complejo industrial papelero en la comarca de Tolosa. Bartolomé Arza poseía tres fábricas; en Berasaluce y Barrena, fábricas de papel continuo y San Miguel en Irurzun, Navarra, especialistas en imprimir papel finos y ordinarios, blancos y a color, fundada es de $1887 .{ }^{391}$

Otros son pequeños pagos de 56 pts., a la compañía transatlántica y un pago mayor a su cuñada Elisa Miguel y Campo, por 1.500 pts.

En total todo el capital activo asciende a $148.674,9$ pts. y el pasivo a $52.646,81$ pts. quedando un capital líquido de 96.028,09 pts.

El 22 de mayo de 1891 se reunieron Agapito Escudero Torres, Mariano Rodríguez Miguel y Valentín Jalón y Gallo, albaceas testamentarios y contadores nombrados en el testamento por Santiago Rodríguez Alonso, con objeto de proceder a la liquidación divisoria y a la adjudicación de la herencia.

De todo el capital, se descuentan los gastos de funerales que ascendieron a 885,47 pts., el legado de 2.000 pts. a favor de su cuñada Elisa Miguel Campo y otros tres legados de 5.000 pts. a Francisco Rodríguez, a $\mathrm{M}^{\mathrm{a}}$ Pilar y María de la Gloria Rodríguez, por la cláusula quinta del testamento para igualarse con sus hermanos casados Luisa y Mariano, quedando un capital líquido de 78.142,62 pts.

Se abonan los legados, pero el resto de capital no se repartió por el interés de todos en el comercio, siendo los cinco herederos Mariano, Luisa, María del Pilar, Francisco y María de la Gloria Rodríguez Miguel, por quintas e iguales partes, los dueños del establecimiento mercantil que

${ }^{391}$ ARIZKUM CELA, A. La especialización industrial de Navarra en los orígenes de la industrialización, 1850-1936 [en línea]. Universidad Pública de Navarra. Disponible en: http://www.econ.unavarra.es/ arizkun/webs/hojaper/ESPNAV.html 
constituyó el caudal hereditario. También se declara que si apareciesen bienes, derechos, acciones, cargas o deudas que no se hubiesen presentado en el inventario, responderían los cinco en igual proporción.

Mariano Rodríguez Miguel se hizo cargo inmediatamente de la Sociedad y publicita su establecimiento familiar en todos los periódicos burgaleses de la época, a pocos meses del fallecimiento de su padre, con el mismo tipo de propaganda bajo las siglas Hijos de Santiago Rodríguez (Figura 3-23).

Imprenta y Librería. Almacén de papel y sobres.

Pasaje de la Flora.- Burgos.

Casa premiada en varias exposiciones.

Papeles de impresión para periódicos y toda clase de obras. Libros y cuadernos rayados. Gran surtido en artículos para pintura y dibujo.

Objetos de escritorio. Fabricación de bolsas para coloniales. Papeles de estraza para envolver. Libros científicos, literarios, de recreo. Impresiones y libros para el comercio. Precios baratísimos. Pasaje de la Flora.- Burgos. ${ }^{392}$

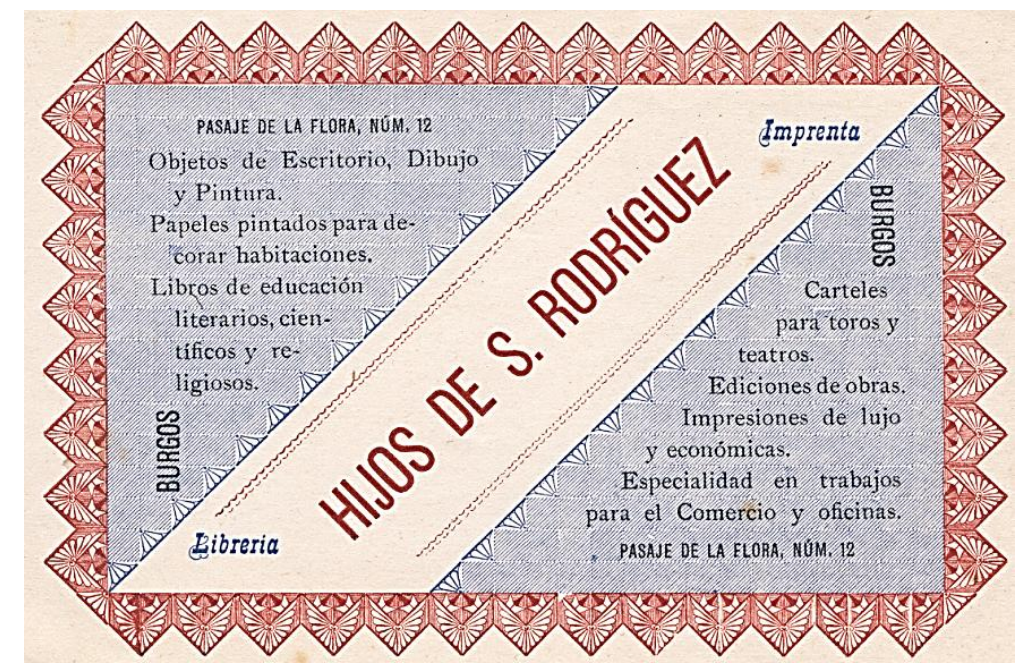

Fig. 3-23: Tarjeta de propaganda de la recién creada empresa editorial Hijos de Santiago Rodríguez, donde se detalla su actividad. Burgos. 1891. Cedida por Mercedes Rodríguez Plaza.

${ }^{392}$ El Papa-Moscas. Año XIV, no 705, 28 de junio de 1891, p. 4. 

4. MARIANO RODRÍGUEZ MIGUEL (1860-1925). EDITORIAL HIJOS DE SANTIAGO RODRÍGUEZ

\section{MARIANO RODRÍGUEZ MIGUEL (1860-1925). EDITORIAL HIJOS DE SANTIAGO RODRÍGUEZ}

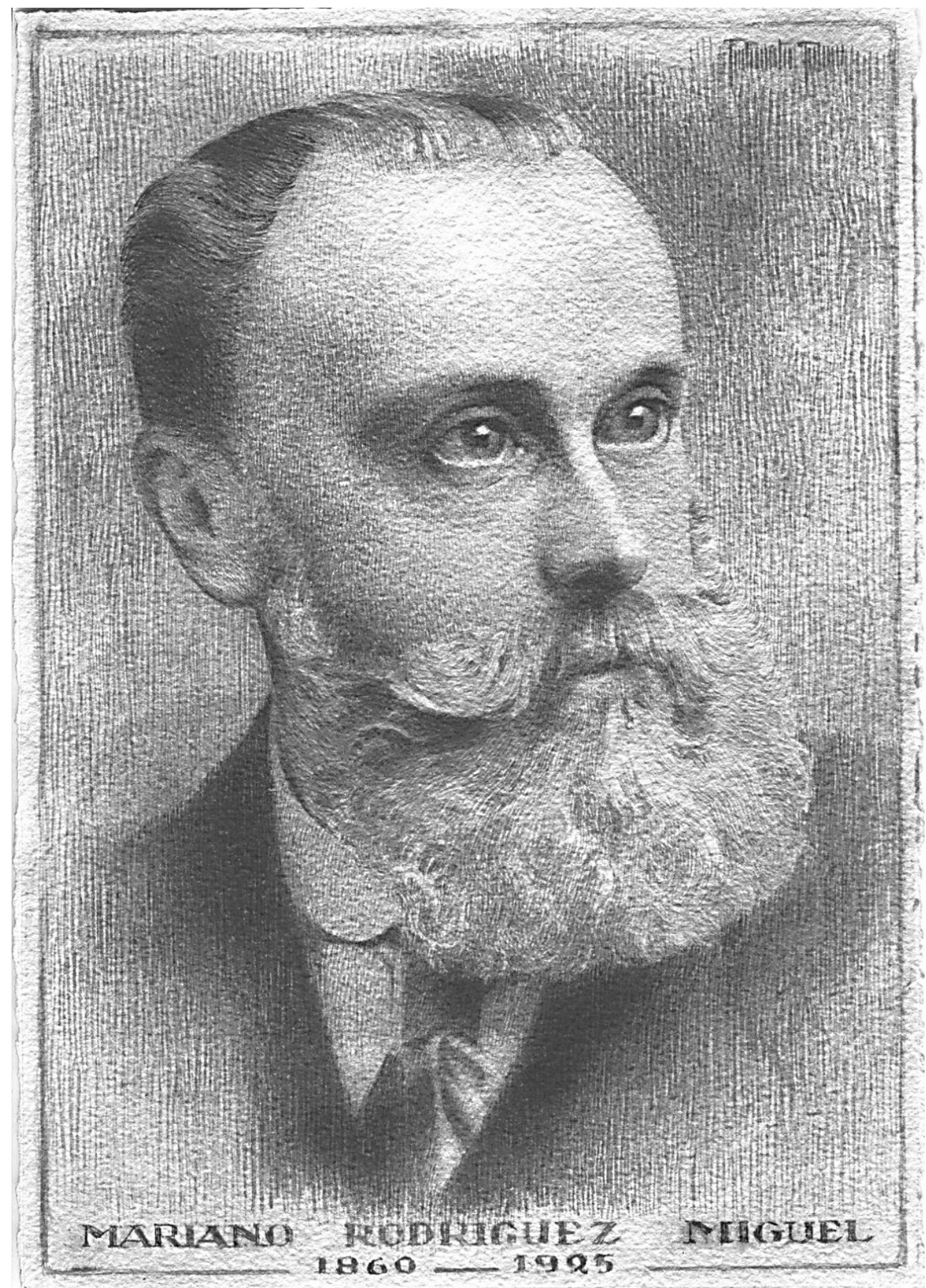

Fig. 4-1: Retrato de Mariano Rodríguez Miguel (1860-1925) realizado por Fortunato Julián. Imagen cedida por Lucas Rodríguez Plaza. 


\subsection{MARIANO RODRÍGUEZ MIGUEL (1860-1825): UNA VIDA DEDICADA A LA VIDA CULTURAL Y LITERARIA TRASPASANDO FRONTERAS}

Llegaba la última década del siglo XIX, con una coyuntura social y política inquietante, y el fin de la época de la Restauración. La prematura muerte de Alfonso XII, en 1885, dejaba la regencia a su esposa $\mathrm{M}^{\mathrm{a}}$ Cristina, embarazada del futuro rey Alfonso XIII, y a Sagasta en el poder durante los primeros años de la regencia. En el terreno social y económico se consiguieron peticiones históricas de normas liberalizadoras. Se aprobaron, entre otras, la libertad de prensa e imprenta (1889), la Ley del Jurado (1888), el sufragio universal masculino (1890), y medidas proteccionistas para promover los intereses de la industria catalana, vasca, de la minería asturiana y de los productores de cereal castellanos (1891). La guerra de Cuba y la pérdida de las últimas colonias españolas, conocida como el desastre del 98, hizo aflorar el descontento que el Régimen de la Restauración había provocado en la clase media y en los intelectuales. Se produjo un movimiento social crítico que se conoce como regeneracionismo.

La ciudad de Burgos languidecía pues el número de habitantes había decrecido en el último decenio, de 1887 a 1897. Contaba con una numerosa población parasitaria compuesta por clases pasivas, numerosos servidores del Estado, rentistas de la deuda pública y municipal, y acreedores de haberes pasivos en tal cantidad que si se cortase la corriente de alimentación del tesoro público no tardaría la ciudad en desplomarse, anulándose la única industria existente que era la de los caseros por cuya influencia trabajaba exclusivamente el Ayuntamiento. ${ }^{393}$

Todos los esfuerzos de las fuerzas vivas de la ciudad se centraron en conseguir una ciudad administrativa, con Capitanía General, Audiencia, Arzobispado y ser cabeza de una provincia amplia que necesitaba todo tipo de materiales destinados a la burocracia civil y religiosa, a los funcionarios, clérigos y a la pequeña burguesía que había en la ciudad y en las Cabezas de Partido.

El panorama industrial en Burgos a principios del siglo, aparte del sector harinero, se centraba en escasos establecimientos como la constitución de la Sociedad Azucarera Burgalesa S. A. en 1900, fruto de la necesidad de crear industrias de azúcar tras la pérdida de Cuba. Ante la escasez de electricidad se crearon concesiones para explotar saltos de agua; de ahí que surgieron la "Compañía de Aguas", "Electra de Castañares",

\footnotetext{
393 CÁMARA MORAL, M. Hoy, como ayer. Crónica de los acontecimientos vividos en Burgos entre 1898 y 1914. Burgos: Estudio Euroláser S.L., 2002, p. 57. Hace referencia a una publicación del periódico burgalés El Diario de Burgos del 13 de febrero de 1899.
} 
"Porvenir de Burgos" y la "Hidroeléctrica del Arlanzón". Otras entidades de menor tamaño eran pequeñas fábricas de elaboración de chocolate, como Baldomero Quintanilla y la firma Calleja y Núñez, licores de Miguel de Simón o sobre el trabajo de la piel con establecimientos que se dedicaban a la botería o a la fabricación de calzado. ${ }^{394}$

Otra industria importante fue la imprenta Hijos de Santiago Rodríguez quien, como se descubre en esta Tesis, se hizo un hueco empresarial con la edición de cuentos y libros, principalmente dedicados a la escuela primaria, y con destino de venta en España e Hispanoamérica. También debemos anotar en la ciudad, y en este mismo sector, la fabricación de naipes con una larga trayectoria como la casa Fournier.

En este contexto, Mariano Rodríguez despliega una gran actividad mercantil e industrial. La prensa nos da una breve pero real y auténtica descripción de Mariano Rodríguez al decir: “...que como siempre se multiplicaba con su perpetua actividad y entusiasmo por todas las cosas". 395

Mariano Rodríguez Miguel nació el 8 de diciembre de 1860, ${ }^{396}$ creció bajo los aires de La Gloriosa siendo su padre parte destacada de la burguesía emergente de la ciudad. Por otra parte la muerte de su madre cuando sólo contaba 13 años configura en él un talante responsable y cercano en todo momento a la gran figura paterna.

Buen estudiante según relata El Papa-Moscas, al hablar del papel que le tocó representar en una actuación para sacar fondos en ayuda de las inundaciones del Levante en 1879. ${ }^{397}$

Cursa estudios en el Instituto Provincial de $2^{\mathrm{a}}$ enseñanza de Burgos junto con Antonio Sivelo Miguel, primo suyo, y Valentín Jalón Gallo, ${ }^{398}$ futuros cuñados al casarse con sus dos hermanas, Pilar y Luisa, respectivamente.

No quedan documentos de sus estudios en la Escuela Normal de Maestros de Burgos, por lo que se apuesta que sea más un título más honorífico que real, ya que en el Catálogo Recuerdo de 1925, en la página 13, nos pone una copia de la placa de plata que se le regaló el 6 de julio de 1905, como Maestro honorario, por sus desvelos y trabajos en pos de la profesión.

\footnotetext{
${ }^{394}$ CORONA VIDA, L. J.; MIGUEL DE LA VILLA, J. L. La industria en Burgos en los siglos XIX y XX. En: J. M. PALOMARES IBÁÑEZ, dir. Historia de Burgos. IV Edad Contemporánea (2). Burgos: Caja de Burgos, 2005, pp. 295-341.

${ }^{395}$ La Voz de Castilla. Año I, número extra, 30 de junio de 1910, p. 1.

${ }^{396}$ Es curioso observar el nacimiento de otro Mariano Rodríguez, hermano suyo, un 17 de diciembre de 1859 como consta en el Archivo Diocesano, pero que no se ha encontrado la partida de bautismo del mismo en ninguna de las parroquias de su entorno vecinal.

${ }^{397}$ El Papa-Moscas. Año II, $\mathrm{n}^{\circ}$ 91, $4^{\circ}$ domingo de noviembre 1879, p. 1. ...Rodríguez, un buen estudiante copiado del natural...

${ }^{398}$ AHPBU. Sección Enseñanza. Sig. 617/3. Instituto de 2 $2^{\mathrm{a}}$ enseñanza de Burgos. Libro de matrículas.
} 
Al infatigable, cariñoso y entusiasta amigo de la enseñanza y de sus apóstoles Don Mariano Rodríguez Miguel, Maestro honorario, el Magisterio burgalés en testimonio del sincero cariño que le profesa. Burgos 6 de julio de 1.905. ${ }^{399}$

Se casa con Luisa Escudero Torres, en agosto de $1886^{400}$ (Figura 4-2). Era la hija menor de D. Pascual Escudero Saiz y Eusebia Torres de Santa María, ${ }^{401}$ dedicados a la construcción y reparación de edificios, obras de cantería, albañilería, carpintería, herrería y fabricación de loza de toda clase y otras diferentes industrias. Forman parte de una clase industrial en auge, en una época de un incremento notable en la construcción, por el estado en que había quedado a principios de siglo XIX el caserío burgalés, después de la Guerra de la Independencia y por las sucesivas desamortizaciones. ${ }^{402}$ Así, se convierten, en una de las familias que más impuestos paga al Ayuntamiento por contribución industrial. ${ }^{403}$

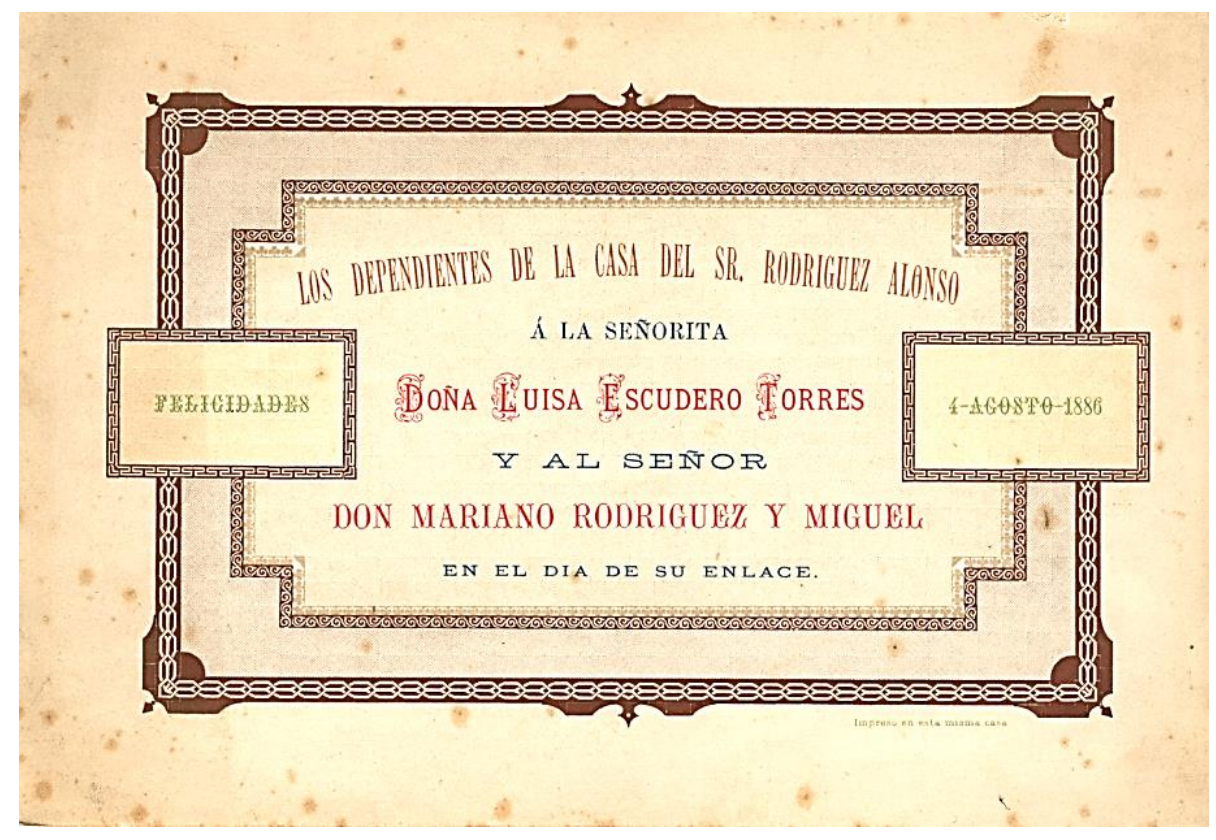

Fig. 4-2: Tarjeta de felicitación de los dependientes de la Casa editorial de Santiago Rodríguez Alonso con motivo del matrimonio del hijo y gerente de la Casa, el día 4 de agosto de 1886. Tarjeta cedida por Mercedes Rodríguez Plaza.

\footnotetext{
399 CATÁloGO 1925, p. 13.

400 ADBU. Parroquia de San Lesmes, $10^{\circ}$ Libro de casados, 1873-1902, libro de matrimonios II-1873 a VII de 1887, 4 de agosto de 1886.

401 ADBU. Parroquia de San Lesmes, $5^{\circ}$ Libro de bautizados (1860-1861), 19 de agosto de 1861. Vid. Anexo 2.2.8. Acta literal de bautismo de Luisa Escudero Torres.

${ }^{402}$ Numerosos trabajos nos hablan de dichos temas con amplia producción de IGLESIAS ROUCO, L. S. Burgos en el siglo XIX. Arquitectura y urbanismo (1813-1900). Valladolid: Universidad de Valladolid, 1979; CASTRILLEJO IBÁÑEZ, F. M. La desamortización de Madoz en la provincia de Burgos, 185569. Valladolid: Universidad de Valladolid, 1987; CRESPO REDONDO, J. Desarrollo urbano y desamortización: el caso de Burgos. En: Actas del Congreso de geografía de Castilla la Vieja y León. Consejo General de Castilla y León, 1982, pp. 299-342.

${ }^{403}$ AMBu. Sig. 10-193.
} 
Los hermanos de Luisa fueron todos miembros destacados de la oligarquía burgalesa. Sus nombres son: Dorotea, Agapito, Lucas, Nazario y Tomasa.

Dorotea Escudero, su hermana mayor, se casa con Pascual Moliner y Vaquero, miembro de una familia de origen valenciano, de Alcora. Se establecen en Burgos, a principios del siglo XIX, como modestos industriales ceramistas, que gracias a su trabajo y al crecimiento de la ciudad se convierten en importantes industriales. Uno de sus hijos, José Tomás Moliner Escudero, realiza estudios de arquitectura consiguiendo ser uno de los arquitectos más señalados de principios del siglo XX. ${ }^{404}$

Agapito Escudero es viudo, y junto con su hermano Lucas, soltero, llevan el negocio familiar. Los dos viven con Tomasa Escudero, hermana soltera, en una casa de su propiedad, en la calle Vitoria $\mathrm{n}^{\mathrm{o}} 15,1^{\circ}$.

Nazario Escudero, casado e industrial, fue propietario de la fábrica de loza "El Alfar", y más adelante se convierte en fabricante de harinas.

Luisa Escudero Torres aportó al matrimonio un importante caudal económico, 45.213,8 pts., de la herencia de sus padres. Poseía dos casas, una en la Calle Miranda, $\mathrm{n}^{\circ} 11$ y n ${ }^{\circ} 13$, y otra en la calle Fernán González, $\mathrm{n}^{\mathrm{o}}$ 51, valorada en 5.000 pts., además de varias posesiones en Cardeñadijo como un molino harinero, una huerta, y varias fincas de distintas medidas. Estas propiedades están valoradas en 7.000 pts., ${ }^{405}$ y las vende 8.200 pts.

En Burgos a cinco de agosto de mil ochocientos noventa y dos... D. Fernando Monterrubio...

Comparece Doña Luisa Escudero Torres de veintinueve años y su esposo D. Mariano Rodríguez Miguel de treinta y un años, con cédulas... y de otra D. Tiburcio del Val y Moral de veintinueve años, casado, propietario...

Vende en Cardeñadijo:

$1^{\circ}$ Un molino harinero sin número con su pradera contigüa al pago llamado Caraba valorado en cuatro mil pesetas.

$2^{o}$ Una huerta al pago denominada Caraba de 3 celemines de sembradura de $2^{a}$ calidad equivalentes a 6 áreas valorada en doscientas pesetas.

$3^{\circ}$ Una tierra al pago llamada Quemadas de doce fanegas de sembradura, de tercera calidad o sea cuatro hectáreas valorada en mil quinientas pesetas.

$4^{\circ}$ Otra tierra al pago llamada Andemandos, de doce fanegas de sembradura o 4 hectáreas valorada en mil quinientas pesetas.

$5^{\circ}$ Otra al pago de Valde-Sauce de dos fanegas de sembradura de $2^{a}$ calidad o cuarenta y ocho áreas valorada en setecientas pesetas.

$6^{\circ}$ Un huerto al pago que llaman Molino, de cinco celemines de sembradura valorada en doscientas cincuenta pesetas.

$7^{\circ}$ Un huerto o Caraba de dos celemines de $1^{a}$ o sea 4 áreas valorada en cincuenta pesetas.

${ }^{404}$ IGLESIAS ROUCO, L. S. Arquitectura y modernidad. Saturnino Martínez Ruiz (1842-1930). José T. Moliner Escudero (1888-1942). En: L. S. IGLESIAS ROUCO, coord. Protagonistas burgaleses del siglo XX. Burgos: Diario de Burgos, 2002, v. I, pp. 41-48.

${ }^{405}$ AHPBU. Sección de Protocolos. Caja 8922, 1-1-1886. 
Estas fincas la corresponden por los títulos siguientes: las 6 primeras por herencia de su madre Doña Eusebia Torres y Santa María y la $7^{a}$ y la última le pertenece también por herencia de su madre que la adquirió por compra a Domingo Penagos Ibañez vecino de Villaldemiro según documento del quince de noviembre de mil ochocientos ochenta y uno. ${ }^{406}$

Por sucesivas herencias de dos de sus hermanos solteros, Lucas y Tomasa, recibe importantes legados; a la muerte del primero, ${ }^{407}$ un legado de 10.000 pts. y el resto de sus bienes se los deja a Tomasa.

$\mathrm{Su}$ hermana Tomasa realiza una permuta con Luisa donde le cambia una parte de la casa de la c/ Vitoria, 15, por una casa en la calle Miranda, número 15, lo cual permitirá a Mariano tener unos amplios locales para su próxima imprenta, inaugurada en 1906, sita en la calle Miranda $\mathrm{n}^{\circ}$ 11, 13 y $15 .{ }^{408}$

En febrero de 1902 incrementa su capital, que asciende a 12.908,15 pts. de una ampliación de la testamentaría de D. Toribio Torre. ${ }^{409}$ El capital se invierte, en los primeros años de su matrimonio, en diversos negocios y más adelante, con la muerte de su suegro, en el propio negocio familiar.

Mariano Rodríguez experimenta y convive desde muy joven en un círculo intelectual donde se manifiesta la gran vocación de escritor y de amante de la literatura. Recordemos que vivía en el piso superior de la librería, conviviendo entre libros desde su infancia y juventud. Escucha y participa como niño y joven de las tertulias de la librería. Fácilmente podemos buscar una analogía con Antonio J. Bastinos que escribía en su autobiografía en 1908:

Entre libros nací, en la imprenta de mi abuelo Estivill, en edad temprana fue aprendiz de encuadernador, después librero, y últimamente editor, no es, pues, de extrañar que habiendo encuadernado, vendido, publicado libros, respirando su ambiente toda mi vida haya caído más de una vez en la tentación de escribirlos, en conjunto o parcialmente. ${ }^{410}$

De igual manera Mariano, junto a su padre, realiza todas las tareas de una imprenta-librería y acaba "tentado" de formar parte de los mismos ambientes en sus comienzos como colaborador en Cartas Burgalesas, de las que no se ha conservado ningún ejemplar.

\footnotetext{
${ }^{406}$ AHPBU. Sección de Protocolos. Caja 10753, 5 de agosto de 1892.

407 AHPBU. Sección de Protocolos. Caja 11227. Nos data su fallecimiento el 23 de noviembre de 1898. Tomasa recibe por herencia de su hermano parte de la casa en la calle Vitoria 15, una casa habitación en la calle Vitoria sin número, un solar de las eras de Santa Clara y algunas fincas en Villatoro. Su hermano Agapito Escudero ejerce como albacea testamentario, realizándose toda la protocolización ante notario el 17 de diciembre de 1901.

${ }^{408}$ AHPBU. Sección de Protocolos. Caja 11124, 23 de diciembre 1899.

${ }^{409}$ AHPBU. Sección de Protocolos. Caja 11147, 5 de febrero de 1902.

${ }^{410}$ DURÁN Y SANPERE, A. Centenario de la librería Bastinos, 1852-1952. Barcelona: José Boch, 1952, p. 101.
} 
A lo largo de su vida escribe para su propia empresa editorial algunas obras que forman parte de sus colecciones o "Bibliotecas", y como impulso de las mismas. Así, se encuentran varios cuentos de la Biblioteca Cuentos para Niños como Pedro el avaricioso, El Vendedor de periódicos y El cornetilla. Para la Biblioteca Selecta escribió la obra Jesucristo haciendo el bien. En la Biblioteca Hispano-Americana publica dos de sus obras: Alma y corazón, escrita anteriormente bajo el título Las lecciones del padre y Los grandes inventos al alcance de los niños, que titulará como Viaje Infantil para la escuela; y una obra inédita, por su contenido para niños como es Nociones de derecho o derecho usual. Todas ellas se analizarán en la última parte.

Toma las riendas del negocio familiar como cercano ayudante y socio en los últimos años de la vida de Santiago Rodríguez. A la muerte de su padre cuenta con la ayuda de su hermano Francisco, de un temperamento más introvertido. El fallecimiento de Francisco, el 17 de noviembre del año $1900,{ }^{411}$ nos descubre a través de su testamento ${ }^{412}$ un carácter generoso y austero, y su predilección por uno de sus sobrinos, Santiago, y por su tía Elisa de Miguel. Nombra por sus únicos y universales herederas a sus hermanas María del Pilar y María de la Gloria Rodríguez de Miguel. ${ }^{413}$

A la muerte de su hermano Francisco, Mariano autoriza a su cuñado, Valentín Jalón Gallo, y a Hilarión Garzón y Gutiérrez -autor de algunos cuentos- para llevar la firma de la empresa Hijos de Santiago Rodríguez en todos los actos y contratos, en la aceptación de letras, en la asistencia a juntas y otras gestiones que la Sociedad tuviera que hacer. ${ }^{414}$

Hombre inquieto, viaja por numerosos países y, gracias al dominio del francés, hecho conocido por su asistencia e intervención en el Congreso

\footnotetext{
${ }^{411}$ ADBU. Parroquia de San Lesmes, $12^{\circ}$ Libro de Difuntos, de enero de 1883 a diciembre de 1902, 17 de noviembre de 1900. Vid. Anexo 2.2.16. Acta literal de defunción en la Iglesia parroquial de San Gil en Burgos de D. Francisco Rodríguez Miguel.

${ }^{412}$ En el testamento expresa que su entierro sea de tercera clase con un solo funeral y que la diferencia de lo que esto cuesta con otro superior, más el importe de la caja, que no quiere sea lujosa y sólo hasta mil pesetas, se reparta a los pobres de la parroquia distribuyéndose el noveno día de su entierro de forma justa y equitativa según las necesidades de los desfavorecidos. Ordena que todo el dinero que encuentren en el día de su muerte en la cartera, bolsillos, se emplee en misas para sufragio de su alma y que se le amortaje con cualquiera de los trajes que está usando.

De la mejora que le legó su padre deja a su tía Elisa de Miguel y Campo dos mil pesetas en agradecimiento a sus cuidados y consejos, cantidad que le entregarán de una vez o en plazos. De la misma mejora legó a su sobrino, Santiago Rodríguez Escudero, dos mil pesetas para ayudar en sus posteriores estudios, cantidades que le entregaran según las necesidades o en el caso de haber terminado sus estudios o estuviera trabajando, se le entregaría dicha cantidad en su mayoría de edad.

También, al referido su sobrino D. Santiago Rodríguez le dona sus tres relojes: el de oro, el estampado con iniciales y el pequeño de níquel, y además le lega sus sortijas la de brillantes, la de oro con iniciales, el ajustador y los alfileres de corbata así como todas cuantas alhajas posea a su muerte.

Las joyas las conservará en su poder su hermana y heredera María del Pilar hasta que su sobrino cumpliese la mayoría de edad a no ser que por su aplicación y juicio se hiciese acreedor para poseerlas antes.

${ }^{413}$ AHPBU. Sección Protocolos. Caja 11168, 17 de noviembre de 1900.

${ }^{414}$ AHPBU. Sección de Protocolos. Caja 11174, 13 de diciembre de 1900.
} 
Internacional de Turismo en Toulouse, recorre numerosos países aunque sólo nos consta uno de los viajes que notifica la prensa en el apartado de "Ecos de Sociedad", sobre el regreso que Mariano Rodríguez hace de un viaje al extranjero. En esos meses, de mayo a octubre de 1914, tuvo lugar en Leipzig, Alemania, la Exposición internacional de las Artes gráficas y de la industria del Libro, coincidiendo las fechas señaladas a finales de julio de 1914, lo que induce a pensar que visita la feria para estar informado de todas las novedades de la época. ${ }^{415}$

Con el paso del tiempo nacen y crecen sus hijos, Tomasa Rodríguez Escudero el 26 de septiembre de 1889; Pascual Rodríguez el 29 de diciembre de 1890; Santiago Rodríguez el 17 de noviembre de 1893; Mariano Rodríguez al año siguiente, el 1 de noviembre; Lucas Rodríguez el 3 de diciembre de 1895; Luisa Rodríguez el 23 de diciembre de 1899; y Pilar Rodríguez el 4 de octubre de $1905 .{ }^{416}$

Mariano forma una familia extensa donde conviven además de su mujer e hijos, su tía Elisa Miguel y Campo, y sus hermanas $\mathrm{M}^{\mathrm{a}}$ del Pilar y $\mathrm{M}^{\mathrm{a}} \mathrm{de}$ la Gloria, todas ellas solteras. ${ }^{417}$

Algunos datos familiares se conocen a través de sucesivos Padrones Municipales ya que después del matrimonio de su hermana $\mathrm{M}^{\mathrm{a}}$ del Pilar, en 1909, con su primo Antonio Sivelo y su traslado a Valladolid, el resto de la familia sigue viviendo en la misma casa familiar. Pascual Rodríguez Escudero es presentado como comerciante, formando parte de todas las acciones y propuestas de su padre, ${ }^{418}$ al igual que hizo Santiago con Mariano.

Del resto de la familia hay pocos datos contrastables. Sólo aparecen en la prensa burgalesa Tierra Hidalga, en el apartado de "Notas de sociedad",

\footnotetext{
${ }^{415}$ Guasa Viva. Año II, no 72, 2 de agosto de 1914, p. 7

${ }^{416}$ Según los diversos padrones del Ayuntamiento: PA-82, PA-197, PA-361, PA-339.

En el Archivo Diocesano encontramos partidas de bautismo de Tomasa Rodríguez en la parroquia de San Lesmes donde por falta de los datos fundamentales como la fecha de nacimiento y los padrinos se inscribe de nuevo a la izquierda de la anterior con los datos correctos como su nacimiento el 26 de septiembre de 1889 y que sus padrinos fueron Lucas y Tomasa Escudero en fecha de 21 de febrero de 1901. Vid. Anexo 2.2.12. Acta literal de bautismo en la Iglesia parroquial San Lesmes en Burgos de Tomasa Eusebia Rodríguez Escudero, nacida el 26 de septiembre de 1889.

El 29 de diciembre de 1890 nacieron mellizos que les pusieron Santiago y Pascual, siendo éste último el que sobrevivió. En este caso sus padrinos son Agapito y Tomasa Escudero. Vid. Anexos 2.2.13. Acta literal de bautismo en la Iglesia parroquial San Lesmes en Burgos de Pascual Rodríguez Escudero, nacido el 29 de diciembre de 1890; Anexo 2.2.14. Acta literal de bautismo en la Iglesia parroquial San Lesmes en Burgos de Santiago Rodríguez Escudero, el 29 de diciembre de 1890.

En los nacimientos posteriores de Santiago, Mariano y Lucas se repiten como padrinos Lucas y Tomasa Escudero. Vid. Anexos 2.2.17. Acta literal de bautismo en la Iglesia parroquial San Gil en Burgos de Santiago Rodríguez Escudero, nacido el 17 de noviembre de 1893; Anexo 2.2.18. Acta literal de bautismo en la Iglesia parroquial San Gil en Burgos de Mariano Rodríguez Escudero, nacido el 1 de noviembre de 1894; Anexo 2.2.19. Acta literal de bautismo en la Iglesia parroquial de San Gil en Burgos de Lucas Rodríguez Escudero, nacido el 3 de diciembre de 1895.

${ }^{417}$ AMBu. Padrones del Ayuntamiento. PA- 156, 1905, $1^{\circ}$ distrito.

${ }^{418}$ AMBu. Padrones del Ayuntamiento. PA- 197, 1911.
} 
el eco de algún hecho reseñable como que Tomasa, su hija mayor, acompaña a su padre Mariano en varios de sus viajes:

Ha regresado de Madrid, acompañado de su bella hija Tomasita, D. Mariano Rodríguez, presidente de la Asociación de la Prensa burgalesa. ${ }^{419}$

Tomasita, diminuto por el que era conocida en todos los círculos locales, cuenta con 27 años. Dos años antes el periódico Tierra Hidalga, en su sección de "Nuestro abanico galante", le dedica una bella poesía. ${ }^{420}$ Forma parte de la "corte de amor" que acompañaba a la reina de la fiesta en los Juegos Florales de Burgos, en 1907. ${ }^{421}$ Pocos datos más se conocen. Se casa con Pedro Fernández Fernández y viven en el Espolón 2 y $4 .{ }^{422}$

Santiago y Lucas se licencian en Derecho, aunque solo ejerce como abogado Santiago. Lucas se dedica a la empresa familiar y a la muerte de Pascual se queda con toda la empresa al comprar a sus hermanos su parte. Después abre unos nuevos locales en la calle Molinillo, estancia definitiva de la Editorial. Santiago Rodríguez Escudero se casa con Felicidad Santervás Tomás.

En la prensa local, en notas de sociedad, se comenta que ha ido a Bilbao el joven Mariano Rodríguez, a la Marina Mercante, con 20 años. ${ }^{423}$ Seis años más tarde se casa en diciembre. Los ecos de sociedad periodística señalan el convento de los Carmelitas como el lugar donde se ofició la boda de Felisa Orejón Hernando con Mariano Rodríguez Escudero. Sin embargo, en el Archivo cita que tuvo lugar en la parroquia San Pedro y San Felices entendemos que la iglesia del Carmen dependía de la parroquia citada-. ${ }^{424}$ La ceremonia fue oficiada por Gregorio Betolaza y Esparta, coadjutor de la parroquia de San Gil y que años atrás, en 1914, había escrito para la editorial una obra sobre la parroquia de San Gil. ${ }^{425}$

Mariano Rodríguez muere en mayo de 1925.

Mariano Rodríguez Miguel esposo de $D^{a}$ Luisa Escudero Torres de 65 años de edad e inconsciencia de neoplastia maligna del estómago murió el 17 de mayo de 1925 a las 10 de la noche en la calle Laín Calvo $n^{\circ} 12$

Entierro de $1^{a}$ clase con acompañamiento y cruz de recomendación.

\footnotetext{
${ }^{419}$ Tierra Hidalga. Año V, no 250, 21 de octubre de 1916, p. 3. Tomasita, como dice el reportaje cuenta con 27 años.

${ }^{420}$ Guasa Viva. Año II, no 48, 15 de febrero de 1914, p. 7. La sección lleva el título: Nuestro abanico galante.

${ }^{421}$ El Papa-Moscas. Año XXX, nº 1.591, 16 de junio de 1907, p. 3.

${ }^{422}$ AMBu. Padrones del Ayuntamiento. PA-361, Año 1935-36.

${ }^{423}$ Guasa Viva. Año II, no 91,13 de diciembre de 1914, p. 6.

${ }^{424}$ La Voz de Castilla. Año XI, n ${ }^{\circ}$ 611, 31 de enero de 1920, p. 3.

${ }^{425}$ Iglesia parroquial de San Gil. Libro de bautizados 1892-1895. 1 de noviembre de 1894. Vid. Anexo 2.2.18. Acta literal de bautismo en la Iglesia parroquial de San Gil en Burgos de Mariano Rodríguez Escudero, nacido el 1 de noviembre de 1894.
} 
Sus padres D. Santiago Rodríguez Alonso y $D^{a}$ Irene Miguel y Campo. Casado con Luisa Escudero Torres.

Tiene 7 hijos: Tomasa, Pascual, Santiago, Mariano, Lucas, Luisa y Pilar.

No se halla otorgado testamento. ${ }^{426}$

Hemos de destacar unas palabras escritas en Guasa Viva sobre la opinión que le merecía Burgos, con un tono de nostalgia y pesadumbre por todos los proyectos valiosos que no se han llevado a cabo por el poco estímulo y dejadez:

Si los burgaleses nos quisiéramos y protegiésemos, como deben quererse y protegerse los que en el mismo suelo nacieron; si pusiéramos en el aplauso y en el estímulo todo el calor que en la práctica y la censura empleamos sería más fecunda la labor de los que trabajan y llegarían a sazón algunas buenas iniciativas que mueren en flor.

Por ser como somos, está Burgos como está.

Mariano Rodríguez Miguel. ${ }^{427}$

Lucas Rodríguez Escudero se casa con Luisa Martín-Cobos Lagüera, cuyo hermano Honorato, abogado, fue político falangista y miembro de la junta civil preparatoria del Alzamiento Nacional en Burgos, con el general Mola, Fidel Dávila (miembro de la familia Rodríguez), José Ramón Echevarrieta y Florentino Martínez Mata.

Honorato Martín-Cobos fue alcalde de la ciudad, de 1960 a 1965, procurador en Cortes durante seis legislaturas, de 1946 a 1965, y presidente de la Diputación de Burgos.

\footnotetext{
${ }^{426}$ ADBU. Parroquia de San Gil de Burgos. Libro 11 ${ }^{\circ}$ Finados de San Gil 1914 a 1928, f. 257. Vid. Anexo 2.2.20. Acta literal de defunción en la Iglesia parroquial de San Gil en Burgos de D. Mariano Rodríguez Miguel, el 17 de mayo de 1925.

${ }^{427}$ Guasa Viva. Año II, no 67, 28 de junio de 1914, p. 9. Vid. Anexo 2.3.5. Artículo breve de opinión de Mariano Rodríguez Miguel sobre su visión de Burgos. Guasa Viva.
} 


\subsection{ASOCIACIONES $Y$ SOCIEDADES DONDE MARIANO RODRÍGUEZ MIGUEL PARTICIPÓ ACTIVAMENTE}

\subsubsection{Cámara de Comercio e Industria de Burgos}

Al igual que su padre, vio en el asociacionismo la clave para la regeneración y la mejora de la sociedad al participar en las Cámaras de Comercio e Industria que el Estado había creado el 9 de abril de 1886. El objetivo era recabar informes y comunicarse con los empresarios siendo éstos, a través de las Cámaras, los que elevarían proposiciones, promoverían exposiciones y enseñanza mercantil. Se iniciaron por medio de los gobernadores civiles; el de Burgos entró en contacto con el Sindicato Gremial en diciembre de 1886 y se nombró una comisión con el encargo de redactar el reglamento y la organización de la Cámara.

En Burgos los inicios de estas propuestas, en defensa del contribuyente y la oferta de servicios, provienen de los grupos de comerciantes al detalle que, participando en la Asociación de Propietarios e Industriales, comienzan a animar la feria de 1881 al subvencionar la cabalgata y el teatro, al patrocinar uno de los premios, y formar parte del jurado. Más adelante, a primeros de agosto de 1886, surgió el Sindicato Gremial del Comercio, origen de las Cámaras de Comercio e Industria. ${ }^{428}$

La Cámara de Comercio se constituye en Burgos el 6 de marzo de 1887, siendo nombrado presidente D. Orestes Blanco Recio, director del Banco de España en Burgos; vicepresidente, Isidro Gil; tesorero, Isidro Plaza; contador, Alejandro Fernández; secretario, Eleuterio Alonso Martínez; y como vocales, José M. Olivan, Juan Gómez Zamora, Víctor Diez-Montero y Julián Fournier. ${ }^{429}$

Inicia su andadura durante la crisis agrícola de finales de los años ochenta sumándose en la defensa de los intereses cerealistas de los pueblos y de diversas regiones castellanas.

En la Asamblea General, del 23 de marzo de 1890, el secretario Eladio Escudero lee la memoria anual detallando los trabajos y gestiones realizadas por la Cámara. Los puntos más importantes estaban relacionados con la ley del timbre, el incremento en la exportación de vinos y alcoholes, la mediación para que los compradores de trigo pudiesen tener una rebaja de tarifa en la contribución, los tratados de comercio, la reforma de aranceles y el rechazo del proyecto de ley sobre la contribución impuesta relativa a las utilidades.

\footnotetext{
${ }^{428}$ CALVO CABALLERO, P. La actividad comercial entre 1875 y 1936. La eclosión del asociacionismo patronal. En: F. J. PEÑA PÉREZ y R. J. PAYO HERNANZ, coords. Historia del Comercio de Burgos. Burgos: Federación de Empresarios de Comercio de Burgos, 2005, p. 269.

429 ARCHIVO DE LA CÁMARA DE COMERCIO E INDUSTRIA DE BURGOS [en adelante ACCBU.]. Libro de Actas de las sesiones de la Cámara de Comercio 1887-1896. Caja 512, Libro 2.
} 
Según el Reglamento, se nombra una comisión para la elección de los cargos salientes con la siguiente candidatura aprobada por unanimidad:

- Presidente: Manuel Rico y Gil.

- Vocal y vicepresidente: Isidro Plaza.

- Vocal: Mariano Rodríguez Miguel

- Vocal: Juan José Redondo

En la Sesión Ordinaria, del 30 de marzo de 1890, la Junta Directiva de la Cámara nombra secretario a Mariano Rodríguez, al sustituir al Sr. Eladio Escudero, por renuncia.

Siempre se destaca Mariano Rodríguez por aportar iniciativas y sugerencias en todas las instituciones en las que estuvo involucrado. En momentos de apatía, como se cuenta en una reunión de la Asamblea General de la Cámara de Comercio para la renovación de cargos, donde se debate suspenderla, y ante la escasa concurrencia, su intervención hace levantar el ánimo y se nombra presidente a Isidro Plaza, vicepresidente a Fidel Quintana y se sustituye a los vocales Rico y Fernández por Saturnino Gutiérrez y Casimiro Ajuria. ${ }^{430}$

Mariano Rodríguez prorroga su mandato de secretario en la Cámara de Comercio hasta 1893 aunque en varias ocasiones presenta su dimisión, que no fue aceptada, pues se decidió que Bonifacio Diez-Montero le ayudase en dichas tareas.

Acta de la sesión ordinaria celebrada por la Junta Directiva de esta Cámara el día 20 de marzo de 1891.

[...]El Secretario D. Mariano Rodríguez presentó la dimisión del cargo que desempeña fundada en que perentorias ocupaciones le habían de impedir el llevar cumplidamente su cometido.

A instancias de los demás compañeros retiró la dimisión presentada acordándose por unanimidad un voto de gracias para dicho secretario. ${ }^{431}$

Acto de la sesión ordinaria 9 de marzo de 1892.

El Sr. Rodríguez manifiesta se había tomado la libertad de citar a la Directiva para el día de hoy en ausencia del Sr. Presidente por creer necesaria la inmediata constitución de la nueva Junta.

[...]Por dicho Rodríguez se expuso la imposibilidad en que se encontraba de continuar desempeñando el cargo de secretario y que por lo tanto presentaba la dimisión, la cual no le fue admitida a pesar de sus repetidas súplicas.

El Sr. Fernández teniendo en cuenta las razones expuestas que el Sr. dimisionario propuso y fue acordado por unanimidad nombrar como vicesecretario al Sr. D. Bonifacio Diez-Montero para que le ayude en los trabajos al secretario a fin de que le sean menos penosos. Dicho Ser. Montero se excusó

\footnotetext{
${ }^{430}$ Ibídem, 8 de marzo de 1891.

${ }^{431}$ Ibídem, sesión ordinaria del 20 de marzo de 1891.
} 
repetidas veces de admitir el honroso cargo que se le confiaba pero reconociendo todos sus especiales aptitudes para ello insistieron en el nombramiento recaído. ${ }^{432}$

Mariano Rodríguez insiste en reunir a todo el comercio industrial de Burgos y agrupar en torno a la Cámara a todos los comerciantes para poder presionar ante los poderes públicos sobre la grave situación del comercio y así evitar la espiral proteccionista y los nuevos aranceles que perjudicaban a la mayoría de los pequeños productores y a los consumidores. Para ello, propone redactar una circular, una ponencia y realizar una reunión sobre los beneficios que la Cámara podía reportar a todos los comerciantes e industriales de la ciudad. En la comisión participan: Manuel Rico, Juan José Redondo, Casimiro Ajuria, Gerardo Santa María y Mariano Rodríguez.

En la misma línea, asiste en Madrid a la Junta del Círculo de Unión Mercantil como representante por Burgos, junto con Juan José Redondo y Bonifacio Diez-Montero. Los diversos compromisarios de las distintas regiones expresaron sus quejas por la falta de Tratados de comercio con otros países y por las elevadas tarifas arancelarias, la ley del Timbre, la elevación de los cambios, la ley de alcoholes, y el nuevo proyecto de tarifas para la contribución industrial. Propusieron volver a las antiguas tarifas arancelarias. ${ }^{433}$ Tuvo que ausentarse de dicha reunión y volver a Burgos, el 9 de enero de 1893, por la prematura muerte de uno de sus hijos. ${ }^{434}$

Cuando en la Cámara de Comercio de Burgos se hablaba sobre tratados comerciales con otros países, Mariano Rodríguez expresa la necesidad de perfilar el tema sobre la propiedad intelectual con las Repúblicas Americanas. ${ }^{435}$ Esto nos hace suponer que trataba de expandir su empresa en estos países, en la última década del siglo XIX.

Las ideas de Mariano Rodríguez sobre la propiedad intelectual son las mismas que unirían a varios intelectuales e impresores catalanes a crear el Instituto Catalán de las Artes del Libro en 1897. De la misma manera también se implantó el Centro de la Propiedad Intelectual formado por editores, libreros, y personas con derecho de propiedad intelectual en 1900 en Barcelona. En Madrid, en 1901, el gremio de libreros y editores fundaron la Asociación de Librería Española para defender el sector frente al intrusismo profesional. ${ }^{436}$

\footnotetext{
432 Ibídem, 9 de marzo de 1892

433 Ibídem, 4 de enero de 1893.

${ }^{434}$ Ibídem, 18 de enero de 1893.

Suponemos por los datos del Archivo Diocesano de Burgos que fue un recién nacido, ya que en el año de 1892 habían fallecido Santiago Rodríguez Escudero el 4 de enero a la edad de 1 años e Irene Rodríguez Escudero fallecida de 7 meses el 17 de diciembre de ese mismo año de 1892.

${ }^{435}$ Ibídem, 20 de marzo de 1892.

436 MARTÍNEZ RUS, A.; SÁNCHEZ GARCÍA, R. Los patronos del libro. Las asociaciones corporativas de editores y libreros. Gijón: Trea, 2004, p. 211.
} 
Otro tema relevante y persistente en la Cámara de Comercio de Burgos fue un proyecto de Sociedad de Socorros Mutuos agrícolas que se quedó en mero papel al no ser factible dicho plan por falta de asociados y el necesario capital social. ${ }^{437}$

Mariano Rodríguez, durante el año 1893, centra sus peticiones en la supresión de la Capitanía General al telegrafiar al Sr. Ministro de la Guerra para que tenga en cuenta la importancia estratégica de la ciudad y seguir como la Capital del Distrito Militar Norte. ${ }^{438}$ En la ciudad se ocasionaron diversos tumultos serenados por el diputado Sr. Aparicio, el teniente de alcalde Conde de Berberana, y el mismo Mariano Rodríguez como secretario de la Cámara de Comercio. ${ }^{439}$

Deja la Junta Directiva el 16 de abril de 1893, aunque algunos socios piden su reelección en su labor de secretario; les agradece sus palabras pero comunica la imposibilidad de continuar. No será hasta la Asamblea General del 3 de octubre de 1897 cuando se reincorpore de nuevo como secretario de la Cámara. Y, aunque manifiesta que tiene muchas ocupaciones que le impiden realizarlo con la diligencia necesaria, acepta ante la insistencia de los socios presentes.

Correspondiendo cesar en sus cargos los Sres. Juan Gómez Zamora, D. Pedro D. Montero, D. Alejandro Domínguez, D. Domingo Hospital, D. Pascual Quevada y D. Remigio Martínez se nombró una comisión compuesta del Sr. Zamora, Sr. Gutiérrez y Sr. Martínez para que propusieran los nombres de los que habían de constituir a los que por reglamento cesaban en los cargos.

Después de breves momentos fue leída la siguiente candidatura que por unanimidad fue aprobada.

Vicepresidente: D. Pedro D. Montero.

Tesorero. Miguel González.

Contador: Marcelino Hernández.

Secretario: Mariano Rodríguez.

Vocales: Eladio Escudero, Fidel Quintana, José Diez Ortega, José Mata.

Durante ese año de 1897, la Junta retoma el interés para la mejora del ferrocarril, por los intereses en la salida de los cereales hacia los puertos $\mathrm{u}$ otros centros de distribución, expresada en la Asamblea General. ${ }^{440}$

\footnotetext{
${ }^{437}$ ACCBU. Libro de Actas de las sesiones de la Cámara de Comercio, 1887-1896. Caja 512, Libro 2, 9 de octubre de 1892.

${ }^{438}$ Ibídem, 12 de marzo 1893.

${ }^{439}$ El Papa-Moscas. Año XVI, no 795, 19 de marzo de 1893, p. 1. Durante la presidencia de Sagasta tiene lugar una reestructuración militar en 7 Regiones Militares para la península, más las Capitanías Generales de Baleares y Canarias y las Comandancias Generales de Ceuta y Melilla, según R. D. del 10 de febrero de 1893. Burgos queda en la $6^{\text {a }}$ Región junto con Navarra, Álava, Guipúzcoa, Vizcaya, Santander y Logroño y la capital se situaría en Miranda de Ebro. Por R. D. de 29 de agosto de 1893, el Cuartel General de la $6^{a}$ Región Militar pasa a Burgos.

${ }^{440}$ ACCBU. Libro de Actas de las sesiones de la Cámara de Comercio 1897-1906. Caja 513, Libro 1, 3 de octubre de 1897. f. 10-11.
} 
Al mismo tiempo, Mariano Rodríguez sigue expresando en sesiones de Junta Directiva, como en años anteriores, la indiferencia de los gobiernos hacia la propiedad intelectual, motivo que ocasiona graves perjuicios para autores y escritores que no pueden llevar sus productos a los principales mercados de América, al no poder hacer frente a las ediciones fraudulentas que de sus obras se hacen en el extranjero. Transmite que España es la Nación que exporta menos libros en castellano, mientras que EE. UU. es el país que alcanza mayores cifras en el mercado hispanoamericano. Se acuerda, en la sesión del 12 de noviembre de 1897, hacer una instancia al Sr. Ministro de Fomento para que considere que la propiedad intelectual se respete en todas las Naciones con las que España tiene tratados y que los consiga con todas las Repúblicas Americanas por ser el mercado más importante de libros en castellano. Asimismo, se acuerda invitar a las demás Cámaras para que secunden este pensamiento. ${ }^{441}$

El comercio de libros con países hispanoamericanos era un tema pendiente de la industria editorial española. Este sector estaba dominado por editores franceses, alemanes y anglosajones, debido al desarrollo que habían alcanzado en sus relaciones comerciales, a la mejora en las artes gráficas, y a operaciones financieras, con pagos más flexibles, así como una mayor propaganda.

Los libros españoles no podían competir en los mercados americanos con otros países por el mayor precio del papel, por el proteccionismo arancelario de la industria papelera española y por el gravamen de impuestos a todas las materias y equipos de procedencia extranjera, necesarios para todos los editores por falta de equipos en España. A esto se unía que las tarifas del transporte también exigían un sobrecoste al precio del libro. Aun con todo, lo más grave era la aparición de ediciones fraudulentas al no tener Tratados de propiedad intelectual sobre todo, en Argentina, Chile, Paraguay, y más en concreto con Uruguay pues al poner Montevideo como lugar de edición eludían cualquier acción judicial y llevaban a la ruina a los editores.

Mariano Rodríguez era uno de los editores españoles perjudicados por la política anterior. La publicación de muchos libros escolares y de lectura hizo que insistiese en el tema. Edita un semanario infantil ilustrado ¿Quieres ser mi amigo? cuyo primer número sale publicado el 5 de enero de 1896 con destino el mercado español y a países de América. El precio de las suscripciones para España es de 2,50 pts. semestre y de 4,50 pts. anual. Para Cuba, Puerto-Rico y Filipinas, todavía colonias españolas, 6 pts., y para el resto de América y Unión Postal 8 pts. A pesar de la buena calidad del semanario tuvo una corta edición al no tener suscriptores suficientes para seguir en el proyecto.

${ }^{441}$ Ibídem, 12 de noviembre de 1897. f. 13. 
Mariano Rodríguez asiste a las diferentes reuniones de otras Cámaras, tal como lo expresa la sesión extraordinaria del día 27 de febrero de 1898.

A continuación leyó el Sr. secretario la invitación que la Cámara de comercio de Valladolid hacía a ésta para asistir a una Asamblea de varias Cámaras que se celebra en aquella ciudad el día 12 de marzo próximo a las 3 de la tarde para tratar sobre el nuevo régimen arancelario de Cuba, Puerto Rico y los EE.UU.

Aceptose el pensamiento y se nombró una comisión compuesta por los Sres. Quintana, Hernando y Rodríguez que vayan a Valladolid en representación de esta asociación. ${ }^{442}$

También estuvo implicado en asuntos internos de la ciudad. En la sesión de la Junta, del 31 de agosto de 1898, el Sr. Montero habló del disgusto que la ciudad tiene sobre el aumento de población penal y el perjuicio que le ocasionaba la competencia que le hacían las industrias que estaban en el presidio, así como la preocupación que sienten los ciudadanos por las personas que acompañan a estos penados. Mariano Rodríguez propuso que la Cámara, de acuerdo con el Ayuntamiento, pudiera elevar ante el Ministro una enérgica protesta por el aumento de penados y solicitar que se suprimiese el penal por las malas condiciones en las que se encontraba. La Junta de la Cámara nombró una comisión compuesta por el Presidente, el vocal Sr. Mata y el secretario, Mariano Rodríguez, para visitar al Alcalde con dicha solicitud.

En esa misma sesión se manifiesta el malestar de la clase jornalera por el precio tan elevado del pan, que no estaba en relación con el precio del trigo, exhortando a la Junta a que tome parte activa para conseguir que el pan tuviese un precio más bajo, al alcance de la clase trabajadora. De esta proposición la Junta decide que la misma comisión trate con el Ayuntamiento sobre el precio del pan en relación con el precio del trigo y que de no conseguirlo viese cómo hacer que el precio del pan costase entre 37 y 40 céntimos. ${ }^{443}$

Mariano Rodríguez renuncia a su cargo de secretario en la Asamblea General del día 9 de octubre de $1898^{444}$ y sale elegido Antonio Leiva. ${ }^{445}$

En otra ocasión a Mariano Rodríguez se le solicita que represente a la Cámara, junto con el Presidente, en la Asamblea General del Comercio en Zaragoza.

Se acordó que la comisión que ha de representar a esta Cámara en Zaragoza la compongan los Sres. Diez. Montero y Rodríguez. ${ }^{446}$

\footnotetext{
442 Ibídem, 27 de febrero de 1898, f. 18

443 Ibídem, 31 de agosto de 1898. f. 21

${ }^{444}$ Ibídem, 9 de octubre de 1898 f. 23-24

445 Ibídem, f. 25. Mariano Rodríguez sigue de secretario hasta el 8 de noviembre ya que Antonio Leiva renuncia al cargo, reconsiderando su decisión por apoyo de varios miembros de la Junta Directiva. 446 Ídem. f. 25.
} 
Días más tarde, el 11 de noviembre, la Cámara recibe una carta y un telegrama donde Mariano renuncia a dicha representación, por lo que se decide que vaya el vicepresidente en su lugar. ${ }^{447}$

A pesar de ello, participa en su preparación de forma activa, como se puede ver en la Asamblea General el día 16 de noviembre, con varias propuestas:

- Los militares no puedan tener derecho a ser senadores ni diputados.

- La elección de comerciantes e industriales pueda estar representada de la misma forma que en la actualidad se hace la de Arzobispos y universidades.

- Solicita que se adicione una nueva petición al cuestionario para que se revisen los ascensos y cruces pensionadas concedidas durante la guerra de Cuba y Filipinas.

- Sobre la elección de representantes a las Cámaras pide que se amplíe a 4 los representantes de la Asamblea General de Cámaras de Comercio. ${ }^{448}$

Participa en la sesión de la Cámara de Comercio que se constituye en Asamblea General para completar las conclusiones que presentarán en la Asamblea de Zaragoza y que fueron las siguientes:

Suspensión del recargo por guerra en todas las contribuciones.

Que se imponga a los poseedores de papel de Estado, una contribución que iguale por lo menos a la impuesta a la territorial.

Que las clases mercantiles tengan verdadera representación en cuantos tratados de Comercio se convenga con otras Naciones.

Que se retire al Banco de España la autorización concedida para que aumente su circulación fiduciaria hasta 2.500 millones de pesetas.

Que todas las rentas del Estado se paguen en moneda española, sea cualquiera su forma aun cuando sus tenedores residan en el extranjero.

Que se vote antes el presupuesto de ingresos que el de gastos.

Que se depuren bien las clasificaciones a derechos pasivos y que se sometan a todas esas clases a un descuento importante y progresivo que esté en relación con los nuevos sacrificios que se exigen a las clases contribuyentes.

Que se supriman todas las Juntas consultivas de la Nación y el Tribunal de cuentas. Que se implante en el ejército un servicio obligatorio y se cierre durante un plazo prudencial las academias militares.

Amortización de las plazas del Generalato y suspensión de los ascensos a él durante el tiempo preciso hasta conseguir que el número de Generalatos sea el estrictamente necesario para el mando de nuestros ejércitos de mar y tierra.

Revisión de los ascensos y cruces pensionadas que hayan concedido durante las guerras de Cuba y Filipinas.

Que se atienda con singular predilección a los inutilizados de estas últimas guerras.

Supresión del Ministerio de Ultramar y del de Marina.

${ }^{447}$ Ibídem, f. 25-26.

${ }^{448}$ Ibídem, f. 27-31. 
Que se declaran incompatibles los cargos de senador y diputado con el de empleado público de consejeros de las grandes empresas excepto el de Ministro y subsecretario.

Descentralización administrativa sin quebrantar vínculos que sostengan la unidad fundamental de la Patria.

Enseñanza obligatoria y gratuita en el primer grado.

Reducción de las tarifas de ferrocarriles y revisión de las mismas.

Reducir el número de empleados actualmente existente al estrictamente necesario creando la inmovilidad de los mismos.

Que se establezca un jurado mercantil de arbitraje para resolver en primera instancia las diferencias entre comerciantes.

Cada Cámara de Comercio de capital de provincia tendrá derecho a nombrar un representante en Cortes.

Que toda industria o fabricación nueva en el país esté libre de tributo durante cinco años a semejanza de los que sucede en Suiza y Alemania.

Que se establezcan escuelas de Comercio en todas las capitales de provincia. ${ }^{449}$

Elabora escritos que son entregados, a través de la Junta Directiva, al Presidente de las Cámaras de Comercio de España, bajo orden de no aparecer su nombre, pidiendo que sea la Cámara la portadora de ese documento y reclama una rectificación en este sentido. ${ }^{450}$

Durante este año la Cámara, a través de su secretario Mariano Rodríguez, despliega una gran actividad en comunicación con otras Cámaras nacionales y entidades internacionales, delegaciones en el ámbito rural, proposición de vocales para la recién creada Junta de Exportación, así como de asuntos locales y provinciales. En el caso de Burgos, la búsqueda de un local para poder reunirse fue motivo de numerosas voces en sesión de Asamblea. ${ }^{451}$

La Cámara de comercio de Burgos, al igual que las del resto de España, se fueron politizando y de ello da cuenta cómo, en una sesión de Asamblea, se estudia la conveniencia de que el Comercio presentase candidatos propios para las próximas elecciones municipales.

Hace presente que a pesar del entusiasmo que reinó en Zaragoza durante la Asamblea de las Cámaras de Comercio en aquella capital, tanto el Gobierno presidido por el Sr. Sagasta, como el que en la actualidad preside no ha hecho nada para tomar en consideración los importantes acuerdos que en la misma se aprobaron por lo que cree es muy conveniente tener representación propia tanto en los Ayuntamientos como en las Diputaciones provinciales y Congreso de Diputados y por lo tanto la pregunta que tiene que hacer a la Asamblea es si cree que es o no conveniente llevar representantes del Comercio a los Municipios en vista de la proximidad de la elecciones. ${ }^{452}$

\footnotetext{
${ }^{449}$ Ibídem, 16 de noviembre de 1899

${ }^{450}$ Ibídem, 26 de febrero de 1899, f. 43.

${ }^{451}$ Ibídem, 19 de abril de 1899, f. 49.

452 Ídem, f. 49
} 
En dicha Asamblea se propone, entre otros, a Mariano Rodríguez para ir en las listas a las elecciones municipales representando a la Cámara.

En Asamblea del 30 de abril de 1899 se dio cuenta de que la candidatura de la Cámara para las próximas elecciones municipales no había sido posible por la dimisión de los candidatos. Mariano Rodríguez expresa que, habiendo renunciado los demás, se ha visto obligado a seguir su misma conducta, aunque se presentará como comerciante independiente en las elecciones municipales de 1899 , de las que saldrá elegido. ${ }^{453}$

Nuevamente los intereses de la Cámara se centran en los cereales y en comunicaciones, sobre todo del ferrocarril, así como en impuestos. En esta sesión se observa otra reivindicación del ferrocarril:

Se recomendará eficazmente a la Diputación de esta provincia lo que solicita la Cámara de Comercio de Industria y Navegación de Madrid referente al proyecto de Ferrocarril de vía estrecha y doble directo de Madrid a Santander por Aranda de Duero y Burgos teniendo en cuenta que debe recomendarse con más interés aquel en el que más breve plazo se haga...

En vista del movimiento que ha adquirido el tráfico de mercancías en esta Estación se excitará el celo de nuestros dignos y activos representantes en Cortes a fin de que en el más breve plazo se haga el edificio definitivo y que éste sea en relación a la importación y desarrollo que hoy tiene Burgos. ${ }^{454}$

En otras ocasiones, la Cámara se moviliza por una situación de catástrofe ante las malas cosechas como, por ejemplo, en la sesión celebrada por la Junta el 11 de junio de 1899:

Dada cuenta de una comunicación del Sindicato de Comercio de Roa solicitando que esta Cámara interponga su concurso cerca del Gobierno de S.M. a fin de que tenga en consideración la precaria situación en que ha quedado tanto la villa como los pueblos del partido por las irreparables pérdidas de las cosechas a consecuencia de las fuertes heladas del mes próximo pasado, se acuerda contestarles que sin pérdida de tiempo se acudirá al Excmo. Sr. Presidente del Consejo de Ministros y representantes en el Congreso y Senado por esta provincia recomendándoles eficazmente su pretensión. ${ }^{455}$

A partir de esos años, según afirman en la propia Asamblea General de las Cámaras de Comercio, algunos participantes censuran que se "se han salido de su esfera de acción”, se han politizado; la propia Cámara responde que éstas sólo marcan el camino para el "engrandecimiento del país". Protestan contra el movimiento separatista iniciado en ciertas regiones y, como siempre, se pusieron en contra de los impuestos que incapacitaban para la creación de centros productores. Se lamentan al Estado de no escuchar a las Cámaras respecto a la reducción de gastos,

\footnotetext{
${ }^{453}$ Ibídem, 30 de abril de 1899, f. 53-54.

${ }^{454}$ Ibídem, 28 de mayo de 1899.

${ }^{455}$ Ibídem, 11 de junio de 1899, f. 57-58.
} 
especialmente en Guerra y Marina, en vez de la supresión de Audiencias, estaciones telegráficas y otros servicios. ${ }^{456}$

En la Asamblea General de 1900 Mariano Rodríguez deja de pertenecer a la Junta pero continúa ayudando en la Sección de Exportación y Museo comercial, como vocal, siendo Presidente de la misma César Gallardo y vocal Fidel Quintana. ${ }^{457}$

Durante los años siguientes participa en las asambleas generales con sus exposiciones, opiniones y propuestas, así como en la comisión nominadora de las nuevas Juntas Directivas. ${ }^{458}$

También se le nombra como mediador, junto con José Miguel Olivan, para que después de hablar con Agustín Rodríguez viesen la mejor manera de que éste devolviese a la Cámara las 2.025 pts. que debía el ex tesorero Gregorio Rodríguez. 459

Las Cámaras de Comercio recibían diversas subvenciones por parte del Ministerio de Agricultura, Industria y Comercio que se justificaban en la organización de eventos y materiales. Así, nos consta un justificante de una subvención del Ministerio, de 2.000 pts., destinada en gran parte al comercio de Hijos de Santiago Rodríguez:

Junta organizadora del $3^{\circ}$ Certamen del Quijote para organizar los festejos 100 pts.

Hijos de Moliner.- 675,25 pts.

Hijos de Santiago Rodríguez.- 1.062,25 pts. Por varios conceptos libramiento 26 abril.

Sucesor de Santamaría por impresos y papeles libramiento 15 mayo.

Esteban Domingo por una muestra o inscripción a Cámara de Comercio según libramiento 19 junio 45 pts.

A Laureano Ruiz por la pintura al óleo de una muestra libramiento 19 junio 20 pts. Total: 2.000 pts. $^{460}$

La Cámara de Comercio de Burgos promovió, a principios de siglo y por iniciativa de Francisco Rodríguez, la creación de una Escuela Mercantil que no pudo materializarse y se pide que admitiesen la devolución del material que se había entregado o el abono de las 500 pts. que correspondían. ${ }^{461}$

\footnotetext{
456 Ibídem, 18 de octubre de 1899, f. 67-69.

457 Ibídem, 10 de enero de 1902. Se formaron las siguientes secciones dentro de la Cámara: Industria, comercio, arbitraje y enseñanza, exportación y museo comercial, comercialización, obra pública, organización comercial, tratados de comercio.

${ }_{458}$ ACCBU. Libro de Actas de las sesiones de la Cámara de Comercio 1906-1912. Caja 513, Libro 2, f.

42 y ss.

459 ACCBU. Caja de correspondencia y censo 1890-1910. Caja 517, Libro 2, 9 de mayo de 1910.

${ }^{460}$ Ibídem, 24 de julio de 1905.

${ }^{461}$ Ibídem, 22 de diciembre de 1905.
} 
4. MARIANO RODRÍGUEZ MIGUEL (1860-1925). EDITORIAL HIJOS DE SANTIAGO RODRÍGUEZ

Su paso por la Cámara de Comercio se corresponde, en una primera etapa, más con intereses comerciales y culturales, distanciándose posteriormente al enfrentarse a los que defendían intereses políticos. 


\subsubsection{Litografia Moliner-Rodríguez}

El auge de las nuevas técnicas de impresión de los libros editados en la última década de los años 90, con cubiertas a color, hizo que urgiese buscar una compañía litográfica cercana al centro de producción de la editorial Hijos de Santiago Rodríguez. Es lo que nos hace suponer su inversión en una sociedad para la fabricación de naipes, con los siguientes socios: Pascual Moliner y Vaquero, casado con Dorotea Escudero (hermana de Luisa Escudero), de 42 años, comerciante con negocio de ferretería y tienda de cristal fino en el Paseo del Espolón; José Moliner y Vaquero, hermano, de 33 años, también comerciante; y Mariano Rodríguez Miguel, de 34 años. ${ }^{462}$ Esta sociedad se constituye el 5 de enero de 1894, y fija la duración de la compañía en diez años, pudiendo anularse antes del vencimiento de dicho plazo, cuando hubiese pérdidas importantes.

Se disuelve el 13 de marzo de 1895, con apenas un año de existencia. En la escritura de disolución se explica que los motivos eran algunas pérdidas en el balance y liquidación, en junio pasado, y la dificultad en la fabricación de naipes por desavenencias entre los socios que impedían la buena marcha de la compañía.

Por lo que se refleja en la escritura hemos de entender que las diferencias se dirimían con respecto a Mariano Rodríguez ya que los hermanos Moliner quedaron a cargo de satisfacer las cantidades adeudadas a Mariano y continuar con la misma actividad manteniendo al maestro de la fábrica de naipes, D. Tomás Vinuolas.

Tras la disolución de la sociedad Mariano Rodríguez recibe en efectivo la cantidad de 13.500 pts., prevista en cuatro plazos durante dos años, y otra restante de 4.000 pts. en forma de naipes. Con este capital de 17.500 pts., que en su día aportó, cede todos los derechos y acciones renunciando a favor de sus consocios y queda desligado de todo compromiso aunque obtendrá, durante dos años, el interés del seis por ciento anual, pero no percibirá intereses del resto de las 4.000 pts. en naipes. ${ }^{463}$

Durante el año de funcionamiento de la empresa Moliner-Rodríguez se hicieron numerosas cubiertas litográficas para la imprenta de Hijos de Santiago Rodríguez. Al disolverse siguió demandando la realización de las

\footnotetext{
462 AHPBU. Sección Protocolos. Caja 10958, 13 de marzo de 1895.

463 De las entregas de naipes se concretan fechas según la cantidad de naipes que se pidiesen: pedidos menores de trescientas docenas se entregarán en los ocho días siguientes; hasta ochocientas docenas, quince días y si fuesen mayores en un mes. Si no se cumpliesen esas fechas se entregará el dinero en metálico. No se podrían hacer entregas menores de veinticinco docenas de cada clase. Si se paralizase totalmente la producción, percibirá en efectivo el importe que resulte y se borrarán de las matrices la palabra Rodríguez, a partir de la fecha de la disolución, sin que por ello se vendan todas aquellas que con anterioridad quedasen con la anterior matriz.
} 
4. MARIANO RODRÍGUEZ MIGUEL (1860-1925). EDITORIAL HIJOS DE SANTIAGO RODRÍGUEZ

cubiertas ya que en varias obras impresas aparece como empresa litográfica A. Moliner. 


\subsubsection{Sociedad Anónima "Automóviles de Burgos"}

Burgos necesitaba contar con mejores comunicaciones para un mayor desarrollo económico. Debido al retraso que llevaban los proyectos ferroviarios desde la Asociación burgalesa Tertulia Mercantil se especula con la apertura de un servicio de autobuses que conectara Burgos con el resto de la provincia. La consumación de este proyecto podría ser una buena idea, y lo que es más importante, un buen negocio, aunque no de forma inmediata sí a largo plazo, y sin duda una mejora para todos los comerciantes implicados.

Los beneficios que hubiese podido reportar a Burgos no necesitamos ponderarlo pues desde hacía varios años sufría la falta de comunicaciones con importantes comarcas de la provincia y este aislamiento repercutía en todas las esferas de la vida, principalmente en la industria y en el comercio.

El automovilismo estaba progresando $\mathrm{y}$, como se manifiesta en el último Salón de París, es un medio de comunicación fácil, seguro y económico que prometía ser un propulsor eficaz para el desarrollo del comercio.

La iniciativa fue de Mariano Rodríguez, presidente de la Asociación Tertulia Mercantil, y José Moliner, dos burgaleses y comerciantes con unas industrias en alza. El 18 de abril se publica una memoria relativa a un proyecto de un servicio público y la constitución de la sociedad anónima "Automóviles de Burgos"

El 2 de junio de 1907 se celebra una reunión en la Cámara de Comercio para hablar sobre el establecimiento del servicio de automóviles. Concurrieron banqueros, abogados, ingenieros, diputados, concejales, industriales y comerciantes en número tal que llenaron el amplio salón en que se verificaba la junta. ${ }^{464}$

En el preámbulo, comienzan manifestando la demanda de comunicaciones con los pueblos de la provincia ya que su escasez había hecho que éstos acudiesen a otras regiones para sus transacciones comerciales. Y, viendo cómo las líneas de ferrocarril no acababan de arrancar, este proyecto trataría de establecer comunicaciones rápidas, regulares y económicas.

El presupuesto inicial necesario se cifró en 149.000 pts. La adquisición de coches automóviles debería hacerse por concurso entre las casas constructoras, estableciendo la condición de que admitiesen el pago de un $50 \%$ en acciones y el resto en efectivo. Hasta tal punto se llegó a pensar en el éxito de la empresa que se especuló en ampliar el sentido hacia Soria, Segovia y Madrid, internándose, más adelante en los pueblos de La Rioja.

\footnotetext{
${ }^{464}$ ACCBU. Libro de Actas de las sesiones de la Cámara de Comercio, años 1906-1912. Caja 513, Libro 2 , p. 23.
} 
Más adelante se protocolizará la Sociedad Anónima "Automóviles de Burgos", el 14 de julio de dicho año, con los siguientes socios:

- Francisco Fernández Villa y Cisneros, casado, abogado y vecino de Burgos.

- Mariano Rodríguez Miguel, casado y comerciante.

- Juan José Arroyo Ontoria, casado y propietario.

- José Moliner Vaquero, casado y comerciante.

- Pedro Jesús García de los Ríos, viudo y abogado.

- David Mercado de la Cuesta, casado y comerciante.

- Tiburcio Santamaría Adrián, casado y comerciante. ${ }^{465}$

Esta Sociedad se constituye por un tiempo limitado con el fin de comunicar Burgos con los pueblos de la provincia, por medio de automóviles que lleven viajeros, correspondencia y transporte de mercancías. El capital social inicial necesario se presupuesta en 250.000 pts., obtenido por medio de cinco mil acciones de 50 pts. cada una.

En los Estatutos fundacionales se manifiesta que la sociedad formada por todos los accionistas en Junta General nombran al Consejo de Administración y aprueban los Estatutos. En el documento notarial se presentan los Estatutos y todo lo relacionado con la nueva Sociedad. ${ }^{466}$

Tal como estaba proyectada la sociedad en un primer momento se concibió para viajeros $\mathrm{y}$, si hubiera tenido éxito, se habría dedicado también al transporte de mercancías.

Se llegaron a plantear varias líneas: Burgos-Lerma-Aranda de $80 \mathrm{~km}$., Burgos- Villadiego-Melgar de $50 \mathrm{~km}$. y Burgos-Salas de $54 \mathrm{~km}$.

Se configuró el cálculo de gastos y los posibles beneficios anuales de unas 10.000 pts. excluyendo el servicio de correo, que sería fácil poder conseguirlo. Los beneficios rondarían en torno a un $4 \%$ con la seguridad y probabilidad de ir aumentando.

No se dispone de suficientes datos para valorarlo, pues el proyecto no se materializó. Muchos comerciantes e industriales de los pueblos tuvieron

\footnotetext{
${ }^{465}$ AHPBU. Sección Protocolos. Caja 11447, 14 de julio de 1907.

${ }^{466}$ La Junta decide todo lo que estime conveniente partiendo de los Estatutos. Examina, repasa y realiza el balance anual, así como toda la gestión económica. Elige los accionistas, cinco más, que forman parte del consejo, resuelve las proposiciones del consejo y de los accionistas. Los acuerdos se realizan por mayoría de votos. Correspondiendo a cada acción un voto hasta un máximo de 25 votos. La Junta general se realiza todos los años en la primera quincena de febrero donde se presenta el balance a 31 de diciembre. La convocatoria se hace ocho días antes anunciándolo por dos veces en los principales periódicos locales y en el Boletín Oficial de la Provincia el día, hora y lugar de la realización de la Junta. La Junta extraordinaria se convoca cuando lo considere el Consejo de Administración o lo soliciten los accionistas que representen el $20 \%$ del capital social emitido. O bien se trate de la reforma de los estatutos, o por aumentar o reducir el capital social, emitir obligaciones o proceder a la liquidación o disolución de la sociedad. El consejo de Administración lo componen 7 accionistas que se renuevan por mitad todos los años en la Junta General, en la primera por sorteo, renovándose el primer año tres y el siguiente cuatro, y así sucesivamente. También se elige un presidente, vicepresidente y secretario.
} 
una gran expectación, ya que los grandes capitales e intereses de los que podían haber invertido en el proyecto se quedaron en sus bolsillos. Este hecho se repitió en otras ocasiones en Burgos, un ejemplo más de porqué la ciudad se quedó atrás en la industrialización y mejora de su actividad. En la Cámara de Comercio hay constancia escrita de que sigue esta actividad hasta 1914, no así en $1921 .{ }^{467}$

${ }^{467}$ ACCBU. Censo electoral de contribuyentes a la Cámara de Comercio de Burgos. Caja 304, carpeta 2. Año 1912; Caja 304, carpeta 3, Año 1914; Caja 304, carpeta 7. Años 1921-22. 


\subsubsection{Federación Nacional de las Artes del Libro}

Desde la liberalización de los gremios, con la llegada de la sociedad liberal, fueron apareciendo numerosas iniciativas de editores y libreros para la difusión del libro que llegaron a constituir asociaciones como las Cámaras del Libro de Madrid y Barcelona fundadas en 1918 y 1922, respectivamente. ${ }^{468}$

El Instituto de las Artes del Libro de Barcelona impulsó la participación en las Exposiciones Internaciones del Libro, de Atenas en 1903 y de Leipzig en 1914, la creación en 1906 de una Escuela Práctica Profesional, para formar a los trabajadores de la industria del libro, y la celebración del Primer Congreso Nacional de las Artes del Libro en la Universidad de Barcelona, en octubre de $1911 .^{469}$ De ahí nace la idea de agruparse para defender sus intereses y conseguir ponerse a la altura de los impresores de Europa. Se constituyen en Federación, impulsada por el impresor y político barcelonés Manuel Henrich y secundada por todos los congresistas.

El segundo Congreso Nacional celebrado en Madrid, en mayo de 1913, elabora una serie de propuestas para trabajar hasta el siguiente Congreso. Se nombra una Junta Directiva presidida por Francisco Mateu, impresor madrileño; con los vicepresidentes José Thomas de Barcelona, Julián Palacios, de Madrid, y Mariano Rodríguez Miguel, todos ellos impresores; como tesorero José González Pintado; secretario Fernando Gaissé, ambos de Madrid; y como vocales, Eduardo Arias y Estanislao Maestre, este último autor y editor de Madrid. Se nombra Presidente honorario de la Federación a Manuel Henrich, por ser socio fundador.

Como conclusiones y trabajo para la Junta Directiva se tuvo en cuenta:

- Implantar un comité mixto de patronos y obreros para resolver de común acuerdo cuestiones que permitiesen implantar las tarifas de salarios, aprendizaje y reglamentación del trabajo evitando las huelgas.

- Solicitar y gestionar cerca de los poderes públicos la reorganización de la Escuela de Artes Gráficas. Hacer gestiones en el Ministerio de Instrucción Pública y Bellas Artes para que en su presupuesto haya cantidades dedicadas a subvencionar la Escuela del Instituto Catalán de las Artes del Libro de Barcelona y todas aquellas de carácter elemental, para la enseñanza de aprendices que se realizan en Asociaciones patronales en las demás provincias de España.

\footnotetext{
${ }^{468}$ Ver: CENDÁN PAZOS, F. Edición y comercio del libro español (1900-1972). Madrid: Editora Nacional 1972; GILI ROIG, G. Bosquejo de una política del libro. Barcelona: Gustavo Gili Barcelona, 1944.

${ }^{469}$ MARTíNEZ RUS, A. La política del libro y las ferias del libro de Madrid (1901-1936). Cuadernos de Historia Contemporánea. 2003, 25, pp. 217-234.
} 
- Solicitar que, en unión de las Asociaciones locales, hiciese gestiones para que en los Aranceles figurase la partida correspondiente para que no hubiese competencia extranjera. Lo mismo que en la rebaja en los derechos de introducción de maquinaria con destino a las Artes Gráficas ya que necesariamente su compra se realizaba en el exterior.

- El estudio de la forma de establecer las tarifas mínimas de precios de venta y los medios para armonizar las relaciones entre patronos y obreros.

- Instar a los poderes públicos la prohibición del trabajo a destajo a menores de 17 años.

- Solicitar que en las subastas, antes de dar por aprobados los pliegos de condiciones para el suministro de Artes gráficas al Estado, fuesen sometidas a informe de la Federación Nacional de las Artes del Libro y que los licitadores presentasen los recibos de la contribución de los dos últimos trimestres de las industrias de las subastas.

La Asamblea acuerda crear un Boletín y que la siguiente Asamblea se realice en Valencia 1914, en 1914.

El Boletín, ${ }^{470}$ creado en febrero de 1914 con muchas dificultades, se imprime en cuadernos de 24 páginas en donde se refleja la vida y el progreso de esta federación que agrupa a muchos empresarios de las industrias gráficas: 155 de Barcelona, 139 de Madrid y en menor número de otras provincias; 32 de Zaragoza, 30 de Valencia, 25 de Málaga, 4 de Albacete, 14 de Logroño, 14 de Valladolid, 18 de Tarragona; y otros empresarios individuales como Heraclio Fournier, descendiente de famosos maestros impresores de París, con establecimiento en Vitoria, con un taller de naipes; Luis Rubalcaba, impresor de Talavera, Cuenca; Federico Viejobueno y Félix Ortiz, impresores de Cuenca; Francisco Román de Medina del Campo, Valladolid. ${ }^{471}$ Mariano Rodríguez se asocia, de forma personal, a partir del Congreso y permanece hasta su disolución. ${ }^{472}$

Debaten sobre las conclusiones del Congreso ofreciendo, a través del Boletín información de las altas y bajas, de los gastos e ingresos de la Federación o artículos profesionales y un amplio reportaje de la Exposición Internacional de las Artes del Libro celebrado en Leipzig. A esta exposición internacional, que tuvo lugar en los meses de mayo a octubre de 1914, se presentó en la Sala Española a 52 editores de Barcelona y 15 de Madrid. Fue patrocinada por Instituto Catalán de las Artes del Libro de Barcelona tras un enfrentamiento entre editores de ambas ciudades. Figuran como personas destacadas, organizadoras del evento a Enrique BaillyBalliére y Manuel Henrich. No contó con apoyo ni financiación estatal.

\footnotetext{
${ }^{470}$ FEDERACIÓN NACIONAL DE LAS ARTES DEL LIBRO. Boletín. Madrid: Imprenta de Antonio Marzo, San Hermenegildo, no 1 al 14. Febrero de 1914 a marzo 1915.

${ }^{471}$ Ibídem, Año I, $\mathrm{n}^{\circ}$ 1, febrero de 1914, p. 8.

472 Ibídem, Año I, nº 13, p. 5. Se reflejan los ingresos y gastos del año 1914, donde Mariano Rodríguez ingresa 15 pesetas, por encima de lo establecido por la Asamblea de 1 pts. al mes.
} 
La Asamblea, en mayo, no se reunió debido a la coincidencia con la Exposición en Leipzig y se pospuso para septiembre, aunque fue suspendida sin fijar la fecha. Después, las distintas Asociaciones patronales no mostraron gran entusiasmo; los industriales aislados no se agruparon y, careciendo de voluntad para realizar pasos en su avance, el Boletín dejó de imprimirse en marzo de 1915 con la disolución de la propia entidad. 


\subsubsection{Asociaciones culturales o educativas}

Mariano Rodríguez se involucra en todas las actividades para la mejora social y económica de la ciudad. Siendo así, no podía faltar su implicación en actividades culturales y educativas.

Entre todos los actos, destacamos los de carácter educativo con la promoción de los Certámenes Pedagógicos, como director de $\mathrm{La}$ Imparcialidad, y en la "Fiesta de la Enseñanza" como integrante de la Junta Provincial de Instrucción Pública. Participa en todas las actividades culturales: en la Junta de la Academia de Ciencias Sociales, en la creación de la Asociación del Turismo en Burgos, en la asociación "Tertulia Mercantil" y al final de sus días, formando parte en la constitución del Ateneo de Burgos.

Siguiendo en la misma línea comercial, desde el periódico $\mathrm{La}$ Imparcialidad promueve los Certámenes Pedagógicos ${ }^{473}$ y costea los programas que se repartían para su participación.

La "Fiesta de la Enseñanza" se implanta, en el Real Decreto de 20 de diciembre de 1907, por el conde de Romanones. Tenía como fin premiar, pública y solemnemente, a los maestros que más se hubiesen señalado durante el año, así como incentivar a los niños y a los padres por su esfuerzo en el fomento de la educación. En Burgos ya regía desde 1905, aunque los antecedentes se sitúan en 1877 y en los años 80, con los Certámenes Pedagógicos. En los años noventa se distinguían públicamente, en el Teatro, a los niños más destacados. ${ }^{474}$

En 1909 forma parte de la comisión que prepara la "Fiesta de la Enseñanza", a petición de la Junta Provincial de Instrucción Pública, participando activamente en la misma junto con el Gobernador Civil, el presidente de la Diputación provincial, el Alcalde, el Presidente del Círculo de Obreros, el Inspector de $1^{\text {a }}$ Enseñanza, el Director de la Escuela Normal de Maestros y otros más. El invitado principal de la fiesta fue D. Andrés Manjón, fundador de las escuelas del Ave-María. Cuenta como hecho novedoso, un nuevo premio de 150 pts. subvencionado por los burgaleses de La Habana, en Cuba ${ }^{475}$ La editorial Hijos de Santiago Rodríguez edita la Memoria de la fiesta escolar de dicho año. ${ }^{476}$

\footnotetext{
${ }^{473}$ El Papa-Moscas. Año XV, $n^{o} 772,9$ de octubre de 1892, p. 2. Por iniciativa del periódico El PapaMoscas, Hijos de Santiago Rodríguez, propietarios de La Imparcialidad promociona uno de los premios del III Certamen Pedagógico con el título: Dado un salón-escuela con buenas condiciones pedagógicas y completo menaje y 80 niños y niñas en el estado intelectual propio de las diversas edades de los que asisten a nuestras escuelas, indicar la marcha de la enseñanza durante una semana.

474 ALBARELloS, J., Op. cit., pp. 221-223. Tomasa Rodríguez Escudero y Domingo del Palacio Álvarez son distinguidos durante el año 1900.

${ }^{475}$ El Papa-Moscas. Año XXXII, no 1.679, 21 de marzo 1909, p. 3.

${ }^{476}$ La Voz de Castilla. Año I, no 57, 8 de marzo de 1910, p. 2.
} 
Mantiene su actividad en Asociaciones culturales y literarias y como miembro de la Junta Directiva de la Academia de Ciencias Sociales en 1907 quedando constituida de la siguiente forma:

- Presidente: Juan Manuel Cápua.

- Contador: León Villa.

- Tesorero: Agustín Ruiz Yanguas.

- Vocales: Pedro Tena, Manuel Esteban, Mariano Rodríguez y José Sarmiento

- Secretario: Manuel Corsini.

En los dos años siguientes se lograron notables proyectos como la organización de los Juegos Florales que se celebraron en las fiestas de San Pedro, la organización de un concurso a la virtud y al trabajo que se conmemoró los mismos días de los Juegos Florales, la organización de la fiesta de la cultura, como medio para combatir el analfabetismo, y la promoción de conferencias para obreros que se celebraron en el Instituto Provincial. Se propuso la creación de un "Monte de Piedad". ${ }^{477}$

Al año siguiente en julio de 1910 la Academia organiza la primera de las excursiones culturales al Monasterio de San Juan de Ortega. Tras la misa cantada, y bajo la arboleda, el señor José Sarmiento Lasuén hizo historia del Santo, habló de la fundación y vicisitudes del monasterio, analizando los edificios y riquezas del lugar. Entre los expedicionarios se encontraba José Alfaro, Zumárraga, Cadiñanos, Berrueta, Cominges, Fernández Cuevas, Ezquerra, Ferrer, Tarduchy, Sarmiento, Alberú, y Mariano Rodríguez, entre otros. ${ }^{478}$

Forma parte activa de la Tertulia Mercantil, en el paseo del Espolón, $\mathrm{n}^{\circ}$ 14 principal, ocupando la presidencia en 1906, siendo vicepresidente José Moliner; contador, Luis Gallardo; tesorero, José Mira; secretario Tiburcio Santamaría; y vocales, Antonio Larrosa y Simón Albillos.

También participa en la creación de la Asociación del Turismo en $\operatorname{Burgos}^{479}$ que, a propuesta del alcalde, reúne a las personalidades más

\footnotetext{
${ }^{477}$ El Papa-Moscas. Año XXXI, $\mathrm{n}^{\circ} 1.617,12$ de enero de 1908.

${ }^{478}$ La Voz de Castilla. Año I, no ${ }^{\circ}$, 31 de julio de 1910, p. 1.

${ }^{479} \mathrm{El}$ turismo en los primeros años del siglo XX en España comenzó a ser una actividad progresivamente en auge, lo que hizo pensar a los gobiernos su interés económico. Se creó en 1905 la Comisión Nacional del Turismo y en numerosas ciudades españolas se crearon Asociaciones para el fomento del Turismo. En Burgos tardaría en cuajar dicha iniciativa pero como paso intermedio nacieron los cursos de la Unión de Estudiantes franceses, en 1908 -cursos Merimée-Sebastián-, uno de los más antiguos y prestigiosos de España que surgió gracias a la amistad entre los profesores Rodrigo de Sebastián y Ernest Mérimée, decano honorario de la Facultad de Letras de la Universidad de Toulouse. Ver el artículo sobre el tema de: RUIZ CARCEDO, J. El turismo en Burgos. Apuntes de un siglo. En: L. S. IGLESIAS ROUCO, dir. Protagonistas burgaleses del siglo. Burgos: Diario de Burgos, 2002, v. II, pp. 129-132.
} 
importantes de la ciudad, el 19 de septiembre de 1910, para constituir una Junta Magna del Turismo. En la primera reunión se nombró una comisión para estudiar la mejora del turismo en Burgos formada por D. Rodrigo Sebastián -profesor del Instituto de Burgos-, José $\mathrm{M}^{\mathrm{a}}$ Fernández Cavada teniente de alcalde- y Mariano Rodríguez Miguel. Un primer acuerdo fue adherirse al Congreso Internacional de Turismo en Toulouse.

En una segunda reunión, el Alcalde participó la decisión tomada en el Pleno de enviar al teniente de alcalde, Sr. Cadiñanos, al Congreso. También se decidió qué personas representarían a Burgos, decantándose que, por el Instituto y Claustro de Profesores, iría el señor Rodrigo Sebastián y por la Cámara de Comercio, César Gallardo; de la Academia de Ciencias Sociales, Martín Domínguez Berrueta, director de El Lábaro, periódico de Salamanca, y de la prensa local Mariano Rodríguez. ${ }^{480}$

En fecha 8 de octubre de 1910 parten de Burgos para asistir al Congreso de Turismo los señores Cadiñanos, Gil, Sebastián y Rodríguez Miguel y se une en Briviesca el señor Echevarría, diputado provincial, ${ }^{481}$ representando a distintas asociaciones. A su llegada a Toulouse fueron acompañados hasta el hotel por una representación del Ayuntamiento, por los señores Merimée -padre e hijos- y el historiógrafo Mr. Cartailhac, el presidente del Sindicato de Iniciativa del evento. ${ }^{482}$

Fruto de este Congreso comienza la Asociación para el Fomento del Turismo con unos primeros estatutos, el 27 de enero de 1912, editados por Hijos de Santiago Rodríguez en un folleto de 12 páginas.

Mariano Rodríguez también coopera en la creación del Ateneo de Burgos, el 9 de marzo de 1924, en una Asamblea Constitutiva en el Salón de la Diputación provincial. Previa aprobación de los Estatutos se constituyó la primera Junta Directiva presidida por Manuel Gaitero junto con Julián Cominges, Carlos Fesser, María Cruz Ebro, Virgilio Ruiz, Mariano Rodríguez, Miguel Domingo Hergueta, Ricardo Gómez Rojí, Rafael López de Haro, Juan Antonio Cortés y Luciano Huidobro.

Todas las actividades del centro se articularon en cinco secciones: Ciencias, Lengua y Literatura, Historia y Bellas Artes, Sociología y Pedagogía y Fomento.

Presidida por el cardenal Belloch, ${ }^{483}$ se celebra el día 30 de marzo un primer acto en el Teatro Principal con la disertación de Rafael López de Haro sobre "Cómo se escribe una novela".

\footnotetext{
${ }^{480}$ La Voz de Castilla. Año I, n 101, 19 de septiembre de 1910, p. 3; n 102, 25 de septiembre de 1910, p.2-3.

${ }^{481}$ La Voz de Castilla. Año I, no 104, 9 de octubre de 1910, p. 3.

${ }^{482}$ La Voz de Castilla. Año I, no 106, 23 de octubre de 1910, p. 2. En el artículo se hace referencia día a día de todas las actividades del Congreso.

${ }^{483}$ ALBERDI ELOLA, L. Op. cit., pp. 255-256.
} 
El Ateneo sobrevive con grandes realizaciones hasta 1932, pero pierde relevancia a partir de 1933 y se disuelve en 1941. Como principales hitos sobresalen el Certamen del Trabajo, en 1927, la Exposición de Libros burgaleses, en 1930, y la creación del Centro de Estudios Castellanos, en 1931.

Como hijo predilecto de Burgos en el homenaje a Marcelino Santa María el 30 de enero de 1925, celebrado en el Teatro Principal, Mariano Rodríguez debido a su enfermedad, -muere en mayo de 1925- se adhiere al acto por escrito, al igual que otras personalidades como el marqués de Heredia, conde de Romanones, de Cerrajerías y de las Navas, Mariano Benlliure, Julio y Enrique Romero de Torres y Henri Merimée. ${ }^{484}$

${ }^{484}$ ALBARELLOS, J. Op. cit., p. 254. 


\subsubsection{Asociación de la Prensa en Burgos}

La Asociación de la Prensa en Madrid fue creada en 1895 y Mariano Rodríguez pertenece como miembro fundador a la Federación de Asociaciones de Periodistas de España.

Surgió ante las pésimas condiciones de la mayoría de los periodistas de Madrid a finales del siglo XIX, liderada por el director del diario El Globo, Alfredo Vicenti. Elaboraron unos estatutos de una agrupación que se llamaría "Asociación de la Prensa". Se eligió al primer presidente de la institución, Miguel Moya, director de El Liberal, que presidiría la entidad durante 25 años.

En Burgos, un grupo de periodistas proyectaron constituir la Asociación de la Prensa en la capital, nombrando a algunos compañeros para la realización de los Estatutos -Mariano Rodríguez colaboró activamenteque, con algunas modificaciones, se aprobaron a primeros de septiembre de 1916 para su presentación al Gobernador Civil de la Provincia. ${ }^{485}$ Durante ese mismo mes se reunieron todos aquellos que quisieron inscribirse directores, redactores, administradores, corresponsales y colaboradorespara nombrar la primera Junta Directiva, saliendo elegidos:

Presidente: Mariano Rodríguez Miguel, director de La Imparcialidad.

Tesorero: Julio Diez-Montero, director de El Papa-Moscas.

Vocal 1 ${ }^{\circ}$ : Ángel Menoyo Portalés, director de Tierra Hidalga.

Vocal 2: Daniel Torre Garrido, director de El Castellano.

Secretario: José Trébol, administrador de La Voz de Castilla. ${ }^{486}$

Esta directiva fue elegida hasta la próxima Junta General que se realizaría en enero de 1818. Mariano Rodríguez dirigirá la Asociación, por elección, hasta su muerte en 1925.

Los fines de la Asociación se centraron en defender y mejorar los intereses morales y materiales de la prensa periódica burgalesa, y de los periodistas que a ella pertenecían. Como fin secundario, la protección entre los asociados ya sean redactores, directores, colaboradores, corresponsales o administradores. Se nombró como presidente honorario al periodista Miguel Moya, presidente de la Asociación madrileña. ${ }^{487}$

El primer acto fue de puro compañerismo: un homenaje a Ángel Menoyo Portalés, en una comida en el restaurante "La Vascongada". A ella no asiste Mariano Rodríguez por tener compromisos en Madrid aunque se

\footnotetext{
${ }^{485}$ Tierra Hidalga. Año V, no 244, 9 de septiembre de 1916, p. 2.

${ }^{486}$ Tierra Hidalga. Año V, no 246, 23 de septiembre de 1916, p. 2.

${ }^{487}$ El Papa-Moscas. Año XXXIX, 24 de septiembre de 1916, p. 3. 
adhiere al acto mandando un telegrama de agradecimiento a la labor del agasajado.

Mariano Rodríguez, como presidente de esta Asociación, tiene en cuenta las aspiraciones de la región, y ante el proyecto de ley de ferrocarriles secundarios y estratégicos que se debatía en el Congreso, en 1917, pide a los representantes de las Cortes por la provincia que gestionen todos los trámites necesarios a fin de que se aprueben los diversos trayectos de interés para Burgos. ${ }^{488}$ Dirige varios telegramas al Presidente del Consejo de Ministros, al ministro de Fomento y a senadores y diputados a Cortes por la provincia. A dichos telegramas contestaron positivamente el Presidente del Consejo de Ministros, el Sr. Conde de Romanones, y los diputados por las provincia: Zumárraga, Aparicio, Bermejo, Luelmo, Arias de Miranda, y el marqués de Buniel y Macorra manifestando estos últimos que interpondrían su influencia para que la ley se aprobase de forma favorable para Burgos.

Madrid 12 - 18:30. Manifestaciones su telegrama coinciden deseos Gobierno Presidente Consejo Ministros. ${ }^{489}$

La Asociación, a iniciativa de Mariano, promueve la adquisición de artículos de alimentación, vestidos y calzado para los socios, en ventajosas condiciones. Para ello insta a todos los comerciantes e industriales que quieran participar indiquen la rebaja o bonificación que se comprometen a hacer en cada artículo o en el total de ellos. ${ }^{490}$

Asiste, como representante de la Asociación al cincuentenario del periódico El Imparcial ocupando un lugar en la mesa de la presidencia en el banquete celebrado en el hotel Ritz. ${ }^{491}$

Fue comisionado para ofrecer a Francisco Bergamín, ministro de Instrucción Pública entre 1913-14, el cargo de Mantenedor en los Juegos Florales de Burgos -1918-, y para organizar las actividades que se desarrollarían. Los premios que se otorgaron partieron tanto de personalidades como de Asociaciones: colegio de Abogados de Burgos, Cámara provincial de Comercio e Industria de Burgos, Cámara Oficial de la Propiedad urbana de Burgos, Cámara Agrícola Oficial de Burgos, Sociedad Salón de Recreo, Sociedad Círculo de la Unión, casa editorial Hijos de Santiago Rodríguez, Ayuntamiento de Burgos, Diputación de Burgos, la propia Asociación de la Prensa, senadores de la provincia (Rafael Bermejo, Luis Calleja y Felipe Alfau), los diputados a Cortes (Francisco Aparicio, Benito de Andrade, Aurelio Gómez, Rufo Luelmo,

\footnotetext{
${ }^{488}$ Tierra Hidalga. Año VI, no 267, 17 de febrero de 1916, p. 3

${ }^{489}$ La Voz de Castilla. Año VIII, no 442, 18 de febrero de 1917, p. 1.

${ }^{490}$ Tierra Hidalga. Año VII, no 326, 7 de abril de 1918, p. 2.

${ }^{491}$ Tierra Hidalga. Año VI, no 271, 17 de marzo de 1917, p. 3.
} 
Ignacio G. de Careaga), el gobernador civil y el presidente de la Audiencia Territorial.

La Casa editorial Hijos de Santiago Rodríguez subvencionó el $14^{\circ}$ premio con un ejemplar de seis tomos, lujosamente encuadernados, de la historia contemporánea, escrita por Pirala, bajo el título del tema: Importancia de la labor educativa del maestro y medios prácticos para conseguir que aquella tenga eficacia y perdure fuera de la escuela. ${ }^{492} \mathrm{La}$ Asociación de Prensa subvencionó el premio con 150 pesetas por la realización de una poesía festiva, que recayó en Marciano Zurita.

También se contó que para el acto principal de los Juegos en el Teatro Principal la Asociación de la Prensa repartiría entradas gratis entre los obreros del "Círculo Católico de Obreros", "Casa del Pueblo", "A.O.B. Tradicionalista" y "Círculo Republicano".

${ }^{492}$ Tierra Hidalga. Año VII, nº 337, 23 de junio de 1918, pp. 1-2. 


\subsubsection{Otras sociedades burgalesas vinculadas con Mariano Rodriguez}

Mariano Rodríguez forma parte de numerosas asociaciones: las plenamente mercantiles, como la sociedad La Soledad; las de carácter benéfico asistencial, como el Patronato de Presos y Penados, la Asociación Antituberculosa burgalesa, la "Tienda-Asilo", la Sociedad "Gota de Leche" y las "Cantinas escolares"; o las recreativas, como la Comisión de toros que se formaban para las Ferias y fiestas de la ciudad, o la Sociedad llamada "Tiro al Pichón".

De tipo mercantil encontramos un poder notarial donde se describe que, desde primeros de julio de 1888, Mariano Rodríguez, José de la Morena y Francisco Cebrián constituyeron, por contrato verbal, la sociedad "La Soledad" dedicada a servicios fúnebres en la capital. Francisco Cebrián es el encargado de llevar las cuentas y demás asuntos. Más tarde fue denunciado porque, dejando de pertenecer los dos primeros a esta sociedad, desde el 31 de julio de 1901, no habían recibido las cuentas pendientes desde esa fecha. ${ }^{493}$

De carácter benéfico forma parte de numerosas asociaciones:

1.- Del patronato general de presos y penados, siendo D. Mariano Rodríguez vocal del mismo, aunque sólo nos queda constancia por el periódico El Papa-Moscas en el año 1904. ${ }^{494}$

La Junta nombrada para la constitución de un patronato general de presos y penados ha quedado constituida en la forma siguiente: presidente: D. Ricardo J. Ortiz, y en sus ausencias, el Sr. Blasco, vocales los señores Rodríguez, y Jarto y secretario Martínez del Campo.

2.- De la Asociación Antituberculosa burgalesa, siendo presidente Marcial Martínez; vicepresidente $1^{\circ}$, Perfecto Ruiz; vicepresidente $2^{\circ}$ José $M^{a}$ Fernández Cavada; y vocales, Basilio Olalla, Celestino Hortigüela, José Díaz Hoyuelos, Gregorio Escolar, Juan Albarellos, Emilio García de la Puente, José Miguel Oliván, Ramón Aguilar y un médico militar designado por el Inspector de Sanidad; vicesecretario, Pedro Bojas; tesorero, Federico de la Llera; y contador Mariano Rodríguez. ${ }^{495}$

\footnotetext{
493 AHPBU. Sección Protocolos. Caja 11223, 22 de agosto de 1901.

${ }^{494}$ El Papa-Moscas. Año XXVII, no 1.453, 6 de marzo de 1904, p. 3.

${ }^{495}$ El Papa-Moscas. Año XXVIII, no $1.503,11$ de febrero de 1905, p. 3.
} 
3.- En Burgos se constituyó, desde 1894, la llamada "Tienda-Asilo", asociación de carácter benéfico, bajo el amparo del Ayuntamiento, siendo alcalde Andrés Dancausa quien convocó a todas las personalidades y asociaciones de la ciudad nombrando la siguiente Junta Directiva:

- Presidente: Benito Peña.

- Vicepresidente: Mariano Rodríguez Miguel.

- Tesorero: Manuel Rico.

- Secretario: Bonifacio Diez Montero.

- Vicesecretario: Agustín Jiménez.

- Vocales: Benito Martín, Francisco Mendieta, Pedro Montero y Atanasio Quintano. ${ }^{496}$

La Tienda-Asilo se inauguraba todos los años a primeros de diciembre hasta la Pascua de Resurrección y se daban raciones de comida a precios muy bajos para la clase social con pocos recursos, por 85 céntimos, como nos relata La Voz de Castilla:

El precio de las raciones es el siguiente, de sopa, 5 céntimos; de cocido (compuesto de garbanzos y patatas, garbanzos y alubias o garbanzos y arroz); 10 céntimos; de carne; 10 céntimos; de pan, 5 céntimos y de vino (1/8 de litro, sin opción a repetir), 5 céntimos. ${ }^{497}$

Promovía iniciativas para que el día de Reyes se repartiesen comidas y juguetes a los niños pobres, aunque tal iniciativa se tuvo que suprimir por repetidos abusos. También proyectó dar bonos de comidas para enfermos pobres. Recurrieron a diversas iniciativas para arbitrar recursos y contribuir al sostenimiento de la obra benéfica. Una de ellas es la función teatral donde actúan ciudadanos burgaleses, tanto hombres como mujeres, entre los que señalamos a Lucas Rodríguez que, al igual que su padre, actúa con 20 años por una buena causa. ${ }^{498} \mathrm{La}$ instalación de una Tómbola durante las fiestas de junio de 1919 fue otro de los proyectos para conseguir fondos para los más necesitados. ${ }^{499}$

Se mantenía con suscripciones, siendo 1 pts. la cuota máxima mensual y se sostenía, también, con donativos dados por personas para que se repartiesen comidas gratis en los días señalados por los donantes.

Con ocasión de la inauguración de los nuevos locales en la calle Miranda, la editorial Hijos de Santiago Rodríguez envía 75 pts. para esta Asociación. ${ }^{500}$

\footnotetext{
${ }^{496}$ La Verdad. Año II, no 302, 7 de noviembre de 1894, p.3.

${ }^{497}$ La Voz de Castilla. Año I, no 27, 27 de enero de 1910, pp. 1-2.

${ }^{498}$ La Voz de Castilla. Año VI, no 381, 19 de diciembre de 1915, p. 2.

${ }^{499}$ La Voz de Castilla. Año X, no 543, 22 de junio de 1919, p. 2.

${ }^{500}$ El Papa-Moscas. Año XXIX, no 1537, 29 de abril de 1906, p. 2.
} 
4.- La Sociedad "Gota de Leche" fue una institución benéfica de la infancia de gran importancia cuando los datos de mortalidad todavía seguían siendo muy elevados. En la Memoria anual de 1915 se relata que de todos los 1.513 menores de dos años existentes en la ciudad, sólo 112 niños estaban inscritos en la Asociación, falleciendo sólo 4; de los restantes murieron 165, con un evidente mayor porcentaje de mortalidad. Se incluyen en la Memoria los datos de los asistidos que fueron 657 niños, 1.265 pesadas y 3 aplicaciones electroterápicas, bajo la dirección del médico-director José Merino.

El estado económico de la Asociación era muy positivo con un saldo a favor de 11.372,03 pts., sostenida por la caridad burgalesa. ${ }^{501}$

La presidencia la ostentaba Mariano Rodríguez, como director figuraba Ramón de la Cuesta, vocal Emilio R. Tarduchy, y secretario, Modesto Díez del Corral. ${ }^{502}$

En el día de Reyes se repartían más de 900 prendas para los niños pobres, además de telas para llevarse a casa y poder confeccionar vestidos, gracias a la ayuda activa de diversas mujeres. ${ }^{503}$

5.- En 1914 se inaugura la institución benéfica "Cantinas escolares" creada por iniciativa de la Junta de Protección a la Infancia, y ubicada en el edificio de la antigua Escuela Normal de Maestros, donde se comenzó a servir comida a 150 pequeños escolares sin recursos pertenecientes a las escuelas públicas de la ciudad. La comida consistía en un plato de sopa, otro de garbanzo y una ración de carne y tocino al que se unía, en la fecha de la inauguración, un guiso de carne costeado por el alcalde, Manuel de la Cuesta.

Fue inaugurada por el señor Cadiñanos, en representación del gobernador, y del señor alcalde, por Mariano Rodríguez y otros muchos. ${ }^{504}$

De tipo recreativo y cultural forma parte:

1.- De la comisión de toros ${ }^{505}$ en las Ferias y Fiestas de Burgos, junto con otros notables de la ciudad. Su afición se remonta desde su juventud. Con ocasión de la llegada del rey Alfonso XIII, la reina madre y la infanta $\mathrm{M}^{\mathrm{a}}$ Teresa, acompañados por el presidente del Consejo de Ministros Eugenio Montero Ríos- y con motivo de unas condiciones favorables para ver el eclipse de 1905, se preparó una corrida de toros en su honor, contratando al célebre espada Montes, con un gasto de treinta mil pesetas. Los organizadores fueron el conde de Berberana, José Sarmiento, Mariano

\footnotetext{
${ }^{501}$ Tierra Hidalga. Año V, no 220, 26 de marzo de 1916, p. 1.

${ }^{502}$ El Papa-Moscas, Año XXXVII, no 1917, 1 de marzo de 1914, p. 2.

${ }^{503}$ La Voz de Castilla, Año II, no 117, 8 de enero de 1911, p. 2.

${ }^{504}$ La Voz de Castilla. Año V, no 276, 18 de enero de 1914, p. 3.

${ }^{505}$ El Papa-Moscas. Año XV, no 757, 8 de junio de 1892.
} 
Villalaín y nuestro protagonista. No pudieron asistir los reyes debido a la noticia que llega: el fallecimiento de un archiduque pariente de la reina. ${ }^{506}$

Sigue, como gran aficionado, formando parte de la comisión organizadora de las corridas de toros ${ }^{507}$ siendo siempre la suscripción de acciones para las corridas en su propia librería y uno de los primeros en unirse a ellas..$^{508}$

2.- En muchas de las sociedades que se crearon en esta época, Mariano Rodríguez se hizo presente formando parte de las Juntas Directivas. En la Sociedad llamada "Tiro al Pichón" figura como presidente, Julio DíezMontero; vicepresidente, Ramón de la Cuesta; tesorero, Ramón J. Almuzara; y vocales, Mariano Rodríguez, José Ma Moliner y Juan Antonio Gutiérrez Moliner. ${ }^{509}$

3.- Junto con Julio Diez-Montero, y ante las constantes repeticiones de las obras que se interpretaban en el Teatro Principal, a veces sin aviso, solicitaron al Ayuntamiento que se les cediese el teatro por unos años para la puesta en escena de la temporada teatral. ${ }^{510}$ Querían forman una sociedad explotadora del teatro, integrada por 500 socios, que aportaran 100.000 pts. sin interés y reintegrables a los 15 o 20 años. El proyecto no se pudo llevar a cabo por no encontrar el capital ni los socios necesarios. ${ }^{511}$

Este tema era algo insistente desde principios de siglo cuando se arrendó por 2.750 pts. anuales al vecino de Valladolid, Ángel García Solalinde y Malena, cuyo contrato fue rescindido en diciembre de 1906 por retrasos en el abono y consentir que algunas compañías no terminasen la temporada.

En 1902 se clausuró el teatro por no reunir las condiciones vigentes en las nuevas Reales Órdenes que fueron subsanadas gracias al presidente de la comisión de Teatro en el Ayuntamiento de Burgos. Mariano Rodríguez Miguel se preocupó por adaptarlo a la nueva normativa como impregnar a las escaleras del escenario con sales de sulfato, que los faroles estuviesen cubiertos con telas metálicas o establecer contadores de gas distintos y poner indicaciones de la dirección de la salida. ${ }^{512}$

4.- Mariano Rodríguez estuvo presente en todas las inauguraciones, ya sea como gerente de su empresa o como director de La Imparcialidad,

\footnotetext{
${ }^{506}$ EBRO, M. C. Op. cit., p. 300.

${ }^{507}$ La Voz de Castilla, Año III, no 219, 8 de diciembre de 1912, p. 2.

${ }^{508}$ Guasa Viva. Año II, no 88, 22 de noviembre de 1914, p. 7.

${ }^{509}$ El Papa-Moscas. Año XXXIV, no $1.834,10$ de marzo de 1912, p. 3.

${ }^{510}$ La Voz de Castilla. Año II, no 116,1 de enero de 1911, p. 1.

511 ALBARELLOS, J. Op. cit., p. 264.

512 ALBERDI ElOLA, L. El Teatro Principal. Burgos: Talleres Gráficos Diario de Burgos. Publicaciones del Excmo. Ayuntamiento de Burgos, 1979, p. 150.
} 
como nos presenta la prensa local en la inauguración de la Estación telefónica instalada en la calle Almirante Bonifaz, $n^{\circ} 19$.

Galantemente invitados por el Inspector general de la compañía Peninsular de Teléfonos, don Eduardo Estelat, asistimos el pasado jueves al acto inaugural de la Estación telefónica [...] La prensa local se hallaba representada por D. Mariano Rodríguez, de "La Imparcilidad"; D. Dionisio Laguía, redactor de "El Mundo", de Madrid, y en nombre de "El Papa-Moscas"; D. Juan Albarellos, de "Diario de Burgos"; D. Daniel Garrido de "El Castellano"; Sr. Saenz de San Pedro, de "Guasa Viva", y nuestro compañero Sr. Trébol [...] $]^{513}$

Y también en la inauguración del nuevo edificio escolar en el próximo barrio de Villalonquejar donde Mariano Rodríguez habla en nombre de la prensa burgalesa, felicitando al Ayuntamiento de Burgos y prometiendo que se haría una campaña con el fin de recabar alguna subvención para ayuda del grupo escolar. ${ }^{514}$ El nuevo edificio tenía un gran salón y ocho amplias ventanas en tres fachadas, según nos cuenta La Voz de Castilla, con arreglo a las normas pedagógicas.

5.- Asiste a homenajes de ilustres burgaleses como en honor a Marceliano Santa María, en enero de 1911, donde se daban cita las personalidades más importantes de la ciudad, ${ }^{515}$ y participa de la vida cultural y literaria que se agrupa entre la sociedad "Salón de Recreo" y en el propio Teatro. La actividad de Mariano es conocida de forma señalada, como nos relata La Voz de Castilla en la fiesta literaria en el Teatro, en 1912. Presidiendo el acto estaba Alejandro Pidal y Mon quién dio una conferencia sobre la batalla de las Navas. En dicho acto ocupaban los restantes puestos de la mesa el Gobernador Civil, el Alcalde, y los señores Aparicio, Macorra, Gil, Amancio Rodríguez, Mariano Rodríguez y Martínez del Campo y Cuesta. ${ }^{516}$

Participa dentro de la Junta Provincial, en la comisión para erigir un monumento a Castelar junto con otros notables burgaleses como Plaza, Ruiz Llorente, Llera, Fernández Izquierdo, Isidro Gil, Ajuria y García de Quevedo y Concellón. ${ }^{517}$

\footnotetext{
${ }^{513}$ La Voz de Castilla. Año IV, no 241, 11 de mayo de 1913, p. 2.

${ }^{514}$ La Voz de Castilla. Año VI, no 356, 5 de septiembre de 1915, p. 2.

${ }^{515}$ La Voz de Castilla. Año II, no 116, 1 de enero de 1911, p. 3.

${ }^{516}$ La Voz de Castilla. Año III, no 199, 21 de julio de 1912, p. 2. ALBARELLOS J. Op. cit., pp. 225-226.

${ }^{517}$ El Papa-Moscas. Año XXV, no 1.384, 9 de noviembre de 1902, p. 3.
} 


\subsection{ACTIVIDAD POLÍTICA DE MARIANO RODRÍGUEZ (1899-1903)}

Continúa los mismos pasos que su padre y se presenta, en 1899, a las elecciones municipales, como candidato independiente, siendo elegido por el $2^{\circ}$ distrito junto con el alcalde José $\mathrm{M}^{\mathrm{a}}$ Fernández Cavada y Obanza, del partido conservador. Éste pertenecía a la familia de los Condes de Bárcenas, militando en el partido de Antonio Maura. Los que salen elegidos como tenientes de alcalde fueron: Juan José Arroyo, Antonio Zumárraga, Julián de las Heras, Manuel Corral Saiz, Vicente Alfonso Ortega, Francisco Regis Cisneros y Luis de San Pedro. Y como regidores: Mariano Rodríguez, Enrique Gil Delgado, Clementino Quintana, Miguel González, Ángel Sevilla, Gregorio Bautista Argachal, Severiano Sáez, Carlos Echevarrieta, Ramón Lozano, Victoriano Santos Cuñado, Félix Mozo, Ignacio González, Ramón de la Cuesta y Pedro Rodríguez. ${ }^{518}$

Algunos de ellos fueron compañeros en la directiva de la Cámara de Comercio o compañeros de la propia Asociación, como Juan José Arroyo, Francisco Regis Cisneros, Miguel González, Luis de San Pedro, Clementino Quintana, Gregorio Bautista Argachal, Félix Mozo, Isidoro Viejo y Juan José Redondo, entre otros. ${ }^{519}$

En este Ayuntamiento forma parte de la comisión de Gobernación, y atenderá los asuntos que en legislaturas anteriores intervenían las comisiones de Secretaría, Teatro, Elecciones y todo lo relativo a festejos. El presidente de esta comisión era Baldomero Amézaga, siendo el resto de vocales: Enrique Gil-Delgado, Pedro Díez-Montero, Francisco de la Azuela, Clementino Quintana, Miguel González, Severiano Sáez, Carlos de Echevarrieta y Ramón de la Cuesta.

De la misma manera, fue vocal de la comisión de Hacienda, de la que Juan José Arroyo era presidente y de Instrucción Pública, con la presidencia de Julián de las Heras.

El primer alcalde del siglo XX, José $\mathrm{M}^{\mathrm{a}}$ Fernández Cavada y Obanza, acometió un amplio programa de reformas en la ciudad. Suya fue la modificación del Paseo del Espolón Viejo y el trazado de la calle que unía la carretera de Francia con la calle de las Calzadas (hoy Alvar García). Según el Diario de Burgos, el 13 de febrero de 1899, en las decisiones del gobierno municipal reinaba la imprevisión, el despilfarro y la rutina, además del caciquismo y la complacencia ${ }^{520}$ de liberales, conservadores, carlistas o republicanos.

\footnotetext{
518 AMBu. Actas del Ayuntamiento. LA-535, sesión inaugural de $1^{\circ}$ de julio de 1899.

${ }^{519}$ ACCBU. Censo electoral de contribuyentes a la Cámara de Comercio de Burgos 1912. Caja 304, carpeta 1.

${ }^{520}$ CÁMARA MORAL, M. Hoy, como ayer. Crónica de los acontecimientos vividos en Burgos entre 1898 y 1914. Op. cit., p. 56.
} 
Durante 1899 lo más destacado para Burgos fue la celebración del V Congreso Católico Nacional. La Iglesia, a lo largo del siglo XIX, no se adaptó ni supo ejercer su influencia religiosa en un mundo moderno de profundos cambios, debidos a la industrialización y laicidad, como sucedió en España en el final de siglo, con profundas polémicas provocadas acerca de la colaboración de los católicos con un régimen inspirado en el liberalismo.

Los Congresos Católicos Españoles se iniciaron en Madrid (1889), a los que siguieron los de Zaragoza (1890), Sevilla (1892), Tarragona (1894), Burgos (1899) y el último de ellos en Santiago (1902).

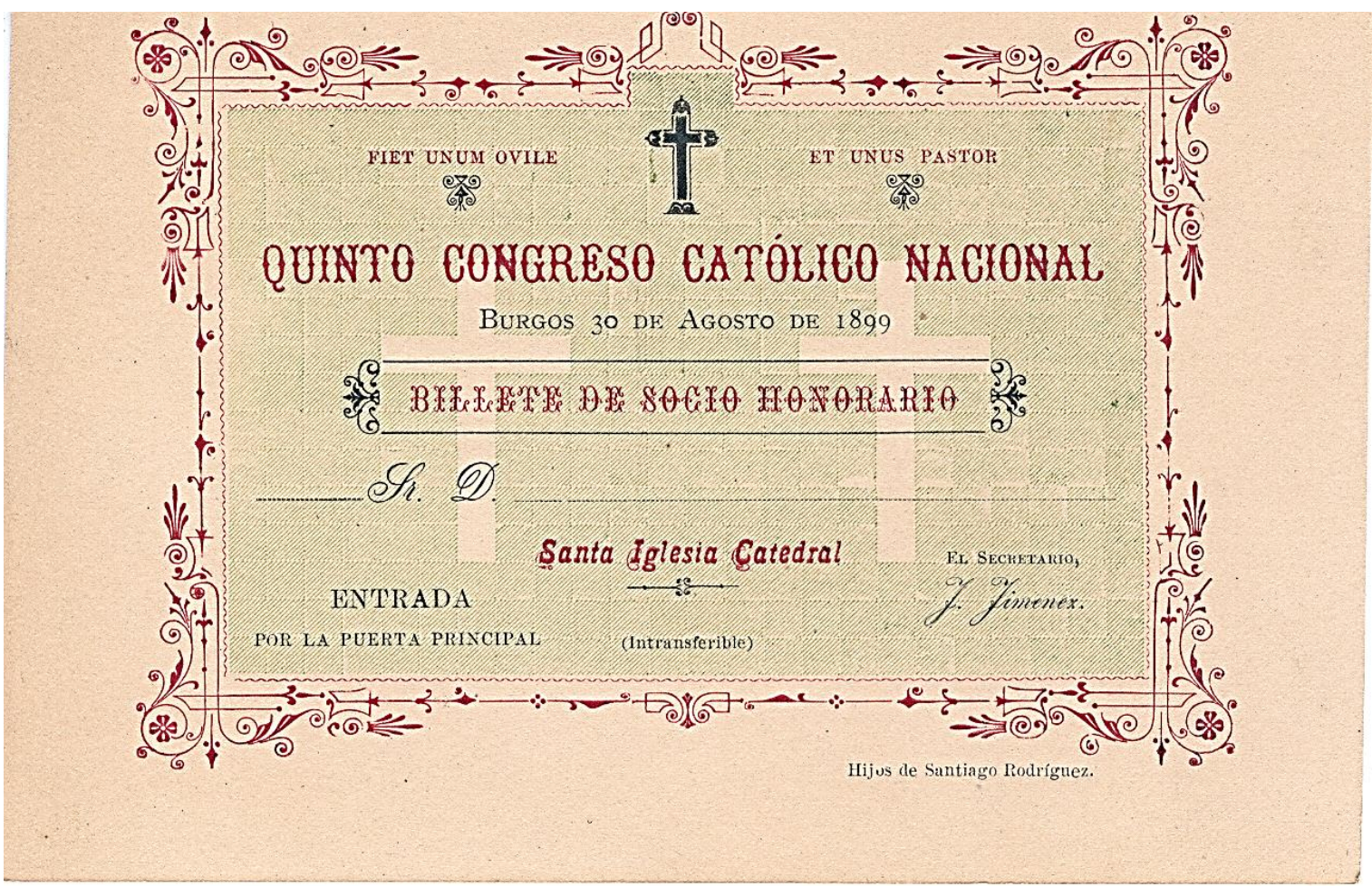

Fig. 4-3: Tarjeta-entrada de socio de honor impresa en la editorial Hijos de Santiago Rodríguez con motivo del V Congreso Católico Nacional realizado en Burgos el 30 de agosto de 1899.Tarjeta cedida por Mercedes Rodríguez Plaza.

El Congreso de Burgos se realizó en un contexto social y político de pesimismo, por el desastre y pérdida colonial, y a la búsqueda de unos objetivos comunes, de mayor unidad y coordinación de los católicos frente al avance del proceso secularizador. Las conclusiones revelaron la agudización del conflicto Iglesia-mundo moderno. ${ }^{521}$

Mariano Rodríguez, como presidente accidental de la Comisión de Gobernación, fue el encargado de organizar los festejos que se celebraron durante el Congreso. Entre ellos sugirió que, sin costo alguno para la

${ }^{521}$ Vid. Crónica del V Congreso Católico Español. Burgos: Imp. y Estereotipia de Polo, 1899. 
Corporación, se hiciese una recepción el día anterior al Congreso para homenajear a los Prelados que asistían al mismo.

Las sesiones comenzaron el 30 de agosto y finalizaron el 4 de septiembre con una procesión desde la Catedral, siguiendo por las calles principales del centro, e invitando a la Corporación a su participación. Asisten, a pesar del voto en contra del socialista Severiano Sáez, que insistía en que las discusiones del Congreso eran más políticas que religiosas.

El balance del Congreso no fue muy alentador. Las conclusiones reafirmaron el retorno a las antiguas tradiciones, al considerar negativos los avances sociales producidos en este periodo de reformas.

Como vocal de la Comisión de Instrucción Pública del Ayuntamiento reclama, en sesión plenaria, que se tomasen medidas para que los niños no estuviesen jugando en las calles durante las horas que son de permanencia en las Escuelas Municipales. ${ }^{522}$ También lleva al pleno una propuesta sobre la necesidad de que los niños de las escuelas municipales salgan de la escuela los jueves para visitar monumentos artísticos, fábricas etc, con sus maestros y maestras, siguiendo las recomendaciones dadas por varias disposiciones ministeriales y por razones de higiene y pedagogía. Propone que se vote en el seno del pleno, pero la mayoría de los ediles conservadores votan a favor de que se resuelva más adelante en la Comisión de Enseñanza, donde tampoco fue aprobada. ${ }^{523}$

No es la única vez que diversos sectores conservadores del Ayuntamiento harían valer su influencia y sus diferencias. En la sesión de 11 de mayo de 1900, se presenta la solicitud de varios comerciantes e industriales de Burgos, en nombre de la Unión Nacional establecida unos días antes en Burgos, ${ }^{524}$ para que se les concediese el Teatro y así poder celebrar una reunión pública con motivo de la llegada de Joaquín Costa.

Mariano Rodríguez, Isidoro Viejo y Clementino Quintana impulsan la resolución del asunto, siendo el presidente de la Comisión de Gobernación, Sr. Amézaga, quien se compromete a tenerlo resuelto en la próxima sesión. La Comisión, de mayoría independiente, suscribe la propuesta pero en el pleno del día 16 de mayo, surge el enfrentamiento en contra de Unión Nacional, por parte de los concejales conservadores liderados por Baldomero Amézaga y Azuela, oponiéndose al esgrimir que había un

\footnotetext{
522 AMBu. Actas del Ayuntamiento. LA-536, 19 de octubre de 1900.

${ }_{523}$ AMBu. Actas del Ayuntamiento. LA- 535, 22 de septiembre de 1899.

524 Papa-Moscas. Año XXXIII, no 1364, 13 de mayo de 1900, p. 2. Mariano Rodríguez Miguel forma parte de la comisión para la designación de la Junta definitiva de Unión Nacional que estuvo formada por Plácido Navas como presidente, Juan José Redondo, vicepresidente, secretario, Francisco Arangüena y vocales: Federico Fernández Izquierdo, José de la Morena, Manuel Sancho, Gregorio Bautista Argachal, Pascual Quemada, Gabriel Martínez, Víctor Peña, Eladio Escudero.
} 
acuerdo municipal de 9 de septiembre de 1891 con la prohibición de conceder el Teatro para reuniones políticas.

Mariano Rodríguez se reafirma en que este decreto fue derogado el 17 de junio de 1896 e insiste que el Ayuntamiento tiene la misión de administrar los bienes del pueblo, y perteneciendo a éste el edificio Teatro, deben concederse sus locales siempre que los verdaderos representantes de Burgos lo soliciten, teniendo muy en cuenta para juzgar el caso presente que los que suscriben la instancia hablan en nombre de la mayoría de los comerciantes e industriales de la ciudad y se proponen tratar asuntos relacionados con la administración general del país, pero no en defensa de ningún ideal político como lo demuestra la distinta procedencia de cuantos forman la agrupación llamada "Unión Nacional".

Amézaga no estaba de acuerdo y sostiene que la Unión Nacional era un nuevo partido que aspiraba a gobernar y que si se le concediese se perdería el fin primigenio del edificio. Mariano Rodríguez le contesta con argumentos sobre ciudades cercanas a la nuestra como Santander, en la que su alcalde cedió el Teatro para que los obreros, declarados en huelga, pudieran celebrar una reunión. Se realiza una votación, con acuerdo favorable de concesión del Teatro por 14 votos a favor de Ordoñez, Mozo, Santos, Lozano, Sáez, Sevilla, Quintana, Montero, Rodríguez, Castilla, Ortega, Corral, Heras y Arroyo y 4 votos en contra, de Azuela, Amézaga, Zumárraga y el Alcalde. Arroyo y Heras expresaron su voto favorable por creer que la Unión Nacional no tenía para ellos carácter político.

Este hecho prueba del enfrentamiento que surgió también a nivel nacional, pues desde los sectores conservadores pretendían frenar toda pretensión de regeneracionismo propugnado por Unión Nacional. Esta situación se refleja en el Ayuntamiento, al ser el propio alcalde el que suspende el acuerdo de concesión del Teatro, a pesar de la anterior votación favorable.

La Cámara de Comercio y la Unión Nacional denuncian esta situación con 507 firmas recogidas entre comerciantes e industriales. La mayoría de los concejales realizaron una moción de censura por la resolución, presentada el 6 de junio, aunque no fue leída hasta la sesión de 20 de junio. En la misma se critica la labor del Alcalde que, aunque dentro de la ley, no defiende el carácter representativo de los ciudadanos y sí defiende posturas afines al Gobierno en contra de la función de servicio a la ciudad.

A esta cuestión, no del todo zanjada, se une la situación de los embargos por impago en los que el alcalde autoriza la entrada en las casas de los morosos para saldar con sus propios bienes, las deudas pendientes. Todo ello motiva un cruce de acusaciones con el alcalde, en la sesión del plenario, por todos los sucesos acontecidos y por el nombramiento de forma ilegal del Depositario municipal, hasta llegar al abandono de un concejal, el señor Cuesta, al que siguieron otros concejales en medio de los 
aplausos del público. Se dirigen al Gobernador Civil, dando de palabra su dimisión, para seguidamente reunirse en la Diputación donde formulan su desacuerdo con un escrito firmado por 23 concejales. ${ }^{525}$

La concordia llega en la sesión del 28 de julio al tomar el protagonismo el primer teniente de alcalde, Juan José Arroyo, representando a los concejales dimisionarios, y retoman las dos cuestiones en fricción: el teatro $\mathrm{y}$ los desahucios.

Primeramente se trató de realizar una moción para que se elevase hasta el Gobierno y pusiera fin a la cuestión de los embargos, además de que se creara una comisión para recoger todas las reclamaciones de los contribuyentes.

Respecto al tema del Teatro, Mariano Rodríguez presenta un informe de la Comisión de la Gobernación solicitando la derogación del acuerdo de 1891, acentuando el carácter administrativo de la gestión municipal y que era un deber de la corporación atender a los deseos de la ciudad, ya que no existían locales amplios y apropiados para celebrar dichas sesiones, indicando que la Unión Nacional no tenía carácter político y expresando sus ideas regeneracionistas:

No hay que olvidar que estos mítines sirven de propaganda a las ideas de progreso y civilización y que no corresponde a los Ayuntamientos suprimir los excesos que puedan ocurrir en esos actos, pues allí concurren los Delegados del Gobernador para cortar o reprimir toda clase de abusos. ${ }^{526}$

En una posterior votación a favor de la proposición se consigue que en lo sucesivo se pudiera utilizar el Teatro para todas las actividades de la ciudad.

Se interesa por las malas condiciones de la calle Miranda, a lo cual responde el alcalde que se enteraría del asunto y vería satisfacer los deseos manifestados por el Sr. Rodríguez. ${ }^{527}$ Se recuerda que varios bloques de viviendas de la calle pertenecen a su familia, los números 11,13 y 15, y estaban previstos como futuros locales de la editorial.

También insiste en muchos plenos sobre un tema pendiente en la ciudad: el cerramiento del río que pasaba por la calle de La Cava, -hoy San Lesmes- pidiendo con insistencia el cubrimiento de la esgueva.

Durante el año 1901 dimite el alcalde, aunque sigue como concejal, tomando su lugar el primer teniente Juan José Arroyo Ontoria, casado con Marta Jalón, hermana de su cuñado Valentín Jalón Gallo. Éste ocupó, durante varios años, la presidencia de la Cámara de Comercio e Industria y

\footnotetext{
${ }^{525}$ El Papa-Moscas. Año XXIII, no 1271, 1 de julio de 1900, p. 3.

${ }^{526}$ AMBu. Actas del Ayuntamiento. LA-536, 28 de julio de 1900. Palabras de Mariano Rodríguez Miguel en la sesión plenaria.

${ }^{527}$ Ibídem, 23 de febrero de 1900.
} 
fue un gran impulsor del ferrocarril, sobre todo del eje Madrid-Burgos hasta llegar al Cantábrico.

En su paso por el Ayuntamiento se realiza, entre otros, el proyecto de edificación del mercado cubierto en la Plaza del General Santocildes Avenida del Cid 3 y 5, actualmente-, se pavimentan numerosas plazas y se abren calles con motivo de las nuevas urbanizaciones. También trata en numerosas ocasiones con el Ministerio de Guerra respecto a la Capitanía General y la permanencia de la guarnición militar en nuestra ciudad.

Las aportaciones de Mariano Rodríguez, durante el año 1901, se centran en expresar su opinión disconforme sobre el nuevo mercado cubierto planteado por el ayuntamiento, y del que Mariano Rodríguez pide se realizase con las nuevas aportaciones y progresos en higiene moderna. ${ }^{528}$

Se vuelve a presentar en la siguiente legislatura, hasta 1903, saliendo elegido por el segundo distrito junto con Antonio Zumárraga -director de la Voz de Castilla- y Ramón Lozano. En la sesión inaugural fue nombrado $2^{\circ}$ teniente de alcalde.

La corporación municipal está compuesta por el alcalde José Plaza Iglesias; tenientes del Alcalde: Julio de las Heras, Mariano Rodríguez, Tomás Medina, Francisco Regis Cisneros, Carlos Echevarrieta, Ramón de la Cuesta y Pedro Rodríguez Castilla; concejales: Miguel López Pintado, Luis Monedero, Antonio Zumárraga, Francisco Arangüena, Clementino Quintana, José Fournier, Federico Ramos, Ángel Sevilla, Lucas Saiz Sevilla, Valeriano Saiz Valpuesta, Arsenio Herreros, Gregorio Bautista Argachal, Ramón Lozano, Baldomero Amézaga, Zacarías Tobar, Victoriano Santos, Félix Mozo, Casimiro Ajuria, Luis Silva, Luis de San Pedro y Luis Prieto.

Mariano Rodríguez forma parte de varias comisiones entre las cuales se encontraba la de "Personajes", presidida por el alcalde y la mayoría de los tenientes de alcalde. Este cargo le hace participe, junto con las grandes autoridades de Burgos, arzobispo, Capitán General, gobernador militar, presidente de la Audiencia territorial y otros magistrados, de todos los actos conmemorativos importantes de la ciudad: la visita del Rey Alfonso XIII, la inauguración del Círculo Católico de Obreros y la visita del ministro de Agricultura, señor Suárez Inclán, y del señor Canalejas, con ocasión del Congreso Agrícola-Minero.

Participa como presidente en las Comisiones de "Paseos y Arbolado" y de "Teatro", y como vocal, en las comisiones de "Beneficencia", -cuya presidencia la ostentaba el Alcalde- y de "Hacienda" e "Instrucción Pública", siendo su presidente Julián de las Heras. ${ }^{529}$

\footnotetext{
${ }^{528}$ Ibídem, 8 de marzo de 1901.

${ }^{529}$ AMBu. Actas del Ayuntamiento. LA-537, 1 de enero de 1902.
} 
Mariano realiza una proposición de rebaja de impuestos aportando datos comparativos de varias ciudades. Presenta cómo Burgos satisface por consumos 422.563,5 pts. con un censo de población, en 1901, de 31.301 habitantes es decir, 13,5 pts. por habitante, en tanto que poblaciones como Murcia, Valencia, Castellón y Almería, entre otras, solo alcanzaban 9,53 pts. por habitante. ${ }^{530}$ Además de pagar más que ninguna población de España, la construcción de la nueva Capitanía imponía muchos sacrificios a los burgaleses. ${ }^{531}$ Se corrige la rebaja del $5 \%$ al comercio, conseguido por el diputado burgalés y subsecretario de Hacienda señor Aparicio. ${ }^{532}$

Otro dato que caracteriza el talante de Mariano Rodríguez Miguel, con sus intervenciones en el pleno del Ayuntamiento, es su preocupación, por la educación, la instrucción de los pequeños, y por los mendigos en calles y plazas. Propone facilitar el trabajo, para aquellos que pudieran hacerlo, desde un fondo común del Ayuntamiento, con ayudas a sectores pobres de la ciudad y su distribución con una buena organización. ${ }^{533}$

Pide explicaciones sobre el arreglo del Puente de Malatos y la construcción de cuadras en el mercado de ganados y, vuelve a insistir un año más y de forma reiterada, con el cubrimiento del río de la Cava. También manifiesta su rechazo por el coste total del nuevo mercado, por encima del precio de la subasta, y pide que constara en $\operatorname{acta}^{534}$ su desacuerdo.

Aporta iniciativas sobre mejoras en la reorganización en el servicio interno del municipio, nombramiento de un oficial de contabilidad y libros de actas de cada comisión. ${ }^{535}$

En 1890 fue presentado el proyecto del Ferrocarril del Meridiano (Santander-Burgos-Madrid); en Santander se llegó a constituir un Sindicato para llevar a cabo dicha iniciativa. En Burgos había opiniones opuestas entre apoyar este proyecto, expresado en una reunión de directores de la prensa local, ${ }^{536}$ con una mayoría partidaria del proyecto como los señores Villén, Gutiérrez, Luna, Hernando y Ontañón, ${ }^{537}$ frente a otros que apoyaban el Ferrocarril de Aranda (Madrid-Aranda y Burgos con ramales

\footnotetext{
${ }^{530}$ Diario de Burgos, 17 de septiembre de 1901.

${ }^{531}$ AMBu. Actas del Ayuntamiento. LA-537, 22 de octubre de 1902, 31 de julio de 1903 y 11 de diciembre de 1903.

532 El Papa-Moscas. Año XXIII, no 1277, 12 de agosto de 1900, p. 3.

${ }^{533}$ Diario de Burgos, 31 de agosto de 1903.

534 AMBu. Actas del Ayuntamiento. LA-538, 15- de diciembre de 1903. En esta sesión manifestó que el mercado cubierto ha costado más cantidad que la que sirvió en la subasta, infringiéndose el párrafo $5^{\circ}$ del artículo $4^{\circ}$ del R.D. de 26 de 1900, y pide que conste en acta para quedar a cubierto de la responsabilidad que le pudiera corresponder.

535 Ibídem, 17 marzo de 1903.

${ }^{536}$ El Papa-Moscas. Año XIII, nº 675, 30 noviembre de 1890, p. 2.

537 El Sr. Villén, del periódico La Gaceta; Sr. Gutiérrez del periódico El Sereno; Sr. Hernando del periódico El Fomento; Sr. Ontañón del periódico El Papa-Moscas.
} 
hacia Santander y Bilbao), como Albarellos, Ruiz-Cobos y Mariano Rodríguez. ${ }^{538}$

En diciembre de ese año Antonio Álvarez Carretero, Ruiz Yanguas y Mariano Rodríguez fueron nombrados consejeros de administración del ferrocarril de Aranda por la influencia de los artículos publicados a favor del proyecto en el periódico La Imparcialidad. ${ }^{539}$

En 1903, forma parte de la comisión para el emplazamiento de la estación de ferrocarril, con Zumárraga y Herrero.

Presidía accidentalmente el Ayuntamiento el 1 de agosto de 1902 y asistió como tal a la reunión de alcaldes castellanos celebrada en Santander, donde es elegido vicepresidente de la Junta Central de Alcaldes. A su vuelta refiere los acuerdos adquiridos y propuso que la siguiente Asamblea se realizase en Burgos. ${ }^{540}$ Esta Asamblea sirvió para dar un aviso al gobierno, del interés descentralizador, por las injerencias que la administración central imponía en las leyes municipales y provinciales.

Siendo alcalde interino, Mariano Rodríguez, dispondrá que con urgencia se procediese a vacunar a todos los alumnos, de ambos sexos, que asistían a las escuelas municipales de la capital y de los barrios de San Pedro de la Fuente, Huelgas y Hospital del Rey. ${ }^{541}$

En su actividad comercial sigue abasteciendo de diversos materiales de papelería y encuadernaciones a las distintas comisiones del Ayuntamiento. ${ }^{542}$ Como ejemplo, vemos que imprime los diferentes diplomas de los premios escolares en los diversos certámenes locales. ${ }^{543}$

Mariano Rodríguez entrega al Ayuntamiento un libro de Actas que adquirió en uno de sus viajes comerciales, ;el libro de actas municipales de 12-3 al 19-12-1814!, que sabe Dios cómo fue a parar a manos extrañas. ${ }^{544}$

En enero de 1903, Isidro Plaza renuncia a la alcaldía siendo sustituido por Antonio Zumárraga, con el poco acuerdo favorable de los tenientes de alcalde. Debido a ello no asiste a la primera sesión de proclamación de candidato como describe la prensa local. ${ }^{545}$ Acabada la legislatura, Mariano Rodríguez no se vuelve a presentar como candidato para el Ayuntamiento.

\footnotetext{
${ }^{538}$ El Sr. Albarellos del periódico La Brújula; el Sr. Ruiz-Cobos del periódico Cartas Burgalesas y Mariano Rodríguez del periódico La Imparcialidad.

${ }_{539}$ El Papa-Moscas. Año XIII, no 679,28 de diciembre de 1890, p. 2.

${ }_{540}^{4 M B u}$. Actas del Ayuntamiento. LA-537, 1 y 29 de agosto de 1902.

${ }^{541}$ El Papa-Moscas. Año XXVI, no 1.436, 8 de noviembre de 1903.

${ }^{542}$ El Papa-Moscas. Año XXXIV, no 1.794, 4 junio de 1911, p. 3, nº 1.815, 30 octubre de 1911, p. 3; $\mathrm{n}^{\circ}$ $1.830,11$ de febrero de 1912, p. 3 .

${ }^{543}$ La Voz de Castilla. Año I, número extra, 30 de junio de 1910, p. 3.

${ }^{544}$ ALBERDI ELOLA, L. Op. cit., p. 304; El Papa-Moscas. Año XXXIII, nº 1.771, 25 de diciembre de 1910.

${ }^{545}$ El Papa-Moscas. Año XXVI, no 1.393, 11 de enero de 1903.
} 


\subsection{EVOLUCIÓN, MEDIOS $Y$ PROCLAMAS EDITORIALES DE ACUERDO A LOS NUEVOS TIEMPOS}

A principios del siglo $\mathrm{XX}$ existen en Burgos 10 imprentas para una pequeña población de 30.000 habitantes, prácticamente analfabeta.

Mariano Rodríguez, fiel al espíritu de su padre continúa la labor iniciada, según el lema "La escuela, redime y civiliza", tal como lo expresa el Catálogo Recuerdo en las bodas de Platino de su fundación, (1850-1925). En él, sus hijos recogen el lema como la fuente que animó el trabajo de su padre y alentó la utopía educativa de la sociedad de su tiempo.

Remontándose a sus orígenes, la casa editorial Hijos de Santiago Rodríguez se propuso conmemorar todos los años, en la primera semana del mes de abril, el aniversario del fallecimiento de Santiago Rodríguez, otorgando un premio de 25 pts. al niño o niña de una escuela que, además de ser pobre, se distinguiese por sus virtudes y amor al estudio. ${ }^{546}$ También, la Editorial entrega "cierta cantidad para la caja de ahorros de las escuelas graduadas de esta capital". 547

El Diario de Burgos indica cómo la imprenta Hijos de Santiago Rodríguez, en 1902, estaba situada en otras dependencias más amplias y cercanas a la librería, en la calle General Santocildes. Contaba ya con cuatro máquinas sistema Marinoni doble y una Bremer, guillotinas, prensas y cuanto se necesitaba para el arte tipográfico. Además disponía de un amplio surtido de caracteres de letra y clichés, hasta el punto de pasar de 3.000 el número de éstos en fotograbado. La imprenta estaba a cargo de Juan Calvo. El Catálogo en que se anuncian sus publicaciones de educación, enseñanza y material escolar, maneja más de 1.349 artículos diferentes. ${ }^{548}$

En 1902 ya exportan a México, Colombia, Uruguay y Paraguay libros de educación y enseñanza. La mayor venta se hacía a México, seguida de Colombia, donde mandan también papel blanco y libros rayados. Conocemos este hecho por una carta que se conserva en la Cámara de Comercio dando contestación a la Junta Ibero Americana en Madrid donde les piden datos sobre empresas de Burgos que exportan a América. ${ }^{549}$ En la misma carta se manifiesta que antes se exportaba a Cuba, Puerto Rico y Filipinas pero que en esos momentos aquellos mercados están cerrados y desean que se estudiase la posibilidad de volver a trabajar en estos territorios.

\footnotetext{
${ }^{546}$ El Papa-Moscas. Año XXIII, no 1.260, 15 de abril de 1900, p. 2. El periódico nos informa que por encargo de la editorial se presentó, sin previo aviso, el inspector de primera enseñanza, Miguel Girado a una de las escuelas donde previamente informado se otorgó un premio de 25 pesetas.

${ }^{547}$ El Papa-Moscas. Año XXVI, no 1.403, 22 de marzo de 1903.

${ }^{548}$ Diario de Burgos. Las industrias burgalesas. Op. cit., p. 1.

${ }^{549}$ ACCBU. Caja de correspondencia y Censo, Caja 517, Libro 2, 6 de marzo de 1902.
} 
Aunque el volumen de la exportación era pequeña, comentan que se hallan en condiciones de poder atender todos los pedidos que se les hiciesen en libros y que pueden competir, en presentación y precios, con los de las casas extranjeras. Por eso explican la necesidad de enviar representantes para conocer bien aquellos países y su comercio. La carta expresa que no tienen inconveniente en mandar muestrarios para exportar a Cuba, Puerto Rico, Filipinas, Colombia, Uruguay, Paraguay, Argentina, y analizar los medios $\mathrm{y}$ facilidades para estar en todos los países hispanoamericanos copados por norteamericanos, franceses o alemanes.

Conocemos la publicación del Catálogo de la librería de Hijos de Santiago Rodríguez de 1893, bajo el epígrafe de "nuevo". Se presenta con gran lujo, con grabados de las obras de enseñanza de la Casa, con una magnífica cubierta al cromo realizada por Evaristo Barrio. ${ }^{550}$ El Catálogo más cercano encontrado es de 1908, con las mismas características (Figura 4-4).

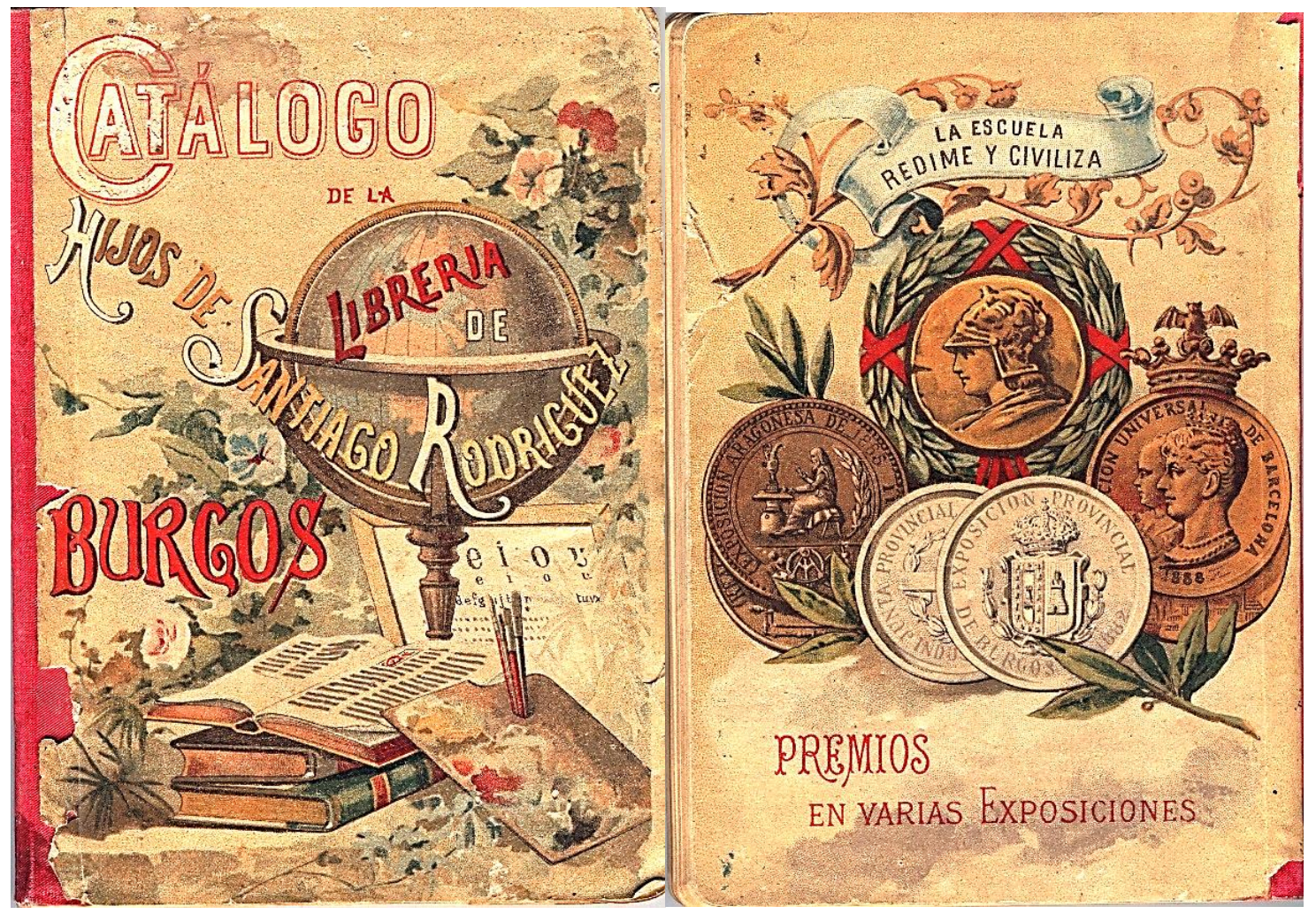

Fig. 4-4: Cubierta y contracubierta del Catálogo de la librería de Hijos de Santiago Rodríguez. Burgos 1908. En la contraportada se pueden distinguir el lema, emblema y principales medallas obtenidas en diversas Exposiciones.

En este Catálogo, al igual que el de 1917, ${ }^{551}$ anuncia libros publicados por la editorial como edición Rodríguez y añade libros de otras editoriales

\footnotetext{
${ }^{550}$ El Papa-Moscas, Año XVI, no 826, 22 de octubre de 1893, p. 3.

${ }^{551}$ HIJOS DE SANTIAGO RODRÍGUEZ. Catálogo General Ilustrado. [En adelante CATÁLOGO 1917]. Burgos: Hijos de Santiago Rodríguez, 1917, p. 290.
} 
que tiene a la venta en su librería. Se incluyen también la comercialización de todo tipo de objetos: orlas y diplomas -algunos de edición Rodríguez-, estuches de todo tipo, rompecabezas educativos, medallas diversas, y todo tipo de material de enseñanza: carteles, mapas, alfabetos, globos geográficos, oraciones y objetos religiosos, tablas de aritmética, pesas y medidas, cajas de cuerpos geométricos, pizarras, útiles de escritorio y de dibujo, muestras de escritura y caligrafía, colecciones de láminas e instrumentos de todas las asignaturas.

En la prensa local, en la sección de publicidad, se informa de otros materiales disponibles como papeles pintados para decorar habitaciones, o papel para la impresión de periódicos y otras obras. También se incluyen sobres y gran surtido de artículos para pintura y dibujo, bolsas para coloniales, papeles de estraza para envolver, con la marca de las empresas $^{552}$ y toda clase de libros científicos, literarios y de recreo, a lo que se suma en 1894, la venta de escudos y banderas, de obligada colocación en todas las escuelas.

Los primeros reconocimientos obtenidos de Hijos de Santiago Rodríguez fueron en la Exposición Pedagógica celebrada en Valladolid en 1894, obteniendo diploma por varias obras de enseñanza; ${ }^{553}$ en la Exposición Agrícola-Industrial de Burgos, en 1902, con medalla de Plata: ${ }^{554}$ y un elogio importante en la Exposición Pedagógica internacional de Barcelona en 1905:

Una de las notas más salientes de la Exposición Pedagógica ha sido la instalación de una escuela hecha por la acreditada casa de los Sres. Hijos de Santiago Rodríguez de esta ciudad. Figura en ella con material pedagógico de lo más moderno, perfectamente distribuido y colocado, entre lo que merece especial mención un hermoso globo terrestre de 2,50 metros de circunferencia, un cosmógrafo, un mapa hipsométrico en relieve de España y Portugal y una colección de mesas personales para los niños sistema Selles. Una vez más ha demostrado la casa Rodríguez el completo surtido que en el ramo de enseñanza tiene y es acreedora por su laboriosidad e inteligencia el favor que el Magisterio le dispensa. ${ }^{555}$

En estos primeros años del siglo $\mathrm{XX}$, sus inquietudes, al igual que su padre, no estuvieron ni en la política -deja el Ayuntamiento en 1903- ni en las instituciones locales. Su pensamiento liberal, de regeneración a través de la cultura y la educación, será para él un fin que transmite a través de su labor editorial.

\footnotetext{
${ }^{552}$ El Papa-Moscas. Año XXIII, no 1.251, 11 de febrero de 1900, p. 3. Las carpetas provisionales de La Azucarera es un trabajo que honra a la tipografía burgalesa y a la casa de los señores Hijos de Rodríguez, donde están hechas.

553 VALERO DE TORNOS, J. Op. cit., p. 110.

${ }^{554}$ El Papa-Moscas. Año XXV, no 1.369, 27 de julio 1902, p. 3.

${ }^{555}$ El Papa-Moscas. Año XXVIII, no $1.525,8$ de julio de 1905, p. 3.
} 
En 1906, cuando Mariano Rodríguez se estrena como presidente de la Tertulia Mercantil, traslada los talleres tipográficos a una nueva y definitiva ubicación en los edificios que poseía por herencia su mujer, Luisa Escudero, en la calle Miranda números 11, 13 y 15.

Según crónicas periodísticas, el despacho principal está presidido por un gran retrato del Sr. Santiago Rodríguez, como tributo de sus hijos, rodeado de todos los diplomas que se habían obtenido a lo largo de toda su historia editorial. El salón de la imprenta medía $236 \mathrm{~m}^{2}$, sin una sola columna, a ambos lados tenían espaciosos almacenes y las máquinas tipográficas. A la semana se consumían $3.000 \mathrm{~kg}$. de papel en los diversos encargos para las ediciones de libros escolares. ${ }^{556}$

Si comparamos Hijos de Santiago Rodríguez con otras empresas editoriales importantes del sector, de Madrid y Barcelona podemos constatar lo siguiente:

- Las grandes empresas catalanas tienen grandes edificios con imprentas propias, talleres de encuadernación, oficinas y almacenes como las editoriales Henrich, Seguí y Espasa, Montaner i Simón, Salvat y Sopena. ${ }^{557}$

- En Madrid, la Casa Calleja tien un modelo empresarial distinto. En 1896 inaugura un establecimiento nuevo, con una extensión de $500 \mathrm{~m}^{2}$ en la Ronda de Valencia, donde sólo existían despachos de dirección y administración, almacén y espacios para pedidos, incluyendo un edificio de domicilio familiar, además de dependencias para portería, conserje, cocheras y otras dependencias. Los trabajos de imprenta, grabado, encuadernación, litografía y estereotipia lo realizan otras empresas. ${ }^{558}$

Hijos de Santiago Rodríguez, en los nuevos locales de 1906, monta una empresa según el modelo catalán, dispone de todo lo necesario para realizar el libro completo, desde la edición, encuadernación, almacenaje, comercialización y distribución, externalizando la parte litográfica.

En esta nueva etapa, la Casa Editorial se presenta a varios certámenes locales, provinciales, nacionales e internacionales para una mayor difusión de sus productos. Consigue medallas de oro en la Exposición Internacional de Madrid de 1907 y en la Exposición Hispano-Francesa de Zaragoza, al año siguiente, por las ediciones de los nuevos libros. ${ }^{559}$

\footnotetext{
${ }^{556}$ El Papa-Moscas. Año XXIX, no 1.536 y 1537, 22 y 29 de abril de 1906, p. 3.

${ }^{557}$ MARTÍNEZ RUS, A. Barcelona y Madrid ante el reto americano: Las expectativas de la industria del libro. En J. CATALÁN I VIDAL, J. A. MIRANDA y R. RAMÓN-MUÑOZ, dirs. Distritos y clusters en la europea del sur. Madrid: LID Editorial, 2011, pp. 81-100.

${ }^{558}$ FERNÁNDEZ DE CÓRDOBA Y CALLEJA, E. Saturnino Calleja y su editorial. Los cuentos de Calleja y mucho más. Madrid: Ediciones de la Torre, 2006, pp. 27-30.

${ }^{559}$ El Papa-Moscas. Año XXXI, nº 1.657, 18 de octubre de 1908, p. 3.
} 
Es digno de destacar su participación y la obtención de la Medalla de Oro en la Exposición Universal del Centenario de Argentina, en 1910. ${ }^{560}$ La Cámara de Comercio de Burgos detalla en su libro de correspondencia diferentes escritos para el envío de materiales a la Exposición, de varios comerciantes burgaleses. El 25 de abril del mismo año, desde la Cámara de Burgos se envía una carta al Presidente de la Cámara de Comercio de Cádiz para que, según instrucciones del Ministro de Fomento, se haga cargo del envío de una caja con un cuadro de libros que pesan 267 kilos, con destino al Pabellón de España en la Exposición Universal en Argentina. ${ }^{561} \mathrm{Se}$ especifica la cantidad que costó el envío a Cádiz por ferrocarril, 124,61 pts., y que el presidente de la Cámara de Burgos le pide al Ministro de Fomento, en carta del 9 de mayo, los fondos para hacerse cargo de la factura, porque según se expone la Cámara no posee liquidez. ${ }^{562}$

A la misma exposición se envía una caja de naipes, cuyo peso es de 140 kg., de la fábrica de D. Antonio Moliner, también con destino a Argentina, por medio de la Cámara de Comercio de Santander. ${ }^{563}$ Se informa en una carta, el 27 de abril de 1910, ${ }^{564}$ al Ministro de Fomento para comunicar la salida de las dos expediciones de Burgos, para la Exposición de Argentina. Más adelante con fecha de 30 de mayo del mismo año, se remite una carta al Ministro de Fomento donde se incluyen los nombres de los comerciantes burgaleses que concurren a la Exposición de Argentina:

- Antonio Moliner, con sus naipes.

- Hijos de Santiago Rodríguez, con libros editados por ellos.

- Vda. e hijos de Tomás Arroyo, con botas para niño. ${ }^{565}$

A partir de dicha Exposición, la Casa Editorial no acude a ninguna exposición o certamen. ${ }^{566}$

Se hace presente la editorial también por algún error que da lugar a una anécdota en la composición del periódico La Imparcialidad, -órgano difusor de los maestros- cuando, con ocasión de la inauguración de los cursos de verano de 1912 para estudiantes extranjeros se tira un número extraordinario en papel cuché. En la primera plana figura la fotografía del Ministro de Instrucción Pública, D. Santiago Alba y Bonifaz, que vino a Burgos para presidir el acto inaugural. D. Eloy García Quevedo redacta el pie de foto que había de figurar debajo de su fotografía, pero a veces su

\footnotetext{
${ }^{560}$ El Papa-Moscas. Año XXXIV, no 1.880, 16 de julio de 1911, p. 3. Todos los Catálogos de la Casa Editorial hacen referencia a dicha distinción.

${ }^{561}$ ACCBU. Caja de correspondencia y censo. Caja 517, libro 2, 25 de abril de 1910.

562 Ibídem, 9 de mayo de 1910.

${ }^{563}$ Ibídem, 1 de abril de 1910.

564 Ibídem, 27 de abril de 1910.

${ }^{565}$ Ibídem, 30 de mayo de 1910.

${ }^{566}$ HIJOS DE SANTIAGO RODRÍGUEZ. Catálogo General publicado con motivo de la Exposición Iberoamericana de Sevilla y de la Exposición Internacional de Barcelona en 1929 [en adelante CATÁLOGO 1929]. Burgos: Hijos de Santiago Rodríguez, 1929, p. 5.
} 
letra era tan confusa que se prestaba a errores de imprenta. Un cajista apodado "Pospós" con gran dificultad compuso la nota poniendo lo siguiente: D. Santiago Alba y Bonifaz, ministro de $5^{\mathrm{a}}$ y $7^{\mathrm{a}}$ clase. La confusión inducida por la premura del tiempo del gerente llamado Juan Calvo, hombre ya mayor, de 70 años, y que había permanecido en la empresa desde muy joven, no corrigió las pruebas. Al comprobarse el error, Mariano Rodríguez, según nos dice la autora "se llevó las manos a la cabeza, y con su nerviosismo característico, hijo de una inteligente actividad ordenó rehacer la tirada, destruyendo los números anteriores". Algunos ejemplares ya estaban en la calle, uno llegó a manos del Ministro que lo leyó y sonriendo dijo: "que no se sorprendía ser de $1^{a}$ clase, pero que ser de $5^{a}$ o $7^{a}$ no se lo esperaba". 567

Fuera del anecdotario, al igual que hizo su padre cuando compra la primera máquina Minerva invita a personalidades burgalesas, a la inauguración de los nuevos medios tipográficos. La representación de la prensa se hizo presente por los señores Abad y Puente de El Castellano, San Pedro de Guasa Viva, Martínez Mata de Tierra Hidalga y Galán de La Voz de Castilla.

En el periódico El Papa-Moscas se ensalza la nueva maquinaria de la editorial con palabras como:

La tipografía burgalesa -industria de consideración- se ha enriquecido con las máquinas "Vitoria", de fotograbados, y "Planeta Tixia", alemana, de tintaje cilíndrico, que es una preciosidad mecánica, emplazadas recientemente en la Imprenta de los señores Hijos de Santiago Rodríguez, a quienes felicitamos por sus adelantos, y agradecemos la atenta invitación para verlas funcionar, pues cuanto contribuye a dar realce a nuestra industria nos sirve de intima satisfacción. ${ }^{568}$

En un tono más desenfadado Guasa Viva expresa la misma noticia:

Aunque no sea cosa de bibliografía, conste que hemos visto la Biblia de cosas gráficas y por eso se lo vamos a colocar a ustedes en esta sección.

Los señores Hijos de Santiago Rodríguez, nos invitaron el pasado viernes a presenciar el funcionamiento de unas nuevas máquinas que han instalado en sus hermosos talleres: Una minerva "Victoria", que ha de proporcionarles victorias sin cuento, y una "Planeta", que es de lo mejorcito que hemos visto en el ídem.

Admiramos también, entre otras cosas, una magnifica "Brement" inglesa, que lleva trabajando la friolera de 39 otoños sin detrimento de sus férreas morbideces. Esta es la primera inglesa entradita en años que ha conseguido arrancarnos cuatro piropos.

Los talleres de los señores Hijos de Rodríguez son un museo de verdaderas joyas tipográficas, y nos felicitamos muy mucho de contar en Burgos con industriales que tan alto ponen el nombre de nuestra querida ciudad.

\footnotetext{
${ }^{567}$ EBRO, M. C. Memorias de una burgalesa. Ayuntamiento de Burgos. Instituto Municipal de Cultura. 2004, pp. 272-274.

${ }^{568}$ El Papa-Moscas, Año XXXVI, nº 1901, 9 de noviembre de 1913, p. 2.
} 
Don Mariano Rodríguez, con exquisita amabilidad, obsequió a sus numerosos y distinguidos invitados con sabroso moka, riquísimas brevas y bebestibles de varias clases.

Y conste que a cierto colega también le cayó su correspondiente breva, aunque no lo ha dicho. ${ }^{569}$

La Voz de Castilla nos amplía la información, describiendo a los representantes de la prensa que asistieron, aportando datos como la sustitución de una de sus "Marinoni" por una máquina moderna, "PlanetaFixia". Expresa que también comprobaron una nueva prensa "Victoria", que no coincide con otras noticias anteriores que nos hablan de una máquina de fotograbado o de una máquina tipográfica. También se añaden datos complementarios sobre las demás dependencias, una de ellas dedicada a la encuadernación y otras dedicadas a almacenamiento de papel en rama.

\section{EN LOS TALLERES RODRÍGUEZ}

\section{Estreno de máquina}

La tarde del viernes, en los talleres tipográficos de los Sres. Hijos de Rodríguez, diose funcionamiento a una nueva máquina impresora adquirida por dicha importante casa, y al acto de cuyo estreno asistieron numerosos amigos de D. Mariano Rodríguez, con representación de Prensa entre ellos los Sres. Abad y Puente, de El Castellano; San pedro, de Diario y Guasa Viva; Martínez Mata, de Tierra Hidalga y nuestro compañero Galán, en quien defirió La Voz de Castilla.

El Sr. Rodríguez, que obsequió exquisitamente a sus visitantes con una sobremesa, dio luego marcha en presencia de ellos a la máquina cuyo estreno se celebraba, y de la que, con el amabilísimo regente de la imprenta, Sr. Calvo, hizo una fácil descripción explicativa, acompañada de varias pruebas de trabajo.

La construcción Planeta-Fixia porque el Sr. Rodríguez ha sustituido una de sus Marinoni, y el viernes estrenada, es en su género lo más perfecto con que la moderna tipografía cuenta, por su segura robustez, por su funcionamiento ligero y silencioso, por la limpieza de su impresión, por su excelente tintaje, por su enorme rendimiento, por su ninguna vibración, por su accesibilidad.

Todos los circundantes rindieron efusivo elogio a las inmejorables condiciones de la Planeta-Fixia y a la calidad de su rápida producción. También tuvieron repetidas frases de encomio para la magnífica prensa "Victoria" montada recientemente por el Sr. Rodríguez, como asimismo para los mil detalles de higiene, competencia y orden que han presidido la instalación de sus talleres, honra de la industria burgalesa.

Regidos por igual sistema ordenador y progresivo están las demás dependencias de la casa, cuya pequeña manufactura de encuadernación, galerías de existencia en impresos y almacén de papel en rama fueron recorridos a continuación por los periodistas, como término a la agradable visita.

Reciba el Sr. Rodríguez de nosotros la sincera felicitación por la próspera vitalidad de su casa, el más caluroso elogio por sus actividades en pró del surgimiento burgalés de la industria y la expresión más cordial de nuestro

\footnotetext{
${ }^{569}$ Guasa Viva. Año I, no 34, 9 de noviembre de 1913, p. 10. Vid. Anexo 2.3.4. Bibliografía. Guasa Viva.
} 
agradecimiento por las deferencias de que hizo objeto al compañero que nos representaba. ${ }^{570}$

Esta renovación de maquinaria se refleja en el libro de contribuyentes de la Cámara de Comercio e Industria de Burgos del año 1912 y 1914. La editorial Hijos de Santiago Rodríguez contribuía, por su establecimiento, compuesto por "4 máquinas de imprimir de 1.000 hojas por hora". En la contribución correspondiente a 1921-22 pagaba por dos conceptos: uno de ellos sigue siendo por las 4 máquinas de imprimir, como en años anteriores, y en otro por dos máquinas más, especificando "dos Minervas". De estas últimas no aclara, como en las anteriores, el número de hojas impresas. ${ }^{571}$

Estos datos son equiparables a otras empresas como el Diario de Burgos, que tenía una sola máquina de imprimir, pero de una mayor capacidad de producción, de 4.000 ejemplares, y de la editorial Monte Carmelo con la misma maquinaria. Otras empresas tipográficas burgalesas, como la Diputación Provincial, poseían una imprenta con dos máquinas para imprimir 1.000 ejemplares. El resto de empresas que realizaban publicaciones burgalesas poseían una sola máquina de imprimir con capacidad para 1.000 ejemplares.

Señalamos estos datos teniendo en cuenta que durante la guerra europea sigue la producción editorial a pesar del encarecimiento del papel y de los productos de artes gráficas, y a la escasez de tintas, ácidos, placas fotográficas, planchas de zinc y otros elementos. El recrudecimiento de las hostilidades entre las potencias enfrentadas mermó el poder adquisitivo y produjo el efecto de aumentar aún más los precios. ${ }^{572}$

Con la finalización del conflicto la comercialización se hizo apremiante, de ahí que Hijos de Santiago Rodríguez negociara la distribución o intercambio de sus fondos con la editorial CALPE, teniendo interés en que sus obras se distribuyesen en la Casa del Libro y en América. ${ }^{573}$

Juan Miguel Sánchez Vigil señala en un cuadro sinóptico a todos los principales editores de España exceptuando Madrid y Barcelona, en 1924. Tomado de la revista Bibliografía Española quedan: Cervantes en Valencia, Fe de Sevilla, Cecilio Gasca de Zaragoza, Beltrán Rivas de

\footnotetext{
${ }^{570}$ La Voz de Castilla. Año IV, no 266, 9 de noviembre de 1913, p. 2.

${ }^{571}$ ACCBU. Censo electoral de contribuyentes. Caja 304 Carpeta 2, 3 y 7 . Años 1912, 1914 y 1921-22.

${ }^{572} \mathrm{La}$ escasez de materia prima para la fabricación de papel y la dificultad de importar pasta de celulosa de los países del norte de Europa reactivó a las papeleras españolas. También se recurrió al reciclaje, recuperando papel viejo, para papel de periódico.

Al comenzar el año 1918 la escasez de materia prima era alarmante, entorpeciendo la exportación de libros españoles hacia América. Tanto la prensa como las editoriales e imprentas vivieron situaciones críticas en los últimos años de la segunda década del XX y entre las más graves la huelga de marzo de 1919.

573 SÁNCHEZ VIGIL, J. M. Calpe. Paradigma editorial (1918-1925). Gijón: Ediciones Trea, S.L. 2005, pp. 127-128 y 157.
} 
Málaga, Francisco Sempere de Valencia e Hijos de Santiago Rodríguez y Mariano Rodríguez de Burgos. ${ }^{574}$

El crecimiento editorial se fue agrandando gracias a potentes reclamos propagandísticos, publicitándose en la contraportada de los libros editados (Figura 4-5).

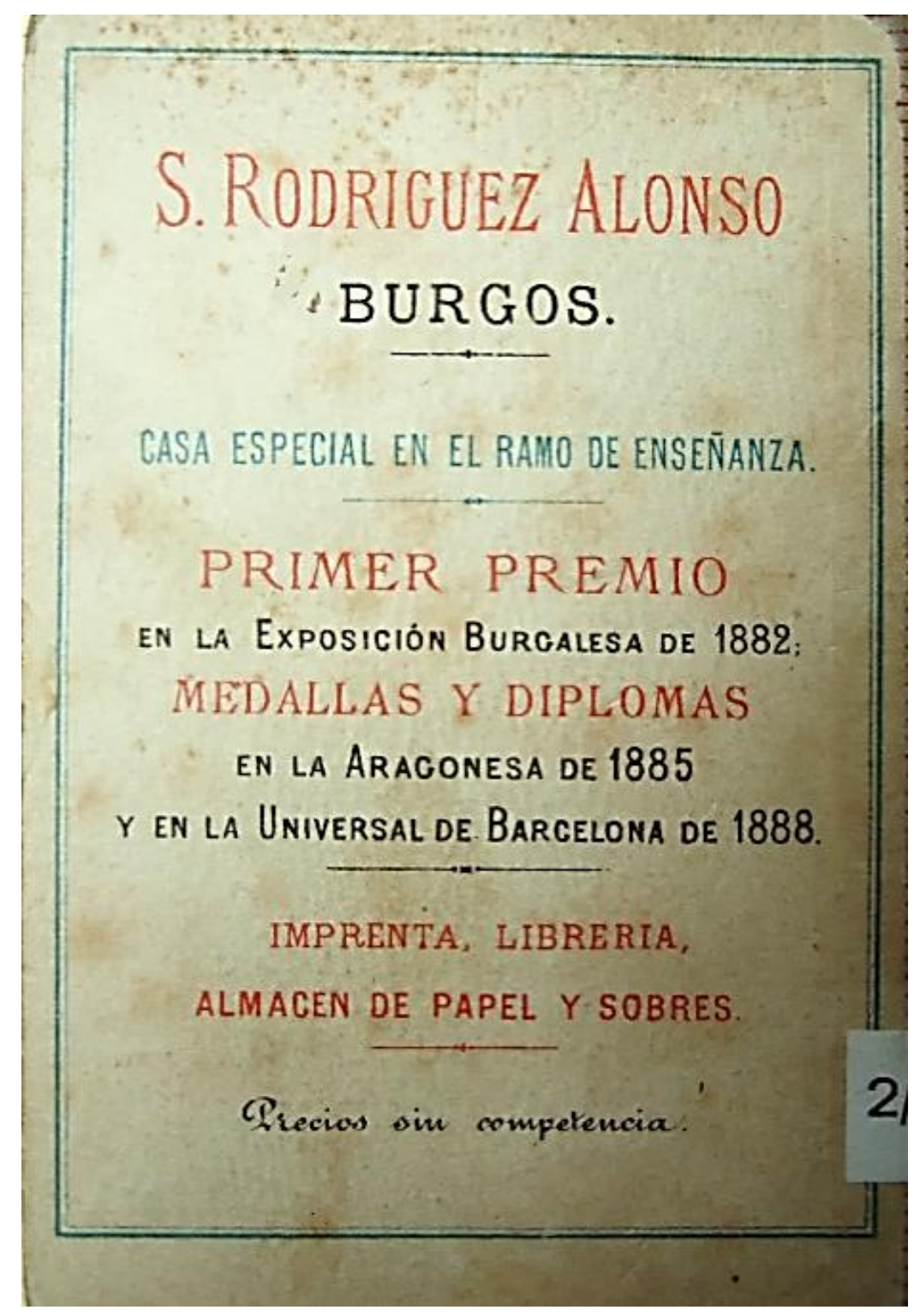

Fig. 4-5: Contracubierta del libro Higiene y Economía Doméstica.

Hijos de Santiago Rodríguez. 1890.

Biblioteca de la Diputación Provincial de Burgos.

Se fueron configurando los emblemas y lemas como señas de identidad de la casa editora y como imagen de calidad en su andadura comercial y

${ }^{574}$ Ibídem, p. 67. 
pedagógica. ${ }^{575}$ Así, desde 1894 nos encontramos en las contraportadas imágenes que aluden a la escuela, a la infancia y a los ideales de sabiduría y civilización; de ahí el lema e icono de la diosa Minerva, como reconocimiento y recordatorio empresarial (Figura 4-6).

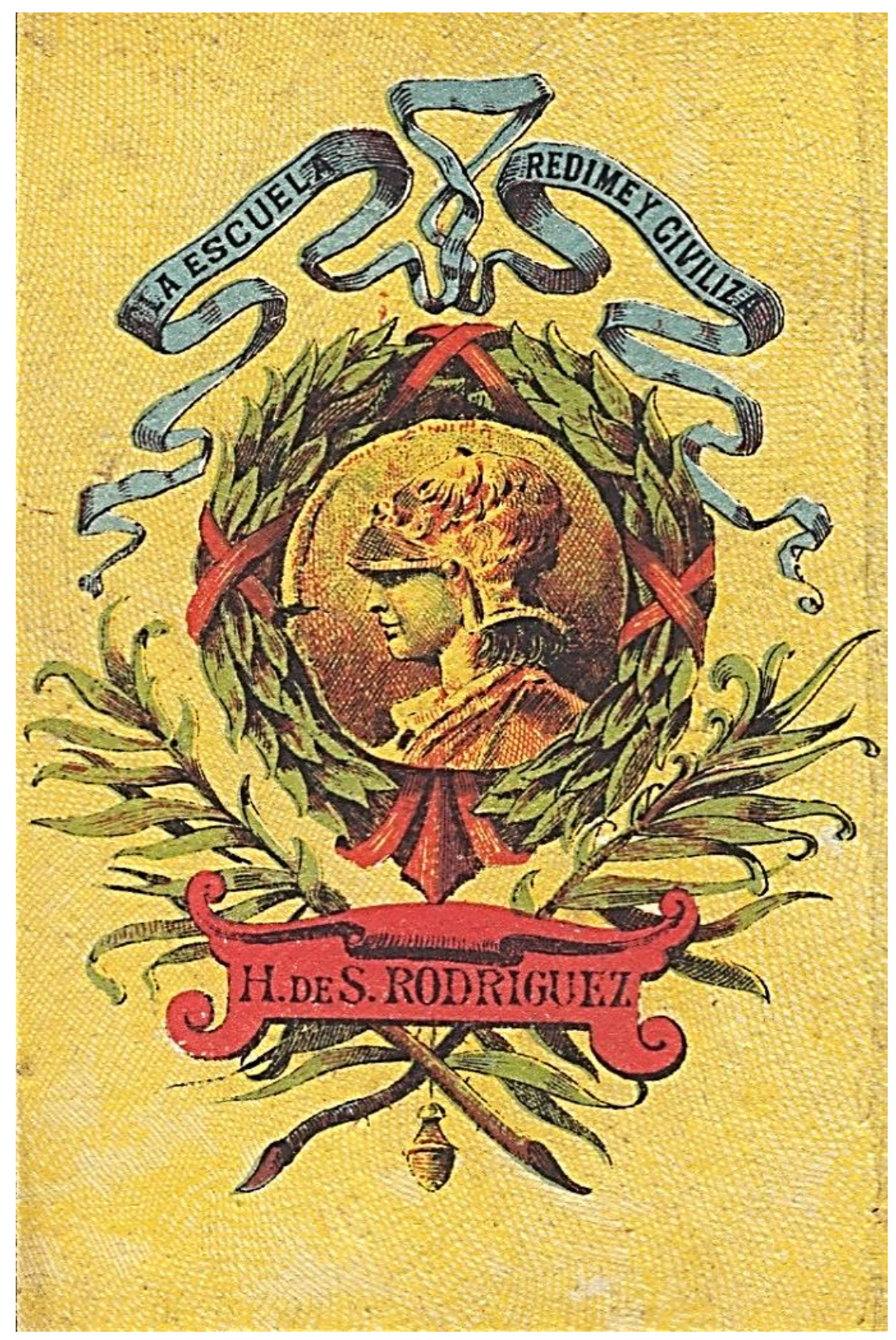

Fig. 4-6: Contracubierta Catecismo histórico o Compendio de la Historia Sagrada y de la doctrina cristiana. Hijos de Santiago Rodríguez. 1895.

Biblioteca de la Diputación Provincial de Burgos.

Este icono va acomodándose de diferentes maneras, según el público a quien se dirigen las obras. Se utiliza desde el principio en las contraportadas colocando el emblema sobre las cintas. Para realzar el fin de

575 ESCOLANO BENITO, A. Libros para la escuela. La primera generación de manuales escolares. En: A. ESCOLANO BENITO, dir. Historia Ilustrada del libro escolar en España. Del Antiguo Régimen a la Segunda República. Op. cit., pp. 19-43. 
algunas colecciones coloca una cartela en la parte inferior para reservar un texto como "Moral Recreativa" (Figura 4-7).

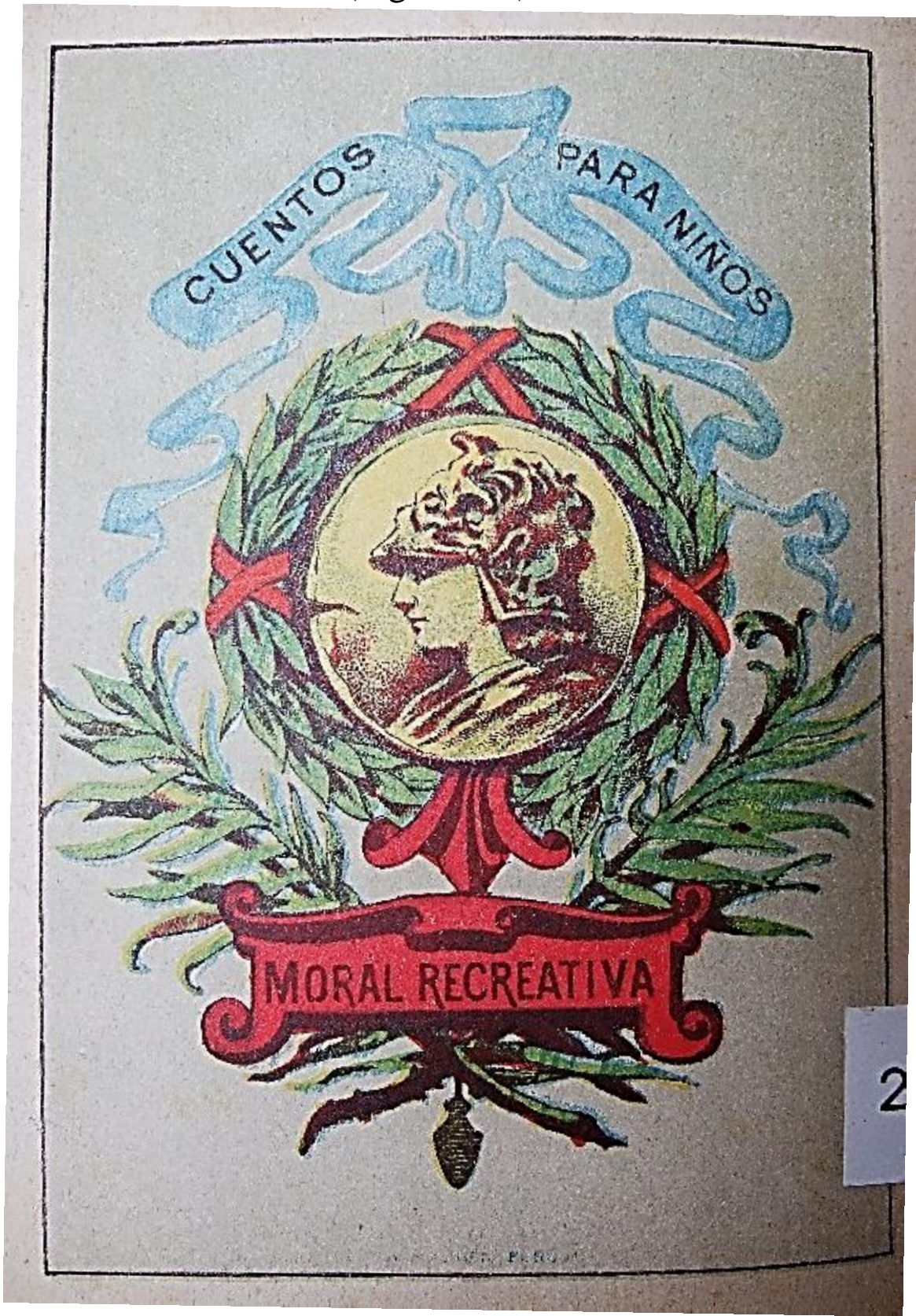

Fig. 4-7: Contracubierta de la Biblioteca Cuentos para Niños.

Hijos de Santiago Rodríguez.

Biblioteca de la Diputación Provincial de Burgos.

Los emblemas van adquiriendo mayor ornamentación en algunas colecciones, de corte más clásico, donde los libros son para gusto no sólo infantil sino también adulto como en la Biblioteca Oro o la Biblioteca Enciclopédica Hispano-Americana (Figura 4-8 y 4-9). 


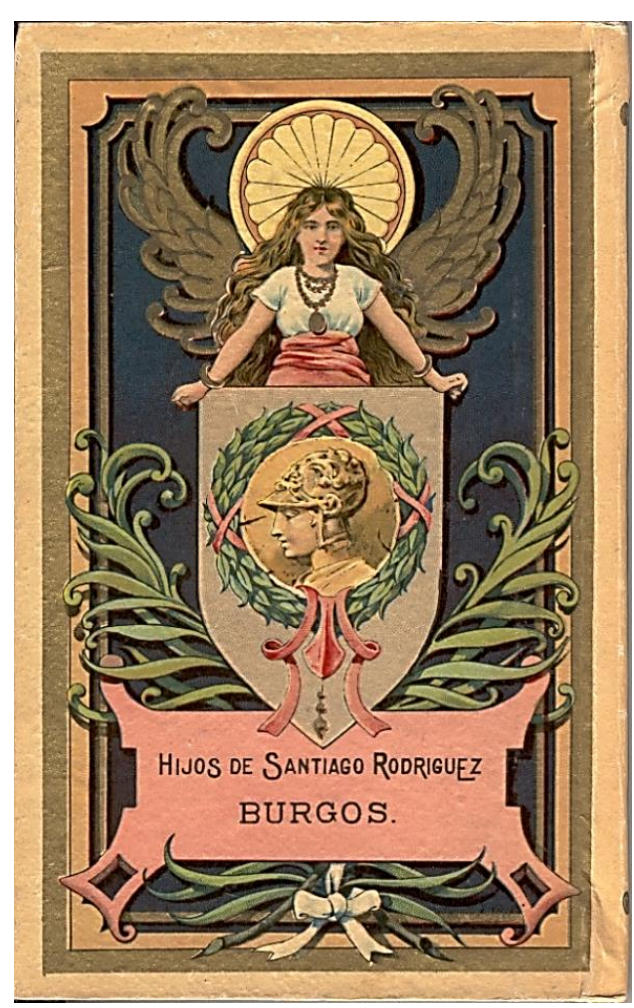

Fig. 4-8: Contracubierta del libro Telémaco de la Biblioteca Hispano-Americana. Obra cedida por Mercedes Rodríguez.

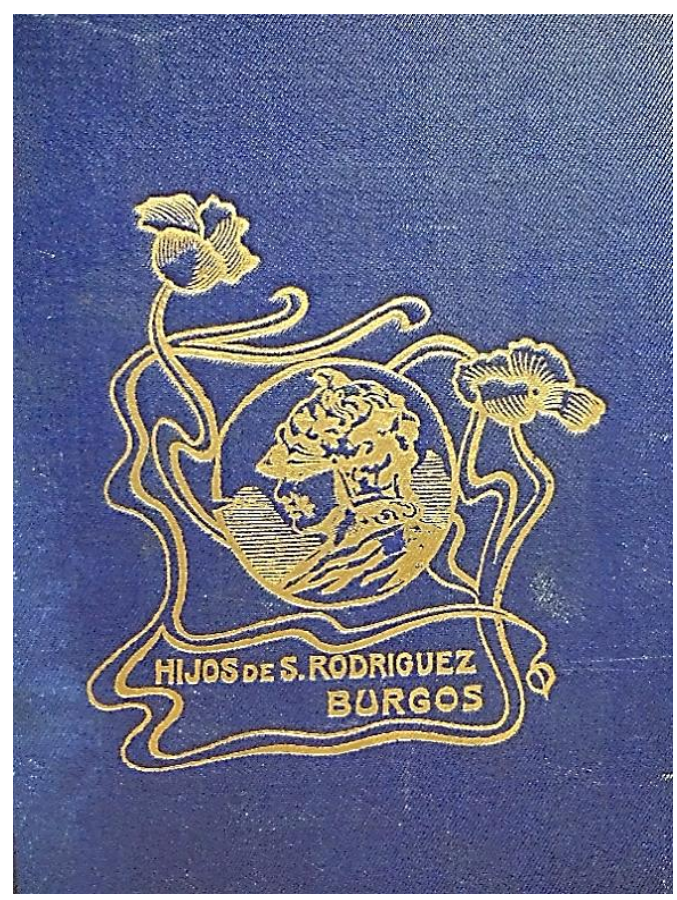

Fig. 4-9: Contracubierta de los libros de la Biblioteca Enciclopédica HispanoAmericana, encuadernada en tela y grabados dorados.

Biblioteca de la Diputación Provincial de Burgos.

Los Catálogos eran otro importante medio de propaganda al remitirse a un amplio colectivo de maestros, a numerosos representantes de la Editorial y a un gran número de librerías de España y América, con objeto de 
difundir y dar a conocer la amplia gama de obras editoriales propias, y el diverso material escolar de la librería.
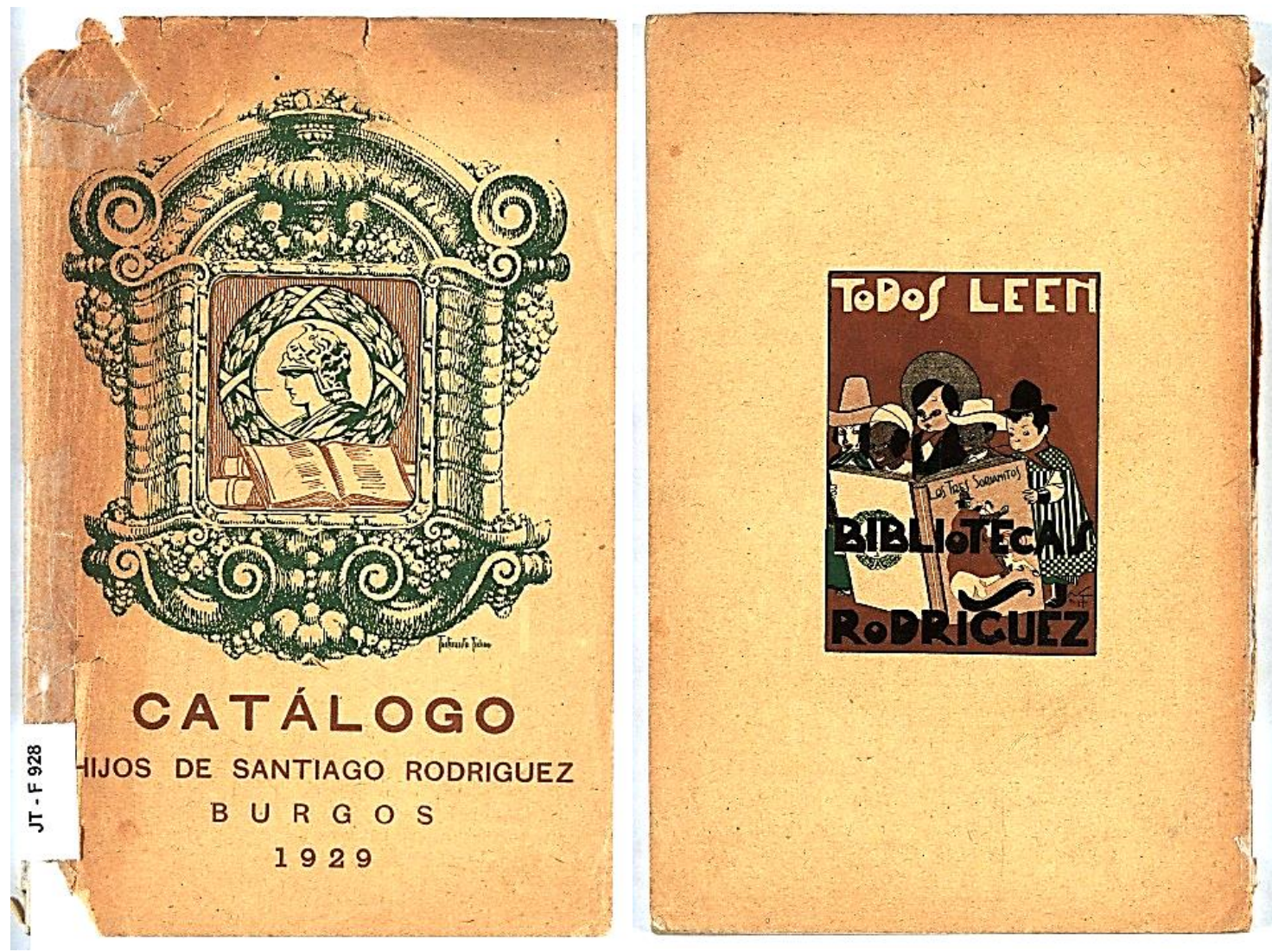

Fig. 4-10: Cubierta y contracubierta del Catálogo General publicado con motivo de la Exposición Iberoamericana de Sevilla y la Exposición Internacional de Barcelona. Hijos de Santiago Rodríguez. 1929. Biblioteca Digital de Castilla y León.

En su interior nos encontramos varios aspectos de especial interés:

1. Presenta sus obras editoriales con todo lujo de detalles. Aporta datos bibliográficos con referencias de su contenido, autores, ilustradores y muestras visibles de los dibujos o grabados de la propia obra. Muestra valoraciones realizadas por diversas personas relevantes o publicaciones en periódicos de tirada local, nacional o iberoamericana. Revela de forma gráfica, sus colaboradores literarios y las próximas publicaciones como anzuelo promocional.

2. Recoge en los Catálogos todos los premios que ha recibido. Presenta recuerdos e historia de la editorial, ${ }^{576}$ cita que los libros editados son

\footnotetext{
576 En el Catálogo Recuerdo 1850-1925 brinda un homenaje a su fundador, Santiago Rodríguez y su continuación en Mariano Rodríguez, manifestando las motivaciones fundacionales en el prólogo y en un artículo posterior que habla de "Retazos y recuerdos", exposición de artículos periodísticos de El Liberal, El Universo, La Monarquía, Toma y Lee de Madrid, Vida Orensana, La Voz de Galicia, de La Coruña,
} 
declarados de utilidad para las escuelas, aprobados por Reales Órdenes y por la Autoridad eclesiástica.

Apunta como imagen de seriedad y tradición la antigüedad de la empresa. En muchos libros y en los Catálogos señala: Hijos de Santiago Rodríguez. Casa fundada en el año 1850.

Anuncia sus textos escolares como los mejores auxiliares para la enseñanza, redactados y editados de acuerdo a las orientaciones pedagógicas modernas, como rasgo definitorio.

Exterioriza el cuidado realizado por la reforma de los textos, con nuevas ediciones puestas al día, en momentos en que muchas editoriales repetían patrones idénticos en sus ediciones sin renovación.

Otro sello importante era su impresión en tipos muy claros, con ilustraciones adecuadas de carácter artístico y con una mayor solidez en las encuadernaciones, (Figura 4-11) para una mayor duración y por encima de las encuadernaciones ordinarias.

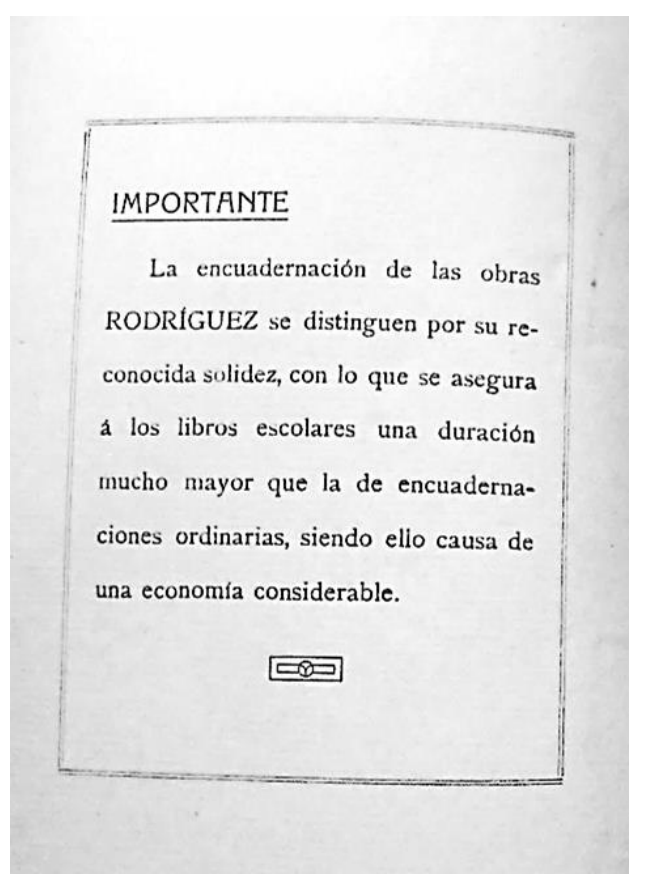

Fig. 4-11: Propaganda en las últimas páginas del libro Para aprender a leer. Grado primero. Hijos de Santiago Rodríguez. 1918.

Ejemplar de la Biblioteca Diputación Provincial de Burgos.

3. Muestra las condiciones de venta, envío, importes y descuentos especiales en relación con el valor de los pedidos. Se conceden importantes bajadas a profesores nacionales y a los centros de enseñanza, así como también a libreros y almacenistas.

La Ciudad de Dios, de El Escorial, Toledo, Castilla La Vieja de Valladolid, El Diario Español de Montevideo y un artículo de Constantino Arce. 
Señala el precio que cuesta cada ejemplar y en muchos de los libros escolares incluía el precio de los ejemplares por docenas, con una rebaja importante, considerándose la editorial que vendía con los precios más bajos del mercado.

Junto a los Catálogos, la editorial elabora una marca-imagen para cada una de las bibliotecas de lectura. Está realizada por acreditados ilustradores que añaden un plus de calidad a la edición.

Los propios libros son un recurso de información y propaganda de otras obras similares y, así, encontramos en las últimas hojas datos sobre secciones de la editorial junto con ilustraciones significativas de los libros. (Figura 4-12). Utiliza la contracubierta como propaganda siguiendo como distintivo desde su fundador (Figura 4-13).

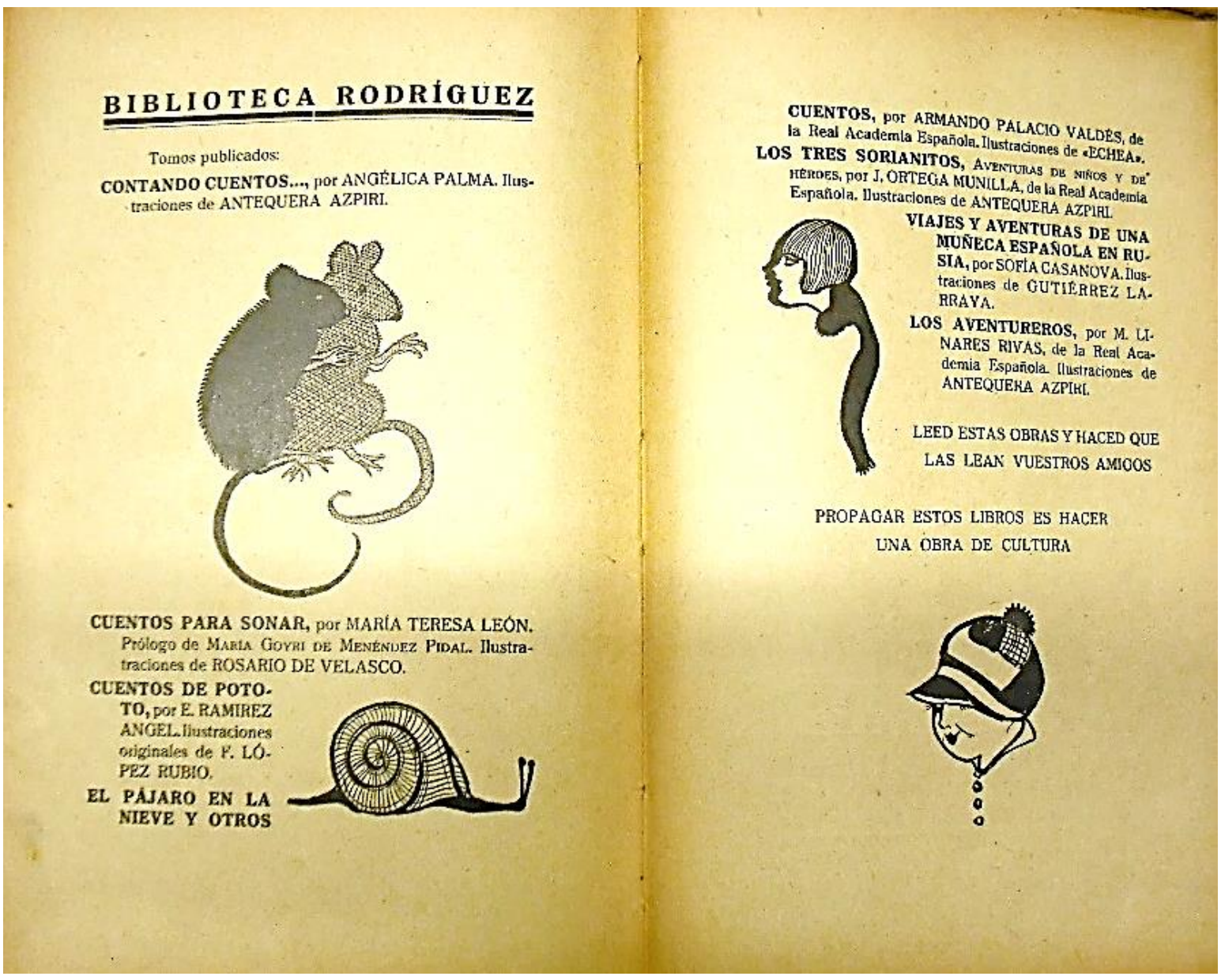

Fig. 4-12: Páginas finales del libro Viejas Memorias. Leyendas y Tradiciones. Mundial Biblioteca. Hijos de Santiago Rodríguez. 


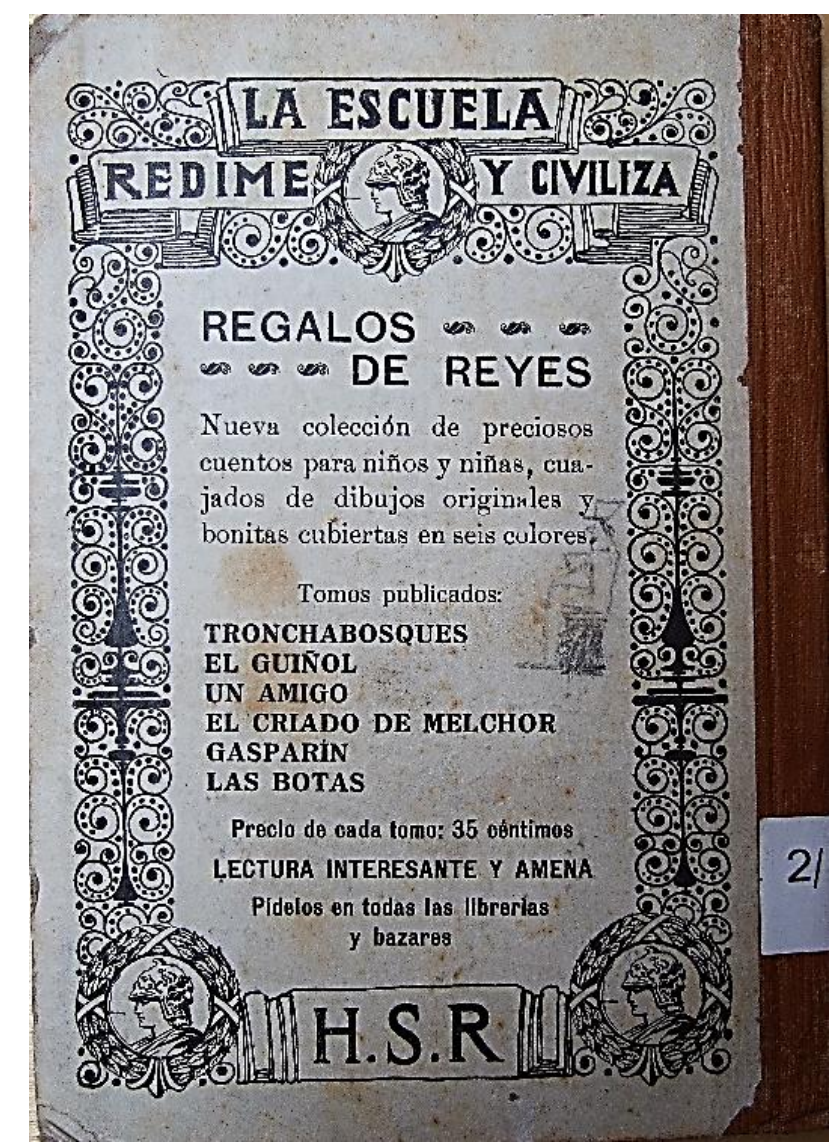

Fig. 4-13: Contracubierta del libro Catón Metódico por Seijas. Hijos de Santiago Rodríguez.

Utiliza muchos recursos para incentivar las ventas como son la inclusión en cada libro de papeletas para el sorteo de lo que llama "LOTES RODRÍGUEZ". Cada seis papeletas se canjea por una participación numerada (Figura 4-14).

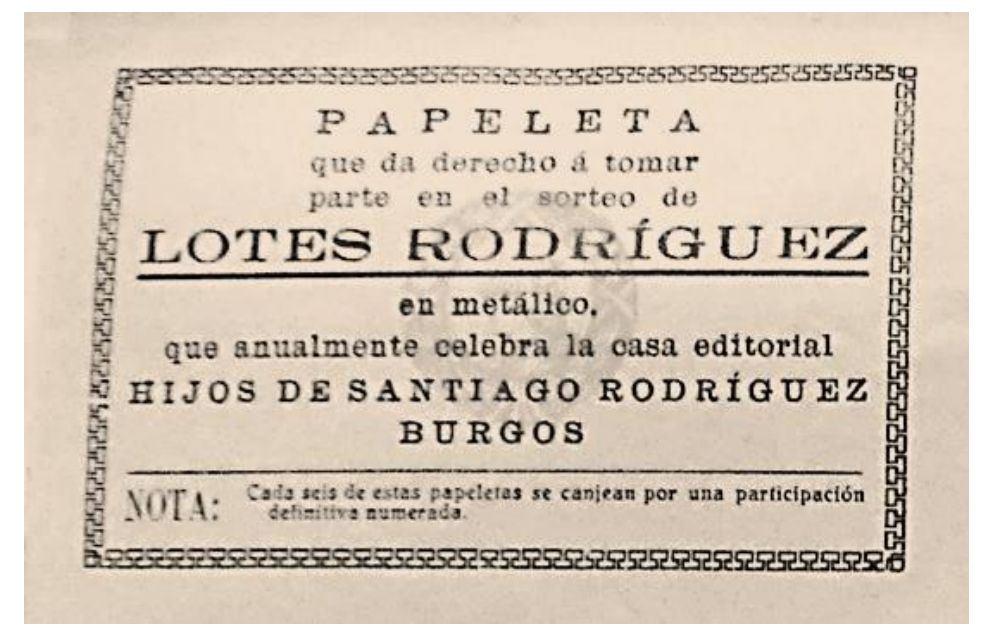

Fig. 4-14: Papeleta de propaganda para sorteo de LOTES RODRÍGUEZ. Biblioteca Diputación Provincial de Burgos. 
En la Biblioteca Paz, cada libro, llevaba una papeleta con un número para un sorteo posterior, cuyos resultados se publicaban en el siguiente libro editado de la misma colección (Figura 4-15).

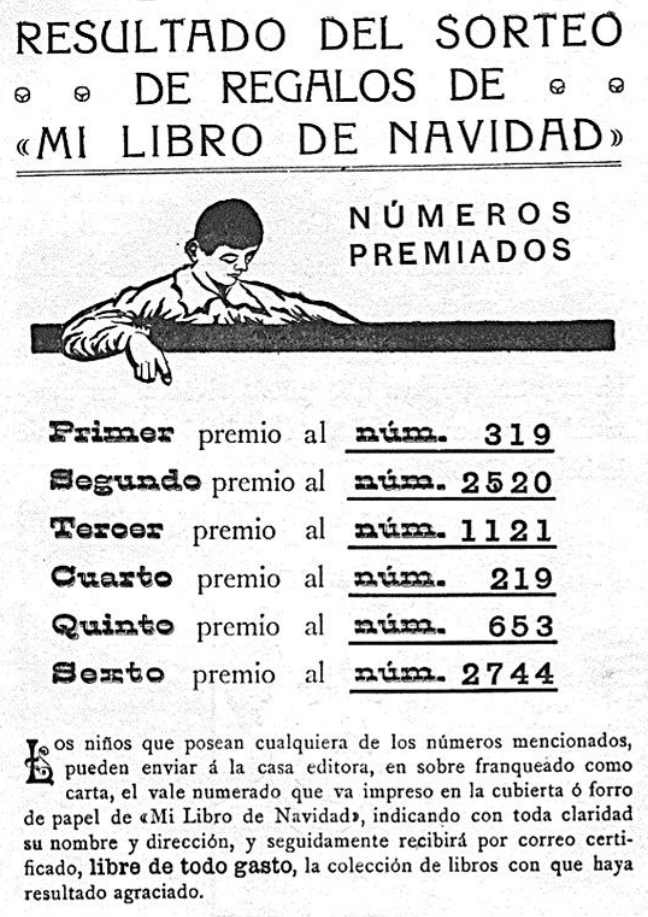

Fig. 4-15: En las Bibliotecas Paz en Mi Libro de Año Nuevo presenta el resultado del sorteo de la anterior publicación como método de venta.

Otras técnicas de propaganda utilizadas son eslóganes sobre la lectura, imágenes alusivas al tema y manifiestos para estimular el gusto por la lectura y por el libro en general (Figuras 4-16, 4-17, 4-18, 4-19, 4-20).

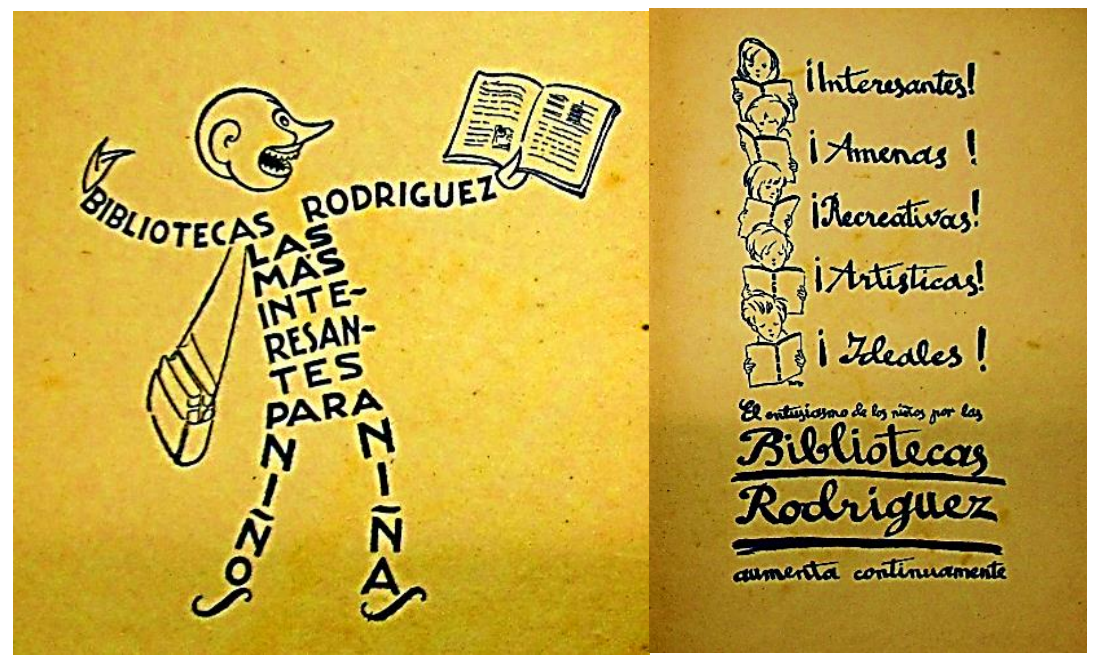

Fig. 4-16: Imágenes en las guardas del libro Cartas a Leonardo. Biblioteca de la Diputación Provincial de Burgos. 


\section{tadas Cecu DIBLIOTECAS RODRICUEZ}
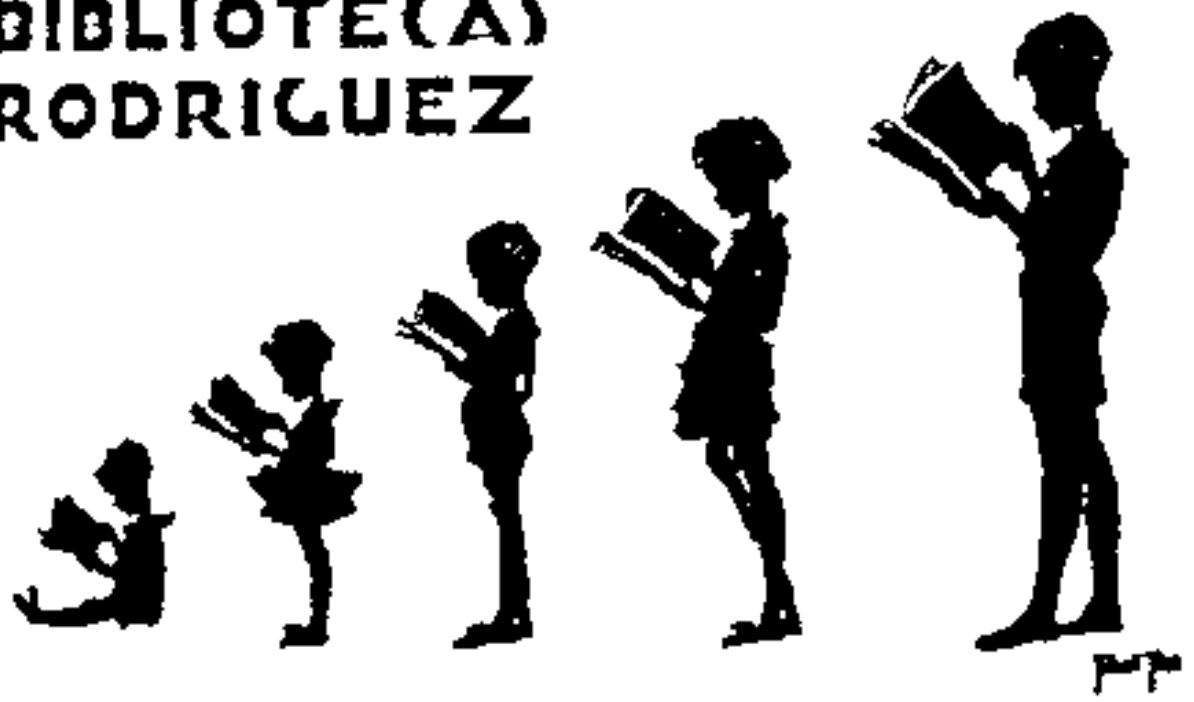

Fig. 4-17: Publicidad que encontramos en numerosos libros para simbolizar que la lectura que presenta la Casa Editorial es para todo el público infantil y juvenil. El motivo está realizado por Fortunato Julián.

\section{Las}

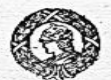

Pide en todas las Bibliotecas Rodríguez

Distraen, educan, entretienen, enseñan y deleitan.

Son el más agradable pasatiempo en las horas de descanso.

Son amenas, instructivas, morales, interesantes y atrayentes.

Están todas ilustradas artísticamente y encuadernadas con sugestivas cubiertas en colores.

Han sido escritas expresamente para los niños por renombrados literatos, y su texto, altamente recreativo, ha sido escrupulosamente revisado.

Constituyen el más interesante y valioso regalo para los muchachos.

\section{$\rightarrow 100$}
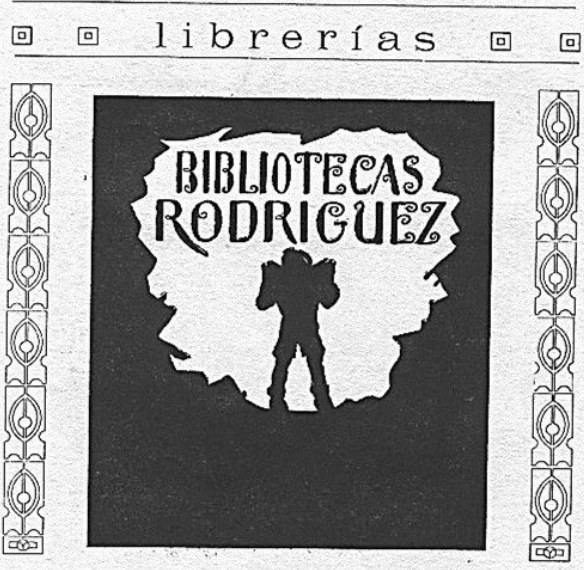

I $n t e r$ e $s$ a $t$ e $s$

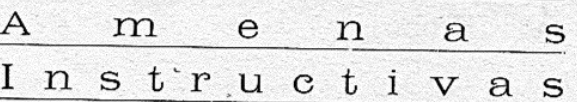

Fig. 4-18: Modelos distintivos de propaganda reflejados en los libros de la Casa Editorial Hijos de Santiago Rodríguez. 


\section{Cuando te prometan un regalo, pide siempre \\ BIBLIOTECAS RODRIGUEZ.}

Mas de 300 ttulos diferentes, debidos á reputados autores é ilustrados por conocidos artistas.

Libros genuinamente infantiles $y$ de lectura interesante एक
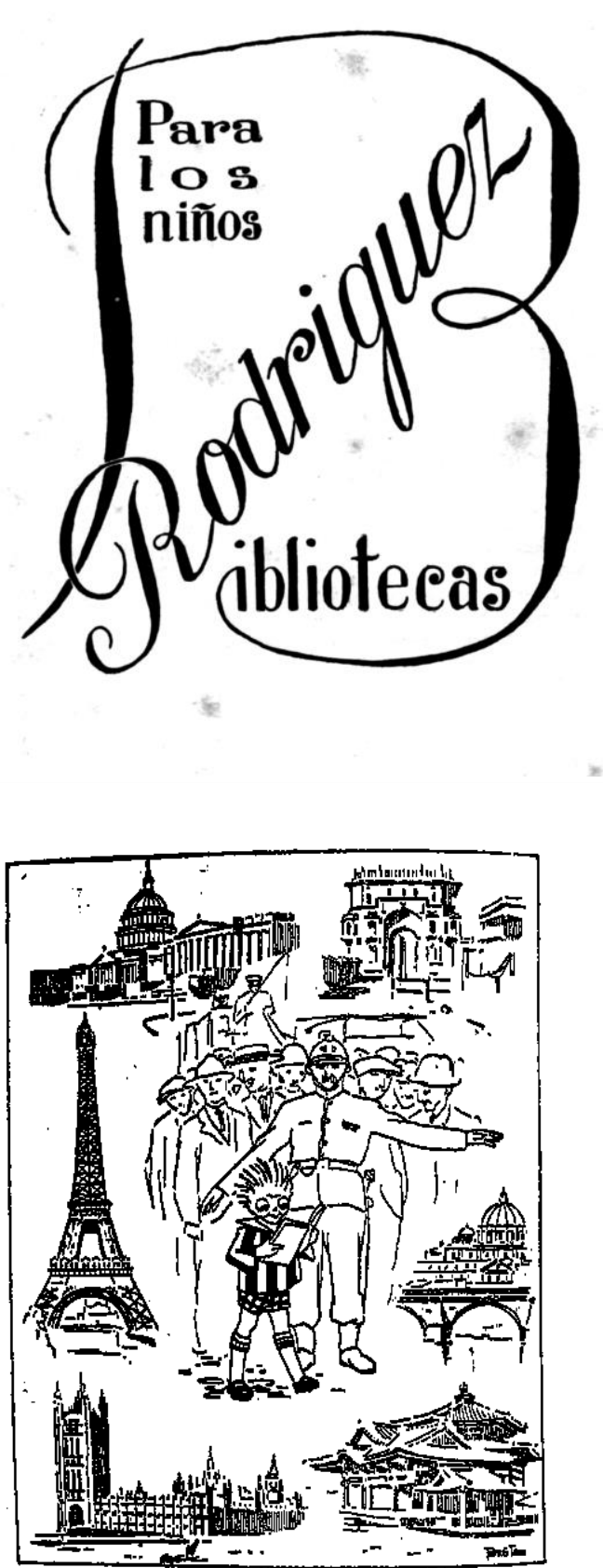

SIN SALIR DE SU BIBLIOTECA, "RODRIGUETE" DA LA VUELTA AL MUNDO LEYENDO LAS BIBLIOTECAS RODRIGUEZ

PIDANSE EN TODAS LAS LIBRERIAS :: : Y BAZARES DE ESPANAA Y AMÉRICA :: :

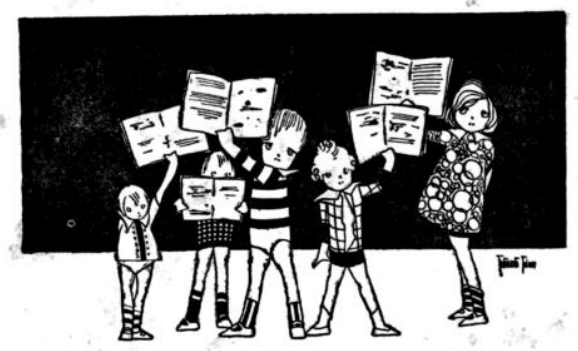

To do s l e e n BIBLIOTECAS $R O D R I ́ G \cup E Z$ LAS MAS $\begin{gathered}\text { instructivas } \\ \text { amenas } \\ \text { morales }\end{gathered}$

$$
\begin{aligned}
& \text { morales } \\
& \text { interesantes }
\end{aligned}
$$

Fig. 4-19: Propaganda de las Bibliotecas Rodríguez con pequeños logotipos, frases sugerentes y utilizando la figura del pequeño y travieso Rodriguete y niños y niñas de todas las edades, así como monumentos de diversas partes del mundo como sugerente para incitar a leer.

Hace exposiciones en fechas señaladas, como el día 5 de Enero, para la venta de libros de cara a la fiesta de Reyes tal y como lo relata $\mathrm{La} \mathrm{Voz}$ de Castilla y Guasa Viva. 
4. MARIANO RODRÍGUEZ MIGUEL (1860-1925). EDITORIAL HIJOS DE SANTIAGO RODRÍGUEZ

Con motivo de la tradicional fiesta de los Reyes Magos visitad mañana lunes la librería de los Hijos de Santiago Rodríguez. ${ }^{577}$

El mejor regalo que pueden hacer los Reyes a los niños son libros, porque, además de entretenerles les enseñan y forma su gusto artístico.

Los que esperéis algo de Melchor, Gaspar o Baltasar, debéis ir a la librería de Hijos de Santiago Rodríguez a ver mil y pico libros de cuentos con láminas de colores y grabados para que elijáis el que los Reyes os han de regalar. Y una vez elegido, escribirles cargándoles que en su viaje por el mundo no olviden traer una buena cantidad de libros Rodríguez. ${ }^{578}$

${ }^{577}$ La Voz de Castilla. Año V, no 274, 4 de enero de 1914, p. 3.

${ }^{578}$ La Voz de Castilla. Año VII, no 435, 31 de diciembre de 1916, p. 3. 


\section{G DABA $V_{\perp} V A^{\circ}$}

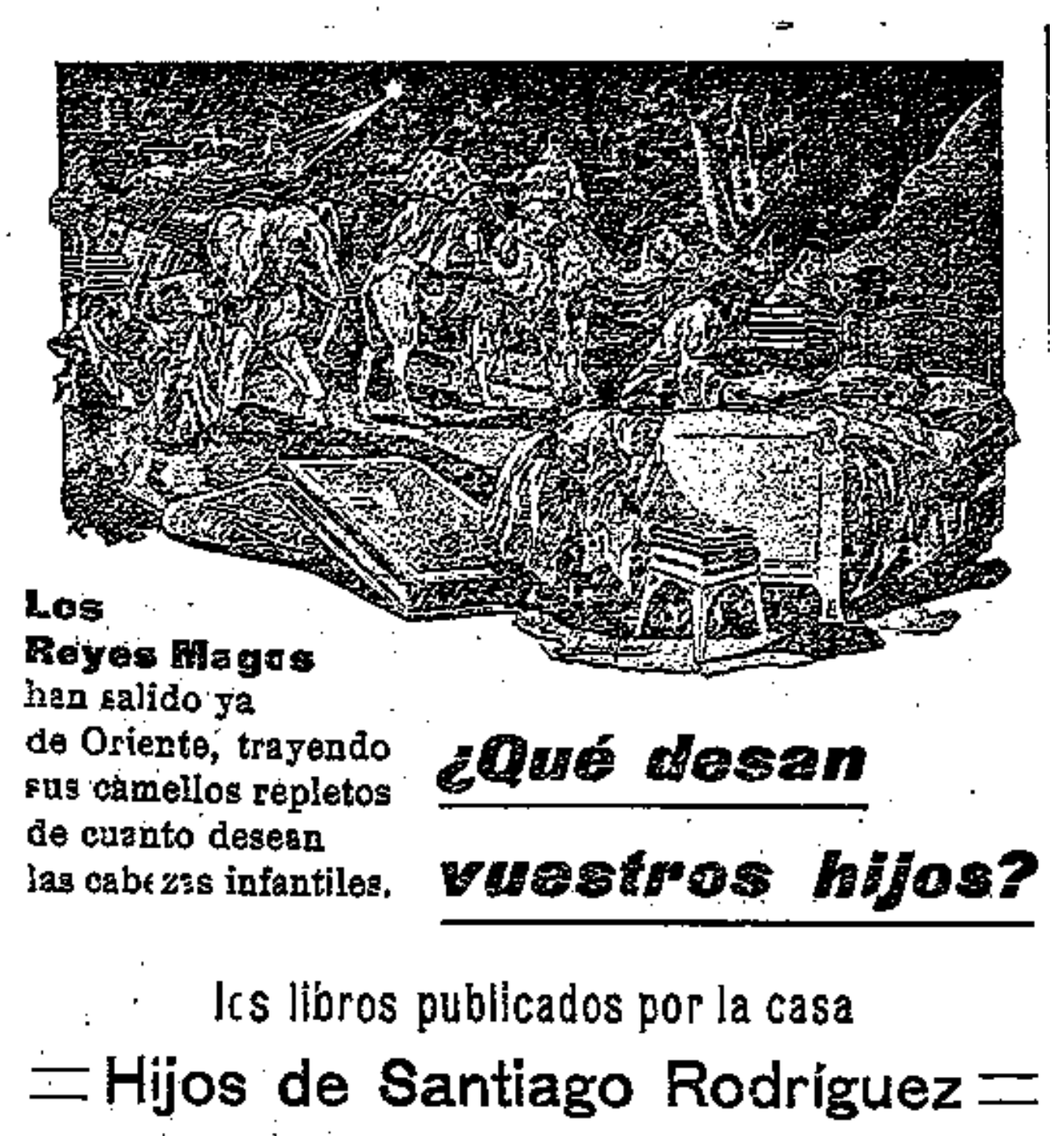

Su lectura sugestiva, amena é instructiva, los deleita y \} ace nacer en ellos el amor al estudio $y$ al bien, $y$ \&us bellas ilustraciones contribugen ć formar an gusto artístic 0 .

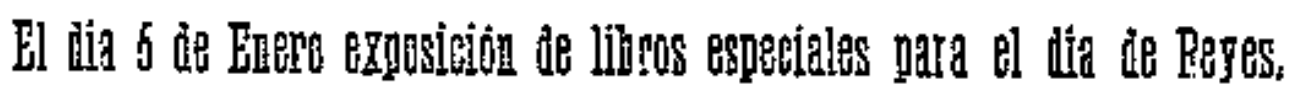

\section{PESATE DE EA FLORE, NUKERO 12, BUBCOS}

Fig. 4-20: Propaganda editorial en el periódico de Burgos Guasa Viva para animar a la compra de libros para el día 6 de enero, festividad de los Reyes Magos.

Aparece un personaje "Rodriguete", en una tira cómica que incita a la lectura animando a los niños a leer en diversos lugares (Figura 4-21). 

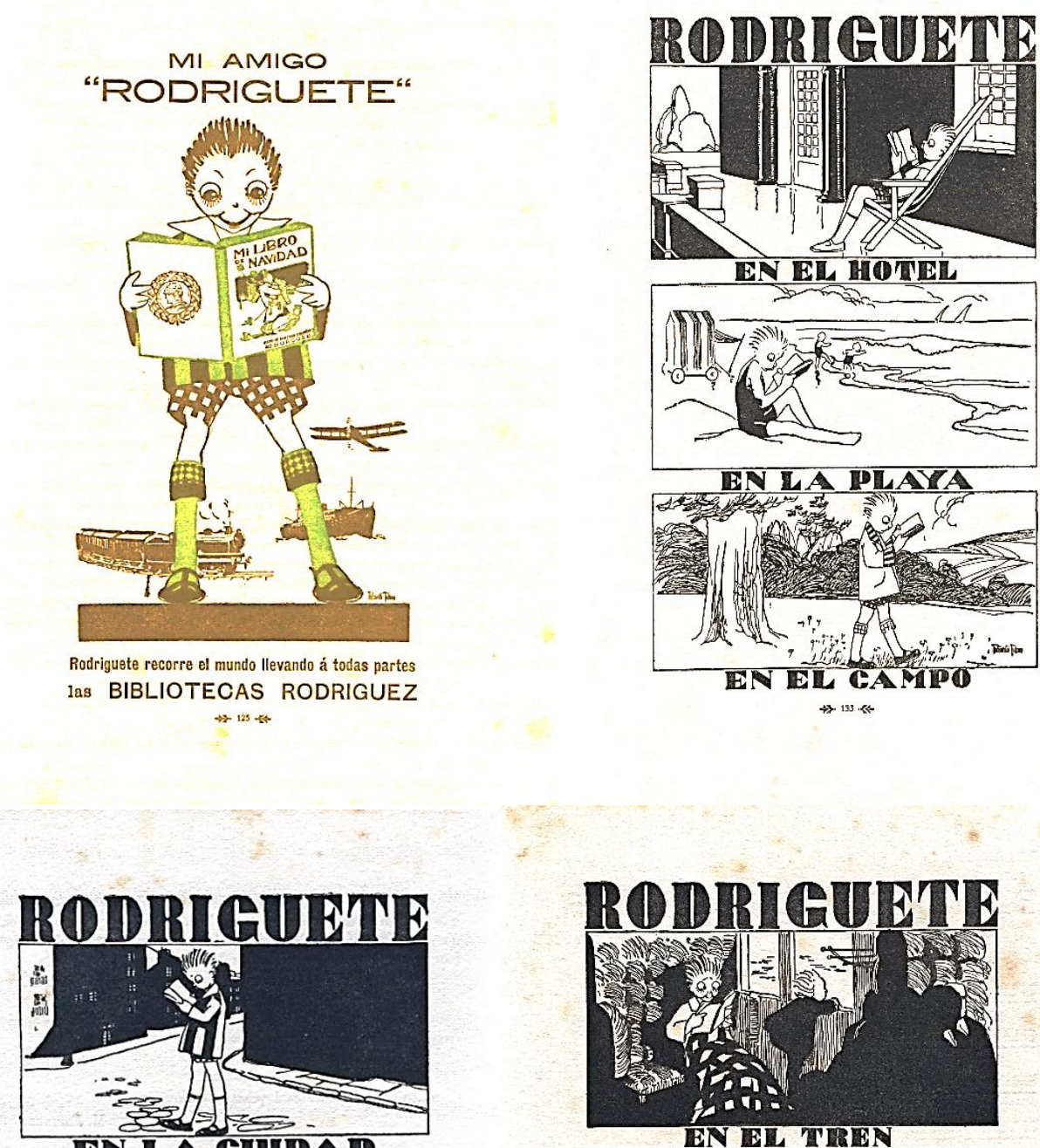

EN LA EIUIDAI
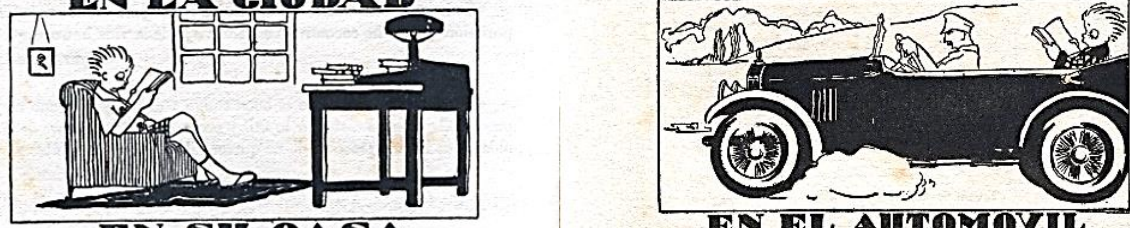

EN EL AUTOMOVIL
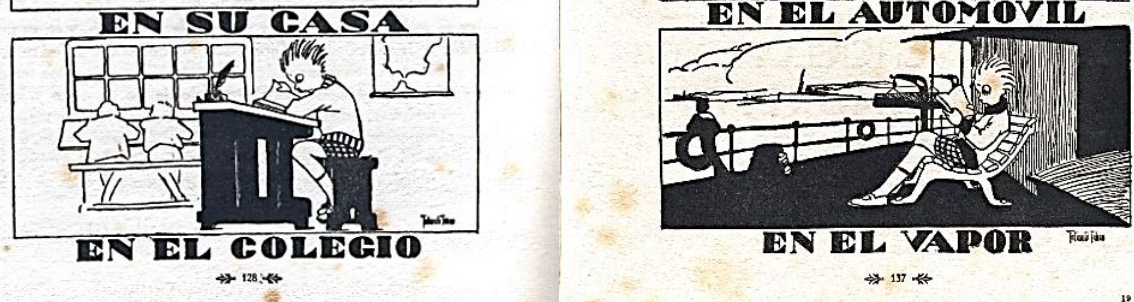

Fig. 4-21: En la Biblioteca Paz "Rodriguete" nace como símbolo de propaganda para animar a los niños a la lectura. Los dibujos están realizados por Fortunato Julián.

Por último, se presentan unas simples pinceladas, aunque sea de manera intermitente e inacabada, donde vislumbramos los logros obtenidos de un señalado librero como Santiago Rodríguez, cuya visión empresarial, cultural y educativa, llevó a lo más alto la edición de libros, en el primer 


\section{tercio del siglo XX, y de cuyo estudio trata con bellas palabras que le dedica la prensa burgalesa en 1914:}

Como burgaleses y amantes de todo cuanto suponga legítimo orgullo por la significación y el esfuerzo industrial que supone editar como lo hacen los Hijos de Santiago Rodríguez, nos sentimos orgullosos de poder contar y aplaudir a una industria que coloca a Burgos a un gran nivel industrial. Es más, se puede decir sin temor a ser tachados de parciales, que Burgos no puede encontrar mejor representado donde se lean obras de los Hijos de Santiago Rodríguez. ${ }^{579}$

En España, desgraciadamente, no se ha generalizado todavía suficientemente la culta y delicada costumbre, arraigada hace ya tiempo en otros países más adelantados, de conceptuar el libro como objeto predilecto para regalo a los muchachos, muy especialmente en los días de Navidad, Año Nuevo y Reyes.

Pero poco a poco, y gracias a los trabajos de algunas casas editoriales, los padres que verdaderamente se interesan por la educación de sus hijos, van relegando al olvido aquellos juguetes y cachivaches, casi siempre inútiles y de pasajero solaz, dando preferencia a estos tomitos que en manos de los incipientes y curiosos lectorcillos constituyen, a no dudarlo, el más preciado y positivo pasatiempo.

La ventaja del libro bueno y bien hecho es indiscutible: se desarrolla en el muchacho el gusto a la lectura y al estudio, aprende mil y mil cosas provechosas, se recrea en las bellas descripciones y conmovedores relatos, aprecia la belleza de los dibujos y grabados y todo ello contribuye poderosamente a que insensiblemente vaya desarrollando sus facultades intelectuales, su gusto y sus aficiones.

$Y$ esto viene a cuento porque hasta nosotros llegan algunos tomos de las interesantes y sugestivas bibliotecas que la casa editorial Hijos de Santiago Rodríguez, de Burgos, ha publicado últimamente.

Son tantas y todas tan bonitas que nos limitaremos a consignar aquí el nombre de algunas de aquellas colecciones: la "Biblioteca Paz", cuyo primer tomo, titulado "Mi Libro de Navidad" es de lo más original, sugestivo y variado que para niños puede hacerse; la "Biblioteca Pro-Cultura" en cuyos tomos se tratan materias tan interesantes como "El Libro de Historia", "El Libro de la Naturaleza", "El Libro de Literatura", "El Libro de Viajes"; los deliciosos "Albums Infantiles", abecedarios que serán el encanto de los pequeños y con los cuales aprenderán los primeros balbuceos del idioma, deleitándose con los atractivos y chispeantes dibujos de que están cuajados; $y$, finalmente la artística y magnifica "Biblioteca Rodríguez" para la juventud, alarde de buen gusto y en la que colaboran los más prestigiosos literatos y artistas contemporáneos.

Muchas otras bibliotecas tienen publicadas esta conocida casa, desde cuentos del más ínfimo precio hasta tomos lujosísimos, que constituyen soberbios regalos y en todos ellos campea la amenidad junto al interés, las enseñanzas provechosas con la más sana moral.

Sinceramente felicitamos a la casa Rodríguez que, con sus publicaciones infantiles, da una nota de alta cultura nacional y de moderna orientación hacia la educación de los niños de hoy, los hombres del porvenir.

Por ello aconsejamos a los padres de familia visiten en estos días la exposición

de libros infantiles que la citada casa Rodríguez tiene instalada, y en ella

${ }^{579}$ El Pueblo. Año III, no 105, 11 de diciembre de 1920, p. 1. 
4. MARIANO RODRÍGUEZ MIGUEL (1860-1925). EDITORIAL HIJOS DE SANTIAGO RODRÍGUEZ

podrán adquirir aquellos que sean más de su agrado, como obsequio duradero y de gran utilidad para sus hijos, no solo en nuestro preciado idioma, sino también en francés e inglés para los niños que estudien estos idiomas. ${ }^{580}$

$Y$ en cuanto a la parte editorial, la imprenta, este sublime y maravilloso arte que con orgullo ostenta los nombres de Ibarra y Monfort, ve aumentarse cada día el colosal monumento que se levanta en España, gracias a los nobles esfuerzos que editores inteligentísimos como los señores Hijos de Santiago Rodríguez hacen un día y otro día.

Orgullosos pueden estar por haber logrado colocar su importante casa a la altura que hoy ven colocada, gracias a los constantes sacrificios que siempre se han impuesto, para llevar a sus talleres todos los modernos adelantos con que hoy cuenta la imprenta española.

Esto sólo lo hacen aquellos que sienten verdadero cariño por el sagrado arte que cultivan. ${ }^{581}$

${ }^{580}$ El Pueblo. Año II, 27 de diciembre de 1919, p. 2. Vid. Anexo 2.3.3.

${ }^{581}$ Guasa Viva. Año II, nº 86, 8 de noviembre de 1914, p. 7. 

SEGUNDA PARTE. CATALOGACIÓN Y ANÁLISIS DE LOS LIBROS ESCOLARES EDITADOS EN HIJOS DE SANTIAGO RODRÍGUEZ 



\section{CATALOGACIÓN DE LA PRODUCCIÓN EDITORIAL (1891-1936)}
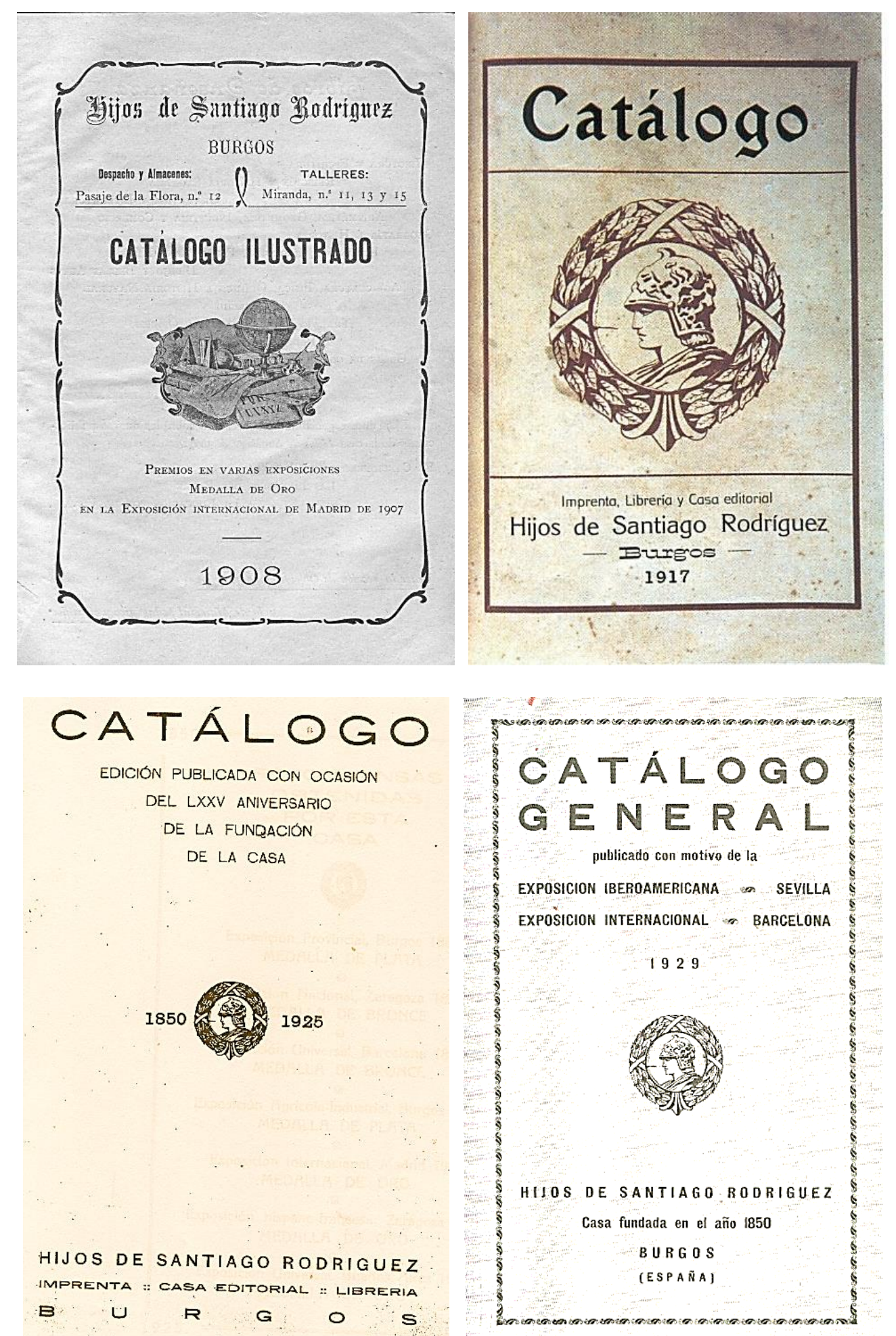

Fig. 5-1: Portada de Catálogos de la editorial Hijos de Santiago Rodríguez. Ejemplares de la Biblioteca de la Diputación Provincial de Burgos y de la Biblioteca Pública de Valladolid. 


\subsection{CONSIDERACIONES PRELIMINARES.}

Si los capítulos precedentes integran la vida de los fundadores de la editorial Hijos de Santiago Rodríguez, abordar el estudio y análisis de sus obras resulta todo un reto lleno de dificultades.

Surge la necesidad de una catalogación y recopilación de las obras, ya que la editorial no guardó ningún registro documental. A pesar de cerrar la empresa en fechas relativamente recientes -1989- los familiares no conservaron ejemplares o escritos registrables que avalen una compilación de sus obras.

Por tanto, se procede a una búsqueda en diversas bibliotecas, tanto en fondos de papel o digitalizados. ${ }^{582} \mathrm{Su}$ recogida se ha plasmado siguiendo un modelo de ficha muy sencillo que se ha utilizado como soporte básico del análisis editorial de la segunda parte del trabajo y que ayudará a sacar conclusiones de carácter pedagógico e histórico.

La ficha consta de los siguientes datos:

- Autor / autores.

- Título.

- Edición y año en que se editó el ejemplar.

- Notas. Se refiere a alguna aclaración que aumente la información.

- Descripción física con el número de páginas, el tamaño, la ilustración en cubierta y en el interior.

- Colección en caso de formar parte de un grupo asociado a un nombre.

- Bibliotecas en las que se conservan ejemplares del mismo.

- Catálogos. Remite información sobre el registro en los diferentes Catálogos utilizados de la Casa Editorial.

Debido a problemas de autoría en numerosos libros se ha ordenado alfabéticamente por el título.

Respecto de la edición, es difícil en muchos casos situar la inicial y las siguientes, bien porque no se dispone de libros originales, ni de sus primeras ediciones, bien porque se reeditaban muchas de sus obras, hecho muy específico del sector editorial de la época. En el estudio se ha ubicado la fecha y la edición más cercana conocida, según los ejemplares localizados, o según los Catálogos, cuando nos señalan su edición.

\footnotetext{
582 Ver artículo donde plantea las ventajas e inconvenientes sobre el tema de las fuentes digitales: BADANELLI RUBIO, A.; OSSENBACH SAUTER, G. Hacer historia en la era digital: nuevas formas de acceso a las fuentes y de conservación del patrimonio histórico-educativo [en línea]. UNED [fecha de consulta 15-4-2013]. Disponible en: http://dialnet.unirioja.es/descarga/articulo/2964256.pdf
} 
En cuanto a la descripción física encontramos problemas parecidos: varía el número de páginas, según la edición, y se toma la descripción de la más cercana.

De la ilustración se ubica al ilustrador o ilustradores de la obra primigenia, aunque también se añade el nombre de otros si la obra se ha reeditado con posterioridad.

En el apartado "Colección" se incluye este dato sólo en el caso de pertenecer a alguna de ellas; en caso contrario se omite.

En la entrada correspondiente a "Bibliotecas" aparece el nombre de todas aquellas donde se pueden encontrar ejemplares de Hijos de Santiago Rodríguez.

El exhaustivo rastreo comienza en las bibliotecas de la ciudad de Burgos donde se encuentran un número muy importante de ejemplares de la editorial como son las Bibliotecas Públicas de Castilla y León, incluyendo la Biblioteca General, la Biblioteca de la Diputación de Burgos, del IES Conde Diego Porcelos y las Bibliotecas Eclesiásticas de Santo Domingo de Silos y San Pedro de Cardeña.

Otras bibliotecas también han sido consultadas físicamente, porque en sus fondos documentales tenían libros únicos y raros como es el caso de:

- Biblioteca Pública de Valladolid.

- Biblioteca Pública de Vitoria.

- Biblioteca Pública de Pamplona.

- Biblioteca Nacional de España.

- Biblioteca del Centro Internacional de la Cultura Escolar [CEINCE].

- Biblioteca de la Universidad de Burgos.

- Biblioteca del Archivo Municipal de Burgos

Para completar la catalogación y conocer la ubicación de las obras se han utilizado los buscadores de catálogos a través de la web.

Numerosas asociaciones y bibliotecas de reconocido prestigio ofrecen sus registros bibliográficos existentes a través de la red para salvar los obstáculos de acceso a los archivos, alejados del lugar de origen del investigador.

Señalamos las siguientes consultadas:

La Biblioteca Virtual de Patrimonio Bibliográfico ${ }^{583}$ es un proyecto cooperativo del Ministerio de Cultura y las Comunidades Autónomas. Sus fondos bibliográficos están formados por bibliotecas españolas, públicas y privadas que por su antigüedad, singularidad o riqueza forman parte del Patrimonio Histórico Español. En el Catálogo aparece la localización de los

583 Catálogo Colectivo del Patrimonio Bibliográfico Español. Ministerio de Educación, Cultura y Deporte [en línea] [fecha de consulta: 8 de febrero 2014]. Disponible en: http://gl.www.mcu.es/bibliotecas/MC/CCPB/. 
libros, junto a una amplia descripción. Se ha verificado un total registro de los mismos.

La Biblioteca Digital Hispánica ${ }^{584}$ es la biblioteca digital de la Biblioteca Nacional de España. Creada en 2008 pretende difundir el patrimonio cultural español para fomentar la investigación, al facilitar la consulta de los fondos digitalizados y ofrecer un canal de cooperación al resto de bibliotecas españolas, europeas y latinoamericanas.

La Biblioteca Digital de Castilla y León $[B D C Y L]^{585}$ es un proyecto de la Consejería de Cultura y Turismo de la Junta de Castilla y León que tiene como principal objetivo acercar a todos los ciudadanos el acceso a los fondos bibliográficos y Archivos de la Comunidad Autónoma. Tiene digitalizadas las principales obras sobre la historia, patrimonio, ciencia, lengua y cultura de Castilla y León. En la misma se han localizado varios libros de la editorial Hijos de Santiago Rodríguez.

Al constatar la falta de algunas de las obras ofrecidas en los Catálogos de la Editorial se hizo un rastreo en otros buscadores fiables, a través de Internet, como la Red de Bibliotecas Universitarias Españolas [REBIUN]. ${ }^{586}$ Se formó en una comisión sectorial de la Conferencia de Rectores de las Universidades Españolas [CRUE] y que desde 1998 se constituyó como un organismo estable en el que estaban representadas todas las bibliotecas universitarias y científicas españolas. La forman actualmente 50 universidades de ámbito público y 25 privadas junto al CSIC (Consejo Superior de Investigaciones Científicas).

Fuera de nuestras fronteras se ha utilizado el buscador Worldcat ${ }^{587}$ (Catálogo Mundial en español) gestionado por el OCLC (Online Computer Library Center).

En el último apartado sobre "Catálogos" se refiere a aquellos que la editorial publicaba para dar a conocer los fondos de la empresa.

Los catálogos han sido estudiados por numerosos autores señalados como Isabel Villaseñor y Manuel Carrión ${ }^{588}$, Jean François Botrel y Raquel Sánchez García. Botrel nos explica que, a principios del siglo XIX lo habitual era que el autor confiaba su obra a los libreros de la capital o a los agentes que esta librería tuviese en otras ciudades. La publicidad no era

\footnotetext{
${ }^{584}$ Biblioteca Digital Hispánica. Biblioteca Nacional de España [en línea] [fecha de consulta: 6 de marzo de 2014]. Disponible en: http://www.bne.es/es/Catalogos/BibliotecaDigitalHispanica/Inicio/index.html.

585 Biblioteca Digital de Castilla y León [en línea] [fecha de consulta: 15 de marzo de 2014]. Disponible en: https://bibliotecadigital.jcyl.es/i18n/estaticos/contenido.cmd?pagina=estaticos/inicio.

${ }^{586}$ Red de Bibliotecas Universitarias Españolas (REBIUN) [en línea] [fecha de consulta: 5 de abril de 2014]. Disponible en: http://www.rebiun.org/Paginas/Inicio.aspx.

${ }^{587}$ Catálogo Mundial. Online Computer Library Center [en línea] [fecha de consulta: 8 de mayo de 2014]. Disponible en: https://www.worldcat.org/.

588 VILLASEÑOR, I. Repertorios con una función análoga a las bibliografías generales internacionales. Catálogos y catálogos colectivos de grandes bibliotecas. En: I. TORRES RAMÍREZ, coord. Las fuentes de información. Madrid: Síntesis, 1999, p. 179-193; CARRIÓN, M. Manual de Bibliotecas. Madrid: Fundación Germán Sánchez Ruipérez, 1993.
} 
muy habitual; de ahí que Pedro González, párroco interino en Soto de Cameros (Logroño), pidiese expresamente a los libreros y editores que enviasen sus catálogos. ${ }^{589}$ La profesora Raquel Sánchez cita y explica los catálogos de la editorial Calleja y la Compañía Iberoamericana de Publicaciones (CIAP). ${ }^{590}$

En el Catálogo de Calleja de 1911 presenta los índices de autores y títulos, e ilustraciones de las portadas y otros dibujos interiores, como reclamo para la venta. El Catálogo de CIAP se publica en 1930, incluyendo información de todas las empresas que componían su grupo editorial.

Pero, más allá de la importancia de conocer el listado de obras y editores de un sector editorial, los catálogos tienen un valor histórico como instrumento de trabajo en la recuperación de los fondos editoriales. ${ }^{591}$

En la ficha se ha añadido en qué Catálogos se localizan las obras registradas como seguimiento y ratificación de la obra.

Aun desconociendo la fecha en que se editaron los primeros Catálogos, se tiene constancia escrita de un catálogo fechado en 1893, -sin localizar-, por lo que se han utilizado 4 Catálogos de diferentes épocas y todos correspondientes a la casa editorial de Hijos de Santiago Rodríguez que son los siguientes:

- Catálogo de la Librería de Hijos de Santiago Rodríguez. Burgos.

En la portada interior lo titula Catálogo Ilustrado. Hijos de Santiago Rodríguez. Burgos. 1908.

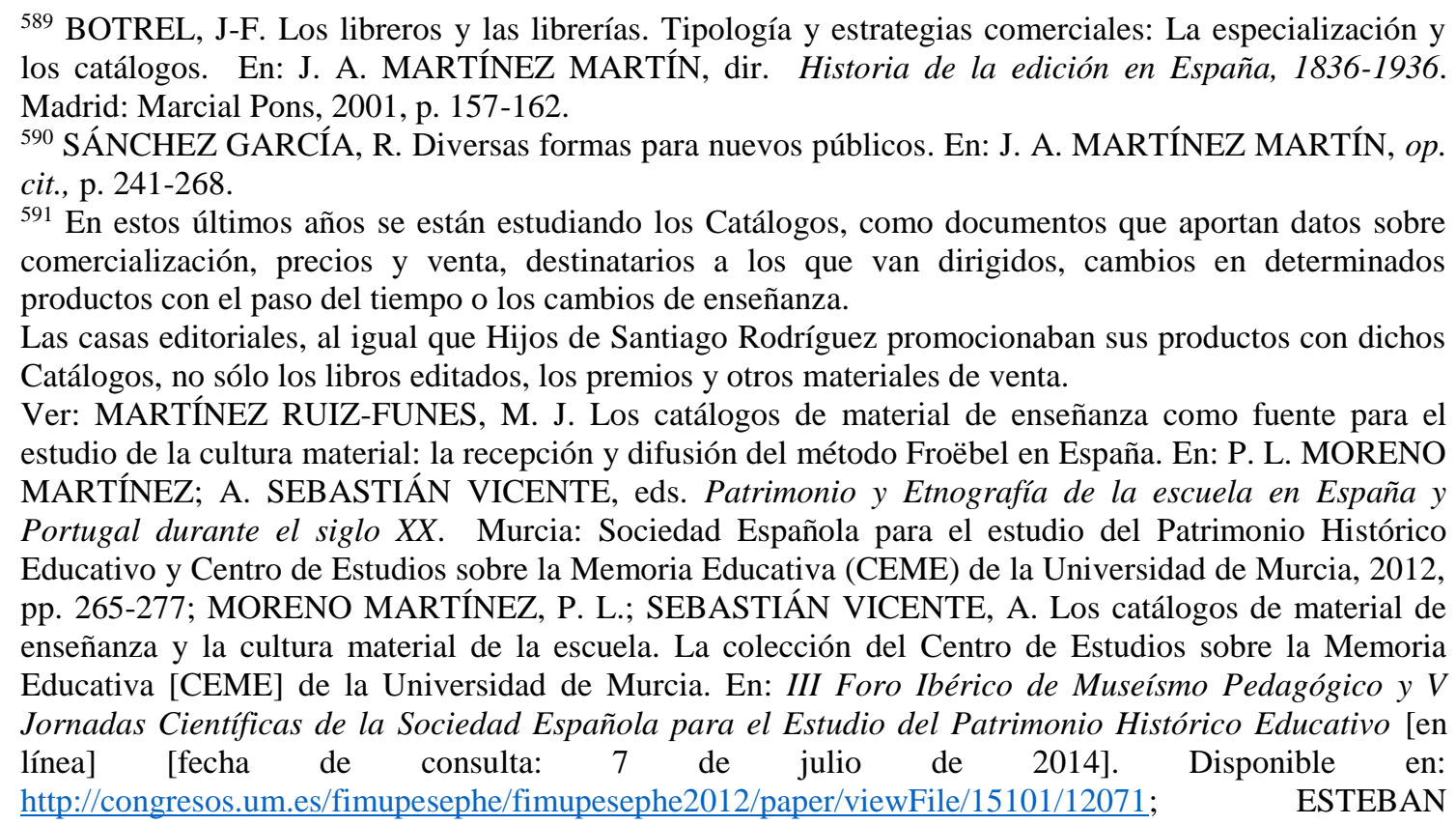
MATEO, L. Los catálogos de librería y material de enseñanza como fuente iconográfica y literarioescolar. Historia de la Educación. 1997, 16, pp. 17-46. 
- Catálogo. Imprenta, Librería y Casa editorial Hijos de Santiago Rodríguez. Burgos. 1917. En la portada interior lo titula Catálogo General Ilustrado. Imprenta, Librería y Casa Editorial de los Hijos de Santiago Rodríguez. Fundada en 1850.

- Catálogo Recuerdo. 1850-1925. Edición publicada con ocasión del LXXV aniversario de la fundación de la Casa. Hijos de Santiago Rodríguez. Imprenta. Casa Editorial. Librería. Burgos.

- Catálogo. Hijos de Santiago Rodríguez. Burgos. 1929.

Catálogo General publicado con motivo de la Exposición Iberoamericana en Sevilla y de la Exposición Internacional de Barcelona.

Gracias a estos Catálogos se ratifica el número de obras de la editorial, especialmente de aquellas que no existen materialmente y que puede ser motivo, en adelante, de búsquedas privadas por la recuperación del fondo editorial.

En la catalogación de algunas obras se ha añadido un apartado de "Notas", para especificar datos complementarios, especialmente si dicho ejemplar había obtenido algún premio meritorio o para señalar la autoría anterior en la Imprenta y librería de Santiago Rodríguez Alonso.

Aunque sea ajeno a este trabajo, los Catálogos de la editorial, además de ser referencia identificativa de la misma, contienen un inventario interno de la producción editorial y del material escolar de un período; son documentos de referencia del patrimonio y constituyen una fuente importante de la búsqueda, análisis, oferta y difusión de la información.

Con todo, insistimos en su valor como instrumentos de trabajo para la recuperación del fondo editorial.

Al margen de las obras de la editorial, los Catálogos de Hijos de Santiago Rodríguez presentan información sobre libros publicados e igualmente publicitan otros materiales como orlas y diplomas, mobiliario, material, menaje escolar y artículos varios de esta casa comercial. 


\subsection{LISTADO ALFABÉTICO DE LAS OBRAS DE LA EDITORIAL EN LAS PRINCIPALES BIBLIOTECAS NACIONALES E INTERNACIONALES}

\section{A}

Autor: B. C.

Título: Adiós a Cuba: recuerdos de un cubano.

Edición: (1900).

Descripción: 271 p.; $21 \mathrm{~cm}$.

Bibliotecas:

Biblioteca de la British Library, St. Pancras, Londres. Inglaterra.

Biblioteca de la Universidad de Erfurt. Alemania (Universitäts-und Forschungsbibliothek Erfurt/Gotha).

Biblioteca de la Universidad de California. Estados Unidos (UC Berkeley Libraries).

Biblioteca Nacional de España.

Catálogos: No aparece en ninguno de los catálogos de 1908, 1917, 1925, 1929.

Autor: VV. AA.

Título: Al borde del abismo.

Edición: (1906).

Notas: Contiene diversos cuentos: Al borde del abismo de Hilario Garzón Gutiérrez, La serpiente, La pesca y El amigo de los pájaros de Alfredo Garzón Antón.

Descripción: 128 p.; 18 cm. Ilustrado, con cubiertas al cromo y oro.

Colección: Museo de la Infancia.

Bibliotecas:

Biblioteca de la Universidad de Castilla La Mancha, Campus de Cuenca.

Catálogos: 1908, 1917, 1925, 1929.

Autor: Cámara Oficial de Comercio e Industria de Burgos.

Título: Algunos de los más importantes informes redactados por la Secretaría de la Cámara Oficial de Comercio e Industria de Burgos, y aprobados por esta corporación durante la vida legal del Pleno que cesó reglamentariamente en 31 de diciembre de 1927.

Edición: (1928).

Descripción: 140 p.; $20 \mathrm{~cm}$.

Bibliotecas:

Biblioteca de la Universidad Pompeu Fabra, Barcelona.

Biblioteca Municipal de Aranda de Duero, Burgos. 
Catálogos: No aparece en ninguno de los catálogos de 1908, 1917, 1925, 1929.

Autor: Rodríguez Miguel, Mariano.

Título: Alma y corazón: cuentos morales.

Edición: (190?).

Notas: La obra está fechada en diciembre de 1905 pero en el Catálogo de 1908 lo pone como "en prensa". Esta obra ya se comercializaba bajo otro título, Lecciones del padre, y formaba parte de libros de lectura para la escuela.

Descripción: 237 p.; $22 \mathrm{~cm}$. Ilustraciones de Evaristo Barrio. Encuadernado en pasta con tapas al cromo y oro.

Colección: Biblioteca Enciclopédica Hispano-Americana, 9.

Bibliotecas:

Biblioteca de la Diputación Provincial, Burgos.

Catálogos: 1908 (en prensa), 1917, 1925, 1929.

Autor: Bueno Rodríguez-Arias, Ángel.

Título: Alma.

Edición: (1897).

Descripción: 32 p.; $15 \mathrm{~cm}$.

Bibliotecas:

Biblioteca Digital Castilla y León.

Biblioteca Pública de Segovia.

Catálogos: No aparece en ninguno de los catálogos de 1908, 1917, 1925, 1929.

Autor: Bolinaga, Josefina.

Título: Amanecer: cuentos para niños y niñas.

Edición: (1934).

Descripción: 167 p.; 19 cm. Ilustraciones de Fortunato Julián.

Bibliotecas:

Biblioteca de la Universidad de Girona.

Biblioteca de la Universidad Jaume I, Castellón de la Plana.

Biblioteca Nacional de España.

Biblioteca Nacional de los Países Bajos.

Catálogos: Posterior a los catálogos analizados.

Autor: Hortera, Hermenegildo.

Título: Amantes verdaderos: zarzuela en dos actos.

Edición: (1903).

Descripción: 48 p.; $19 \mathrm{~cm}$.

Bibliotecas: 
Biblioteca Nacional de España.

Catálogos: No aparece en ninguno de los catálogos de 1908, 1917, 1925, 1929.

Autor: Salgado Biempica, Manuel.

Título: Apuntes de aritmética: adaptados al texto de Salinas y Benítez.

Edición: (191-?), (1922?).

Descripción: 82 p.; $22 \mathrm{~cm}$.

Bibliotecas:

Biblioteca Pública de Burgos.

Biblioteca Pública de Ourense.

Biblioteca Nacional de España.

Catálogos: No aparece en ninguno de los catálogos de 1908, 1917, 1925, 1929.

Autor: Cantón Salazar, Leocadio.

Título: Apuntes para una guía de Burgos: La Catedral, la Cartuja, el Real Monasterio de las Huelgas y el Hospital del Rey.

Edición: (1888).

Notas: Se imprime en la Imprenta y librería de Santiago Rodríguez Alonso.

Descripción: 95 p.; $21 \mathrm{~cm}$.

Bibliotecas:

Biblioteca Pública de Burgos.

Biblioteca de la Diputación Provincial de Burgos.

Biblioteca del Archivo Municipal de Burgos.

Catálogos: No aparece en ninguno de los catálogos de 1908, 1917, 1925, 1929.

Autor: S. M.

Título: Aritmética y nociones de geometría: clase de ingreso.

Edición: 2a edición (1935).

Descripción: 186 p.; 19 cm. Ilustrada

Bibliotecas:

Biblioteca de la UNED, proyecto Manes.

Catálogos: Posterior a los catálogos analizados.

Autor: Salignac de la Mothe, Francisco de [Fenelon]. (Traducción y adaptación de Ángel Bueno Rodríguez-Arias).

Título: Aventuras de Telémaco.

Edición: $3^{\mathrm{a}}$ edición (19--), $4^{\mathrm{a}}$ edición (19--), Edición artísticamente ilustrada (1902).

Descripción: 200 a 300 p.; 22 cm. Ilustraciones de Evaristo Barrio con cubierta al cromo y oro. 
Colección: Biblioteca Enciclopédica Hispano-Americana, 8.

\section{Bibliotecas:}

Ateneo Riojano, Logroño.

Biblioteca de la Diputación Provincial de Burgos.

Biblioteca de la Universidad de Cantabria, Santander

Biblioteca de la Universidad de Castilla La Mancha, Campus de Cuenca.

Biblioteca de la Universidad de Extremadura, Badajoz

Biblioteca de la Universidad de Murcia.

Biblioteca de la Universidad de Santiago de Compostela.

Biblioteca del Archivo Municipal, Burgos.

Biblioteca del IES Cardenal Cisneros, Madrid.

Biblioteca Estatal de Bavaria, Munich. Alemania.

Biblioteca Pública de Castilla y León, Valladolid.

Biblioteca Pública de Zamora.

Biblioteca Pública Municipal de Elda, Alicante.

Biblioteca Pública Municipal Lope de Vega, Ciudad Real.

Biblioteca Puerto de Santa $M^{a}$, Cádiz.

CEINCE.

Fundación González Allende, Toro, Valladolid.

Catálogos: 1908, 1917, 1925, 1929.

Autor: López, S. C.

Título: Aventuras de un huérfano.

Edición: (19--).

Descripción: 150 p.; 21 cm. Ilustraciones de Evaristo Barrio.

Colección: Biblioteca Oro, 2.

Bibliotecas:

Biblioteca de la Diputación Provincial de Burgos.

Biblioteca Pública de Castilla y León, Valladolid.

CEINCE

Catálogos: 1917, 1925, 1929.

Autor: Sée, Carlos traducido y ampliado por Fernando Altolaguirre Garrido.

Título: Auxiliar del Arquitecto y del Ingeniero Constructor para el cálculo de Construcciones.

Descripción: 292 p.; $19 \mathrm{~cm}$.

\section{Bibliotecas:}

Biblioteca Histórica Militar de la Región de Sevilla, Sevilla.

Biblioteca de la Escuela de Ingeniería Minera e Industrial de Almadén, Ciudad Real.

Catálogos: 1917. 


\section{B}

Autor: Ayuntamiento de Burgos.

Título: Bandos para el buen régimen y gobierno de todo lo concerniente a la Policía Urbana y Rural.

Edición: (1898).

Descripción: 78 p.; $16 \mathrm{~cm}$.

Bibliotecas:

Biblioteca de la Universidad Complutense de Madrid.

Catálogos: No aparece en ninguno de los catálogos de 1908, 1917, 1925, 1929.

Autor: Centro de Estudios Castellanos.

Título: Bases del Reglamento y Exposición a las Entidades Corporativas.

Edición: (1931).

Descripción: 16 p.; $25 \mathrm{~cm}$.

\section{Bibliotecas:}

Biblioteca de la Diputación Provincial de Burgos.

Biblioteca del Archivo Histórico Provincial de Burgos.

Biblioteca del Archivo Municipal de Burgos.

Biblioteca Nacional de España.

Biblioteca Pública de Castilla y León, Valladolid.

Catálogos: Posterior a los catálogos analizados.

Autor: VV. AA.

Título: Bazar de cuentos.

Edición: (19--).

Descripción: 128 p.; 18 cm. Ilustrado con cubiertas al cromo y oro.

Colección: Biblioteca Oro, 3.

Bibliotecas:

Biblioteca de la Universidad de Carolina del Sur, Columbia. Estados Unidos.

Biblioteca Nacional de Maestros, Buenos Aires. Argentina

Catálogos: 1917, 1925, 1929.

Autor: Ayuntamiento de Burgos.

Título: Boletín de la estadística municipal de la ciudad de Burgos.

Edición: Comenzó 1913.

Descripción: $31 \mathrm{~cm}$. Periodicidad mensual. N 4 (diciembre 1913). Anuarios 1944, 1945, 1946, 1947, 1948 y 1949.

\section{Bibliotecas:}

Biblioteca del Archivo Municipal de Burgos.

Biblioteca Digital de Castilla y León. 
Biblioteca Pública de Burgos.

Catálogos: No aparece en ninguno de los catálogos de 1908, 1917, 1925, 1929.

Autor: Desconocido.

Título: Breve reseña histórica de la milagrosa imagen de Jesús Crucificado que se venera en el Real Monasterio de Palacios de Benaver.

Edición: (1899).

Descripción: 16 p.; $15 \mathrm{~cm}$.

Bibliotecas:

Biblioteca de la Abadía de Santo Domingo de Silos, Burgos.

Museo Cerralbo, Madrid.

Catálogos: No aparece en ninguno de los catálogos de 1908, 1917, 1925, 1929.

Autor: Salvá Pérez, Anselmo

Título: Burgos en las Comunidades de Castilla.

Edición: (1895). Reproducción de la edición de 1895 (Maxtor, 2002).

Descripción: 189 p.; $20 \mathrm{~cm}$.

Bibliotecas:

Archivo Silveriano de la Provincia Carmelitana O.C.D. Burgense de Burgos.

Biblioteca de la Abadía de Santo Domingo de Silos, Burgos.

Biblioteca de la Facultad de Teología del Norte de España, Burgos.

Biblioteca de la Real Academia de Historia en Madrid.

Biblioteca de la Real Academia Española de Madrid.

Biblioteca de la Universidad Complutense de Madrid.

Biblioteca de la Universidad de Berna. Suiza (University of Bern, Switzerland).

Biblioteca de la Universidad de Burgos.

Biblioteca de la Universidad de Castilla La Mancha, Campus de Ciudad Real.

Biblioteca de la Universidad de Toulouse Le Mirail. Francia.

Biblioteca de la Universidad de Valladolid.

Biblioteca de la Universidad Pontificia Comillas de Madrid.

Biblioteca del Archivo Histórico Nacional de Madrid.

Biblioteca del Archivo Histórico Provincial de Burgos.

Biblioteca del Archivo Municipal de Burgos.

Biblioteca del Consejo Superior de Investigaciones Científicas.

Biblioteca del IES Conde Diego Porcelos, Burgos.

Biblioteca del Monasterio de San Pedro de Cardeña, Burgos

Biblioteca Digital de Castilla y León.

Biblioteca Franciscana de Santa María La Real de Nájera, La Rioja. 
Biblioteca Municipal Gonzalo de Berceo, Burgos.

Biblioteca Municipal Miguel de Cervantes, Burgos.

Biblioteca Nacional de España.

Biblioteca Nacional de París. Francia.

Biblioteca Pública de Burgos.

Biblioteca Pública de Castilla y León, Valladolid.

Biblioteca Pública Marqués de Piedras Albas, Ávila.

Fundación Lázaro Galdiano de Madrid.

Instituto Nacional de Administración Pública de Madrid.

Catálogos: No aparece en ninguno de los catálogos de 1908, 1917, 1925, 1929.

Autor: Pablo Ibáñez, Luis de.

Título: Burgos y su provincia: apuntes y notas para el visitante.

Edición: (1925?).

Descripción: 150 p.; $18 \mathrm{~cm}$. Dispone de un plano de la ciudad y un mapa de la provincia en colores. Fotograbados y fotografías de A. Vadillo.

\section{Bibliotecas:}

Biblioteca de la Universidad de Valencia.

Biblioteca Digital de Castilla y León.

Biblioteca Municipal Miguel de Cervantes, Burgos.

Biblioteca Pública de Burgos.

Biblioteca Pública de Castilla y León, Valladolid.

Museo Provincial de Pontevedra.

Catálogos: 1925, 1929.

C

Autor: Ferrer Domingo, Benigno.

Título: Camino adelante: El libro de los niños.

Edición: $1^{a}$ edición (1931).

Descripción: 76 p.; 19 cm. Ilustraciones de Fortunato Julián.

Bibliotecas:

Biblioteca Nacional de España.

Catálogos: Es posterior a los catálogos analizados.

Autor: García Ansótegui, Lino.

Título: Cancionero de la infancia: lecturas poéticas escritas para niños y niñas.

Edición: $8^{a}$ edición (1907).

Descripción: 170 p.; 16 cm. Ilustraciones de Evaristo Barrio con cubierta al cromo y oro.

\section{Bibliotecas:}


Biblioteca de la Diputación Provincial de Burgos.

Biblioteca de la UNED, proyecto Manes.

Biblioteca de la Universidad Autónoma de Madrid.

Biblioteca del IES Cardenal Cisneros, Madrid.

Biblioteca Nacional de España.

Biblioteca Pública de Castilla y León, Valladolid.

Biblioteca Pública de San Sebastián.

CEINCE.

Catálogos: 1908, 1917 (4 edición), 1925 (7ª edición), 1929 (8ª edición).

Autor: Ferrer Domingo, Benigno.

Título: Cartas de Leonardo, correspondencia de un niño.

Edición: $2^{a}$ edición (1930). Novísima edición con aumento de texto y nuevos fotograbados.

Descripción: 106 p.; 19 cm. Cubierta por Fortunato Julián.

\section{Bibliotecas:}

Biblioteca de la Diputación Provincial de Burgos.

Biblioteca de la Universidad de Granada.

Biblioteca de la Universidad de Murcia.

Biblioteca de la Universidad Pompeu Fabra, Barcelona.

Biblioteca del Consejo Superior de Investigaciones Científicas.

Biblioteca Nacional de España.

Biblioteca Pública de Cáceres.

Biblioteca Pública de Jerez de la Frontera, Cádiz.

Catálogos: Es posterior a los catálogos analizados.

Autor: Cañaza y Férriz, Francisco.

Título: Cartilla de lectura elemental por el nuevo deletreo.

Edición: (1890).

Descripción: 68 p.; $17 \mathrm{~cm}$.

Bibliotecas:

Biblioteca de la Universidad de Las Islas Baleares.

Catálogos: No aparece en ninguno de los catálogos de 1908, 1917, 1925, 1929.

Autor: S. Cardiel, Guillermo.

Título: Cartilla para reclusos.

Edición: (1921).

Descripción: 24 p.; $16 \mathrm{~cm}$.

Bibliotecas:

Biblioteca de la Diputación Provincial de Burgos.

Biblioteca del Archivo Municipal de Burgos. 
Catálogos: No aparece en ninguno de los catálogos de 1908, 1917, 1925, 1929.

Autor: García Vedota, A.

Título: Castilla y saltos del Duero.

Edición: (1930). Fecha en el prólogo y en el fin del texto.

Descripción: 50 p.; $18 \mathrm{~cm}$. Aporta varios gráficos.

Bibliotecas:

Biblioteca de la Diputación Provincial de Burgos.

Biblioteca de la Universidad de Valladolid.

Biblioteca de la Universidad Politécnica de Madrid.

Biblioteca del Archivo Histórico Provincial de Valladolid.

Biblioteca Municipal de Aranda de Duero, Burgos.

Biblioteca Municipal Miguel de Cervantes, Burgos.

Biblioteca Nacional de España.

Catálogos: Posterior a los catálogos analizados.

Autor: Hijos de Santiago Rodríguez.

Título: Catálogo General Ilustrado.

Edición: (1917).

Descripción: 290 p.; 25 cm.

Bibliotecas:

Biblioteca de la Diputación Provincial de Burgos.

Catálogos: 1917.

Autor: Hijos de Santiago Rodríguez.

Título: Catálogo general publicado con motivo de la Exposición Iberoamericana de Sevilla y de la Exposición Internacional de Barcelona.

Edición: (1929).

Descripción: 116 p.; $21 \mathrm{~cm}$.

Bibliotecas:

Biblioteca de la Junta de Andalucía.

Biblioteca del Consejo Superior de Investigaciones Científicas.

Biblioteca Pública de Castilla y León, Valladolid.

Biblioteca Pública de Córdoba.

Catálogos: 1929.

Autor: Hijos de Santiago Rodríguez.

Título: Catálogo: edición publicada con ocasión del LXXV aniversario de la fundación de la Casa: 1850-1925.

Edición: (1925).

Descripción: 164 p.; 27 cm. Ilustrada.

Bibliotecas: 
Biblioteca de la Diputación de Burgos.

Biblioteca Nacional de México.

Catálogos: 1925.

Autor: Hijos de Santiago Rodríguez.

Título: Catálogo Ilustrado de libros, orlas, diplomas y artículos para premio.

Edición: (1932).

Descripción: 69 p.

Bibliotecas:

Biblioteca de la Universidad de Murcia.

Catálogos: Posterior a los catálogos analizados.

Autor: Álvarez Carretero, Antonio.

Título: Catecismo de higiene y economía domésticas: precedido de unas nociones de fisiología.

Edición: $2^{a}$ edición (1884), $3^{\text {a }}$ edición (1889).

Notas: Obra de texto aprobada por Real Decreto, recomendada por la Junta provincial de Instrucción Pública de Burgos, premiada en la Exposición Pedagógica de 1882, en la de Zaragoza de 1885 y Barcelona, 1888.

Publicación en la Imprenta y librería de Santiago Rodríguez Alonso.

Descripción: 164 p.; 16 cm. Ilustrada.

\section{Bibliotecas:}

Biblioteca de la Abadía de Santo Domingo de Silos, Burgos.

Biblioteca Pública de Burgos.

Catálogos: Es anterior a los Catálogos estudiados

Autor: Astete, Gaspar, corregido y adicionado por disposición del Excmo. e Ilmo. Sr. D. Pedro Cirilo Uriz y Labairu, Obispo que fue de Pamplona, para uso de los fieles de este Diócesis.

Título: Catecismo de la Doctrina Cristiana.

Edición: Autorizado su publicación en Pamplona: viuda de T. Descansa, $D^{a}$ Blanca de Navarra, 25. Edición Especial para la Diócesis de Navarra.

Descripción: 64 p.; $13 \mathrm{~cm}$.

Bibliotecas:

Biblioteca Pública de Navarra.

Catálogos: 1908, 1917, 1925, 1929.

Autor: Astete, Gaspar; añadido por Gabriel Menéndez Luarca.

Título: Catecismo de la doctrina cristiana.

Edición: (1897).

Descripción: 64 p.; $13 \mathrm{~cm}$. Con grabados. Cubierta en cartulina fuerte.

Bibliotecas: 
Biblioteca de la Diputación Provincial de Burgos.

Biblioteca del Instituto de Estudios Riojanos, Logroño.

Biblioteca del Monasterio de San Millán de la Cogolla de Yuso, La Rioja.

Biblioteca del Monasterio de Sancti Spiritus el Real (MM. Dominicas), Toro, Zamora.

Biblioteca Digital de Castilla y León.

Biblioteca Municipal Mariano Suárez Pola de Luanco, Asturias.

Biblioteca Nacional de España.

Biblioteca Pública de Castilla y León, Valladolid.

Biblioteca Pública de Gijón.

Biblioteca Pública de Lazkao, Gordailua, Guipúzcoa.

Biblioteca Pública de Oviedo.

Bibliotecas de la Abadía de Santo Domingo de Silos, Burgos.

Catálogos: 1908, 1917 y 1925 (Dos ediciones: una edición especial de la casa con encuadernación en rústica y con cubierta a color y otra edición forma "Regente" ilustrada), 1929.

Autor: Astete, Gaspar; Fleury, Claude; Arzobispado de Burgos.

Título: Catecismo del arzobispado de Burgos: texto oficial de la congregación de la doctrina cristiana con la aprobación del Excmo. e Ilmo. Sr. D. Gregorio M $M^{a}$ Aguirre y García, cardenal de Toledo y Primado de las Españas.

Edición: (1907).

Descripción: 176 p.; $18 \mathrm{~cm}$. Cubierta con cartulina en color. Contiene el Catecismo del P. Astete, aumentado con epígrafes aclaratorios; el Diálogo histórico del Abad Fleury, corregido; y las oraciones y cánticos de la Catequesis.

\section{Bibliotecas:}

Biblioteca de la Diputación Provincial de Burgos.

Biblioteca de la Facultad de Teología del Norte de España, Burgos.

Biblioteca del Consejo Superior de Investigaciones Científicas.

Catálogos: 1925, 1929.

Autor: Fleury, Claude.

Título: Catecismo histórico o Compendio de la Historia Sagrada y de la doctrina cristiana.

Edición: (1895).

Descripción: 136 p.; $17 \mathrm{~cm}$. Con grabados y encuadernación en pasta con cubiertas al cromo.

\section{Bibliotecas:}

Biblioteca Arqueológica de Galicia.

Biblioteca de la Diputación Provincial de Burgos.

Biblioteca de la UNED, proyecto Manes. 
Biblioteca de la Universidad Pontificia de Salamanca.

Biblioteca Municipal de Ferrol, A Coruña.

Biblioteca Pública de Burgos.

Biblioteca Pública de Castilla y León, Valladolid.

Biblioteca Pública Museos de Gijón.

CEINCE.

Catálogos: 1908, 1917, 1925 (Edición especial).

Autor: Ripalda, Jerónimo.

Título: Catecismo de la Doctrina Cristiana.

Edición: (19--).

Descripción: 96 p.; $13 \mathrm{~cm}$. Con grabados. Encuadernado en rústica y cubierta en color.

\section{Bibliotecas:}

Biblioteca de la Universidad de Burgos.

Biblioteca de la Universidad de Dresden. Alemania (Sächsische Landesbibliothek-Staats-und).

Biblioteca de la Universidad de Salamanca.

Biblioteca de la Universidad Eichstät-Ingolstadt. Alemania.

Biblioteca Nacional de España.

Biblioteca Nacional y universitaria de Strarburgo. Francia (Bibliothéque Nationale et Universitaire Strasbourg-BNUS).

Catálogos: 1908, 1917, 1925, 1929.

Autor: Hijos de Santiago Rodríguez.

Título: Catedral de Burgos: séptimo centenario de su fundación, 1221.

Edición: (1921). Edición limitada.

Descripción: 244 p.; 17 cm. Ilustrada.

Bibliotecas:

Biblioteca de la Diputación Provincial de Burgos.

Biblioteca de la Universidad de Deusto, Bilbao.

Biblioteca de la Universidad de Málaga.

Biblioteca del Archivo Municipal de Burgos.

Biblioteca del Seminario Diocesano de Segovia.

Biblioteca Digital de Castilla y León.

Biblioteca Municipal Miguel de Cervantes, Burgos.

Biblioteca Pública de Castilla y León, Valladolid.

Catálogos: No aparece en ninguno de los catálogos de 1908, 1917, 1925, 1929.

Autor: Dotor y Municio, Ángel. Prólogo de Marceliano Santa María.

Título: Catedrales de España: Guía histórico-descriptiva.

Edición: (1928). 
Descripción: 316 p.; $21 \mathrm{~cm}$. Contiene 62 láminas.

Bibliotecas:

Biblioteca Pública Cánovas del Castillo, Málaga.

Catálogos: 1929.

Autor: González Seijas, José; aumentado y corregido por Victoriano Hernando.

Título: Catón metódico de los niños.

Edición: (1900). Nueva edición ilustrada.

Descripción: 96 p.; 15,5 cm. Ilustrada. Encuadernada en pasta y con tapas al cromo en las ediciones hasta 1917. En adelante cubierta de colores.

\section{Bibliotecas:}

Biblioteca de la Diputación Provincial de Burgos.

Biblioteca de la UNED, proyecto Manes.

Biblioteca de la Universidad Pontificia de Salamanca.

CEINCE.

Catálogos: 1908, 1917, 1925, 1929.

Autor: Benejam Vives, Juan.

Título: Ciencias físicas y naturales.

Edición: Novísima edición ilustrada (1907).

Descripción: 232 p.; $22 \mathrm{~cm}$. Cubierta a color ilustrada de Evaristo Barrio e interiores en fotograbados, con dibujos de Pedrero, Isidro Gil y Evaristo Barrio y encuadernación en pasta con tapas al cromo.

Colección: Biblioteca Enciclopédica Hispano-Americana, 5.

Bibliotecas:

Biblioteca de la Generalitat de Cataluña, Barcelona.

Biblioteca de la Universidad Autónoma de Madrid.

Biblioteca de la Universidad Complutense de Madrid.

Biblioteca de la Universidad de Las Islas Baleares.

Biblioteca del Archivo Municipal de Burgos.

Biblioteca del Consejo Superior de Investigaciones Científicas.

Biblioteca del IES Cardenal Cisneros, Madrid.

Biblioteca Pública Municipal Lope de Vega, Ciudad Real.

CEINCE.

Catálogos: 1908, 1917, 1929, 1925.

Autor: Fernández, Clemente; García de Medrano, Jorge.

Título: Compendio de aritmética.

Edición: 29a edición (1888). En el Catálogo de 1908 cita más de 33a ediciones. En el de 1917 anota sus más de 35 ediciones y en el de 1925 más de 30 ediciones. 
Notas: Comenzó su impresión en la Imprenta y librería de Santiago Rodríguez Alonso.

Descripción: 40 p.; $16 \mathrm{~cm}$. Encuadernado en holandesa y cubierta al cromo en los catálogos anteriores a 1917 y en pasta cubierta de colores desde 1925. Fue aprobado para servir de texto en las Escuelas por Real Orden de 5 de mayo de 1879.

\section{Bibliotecas:}

Biblioteca de la Diputación Provincial de Burgos.

Biblioteca de la Universidad de Castilla La Mancha, Campus de Cuenca. Biblioteca Pública de Castilla y León, Valladolid.

Catálogos: 1908, 1917, 1925, 1929.

Autor: Casas y Arriola, Eudoro con un prólogo de Julián Apraiz.

Título: Compendio de Historia de España.

Edición: $3^{\text {a }}$ edición ilustrada con grabados y 16 láminas intercaladas en el texto (1908?), $4^{\text {a }}$ edición ilustrada con numerosos grabados y 4 láminas intercalados en el texto (1912), $5^{\text {a }}$ edición ilustrada (1920).

Notas: Obra premiada en la exposición escolar de Vitoria en 1894. Diploma de Honor y Diploma de Gran premio en las Exposiciones internacionales celebradas en París en 1899 y 1900.

Descripción: 356 p.; 22 cm. Ilustraciones de Evaristo Barrio.

Bibliotecas:

Biblioteca de la Diputación Provincial de Burgos.

Biblioteca del Ateneo Riojano, Logroño.

Biblioteca del Instituto de Estudios Riojanos, Logroño.

Biblioteca Nacional de España.

Biblioteca Pública de Castilla y León, Valladolid.

Biblioteca Pública Municipal de Jaca, Huesca.

CEINCE.

Catálogos: No aparece en ninguno de los catálogos de 1908, 1917, 1925, 1929.

Autor: Salvá Pérez, Anselmo.

Título: Compendio de Historia de España: primer grado.

Edición: $3^{\mathrm{a}}$ edición corregida (1910), $6^{\mathrm{a}}$ edición corregida (1910), $7^{\mathrm{a}}$ edición corregida (1930).

Descripción: 144 p.; 18 cm. Ilustraciones de Evaristo Barrio con cubierta en colores.

\section{Bibliotecas:}

Biblioteca de la Diputación Provincial de Burgos.

Biblioteca de la Universidad de Córdoba.

Biblioteca de la Universidad de Santiago de Compostela.

Biblioteca de la Universidad de Vigo. 
Biblioteca Pública Municipal de Sueca, Valencia.

CEINCE.

Catálogos: 1908 (en prensa), 1917 ( $4^{\mathrm{a}}$ edición), 1925 ( $7^{\mathrm{a}}$ edición corregida), 1929 (7 $7^{\mathrm{a}}$ edición).

Autor: Salvá Pérez, Anselmo.

Título: Compendio de Historia de España: segundo grado y grado superior.

Edición: $5^{\text {a }}$ edición corregida y ampliada por F.Y.A. (1927).

Descripción: 400 p.; $19 \mathrm{~cm}$. Ilustrada y añade 10 mapas.

Bibliotecas:

Biblioteca de la Diputación Provincial de Burgos.

Biblioteca de la Universidad de Hamburgo. Alemania (Staats-und Universitäsbibliothek Hamburg Carl von Ossietzky).

Biblioteca Pública de Castilla y León, Valladolid.

Catálogos: 1925 ( $5^{\text {a }}$ edición reformada), 1929 ( $5^{\text {a }}$ edición corregida y ampliada).

Autor: Salvá Pérez, Anselmo.

Título: Compendio de Historia de España: segundo grado.

Edición: $4^{a}$ edición.

Descripción: 232 p.; $18 \mathrm{~cm}$. Ilustrada.

Bibliotecas:

Biblioteca de la Diputación Provincial de Burgos.

Catálogos: 1917 ( $4^{\mathrm{a}}$ edición).

Autor: Nicolás Loriquet, Jean.

Título: Compendio de la Historia Sagrada y de la vida de Nuestro Señor Jesucristo.

Edición: Edición reformada y corregida por Mariano Rodríguez Miguel (1907), (1909), (1910).

Descripción: 162-173 páginas según ediciones; $16 \mathrm{~cm}$. En las primeras ediciones está encuadernado en pasta, la cubierta cromada, conteniendo fotograbados y seis láminas en color. Las ediciones posteriores mantienen las ilustraciones y encuadernación en pasta con cubierta de colores de Fortunato Julián.

\section{Bibliotecas:}

Biblioteca de la Diputación Provincial de Burgos.

Biblioteca de la Universidad Pontificia de Salamanca.

Biblioteca Pública de Asturias, Gijón

Biblioteca Pública de Castilla y León, Valladolid.

Bibliotecas del Seminario Diocesano de Segovia.

CEINCE. 
Catálogos: 1908, 1917, 1925, 1929.

Autor: Salvá Pérez, Anselmo.

Título: Compendio de ortografía castellana, según las reglas de la Real Academia Española.

Edición: (1893).

Descripción: 24 p.; $15 \mathrm{~cm}$. Encuadernado en cartulina fuerte.

Bibliotecas:

Biblioteca de la Universidad Pontificia de Salamanca.

Biblioteca Digital de Castilla y León.

Biblioteca Pública de Burgos.

Biblioteca Pública de Castilla y León, Valladolid.

Catálogos: 1908, 1917, 1925, 1929.

Autor: Desconocido.

Título: Compendio de reglas de pronunciación francesa.

Edición: (1911).

Descripción: 34 p.; $19 \mathrm{~cm}$.

Bibliotecas:

Biblioteca Pública de Burgos.

Catálogos: No aparece en ninguno de los catálogos de 1908, 1917, 1925, 1929.

Autor: Desconocido.

Título: Condiciones reglamentarias establecidas por la expresada compañía para el servicio de suministro de agua.

Edición: (1894), (1900).

Descripción: 16 p.; $22 \mathrm{~cm}$.

Bibliotecas:

Biblioteca de la Diputación Provincial de Burgos.

Catálogos: No aparece en ninguno de los catálogos de 1908, 1917, 1925, 1929.

Autor: Díez-Montero, Bonifacio.

Título: Consideraciones acerca de la beneficencia y mendicidad en Burgos.

Edición: (1904).

Descripción: 33 p.; $21 \mathrm{~cm}$.

Bibliotecas:

Biblioteca del Archivo Municipal de Burgos.

Catálogos: No aparece en ninguno de los catálogos de 1908, 1917, 1925, 1929. 
Autor: Palma Román, Angélica.

Título: Contando cuentos.

Edición: $1^{a}$ edición (1930).

Descripción: 134 p.; 25 cm. Ilustraciones de Antequera Azpiri.

Colección: Bibliotecas Rodríguez, 7.

Bibliotecas:

Biblioteca de la Universidad de Illinois. Estados Unidos (University of Illinois at Urbana Champaign).

Biblioteca de la Universidad de Illinois. Estados Unidos (University of Illinois, Latin American ARL Recon).

Biblioteca del Congreso en Washington. Estados Unidos.

Biblioteca del Consejo Superior de Investigaciones Científicas.

Biblioteca del Ministerio de Educación, Buenos Aires. Argentina.

Biblioteca Nacional de España.

La Biblioteca de la Universidad de Braunschweig. Alemania (Technische Universität Braunschweig).

Catálogos: 1929.

Autor: Ayuntamiento de Burgos.

Título: Contestación de la Compañía de Aguas de Burgos a la Memoria que la Comisión designada para el estudio de la municipalización del servicio de aguas.

Edición: (1930).

Descripción: 103 p.; $22 \mathrm{~cm}$.

Bibliotecas:

Biblioteca de la Diputación Provincial de Burgos.

Biblioteca Municipal Miguel de Cervantes, Burgos.

Biblioteca Pública de Burgos.

Biblioteca Pública José Celestino Mutis, Cádiz.

Catálogos: No aparece en ninguno de los catálogos de 1908, 1917, 1925, 1929.

Autor: Candendo, Santiago.

Título: Conversación telegráfica en francés para uso de los opositores al cuerpo de telégrafos.

Edición: (1910).

Descripción: 85 p.; $22 \mathrm{~cm}$.

Bibliotecas:

Biblioteca Nacional de España.

Biblioteca Pública de Burgos.

Catálogos: No aparece en ninguno de los catálogos de 1908, 1917, 1925, 1929. 
Autor: Rodríguez García, Jesús.

Título: Cooperación al estudio de la dacriocistitis.

Edición: (1909).

Descripción: 36 p.; $22 \mathrm{~cm}$.

\section{Bibliotecas:}

Biblioteca de la Universidad Complutense de Madrid (tesis de la Universidad Central, Facultad de Medicina, 1907).

Catálogos: No aparece en ninguno de los catálogos.

Autor: VV. AA.

Título: Cristina y su corderito: cuentos escogidos por varios autores nacionales y extranjeros.

Edición: (1920?).

Descripción: 118 p.; 21 cm. Ilustraciones de Isidro Gil.

Colección: Biblioteca Oro, 7.

Bibliotecas:

Biblioteca de la Diputación Provincial de Burgos.

Biblioteca Nacional de España.

CEINCE.

Catálogos: 1917 (en prensa), 1925, 1929.

Autor: Guardiola, Antonio.

Título: Cuatro niños maravillosos.

Edición: (1940?).

Descripción: 116 p.; $18 \mathrm{~cm}$. Con ilustraciones de Fortunato Julián y cubiertas al cromo y oro.

Colección: Biblioteca Oro, 9.

Bibliotecas:

Biblioteca Nacional de España.

Catálogos: 1929.

Autor: Karr i Alfonsetti, Carmen.

Título: Cuentos a mis nietos.

Edición: $1^{a}$ edición (1932).

Descripción: 96 p.; 25 cm. Ilustraciones de Rosario de Velasco.

Colección: Biblioteca Rodríguez.

Bibliotecas:

Biblioteca de la Universidad de Castilla La Mancha, Campus de Cuenca.

Biblioteca del IES Cardenal Cisneros, Madrid.

Biblioteca Nacional de España.

Biblioteca Pública de Burgos.

Catálogos: Posterior a los catálogos analizados. 
Autor: VV. AA.

Título: Cuentos cortos.

Edición: (19--).

Descripción: 128 p.; 18 cm. Ilustrado, con cubiertas al cromo y oro.

Colección: Biblioteca Oro, 2.

Bibliotecas:

Biblioteca Nacional de Maestros, Buenos Aires. Argentina

Catálogos: 1917, 1925, 1929

Autor: Ramírez Ángel, Emiliano.

Título: Cuentos de Pototo.

Edición: (1925).

Descripción: 126 p.; 25 cm. Ilustraciones de Francisco López Rubio.

Colección: Bibliotecas Rodríguez, 5.

Bibliotecas:

Biblioteca de la Universidad de Castilla La Mancha, Campus de Cuenca.

Biblioteca de la Universidad de Murcia.

Biblioteca Nacional de España.

CEINCE.

Catálogos: 1929.

Autor: Bueno Rodríguez-Arias, Ángel.

Título: Cuentos escogidos.

Edición: (1910).

Descripción: 207 p.; 22,5 cm. Ilustraciones de Isidro Gil. Encuadernado en pasta al cromo y oro.

Colección: Biblioteca Enciclopédica Hispano-Americana, 6.

Bibliotecas:

Biblioteca de la Diputación Provincial de Burgos.

Biblioteca de la Universidad de Harvard, Cambridge, Massachusetts. Estados Unidos.

Biblioteca de la Universidad de Toulouse. Francia (Univesité de ToulouseLe Mirail).

Biblioteca del Archivo Municipal de Burgos.

Biblioteca Nacional de España.

Biblioteca Pública de Castilla y León, Valladolid.

Biblioteca Pública de León.

Biblioteca Pública de Zamora.

Catálogos: 1908 (en prensa), 1917, 1925, 1929.

Autor: Bueno Rodríguez-Arias, Ángel.

Título: Cuentos mexicanos originales, inspirados en las costumbres de los antiguos mexicanos. 
Edición: $2^{a}$ edición (1905). Ed. facs. (2012).

Descripción: 196 p.; 22 cm. Ilustraciones de Evaristo Barrio.

Colección: Biblioteca Enciclopédica Hispano-Americana, 7.

Bibliotecas:

Biblioteca de la Universidad Autónoma de Madrid.

Biblioteca de la Universidad de Castilla La Mancha, Campus de Cuenca.

Biblioteca de la Universidad de Córdoba.

Biblioteca de la Universidad de Hamburgo. Alemania (Staats-un Universitätsbibliothek Hamburg Carl von Ossietzky).

Biblioteca de la Universidad de Miami. Estados Unidos (Otto G. Richter Library).

Biblioteca de la Universidad de Yale, New Haven, Connecticut. Estados Unidos.

Biblioteca de Stony Brook, Nueva York. Estados Unidos.

Biblioteca Digital de Castilla y León.

Biblioteca Nacional de España.

Biblioteca Pública de Castilla y León, Valladolid.

Catálogos: 1908, 1917, 1925, 1929.

Autor: Ossorio y Bernard, Manuel.

Título: Cuentos para los niños.

Edición: (1900).

Descripción: 368 p.; $21 \mathrm{~cm}$.

Bibliotecas:

Biblioteca Nacional de España.

Biblioteca Pública de Burgos.

Catálogos: 1917

Autor: León, Ma Teresa (1903-1988). Prólogo de María Teresa Goyri de Menéndez Pidal.

Título: Cuentos para soñar.

Edición: (1928). Reproducción de la edición de 1928. Instituto Municipal de Cultura. Burgos. 2003 y Edaf, 2000.

Descripción: 111 p.; 26 cm. Ilustraciones de Rosario Velasco.

Colección: Bibliotecas Rodríguez, 6.

Bibliotecas:

Biblioteca del Consejo Superior de Investigaciones Científicas.

Biblioteca Nacional de España.

Biblioteca Pública de Burgos.

Biblioteca Pública de Castilla y León, Valladolid.

CEINCE.

Catálogos: 1929. 
Autor: Méndez de Cuenca, Laura; Iriarte, Tomás de; Samaniego, Félix Mª Título: Cuentos y fábulas.

Edición: (19--).

Descripción: 64 p.; 22 cm. Ilustraciones de Evaristo Barrio.

Colección: Biblioteca Ideal, 1.

Bibliotecas:

Biblioteca de la Diputación Provincial de Burgos.

Biblioteca Pública de Burgos.

CEINCE.

Catálogos: 1917, 1925, 1929.

D

Autor: Ruiz de la Peña, Francisco.

Título: De la instrucción y la educación en España, de las industrias en general y de las clases productoras.

Edición: (1907).

Descripción: 153 p.; $20 \mathrm{~cm}$.

Bibliotecas:

Biblioteca Nacional de España.

Biblioteca Pública de Vitoria.

Bibliotecas del IES Conde Diego Porcelos, Burgos.

Catálogos: No aparece en ninguno de los catálogos de 1917, 1925, 1929.

Autor: Rodríguez Miguel, Mariano.

Título: Derecho usual: primer grado.

Edición: $3^{a}$ edición (1906), 6 a edición notablemente corregida (1915).

Descripción: 64 p.; $17 \mathrm{~cm}$. Ilustraciones de Evaristo Barrio. Cubierta al cromo y oro o en colores.

\section{Bibliotecas:}

Biblioteca de la Abadía de Santo Domingo de Silos, Burgos.

Biblioteca de la Diputación Provincial de Burgos.

Biblioteca de la Universidad de Córdoba.

Biblioteca de Las Islas Baleares.

Biblioteca del IES Cardenal López de Mendoza, Burgos

Biblioteca Nacional de España.

Biblioteca Pública de Burgos.

Catálogos: 1908 ( $2^{a}$ edición), 1917 (5 $5^{\text {a }}$ edición), 1925 (5 $5^{\text {a }}$ edición), 1929 (6 $6^{\text {a }}$ edición).

Autor: Desconocido.

Título: Devoción de los siete domingos de San José.

Edición: Nueva edición (1909). 
Descripción: 310 p.

\section{Bibliotecas:}

Biblioteca de la Universidad de Las Islas Baleares.

Catálogos: 1917, 1925, 1929.

Autor: Villén y Negro, León.

Título: Diccionario de contabilidad municipal.

Edición: (1889).

Notas: Impreso en la Imprenta y librería de Santiago Rodríguez Alonso.

Descripción: 492 y 593 p.; $31 \mathrm{~cm}$.

Bibliotecas:

Biblioteca del Archivo Municipal de Burgos.

Biblioteca Marqués de Piedras Albas, Ávila.

Biblioteca Pública de Burgos.

Catálogos: Es anterior a los Catálogos estudiados.

Autor: Prat, Ferdinand.

Título: Dionisio el Cartujano y los nuevos editores de sus obras.

Edición: (1897).

Descripción: 16 p.; $22 \mathrm{~cm}$.

\section{Bibliotecas:}

Biblioteca de la UNED, proyecto Manes.

Biblioteca de la Universidad Pontificia Comillas de Madrid.

Biblioteca Pública de Navarra.

Catálogos: No aparece en ninguno de los catálogos de 1908, 1917, 1925, 1929.

Autor: Ruiz Yanguas, Agustín.

Título: Discurso del profesor Don Agustín Ruiz Yanguas en la conferencia celebrada el día veinticinco de agosto de 1890.

Edición: (1890).

Notas: Impreso en la Imprenta y librería de Santiago Rodríguez Alonso.

Descripción: 22 p.; $22 \mathrm{~cm}$.

\section{Bibliotecas:}

Biblioteca del Archivo Municipal de Burgos.

Biblioteca Pública de Burgos.

Catálogos: No aparece en ninguno de los catálogos de 1908, 1917, 1925, 1929.

Autor: Ruiz Yanguas, Agustín.

Título: Discurso en la solemne distribución de Premios a los niños y niñas de las Escuelas Municipales, el día 2 de julio de 1891.

Edición: (1891). 
Descripción: 14 p.; $20 \mathrm{~cm}$.

\section{Bibliotecas:}

Biblioteca del Archivo Municipal de Burgos.

Biblioteca Pública de Burgos.

Catálogos: No aparece en ninguno de los catálogos de 1908, 1917, 1925, 1929.

Autor: Ruiz Yanguas, Agustín.

Título: Discurso en la solemne distribución de Premios a los niños y niñas de las Escuelas Municipales, el día 2 de julio de 1897.

Edición: (1897).

Descripción: 16 p.; $20 \mathrm{~cm}$.

Bibliotecas:

Biblioteca del Archivo Municipal de Burgos.

Catálogos: No aparece en ninguno de los catálogos de 1908, 1917, 1925, 1929.

Autor: Lázaro Castro, Domingo.

Título: Doctrina y vida cristianas y algunas notas de sagrada liturgia. Curso superior.

Edición: $5^{\text {a }}$ edición refundida y completada por Félix Fernández (1934).

Descripción: 509 p.; $20 \mathrm{~cm}$.

Bibliotecas:

Biblioteca de la Diputación Provincial de Burgos.

Biblioteca de la UNED, proyecto Manes.

Biblioteca de la Universidad Autónoma de Madrid.

Biblioteca de la Universidad de Cádiz.

Biblioteca Pública de Burgos.

Catálogos: No aparece en ninguno de los catálogos de 1908, 1917, 1925, 1929.

Autor: Álvarez Bollo Carretero, Mariana.

Título: Dos primos célebres: leyenda histórica.

Edición: (190?).

Descripción: 96 p.; 15,5 cm. Ilustraciones de Evaristo Barrio. Encuadernación en pasta fina y cubierta al cromo y oro.

Colección: Biblioteca Selecta, 3

Bibliotecas:

Biblioteca Pública de Castilla y León, Valladolid.

Biblioteca Pública de San Sebastián.

Catálogos: 1908, 1917, 1925, 1929. 
$\mathbf{E}$

Autor: Salvá Pérez, Anselmo.

Título: Educación indirecta: ligeros apuntes.

Edición: (1898).

Descripción: 143 p.; $21 \mathrm{~cm}$.

\section{Bibliotecas:}

Biblioteca de la Abadía de Santo Domingo de Silos, Burgos

Biblioteca de la Diputación Provincial de Burgos.

Biblioteca de la Facultad de Teología del Norte de España, Burgos.

Biblioteca de la Real Academia de Ciencias Morales y Políticas de Madrid.

Biblioteca de la Real Academia Española de Madrid.

Biblioteca de la Universidad de Bloomington, Indiana. Estados Unidos (Indiana University Bloomington).

Biblioteca de la Universidad de Columbia en Nueva York. Estados Unidos (Columbia University In the City of New York).

Biblioteca de la Universidad de Florida. Estados Unidos.

Biblioteca de la Universidad de Pensilvania. Estados Unidos (Pennsylvania State University Libraries).

Biblioteca de la Universidad de Toulouse, Francia (Université de ToulouseLe Mirail).

Biblioteca del Ateneo de Madrid.

Biblioteca del Consejo Superior de Investigaciones Científicas.

Biblioteca del IES Conde Diego Porcelos, Burgos

Biblioteca Museo Víctor Balaguer en Villanueva y Geltrú, Barcelona.

Biblioteca Nacional de España.

Biblioteca Pública de Burgos.

Catálogos: No aparece en ninguno de los catálogos de 1908, 1917, 1925, 1929.

Autor: VV. AA.

Título: El abandonado.

Edición: (1905).

Descripción: 128 p.; $18 \mathrm{~cm}$. Ilustrado con cubiertas al cromo y oro.

Colección: Museo de la Infancia.

Bibliotecas:

CEINCE.

Catálogos: 1908, 1917, 1925, 1929.

Autor: Eguilaz de Parada, Rosa.

Título: El abrigo escocés.

Edición: (19--). 
Descripción: 16 p.; 16 cm. Ilustraciones de Evaristo Barrio.

Colección: Cuentos para Niños, 58.

Bibliotecas:

Biblioteca de la Diputación Provincial de Burgos.

Catálogos: 1908, 1917, 1925, 1929. En los Catálogos de 1908 y 1917 no describe el título de las obras editadas.

Autor: Gil Muñiz, Alfredo.

Título: El alma de la Raza: (poesías dedicadas a España). Lecturas escolares escogidas.

Edición: (1927). Dedicatoria fechada por el autor.

Descripción: 308 p., $19 \mathrm{~cm}$. Ilustraciones originales, encuadernado en cartoné con elegante cubierta.

Colección: Hispania Mater; 2.

Bibliotecas:

Biblioteca de la UNED, proyecto Manes.

Biblioteca de la Universidad de Córdoba.

Biblioteca de la Universidad de Málaga.

Biblioteca de la Universidad de Murcia.

Biblioteca del Consejo Superior de Investigaciones Científicas.

Biblioteca del IES Cardenal Cisneros, Madrid.

Biblioteca Pública de Andalucía, Sevilla.

Biblioteca Pública de Málaga.

Catálogos: 1929.

Autor: Abate Sabatier, traducción de Juan de Escoiquiz.

Título: El amigo de los niños.

Edición: Nueva edición ilustrada (1895).

Descripción: 176 p.; $16 \mathrm{~cm}$. Ilustrada en blanco y negro, con encuadernación en pasta con tapas al cromo y posteriormente con cubierta en colores.

\section{Bibliotecas:}

Biblioteca del Seminario Diocesano Santa Catalina de Mondoñedo, Lugo.

Biblioteca Pública de San Sebastián.

CEINCE.

Catálogos: 1908 y 1917 (Edición corregida y aumentada con las Reglas de Urbanidad en verso), 1925, 1929.

Autor: Santiago Fuentes, Magdalena.

Título: El capricho de Susú.

Edición: (1915).

Descripción: 16 p.; $16 \mathrm{~cm}$.

Colección: Cuentos para los niños, 33. 


\section{Bibliotecas:}

Biblioteca Nacional de España.

Catálogos: 1917, 1925, 1929.

Autor: Gil Gabilondo, Isidro

Título: El Castillo de Loarre y El Alcázar de Segovia.

Edición: (1905).

Descripción: 78 p.; $28 \mathrm{~cm}$. Contiene 24 láminas de Isidro Gil, algunas con anotaciones personales.

\section{Bibliotecas:}

Biblioteca British St Pancras. Londres.

Biblioteca Central Militar. Instituto de Historia y Cultura Militar en Madrid.

Biblioteca de la Diputación Provincial de Burgos.

Biblioteca de la Universidad Complutense de Madrid.

Biblioteca de la Universidad de Burgos.

Biblioteca de la Universidad de Navarra.

Biblioteca de la Universidad de Paris. Francia (École nationale des Chartes).

Biblioteca de la Universidad de Toulouse. Francia (Université de ToulouseLe Mirail).

Biblioteca de la Universidad de Zaragoza.

Biblioteca del Archivo Municipal de Burgos.

Biblioteca del Consejo Superior de Investigaciones Científicas.

Biblioteca del Instituto Ibero-americano, Berlín. Alemania (IberoAmerikanisches Institut Preussischer Kulturbesitz Bibliothek).

Biblioteca del Museo de Burgos.

Biblioteca Digital de Castilla y León.

Biblioteca Municipal de Aranda de Duero, Burgos.

Biblioteca Nacional Británica, Wetherby, West Yorkshire. Inglaterra.

Biblioteca Nacional de España.

Biblioteca Pública de Ávila.

Biblioteca Pública de Burgos.

Biblioteca Pública de Castilla y León, Valladolid.

Biblioteca Pública Municipal de Calatayud, Zaragoza.

Catálogos: No aparece en ninguno de los catálogos de 1908, 1917, 1925, 1929.

Autor: Álvarez Álvarez, Jesús.

Título: El Cid y Cardeña.

Edición: (1900).

Descripción: 299 p.; 21 cm. Contiene 18 láminas y un mapa.

\section{Bibliotecas:}


Biblioteca de la Universidad de Navarra.

Catálogos: No aparece en ninguno de los catálogos de 1908, 1917, 1925, 1929.

Autor: Bueno Rodríguez-Arias, Ángel.

Título: El ciudadano: lecturas manuscritas.

Edición: Novísima edición ilustrada (1900).

Descripción: 168 p.; $16 \mathrm{~cm}$. Ilustrada a pluma por Evaristo Barrio con cubierta al cromo.

\section{Bibliotecas:}

Biblioteca de la Diputación Provincial de Burgos.

Biblioteca de la UNED, proyecto Manes.

Biblioteca de la Universidad de Castilla La Mancha, Campus de Cuenca.

Biblioteca del Consejo Superior de Investigaciones Científicas.

Biblioteca Digital de Castilla y León.

Biblioteca Nacional de España.

Biblioteca Pública de Burgos.

Biblioteca Pública de Castilla y León, Valladolid.

CEINCE.

Catálogos: 1908 (9ª edición), 1917 (17ª edición), 1925 (25 edición), 1929 (26 edición).

Autor: VV. AA.

Título: El cojito y otros cuentos.

Edición: (191-).

Notas: Contiene diversos cuentos: El cojito, El pequeño aeronauta, Juan el atolondrado y La codicia (leyenda árabe).

Descripción: 64 p.; $22 \mathrm{~cm}$. Ilustrado con cubierta en acuarela.

Colección: Biblioteca Ideal, 2.

Bibliotecas:

Biblioteca de la Diputación Provincial de Burgos.

Biblioteca del Archivo Municipal de Burgos.

Catálogos: 1917, 1925, 1929.

Autor: Bueno Rodríguez-Arias, Ángel.

Título: El Cristo yacente.

Edición: (1915).

Descripción: 15 p.; $16 \mathrm{~cm}$. Ilustrado en blanco y negro con cubierta al cromo.

Colección: Cuentos para Niños, 19.

Bibliotecas:

Biblioteca Nacional de España.

Catálogos: 1917, 1925, 1929. 
Autor: Salvá Pérez, Anselmo.

Título: El Día del Señor en Burgos.

Edición: $1^{a}$ edición (1900), $2^{a}$ edición (1937).

Descripción: 114 p.; $21 \mathrm{~cm}$.

Bibliotecas:

Archivo Silveriano de la Provincia Carmelitana O.C.D. Burgense, Burgos.

Biblioteca de la Abadía de Santo Domingo de Silos, Burgos.

Biblioteca de la Diputación Provincial de Burgos.

Biblioteca de la Universidad de Brigham Young, Harold B. Lee, Provo, Utah. Estados Unidos

Biblioteca del Archivo Histórico Provincial de Burgos.

Biblioteca del Archivo Municipal de Burgos.

Biblioteca del Consejo Superior de Investigaciones Científicas.

Biblioteca Digital de Castilla y León.

Biblioteca Nacional de España.

Biblioteca Pública de Burgos.

Biblioteca Pública de Castilla y León, Valladolid.

Catálogos: No aparece en ninguno de los catálogos de 1908, 1917, 1925, 1929.

Autor: Bueno Rodríguez-Arias, Ángel.

Título: El Divino Infante: Leyenda Bíblica.

Edición: (1900).

Descripción: 127 p.; 15,5 cm. Ilustrada por Evaristo Barrio con cubierta al cromo y oro.

Colección: Biblioteca Selecta, 4.

Bibliotecas:

Biblioteca de la Diputación Provincial de Burgos.

Biblioteca Pública de San Sebastián.

Centro Cervantino de La Roda, Albacete.

Catálogos: 1908, 1917, 1925, 1929.

Autor: Sturm, M.; Cousin, Luis; Tomás Cuchi. Recopilada por Antonio Moral.

Título: El educador o Maravillas de la creación, así en el reflejo de las plantas, como en el instituto de los cuadrúpedos, aves e insectos.

Edición: (1892).

Descripción: 249 p.; $17 \mathrm{~cm}$.

Bibliotecas:

Biblioteca de la Facultad de Teología del Norte de España, Burgos.

Biblioteca Nacional de España.

Biblioteca Pública de Burgos. 
Catálogos: No aparece en ninguno de los catálogos de 1908, 1917, 1925, 1929.

Autor: Comisión Burgalesa de Iniciativas Ferroviarias.

Título: El ferrocarril directo Madrid-Burgos.

Edición: (1932).

Descripción: 76 p.; $25 \mathrm{~cm}$. Con 1 mapa plegable e ilustrado.

Bibliotecas:

Biblioteca Pública de Museos de Gijón. Museo de ferrocarriles de Asturias. Biblioteca Pública de Navarra.

Catálogos: No aparece en ninguno de los catálogos de 1908, 1917, 1925, 1929.

Autor: VV. AA.

Título: El fin de una huelga y otros cuentos.

Edición: (191-).

Notas: Contiene diversos cuentos: El fin de una huelga, Una consulta original y Haz el bien sin mirar a quien.

Descripción: 62 p.; $23 \mathrm{~cm}$. Contiene ilustraciones en plana entera a color y en la cubierta tiene un dibujo en acuarela.

Colección: Biblioteca Ideal, 7.

Bibliotecas:

Biblioteca del Archivo Municipal de Burgos.

Catálogos: 1917, 1925, 1929.

Autor: Bendito y Trujillo, Enrique de.

Título: El hijo del Capitán Nemo: viajes y aventuras.

Edición: (189?).

Descripción: 428 p.; $26 \mathrm{~cm}$. Ilustrada y encuadernada con tapas al cromo y oro.

Colección: Biblioteca Azul y Rosa, 1.

Bibliotecas:

Biblioteca de la Diputación de Burgos.

Biblioteca de la Universidad de Castilla-La Mancha, Campus de Cuenca.

Biblioteca Nacional de España.

Biblioteca Pública de Castilla y León, Valladolid.

Catálogos: 1908 (Bajo el título: Los Hijos del Capitán Nemo y en prensa) 1917, 1925, 1929.

Autor: Salvá Pérez, Anselmo.

Título: El ideal de una niña.

Edición: (1897). 
Descripción: 202 p.; $17 \mathrm{~cm}$. Ilustraciones de Evaristo Barrio, encuadernado en pasta con cromos en las tapas.

\section{Bibliotecas:}

Biblioteca de la Diputación Provincial de Burgos.

Biblioteca Nacional de España.

Biblioteca Pública de Burgos.

Biblioteca Pública José Celestino Mutis de Cádiz.

CEINCE.

Instituto Bibliográfico Aragonés, Zaragoza.

Catálogos: 1908 ( $5^{\text {a }}$ edición), 1917 (9ª edición), 1925 ( $15^{\text {a }}$ edición), 1929 (16 edición).

En los distintos catálogos la descripción es diferente.

Autor: Galán, Manuel y Bueno Rodríguez-Arias, Ángel

Título: El libro de la naturaleza.

Edición: (1918).

Descripción: 118-121 p.; 24 cm. La cubierta es de Fortunato Julián.

Colección: Biblioteca Pro-Cultura, 3.

Bibliotecas:

Biblioteca de la Diputación Provincial de Burgos.

Biblioteca de la Junta de Andalucía.

Biblioteca de la Universidad Complutense de Madrid.

Biblioteca de la Universidad de Barcelona.

Biblioteca de la Universidad de Córdoba.

Biblioteca de la Universidad de Extremadura.

Biblioteca de la Universidad de Lérida.

Biblioteca de la Universidad de Salamanca.

Biblioteca de la Universidad de Santiago de Compostela.

Biblioteca de la Universidad de Valencia.

Biblioteca de la Universidad Pública de Navarra.

Biblioteca del Consejo Superior de Investigaciones Científicas.

Biblioteca del IES Cardenal Cisneros, Madrid.

Biblioteca Pública de Burgos.

Biblioteca Pública Municipal Lope de Vega, Ciudad Real.

CEINCE.

Catálogos: 1917, 1925, 1929.

Autor: Domínguez Berrueta, Martín.

Título: El libro de Historia. Lecturas instructivas sobre Historia Universal.

Edición: (1918).

Descripción: 122 p.; $24 \mathrm{~cm}$. Ilustrado con 10 fotograbados.

Colección: Biblioteca Pro-Cultura, 4. 


\section{Bibliotecas:}

Biblioteca Central Militar. Instituto de Historia y Cultura Militar, Madrid.

Biblioteca de la Diputación Provincial de Burgos.

Biblioteca de la Junta de Andalucía.

Biblioteca de la Universidad de Córdoba.

Biblioteca de la Universidad de Granada.

Biblioteca de la Universidad de Málaga.

Biblioteca de la Universidad de Valencia.

Biblioteca de la Universidad del Sur de Florida, Tampa. Estados Unidos.

Biblioteca del Consejo Superior de Investigaciones Científicas.

Biblioteca del IES Cardenal Cisneros, Madrid.

Biblioteca Pública de Burgos.

Biblioteca Pública de Castilla y León, Valladolid.

Biblioteca Pública Municipal de Borges Blanques, Lleida.

CEINCE.

Catálogos: 1917 (en prensa y en preparación), 1925, 1929.

Autor: Domínguez Berrueta, Martín.

Título: El libro de literatura: lecturas instructivas sobre los grandes autores, su vida y sus obras.

Edición: (1917).

Descripción: 106 p.; 24 cm. Ilustraciones de Evaristo Barrio.

Colección: Biblioteca Pro-Cultura, 2.

Bibliotecas:

Biblioteca Arqueológica Histórico Provincial de Lugo.

Biblioteca Central Militar. Instituto de Historia y Cultura Militar en Madrid.

Biblioteca de Cataluña, Barcelona.

Biblioteca de la Universidad de Castilla La Mancha, Campus de Cuenca.

Biblioteca de la Universidad de Córdoba.

Biblioteca de la Universidad de Granada.

Biblioteca de la Universidad de Lérida.

Biblioteca de la Universidad de Santiago de Compostela.

Biblioteca de la Universidad Pompeu Fabra, Barcelona.

Biblioteca del IES Cardenal Cisneros, Madrid.

Biblioteca Junta de Andalucía.

Biblioteca Pública de Burgos.

Biblioteca Pública de Castilla y León, Valladolid.

Biblioteca Pública de San Sebastián.

CEINCE.

Catálogos: 1917 (en preparación), 1925, 1929.

Autor: Menoyo Portalés, Ángel. 
Título: El libro de viajes.

Edición: (1917).

Descripción: 100 p.; $24 \mathrm{~cm}$. Ilustrado con diez dibujos y fotografías.

Colección: Biblioteca Pro-Cultura, 1.

Bibliotecas:

Biblioteca de la Diputación Provincial de Burgos.

Biblioteca de la Universidad de Barcelona.

Biblioteca de la Universidad de Castilla La Mancha, Campus de Cuenca.

Biblioteca de la Universidad de Córdoba.

Biblioteca de la Universidad de Murcia.

Biblioteca de la Universidad de Navarra.

Biblioteca del Consejo Superior de Investigaciones Científicas.

Biblioteca Junta de Andalucía.

Biblioteca Nacional de España.

Biblioteca Pública de Burgos.

Biblioteca Pública de Castilla y León, Valladolid.

CEINCE.

Catálogos: 1917, 1925, 1929.

Autor: Baldó Massanet, María.

Título: El Libro del Hogar.

Edición: $1^{a}$ edición (1933).

Descripción: 236, 320 p.; 19 cm. Ilustrada con 150 grabados y cubierta de Fortunato Julián.

\section{Bibliotecas:}

Biblioteca de la Diputación Provincial de Burgos.

Biblioteca de la UNED, proyecto Manes.

Biblioteca de la Universidad de Cantabria.

Biblioteca de la Universidad de Castilla La Mancha, Campus de Cuenca y

Ciudad Real.

Biblioteca de la Universidad Pública de Navarra.

Biblioteca de la Universidad Rovira i Virgili, Tarragona.

Biblioteca del Consejo Superior de Investigaciones Científicas.

Biblioteca Nacional de España.

Biblioteca Pública de Burgos.

Biblioteca Pública de Castilla y León, Valladolid.

CEINCE.

Catálogos: Posterior a los catálogos analizados.

Autor: VV. AA.

Título: El limpiabotas.

Edición: (1900?). 
Notas: Contiene diversos cuentos: El marquesito, El hijo del mar y A buen rey mejor vasallo (leyenda mexicana) de Ángel Bueno.

Descripción: 116 p.; $17 \mathrm{~cm}$. Con numerosas ilustraciones.

Colección: Museo de la Infancia.

\section{Bibliotecas:}

\section{CEINCE.}

Catálogos: 1908 (Museo de la Infancia, 20), 1917 (Museo de la Infancia, 12), 1925, 1929 (Museo de la Infancia, 10).

Autor: Pérez, Rogelio

Título: El malestar de la clase médica.

Edición: (1910), (1912).

Descripción: 196 p.; $20 \mathrm{~cm}$.

Bibliotecas:

Biblioteca de la Universidad Complutense de Madrid.

Biblioteca de la Universidad de Valencia.

Biblioteca Pública de Burgos.

Catálogos: No aparece en ninguno de los catálogos de 1908, 1917, 1925, 1929.

Autor: Osés Larumbe, José.

Título: El mejor tesoro.

Descripción: 136 p.; 20,5 cm. Ilustraciones a plana entera de Isidro Gil y Evaristo Barrio, con cubierta de cromo y oro de Evaristo Barrio.

Colección: Biblioteca Oro, 6.

Bibliotecas:

Biblioteca de la UNED, proyecto Manes.

Catálogos: 1917, 1925, 1929.

Autor: VV. AA.

Título: El músico callejero y otros cuentos y leyendas.

Edición: (191-).

Notas: Contiene diversos cuentos: El músico callejero de Alfredo Garzón Antón, Enriqueta de Hilario Garzón Gutiérrez, La bendición de los náufragos y Los niños caritativos de autores desconocidos.

Descripción: 64 p.; $23 \mathrm{~cm}$. Con numerosas ilustraciones.

Colección: Biblioteca Ideal, 3.

Bibliotecas:

CEINCE.

Catálogos: 1917, 1925, 1929.

Autor: Vega y Relea, Juvenal de.

Título: El mutualismo escolar. 
Edición: (19--).

Notas: Libreta de Mutualidad escolar. Edición Hijos de Santiago Rodríguez, válida para niños de doce años, 34 páginas en tamaño de $18 \mathrm{~cm}$. Trabajo premiado por la Caja de Ahorros Vizcaína en el Certamen pedagógico social celebrado en Guernica en 1925.

Descripción: 112 p.; $26 \mathrm{~cm}$.

Bibliotecas:

Biblioteca de la Universidad de Málaga.

Catálogos: 1929.

Autor: VV. AA.

Título: El niño en la tumba y otros cuentos morales.

Edición: (191-).

Notas: Contiene diversos cuentos: El niño en la tumba, Bajo Tiberio, La estrella de mar y Amor filial de Hilario Garzón Gutiérrez.

Descripción: 64 p.; $22 \mathrm{~cm}$. Con numerosas ilustraciones.

Colección: Biblioteca Ideal, 6.

Bibliotecas:

Biblioteca del Archivo Municipal de Burgos.

Catálogos: 1917, 1929 (Biblioteca Ideal, 7).

Autor: Berthoud, Samuel-Henry. Traducido por Francisco Rodríguez Miguel.

Título: El padrenuestro de Fenelón: Historia religiosa.

Edición: (1896), Novísima edición ilustrada (1897).

Descripción: 136 p.; $16 \mathrm{~cm}$. Ilustraciones de Evaristo Barrio, encuadernado en pasta con tapas al cromo o cubierta en colores.

\section{Bibliotecas:}

Biblioteca de la Diputación Provincial de Burgos.

Biblioteca Nacional de España.

Biblioteca Pública de Burgos.

Catálogos: 1908, 1917, 1925 (7ª edición), 1929.

Autor: Santocildes Barrio, Alejandro A. de.

Título: El padrino de los dos: drama en cuatro actos.

Edición: (1909).

Descripción: 47 p.; $21 \mathrm{~cm}$.

Bibliotecas:

Biblioteca Pública de Burgos.

Biblioteca Nacional de España.

Catálogos: No aparece en ninguno de los catálogos de 1908, 1917, 1925, 1929. 
Autor: Palacio Valdés, Armando.

Título: El pájaro en la nieve y otros cuentos.

Edición: (192-).

Descripción: 91 p.; 24 cm. Ilustraciones de Echea.

Colección: Biblioteca Rodríguez, 4.

Bibliotecas:

Biblioteca Pública de Asturias, Oviedo.

Biblioteca Pública de Ávila.

Biblioteca Pública de Mieres, Asturias.

Biblioteca Pública de Orihuela, Alicante.

Biblioteca Pública de Pola de Laviana, Asturias.

Biblioteca Pública Municipal de Jaca, Huesca.

Catálogos: 1925, 1929.

Autor: Andersen, Hans Christian; Grimm, Jacob y Wilhelm y otros.

Título: El paraíso de los niños: cuentos escogidos y morales.

Edición: (192?).

Descripción: 79 p.; $21 \mathrm{~cm}$. Con ilustraciones y con cubierta de 4 colores.

Colección: Cuentos de Ayer y de Hoy.

Bibliotecas:

Biblioteca Pública de Castilla y León, Valladolid.

Catálogos: 1929.

Autor: Garzón Antón, Alfredo.

Título: El pastorcillo.

Edición: (1920).

Descripción: 16 p.; 16 cm. Ilustraciones de Evaristo Barrio.

Colección: Cuentos para Niños, 50.

Bibliotecas:

Biblioteca de la Diputación Provincial de Burgos.

Catálogos: 1908, 1917, 1925, 1929. En los dos primeros catálogos no describe los títulos de los ejemplares.

Autor: Álvarez Carretero, Antonio.

Título: El previsor: lecturas utilísimas sobre artes, oficios, carreras, etc.

Edición: (1887) $2^{\mathrm{a}}$ edición, (1889) $3^{\mathrm{a}}$ edición), (1895) $5^{\mathrm{a}}$ edición ilustrada; novísima edición reformada cuidadosamente por Ángel Bueno (1896), 10 edición ilustrada por Isidro Gil y Evaristo Barrio, $11^{\mathrm{a}}$ edición (1900).

Descripción: 260 p.; $17,5 \mathrm{~cm}$. Ilustraciones con fotograbados, encuadernación en pasta y tapas al cromo o en colores.

\section{Bibliotecas:}

Biblioteca de la Abadía de Santo Domingo de Silos, Burgos.

Biblioteca de la Diputación Provincial de Burgos. 
Biblioteca de la Universidad Complutense de Madrid.

Biblioteca de la Universidad de Salamanca, España.

Biblioteca del Consejo Superior de Investigaciones Científicas.

Biblioteca del Seminario Diocesano Segovia.

Biblioteca del Seminario Mayor San José de Vigo, Pontevedra.

Biblioteca Nacional de España.

Biblioteca Pública de Burgos.

Biblioteca Pública de Castilla y León, Valladolid.

CEINCE.

Instituto Bibliográfico Aragonés, Zaragoza.

Catálogos: 1908 ( $8^{\mathrm{a}}$ edición), 1917 (9ª edición), 1925.

Autor: Izquierdo Saiz, Valero.

Título: El primer vuelo: método para la enseñanza simultánea de la lectura y escritura, dividido en cuatro partes.

Edición: 10ª edición ilustrada (1909), $8^{a}$ edición corregida (192?).

Notas: Premiada en la Exposición Pedagógica de Bilbao.

Descripción: 176 p.; $17,5 \mathrm{~cm}$. Con numerosas ilustraciones y tapas al cromo.

\section{Bibliotecas:}

Biblioteca de la Diputación Provincial de Burgos.

Biblioteca de la UNED, proyecto Manes.

Biblioteca de la Universidad de Murcia.

Biblioteca Pública de Castilla y León, Valladolid.

Biblioteca Pública Nodal de Orense.

Catálogos: 1908 ( $2^{\mathrm{a}}$ edición ilustrada con el título: El primer vuelo: arte gradual de lectura y escritura simultánea $), 1917$ ( $6^{\mathrm{a}}$ edición), 1925 (10 edición), 1929 (10ª edición).

Autor: Vega y Relea, Juvenal de.

Título: El problema de la selección y protección de los niños superdotados.

Edición: (1932).

Descripción: 120 p.; $18 \mathrm{~cm}$.

Bibliotecas:

Biblioteca de la Universidad Complutense de Madrid.

Biblioteca de la Universidad de Castilla La Mancha, Campus de Ciudad Real.

Biblioteca de la Universidad de Girona.

Biblioteca de la Universidad de Granada.

Biblioteca de la Universidad de La Rioja.

Biblioteca de la Universidad de León.

Biblioteca de la Universidad de Málaga. 
Biblioteca de la Universidad de Vigo.

Biblioteca de la Universidad Jaume I, Castellón.

Biblioteca del Consejo Superior de Investigaciones Científicas.

Biblioteca Nacional de España.

Biblioteca Pública de Cataluña, Barcelona.

Biblioteca Pública de Pontevedra.

Catálogos: No aparece en ninguno de los catálogos de 1908, 1917, 1925, 1929.

Autor: Giménez de V. y Mingo, Víctor.

Título: El progreso: silabario teórico-práctico.

Edición: $1^{\text {a }}$ edición (1884).

Descripción: 24 p.; $16 \mathrm{~cm}$.

Bibliotecas:

Biblioteca Pública de Burgos.

Catálogos: No aparece en ninguno de los catálogos de 1908, 1917, 1925, 1929.

Autor: Serrano, Luciano O.S.B., abad de Silos.

Título: El Real Monasterio de Santo Domingo de Silos (Burgos): su historia y tesoro artístico.

Edición: En página 125 figura la fecha de 1917, (1920), (1925?).

Descripción: 196 p.; $17 \mathrm{~cm}$. Contiene 36 fotograbados en papel estucado, con cubierta cuatricolor.

\section{Bibliotecas:}

Biblioteca de la Diputación Provincial de Burgos.

Biblioteca de la Universidad de Barcelona.

Biblioteca de la Universidad de Deusto.

Biblioteca de la Universidad de Oviedo.

Biblioteca de la Universidad Politécnica de Madrid.

Biblioteca del Archivo Histórico Provincial de Burgos.

Biblioteca del Archivo Histórico Provincial de Valladolid.

Biblioteca del Archivo Municipal de Burgos.

Biblioteca del convento de los Sagrados Corazones de Miranda de Ebro, Burgos.

Biblioteca del IES Brianda de Mendoza, Guadalajara.

Biblioteca del IES Cardenal Cisneros, Madrid.

Biblioteca del Seminario Mayor San José, Vigo.

Biblioteca digital de Castilla y León.

Biblioteca La Casona de Tudanca, Cantabria.

Biblioteca Municipal Miguel de Cervantes, Burgos.

Biblioteca Museo Arqueológico de Asturias.

Biblioteca Nacional de España. 
Biblioteca Pública de Burgos.

Biblioteca Pública de Castilla La Mancha, Toledo.

Biblioteca Pública de Castilla y León, Valladolid.

Biblioteca Pública de San Sebastián.

Biblioteca Pública de Tudela, Navarra.

Biblioteca Pública Jovellanos de Asturias.

Biblioteca Pública Municipal Carles Ros, Valencia.

Biblioteca Pública Regional de Murcia.

Centro Cultural de los Ejércitos, Madrid.

Centro de Estudios Extremeños, Badajoz.

Museo de América, Madrid.

Catálogos: 1929.

Autor: Arreglado por el R. P. Ignacio de la Cruz Baños.

Título: El Reinado Social del Sagrado Corazón de Jesús en las familias cristianas.

Edición: (1917), $2^{\text {a }}$ edición corregida (1926).

Descripción: 400 p.; $17 \mathrm{~cm}$. Encuadernación en tela, plancha dorada y canto rojo.

Colección: Devocionario.

Bibliotecas:

Archivo Silveriano de la Provincia Carmelitana O.C.D. Burgense, Burgos.

Biblioteca de la Universidad de Deusto.

Biblioteca de la Universidad de Santiago de Compostela.

Biblioteca del Colegio Sagrados Corazones de Miranda de Ebro, Burgos.

Biblioteca Nacional de España.

Catálogos: 1925, 1929.

Autor: A. R. B.

Título: El Secretario: estilo general de cartas.

Edición: Novísima edición (1897), $4^{a}$ edición (1898).

Descripción: 224 p.; $16 \mathrm{~cm}$.

Bibliotecas:

Biblioteca de la Abadía de Santo Domingo de Silos, Burgos.

Biblioteca de la Diputación Provincial de Orense.

Biblioteca de la Universidad Iberoamericana. México DF.

Biblioteca Pública de Castilla y León, Valladolid.

Catálogos: 1908, 1917 (4ª edición), 1925 (6ª edición), 1929 (7ª edición).

Autor: Rodríguez Miguel, Mariano.

Título: El vendedor de periódicos.

Edición: (1915). 
Descripción: 16 p.; $16 \mathrm{~cm}$. Ilustraciones en blanco y negro, cubierta a colores.

Colección: Cuentos para Niños, 6 .

Bibliotecas:

Biblioteca Nacional de España.

Catálogos: 1908, 1917, 1925, 1929.

Autor: García de Diego, Vicente (1878-1978).

Título: Elementos de gramática histórica gallega.

Edición: (1909). La fecha aparece en la cubierta.

Descripción: 200 p.; 22 cm.

Bibliotecas:

Biblioteca Arqueológica do Reino de Galicia, A Coruña

Biblioteca Central de Capuchinos. Provincia de Navarra, Cantabria y Aragón, Pamplona.

Biblioteca de la Universidad de Castilla La Mancha, Campus de Ciudad Real.

Biblioteca de la Universidad de Deusto.

Biblioteca de la Universidad de Islas Baleares.

Biblioteca de la Universidad de Salamanca.

Biblioteca de la Universidad de Santiago de Compostela.

Biblioteca de la Universidad de Vigo.

Biblioteca de la Universidad Politécnica de Madrid.

Biblioteca de la Universidad Rey Juan Carlos.

Biblioteca del Colegio Sagrado Corazón, León.

Biblioteca del Consejo Superior de Investigaciones Científicas.

Biblioteca del IES Cardenal Cisneros, Madrid.

Biblioteca del Museo Provincial de Pontevedra.

Biblioteca Nacional de España.

Biblioteca Pública de Córdoba.

Biblioteca Pública de Oviedo

Biblioteca Xunta de Galicia

Centro Superior Bibliográfico de Galicia, Santiago de Compostela.

Diputación Provincial de Ourense.

Catálogos: No aparece en ninguno de los catálogos de 1908, 1917, 1925, 1929.

Autor: García de Diego, Vicente.

Título: Elementos de gramática latina: para usos de institutos y seminarios.

Edición: (1904).

Descripción: 263 p.; 22 cm.

Bibliotecas: 
Biblioteca Municipal de Aranda de Duero, Burgos.

Biblioteca Nacional de España.

Biblioteca Pública de Pontevedra.

Museo Provincial de Pontevedra.

Catálogos: No aparece en ninguno de los catálogos de 1908, 1917, 1925, 1929.

Autor: Bueno Rodríguez-Arias, Ángel.

Título: Emilín.

Edición: (1901).

Descripción: 127 p.; 18 cm. Con ilustraciones de Isidro Gil y de Evaristo Barrio. Encuadernado con tapas al cromo.

Colección: Museo de la Infancia.

Bibliotecas:

Biblioteca de la Universidad de Castilla La Mancha, Campus de Cuenca.

Catálogos: 1908 y 1917 (Museo de la Infancia), 1925, 1929.

Autor: Bueno Rodríguez-Arias, Ángel.

Título: En el campo: Lecturas educativas y ordenadas sobre agricultura racional. Primer grado.

Edición: $3^{\text {a }}$ edición (1912).

Descripción: 102 p.; 16,5 x 11,5 cm. Con ilustraciones y tapas al cromo.

Bibliotecas:

Biblioteca de la Diputación Provincial de Burgos.

Biblioteca de la Universidad de Lérida.

Biblioteca de la Universidad de Murcia.

Biblioteca de la Universidad de Salamanca.

Biblioteca de la Universidad Politécnica de Madrid.

Biblioteca del IES Cardenal Cisneros, Madrid.

Biblioteca Nacional de España.

CEINCE.

Catálogos: 1908 (en prensa con el título: En el campo. Nociones de Agricultura), 1917 (4ª edición), 1925 (5ª edición).

Autor: Bueno Rodríguez-Arias, Ángel.

Título: En el Campo: lecturas educativas y ordenadas, sobre agricultura racional: segundo grado.

Edición: (1909).

Descripción: 380 p.; $16 \mathrm{~cm}$. Ilustraciones con fotograbados y dibujos. Encuadernado en pasta y cubierta en colores.

\section{Bibliotecas:}

Biblioteca de la Diputación Provincial de Burgos.

Biblioteca de la UNED, proyecto Manes. 
Biblioteca de la Universidad Complutense de Madrid.

Biblioteca de la Universidad de Lérida.

Biblioteca de la Universidad de Salamanca.

Biblioteca de la Universidad Pública de Navarra.

Biblioteca Nacional de España.

Biblioteca Pública de Asturias, Gijón.

Biblioteca Pública Municipal Lope de Vega, Ciudad Real.

CEINCE.

Catálogos: 1908 (en prensa con el título: En el campo. Nociones de Agricultura), 1917 ( $2^{\text {a }}$ edición), 1925 ( $2^{\text {a }}$ edición), 1929 (3 ${ }^{\text {a }}$ edición corregida).

Autor: Garzón Gutiérrez, Hilario.

Título: Enriqueta.

Edición: (1920).

Descripción: 16 p.; $16 \mathrm{~cm}$. Con ilustraciones en blanco y negro y cubierta a color.

Colección: Cuentos para Niños, 38.

Bibliotecas:

Biblioteca de la Diputación Provincial de Burgos.

Catálogos: 1908 y 1917 (Museo de la Infancia), 1925, 1929.

Autor: Orío y Rubio, Millán.

Título: Epítome de la gramática de la lengua española.

Edición: 9a edición (1900), 11 a edición (19--).

Descripción: 120 p.; $17 \mathrm{~cm}$.

Bibliotecas:

Biblioteca de la Universidad de Navarra.

Biblioteca de la Universidad de Santiago de Compostela.

Biblioteca de la Universidad Pontificia de Salamanca.

Biblioteca del Consejo de Investigaciones Científicas.

Biblioteca del Instituto de Estudios Riojanos, Logroño.

Biblioteca del Seminario Diocesano. Facultad de Teología de Vitoria.

Biblioteca Pública de Castilla y León, Valladolid.

Biblioteca Pública La Rioja.

Catálogos: 1917 (No aparece en los catálogos siguientes).

Autor: Gil Muñiz, Alfredo.

Título: España histórica y artística: (ciudades-museos, monumentos y narraciones heroicas): lecturas escolares escogidas.

Edición: Prólogo fechado en 1929.

Descripción: 179 p.; 19 cm. Con ilustraciones.

Bibliotecas: 
Biblioteca de la Diputación Provincial de Burgos.

Biblioteca de la Universidad de Córdoba.

Biblioteca del Consejo Superior de Investigaciones Científicas.

Biblioteca del IES Conde Diego Porcelos, Burgos.

Biblioteca Nacional de España.

Biblioteca Pública de Castilla y León, Valladolid.

Biblioteca Pública de Málaga.

Catálogos: 1929 (en prensa).

Autor: Gil Muñiz, Alfredo

Título: España regional y pintoresca: (paisajes, tipos y costumbres). Lecturas escolares escogidas.

Edición: (1929).

Descripción: 388 p.; 19 cm. Con ilustraciones.

\section{Bibliotecas:}

Biblioteca de la Diputación Provincial de Burgos.

Biblioteca de la Universidad Autónoma de Madrid.

Biblioteca de la Universidad de Castilla La Mancha, Campus de Toledo.

Biblioteca de la Universidad de Córdoba.

Biblioteca de la Universidad de Deusto.

Biblioteca de la Universidad de Málaga.

Biblioteca del IES Cardenal Cisneros, Madrid

Biblioteca Nacional de España.

Biblioteca Pública de Andalucía, Sevilla.

Biblioteca Pública de Castilla y León, Valladolid.

Biblioteca Pública de Córdoba.

Biblioteca Pública de Málaga.

Biblioteca Pública de Villaharta, Córdoba

Biblioteca Seminario Menor San Torcuato en Guadix, Granada.

Catálogos: 1929.

Autor: Desconocido.

Título: España, ante el Estatuto catalán: asamblea celebrada en Burgos los días 16 y 17 de enero de 1932.

Edición: (1932).

Descripción: 14 p.; $23 \mathrm{~cm}$.

Bibliotecas:

Biblioteca del Archivo Municipal de Burgos.

Catálogos: Posterior a los catálogos analizados.

Autor: Cooperativa de Casas Baratas (Aunós).

Título: Estatutos de la Cooperativa de Casas Baratas (Aunós).

Edición: (1929). 
Descripción: 6 p.; $18 \mathrm{~cm}$.

Bibliotecas:

Biblioteca de la Diputación Provincial de Burgos.

Catálogos: Posterior a los catálogos analizados.

Autor: Asociación del Fomento del Turismo de Burgos.

Título: Estatutos. Asociación del Fomento de Turismo de Burgos.

Edición: (1912).

Descripción: 12 p.; 22 cm. Precede al título: VII Centenario de las Navas de Tolosa.

\section{Bibliotecas:}

Biblioteca del Archivo Municipal de Burgos.

Catálogos: No aparece en los catálogos analizados de 1908, 1917, 1925 y 1929.

\section{$\mathbf{F}$}

Autor: Chave y Castilla, Julián.

Título: Fábulas.

Edición: $3^{\text {a }}$ edición (1890).

Descripción: 144 p.; 25 cm.

Bibliotecas:

Biblioteca de la Universidad de Burgos.

Catálogos: 1929.

Autor: Samaniego, Félix María.

Título: Fábulas en verso castellano: para las escuelas de instrucción primaria.

Edición: Novísima edición ilustrada (1898).

Descripción: 176 p.; 16 cm. Con lustraciones de Evaristo Barrio y cubierta de Fortunato Julián, con tapas al cromo o con tapas en colores.

Bibliotecas:

Biblioteca de la Abadía de Santo Domingo de Silos, Burgos.

Biblioteca de la Diputación Provincial de Burgos.

Biblioteca de la UNED, proyecto Manes.

Biblioteca de la Universidad americana en Dubai. Emiratos Árabes (American University of Dubai).

Biblioteca de la Universidad de Pretoria. Sudáfrica (UNISA. Muckleneuk campus).

Biblioteca de la Universidad privada de Gaborone. Botswana (ABM University Collage).

Biblioteca de la Universidad privada de Yeddah. Arabia Saudita (DAR ALHekma Collage). 
Biblioteca del Colegio Sagrados Corazones de Miranda de Ebro, Burgos. Biblioteca del IES Cardenal Cisneros, Madrid.

Biblioteca en Abu Dhabi. Emiratos Árabes (Emirates Center for Strategic Studes \& Research).

Biblioteca en Isa Town. Bahrein en la School Bahrain Bayan.

Biblioteca Nacional de España.

Biblioteca Pública de Burgos.

Biblioteca Pública de Castilla y León, Valladolid.

Biblioteca Pública de San Sebastián.

CEINCE.

Catálogos: 1908 (Edición especial de la casa con 58 fotograbados con el título: Fábulas literarias), 1917, 1925, 1929.

Autor: Iriarte, Tomás de.

Título: Fábulas literarias.

Edición: (1897), Nueva edición ilustrada y aumentada con algunas fábulas póstumas del autor (1935).

Descripción: 112 p.; $16 \mathrm{~cm}$. Con ilustraciones de Evaristo Barrio y Fortunato Julián. Cubierta al cromo o en colores.

\section{Bibliotecas:}

Biblioteca de la Abadía de Santo Domingo de Silos, Burgos.

Biblioteca de la Diputación Provincial de Burgos.

Biblioteca de La Rioja, Logroño.

Biblioteca del Instituto Cervantes, Madrid.

Biblioteca Nacional de España.

Biblioteca Pública de Almería.

Biblioteca Pública de Castilla y León, Valladolid.

Biblioteca Pública de San Sebastián.

CEINCE.

Instituto Bibliográfico Aragonés. Zaragoza.

Catálogos: 1908, 1917, 1925, 1929.

Autor: P. Croisset, S.J., compendiadas por Antonio Moral.

Título: Festividades de la Iglesia.

Edición: (1888). $3^{\text {a }}$ edición ilustrada (1897).

Notas: Impreso inicialmente en la Imprenta y librería de Santiago Rodríguez Alonso.

Descripción: 156 p.; 16 x $11 \mathrm{~cm}$. Con grabados, encuadernado con pastas y tapas al cromo.

\section{Bibliotecas:}

Biblioteca de la Universidad Autónoma de Madrid.

Biblioteca Nacional de España.

Catálogos: 1908 ( (2 edición ilustrada), 1917 (4ª edición), 1929. 
Autor: Ruiz Yanguas, Agustín.

Título: Fin religioso y social de la instrucción primaria: medios para su consecución.

Edición: (1889).

Notas: Impreso en la Imprenta y librería de Santiago Rodríguez Alonso. Composición premiada en el Certamen pedagógico de las Ferias y Fiestas de San Pedro y San Pablo de 1889.

Descripción: 37 p.; $23 \mathrm{~cm}$.

Bibliotecas:

Biblioteca del Archivo Municipal de Burgos.

Biblioteca Pública de Burgos.

Catálogos: Es anterior a los Catálogos analizados.

Autor: Francés y Gutiérrez, Rogelio.

Título: Fisiología e higiene.

Edición: Portada: Primer grado y grado medio, $5^{\text {a }}$ edición (1906), (1910), $6^{\mathrm{a}}$ edición (1925)

Descripción: 112 p.; 16,5 cm. Con fotograbados y tapas al cromo y oro.

Bibliotecas:

Biblioteca de la Diputación Provincial de Burgos.

Biblioteca de la Universidad de Córdoba.

Biblioteca Nacional de España.

Biblioteca Pública de Castilla y León, Valladolid.

Catálogos: 1908 (novísima edición), 1917 (4ª edición), 1925 (6ª edición), 1929.

G

Autor: Desconocido

Título: Gasparín.

Edición: (1922).

Descripción: 11 p.; $14 \mathrm{~cm}$. Con ilustraciones y cubierta estampada en colores.

Colección: Regalo de Reyes, 5.

Bibliotecas:

Biblioteca de la Diputación Provincial de Burgos.

Catálogos: 1925, 1929.

Autor: Osés Larumbe, José.

Título: Geografía para niños: primer grado. 
Edición: $7^{\mathrm{a}}$ edición, $9^{\mathrm{a}}$ edición, $11^{\mathrm{a}}$ edición, $12^{\mathrm{a}}$ edición, $13^{\mathrm{a}}$ edición ilustrada por Evaristo Barrio (1925), 14 a edición corregida e ilustrada (1932), 15 a edición (1932).

Descripción: 128 p.; $16 \mathrm{~cm}$. Con ilustraciones y 8 mapas y grabados, 1 mapa de España en color. Tapas al cromo y cubierta de colores.

\section{Bibliotecas:}

Biblioteca de la Diputación Provincial de Burgos.

Biblioteca de la UNED, proyecto Manes.

Biblioteca de la Universidad de La Coruña.

Biblioteca de la Universidad de Murcia.

Biblioteca de la Universidad de Santiago de Compostela.

Biblioteca de la Universidad de Vigo.

Biblioteca del Consejo de Investigaciones Científicas.

Biblioteca Junta de Andalucía, Sevilla.

Biblioteca Pública de Castilla y León, Valladolid.

Biblioteca Pública de León.

Biblioteca Pública de San Sebastián.

CEINCE.

Catálogos: 1908 ( $1^{\text {a }}$ edición), 1917 (7ª edición), 1925 (13ª edición), 1929 (14 edición).

Autor: Osés Larumbe, José.

Título: Geografía para niños: segundo grado.

Edición: $3^{\mathrm{a}}$ edición, $4^{\mathrm{a}}$ edición, $6^{\mathrm{a}}$ edición corregida a los datos más recientes (1925), $7^{\mathrm{a}}$ edición (1929).

Descripción: 272 p.; $17,5 \mathrm{~cm}$. Con ilustraciones y 7 mapas a doble página en colores y 70 fotograbados y dibujos. Tapas al cromo y cubierta en colores.

\section{Bibliotecas:}

Biblioteca de la Diputación Provincial de Burgos.

Biblioteca de la UNED, proyecto Manes.

Biblioteca de la Universidad Complutense de Madrid.

Biblioteca de la Universidad de Cantabria.

Biblioteca de la Universidad de Córdoba.

Biblioteca de la Universidad de Murcia.

Biblioteca de la Universidad de Vigo.

Biblioteca del Consejo de Investigaciones Científicas.

Biblioteca Pública de Castilla y León, Valladolid.

CEINCE.

Catálogos: 1908 (en prensa), 1917 ( $3^{\text {a }}$ edición), 1925 ( $6^{\text {a }}$ edición corregida y aumentada con las divisiones políticas de los Nuevos Estados), 1929 (7 edición corregida y aumentada). 
Autor: Reca, Lorenzo.

Título: Gramática castellana: clase de ingreso.

Edición: (1932).

Descripción: 120 p.; $19 \mathrm{~cm}$.

Bibliotecas:

Biblioteca de la Universidad Autónoma de Madrid.

Catálogos: Posterior a los catálogos analizados.

Autor: Nuñez y Muriel, Guillermo.

Título: Gramática elemental de la lengua castellana.

Edición: $2^{a}$ edición (1905).

Notas: En la portada expresa que es una obra declarada de mérito por Consejo de Instrucción Pública y adoptada en varios Institutos.

Descripción: 226 p.; 24 cm.

\section{Bibliotecas:}

Biblioteca de la UNED, proyecto Manes.

Biblioteca Nacional de España.

\section{CEINCE.}

Museo Provincial de Pontevedra.

Catálogos: No aparece en ninguno de los catálogos de 1908, 1917, 1925, 1929.

Autor: Balneario de Cucho (Burgos).

Título: Guía indicador de los baños y aguas sulfurosas cálcicassulfhídricas de Cucho (Burgos) condado de Treviño: temporada oficial de 25 de junio a 25 de septiembre.

Edición: (1900).

Descripción: 26 p.; $13 \mathrm{~cm}$.

Bibliotecas:

Biblioteca de la Universidad Complutense de Madrid.

Catálogos: No aparece en ninguno de los catálogos de 1908, 1917, 1925, 1929.

\section{$\mathbf{H}$}

Autor: Domínguez Berrueta, Martín.

Título: Historias de la Historia.

Edición: (1920?).

Descripción: 104 p.; $19 \mathrm{~cm}$. Con ilustraciones de Evaristo Barrio y cubiertas en tela inglesa.

Colección: Mundial Biblioteca, 6

Bibliotecas:

Biblioteca de la Universidad de Valencia. 
Catálogos: 1917 (en prensa), 1925, 1929.

Autor: Domínguez Berrueta, Martín.

Título: Historias de D. Quijote.

Edición: (1913). Reproducción de la edición de 1913. Instituto Municipal de Cultura. Burgos (2005)

Descripción: 127 p.; 18 cm. Ilustraciones de Evaristo Barrio.

Contenido: Mundial Biblioteca, 1.

Bibliotecas:

Biblioteca de la Junta de Andalucía, Sevilla.

Biblioteca de la Diputación Provincial de Burgos.

Biblioteca de la Universidad de Burgos.

Biblioteca de la Universidad de Granada.

Biblioteca de la Universidad Estatal de Wayne, Detroit. Estados Unidos.

Biblioteca del Archivo Municipal de Burgos.

Biblioteca del Consejo Superior de Investigaciones Científicas.

Biblioteca del IES Cardenal Cisneros, Madrid.

Biblioteca McFarlin de la universidad de Tulsa, Oklahoma. Estados Unidos

(The University of Tulsa, Mcfarlin Library)

Biblioteca Mullins de la Universidad de Arkansas. Estados Unidos

(University of Arkansas-Fayetteville, David W. Mullins Library).

Biblioteca Municipal de Aranda de Duero, Burgos.

Biblioteca Nacional de España.

Biblioteca Nacional de México.

Biblioteca Pública de Órgiva de Granada.

Biblioteca Pública de San Sebastián.

Biblioteca Regional de Madrid Joaquín Leguina.

Biblioteca San Pedro de Alcántara de Málaga.

Centro Cervantino de la Roda, Albacete.

Catálogos: 1917, 1925, 1929.

Autor: Menoyo y Portalés, Ángel.

Título: Historias de Gil Blas.

Edición: (1914), (1923).

Descripción: 148 p.; 18 cm. Con ilustraciones de Evaristo Barrio.

Colección: Biblioteca Mundial, 5.

Bibliotecas:

Biblioteca de la Diputación Provincial de Burgos.

Biblioteca del Consejo Superior de Investigaciones Científicas.

Biblioteca del IES Cardenal Cisneros, Madrid.

Biblioteca Nacional de Australia, Canberra. Australia.

Biblioteca Nacional de España.

Biblioteca Pública de Castilla y León, Valladolid. 
Biblioteca Pública Jovellanos, Gijón.

Catálogos: 1917, 1925, 1929.

Autor: Zurita y Rodríguez, Marciano.

Título: Historias de Zorrilla.

Edición: (1913).

Descripción: 135 p.; 18 cm. Con ilustraciones de Evaristo Barrio.

Colección: Mundial Biblioteca, 3.

Bibliotecas:

Biblioteca de la Diputación Provincial de Burgos.

Biblioteca de la Fundación Instituto Juan March, Madrid.

Biblioteca de la Junta de Andalucía, Sevilla.

Biblioteca de la Universidad Complutense de Madrid.

Biblioteca de la Universidad de Murcia.

Biblioteca del Archivo Municipal de Burgos.

Biblioteca del Consejo Superior de Investigaciones Científicas.

Biblioteca del Instituto Ibero-Americano, Berlín. Alemania.

Biblioteca Digital de Castilla y León.

Biblioteca Pública de Castilla y León, Valladolid.

Catálogos: 1917, 1925, 1929.

\section{$\mathbf{I}$}

Autor: Vázquez Campo, Antonio.

Título: Ideario notarial: naturaleza y desenvolvimiento del poder legitimador del Estado.

Edición: (1928).

Descripción: 136 p.; $21 \mathrm{~cm}$.

Bibliotecas:

Biblioteca de la Universidad Autónoma de Madrid.

Biblioteca de la Universidad de Córdoba.

Biblioteca de la Universidad de Málaga.

Biblioteca de la Universidad de Santiago de Compostela.

Biblioteca del Senado en Madrid.

Catálogo: No aparece en los catálogos analizados.

Autor: Instituto General y Técnico de Burgos. Leída por Rodrigo Sebastián y Rives.

Título: Instituto de Burgos: memoria acerca de su estado durante el curso académico de 1904 a 1905.

Edición: (1905).

Descripción: 56 p.; $27 \mathrm{~cm}$.

Bibliotecas: 
Biblioteca Pública de Segovia.

Biblioteca Pública de Vitoria.

Catálogos: No aparece en ninguno de los catálogos de 1908, 1917, 1925, 1929.

Autor: Instituto General y Técnico de Burgos. Leída por Eloy García de Quevedo y Concellón.

Título: Instituto de Burgos: memoria acerca de su estado durante el curso académico de 1905 a 1906.

Edición: (1907).

Descripción: 62 p.; $27 \mathrm{~cm}$.

Bibliotecas:

Biblioteca Pública de Burgos.

Catálogos: No aparece en ninguno de los catálogos de 1908, 1917, 1925, 1929.

Autor: Instituto General y Técnico de Burgos. Leída por Eloy García de Quevedo y Concellón.

Título: Instituto de Burgos: memoria acerca de su estado durante el curso académico de 1906 a 1907.

Edición: (1908).

Descripción: 58 p.; $27 \mathrm{~cm}$.

Bibliotecas:

Biblioteca del Archivo Municipal de Burgos.

Catálogos: No aparece en ninguno de los catálogos de 1908, 1917, 1925, 1929.

Autor: Instituto General y Técnico de Burgos. Leída por Eloy García de Quevedo y Concellón.

Título: Instituto de Burgos: memoria acerca de su estado durante el curso académico de 1907 a 1908.

Edición: (1908).

Descripción: 56 p.; $27 \mathrm{~cm}$.

Bibliotecas:

Biblioteca del Archivo Municipal de Burgos.

Biblioteca Pública de Vitoria.

Catálogos: No aparece en ninguno de los catálogos de 1908, 1917, 1925, 1929.

Autor: Instituto General y Técnico de Burgos. Leída por Eloy García de Quevedo y Concellón.

Título: Instituto de Burgos: memoria acerca de su estado durante el curso académico de 1908 a 1909. 
Edición: (1910).

Descripción: 74 p.; 27 cm.

Bibliotecas:

Biblioteca del Archivo Municipal de Burgos.

Catálogos: No aparece en ninguno de los catálogos de 1908, 1917, 1925, 1929.

Autor: Instituto General y Técnico de Burgos. Leída por Eloy García de Quevedo y Concellón.

Título: Instituto de Burgos: memoria acerca de su estado durante el curso académico de 1910 a 1911.

Edición: (1911).

Descripción: 68 p.; $27 \mathrm{~cm}$.

Bibliotecas:

Biblioteca del Archivo Municipal de Burgos.

Catálogos: No aparece en ninguno de los catálogos de 1908, 1917, 1925, 1929.

Autor: Instituto General y Técnico de Burgos. Leída por Eloy García de Quevedo y Concellón.

Título: Instituto de Burgos: memoria acerca de su estado durante el curso académico de 1912 a 1913.

Edición: (1913).

Descripción: 72 p.; $27 \mathrm{~cm}$.

Bibliotecas:

Biblioteca del Archivo Municipal de Burgos.

Catálogos: No aparece en ninguno de los catálogos de 1908, 1917, 1925, 1929.

Autor: Instituto General y Técnico de Burgos. Leída por Eloy García de Quevedo y Concellón.

Título: Instituto de Burgos: memoria acerca de su estado durante el curso académico de 1915 a 1916.

Edición: (1916).

Descripción: 62 p.; $27 \mathrm{~cm}$.

Bibliotecas:

Biblioteca de la Diputación Provincial de Burgos.

Biblioteca Municipal de Aranda de Duero, Burgos.

Catálogos: No aparece en ninguno de los catálogos de 1908, 1917, 1925, 1929.

Autor: Magallón, Mariano.

Título: Instrucciones para el manejo del planímetro polar de Ausler. 
Edición: (1912).

Descripción: 14 p.; $15 \mathrm{~cm}$.

Bibliotecas:

Biblioteca Nacional de España.

Catálogos: No aparece en ninguno de los catálogos de 1908, 1917, 1925, 1929.

J

Autor: Rodríguez Miguel, Mariano.

Título: Jesucristo haciendo el bien: ejemplos, milagros y parábolas.

Edición: (1920).

Descripción: 102 p.; $15,5 \mathrm{~cm}$. Con ilustraciones y cubierta al cromo y oro.

Colección: Biblioteca Selecta, 2

Bibliotecas:

Biblioteca de la Diputación Provincial de Burgos.

Catálogos: 1908, 1917, 1925, 1929 (Jesucristo sembrando el bien).

Autor: Bueno Rodríguez-Arias, Ángel

Título: José o El soñador cananeo. Leyenda bíblica.

Edición: (193-).

Descripción: 115 p.; $15,5 \mathrm{~cm}$. Con ilustraciones y cubierta al cromo y oro.

Colección: Biblioteca Selecta, 1.

Bibliotecas:

Biblioteca del Archivo Municipal de Burgos.

Biblioteca Pública de Castilla y León, Valladolid.

Biblioteca Pública de San Sebastián.

Catálogos: 1908, 1917, 1925 (Biblioteca Selecta, 5), 1929 (Historia de José).

Autor: Álvarez Bollo Carretero, Mariana.

Título: Judit: Leyenda bíblica.

Edición: (19--?).

Descripción: 103 p.; 16 cm. Con 11 dibujos originales.

Colección: Biblioteca Selecta, 5.

Bibliotecas:

Biblioteca de la Universidad de Castilla La Mancha, Campus de Cuenca.

Biblioteca de la Universidad de Harvard, Cambridge, Massachusetts.

Estados Unidos.

Biblioteca Pública de Las Palmas, Canarias.

Biblioteca Pública de San Sebastián.

Catálogos: 1908 y 1917 (en prensa), 1925, 1929. 
Autor: Andrade y Uribe, Benito Mariano.

Título: Juegos florales en Burgos.

Edición: (1902).

Descripción: 16 p.; 27 cm. Discurso leído el 4 de julio de 1902.

Bibliotecas:

Biblioteca de la Diputación Provincial de Burgos.

Catálogos: No aparece en ninguno de los catálogos de 1908, 1917, 1925, 1929.

Autor: Bustos Barredo, Mateo.

Título: Justicia divina: drama en tres actos y en prosa.

Edición: (1905).

Descripción: 31 p.; $19 \mathrm{~cm}$.

Bibliotecas:

Biblioteca Nacional de España.

Biblioteca Pública de Burgos.

Catálogos: No aparece en ninguno de los catálogos de 1908, 1917, 1925, 1929.

$\mathbf{L}$

Autor: León, $\mathrm{M}^{\mathrm{a}}$ Teresa.

Título: La bella del mal amor: cuentos literarios.

Edición: $1^{a}$ edición (1930).

Descripción: 159 p.; 22 cm. Con ilustraciones de Rosario de Velasco.

Bibliotecas:

Biblioteca de la Universidad de Extremadura.

Biblioteca de la Universidad de Utrecht. Holanda.

Biblioteca de la Universidad de Valladolid.

Biblioteca de la Universidad Jean Monnet, St. Etienne. Francia.

Biblioteca Estatal de Bavaria, Munich. Alemania.

Biblioteca Nacional de España.

Biblioteca Nacional de Francia, París.

Biblioteca Pública de Burgos.

Biblioteca Pública Jovellanos, Gijón.

Catálogos: Es posterior a los catálogos analizados.

Autor: VV. AA.

Título: La bruja.

Edición: (1902).

Descripción: 127 p.; $18 \mathrm{~cm}$. Con varias ilustraciones de Evaristo Barrio y encuadernado con tapas al cromo. 
Colección: Museo de la Infancia.

\section{Bibliotecas:}

Biblioteca de la Universidad de Castilla La Mancha, Campus de Cuenca.

Catálogos: 1908 y 1917, 1925, 1929.

Autor: Hidalgo Rey, Encarnación.

Título: La caída de la hoja.

Edición: (1900).

Descripción: 16 p.; $16 \mathrm{~cm}$. Con ilustraciones de Evaristo Barrio.

Colección: Cuentos para Niños, 63.

Bibliotecas:

Biblioteca de la Diputación Provincial de Burgos.

Catálogos: 1908?, 1917?, 1925, 1929.

Autor: B. de A.

Título: La Cartuja de Miraflores.

Edición: (1899).

Descripción: 78 p.; $20 \mathrm{~cm}$. Con ilustraciones de J. A. Cortés.

Bibliotecas:

Archivo Silveriano de la Provincia Carmelitana O.C.D. Burgense, Burgos.

Biblioteca de la Abadía de Santo Domingo de Silos, Burgos

Biblioteca de la Diputación Provincial de Burgos.

Biblioteca de la Facultad de Teología de Vitoria.

Biblioteca de la Facultad de Teología del Norte de España, Burgos.

Biblioteca de la Real Academia de la Historia. Madrid.

Biblioteca de la Universidad de Oviedo.

Biblioteca de la Universidad de Santiago de Compostela.

Biblioteca de la Universidad de Sevilla.

Biblioteca de la Universidad Pontificia Comillas de Madrid.

Biblioteca de Museo Arqueológico de Asturias, Gijón.

Biblioteca del Consejo Superior de Investigaciones Científicas.

Biblioteca Digital de Castilla y León.

Biblioteca Municipal Miguel de Cervantes, Burgos.

Biblioteca Pública de Castilla y León, Valladolid.

Biblioteca Pública Episcopal del Seminario de Barcelona.

Biblioteca Pública Jovellanos, Gijón.

Centro de Investigación del Patrimonio Etnológico [CIPE]. Museo del Traje. Madrid.

Catálogos: No aparece en ninguno de los catálogos de 1908, 1917, 1925, 1929.

Autor: Dotor y Municio, Ángel. Prólogo del Sr. Marceliano Santa María.

Título: La Catedral de Burgos: guía histórico-descriptiva. 
Edición: $2^{a}$ edición (1928). Edición de lujo y edición normal en formato más pequeño.

Descripción: 316 p.; 20 cm. Con 60 páginas de láminas ilustradas.

\section{Bibliotecas:}

Biblioteca Archivo Municipal de Burgos.

Biblioteca Auxiliar Museo de Santa Cruz, Toledo.

Biblioteca de la Diputación Provincial de Burgos.

Biblioteca de La Rioja, Logroño.

Biblioteca de la Universidad Autónoma de Madrid.

Biblioteca de la Universidad de Barcelona.

Biblioteca de la Universidad de Cantabria.

Biblioteca de la Universidad de Deusto.

Biblioteca de la Universidad de Extremadura, Badajoz.

Biblioteca de la Universidad de Granada.

Biblioteca de la Universidad de Las Palmas de Gran Canaria.

Biblioteca de la Universidad de Navarra.

Biblioteca de la Universidad de Valladolid.

Biblioteca de la Universidad Politécnica de Madrid.

Biblioteca de la Universidad Politécnica de Valencia.

Biblioteca de la Universidad San Pablo-CEU.

Biblioteca del Consejo Superior de Investigaciones Científicas.

Biblioteca del IES Goya, Zaragoza.

Biblioteca del Instituto de Estudios Riojanos, Logroño.

Biblioteca del Instituto Nacional de Administración Pública en Madrid.

Biblioteca del Museo de Burgos.

Biblioteca del Museo Nacional de Artes Decorativas en Madrid.

Biblioteca del Seminario Mayor San José de Vigo.

Biblioteca del Seminario Obispado Priorato de Ciudad Real.

Biblioteca del Senado en Madrid.

Biblioteca Municipal de Aranda de Duero, Burgos.

Biblioteca Municipal Miguel de Cervantes, Burgos.

Biblioteca Pública de Burgos.

Biblioteca Pública de Castilla y León, Valladolid.

Biblioteca Pública de Ciudad Real.

Biblioteca Pública de Palma de Mallorca.

Biblioteca Pública de Pontevedra.

Biblioteca Pública de Teruel.

Biblioteca Pública de Zamora.

Biblioteca Pública Municipal de Calatayud, Zaragoza.

Biblioteca Pública Municipal de Llanes, Asturias.

Catálogos: 1929

Autor: Campo Moreno, José 
Título: La corteza.

Edición: facs. (2006).

Descripción: 15 p.; $16 \mathrm{~cm}$. Con lustraciones en blanco y negro y portada a color.

Colección: Cuentos para Niños, 59.

Bibliotecas:

Biblioteca Pública de Burgos.

Catálogos: 1908, 1917?, 1925, 1929.

Autor: VV. AA.

Título: La cuenta del doctor y otros cuentos morales.

Edición: (1920).

Notas: Contiene diversos cuentos: La cuenta del doctor, El buen hermano de Hilario Garzón Gutiérrez, Dar posada al peregrino.

Descripción: 64 p.; 23 cm. Con ilustraciones de Evaristo Barrio.

Colección: Biblioteca Ideal.

Bibliotecas:

Biblioteca del Archivo Municipal de Burgos.

Biblioteca de la Diputación Provincial de Burgos.

Catálogos: 1917 (número 5), 1929 (número 8). En el catálogo de 1925 no aparece.

Autor: Ossorio y Bernard, Manuel.

Título: La cuadratura del círculo.

Edición: (189-).

Descripción: 16 p.; $16 \mathrm{~cm}$. Con ilustraciones de Evaristo Barrio y cubierta a color.

Colección: Biblioteca Cuentos para Niños, 5.

Bibliotecas:

Biblioteca de la Diputación Provincial de Burgos.

Catálogos: 1908, 1917, 1925, 1929.

Autor: Bueno Rodríguez-Arias, Ángel.

Título: La educación por la vista.

Edición: $3^{\text {a }}$ edición (1906), (1907), $5^{\text {a }}$ edición corregida y aumentada (1917), $7^{a}$ edición corregida (1925).

Descripción: Paginación variable según las ediciones; $22 \mathrm{~cm}$. Contiene de 800 a 850 fotograbados según ediciones y encuadernada con tapas al cromo.

\section{Bibliotecas:}

Biblioteca de la UNED, proyecto Manes.

Biblioteca de la Universidad de Berkeley, California. Estados Unidos (UC Berkeley Libraries) 
Biblioteca de la Universidad de Castilla La Mancha, Campus de Cuenca. Biblioteca de la Universidad de Córdoba.

Biblioteca de la Universidad de La Laguna.

Biblioteca de la Universidad de Richmond, California. Estados Unidos (University of California NRLF, Northern Regional Library Facility).

Biblioteca de la Universidad de Toulouse. Francia (Université de ToulouseLe Mirail).

Biblioteca de la Universidad Pontificia Comillas de Madrid.

Biblioteca de la Universidad Pública de Navarra.

Biblioteca Nacional de España.

Biblioteca Pública de Aranda de Duero, Burgos.

Biblioteca Pública de Castilla y León, Valladolid.

Biblioteca Pública de San Sebastián.

CEINCE.

Catálogos: 1908,1917 ( $5^{\text {a }}$ edición corregida y aumentada), 1925 ( $7^{\text {a }}$ edición corregida, 800 fotograbados, 260 p.; encuadernado con tapas al cromo), 1929 (Solo publicita el Libro del Maestro, ya que la obra es de sobra conocido).

Autor: Bueno Rodríguez-Arias, Ángel.

Título: La educación por la vista. Libro del maestro.

Descripción: 31 p.; $22 \mathrm{~cm}$.

\section{Bibliotecas:}

Biblioteca de la Universidad de Castilla La Mancha. Escuela Universitaria del Profesorado de EGB, Campus de Ciudad Real.

Catálogos: No aparece en ninguno de los catálogos de 1908, 1917, 1925, 1929.

Autor: Santiago Fuentes, Magdalena.

Título: La escuela y la patria: lecturas manuscritas para niñas.

Edición: (1898), (1899), (1902), $7^{\mathrm{a}}$ edición ilustrada (1905), $8^{\mathrm{a}}$ y $9^{\mathrm{a}}$ edición

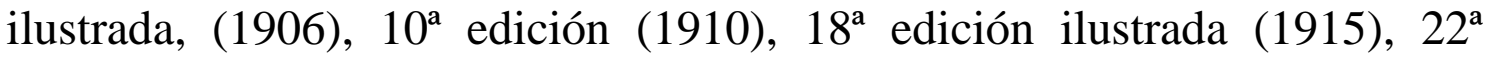
edición con ilustraciones de Evaristo Barrio (1925), 23 ${ }^{\mathrm{a}}$ y $24^{\mathrm{a}}$ edición, $25^{\mathrm{a}}$ edición (1930), 26a $, 27^{\mathrm{a}}, 28^{\mathrm{a}}$ y $29^{\mathrm{a}}$ edición reformada (1943), $1^{\mathrm{a}}$ edición impresa en caracteres de imprenta (1937), $2^{a}$ edición en caracteres de imprenta, (1938), $3^{\mathrm{a}}$ edición en caracteres de imprenta (1940), , $4^{\mathrm{a}}$ edición en caracteres de imprenta (1943).

Descripción: 160 p.; $16 \mathrm{~cm}$. Con ilustraciones de Evaristo Barrio. (Fortunato Julián en la $27^{\mathrm{a}}$ edición reformada, $2^{\mathrm{a}}$ edición en caracteres de imprenta). Tapas al cromo o cubierta en colores.

\section{Bibliotecas:}

Biblioteca Central de Madrid.

Biblioteca de la Diputación Provincial de Burgos. 
Biblioteca de la Facultad de Teología del Norte de España, Burgos. Biblioteca de la Universidad Complutense de Madrid.

Biblioteca de la Universidad de A Coruña.

Biblioteca de la Universidad de Castilla La Mancha, Campus de Cuenca.

Biblioteca de la Universidad de Navarra.

Biblioteca de la Universidad de Salamanca.

Biblioteca de las Parroquias de Arnedo, La Rioja.

Biblioteca del Consejo Superior de Investigaciones Científicas.

Biblioteca Nacional de España.

Biblioteca Pública de Burgos.

Biblioteca Pública de Castilla y León, Valladolid.

Biblioteca Pública Municipal de Estella, Navarra.

Biblioteca Pública Nodal de Vigo, Pontevedra.

Biblioteca UNED, proyecto Manes.

Bibliotecas Eclesiásticas Segovia. Monasterio de Santo Domingo el Real, Segovia.

CEINCE.

Catálogos: 1908 ( $8^{\text {a }}$ edición), 1917 (15ª edición), 1925 (22ª edición), 1929 ( $24^{\mathrm{a}}$ edición).

Autor: Two Captains

Título: La Guerra Europea.

Edición: (1914).

Descripción: 112 p.; $20 \mathrm{~cm}$. Contiene 4 croquis del teatro de la guerra en doble página. Cubierta en color.

\section{Bibliotecas:}

Biblioteca de la Universidad de Córdoba.

Biblioteca de la Universidad de Deusto, Bilbao.

Biblioteca de la Universidad de Extremadura.

Biblioteca de la Universidad de Harvard, Cambridge, Massachusetts. Estados Unidos.

Biblioteca de la Universidad de Las Palmas de Gran Canaria.

Biblioteca de la Universidad Pontificia Comillas de Madrid.

Biblioteca Nacional de España.

Biblioteca Pública Marqués de Piedras Albas, Ávila.

Centro Cultural de los Ejércitos en Madrid.

Catálogos: 1917, 1925.

Autor: Varios autores.

Título: La hija del desterrado: colección de cuentos.

Edición: (1919). 
Notas: Contiene diversos cuentos: La hija del desterrado de Mateo Bustamante, Un genio de Isidro Gil y El espejo de María de autor desconocido.

Descripción: 64 p.; $23 \mathrm{~cm}$. Contiene 12 láminas ilustradas a color.

Colección: Biblioteca Ideal, 8.

\section{Bibliotecas:}

Biblioteca de la Diputación Provincial de Burgos.

Catálogos: 1917, 1925 (Biblioteca Ideal, 4).

Autor: Maestre, Estanislao.

Título: La hija del usurero.

Edición: (1914).

Descripción: 128 p.; $18 \mathrm{~cm}$. Con ilustraciones a color en página entera de Isidro Gil. Encuadernación en tela inglesa.

Colección: Mundial Biblioteca, 4.

\section{Bibliotecas:}

Biblioteca de la Universidad de Deusto, Bilbao.

Biblioteca de la Universidad de Málaga.

Biblioteca de la Universidad de Valladolid.

Biblioteca de la Universidad Weslayana de Indiana, Marion. Estados Unidos (Jackson Library).

Biblioteca de la Universidad Weslayana de Ohio, Delaware. Estados Unidos.

Biblioteca del IES Cardenal Cisneros, Madrid.

Biblioteca Nacional de España.

Biblioteca Nacional de Santiago de Chile. Chile.

Catálogos: 1917, 1925, 1929.

Autor: Andrade y Uribe, Benito Mariano.

Título: La Iglesia y la política: (católicos y liberales).

Edición: (1911).

Descripción: 340 p.; $21 \mathrm{~cm}$.

\section{Bibliotecas:}

Biblioteca de la Universidad Autónoma de Barcelona.

Biblioteca de la Universidad Complutense de Madrid.

Biblioteca de la Universidad de Barcelona.

Biblioteca de la Universidad de Deusto, Bilbao.

Biblioteca de la Universidad de San Antonio, Texas. Estados Unidos (Texas A\&M University-San Antonio).

Biblioteca de la Universidad de West, Rosemead, California. Estados Unidos.

Biblioteca de la Wheaton Collage, Illinois. Estados Unidos (Wheaton Collage-Buswell Library). 
Biblioteca del IES Cardenal López de Mendoza, Burgos.

Biblioteca del Archivo Municipal de Burgos.

Biblioteca Digital Hathi Trust, Michigan. Estados Unidos.

Biblioteca Nacional de España.

Biblioteca Provincial en Lugo.

Biblioteca Pública de Ávila.

Catálogos: 1929.

Autor: Pérez Nieva, Alfonso.

Título: La madre pequeñita.

Edición: (1900).

Descripción: 15 p.; $16 \mathrm{~cm}$. Con ilustraciones de Evaristo Barrio.

Colección: Cuentos para Niños, 1.

Bibliotecas:

Biblioteca de la Diputación Provincial de Burgos.

Catálogos: 1908, 1917, 1925, 1929.

Autor: Gonzalo Morón, Dolores.

Título: La mejor fiesta.

Edición: (19-?).

Descripción: 16 p.; $16 \mathrm{~cm}$. Con ilustraciones.

Colección: Cuentos para Niños, 57.

Bibliotecas:

Biblioteca de la UNED, proyecto Manes.

Catálogos: 1908, 1917, 1925, 1929.

Autor: Ebro Fernández, $\mathrm{M}^{\mathrm{a}}$ Cruz.

Título: La niña: novela feminista.

Edición: (1917), (1918).

Descripción: 304 p.; $20 \mathrm{~cm}$. Cubierta en colores.

Bibliotecas:

Biblioteca de la Diputación Provincial de Burgos.

Biblioteca de la Universidad de Colorado. Estados Unidos (University of

Colorado at Boulder).

Biblioteca de la Universidad de Deusto, Bilbao.

Biblioteca Municipal de Aranda de Duero, Burgos.

Biblioteca Nacional de España.

Biblioteca Pública Nodal de Ourense.

Catálogos: 1925.

Autor: Santiago-Fuentes, Magdalena.

Título: La novela de la infancia.

Edición: (192?), (1931). 
Descripción: 184 p.; 22 cm. Con ilustraciones de Evaristo Barrio.

Contenido: Biblioteca Enciclopédica Hispano-Americana, 10.

Bibliotecas:

Biblioteca de la Junta de Andalucía, Sevilla.

Biblioteca de la Universidad de Castilla La Mancha, Campus de Cuenca.

Biblioteca de la Universidad de Córdoba.

Biblioteca de la Universidad de Oviedo.

Biblioteca del Archivo Municipal de Burgos.

Biblioteca del IES Cardenal Cisneros, Madrid.

Biblioteca Nacional de España.

Biblioteca Pública de Burgos.

Biblioteca Pública de Castilla y León, Valladolid.

Biblioteca Pública Municipal de la Puebla de Híjar, Teruel.

Catálogos: 1917 (en prensa), 1925, 1929.

Autor: Sarmiento Lasuén, José.

Título: La obra de Manjón: memoria-discurso.

Edición: (1910).

Descripción: 15 p.; $23 \mathrm{~cm}$.

Bibliotecas:

Biblioteca del IES Cardenal López de Mendoza, Burgos.

Biblioteca Digital de Castilla y León.

Biblioteca Nacional de España.

Biblioteca Pública de Burgos.

Biblioteca Pública de Castilla y León, Valladolid.

Catálogos: No aparece en ninguno de los catálogos de 1908, 1917, 1925, 1929.

Autor: G. Sánchez Román, José.

Título: La práctica del idioma en la Escuela Primaria.

Edición: $1^{a}$ edición (1931).

Descripción: 97 p.; $18 \mathrm{~cm}$.

Bibliotecas:

Biblioteca de la Universidad de Málaga.

Biblioteca de la Universidad de Murcia.

Biblioteca de la Universidad de Salamanca.

Biblioteca de la Universidad de Vigo.

Biblioteca del IES Cardenal Cisneros, Madrid.

Biblioteca Nacional de España.

Catálogos: No aparece en ninguno de los catálogos de 1908, 1917, 1925, 1929.

Autor: Antequera Azpiri, Pedro. 
Título: La publicidad artística para todos.

Edición: (1928).

Descripción: 223 p.; $25 \mathrm{~cm}$. Con 100 ilustraciones en negro y bicolor y 5 láminas tricolor. Cubierta en colores.

\section{Bibliotecas:}

Biblioteca de la Universidad de Burgos.

Biblioteca de la Universidad Pompeu Fabra, Barcelona.

Biblioteca del Consejo Superior de Investigaciones Científicas.

Biblioteca Nacional de México.

Biblioteca Púbica de Castilla y León, Valladolid.

Catálogos: 1929.

Autor: Tarín y Juaneda, Francisco.

Título: La Real Cartuja de Miraflores: su historia y descripción.

Edición: (1896), (1897), $2^{a}$ edición ilustrada (compendio de la edición $1^{\text {a }}$ de 1896), (1924), $3^{a}$ edición ilustrada con 40 fotograbados y dibujos (Compendio de la $1^{a}$ edición de 1.896) (1924), $2^{a}$ edición ilustrada (1926). Reproducción facsímil de la $3^{\mathrm{a}}$ edición ilustrada con 40 fotograbados y dibujos (Compendio de la $1^{\mathrm{a}}$ ed. de 1896).

Descripción: 244 p.; $18 \mathrm{~cm}$.; 30 fotograbados, encuadernado con lomo y puntas de tela y cubierta de colores.

\section{Bibliotecas:}

Archivo Biblioteca de los Barones de Valdeolivos en Fonz, Huesca.

Ateneo Riojano en Logroño.

Biblioteca Auxiliar del Archivo Histórico Nacional de Madrid.

Biblioteca Convento de San Pablo, Palencia.

Biblioteca de la Abadía Benedictina de Valvanera, La Rioja.

Biblioteca de la Abadía de Santo Domingo de Silos, Burgos.

Biblioteca de la Diputación Provincial de Burgos.

Biblioteca de la Provincia Franciscana de Castilla-La Mancha OFM San Juan de los Reyes, Toledo.

Biblioteca de la Universidad de Navarra.

Biblioteca de la Universidad de Oviedo.

Biblioteca de la Universidad de Valencia.

Biblioteca de la Universidad de Vic. Barcelona.

Biblioteca de la Universidad Pontificia Comillas de Madrid.

Biblioteca del Archivo Histórico Provincial de Burgos.

Biblioteca del Archivo Municipal de Burgos.

Biblioteca del Archivo Municipal de Sevilla.

Biblioteca del Colegio Sagrados Corazones de Miranda de Ebro, Burgos.

Biblioteca del Convento de San Pablo, Palencia.

Biblioteca del I.E.R. [Instituto de Estudios Riojanos], gobierno de La Rioja. Biblioteca del Museo de Burgos. 
Biblioteca del Museo Nacional de Artes Decorativas en Madrid.

Biblioteca del Seminario Diocesano de Segovia.

Biblioteca Digital de Castilla y León.

Biblioteca Estatal de Berlín. Prussian Cultural Heritage, Berlín. Alemania.

Biblioteca Franciscana de Santa María La Real de Nájera, La Rioja.

Biblioteca Municipal de Briviesca, Burgos.

Biblioteca Municipal Gonzalo de Berceo, Burgos.

Biblioteca Municipal Miguel de Cervantes, Burgos.

Biblioteca Nacional de España.

Biblioteca Pública Cánovas del Castillo, Málaga.

Biblioteca Pública de Ávila.

Biblioteca Pública de Burgos.

Biblioteca Pública de Castilla y León, Valladolid.

Biblioteca Pública de La Rioja, Logroño.

Biblioteca Pública de Lazkao. Gordailua, Gipuzkoa.

Biblioteca Pública de Llanes, Asturias.

Biblioteca Pública de Loyola. Gipuzkoa.

Biblioteca Pública de Oviedo, Asturias.

Biblioteca Pública de San Sebastián.

Biblioteca Pública Regional de Murcia.

Instituto Nacional de Administración Pública, Madrid.

Palacio Arzobispal, Patrimonio Diocesano de la Iglesia, Zaragoza.

Santuario de Loyola. Azpeitia, Guipúzcoa.

Catálogos: 1929.

Autor: Romo Bayo, Simona.

Título: La riqueza del alma: libro de lecturas religioso-morales escrito para las niñas.

Edición: (1901).

Descripción: 287 p.; $17 \mathrm{~cm}$.

Bibliotecas:

Biblioteca de la Universidad de Deusto.

Catálogos: No aparece en ninguno de los catálogos.

Autor: VV. AA.

Título: La serpiente y otros cuentos.

Edición: (191-).

Notas: Contiene diversos cuentos: La serpiente, La pesca, El amigo de los pájaros y Batalla campal.

Descripción: 64 p.; $23 \mathrm{~cm}$. Con ilustración y con cubierta con acuarela por Evaristo Barrio.

Colección: Biblioteca Ideal, 6 .

Bibliotecas: 
Biblioteca del Archivo Municipal de Burgos.

Biblioteca Pública de Castilla y León, Valladolid.

Catálogos: 1917, 1925 y 1929 (Biblioteca Ideal, 6),

Autor: Rodríguez de Francés, Elpidia.

Título: La tiranuela.

Edición: (1915).

Descripción: 16 p.; $16 \mathrm{~cm}$. Con ilustraciones.

Colección: Cuentos para Niños, 43.

Bibliotecas:

Biblioteca Nacional de España.

Catálogos: 1908, 1917, 1925, 1929.

Autor: Pérez Nieva, Alfonso

Título: La tortilla de magia.

Edición: (190-).

Descripción: 15 p.; 16 cm. Con ilustraciones de Evaristo Barrio.

Colección: Cuentos para Niños, 25.

Bibliotecas:

CEINCE

Catálogos: 1908, 1917, 1925, 1929.

Autor: Puerta, Hernán de la

Título: La "Unión Nacional de Maestros" y el presupuesto de Instrucción Pública para 1915.

Edición: (191-).

Descripción: 7 p.; $21 \mathrm{~cm}$.

Bibliotecas:

Biblioteca de la Universidad de Córdoba.

Biblioteca Pública de Cataluña, Barcelona.

Biblioteca Pública de La Rioja.

Catálogos: No aparece en ninguno de los catálogos de 1908, 1917, 1925, 1929.

Autor: Ruiz Yanguas, Agustín.

Título: La venganza de las flores.

Edición: (190-).

Descripción: 15 p.; $16 \mathrm{~cm}$. Con ilustraciones de Isidro Gil.

Colección: Cuentos para Niños, 22.

Bibliotecas:

Biblioteca Nacional de España.

Catálogos: 1908, 1917, 1925, 1929. 
Autor: Álvarez Bollo Carretero, Mariana. [A. B. C.]

Título: La viuda de Naín o Verónica.

Edición: (1922).

Descripción: 96 p.; 15,5 cm. Con ilustraciones de Evaristo Barrio.

Colección: Biblioteca Selecta, 6.

Bibliotecas:

Biblioteca de la Universidad de Alicante.

Biblioteca de la Universidad de Oviedo.

Biblioteca Pública de San Sebastián.

Catálogos: 1908, 1917.

Autor: VV. AA.

Título: La vuelta de la guerra y otros cuentos morales ilustrados.

Edición: (1900).

Descripción: 128 p.; $18 \mathrm{~cm}$. Con ilustraciones con grabados y cubierta al cromo y oro.

Colección: Museo de la Infancia, 12.

Bibliotecas:

Biblioteca Pública de Castilla y León, Valladolid.

Catálogos: 1908 y 1917 (Museo de la Infancia, 5), 1925, 1929.

Autor: Salvá Pérez, Anselmo.

Título: Las Cortes de 1392 en Burgos.

Edición: (1891).

Descripción: 116 p.; $21 \mathrm{~cm}$.

\section{Bibliotecas:}

Archivo Silveriano de la Provincia Carmelitana O.C.D. Burgense, Burgos. Biblioteca de la Abadía de Santo Domingo de Silos, Burgos.

Biblioteca de la Facultad de Teología del Norte de España, Burgos.

Biblioteca de la Real Academia de Ciencias Morales y Políticas, Madrid.

Biblioteca de la Real Academia de la Historia en Madrid.

Biblioteca de la Real Academia Española en Madrid.

Biblioteca de la Universidad de Deusto, Bilbao. España.

Biblioteca de la Universidad de Leipzig. Alemania (Universitätsbibliothek Leipzig).

Biblioteca de la Universidad de Oviedo.

Biblioteca del Archivo Municipal de Burgos.

Biblioteca del Ateneo de Madrid.

Biblioteca del Estado de Sajonia-Biblioteca Estatal y Universitaria de Dresde [SLUB], Alemania.

Biblioteca del IES Cardenal López de Mendoza, Burgos.

Biblioteca del IES Conde Diego Porcelos, Burgos.

Biblioteca del IES Universidad Laboral, Gijón. 
Biblioteca del Monasterio de San Millán de la Cogolla de Yuso, La Rioja. Biblioteca del Senado en Madrid.

Biblioteca Digital de Castilla y León.

Biblioteca Estatal de Berlín - Patrimonio Cultural Prusiano. Alemania (Staatsbibliothek zu Berlin- Preussicher Kulturbesitz).

Biblioteca IAI, Berlín. Alemania (Ibero-Amerikanisches Institut Preußisches Kulturbesitz).

Biblioteca Nacional de España.

Biblioteca Pública de Burgos.

Biblioteca Pública de Cáceres.

Biblioteca Pública de Castilla y León, Valladolid.

Fundación Lázaro Galdiano de Madrid.

Catálogos: No aparece en ninguno de los catálogos de 1908, 1917, 1925, 1929.

Autor: Saleta y Cruxént, Honorato de.

Título: Las dos Granadas.

Edición: $2^{a}$ edición (1898). Reproducción facs. 2a edición 1898 (Alhacaba, 1981).

Descripción: 112 p.; $18 \mathrm{~cm}$.

Bibliotecas:

Biblioteca de la Abadía Benedictina de Valvanera, La Rioja.

Biblioteca de la Abadía de Santo Domingo de Silos, Burgos.

Biblioteca de la Universidad de Granada.

Biblioteca del Instituto de Historia y Cultura Militar en Madrid.

Biblioteca Nacional de España.

Biblioteca Pública de Burgos.

Biblioteca Pública de Navarra, Pamplona

Catálogos: No aparece en ninguno de los catálogos de 1908, 1917, 1925, 1929.

Autor: Rodríguez Miguel, Mariano.

Título: Las lecciones del padre: educación moral y cívica.

Edición: (1905), 6 $6^{a}$ edición (1917), 12a edición ilustraciones de Evaristo

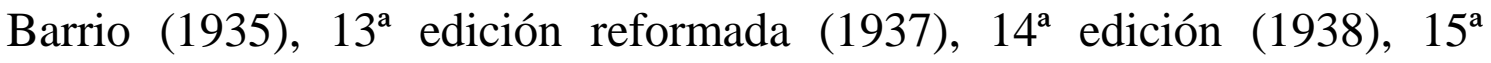

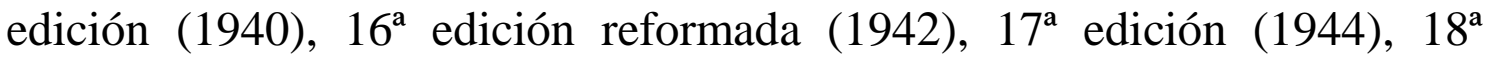
edición, ilustraciones de Fortunato Julián (1948), 19 a edición (1950), 20 a edición reformada (1955), 21 a edición (1958), ilustraciones de Cristino Soravilla, 22 a edición reformada (1962).

Descripción: 240 p.; 17,5 cm. Ilustraciones de Evaristo Barrio y Fortunato Julián. Cubierta con tapas al cromo y oro.

\section{Bibliotecas:}

Biblioteca Central de Madrid. 
Biblioteca de la Diputación Provincial de Burgos.

Biblioteca de la Universidad de Toulouse. Francia (Université de ToulouseLe Mirail).

Biblioteca del IES Conde Diego Porcelos, Burgos.

Biblioteca del Seminario Diocesano Segovia.

Biblioteca Nacional de España.

Biblioteca Pública de Asturias. Biblioteca y papeles de Tolivar Alas.

Biblioteca Pública de Burgos.

Biblioteca Pública de León.

Biblioteca Pública Museos de Gijón. Museo Jovellanos.

CEINCE.

Catálogos: 1908 (Novísima edición ilustrada), 1917 (6 $6^{\text {a }}$ edición), 1925 (10 edición), 1929 (11 ${ }^{\text {a }}$ edición).

Autor: VV. AA.

Título: Las mariposas: Cuentos morales.

Edición: (1890), (1904), (1905), (193?).

Notas: Contiene diversos cuentos: Las mariposas de María Carbonel Sánchez, Pedrillo de Alfredo Garzón Gutiérrez, Los deseos de autor desconocido, Mariposa de Magdalena Santiago-Fuentes, El cuento del abuelo de José Osés Larumbe.

Descripción: 126 p.; 18 cm. Con ilustraciones de Evaristo Barrio e Isidro Gil.

Colección: Museo de la Infancia, 17.

\section{Bibliotecas:}

Biblioteca de la Diputación Provincial de Burgos.

Biblioteca Pública de San Sebastián.

Catálogos: 1908, 1917, 1925, 1929.

Autor: Martí Alpera, Félix.

Título: Las primeras lecciones de geometría: grado elemental.

Edición: $7^{\mathrm{a}}$ edición, $9^{\mathrm{a}}$ edición, $10^{\mathrm{a}}$ edición corregida, $11^{\mathrm{a}}$ y $12^{\mathrm{a}}$ edición corregida e ilustrada con 251 figuras y dibujos, $13^{\mathrm{a}}$ edición corregida e ilustrada.

Descripción: 104 p.; $16,5 \mathrm{~cm}$. Contiene 250 figuras y dibujos de Evaristo Barrio. Encuadernado con tapas al cromo y oro o cubierta en colores.

\section{Bibliotecas:}

Biblioteca de Cataluña.

Biblioteca de la UNED, proyecto Manes.

Biblioteca de la Universidad de Barcelona.

Biblioteca de la Universidad de Murcia.

Biblioteca de la Universidad de Salamanca.

Biblioteca de la Universidad Rovira i Virgili, Tarragona. 
Biblioteca Nacional de España.

Biblioteca Pública de Castilla y León, Valladolid.

Biblioteca Pública de Córdoba.

CEINCE.

Catálogos: 1908 (en prensa), 1917 ( $5^{\text {a }}$ edición), 1925 ( $11^{\text {a }}$ edición) ,1929 (12 edición).

Autor: Ducrest de St-Aubin, Stéphanie Félicité [Condesa de Genlis].

Título: Las veladas de la quinta.

Edición: (19--).

Descripción: 432 p.; $25 \mathrm{~cm}$. Con ilustraciones de grabados y viñetas. Cubierta al cromo y oro barnizada.

Colección: Biblioteca Azul y Rosa.

Bibliotecas:

Biblioteca del Archivo Municipal de Burgos.

Biblioteca Pública de Burgos.

Biblioteca Pública de Castilla y León, Valladolid.

Catálogos: 1908 (en prensa), 1917, 1925, 1929.

Autor: Seco y Marcos, Tarsicio.

Título: Lecturas francesas.

Edición: $7^{\mathrm{a}}$ edición (1933), $8^{\mathrm{a}}$ edición (1934).

Descripción: Tomo II. 230 p.; 19 cm.

\section{Bibliotecas:}

Biblioteca de la Universidad de Las Palmas de Gran Canaria.

Biblioteca de la Universidad de Oviedo.

Biblioteca de la Universidad Pontificia Comillas de Madrid.

Biblioteca Domínguez Berrueta, León.

Biblioteca Nacional de España.

Biblioteca Pública del Estado en Las Palmas.

Biblioteca Pública Municipal de Requena, Valencia.

Catálogos: Es posterior a los catálogos analizados.

Autor: Bustamante y Junquera, Mateo.

Título: Lecturas morales, coleccionadas por los niños de ambos sexos.

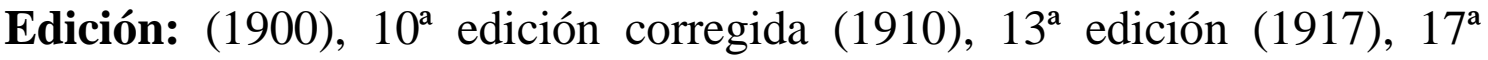
edición (1925).

Descripción: 175 p.; $16 \mathrm{~cm}$. Con ilustraciones de Evaristo Barrio y encuadernado en pasta y tapas en cromo o cubierta en colores.

\section{Bibliotecas:}

Biblioteca de la UNED, proyecto Manes.

Biblioteca del IES Cardenal Cisneros, Madrid.

Biblioteca Digital de Castilla y León. 
Biblioteca Nacional de España.

Biblioteca Pública de Castilla y León, Valladolid.

Catálogos: 1908, 1917 (13 a edición notablemente corregida, $1925\left(17^{\mathrm{a}}\right.$ edición corregida), 1929 (18 edición).

Autor: Seco y Marcos, Tarsicio.

Título: Lengua francesa: método práctico-teórico ajustado al cuestionario oficial: primer curso.

Edición: (1930), $3^{\text {a }}$ edición (1935).

Descripción: 238 p.; $20 \mathrm{~cm}$.

Bibliotecas:

Biblioteca Pública de Castilla y León, Valladolid.

Biblioteca Nacional de España.

CEINCE.

Catálogos: Es posterior a los catálogos analizados.

Autor: Seco y Marcos, Tarsicio.

Título: Lengua francesa: método práctico-teórico, ajustado al cuestionario oficial: $2^{\circ}$ grado.

Edición: (1930).

Descripción: 268 p.; $20 \mathrm{~cm}$.

Bibliotecas:

Biblioteca de la Universidad de Deusto.

Biblioteca de la Universidad de Huelva.

Biblioteca de la Universidad Rovira i Virgili, Tarragona.

Biblioteca Museo Jovellanos, Gijón.

Biblioteca Pública de León.

Biblioteca Regional Domínguez Berrueta, León.

Catálogos: Es posterior a los catálogos analizados.

Autor: Cuesta Hernáiz, Juan de la.

Título: Libro primero o silabario.

Edición: (19--).

Descripción: 16 p.; 19 cm. Encuadernado con cartulina fuerte.

Bibliotecas:

Biblioteca Pública de Castilla y León, Valladolid.

Catálogos: 1908, 1917, 1925, 1929

Autor: Giraldo Atienza, Miguel.

Título: Libro registro de contabilidad y resúmenes de matrícula y asistencia media para uso de las escuelas públicas de primera enseñanza.

Edición: (1888) Imprenta y librería de Santiago Rodríguez Alonso, (1896). Descripción: 71 p.; $28 \mathrm{~cm}$. 


\section{Bibliotecas:}

Biblioteca del Archivo Municipal de Sevilla.

Biblioteca Pública de Santander.

Catálogos: No aparece en los catálogos de 1908, 1917, 1925 y 1929.

Autor: Tarín y Juaneda, F. Prólogo de Matías Martínez Burgos.

Título: Los antiguos gremios de artesanos: bosquejo histórico.

Edición: $1^{a}$ edición (1931).

Descripción: 48 p.; $21 \mathrm{~cm}$.

\section{Bibliotecas:}

Biblioteca de la Universidad de Alcalá.

Biblioteca Nacional de España.

Biblioteca Pública de Burgos.

Catálogos: Es posterior a los catálogos analizados.

Autor: Linares Rivas, Manuel.

Título: Los aventureros.

Edición: (1919), 2a edición (1935).

Descripción: 113 p.; $26 \mathrm{~cm}$. Con ilustraciones, algunas tricolores de Antequera Azpiri. Varias encuadernaciones en cartoné y en tela.

Colección: Biblioteca Rodríguez, 1.

\section{Bibliotecas:}

Biblioteca de la Diputación Provincial de Burgos.

Biblioteca de la Universidad Autónoma de Madrid.

Biblioteca de la Universidad de Castilla La Mancha, Campus de Cuenca.

Biblioteca de la universidad de Fort Hays, Kansas. Estados Unidos.

Biblioteca de la Universidad de Harvard, Cambridge, Massachussets.

Estados Unidos.

Biblioteca de la Universidad de Murcia.

Biblioteca de la Universidad de Santiago de Compostela.

Biblioteca de la Universidad Técnica de Brunswick de Alemania.

Biblioteca del Archivo Municipal de Burgos.

Biblioteca del Consejo Superior de Investigaciones Científicas.

Biblioteca del IES Cardenal Cisneros, Madrid.

Biblioteca Nacional de España.

Biblioteca Pública de Castilla y León, Valladolid.

Biblioteca Regional de Madrid Joaquín Leguina.

Biblioteca Smithsonian de Washington. Estados Unidos.

Catálogos: 1925, 1929.

Autor: Seco, Lázaro.

Título: Los benedictinos españoles en el siglo XX.

Edición: $1^{a}$ edición ilustrada con 75 fotograbados y dibujos (1931). 
Descripción: 330 p.; $21 \mathrm{~cm}$.

\section{Bibliotecas:}

Archivo Silveriano de la Provincia Carmelitana O.C.D. Burgense, Burgos.

Biblioteca de la Universidad Pontificia Comillas de Madrid.

Biblioteca de Cataluña.

Biblioteca de la Escuela de Guerra en Madrid.

Biblioteca de la Universidad de Barcelona.

Biblioteca de la Universidad de Deusto.

Biblioteca de la Universidad de Extremadura.

Biblioteca de la Universidad de Málaga.

Biblioteca de la Universidad de Navarra.

Biblioteca de la Universidad de Valladolid.

Biblioteca del Consejo Superior de Investigaciones Científicas.

Biblioteca Nacional de España.

Biblioteca Pública de Lazkao, Gordailua, Gipuzkoa.

Biblioteca Pública de Tudela, Navarra.

Biblioteca Pública de Zaragoza.

Biblioteca Pública Municipal de Calatayud, Zaragoza.

Catálogos: Es posterior a los catálogos analizados.

Autor: Comisión Burgalesa de Iniciativas Ferroviarias.

Título: Los ferrocarriles en construcción: el ferrocarril directo MadridBurgos.

Edición: (1932).

Descripción: 76 p.; 24 cm. Con 1 mapa plegable.

\section{Bibliotecas:}

Biblioteca Central Militar. Instituto de Historia y Cultura Militar en Madrid.

Biblioteca de la Universidad Pompeu Fabra, Barcelona.

Biblioteca Pública de Cataluña, Barcelona.

Biblioteca Regional Joaquín Legina de Madrid.

Catálogos: Es posterior a los catálogos analizados.

Autor: Comisión Burgalesa de Iniciativas Ferroviarias.

Título: Los ferrocarriles internacionales y la red peninsular.

Edición: (1919), (1932).

Descripción: 52 p.; incluye 6 anexos.

Colección: Ponencia presentada a la deliberación del Congreso Nacional de Ingeniería.

\section{Bibliotecas:}

Biblioteca Central Militar. Instituto de Historia y Cultura Militar en Madrid.

Biblioteca de la Diputación Provincial de Burgos. 
Biblioteca de la Universidad Politécnica de Madrid.

Biblioteca del Archivo Municipal de Burgos.

Biblioteca del Senado en Madrid.

Biblioteca Municipal de Aranda de Duero, Burgos.

Biblioteca Nacional de España.

Biblioteca Pública de Burgos.

Biblioteca Pública de Castilla y León, Valladolid.

Biblioteca Pública de Museos. Museo de Ferrocarriles de Asturias, Gijón.

Biblioteca Regional Joaquín Leguina de Madrid.

Catálogos: No aparece en los catálogos estudiados de 1908, 1917, 1925, 1929.

Autor: Rodríguez Miguel, Mariano.

Título: Los grandes inventos al alcance de los niños.

Edición: (1902), (1925).

Descripción: 196 p.; 22,2 cm. Con ilustraciones de Evaristo Barrio, Isidro Gil y Pedrero. Encuadernado en pasta y con tapas al cromo y oro y otra especial en tela con planchas en oro y negro con cortes dorados.

Colección: Biblioteca Enciclopédica Hispano-Americana, 1.

\section{Bibliotecas:}

Biblioteca de la Diputación Provincial de Burgos.

Biblioteca de la Universidad de Castilla La Mancha, Campus de Cuenca.

Biblioteca de la Universidad de Córdoba.

Biblioteca del Archivo Municipal de Burgos.

Catálogos: 1908, 1917, 1925, 1929.

Autor: González de Echávarri Castañeda, Vicente.

Título: Los juegos de azar ante la moral y el derecho.

Edición: (1904).

Descripción: 157 p.; $19 \mathrm{~cm}$.

Bibliotecas:

Biblioteca de la Universidad de Deusto.

Catálogos: No aparece en los catálogos estudiados de 1908, 1917, 1925, 1929.

Autor: VV. AA.

Título: Los niños caritativos: cuentos morales.

Edición: (19--).

Notas: Contiene diversos cuentos: Los niños caritativos de L.G.S., El imperio de las rosas de Luis Villazul, Los hijos del Sr. Martín de Carlos Frontaura, La suerte de Anselmo Salvá y La ambición de Manuel Ossorio Bernard.

Descripción: 113 p.; 17 cm. Con numerosas ilustraciones. 
Colección: Museo de la Infancia, 1.

Bibliotecas:

Biblioteca del IES Cardenal Cisneros, Madrid.

Catálogos: 1908, 1917, 1925, 1929.

Autor: Lastra y Eterna, Pablo.

Título: Los niños y las abejas.

Edición: (1931).

Descripción: 30 p.; 17 cm. Con ilustraciones de Fortunato Julián.

Bibliotecas:

Biblioteca de la Universidad Pompeu Fabra, Barcelona.

Biblioteca del Consejo Superior de Investigaciones Científicas.

Biblioteca Nacional de España.

Catálogos: Es posterior a los catálogos analizados.

Autor: Desconocido.

Título: Los niños y los árboles. Porqué deben amar los niños a los árboles. Edición: (193?).

Descripción: 16 p.; $22 \mathrm{~cm}$.

Bibliotecas:

Biblioteca de la Universidad Pompeu Fabra, Barcelona.

Catálogos: 1929.

Autor: Almarza Martínez, Pedro.

Título: Los niños y los gusanos de seda.

Edición: (1931).

Descripción: 31 p.; 17 cm. Con ilustraciones de Fortunato Julián.

Bibliotecas:

Biblioteca del Consejo Superior de Investigaciones Científicas.

Biblioteca Nacional de España.

Catálogos: Es posterior a los catálogos analizados.

Autor: Ortega Munilla, José.

Título: Los tres sorianitos.

Edición: (1921).

Descripción: 158 p.; $25 \mathrm{~cm}$. Contiene numerosos dibujos y 6 láminas en tricolor colocadas sobre cartulina de fondo e ilustradas por Pedro Antequera Azpiri. Encuadernaciones con cubierta de colores y en tela con planchas y canto dorado.

Colección: Biblioteca Rodríguez, 3.

Bibliotecas:

Biblioteca de la Diputación Provincial de Burgos.

Biblioteca de la Universidad de California Berkeley. Estados Unidos. 
Biblioteca de la Universidad de Castilla La Mancha, Campus de Cuenca. Biblioteca de la Universidad de La Laguna.

Biblioteca del Consejo Superior de Investigaciones Científicas.

Biblioteca del IES Cardenal Cisneros, Madrid.

Biblioteca Digital de Castilla y León.

Biblioteca Nacional de España.

Biblioteca Pública de Burgos.

Biblioteca Pública de Castilla y León, Valladolid.

Biblioteca Pública de Guadalajara.

Biblioteca Pública de Soria.

Biblioteca Pública Municipal de Sollana, Valencia.

Catálogos: 1925, 1929.

\section{M}

Autor: Llenera, Juan.

Título: Males del Régimen en la primera enseñanza: remedios eficaces.

Edición: (1931).

Descripción: 110 p.; $20 \mathrm{~cm}$.

Bibliotecas:

Biblioteca de Cataluña.

Biblioteca de la Universidad de Córdoba.

Biblioteca de la Universidad de Girona.

Biblioteca de la Universidad de Málaga.

Biblioteca de la Universidad de Murcia.

Biblioteca de la Universidad Pontificia Comillas de Madrid.

Biblioteca del Archivo Municipal de Burgos.

Biblioteca del Consejo Superior de Investigaciones Científicas.

Biblioteca Nacional de España.

Biblioteca Pública de Cáceres.

Biblioteca Pública de Castilla y León, Valladolid.

Catálogos: Es posterior a los catálogos analizados.

Autor: Heras Fernández, Eusebio (adaptación castellana).

Título: Maravillosas aventuras de un cascanueces: un juguete animado.

Edición: (192?).

Descripción: 105 p.; $21 \mathrm{~cm}$. Con ilustraciones de Fortunato Julián.

Cubiertas al cromo.

Contenido: Biblioteca Oro, 8.

Bibliotecas:

Biblioteca del Archivo Municipal de Burgos.

Biblioteca Junta de Andalucía, Sevilla. 
Biblioteca Nacional de España.

Catálogos: 1929.

Autor: Andrade y Uribe, Benito Mariano.

Título: Maura y el partido conservador.

Edición: (1896), (1910).

Descripción: 120 p.; 23 cm.

Bibliotecas:

Biblioteca Casa de Velázquez, Madrid.

Biblioteca de Documentación Internacional Contemporánea de París, Francia.

Biblioteca de la IAI de Berlín. Alemania (Ibero-Amerikanisches Institut Preussischer Kulturbesitz).

Biblioteca de la Universidad de Alcalá.

Biblioteca de la Universidad de Oviedo.

Biblioteca de la Universidad Pontificia Comillas de Madrid.

Biblioteca del Estado de Berlín. Fundación del Patrimonio Cultural Prusiano. Alemania.

Biblioteca del IES Cardenal López de Mendoza, Burgos.

Biblioteca del Senado en Madrid.

Biblioteca Municipal de Aranda de Duero, Burgos.

Biblioteca Nacional de España.

Biblioteca Pública de Castilla y León, Valladolid.

Biblioteca Universidad de Deusto, Bilbao.

Catálogos: 1929.

Autor: García Alía, José.

Título: Memorandum del maestro para 1914.

Edición: (1914).

Descripción: 254 p.; $20 \mathrm{~cm}$.

Bibliotecas:

Biblioteca Diocesana de Zamora.

Biblioteca de la Universidad de Murcia.

Catálogos: No aparecen en los catálogos analizados de 1908, 1917, 1925, 1929.

Autor: García Alía, José.

Título: Memorandum del maestro para 1916.

Edición: (1915?).

Descripción: 556 p.; $20 \mathrm{~cm}$.

Bibliotecas:

Biblioteca de la Universidad de Las Palmas de Gran Canaria.

Biblioteca Nacional de España. 
Biblioteca Pública de Guadalajara.

Catálogos: 1917.

Autor: Instituto Provincial de Segunda Enseñanza. Burgos.

Título: Memoria acerca del estado del Instituto Provincial de Segunda Enseñanza de Burgos durante el curso escolar de 1891 a 1892.

Edición: (1892).

Descripción: 56 p.; $21 \mathrm{~cm}$.

Bibliotecas:

Biblioteca del IES Cardenal López de Mendoza, Burgos.

Catálogos: No aparecen en los catálogos analizados de 1908, 1917, 1925, 1929.

Autor: Sebastián y Rives, Rodrigo.

Título: Memoria acerca del estado del Instituto Provincial de Segunda Enseñanza de Burgos durante el curso escolar de 1892 a 1893. Leída por Rodrigo Sebastián Rives.

Edición: (1893).

Descripción: 52 p.; $21 \mathrm{~cm}$.

Bibliotecas:

Biblioteca del IES Cardenal López de Mendoza, Burgos.

Catálogos: No aparecen en los catálogos analizados de 1908, 1917, 1925, 1929.

Autor: Llorente y Arregui, Aniceto.

Título: Memoria acerca del estado del Instituto Provincial de Segunda Enseñanza de Burgos durante el curso escolar de 1896 a 1897. Leída por Aniceto Llorente y Arregui.

Edición: (1898).

Descripción: 58 p.; $21 \mathrm{~cm}$.

Bibliotecas:

Biblioteca del IES Cardenal López de Mendoza, Burgos.

Catálogos: No aparecen en los catálogos analizados de 1908, 1917, 1925, 1929.

Autor: Sebastián y Rives, Rodrigo.

Título: Memoria acerca del estado del Instituto Provincial de Segunda Enseñanza de Burgos durante el curso escolar de 1897 a 1898. Leída por Rodrigo Sebastián y Rives.

Edición: (1899).

Descripción: 56 p.; $21 \mathrm{~cm}$.

Bibliotecas:

Biblioteca del IES Cardenal López de Mendoza, Burgos. 
Catálogos: No aparecen en los catálogos analizados de 1908, 1917, 1925, 1929.

Autor: Sebastián y Rives, Rodrigo.

Título: Memoria acerca del estado del Instituto Provincial de Segunda Enseñanza de Burgos durante el curso escolar de 1898 a 1899. Leída por Rodrigo Sebastián Rives.

Edición: (1900).

Descripción: 56 p.; $21 \mathrm{~cm}$.

Bibliotecas:

Biblioteca del IES Cardenal López de Mendoza, Burgos.

Catálogos: No aparecen en los catálogos analizados de 1908, 1917, 1925, 1929.

Autor: Sebastián y Rives, Rodrigo.

Título: Memoria acerca del estado del Instituto Provincial de Segunda Enseñanza de Burgos durante el curso escolar de 1899 a 1900. Leída por Rodrigo Sebastián y Rives.

Edición: (1901).

Descripción: 51 p.; $21 \mathrm{~cm}$.

Bibliotecas:

Biblioteca del IES Cardenal López de Mendoza, Burgos.

Catálogos: No aparecen en los catálogos analizados de 1908, 1917, 1925, 1929.

Autor: Sebastián y Rives, Rodrigo.

Título: Memoria acerca del estado del Instituto Provincial de Segunda Enseñanza de Burgos durante el curso escolar de 1900 a 1901. Leída por Rodrigo Sebastián y Rives.

Edición: (1902).

Descripción: 54 p.; $21 \mathrm{~cm}$.

Bibliotecas:

Biblioteca de la Universidad de Valencia.

Biblioteca del IES Cardenal López de Mendoza, Burgos.

Catálogos: No aparecen en los catálogos analizados de 1908, 1917, 1925, 1929.

Autor: García de Quevedo y Concellón, Eloy.

Título: Memoria acerca del estado del Instituto Provincial de Segunda Enseñanza de Burgos durante el curso escolar de 1916 a 1917 por Eloy García de Quevedo y Concellón.

Edición: (1917).

Descripción: 64 p.; $21 \mathrm{~cm}$. 


\section{Bibliotecas:}

Biblioteca del IES Cardenal López de Mendoza, Burgos.

Catálogos: No aparecen en los catálogos analizados de 1908, 1917, 1925, 1929.

Autor: García de Quevedo y Concellón, Eloy.

Título: Memoria acerca del estado del Instituto Provincial de Segunda Enseñanza de Burgos durante el curso escolar de 1917 a 1918 por Eloy García de Quevedo y Concellón.

Edición: (1918).

Descripción: 64 p.; $21 \mathrm{~cm}$.

\section{Bibliotecas:}

Biblioteca del IES Cardenal López de Mendoza, Burgos.

Catálogos: No aparecen en los catálogos analizados de 1908, 1917, 1925, 1929.

Autor: García de Quevedo y Concellón, Eloy.

Título: Memoria acerca del estado del Instituto provincial de segunda enseñanza de Burgos durante el curso académico de 1921 a 1922.

Edición: (1922).

Descripción: 56 p.; $27 \mathrm{~cm}$.

Bibliotecas:

Biblioteca del IES Cardenal López de Mendoza, Burgos.

Biblioteca Pública de Málaga.

Catálogos: No aparecen en los catálogos analizados de 1908, 1917, 1925, 1929.

Autor: García de Quevedo y Concellón, Eloy.

Título: Memoria acerca del estado del Instituto Provincial de Segunda Enseñanza de Burgos durante el curso académico de 1923 a 1924.

Edición: (1925).

Descripción: 56 p.; $27 \mathrm{~cm}$.

Bibliotecas:

Biblioteca del IES Cardenal López de Mendoza, Burgos.

Catálogos: No aparecen en los catálogos analizados de 1908, 1917, 1925, 1929.

Título: Memoria leída en la Junta General de accionistas de la Sucursal del Banco de España en Burgos, el 21 de febrero de 1886.

Edición: (1886).

Nota: Impreso en la Imprenta y librería de Santiago Rodríguez Alonso.

Descripción: 1 v.; 28 cm.

\section{Bibliotecas:}


Biblioteca Pública de Burgos.

Catálogos: Es anterior a los Catálogos analizados.

Título: Memoria relativa a un proyecto de conducción de aguas a Burgos y creación de una sociedad anónima para la realización de las obras y explotación del servicio en sus diversas aplicaciones.

Edición: (1889).

Notas: Impreso en la Imprenta y librería de Santiago Rodríguez Alonso.

Descripción: 47 p.; $20 \mathrm{~cm}$.

Bibliotecas:

Biblioteca de la Diputación Provincial de Burgos.

Biblioteca Municipal de San Sebastián.

Biblioteca Pública de Burgos.

Catálogos: Es anterior a los Catálogos analizados.

Autor: Asociación del Fomento del Turismo de Burgos.

Título: Memoria referente al año 1914 leída por el secretario de la Junta general celebrada en las casas consistoriales el día 31 de enero de 1915.

Edición: (1915).

Descripción: 22 p.; $22 \mathrm{~cm}$.

Bibliotecas:

Biblioteca Pública de Burgos.

Catálogos: No aparecen en los catálogos analizados de 1908, 1917, 1925, 1929.

Autor: Chave y Castilla, Julián.

Título: Memoria sobre el problema geométrico de la rectificación gráfica de la circunferencia.

Edición: (189-), (1916).

Descripción: 43 p.; $20 \mathrm{~cm}$. Con ilustraciones.

Bibliotecas:

Biblioteca del IES Cardenal López de Mendoza, Burgos.

Biblioteca Nacional de España.

Biblioteca Pública de Burgos.

Catálogos: No aparecen en los catálogos analizados de 1908, 1917, 1925, 1929.

Autor: Santiago y Gómez, José de.

Título: Metafísica del individualismo.

Edición: (1920).

Descripción: 258 p.; $22 \mathrm{~cm}$.

Bibliotecas:

Biblioteca de la Universidad de Málaga. 
Biblioteca de la Universidad San Pablo-CEU.

Biblioteca del Senado en Madrid.

Biblioteca Nacional de España.

Catálogos: 1925, 1929.

Autor: Seco y Marcos, Tarsicio.

Título: Método de Lengua Francesa: Primer curso, ciclo A.

Edición: $3^{\text {a }}$ edición adaptada al nuevo plan de bachillerato (1933), $4^{\text {a }}$ edición (1934), $6^{\mathrm{a}}$ edición adaptada al Cuestionario oficial (1936), $7^{\mathrm{a}}$ edición (1939), $8^{a}$ edición (1941), $9^{\text {a }}$ edición (1942), 10ª edición adaptada al cuestionario oficial (1943), $11^{\text {a }}$ edición adaptada al cuestionario oficial (1944), 14ª edición adaptada al cuestionario oficial (1947).

Descripción: 195 p.; $19 \mathrm{~cm}$. Con ilustraciones. (En posteriores ediciones cambia la descripción).

\section{Bibliotecas:}

Biblioteca de la Universidad de Valladolid.

Biblioteca de la Universidad Pontificia Comillas de Madrid.

Biblioteca del IES Conde Diego Porcelos, Burgos.

Biblioteca Nacional de España.

Biblioteca Pública de León.

Biblioteca Pública en Palma de Mallorca.

Catálogos: Posterior a los catálogos analizados.

Autor: Seco y Marcos, Tarsicio.

Título: Método de Lengua Francesa: Primer curso.

Edición: $1^{\text {a }}$ edición (1932), $2^{\text {a }}$ edición (1933 adaptada al nuevo Plan de Bachillerato), $5^{a}$ edición (1935), $7^{\text {a }}$ edición (1939), $8^{a}$ edición (1944), 10 ${ }^{a}$ edición (1945), 11 a edición (1946), $16^{\mathrm{a}}$ edición (1949), (1952).

Descripción: 383 p.; 19 cm. Con ilustraciones. (En posteriores ediciones cambia la descripción).

\section{Bibliotecas:}

Biblioteca de la UNED, proyecto Manes.

Biblioteca de la Universidad de Granada.

Biblioteca de la Universidad de Navarra.

Biblioteca del IES El Greco de Toledo.

Biblioteca del Seminario Obispado Priorato de Ciudad Real.

Biblioteca Junta de Andalucía.

Biblioteca Nacional de España.

Biblioteca Pública de Burgos.

Biblioteca Pública de Cabra de Córdoba.

Biblioteca Pública de Castilla y León, Valladolid.

Biblioteca Pública de Palma de Mallorca.

Biblioteca Pública de Segovia. 
Biblioteca Pública Municipal Huétor Santillán, Granada.

Catálogos: Posterior a los catálogos analizados.

Autor: Seco y Marcos, Tarsicio.

Título: Método de lengua francesa: segundo curso. Ciclo B.

Edición: $1^{a}$ edición (1932), $2^{a}$ edición (1933), $3^{\text {a }}$ edición (1934), $6^{\text {a }}$ edición (1941), $7^{a}$ edición (1942), $8^{\text {a }}$ edición (1943).

Descripción: 233 p.; $19 \mathrm{~cm}$. Con ilustraciones. Tiene diferentes descripciones según las ediciones.

\section{Bibliotecas:}

Biblioteca de La Rioja, Logroño.

Biblioteca del IES Brianda de Mendoza, Guadalajara.

Biblioteca del IES Maestro Juan de Ávila de Ciudad Real.

Biblioteca Domínguez Berrueta, León.

Biblioteca Nacional de España.

Biblioteca Pública de San Sebastián.

Biblioteca Pública del Estado en Guadalajara. Colección Miguel Picazo.

Biblioteca Pública Municipal Lope de Vega, Ciudad Real.

Catálogos: Posterior a los catálogos analizados.

Autor: Seco y Marcos, Tarsicio.

Título: Método de Lengua Francesa: segundo grado.

Edición: $1^{\text {a }}$ edición (1932), $4^{\text {o }}$ edición adaptada al cuestionario oficial (1935), $5^{\text {a }}$ edición (1939), $12^{\text {a }}$ edición adaptada al cuestionario oficial (1934), $4^{a}$ edición (1935), $7^{\text {a }}$ edición (1942), $9^{\mathrm{a}}$ edición (1944), 10ª edición (1945), 11 a edición (1946), 12 a edición (1947).

Descripción: Distintas descripciones según las ediciones.

Bibliotecas:

Biblioteca de la Diputación Provincial de Burgos.

Biblioteca de la UNED, proyecto Manes.

Biblioteca de la Universidad de Castilla La Mancha, Campus de Cuenca.

Biblioteca de la Universidad de Las Palmas de Gran Canaria.

Biblioteca de la Universidad de Valencia.

Biblioteca de la Universidad de Valladolid.

Biblioteca de la Universidad Politécnica de Madrid.

Biblioteca del IES Ramiro de Maeztu en Madrid.

Biblioteca Domínguez Berrueta, León.

Biblioteca Municipal Las Navas del Marqués, Ávila.

Biblioteca Nacional de España.

Biblioteca Pública de Burgos.

Biblioteca Pública de Castilla y León, Valladolid.

Biblioteca Pública de Cuenca. Colección Rogelio Sánchez.

Biblioteca Pública de Palencia. 
Biblioteca Pública de Segovia.

Biblioteca Pública del Estado. Colección Magariños, Guadalajara.

Biblioteca Pública del Estado, Santander.

Catálogos: Posterior a los catálogos analizados.

Autor: Seco y Marcos, Tarsicio.

Título: Método de lengua francesa: tercer curso, Ciclo C.

Edición: $1^{\mathrm{a}}$ edición (1932), (1933), $2^{\mathrm{a}}$ edición (1934), $3^{\mathrm{a}}$ edición (1935), $4^{\mathrm{a}}$ edición adaptada al cuestionario oficial (1939), $5^{\text {a }}$ edición adaptada al nuevo cuestionario oficial (1941), $6^{\mathrm{a}}$ edición (1942), $7^{\mathrm{a}}$ edición (1943), $8^{\mathrm{a}}$ edición adaptada al cuestionario oficial (1944), 10 a edición (1946), 11 ${ }^{\mathrm{a}}$ edición (1947), 13ª edición (1949).

Descripción: 285 p.; 19 cm. (Cambia según las ediciones).

\section{Bibliotecas:}

Biblioteca de La Rioja.

Biblioteca de la Universidad de Castilla La Mancha. Escuela Universitaria del profesorado de EGB, Campus de Ciudad Real.

Biblioteca de la Universidad de Córdoba.

Biblioteca de la Universidad de Granada.

Biblioteca de la Universidad de Huelva.

Biblioteca de la Universidad de Navarra.

Biblioteca de la Universidad de Oviedo.

Biblioteca de Segovia.

Biblioteca del IES Conde Diego Porcelos, Burgos.

Biblioteca del Instituto de Bachillerato Padre Suárez de Granada.

Biblioteca Domínguez Berrueta, León.

Biblioteca Nacional de España.

Biblioteca Pública de Burgos.

Biblioteca Pública de Castilla y León, Valladolid.

Biblioteca Pública de León.

Biblioteca Pública de Palma de Mallorca.

Biblioteca Pública de San Sebastián.

Biblioteca Pública de Vitoria.

Catálogos: Posterior a los catálogos analizados.

Autor: Rodríguez García, Gerardo.

Título: Metodología didáctica de la lectura: estudio pedagógico en relación con los libros del alumno titulados "Para aprender a leer".

Edición: (1916), (1917), (1920?).

Descripción: 308 p.; 21 cm. Encuadernación en rústica y en tela.

Bibliotecas:

Biblioteca de la Universidad de Barcelona.

Biblioteca de la Universidad de Córdoba. 
Biblioteca de la Universidad de La Rioja.

Biblioteca de la Universidad de Salamanca.

Biblioteca de la Universidad de Vigo.

Biblioteca del Ateneo de Madrid.

Biblioteca Nacional de España.

Biblioteca Pública de Burgos.

Biblioteca Pública Museos. Museo de Jovellanos, Gijón.

Catálogos: 1917 (Para aprender a leer. Grado $1^{\circ}$ y 2 ${ }^{\circ}$ ), 1925, 1929.

Autor: Rodríguez García, Gerardo

Título: Metodología: didáctica general.

Edición: (1897).

Descripción: 96 p.; $20 \mathrm{~cm}$.

Bibliotecas:

Biblioteca de la Universidad de Castilla La Mancha. Escuela Universitaria del Profesorado Fray Luis de León. Campus de Cuenca.

Biblioteca de la Universidad de Córdoba.

Biblioteca de la Universidad de Santiago de Compostela.

Biblioteca de la Universidad de Valencia.

Biblioteca de la Universidad de Valladolid.

Biblioteca del Consejo Superior de Investigaciones Científicas.

Biblioteca Nacional de España.

Catálogos: 1908, 1917.

Autor: Rodríguez García, Gerardo.

Título: Metodología didáctica de la Lectura.

Edición: (1916).

Descripción: 308 p.; 26 cm.

Bibliotecas:

Biblioteca de la Universidad de Salamanca.

Biblioteca Nacional de España.

Biblioteca Pública de Burgos.

Catálogos: 1929.

Autor: VV. AA.

Título: Mi libro bazar: cuentos, narraciones, viajes, poesías, curiosidades, historietas, misceláneas etc.

Edición: (1929?), (1933?).

Descripción: 127 p.; 25 cm. Con ilustraciones a color de Pedro Antequera Azpiri. Cubierta en colores.

Contenido: Bibliotecas Paz, 7.

Bibliotecas:

Biblioteca de Castilla La Mancha, Campus de Cuenca. 
Biblioteca de la Diputación Provincial de Burgos.

Biblioteca de la Universidad de La Laguna.

Biblioteca de la Universidad de Saint Mary of the Woods, Indiana. Estados Unidos.

Biblioteca Pública Central de Jerez.

Biblioteca Pública de Castilla y León, Valladolid.

CEINCE

Catálogos: 1929.

Autor: VV. AA.

Título: Mi libro de Año Nuevo.

Edición: (1920).

Descripción: 156 p.; 25 cm. Con lustraciones a color de Fortunato Julián. Cubierta en colores.

Colección: Biblioteca Paz, 2.

\section{Bibliotecas:}

Biblioteca de la Universidad Autónoma de Madrid.

Biblioteca de la Universidad de Middlebury, Vermont. Estados Unidos (Middelebury Collage).

Biblioteca de la Universidad de Murcia.

Biblioteca de la Universidad Saint Mary of the Woods, Indiana. Estados Unidos (Saint Mary of the Woods College).

Biblioteca del Consejo Superior de Investigaciones Científicas.

Biblioteca del IES Cardenal Cisneros, Madrid.

Biblioteca Junta de Andalucía, Sevilla.

Biblioteca Nacional de México.

Biblioteca Pública de Castilla y León, Valladolid.

Biblioteca Pública de San Francisco. Estados Unidos (San Francisco Public Library Main Library).

Biblioteca Pública en Norfolk, Virginia, Estados Unidos (Norfolk Public Library).

Catálogos: 1925, 1929.

Autor: VV. AA.

Título: Mi libro de estampas y cuentos: relatos, viajes, arte, cuentos, miscelánea, biografías, inventos, deportes, narraciones etc.

Edición: (192-).

Descripción: 139 p.; 24 cm. Con lustraciones a color de Evaristo Barrio, Fortunato Julián y Antequera Azpiri. Cubierta en colores.

Colección: Biblioteca Paz, 5.

Bibliotecas:

Biblioteca de la Universidad de Middlebury, Vermont. Estados Unidos.

Biblioteca Diputación Provincial de Burgos. 
Biblioteca Pública de Burgos.

Biblioteca Pública de Castilla y León, Valladolid.

Catálogos: 1925, 1929.

Autor: VV. AA.

Título: Mi libro de Navidad.

Edición: (1919).

Descripción: 169 p.; $25 \mathrm{~cm}$. Con ilustraciones y cubierta a color.

Colección: Biblioteca Paz, 1.

Bibliotecas:

Biblioteca de la Universidad de Murcia.

Biblioteca del IES Cardenal Cisneros, Madrid.

Biblioteca Pública de Castilla y León, Valladolid.

Catálogos: 1925.

Autor: VV. AA.

Título: Mi libro de Recreo.

Edición: (1926).

Descripción: 137 p.; $25 \mathrm{~cm}$. Con ilustraciones y cubierta a color

Colección: Biblioteca Paz, 6.

Bibliotecas:

Biblioteca de la Diputación Provincial de Burgos.

Biblioteca de la Universidad St. Mary of the Woods, Indiana. Estados Unidos.

Biblioteca Junta de Andalucía, Sevilla.

Biblioteca Nacional de España.

Catálogos: 1929.

Autor: VV. AA.

Título: Mi libro de Reyes.

Edición: (1922).

Descripción: 137 p.; $25 \mathrm{~cm}$. Con ilustraciones y cubierta a color.

Colección: Bibliotecas Paz, 3.

Bibliotecas:

Biblioteca de la Universidad de Castilla La Mancha, Campus de Cuenca.

Biblioteca de la Universidad de Murcia.

Biblioteca del IES Cardenal Cisneros, Madrid.

Biblioteca Junta de Andalucía, Sevilla.

Biblioteca Pública de Castilla y León, Valladolid.

Catálogos: 1925, 1929.

Autor: VV. AA.

Título: Mi libro de Vacaciones. 
Edición: (1918), (192?).

Descripción: 150 p.; $25 \mathrm{~cm}$. Con ilustraciones de Larraya.

Colección: Bibliotecas Paz, 4.

Bibliotecas:

Biblioteca de la Universidad de Middlebury, Vermont. Estados Unidos (Middelebury College).

Biblioteca de la Universidad Saint Mary of the Woods. Indiana, Estados Unidos (Saint Mary of the Woods College).

Biblioteca Junta de Andalucía, Sevilla.

Biblioteca Pública de Castilla y León, Valladolid.

Biblioteca Pública de San Sebastián.

Catálogos: 1925, 1929.

Autor: VV. AA.

Título: Mi libro ideal: Cuentos, narraciones, viajes, poesías, curiosidades, historietas, miscelánea, pensamiento etc.

Edición: $1^{a}$ edición (1933).

Descripción: 150 p.; 24 cm. Con ilustraciones a color de Antequera Azpiri, Emilio Ferrer, Rosario de Velasco, Fortunato Julián y otros.

Colección: Biblioteca Paz, 8.

Bibliotecas:

Biblioteca de la UNED, proyecto Manes.

Biblioteca de la Universidad de Barcelona.

Biblioteca del Consejo Superior de Investigaciones Científicas.

Biblioteca Nacional de España.

Biblioteca Pública de Castilla y León, Valladolid.

Biblioteca Pública Municipal de Alcañiz en Teruel.

CEINCE.

Catálogos: 1929.

Autor: Enciso Villanueva, Gabino.

Título: Mi patria: lo que ha sido, lo que es y lo que puede ser España.

Edición: Edición ilustrada (1915), $2^{\text {a }}$ edición corregida e ilustrada con 250 grabados, (1917?), $3^{a}$ edición corregida e ilustrada (192-), $4^{\text {a }}$ edición (1925) $5^{a}$ edición corregida (1930).

Descripción: Las descripciones varían mucho según las ediciones; $20 \mathrm{~cm}$. Con numerosas ilustraciones.

\section{Bibliotecas:}

Biblioteca de la Davidson Collage, Carolina del Norte. Estados Unidos. Biblioteca de la Diputación Provincial de Burgos.

Biblioteca de la UNED, proyecto Manes.

Biblioteca de la Universidad Christian de Texas. Estados Unidos.

Biblioteca de la Universidad Complutense de Madrid. 
Biblioteca de la Universidad de Barcelona.

Biblioteca de la Universidad de Castilla La Mancha. Escuela Universitaria del Profesorado de EGB, Campus de Ciudad Real.

Biblioteca de la Universidad de Córdoba.

Biblioteca de la Universidad de Murcia.

Biblioteca de la Universidad de Oviedo.

Biblioteca de la Universidad de Salamanca.

Biblioteca de la Universidad de Zaragoza.

Biblioteca de la Universidad Jaume I, Castellón.

Biblioteca de la Universidad Pontificia Comillas de Madrid.

Biblioteca de la Universidad Pontificia de Salamanca.

Biblioteca del Archivo Municipal de Burgos.

Biblioteca del Consejo Superior de Investigaciones Científicas.

Biblioteca del IES Cardenal Cisneros, Madrid.

Biblioteca Junta de Andalucía, Sevilla.

Biblioteca Municipal de Toro, Zamora.

Biblioteca Nacional de España.

Biblioteca Pública de Burgos.

Biblioteca Pública de Castilla y León, Valladolid.

Biblioteca Pública de San Sebastián.

Biblioteca Pública de Teruel.

Biblioteca Pública Ikust-Alaia. Fondo Mourlane Michelena, Gipuzkoa.

CEINCE.

Instituto Bibliográfico Aragonés, Zaragoza.

Catálogos: 1917, 1925, 1929.

Autor: Lampreave Compains, Mariano.

Título: Mi sendero: primer manuscrito para niños y niñas.

Edición: $1^{a}$ edición (1931), $2^{a}$ edición (1937), $4^{\text {a }}$ edición (1941), $5^{\text {a }}$ edición (1943), $6^{a}$ edición (1943), $7^{a}$ edición (1944), $8^{a}$ edición (1947), $10^{a}$ edición (1952), $11^{\text {a }}$ edición (1956).

Descripción: 78 p.; 19 cm. Con ilustraciones de Antequera Azpiri.

Bibliotecas:

Biblioteca Central de Madrid.

Biblioteca de la Diputación Provincial de Burgos.

Biblioteca de la Universidad de Murcia.

Biblioteca Nacional de España.

Biblioteca Pública de Burgos.

Biblioteca Pública de Castilla y León, Valladolid.

Biblioteca Pública de León.

Biblioteca Pública de San Sebastián.

Catálogos: Posterior a los catálogos analizados. 
Autor: Álvarez Bollo Carretero, Mariana.

Título: Moisés: relato bíblico.

Edición: (1920).

Descripción: 84 p.; $17 \mathrm{~cm}$. Con ilustraciones de Pedro Antequera Azpiri.

Colección: Biblioteca Selecta, 6.

Bibliotecas:

Biblioteca de la Diputación Provincial de Burgos.

Biblioteca Pública de San Sebastián.

Catálogos: 1917 (en prensa), 1925, 1929.

Autor: Cantón Salazar, Leocadio.

Título: Monografía histórico-arqueológica del Palacio de los Condestables de Castilla.

Edición: (1884).

Notas: Publicado en la Imprenta y librería de Santiago Rodríguez Alonso.

Descripción: 82 p. más 6 sin foliar

Bibliotecas:

Biblioteca Digital de Castilla y León.

Biblioteca Pública de Castilla y León, Valladolid.

Biblioteca Pública de Burgos.

Biblioteca del Archivo Histórico Provincial de Burgos.

Biblioteca del Archivo Municipal de Burgos.

Biblioteca de la Diputación Provincial de Burgos.

Biblioteca del Seminario Mayor de León.

Biblioteca de la Abadía de Santo Domingo de Silos, Burgos.

Catálogos: No aparece en los catálogos estudiados de 1917, 1925, 1929.

$\mathbf{N}$

Autor: Ruiz Yanguas, Agustín.

Título: Necesidad de la enseñanza religiosa en las escuelas primarias, dada por el mismo maestro.

Edición: (1884).

Notas: Publicada en la Imprenta y librería de Santiago Rodríguez Alonso.

Descripción: XII p.; 24 cm.

Bibliotecas:

Biblioteca del Archivo Municipal de Burgos.

Catálogos: Es anterior a los Catálogos estudiados.

Autor: Santos Revuelta, Antonio.

Título: Neuralgia del trigémino y su tratamiento.

Edición: (1910). 
Descripción: 57 p.; $22 \mathrm{~cm}$.

\section{Bibliotecas:}

Biblioteca de la Universidad Complutense de Madrid. (Tesis de la Universidad Central, Facultad de Medicina).

Catálogos: No aparece en los catálogos estudiados de 1917, 1925, 1929.

Autor: Julián, Joaquín.

Título: Nociones de aritmética con el sistema métrico.

Edición: $5^{\text {a }}$ edición (1906).

Descripción: 65 p.; $16 \mathrm{~cm}$.

Bibliotecas:

Biblioteca Nacional de España.

Catálogos: No aparece en los catálogos estudiados de 1917, 1925, 1929.

Autor: S. M.

Título: Nociones de aritmética y ejercicios de cálculo mental.

Edición: $3^{\text {a }}$ edición (1900).

Descripción: 126 p.; $19 \mathrm{~cm}$. Con ilustraciones.

Bibliotecas:

Biblioteca de la UNED, proyecto Manes.

Biblioteca del Consejo Superior de Investigaciones Científicas.

Catálogos: No aparece en los catálogos estudiados de 1917, 1925, 1929.

Autor: Fernández, Clemente; García Medrano, Jorge.

Título: Nociones generales de aritmética teórico-práctica.

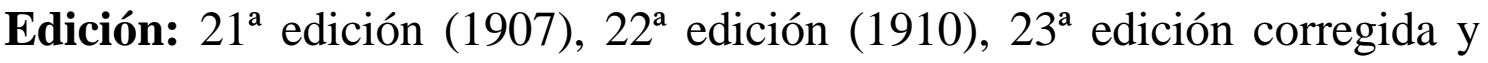
aumentada (1912), 24 a edición corregida y aumentada (1915).

Notas: Premiada con diploma de $1^{\text {a }}$ clase en la Exposición logroñesa de 1880.

Descripción: 96 p.; 16 cm. Cubierta al cromo o en varios colores.

Bibliotecas:

Biblioteca de la Diputación Provincial de Burgos.

Biblioteca Pública de Burgos.

Biblioteca de la Universidad Complutense de Madrid.

Biblioteca de la Universidad de Castilla La Mancha, Campus de Cuenca.

Biblioteca de la Universidad Pontificia de Salamanca.

Catálogos: 1908 (21 a edición), 1917 (Compendio de Aritmética. 35 ediciones), 1925 (24ª edición), 1929.

Autor: Recopiladas por Mayo Izarra, Margarita.

Título: Nuestros prosistas y poetas: lecturas literarias de autores españoles para la juventud.

Edición: (19--). 
Descripción: 282 p.; 19 cm. Con ilustraciones de Antequera Azpiri. Bibliotecas:

Biblioteca de la UNED, proyecto Manes.

Biblioteca de la Universidad Brigham Young, Provo, UTA (Library Harold

B. Lee. Brigham Young University).

Biblioteca de la Universidad de Córdoba.

Biblioteca de la Universidad Rovira i Virgili, Tarragona.

Biblioteca Pública de Gipuzkoa, San Sebastián.

Biblioteca Pública Municipal Lope de Vega, Ciudad Real.

Catálogos: 1925 (en prensa), 1929.

Autor: Martí Alpera, Felix.

Título: Nueva enciclopedia escolar: grado primero.

Edición: $1^{\text {a }}$ edición (1930), $3^{\text {a }}$ edición corregida (1931), $4^{\text {a }}$ edición corregida (1932), $5^{a}$ edición (1933), $8^{a}$ edición (1935), $9^{a}$ edición (1936), $11^{a}$ edición (1937). Se siguió editando hasta 1960.

Descripción: 297 p.; 19 cm. Ilustrada con dibujos originales.

Colección: Enciclopedias.

Bibliotecas:

Biblioteca de la Diputación Provincial de Burgos.

Biblioteca de la UNED, proyecto Manes.

Biblioteca de la Universidad de Alicante.

Biblioteca de la Universidad de Castilla La Mancha, Campus de Ciudad Real.

Biblioteca de la Universidad de Deusto, San Sebastián.

Biblioteca de la Universidad de Girona.

Biblioteca de la Universidad de La Laguna, Santa Cruz de Tenerife.

Biblioteca de la Universidad de Lleida.

Biblioteca de la Universidad de Málaga.

Biblioteca de la Universidad de Murcia.

Biblioteca de la Universidad de Santiago de Compostela.

Biblioteca de la Universidad de Sevilla.

Biblioteca de la Universidad Pontificia de Salamanca.

Biblioteca de la Universidad Rovira y Virgili, Tarragona.

Biblioteca del Consejo Superior de Investigaciones Científicas.

Biblioteca del Ministerio de Educación, Cultura y Deporte. Biblioteca de Educación.

Biblioteca Digital de Castilla y León.

Biblioteca Nacional de España.

Biblioteca Pública de Cataluña, Barcelona.

Biblioteca Pública de San Sebastián.

Biblioteca Pública Rafael de Pablos, Cádiz. 


\section{CEINCE}

Catálogos: 1929 (en prensa. Grado $1^{\circ}, 2^{\circ}, 3^{\circ}$ ).

Autor: Martí Alpera, Félix.

Título: Nueva enciclopedia escolar: grado segundo.

Edición: (1931), 4 edición (1933), $5^{\text {a }}$ edición (1934), 10ª edición (1937).

Se siguió editando hasta 1966.

Descripción: 583 p.; 19 cm. Ilustrada con más de 400 dibujos.

Colección: Enciclopedias.

\section{Bibliotecas:}

Biblioteca de la Universidad Autónoma de Madrid.

Biblioteca de la Universidad Complutense de Madrid.

Biblioteca de la Universidad de Alicante.

Biblioteca de la Universidad de Castilla La Mancha, Campus de Ciudad Real.

Biblioteca de la Universidad de Coruña.

Biblioteca de la Universidad de Islas Baleares.

Biblioteca de la Universidad de Murcia.

Biblioteca de la Universidad de Sevilla.

Biblioteca de la Universidad de Valencia.

Biblioteca de la Universidad Pontificia de Salamanca.

Biblioteca Digital de Castilla y León.

Biblioteca Fundación Alvargonzález, Asturias.

Biblioteca Nacional de España.

Biblioteca Pública de San Sebastián.

CEINCE

Catálogos: 1929 (en prensa).

Autor: Martí Alpera, Félix.

Título: Nueva enciclopedia escolar: grado tercero.

Edición: $1^{a}$ edición (1935), $2^{a}$ edición ilustrada (1937), $3^{a}$ edición (1941), $5^{\text {a }}$ edición (1943), $8^{a}$ edición ilustrada (1947). Se siguió editando hasta 1965.

Descripción: La primera edición 1011 p.; 19 cm. Está ilustrada con más de 500 dibujos

Colección: Enciclopedias.

Bibliotecas:

Biblioteca de la UNED. Proyecto Manes.

Biblioteca de la Universidad de Castilla La Mancha. Escuela de Ingeniería Minera e Industrial de Almadén. Campus de Ciudad Real.

Biblioteca de la Universidad de Extremadura.

Biblioteca de la Universidad de Girona.

Biblioteca de la Universidad de Jaime I, Castellón. 
Biblioteca de la Universidad de La Laguna, Santa Cruz de Tenerife. Biblioteca de la Universidad de Sevilla.

Biblioteca de la Universidad Rovira i Virgili, Tarragona.

Biblioteca Digital de Castilla y León.

Biblioteca Nacional de España.

Biblioteca Pública de Navarra.

Biblioteca Pública de San Sebastián.

CEINCE

Catálogos: 1929 (en prensa).

Autor: Díez Pérez, Pedro.

Título: Nueva guía de Burgos y su provincia.

Edición: $1^{\text {a }}$ edición (1930), $2^{\text {a }}$ edición (1938).

Descripción: 200 p.; 1 mapa plegado; $18 \mathrm{~cm}$. Contiene apéndice, 1 mapa plegado, 35 dibujos de Fortunato Julián e itinerarios de la provincia de Burgos originales por José Sarmiento Lasuén.

\section{Bibliotecas:}

Biblioteca de la AECID, Bibliotecas Hispánica e Islámica.

Biblioteca de la Diputación Provincial de Burgos.

Biblioteca de la Universidad Autónoma de Madrid.

Biblioteca de la Universidad de Navarra.

Biblioteca de la Universidad de Salamanca.

Biblioteca de la Universidad de Valladolid.

Biblioteca de la Universidad Politécnica de Madrid.

Biblioteca del Archivo Municipal de Burgos.

Biblioteca del Consejo Superior de Investigaciones Científicas.

Biblioteca del Instituto de Estudios Riojanos, Logroño.

Biblioteca del Museo de Burgos.

Biblioteca Municipal Miguel de Cervantes, Burgos.

Biblioteca Pública de Burgos.

Biblioteca Pública de Castilla y León, Valladolid.

Biblioteca Pública de Cataluña. Barcelona.

Biblioteca Pública de Zamora.

Biblioteca Pública Municipal de Calatayud en Zaragoza.

Catálogos: 1929 (en prensa).

Autor: Martín Alpera, Félix.

Título: Nuevas lecciones de geometría: con aplicaciones al dibujo, a la agrimensura, a la arquitectura y al trabajo manual. (Grado medio, grado superior).

Edición: $3^{\text {a }}$ edición (1917), $6^{\text {a }}$ edición (1911), $7^{\text {a }}$ edición (1922), $8^{a}$ edición corregida e ilustrada con 316 dibujos y figuras (19-?), (2007) Reproducción facsímil de la edición de 1911. 
Descripción: 208 p.; 17 cm.; 154 p.; 19 cm., según ediciones.

\section{Bibliotecas:}

Biblioteca de la Diputación Provincial de Burgos.

Biblioteca de la UNED. Proyecto Manes.

Biblioteca de la Universidad Autónoma de Madrid.

Biblioteca de la Universidad de Coruña.

Biblioteca de la Universidad de Deusto.

Biblioteca de la Universidad de Jaén.

Biblioteca de la Universidad de Murcia.

Biblioteca de la Universidad de Oviedo.

Biblioteca de la Universidad de Valladolid.

Biblioteca de la Universidad Pontificia de Salamanca.

Biblioteca del Seminario Diocesano de Segovia.

Biblioteca Municipal de Aranda de Duero, Burgos.

Biblioteca Municipal La Robla. León.

Biblioteca Municipal Las Navas del Marqués, Ávila.

Biblioteca Nacional de España.

Biblioteca Pública de Castilla y León, Valladolid.

Biblioteca Pública de Badajoz.

Biblioteca Pública de León.

Biblioteca Pública de Segovia.

Biblioteca Pública Nodal de Vigo, Pontevedra.

CEINCE.

Catálogos: 1908 (en prensa. Será el $2^{\circ}$ grado del anterior Las primeras lecciones de Geometría, 1917 ( $3^{\mathrm{a}}$ edición), 1925 ( $6^{\mathrm{a}}$ edición), 1929 (7 edición).

Autor: Ortiz de Pinedo, J.

Título: Nuevo teatro infantil: comedias, juguetes, diálogos, monólogos, farsas, fantasías.

Edición: (1925?).

Descripción: 176 p.; 20 cm. Cubierta en colores.

\section{Bibliotecas:}

Biblioteca de la Diputación Provincial de Burgos.

Biblioteca de la Universidad de Castilla La Mancha, Campus de Cuenca.

Biblioteca Pública de San Sebastián.

Catálogos: No aparece en los catálogos estudiados de 1908, 1917, 1925, 1929.

P

Autor: Benejam Vives, Juan.

Título: Páginas sobre ciencias físicas y naturales. Grado primero. 
Edición: $2^{a}$ edición (1901), (1902), $3^{\text {a }}$ edición (1907), $4^{\text {a }}$ edición (1908), (1915), $4^{a}$ edición (1917), $6^{\text {a }}$ edición, $7^{\text {a }}$ edición (1929).

Descripción: 116 p. o 128 p.; $18 \mathrm{~cm}$. Ilustrada con fotograbados y dibujos. Tapas y cubierta al cromo.

\section{Bibliotecas:}

Biblioteca de la UNED, proyecto Manes.

CEINCE.

Catálogos: 1908 (3 $3^{\text {a }}$ edición ilustrada), 1917 (Grado 1º: $4^{\text {a }}$ edición), 1925 ( $7^{\text {a }}$ edición), 1929 ( $7^{\text {a }}$ edición).

Autor: Benejam Vives, Juan.

Título: Páginas sobre Ciencias físicas y naturales. Grado superior.

Edición: $7^{\text {a }}$ edición (190?). Fechado en 1900 en p. 5.

Descripción: 298 p.; $16,5 \mathrm{~cm}$. Con Ilustraciones en fotograbados y encuadernación en pasta con tapas al cromo.

\section{Bibliotecas:}

Biblioteca de la Real Sociedad Económica Extremeña de Amigos del País, Badajoz.

Biblioteca de la Universidad de Córdoba.

Biblioteca Nacional de España.

Biblioteca Pública de Burgos.

CEINCE.

Catálogos: 1908 (en prensa grado primero y grado medio), 1917 (Grado primero: $4^{a}$ edición, grado medio: en prensa y grado superior: $8^{\mathrm{a}}$ edición), 1925 (Grado primero: $7^{\mathrm{a}}$ edición y grado superior: $8^{\mathrm{a}}$ edición), 1929 (Grado primero: $7^{\mathrm{a}}$ edición y grado superior: $8^{\mathrm{a}}$ edición).

Autor: Rodríguez García, Gerardo.

Título: Para aprender a leer. Grado primero.

Edición: $7^{\text {a }}$ edición ilustrada (1925?).

Descripción: 76 p.; $21 \mathrm{~cm}$. Con fotograbados y dibujos. Tapas al cromo o en colores según ediciones. Cubierta cuatricolor.

\section{Bibliotecas:}

Biblioteca de la Diputación Provincial de Burgos.

Biblioteca Nacional de España.

Biblioteca Pública Museos. Museo Casa Natal de Jovellanos, Gijón.

Catálogos: 1917, 1925 (6ª edición), 1929 (7ª edición).

Autor: Rodríguez García, Gerardo.

Título: Para aprender a leer. Grado segundo.

Edición: $5^{\text {a }}$ edición (1925).

Descripción: 132 p.; 21 cm. Dibujos a tinta en color. Cubierta cuatricolor. Bibliotecas: 
Biblioteca de la Diputación Provincial de Burgos.

Biblioteca Nacional de España.

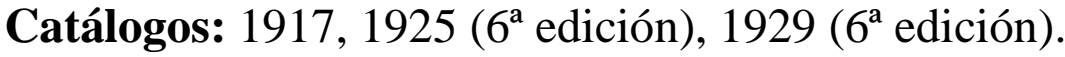

Autor: Georges Art. Prefacio de Emilio Faquet. Traducción y adaptación al castellano de la segunda edición francesa por Leoncio Urabayen.

Título: Para desarrollar nuestra memoria por la audición, la visión, la idea.

Edición: (1900).

Descripción: 262 p.; $21 \mathrm{~cm}$. Cubierta a color.

Bibliotecas:

Biblioteca de la Escuela Universitaria del Profesorado de EGB en Ciudad Real.

Biblioteca de la Universidad de La Laguna.

Biblioteca de la Universidad de Oviedo.

Biblioteca de la Universidad de Salamanca.

Biblioteca de la Universidad Pública de Navarra.

Biblioteca Nacional de España.

Biblioteca Nacional de Santiago de Chile. Chile.

Biblioteca Pública de Albacete.

Biblioteca Pública de Vitoria.

Biblioteca Pública Municipal de Cuenca.

Biblioteca Pública Nodal de Ourense.

Catálogos: 1917, 1925, 1929.

Autor: Araujo, Carlos.

Título: Para exámenes y fiestas escolares: nueva colección de monólogos, discursos y recitaciones infantiles, propias para veladas infantiles.

Edición: (1930).

Descripción: 97 p.; $21 \mathrm{~cm}$.

Bibliotecas:

Biblioteca Pública de Málaga.

Catálogos: Es posterior a los catálogos analizados.

Autor: Bustamante, Mateo.

Título: Para mi hijo: libro primero de lectura para niños y niñas.

Edición: $2^{\mathrm{a}}$ edición (1898), 17 ${ }^{\mathrm{a}}$ edición. Nueva edición ilustrada, $27^{\mathrm{a}}$ edición ilustrada (1920), 30 a edición ilustrada (1925-1935). Siguió editándose hasta la $55^{\text {a }}$ edición en 1963.

Descripción: Varios formatos e ilustradores según las ediciones. En los catálogos analizados: 152-160 p.; $18 \mathrm{~cm}$. Tapas en cromolitografía y cubierta con colores. (Los ilustradores cambian según la época: Evaristo 
Barrio, Fortunato Julián, Julio Algora, Cristino Soravilla o Rosario de Velasco).

\section{Bibliotecas:}

Biblioteca Central de Madrid.

Biblioteca de la Diputación Provincial de Burgos.

Biblioteca de la Universidad de La Laguna.

Biblioteca de la Universidad Pública de Navarra.

Biblioteca Nacional de España.

Biblioteca Pública de La Rioja, Logroño.

Biblioteca Pública de Burgos.

Biblioteca Pública de Luarco, Asturias.

Biblioteca Pública de Navarra.

Biblioteca Pública de San Sebastián.

Biblioteca Universidad Complutense de Madrid.

CEINCE.

Claremont Colleges Library. Claremont University Consortium.

Catálogos: 1908 ( $8^{\text {a }}$ edición), 1917 (18 a edición), 1925 (27 edición), 1929 (30 edición).

Autor: Rodríguez-Navas, Manuel.

Título: Para saberlo todo, para recordarlo todo: enciclopedia del siglo $X X$.

Edición: $1^{a}$ edición (1911), $2^{a}$ edición notablemente aumentada y corregida (1914), $3^{\text {a }}$ edición corregida y aumentada por Manuel Rodríguez Navas.

Descripción: Entre 630 p. y 1032 p. según ediciones; $20 \mathrm{~cm}$. Ilustrada de 700 a 850 grabados y entre 7 y 12 mapas a color según las ediciones. Encuadernación en tela inglesa con planchas doradas.

\section{Bibliotecas:}

Archivo Municipal de Burgos.

Biblioteca de Extremadura, Cáceres.

Biblioteca de la Diputación Provincial de Burgos.

Biblioteca de la Universidad de Murcia.

Biblioteca de la Universidad de Princeton, Nueva Jersey. Estados Unidos.

Biblioteca de la Universidad de Wheaton, Illinois. Estados Unidos.

Biblioteca del Seminario Diocesano de Segovia.

Biblioteca Digital de Castilla y León.

Biblioteca Digital Hathi Trust, Universidad de Michigan. Estados Unidos.

Biblioteca Municipal de Aranda de Duero, Burgos.

Biblioteca Nacional de España.

Biblioteca Nacional de México.

Biblioteca Pública Asturiana. Biblioteca y papeles de Clarín, Gijón.

Biblioteca Pública de Burgos.

Biblioteca Pública de Castilla La Mancha, Toledo. 
Biblioteca Pública de Castilla y León, Valladolid.

Biblioteca Pública de San Sebastián.

Biblioteca Pública Municipal San Pedro del Pinatar, Murcia.

Biblioteca Pública Nodal de Ourense.

Biblioteca Pública San Nicolás. Fondo Erreserbako, Gipuzkoa.

Biblioteca Universidad San Antonio, Texas. Estados Unidos.

Centro Cervantino de la Roda, Albacete.

Catálogos: 1917 ( $2^{a}$ edición. 1016 páginas. Título: Para saberlo todo, para recordarlo todo. Nueva enciclopedia de conocimientos útiles), 1925 ( $3^{\mathrm{a}}$ edición), 1929.

Autor: Araste, Eduardo.

Título: Parlerías.

Edición: (1918?).

Descripción: 85 p.; $17 \mathrm{~cm}$.

Bibliotecas:

Biblioteca Digital de Castilla y León.

Biblioteca Nacional de España.

Biblioteca Pública de Castilla y León, Valladolid.

Catálogos: No aparece en los catálogos estudiados de 1908, 1917, 1925, 1929.

Autor: Betolaza y Esparta, Gregorio.

Título: Parroquia de San Gil de Burgos.

Edición: (1914).

Descripción: 86 p.; 20 cm. Contiene 13 láminas.

Bibliotecas:

Archivo Silveriano de la Provincia Carmelitana O.C.D. Burgense, Burgos.

Biblioteca de la Diputación Provincial de Burgos.

Biblioteca de la Universidad de Harvard, Cambridge Massachussets. Estados Unidos.

Biblioteca de la Universidad de Middlebury, Vermont. Estados Unidos.

Biblioteca de la Universidad de Valladolid.

Biblioteca de la Universidad Politécnica de Madrid.

Biblioteca del Archivo Histórico Provincial de Burgos.

Biblioteca del Archivo Municipal de Burgos.

Biblioteca del Museo de Burgos.

Biblioteca digital en Castilla y León.

Biblioteca Frick Art Reference, Nueva York. Estados Unidos (Library of The Frick Collection).

Biblioteca Municipal Miguel de Cervantes, Burgos.

Biblioteca Nacional de España.

Biblioteca Pública de Burgos. 
Biblioteca Pública de Castilla y León, Valladolid.

Bibliotecas de la AECID. Bibliotecas Hispánica e Islámica.

Museo Nacional de Artes Decorativas en Madrid.

Catálogos: No aparece en los catálogos estudiados de 1908, 1917, 1925, 1929.

Autor: Antequera Azpiri, Pedro.

Título: Patachín patachán: consejas del Papa Moscas.

Edición: (19--).

Descripción: 14 p.; 22 cm. Ilustraciones de Antequera Azpiri.

Colección: Papa-Moscas, 1.

Bibliotecas:

Biblioteca Pública de Castilla y León, Valladolid.

Catálogos: 1929

Autor: A. de Santocildes Barrio, Alejandro.

Título: Patria, religión y amor: boceto histórico.

Edición: (1909).

Descripción: 23 p.; $21 \mathrm{~cm}$.

Bibliotecas:

Biblioteca de la Universidad de Harvard, Cambridge, Massachusetts. Estados Unidos.

Biblioteca Nacional de España.

Biblioteca Pública de Burgos.

Catálogos: No aparece en los catálogos estudiados de 1908, 1917, 1925, 1929.

Autor: Málaga García, Eduardo.

Título: Pedagogía General.

Edición: (19--).

Descripción: 224 p.; $20 \mathrm{~cm}$.

Bibliotecas:

Biblioteca de la Universidad de Málaga.

Catálogos: No aparece en los catálogos estudiados de 1908, 1917, 1925, 1929.

Autor: Blanco-Belmonte, Marcos Rafael.

Título: Pompas de jabón.

Edición: (1913).

Descripción: 143 p.; 18 cm. Con ilustraciones de Evaristo Barrio.

Colección: Biblioteca Mundial, 2.

Bibliotecas:

Biblioteca de la Diputación Provincial de Burgos. 
Biblioteca de la Universidad de La Laguna.

Biblioteca de la Universidad de Oviedo.

Biblioteca de la Universidad de Sevilla.

Biblioteca del IES Cardenal Cisneros, Madrid.

Biblioteca Junta de Andalucía.

Biblioteca Municipal de Aranda de Duero, Burgos.

Biblioteca Municipal de Laguna de Duero, Valladolid.

Biblioteca Municipal de Medina del Campo, Valladolid,

Biblioteca Pública de Burgos.

Biblioteca Pública de Castilla y León, Valladolid.

Biblioteca Pública de Soria.

Catálogos: 1917, 1925, 1929.

Autor: Santos Vila, Ángel.

Título: Por la raza, para ser sanos y fuertes: alcoholismo, tuberculosis, eugenética. Lecturas de popularización higiénico-social.

Edición: (1921?).

Notas: Premiada con Diploma de Mérito por el Consejo Superior de Protección a la Infancia.

Descripción: 96 p.; $19 \mathrm{~cm}$. Con ilustraciones y cubierta en colores.

Bibliotecas:

Biblioteca de la Universidad de Castilla La Mancha. Campus de Cuenca.

Biblioteca de la Universidad de Valencia.

Biblioteca del Ateneo Riojano, Logroño.

Biblioteca Nacional de España.

Biblioteca Pública de Burgos.

Biblioteca Pública de Castilla y León, Valladolid.

Catálogos: 1925 ( (2ª edición), 1929.

Autor: Mira, José.

Título: Premio a la caridad y castigo a la avaricia (cuento).

Edición: (1928).

Descripción: 31 p.; $22 \mathrm{~cm}$.

Bibliotecas:

Biblioteca de la Universidad Complutense de Madrid.

Catálogos: No aparecen en los catálogos analizados.

Autor: Peñín y Rubio, Manuel.

Título: Primer curso de Lengua Española: para la primera enseñanza.

Edición: $2^{a}$ edición (1931).

Descripción: 116 p.; 26 cm.

Bibliotecas:

Biblioteca de la Universidad de Murcia. 
Catálogos: 1929.

Autor: Álvarez Carretero, Antonio.

Título: Principios de higiene y economía domésticas, precedido de unas nociones de fisiología.

Edición: $4^{\mathrm{a}}$ edición aumentada con unas nociones de urbanidad, en verso, y corregida la Higiene por un licenciado en medicina y cirugía de esta Universidad (1896).

Notas: Obra de texto aprobada por Real Decreto, recomendada por la Junta provincial de Instrucción Pública de Burgos, premiada en la Exposición Pedagógica de 1882, en la de Zaragoza y Barcelona.

Descripción: 163 p.; 19 cm. Ilustraciones de Isidro Gil.

Bibliotecas:

Biblioteca de la Diputación Provincial de Burgos.

Biblioteca de la Universidad Complutense de Madrid.

Biblioteca de la Universidad de Córdoba.

Biblioteca de la Universidad de Lérida.

Biblioteca de la Universidad de Santiago de Compostela.

Biblioteca de la Universidad Pública de Navarra.

Biblioteca Pública Jovellanos, Asturias.

Catálogos: 1908, 1917, 1925.

Autor: Álvarez Carretero, Antonio.

Título: Prontuario de Pedagogía.

Edición: $3^{a}$ edición (1883), 4a edición (1893), (1894), (1895). Edición corregida y aumentada según el programa oficial de oposiciones (1894).

Notas: Obra premiada en la Exposición aragonesa de 1885 y en la Universal de Barcelona de 1888.

Descripción: 149 p.; $20 \mathrm{~cm}$. Encuadernado en pasta con tapas en tela, con adornos.

\section{Bibliotecas:}

Biblioteca de la Universidad de Castilla La Mancha, Campus de Toledo.

Biblioteca de la Universidad de Las Islas Baleares.

Biblioteca de la Universidad de Lérida.

Biblioteca de la Universidad de Murcia.

Biblioteca de la Universidad de Santiago de Compostela.

Biblioteca del Consejo Superior de Investigaciones Científicas.

Biblioteca Nacional de España.

Biblioteca Pública de Burgos.

Catálogos: 1908 ( $4^{\mathrm{a}}$ edición), 1917 (4ª edición notablemente corregida y aumentada). 
Autor: Martínez Rives, José.

Título: Programa de las lecciones de la asignatura de Historia Universal: libros de texto.

Edición: (1889).

Descripción: 31 p.; $20 \mathrm{~cm}$.

Bibliotecas:

Biblioteca del Consejo Superior de Investigaciones Científicas.

Biblioteca Pública de Burgos.

Catálogos: No aparece en los catálogos analizados.

Autor: Martínez Rives, José.

Título: Programa de las lecciones de la asignatura de Historia de España.

Edición: (1889).

Descripción: 26 p.; $21 \mathrm{~cm}$.

Bibliotecas:

Biblioteca Pública de Burgos.

Catálogos: No aparece en los catálogos analizados.

Autor: Sandoval, Manuel de.

Título: Prosistas Castellanos.

Edición: (1901).

Descripción: 211 p.; 19 cm.

Bibliotecas:

Biblioteca de la Universidad de Córdoba.

Biblioteca de la Universidad de Málaga.

Biblioteca del IES Conde Diego Porcelos, Burgos.

Catálogos: 1917, 1929.

\section{Q}

Autor: Pérez Ortiz, Jerónimo.

Título: ¿Quiere usted conservar la belleza?

Edición: (1920).

Descripción: 64 p.; $20 \mathrm{~cm}$. Con varias ilustraciones.

Colección: Biblioteca Popular de Medicina e Higiene, 12. (Segunda serie).

Bibliotecas:

Biblioteca Nacional de España.

Catálogos: 1925, 1929.

Autor: Younger, Frank J.

Título: ¿Quiere usted conservar la dentadura?

Edición: (1920).

Descripción: 71 p.; $20 \mathrm{~cm}$. Con varias ilustraciones. 
Colección: Biblioteca Popular de Medicina e Higiene, 13. (Segunda serie). Bibliotecas:

Biblioteca de la Universidad de Navarra.

Biblioteca Nacional de España.

Biblioteca Pública de Cáceres.

Catálogos: 1925, 1929.

Autor: Urraca A. Reyero, César.

Título: ¿Quiere usted conservar la vista?

Edición: (1914).

Descripción: 53 p.; $20 \mathrm{~cm}$. Con varias ilustraciones.

Colección: Biblioteca popular de Medicina e Higiene, 7. (Primera serie).

Bibliotecas:

Biblioteca Nacional de España.

Biblioteca Pública de Burgos.

Biblioteca Pública de Córdoba.

Catálogos: 1917, 1925 (segunda serie), 1929.

Autor: Merino, José.

Título: ¿Quiere usted criar bien a sus hijos?

Edición: (1914).

Descripción: 47 p.; $20 \mathrm{~cm}$. Con varias ilustraciones.

Colección: Biblioteca Popular de Medicina e Higiene, 2. (Primera serie).

Bibliotecas:

Biblioteca Nacional de España.

Biblioteca Pública de Burgos.

Catálogos: 1917, 1925, 1929.

Autor: Pérez Ortiz, Jerónimo

Título: ¿Quiere usted curar y evitar la hernia?

Edición: (1919).

Descripción: 60 p.; 20 cm.; Con grabados.

Colección: Biblioteca Popular de Medicina e Higiene, 11. (Segunda serie).

Bibliotecas:

Biblioteca de la Universidad Politécnica de Madrid.

Catálogos: 1925, 1929.

Autor: Olavide y Torres, José.

Título: ¿Quiere usted evitar las enfermedades venéreas?

Edición: (1917).

Descripción: 50 p.; $20 \mathrm{~cm}$. Con varias ilustraciones.

Colección: Biblioteca Popular de Medicina e Higiene, 5. (Primera serie).

Bibliotecas: 
Biblioteca Nacional de España.

Catálogos: 1917 (nº 7), 1925, 1929.

Autor: López de Rego, Juan.

Título: ¿Quiere usted evitar las infecciones?

Edición: (1917).

Descripción: 68 p.; $20 \mathrm{~cm}$. Con varias ilustraciones.

Contenido: Biblioteca Popular de Medicina e Higiene, 9. (Segunda serie).

Bibliotecas:

Biblioteca Rafael Pablo de Cádiz.

Biblioteca del Seminario Diocesano de Segovia.

Biblioteca Nacional de España.

Biblioteca Pública de Burgos.

Catálogos: 1925, 1929.

Autor: Verdes Montenegro y Montoro, José.

Título: ¿Quiere usted tener sano el aparato respiratorio?: lo que para ello debe hacerse.

Edición: (1917?).

Descripción: 62 p.; $20 \mathrm{~cm}$. Con varias ilustraciones.

Contenido: Biblioteca Popular de Medicina e Higiene, 4. (Primera serie).

Bibliotecas:

Biblioteca Nacional de España.

Biblioteca Pública de Burgos.

Biblioteca Pública de Córdoba.

Catálogos: 1917 (nº 6), 1925, 1929.

Autor: Mut, Antonio

Título: ¿Quiere usted tener sano el corazón?

Edición: (1917).

Descripción: 62 p.; $20 \mathrm{~cm}$. Con varias ilustraciones.

Colección: Biblioteca popular de Medicina e Higiene, 8. (Segunda serie).

Bibliotecas:

Biblioteca Pública Jovellanos.

Biblioteca de la Universidad de Santiago de Compostela.

Biblioteca Nacional de España.

Biblioteca Pública de Burgos.

Catálogos: 1917 (nº 3), 1925 (Segunda serie), 1929.

Autor: Carro, Santiago.

Título: ¿Quiere usted tener sano el estómago?

Edición: (1917?).

Descripción: 58 p.; $20 \mathrm{~cm}$. Con varias ilustraciones. 
Colección: Biblioteca Popular de Medicina e Higiene, 6. (Primera serie). Bibliotecas:

Biblioteca Nacional de España.

Biblioteca Pública de Burgos.

Biblioteca Pública de Castilla y León, Valladolid.

Catálogos: 1917 (nº 8), 1925, 1929.

Autor: Álvarez Gómez-Salazar, Ramón.

Título: ¿Quiere usted tener sano el sistema nervioso?

Edición: (1917?).

Descripción: 63 p.; $20 \mathrm{~cm}$. Con varias ilustraciones.

Colección: Biblioteca Popular de Medicina e Higiene, 3. (Primera serie). Bibliotecas:

Biblioteca de la Universidad de La Laguna de Santa Cruz de Tenerife.

Biblioteca Nacional de España.

Biblioteca Pública de Burgos.

Biblioteca Pública de Oviedo.

Catálogos: 1917 (nº 5), 1925, 1929.

Autor: Carazo, Abelardo.

Título: ¿Quiere usted tener un buen embarazo?

Edición: (1918).

Descripción: 60 p.; $20 \mathrm{~cm}$. Con varias ilustraciones.

Colección: Biblioteca Popular de Medicina e Higiene, 10. (Segunda serie).

Bibliotecas:

Biblioteca Nacional de España.

Biblioteca Pública de Burgos.

Biblioteca Pública de Castilla y León, Valladolid.

Catálogos: 1917 (nº 9), 1925, 1929.

Autor: Tamayo, Benjamín.

Título: ¿Quiere usted vivir muchos años?, lo que para conseguirlo debe hacerse.

Edición: (1914), (1917?).

Descripción: 44 p.; $20 \mathrm{~cm}$. Con varias ilustraciones.

Colección: Biblioteca Popular de Medicina e Higiene, 8 (Segunda serie).

Bibliotecas:

Biblioteca Nacional de España.

Biblioteca Pública de Burgos.

Biblioteca Pública de Castilla y León, Valladolid.

Biblioteca Pública de Oviedo.

Catálogos: 1917 (nº 1), 1925, 1929. 
Autor: VV. AA.

Título: ¿Quieres ser mi amigo?

Edición: (19--).

Descripción: 128 p.; $21 \mathrm{~cm}$. Ilustrada, con tapas al cromo y oro.

Colección: Biblioteca Oro, 1.

Bibliotecas:

Biblioteca de la Universidad de Toulouse (Université de Toulouse-Le Mirail). Francia.

Biblioteca Pública de Castilla y León, Valladolid.

Catálogos: 1917, 1925, 1929

Autor: Hijos de Santiago Rodríguez.

Título: ¿Quieres ser mi amigo? Publicación periódica. Semanario infantil ilustrado.

Edición: (1896). Semanal. Año I, no 1 (5 en 1896)

Descripción: 12p.; $26 \mathrm{~cm}$. Con ilustraciones y pasatiempos.

Bibliotecas:

Biblioteca Pública de Vitoria.

Catálogos: No aparece en ninguno de los catálogos analizados.

Autor: Sienkiewicz, Enrique. Adaptación para la juventud por Margarita de Mayo.

Título: ¿Quo Vadis?

Edición: (192-).

Descripción: 119 p.; $22 \mathrm{~cm}$. Con ilustraciones de Antequera Azpiri. Cubierta al cromo y oro.

Colección: Biblioteca Enciclopédica Hispano-Americana, 11.

Bibliotecas:

Archivo Municipal de Burgos.

Biblioteca Pública de Castilla y León, Valladolid.

Catálogos: 1925, 1929.

Autor: Romeo Rodrigo, Octaviano.

Título: Química celeste e investigaciones espectroscópicas realizadas en el último eclipse de sol desde el globo "Júpiter". Conferencia dada en el Salón de Recreo de Burgos el día $1^{\circ}$ de abril de 1906.

Edición: (1906).

Descripción: 36 p.; $25 \mathrm{~cm}$.

Bibliotecas:

Biblioteca de la Universidad de Oviedo.

Biblioteca de la Universidad de Sevilla.

Biblioteca de la Universidad Politécnica de Madrid.

Biblioteca Municipal de Aranda de Duero, Burgos. 
Catálogos: No aparece en ninguno de los catálogos de 1908, 1917, 1925, 1929.

\section{$\mathbf{R}$}

Autor: Bueno Rodríguez-Arias, Ángel.

Título: Rafael: cuentos y fantasías.

Edición: $2^{a}$ edición (1901).

Descripción: 187 p.; $22 \mathrm{~cm}$. Con ilustraciones de Evaristo Barrio. Encuadernado con tapas al cromo y oro y otros con tapas con telas con planchas de negro y oro y cortes dorados.

Colección: Biblioteca Enciclopédica Hispano-Americana, 2.

Bibliotecas:

Biblioteca Digital de Castilla y León.

Biblioteca Nacional de España.

Biblioteca Pública Marqués de Piedras Albas, Ávila.

Catálogos: 1908, 1917, 1925, 1929.

Autor: Desconocido.

Título: Real Monasterio de las Huelgas. Burgos.

Edición: (192?).

Descripción: 5 p.; $16 \mathrm{~cm}$.

Bibliotecas:

Biblioteca Pública de Castilla y León, Valladolid.

Catálogos: 1929 (en prensa).

Autor: Carro, Santiago. Prólogo del Dr. Ramón Luis y Yagüe.

Título: Regímenes alimenticios de las enfermedades del aparato digestivo $y$ de la nutrición.

Edición: (1917).

Descripción: 218 p.; $21 \mathrm{~cm}$.

\section{Bibliotecas:}

Biblioteca de la Universidad Complutense de Madrid.

Biblioteca de la Universidad de León.

Biblioteca de la Universidad de Murcia.

Biblioteca de la Universidad de Navarra.

Biblioteca de la Universidad de Santiago de Compostela.

Biblioteca de la Universidad de Zaragoza.

Biblioteca de la Universidad Politécnica de Madrid.

Biblioteca del Centro Superior Bibliográfico de Galicia, Santiago de Compostela.

Biblioteca Nacional de España. 
Biblioteca Pública de Almería.

Biblioteca Pública de Castilla y León, Valladolid.

Biblioteca Pública Municipal de Vegadeo, Asturias.

Biblioteca Pública Nodal de Orense.

Catálogos: 1925, 1929.

Autor: Ateneo de Burgos.

Título: Reglamento.

Edición: (1924)

Descripción: 27 p.; $15 \mathrm{~cm}$.

Bibliotecas:

Biblioteca Municipal de Aranda de Duero, Burgos.

Catálogos: No aparece en ninguno de los catálogos de 1908, 1917, 1925, 1929.

Autor: Ayuntamiento de Burgos.

Título: Reglamento para el régimen y gobierno del Banco Regulador de Burgos.

Edición: (1892), (1906).

Descripción: 16 p.; $16 \mathrm{~cm}$.

Colección:

Bibliotecas:

Biblioteca Central del Ministerio del Interior en Madrid.

Biblioteca de la Diputación Provincial de Burgos.

Biblioteca de la Universidad Complutense de Madrid.

Biblioteca del Archivo Municipal de Burgos.

Catálogos: No aparece en ninguno de los catálogos de 1908, 1917, 1925, 1929.

Autor: Ayuntamiento de Burgos.

Título: Reglamento del servicio de coches de plaza.

Edición: (1920).

Descripción: 14 p.; $16 \mathrm{~cm}$.

Bibliotecas:

Biblioteca Central del Ministerio del Interior en Madrid.

Catálogos: No aparece en ninguno de los catálogos de 1908, 1917, 1925, 1929.

Autor: Ayuntamiento de Burgos.

Título: Reglamento para el servicio interior de las oficinas del Ayuntamiento de Burgos.

Edición: (1914).

Descripción: 50 p.; $16 \mathrm{~cm}$. 


\section{Bibliotecas:}

Biblioteca de la Diputación Provincial de Burgos.

Catálogos: No aparece en ninguno de los catálogos de 1908, 1917, 1925, 1929.

Autor: Salvá Pérez, Anselmo.

Título: Remembranzas burgalesas.

Edición: (1892), (1894).

Descripción: 95 p.; 20 cm.; 166 p.; 20 cm., según ediciones.

\section{Bibliotecas:}

Abadía Benedictina de Valvanera, La Rioja.

Archivo Silveriano de la Provincia Carmelitana O.C.D. Burgense, Burgos.

Biblioteca de la Abadía de Santo Domingo de Silos, Burgos

Biblioteca de la Diputación Provincial de Burgos.

Biblioteca de la Facultad de Teología del Norte de España, Burgos.

Biblioteca de la Universidad Autónoma de Madrid.

Biblioteca de la Universidad de Alcalá.

Biblioteca de la Universidad de Burgos.

Biblioteca de la Universidad de Princeton, Nueva Jersey. Estados Unidos.

Biblioteca de la Universidad de Valladolid.

Biblioteca del Archivo Municipal de Burgos.

Biblioteca del Archivo Histórico Provincial de Burgos.

Biblioteca del Ateneo de Madrid.

Biblioteca del Consejo Superior de Investigaciones Científicas.

Biblioteca del IES Conde Diego Porcelos, Burgos.

Biblioteca del IES Práxedes Mateo Sagasti, Logroño.

Biblioteca del Monasterio de Santo Tomás de Ávila.

Biblioteca del Real Instituto de Estudios Asturianos, Oviedo.

Biblioteca del Seminario Diocesano de Palencia.

Biblioteca Digital de Castilla y León.

Biblioteca Digital Hathi Trust, Michigan. Estados Unidos.

Biblioteca Municipal Miguel de Cervantes.

Biblioteca Nacional de España.

Biblioteca Pública de Burgos.

Biblioteca Pública de Cáceres.

Biblioteca Pública de Castilla y León, Valladolid.

Biblioteca Real o Biblioteca Nacional de Holanda.

Fundación Lázaro Galdiano, Madrid.

Instituto Nacional de Administración Pública. Madrid.

Catálogos: No aparece en ninguno de los catálogos de 1908, 1917, 1925, 1929.

Autor: Álvarez Bollo Carretero, Mariana. 
Título: Resumen de Higiene y Economía domésticas.

Edición: Novísima edición ilustrada (1895), 12a edición ilustrada (1890?), $14^{a}$ edición. Prólogo de la autora firmado en 1890.

Descripción: 80 p.; $17 \mathrm{~cm}$. Con ilustraciones en fotograbados y tapas al cromo.

\section{Bibliotecas:}

Biblioteca del Monasterio de San Pedro de Cardeña, Burgos.

Biblioteca Nacional de España.

Biblioteca Rafael Pablos de Cádiz.

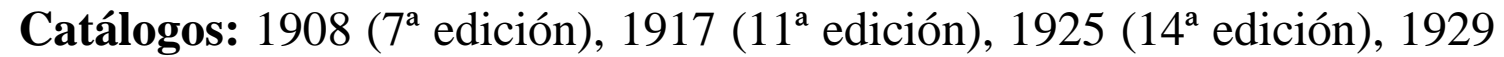
(15 edición).

Autor: Salvá Pérez, Anselmo.

Título: Resumen de Historia de España: para uso de los niños en las escuelas.

Edición: Novísima edición ilustrada (1896), $3^{\text {a }}$ edición ilustrada (1903).

Descripción: 223 p.; $18 \mathrm{~cm}$.

\section{Bibliotecas:}

Biblioteca de la Universidad de Castilla La Mancha, Campus de Cuenca. Biblioteca de la Universidad de Navarra.

Biblioteca Nacional de España.

Biblioteca Pública de Castilla La Mancha, Toledo.

Catálogos: 1917 (Compendio de la Historia de España. Grado primero y segundo: $4^{\mathrm{a}}$ edición), 1925 (Primer grado: $7^{\mathrm{a}}$ edición corregida. Segundo grado y grado superior: en preparación), 1929 (Primer grado y $2^{\circ}$ grado y superior es la $5^{\text {a }}$ edición corregida y ampliada).

\section{$\mathbf{S}$}

Autor: Peñín y Rubio, Manuel.

Título: Segundo curso de Lengua Española: para la primera enseñanza. Edición: (1931).

Descripción: 222 p.; $25 \mathrm{~cm}$.

\section{Bibliotecas:}

Biblioteca de la Universidad de Murcia.

Catálogos: 1929.

Autor: Cuesta Hernáiz, Juan de la.

Título: Silabario español por el orden de facilidad, libro primero de los niños.

Edición: (19--).

Descripción: 16 p.; 16 cm. Encuadernado en cartulina fuerte.

\section{Colección:}




\section{Bibliotecas:}

Biblioteca Pública de Castilla y León, Valladolid.

Catálogos: 1908 (Libro Primero o Silabario), 1917, 1925, 1929.

Autor: Ayuntamiento de Burgos.

Título: Supresión del Impuesto de Consumos.

Edición: (1906).

Descripción: 23 p.; $27 \mathrm{~cm}$.

Bibliotecas:

Biblioteca de la Diputación Provincial de Burgos.

Biblioteca Municipal de Santander.

Catálogos: No aparece en ninguno de los catálogos de 1917, 1925, 1929.

$\mathbf{T}$

Autor: Álvarez Carretero, Antonio; Ruiz Yanguas, Agustín.

Título: Tablas de reducción del antiguo sistema al métrico decimal de kilogramos a arrobas castellanas.

Edición: (1883), (1887), (1900).

Descripción: 64 p.; $12 \mathrm{~cm}$. Con cubierta en rústica a color.

Bibliotecas:

Biblioteca de la Diputación Provincial de Burgos.

Biblioteca Nacional de España.

Catálogos: 1908, 1929.

Autor: Desconocido.

Título: Tablas de sumar, restar, multiplicar y partir y sistema métrico decimal.

Edición: (18--).

Descripción: 8 p. Con cubierta en rústica a color.

Bibliotecas:

Biblioteca Pública de Castilla y León, Valladolid.

Catálogos: 1908 (Tablas de Aritmética), 1929 (Tablas de Aritmética de sumas...)

Autor: Rodríguez, Juan Antonio

Título: Tesoro de paz.

Edición: (1935? 1940?).

Descripción: 93 p.; $16 \mathrm{~cm}$. Con ilustraciones.

Bibliotecas:

Biblioteca de la Universidad de Deusto, Bilbao.

Biblioteca Pública de Castilla y León, Valladolid. 
Catálogos: No aparece en ninguno de los catálogos de 1908, 1917, 1925, 1929.

Autor: Parravicini, Luigi Alessandro, corregida y aumentada la edición original por Ángel Bueno.

Título: Tesoro escolar: obra elemental de educación escrita en italiano con el título de "Juanito".

Edición: (1902).

Descripción: 312 p.; $16 \mathrm{~cm}$. Ilustrada con más de 500 fotograbados y tapas al cromo.

\section{Bibliotecas:}

Biblioteca de la Universidad Pontificia de Salamanca.

Biblioteca Nacional de España.

Biblioteca Pública de Burgos.

Catálogos: 1908, 1917, 1925, 1929.

Autor: Salvá Pérez, Anselmo.

Título: Tipos burgaleses.

Edición: (1892).

Descripción: 95 p.; $20 \mathrm{~cm}$.

Bibliotecas:

Biblioteca de la Facultad de Teología del Norte de España, Burgos.

Biblioteca de la Real Academia de Jurisprudencia y Legislación de Madrid.

Biblioteca de la Real Academia de la Historia de Madrid.

Biblioteca de la Universidad de Castilla La Mancha.

Biblioteca de la Universidad de Toronto. Robarts Library. Canadá.

Biblioteca del Archivo Municipal de Burgos.

Biblioteca del Ateneo de Madrid.

Biblioteca del Museo Arqueológico Nacional de Madrid.

Biblioteca Digital de Castilla y León.

Biblioteca Nacional de España.

Biblioteca Pública de Burgos.

Biblioteca Pública de Castilla y León, Valladolid.

Catálogos: No aparece en ninguno de los catálogos de 1908, 1917, 1925, 1929.

Autor: Desconocido.

Título: Todo el Esperanto y el modo de aprenderlo leyendo una pequeña novela.

Edición: (1909).

Descripción: 24 p.; $12 \mathrm{~cm}$.

Bibliotecas:

Biblioteca de Cataluña, Barcelona. 
Biblioteca Nacional de España.

Catálogos: No aparece en ninguno de los catálogos de 1908, 1917, 1925, 1929.

Autor: Mayo Izarra, Margarita.

Título: Tradiciones y leyendas de Toledo.

Edición: (1926), (1935).

Descripción: 118 p.; 17 cm. Con ilustraciones de Antequera Azpiri.

Contenido: Biblioteca Mundial, 7.

Bibliotecas:

Archivo Histórico Municipal de Toledo.

Biblioteca de la Universidad de Castilla La Mancha.

Biblioteca de la Universidad de La Laguna.

Biblioteca del Archivo Municipal de Burgos.

Biblioteca Estatal y Universitaria de Hamburgo (Staats-und Universitätsbibliothek Hamburg Carl von Ossietzky). Alemania.

Biblioteca IAI, Berlín. Alemania [Ibero-Amerikanisches Institut Preußisches Kulturbesitz].

Biblioteca Junta de Andalucía, Sevilla.

Biblioteca Nacional de España.

Biblioteca Pública de San Sebastián.

Catálogos: 1929.

Autor: Escoiquiz, Juan de.

Título: Tratado de las obligaciones del hombre.

Edición: Novísima edición corregida y aumentada (1892).

Descripción: 88 p.; $16 \mathrm{~cm}$. Con fotograbados y tapas al cromo o con cubiertas en colores.

\section{Bibliotecas:}

Biblioteca de Cataluña, Barcelona.

Biblioteca del Seminario Mayor de León.

Catálogos: 1908 y 1917 (Obligaciones del Hombre), 1925, 1929.

Autor: Bárcena Llorente, Alfredo.

Título: Treinta días de un diario de navegación.

Edición: (1899).

Descripción: 236 p.; $21 \mathrm{~cm}$.

Bibliotecas:

Biblioteca Municipal de Aranda de Duero, Burgos.

Biblioteca Nacional de España.

Biblioteca Pública de Burgos.

Catálogos: No aparece en ninguno de los catálogos de 1908, 1917, 1925, 1929. 


\section{$\mathbf{U}$}

Autor: Desconocido.

Título: Un amigo.

Edición: (1922).

Descripción: 11 p.; $14 \mathrm{~cm}$. Con ilustraciones y con cubierta en colores.

Colección: Regalo de Reyes, 3.

Bibliotecas:

Biblioteca de la Diputación Provincial de Burgos.

Catálogos: 1925, 1929.

Autor: García Rámila, Ismael. Prólogo de D. Eloy García de Quevedo.

Título: Un burgalés ilustre: el Bailio, Ministro, Capitán General de la Armada, Caballero de San Juan y del Toisón, Excmo. D. Fray Antonio Valdés y Bazán.

Edición: $1^{a}$ edición (1930).

Descripción: 332 p.; 22 cm.

Bibliotecas:

Biblioteca de la Casa de Velázquez, Madrid.

Biblioteca de la Diputación Provincial de Burgos.

Biblioteca de la Universidad de Burgos.

Biblioteca de la Universidad de Oviedo.

Biblioteca de la Universidad de Valladolid.

Biblioteca de la Universidad San Pablo-CEU.

Biblioteca del Archivo Municipal de Burgos.

Biblioteca del Consejo Superior de Investigaciones Científicas.

Biblioteca del IES Cardenal López de Mendoza, Burgos.

Biblioteca del IES Conde Diego Porcelos, Burgos.

Biblioteca del Museo de Bellas Artes de Oviedo.

Biblioteca Digital de Castilla y León.

Biblioteca Municipal Miguel de Cervantes.

Biblioteca Pública de Burgos.

Biblioteca Pública de Castilla y León, Valladolid.

Biblioteca Pública de Oviedo.

Catálogos: Posterior a los catálogos analizados.

Autor: Gil Gabilondo, Isidro.

Título: Un genio.

Edición: (1915).

Descripción: 15 p.; $16 \mathrm{~cm}$. Con ilustraciones de Isidro Gil.

Colección: Cuentos para Niños, 21.

Bibliotecas: 
Biblioteca Nacional de España.

Catálogos: 1908?, 1917?, 1925, 1929.

Autor: Grupo de maestros burgaleses.

Título: Una excursión pedagógica a Zaragoza, Barcelona y Valencia: del 27 de abril al 12 de mayo del año II de la República.

Edición: (1932).

Descripción: 173 p.; $18 \mathrm{~cm}$.

Bibliotecas:

Biblioteca de la Diputación Provincial de Burgos.

Biblioteca de la Universidad Francisco de Vitoria.

Biblioteca del Archivo Municipal de Burgos.

Biblioteca del Consejo Superior de Investigaciones Científicas.

Biblioteca Nacional de España.

Catálogos: Posterior a los catálogos analizados.

V

Autor: Rodríguez Miguel, Mariano.

Título: Viaje infantil. Ligeros conocimientos sobre los grandes inventos al alcance de los niños.

Edición: (1893), 6 ${ }^{a}$ edición (1902), $9^{\mathrm{a}}$ edición ilustrada (1907), 10 a edición

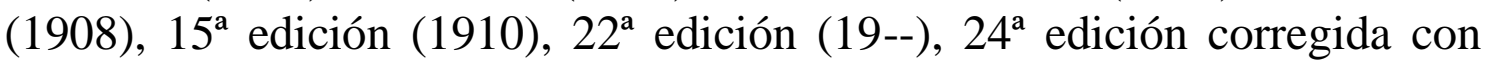
ilustraciones de Evaristo Barrio, (1924), 26 a edición ilustrada (19--). Las siguientes ediciones fueron corregidas y aumentadas por Antonio J. Onieva e ilustrada por Fortunato Julián en unas ediciones y las posteriores por Soravilla y A. Cobos. Su última edición fue de 1963.

Descripción: Varios formatos según las ediciones. Encuadernado en pasta y con cubiertas al cromo o en varios colores. Aprobada por Real Orden 15 de marzo de 1.893 .

\section{Bibliotecas:}

Biblioteca Central de Madrid.

Biblioteca de la Diputación Provincial de Burgos.

Biblioteca de la UNED, proyecto Manes.

Biblioteca de la Universidad de Alicante.

Biblioteca del Archivo Municipal de Burgos.

Biblioteca Municipal de Fermoselle, Zamora.

Biblioteca Nacional de España.

Biblioteca North Shore Community College, Danvers, Massachusetts. Estados Unidos.

Biblioteca Pública de Burgos.

Biblioteca Pública de Castilla y León, Valladolid. 
Biblioteca Pública de Museos. Museo de ferrocarriles de Asturias, Gijón. Biblioteca Pública Regional de Murcia.

Bibliotecas de Autores. Biblioteca José Ma Tejero, Valladolid.

CEINCE.

Catálogos: 1908 (9ª edición), 1917 (16ª edición), 1925 (24ª edición), 1929 ( $25^{\text {a }}$ edición).

Autor: Casanova, Sofía.

Título: Viajes y aventuras de una muñeca española en Rusia.

Edición: (1920), (1922).

Descripción: 108 p.; 26 cm. Con ilustraciones de Gutiérrez Larraya.

Colección: Biblioteca Rodríguez, 2.

Bibliotecas:

Biblioteca de la Columbia University In the City of New Cork. Estados Unidos.

Biblioteca de la Universidad de Barcelona.

Biblioteca de la Universidad de Castilla La Mancha, Campus de Ciudad Real.

Biblioteca de la Universidad de Murcia.

Biblioteca de la Universidad de Santiago de Compostela.

Biblioteca de la Universidad de Valencia.

Biblioteca de la Universidad Politécnica de Madrid.

Biblioteca de la Universidad Pompeu Fabra, Barcelona.

Biblioteca de la Universidad Técnica de Brunswick de Alemania.

Biblioteca de Mieres, Asturias.

Biblioteca de Salas, Asturias.

Biblioteca del Consejo Superior de Investigaciones Científicas.

Biblioteca del IES Cardenal Cisneros, Madrid.

Biblioteca del Instituto Cervantes, Madrid.

Biblioteca Fuenmayor de La Rioja, Logroño.

Biblioteca Municipal del Puerto del Rosario, Fuerteventura.

Biblioteca Nacional de España.

Biblioteca Pública de Ávila.

Biblioteca Pública de Burgos.

Biblioteca Pública de Castilla y León, Valladolid.

Biblioteca Pública de Ciudad Real.

Biblioteca Pública de Cuenca.

Biblioteca Pública Isabel Pérez Valera, Ciudad Real.

Biblioteca Pública Municipal de Monreal del Campo, Teruel.

Catálogos: 1925, 1929.

Autor: Ruiz de Dulanto, Ramiro.

Título: Victoria blanca: poema lírico descriptivo en prosa y verso. 
Edición: (1927).

Descripción: 295 p.; $20 \mathrm{~cm}$.

Bibliotecas:

Biblioteca Pública Museos de Gijón.

Catálogos: 1929.

Autor: Foë, Daniel de. Traducción de Ángel Bueno Rodríguez-Arias.

Título: Vida y aventuras de Robinsón Crusoe.

Edición: (1901), Novísima edición ilustrada.

Descripción: 208 p.; $22 \mathrm{~cm}$. Con ilustraciones de Antequera Azpiri. Cubierta al cromo y oro barnizada. Algunas ediciones están encuadernadas con tapas de tela con planchas de oro y negras y cortes dorados.

Colección: Biblioteca Enciclopédica Hispano-Americana, 3.

Bibliotecas:

Biblioteca Castilla La Mancha, Toledo

Biblioteca de la Diputación Provincial de Burgos.

Biblioteca de la Universidad de Castilla La Mancha, Campus de Cuenca.

Biblioteca de la Universidad de Córdoba.

Biblioteca de la Universidad de La Laguna.

Biblioteca de Medina de Rioseco, Valladolid.

Biblioteca del Archivo Municipal de Burgos.

Biblioteca Nacional de España.

Catálogos: 1908 (Novísima edición), 1917, 1925, 1929.

Autor: Bueno Rodríguez-Arias, Ángel.

Título: Viejas memorias: leyendas y tradiciones universales.

Edición: (1907), (1915).

Descripción: 183 p.; $22 \mathrm{~cm}$. Con ilustraciones de Isidro Gil. Tapas al cromo y oro. Algunas ediciones están encuadernados en tela, con planchas de oro y negro con cortes dorados.

Colección: Biblioteca Enciclopédica Hispano Americana, 4.

Bibliotecas:

Biblioteca de la Diputación Provincial de Burgos.

Biblioteca de la Junta de Andalucía, Sevilla.

Biblioteca de la Universidad de Salamanca.

Biblioteca de la Universidad de Valladolid.

Biblioteca del IES Cardenal Cisneros, Madrid.

Biblioteca Nacional de España.

Biblioteca Pública de Castilla y León, Valladolid.

Catálogos: 1908, 1917, 1925, 1929. 


\subsection{LIBROS DE LA EDITORIAL QUE NO APARECEN EN LAS BIBLIOTECAS}

\section{A}

Autor: Iglesia Serrano, Antonio de la.

Título: Abecedario y Silabario.

Descripción: 16 p.; $16 \mathrm{~cm}$. Encuadernado en cartulina fuerte.

Catálogos: 1908, 1917, 1925 y 1929.

Autor: Domínguez Berrueta, Martín.

Título: Aires de Cuentos.

Descripción: 128 p.; $19 \mathrm{~cm}$. Con ilustraciones de Evaristo Barrio y cubiertas en tela inglesa.

Colección: Mundial Biblioteca.

Catálogos: 1917 (en prensa).

Autor: VV. AA.

Título: Alrededor del Mundo.

Descripción: 40 tomos de 160 p.; $20 \mathrm{~cm}$. Con fotograbados y vistas de monumentos del Mundo. Tomos: España, Castilla La Vieja, Castilla La Nueva, Cataluña. Encuadernado con tapas al cromo y oro.

Catálogos: 1908 (en preparación).

Autor: VV. AA.

Título: Antoñito.

Descripción: 128 p.; $18 \mathrm{~cm}$. Con ilustraciones y con cubiertas al cromo y oro.

Colección: Museo de la Infancia.

Catálogos: 1908, 1917, 1925, 1929.

Autor: Hijos de Santiago Rodríguez.

Título: Aritmética escolar. Grado Elemental.

Descripción: 100 p.; 25 cm.

Colección: Nuevos textos escolares Rodríguez.

Catálogos: 1929.

Autor: Hijos de Santiago Rodríguez.

Título: Aritmética escolar. Grado superior.

Descripción: 300 p.; $25 \mathrm{~cm}$. Con multitud de problemas y ejercicios gráficos.

Colección: Nuevos textos escolares Rodríguez.

Catálogos: 1929 (en prensa). 
Autor: Anónimo.

Título: Aventuras de Rodriguete, relatadas por Martinillo.

Descripción: 16 p.; $22 \mathrm{~cm}$. Con ilustraciones y cubiertas en colores.

Colección: Colección Papa-Moscas.

Catálogos: 1925.

C

Autor: Sagarna, Cecilio.

Título: Cancionero escolar.

Descripción: $27-30 \mathrm{~cm}$.

Catálogos: 1929 (en prensa).

Autor: Desconocido.

Título: Caridad.

Descripción: 16 p.; $16 \mathrm{~cm}$. Contiene 3 ilustraciones interiores en blanco y negro. Encuadernado con tapas al cromo de Evaristo Barrio.

Colección: Cuentos para Niños, 55.

Catálogos: 1908?, 1917?, 1925, 1929.

Autor: Astete, Gaspar.

Título: Catecismo de la Doctrina Cristiana.

Descripción: 80 p.; $17 \mathrm{~cm}$. Hay otra edición especial para la Diócesis de Navarra de 64 p.; $13 \mathrm{~cm}$. que está en la Biblioteca de Navarra y otro de Edición especial, forma "Regente", de 64 p.; 17 cm. (1929).

Catálogos: 1908, 1917, 1925, 1929.

Autor: San Casiano.

Título: Catón Cristiano y Doctrina Cristiana.

Descripción: 56 p.; $16 \mathrm{~cm}$. Contiene grabados y está encuadernado en pasta y elegante cubierta. Aprobado por Real Orden y por la Autoridad Eclesiástica.

Catálogos: 1908, 1917, 1925, 1929.

Autor: Calonge y Pérez, Ignacio.

Título: Compendio de Historia Sagrada.

Descripción: 192 p.; 22 cm.

Catálogos: 1929.

Autor: Herranz y Quirós, Diego Narciso. Corregida y aumentada por José María Sbarbi. 
Título: Compendio mayor de Gramática castellana.

Descripción: 126 p.; $18 \mathrm{~cm}$.

Catálogos: 1929.

Autor: VV. AA.

Título: Cuentos de Ayer y Hoy.

Descripción: 150 a 250 p.; $22 \mathrm{~cm}$. Con ilustraciones y cubiertas al cromo y oro. Otras encuadernaciones: Especial, lomo y puntas tela, planos papel japonés y canto rojo; Tela, planchas en negro y oro y cantos dorados.

Colección: Biblioteca Enciclopédica Hispano-Americana.

Catálogos: 1925 (en prensa).

Autor: Grimm, Jacob y Wilhelm

Título: Cuentos de Grimm.

Descripción: 88 p.; $20 \mathrm{~cm}$. Con ilustraciones y cubierta en cuatro colores.

Colección: Cuentos de Ayer y de Hoy.

Catálogos: 1929.

Autor: VV. AA.

Título: Cuentos de la Edad Media.

Descripción: 150 a 250 p.; $22 \mathrm{~cm}$. Con ilustraciones y cubiertas al cromo y oro. Otras encuadernaciones: Especial, lomo y puntas tela, planos papel japonés y canto rojo; Tela, planchas en negro y oro y cantos dorados.

Colección: Biblioteca Enciclopédica Hispano-Americana.

Catálogos: 1929 (en prensa).

Autor: Desconocido.

Título: Cuentos del Papa-Moscas.

Descripción: 16 p.; $22 \mathrm{~cm}$. Con ilustraciones en bicolor, cubiertas en cinco colores.

Colección: Colección Papa-Moscas.

Catálogos: 1925.

Autor: VV. AA.

Título: Cuentos regionales.

Descripción: 128 p.; $18 \mathrm{~cm}$. Con ilustraciones y cubiertas al cromo y oro.

Colección: Biblioteca Oro.

Catálogos: 1929 (en prensa).

\section{D}

Autor: Fleury, Abad Claude.

Título: Diálogo del Catecismo Histórico. 
Descripción: 96 p.; $13 \mathrm{~cm}$. Encuadernado en rústica, con cubierta en color. Catálogos: En el catálogo de 1917 contiene el libro dos partes, $1^{\mathrm{a}}$ y $2^{\mathrm{a}}$ parte, siendo la más completa que se ha publicado. En los catálogos de 1925 y 1929 es una nueva edición de 32 páginas, $13 \mathrm{~cm}$.

Autor: Cervantes, Miguel de.

Título: Don Quijote de la Mancha.

Descripción: 900 p.; $18 \mathrm{~cm}$. Con ilustraciones, cubierta al cromo y oro barnizada.

Colección: Biblioteca Azul y Rosa.

Catálogos: 1917. En los siguientes catálogos pone como título: El ingenioso hidalgo Don Quijote de la Mancha (nueva edición en 1935), 1925 (en prensa), 1929 (en prensa).

$\mathbf{E}$

Autor: Frontaura, Carlos.

Título: El abuelo y el nieto.

Descripción: 16 p.; $16 \mathrm{~cm}$. Contiene 3 ilustraciones y cubierta de Evaristo Barrio y encuadernado con tapas al cromo.

Colección: Cuentos para Niños, 3.

Catálogos: 1908?, 1917?, 1925, 1929.

Autor: Desconocido.

Título: El amigo de Melchor.

Descripción: 11 p.; $14 \mathrm{~cm}$. Con ilustraciones de Antequera Azpiri y cubierta en colores.

Colección: Regalo de Reyes, 4.

Catálogos: 1925, 1929.

Autor: Desconocido.

Título: El Arca de Noé.

Descripción: Álbum 36 x $24 \mathrm{~cm}$. Con ilustraciones de Fortunato Julián en varios colores, cubiertas en colores de Antequera Azpiri.

Colección: Albums Infantiles. (Abecedario infantil ilustrado).

Catálogos: 1929.

Autor: Medina Fernández, Miguel.

Título: El castillo del águila negra.

Descripción: 16 p.; $16 \mathrm{~cm}$. Contiene 3 ilustraciones y cubierta de Evaristo Barrio. Encuadernado con tapas al cromo.

Colección: Cuentos para Niños, 13. 
Catálogos: 1908?, 1917?, 1925, 1929.

Autor: Rodríguez Miguel, Mariano.

Título: El cornetilla.

Descripción: 16 p.; $16 \mathrm{~cm}$. Contiene 3 ilustraciones y cubierta de Evaristo Barrio. Encuadernado con tapas al cromo.

Colección: Cuentos para Niños, 2.

Catálogos: 1908?, 1917?, 1925, 1929.

Autor: Desconocido.

Título: El espejo de María.

Descripción: 16 p.; $16 \mathrm{~cm}$. Contiene 3 ilustraciones y cubierta de Evaristo Barrio. Encuadernado con tapas al cromo.

Colección: Cuentos para Niños, 62.

Catálogos: 1908?, 1917?, 1925, 1929.

Autor: Villazul, Luis.

Título: El imperio de las flores (rosas).

Descripción: 16 p.; $16 \mathrm{~cm}$. Contiene 3 ilustraciones y cubierta de Evaristo Barrio. Encuadernado con tapas al cromo.

Colección: Cuentos para Niños, 27.

Catálogos: 1908?, 1917?, 1925, 1929.

Autor: Rodríguez Escudero, Pascual.

Título: El Libro de Arte.

Descripción: 96 a 112 p. Con ilustraciones en color, cubierta en cuatricromía.

Colección: Biblioteca Pro-Cultura, 5.

Catálogos: 1917. (En 1925 y 1929 están como en prensa).

Autor: Romeo, Octaviano.

Título: El Libro de Ciencias.

Descripción: 96 a 112 p. Con ilustraciones en color, cubierta en cuatricromía.

Colección: Biblioteca Pro-Cultura, 5.

Catálogos: 1917 (Biblioteca Pro-Cultura, 4), 1925 (en prensa).

Autor: VV. AA.

Título: El libro de la gente menuda.

Descripción: 16 p.; $22 \mathrm{~cm}$. Con ilustraciones y cubiertas en colores.

Colección: Colección Papa-Moscas.

Catálogos: 1925. 
Autor: Hijos de Santiago Rodríguez.

Título: El Libro de la pequeña ama de casa.

Descripción: 250 p.; 26 p. Con 100 dibujos intercalados.

Colección: Nuevos textos escolares Rodríguez.

Catálogos: 1929 (en prensa).

Autor: Desconocido.

Título: El Libro de las Costumbres.

Descripción: 96 a 112 p. Con ilustraciones en color, cubierta en cuatricromía.

Colección: Biblioteca Pro-Cultura.

Catálogos: 1917 (en prensa).

Autor: Desconocido.

Título: El Libro de los Mares.

Descripción: 96 a 112 p. Con ilustraciones en color, cubierta en cuatricromía.

Colección: Biblioteca Pro-Cultura.

Catálogos: 1929 (en prensa).

Autor: Desconocido.

Título: El Libro del Cielo.

Descripción: 96 a 112 p. Con ilustraciones en color, cubierta en cuatricromía.

Colección: Biblioteca Pro-Cultura.

Catálogos: 1929 (en prensa).

Autor: Bueno Rodríguez-Arias, Ángel

Título: El Libro del Progreso.

Descripción: 96 a 112 p. Con ilustraciones en color, cubierta en cuatricromía.

Colección: Biblioteca Pro-Cultura, 5

Catálogos: 1925, 1929.

Autor: Vidal, René.

Título: El Libro Ideal de cocina.

Descripción: 400 p.; $26 \mathrm{~cm}$.

Catálogos: 1925, 1929.

Autor: Desconocido.

Título: El Marquesito.

Descripción: 16 p.; $16 \mathrm{~cm}$. Contiene 3 ilustraciones y cubierta de Evaristo Barrio. Encuadernado con tapas al cromo. 
Colección: Cuentos para Niños, 66.

Catálogos: 1908?, 1917?, 1925, 1929.

Autor: Vidal, Diego.

Título: El nido y la choza.

Descripción: 16 p.; 16 cm.; Contiene 3 ilustraciones y cubierta de Evaristo Barrio. Encuadernado con tapas al cromo.

Colección: Cuentos para Niños, 17.

Catálogos: 1908?, 1917?, 1925, 1929.

Autor: Bueno Rodríguez-Arias, Ángel.

Título: El Nuevo Ciudadano. Lecturas Cívicas.

Descripción: 150 p.; $26 \mathrm{~cm}$.

Catálogos: 1929.

Autor: Desconocido.

Título: El perro ratonero.

Descripción: 16 p.; $16 \mathrm{~cm}$. Contiene 3 ilustraciones y cubierta de Evaristo Barrio. Encuadernado con tapas al cromo.

Colección: Cuentos para Niños, 75.

Catálogos: 1908?, 1917?, 1925, 1929.

Autor: Desconocido.

Título: El Piratilla.

Descripción: 24 p.; $26 \mathrm{~cm}$; Tiene forma de álbum e ilustraciones en colores y en negro por Antequera Azpiri.

Colección: Cuentos Nuevos en colores.

Catálogos: 1925, 1929.

Autor: Desconocido.

Título: El premio.

Descripción: 16 p.; $16 \mathrm{~cm}$. Contiene 3 ilustraciones y cubierta de Evaristo Barrio. Encuadernado con tapas al cromo.

Colección: Cuentos para los Niños, 20.

Catálogos: 1908?, 1917?, 1925, 1929.

Autor: Bessón, Eduardo A de.

Título: El primer Libro en la Escuela.

Descripción: 96 p.; 16 x $11 \mathrm{~cm}$. Está encuadernado en pasta con cubierta al cromo. Complemento del "Método Nuevo". Aprobado por R. O. y por la Autoridad Eclesiástica.

Catálogos: 1908. 
Autor: Desconocido.

Título: En el Parque zoológico Krone.

Descripción: 16 p.; $22 \mathrm{~cm}$. Tiene ilustraciones impresas en dos colores y cubiertas en cinco colores, por Antequera Azpiri.

Colección: Colección Papa-Moscas.

Catálogos: 1929 (en prensa).

Autor: Desconocido.

Título: Estatuto general del Magisterio Nacional Primario conforme a las instrucciones 19, 22 y 25 de mayo de 1923.

Descripción: $18 \mathrm{~cm}$.

Catálogos: 1925.

$\mathbf{F}$

Autor: Alonso Cortés, Narciso.

Título: Fábulas Castellanas.

Descripción: 140 p.; 22 cm.

Catálogos: 1929.

Autor: Francés y Gutiérrez, Rogelio.

Título: Fisiología e Higiene. Veladas instructivas. Grado superior.

Descripción: 200? p.; 17,6 x $12 \mathrm{~cm}$. Con fotograbados. Encuadernado con tapas al cromo o en colores.

Catálogos: 1908, 1917, 1925 y 1929 (en todos los catálogos en preparación o en prensa).

$\mathbf{H}$

Autor: Desconocido.

Título: Haz el bien sin mirar a quien.

Descripción: 16 p.; $16 \mathrm{~cm}$. Contiene 3 ilustraciones y cubierta de Evaristo Barrio. Encuadernado con tapas al cromo.

Colección: Cuentos para Niños, 45.

Catálogos: 1908, 1917, 1925, 1929.

Autor: Desconocido.

Título: Hazañas del valeroso Cid Campeador.

Descripción: 16 p.; $22 \mathrm{~cm}$. Tiene ilustraciones en bicolor y cubiertas en cinco colores.

Colección: Colección Papa-Moscas. 
Catálogos: 1925. En el catálogo de 1929 el título es Hazañas del Cid Campeador, pone en prensa.

Autor: Desconocido.

Título: Hermoso modelo.

Descripción: 16 p.; $16 \mathrm{~cm}$. Contiene 3 ilustraciones y cubierta de Evaristo Barrio. Encuadernado con tapas al cromo.

Colección: Cuentos para Niños, 67.

Catálogos: 1908, 1917, 1925, 1929.

Autor: Salvá Pérez, Anselmo.

Título: Himno a Burgos. Letra de Marciano Zurita y música de Rafael Calleja. Cubierta de Marceliano Santa María.

Catálogos: 1929.

Autor: Desconocido.

Título: Historia del año.

Descripción: 16 p.; $16 \mathrm{~cm}$. Contiene 3 ilustraciones y cubierta de Evaristo Barrio. Encuadernado con tapas al cromo.

Colección: Cuentos para Niños, 72.

Catálogos: 1908, 1917, 1925, 1929.

Autor: Sánchez de la Campa, J. M.

Título: Historia filosófica de la Instrucción pública en España desde sus primitivos tiempos.

Descripción: 2 vols. de unas 400 p.; 27-30 cm.

Catálogos: 1929.

Autor: Desconocido.

Título: Historias de Lope de Vega.

Descripción: 128 p.; $19 \mathrm{~cm}$. Con ilustraciones de Evaristo Barrio y cubiertas en tela inglesa.

Colección: Mundial Biblioteca.

Catálogos: 1929 (en prensa).

Autor: Desconocido.

Título: Historias del Duque de Rivas.

Descripción: 128 p.; $19 \mathrm{~cm}$. Con ilustraciones de Evaristo Barrio y cubiertas en tela inglesa.

Colección: Mundial Biblioteca.

Catálogos: 1929 (en prensa).

Autor: Desconocido. 
Título: Historias del Romancero.

Descripción: 128 p.; $19 \mathrm{~cm}$. Con ilustraciones de Evaristo Barrio y cubiertas en tela inglesa.

Colección: Mundial Biblioteca.

Catálogos: 1929 (en prensa).

Autor: Desconocido.

Título: Historietas del Papa-Moscas.

Descripción: 16 p.; $22 \mathrm{~cm}$. Contiene ilustraciones impresas en dos colores y cubiertas en cinco colores.

Colección: Colección Papa-Moscas

Catálogos: 1929.

Autor: Manjón, Pedro.

Título: Hojitas amenas.

Descripción: 200 p.; $26 \mathrm{~cm}$.

Catálogos: 1929.

$\mathbf{L}$

Autor: Ossorio Bernard, Manuel.

Título: La ambición.

Descripción: 16 p.; $16 \mathrm{~cm}$. Contiene 3 ilustraciones y cubierta de Evaristo Barrio. Encuadernado con tapas al cromo.

Colección: Cuentos para Niños, 11.

Catálogos: 1908?, 1917?, 1925, 1929.

Autor: García Rua, J.; González Salomón, J.

Título: La Aritmética en la Escuela. Ejercicios de cálculo.

Descripción: 32 p.; $26 \mathrm{~cm}$.

Catálogos: 1929.

Autor: Desconocido.

Título: La bendición de los náufragos.

Descripción: 16 p.; $16 \mathrm{~cm}$. Contiene 3 ilustraciones y cubierta de Evaristo Barrio. Encuadernado con tapas al cromo.

Colección: Cuentos para Niños, 51.

Catálogos: 1908?, 1917?, 1925, 1929.

Autor: Desconocido.

Título: La carta de recomendación. 
Descripción: 16 p.; $16 \mathrm{~cm}$. Contiene 3 ilustraciones y cubierta de Evaristo Barrio. Encuadernado con tapas al cromo.

Colección: Cuentos para Niños, 37.

Catálogos: 1908?, 1917?, 1925, 1929.

Autor: Bueno Rodríguez-Arias, Ángel.

Título: La educación por la vista: Libro del Maestro.

Descripción: 32 p.; $26 \mathrm{~cm}$.

Catálogos: 1925, 1929.

Autor: Desconocido.

Título: La historia de Narizotas.

Descripción: 24 p.; $27 \mathrm{~cm}$. Tiene forma de álbum con ilustraciones en colores y en negro por Antequera Azpiri.

Colección: Cuentos Nuevos en colores.

Catálogos: 1925, 1929.

Autor: Desconocido.

Título: La maldición del baturro.

Descripción: 16 p.; $16 \mathrm{~cm}$. Contiene 3 ilustraciones y cubierta de Evaristo Barrio. Encuadernado con tapas al cromo.

Colección: Cuentos para Niños, 56.

Catálogos: 1908?, 1917?, 1925, 1929.

Autor: Desconocido.

Título: La mano de Dios.

Descripción: 16 p.; $16 \mathrm{~cm}$. Contiene 3 ilustraciones y cubierta de Evaristo Barrio. Encuadernado con tapas al cromo.

Colección: Cuentos para Niños, 74.

Catálogos: 1908?, 1917?, 1925, 1929.

Autor: Gonzalo Morón, Dolores.

Título: La mejor fiesta.

Descripción: 16 p.; $16 \mathrm{~cm}$. Contiene 3 ilustraciones y cubierta de Evaristo Barrio. Encuadernado con tapas al cromo.

Colección: Cuentos para Niños, 57.

Catálogos: 1908?, 1917?, 1925, 1929.

Autor: Desconocido.

Título: La mentira de Lola.

Descripción: 16 p.; $16 \mathrm{~cm}$. Contiene 3 ilustraciones y cubierta de Evaristo Barrio. Encuadernado con tapas al cromo.

Colección: Cuentos para Niños, 65. 
Catálogos: 1908?, 1917?, 1925, 1929.

Autor: Ortiz de Pinedo, J.; Araujo, Carlos.

Título: La Poesía en la Escuela. Para exámenes, veladas y fiestas escolares.

Descripción: 140 p.; 27-30 cm.

Catálogos: 1929.

Autor: Desconocido.

Título: La vuelta de la guerra.

Descripción: 16 p.; $16 \mathrm{~cm}$. Contiene 3 ilustraciones y cubierta de Evaristo Barrio. Encuadernado con tapas al cromo.

Colección: Cuentos para Niños, 42.

Catálogos: 1908 y 1917 (Museo de la Infancia, 128 p.; 17,5 cm.; ilustrado y encuadernado con tapas al cromo y oro), 1925, 1929.

Autor: Desconocido.

Título: Las botas.

Descripción: 11 p.; $14 \mathrm{~cm}$. Con ilustraciones de Antequera Azpiri y cubierta en colores.

Colección: Regalo de Reyes, 6.

Catálogos: 1925, 1929.

Autor: Carbonel y Sánchez, María.

Título: Las mariposas.

Descripción: 16 p.; $16 \mathrm{~cm}$. Contiene 3 ilustraciones y cubierta de Evaristo Barrio. Encuadernado con tapas al cromo.

Colección: Cuentos para Niños, 41.

Catálogos: 1908 y 1917 (Museo de la Infancia, 128 p.; 17,5 cm.; ilustrado y encuadernado con tapas al cromo y oro), 1925, 1929.

Autor: Antequera Azpiri, Pedro.

Título: Lazarillo de Tormes.

Descripción: 16 p.; $22 \mathrm{~cm}$. Con ilustraciones impresas en dos colores y cubiertas en cinco colores.

Colección: Colección Papa-Moscas.

Catálogos: 1929.

Autor: Moreno Alcañiz, Emilio.

Título: Lecturas científicas.

Descripción: 200 p.; $18 \mathrm{~cm}$.

Catálogos: 1929. 
Autor: Desconocido.

Título: Leyendas de Oriente.

Descripción: 150 a 250 p.; $22 \mathrm{~cm}$. Con ilustraciones, cubiertas al cromo y oro. Otras encuadernaciones: con lomo y puntas tela, planos papel japonés y canto rojo; Tela, planchas en negro y oro y cantos dorados.

Colección: Biblioteca Enciclopédica Hispano-Americana.

Catálogos: 1929 (en prensa).

Autor: Real Academia de la Lengua.

Título: Libro Segundo de los Niños.

Descripción: 72 p.; $15,5 \mathrm{~cm}$. Encuadernado en pasta y elegantes cubiertas.

Catálogos: 1908, 1917, 1925, 1929. Arreglado al de la Real Academia, para aprender a leer y corregido y aumentado con las reglas de urbanidad.

Autor: VV. AA.

Título: Lo que puede la voluntad.

Descripción: 128 p.; $18 \mathrm{~cm}$. Con ilustraciones y cubiertas al cromo y oro.

Colección: Biblioteca Oro.

Catálogos: 1917 (en prensa).

Autor: Pérez Nieva, Alfonso.

Título: Lobito.

Descripción: 16 p.; $16 \mathrm{~cm}$. Contiene 3 ilustraciones y cubierta de Evaristo Barrio. Encuadernado con tapas al cromo.

Colección: Cuentos para Niños, 54.

Catálogos: 1908?, 1917?, 1925, 1929.

Autor: L. G. S.

Título: Los niños caritativos.

Descripción: 16 p.; $16 \mathrm{~cm}$. Contiene 3 ilustraciones y cubierta de Evaristo Barrio. Encuadernado con tapas al cromo.

Colección: Cuentos para Niños, 44.

Catálogos: 1908 y 1917 (Museo de la Infancia), 1925, 1929.

Autor: Desconocido.

Título: Los niños y los pájaros. Porqué deben amar los niños a los árboles.

Descripción: 16 p.; $22 \mathrm{~cm}$.

Catálogos: 1929.

Autor: Desconocido.

Título: Los tres amigos. 
Descripción: 16 p.; 16 cm.; Contiene 3 ilustraciones y cubierta de Evaristo Barrio. Encuadernado con tapas al cromo.

Colección: Cuentos para Niños, 7.

Catálogos: 1908?, 1917?, 1925, 1929.

Autor: Desconocido.

Título: Luisito.

Descripción: 16 p.; $16 \mathrm{~cm}$. Contiene 3 ilustraciones y cubierta de Evaristo Barrio. Encuadernado con tapas al cromo.

Colección: Cuentos para Niños, 47.

Catálogos: 1908 y 1917 (Museo de la Infancia), 1925, 1929.

\section{M}

Autor: Desconocido.

Título: Más historietas del Papa-Moscas.

Descripción: 16 p.; $22 \mathrm{~cm}$. Contiene ilustraciones impresas en dos colores y cubiertas en cinco colores, por Antequera Azpiri.

Colección: Colección Papa-Moscas.

Catálogos: 1929 (en prensa).

Autor: Bessón, Eduardo A. de.

Título: Método Nuevo para aprender a leer en las escuelas de niños y adultos.

Descripción: 64 p.; $16 \mathrm{~cm}$. Encuadernado en pasta y tapas al cromo.

Catálogos: 1908 ( $4^{\mathrm{a}}$ edición).

Autor: Desconocido.

Título: Mis amigos los números. Período de iniciación.

Colección: Nuevos textos escolares Rodríguez.

Descripción: 40 p. Con numerosas ilustraciones.

Catálogos: 1929 (en prensa).

Autor: Desconocido.

Título: Mis Amigos.

Descripción: Álbum $36 \mathrm{~cm}$. Con ilustraciones de Fortunato Julián en varios colores, cubiertas en colores.

Colección: Albums Infantiles. (Abecedario infantil ilustrado).

Catálogos: 1929. 
Autor: Rodríguez Miguel, Mariano.

Título: Nociones de derecho usual. Segundo grado y grado superior. Descripción: 200 p; $19-22 \mathrm{~cm}$. Con fotograbados.

Catálogos: 1908 ( $1^{\text {a }}$ edición. Segundo Grado). En prensa en los catálogos de 1917, 1925 y 1929.

$\mathbf{P}$

Autor: Mut, Antonio; Verdes Montenegro y Montoro, José; Álvarez Gómez-Salazar, Ramón; Urraca, César; Tamayo, Benjamín; Olavide, José; Carazo, Abelardo.

Título: Para conservarnos sanos y fuertes.

Descripción: 500 p.; 26 cm. Contiene grabados de plana entera.

Catálogos: 1917.

Autor: VV. AA.

Título: Para la gente menuda.

Descripción: 88 p.; 20 x 14 cm. Tiene ilustraciones, con cubierta en cuatro colores.

Colección: Cuentos de Ayer y de Hoy.

Catálogos: 1929.

Autor: Desconocido.

Título: Pepe y Pepa en el Circo.

Descripción: 16 p.; $22 \mathrm{~cm}$. Contiene ilustraciones impresas en dos colores y cubiertas en cinco colores por Antequera Azpiri.

Colección: Colección Papa-Moscas.

Catálogos: 1929 (en prensa).

Autor: A. B.

Título: Poemas de la Biblia.

Descripción: 150 a 250 p.; $22 \mathrm{~cm}$. Contiene ilustraciones, con cubiertas al cromo y oro.

Otras encuadernaciones: Especial, lomo y puntas tela, planos papel japonés y canto rojo; Tela, planchas en negro y oro y cantos dorados.

Colección: Biblioteca Enciclopédica Hispano-Americana.

Catálogos: 1908 (en preparación), 1917 (en prensa), 1925 (en prensa), 1929 (en prensa).

\section{Q}

Autor: Pérez Ortiz, Jerónimo. 
Título: ¿Quiere usted curar y evitar la hernia?

Descripción: 48 a 64 p.; $20 \mathrm{~cm}$. Con grabados.

Colección: Biblioteca Popular de Medicina e Higiene, 11.

Catálogos: 1925, 1929.

$\mathbf{R}$

Autor: Salvá Pérez, Anselmo.

Título: Reglas de urbanidad para uso de las niñas.

Descripción: 40 p.; 19-22 cm. Ilustraciones de Isidro Gil. Cubiertas al cromo.

Catálogos: 1908 (6ª edición), 1917, 1925, 1929.

Autor: Salvá Pérez, Anselmo.

Título: Reglas de urbanidad para uso de los niños.

Descripción: 48 p.; 19-22 cm. Grabados y cubiertas al cromo.

Catálogos: 1908 (6ª edición), 1917, 1925, 1929.

$\mathbf{S}$

Autor: Peñín y Rubio, Manuel.

Título: Segundo curso de Lengua Española.

Descripción: 224 p.; 22 ? cm.

Catálogos: 1929.

Autor: Desconocido.

Título: Silabario de San Antonio.

Descripción: 16 p; $16 \mathrm{~cm}$. Encuadernado en cartulina fuerte.

Catálogos: 1908, 1917. En los catálogos de 1925 y 1929 el título es Silabario Español.

Autor: Desconocido.

Título: Socorrer al necesitado.

Descripción: 16 p.; $16 \mathrm{~cm}$. Contiene 3 ilustraciones y cubierta de Evaristo Barrio. Encuadernado con tapas al cromo.

Colección: Cuentos para Niños, 46.

Catálogos: 1908 y 1917 (Museo de la Infancia), 1925, 1929.

$\mathbf{T}$

Autor: Desconocido.

Título: Tal para cual. 
Descripción: 16 p.; $16 \mathrm{~cm}$. Contiene 3 ilustraciones y cubierta de Evaristo Barrio. Encuadernado con tapas al cromo.

Colección: Cuentos para Niños, 64.

Catálogos: 1908 y 1917 (Museo de la Infancia), 1925, 1929.

Autor: Desconocido.

Título: Trochabosques.

Descripción: 11 p.; 14 cm. Contiene ilustraciones de Antequera Azpiri con cubierta en colores.

Colección: Regalo de Reyes, 1.

Catálogos: 1925, 1929.

\section{$\mathbf{U}$}

Autor: Desconocido.

Título: Un ángel.

Descripción: 16 p.; $16 \mathrm{~cm}$. Contiene 3 ilustraciones y cubierta de Evaristo Barrio. Encuadernado con tapas al cromo.

Colección: Cuentos para Niños, 60.

Catálogos: 1908?, 1917?, 1925, 1929.

Autor: Desconocido.

Título: Un día de vacaciones.

Descripción: 16 p.; $16 \mathrm{~cm}$. Contiene 3 ilustraciones y cubierta de Evaristo Barrio. Encuadernado con tapas al cromo.

Colección: Cuentos para Niños, 49.

Catálogos: 1908?, 1917?, 1925, 1929.

Autor: Desconocido.

Título: Un guiñol.

Descripción: 11 p.; 14 cm. Tiene ilustraciones de Antequera Azpiri con cubierta en colores.

Colección: Regalo de Reyes, 2.

Catálogos: 1925, 1929.

Autor: Ossorio Bernard, Manuel.

Título: Un héroe infantil.

Descripción: 16 p.; $16 \mathrm{~cm}$. Contiene 3 ilustraciones y cubierta de Evaristo Barrio. Encuadernado con tapas al cromo.

Colección: Cuentos para Niños, 4.

Catálogos: 1917?, 1925, 1929.

Autor: Desconocido. 
Título: Un hijo del mar.

Descripción: 16 p.; $16 \mathrm{~cm}$. Contiene 3 ilustraciones y cubierta de Evaristo Barrio. Encuadernado con tapas al cromo.

Colección: Cuentos para Niños, 68.

Catálogos: 1908?, 1917?, 1925, 1929.

Autor: Desconocido.

Título: Una consulta original.

Descripción: 16 p.; $16 \mathrm{~cm}$. Contiene 3 ilustraciones y cubierta de Evaristo Barrio. Encuadernado con tapas al cromo.

Colección: Cuentos para Niños, 73.

Catálogos: 1908?, 1917?, 1925, 1929.

Autor: Desconocido.

Título: Una tarde de risa y regocijo.

Descripción: 16 p.; $22 \mathrm{~cm}$. Con ilustraciones y cubiertas en colores.

Colección: Colección Papa-Moscas.

Catálogos: 1925.

\section{V}

Autor: Rodríguez Miguel, Mariano.

Título: Vidas que quedan.

Descripción: 304 p.; $18 \mathrm{~cm}$. Con ilustraciones, cubierta al cromo y oro barnizada.

Colección: Biblioteca Azul y Rosa.

Catálogos: 1908 (en prensa), 1917 (en prensa). 1925 (en prensa), 1929 (en prensa)

Se señalan sólo las obras que aparecen en los Catálogos estudiados y no han aparecido en los registros bibliográficos. 


\subsection{LIBROS DE COLECCIONES PARTICULARES}

Autor: Bueno Rodríguez-Arias, Ángel.

Título: A buen rey mejor vasallo.

Descripción: 16 p.; $16 \mathrm{~cm}$. Contiene 3 ilustraciones y cubierta de Evaristo Barrio. Encuadernado con tapas al cromo.

Colección: Cuentos para Niños, 70.

Catálogos: 1908, 1917, 1925, 1929.

Biblioteca particular de $\mathrm{M}^{\mathrm{a}}$ Pilar Alonso Castro.

Autor: Santiago-Fuentes, Carmen de.

Título: Casa de muñecas.

Descripción: 130 p.; $21 \mathrm{~cm}$. Contiene ilustraciones a plana entera de Evaristo Barrio, con cubierta de cromo y oro.

Colección: Biblioteca Oro, 5.

Catálogos: 1917, 1925, 1929.

Biblioteca particular de $\mathrm{M}^{\mathrm{a}}$ Pilar Alonso Castro.

Autor: Hijos de Santiago Rodríguez.

Título: Catálogo de la Librería de Hijos de Santiago Rodríguez.

Descripción: 194 p.; 21,5 cm. Ilustrado.

Catálogos: 1908.

Biblioteca particular de $\mathrm{M}^{\mathrm{a}}$ Pilar Alonso Castro.

Autor: Azpiri Antequera, Pedro.

Título: Dibujarás y pintarás.

Descripción: Siete cuadernos de $22 \mathrm{~cm}$.

Notas: De los siete cuadernos, se dispone del $n^{\circ} 4$ y 7 .

Catálogos: 1929.

Biblioteca particular de $\mathrm{M}^{\mathrm{a}}$ Pilar Alonso Castro.

Autor: Garzón Gutiérrez, Hilario.

Título: El buen hermano.

Descripción: 16 p.; $16 \mathrm{~cm}$. Contiene 3 ilustraciones y cubierta de Evaristo Barrio. Encuadernado con tapas al cromo.

Colección: Cuentos para Niños, 52.

Catálogos: 1908?, 1917?, 1925, 1929.

Biblioteca particular de $\mathrm{M}^{\mathrm{a}}$ Pilar Alonso Castro.

Autor: Benejam y Saura, Juan.

Título: El grumete. 
Descripción: 16 p.; 16 cm. Contiene 3 ilustraciones y cubierta de Evaristo Barrio. Encuadernado con tapas al cromo.

Colección: Cuentos para Niños, 10.

Catálogos: 1908?, 1917?, 1925, 1929.

Biblioteca particular de Lucas Rodríguez Plaza.

Autor: Álvarez Bollo Carretero, Mariana.

Título: El miedo.

Descripción: 16 p.; $16 \mathrm{~cm}$. Contiene 3 ilustraciones y cubierta de Isidro Gil. Encuadernado con tapas al cromo.

Colección: Cuentos para Niños, 34 .

Catálogos: 19081917, 1925, 1929.

Biblioteca particular de Lucas Rodríguez Plaza.

Autor: Rodríguez, Miguel.

Título: El pequeño aeronauta.

Descripción: 16 p.; $16 \mathrm{~cm}$. Contiene3 ilustraciones y cubierta de Evaristo Barrio. Encuadernado con tapas al cromo.

Colección: Cuentos para Niños, 32.

Catálogos: 1908 y 1917 (Museo de la Infancia), 1925, 1929.

Biblioteca particular de Lucas Rodríguez Plaza.

Autor: Bueno Rodríguez-Arias, Ángel.

Título: Emilín.

Descripción: 16 p.; $16 \mathrm{~cm}$. Contiene 3 ilustraciones y cubierta de Evaristo Barrio. Encuadernado con tapas al cromo.

Colección: Cuentos para Niños, 18.

Catálogos: 1908 y 1917 (Museo de la Infancia), 1925, 1929.

Biblioteca particular de Lucas Rodríguez Plaza.

Autor: Bueno Rodríguez-Arias, Ángel.

Título: Felicidad en la buhardilla.

Descripción: 16 p.; $16 \mathrm{~cm}$. Contiene 3 ilustraciones y cubierta de Evaristo Barrio. Encuadernado con tapas al cromo.

Colección: Cuentos para Niños, 39.

Catálogos: 1908?, 1917?, 1925, 1929.

Biblioteca particular de Lucas Rodríguez Plaza.

Autor: Álvarez Bollo Carretero, Mariana.

Título: Ferrús o El ermitaño del Abrojo.

Descripción: 84 p.; $16 \mathrm{~cm}$. Contiene ilustraciones de Evaristo Barrio y cubierta al cromo y oro.

Colección: Biblioteca Selecta, 5. 
Catálogos: 1908, 1917.

Biblioteca particular de $\mathrm{M}^{\mathrm{a}}$ Pilar Alonso Castro.

Autor: Malot, Hector; Puschkin, A. Traducido por Eusebio Heras.

Título: Flor de aventuras.

Descripción: 304 p.; $18 \mathrm{~cm}$. Con numerosas ilustraciones y cubierta al cromo y oro barnizada.

Colección: Biblioteca Azul y Rosa.

Catálogos: 1908 (en prensa), 1917, 1925, 1929.

Biblioteca particular de $\mathrm{M}^{\mathrm{a}}$ Pilar Alonso Castro.

Autor: Rodríguez Miguel, Mariano.

Título: La batalla campal.

Descripción: 16 p.; $16 \mathrm{~cm}$. Contiene 3 ilustraciones y cubierta de Evaristo Barrio. Encuadernado con tapas al cromo.

Colección: Cuentos para Niños, 35.

Catálogos: 1908 y 1917 (Museo de la Infancia, 128 p.; 17,5 x $12 \mathrm{~cm}$. Ilustrado y encuadernado con tapas al cromo y oro), 1925, 1929.

Biblioteca particular de Lucas Rodríguez Plaza.

Autor: D’Arneuil, Héctor.

Título: La curiosidad castigada.

Descripción: 16 p.; $16 \mathrm{~cm}$. Contiene 3 ilustraciones y cubierta de Isidro Gil. Encuadernado con tapas al cromo.

Colección: Cuentos para Niños, 12.

Catálogos: 1908?, 1917?, 1925, 1929.

Biblioteca particular de Lucas Rodríguez Plaza.

Autor: Santiago Fuentes, Magdalena.

Título: La estrella de mar.

Descripción: 16 p.; $16 \mathrm{~cm}$. Contiene 3 ilustraciones y cubierta de Isidro Gil. Encuadernado con tapas al cromo.

Colección: Cuentos para Niños, 40.

Catálogos: 1908?, 1917?, 1925, 1929.

Biblioteca particular de Lucas Rodríguez Plaza.

Autor: Bustamante Junquera, Mateo.

Título: La hija del desterrado.

Descripción: 16 p.; $16 \mathrm{~cm}$. Con 3 ilustraciones y cubierta de Evaristo Barrio. Encuadernado con tapas al cromo.

Colección: Cuentos para Niños, 16.

Catálogos: 1908 (Museo de la Infancia), 1917?, 1925, 1929.

Biblioteca particular de Lucas Rodríguez Plaza. 
Autor: Antequera Azpiri, Pedro.

Título: La larva y el Águila.

Descripción: 20 p.; 16 x $26 \mathrm{~cm}$. Con ilustraciones y cubierta en negro y color por Pedro Antequera Azpiri. En la cubierta aparece que está realizado por la litografía Laborde Labayen de Tolosa.

Colección: Cuentos Nuevos en colores, 2.

Catálogos: 1925, 1929.

Biblioteca particular de $\mathrm{M}^{\mathrm{a}}$ Pilar Alonso Castro.

Autor: Anónimo.

Título: La manta de lana.

Descripción: 16 p.; $16 \mathrm{~cm}$. Contiene 3 ilustraciones y cubierta de Evaristo Barrio. Encuadernado con tapas al cromo.

Colección: Cuentos para Niños, 36.

Catálogos: 1908?, 1917?, 1925, 1929.

Biblioteca particular de $\mathrm{M}^{\mathrm{a}}$ Pilar Alonso Castro.

Autor: Santiago Fuentes, Magdalena.

Título: La noche de Reyes.

Descripción: 16 p.; 16 cm. Contiene 3 ilustraciones interiores de Evaristo Barrio y cubierta de Fortunato Julián y encuadernado con tapas al cromo.

Colección: Cuentos para Niños, 15.

Catálogos: 1908?, 1917?, 1925, 1929.

Biblioteca particular de Lucas Rodríguez Plaza.

Este cuento también lo encontramos en el libro La tiranuela del Museo de la Infancia.

Autor: Salvá Pérez, Anselmo.

Título: La suerte.

Descripción: 16 p.; $16 \mathrm{~cm}$. Contiene 3 ilustraciones y cubierta de Evaristo Barrio. Encuadernado con tapas al cromo.

Colección: Cuentos para Niños, 30.

Catálogos: 1908?, 1917?, 1925, 1929.

Biblioteca particular de Lucas Rodríguez Plaza.

Autor: Rodríguez Miguel, Francisco.

Título: Leal.

Descripción: 16 p.; $16 \mathrm{~cm}$. Contiene 3 ilustraciones y cubierta de Isidro Gil. Encuadernado con tapas al cromo.

Colección: Cuentos para Niños, 28.

Catálogos: 1908?, 1917?, 1925, 1929.

Biblioteca particular de Lucas Rodríguez Plaza. 
Autor: AA. VV.

Título: Lee estos cuentos.

Descripción: 90 p.; $20 \mathrm{~cm}$. Con ilustraciones de Fortunato Julián, con cubierta a cuatro colores.

Colección: Cuentos de Ayer y de Hoy, 2.

Catálogos: 1929.

Biblioteca particular de $\mathrm{M}^{\mathrm{a}}$ Pilar Alonso Castro.

Autor: Osés Larumbe, José

Título: Lo que puede la fe.

Descripción: 16 p.; $16 \mathrm{~cm}$. Contiene 3 ilustraciones y cubierta de Evaristo Barrio. Encuadernado con tapas al cromo.

Colección: Cuentos para Niños, 71.

Catálogos: 1908?, 1917?, 1925, 1929.

Biblioteca particular de $\mathrm{M}^{\mathrm{a}}$ Pilar Alonso Castro.

Autor: Frontaura, Carlos.

Título: Los hijos del señor Martín.

Descripción: 16 p.; $16 \mathrm{~cm}$. Contiene 3 ilustraciones y cubierta de Evaristo Barrio. Encuadernado con tapas al cromo.

Colección: Cuentos para Niños, 31.

Catálogos: 1908?, 1917?, 1925, 1929.

Biblioteca particular de Lucas Rodríguez Plaza.

Autor: Manín, J.

Título: Mikolán y $C^{i a}$.

Descripción: 20 p.; 16 x 26 cm. Con ilustraciones y cubierta en negro y color por Pedro Antequera Azpiri. En la cubierta aparece que está realizado por la litografía S. Durá en Valencia.

Colección: Cuentos Nuevos en colores, 3.

Catálogos: 1925, 1929.

Biblioteca particular de $\mathrm{M}^{\mathrm{a}}$ Pilar Alonso Castro.

Autor: Bueno Rodríguez-Arias, Ángel.

Título: Mi primera comunión.

Descripción: 16 p.; $16 \mathrm{~cm}$. Con 3 ilustraciones y cubierta de Evaristo Barrio. Encuadernado con tapas al cromo.

Colección: Cuentos para Niños, 8.

Catálogos: 1908?, 1917?, 1925, 1929.

Biblioteca particular de Lucas Rodríguez Plaza.

Autor: Desconocido. 
Título: Morir por la patria.

Descripción: 16 p.; $16 \mathrm{~cm}$. Contiene 3 ilustraciones y cubierta de Isidro Gil. Encuadernado con tapas al cromo.

Colección: Cuentos para Niños, 9.

Catálogos: 1908?, 1917?, 1925, 1929.

Biblioteca particular de Lucas Rodríguez Plaza.

Autor: Rodríguez Miguel, Mariano.

Título: Pedro el avaricioso.

Descripción: 16 p.; $16 \mathrm{~cm}$. Con ilustraciones de Evaristo Barrio y cubierta al cromo.

Colección: Cuentos para Niños, 23.

Catálogos: 1908?, 1917?, 1925, 1929.

Biblioteca particular de Lucas Rodríguez Plaza.

Autor: Ossorio Bernard, Manuel.

Título: Presumir de hombre.

Descripción: 16 p.; $16 \mathrm{~cm}$. Contiene 3 ilustraciones de Isidro Gil y cubierta de Fortunato Julián. Encuadernado con tapas al cromo.

Colección: Cuentos para Niños, 26.

Catálogos: 1908?, 1917?, 1925, 1929.

Biblioteca particular de Lucas Rodríguez Plaza.

Autor: Desconocido.

Título: Rinconete y Cortadillo y Comparsa.

Descripción: 16 p.; $22 \mathrm{~cm}$. Contiene lustraciones en bicolor de Pedro Antequera Azpiri, con cubiertas en cinco colores.

Colección: Colección Papa-Moscas.

Catálogos: 1925, 1929 (Rinconete y Cortadillo).

Biblioteca particular de $\mathrm{M}^{\mathrm{a}}$ Pilar Alonso Castro.

Autor: Álvarez Carretero, Antonio.

Título: Siempre que puedas haz el bien.

Descripción: 16 p.; $16 \mathrm{~cm}$. Contiene 3 ilustraciones y cubierta de Evaristo Barrio. Encuadernado con tapas al cromo.

Colección: Cuentos para Niños, 29.

Catálogos: 1908?, 1917?, 1925, 1929.

Biblioteca particular de Lucas Rodríguez Plaza.

Autor: Rodríguez Miguel, Francisco.

Título: Trafalgar.

Descripción: 16 p.; $16 \mathrm{~cm}$. Contiene 3 ilustraciones y cubierta de Evaristo Barrio. Encuadernado con tapas al cromo. 
Colección: Cuentos para Niños, 24.

Catálogos: 1908?, 1917?, 1925, 1929.

Biblioteca particular de Lucas Rodríguez Plaza.

Autor: Álvarez Carretero, Antonio.

Título: Una venta original.

Descripción: 16 p.; $16 \mathrm{~cm}$. Contiene 3 ilustraciones y cubierta de Isidro Gil. Encuadernado con tapas al cromo.

Colección: Cuentos para Niños, 14.

Catálogos: 1908?, 1917?, 1925, 1929.

Biblioteca particular de Lucas Rodríguez Plaza. 



\section{BIBLIOTECAS Y LIBROS ESCOLARES}

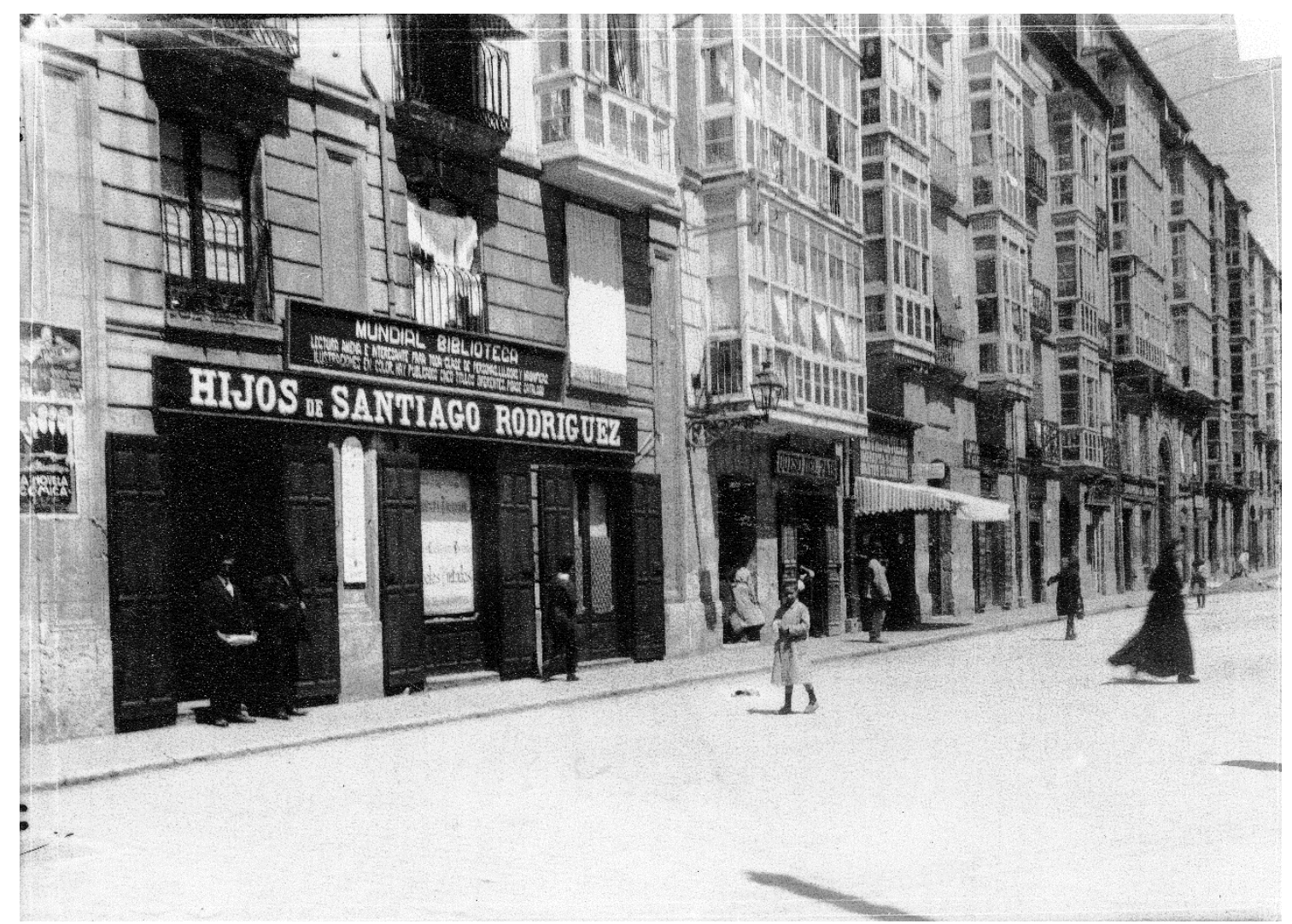

Fig. 6-1: Fotografía de la calle Laín Calvo. Librería Hijos de Santiago Rodríguez. Archivo Municipal de Burgos. 


\subsection{LIBROS DE LECTURA: LAS BIBLIOTECAS RODRÍGUEZ}

Los libros de lectura infantiles que hoy llenan las estanterías de librerías y bibliotecas en sus diversos formatos y diseños es un fenómeno reciente. Carmen Bravo Villasante aporta datos relevantes sobre la evolución histórica y el desarrollo de la literatura infantil y juvenil. ${ }^{52}$ Esta autora narra cómo cartillas, silabarios y libros religiosos fueron los primeros libros que pudieron disponer los niños de siglos anteriores, más como libro escolar de aprendizaje que como instrumento de recreo y diversión. A finales del siglo XIX y principios del XX, con los avances en el estudio del niño como un ser independiente, no como un adulto en miniatura y con una visión diferente de la realidad, es cuando comienza el gran desarrollo de los cuentos infantiles. Hasta entonces, los niños leían obras del mundo adulto con afán instructivo: refraneros, libros de fábulas (Iriarte, Samaniego), cuentos moralizantes, y textos de urbanidad o piadosos.

En Europa, durante el siglo XIX, los hermanos Grimm escribieron sus Cuentos para la infancia y el hogar (1812-1822), donde aparecen personajes que se hacen famosos: Pulgarcito, Blancanieves, Cenicienta, Caperucita, conocidos en la versión de Perrault en el siglo anterior. Andersen continúa en la línea de los hermanos Grimm con Cuentos para los niños escritos en 1835.

Durante mucho tiempo las lecturas adaptadas más habituales fueron el Juanito de Parravicini, las Aventuras de Telémaco de monseñor François de Salignae de la Mothe, Veladas de la Quinta de la condesa de Genlis, Robinson Crusoe de Daniel Defoe y los cuentos de Cecilia Böhl de Faber, con seudónimo de Fernán Caballero, quién desempeñó en nuestro país la misma función divulgativa que los hermanos Grimm en Alemania.

En lo que concierne a la literatura infantil española, durante los siglos XIX y XX, continúan desarrollándose obras de carácter moralizante según la tradición heredada del siglo anterior. Tanto es así que muchos autores encontraron su fuente de inspiración en los cuentos populares y en antiguas leyendas recuperadas para los niños.

Con el triunfo de la revolución industrial, la pujanza de la burguesía, un mayor interés por la alfabetización de la clases populares y del público en general, así como las nuevas disposiciones oficiales, facilitaron la aparición en España de varias bibliotecas y editoriales: Biblioteca Nueva Infantil (Madrid, 1844), Biblioteca Moral Recreativa (Barcelona, 1862), La Biblioteca Infantil (Barcelona, 1884) y las editoriales Hernando (1828),

\footnotetext{
592 BRAVO VILLASANTE, C. Historia de la literatura infantil española. Madrid: Escuela Española, 1985 , p. 357.
} 
Bastinos (1852), Hijos de Santiago Rodríguez (1850), y Calleja (1876), antes de finalizar el siglo.

De todas estas bibliotecas y editoriales, la más conocida y estudiada por su abundante edición y adaptación de sus cuentos, en diversidad de formatos y precios sin competencia, son los Cuentos de Calleja, ${ }^{593}$ como bien lo muestra, además, el popular dicho: "tienes más cuento que Calleja".

La editorial Hijos de Santiago Rodríguez, al igual que las anteriormente citadas, imprime y edita libros de lectura en un amplio conjunto de colecciones que publicita como Bibliotecas, desde el período entre siglos, hasta tal punto que competía en el mercado nacional e internacional. En 1891, a la muerte del fundador, la empresa sigue en manos de sus hijos, amplía sus ediciones y comienza con la edición de las BIBLIOTECAS RODRÍGUEZ. La clave de su éxito la ciframos en varios hechos importantes.

En primer lugar, contrató a escritores ya conocidos en el ámbito nacional e internacional como Frontaura, Ossorio Bernard, Schmid, Marciano Zurita, Estanislao Maestre, Manuel Linares Rivas, Emiliano Ramírez Ángel, Sofía Casanova, José Ortega Munilla, Armando Palacio Valdés, $\mathbf{M}^{\mathrm{a}}$ Teresa León, Angélica Palma, entre otros muchos.

En segundo lugar, incluyó en sus publicaciones a autores del campo de la enseñanza, maestros de escuela, inspectores, directores y profesores de Escuelas Normales conocedores del mundo infantil, como Anselmo Salvá, Antonio Álvarez Carretero, Mariana Álvarez Bollo Carretero, Magdalena Santiago Fuentes, Ángel Bueno Rodríguez-Arias, Alfonso Pérez Nieva, Juan Benejam, José Oses Larumbe, Ángel Menoyo Portalés, Pedro Diez Pérez, Martín Domínguez Berrueta, Pedro Martí Alpera, etc. Incluso los propietarios de la casa editora, -Mariano Rodríguez Miguel, Francisco Rodríguez Miguel y Pascual Rodríguez Escudero que fueron autores de varios cuentos o artículos.

$\mathrm{Y}$ en tercer lugar, se rodea de ilustradores, desde los que siguen los cánones más clásicos -Isidro Gil, Evaristo Barrio, Manero o Fortunato Julián- hasta aquellos que forman parte de las nuevas vanguardias, caso de Pedro Antequera Azpiri, Francisco López Rubio, Rosario de Velasco, Gutiérrez Larraya o Echea, entre otros.

Quizá la casa Hijos de Santiago Rodríguez sea más reconocida por su etapa posterior franquista pero, sin duda, el camino seguido desde el

\footnotetext{
${ }^{593}$ Numerosos autores han estudiado y publicado estudios sobre dicha editorial y que están señalados en la bibliografía, destacando a Julio Ruiz Berrio, Carmen Bravo Villasante, Luis Bello Trompeta, Enriqueta Albizua Huarte, Anastasio Martínez Navarro, Carmen Colmenar Orzaes, Miryam Carreño.
} 
cambio de siglo, de la mano de Mariano Rodríguez, marcó una época espléndida por su calidad editora. Este hombre inquieto, respondía y se involucraba en todos los movimientos sociales, económicos y culturales de la ciudad burgalesa que contaba con unos estamentos anquilosados, de carácter rentista y poco inversor. A pesar de todo, logró crear una empresa editorial avanzada, con los medios adquiridos por la inversión familiar. Editó obras, mezcolanza de lo nuevo y viejo, con escritores e ilustradores de tendencias opuestas, en el primer tercio del siglo XX. Y, es preciso resaltar que, por encima de lo comercial, disfrutaba realizando libros de una calidad literaria y artística contrastada. 


\subsubsection{Cuentos para Niños}

Esta colección comenzó en 1894 con seis cuentos, bajo el título de Cuentos Morales, y que más adelante, en los catálogos analizados, ${ }^{594}$ se señalan como Cuentos para Niños.

Pedro el avaricioso, El imperio de la flores, La venganza de las flores, El vendedor de periódicos, Los tres amigos del hombre y Leal; son los títulos de los cuentos que ya han puesto a la venta y que pueden recomendarse por su utilidad, aplicación y ventajas sobre algunos otros libros de la misma índole.

Esta biblioteca se compondrá por lo menos de 30 cuentos diferentes debidos a reputados escritores, entre los que figura D. Carlos Frontaura, D. Manuel Ossorio, D. Anselmo Salvá, D. Gonzalo Sanz, D. Antonio Carretero, D. Agustín Ruiz Yanguas y D. Diego Vidal.

Están en prensa y prontos a terminarse La cuadratura del círculo, Presumir de hombre, Siempre que puedas haz el bien, Una venta original, El premio, Un genio, El nido y la choza.

Los señores Barrio y Gil son los autores de los cromos de las cubiertas y grabados que están muy bien hechos en la litografía de los Sres. Moliner y Rodríguez.

Como se ve todo cuanto encierra esta biblioteca está confeccionado en nuestra capital y a pesar de los muchos gastos que originen estas publicaciones, el precio de cada ejemplar no cuesta más que la insignificante cantidad de 10 céntimos. ${ }^{595}$

El artículo anterior del periódico El Papa-Moscas no incluye a Mariano Rodríguez Miguel como autor de algunos de esos cuentos, en concreto el de Pedro el avaricioso y El vendedor de periódicos, ni a su hermano Francisco Rodríguez Miguel que escribe el cuento titulado Leal, así como tampoco a Luis Villazul, autor de El imperio de las flores. De estos primeros cuentos, La venganza de las flores, el escritor es Agustín Ruiz Yanguas y se desconoce la autoría de Los tres amigos del hombre. Cita, como en prensa, La cuadratura del círculo y Presumir de hombre, de Manuel Ossorio Bernard, Un genio, de Isidro Gil, El nido y la choza, de Diego Vidal y, Siempre que puedas haz el bien y Una venta original de Antonio Álvarez Carretero. Desconocemos el autor del cuento El premio.

Al año siguiente, en junio de 1895, apenas pasados 6 meses de los anteriores, publicaron ocho nuevos cuentos.

El abuelo y el nieto por Carlos Frontaura, El cornetilla por Mariano Rodríguez, El nido y la choza por Diego Vidal, La Suerte por Anselmo Salvá, La Cuadratura del Círculo por Ossorio y Bernard, Un genio por Isidro Gil.

\footnotetext{
${ }^{594}$ Se han estudiado los Catálogos de la Editorial Hijos de Santiago Rodríguez de 1908, 1917, 1925 y 1929 para el análisis de las obras de la editorial.

${ }^{595}$ El Papa-Moscas. Año XVII, nº 881, 11 de noviembre de 1894, p. 2.
} 
Los hijos del Sr. Martín por Frontaura y En Trafalgar por Francisco Rodríguez son los títulos y los autores de los ocho nuevos cuentos con que los conocidos y acreditados editores de esta plaza Sres. Hijos de Santiago Rodríguez han aumentado su preciosa biblioteca moral "Cuentos para niños" y de los que han tenido la atención de enviarnos un ejemplar.

Las condiciones de los mismos son inmejorables, tanto la parte artística y literaria como los materiales. Editados con verdadero lujo, ilustrados con preciosos y artísticos grabados debido a los reputados artistas Sr. Barrio y Gil y adornados con alegóricas cubiertas cromolitografía las de gran novedad son muy a propósito para los niños a quienes se dedican por lo que se les recomendamos a los Sres. Maestros y padres de familia. ${ }^{596}$

De todos los cuentos escritos hasta esa fecha, los gerentes Mariano y Francisco Rodríguez Miguel escribieron seis de los mismos. En ese mismo año -diciembre- se publicaron otros seis nuevos números según nos relata el periódico El Papa-Moscas:

Nuestros queridos amigos, los Sres. Hijos de Santiago Rodríguez acaban de aumentar su preciosa colección de Cuentos para niños, con seis nuevos, debidos a los reputados autores Sres. Pérez Nieva, Bueno, Ossorio Bernard y Bustamante.

La hija del desterrado, El Cristo yacente, La madre pequeñita, Emilín, La Tortilla mágica, Un héroe infantil; son los títulos de los nuevos cuentos, que son otras tantas relaciones amenas e instructivas que encierran gran enseñanza moral.

Esto hace que cada día tenga más aceptación la citada colección, que cuenta ya con 23 cuentos diferentes de los Sres. Gil, Frontaura, Carretero, Yanguas, Villazul, Rodríguez, Vidal y Salvá.

La competencia de autores y las inmejorables condiciones de la edición hace que por si solo se recomienden.

Los Hijos de Santiago Rodríguez han dado prueba más del buen gusto presentando los citados cuentos con lujo y esmero. ${ }^{597}$

No se dispone de la fecha de edición de los restantes cuentos de esta colección, bien porque no se han rescatado muchos de ellos, o porque, en otros casos, la prensa escrita burgalesa no da cuenta de su publicación, en los siguientes años.

Observamos que los autores principales de estos cuentos venden a la editorial la propiedad intelectual en fecha muy próxima a su edición, en $1896 .{ }^{598}$

En el Catálogo de 1908, en la primera sección Bibliotecas para premios que titula Cuentos para Niños informa que se habían publicado 90 títulos, de los doscientos que formarían la colección. Añade, a la lista publicada

\footnotetext{
${ }^{596}$ El Papa-Moscas. Año XVIII, no 912,16 de junio de 1895, p. 3.

${ }^{597}$ El Papa-Moscas. Año XVIII, no 937,15 de diciembre de 1895, p. 3.

598 Vid. Anexo 2.1.17. Los autores que venden la propiedad intelectual de los cuentos de esta Biblioteca son Carlos Frontaura, Alfonso Pérez Nieva, Manuel Ossorio Bernard, Miguel Medina, Ángel Bueno, Anselmo Salvá y Mateo Bustamante, con un total de 14 cuentos.
} 
por el periódico El Papa-Moscas en 1894, a Juan Benejam Saura. ${ }^{599}$ En el Catálogo de 1917 se notifica que hay publicados 100 títulos diferentes, incorporando ahora a la lista al autor José Osés Larumbe. En cambio, en el Catálogo de 1925 describía 3 series de 25 cuentos en cada serie; sólo se añade que en breve aparecerían otros diez títulos más. Por último, en el Catálogo de 1929 reproducía las tres series anteriores con los mismos cuentos en cada serie, no apareciendo ninguna ampliación de la colección.

\section{CUADRO I: RELACIÓN DE TÍTULOS DE LA BIBLIOTECA CUENTOS PARA NIÑOS, CON EL AUTOR, ILUSTRADOR Y CATÁLOGOS EDITORIALES.}

\begin{tabular}{|c|c|c|c|c|c|c|}
\hline TÍTULO & AUTOR & ILUSTRADOR & $\begin{array}{c}\text { CATÁLOGO } \\
1908\end{array}$ & $\begin{array}{c}\text { CATÁLOGO } \\
1917\end{array}$ & $\begin{array}{c}\text { CATÁLOGO } \\
1925\end{array}$ & $\begin{array}{c}\text { CATÁLOGO } \\
1929\end{array}$ \\
\hline La madre pequeñita & Alfonso Pérez Nieva & Evaristo Barrio & $\mathrm{x}$ & $\mathrm{x}$ & $\mathrm{x}$ & $\mathrm{x}$ \\
\hline El cornetilla & Mariano Rodríguez Miguel & Evaristo Barrio & $\mathrm{x}$ & $\mathrm{x}$ & $\mathrm{x}$ & $\mathrm{x}$ \\
\hline El abuelo y el nieto & Carlos Frontaura & Evaristo Barrio & $\mathrm{x}$ & $\mathrm{x}$ & $\mathrm{x}$ & $\mathrm{x}$ \\
\hline Un héroe infantil & Manuel Ossorio Bernard & Isidro Gil & $\mathrm{x}$ & $\mathrm{x}$ & $\mathrm{x}$ & $\mathrm{x}$ \\
\hline $\begin{array}{l}\text { La cuadratura del } \\
\text { círculo }\end{array}$ & Manuel Ossorio Bernard & Evaristo Barrio & $\mathrm{x}$ & $\mathrm{x}$ & $\mathrm{x}$ & $\mathrm{x}$ \\
\hline $\begin{array}{l}\text { El vendedor de } \\
\text { periódicos }\end{array}$ & Mariano Rodríguez Miguel & Evaristo Barrio & $\mathrm{x}$ & $\mathrm{x}$ & $\mathrm{x}$ & $\mathrm{x}$ \\
\hline Los tres amigos & & Isidro Gil & $\mathrm{x}$ & $\mathrm{x}$ & $\mathrm{x}$ & $\mathrm{x}$ \\
\hline Mi primera comunión & Ángel Bueno Rodríguez-Arias & Evaristo Barrio & $\mathrm{x}$ & $\mathrm{x}$ & $\mathrm{x}$ & $\mathrm{x}$ \\
\hline Morir por la patria & & Isidro Gil & $\mathrm{x}$ & $\mathrm{x}$ & $\mathrm{x}$ & $\mathrm{x}$ \\
\hline El grumete & Juan Benejam y Saura & Evaristo Barrio & $\mathrm{X}$ & $\mathrm{x}$ & $\mathrm{x}$ & $\mathrm{x}$ \\
\hline La ambición & Manuel Ossorio y Bernard & Evaristo Barrio & $\mathrm{x}$ & $\mathrm{x}$ & $\mathrm{x}$ & $\mathrm{x}$ \\
\hline $\begin{array}{l}\text { La curiosidad } \\
\text { castigada }\end{array}$ & Hector D’Arneuil & Isidro Gil & $x$ & $\mathrm{X}$ & $\mathrm{x}$ & $\mathrm{x}$ \\
\hline $\begin{array}{l}\text { El castillo del águila } \\
\text { negra }\end{array}$ & Miguel Medina Fernández & Evaristo Barrio & $\mathrm{x}$ & $\mathrm{x}$ & $\mathrm{x}$ & $\mathrm{x}$ \\
\hline Una venta original & & & $\mathrm{x}$ & $\mathrm{x}$ & $\mathrm{x}$ & $\mathrm{x}$ \\
\hline La noche de Reyes & Magdalena Santiago Fuentes & Evaristo Barrio & $\mathrm{x}$ & $\mathrm{x}$ & $\mathrm{x}$ & $\mathrm{x}$ \\
\hline La hija del desterrado & Mateo Bustamante & Evaristo Barrio & $\mathrm{x}$ & $\mathrm{x}$ & $\mathrm{x}$ & $\mathrm{x}$ \\
\hline El nido y la choza & Diego Vidal & Evaristo Barrio & $\mathrm{x}$ & $\mathrm{x}$ & $\mathrm{x}$ & $\mathrm{x}$ \\
\hline Emilín & Ángel Bueno Rodríguez-Arias & Evaristo Barrio & $\mathrm{x}$ & $\mathrm{x}$ & $\mathrm{x}$ & $\mathrm{x}$ \\
\hline El Cristo yacente & Ángel Bueno Rodríguez-Arias & Evaristo Barrio & $\mathrm{x}$ & $\mathrm{x}$ & $\mathrm{x}$ & $\mathrm{x}$ \\
\hline El premio & & Evaristo Barrio & $\mathrm{x}$ & $\mathrm{x}$ & $\mathrm{x}$ & $\mathrm{x}$ \\
\hline Un genio & Isidro Gil Gabilondo & Isidro Gil & $\mathrm{x}$ & $\mathrm{x}$ & $\mathrm{x}$ & $\mathrm{x}$ \\
\hline
\end{tabular}

${ }^{599}$ Juan Benejam Saura era hijo del maestro y pedagogo menorquín Joan Benejam Vives. Vid. MOTILLA SALAS, X.; GONZÁLEZ GÓMEZ, S. La utilización del grabado en El buen amigo. Periódico para la enseñanza de niños y adultos de Joan Benejam Vives. En: Actas del XVIII Coloquio de Historia de la Educación: Arte, literatura y educación. Vic: Universitat de Vic-Universitat Central de Catalunya, 2015, pp. 409-423. 
LA EDITORIAL BURGALESA HIJOS DE SANTIAGO RODRÍGUEZ (1891-1936):

ANÁLISIS DE LOS LIBROS ESCOLARES

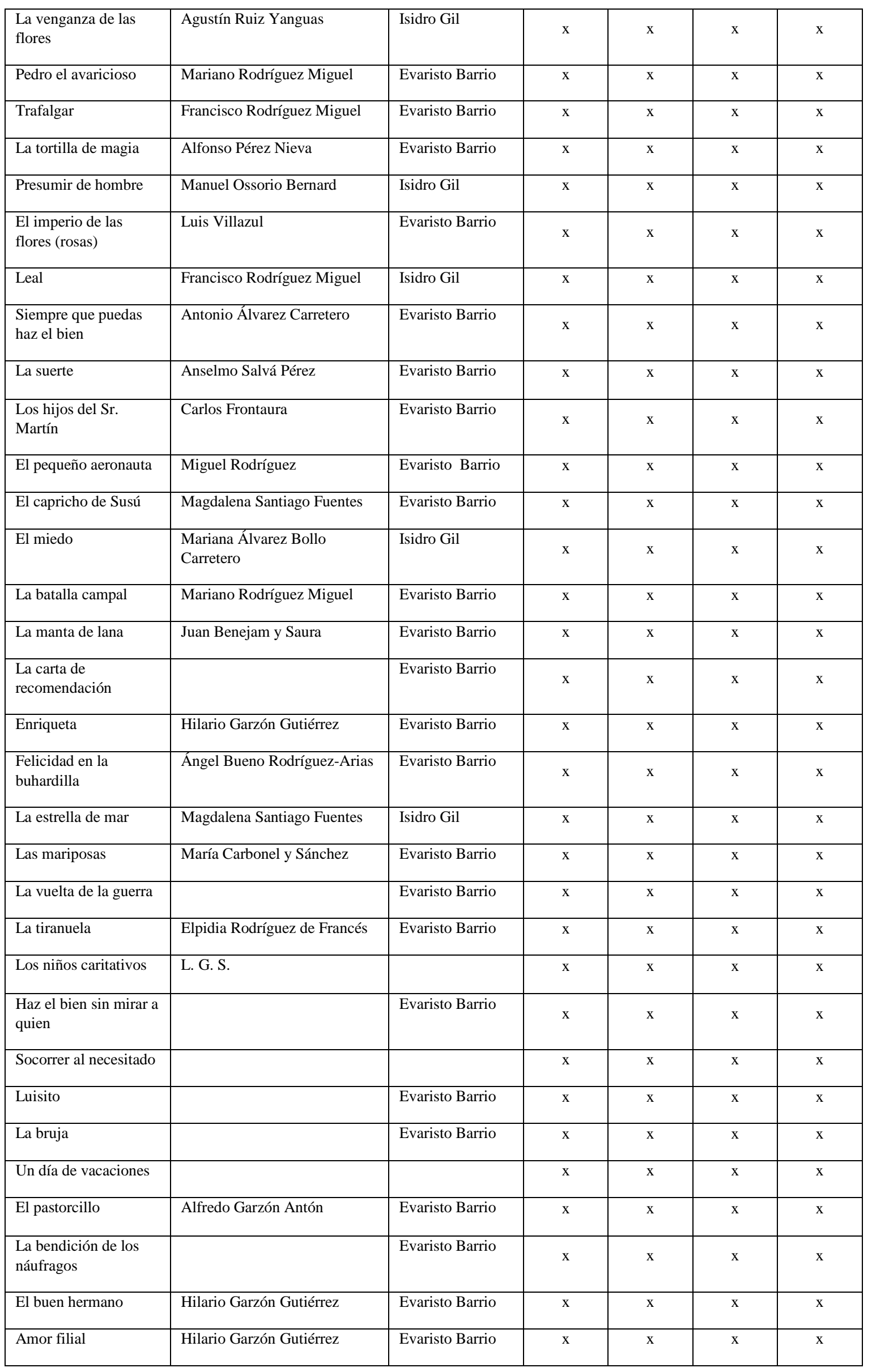


6. BIBLIOTECAS Y LIBROS ESCOLARES

\begin{tabular}{|c|c|c|c|c|c|c|}
\hline Lobito & & Evaristo Barrio & $\mathrm{X}$ & $\mathrm{x}$ & $\mathrm{x}$ & $\mathrm{x}$ \\
\hline Caridad & & Evaristo Barrio & $\mathrm{x}$ & $\mathrm{x}$ & $\mathrm{x}$ & $\mathrm{x}$ \\
\hline $\begin{array}{l}\text { La maldición del } \\
\text { baturro }\end{array}$ & & Evaristo Barrio & $\mathrm{x}$ & $\mathrm{x}$ & $\mathrm{x}$ & $\mathrm{x}$ \\
\hline La mejor fiesta & Dolores Gonzalo Morón & Evaristo Barrio & $\mathrm{x}$ & $\mathrm{x}$ & $\mathrm{x}$ & $\mathrm{x}$ \\
\hline El abrigo escocés & Rosa Eguilaz de Parada & Evaristo Barrio & $\mathrm{x}$ & $\mathrm{x}$ & $\mathrm{x}$ & $\mathrm{x}$ \\
\hline La corteza & José Campo Moreno & Evaristo Barrio & $\mathrm{x}$ & $\mathrm{x}$ & $\mathrm{x}$ & $\mathrm{x}$ \\
\hline Un ángel & & Evaristo Barrio & $\mathrm{x}$ & $\mathrm{x}$ & $\mathrm{x}$ & $\mathrm{x}$ \\
\hline El limpiabotas & & Evaristo Barrio & $\mathrm{x}$ & $\mathrm{x}$ & $\mathrm{x}$ & $\mathrm{x}$ \\
\hline El espejo de María & & Evaristo Barrio & $\mathrm{x}$ & $\mathrm{x}$ & $\mathrm{x}$ & $\mathrm{x}$ \\
\hline La caída de la hoja & Encarnación Hidalgo Rey & Evaristo Barrio & $\mathrm{x}$ & $\mathrm{x}$ & $\mathrm{x}$ & $\mathrm{x}$ \\
\hline Tal para cual & & & $\mathrm{x}$ & $\mathrm{x}$ & $\mathrm{x}$ & $\mathrm{x}$ \\
\hline La mentira de Lola & & Evaristo Barrio & $\mathrm{x}$ & $\mathrm{x}$ & $\mathrm{x}$ & $\mathrm{x}$ \\
\hline El marquesito & & Evaristo Barrio & $\mathrm{x}$ & $\mathrm{x}$ & $\mathrm{x}$ & $\mathrm{x}$ \\
\hline Hermoso modelo & & Evaristo Barrio & $\mathrm{x}$ & $\mathrm{x}$ & $\mathrm{x}$ & $\mathrm{x}$ \\
\hline Un hijo del mar & & & $\mathrm{x}$ & $\mathrm{x}$ & $\mathrm{x}$ & $\mathrm{x}$ \\
\hline La reina mora & Ángel Bueno Rodríguez-Arias & Evaristo Barrio & $\mathrm{x}$ & $\mathrm{x}$ & $\mathrm{x}$ & $\mathrm{x}$ \\
\hline $\begin{array}{l}\text { A buen rey mejor } \\
\text { vasallo }\end{array}$ & Ángel Bueno Rodríguez-Arias & Evaristo Barrio & $\mathrm{x}$ & $\mathrm{x}$ & $\mathrm{x}$ & $\mathrm{x}$ \\
\hline Lo que puede la fe & José Osés Larrumbe & Evaristo Barrio & $\mathrm{x}$ & $\mathrm{x}$ & $\mathrm{x}$ & $\mathrm{x}$ \\
\hline Historia del año & & & $\mathrm{x}$ & $\mathrm{x}$ & $\mathrm{x}$ & $\mathrm{x}$ \\
\hline Una consulta original & & Evaristo Barrio & $\mathrm{x}$ & $\mathrm{x}$ & $\mathrm{x}$ & $\mathrm{x}$ \\
\hline La mano de Dios & & Evaristo Barrio & $\mathrm{x}$ & $\mathrm{x}$ & $\mathrm{x}$ & $\mathrm{x}$ \\
\hline El perro ratonero & & & $\mathrm{x}$ & $\mathrm{x}$ & $\mathrm{x}$ & $\mathrm{x}$ \\
\hline
\end{tabular}

Fuente: Catálogos de la Editorial Hijos de Santiago Rodríguez. Años 1908, 1917, 1925, 1929. Bibliotecas públicas y universitarias de España. Biblioteca Nacional de España. CEINCE. Prensa de Burgos. [Elaboración propia].

\section{Estructura externa}

Cada ejemplar está formado por 16 páginas, con un tamaño de $15 \mathrm{x}$ $10,5 \mathrm{~cm}$., en buen papel y encuadernado con cubiertas en cartulina, e ilustraciones realizadas por Evaristo Barrio o Isidro Gil.

Las portadas de estos cuentos comienzan a realizarse en la litografía de Moliner y Rodríguez y, después de su disolución empresarial, en la Litografía de A. Moliner. También utiliza la casa litográfica burgalesa 
Fournier, dedicada a la elaboración de naipes -Litografía de la hija de Braulio Fournier.
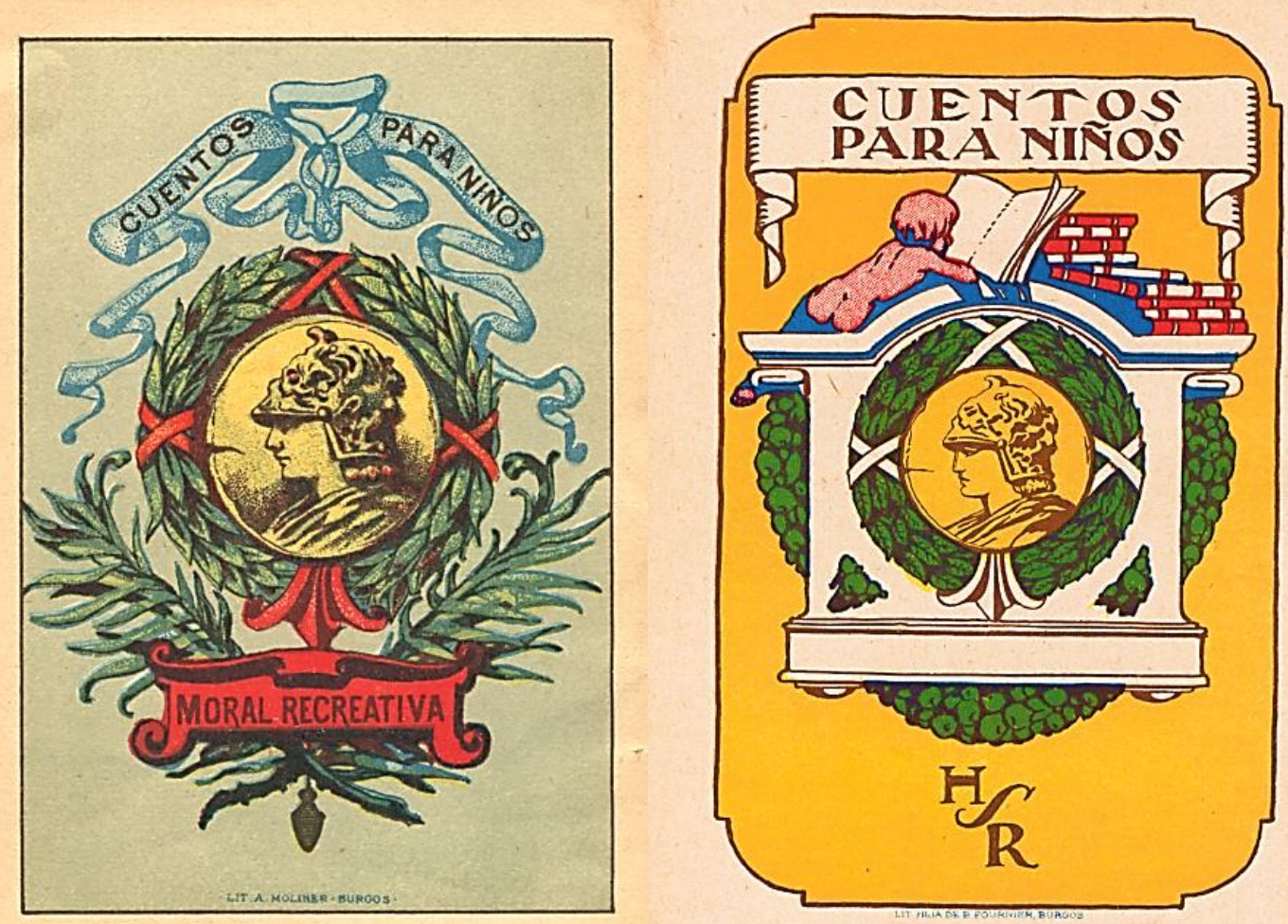

Fig. 6-2: Contraportadas de la casas litográficas burgalesas de A. Moliner y de la hija de Braulio Fournier para la Biblioteca Cuentos para Niños. Hijos de Santiago Rodríguez. Ejemplares de Lucas Rodríguez Plaza.

Además de estas casas litográficas, la editorial encarga a otras empresas, fuera de Burgos, la impresión de sus cubiertas como la de S. Durá, de la calle S. Vicente en Valencia, o en las litografías de Mateu o de Romillo, ambas de Madrid.

En estos cuentos se cuida mucho la ilustración y, junto a la cubierta realizada a todo color, en su interior presenta 3 dibujos relacionados con el cuento que narra, de plana entera en blanco y negro, ilustrados por los mismos artistas que compusieron las cubiertas.

La contraportada está ricamente decorada con el emblema de la casa editorial, la imagen de la diosa Minerva rodeada de una corona de laurel, con cintas a su alrededor, o en forma de bello marco donde, a modo de filacteria, figura el texto CUENTOS PARA NIÑOS. Además, en algunas ocasiones aparece en la parte inferior una cartela intitulada MORAL RECREATIVA. 
En la mayoría de las Bibliotecas ofrece un logotipo, señal de calidad y de propaganda, como se aprecia en la figura 6-3. La imagen representa a un niño y una niña, lectores de la editorial, en evidente marca del carácter igualitario en el acceso a la lectura de sus cuentos.

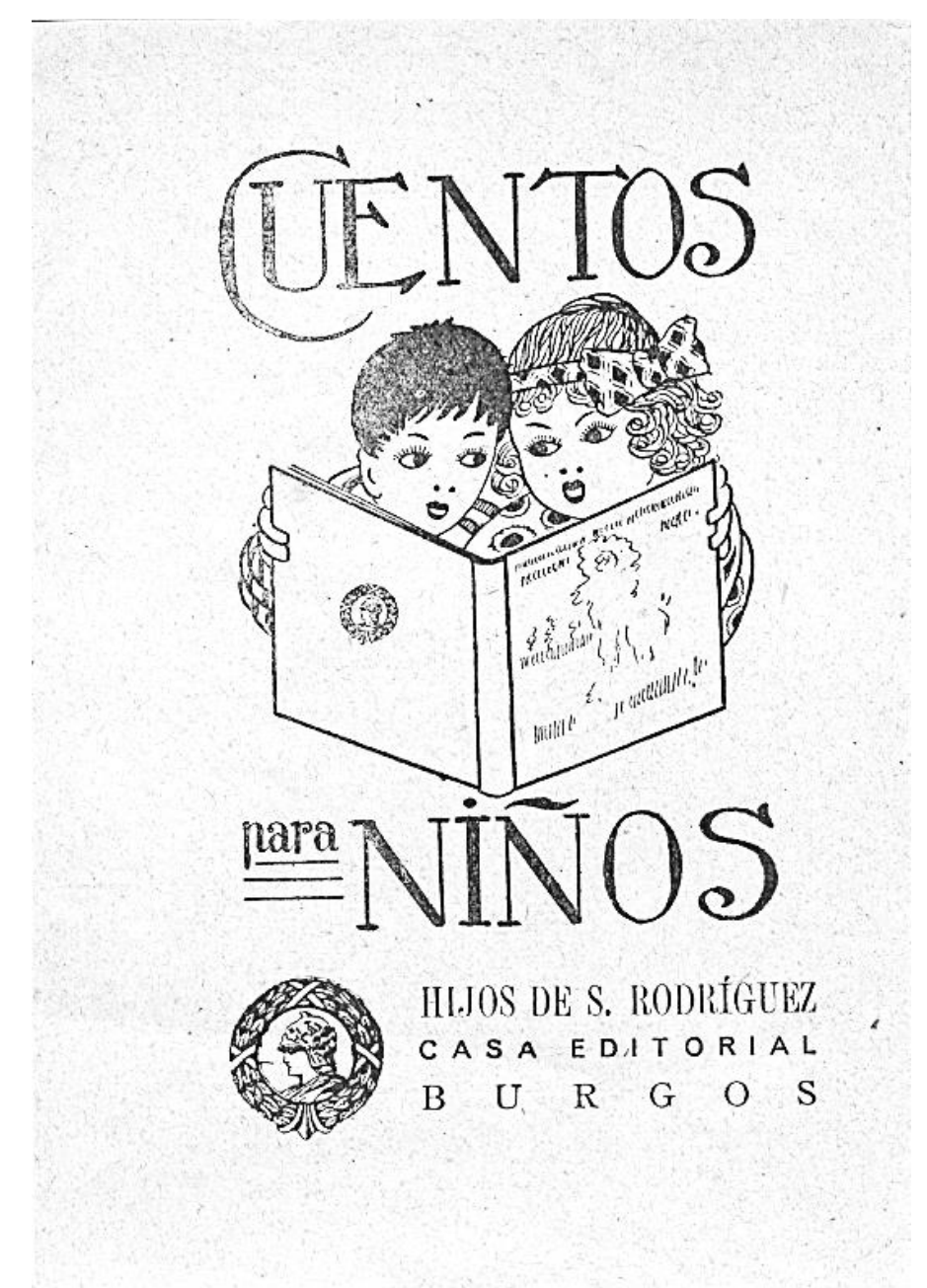

Fig. 6-3: Logotipo de la Biblioteca Cuentos para Niños. Hijos de Santiago Rodríguez.

El tipo de letra se ajusta al contenido del libro, en tamaño 10 ó 12, ya que todos cuentan con la limitación de 16 páginas. Su precio es muy económico pues se podían adquirir por 10 céntimos, desde 1894 hasta $1917,{ }^{600}$ y 15 céntimos, a partir de $1925 .{ }^{601}$ Para abaratar el coste, al igual que hacen otros editores, están grapados por la mitad.

Podemos ver comparativamente que la editorial Calleja edita una colección con el mismo nombre Cuentos para niños, con un número

${ }^{600}$ HIJOS DE SANTIAGO RODRÍGUEZ. Catálogo de la librería de Hijos de Santiago Rodríguez. [En adelante: CATÁLOGO 1908]. Burgos: Hijos de Santiago Rodríguez, 1908, p. 87; CATÁLOGO 1917, p. 89.

${ }^{601}$ CATÁlOGO 1925, p. 57; CATÁLOGO 1929, p. 32. 
parecido de tomos. El Catálogo de Calleja, de 1900, cita 141 tomos, y el de 1903, 200 tomos. En el Catálogo-Extracto (1876-1930) se indica que contaba con 160 cuentos, a un precio de 10 céntimos de peseta cada uno, con unas medidas similares, de 10 x 14,5 cm., de 16 páginas e ilustración a color de la cubierta. El final de uno de los cuentos de esta colección, titulado Renacuajo, fue escrito por Rafael Calleja ${ }^{602}$ en 1894, cuando tenía 6 años, fecha coincidente con la colección en Hijos de Santiago Rodríguez. También indica que Saturnino Calleja fue el autor de algunos de los cuentos al igual que, en Hijos de Santiago Rodríguez, lo fueron Mariano y Francisco Rodríguez Miguel, propietarios de la editorial.

\section{Estructura interna}

Los Catálogos de la editorial Hijos de Santiago Rodríguez manifiestan la finalidad de los cuentos como premios de gran lucimiento, lujosos y económicos, de lectura amenísima y moralizadora; para despertar en el niño el deseo del bien, de la belleza y de la verdad, inculcando principios de sana moral y provechosas enseñanzas.

En todos los cuentos que hemos podido leer -más de la mitad-, constatamos la clara intención moralizadora, según la tradición racionalista del siglo ilustrado, continuada y prolongada durante el siglo XIX hasta los comienzos del siglo XX. Ensalzan los principios morales de la época: aceptación de la caridad, el amor a los demás, el premio por las buenas obras, la obediencia y el cuidado a los mayores, la sumisión de la mujer, el perdón y arrepentimiento, la honradez, la abnegación, la pertenencia a una clase social, etc. y la reprobación de los vicios como la pereza, el orgullo, el egoísmo, la envidia, la avaricia...

A modo de ejemplo, estos fragmentos de Mariano Rodríguez Miguel e Hilario Garzón Gutiérrez, en sus respectivos cuentos, Pedro el avaricioso y Amor filial, pueden ilustrar algunos principios morales:

Disfrutaba de salud y de suficiente fortuna para atender holgadamente a las necesidades de su casa y, sin embargo, siempre estaba triste... la idea de ser muy rico le producía muy mal humor [...] (se fue a América donde existían millones de leguas de terreno que se daban gratis al que quisiera cultivarlas) en su descenso hacia su soñada fortuna; cayó para no levantarse más: un aneurisma del corazón le había producido la muerte.

\footnotetext{
${ }^{602}$ FERNÁNDEZ DE CÓRDOBA Y CALLEJA, E. Saturnino Calleja y su Editorial. Los cuentos de Calleja y mucho más. Madrid, Ediciones de la Torre, 2006, pp. 92-93.
} 
La avaricia, hijos míos, es uno de los vicios más abominables, y siempre da funestos resultados, como habéis visto en la historia del desgraciado Pedro. El trabajo enaltece al hombre y la codicia lo envilece. ${ }^{603}$

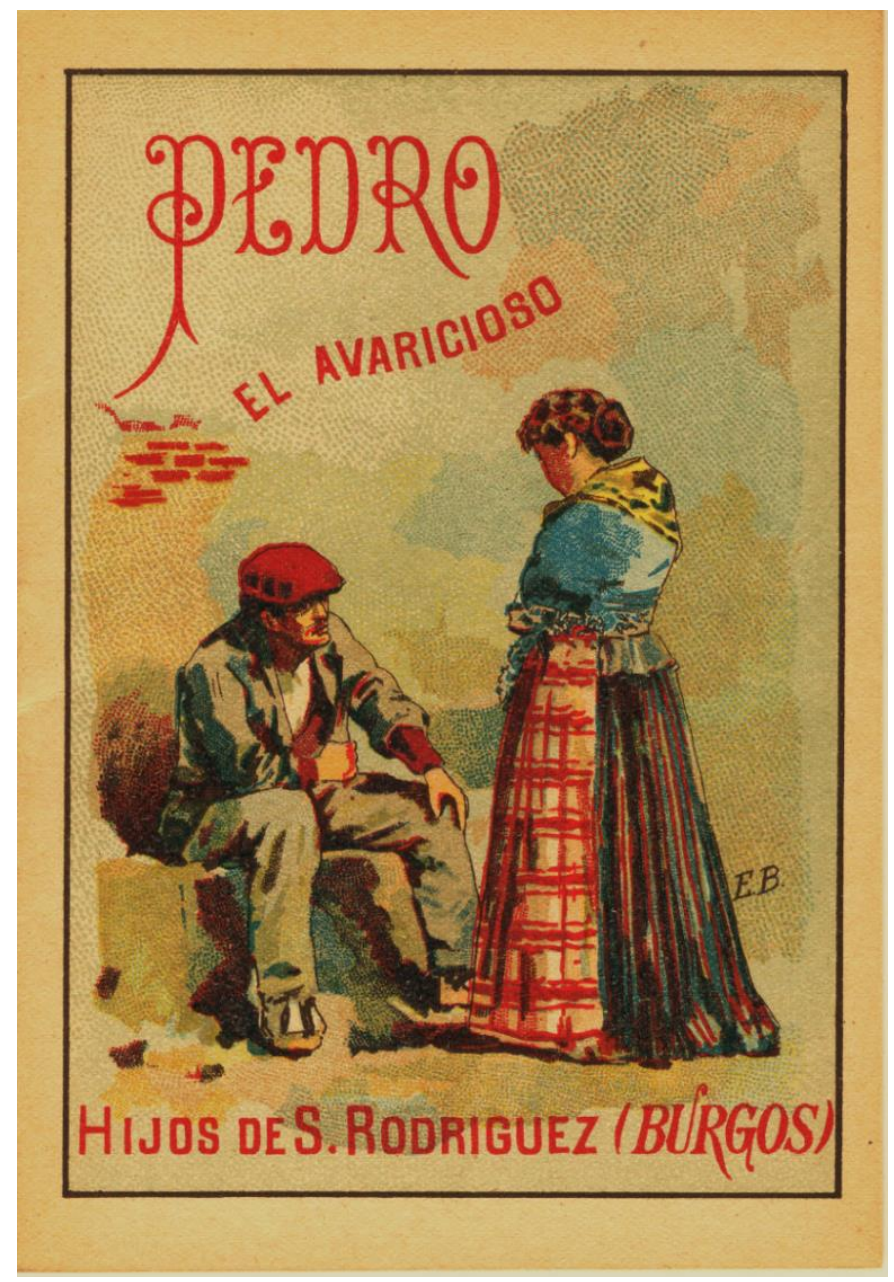

Fig. 6-4: Cubierta de Evaristo Barrio para el cuento Pedro el avaricioso. Biblioteca Cuentos para Niños. Hijos de Santiago Rodríguez.

Felisa era buena, leal, sumisa y condescendiente. Una buena educación...unos padres celosos de enseñarla con todo cuidado religión, moralidad, respeto y amor al prójimo, además de la instrucción ideal para las niñas de su edad...rezaba por las noches, acudía a misa, meditaba sobre el poder de Dios, su soberanía y el amor y sumisión que le debemos [...]

Imitad a Felisa amando a vuestros padres a vuestros maestros y a vuestros semejantes; ved con pena los defectos extraños, corregid sin piedad los propios y conseguiréis así una conciencia tranquila, exenta de envidias, remordimientos y temores, y como consecuencia una vida feliz con la esperanza de alcanzar algún día el premio que a los buenos Dios tiene destinado. ${ }^{604}$

${ }^{603}$ RODRÍGUEZ MIGUEL, M. Pedro el avaricioso. Burgos: Hijos de Santiago Rodríguez, pp. 1 y 16. Vid. Anexo 3.1.29. Ilustraciones interiores del cuento Pedro el avaricioso de la Biblioteca Cuentos para Niños.

${ }^{604}$ GARZÓN GUTIÉRREZ, H. Amor filial. Burgos: Hijos de Santiago Rodríguez, pp. 4, 15-16. 
Otro elemento muy repetido en la mayoría de los cuentos es el fuerte sentido religioso que impregna todas las actividades humanas; y hace de amalgama de todas las virtudes, al presentar a un Dios que las premia.

El cuento Los tres amigos del hombre nos alerta de que, ante la culpabilidad de robo de un niño, éste presenta a tres amigos para demostrar su inocencia, pero sólo el último es capaz de hacerlo. Relata un final con un símil, un tanto forzado, de tipo religioso:

El hombre tiene tres amigos predilectos [...] ¿Cómo se comportan a la hora de la muerte, cuando Dios le llama ante su tribunal?

El Dinero, su amigo del alma, su compañero más querido de quien todo lo espera, le abandona y se queda en este mundo. Los parientes y deudos, le acompañan hasta el sepulcro, dejándolo sólo en el Cementerio. El tercer amigo, sus buenas obras, no le abandona, al contrario, le precede y acompañan hasta el Tribunal de Dios hablan en su favor con sublime elocuencia y consiguen siempre misericordia y perdón.

¡No dudéis, hijos míos, esta querida verdad! ${ }^{605}$

Los protagonistas de las historias son personajes con nombre propio, al contrario de los protagonistas de los cuentos populares europeos donde se designan por genéricos o por características adquiridas como Blancanieves, Cenicienta, Pulgarcito, Caperucita Roja... En cuanto al comportamiento, contrapone a un niño o a una niña como prototipo de niño/a perfectos, dechado de virtudes, frente al niño desobediente, egoísta, orgulloso, según el binomio clásico niño/a bueno/a - niño/a malo/a. La bondad-maldad entre niños de distinta condición social es un clásico en los cuentos como $\mathrm{La}$ tiranuela ${ }^{606}$ o El capricho de Susú ${ }^{607}$ También esta dualidad se refleja en niños de posiciones sociales parecidas como en el cuento de La madre pequeñita, donde se presenta a dos hermanos cuyos padres habían acogido a unos sobrinos huérfanos y que, a la muerte de éstos, el hermano no asume hacerse cargo de sus primos y deja a su hermana sola, al frente de ellos, con tan sólo 15 años. Tras muchas vicisitudes, el marqués de Trébol, que vivía enfrente, deja toda su fortuna a la pequeña madre:

...estaba enterado de cómo $V$. vivía, sabía su abnegación y su firmeza para sacar adelante a sus dos huerfanitos y admirado de tanta virtud y tal mesura a los 15 años y siendo solo en el mundo, he dejado...como heredera de todos los bienes [...]

Encuentra a su hermano cojo y manco pidiendo limosna: La niña le abrió los brazos, le perdonó ante las muestras de su arrepentimiento y se lo llevó a casa.

Ya veis cómo Dios premia la caridad y castiga el egoísmo. ${ }^{608}$

${ }^{605}$ [Anón.]. Los tres amigos. Burgos: Hijos de Santiago Rodríguez, pp. 14-15.

${ }^{606}$ RODRÍGUEZ DE FRANCÉS, E. La tiranuela. Burgos: Hijos de Santiago Rodríguez.

${ }^{607}$ SANTIAGO FUENTES, M. El capricho de Susú. Burgos: Hijos de Santiago Rodríguez. Vid. Anexos 3.1.11; 3.1.12.

${ }^{608}$ PÉREZ NIEVA, A. La madre pequeñita. Burgos: Hijos de Santiago Rodríguez, 1895, pp. 14-16. 


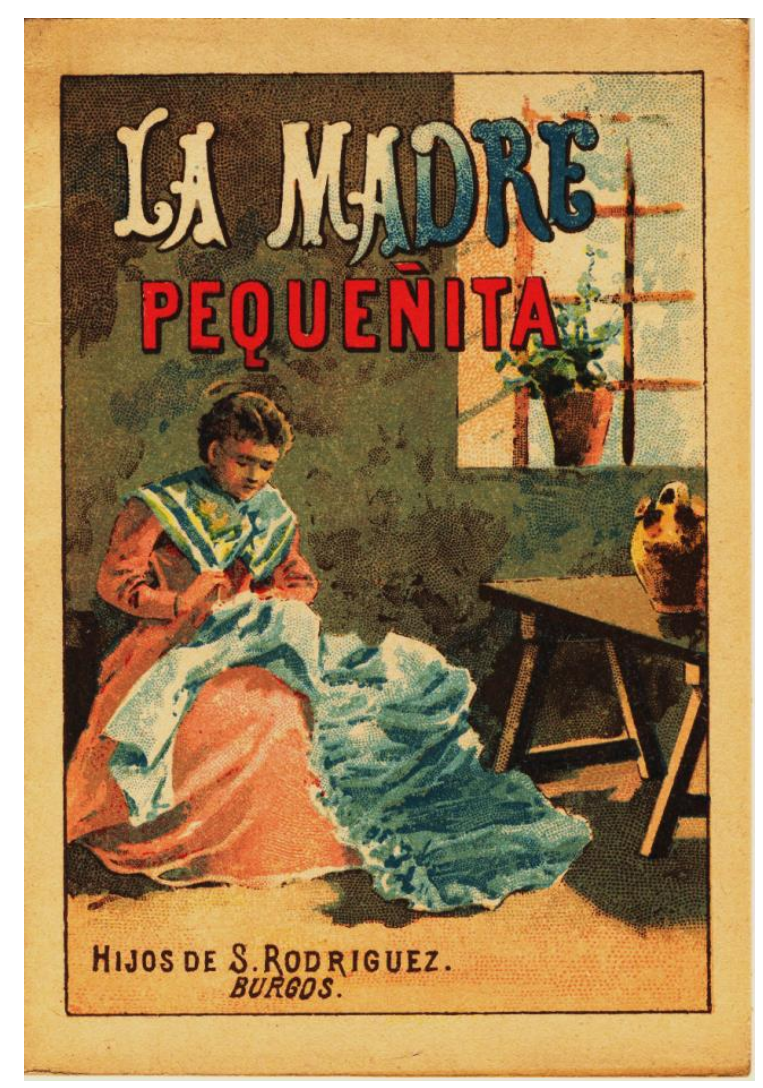

Fig. 6-5: Cubierta de Evaristo Barrio para el cuento La madre pequeñita. Biblioteca Cuentos para Niños. Hijos de Santiago Rodríguez.

Ejemplar cedido por Lucas Rodríguez Plaza.

En varios cuentos aparece enaltecida la figura del maestro, pieza clave en este tipo de educación, como se desprende de La corteza escrito por José Campo Moreno.

- QQué razón tenía el maestro! Lo más equivocado de este mundo es juzgar por la corteza, pues el árbol más feo durante el invierno, da espléndidas hojas y magníficas flores en la primavera. El todo es la savia, el corazón, lo de dentro. ${ }^{609}$

Durante los siglos anteriores, siglo XVIII y XIX, la novela era reflejo de la vida familiar aristocrática, cuyo representante más genuino sería la Condesa de Segur. A finales del XIX y durante el XX, los escritores se centran en las clases medias preferentemente, como vemos en muchos de los cuentos de la editorial. Entre los más destacados, encontramos: $E l$ abuelo y el nieto, ${ }^{610}$ La cuadratura del círculo, ${ }^{611}$ La noche de Reyes, ${ }^{612} \mathrm{El}$ nido y la choza, ${ }^{613}$, Emilín, ${ }^{614}$ La tortilla de magia, ${ }^{615}$ Presumir de

\footnotetext{
${ }^{609}$ CAMPO MORENO, J. La corteza. Burgos: Hijos de Santiago Rodríguez, p. 16.

${ }^{610}$ FRONTAURA VÁZQUEZ, C. El abuelo y el nieto. Burgos: Hijos de Santiago Rodríguez, 1895.

${ }^{611}$ OSSORIO BERNARD, M. La cuadratura del círculo. Burgos: Hijos de Santiago Rodríguez, 1895.

${ }^{612}$ SANTIAGO FUENTES, M. La noche de Reyes. Burgos: Hijos de Santiago Rodríguez, 16 p. Vid. Anexo 3.1.28; 3.3.2.

${ }^{613}$ VIDAL, D. El nido y la choza. Burgos: Hijos de Santiago Rodríguez, 1895.
} 
hombre ${ }^{616}$ Los hijos del Sr. Martín, ${ }^{617}$ La batalla campal $^{618}$ y Las mariposas. ${ }^{619}$

En ellos también se refleja el realismo frente al subjetivismo, con inspiración en la vida cotidiana y en la observación directa del acontecer diario. Este matiz no aparecía anteriormente en los libros para niños, donde abundaban los consejos y máximas aleccionadoras.

Los autores extraen los temas de sus obras del entorno circundante, buscando sus argumentos entre los que sufrían. El tratamiento literario, definido como realismo social sentimental, describe situaciones sociales injustas aunque no para denunciarlas o cambiarlas, como sucede en la literatura europea. También se fijaban en lo popular y típico de cada pueblo desarrollando un realismo de tipo costumbrista.

Como ejemplo de realismo social sentimental podemos leer El Cristo yacente. El cuento narra la procesión del Viernes Santo de Burgos con los pasos de María con la corona de espinas y de Jesús muerto en una urna de cristal. ${ }^{620} \mathrm{Y}$ como colofón, un hombre reza en silencio, oye a un niño que en alto expresa haber perdido a su padre y a su madre, y ahora a Jesús; ante los lamentos, se conmueve profundamente y le lleva con él.

Hijo querido, Dios está en todas partes y el hombre, siendo bueno, le ve donde quiere que se encuentre. Sé bueno y honrado siempre, y le verás a todas horas a tu lado, y te querrá siempre mucho...

- iSí, me voy con usted y haré cuanto me mande; yo procuraré ser bueno!

¿Qué beso estampó en la urna, y qué par de lágrimas rodaron por ella! ${ }^{621}$

También la mendicidad, tema de indudable raigambre, fue tratada en los cuentos. Era una realidad social, una verdad incontestable de la España del siglo XIX, pero abordada de una manera tal que dichas situaciones injustas se solucionaban con la caridad de las personas. Lo vemos reflejado en el cuento de Felicidad en la buhardilla.

\footnotetext{
${ }^{614}$ BUENO RODRÍGUEZ-ARIAS, A. Emilín. Burgos: Hijos de Santiago Rodríguez. Vid. Anexos 3.1.21; 3.1.22.

${ }^{615}$ PÉREZ NIEVA, A. La tortilla de magia. Burgos: Hijos de Santiago Rodríguez.

${ }^{616}$ OSSORIO BERNARD, M. Presumir de hombre. Burgos: Hijos de Santiago Rodríguez, 1895. Vid. Anexo 3.3.1.

${ }^{617}$ FRONTAURA Y VÁZQUEZ, C. Los hijos del Sr. Martín. Burgos: Hijos de Santiago Rodríguez, 1895.

${ }^{618}$ RODRÍGUEZ MIGUEL, M. La batalla campal. Burgos: Hijos de Santiago Rodríguez. Vid. Anexos $3.1 .9 ; 3.1 .10$.

${ }^{619}$ CARBONELL Y SÁNCHEZ, M. Las mariposas. Burgos: Hijos de Santiago Rodríguez.

${ }^{620} \mathrm{El}$ autor se inspira en la procesión del Viernes Santo de Burgos, con el Cristo yacente en una urna de cristal cuya estatua pertenece al cabildo de la Catedral.

${ }^{621}$ BUENO RODRÍGUEZ-ARIAS, A. El Cristo yacente. Burgos: Hijos de Santiago Rodríguez, pp. 14-
} 15. 
Te acompaño al pórtico, abuelito, porque es mi deber; no pido, porque trabajo y gano; te dejo pedir, porque no podríamos vivir de otro modo; pero en cuanto gane dos reales más no lo consentiré; que teniendo lo preciso, fuera ofender a Dios; y es muy triste alargar la mano, y no quiero yo que tú pases vergüenzas y fríos. ${ }^{62}$

Quedan igualmente testimoniados los trabajos que realizaban los niños, desde edades tempranas, sin completar los estudios, como en los cuentos Enriqueta, ${ }^{623}$ La manta de lana, ${ }^{624}$ El pastorcillo, ${ }^{625}$ o El grumete ${ }^{626}$

Un tema tan social como el suicidio, ante la miseria y desesperación, fue tratado también en estos cuentos para niños. Aunque reflejo de la realidad social, no era habitual abordarlo en la temática de los libros para niños. José Osés Larumbe lo hace dulcificándolo con un final feliz, de carácter religioso.

El ruido del río Meuse detuvo sus pasos:

- OOh!, iqué hermoso sería hundir este cuerpo aniquilado por el dolor en la corriente del río! -se dijo Hullus inclinando la cabeza fuera del pretil de la ribera.

Hullus no vaciló. Se disponía ya a depositar en las aguas el secreto de su miseria. $^{627}$

Aprovecharon los espacios circundantes, toponímicos y nombres de lugares de Burgos, como el cuento La batalla campal, ${ }^{628}$ que relata una batalla entre niños de distintos barrios ...los de la calle de Santa Clara se han empeñado en que haya camorra y la habrá... ipues no faltaba más que nos dejáramos zurrar los de la calle de Santander! ${ }^{629}$

A través de los cuentos, explicaban hechos y realidades históricas adornadas con leyendas, recreando in situ la acción, tal como se narra en $L a$ reina mora con las ruinas del monasterio de Fredesval, cuya fundación data Ángel Bueno a principios del siglo XV. Nos relata la cristianización de una reina mora a través del encuentro con su hijo, monje de dicho monasterio, que tuvo de una relación con un cristiano. El cuento sirve para explicar cómo surgió y continuó el convento.

\footnotetext{
${ }^{622}$ BUENO RODRÍGUEZ-ARIAS, A. Felicidad en la buhardilla. Burgos: Hijos de Santiago Rodríguez, p. 7. Vid. Anexo 3.1.27.

${ }^{623}$ GARZÓN GUTIÉRREZ, H. Enriqueta. Burgos: Hijos de Santiago Rodríguez. Vid. Anexos 3.1.23; 3.1.24.

${ }^{624}$ BENEJAM Y SAURA, J. La manta de lana. Burgos: Hijos de Santiago Rodríguez. Vid. Anexos 3.1.7; 3.1.8.

${ }^{625}$ GARZÓN ANTÓN, A. El pastorcillo. Burgos: Hijos de Santiago Rodríguez. Vid. Anexos 3.1.15; 3.1.16.

${ }^{626}$ BENEJAM Y SAURA, J. El grumete. Burgos: Hijos de Santiago Rodríguez. Vid. Anexos 3.1.13; 3.1.14.

${ }^{627}$ OSÉS LARUMBE, J. Lo que puede la fe. Burgos: Hijos de Santiago Rodríguez, p. 11. Vid. Anexos 3.1.3; 3.1.4

${ }^{628}$ RODRÍGUEZ MIGUEL, M. La batalla campal. Op. cit.

${ }^{629}$ Calle Santa Clara, situado en la zona sur de Burgos y los de la Calle Santander, zona centro de la ciudad.
} 
En la época, los cuentos eran objeto de relatos ambientados en el entorno escolar. En uno de ellos, La suerte, se retrata a dos amigos con el esquema polar niño bueno y niño malo, con las consiguientes medallas de aplicación:

Esteban, dócil, aplicado, muy constante a la escuela y muy obediente a padres, maestros y superiores.

Natalio, discolillo, holgazán y de los novilleros muy conocido.

[...] se presentó el Sr. cura acompañado de un anciano, muy majo y pulcro...el anciano era un antiguo catedrático oriundo del pueblo riquísimo y aficionado a la enseñanza y a los niños... a los designados por el maestro como los más aplicados los distinguió con otra medallita especial y un fuerte abrazo. ${ }^{630}$

También, se hacen eco de la infancia abandonada -falta de salud, la marginación infantil, etc.-. La estructura de la narración despliega la odisea de uno o varios niños/as huérfanos/as o con padres enfermos que al final, tras muchas vicisitudes, se veían socorridos por otros niños/as, felizmente.

En La noche de Reyes describe cómo la víspera de dicho día, al salir de la escuela en una zona cercana a la Catedral (en Burgos había escuelas privadas muy cerca de la Seo) Conchita se encontró a Rosa, una antigua compañera del colegio, que no asiste a la escuela porque, desde que su padre se cayó de un andamio, su madre le tiene que cuidar y ella debe vender castañas para subsistir. Conchita va a su casa, le cuenta a su madre lo sucedido y decide romper la hucha para llevar los ahorros depositados a su amiga.

En El abrigo escocés se habla de la recogida de dos niños huérfanos, una de ellos muy enferma, Amalia. En otros cuentos anteriormente nombrados también aparecen personajes huérfanos como en $\mathrm{El}$ Cristo yacente, La madre pequeñita, etc.

Otro componente que se introduce en los cuentos infantiles es el contacto y el aprendizaje a través de la naturaleza, educación ambiental matizada con enseñanzas moralizantes, como en el caso de Las mariposas, El nido y la choza y La venganza de las flores. ${ }^{631}$

En el primero, un jardinero explica a unos niños el desarrollo de una oruga y su conversión en mariposa, con un final moralizante y religioso:

Este es el premio otorgado por Dios a su constancia, a su paciencia y sumisión... pues seamos buenos, humildes y sufridos como las pobrecitas orugas, para convertirnos en ángeles como ellas se convierten en mariposas. ${ }^{632}$

\footnotetext{
${ }^{630}$ SALVÁ PÉREZ, A. La suerte. Burgos. Hijos de Santiago Rodríguez, pp. 1 y 12-13.

${ }^{631}$ RUIZ YANGUAS, A. La venganza de las flores. Burgos. Hijos de Santiago Rodríguez. Ver ilustraciones en Anexos 3.2.7; 3.2.8.

${ }^{632}$ CARBONELL Y SÁNCHEZ, M. Las mariposas. Op. cit., p. 16.
} 
Todas las mañanas acudían Pura y Luis al jardín, donde paseaban algunas horas agradablemente, respirando aquel ambiente tan puro, contemplando aquellas hermosas y variadas flores y particularmente el nido en que piaban los cuatro pajarillos. $^{633}$

Todos los cuentos tienen como protagonista a un niño o adolescente que se destaca por sus cualidades de superación personal, de maduración, que provoca una conversión moral o religiosa. En este sentido, un cuento muy interesante, de Manuel Ossorio Bernard, es Presumir de hombre. El cuento narra cómo Hipólito había sido enviado por sus padres a Madrid para seguir la carrera de abogado después de conseguir el título de bachiller en Artes. Éstos tenían una hacienda en el campo. En Madrid quedó a cargo de unos amigos de sus padres que, no teniendo sitio en su casa, lo alojan en una casa de huéspedes. Libre de las recomendaciones y advertencias de su madre y viviendo en compañía de otros estudiantes de más edad, alegres y traviesos, se prometió vivir como ellos, y fumar, comprar un bastón de estoque y una sortija que pagaría a plazos. Pero un día, un jovencito le intentó arrebatar dicha sortija, comenzando una serie de vicisitudes que le hacen reflexionar y comprender su error. Aprendida la lección, desde ese día, empezó a estudiar y ser ejemplar.

Otros cuentos narran hechos o personajes históricos como la actuación de un joven huérfano, reflejada en Un héroe infantil, ${ }^{634}$ situando la acción en Madrid, en los días de mayo de 1808. Este joven valiente, llamado Mendrugo, estuvo en el sitio de Madrid al lado de Velarde. Tras ser herido y recogido por la familia de un oficial, después de su convalecencia marcha hacia Andalucía para reunirse con el ejército, prometiendo a la familia que cuidaría de su hijo. En otro ejemplo, el cuento Un genio ${ }^{635}$ explica las proezas del músico Wolfgang Amadeo Mozart a la edad de 13 años, en Roma, un Viernes Santo de 1769.

En algunos de los cuentos los autores aprovechan para detallar información sobre lugares lejanos y hechos históricos, tanto actuales como ocurridos en el pasado.

Lieja, antigua e industriosa ciudad, es hoy una bonita población de 120.000 habitantes, capital de la provincia de Lieja, en Bélgica, y uno de los pueblos más renombrados hoy en Europa por su gran movimiento fabril y manufacturero [...] A un lado, una masa enorme de edificios, de alturas desiguales ... a veces miles y miles de gigantescas chimeneas de ladrillo que arrojan densas columnas de humo

\footnotetext{
${ }^{633}$ VIDAL, D. El nido y la choza. Op. cit., p. 8.

${ }^{634}$ OSSORIO BERNARD, M. Un héroe infantil. Burgos: Hijos de Santiago Rodríguez, 1895.

${ }^{635}$ GIL Y GABILONDO, I. Un genio. Burgos: Hijos de Santiago Rodríguez, 16 p. Vid. Anexos 3.2.13; 3.2.14.
} 
de todos los matices, desde el negro como una raya de carbón que se traza en el horizonte, hasta el rojo y el amarillo. ${ }^{636}$

A corta distancia de la ciudad de Lille, uno de los principales centros manufactureros de la Francia septentrional, funciona una importante fábrica de mantas de lana en donde trabajan, aparte de algunos hombres, muchas mujeres y algunas niñas. ${ }^{637}$

La pasión por viajar, visitar, conocer otras tierras, otros mundos y lugares lejanos y de ensueño, a través de la lectura, se presentaba con protagonistas infantiles donde les ocurrían toda clase de aventuras y peripecias, como las situadas en la antigua Persia, del cuento El buen hermano, ${ }^{638}$ o en Siberia o San Petesburgo durante la época de los zares, en el cuento La hija del desterrado. ${ }^{639}$

Se recurre a un vocabulario diferenciado según los protagonistas. Para los adultos, las palabras empleadas más repetidas son: justos, trabajadores, honrados; en los niños, se acude a palabras como la hermosura, la bondad, ángeles, obedientes, vanidosillos, juguetones, pobre muchacho, dependiendo de la posición social. Se reproducen algunas estructuras temáticas que se refieren a aspectos sociales como la pobreza, la bondad, la caridad, abnegación, aceptación. Son fórmulas que pretenden conformar en la mente del niño un determinado status social. Emplean un léxico accesible a niños que recibían una buena educación, tanto por la cantidad de palabras, cuanto por la riqueza de descripciones que utilizan.

$\mathrm{El}$ componente religioso es muy intenso y remarcado en el vocabulario. Son frecuentes palabras como pureza, celestial, caridad, compasión, creyente, cristiano y otras referentes a ideas, hechos, personajes, momentos y lugares religiosos.

Se destaca que aparecen en estos cuentos muchos sustantivos relacionados con conceptos abstractos contrapuestos vinculados con el aspecto moral o ético (compasión, humildad, sencillez, ambición, orgullo, vanidad, ociosidad). Los adjetivos se definen según el plano social (pobre o rico) o sobre el plano moral (travieso, caritativo, trabajador).

El desarrollo de los cuentos es ágil, se mezclan las descripciones de los lugares y personas que intervienen, con diálogos cortos, para asentar lo que va narrando. También utilizan grandes párrafos y frases subordinadas, llenas de nexos y signos de puntuación, porque era la forma de escribir en la literatura de la época.

\footnotetext{
${ }^{636}$ OSÉS LARUMBE, J. Lo que puede la fe. Op. cit., pp. 3-4.

${ }^{637}$ BENEJAM Y SAURA, J. Op. cit., La manta de lana, p. 3.

${ }^{638}$ GARZÓN GUTIÉRREZ, H. El buen hermano. Burgos: Hijos de Santiago Rodríguez. Vid. Anexos 3.1.5; 3.1.6.

${ }^{639}$ BUSTAMANTE JUNQUERA, M. La hija del desterrado. Burgos: Hijos de Santiago Rodríguez. 
Los títulos de los cuentos forman parte de la narración del cuento y tienen relación directa con el tema central del mismo.

\section{Ilustradores}

La mayoría de los cuentos fueron ilustrados por Evaristo Barrio. Nacido en Zaragoza, vive la mayor parte de su vida en Burgos debido al traslado de su padre militar. Interviene en la guerra de África, a los 20 años, donde resulta gravemente herido, perdiendo la movilidad del brazo izquierdo. Desarrolla sus cualidades artísticas, obteniendo el grado de Académico de la Real Academia de Bellas Artes de San Fernando, en 1874. Fue profesor y director de la Academia Provincial de Dibujo de Burgos. ${ }^{640}$

La mayor parte de sus trabajos los realiza para la editorial Hijos de Santiago Rodríguez. Ilustra la mayoría de los cuentos infantiles y otras obras de carácter histórico, recreando hechos pasados. Las ilustraciones están inspiradas en escenas de la vida real que reproducía con cierta fidelidad. ${ }^{641}$

Por su parte, Isidro Gil, hijo de un médico burgalés, estudia Derecho aunque su verdadera vocación fue la pintura. Académico de la Real Academia de las Bellas Artes, pertenece a la Comisión Provincial de Monumentos, y ejerce de director de la Academia del Consulado del Mar, de concejal y teniente de alcalde del Ayuntamiento de Burgos.

Fue un brillante ilustrador de libros infantiles de la editorial Hijos de Santiago Rodríguez, ${ }^{642}$ y de otros libros sobre monumentos de Burgos y de otras ciudades. Como publicista su pasión fue el estudio de castillos, sobre todo de la arquitectura militar de la Edad Media.

Ambos autores, Evaristo Barrio e Isidro Gil, recrean imágenes como refuerzo a lo escrito, según las ideas de la época, con un fuerte didactismo. Nos suministran toda clase de ejemplos visuales, con una visión idealizada de la realidad, donde predominan los valores supremos de la virtud y el sacrificio. Son imágenes que presentan a la infancia -debido a su inocencianecesitada de protección adulta, en forma de ejemplos y enseñanzas moralizadoras. ${ }^{643}$

En reediciones posteriores de algunos cuentos las cubiertas fueron realizadas por Fortunato Julián. No se sabe el número de ellas, ni la época en la que se realizaron, aunque por los trazos y formas apreciamos que son

\footnotetext{
${ }^{640}$ ZAPARAÍN YÁÑEZ, M. J.: Diseño gráfico y encuadernación. En: L. S. IGLESIAS ROUCO, dir. Protagonistas burgaleses del Siglo XX. Op. cit., v. II, pp. 153-154.

${ }^{641}$ Vid. Anexos 3.1. Evaristo Barrio (Zaragoza, 1841-Burgos 1924).

${ }^{642}$ Vid. Anexos 3.2. Isidro Gil Gabilondo (Azcoitia, Guipuzcoa, 1840- Burgos 1917).

${ }^{643}$ GARCÍA PADRINO, J. Formas y valores: La ilustración infantil en España. Cuenca: Ediciones de la Universidad de Castilla La Mancha, 2004, pp. 26-37.
} 
más acordes con la época modernista, de los años 20-30 del siglo XX. (Figura 6-6).
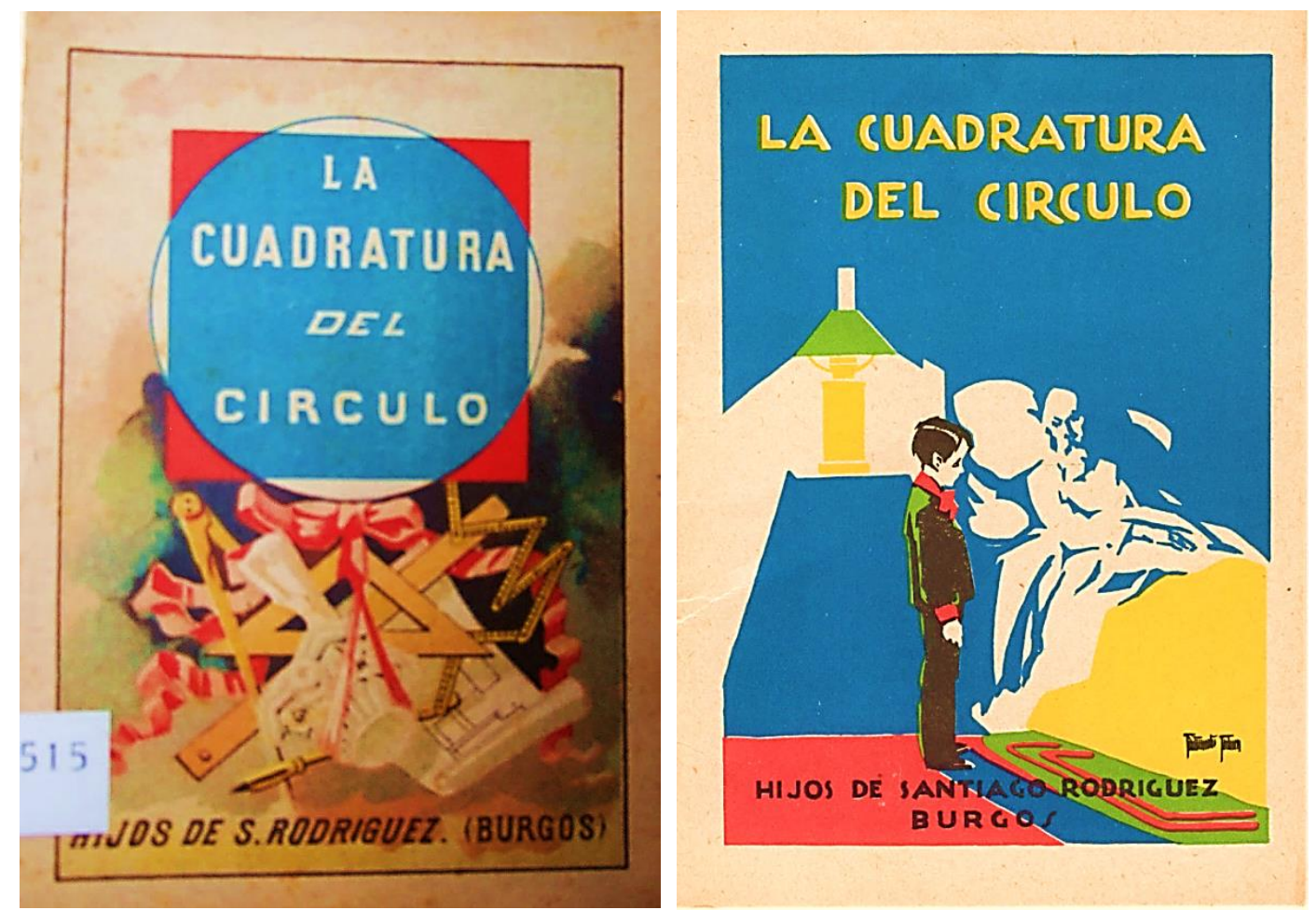

Fig. 6-6: Cubierta de Evaristo Barrio y Fortunato Julián en distintas reediciones del cuento La cuadratura del círculo. Biblioteca Cuentos para Niños.

Hijos de Santiago Rodríguez. La primera imagen pertenece a la Biblioteca de la Diputación Provincial de Burgos y la segunda es una imagen cedida por Lucas

Rodríguez Plaza.

\section{Escritoras de la colección Cuentos para Niños}

Llama la atención que en esta colección la cuarta parte de los autores sean mujeres aunque en la propaganda de sus Catálogos y en las noticias de los periódicos locales publicita a los novelistas masculinos.

Estas escritoras fueron: Magdalena Santiago Fuentes, María Carbonell y Sánchez, Elpidia Rodríguez de Francés, Mariana Álvarez Bollo Carretero, Encarnación Hidalgo Rey, Dolores Gonzalo Morón y Rosa Eguilaz de Parada.

No hace falta resaltar que el contexto social en el que transcurren sus existencias no fue fácil para que las mujeres manifestaran sus inquietudes y cualidades literarias. Abrirse camino, en este ámbito profesional, conllevaba luchar contra unos prejuicios, muy difíciles de superar, ya que se alejaban de lo que se consideraba femenino. Por ello se abren paso a través de la enseñanza, espacio entendido como natural. Y aunque se conocen pocos datos de las mismas, se observa que las cinco primeras son 
maestras de escuelas elementales y ascienden, por oposición, a escalafones más altos como Maestras Superiores y profesoras de Escuelas Normales.

De Dolores Gonzalo Morón apenas hay reseñas, pero sí se sabe que colabora en un diario liberal, El Baluarte de Sevilla, en 1901, ${ }^{644}$ y escribe para la editorial un cuento titulado La mejor fiesta, componente de la Biblioteca Cuentos para Niños.

Rosa de Eguilaz y Renart de Parada Sentín nace en Madrid -1864- en el seno de una familia culta. Su padre, Luis de Eguilaz, fue poeta y dramaturgo, y su madre es descendiente del iniciador del teatro catalán, Francisco Renart. Amiga de Carmen de Burgos, publica varias obras teatrales en 1889 y colabora con varias revistas infantiles, El Mundo de los Niños y La Edad Dichosa, en Madrid, llegando a ser propietaria de la revista Para Todos. ${ }^{645}$ Escribe para la editorial burgalesa El abrigo escocés.

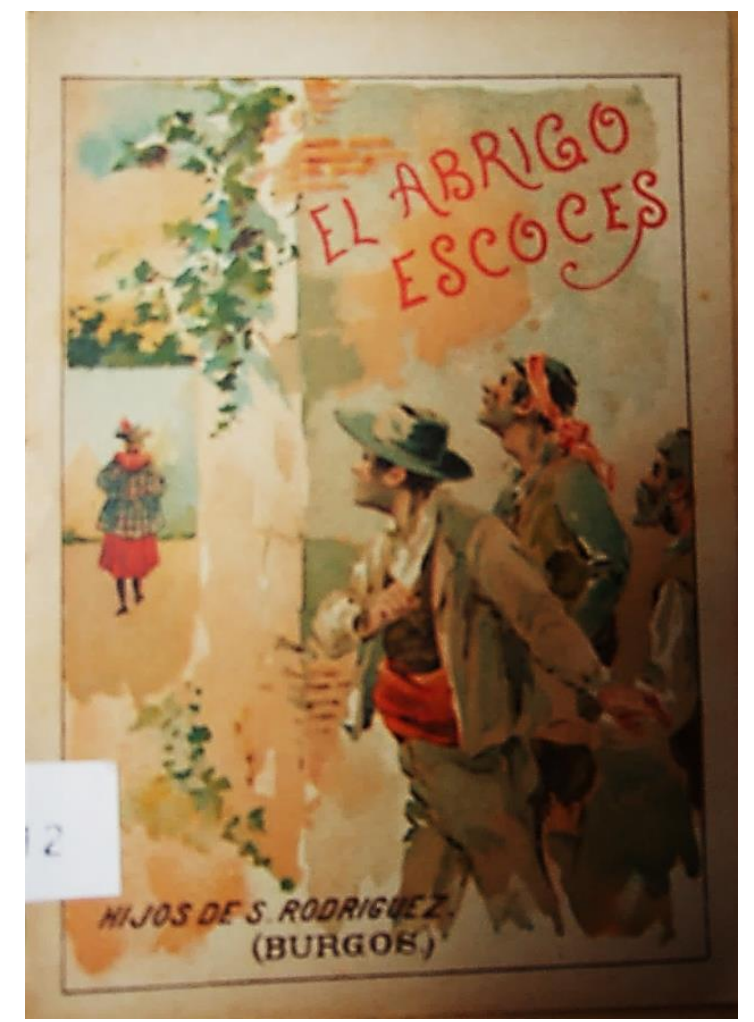

Fig. 6-7: Cubierta del cuento El abrigo escocés de Rosa de Eguilaz.

Biblioteca Cuentos para Niños. Hijos de Santiago Rodríguez.

Ejemplar de la Biblioteca de la Diputación Provincial de Burgos.

María Carbonell y Sánchez nace y muere en Valencia (1852-1926); fue una de las grandes intelectuales de la época. Obtuvo el título de Profesora

\footnotetext{
${ }^{644}$ RAMÍREZ GÓMEZ, C. Mujeres escritoras en la prensa andaluza del siglo XX (1900-1950). Sevilla: Universidad de Sevilla. Secretariado de Publicaciones, 2000, p. 175.

${ }^{645}$ Ibídem, p. 139.
} 
en la Escuela Central Normal de Valencia en 1891. Se especializó en el estudio y la práctica de la educación de alumnos con dificultades y se la considera una gran defensora de la instrucción femenina. Su pensamiento queda plasmado en numerosas obras y en los artículos publicados en Escuela Moderna, de Madrid, y de Feminal, de Barcelona. ${ }^{646}$ Para la editorial Hijos de Santiago Rodríguez escribe el cuento Las mariposas, en la Biblioteca Cuentos para Niños y en la Biblioteca Museo de la Infancia.

De Elpidia Rodríguez González apenas hay datos. Estuvo casada con Rogelio Francés Gutiérrez -autor de varias obras en la editorial- y de ahí que sea conocida como Elpidia Rodríguez de Francés, profesora de la Escuela Normal de La Laguna, en Canarias, desde 1910 hasta su cese en 1930 por traslado a la Escuela Normal de Zaragoza. ${ }^{647}$ Escribe para la editorial burgalesa La tiranuela, en la Biblioteca Cuentos para Niños y Museo de la Infancia.

Mariana Álvarez Bollo Carretero nace en Zamora, el 6 de marzo de $1866 .{ }^{648}$ Se traslada, desde pequeña a Burgos, por el trabajo de su padre, Antonio Álvarez Carretero, al ser nombrado maestro Normal y regente de la Escuela Normal de Maestros de Burgos. Ejerce la enseñanza en una de las escuelas municipales de Burgos, recibiendo la felicitación del Ayuntamiento, en la sesión del 25 de junio de 1902, por el reconocimiento a su labor. ${ }^{649}$

Su primer libro titulado Resumen del Catecismo de Higiene y Economía doméstica, publicado en la Imprenta y Librería de Santiago Rodríguez Alonso, en 1890, alude, en el prólogo, a los artífices e impulsores de dicha obra, debida a la insistencia de Santiago Rodríguez e influencia de su padre, Antonio Álvarez Carretero.

El texto que sale a la luz es un compendio o resumen de la obra de su padre Principios de higiene y economía domésticas, precedidas de unas nociones de fisiología, aprobada por el Consejo de Instrucción Pública como texto para las Escuelas Normales de Maestras. Recordemos que la

\footnotetext{
${ }^{646}$ FERNÁNDEZ DE CANO, J. R. Carbonell y Sánchez, María (ss. XIX-XX). [En línea]. La web de las biografías [fecha de consulta 17-9-2014]. Disponible en: http://www.mcnbiografias.com/appbio/do/show?key=carbonell-y-sanchez-maria

${ }^{647}$ ASENSIO GONZÁLEZ, R. La Estudiantina de la Escuela Superior de Maestras de La Laguna (Tenerife): 1921-1929. Estudio histórico y consideraciones [en línea]. TUNAE MUNDI. 2013 [fecha de consulta 19-10-2014]. Disponible en: http://tunaemundi.com/index.php/component/content/article/7tunaemundi-cat/252-la-estudiantina-de-la-escuela-superior-de-maestras-de-la-laguna-tenerife-1921-1929estudio-historico-y-consideraciones

${ }^{648}$ FERNÁNDEZ DE CANO, J. R. Álvarez Bollo Carretero, Mariana (1866-) [en línea]. La web de las biografías [fecha de consulta 17-9-2014]. Disponible en: http://www.mcnbiografias.com/appbio/do/show?key=carbonell-y-sanchez-maria

${ }^{649}$ AMBu. Actas del Ayuntamiento. LA-537, 18 de junio de 1902. Esta felicitación nace de la distinción realizada a su labor desde el secretariado de $1^{\mathrm{a}}$ enseñanza y Escuelas Normales, en una carta enviada por el Rector de Valladolid.
} 
casa editorial había obtenido numerosos premios con la obra citada, en la Exposición provincial pedagógica, de 1882, en la de Zaragoza y Barcelona de 1885 y 1888 respectivamente.

De esta primera obra, subrayamos el éxito de su publicación con numerosas reediciones. Según nos señala el Catálogo de la Editorial en 1908, llega a la $7^{a}$ edición, y el libro estaba adoptado en la mayor parte de las Escuelas de España y América. ${ }^{650}$ En el Catálogo de 1929 se señala que la publicación alcanza su $15^{\text {a }}$ edición. ${ }^{651}$

Mariana escribe para la editorial varios libros más, tres de ellos en la Biblioteca Selecta, como Dos primos célebres, La viuda de Naín, Judith: leyenda bíblica y otro cuento, El miedo, en la Biblioteca Cuentos para Niños.

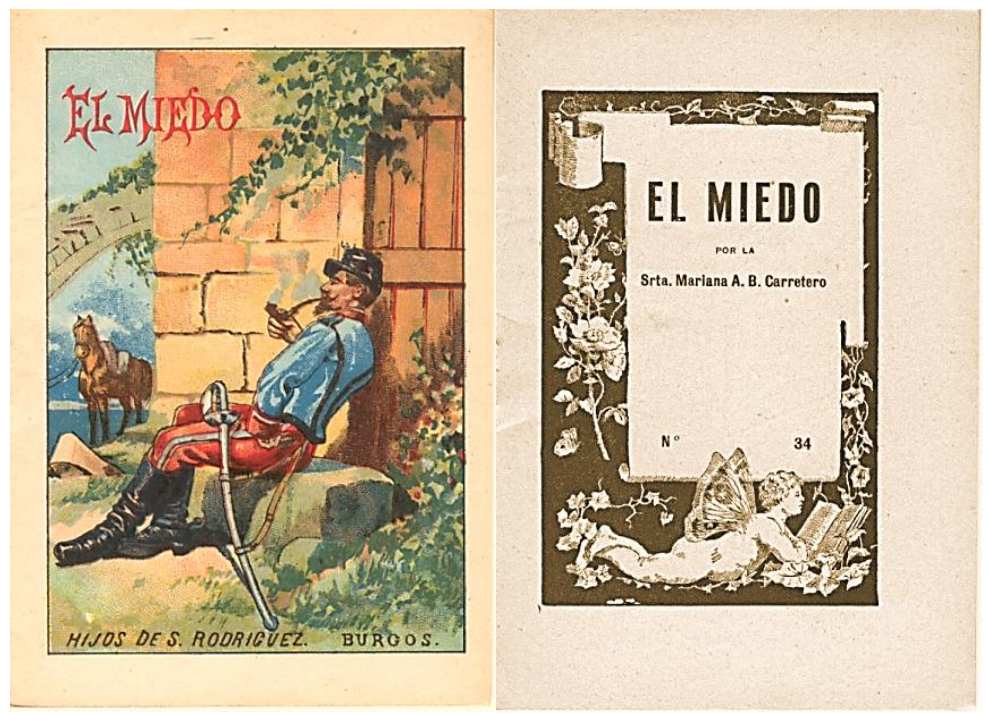

Fig. 6-8: Cubierta y portada del cuento El miedo de la Biblioteca Cuentos para Niños.

Hijos de Santiago Rodríguez. Imagen cedida por Lucas Rodríguez Plaza.

Menos datos se tienen de Encarnación Hidalgo Rey. Solo a través de una obra, Método de corte, publicada en Zaragoza, en 1896, en la Imprenta de Calixto Ariño, reconocemos a la autora como Maestra de Primera Enseñanza Superior. Para la editorial escribe la obra La caída de la hoja, en la Biblioteca Cuentos para Niños y Museo de la Infancia.

Magdalena Santiago Fuentes, nacida en Cuenca en 1873, fue una mujer poco conocida. Siendo su padre profesor y periodista, se traslada a Madrid, Logroño y Burgos. La enfermedad y muerte prematura de su padre hizo que Magdalena abandonase los estudios de Farmacia, en la Universidad Central, para trabajar de telefonista y mantener a su familia. A los diecisiete años, y en pocos meses, consigue aprobar los estudios de Maestra

${ }^{650}$ CATÁLOLGO 1908, p. 53.

${ }^{651}$ CATÁLOGO 1929, p. 27. 
Elemental y luego de Maestra Superior. Después se presenta y obtiene, por oposición, la Cátedra de la Escuela Normal de Barcelona que permuta para dirigirse a Madrid.

Escribe numerosas obras en las editoriales de la época: Bastinos, Hernando, Ramón Sopena, Henrich y Cía. Colabora en periódicos como $\mathrm{La}$ Correspondencia de España, El magisterio español, Blanco y Negro, Nuevo Mundo, y El Imparcial. ${ }^{652}$ Fue becada por la Junta para la Ampliación de Estudios e investigaciones Científicas, institución creada en 1909 en el marco de la Institución Libre de Enseñanza, convirtiéndose en una de las pocas mujeres investigadoras.

Son varias las obras que escribe para la Editorial Hijos de Santiago Rodríguez, algunos cuentos cortos de la Biblioteca Cuentos para Niños como El capricho de Susú, La noche de Reyes, La mariposa, del libro Las mariposas en la Biblioteca Museo de la Infancia, y una novela infantil, La novela de la Infancia, de la Biblioteca Enciclopédica Hispanoamericana. Es conocida por el libro La Escuela y la Patria que llegó hasta su $29^{\circ}$ edición en 1943.

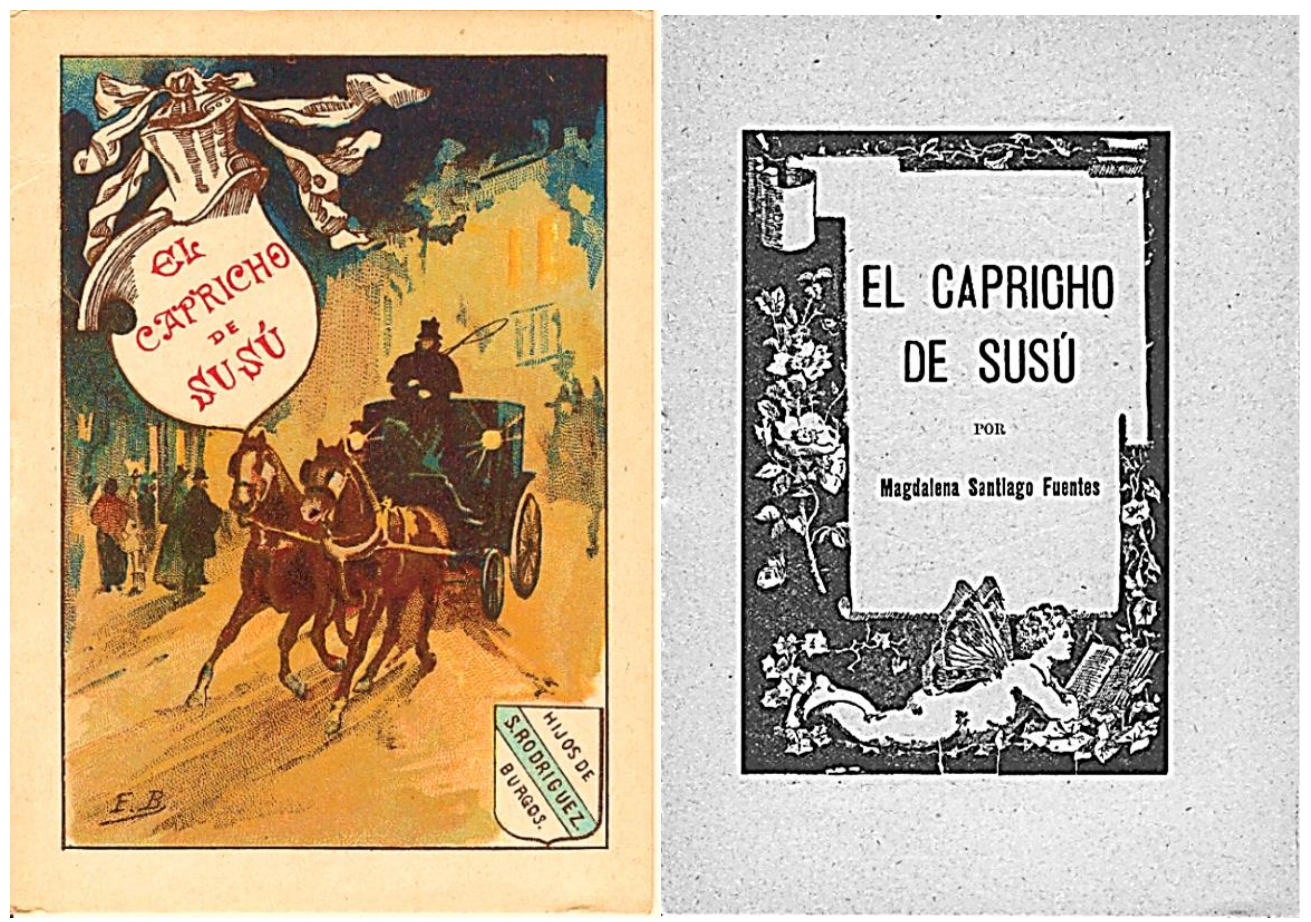

Fig. 6-9: Cubierta y portada del cuento El capricho de Susú de la Biblioteca Cuentos para Niños. Hijos de Santiago Rodríguez. Imágenes cedidas por Lucas Rodríguez Plaza.

\footnotetext{
${ }^{652}$ MUÑOZ OLIVARES, C. Los rincones de la vida. Mujeres comprometidas. Magdalena de SantiagoFuentes. Cuenca: Diputación Provincial de Cuenca. Departamento de Publicaciones, 2004, p. 238.
} 


\subsubsection{Museo de la Infancia}

En el Catálogo de 1908 presenta esta biblioteca, al igual que la anterior, como una colección de cuentos para premios y de lecturas morales. Los autores son los mismos que en la de Cuentos para Niños. Se comprueba que cada libro está compuesto de 4 ó 5 cuentos, aunque la mayoría de ellos pertenecen a la anterior colección, con un formato diferente. En su propaganda señala que pueden competir con ventaja con las del extranjero. ${ }^{653}$

La colección se compone de 50 tomos de los que, según el mismo Catálogo de 1908, ya habían publicado 20, en prensa tenían 8 más, y 10 en preparación. En el Catálogo de 1917 siguen los mismos números, excepto la inclusión de otro título, La hija del desterrado.

Hay cambios importantes en los otros Catálogos de 1925 y 1929 al reducir el número de libros.

\section{Estructura externa}

Cada tomo está formado por unas 128 páginas con un tamaño de $17,5 \mathrm{x}$ $11,8 \mathrm{~cm}$, en papel ahuesado, encuadernado con cubiertas en pasta y lomo en tela. Las ilustraciones de las cubiertas e interiores son las mismas que la Biblioteca Cuentos para Niños con la única diferencia de tener, en la cubierta y contracubierta, un marco dorado con flores y hojas. En el lomo coloca el nombre de la biblioteca: MUSEO DE LA INFANCIA. Los tomos que se conservan se realizaron en la litografía de S. Durá, de la calle S. Vicente, en Valencia.

El tipo de letra es legible, y con un buen interlineado, que facilita una lectura cómoda a los lectores infantiles. En estos cuentos se cuida mucho la ilustración mostrando en su interior de 12 a 15 imágenes de plana entera en blanco y negro, realizadas por los mismos artistas que iluminaron las cubiertas y relacionadas con el cuento que narra. Se coloca la ilustración de la cubierta a todo color del primer cuento de la obra coincidiendo con la que utilizaba para la Biblioteca Cuentos para Niños. La contracubierta, la misma que en la anterior biblioteca, está ricamente decorada con el emblema de la casa editorial, la diosa Minerva, rodeado de una corona de laurel con cintas y cartela como en la anterior Biblioteca. Los precios son de 0,75 pts., en 1908 y 1917, y de 1,50 en 1925 y 1929.

${ }^{653}$ CATÁLOGO 1908, p. 91. 


\section{Estructura interna}

Tanto la estructura interna como los elementos morfosintácticos son los mismos que lo comentado en la Biblioteca Cuentos para Niños, ya que los cuentos coinciden con los de dicha biblioteca. Sólo hay tres 3 cuentos como vemos en el cuadro comparativo -Cuadro II- que no pertenecen a la colección anterior: El abandonado, Antoñito y Al borde del abismo.

Del primer libro, El Abandonado, se encuentra un ejemplar en la biblioteca del CEINCE, con una edición fechada en 1905. Está formado por 4 cuentos. El primero que lleva el título del libro es de Alfredo Garzón Antón. ${ }^{654}$ Nos cuenta cómo el capitán de un barco de vapor, que hacía la ruta de Nantes a Marainville, se encuentra, ocultos en su gabinete a un muchacho de unos 8 o 9 años, llamado Calí, y a su perro Tafar, ya que no tenían dónde ir. El capitán Sr. Moreau le acoge y le enseña todos los entresijos del trabajo en el mar, llegando a ser un rico comerciante. En un final feliz, Calí cuida a su benefactor en su ancianidad. Tiene 5 ilustraciones en blanco y negro de Evaristo Barrio en las que se relata parte de estas aventuras.

El siguiente cuento titulado El fin de una huelga, de José Osés Larumbe, forma parte también de la siguiente colección -Biblioteca Idealcon una obra del mismo nombre. Comienza explicando la situación textil en Cataluña situando la acción en un pueblecito, entre Manresa y Berga, en una industria textil catalana. Narra como la pericia del hijo del industrial, al montar una nueva empresa con maquinaria moderna, es capaz de dar continuidad a la empresa y dar trabajo a 300 empleados. Tiene 3 ilustraciones en blanco y negro de Evaristo Barrio.

El tercer cuento Una consulta original pertenece también a la Colección de Cuentos para Niños. Relata la situación de un aldeano de la provincia de Burgos que va a la consulta de un abogado para que le pusiese por escrito un consejo. Éste lo hizo y le pide de honorario profesional 3 pesetas. Cumple el consejo al llegar a casa y, aunque era tarde, recoge la hierba pudiendo salvarla de la fuerte lluvia nocturna. Dicho consejo era: "No dejes para mañana lo que puedas hacer hoy". Tiene 3 ilustraciones alusivas al tema de Evaristo Barrio.

El último cuento, El imperio de las rosas, de Luis Villazul, pertenece también a la Colección Cuentos para Niños. En él se narra que llegan

\footnotetext{
${ }^{654}$ Alfredo Garzón Antón (1884-1944) fue funcionario del Ayuntamiento y secretario de la Junta de Fomento y Mejora de Casas Baratas en Burgos. Presentó un proyecto a la Corporación para solucionar el problema de la vivienda en Burgos, y paliar su problemática plasmado en un Acuerdo Municipal de mayo de 1926 que movilizó un movimiento cooperativista y de construcción de Casas Baratas pionero en España, según nos relata Begoña Bernal Santa Olalla. Vid. BERNAL SANTA OLALLA, B. Alfredo Garzón Antón y el fomento de la vivienda. En: L. S. IGLESIAS ROUCO, dir. Protagonistas burgaleses del Siglo XX. Op. cit., v. I, pp. 41-42.
} 
noticias a España sobre la fama del Imperio de las Rosas y los tres hijos del monarca decidieron conocerlo. El primer hijo, como gran soldado, fue a su conquista entre guerras y peleas; el segundo, lo buscó entre libros y legajos; y el tercero no salió hasta que llegaron sus hermanos y gracias a su bondad natural lo descubrió. Tiene 3 ilustraciones del tema, a plana entera, de Evaristo Barrio.

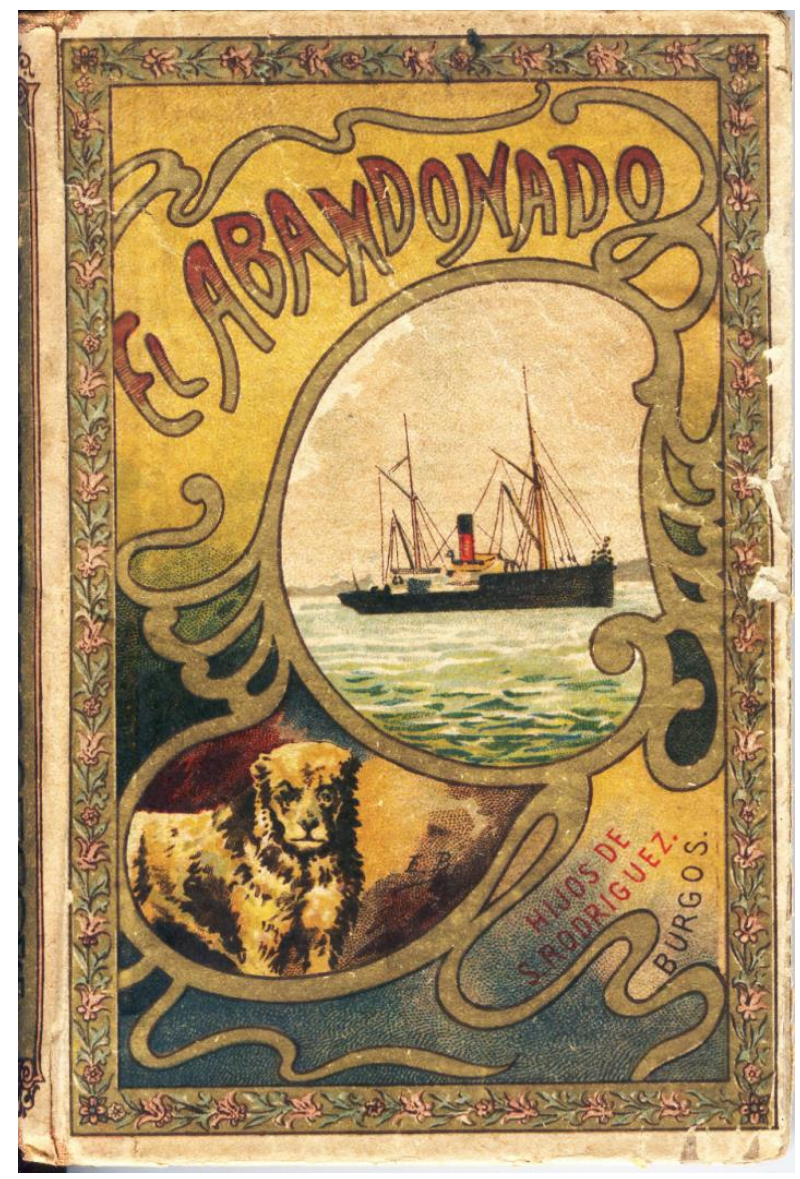

Fig. 6-10: Cubierta de El abandonado de la Biblioteca Museo de la Infancia.

Hijos de Santiago Rodríguez. 1905.

La Universidad de Castilla-La Mancha, campus de Cuenca, dispone de un ejemplar del último de los tres señalados anteriormente, Al borde del abismo. Comprobamos que el libro forma parte de un conjunto de cuentos entre los que encontramos, además del correspondiente al título, otros como La serpiente, La pesca, El amigo de los pájaros, aunque ninguno de ellos corresponde a la colección de Cuentos para Niños.

El primer cuento que coincide con el título de la cubierta del libro $\mathrm{Al}$ borde del abismo, -figura 6-11- y cuyo autor Hilario Garzón Gutiérrez, nos presenta a través de dos personajes, D. Andrés y su protegido Federico, una lección de moralidad acerca de cómo el juego es un vicio que lleva a la ruina, y sólo a través del trabajo constante y honrado se llega a ser un comerciante respetable. 
El segundo cuento, La serpiente, utiliza los mismos recursos, siendo la valentía de un pequeño muchacho la que les libre de caer en manos de los enemigos. El autor era su hijo, Alfredo Garzón Antón.

En el tercer cuento, La pesca, nos muestra como protagonista a un joven muchacho, Alfredo, con todos los rasgos de la picaresca española: niño engañado, aprende de las maldades de los mayores y con ingenio consigue lo que se propone. Es un bello cuento realizado por el mismo autor, sólo coloca las siglas A. G., que puede coincidir con las iniciales de Alfredo Garzón.

El último cuento, El amigo de los pájaros, de la misma autoría que los dos anteriores, también nos recrea el escenario de un lugar burgalés -La Quinta- con una anécdota sobre cuidar a los pájaros y no darles muerte, ni a ellos ni a sus crías en sus nidos.

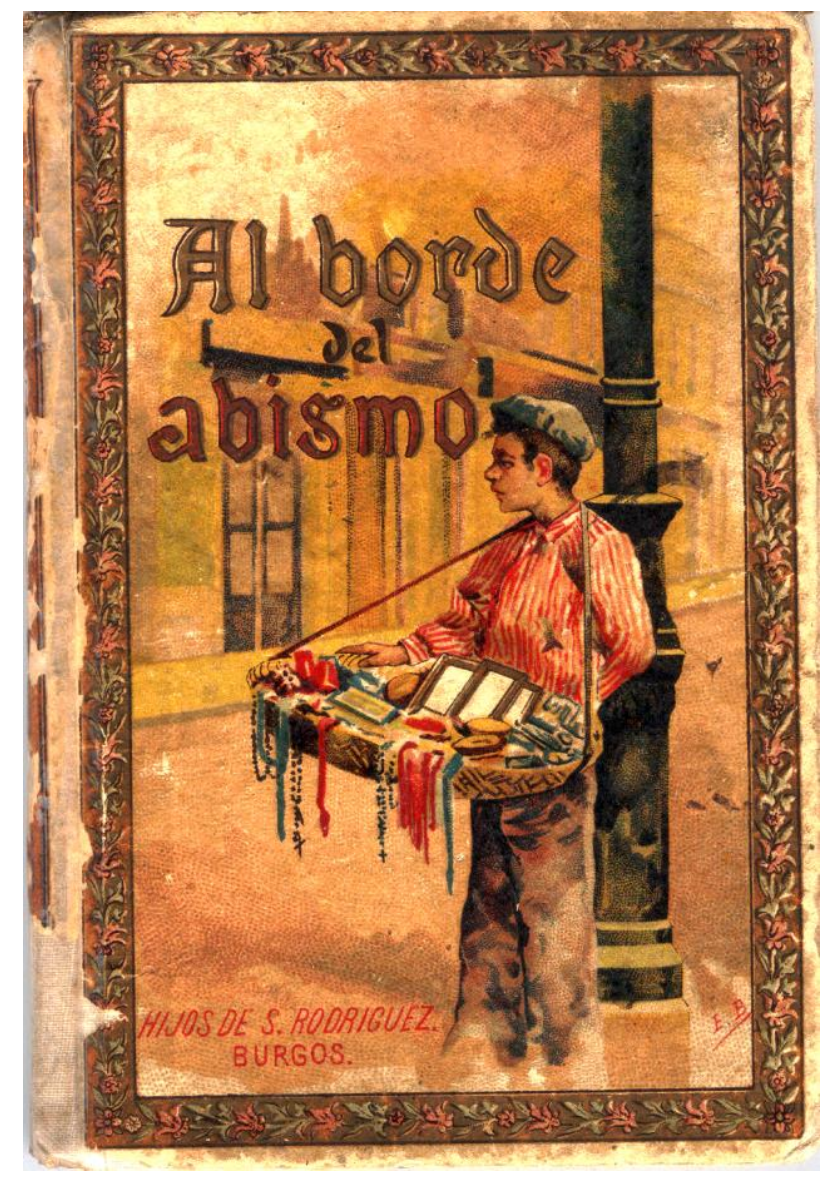

Fig. 6-11: Cubierta de cuento Al borde del abismo. Biblioteca Cuentos para Niños.

Hijos de Santiago Rodríguez. 1906.

El cuento Antoñito no se ha localizado en ninguna biblioteca o entidad pública ni privada. 
Pocos ejemplares quedan del resto de los títulos que presentan los Catálogos. Encontramos 4 de los mismos, aunque sólo hemos podido leer tres.

En el limpiabotas -ejemplar único encontrado en el CEINCE- se presentan tres cuentos, además del que hace honor al título. Todos ellos, $E l$ Marquesito, El hijo del mar, y A buen rey, mejor vasallo, pertenecen a la Biblioteca Cuentos para Niños y están ilustrados por Evaristo Barrio.

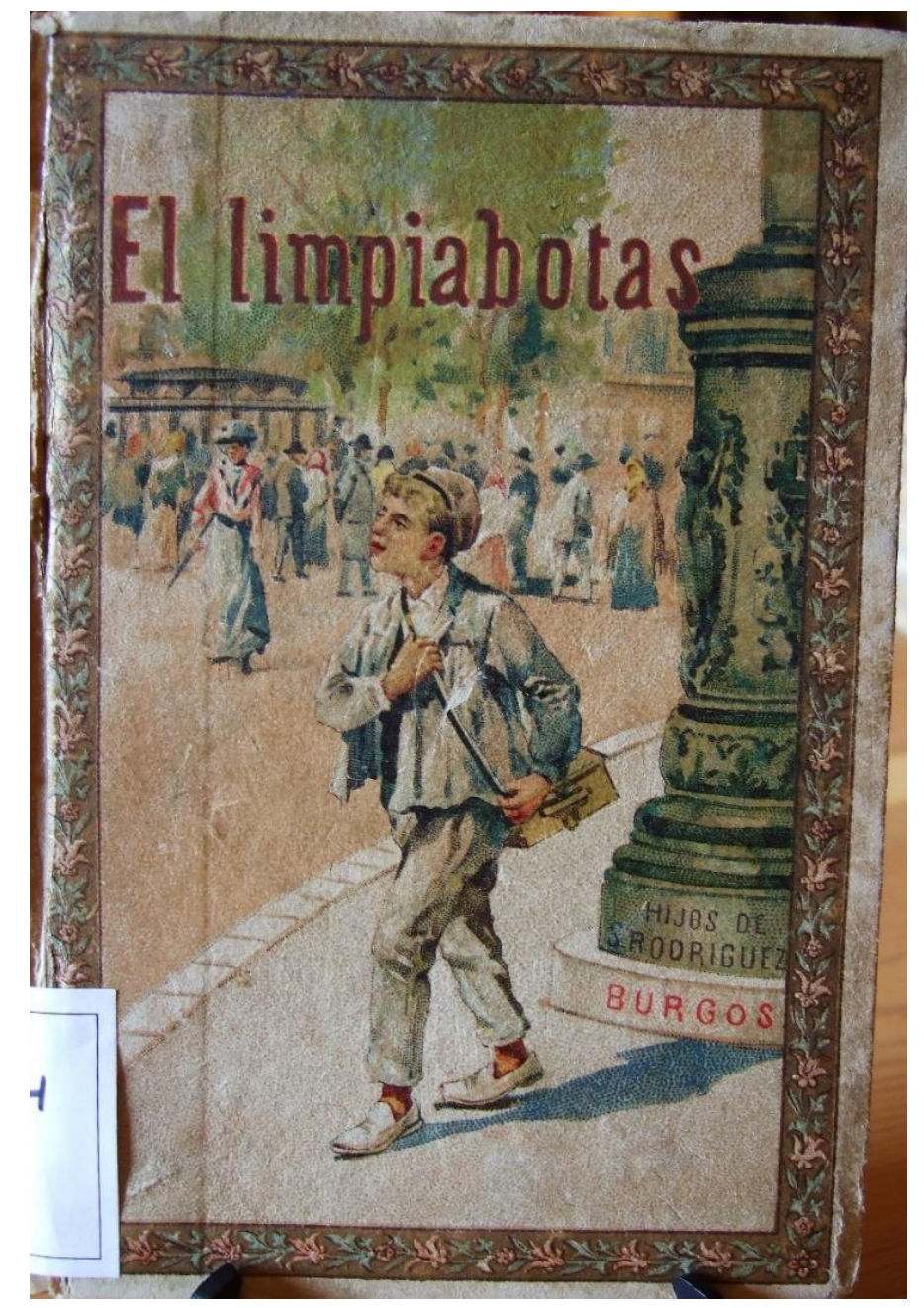

Fig. 6-12: Cubierta de El limpiabotas de la Biblioteca Museo de la Infancia. Hijos de Santiago Rodríguez. Ejemplar del CEINCE.

El libro Las mariposas (figura 6-13) está formado también por 4 cuentos pero sólo el que lleva el título pertenece a la Biblioteca Cuentos para Niños, escrito por María Carbonel Sánchez, con tres ilustraciones de Evaristo Barrio.

Los otros tres cuentos son: Pedrillo cuyo autor nos lo señala con las siglas A.G. [Alfredo Garzón], Los deseos sin nombrar su autor, Mariposa de Magdalena Santiago Fuentes y El cuento del abuelo de José Osés 
Larumbe. Todos tienen tres ilustraciones, en blanco y negro, de Evaristo Barrio.

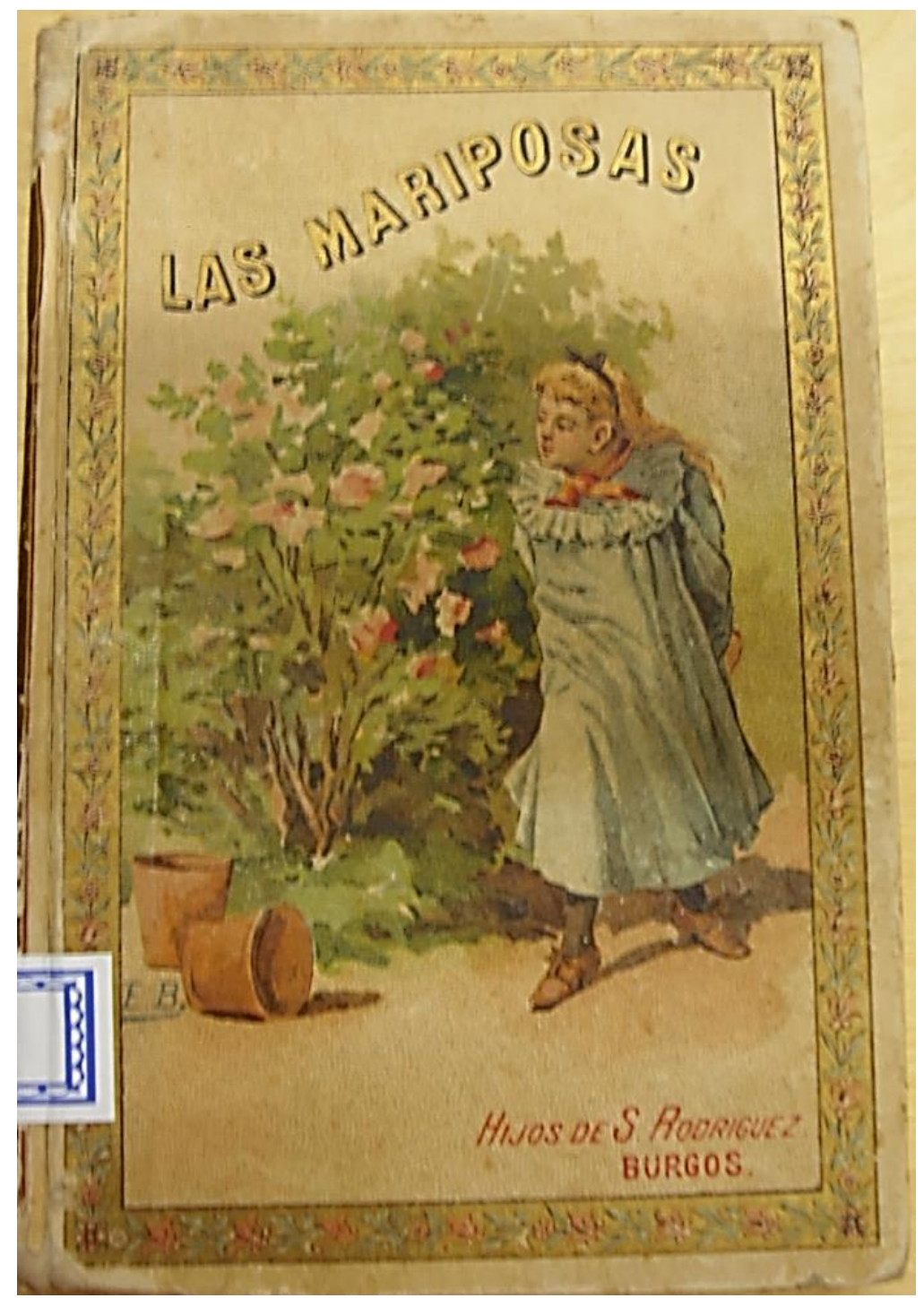

Fig. 6-13: Cubierta de Evaristo Barrio de Las mariposas. Biblioteca Museo de la Infancia. Hijos de Santiago Rodríguez. 1904.

Ejemplar de la Biblioteca de la Diputación Provincial de Burgos.

La tiranuela ${ }^{655}$ está formado por cuatro cuentos; todos ellos de la Biblioteca Cuentos para Niños. El primer cuento, del mismo título que nos presenta la cubierta es de Elpidia Rodríguez de Francés, y al igual que todos los demás, lleva tres ilustraciones de Evaristo Barrio. Los siguientes cuentos son El nido y la choza, de Diego Vidal, Felicidad en la buhardilla, de Ángel Bueno y La noche de Reyes, de Magdalena Santiago Fuentes.

${ }^{655}$ Vid. Anexo 3.1.39. 
CUADRO II: RELACIÓN DE LA BIBLIOTECA MUSEO DE LA INFANCIA CON LA BIBLIOTECA CUENTOS PARA NIÑOS Y LOS CATÁLOGOS DE LA EDITORIAL HIJOS DE SANTIAGO RODRÍGUEZ.

\begin{tabular}{|c|c|c|c|c|c|}
\hline $\begin{array}{l}\text { MUSEO DE LA } \\
\text { INFANCIA }\end{array}$ & $\begin{array}{l}\text { CUENTOS } \\
\text { PARA NIÑOS } \\
\text { (Número) }\end{array}$ & $\begin{array}{c}\text { CATÁLOGO } \\
1908 \\
\end{array}$ & $\begin{array}{c}\text { CATÁLOGO } \\
1917 \\
\end{array}$ & $\begin{array}{c}\text { CATÁLOGO } \\
1925 \\
\end{array}$ & $\begin{array}{c}\text { CATÁLOGO } \\
1929 \\
\end{array}$ \\
\hline Luisito & 47 & $\mathrm{X}$ & $\mathrm{X}$ & & \\
\hline El abandonado. & & $\mathrm{X}$ & $\mathrm{X}$ & $\mathrm{X}$ & $\mathrm{X}$ \\
\hline Antoñito. & & $\mathrm{X}$ & $\mathrm{x}$ & & \\
\hline $\begin{array}{l}\text { Los niños } \\
\text { caritativos. }\end{array}$ & 44 & $\mathrm{x}$ & $\mathrm{X}$ & $\mathrm{X}$ & $\mathrm{X}$ \\
\hline $\begin{array}{l}\text { La Vuelta de la } \\
\text { Guerra. }\end{array}$ & 42 & $\mathrm{X}$ & $\mathrm{X}$ & & $\mathrm{X}$ \\
\hline La Tiranuela. & 43 & $\mathrm{x}$ & $\mathrm{x}$ & & \\
\hline La bruja. & 48 & $\mathrm{x}$ & $\mathrm{X}$ & $\mathrm{X}$ & $\mathrm{X}$ \\
\hline Enriqueta. & 38 & $\mathrm{X}$ & $\mathrm{x}$ & & \\
\hline $\begin{array}{ll}\text { El } & \text { Héroe } \\
\text { infantil. } & \\
\end{array}$ & 4 & $\mathrm{x}$ & $\mathrm{X}$ & $\mathrm{X}$ & $\mathrm{X}$ \\
\hline Batalla campal. & 35 & $\mathrm{x}$ & $\mathrm{x}$ & & \\
\hline $\begin{array}{l}\text { El pequeño } \\
\text { aeronauta. }\end{array}$ & 32 & $\mathrm{X}$ & $\mathrm{X}$ & $\mathrm{X}$ & $\mathrm{X}$ \\
\hline El Limpiabotas. & 61 & $\mathrm{X}$ & $\mathrm{X}$ & & $\mathrm{x}$ \\
\hline Emilín. & 18 & $\mathrm{X}$ & $\mathrm{x}$ & & \\
\hline Tal para Cual. & 64 & $\mathrm{X}$ & $\mathrm{X}$ & & $\mathrm{X}$ \\
\hline $\begin{array}{ll}\begin{array}{l}\text { Socorrer } \\
\text { necesitado. }\end{array} & \text { al } \\
\end{array}$ & 46 & $\mathrm{x}$ & $\mathrm{X}$ & & \\
\hline $\begin{array}{l}\text { La tortilla de } \\
\text { magia. }\end{array}$ & 25 & $\mathrm{x}$ & $\mathrm{X}$ & & \\
\hline $\begin{array}{l}\text { Al Borde del } \\
\text { abismo. }\end{array}$ & & $\mathrm{X}$ & $\mathrm{X}$ & & $\mathrm{X}$ \\
\hline $\begin{array}{ll}\text { El } & \text { Cristo } \\
\text { yacente. } & \\
\end{array}$ & 19 & $\mathrm{X}$ & $\mathrm{X}$ & & \\
\hline Las mariposas. & 41 & $\mathrm{x}$ & $\mathrm{X}$ & & \\
\hline Lobito. & 54 & & & $\mathrm{X}$ & $\mathrm{X}$ \\
\hline $\begin{array}{l}\text { La caída de la } \\
\text { hoja. }\end{array}$ & 63 & & & $\mathrm{X}$ & $\mathrm{X}$ \\
\hline $\begin{array}{l}\text { La hija del } \\
\text { Desterrado }\end{array}$ & 16 & $\mathrm{x}$ & & & \\
\hline La caridad. & 55 & & & $\mathrm{X}$ & $\mathrm{X}$ \\
\hline
\end{tabular}

Fuente: Catálogos de la Editorial Hijos de Santiago Rodríguez. Años 1908, 1917, 1925,1929. Bibliotecas públicas y universitarias de España. CEINCE. Biblioteca Nacional de España. [Elaboración propia]. 


\subsubsection{Biblioteca Ideal}

Esta Biblioteca, aunque desconocemos la fecha de comienzo, la podemos situar con posterioridad a 1908 y se sabe que, en 1917, la colección estaba ya formada por ocho libros. Se mantuvo y se reeditó en numerosas ocasiones.

Gracias a la existencia de ejemplares en las diversas bibliotecas públicas se puede analizar de forma íntegra. Al igual que en otras colecciones, topamos con cuentos que ya estaban publicados en otras bibliotecas, dado que cada libro está formado por varios de ellos.

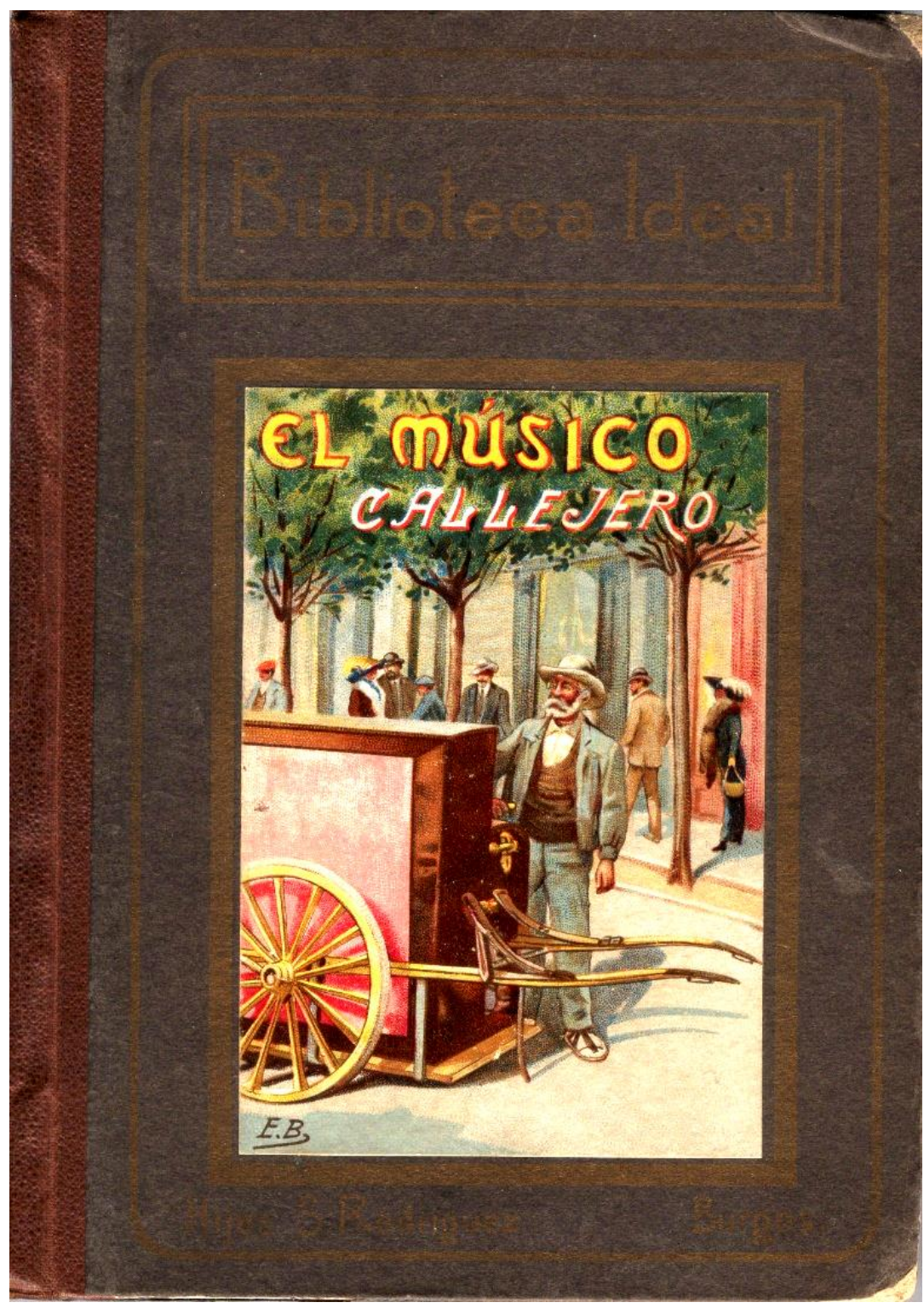

Fig. 6-14: Cubierta a color de Evaristo Barrio en El músico callejero. Biblioteca Ideal. Hijos de Santiago Rodríguez. 


\section{Estructura externa.}

Todos los libros tienen un tamaño de $22 \times 16 \mathrm{~cm}$. con unas 62 páginas y contienen 3 o cuatro cuentos. Están encuadernados en pasta dura, con lomo de tela. En la cubierta, lo más destacado se sitúa en el centro con una preciosa ilustración y título a color. En la parte superior figura el nombre de la Biblioteca Ideal y en la parte inferior, con letras doradas, el nombre de la editorial (Figura 6-14). En la contracubierta, en dorado, se registra el icono de la editorial. Están impresos sobre papel fuerte ahuesado, de buena calidad, en letra grande y muy clara que hace posible una lectura fácil para los niños.

Comprobamos la existencia de dos tipos de ediciones de esta colección que mantienen el mismo formato para la cubierta y contracubierta, pero con diferencias en las guardas y portadas. En las ediciones de los años 20, siguiendo cánones ilustrativos, añaden una greca geométrica en la portada y recargan las páginas con líneas de puntos.

Cada uno de los cuentos tiene dos o tres ilustraciones de Evaristo Barrio, a plana entera. Según las ediciones, aparece un único color distinto -rojo, azul, verde o negro-, relacionados directamente con la temática del cuento y con un pie tomado del texto. Los dibujos son los mismos y coinciden con cuentos de bibliotecas ya descritas.

Las ediciones más antiguas no tienen propaganda en las últimas páginas. En cambio, las ediciones posteriores a los años 20 publicitan las últimas nuevas colecciones. El precio oscila de, 1 pts. en 1917, a 1,75 pts. en 1925 y 1929.

\section{Estructura interna}

El contenido de los cuentos mantiene todos los elementos que hemos descrito para la Biblioteca Cuentos para Niños. Son cuentos de carácter moralizante, donde predominan personajes en papeles duales, de bondad y maldad, triunfando siempre el bien. Nos proponen los valores morales y religiosos de la época, destinados a todas las capas sociales, y están dirigidos a las escuelas, donde se perpetúa el orden moral imperante.

El primer libro, Cuentos y fábulas, de L. Méndez de Cuenca, Iriarte y Samaniego, narra en forma poética diversas historias y fábulas con moraleja, siguiendo la tradición fabulística. Todas las ilustraciones son de Evaristo Barrio, una por cada texto de los cuentos y fábulas del libro. Contiene un total de 22 dibujos, 20 de ellos al comienzo del texto y dos intercalados en el mismo. 
El segundo, El Cojito, ${ }^{656}$ está formado por un conjunto de cuatro cuentos: El Cojito, El pequeño aeronauta, Juan el atolondrado, y La codicia. De ellos, El pequeño aeronauta formaba parte de la Biblioteca Cuentos para Niños.

El tercero, El Músico callejero ${ }^{657}$ incluye otros cuatro cuentos más: $E l$ Músico callejero, Enriqueta, La bendición de náufragos, y Los niños caritativos, pertenecen a la Biblioteca Cuentos para Niños, excepto el que da origen al título.

La hija del desterrado ${ }^{658}$ está formado por el propio cuento del título, además de, Pedro el avaricioso, Un genio, y El espejo de María. Todos ellos provienen de Cuentos para Niños.

El fin de una huelga ${ }^{659}$ lo conforman tres cuentos: el que da nombre al título del tomo, Una consulta original y Haz el bien sin mirar a quien. Estos dos títulos también forman parte de Cuentos para Niños.

La serpiente ${ }^{660}$ incluye cuatro cuentos: La serpiente, La pesca, El amigo de los pájaros y Batalla campal. De todos ellos, tenemos constancia que el último figuraba en Cuentos para Niños y también en la Biblioteca Museo de la Infancia.

El niño en la tumba ${ }^{661}$ también está compuesto por cuatro cuentos: $E l$ niño en la tumba, Bajo Tiberio, La estrella del mar, y Amor filial, de los cuales el último procede de la Biblioteca Cuentos para Niños.

El último título, La Cuenta del doctor ${ }^{662}$ lo integra el cuento que le da nombre, El buen hermano, y Dar posada al peregrino, estando el segundo ya incluido en Cuentos para Niños.

${ }^{656}$ MÉNDEZ DE CUENCA, L., IRIARTE, SAMANIEGO. El cojito. Burgos: Hijos de Santiago Rodríguez.

${ }^{657}$ VV. AA. El músico callejero. Burgos: Hijos de Santiago Rodríguez. Vid. Anexo 3.1.31.

${ }^{658}$ VV. AA. La hija del desterrado. Burgos: Hijos de Santiago Rodríguez.

${ }^{659}$ VV. AA. El fin de una huelga. Burgos: Hijos de Santiago Rodríguez.

${ }^{660}$ VV. AA. La serpiente. Burgos: Hijos de Santiago Rodríguez.

${ }^{661}$ VV. AA. El niño en la tumba. Burgos: Hijos de Santiago Rodríguez.

${ }^{662}$ VV. AA. La cuenta del doctor. Burgos: Hijos de Santiago Rodríguez. 
CUADRO III: RELACIÓN DE LOS TÍTULOS DE LA BIBLIOTECA IDEAL CON LOS CATÁLOGOS HIJOS DE SANTIAGO RODRÍGUEZ.

\begin{tabular}{|l|l|l|l|}
\hline Títulos & $\begin{array}{c}\text { CATÁLOGO } \\
\mathbf{1 9 1 7}\end{array}$ & $\begin{array}{c}\text { CATÁLOGO } \\
\mathbf{1 9 2 5}\end{array}$ & $\begin{array}{c}\text { CATÁLOGO } \\
\mathbf{1 9 2 9}\end{array}$ \\
\hline Cuentos y fábulas & $\mathrm{x}$ & $\mathrm{x}$ & $\mathrm{x}$ \\
\hline El Cojito & $\mathrm{x}$ & $\mathrm{x}$ & $\mathrm{x}$ \\
\hline El Músico callejero & $\mathrm{x}$ & $\mathrm{x}$ & $\mathrm{x}$ \\
\hline La Hija del desterrado & $\mathrm{x}$ & $\mathrm{x}$ & $\mathrm{x}$ \\
\hline El Fin de una huelga & $\mathrm{x}$ & $\mathrm{x}$ & $\mathrm{x}$ \\
\hline La Serpiente & $\mathrm{x}$ & $\mathrm{x}$ & $\mathrm{x}$ \\
\hline El Niño en la tumba & $\mathrm{x}$ & & $\mathrm{x}$ \\
\hline La Cuenta del Doctor & $\mathrm{x}$ & & $\mathrm{x}$ \\
\hline
\end{tabular}

Fuente: Catálogos de la Editorial Hijos de Santiago Rodríguez. Años 1917, 1925, 1929. Bibliotecas públicas y universitarias de España. CEINCE. Biblioteca Nacional de España. [Elaboración propia]. ${ }^{663}$

CUADRO IV: RELACIÓN DE LOS CUENTOS PUBLICADOS EN LAS BIBLIOTECAS CUENTOS PARA NIÑOS, MUSEO DE LA INFANCIA Y BIBLIOTECA IDEAL.

\begin{tabular}{|l|l|l|}
\hline CUENTOS PARA NIÑOS & MUSEO DE LA INFANCIA & BIBLIOTECA IDEAL \\
\hline La madre pequeñita & & \\
\hline El cornetilla & & \\
\hline El abuelo y el nieto & $\mathrm{x}$ & \\
\hline Un héroe infantil & & \\
\hline La cuadratura del círculo & & \\
\hline El vendedor de periódicos & & \\
\hline Los tres amigos & & \\
\hline Mi primera comunión & & \\
\hline Morir por la patria & & \\
\hline El grumete & & \\
\hline La ambición & & \\
\hline La curiosidad castigada & & \\
\hline El castillo del águila negra & & \\
\hline Una venta original & & \\
\hline La noche de Reyes & $\mathrm{x}$ & \\
\hline La hija del desterrado & & \\
\hline El nido y la choza & & \\
\hline Emilín & & \\
\hline El Cristo yacente & & \\
\hline El premio & & \\
\hline
\end{tabular}

${ }^{663}$ Los libros de esta Biblioteca la podemos encontrar de manera íntegra en las distintas bibliotecas españolas. 
LA EDITORIAL BURGALESA HIJOS DE SANTIAGO RODRÍGUEZ (1891-1936):

ANÁLISIS DE LOS LIBROS ESCOLARES

\begin{tabular}{|c|c|c|}
\hline Un genio & & $\mathrm{X}$ \\
\hline Una venganza de las flores & & \\
\hline Pedro el avaricioso & & $\mathrm{X}$ \\
\hline Trafalgar & & \\
\hline La tortilla de magia & $\mathrm{x}$ & \\
\hline Presumir de hombre & & \\
\hline El imperio de las flores & & \\
\hline Leal & & \\
\hline Siempre que puedas haz el bien & & \\
\hline La suerte & & \\
\hline Los hijos del Sr. Martín & & \\
\hline El pequeño aeronauta & $\mathrm{x}$ & $\mathrm{x}$ \\
\hline El capricho de Susi & & \\
\hline El miedo & & \\
\hline La batalla campal & $\mathrm{x}$ & $\mathrm{X}$ \\
\hline La manta de lana & & \\
\hline La carta de recomendación & & \\
\hline Enriqueta & $\mathrm{x}$ & $\mathrm{X}$ \\
\hline Felicidad en la buhardilla & & \\
\hline La estrella de mar & & \\
\hline Las mariposas & $\mathrm{x}$ & \\
\hline La vuelta de la guerra & $\mathrm{x}$ & \\
\hline La tiranuela & $\mathrm{x}$ & \\
\hline Los niños caritativos & $\mathrm{x}$ & $\mathrm{X}$ \\
\hline Haz el bien sin mirar a quien & & $\mathrm{x}$ \\
\hline Socorrer al necesitado & $\mathrm{x}$ & \\
\hline Luisito & $\mathrm{x}$ & \\
\hline La bruja & $\mathrm{x}$ & \\
\hline Un día de vacaciones & & \\
\hline El pastorcillo & & \\
\hline La bendición de los náufragos & & $\mathrm{x}$ \\
\hline El buen hermano & & $\mathrm{x}$ \\
\hline Amor filial & & $\mathrm{X}$ \\
\hline Lobito & $\mathrm{x}$ & \\
\hline Caridad & $\mathrm{x}$ & \\
\hline La maldición del baturro & & \\
\hline La mejor fiesta & & \\
\hline El abrigo escocés & & \\
\hline La corteza & & \\
\hline
\end{tabular}


6. BIBLIOTECAS Y LIBROS ESCOLARES

\begin{tabular}{|l|l|l|}
\hline Un ángel & & \\
\hline El limpiabotas & $\mathrm{x}$ & \\
\hline El espejo de María & $x$ & \\
\hline La caída de la hoja & $x$ & \\
\hline Tal para cual & & \\
\hline La mentira de Lola & & \\
\hline El marquesita & & \\
\hline Hermoso modelo & & \\
\hline Un hijo del mar & & \\
\hline La reina mora & & \\
\hline A buen rey mejor vasallo & & \\
\hline Lo que puede la fe & & \\
\hline Historia del año & & \\
\hline Una consulta original & & \\
\hline La mano de Dios & & \\
\hline El perro ratonero & & \\
\hline
\end{tabular}

Fuente: Catálogos de la Editorial Hijos de Santiago Rodríguez. Años 1908, 1917, 1925,1929. Bibliotecas públicas y universitarias de España. CEINCE. Biblioteca Nacional de España. [Elaboración propia].

En la Biblioteca Ideal, constatamos la inclusión de cuentos que figuran en Catálogo como Cuentos para Niños, identificando 13 de los 75 títulos que componen esta Biblioteca.

No se puede saber con certeza todos los cuentos que ya tenían editados en la Biblioteca Museo de la Infancia, puesto que no se han encontrado los libros que formaron esta biblioteca, pero es suficiente para hacernos ver la utilización de los mismos cuentos en diversas bibliotecas (Cuadro IV). 


\subsubsection{Biblioteca Oro}

En el Catálogo de 1917 presenta esta Biblioteca con un conjunto de seis libros y dos en prensa. Cada tomo contiene cuentos, narraciones, novelitas y leyendas de autores como Andersen, Schmid, ${ }^{664}$ Tolstoi y un conjunto de escritores nacionales como Carmen Santiago Fuentes, ${ }^{665}$ Magdalena Santiago Fuentes, Encarnación Hidalgo Rey, José Osés Larumbe, ${ }^{666}$ Juan Benejam y Saura, Gracián Friviños y S. C. López. ${ }^{667}$

Se comprueba, con los libros encontrados, una estructuración diversa en su planteamiento. Mientras alguno está formado por un solo cuento, caso de Las aventuras de un huérfano o Maravillosas aventuras de un cascanueces y Cuatro niños maravillosos, el resto lo compone un conjunto diverso de cuentos, algunos de ellos, en menor número, publicados en anteriores Bibliotecas.

\section{Estructura externa}

Cada tomo tiene un tamaño de 20,5 x $13 \mathrm{~cm}$. con unas 130 páginas en papel superior. Está encuadernado en pasta dura y lomo en tela, con ilustraciones a todo color en las cubiertas y en blanco y negro en su interior. Los ilustradores son Isidro Gil ${ }^{668}$ y Evaristo Barrio ${ }^{669}$ y el proceso litográfico está realizado en Valencia, por S. Durá. La contracubierta aparece profusamente ilustrada (Figura 6-16).

\footnotetext{
${ }^{664}$ SCHMIDT, S. Cristina y su corderito. Burgos: Hijos de Santiago Rodríguez. Ver ilustración de la cubierta de Isidro Gil en Anexo 3.2.28.

665 SANTIAGO FUENTES, C. Casa de muñecas. Burgos: Hijos de Santiago Rodríguez. Esta autora es hermana de Magdalena Santiago Fuentes.

${ }^{666}$ OSÉS LARUMBE, J. El mejor tesoro. Burgos: Hijos de Santiago Rodríguez.

${ }^{667}$ LÓPEZ, S. C. Aventuras de un huérfano. Burgos: Hijos de Santiago Rodríguez.

${ }^{668}$ Podemos ver algunos ejemplos en: Anexos 3.2.15; 3.2.17; 3.2.18; 3.2.19; 3.2.20.

${ }^{669}$ Vid. Anexos 3.1.37; 3.1.38.
} 


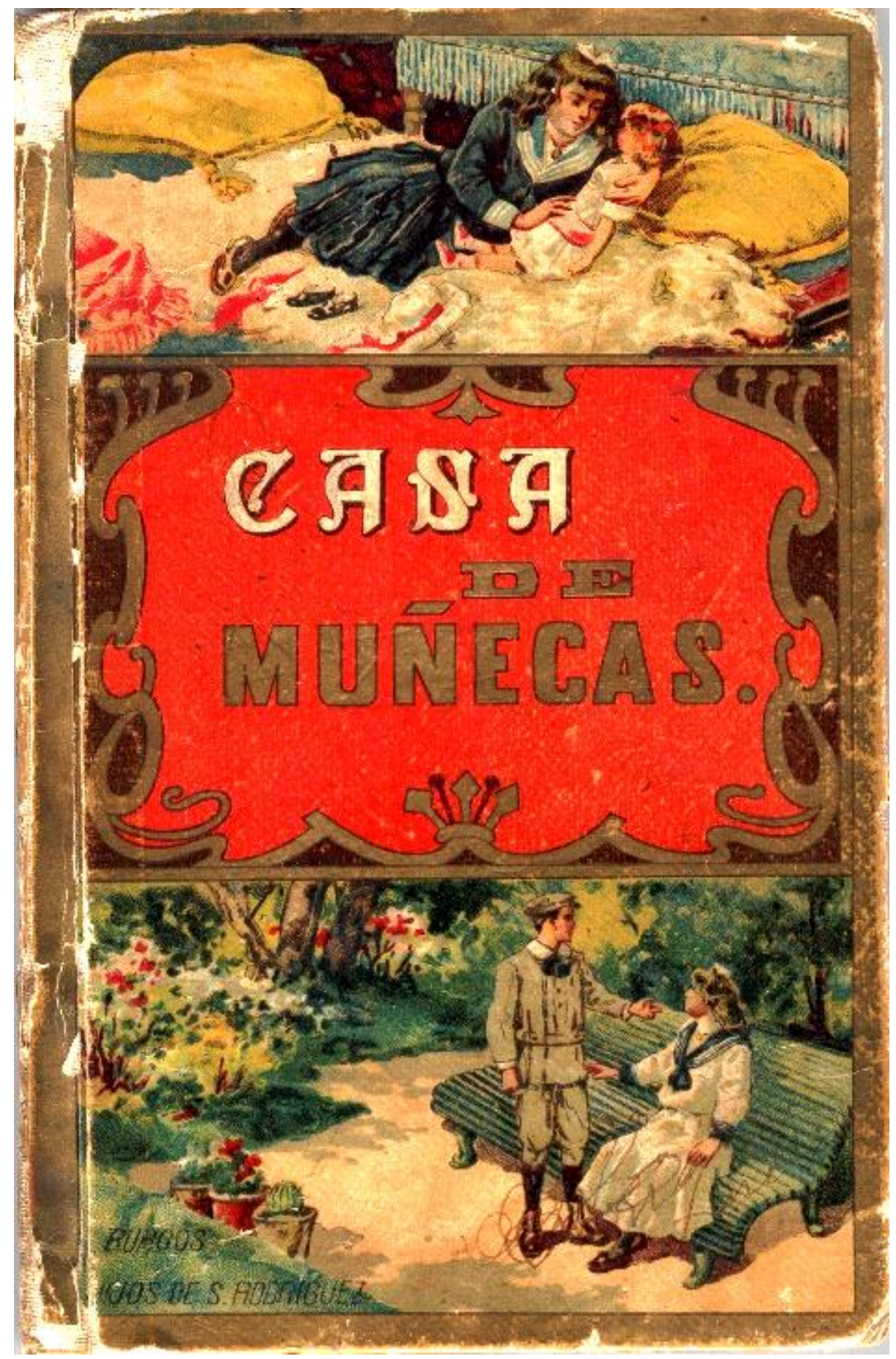

Fig. 6-15: Cubierta de la obra Casa de muñecas por Carmen de Santiago-Fuentes. Biblioteca Oro. Hijos de Santiago Rodríguez.

Las ilustraciones siguen, en la mayoría de los cuentos, el mismo patrón de distribución que en las colecciones aludidas: tres, en cada uno de los cuentos, realizadas por Evaristo Barrio e Isidro Gil. Generalmente, son de plana entera, en blanco y negro, relacionadas con el argumento del cuento. Incluyen, al pie de la ilustración, el texto de anclaje correspondiente. El precio es de 1,25 pts., en 1917, y de dos pts. a partir de 1925. 
LA EDITORIAL BURGALESA HIJOS DE SANTIAGO RODRÍGUEZ (1891-1936): ANÁLISIS DE LOS LIBROS ESCOLARES

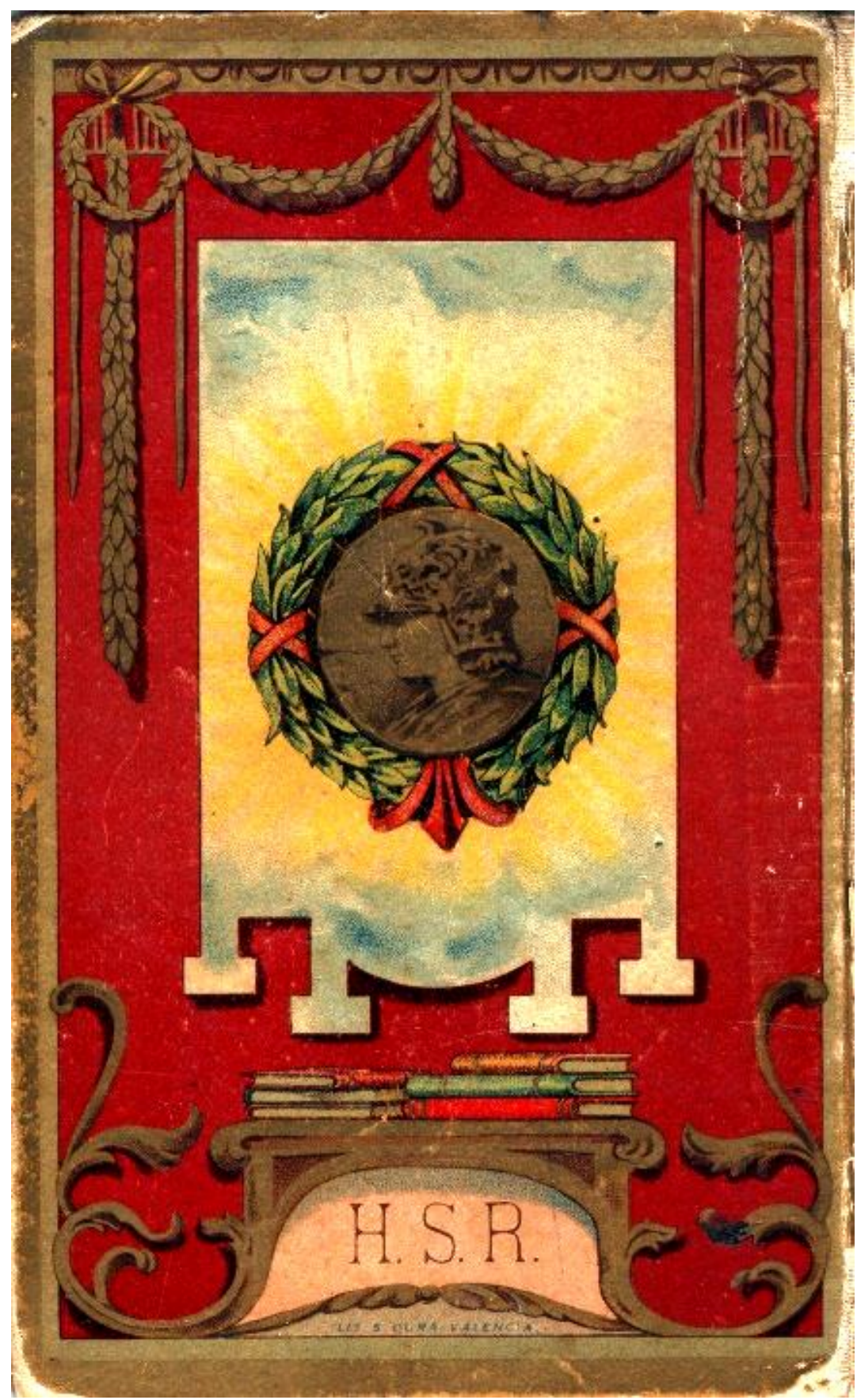

Fig. 6-16: Contraportada del libro Casa de muñecas de la Biblioteca Oro. Hijos de Santiago Rodríguez. Litografía de S. Durá. Valencia. 


\section{Estructura interna}

El contenido de los cuentos tiene un carácter moralizante, ensalzan los principios de la moral existente, inspirada en la realidad social, añadiendo consejos y cualidades de superación personal; al igual que otras colecciones como Cuentos para Niños, Museo de la Infancia y Biblioteca Ideal.

De los once tomos (Cuadro V), sólo cuatro de ellos están en distintas bibliotecas de España, y otros tres pertenecen a una colección particular. Del resto, otros cuatro, no tenemos constancia de ninguno: Cuentos cortos, Bazar de cuentos, Lo que puede la voluntad y Cuentos regionales.

A modo de ejemplo, explicaremos algunos tomos donde se aprecia este tipo de lectura moral.

Entre los autores extranjeros, Christoph von Schmid, conocido como el Canónigo Schmid, sacerdote inspector de las escuelas eclesiásticas en Alemania, escribe relatos preocupado por la escasez de lecturas para jóvenes, a principios del siglo XIX. En la escritura de su cuento, Cristina y su corderito, ${ }^{670}$ se pueden comprobar las raíces populares e históricas de leyendas. Los personajes pertenecen al regimiento prusiano de húsares, con una trama implícita de acción y acontecimientos militares contra Napoleón, aunque no lo narra expresamente. La metáfora, o la lección que se deduce, es que de las derrotas también sale lo mejor de las personas: generosidad, ayuda, valor. Las historias que va narrando, en distintos capítulos, desarrollan las dramáticas peripecias de dos familias, pobre y rica, y las consecuencias de las guerras, especialmente nefastas para las mujeres e hijos, pero con un final siempre tranquilizador. Vencen la bondad y la justicia que transmiten al lector el convencimiento de la fortaleza que da el fuerte sentimiento religioso.

Aventuras de un huérfano narra, en doce capítulos, las aventuras de un niño llamado Estéfano. La sinopsis del cuento desvela como sus tíos intentan matarlo, dejándolo sólo en una cueva impenetrable. Pero, gracias a la ayuda de numerosas personas, desde su salvador en la cueva y otras más, supo forjarse una posición, estudiar Bellas Artes y, finalmente, recuperar la granja, herencia de sus padres. Nuevamente, observamos el mismo esquema que en el libro anterior: bondad-maldad, con recompensa final por las buenas obras.

\footnotetext{
${ }^{670}$ El cuento Cristina y su corderito, título del libro, es el primer cuento, al que acompañan otros dos que llevan por títulos: La ambición y Enriqueta. Este último cuento forma parte de varias Bibliotecas: Cuentos para Niños y Museo de la Infancia.
} 
Eusebio Heras traduce para la editorial el cuento El cascanueces y el rey de los ratones, escrito por Ernst Hoffmann, con el título Maravillosas aventuras de un cascanueces. La historia empieza en la fiesta de Navidad, en casa de Stahlbaum, donde los niños Clara y Fritz reciben regalos. Clara recoge un gran cascanueces de madera, con forma de soldado, y su hermano el Rey de los Ratones. Antes de medianoche y después de acostarse, Clara comienza a soñar y todo cobra vida: los ratones con su rey pelean contra los soldados y el Cascanueces. Éste mata al rey ratón y se transforma en un hermoso príncipe que invita a los hermanos a un viaje por el Reino de las Nieves y el Reino de los Dulces, donde los recibe el Hada de Azúcar. Luego, todo se va esfumando y Clara se despierta alegre por su aventura y con su cascanueces de madera.

El cuento fue ilustrado por Fortunato Julián ${ }^{671}$ y publicado en torno a 1930, ya que le encontramos por primera vez en el Catálogo de 1929. Esto nos hace pensar -como veremos más adelante en otras bibliotecas cercanas a estos años- en otros géneros, sin tanto sesgo moralizante, más próximos al "nonense" o al mundo de la fantasía, el humor y la imaginación como un género adecuado para la infancia.

Este relato comparte el juego de lo fantástico o lo maravilloso, no tiene la tipificación del cuento clásico, y son seres inanimados los que toman vida al margen de toda normativa.

CUADRO V: RELACIÓN DE TÍTULOS DE LA BIBLIOTECA ORO EN LOS CATÁLOGOS DE LA EDITORIAL HIJOS DE SANTIAGO RODRÍGUEZ.

\begin{tabular}{|l|l|l|l|}
\hline TÍTULOS & $\begin{array}{c}\text { CATÁLOGO } \\
1917\end{array}$ & $\begin{array}{l}\text { CATÁLOGO } \\
1925\end{array}$ & $\begin{array}{c}\text { CATÁLOGO } \\
1929\end{array}$ \\
\hline ¿Quieres ser mi amigo? & $\mathrm{x}$ & $\mathrm{x}$ & $\mathrm{x}$ \\
\hline Cuentos cortos & $\mathrm{x}$ & $\mathrm{x}$ & $\mathrm{x}$ \\
\hline Bazar de cuentos & $\mathrm{x}$ & $\mathrm{x}$ & $\mathrm{x}$ \\
\hline Casa de muñecas & $\mathrm{x}$ & $\mathrm{x}$ & $\mathrm{x}$ \\
\hline Aventuras de un huérfano & $\mathrm{x}$ & $\mathrm{x}$ & $\mathrm{x}$ \\
\hline Lo que puede la voluntad & En prensa & & \\
\hline El mejor tesoro & $\mathrm{x}$ & $\mathrm{x}$ & $\mathrm{x}$ \\
\hline Cristina y su corderito & En prensa & $\mathrm{x}$ & $\mathrm{x}$ \\
\hline Maravillosas aventuras de un cascanueces & & & $\mathrm{x}$ \\
\hline Cuatro niños maravillosos & & & $\mathrm{x}$ \\
\hline Cuentos regionales & & & En prensa \\
\hline
\end{tabular}

Fuente: Catálogos de la Editorial Hijos de Santiago Rodríguez. Años 1917, 1925, 1929. Bibliotecas públicas y universitarias de España. CEINCE. Biblioteca Nacional de España. [Elaboración propia].

${ }^{671}$ Vid. Anexos 3.3.19; 3.3.20. 


\subsubsection{Biblioteca Selecta}

\section{Estructura externa.}

Todos los libros de esta biblioteca tienen un tamaño de $16 \times 10,5 \mathrm{~cm}$, con un número de páginas mínimo de 84 y máximo de 127, con papel de buena calidad. El tipo de letra, grande, y las ilustraciones ayudan a entender su lectura. Además, deja espacios de descanso, colocando algún dibujo geométrico.

Están encuadernados en pasta dura, con artística cubierta al cromo y oro, pero no nombra al ilustrador, en algunos ejemplares, y cuando lo hace son de Evaristo Barrio. ${ }^{672}$ Lo mismo ocurre con las ilustraciones del interior, excepto Moisés, pertenecientes a Pedro Antequera Azpiri.

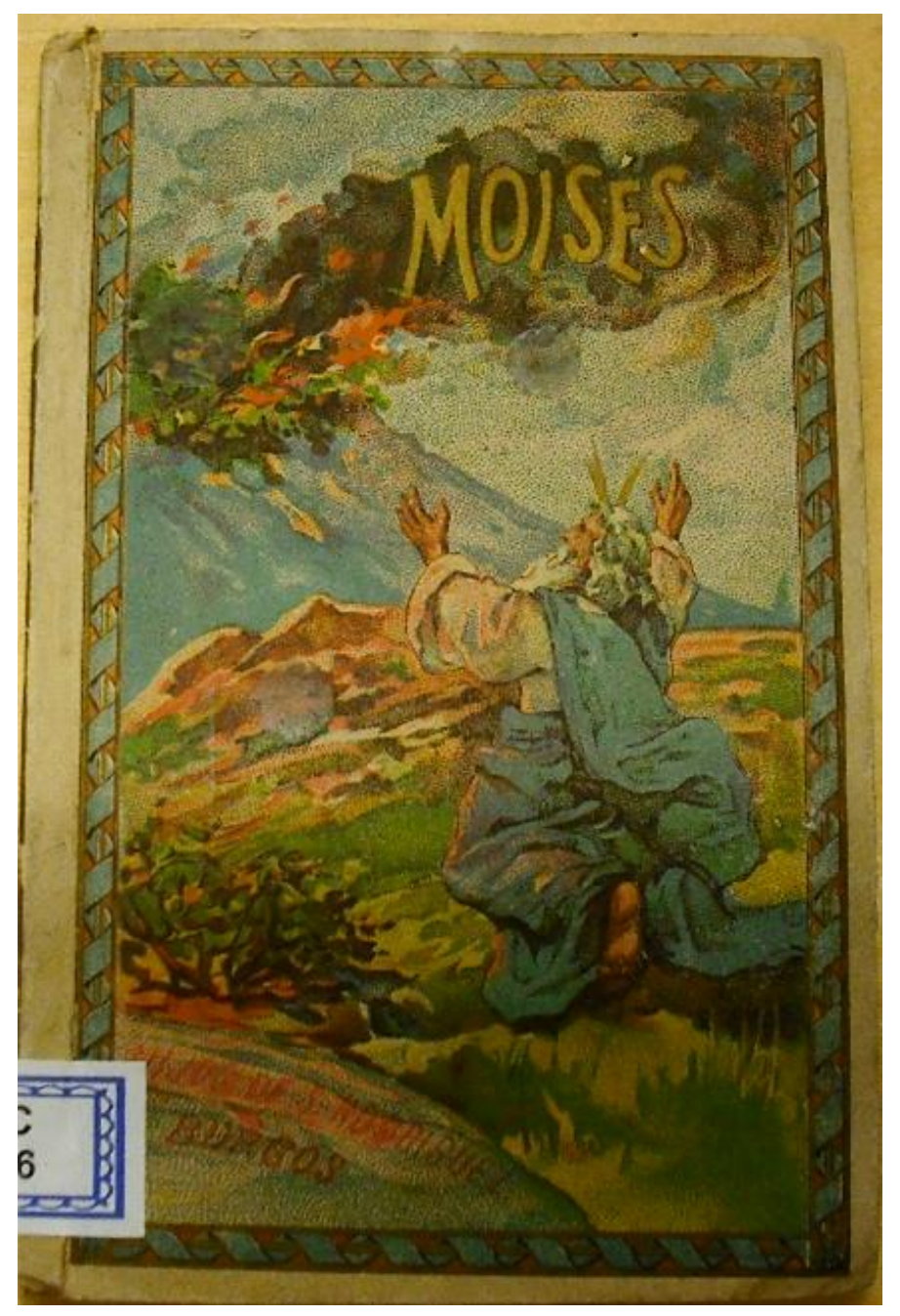

Fig. 6-17: Cubierta del libro Moisés de la Biblioteca Selecta.

Hijos de Santiago Rodríguez. Ejemplar de la Biblioteca de la Diputación Provincial de Burgos.

${ }^{672}$ Vid. Anexo 3.1.32. Cubierta del libro Dos primos célebres. 
Las ilustraciones interiores, relacionadas con el tema, están impresas en blanco y negro a plana entera, o bien están insertas en el texto, son grandes, generalmente, y contienen gran cantidad de detalles, lo cual despierta la imaginación de los niños.

El lomo de tela está recubierto con papel y lleva escrito el nombre de la Biblioteca Selecta, con bonitos grabados dorados. La contraportada está bellamente decorada con marco dorado. Incluye el emblema de la editorial, con la figura central de Minerva, rodeada con la corona de laurel. En la parte superior, está inscrita Moral Recreativa sobre una cinta azul; en la parte inferior, aparece una cartela sin nombre, aunque en otros libros sí titula la editorial H.S.R. [Hijos de Santiago Rodríguez] (Figura 6-18).

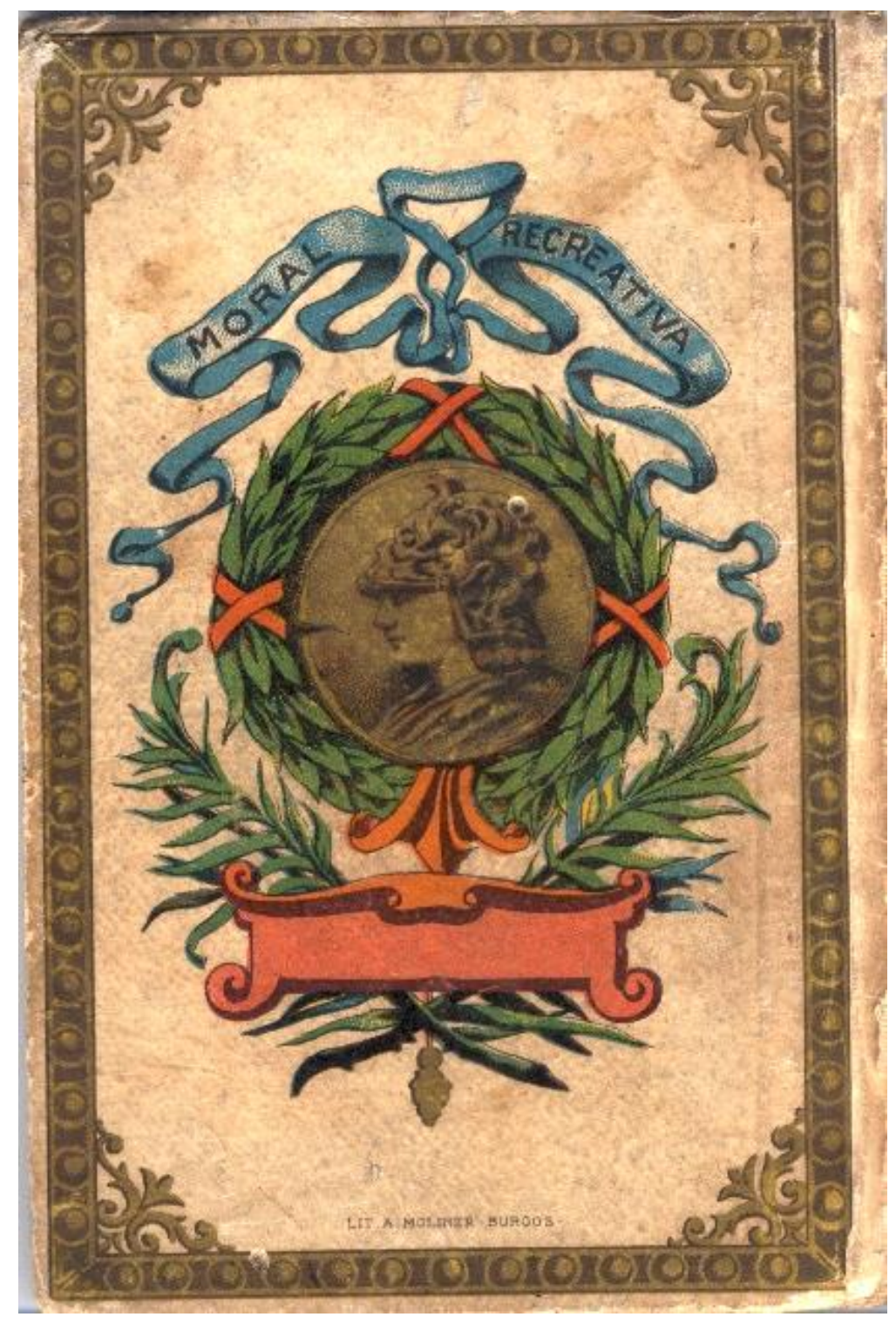

Fig. 6-18: Contracubierta de la Biblioteca Selecta. Litografía de A. Moliner. Burgos. 
Por otra parte, comprobamos que las casas litográficas donde realizan estos trabajos son, en unos casos, A. Moliner, de Burgos y, en otros, S. Durá, de Valencia.

En el Catálogo de 1908 nos describe esta biblioteca para premios que la formarán 60 tomos de un tamaño de $15,5 \times 10,5 \mathrm{~cm}$, impresa en papel de lujo con grabados y encuadernados en pasta fina con elegantes cubiertas al cromo y oro. ${ }^{673}$ En el resto de los Catálogos (1917, 1925 y 1929) no hace alusión al número de publicaciones; sólo en el Catálogo de 1917 describe los libros de Judith y Moisés como en prensa (Cuadro VI).

Los precios son baratos, viendo la calidad de las ilustraciones, tal como anuncia la editorial en numerosas ocasiones; desde 0,50 pts., en los Catálogos de 1908 y 1917, a 0,90 pts., en 1925, y 1 pts., en el de 1929.

\section{Estructura interna.}

Esta biblioteca fue diseñada especialmente para dar a conocer a los niños, con un lenguaje ameno e interesante, los principales acontecimientos de la Historia Sagrada, con personajes del Antiguo y Nuevo Testamento y figuras históricas de grandes gestas. En el Catálogo de 1908 se publicita la Biblioteca como regalo para los muchachos de las familias cristianas.

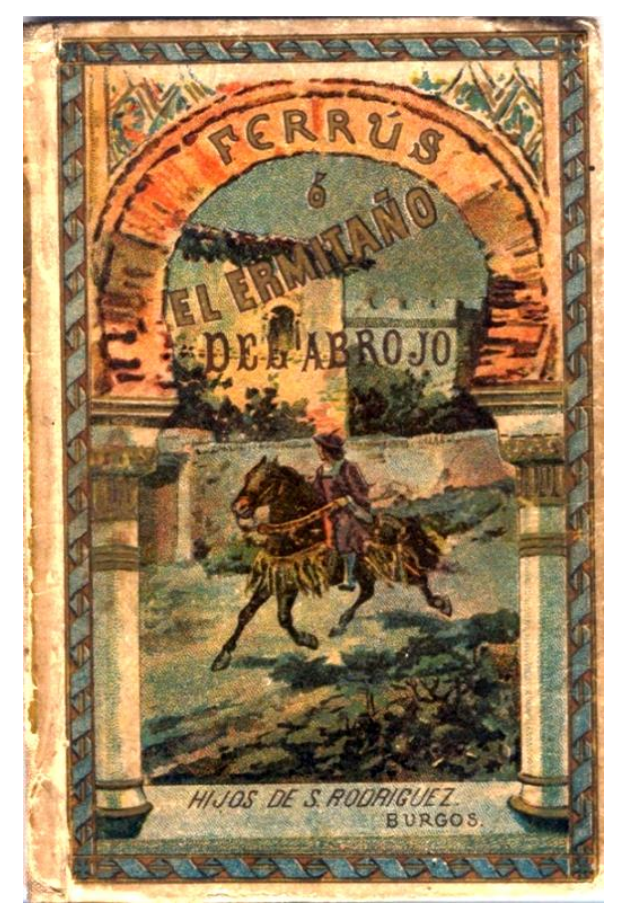

Fig. 6-19: Cubierta del libro Ferrús o el ermitaño del abrojo escrito por Mariana Álvarez Bollo Carretero. Biblioteca Selecta. Hijos de Santiago Rodríguez.

${ }^{673}$ CATÁLOGO 1908, pp. 89-90. 
En el caso del libro titulado Ferrús o El Ermitaño del Abrojo, cuenta hechos desarrollados durante el reinado de Alfonso V de León basados posiblemente, en la novela histórica escrita en 1857 por Manuel Torrijos. ${ }^{674}$ Narra cómo el rey Alfonso de León negociaba el casamiento de su hermana Teresa con el rey de Toledo, sin atender a que la Infanta era la amante de D. Gonzalo, noble castellano emparentado con Sancho Garcés, conde de Castilla. Cuenta los conflictos, de forma novelada, entre el reino de León, Castilla y Navarra, de la mano de Ferrús, amigo de D. Gonzalo.

De la misma temática histórica es el libro Dos primos célebres, donde nos habla de las figuras de D. Rodrigo, último soberano de la España visigoda, y D. Pelayo, primer rey de Asturias y sucesor del anterior. En el texto se entremezcla leyendas y mitos con datos históricos, ante la gran confusión sobre la genealogía de D. Pelayo.

La autora de ambos libros es Mariana Álvarez Bollo Carretero, maestra de una de las escuelas municipales de Burgos, que escribe bajo las siglas M. A. B. C. De esta misma colección, es autora de los libros Judith y La viuda de Naín o Verónica donde describe la vida de los personajes bíblicos de Judith y la viuda de Naín, respectivamente.

Ángel Bueno Rodríguez-Arias, escribe tres obras en esta Biblioteca. La primera, El Divino Infante, sobre la infancia de Jesús, desde su nacimiento hasta el anuncio hecho por Juan el Bautista. Nos explicita en una nota final del libro que, aunque inspirado en los Evangelios, hay detalles de fantasía, de tradiciones y de suposiciones personales fundadas en las costumbres judías. La segunda obra, titulada José o El Soñador Cananeo, cuenta la historia de José (personaje del Antiguo Testamento, hijo de Jacob, vendido por sus hermanos y que llegó a ser el ministro principal del faraón de Egipto). Sin embargo, en esta obra aclara que ha modificado algunos nombres, como el homónimo del país de Egipto y el de su soberano, así como algunos aspectos secundarios, pero sin cambiar la esencia bíblica. La tercera obra, Moisés, describe la biografía del personaje bíblico.

El autor vende a la editorial los derechos de estas obras por el precio de 25 pts. cada una. ${ }^{675}$

El cuento, Jesucristo haciendo el bien, escrito por M. R. M. [Mariano Rodríguez Miguel], cuenta hechos de la infancia, los milagros que hizo y las parábolas de las que habló Jesús.

\footnotetext{
674 TORRIJOS, M. La infanta Doña Teresa. Madrid: Imprenta de Ginés Hernández y Artés, 1857, p. 327. Ver ejemplar en la Biblioteca Digital Hispánica. Biblioteca Nacional de España.

${ }^{675}$ AHPBU. Sección Protocolos. Caja 11448, 14 de noviembre de 1907. Vid. Anexo 2.1.19.
} 


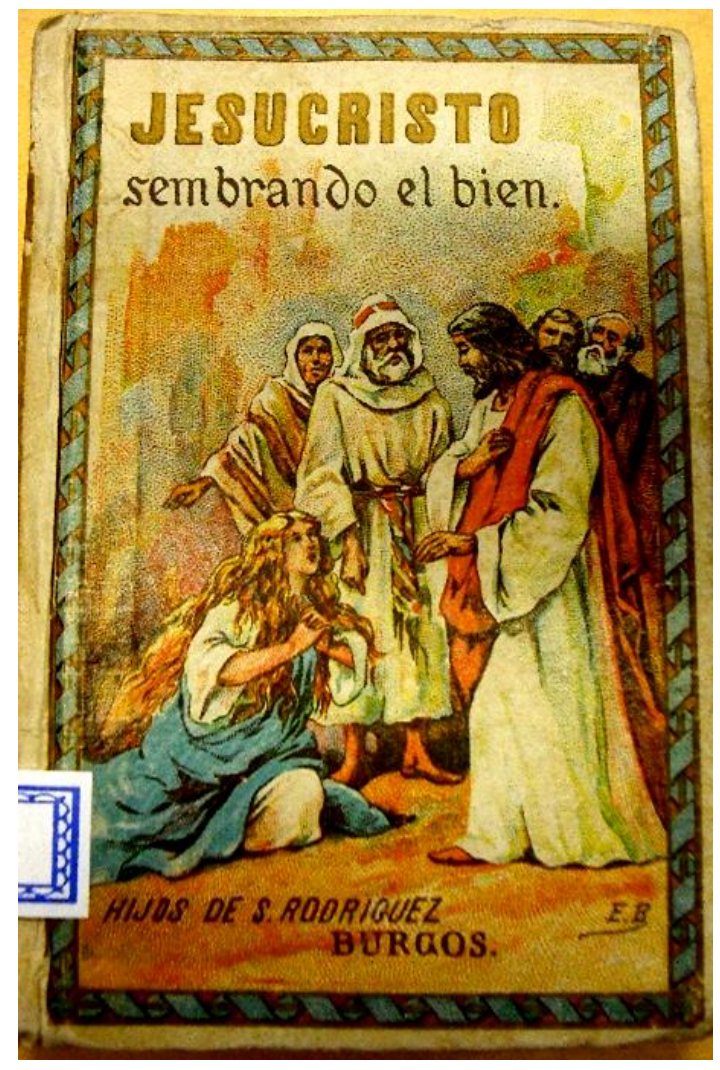

Fig. 6-20: Cubierta de Evaristo Barrio de la obra Jesucristo sembrando el bien escrita por Mariano Rodríguez Miguel. Biblioteca Selecta. Hijos de Santiago Rodríguez.

CUADRO VI: RELACIÓN DE LOS TÍTULOS DE LA BIBLIOTECA SELECTA EN LOS CATÁLOGOS DE LA EDITORIAL HIJOS DE SANTIAGO RODRÍGUEZ.

\begin{tabular}{|l|l|l|l|l|}
\hline Títulos & \multicolumn{1}{|c|}{$\begin{array}{c}\text { CATÁLOGO } \\
1908\end{array}$} & $\begin{array}{c}\text { CATÁLOGO } \\
1917\end{array}$ & \multicolumn{1}{c|}{$\begin{array}{c}\text { CATÁLOGO } \\
1925\end{array}$} & $\begin{array}{c}\text { CATÁLOGO } \\
1929\end{array}$ \\
\hline $\begin{array}{l}\text { Historia de José } \\
\text { José o El Soñador } \\
\text { Cananeo }\end{array}$ & $\mathrm{x}$ & \multicolumn{1}{|c|}{$\mathrm{x}$} & $\mathrm{x}$ & $\mathrm{x}$ \\
\hline $\begin{array}{l}\text { Jesucristo } \\
\text { haciendo/sembrando } \\
\text { el bien }\end{array}$ & $\mathrm{x}$ & $\mathrm{x}$ & $\mathrm{x}$ & $\mathrm{x}$ \\
\hline Dos primos célebres & $\mathrm{x}$ & $\mathrm{x}$ & $\mathrm{x}$ & $\mathrm{x}$ \\
\hline $\begin{array}{l}\text { El Divino Infante } \\
\text { Ferrús o El Ermitaño } \\
\text { del Abrojo }\end{array}$ & $\mathrm{x}$ & $\mathrm{x}$ & $\mathrm{x}$ & $\mathrm{x}$ \\
\hline $\begin{array}{l}\text { Viuda de Naín o } \\
\text { Verónica }\end{array}$ & $\mathrm{x}$ & $\mathrm{x}$ & $\mathrm{x}$ & \\
\hline $\begin{array}{l}\text { Judith: } \\
\text { bíblica }\end{array}$ & & $\mathrm{En}$ prensa & $\mathrm{x}$ & $\mathrm{x}$ \\
\hline Moisés & & En prensa & $\mathrm{x}$ & $\mathrm{x}$ \\
\hline
\end{tabular}

Fuente: Catálogos de la Editorial Hijos de Santiago Rodríguez. Años 1908, 1917, 1925, 1929. Bibliotecas públicas y universitarias de España. CEINCE. Biblioteca Nacional de España. [Elaboración propia] 


\subsubsection{Biblioteca Pro-Cultura}

Esta colección de cuentos, según se anuncia en los Catálogos, va dirigida a jóvenes que ya poseen los primeros conocimientos que proporciona la enseñanza elemental. ${ }^{676}$

En un artículo de prensa, Tierra Hidalga pone como ejemplo a la editora burgalesa Hijos de Santiago Rodríguez por la publicación de los dos primeros tomos de la Biblioteca Pro-Cultura para reflejar que las obras están a la altura de los libros extranjeros.

Hora es ya de que prestemos alguna atención a las publicaciones destinadas especialmente a los jóvenes lectorcillos, a los hombres de mañana.

Poco a poco, vemos irse anulando aquellas palabras de gran dramaturgo español: "En literatura destinada a los niños hemos sido por mucho tiempo importadores de libros extranjeros".

Hoy no; aunque con alguna lentitud, pues el mercado aprecia poco esta clase de libros, ya que en España todavía no se ha difundido todo lo que debiera la culta costumbre de regalar a los muchachos libros en lugar de otros objetos inútiles.

Llegan a nosotros dos tomos de la nueva y curiosa colección de libros que está editando la casa Hijos de Santiago Rodríguez de Burgos, para enriquecer y aumentar sus ya conocidísimas bibliotecas para regalo a la juventud.

En esta serie encontramos la amenidad en su texto, la parte instructiva que en esta clase de obras debe haber siempre y por último una presentación irreprochable, moderna, sugestiva y poco común hasta ahora en libros de esta indole. Justamente pueden competir con sus famosos similares extranjeros, teniendo la ventaja de estar escritos todos por conocidos autores nacionales. ${ }^{677}$

\section{Estructura externa}

El tamaño de cada tomo es de 23,5 x $16 \mathrm{~cm}$. con un número de páginas variable, entre 90 y 120 hojas. Está encuadernado en cartón duro, con lomo de tela. Las cubiertas son ilustraciones a color realizadas por Fortunato Julián y por Manero. En la contraportada figura el emblema de la editorial con su lema. (Figura 6-21). En su interior, tiene varias ilustraciones, entre 8 y 10, de Evaristo Barrio, Isidro Gil y Luis Manero. El precio de los tomos es de 1,75 pts., según Catálogo de 1917, y de 3 pts. en los siguientes Catálogos de 1925 y 1929.

${ }^{676}$ CATÁLOGO 1917, p. 94.

${ }^{677}$ Tierra Hidalga. Año VI, no 291, 4 de agosto de 1917, p. 2. 


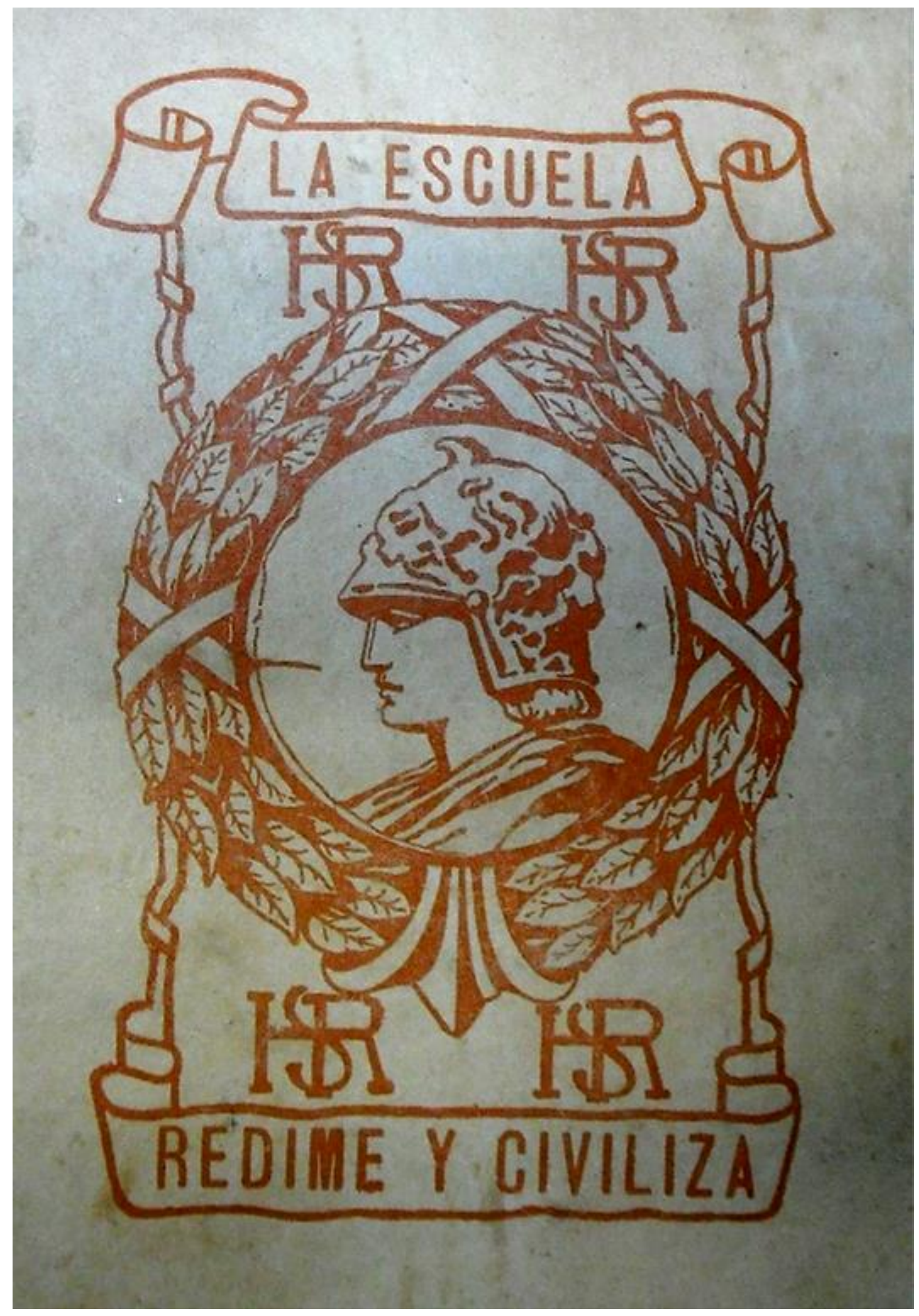

Fig. 6-21: Contracubierta de los libros de la Biblioteca Pro-Cultura. Lema de la editorial La escuela redime y civiliza. Hijos de Santiago Rodríguez. 


\section{Contenido de cada libro}

El Libro de Viajes, escrito por Ángel Menoyo Portalés, director del periódico burgalés Tierra Hidalga sale publicado en 1917. Narrado en primera persona, desde el prólogo, va contando a un sobrino la importancia del conocimiento a través de los viajes:

Los viajes por sí solos, claro está que no hacen a los hombres sabios como los estudios profundos en los libros; pero suplen a estos muchas veces y desde luego los completan. ${ }^{678}$

Presenta a los lectores los esfuerzos que realizaron muchos hombres para descubrir tierras lejanas como América, la conquista de los Polos, la vida de algunos exploradores importantes e incluye datos sobre capitales de América y Europa.

El Libro de la Naturaleza, ${ }^{679}$ escrito por Manuel Galán y Ángel Bueno, tiene dos partes diferenciadas: la primera, hace un elogio de la belleza natural, y la segunda pasa a enumerar los distintos seres vivos, no desde una perspectiva anatómica sino desde la necesidad de los mismos en el medio en el que viven.

El Libro de la Literatura, escrito por Martín Domínguez Berrueta, nos acerca a lo que para él son las principales obras maestras y quienes fueron sus autores. Recoge, como primeras obras maestras, el Evangelio de San Juan, La Ilíada, La Divina Comedia, de Dante, La vida de Santa Teresa, de Fray Luis de León, Don Quijote de la Mancha, de Cervantes y El Paraíso Perdido, de Milton. Todos estos relatos están salpicados con párrafos originales de los textos narrados $\mathrm{y}$, además, el autor hace alusiones constantes al lector, de una forma directa, para que reflexione sobre lo leído.

El Libro de Historia, con el subtítulo Lecturas instructivas de Historia Universal escrito igualmente por Martín Domínguez Berrueta, nos cuenta de forma amena, más literaria que didáctica, la historia de los griegos, de los romanos, del cristianismo, de los árabes, de las cruzadas, la historia de América y, por último, la historia de Lutero. De los demás libros sólo conocemos la información que nos detallan los Catálogos (Cuadro VII).

\footnotetext{
${ }^{678}$ MENOYO PORTALÉS, A. El Libro de Viajes. Burgos: Hijos de Santiago Rodríguez, Biblioteca ProCultura, 1917, p. 8. Vid. Anexo 3.2.16.

${ }^{679}$ La cubierta está ilustrada por Fortunato Julián. Vid. Anexo 3.3.13. 
El Libro de las Ciencias, obra de Octaviano Romeo, trata sobre los grandes inventos y los últimos descubrimientos de las ciencias.

El Libro de Arte, cuyo autor Pascual Rodríguez es hermano de Mariano Rodríguez, explica conocimientos elementales sobre pintura, escultura, arquitectura y vida de los grandes artistas.

El Libro del Progreso, de Ángel Bueno Rodríguez-Arias, contiene páginas instructivas de los grandes inventos.

No hay ninguna referencia de los tres últimos tomos que en el Catálogo de 1925 se anuncian en prensa. Otros libros que señala como publicados en el Catálogo de 1917 son: El Libro de Ciencias y El Libro de Arte; y en el Catálogo de 1925: El Libro del Progreso. Podemos tener dudas muy razonables de su publicación, ante el hecho de no aparecer en ninguna biblioteca y en los demás Catálogos aparezca como "en prensa".

Los mismos tomos de esta Biblioteca fueron editados como libros para lecturas escolares, desde 1917, bajo el título Nueva serie de textos escolares, con referencias en el Catálogo de 1925.

CUADRO VII: RELACIÓN DE LOS TÍTULOS DE LA BIBLIOTECA PROCULTURA EN LOS CATÁLOGOS DE LA EDITORIAL HIJOS DE SANTIAGO RODRÍGUEZ.

\begin{tabular}{|l|l|l|l|}
\hline Títulos & $\begin{array}{c}\text { CATÁLOGO } \\
1917\end{array}$ & $\begin{array}{l}\text { CATÁLOGO } \\
1925\end{array}$ & $\begin{array}{c}\text { CATÁLOGO } \\
1929\end{array}$ \\
\hline El Libro de Viajes. & $\mathrm{x}$ & $\mathrm{x}$ & $\mathrm{x}$ \\
\hline El Libro de Literatura & $\mathrm{x}$ & $\mathrm{x}$ & $\mathrm{x}$ \\
\hline El Libro de la Naturaleza & $\mathrm{x}$ & $\mathrm{x}$ & $\mathrm{x}$ \\
\hline El Libro de Historia & En prensa & $\mathrm{x}$ & $\mathrm{x}$ \\
\hline El Libro de Ciencias & $\mathrm{x}$ & En prensa & \\
\hline El Libro de las Costumbres & En prensa & & \\
\hline El Libro de Arte & $\mathrm{x}$ & En prensa & En prensa \\
\hline El Libro del Progreso & En prensa & $\mathrm{x}$ & En prensa \\
\hline El Libro de los Mares & & & En prensa \\
\hline El Libro del Cielo & & & En prensa \\
\hline El Libro de la Electricidad & & & En prensa \\
\hline
\end{tabular}

Fuente: Catálogos de la Editorial Hijos de Santiago Rodríguez. Años 1917, 1925, 1929. Bibliotecas públicas y universitarias de España. CEINCE. Biblioteca Nacional de España. [Elaboración propia]. 


\subsubsection{Mundial Biblioteca}

Es una colección destinada a jóvenes pero, por su lectura amena e instructiva, es accesible a toda clase de personas. Cada tomo está formado por novelas, leyendas y cuentos escogidos, sobre historia, costumbres, etc.

\section{Estructura externa.}

El tamaño de cada tomo responde a las medidas de $17,5 \times 14,5 \mathrm{~cm}$., con una extensión variable entre 115 y 150 páginas. Están encuadernados en tela inglesa e impreso el título, autor, ilustrador y biblioteca con letras en oro. En la parte superior de la cubierta, pegada a la misma, aparece una ilustración a todo color, relacionada con el primer cuento de la obra. Las ilustraciones de las cubiertas están realizadas por Evaristo Barrio, excepto La Hija del Usurero ${ }^{680}$ y Tradiciones y leyendas de Toledo ${ }^{681}$ que se deben a Isidro Gil. En la contracubierta aparece, en forma de sello estampado, el emblema de la editorial. (Figura 6-22).
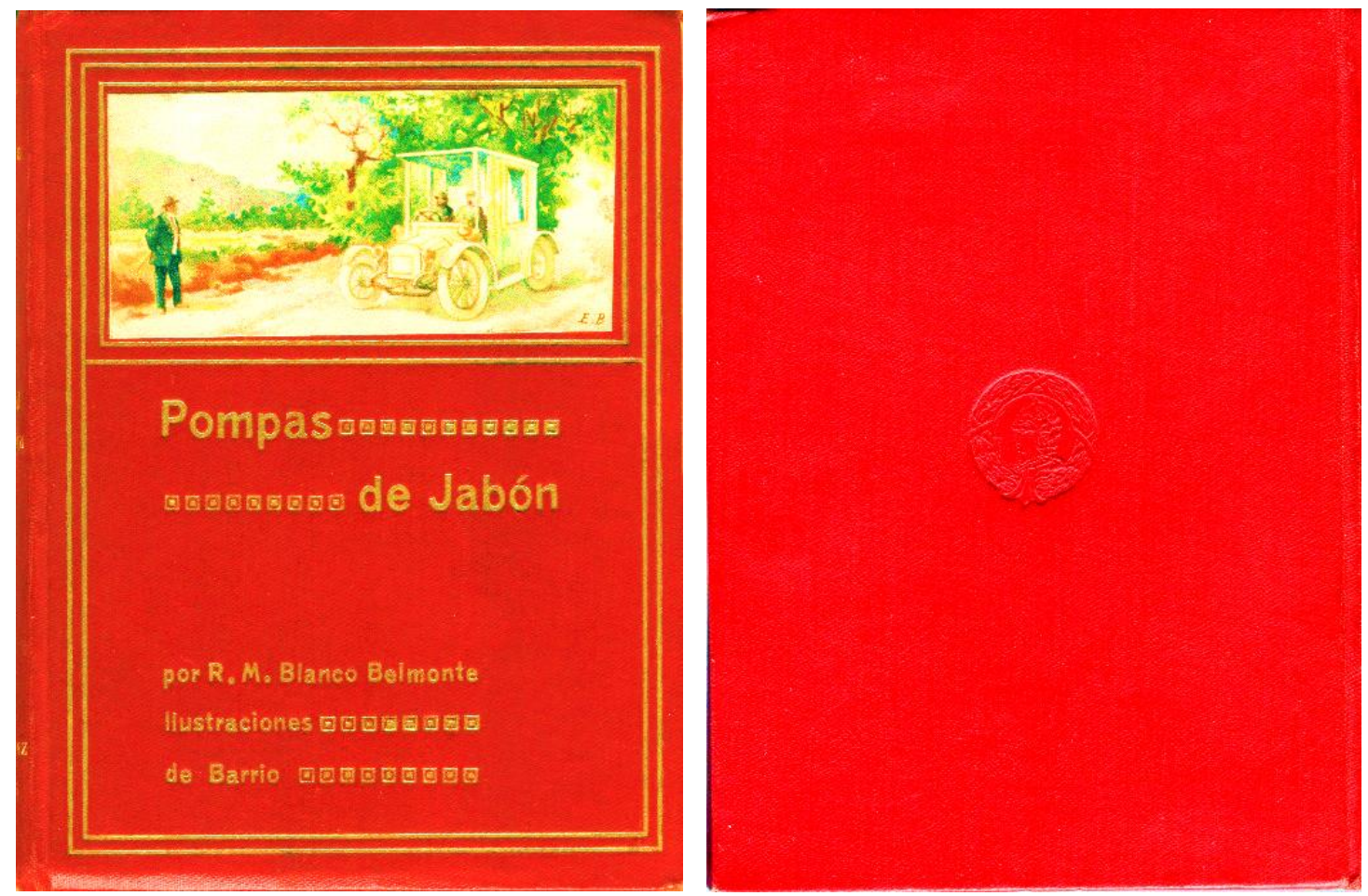

Fig. 6-22: Pompas de jabón de Rafael Marcos Blanco Belmonte.

Cubierta y contracubierta. Acuarela ilustrada de Evaristo Barrio.

Hijos de Santiago Rodríguez.

\footnotetext{
${ }^{680}$ MAESTRO, E. La Hija del Usurero. Burgos: Hijos de Santiago Rodríguez, Biblioteca Mundial, 1914. Esta obra fue premiada por la "Biblioteca Patria". Las ilustraciones interiores son 9 láminas a plana entera de Isidro Gil.

${ }^{681}$ MAYO, M. Tradiciones y leyendas de Toledo. Burgos: Hijos de Santiago Rodríguez, Biblioteca Mundial, 1926.
} 
La mayoría de las ilustraciones interiores son de Evaristo Barrio, entre 10 y 12, intercaladas en el texto, a plana entera, e impresas en tinta de doble tono sobre papel cuché, para permitir una mejor definición y un rango cromático más amplio. La hija del usurero tiene nueve láminas interiores de Isidro Gil, y en el último tomo, Tradiciones y leyendas de Toledo, las ilustraciones interiores son de Pedro Antequera Azpiri.

Es una colección que salió al mercado en 1913 y que tuvo diversas reimpresiones; de ahí que nos encontremos varios colores en las telas de los libros. El precio de estos libros es de 2 pts., en 1917, y de 3,50 en los años siguientes, tal como nos consta en los Catálogos de 1925 y 1929.

\section{Contenido de los libros}

Historias de Don Quijote e Historias de la Historia, primero y sexto libro de la biblioteca, fueron escritos por Martín Domínguez Berrueta ${ }^{62}$ (Figuras 6-23, 6-24). En la primera obra relata las principales aventuras del ingenioso hidalgo con la pretensión de ayudar a niños y adultos a saborear la lectura de la gran obra maestra cervantina y no tenerla en hermosas vitrinas, como indica el texto extraído del prólogo:

Poner en buen camino, a niños y a grandes, para la lectura saboreada de las obras maestras de nuestra literatura, parece que es un santo propósito que puede justificar estas historias de Don Quijote. ${ }^{683}$

\footnotetext{
${ }^{682}$ Véase: JABATO DEHESA, M. J. D. Martín Domínguez Berrueta: Vida y obra de un profesor universitario. Contribuciones ético-sociales, pedagógicas y literarias. Tesis doctoral inédita. Universidad de Burgos, 2013.

${ }^{683}$ DOMÍNGUEZ BERRUETA, M. Historias de Don Quijote. Burgos: Hijos de Santiago Rodríguez, Biblioteca Mundial, 1913, pp. 6-7.
} 


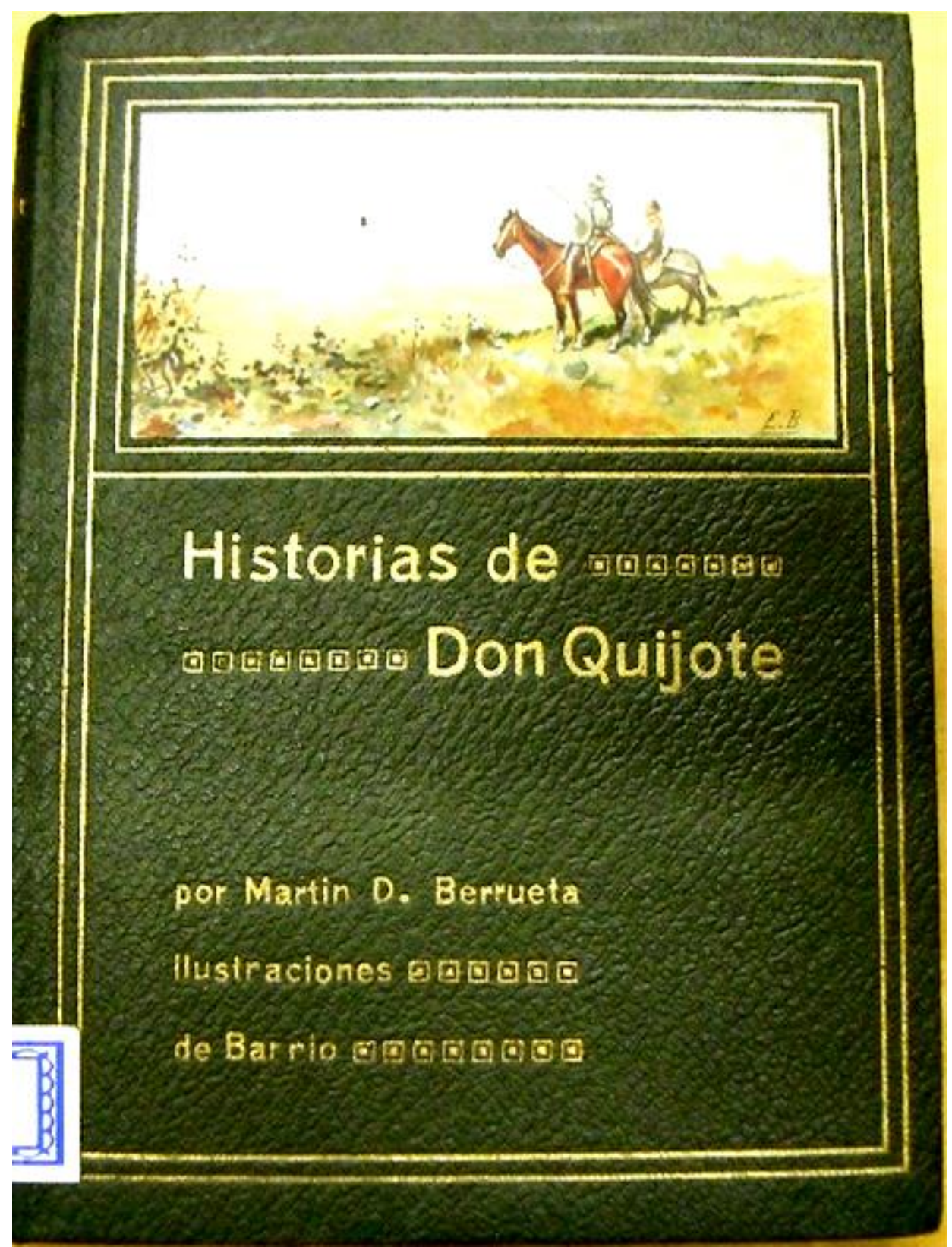

Fig. 6-23: Historias de Don Quijote de Martín Domínguez Berrueta. Acuarela ilustrada de Evaristo Barrio. Hijos de Santiago Rodríguez.

La segunda obra Historias de la Historia versa sobre 7 narraciones de hechos históricos donde su deseo, expresado en el prólogo, fue realizarlas sobre mujeres geniales que encarnan nuestra raza. ${ }^{684}$ Los protagonistas y títulos fueron los siguientes: De la muerte del Rey Don Sancho, El laurel de la Reina, Doña María la Brava, Los siete Infantes, Doña Juana La Loca, La hazaña del Ave María y El príncipe Culebra. Contiene una ilustración en cada historia, de Evaristo Barrio.

684 DOMínguEZ BERRUETA, M. Historias de la Historia. Burgos: Hijos de Santiago Rodríguez, Biblioteca Mundial, p. 6. 


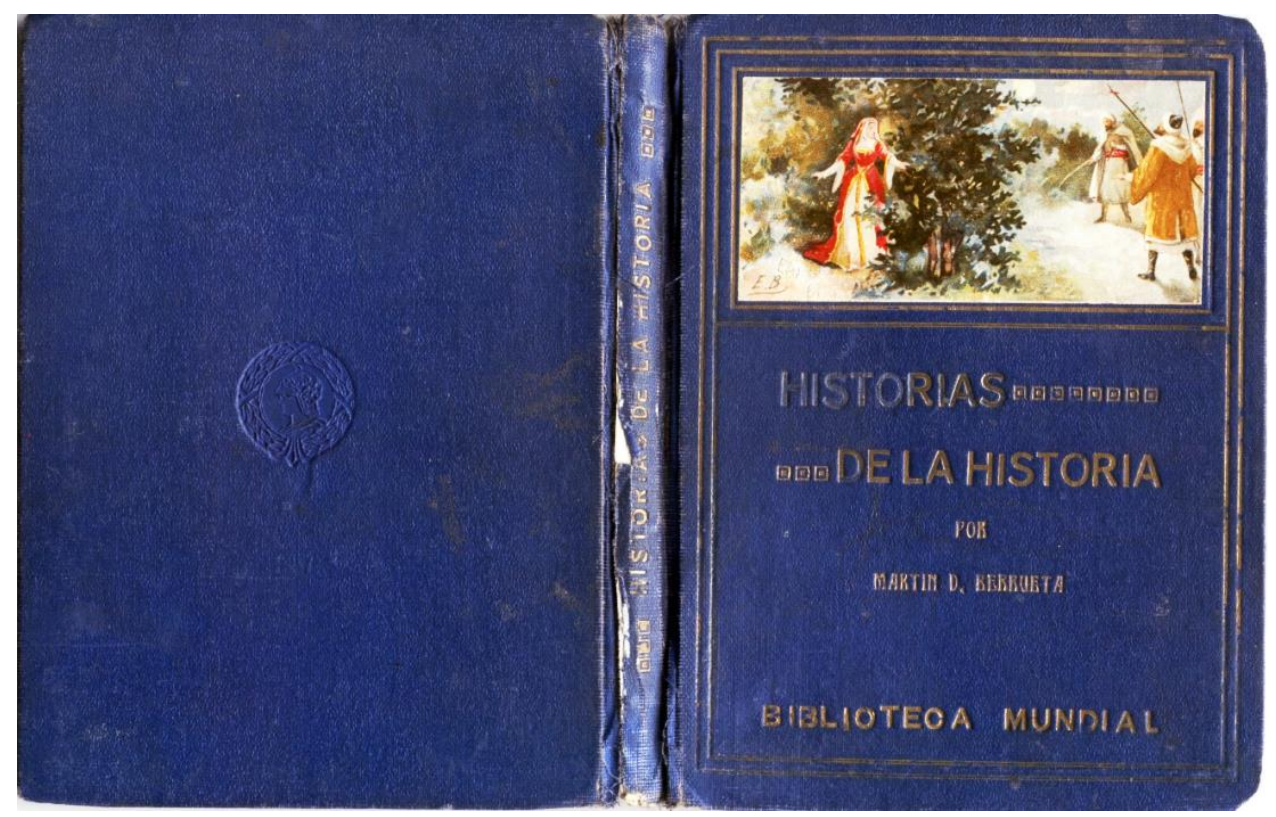

Fig. 6-24: Acuarela ilustrada de Evaristo Barrio de la obra Historias de la Historia escrito por Martín Domínguez Berrueta. Hijos de Santiago Rodríguez.

Pompas de jabón, es una colección de 20 cuentos, escritos por Marcos Rafael Blanco-Belmonte, destacado poeta joven, colaborador en $L a$ Ilustración Española y Americana, y en otros periódicos de España y América. Escribe los diversos capítulos en forma de crónicas periodísticas entre las que sobresalen: "Fuego fatuo", "Retratos femeninos", "Crepúsculo del beso" y "Cenicienta". ${ }^{685}$

Historias de Zorrilla, es una obra escrita por Marciano Zurita. Utiliza la prosa para narrar las leyendas más conocidas del gran literato José Zorrilla. Entre ellas están: Para verdades el tiempo; A buen juez, mejor testigo; Recuerdos de Valladolid; Justicias del rey D. Pedro; Los borceguies de Enrique II; El Capitán Montoya; Una aventura de 1360; Margarita la tornea; Príncipe Rey; El caballero de la buena memoria y El desafio del diablo.

Cuando sale a la venta, esta obra se publicita en la sección de "Bibliografía" de los periódicos burgaleses ensalzando al autor, al ilustrador y a la propia editorial.

La difícil empresa del Sr. Zurita, de poner en prosa las leyendas que el inmortal Zorrilla nos legó en hermosísimas estrofas, ha sido llevada a cabo con notable acierto, presentándonos en admirable lenguaje la narración de la fábula que las dio vida. El Sr. Barrio, con el arte que todos los burgaleses conocemos, ha ilustrado el libro del señor Zurita y la casa editorial ha dado una muestra más de

${ }^{685}$ La Voz de Castilla. Año IV, no 269, 30 de noviembre de 1913, p. 2. Ver ilustraciones interiores en Anexo 3.1.36. 
los elementos con que cuenta para esta clase de trabajo, presentando un libro modelo de estampación y buen gusto.

Más de una vez hemos tributado a la casa editorial Hijos de Santiago Rodríguez los elogios que se merece y que hoy reproducimos con motivo de la nueva obra. ${ }^{686}$

La hija del usurero, obra de Estanislao Maestre, se editó en la Biblioteca Patria, en Madrid. Hijos de Santiago Rodríguez la imprime, en 1914.

Historias de Gil Blas cuenta interesantísimos relatos y aventuras, entresacadas de la famosa obra de Le Sage, en la que Ángel Menoyo Portalés describe magistralmente las costumbres españolas del tiempo de Felipe IV, con un relato donde triunfa la bondad innata del protagonista. Está escrita de forma sencilla, para una lectura amena de los más pequeños.

Aunque no escribiésemos más, por lo dicho puede comprender al lector que hemos hecho del autor de "Historias de Gil Blas" el mayor elogio, pues solo un escritor de claro criterio, de no vulgar cultura, puede llenar con éxito arduo cometido de extraer de una obra del tono el carácter de "Gil Blas de Santillana" la esencia de ella, sin desfigurar la acción que en sus páginas se desarrolla, y envolviéndola en una forma amena, sencilla, bella por su diafanidad y precisión, hacer que llegue al ánimo de los pequeños, distrayéndoles y enseñándoles, y solazar el espíritu de los grandes en las horas de ocio, cuando en la lectura de un libro buscamos, como en la conversación de un amable e ingenioso amigo, reposo y alivio a nuestros afanes y trabajos. ${ }^{67}$

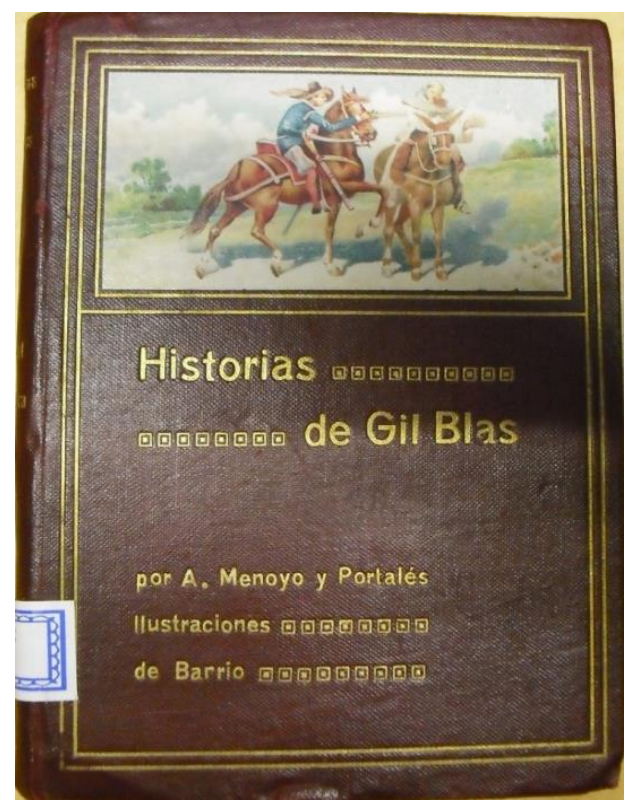

Fig. 6-25: Cubierta del libro Historias de Gil Blas escrito por Ángel Menoyo Portalés. Hijos de Santiago Rodríguez. Ejemplar de la Biblioteca de la Diputación Provincial de Burgos.

${ }^{686}$ El Papa-Moscas. Año XXXVII, no 1.949, 18 de octubre de 1914, p. 3.

${ }^{687}$ La Voz de Castilla. Año VI, no 374, 31 de octubre de 1915, p. 2. 
En el tomo Tradiciones y leyendas de Toledo, Margarita Mayo nos narra ocho leyendas de la ciudad que forman parte de la literatura fantástica y caballeresca de la época medieval. Sus títulos son los siguientes: $E l$ palacio encantado, La cueva de Hércules, El Cristo de la luz, El Pozo amargo, Noche toledana, Galiana, La peña del rey moro y Allá van leyes doquier en reyes.

Se publicita otra obra de Augusto Riera, Cuentos de Cuentos, que en el libro Pompas de jabón la da a conocer como "Tomo en prensa", pero no aparece en ningún Catálogo que lo corrobore.

Del resto de las obras que aparecen en el Cuadro VIII como en prensa no encontramos registros ni ejemplares, lo cual nos hace dudar de su salida.

CUADRO VIII: RELACIÓN DE TÍTULOS DE LA MUNDIAL BIBLIOTECA EN LOS CATÁLOGOS DE LA EDITORIAL HIJOS DE SANTIAGO RODRÍGUEZ.

\begin{tabular}{|l|l|l|l|}
\hline Títulos & $\begin{array}{c}\text { CATÁLOGO } \\
1917\end{array}$ & $\begin{array}{l}\text { CATÁLOGO } \\
1925\end{array}$ & $\begin{array}{c}\text { CATÁLOGO } \\
1929\end{array}$ \\
\hline Historias de Don Quijote & $\mathrm{x}$ & $\mathrm{x}$ & $\mathrm{x}$ \\
\hline Pompas de Jabón & $\mathrm{x}$ & $\mathrm{x}$ & $\mathrm{x}$ \\
\hline Historias de Zorrilla & $\mathrm{x}$ & $\mathrm{x}$ & $\mathrm{x}$ \\
\hline La Hija del Usurero & $\mathrm{x}$ & $\mathrm{x}$ & $\mathrm{x}$ \\
\hline Historias de Gil Blas & $\mathrm{x}$ & $\mathrm{x}$ & $\mathrm{x}$ \\
\hline Historias de la Historia & En prensa & $\mathrm{x}$ & $\mathrm{x}$ \\
\hline Aires de Cuentos & En prensa & & \\
\hline Tradiciones y leyendas de Toledo & & & $\mathrm{x}$ \\
\hline Historias del Romancero & & & En prensa \\
\hline Historias del Duque de Rivas & & & En prensa \\
\hline Historias de Lope de Vega & & & En prensa \\
\hline
\end{tabular}

Fuente: Catálogos de la Editorial Hijos de Santiago Rodríguez. Años 1917, 1925, 1929. Bibliotecas públicas y universitarias de España. CEINCE. Biblioteca Nacional de España. [Elaboración propia]. 


\subsubsection{Biblioteca Enciclopédica Hispano- Americana}

En la propaganda del Catálogo de 1908 nos habla de un conjunto de 25 tomos que formará la colección, orientados a los jóvenes de ambos lados del océano. En esta Biblioteca se quiere incorporar información relativa a los últimos adelantos de la ciencia, los datos más minuciosos de la historia, novelas morales, cuentos, leyendas y cuadros de costumbres.
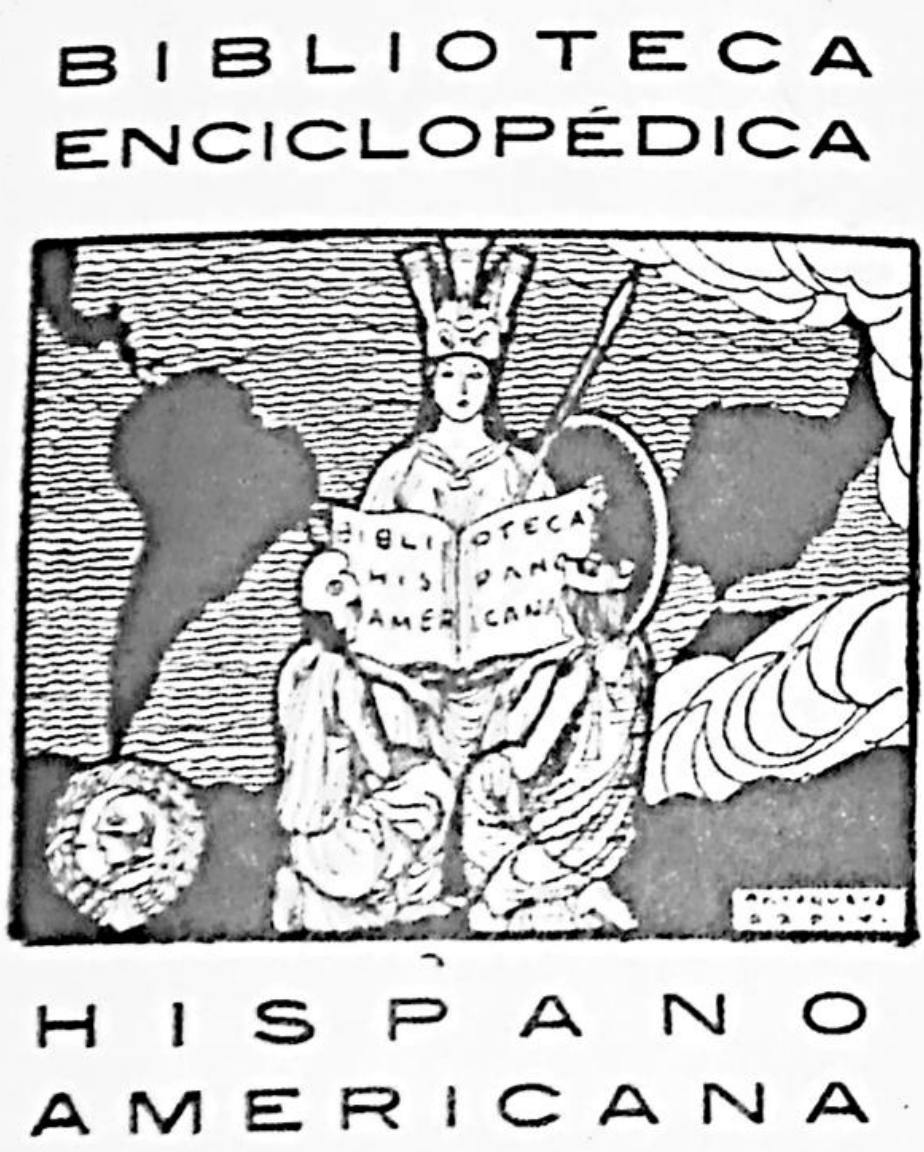

Fig. 6-26: Logotipo de Pedro Antequera Azpiri para la Biblioteca Enciclopédica Hispano-Americana. Hijos de Santiago Rodríguez. 


\section{Estructura externa}

El tamaño de los libros de la colección es de 22 x $14 \mathrm{~cm}$, con un número de páginas variable, de 200 a 250. Están impresos en buen papel y encuadernados de varias formas; las más sencillas en pasta dura, con cubiertas y contracubiertas muy ilustradas; otras, más lujosas en tela, con cantos dorados; y una última, llamada especial, con lomo y puntas de tela, papel japonés y canto rojo. ${ }^{688}$

El precio de cada libro, que reza en el Catálogo de 1908, es de dos pts., en los siguientes, de 1925 y 1929, 3,75 pts., con la encuadernación de pasta, el especial 5 pts, y en tela 8 pts.

\section{Contenido}

De los 11 tomos que formaron la Biblioteca, seis son obras escritas por Ángel Bueno Rodríguez-Arias. Adapta obras conocidas de la literatura como Vida y aventuras de Robinsón Crusoe, de Daniel de Foé, Aventuras de Telémaco, ${ }^{689}$ de Fenelón. Recopila relatos de otros autores como Cuentos escogidos, Cuentos Mexicanos y Viejas Memorias: Leyendas y Tradiciones. ${ }^{690}$ De esta última obra y la novela Rafael $^{691}$ vende la propiedad intelectual a la editorial por 40 pts. cada una. ${ }^{692}$

A modo de ejemplo, el quinto volumen publicado en enero de 1910, titulado Cuentos Escogidos está compuesto de varios cuentos coleccionados y traducidos por Ángel Bueno, con más de 28 ilustraciones de Isidro Gil, dos o tres en cada narración, intercaladas en el texto de más de 200 páginas. La prensa burgalesa lo recibe con alusiones muy positivas.

En ellos se desarrollan asuntos de patriotismo, historia, cultura moral, caridad y amor a los semejantes, y sus autores pueden decirse que forman la plana mayor de los cuentistas europeos. Entre ellos figuran Alphonse Dandet, Dickens, Edgard Poe, Gantier, Scott, Pérez Nieva ...todos literatos de universal fama.

Es muy a propósito para libro de lectura en las clases primarias, constituyendo además un bonito presente, como premio para los niños. ${ }^{693}$

Los cuentos y sus autores son los siguientes: La última clase. Relato de un pequeño alsaciano, de Alphonse Daudet; El corazón del mercader, de

\footnotetext{
${ }^{688}$ CATÁLOGO 1925. Op. cit., p. 77.

${ }^{689}$ Ver ilustración de la cubierta de Evaristo Barrio en: Anexo 3.1.40.

${ }^{690}$ Ver ilustraciones de la cubierta e interiores de esta obra en: Anexos 3.2.25; 3.2.26; 3.2.27.

${ }^{691}$ Ver ilustración de la cubierta de Evaristo Barrio en: Anexo 3.1.41.

${ }^{692}$ AHPBU. Sección de protocolos, caja 11448, 14 de noviembre de 1907. Vid. Anexo 2.1.19.

${ }^{693}$ La Voz de Castilla. Año I, no 6, 7 de enero de 1910, p. 1.
} 
Charles Dickens; El esfinge, de Edgard A. Poe; El niño de los zapatos de pan, de Théophile Gautier; El cazador, de Walter Scott; Las figuras del nacimiento, de Alfonso Pérez Nieva; La princesa y el granuja, cuyo autor escribe bajo las siglas B.P.G.; El pequeño vigía lombardo de Edmundo de Amicis; Pariente Moral, de E. B.; y El corneta de los húsares azules, de Erckmann y Chatrian.

Alma y Corazón y Los Grandes inventos son dos obras realizadas por Mariano Rodríguez Miguel. Curiosamente, ya estaban publicadas con el mismo contenido bajo otros títulos como Lecciones del padre y Viaje Infantil, respectivamente, y se presentan como libros para la escuela.

En la introducción, Mariano Rodríguez, autor de Alma y Corazón, comienza la narración en forma dialogada entre un padre y sus hijos, llamados igual que los suyos propios, Pascualín y Tomasita, con un aparente carácter autobiográfico. Comenta que deben aficionarse a leer libros de viajes, de héroes y ejemplos de virtudes, prometiéndoles que les leerá, todos los domingos, un capítulo antes de la cena.

Al final de cada uno de los trece relatos entabla un diálogo con sus hijos y acepta preguntas para reforzar algunos valores. La intervención del niño, Pascualín, toma la palabra cuando son valores como la bandera, la patria, la honra, el trabajo, el heroísmo, el respeto; y la de la niña, Tomasita, cuando tratan sobre soberbia, envidia, vanidad, caridad y gratitud; y en otros temas, como el amor filial o la amistad, participan ambos por igual, asignando un rol al niño y otra a la niña, dentro de los parámetros sociales de la sociedad en la que viven.

A lo largo de los cuentos presenta personajes, lugares o instituciones burgalesas como Santiago, Mariano, Lucas -los siguientes hijos nacidos hasta la fecha de su edición-, tía Elisa, calles como San Juan y Santander, la Isla, sobre el regimiento La Lealtad, y los Gigantones.

Fechado el 22 de diciembre de 1905, está encuadernado en pasta dura e ilustrado con un dibujo central en la cubierta sobre uno de los cuentos de Evaristo Barrio, el resto en rojo y dorado (Figura 6-27). 


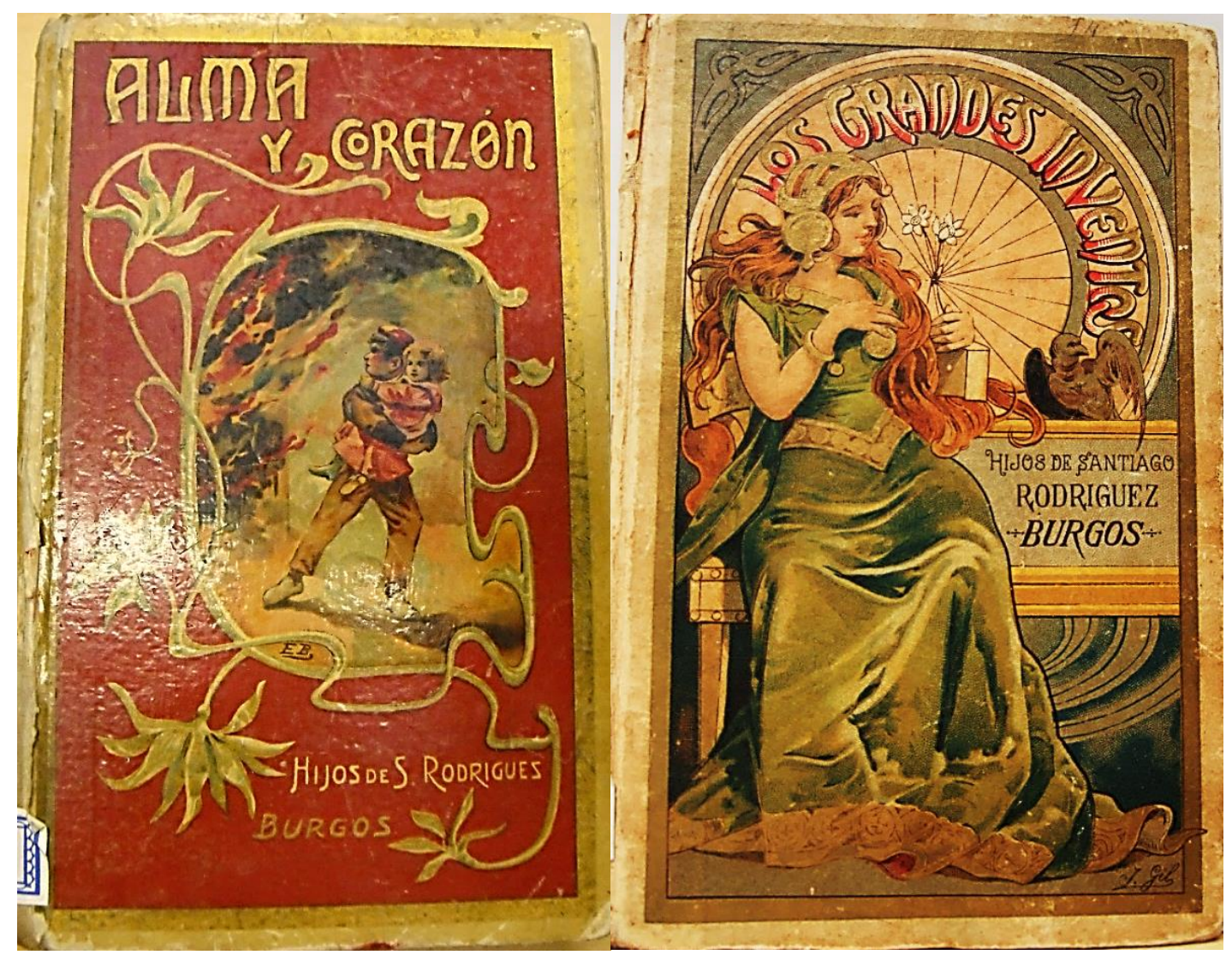

Fig. 6-27: Cubiertas ilustradas de Los grandes inventos y Alma y corazón de la Biblioteca Enciclopédica Hispano-Americana. Hijos de Santiago Rodríguez.

En la obra Los grandes inventos, el autor sitúa la narración inicial del cuento en un pueblo no citado, el último día de escuela, cuando el cura, el alcalde, el maestro y dos concejales entregaban los premios a los niños destacados durante el curso escolar. Un niño -Santiaguito- feliz por su condecoración, recibe de su familia, como premio a su aplicación y buenas notas, ir con su padre a Barcelona. Durante el viaje, éste le va explicando cada uno de los medios de locomoción y cómo funcionan.

Cuando llega a Barcelona comienza a narrar los grandes inventos de la época: telégrafo, teléfono, globo, fonógrafo, imprenta y litografía, fotografía, luz eléctrica, cinematógrafo, pararrayos, microscopio y telescopio, sobre navegación, rayos $\mathrm{X}$, el cristal y el barro. En el último capítulo, Santiaguito, ingeniero y director de un centro industrial, va al pueblo para llevarse consigo a sus padres; allí, se reencuentra con D. Severiano, su maestro y, ante la situación de desamparo económica, le regala la casa con la huerta de sus padres.

Es un libro ilustrado por Evaristo Barrio, Isidro Gil y Pedrero. 
Magdalena Santiago-Fuentes escribe para esta Biblioteca La novela de la infancia,${ }^{694}$ en los primeros años veinte. Se encuentra un ejemplar en la Biblioteca Pública de Burgos firmada, en abril de 1923, por la editorial " $A$ los efectos de la Ley de Propiedad intelectual”. Y en el Catálogo de 1925, se publicita como el décimo de los libros de la Biblioteca, de un total de once tomos.

La novela narra el paso de la infancia, bulliciosa y alegre, a la edad adulta de la mano de la familia numerosa Moncada. La acción se sitúa en la casa número 7 , de la calle Real, donde conviven en hermandad diversos personajes de todas las clases sociales. Los juegos e iniciativas de los niños forman el argumentario del acontecer familiar. Aun siendo una novela moralista, donde triunfan los valores familiares y sociales de la época, se puede ver cómo la autora insiste en resaltar juegos de creación propia, de estímulos interesantes y gratos recuerdos, con la intervención de todos los niños/as.

Los personajes infantiles que nos presenta van abriendo un camino más abierto para las mujeres; frente a la niña que con 17 años espera su presentación en sociedad para casarse, nos muestra a otra niña que estudia para Maestra Normal y consigue ser independiente.

La autora escribe diferentes novelas infantiles para importantes editoriales españolas: El tesoro de Abigail, narración de Tierra Santa, en Friburgo de Brisgovia, Alemania; Emprendamos nueva vida, en Henrich y Cía; Cuentos orientales, en Antonio J. Bastinos; Cuentos del sábado, en Benziger y Cía, Suiza; Aves de paso, en Talleres y tipografía de L. Pérez, Huesca; Visión de vida, en Abadía y Capapé, Zaragoza; y Vida del colegio, en Sucesores de Hernando, obra conjunta con su hermana Carmen. ${ }^{695}$

¿Quo Vadis? forma parte de esta Biblioteca, escrita por Sienkiewicz y adaptada por Margarita de Mayo. Es la última obra de esta colección pues los siguientes títulos aparecen como en prensa y no se tiene constancia más que por los catálogos, lo cual hace albergar dudas acerca de su publicación. Otro tanto sucede con Poemas de la Biblia, ya que sólo aparece en el Catálogo de 1917 y no hemos encontrado ningún ejemplar. (Cuadro IX).

\footnotetext{
${ }^{694}$ Vende la propiedad intelectual de la obra ante notario el 19 de noviembre de 1902. Vid. Anexo 2.1.18. ${ }^{695}$ MUÑOZ OLIVARES, C. Op. cit., pp. 64-65.
} 
6. BIBLIOTECAS Y LIBROS ESCOLARES

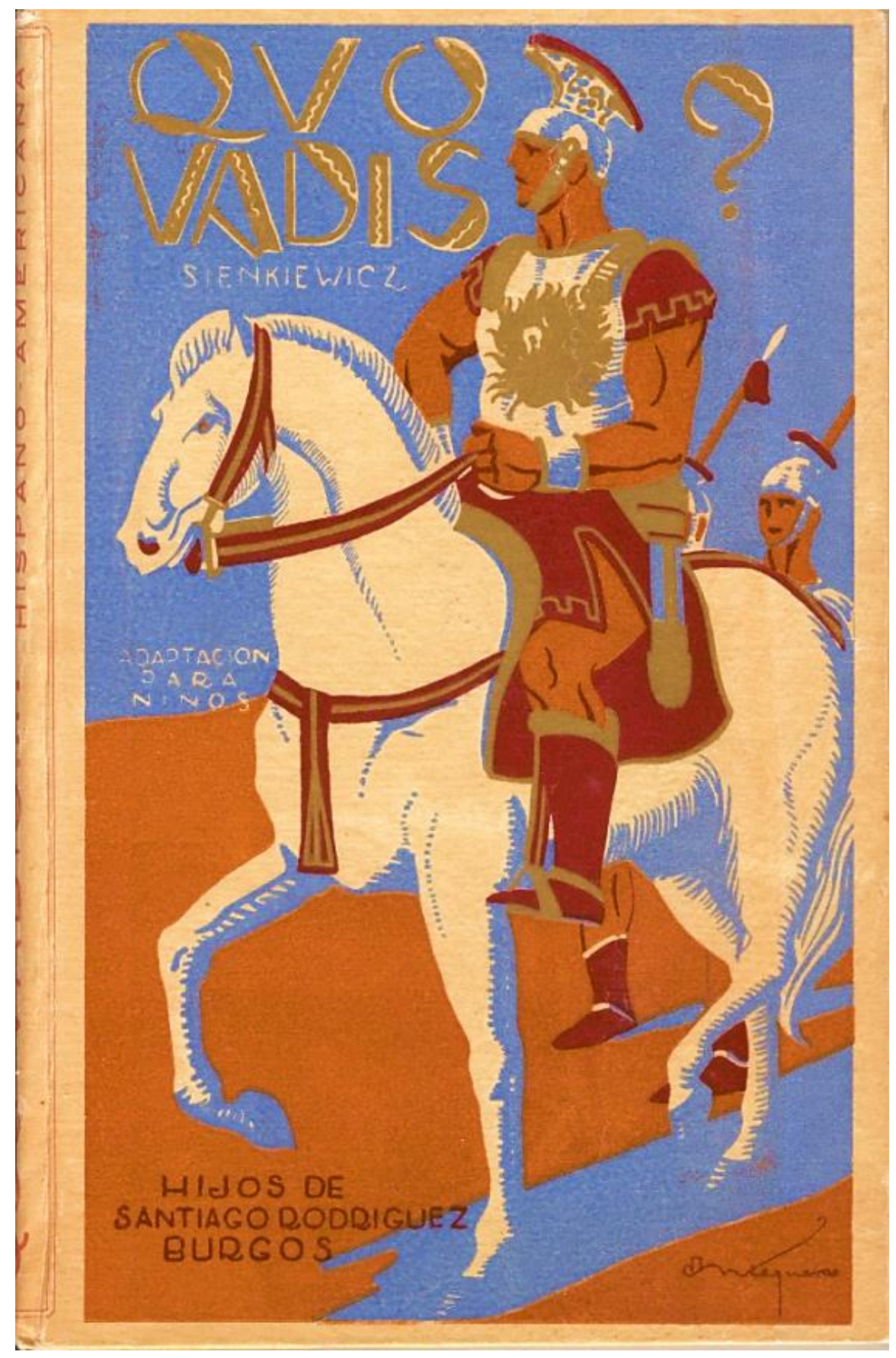

Fig. 6-28: Cubierta de Antequera Azpiri de la obra de Quo Vadis? Biblioteca Enciclopédica Hispano-Americana. Burgos. Hijos de Santiago Rodríguez. 
CUADRO IX: RELACIÓN DE TÍTULOS DE LA BIBLIOTECA ENCICLOPÉDICA HISPANO-AMERICANA EN LOS CATÁLOGOS DE LA EDITORIAL HIJOS DE SANTIAGO RODRÍGUEZ.

\begin{tabular}{|c|c|c|c|c|}
\hline Títulos & $\begin{array}{l}\text { CATÁLOGO } \\
1908\end{array}$ & $\begin{array}{l}\text { CATÁLOGO } \\
1917\end{array}$ & $\begin{array}{l}\text { CATÁLOGO } \\
1925\end{array}$ & $\begin{array}{l}\text { CATÁLOGO } \\
1929\end{array}$ \\
\hline Rafael & $\mathrm{X}$ & $\mathrm{x}$ & $\mathrm{x}$ & $\mathrm{x}$ \\
\hline Los Grandes Inventos & $\mathrm{x}$ & $\mathrm{x}$ & $\mathrm{x}$ & $\mathrm{x}$ \\
\hline Vida y aventuras de Robinsón Crusoe & $\mathrm{x}$ & $\mathrm{x}$ & $\mathrm{x}$ & $\mathrm{x}$ \\
\hline Leyendas y Tradiciones & $\mathrm{x}$ & $\mathrm{x}$ & $\mathrm{x}$ & $\mathrm{x}$ \\
\hline Ciencias físicas y naturales & $\mathrm{x}$ & $\mathrm{x}$ & $\mathrm{x}$ & $\mathrm{x}$ \\
\hline Cuentos escogidos & En prensa & $\mathrm{x}$ & $\mathrm{x}$ & $\mathrm{x}$ \\
\hline Cuentos Mexicanos & $\mathrm{x}$ & $\mathrm{x}$ & $\mathrm{x}$ & $\mathrm{x}$ \\
\hline Aventuras de Telémaco & $\mathrm{x}$ & $\mathrm{x}$ & $\mathrm{x}$ & $\mathrm{x}$ \\
\hline Alma y corazón & En prensa & $\mathrm{x}$ & $\mathrm{x}$ & $\mathrm{x}$ \\
\hline La Novela de la Infancia & En prensa & $\mathrm{x}$ & $\mathrm{x}$ & $\mathrm{x}$ \\
\hline Quo Vadis? & & & $\mathrm{x}$ & $\mathrm{x}$ \\
\hline Poemas de la Biblia & En prensa & $\mathrm{x}$ & En prensa & En prensa \\
\hline Cuentos de la Edad Media & & & & En prensa \\
\hline Leyendas de Oriente & & & & En prensa \\
\hline Cuentos de Ayer y Hoy & & & En prensa & \\
\hline Vida de N. S. Jesucristo & En prensa & & & \\
\hline En las entrañas de la Tierra & En prensa & & & \\
\hline
\end{tabular}

Fuente: Catálogos de la Editorial Hijos de Santiago Rodríguez. Años 1908, 1917, 1925, 1929. Bibliotecas públicas y universitarias de España. CEINCE. Biblioteca Nacional de España. [Elaboración propia]. 


\subsubsection{Biblioteca Azul y Rosa}

Esta colección está dirigida a niños a partir de diez-doce años; son libros para el ocio y entretenimiento y es presentada en los distintos Catálogos como una biblioteca para la adquisición de nuevos conocimientos y poder así ampliar su educación. Desde el Catálogo de 1908 comenta su finalidad:

No hemos omitido gasto ni sacrificio alguno para poder ofrecer al público libros de verdadero mérito, llenos de palpitante interés y ricos en provechosas enseñanzas, dignos de figurar entre las más selectas bibliotecas. ${ }^{696}$

En el mismo se informa que se han publicado cuatro tomos, de los doce que compondrán la colección, aunque a continuación se produce una contradicción al relegar la Biblioteca como "en prensa". Cada uno de los tomos tiene un tamaño de $26 \times 17 \mathrm{~cm}$., con más de 400 páginas, impresas en buen papel. Están encuadernados en pasta dura con cubiertas estampadas en doce colores y oro y fueron realizadas por Evaristo Barrio en los libros de El Hijo del Capitán Nemo y Flor de Aventuras, y J. Folch en Las Veladas de la Quinta. La contracubierta es la misma en todos los tomos con el emblema de la editorial, a varios colores y en dorado (Figura 6-29).

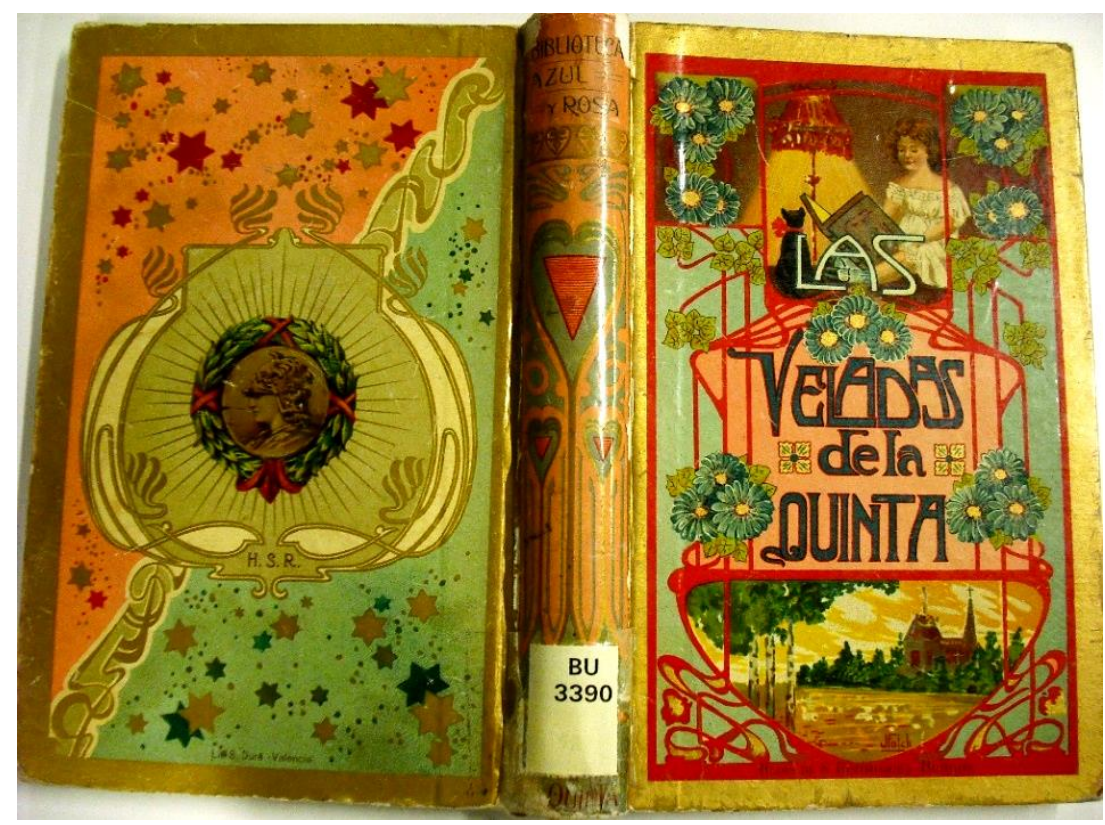

Fig. 6-29: Encuadernación de la Biblioteca Azul y Rosa.

Hijos de Santiago Rodríguez.

Ejemplar de la Biblioteca Pública de Burgos.

${ }^{696}$ CATÁLOGO 1908, pp. 102-103. 
Las ilustraciones interiores son la mayoría de plana entera, en blanco y negro, y otros insertos en el texto, también de Evaristo Barrio, excepto en Las Veladas de la Quinta, cuyo autor fue Luis Manero, y anota el año de 1915.

También ofrece la editorial estos tomos encuadernados en tela con adornos en relieve en negro y rótulos dorados, en los Catálogos de 1908 y 1917; en los de 1925 y 1929 resalta la encuadernación de lujo, siendo los lomos y puntas en tela, y el canto dorado. El precio varía según los Catálogos: mientras en 1908 el precio es de 4 pts. y 6 en tela, en 1917 cuesta 5 pts. y 7 pts. en tela. Los Catálogos de 1925 y 1929 ofertan el precio de cada tomo en 7,50 pts. y 12 en tela.

\section{Contenido e influencias}

El Hijo del Capitán Nemo es una novela de viajes y aventuras escrita por Enrique de Bendito y Trujillo, jefe de artillería, editada en mayo de 1912, con numerosos dibujos, y encuadernada lujosamente, al cromo y oro $^{697}$ (Figura 6-30).

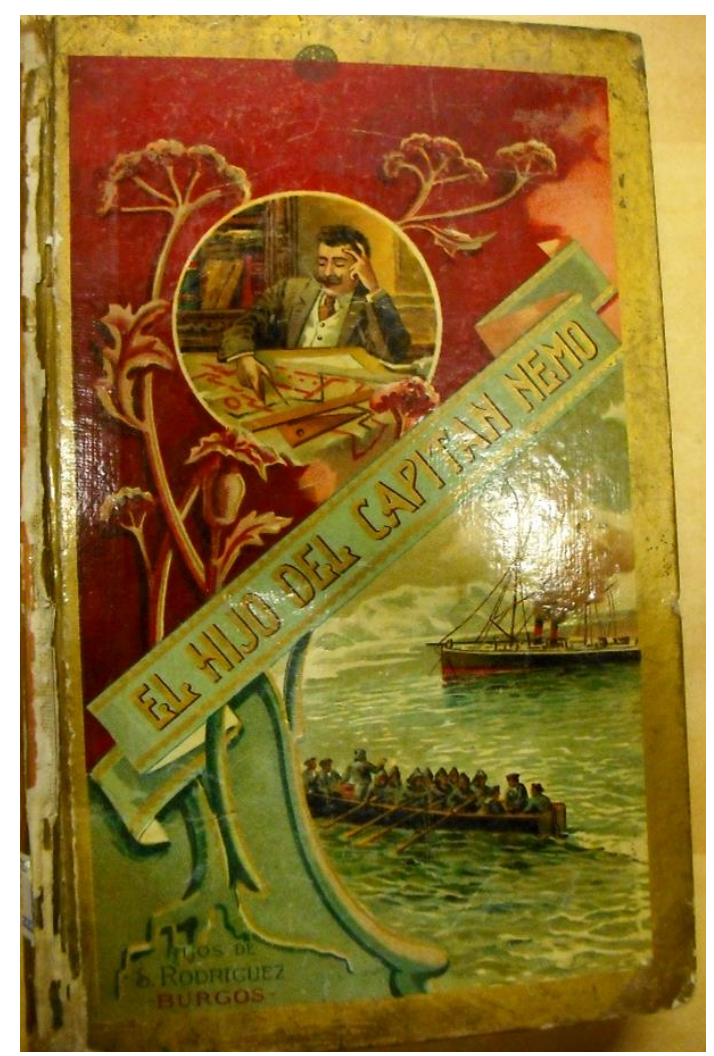

Fig. 6-30: Cubierta de la obra El hijo del capitán Nemo. Biblioteca Azul y Rosa. Hijos de Santiago Rodríguez. Biblioteca de la Diputación Provincial de Burgos.

${ }^{697}$ La Voz de Castilla. Año III, no 192,9 de junio de 1912, p. 2. 
Flor de aventuras ${ }^{698}$ es la segunda obra de esta colección que sale a la luz en abril de $1913,{ }^{699}$ traducida por Eusebio Heras de la novela Román Kalbris, del escritor francés Hector Malot, y editada en París en J. Hetzel \& cie, en 1869. Narra las aventuras del pequeño Román, hijo y nieto de pescadores y marinos, que busca ser como su padre. Relata toda una sucesión de lances extraordinarios, con rasgos verosímiles y variadas aventuras del personaje: desde escapar de su tío, que le mataba de hambre, hasta la llegada a un circo, con la domadora de leones que al final se convertirá en su compañera.

El tratamiento continúa en línea de influencia roussoniana: un niño es obligado a afrontar las dificultades de la vida y cómo, a base de coraje y bondad, termina por encontrar la felicidad y reconstruirla a su alrededor.

Las Veladas de la Quinta, escrita por Madame de Genlis fue traducida al castellano y editada en $1916 .^{700}$ En el título de la obra añade: novelas, historias morales para que las madres de familia puedan instruir a sus hijos juntando la doctrina con el recreo.

La autora, y su contemporáneo Armand Berquin, son seguidores de la pedagogía roussoniana. Su influencia es enorme porque sus libros son traducidos en todos los países europeos, dando lugar a una serie de obras que reciben el nombre de berquinadas. ${ }^{701}$ Según este modelo moralista, aparece la dicotomía entre niño bueno, que triunfa, y el malo, merecedor de castigo, aunque es más bien el niño travieso al que le gusta hacer diabluras.

En el prólogo, la autora habla de las motivaciones que la impulsaron a escribir esta novela para las madres de familia uniendo la diversión con la instrucción:

El objeto principal que me proponía era hacer cuanto me fuese posible para inspirar a los jóvenes las inclinaciones sencillas, la vida pacífica y tranquila del campo, y para conseguirlo era preciso más de una historia, más de una conversación, por cuyo motivo insisto en ellas con preferencia.

Todo asunto moral puede tratarse con amenidad y los libros de dicho carácter dejan de ser útiles cuando se hacen cansados [...]

El raciocinio severo y frío jamás corregirá a la humanidad, sino los eficaces ejemplos, los cuadros creados exclusivamente para interesar, para grabarse de un modo indeleble en la memoria: en una palabra, la moral puesta en acción..$^{702}$

\footnotetext{
${ }^{698}$ Ver ilustraciones interiores en Anexos 3.1.34; 3.1.35.

${ }^{699}$ La Voz de Castilla. Año IV, no 240, 4 de mayo de 1913, p. 2.

${ }^{700}$ El Papa-Moscas. Año XXXIX, no 2.023, 2 de abril de 1916, p. 3.

701 BRAVO-VILLASANTE, C. Ensayos de literatura infantil. Murcia: Universidad, Secretariado de Publicaciones, 1989.

${ }_{702}$ DUCREST DE SAINT AUBIN, C-S-F. (condesa de Genlis). Las veladas de la Quinta. Burgos: Hijos de Santiago Rodríguez, 1915.
} 
De El ingenioso hidalgo Don Quijote de la Mancha encontramos una obra, con el mismo título, posterior a 1935, editada como Nueva edición, reformada por Felipe Romero Juan e ilustrada por Manuel Huete, pero no perteneciente a esta colección. Sólo aparece publicidad de la misma en el Catálogo de 1917, como obra de venta al público, donde se manifiesta que los editores han hecho un tributo de admiración al inmortal Cervantes. Los dibujos son de Evaristo Barrio.

La obra, Vidas que quedan, aflora en todos los Catálogos como "en prensa" y con informaciones contradictorias acerca de su autor. En los Catálogos de 1925 y 1929 la publicitan como un libro que narra las biografías de los grandes hombres de todas las épocas y de todos los tiempos, de Ángel Bueno Rodríguez-Arias, aunque se publicita anteriormente como obra de Mariano Rodríguez Miguel. ${ }^{703}$

No tenemos datos de su publicación, pero se conserva la cubierta que Evaristo Barrio dibujó para dicha obra (Figura 6-31).

Los cuatro títulos de la misma remarcan la baratura del precio frente a otras similares de edición extranjera; de 4 pts., en encuadernación con tapas al cromo y oro, y de 6 pts., en tela con adornos en relieve, en negro y oro, y con cortes dorados.

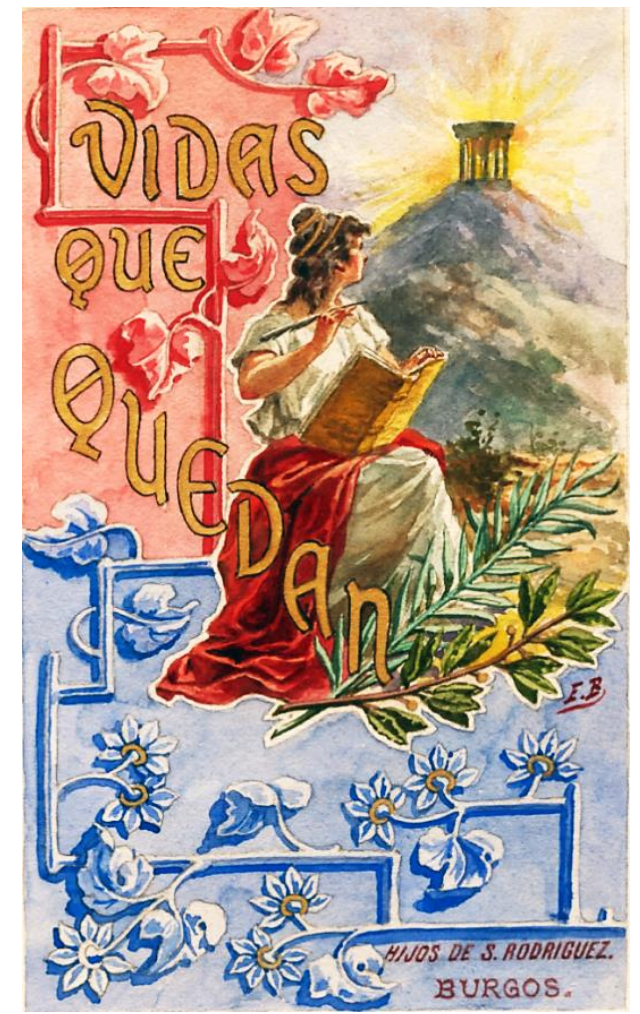

Fig. 6-31: Cubierta de la obra Vidas que quedan realizada por Evaristo Barrio.

Biblioteca Azul y Rosa. Hijos de Santiago Rodríguez.

Imagen cedida por Lucas Rodríguez Plaza.

${ }^{703}$ BLANCO BELMONTE, R. M. Op. cit., páginas finales de publicidad sin numerar, en 1913. 
CUADRO X: RELACIÓN DE TÍTULOS DE LA BIBLIOTECA AZUL Y ROSA EN LOS CATÁLOGOS DE LA EDITORIAL HIJOS DE SANTIAGO RODRÍGUEZ.

\begin{tabular}{|l|l|l|l|l|}
\hline Títulos & $\begin{array}{c}\text { CATÁLOGO } \\
1908\end{array}$ & $\begin{array}{l}\text { CATÁLOGO } \\
1917\end{array}$ & $\begin{array}{l}\text { CATÁLOGO } \\
1925\end{array}$ & $\begin{array}{c}\text { CATÁLOGO } \\
1929\end{array}$ \\
\hline El Hijo del Capitán Nemo & En prensa & $\mathrm{x}$ & $\mathrm{x}$ & $\mathrm{x}$ \\
\hline Flor de aventuras & En prensa & $\mathrm{x}$ & $\mathrm{x}$ & $\mathrm{x}$ \\
\hline Las veladas de la Quinta & En prensa & $\mathrm{x}$ & $\mathrm{x}$ & $\mathrm{x}$ \\
\hline Don Quijote de la Mancha & & $\mathrm{x}$ & & \\
\hline Vidas que quedan & En prensa & En prensa & En prensa & En prensa \\
\hline $\begin{array}{l}\text { El ingenioso hidalgo Don Quijote } \\
\text { de la Mancha }\end{array}$ & & & En prensa & En prensa \\
\hline
\end{tabular}

Fuente: Catálogo de la Editorial Hijos de Santiago Rodríguez. Años 1908, 1917, 1925, 1929. Bibliotecas públicas y universitarias de España. CEINCE. Biblioteca Nacional de España. [Elaboración propia]. 


\subsubsection{Biblioteca Viajes del Siglo $X X$}

En el Catálogo de 1908 se anuncia el título de una Biblioteca, "Alrededor del Mundo", ${ }^{704}$ que versará sobre los viajes por Europa, América, Asia y África, y estará escrita por señalados literatos, sin especificar sus nombres. Adelanta que serán unos 40 tomos, de unas 160 páginas cada uno, en un tamaño de 19,5 x 12,5 cm., con numerosas láminas de fotograbado, vistas de los principales monumentos del mundo, y encuadernados con tapas al cromo y oro.

Los primeros tomos, iniciadores de la Biblioteca, tratarán de España: Castilla la Vieja, Castilla la Nueva y Cataluña. Sin embargo, no tenemos constancia de ninguno, puesto que en los Catálogos de 1917 y 1925 no se refleja ninguna referencia.

Ahora bien, el Catálogo de 1929 muestra la Biblioteca Viajes del siglo $\mathrm{XX}$, con un carácter recreativo e instructivo. Se describen viajes, exploraciones y las travesías realizadas, en estos últimos años, a través de mares y continentes.

Se presenta como relatos verídicos, sensacionalistas, con proezas auténticas, vividas por hombres arriesgados y audaces que para realizarlas emplearon todos los modernos medios de transporte: el aeroplano, el dirigible, el automóvil etc. Se relatan hazañas sorprendentes, intercalando observaciones sobre las razas, las costumbres, y la flora y fauna de los lugares que recorren, al mismo tiempo se explican los aparatos y medios empleados.

También nos señala que la colección es propicia para premios y regalos, con la intención de atraer a lectores de ocho a doce años. Hay varios tomos en prensa, de unos $16 \mathrm{~cm}$ de tamaño y entre 150 a 200 páginas con numerosas ilustraciones. ${ }^{705}$ No se puede saber con seguridad si se imprimieron dichos tomos; lo cierto es que no se ha encontrado ningún ejemplar en las bibliotecas españolas.

${ }^{704}$ CATÁLOGO 1908, p. 95.

${ }^{705}$ CATALOGO 1929, pp. 39-40 


\subsubsection{Biblioteca Popular de Medicina e Higiene.}

Es una Biblioteca formada por libros de tipo divulgativo, escritos por médicos especialistas, que tratan de presentar los preceptos higiénicos necesarios para mantener y conservar los principales órganos del cuerpo y evitar enfermedades. Están escritos de forma clara, sencilla, y con un vocabulario asequible a todos los lectores.

CUADRO XI: RELACIÓN DE LOS TÍTULOS DE LA BIBLIOTECA MEDICINA E HIGIENE EN LOS CATÁLOGOS DE LA EDITORIAL HIJOS DE SANTIAGO RODRÍGUEZ.

\begin{tabular}{|c|c|c|c|}
\hline Títulos & $\begin{array}{c}\text { CATÁLOGO } \\
1917\end{array}$ & $\begin{array}{l}\text { CATÁLOGO } \\
1925\end{array}$ & $\begin{array}{l}\text { CATÁlOGO } \\
1929\end{array}$ \\
\hline \multicolumn{4}{|l|}{$\mathbf{1}^{\mathrm{a}}$ serie } \\
\hline ¿Quiere usted vivir muchos años? & $\mathrm{x}$ & $\mathrm{x}$ & $\mathrm{x}$ \\
\hline ¿Quiere usted criar bien a sus hijos? & $\mathrm{x}$ & $\mathrm{x}$ & $\mathrm{x}$ \\
\hline $\begin{array}{l}\text { ¿Quiere usted tener sano el sistema } \\
\text { nervioso? }\end{array}$ & $\mathrm{x}$ & $\mathrm{x}$ & \\
\hline $\begin{array}{l}\text { ¿Quiere usted tener sano el aparato } \\
\text { respiratorio? }\end{array}$ & $\mathrm{x}$ & $\mathrm{x}$ & $\mathrm{x}$ \\
\hline $\begin{array}{l}\text { ¿Quiere usted evitar las enfermedades } \\
\text { venéreas? }\end{array}$ & $\mathrm{x}$ & $\mathrm{x}$ & $\mathrm{X}$ \\
\hline ¿Quiere usted tener sano el estómago? & $\mathrm{x}$ & $\mathrm{x}$ & $\mathrm{x}$ \\
\hline \multicolumn{4}{|l|}{$2^{\mathrm{a}}$ serie } \\
\hline ¿Quiere usted conservar la vista? & $\mathrm{x}$ & $\mathrm{x}$ & $\mathrm{x}$ \\
\hline ¿Quiere usted tener sano el corazón? & $\mathrm{x}$ & $\mathrm{x}$ & $\mathrm{x}$ \\
\hline ¿Quiere usted evitar las infecciones? & & $\mathrm{x}$ & $\mathrm{x}$ \\
\hline ¿Quiere usted tener buen embarazo? & $\mathrm{x}$ & $\mathrm{x}$ & $\mathrm{x}$ \\
\hline ¿Quiere usted conservar la belleza? & & $\mathrm{x}$ & $\mathrm{x}$ \\
\hline ¿Quiere usted curar y evitar la hernia? & & $\mathrm{x}$ & $\mathrm{x}$ \\
\hline ¿Quiere usted conservar la dentadura? & & $\mathrm{x}$ & $\mathrm{x}$ \\
\hline
\end{tabular}

Fuente: Catálogos de la Editorial Hijos de Santiago Rodríguez. Años 1917, 1925, 1929. Bibliotecas públicas y universitarias de España. CEINCE. Biblioteca Nacional de España. [Elaboración propia].

En las distintas bibliotecas nos encontramos todos los títulos menos ¿Quiere usted curar y evitar la hernia? 


\section{Estructura y contenido}

Son libros muy manejables, de $20 \times 14 \mathrm{~cm}$., y con un máximo de 70 páginas. Están encuadernados con grapas y con cubiertas en cartulina, de color marrón oscuro, sin ilustrar. En el centro de la cubierta, además del título en letras grandes, hay una pequeña tesela geométrica y una figura circular con el emblema editorial (Figura 6-32). En el interior aparecen ilustraciones diversas, algunas sin autor y otras por Luis Manero.

Salen publicadas cuatro obras de toda la Biblioteca, en junio de $1914 .^{706}$ $\mathrm{Al}$ año siguiente se editan dos nuevos tomos ${ }^{707} \mathrm{y}$, en 1916, otras dos nuevas obras de la colección. ${ }^{708}$ En 1917 sale a la venta, en todas las librerías, la segunda serie de la Biblioteca con el primer volumen, ¿Quiere usted evitar las infecciones?, escrito por el médico López de Rego. ${ }^{709}$

En los Catálogos se manifiesta la importancia de esta Biblioteca porque la salud es la primera y más importante de todos los bienes y para ello es necesario cuidarla. Habla de la necesidad de la higiene, para evitar enfermedades, y la presenta como un deber nacional. Encontramos consejos y preceptos higiénicos para conservarnos y evitar las enfermedades.

Insiste en que el precio de venta es baratísimo: 0,90 pts., en $1917,{ }^{710} \mathrm{y}$ 1,25 o 1,75 pts, en los siguientes Catálogos, según sean de la $1^{\mathrm{a}} \mathrm{o}$ de la $2^{\mathrm{a}}$ serie (Cuadro XI).

Todo desembolso hecho en nombre de la higiene es una economía. Menos cuesta y más vale prevenir que curar. ¿Por qué sufrir y padecer enfermedades siendo tan fácil evitarlas? LA HIGIENE ES LA SALUD. LA SALUD ES LA VIDA. ${ }^{711}$

\footnotetext{
${ }^{706}$ La Voz de Castilla. Año V, no extraordinario, 11 de junio de 1914, pp. 2-3. Los tomos que se publican son los siguientes: ¿Quiere usted vivir muchos años?, ¿Quiere usted conservar la vista?, ¿Quiere usted tener sano el corazón? y ¿Quiere usted criar bien a sus hijos?

707 El Papa-Moscas. Año XXXVIII, n1 1976, 2 de mayo de 1915, p. 2. Los nuevos tomos publicados son los siguientes: ¿Quiere usted tener sano el sistema nervioso?, escrito por el médico Ramón Álvarez Gómez-Salazar, miembro de la Sociedad Clínica de Medicina de París y Jefe del Dispensario de Enfermedades nerviosas y mentales y ¿Quiere usted tener sano el aparato respiratorio? escrito por el doctor Verdes Montenegro, profesor de enfermedades del corazón y de los pulmones en el Instituto Rubio y director del Dispensario Antituberculoso "María Cristina" de Madrid.

${ }^{708}$ El Papa-Moscas. Año XXXXIX, no 2.039, 23 de julio de 1916, p. 3; La Voz de Castilla. Año VII, no 412, 23 de julio de 1916, p. 1. Ambos artículos dan cuenta de los tomos: ¿Quiere usted evitar las enfermedades venéreas? por el doctor José Olavide Torres, del Instituto Rubio y del Laboratorio Municipal de Madrid, especialista en enfermedades de piel y venéreas y ¿Quiere usted tener sano el estómago? por el doctor Santiago Carro, profesor de las vías digestivas en el Instituto Rubio de Madrid, ex ayudante de Fisiología e Higiene de la Facultad de Medicina de Santiago en Galicia.

${ }^{709}$ Tierra Hidalga. Año VI, no 293, 18 de agosto de 1917, p. 3.

${ }^{710}$ Tierra Hidalga. Año V, $\mathrm{n}^{\circ}$ 221, 2 de abril de 1916, pp. 2-3.

${ }^{711}$ CATÁLOGO 1925, p. 108-109; CATÁLOGO 1929, pp. 58-59.
} 
En tono más desenfadado, el periódico burgalés Guasa Viva anima a la compra de esta colección:

Sobre la puerta de la librería de "Hijos de Santiago Rodríguez" hay un cartel que dice:

“Quiere V. vivir muchos años?-noventa céntimos”. Y como nosotros amamos la vida, cueste lo que cueste, al ver que nos la ofrecen por tan poco dinero, nos hemos apresurado a entrar por ella.

Pero, joh, decepción!, cuando hemos ido a introducir los dátiles en el bolsillo del chaleco, con dolor hemos visto que estaba exhausto. Y nos ha dado una grande tristeza ver que, por miserables no podemos prolongar nuestra existencia.

D. Mariano Rodríguez, ese hombre inteligente y laborioso que tan alto pone el nombre de Burgos se ha hecho cargo al momento de nuestras amarguras, y con una extremada generosidad nos ha proporcionado el elixir maravilloso que anhelábamos.

Y y a somos dichosos. Poseemos tres tomos elegantes, preciosamente editados en la citada casa, y escritos en etilo claro, breve, preciso, para que lleguen, sus doctrinas sabias, a todas las inteligencias.

Titulase: “QQuiere usted vivir muchos años?”, “Quiere usted conservar la vista?” “QQuiere usted tener sano el corazón?” ¿Quién no quiere éstas cosas? Un hombre con la vida asegurada, con pupila y de corazón sano es un verdadero prodigio, ¿verdad?

Pues todo ello puede conseguirse por dos pesetas sesenta céntimos.

Pedir más, sería gollería. ${ }^{712}$

En los Catálogos de 1925 y 1929, refiere lo que se escribió en algunas publicaciones sobre esta Biblioteca. Señalamos alguna de ellas.

No conocemos altruismo igual al del médico, que, despojándose del tradicional empaque de esta ciencia, habla a las gentes en el lenguaje de las gentes, ni hay difusión de cultura que preste tan gran servicio a la raza como esta en los conocimientos médicos. Nuevo Mundo-Madrid. ${ }^{713}$

Comentaremos uno de cada serie:

El primero, de la $1^{\text {a }}$ serie: ¿Quiere usted vivir muchos años?, está escrito por el doctor Benjamín Tamayo. Detrás de la portada nos muestra la escultura de Creugas, dibujada por Luis Manero. En el pie de la imagen explicita el siguiente texto: - "Salud, fuerza y belleza se obtienen por los ejercicios bien ordenados. Para llegar a viejo y con buena salud, haced todos los días algunos minutos de ejercicios sin aparatos”. Hay varias partes bien definidas en el texto. La primera, trata de aspectos relacionados con los hábitos personales: sueño, trabajo, descanso, aseo y limpieza de distintas partes del cuerpo. La segunda, hace referencia a todo lo exterior: vestido, alimentación, cambios de temperatura, habitación, ejercicios y

${ }^{712}$ Guasa Viva. Año II, no 66, 21 de junio de 1914, p. 9.

${ }^{713}$ CATÁlOGO 1925, p. 109. CATÁLOGO 1929, p. 59. 
contagio de animales. Y la última parte, la dedica a dar consejos, marcar un decálogo de la ley vital humana, sobre gimnasia y los diez mandamientos de las escuelas suecas e inglesas. En las páginas finales, van diversos pensamientos y máximas mezclando autores clásicos con varios de los boy scouts de España.

Hay algunos fragmentos que evidencian cómo el libro es fiel a los potenciales compradores de clase social media al ensalzar el trabajo intelectual ante el manual. Extraemos, de algunos temas, varias frases ilustrativas a modo de ejemplo:

- Sobre la salud: "El hombre destruye su cuerpo...lo mismo cuando trabaja más de lo que puede, que cuando trabaja menos de lo que debe". ${ }^{114}$

- El sueño, trabajo y descanso: "El sueño es más necesario después del trabajo mental que después del ejercicio físico, por eso los labradores y artesanos no necesitan dormir tanto como los que se dedican a trabajos intelectuales". ${ }^{715}$

El sueño: debe acostarse a las 10 horas y levantarse temprano, a las 7 durante el invierno y a las 5 de la mañana en verano, marcando que "todos los que han vivido muchos años han sido grandes madrugadores". ${ }^{716}$

- Aseo: "Cada ocho días tomar un baño jabonoso a $35^{\circ}$ y de 10 minutos de duración".

- Sobre el ejercicio físico: "Modérate, sobre todo, si estás obligado a estudiar mucho, porque cuando el cerebro está muy fatigado, el ejercicio fisico lo hace cansar más pronto". 717

Cuando se refiere a gimnasia, nos muestra dos láminas de Luis Manero que representan a un hombre en diversas posiciones.

El libro ¿Quiere usted conservar la vista? escrito por el médico oculista César Urraca, perteneciente a la $2^{\text {a }}$ serie, consta de 53 páginas con una portada de Luis Manero, tras la que hay un doble dibujo, a plana entera, donde se sitúa la forma de leer correctamente y cómo no se debe hacerse. A continuación, el autor nos explica que por la insistencia de un amigo suyo hemos de pensar en Mariano Rodríguez- escribe este libro, no como texto para médicos sino de divulgación, no sobre medicamentos y enfermedades, propios de los médicos, sino lo que se debe saber para evitar enfermedades y primeros auxilios, hasta llegar a la consulta del médico.

El libro consta de nueve capítulos:

$1^{\circ}$.- Cuidados que necesitan los ojos en los primeros años de vida.

\footnotetext{
714 TAMAYO, B. ¿Quiere usted vivir muchos años? Burgos: Hijos de Santiago Rodríguez, p. 8.

${ }^{715}$ Ibídem, p. 9.

${ }^{716}$ Ibídem, p. 10.

${ }^{717}$ Ibídem, p. 20. 
$2^{\mathrm{o}}$.- Precauciones que deben tomarse para que no sean lesionados.

$3^{\circ}$.- Higiene de la vista en las escuelas.

$4^{\circ}$.- Luces artificiales.

$5^{\circ}$.- Uso de las lentes y adquisición de las mismas. (Graduación).

$6^{\circ}$.- Condiciones en que debe realizarse el trabajo.

$7^{\circ}$.- Modo de evitar la penetración de cuerpos extraños en los ojos y extracción de aquellos.

$8^{\circ}$.- Higiene profesional.

$9^{\circ}$.- Peligro de la aplicación de remedios caseros.

Proporciona un ejemplo para conocer el estado de la vista a través de un dibujo y así ver si padecemos astigmatismo. Las siguientes hojas nos muestran letras, de diferente tamaño, para ver de cerca y de lejos.

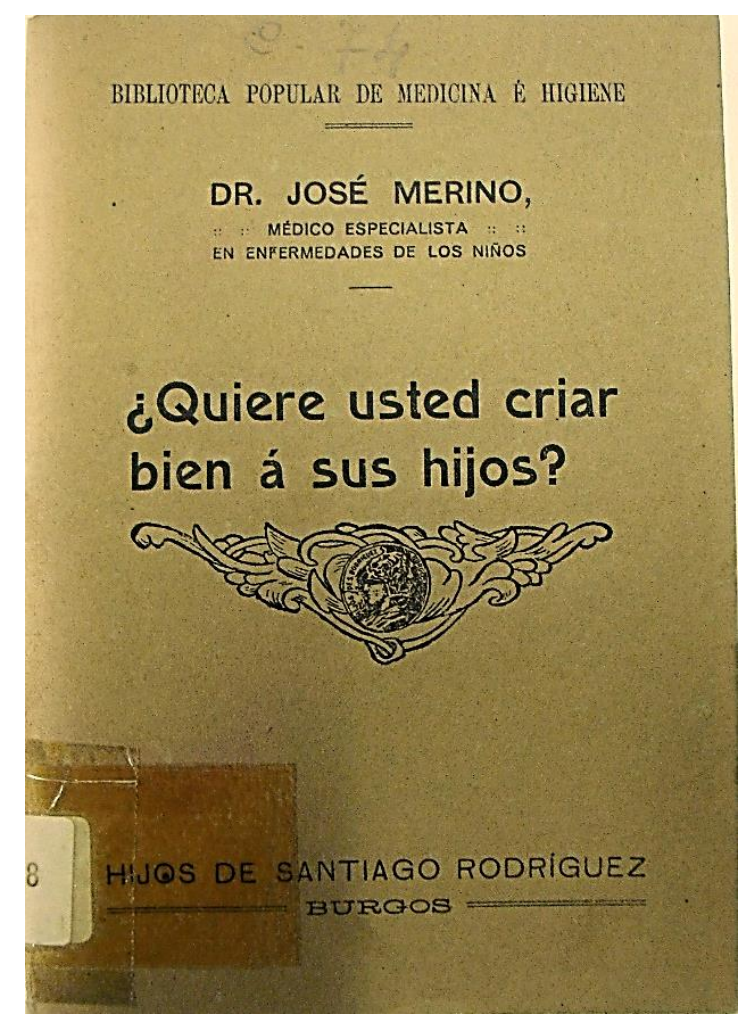

Fig. 6-32: Cubierta del libro ¿Quiere usted criar bien a sus hijos? Biblioteca Popular de Medicina e Higiene. Hijos de Santiago Rodríguez.

Ejemplar de la Biblioteca Pública de Burgos. 


\subsubsection{Regalo de Reyes}

Son cuentos pequeños de unas 10 páginas, con un tamaño de 14 x 14 $\mathrm{cm}$. Están encuadernados y grapados, para abaratar costes, con cubiertas de cartulina, estampadas en colores por Pedro Antequera Azpiri. (Figura 6-34, 6-36). Cada uno presenta cinco ilustraciones interiores en blanco y negro y otra en varios colores, del mismo autor que las cubiertas. La primera letra de cada cuento la conjuga gráficamente con el personaje del cuento; la última página coincide con la parte final del cuento ilustrada.

Antequera Azpiri diseñó el logotipo de la biblioteca, situándola en la página anterior a la contraportada, donde un Rey Mago deja un cuento de regalo. Superpuesto al dibujo figura el nombre de la editorial y de la Biblioteca Regalo de Reyes, con el copyright fechado en 1922 (Figura 633). Los precios indicados en los dos Catálogos de 1925 y 1929 son de 0,35 pts.

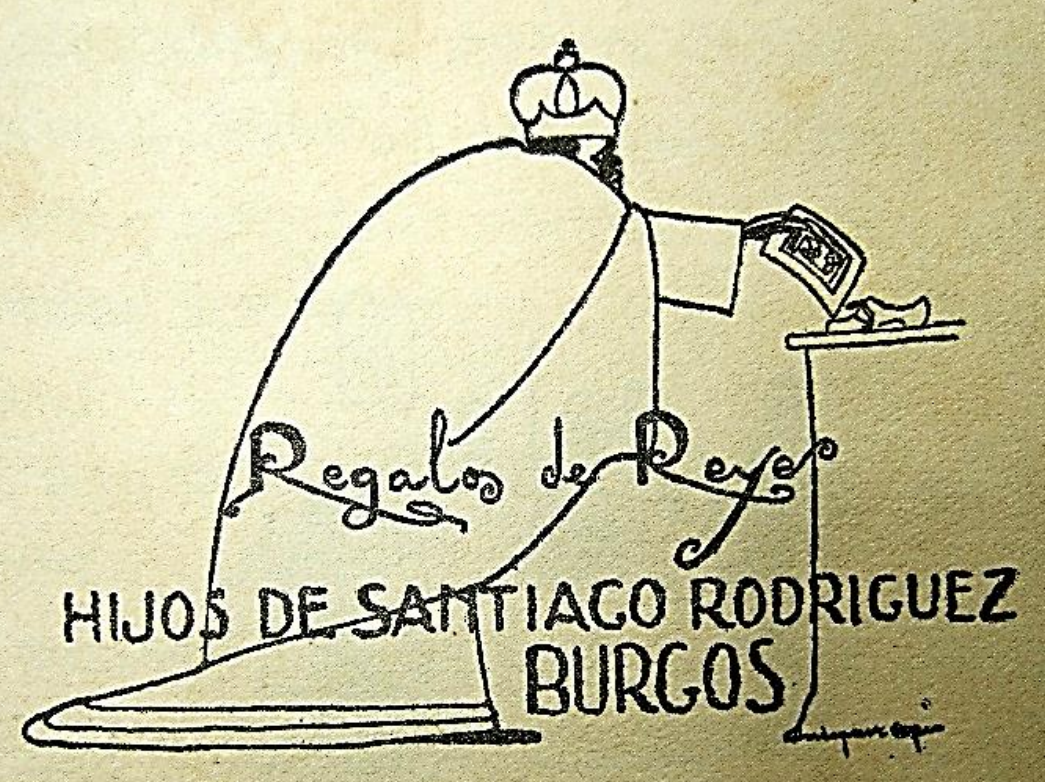

Es propiedad de los editores.

Copyright 1922.

Fig. 6-33: Logotipo de la Biblioteca Regalo de Reyes. Ilustrado por Antequera Azpiri. Hijos de Santiago Rodríguez. Biblioteca de la Diputación Provincial de Burgos. 


\section{Contenido}

De todas las bibliotecas rastreadas, sólo hemos podido encontrar dos de los seis tomos de la colección: Gasparín y Un amigo.

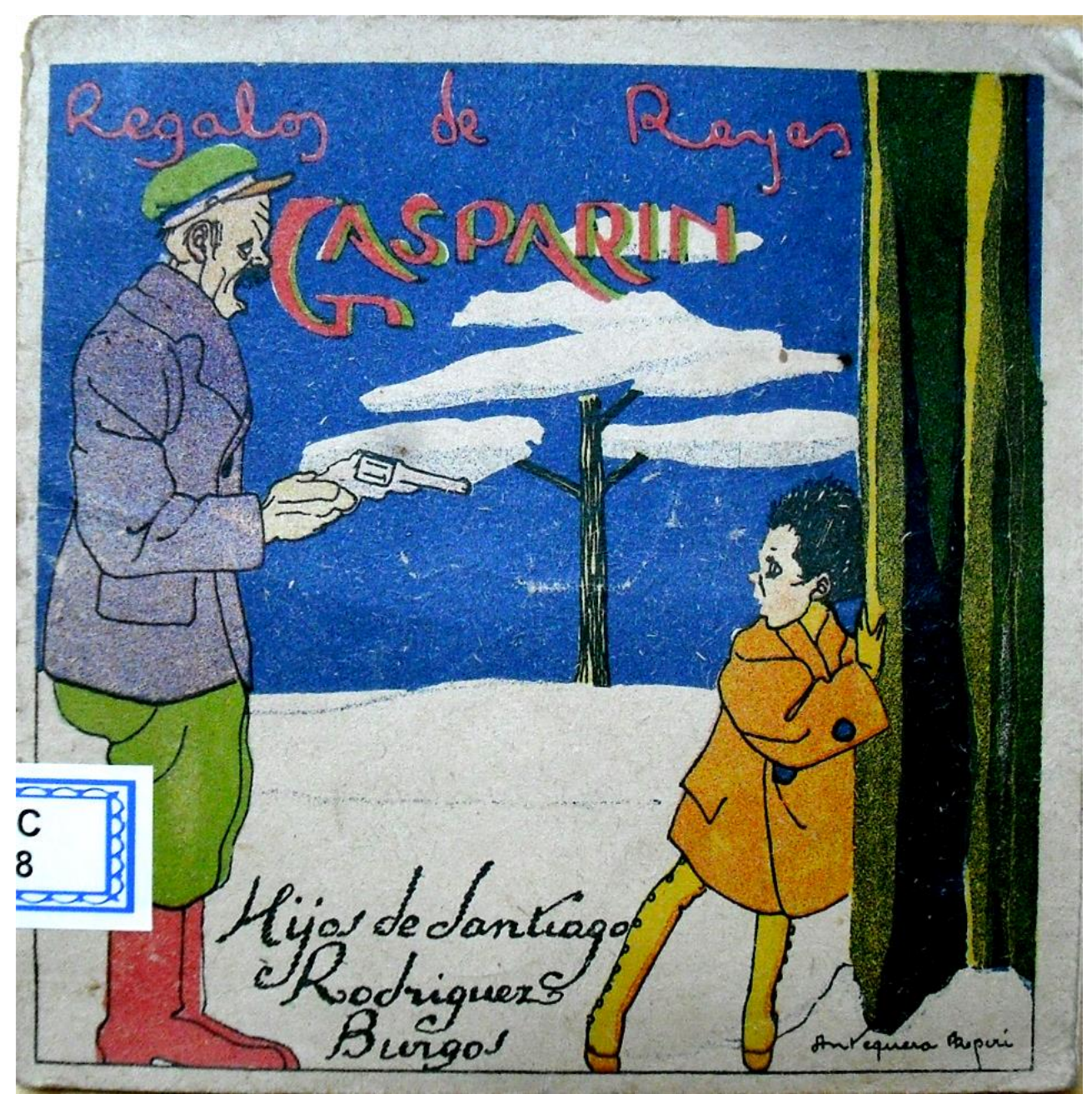

Fig. 6-34: Cubierta del cuento Gasparín ilustrado por Antequera Azpiri.

Biblioteca Regalo de Reyes. Hijos de Santiago Rodríguez.

Ejemplar de la Biblioteca de la Diputación Provincial de Burgos.

Del primero, comenta que Gasparín no era sobrino del rey Gaspar sino un simple niño aplicado, del pueblo de Egea, y que la víspera de Reyes, después de jugar, se fue a casa para ir a dormir pronto. De camino a casa fue secuestrado, al parecer por equivocación, y sus tres captores le llevan a una cabaña de la montaña donde les espera la señora Mendrugo que le da vino para entrar en calor. A medianoche, aparecen los Reyes Magos con un gran séquito de soldados y salvan al niño. Cuando despierta, está en su cama rodeado de sus padres, el maestro, el médico y el juez, y los Reyes que le han dejado un montón de juguetes. Como nota curiosa, los Reyes 
Magos aparecen con criados y guerreros vestidos a la manera del Cid Campeador (Figura 6-35).

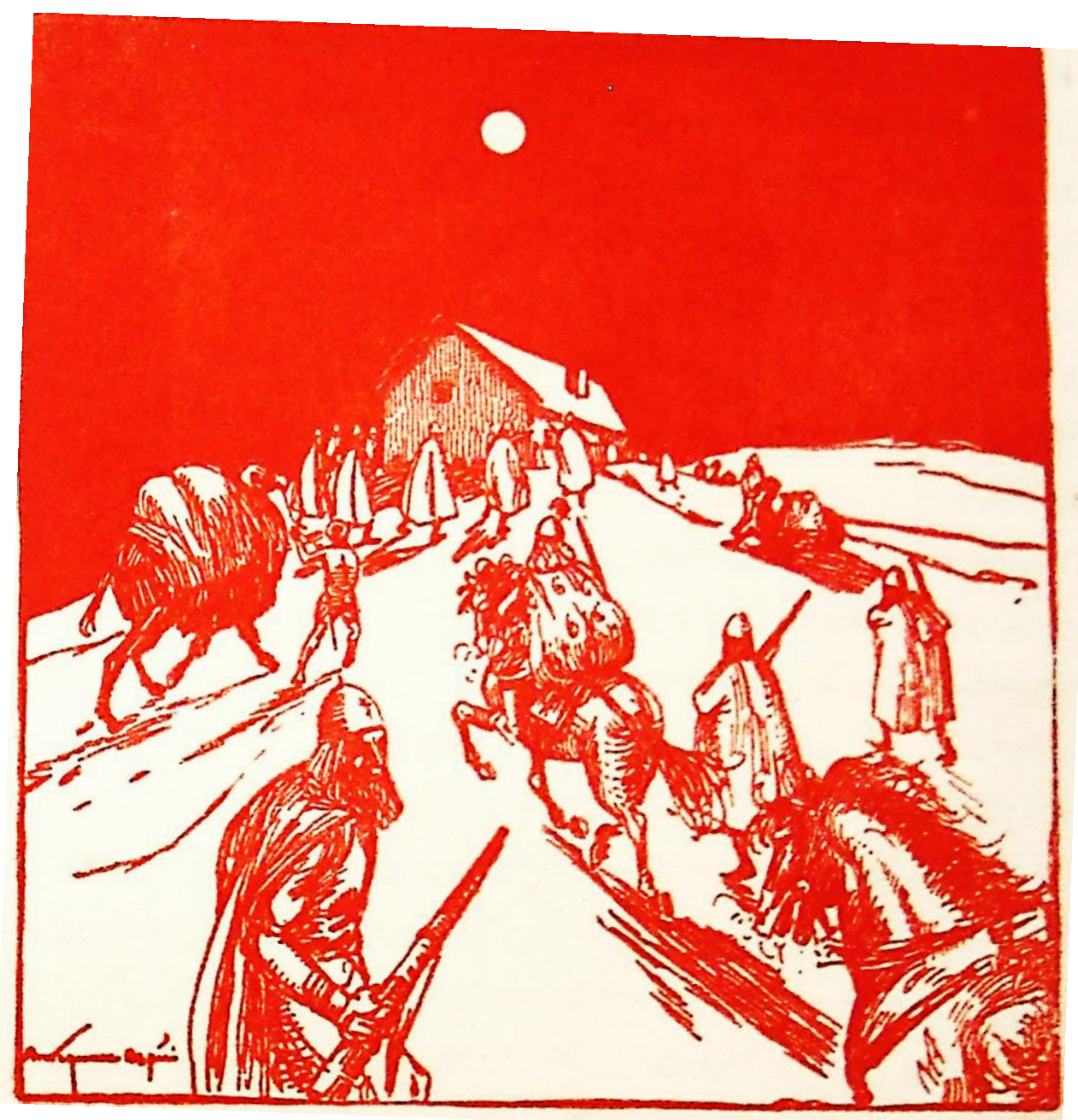

Fig. 6-35: Ilustración interior a color de Antequera Azpiri del cuento Gasparín. Biblioteca Regalo de Reyes. Hijos de Santiago Rodríguez.

Ejemplar de la Biblioteca de la Diputación Provincial de Burgos.

En el cuento Un amigo, se narra cómo Andrés, un chico que vivía en plena montaña aragonesa, cuidaba el rebaño de corderos. Un día se encontró con un oso herido al que curó y proporcionó cuidados hasta su recuperación. Pasado un tiempo, el oso le salvó del ataque de unos lobos y le siguió agradeciendo su gesto llevando al caserío toda clase de regalos: leña, un jabalí, y un brillante muñeco que, al tomarlo, tocaba unos platillos, que al parecer unos hombres en camellos habían dejado caer en la nieve. 


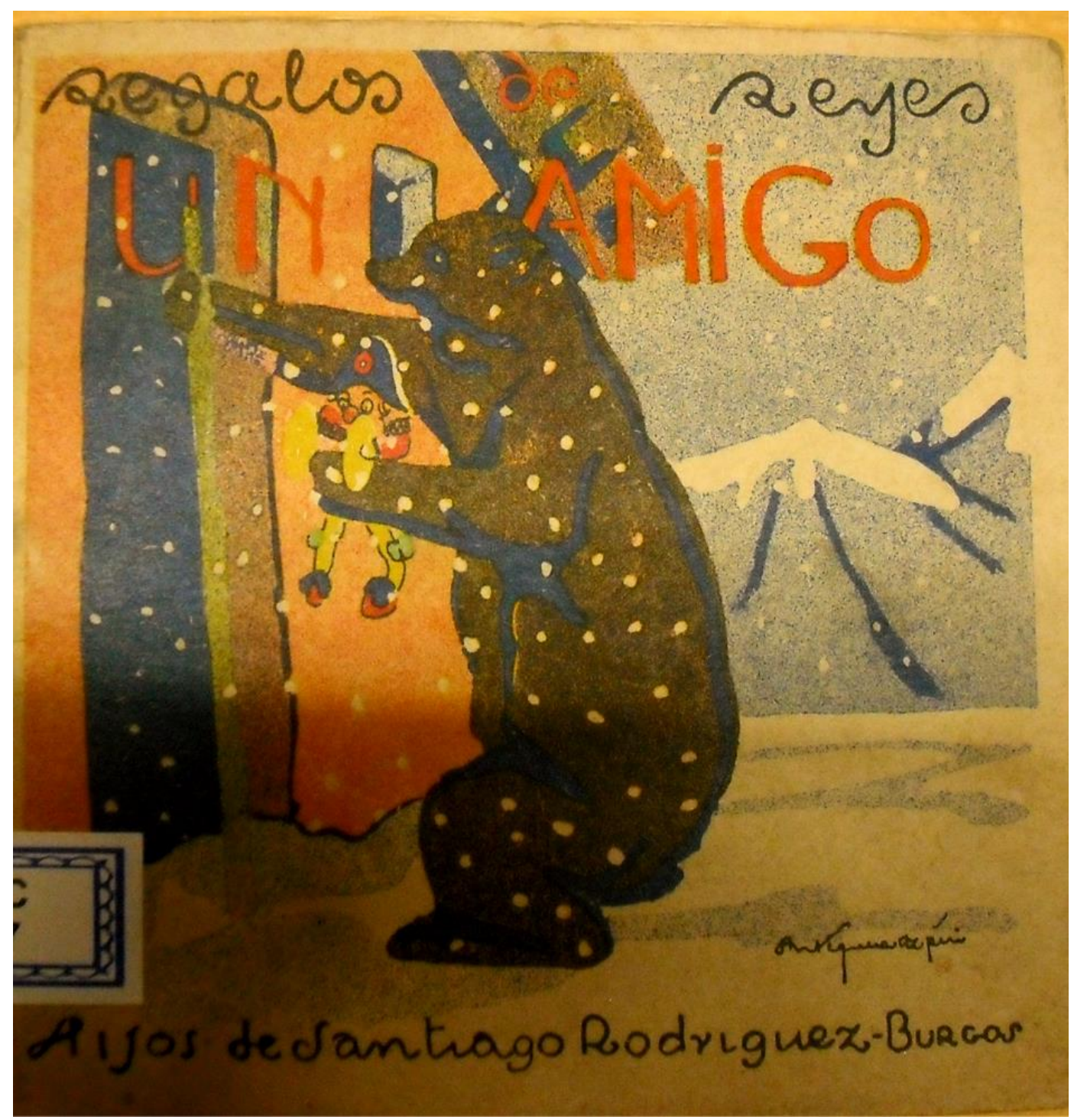

Fig. 6-36: Cubierta del cuento Un amigo ilustrado por Antequera Azpiri.

Biblioteca Regalo de Reyes. Hijos de Santiago Rodríguez.

Ejemplar de la Biblioteca de la Diputación Provincial de Burgos.

La colección pretende educar e influir en el comportamiento de los niños al presentar que los Reyes Magos dejan regalos cuando son buenos y ejemplares. En ambos cuentos encontramos afirmaciones como:

Era Gasparín, un niño moreno, de ojos vivos y frente despejada, estudioso, bueno y obediente a sus padres.

No le dolía las proximidades del fin de las vacaciones como en otros niños que yo me sé muy bien que adelgazan hasta hacer precisa la intervención del aceite de hígado de bacalao.",718

"El buen chico se llamaba Andrés y se dedicaba a guardar el pequeño hato de ganado que constituía con la choza, el único patrimonio de padre e hijo. ${ }^{719}$

718 [Anón.]. Gasparín. Burgos: Hijos de Santiago Rodríguez, Regalo de Reyes, 1922, pp. 2-3.

719 [Anón.]. Un amigo. Burgos: Hijos de Santiago Rodríguez, Regalo de Reyes, 1922, p. 2. 
Aunque las peripecias que narra están dentro de los cuentos moralizantes, las descripciones llevan a los lectores a ponerles en contacto con lugares y personas desconocidas, como buen relato que se precie. La intervención de los Reyes Magos es sorprendente, sirve para reforzar la creencia y su poder, al incluir en el final el hecho de que todos los niños reciben un regalo.

CUADRO XII: RELACIÓN DE LOS TÍTULOS DE LA BIBLIOTECA REGALO DE REYES EN LOS CATÁLOGOS DE LA EDITORIAL HIJOS DE SANTIAGO RODRÍGUEZ.

\begin{tabular}{|l|l|l|}
\hline TíTULOS & CATÁLOGO 1925 & CATÁLOGO 1929 \\
\hline Tronchabosques & $\mathrm{x}$ & $\mathrm{x}$ \\
\hline El Guiñol & $\mathrm{x}$ & $\mathrm{x}$ \\
\hline Un amigo & $\mathrm{x}$ & $\mathrm{x}$ \\
\hline El criado de Melchor & $\mathrm{x}$ & $\mathrm{x}$ \\
\hline Gasparín & $\mathrm{x}$ & $\mathrm{x}$ \\
\hline Las botas & $\mathrm{x}$ & $\mathrm{x}$ \\
\hline
\end{tabular}

Fuente: Catálogos de la Editorial Hijos de Santiago Rodríguez. Años 1925, 1929. Bibliotecas públicas y universitarias de España. CEINCE. Biblioteca Nacional de España. [Elaboración propia]. 


\subsubsection{Colección Papa-Moscas}

Se trata de una colección exclusiva para niños pequeños. El Catálogo de 1925 advierte que su formato y composición presenta alguna semejanza con las antiguas aleluyas. Sin embargo, en el Catálogo de 1929 no la relaciona con las mismas y la señala como una nueva serie para disfrutar y reír con sus historietas. Contiene sugestivas ilustraciones interiores en bicolor, y bellas cubiertas de carácter artístico en cinco colores (Cuadro XIII).

Al no contar con ningún libro de la colección correspondiente a la primera publicación, situada en los años 20, es imposible analizarla. Según el Catálogo de 1925 son historietas cómicas relatadas por el secretario de El Papa-Moscas, "Martinillo". ${ }^{720}$

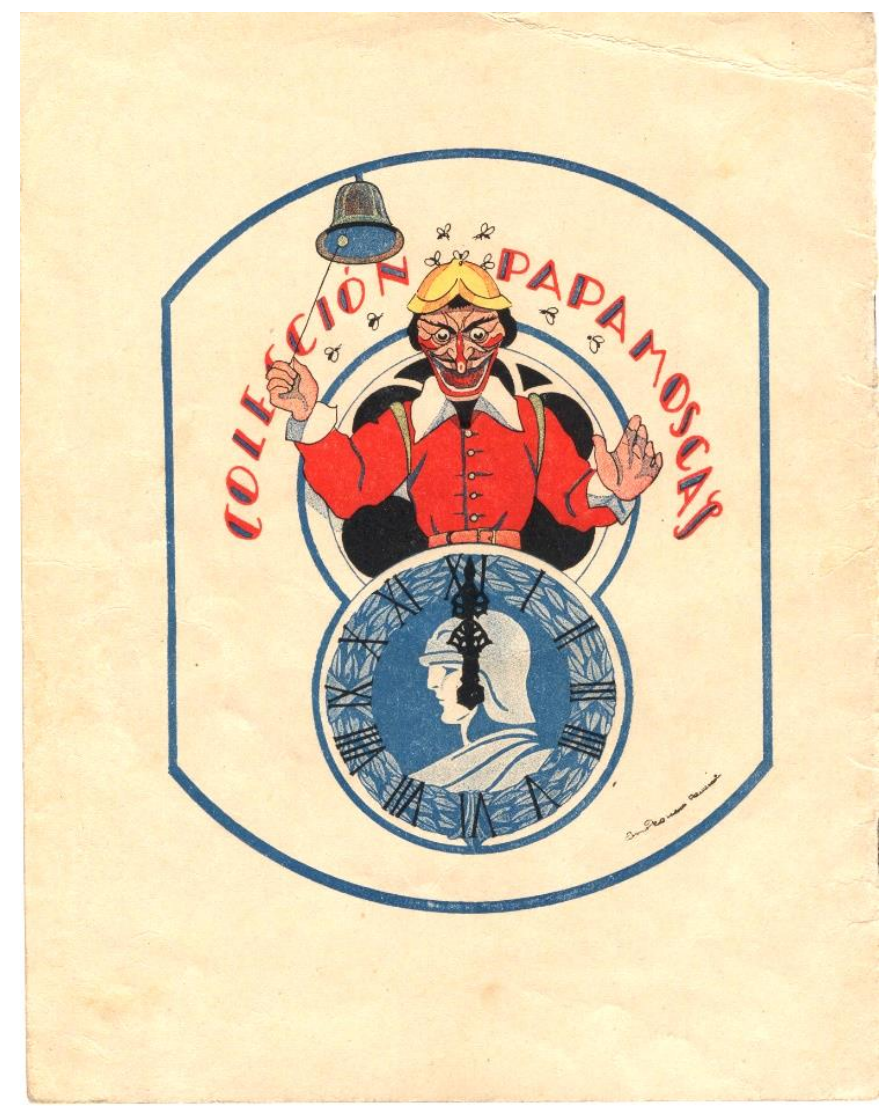

Fig. 6-37: Contracubierta de la Colección Papa-Moscas.

Ilustrado por Pedro Antequera Azpiri.

Hijos de Santiago Rodríguez.

\footnotetext{
${ }^{720}$ En la catedral de Burgos, a los pies de la nave mayor, en la parte superior hay un reloj con una figura articulada, que todas las horas en punto mueve un brazo con el que da un campanazo y abre al mismo tiempo la boca; se trata de un autómata que recibe el nombre de Papa-Moscas. A su derecha, en un balcón, se encuentra otro autómata que se encarga de anunciar los cuartos de hora golpeando las campanas que se encuentran a ambos lados, su nombre es Martinillo. También se recuerda con el pseudónimo de Martinillo a Jacinto Ontañón, editor del periódico burgalés El Papa-Moscas, publicación de carácter satírico.
} 
Sólo encontramos dos ejemplares, Patachín Patachán, en la Biblioteca de Castilla y León y Rinconete y Cortadillo en una colección particular.

Se trata de tomos de $22 \times 17 \mathrm{~cm}$., de 16 páginas, impresos en excelente papel satinado, encuadernados en cartulina fuerte y grapados. La cubierta está bellamente ilustrada con los dibujos de los personajes. La contracubierta tiene un dibujo-logotipo de la colección realizado por Pedro Antequera Azpiri, al igual que la cubierta y portada. El dibujo es una caricatura del reloj-autómata, el Papa-Moscas de la Catedral de Burgos, a la que añade unas simpáticas moscas que le da un tono más satírico y humorístico. (Figura 6-37). Mientras que el precio de 1925 era de 1 pts., en 1929 se rebaja a 0,75 pts. cada tomo.

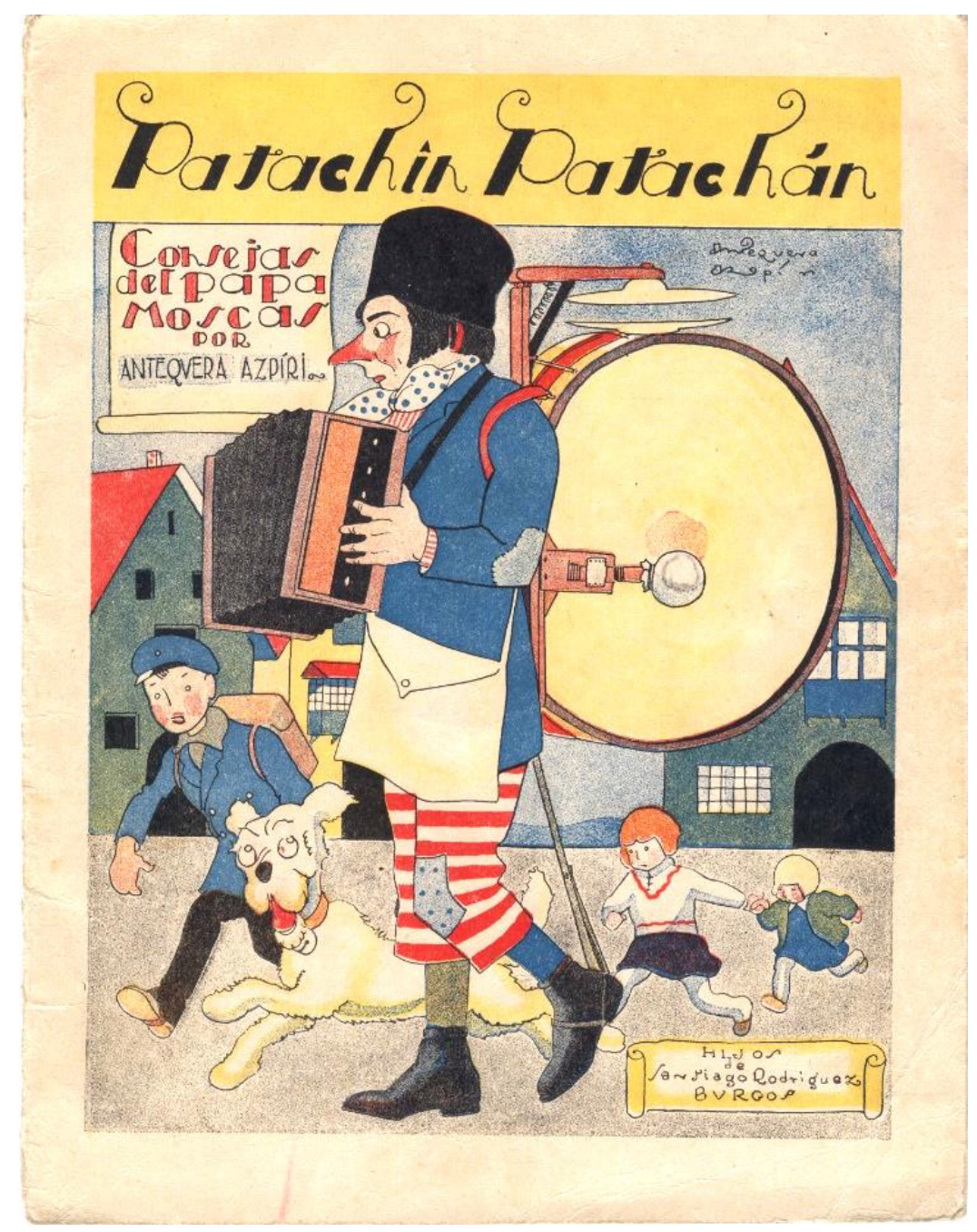

Fig. 6-38: Patachín Patachán. Consejas del Papa-Moscas. Ilustrado por Antequera Azpiri. Colección Papa-Moscas. Hijos de Santiago Rodríguez.

El argumento del cuento nos transporta a un pueblecito danés donde vive Jorge Sprint con su hermana, en casa de su tía Carlota, al morir sus padres. Ésta le obliga a trabajar utilizando un instrumento que consistía en 
un acordeón, un bombo y unos platillos, de ahí el sobrenombre Patachín Patachán (Figura 6-38). Salía por las calles tocando diversas melodías, pero los guardias le retiraban para que no molestase a los paseantes, no pudiendo así recibir el dinero que algunos generosamente le daban. La hija del alcalde después de conocer su situación, hizo que su padre interviniese haciendo comparecer a la tía para recriminarla el abuso. Resuelven que Clarita, la hermana pequeña se quedará en casa del alcalde, estudie y consiga, en la edad adulta, ser la directora de un importante colegio en Copenhage; Jorge aprende música y llega a ser un gran concertista a nivel mundial. Tanto el texto como las ilustraciones son de Pedro Antequera Azpiri. ${ }^{721}$

El libro Rinconete y Cortadillo es una adaptación que, según expresa la nota preliminar, pretende presentar a estos dos conocidos héroes-pícaros de la literatura española, de forma plástica y pintoresca, al público infantil para motivarles a, que más adelante, puedan desear leer la obra original, Novelas Ejemplares, de Miguel de Cervantes.

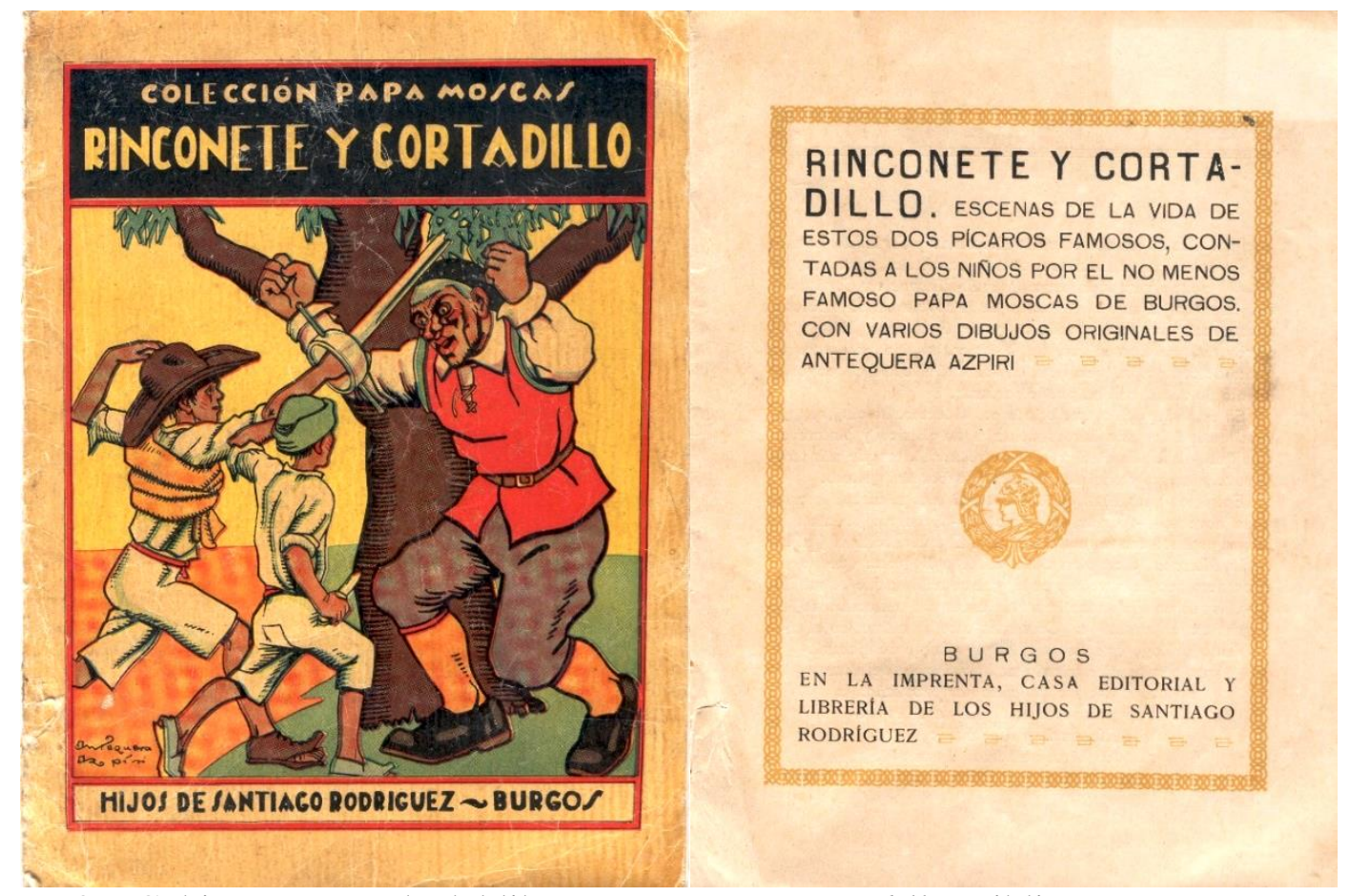

Fig. 6-39: Cubierta y portada del libro Rinconete y Cortadillo. Biblioteca Papa-Moscas. Hijos de Santiago Rodríguez.

Todas las ilustraciones, al igual que la cubierta, fueron realizadas por Pedro Antequera Azpiri recreando lugares y momentos de la época cervantina en Sevilla. (Figuras 6-39, 6-40). ${ }^{721}$ Podemos observar algunas ilustraciones interiores de Pedro Antequera Azpiri para este cuento en:
Anexo 3.4.14; 3.4.29. 


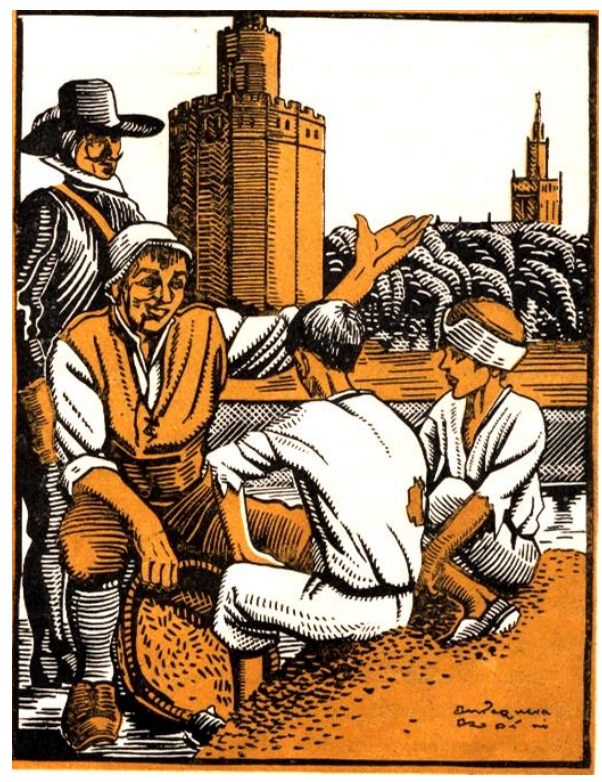

Fig. 6-40: Ilustración interior del libro Rinconete y Cortadillo. Hijos de Santiago Rodríguez.

CUADRO XIII: RELACIÓN DE TÍTULOS DE LA BIBLIOTECA COLECCIÓN PAPA-MOSCAS EN LOS CATÁLOGOS DE LA EDITORIAL HIJOS DE SANTIAGO RODRÍGUEZ.

\begin{tabular}{|l|l|l|}
\hline Títulos & \multicolumn{1}{|c|}{ CATÁLOGO } \\
& $\begin{array}{c}\text { CATÁLOGO } \\
1929\end{array}$ \\
\hline Hazañas del valeroso Cid Campeador & $\mathrm{x}$ & \\
\hline Cuentos del Papa-Moscas & $\mathrm{x}$ & $\mathrm{x}$ \\
\hline $\begin{array}{l}\text { Rinconete, Cortadillo... y Comparsa } \\
\text { Rinconete y Cortadillo }\end{array}$ & $\mathrm{x}$ & \\
\hline Una tarde de risa y regocijo & $\mathrm{x}$ & \\
\hline El Libro de la gente menuda & $\mathrm{x}$ & $\mathrm{x}$ \\
\hline Aventuras de Rodriguete & $\mathrm{x}$ & $\mathrm{x}$ \\
\hline Patachín Patachán & & $\mathrm{x}$ \\
\hline Historietas del Papa-Moscas & & En prensa \\
\hline Lazarillo de Tormes & & En prensa \\
\hline Pepa y Pepe en el Circo & & En prensa \\
\hline Más historietas del Papa-Moscas & & En prensa \\
\hline Hazañas del Cid Campeador & & \\
\hline En el parque zoológico Krone & & \\
\hline
\end{tabular}

Fuente: Catálogos de la Editorial Hijos de Santiago Rodríguez. Años 1925, 1929. Bibliotecas públicas y universitarias de España. CEINCE. Biblioteca Nacional de España. [Elaboración propia]. 


\subsubsection{Cuentos Nuevos en Colores}

Es una colección de cuentos dirigida a pequeños lectores, y editada con las modernas técnicas de impresión correspondientes a la segunda década del siglo XX.

\section{CUENTOS NUEVOS EN COLORES}

Bonitísimos álbums tamaño $27 \times 16 \frac{1}{2}$ centímetros, de 24 páginas

:: :: con multitud de ilustraciones en negro y en colores $\quad$ :: ::

Texto interesante y ameno of of of Dibujos variadísimos y originales

Esta nueva serie de cuentos constituye el acontecimiento infantil del año, por su presentación artística y la novedad de su texto.

TOMOS PUELICADOS

La Historia de Narizotas

Referida é ilustrada por ANTEQUERA AZPIRI.

La Larva y el Aguila

Cuento escrito é ilustrado por PEDRO A. AZPIRI.

Mikolán y C..

por F. MANÍN, con ilustraciones de AN. TEQUERA AZPIRI.

El Piratilla

Cuento escrito é ilustradopor PEDRO AN. TEQUERA AZPIRI.

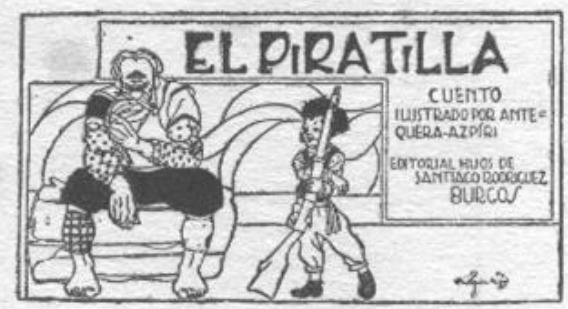

Precio de cada tomo: 1'25 ptas.

$\Rightarrow 136<$

Fig. 6-41: Propaganda de la Biblioteca Cuentos Nuevos en Colores en Mi Libro de Estampas y Cuentos. Biblioteca Paz.

Hijos de Santiago Rodríguez. 


\section{Estructura externa}

Tienen forma de álbumes, tamaño $26 \times 15,5 \mathrm{~cm}$., con un total de 20 páginas. Están encuadernados, con cartulina fuerte, y grapados para abaratar costes. La cubierta está ilustrada con dibujos, en vivos colores, combinados con amarillos, rojos, azules y verdes. Destaca la gran sencillez y elegancia de los dibujos a línea, que representan escenas relacionadas con el cuento y desarrollan una visión humorística.

La contracubierta, en cartulina, está marcada por dos emblemas de la editorial, en la esquina superior izquierda e inferior derecha. Las guardas también están ilustradas con personajes del propio cuento en la parte superior izquierda e inferior derecha. La portada está bellamente decorada en blanco y negro, con los personajes de la historia junto con el título, autor y editor. En la contraportada, dibujada en blanco y negro, aparece el logotipo de la biblioteca donde nos coloca a tres niños, en diversas posiciones, leyendo. En la parte inferior derecha se sitúa el emblema de la editorial.

Las 18 páginas del cuerpo del cuento disponen de 15 a 18 ilustraciones, cuatro a color y dos de ellos a toda plana, del mismo estilo que la cubierta. Su autor, Pedro Antequera Azpiri dibuja y colorea la primera letra del texto.

En el final del cuento, Mikolán y $C^{i a}$, nos avisa en una nota que los apuntes de las ilustraciones han sido tomados, expresamente, en París por el dibujante. El precio es de 1,25 pts. según marcan los Catálogos editoriales.

Por otra parte, señalamos que únicamente las litografías del libro $\mathrm{La}$ larva y el Águila se realizaron en Tolosa, en la Litografía Laborde Labayen.

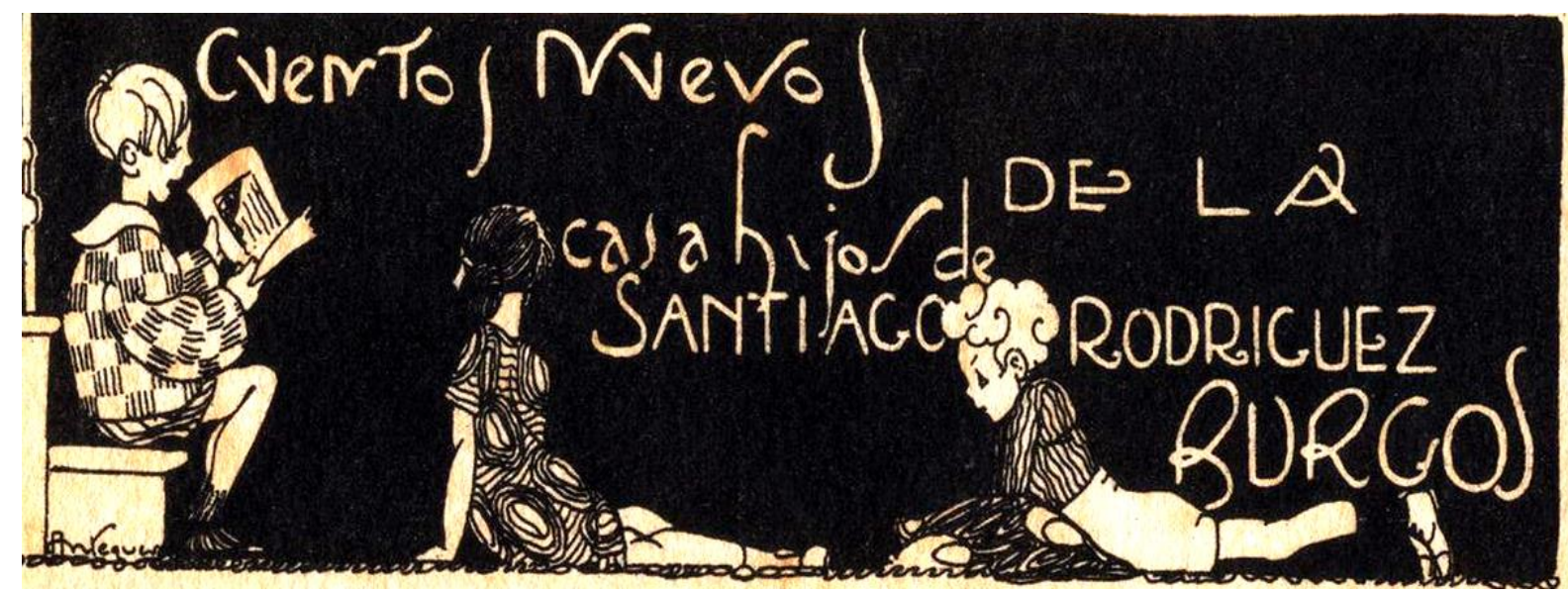

Fig. 6-42: Logotipo de la Colección Cuentos Nuevos en Colores. Hijos de Santiago Rodríguez. 


\section{Contenido}

De toda la colección, sólo disponemos de dos de los cuentos: Mikolán y $C^{i a}$., escrito por J. Manín, y La larva y el Águila, por Antequera Azpiri.

Mikolán y $C^{i a}$, narrado en primera persona, sitúa el comienzo de la acción en París, en el Jardín de la Aclimatación, donde varios monos se habían escapado del zoo en los comienzos de la Primera Guerra Mundial. El protagonista se encuentra con un grupo de monos que hablan, son perseguidos y enfocados por los proyectores de la Torre Eiffel:

...jmonos! que parecían tratar cuestiones muy difíciles a juzgar por el discurso verdaderamente parlamentario que en correcto francés, aunque algo infantil, pronunciaba un mono de fisonomía inteligente, a quien escuchaban con devoción varios micos de distintas castas. Todos se habían escapado del Jardín de Aclimatación... ${ }^{722}$

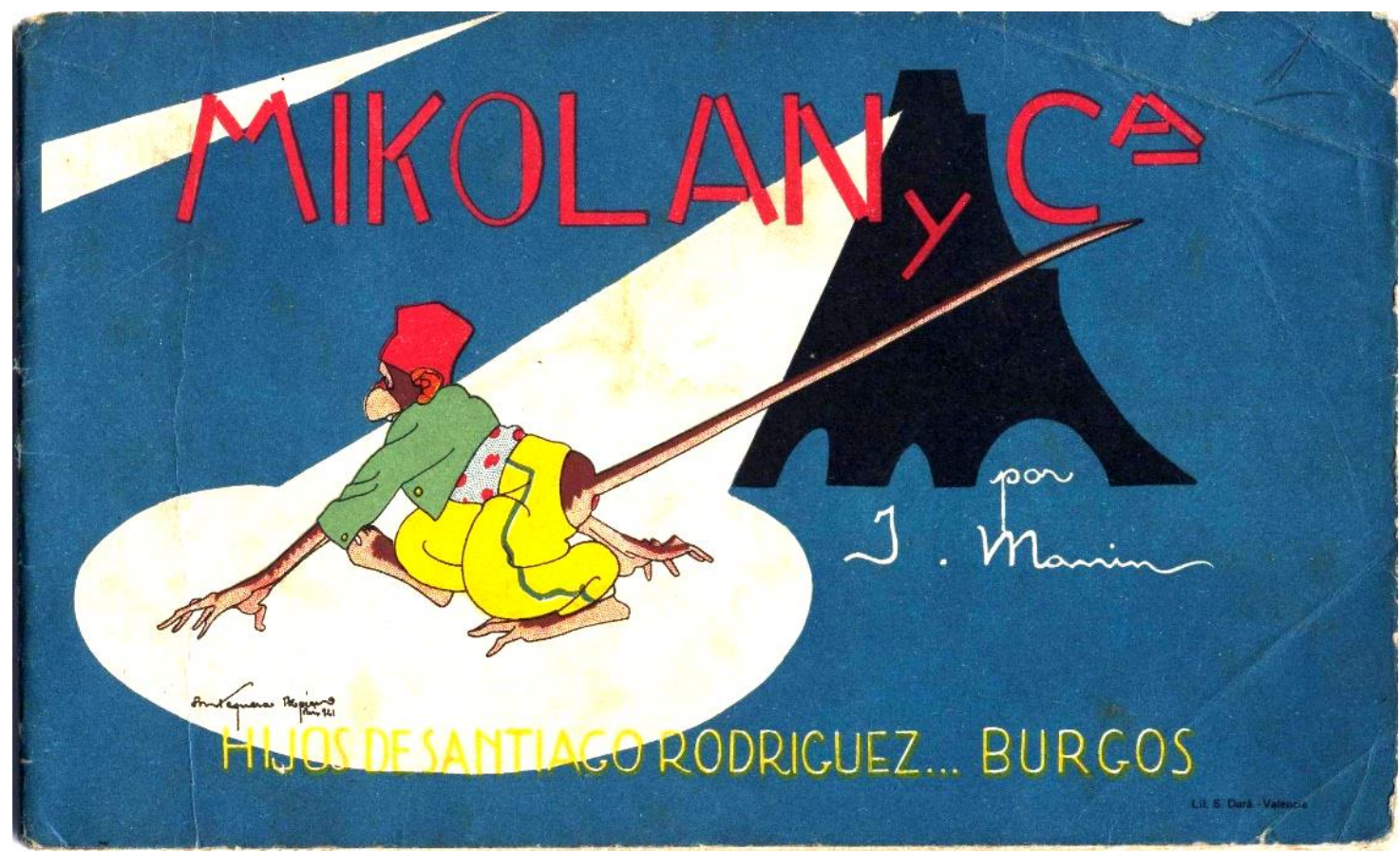

Fig. 6-43: Cubierta a color del cuento Mikolán y Cía por Antequera Azpiri.

Biblioteca Cuentos Nuevos en Colores. Hijos de Santiago Rodríguez.

Terminada la guerra, el narrador explica cómo entró de nuevo en el mismo jardín y el reencuentro con uno de los monos, de nombre Mikolán, que le describe sus desventuras durante la contienda y su desesperanza por estar solo. Varios días después, un titular de periódico informa de una

${ }_{722}$ MANÍN, J. Mikolán y $C^{\text {ía }}$. Burgos: Hijos de Santiago Rodríguez, p. 6. Ver ilustraciones interiores en: Anexo 3.4.8; 3.4.26. 
noticia sobre Mikolán dejándose devorar por unos osos. El final del cuento termina con una conclusión no cerrada pues dispone al lector a elucubrar sus propios pensamientos.

En este cuento incluye algunos elementos nuevos como dar cualidades humanas a animales, con comportamientos semejantes, aunque el tratamiento del tema es para adultos. Sin embargo, a través de los personajes animales, introduce cuestiones y consecuencias sobre la guerra mundial, relacionadas con el suicidio de Mikolán. Desde esta perspectiva, el planteamiento es novedoso al introducir un cambio en la temática frente al moralismo de las bibliotecas anteriores.

El cuento La larva y el Águila, de autor desconocido, nos narra una historia situada en una montaña de Afganistán, habitada por Almír, sabio pobre, y Kaschilás, un cacique de la región capaz de matar a un niño cojo. Se establece un dialogo cuando, en una ocasión, Kaschilás, cae al fango a la vista de Almír, quien le dijo:

¿Qué caiga un ruiseñor herido no es extraño, pero lo que jamás observé en mi vida de solitario, es que un águila, sin daño alguno, se abata de modo tan fútil! iSi yo fuera fuerte te dispararía una flecha, miserable! ${ }^{723}$

La respuesta de Kaschilás fue:

- ¿Acaso tú, larva estúpida, puedes reír de mi caída? ¡Guárdete el demonio si no vienes a limpiarme de rodillas mis vestiduras!

Después, Kaschilás lo cogió de la cintura y lo arrojó a un gran charco. Amedrentado, Almír huyó de aquellos lugares llevándose todos los conocimientos adquiridos sobre remedios naturales. Llega a un mercado donde los vende y cura a la hija del general Mr. Lawilson de una picadura de alacrán que ninguno supo ver. En agradecimiento el general inglés le acompaña a Londres donde se convierte en un eminente científico. Vuelve a su país en una expedición y allí se encuentra con un prisionero condenado a muerte, Kaschilás. Aprovecha la ocasión y le hace ver quién es la larva y quién el águila. El final del cuento deja que cada uno saque su moraleja.

${ }^{723}$ ANTEQUERA AZPIRI, P. La larva y el águila. Burgos: Hijos de Santiago Rodríguez, p. 7. Ver ilustración a color de Pedro Antequera Azpiri en: Anexo 3.4.7. 


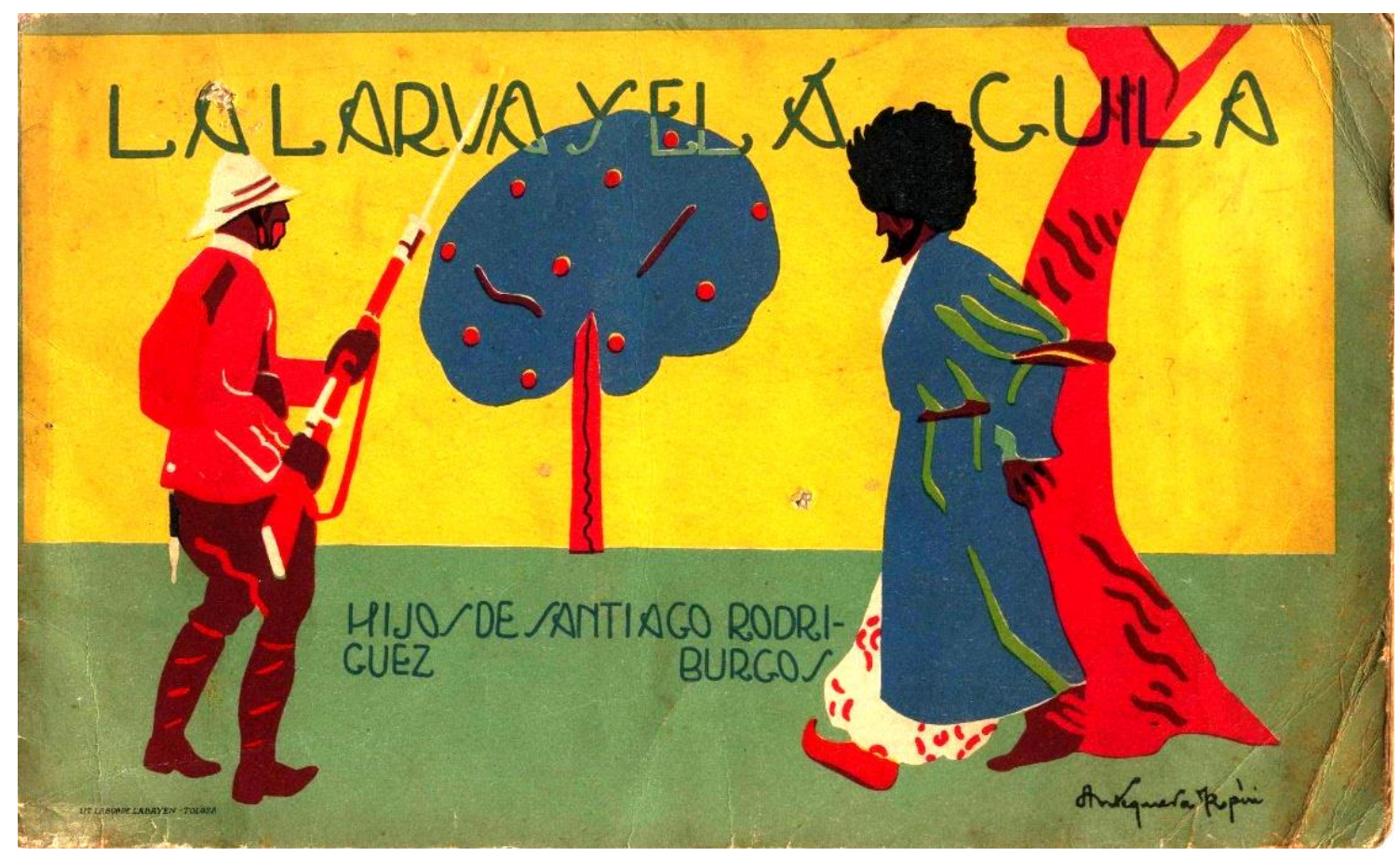

Fig. 6-44: Cubierta del cuento La larva y el águila de Antequera Azpiri. Biblioteca Cuentos Nuevos en Colores. Hijos de Santiago Rodríguez.

En ambos cuentos se sitúan los hechos en países lejanos, propio de la curiosidad de la época por conocer países y lugares exóticos. Aunque pueden parecer cuentos exclusivamente moralistas es evidente que presenta realidades sociales diferentes, propone cambios en la estructuración de la sociedad y en la necesidad de un conocimiento científico.

En estas últimas colecciones no sólo cambia la temática, visto desde el contenido de los cuentos, sino también la tonalidad y el carácter o tipo de ilustración. Hasta entonces, las ilustraciones afianzan el contenido con dibujantes como Evaristo Barrio e Isidro Gil que siguen una línea realista y costumbrista. En cambio, con la aparición del movimiento modernista, representado por Pedro Antequera Azpiri, en la editorial Hijos de Santiago Rodríguez, se revoluciona la impresión gráfica. Se desarrolla una mayor creatividad, de tonos más festivos, coloristas, con combinados de colores, principalmente amarillos, rojos, azules y verdes, que marcan un nuevo lenguaje, inusual en la ilustración. ${ }^{724}$

Se utiliza la agilidad de las líneas, principal característica del modernismo, para expresar sentimientos y emociones, así como la disposición de varias escenas sobre el plano, a veces lejanas y diminutas, con una perspectiva aérea muy original, junto a una visión humorística muy

\footnotetext{
${ }^{724}$ Vid. Anexos 3.4. Pedro Antequera Azpiri.
} 
destacada. ${ }^{725}$ Posiblemente, Pedro Antequera Azpiri sea uno de los grandes olvidados de los ilustradores de cuentos infantiles, de los años 1920-1930, que iguala en talento y arte a otros, como Penagos y Bartolozzi, en la ilustración de libros infantiles.

Pedro Antequera Azpiri fue pintor, caricaturista, dibujante y periodista. De origen vasco, nace en Madrid el 29 de junio de 1892; estudia derecho y dibujo. Recibe varios premios a corta edad. En 1917 obtiene la plaza de archivero interino, en la sección de Bellas Artes de la Biblioteca Nacional, y se mueve en los círculos artísticos de ciudades españolas y europeas.

Colabora en revistas, periódicos y en la ilustración de cuentos infantiles, con gracia y belleza, como los realizados para la editorial Hijos de Santiago Rodríguez. Interviene en las colecciones Regalo de Reyes, Papa-Moscas, Álbumes infantiles, Biblioteca Paz; en los libros, Vida de Robinson Crusoe, Los aventureros, Los tres sorianitos y Contando cuentos, Tradiciones y leyendas de Toledo, Quo Vadis y La publicidad Artística para todos; y, además, en un método de enseñanza, Dibujarás y pintarás.

Implicado en la causa republicana, cuando acaba la guerra civil es encarcelado y, tras una serie de traslados por diversas prisiones, fue puesto en libertad condicional, en noviembre de 1943. La salida de prisión fue dura ya que no encontró trabajo y tuvo que subsistir con colaboraciones anónimas de publicidad. En 1946 solicita el indulto, que no le sería concedido hasta 1948. Sigue colaborando con sus dibujos y textos en $L a$ Nación de Buenos Aires, como antes de la guerra. En los años 50 retoma su colaboración con $A B C$ y Blanco y Negro, gracias a su amistad con el director Juan Ignacio Luca de Tena. Fallece en septiembre de $1975 .{ }^{726}$

Sus numerosas ilustraciones perviven y sería buena noticia que saliese a la luz sus personajes fantásticos barbudos, los niños que reflejan una mirada pícara y curiosa, sus brujas, sus hadas, etc. Desde aquí rendimos un homenaje a algunos de sus personajes más desconocidos de esta Biblioteca (Figura 6-45).

\footnotetext{
725 Vid. Anexo 3.4.30. Presenta caricaturas de personajes sociales y zonas españolas visitando la Exposición Internacional de Barcelona en 1929.

${ }^{726}$ LERTXUNDI GALIANA, M. Retratos sobre la prisión. Pedro Antequera Azpiri y David Álvarez Flores [en línea]. San Sebastián: Koldo Mitxelena Kulturanea [fecha de consulta 14-4-2013]. Disponible en: https://kmk.gipuzkoakultura.net.
} 


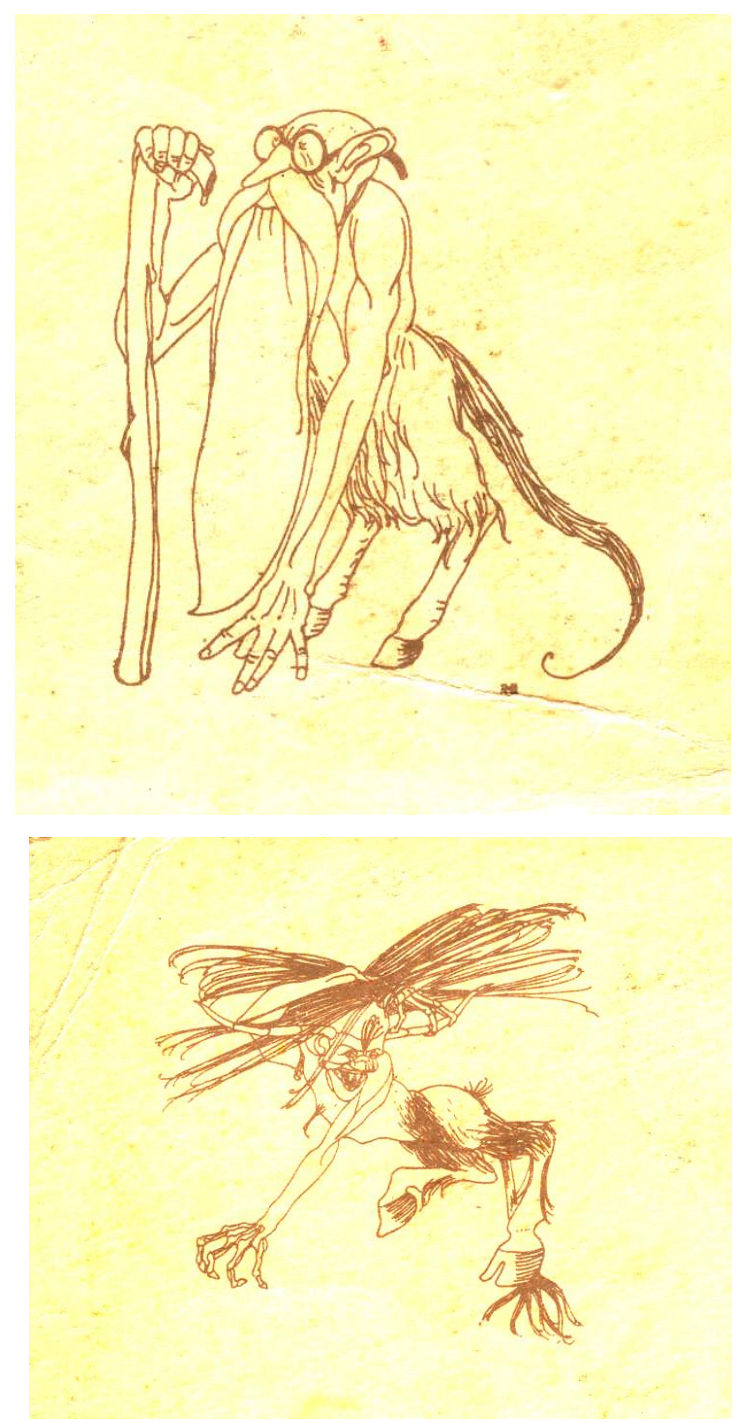

Fig. 6-45: Ilustraciones interiores del cuento La larva y el águila de Antequera Azpiri. Biblioteca Cuentos Nuevos en Colores. Hijos de Santiago Rodríguez.

CUADRO XIV: RELACIÓN DE TÍTULOS DE LA BIBLIOTECA CUENTOS NUEVOS EN COLORES EN LOS CATÁLOGOS DE LA EDITORIAL HIJOS DE SANTIAGO RODRÍGUEZ.

\begin{tabular}{|l|l|l|}
\hline CATÁLOGO & 1925 & 1929 \\
\hline La Historia de Narizotas & $\mathrm{x}$ & $\mathrm{x}$ \\
\hline La Larva y el Águila & $\mathrm{x}$ & $\mathrm{x}$ \\
\hline Mikolán y Compañía & $\mathrm{x}$ & $\mathrm{x}$ \\
\hline El Piratilla & $\mathrm{x}$ & $\mathrm{x}$ \\
\hline
\end{tabular}

Fuente: Catálogos de la Editorial Hijos de Santiago Rodríguez. Años 1925, 1929. Bibliotecas públicas y universitarias de España. CEINCE. Biblioteca Nacional de España. [Elaboración propia]. 


\subsubsection{Cuentos de Ayer y de Hoy}

Esta colección sólo aparece en el Catálogo de 1929, con cuatro cuentos publicados: Cuentos de Grimm, Lee estos cuentos, El Paraíso de los niños, y Para gente menuda. En las distintas bibliotecas únicamente se ha encontrado El Paraíso de los niños y, de una colección particular, Lee estos cuentos.

\section{Estructura externa}

Son volúmenes de tamaño $20 \times 14 \mathrm{~cm}$., de unas 80 páginas. Están encuadernados en pasta dura e ilustrados por Fortunato Julián, con cubiertas en cuatro colores. La contracubierta está configurada por el título de la colección, a color, y el emblema de la editorial, enmarcado en una greca de hojas y frutas a color. Cada tomo está formado por distintos cuentos, escritos por varios autores nacionales y extranjeros.

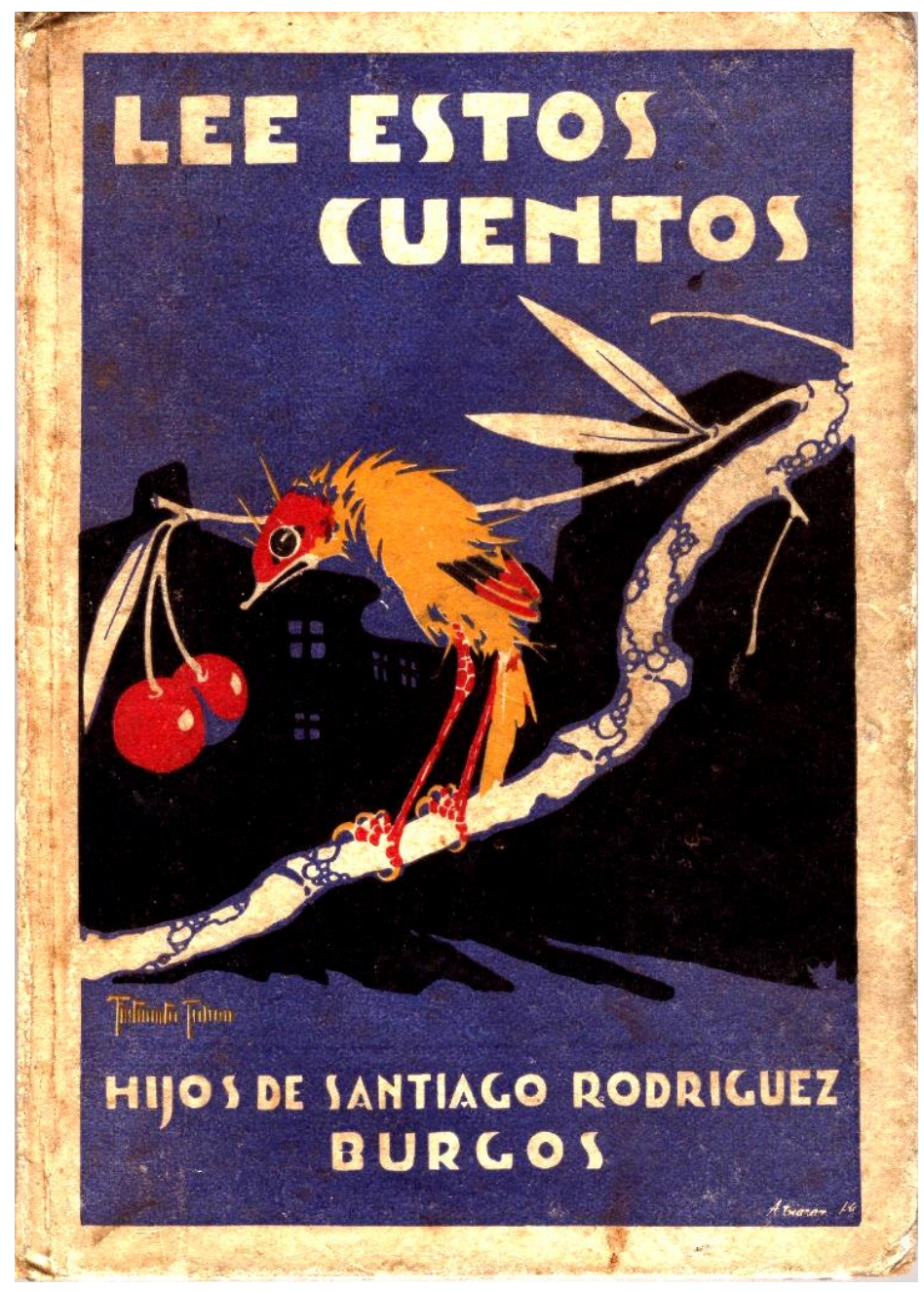

Fig. 6-46: Cubierta de Lee estos cuentos ilustrado por Fortunato Julián. Hijos de Santiago Rodríguez. 
Las ilustraciones de los diferentes cuentos están realizadas en su mayoría por Fortunato Julián, artista burgalés, que destaca en el diseño gráfico por la ilustración de libros y en la ilustración de sus cubiertas. Colabora de forma habitual con la editorial Hijos de Santiago Rodríguez, con sus dibujos de escenas infantiles. Transmite con acierto la sensibilidad de las diferentes épocas, pudiendo encontrar desde planteamientos realistas y costumbristas hasta las modernas tendencias de los años 20. En este último caso, los diseños, de atrevida modernidad, conviven junto a otros ligados a gustos más conservadores. Algunos de los títulos en los que participa son Mis amigos y El Arca de Noé (1918), en las colecciones Biblioteca Paz, Biblioteca Oro y otras numerosas obras de la época. ${ }^{727}$

Fortunato Julián García Hernando nace en Burgos, aunque de condición humilde, pues su padre era zapatero, apoyó y alentó los estudios de su hijo en la Academia de Dibujo desde 1904, donde obtuvo diversos premios. Marcha a Madrid para continuar estudios en la Escuela de Artes y oficios siendo galardonado con Premio Extraordinario en 1916. Regresa a Burgos, en 1919, como profesor de Arte Decorativo en la Academia Provincial de Dibujo. Fue secretario, a partir de 1936, y director al año siguiente hasta el curso 1962-63 en que se jubila. Trabaja y domina la mayoría de las especialidades artísticas. Muere en 1972. ${ }^{728}$

El único tomo al que hemos podido acceder -Lee estos cuentos ${ }^{-729}$ está formado por diversos cuentos:

- El Gigante arrepentido. Inspirado en un cuento de Oscar Wilde.

- El Sueño de Juan. Comenta los pasos de un camino físico y espiritual.

- Las cerezas de Pedro I. El título da origen a la ilustración del tomo y habla sobre Pedro I de Rusia que plantó unos cerezos y de cómo tuvo que compartir las cerezas con los pájaros.

- El Príncipe que conquistó un mundo y el que se contentó con menos. Cuento que narra los hechos acaecidos a dos hermanos príncipes, a la muerte de su padre. Amaro cuidaría la gobernación del Estado y Delio conquistaría tierras para añadir a su reino. Después de un año, donde cada uno había realizado su sueño, un genio expresa en el final que mejor que guerrear es vivir en paz, creando un mundo más justo e igualitario, como había hecho Amaro.

\footnotetext{
727 Vid. Anexos 3.3. Fortunato Julián.

728 ZAPAÍN YÁNEZ, M. J. Fortunato Julián García Hernando (1891-1972). En: L. S. IGLESIAS ROUCO, dir. Protagonistas burgaleses del Siglo XX. Op. cit., v. I, p. 69-72.

${ }^{729}$ Ver algunas ilustraciones de los cuentos que forman el libro en Anexos 3.3.6; 3.3.7.
} 
- Lección saludable. Cuenta cómo Carlos, un niño malcriado, cuando llega a la edad adulta, y muertos sus padres, dilapidó toda su fortuna. Acude a pedir ayuda a su tío que le hizo trabajar duramente hasta que hiciese un agujero en el agua. Tras dos años de fatigas, un día de invierno, descubrió que podía hacer un agujero en el hielo. Carlos aprendió una gran lección, volvió a ser rico y jamás abandonó el trabajo. La moraleja que se desprende es que la voluntad e inteligencia valen mucho más que el poder y la riqueza.

- La oruga. Narra cómo Pedro al salir del jardín oyó una voz de una oruga en forma de crisálida que le expresó que al igual que ella su suerte cambiaría y que se pusiese en un lugar sin peligros. El niño la recogió llevándola a su habitación y, cuando creía que lo había soñado, descubrió a una bella mariposa que le decía dónde podía encontrar, oculta debajo de un árbol, una jarra llena de monedas, salvando así a su familia de la miseria.

- La sombra del maestro. Un viejo maestro de escuela, D. Moisés, se aparece, una vez muerto, a un niño que entra en la escuela para coger la caja de caramelos del cajón del maestro. Ante tal aparición, promete que se comportará bien de ahora en adelante.

- Vale más maña que fuerza. En un lugar próximo al Himalaya, tenía fama entre todos el jardín de Sabih por la belleza y lozanía de sus flores y frutos. Un día entraron cuatro ladrones saqueando y destruyéndolo, pero Sabih utilizó la astucia para reducirles. 


\subsubsection{Albums Infantiles.}

Esta colección se presenta en los Catálogos de 1925 y 1929 como álbumes para los más pequeños. Con un tamaño de 36 x $24 \mathrm{~cm}$., contienen multitud de originales y atrayentes ilustraciones en su interior, realizadas por Fortunato Julián, en varios colores. Están encuadernados con artísticas cubiertas realizadas por Pedro Antequera Azpiri.

Se publicaron dos tomos: Mis Amigos y El Arca de Noé, ambos son dos abecedarios infantiles ilustrados; el último, con más de 50 dibujos de animales. Se publicita, en ambos catálogos, como el mejor y más útil de los regalos que se pueden hacer a niños y niñas de pocos años, para aprender a leer con gusto. Añade, que los niños y niñas recibirán este abecedario con la misma alegría que les proporcionaría el juguete más codiciado y sugestivo, pues resultará un pasatiempo instructivo y agradable. El precio de cada tomo de los Catálogos es de 2,50 pts.

Aunque no se ha encontrado ninguno de los dos "Albums", titulados Mis amigos y El Arca de Noé, el periódico local El Pueblo los presenta en el apartado de "Bibliografía" como libros de la última producción de la casa editorial Hijos de Santiago Rodríguez, en 1918:

Tratase de dos abecedarios ilustrados, con los cuales es indudable que será factible enseñar deleitando. Los niños encontrarán en ellos rica amenidad, amenidad que al volar de las hojas se convertirá en ventajosa instrucción.

Las portadas son debidas al notable dibujante Antequera Azpiri y los dibujos del texto del burgalés Fortunato Julián.

Siendo como decimos obras de recreación y enseñanza estos "Albums" creémonos en el deber de recomendarlo como bello regalo para los niños, útil, instructivo y de una gran distracción. ${ }^{730}$

\footnotetext{
${ }^{730}$ El Pueblo. Año I, nº 6, 28 de diciembre de 1918, p. 1.
} 


\subsubsection{Bibliotecas Paz}

En esta colección, compuesta de ocho tomos (Cuadro XIV), el contenido asimila una mezcla y variedad de cuentos que versan sobre arte, literatura, historia, narraciones, viajes, biografías, inventos, deportes, dibujos cómicos, pensamientos, fábulas, refranes, etc.

\section{Estructura externa}

Tienen un tamaño de 24 x $18 \mathrm{~cm}$., y de 130 a 170 páginas, impresos en papel pluma especial. Están encuadernados en pasta dura con ilustraciones a color, en la cubierta, mientras que en la contraportada mantiene el emblema de la editorial, a un color (Figura 6-50).

La primera obra de esta colección, Mi Libro de Navidad, fue publicada para su venta en diciembre de 1919 y, al mes siguiente, Mi Libro de Año Nuevo ${ }^{731}$, siguiendo estrategias publicitarias. Las cubiertas del primer libro fueron realizadas por Fortunato Julián, ${ }^{732}$ presentando a un abuelo cargado de paquetes de regalo, del cual tira su nieta; y en el segundo, un anciano rodeado de niños. (Figura 6-47). Este mismo autor, también ilustra la siguiente obra, Mi Libro de Reyes, publicada en 1922.

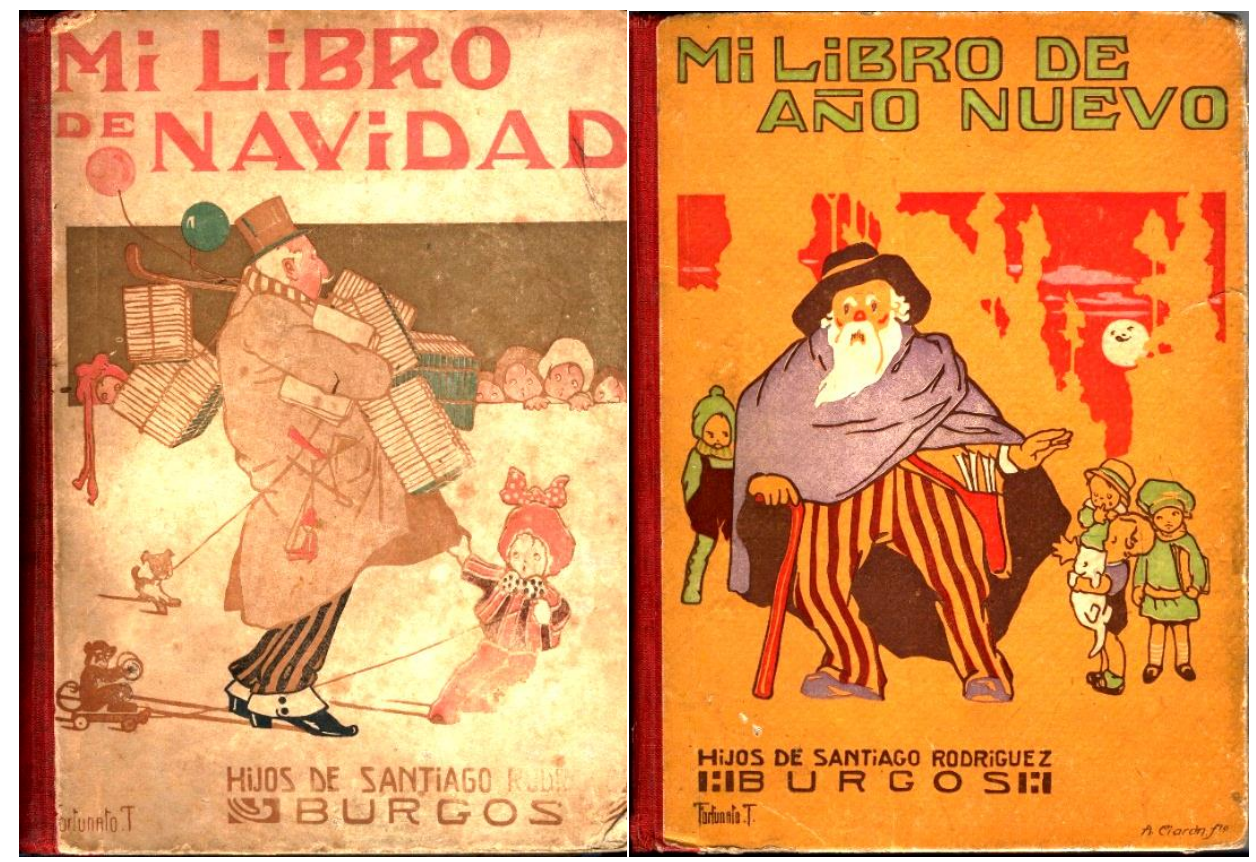

Fig. 6-47: Cubiertas de los dos primeros libros de Bibliotecas Paz, ilustrados por Fortunato Julián. Hijos de Santiago Rodríguez.

\footnotetext{
${ }^{731}$ El Pueblo. Año III, no 113, 5 de febrero de 1920, p. 2.

${ }^{732}$ Fortunato Julián también ilustró el interior como podemos observar en: Vid. Anexos 3.3.5; 3.3.8; 3.3.12; 3.3.15.
} 
Mi Libro de Vacaciones tiene una bella ilustración de Larraya: una cigüeña con una lombriz en el pico. Por otra parte, su título se asemeja al primer cuento, en clara referencia estacional y, posiblemente, comercial. Se desconoce el año de publicación, pero fue anterior a 1925 ya que en el Catálogo de dicho año aparece anunciado.

El siguiente libro de la colección, Mi Libro de Estampas y Cuentos, se publica antes de 1925 y su cubierta fue ilustrada por Pedro Antequera Azpiri; ${ }^{733}$ los siguientes, (Cuadro XV), fueron editados antes de $1927 \mathrm{y}$, el último, Mi Libro Ideal, el 7 de abril de 1933, con cubierta de Fortunato Julián. Se desconoce el autor o autores de las cubiertas de las otras obras.

Todos los libros tienen unas características y estructura similares. Contienen diversas fábulas, tanto en la portadilla como en la contraportadilla. Mantienen, al igual que el resto de las colecciones, un distintivo o logotipo que invita a la lectura. También publicita su lectura con dos dibujos, en la guarda y contraguarda, donde aparecen representados unos niños leyendo, en dos dibujos; unos, en torno a una estufa de carbón, en diversas posiciones y otros en la playa, alrededor de una barca para, de esta manera, invitar a la lectura durante todo el año. (Figura 6-48).

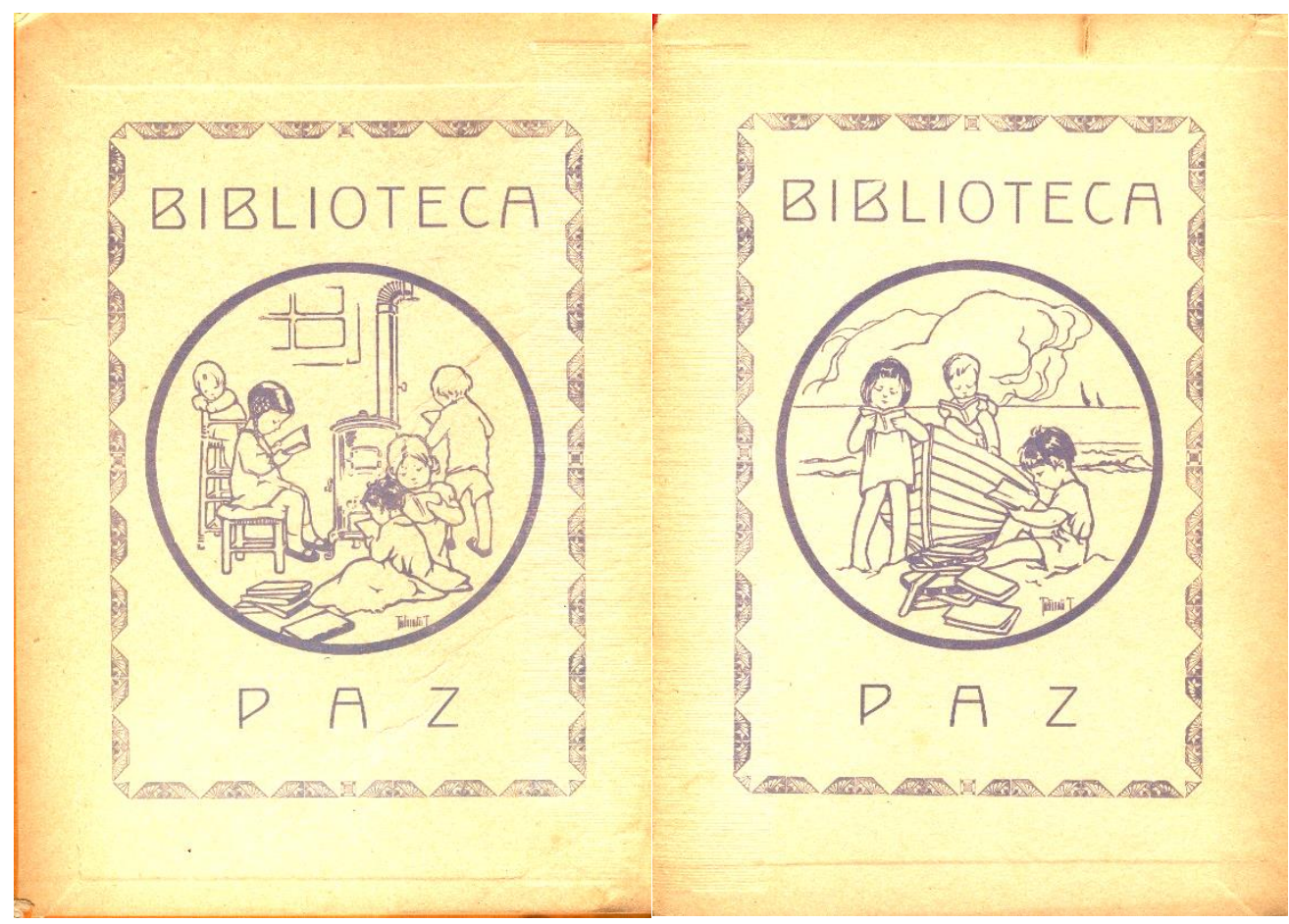

Fig. 6-48: Guardas ilustradas con el logotipo de Bibliotecas Paz, ilustradas por Fortunato Julián. Hijos de Santiago Rodríguez.

${ }^{733}$ En su interior observamos numerosas ilustraciones de Fortunato Julián. Ver algunos ejemplos en: Anexos 3.3.9; 3.3.16; 3.3.17; 3.3.18 y de Pedro Antequera Azpiri. Vid. Anexo 3.4.1; 3.4.27; 3.4.28. 
Según ediciones podemos ver algunas variantes como colocar los dos dibujos en ambas guardas, eliminar las fábulas, incluir grecas geométricas a color, en la portada, y poner sobrecubiertas, a modo de solapas, en cartulina blanca, con indicación de título, y dibujos de Fortunato Julián (Figura 649).
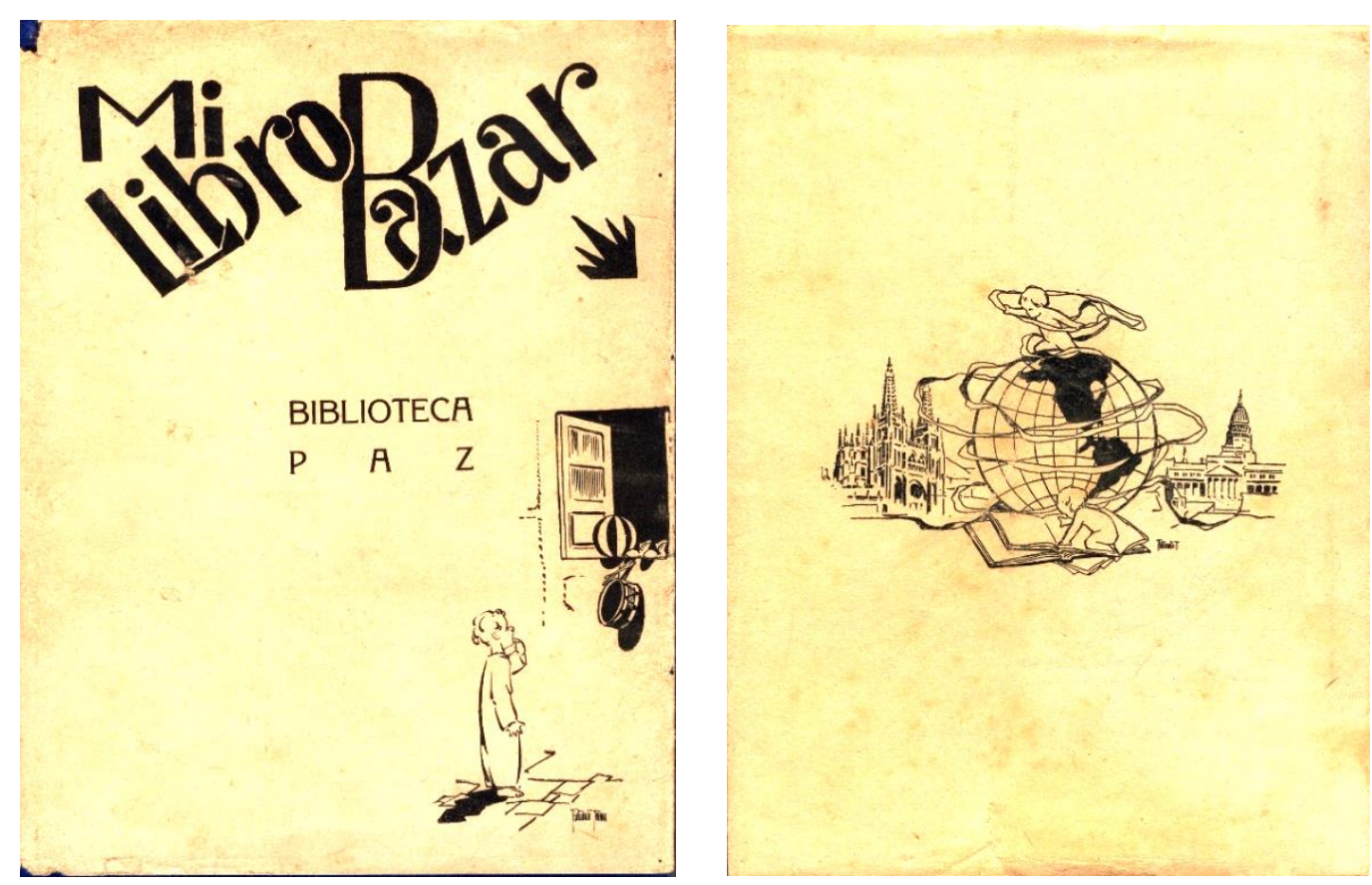

Fig. 6-49: Sobrecubiertas del libro Mi Libro Bazar.

Bibliotecas Paz. Hijos de Santiago Rodríguez.

Cada tomo porta una papeleta con números para un sorteo posterior y cuya resolución se incluye en la siguiente publicación. ${ }^{734}$ El precio de cada tomo es de 4,5 pts., según señala en el Catálogo Recuerdo de 1925, y de 5 pts. en el de 1929.

Bajo el pseudónimo Xácomé-Trezzo se escribe en El Papa-Moscas un amplio artículo sobre la técnica gráfica del libro que elogia a la casa editorial y a los ilustradores. En especial, a Fortunato Julián, junto a López Rubio, y el burgalés Manero. ${ }^{735}$ También, en La Voz de Castilla, se hace un encomiástico relato sobre el valor pedagógico y recreativo de la editorial con una nota de patriotismo, en el prólogo, al enviar un efusivo abrazo a los hermanos y niños de las repúblicas latinoamericanas. ${ }^{736}$

\footnotetext{
${ }^{734}$ Ver Figura 4-14.

${ }^{735}$ El Papa-Moscas. Año XL, no 2180, 28 de diciembre de 1919, p. 6.

${ }^{736}$ La Voz de Castilla. Año XI, no 572, 11 de enero de 1920, p. 3.
} 


\section{Contenido de los libros}

Tienen un formato original, alejado de los estándares al uso, con una mezcla de cuentos, leyendas, relatos, fábulas con curiosidades de historia, literatura, geografía, biografías de hombres célebres, descubrimientos, inventos e historietas cómicas realizadas por los mejores dibujantes de la época.

Toda la colección va dirigida a los niños para su recreo y enseñanza. Desde el primer libro, nos habla de la lengua común inmortalizada por Cervantes, que une a familias que se encuentran a muchas millas. La colección está dirigida hacia al público hispanoamericano, con intención de incrementar las ventas.

Como ejemplo, observamos que en el prólogo de Mi Libro de Estampas, escribe:

La biblioteca Paz saluda a todos los niños y niñas de España y América, y les ofrece este libro, esperando que en sus páginas hallarán todo lo necesario para recrearse, aprender y divertirse.

El simpático "Rodriguete" está ahora ocupadísimo preparando dos nuevos y estupendos tomos de esta misma biblioteca, que pronto aparecerán en los escaparates de todas las librerías, con los títulos de MI LIBRO PREDILECTO Y MI LIBRO DE RECREO.

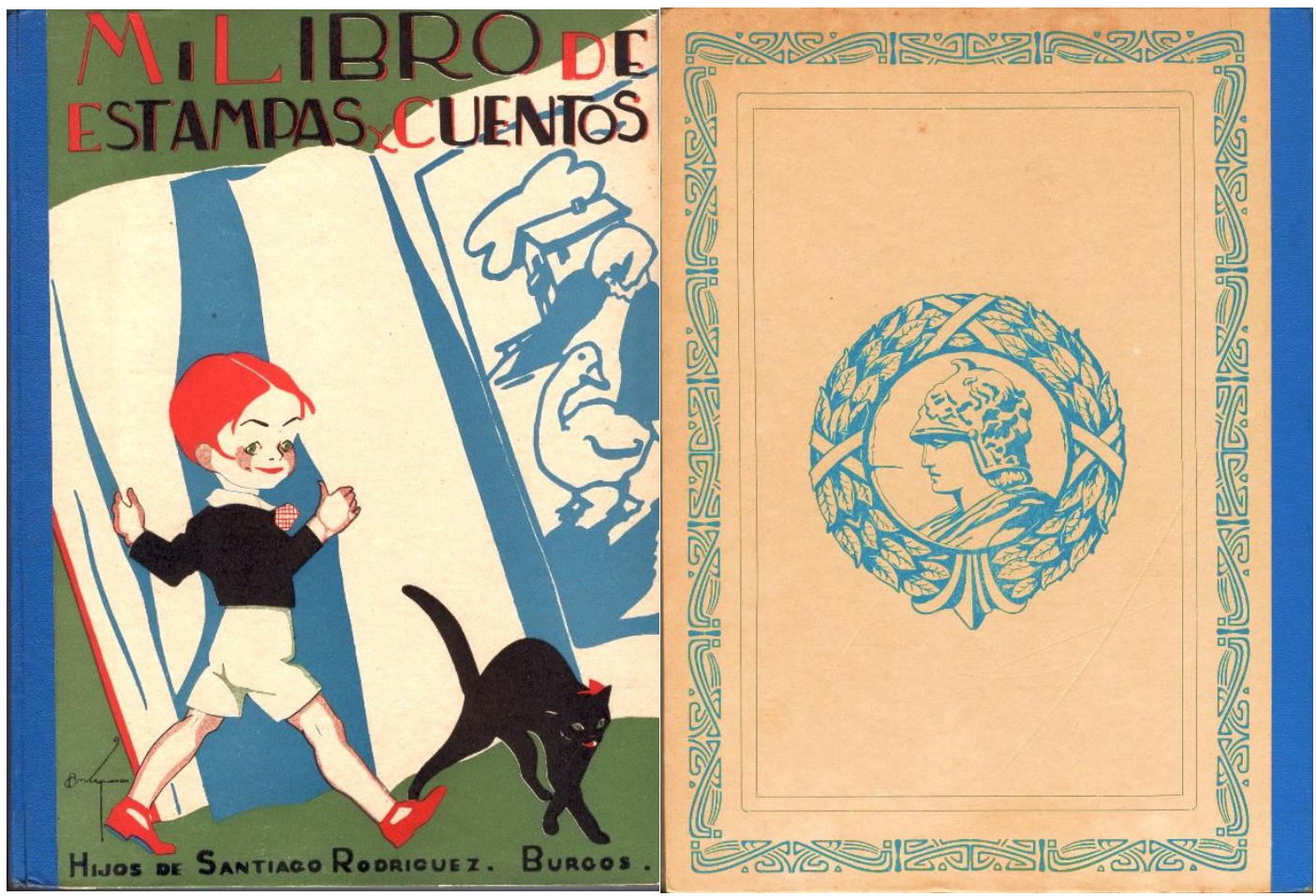

Fig. 6-50: Cubierta y contracubierta de Mi Libro de Estampas y Cuentos. Bibliotecas Paz. Hijos de Santiago Rodríguez. 
Asimismo, Jose $\mathrm{M}^{\mathrm{a}}$ Salaverría, novelista, poeta, ensayista y gran viajero, escribe en el prólogo de Mi Libro Bazar unas bellas palabras, incitando a la lectura:

Hasta los grandes almacenes, esas enciclopedias mercantiles, esos bazares cósmicos donde es posible hallar todas las cosas inimaginables, se les reserva ya a los libro de regalo un sitio junto a los montones de juguetes. Ya no son únicamente los caballos de cartón, los automóviles de cinc y las muñecas de trapo o de celuloide los juguetes que en la Noche de Reyes pueden acalorar las imaginaciones de los chicos; un haz de cuentos ilustrados con fantasía otorgan, en efecto, al alma infantil proyecciones placenteras mucho más hondas que todos los juguetes tradicionales. ${ }^{737}$

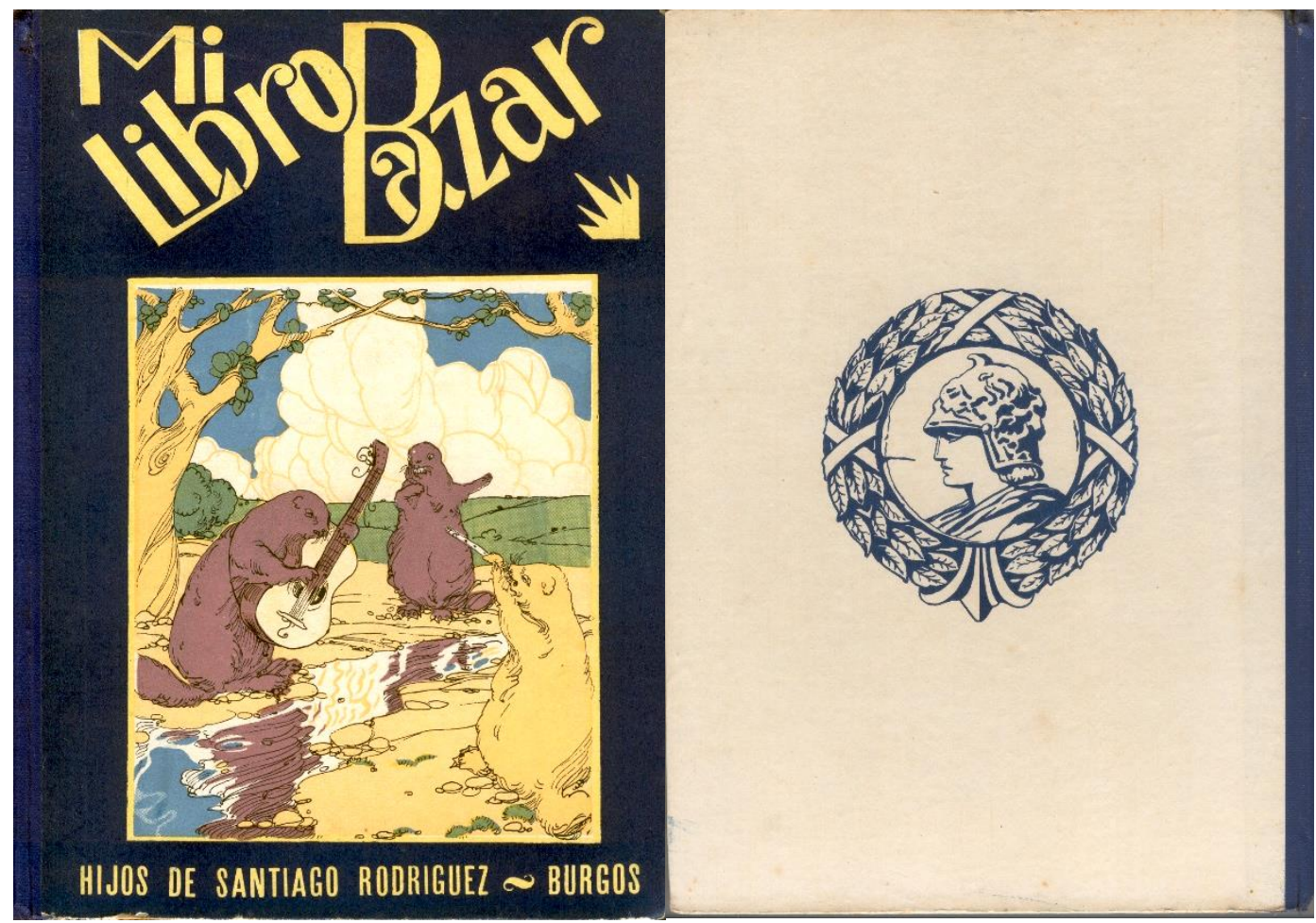

Fig. 6-51: Cubierta y contracubierta de Mi Libro Bazar. Bibliotecas Paz. Hijos de Santiago Rodríguez.

En el mismo sentido, el prólogo de la última obra de esta colección, $M i$ Libro Ideal, participa del entusiasmo por la lectura y el conocimiento de los pueblos latinoamericanos:

En el primer tomo aparecido en esta colección de título Mi libro de Navidad, los editores mandaron un saludo cordial y efusivo a todos los niños y niñas de la América española. Del viejo solar castellano brotó este cariñoso saludo para la juventud de "los veinte pueblos -como dijo Gómez Carrillo- que fueron territorios de la Corona de Castilla y que hoy son comarcas de la lengua y el espíritu nacionales y que están aún unidos a la antigua metrópoli por la letra impresa". Las

${ }^{737}$ VV. AA. Mi Libro Bazar. Burgos: Hijos de Santiago Rodríguez, 1928, p. 8. 
flechas gemelas de la Catedral de Burgos lanzaron al espacio este mensaje de salutación, que cruzó los mares para llegar hasta los pequeños lectores que viven en tierras lejanas, separadas por la distancia, pero unidas por el idioma común, bello, expresivo, sonoro, armonioso, inmortal..., lazo el más fuerte y duradero de cuantos existen.

Hoy, al publicar el tomo último de esta BIBLIOTECA PAZ que tan favorable acogida alianza aquí y allá, los editores se complacen recogiendo y publicando aquí, en lugar preferente, el fraternal mensaje enviado por los niños argentinos o los españoles. Dice así:

"El día de la raza rememora una de las más trascendentales gloria de la humanidad y el gesto más solicitado de nuestra madre patria al descubrimiento de un nuevo Mundo. Niños españoles y argentinos unámonos en un fuerte abrazo fraternal, acortando la distancia del inmenso océano, que materialmente nos separa y espiritualmente nos une"

Alumnos de $6^{\circ}$ grado de las Escuelas $n^{\circ} 21$ de Apóstoles-Misiones (República Argentina) y enviado al embajador de la Argentina en Madrid, el señor $G^{a}$ Mansilla en $1930 .{ }^{738}$

Los autores de cuentos y artículos de los tomos publicados forman parte de un grupo de escritores menos conocidos o estudiados por la literatura, especialmente la infantil. En esta colección, aparecen nombres como José Ortiz de Pinedo, Ángel Menoyo Portalés, Ángel Arbeo, Pedro Díez Pérez, Augusto Riera, Ángel Martínez Zapater, Vicente M. de Murviedro y Pascual Rodríguez Escudero, entre otros.

José Ortiz de Pinedo, de ascendencia burgalesa, nace en Jaén, el 20 de febrero de 1880, por la profesión militar de su padre. Cursa estudios de bachillerato en Guadalajara y se licencia en Derecho en Madrid. Colabora en periódicos de orientación republicana y se relaciona con escritores de reconocido prestigio de la bohemia madrileña. ${ }^{739}$ Escribe para la editorial varias obras, entre ellas una de teatro sobre la noche de Reyes titulada "La cabalgata de la ilusión", y un cuento original "La sombra del Maestro". Este cuento publicado en varias Bibliotecas relata, en tercera persona, los sucesos de un anciano maestro, D. Moisés, con su díscolo alumno Ángel, presentando una realidad social de infortunio, de la viudedad de la madre y la abuela del pequeño, viendo en el niño el nieto que nunca tuvo.

Pedro Díez Pérez fue profesor auxiliar de la Escuela Normal de Maestros de Burgos, Sección de letras, en el bienio 1926-1928. Militante socialista, director de la Escuela Normal de Santander e impulsor de las Misiones Pedagógicas fue apresado por las tropas sublevadas y fusilado en

\footnotetext{
738 VV.AA. Mi libro Ideal. Burgos: Hijos de Santiago Rodríguez, 1930, p. 3.

${ }^{739}$ CRUZ QUINTÁS, J. M. Algunos episodios biográficos de José Ortiz de Pinedo. Un escritor jaenés en el Madrid de la primera mitad del siglo XX. Elucidario: Semanario bio-bibliográfico Manuel Caballero Venzalá, 2007, [fecha de consulta 15-1-2013]. Disponible en: http://dialnet.unirioja.es/descarga/articulo/2523266.pdf.
} 
Oviedo, el 24 de abril de $1937 .{ }^{740}$ Durante su estancia en Burgos, escribe varios artículos en los libros de la Biblioteca Paz editados en estos años: Andersen, cuento biográfico, Del Antiguo y maravilloso Egipto, Las campanas y Las posesiones españolas en África.

Pascual Rodríguez Escudero, -hijo de Mariano Rodríguez Miguel- sigue los pasos de su padre, lleva la gerencia de la empresa y escribe artículos para esta colección, bajo las siglas P. R. E., como El pequeño cicerone toledano, Mi primera visita al museo del Louvre, De tejedor a multimillonario y A través del Atlántico.

Ángel Menoyo Portalés escribe para la editorial, otros libros descritos anteriormente, y es considerado uno de los escritores secundarios de la generación del 98, sin que dicho adjetivo denote inferioridad. Entre sus obras destacaremos: Los gorriones del retiro, El príncipe Flicto, La mano de la providencia y La gratitud.

De Ángel Martínez Zapater solo conocemos que fue inspector de $1^{\mathrm{a}}$ enseñanza, en Albacete, y escritor de artículos y cuentos en diversos libros de esta colección. De otros autores, como Ángel Arbeo, Augusto Riera y Vicente Rodríguez de Murviedro, se desconocen datos biográficos pero escriben numerosos artículos y cuentos en estos libros de la Biblioteca Paz.

Muchos artículos sobre páginas de arte, vida de autores, deportes, datos, sucesos y curiosidades, no llevan autor, por lo que entendemos que la propia editorial haría esa labor de selección.

Además de fábulas, algunas de autores españoles y otras extranjeras, en la mayoría de los libros se narran algunos de los cuentos de los hermanos Grimm. También, para esta colección contribuyen, con diversas publicaciones, José Ortega Munilla y Rafael Pombo.

Las ilustraciones corren a cargo de importantes artistas como Robledano, Francisco López Rubio, Antequera Azpiri, Emilio Ferrer, Gutiérrez Larraya, Fortunato Julián, Basilio, Prada y otros.

En aquellos momentos, aparecen nuevos conceptos estéticos que proponían la superación radical de las corrientes decimonónicas en las que la imagen estaba al servicio del texto, de forma que todos los elementos literarios, plásticos y gráficos formasen un todo unitario. Y si bien, estas

740 GUTIÉRREZ FLORES, J.; OBREGÓN GOYARROLA, F.; GUDÍN DE LA LAMA, E.; MENÉNDEZ CRIADO, E. Entre la espada y la pared. La represión del profesorado cántabro durante la Guerra civil y la postguerra. Santander: Asociación de Investigadores e Historiadores de la Guerra Civil y el Franquismo, 2011, p. 56. 
novedades se perciben con más prontitud en Madrid y Barcelona, la editorial Hijos de Santiago Rodríguez introduce las influencias a finales de la primera década, en las colecciones anteriormente descritas, como en Regalo de Reyes, Papa Moscas y Cuentos Nuevos en Colores, en las que tendrá una mayor visibilidad.

El estilo se caracteriza por la presencia de figuras alargadas, un gusto por la línea precisa y clara, con fuertes contrastes entre blancos y negros, que evoluciona hacia una mayor simplicidad, con formas suaves $y$ redondeadas, donde se pretende sumar la formación estética de los lectores, más allá de la instrucción. ${ }^{741}$

También la historieta cómica tuvo un lugar propio en esta colección, al contar con ilustradores que colaboraban en las principales publicaciones periódicas españolas.

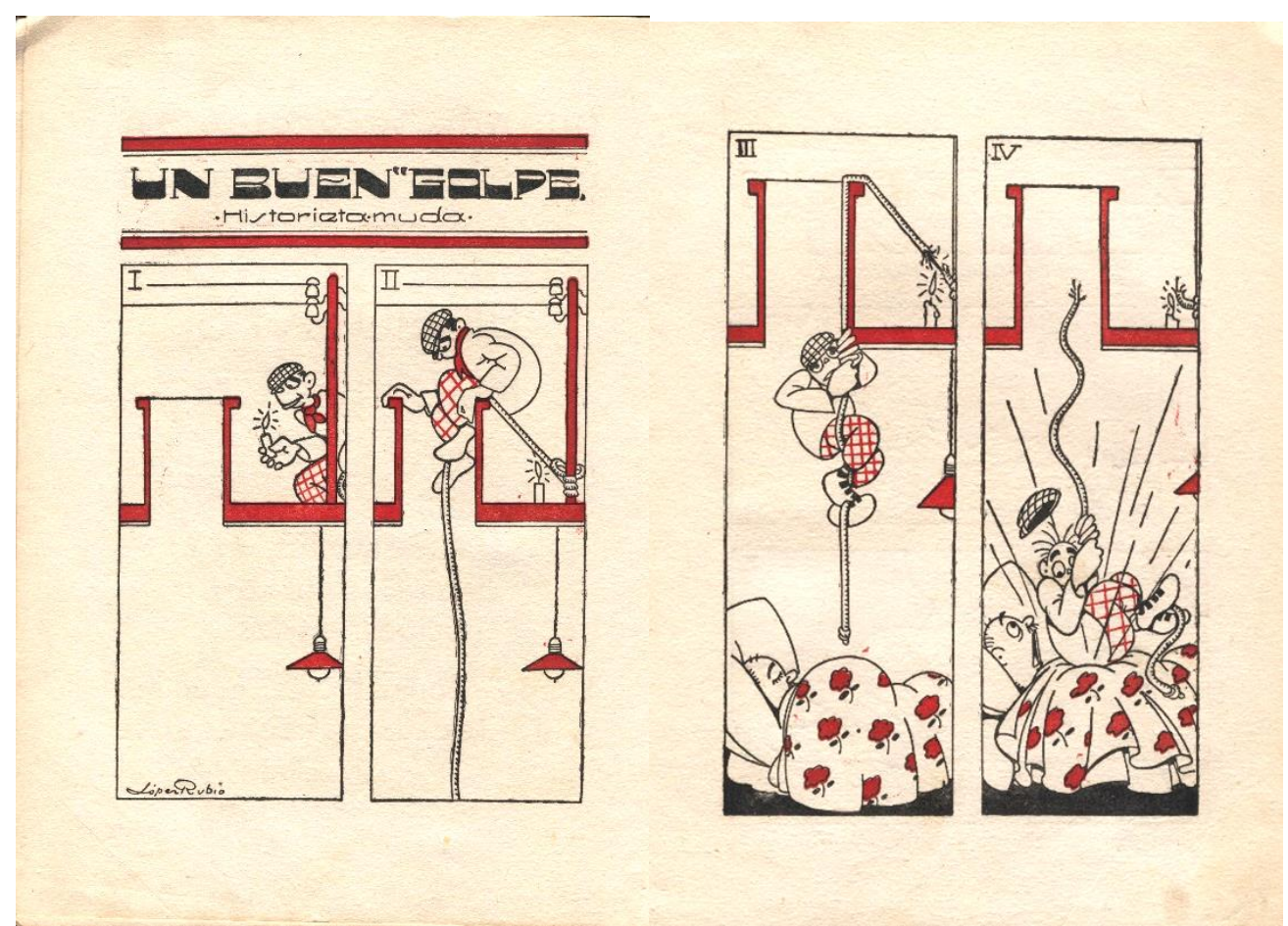

Fig. 6-52: Historieta muda "Un buen golpe" de Francisco López Rubio en Mi Libro de Año Nuevo. Bibliotecas Paz. Hijos de Santiago Rodríguez.

Francisco López Rubio es un gran dibujante de estilo esquemático y dominio de la línea, con predominio de las formas geométricas inspiradas en la fórmula moderna de "menos es más". Fue, en la Exposición Nacional de Bellas Artes, en 1920, donde se consolidó como dibujante de los principales periódicos de la época, como El Sol y Vida Nueva, y en un sinfín de revistas. En 1928, comienza su colaboración en Blanco y Negro y, posteriormente, en el suplemento infantil Gente Menuda. Durante la guerra civil vivió en la semiclandestinidad para después de terminada volver a

${ }^{741}$ GARCÍA PADRINO, J. Op. cit., pp. 41-49. 
colaborar en ABC. Se hizo popular por la creación de personajes como el conejo Roenueces, don Oppas, el mago Pirulo, el profesor Bismuto y los pequeños Lita y Lito. $^{742}$

Para la Biblioteca Paz realiza varias tiras cómicas: ${ }^{743}$ Donde las dan, las toman ${ }^{744}$ El suicidio de D. Pero ${ }^{745}$ y Las víctimas de la ciencia, ${ }^{746}$ todas ellas historietas publicadas en Mi Libro de Reyes; en Mi Libro de Navidad, otras como El beso de dos golosos ${ }^{747}$ y El trampolín improvisado ${ }^{748}$ y en Mi Libro de Año Nuevo, La caza de la pantera ${ }^{749}$ Tiempo aprovechado ${ }^{750}$ Un buen golpe (figura 6-52) y El último recurso que, como novedad, sitúa al personaje principal fuera de la viñeta (Figura 6-53).

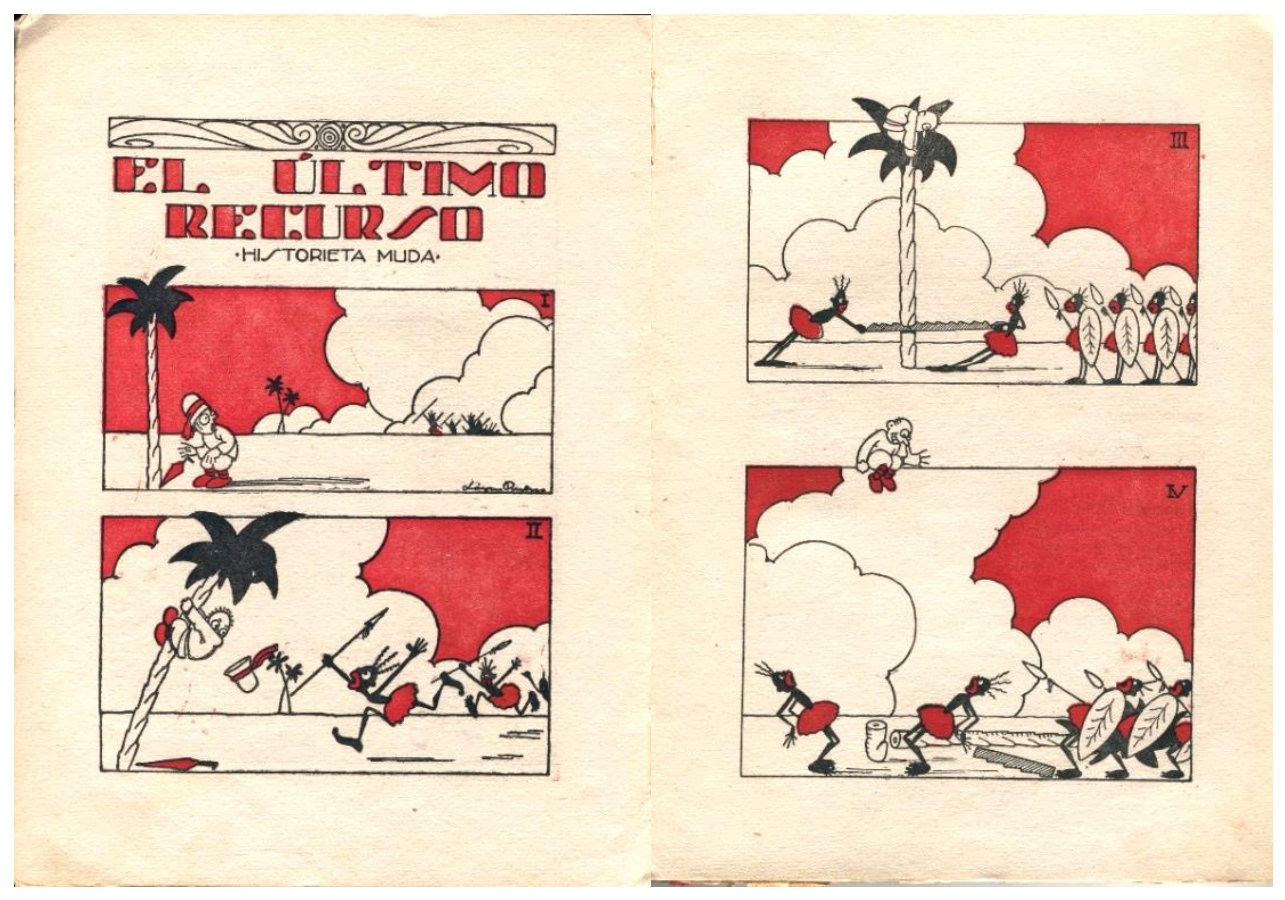

Fig. 6-53: Historieta muda "El último recurso" de Francisco López Rubio en Mi Libro de Año Nuevo. Bibliotecas Paz. Hijos de Santiago Rodríguez.

\footnotetext{
742 Varias exposiciones en estos años devuelven a la memoria la importante figura de un gran dibujante. Ver: Francisco López Rubio. Maestro de la línea clara. [en línea]. Museo ABC. Madrid: 4 dic de 2012 a 20 de enero 2013. [fecha de consulta 18-8-2014]. Disponible en: http://museo.abc.es/exposicion.php?lang=es\&id=178; El dibujo de un maestro de la línea clara. Francisco López Rubio. [en línea]. Granada: Centro de Exposiciones CajaGRANADA. Puerta Real. Del 24 de enero al 30 de marzo de 2014. [fecha de consulta 18-8-2014]. Disponible en: http://www.hoyesarte.com/evento/2014/01/maestro-de-la-linea-clara/

743 Vid. Anexo 3.6.5.

${ }^{744}$ Vid. Anexo 3.6.6.

745 Vid. Anexo 3.6.7.

746 Vid. Anexo 3.6.8.

747 Vid. Anexo 3.6.3.

748 Vid. Anexo 3.6.4.

749 Vid. Anexo 3.6.1.

750 Vid. Anexo 3.6.2.
} 
Continúa su colaboración en la siguiente colección de libros, Bibliotecas Rodríguez, con las bellas ilustraciones de los Cuentos de Pototo. ${ }^{751}$

Emilio Ferrer Cabrera (1888-1962) fue pintor especializado en escenas y tipos costumbristas de su región valenciana, e ilustrador en diferentes revistas gráficas, particularmente en La Esfera. Se desconoce la relación con la editorial pero plasma varias historietas en Mi Libro Bazar, ${ }^{752}$ como A falta de antena, Siempre se exagera un poco, Recompensa merecida, Vaya un juego, y en Mi Libro Ideal, ${ }^{753}$ La duda del hijo de Guillermo Tell y Fábula.

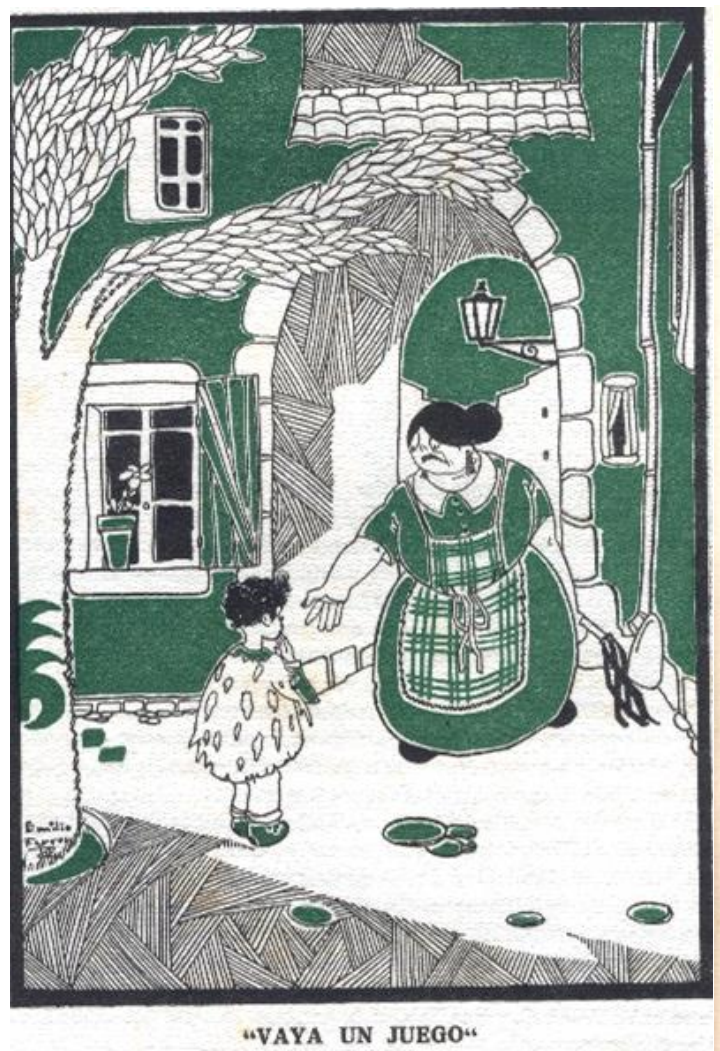

A FALTA DE ANTENA.... HISTORIETA POR EMILIO 'FERRER
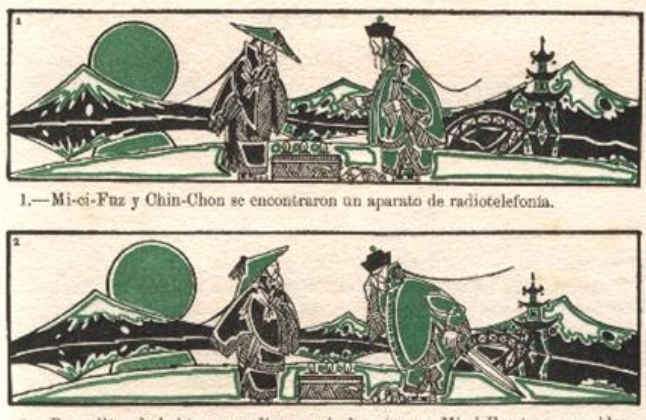

2. - Pero alli nada habia que padiers servir de untera, $y$ Mi-ci-Pus lavo una idea.

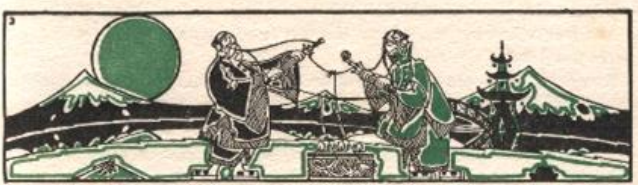

3.-Cogieron las colectes, las atancon por las puntas, pusieron los dos paraguss en lugur de madens $y . .$.

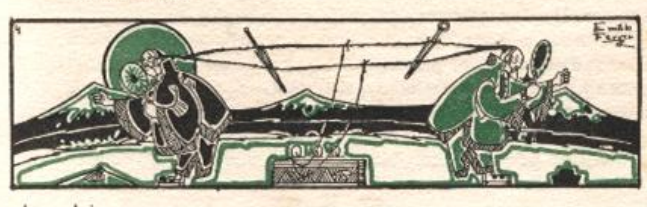

4,- -....Asi se recrearou.

Fig. 6-54: Historietas cómicas de Emilio Ferrer en Mi Libro Bazar. Bibliotecas Paz. Hijos de Santiago Rodríguez.

Rosario Velasco, que ya había puesto su firma años antes en Cuentos para soñar, de $\mathrm{M}^{\mathrm{a}}$ Teresa León, y Cuentos a mis nietos, de Carmen Karr, ilustra varios cuentos del último libro de la colección. En ellos, Los dos zagales, El príncipe y sus compañeros de viaje, La grulla y Seres

\footnotetext{
${ }^{751}$ Vid. Anexo 3.6.9; 3.6.10; 3.6.11.

${ }^{752}$ AA.VV. Mi Libro Bazar. Burgos: Hijos de Santiago Rodríguez, pp. 17, 41, 48-49, 105.

753 AA.VV. Mi Libro Ideal. Burgos: Hijos de Santiago Rodríguez, 1933, pp. 112 y en la guarda anterior a la portada.
} 
abnegados, ${ }^{754}$ se puede observar una mayor suavidad en las líneas, con formas más redondeadas, y un mayor número de detalles en sus dibujos.

CUADRO XV: RELACIÓN DE TÍTULOS DE LA BIBLIOTECA PAZ EN LOS CATÁLOGOS DE LA EDITORIAL HIJOS DE SANTIAGO RODRÍGUEZ.

\begin{tabular}{|l|l|l|}
\hline Títulos & \multicolumn{1}{|c|}{$\begin{array}{c}\text { CATÁLOGO } \\
1925\end{array}$} & $\begin{array}{c}\text { CATÁLOGO } \\
1929\end{array}$ \\
\hline Mi Libro de Navidad & $\mathrm{x}$ & $\mathrm{x}$ \\
\hline Mi Libro de Año Nuevo & $\mathrm{x}$ & $\mathrm{x}$ \\
\hline Mi Libro de Reyes & $\mathrm{x}$ & $\mathrm{x}$ \\
\hline Mi Libro de Vacaciones & $\mathrm{x}$ & $\mathrm{x}$ \\
\hline Mi Libro de Estampas y Cuentos & $\mathrm{x}$ & $\mathrm{x}$ \\
\hline Mi Libro de Recreo & & $\mathrm{x}$ \\
\hline Mi Libro Bazar & & $\mathrm{x}$ \\
\hline Mi Libro Ideal & & $\mathrm{x}$ \\
\hline
\end{tabular}

Fuente: Catálogos de la Editorial Hijos de Santiago Rodríguez. Años 1925, 1929. Bibliotecas públicas y universitarias de España. CEINCE. Biblioteca Nacional de España. [Elaboración propia].

${ }^{754}$ Vid. Anexos 3.7.4; 3.7.5; 3.7.6; 3.7.7. 


\subsubsection{Biblioteca Rodriguez}

Es la última Biblioteca, publicada en los años 20, de la que se poseen referencias desde el Catálogo Recuerdo de 1925, autocitándola como la más selecta y mejor presentada, con destino a la juventud.

...como la expresión más delicada y exquisita de lo que se merecen esas nuevas generaciones de infatigables lectores... unir a ella, para mayor prestigio y como prueba de mayor acierto, el nombre de las primeras figuras de nuestra literatura contemporánea, que hasta ahora tenían casi olvidado al público infantil[...]

Por eso, en su nombre y en el nuestro propio, agradecemos y estimamos en lo mucho que vale la honrosa colaboración y la excepcional cesión de que hemos sido objeto por parte de nuestros grandes literatos. Todos, con noble desinterés y entusiasmo, aceptaron nuestra invitación de escribir algo para los hombres de mañana, y tuvieron para nuestra idea original palabras de aliento y estímulo que no olvidaremos.

Quisimos también y creemos haberlo conseguido que cada tomo de esta Biblioteca fuera una prueba fehaciente de presentación moderna y artística, poco frecuente en esta clase de libros. Y así, el prestigio de la firma literaria resulta avalorado por la gracia atractiva de una ilustración abundante, esmerada y originalísima debida a inspirados artistas de sólido renombre. ${ }^{755}$

Forman la colección ocho tomos (Cuadro XVI) de un tamaño de $25 \mathrm{x}$ $19 \mathrm{~cm}$., con un total de 100 a 160 páginas, impresas en papel pluma ahuesado. Las cubiertas aportan diferentes y originales dibujos tricolores, estampados y colocados sobre cartulina de color. La contracubierta porta el emblema de la editorial. Hay dos clases de libros, según su encuadernación: en cartoné, con un precio de 8 pesetas, y de lujo en tela, con planchas y canto dorado, por 12 pesetas. En la portadilla encontramos el dibujologotipo ilustrado de la Biblioteca Rodríguez donde un niño y una niña posan, encima de un libro como si fuese un barquito, rodeados de patos (Figura 6-55). Las portadas están profusamente ilustradas.

${ }^{755}$ CATÁLOGO 1925, pp. 85-86. 


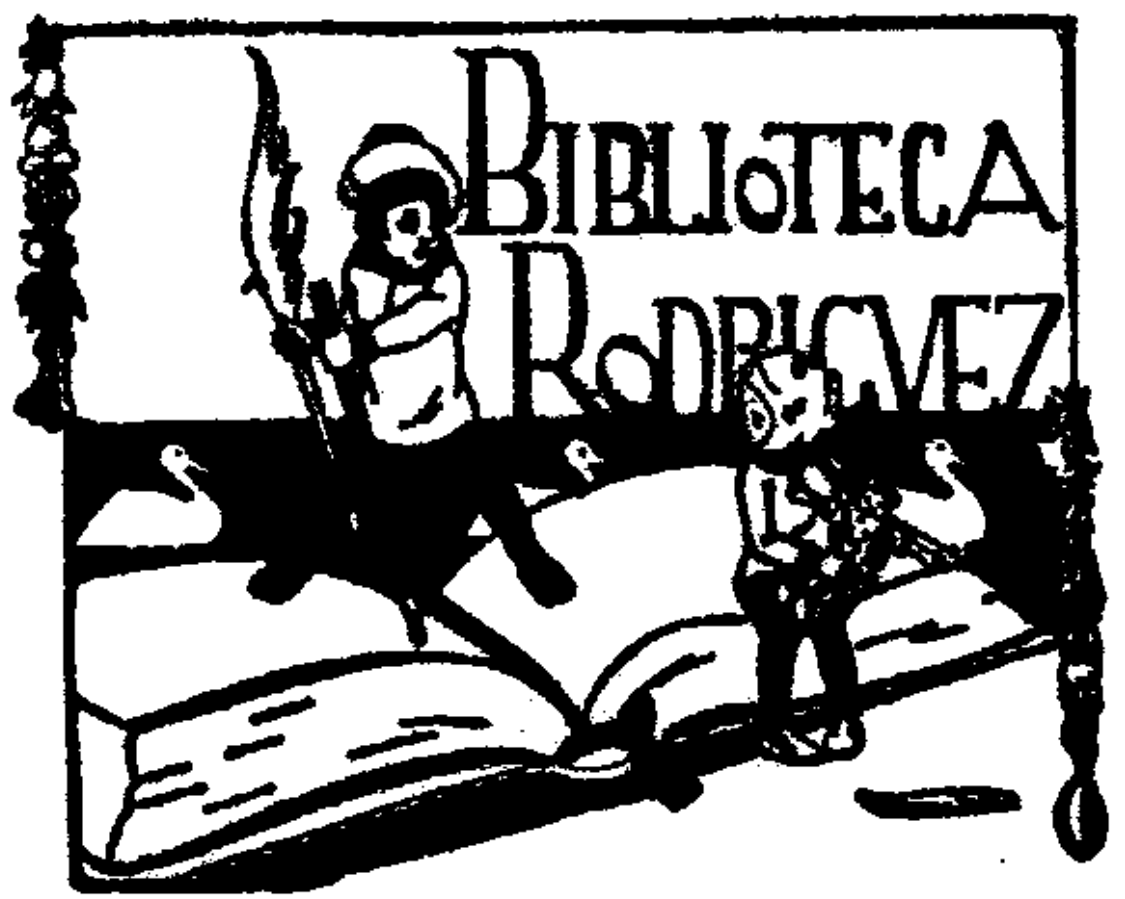

Fig. 6-55: Logotipo de la colección Biblioteca Rodríguez.

Hijos de Santiago Rodríguez.

El primer libro de esta Biblioteca, Los aventureros, escrito por Manuel Linares Rivas, político y dramaturgo español, narra con un picante buen humor galaico, encantamientos de hadas, viajes y despropósitos. Ilustrado en negro y en color por Antequera Azpiri, sale al público en octubre de 1919, según nos detalla el periódico burgalés La Voz de Castilla y sobre el que se explaya con grandes elogios.

En el cuento de Linares es amena la descripción; deleita la sencillez. expositiva del asunto; hay en casi todas las páginas una agridulce ironía, y bajo ella, en apariencia inocente gracejo de la frase, late el pensamiento educador. No se puede con más acierto - el de dar a conocer esta delicada obra del escritor insigne- inaugurar la serie de las que han de formar tan exquisita biblioteca.

Tal vez hubiera convenido, para su más cómodo transporte y manejo, que el tamaño de los volúmenes fuera más reducido.

Pero esto es lo de menos; lo importante es y por ello no escatimamos el justo elogio que además de impresionarnos gratamente la parte literaria y las originales y bellísima ilustraciones de Antequera Azpiri, nos satisface y mueve a simpatía el saber que la parte editorial, toda ella-cubierta, tricolores, texto- ha sido ejecutada en los talleres de la Casa Rodríguez, compitiendo el trabajo, por 
su perfección y arte, con cualquiera otro de importante establecimientos similares del extranjero. ${ }^{756}$

Este bello cuento, articulado en trece capítulos, relata las aventuras de tres muchachos (Juan, Luis y Miguel), oriundos de un recóndito pueblo de la montaña palentina, que quieren conseguir riqueza, poder y felicidad. El final nos aclarará que todo fue un sueño. Contiene 27 ilustraciones, en blanco y negro, de Pedro Antequera Azpiri, con dibujos que caricaturizan los rasgos marcados de las personas de la montaña y con la silueta de los personajes en negro, característica del dibujo de Azpiri. También tiene intercaladas sobre cartulina cinco imágenes tricolores, del mismo autor.

Vida y Aventuras de una Muñeca española en Rusia, escrito por Sofía Casanova e ilustrado por Gutiérrez Larraya, fue publicado en diciembre de 1920. En aquella época, la autora escribía artículos, con gran profusión, y viajaba a España en numerosas ocasiones, aunque vivía en Varsovia. Narra, por boca de una muñeca, su nacimiento cuando es comprada por una familia y viaja desde España a Varsovia, pasando por París, hasta llegar a Moscú y San Petersburgo. Posteriormente regresa a Varsovia, después de la $1^{a}$ Guerra Mundial, donde permanecerá con la niña para siempre. Los viajes son el hilo conductor para contar las situaciones bélicas de la guerra, cuando el avance alemán les indujo a evacuar Varsovia y dirigirse a Rusia, donde sufrieron los movimientos revolucionarios que acabarían con la familia del zar. Son, en realidad, las experiencias y recuerdos de su propia vida, obligada a salir de Varsovia ante el avance alemán hacia la capital rusa. Allí se ve inmersa en la revolución de 1917 y un año más tarde se traslada a su patria adoptiva, después de la independencia de Polonia.

La narración adopta una forma muy fresca, desenfadada y abierta, al escribir diálogos sencillos, reflejo directo del mundo infantil. La prensa burgalesa elogia la publicación con bellas palabras:

Es una labor cultural la de este libro y por ella felicitamos a sus editores, que sin reparar en gastos ni en trabajo, se preocupan de la infancia proporcionándola medios prácticos de enseñanzas modernas.

Parece mentira que entre la neblina asustadiza de una provincia donde los libros se aburren en las estanterías, salga una casa editorial poniéndose, a fuerza de trabajo, a la cabeza de las editoriales españolas.

Porque la casa "Hijos de Santiago Rodríguez" trabajando silenciosamente, sin lentejuelas de vanidad, de orgullo, ha llegado a demostrarnos que sus talleres y su dirección nada pueden envidiar a los de las primeras casas editoriales españolas.

Nos lo demuestra claramente este bello libro, "Aventuras de una muñeca española en Rusia”, donde el gusto y el conocimiento artístico se unen amistosamente al desenfado de los gastos y a la limpieza de la composición. ${ }^{757}$

\footnotetext{
${ }^{756}$ La Voz de Castilla. Año X, no 560, 19 de octubre de 1919, p. 1.

${ }^{757}$ La Voz de Castilla. Año XI, no 618, 19 de diciembre de 1920, p. 2.
} 
En su interior incluye 29 ilustraciones, en blanco y negro, intercaladas en el texto y a plana entera. Además de 4 dibujos, a todo color, sobre cartulina oscura, de carácter modernista y realista.

Los tres Sorianitos está escrito por José Ortega Munilla, periodista y escritor. Fue director y copropietario de Los lunes del Imparcial, y en sus páginas recalaron los principales autores de la Generación del 98. En 1901, ingresó en la Real Academia Española aunque se ve eclipsado por su hijo, José Ortega y Gasset.

El estilo de Ortega Munilla, como se afirma en estas líneas, es ágil, de vocabulario abundante y florido por influencia romántica y naturalista. Cuenta la historia y vicisitudes de tres niños obligados a viajar de su lugar natal, Soria, después de la muerte de sus padres, hasta el Nuevo Continente, en Argentina, donde tenían que hacerse cargo de la inmensa herencia de un tío, hermano de su madre.

La cubierta a color, realizada por Antequera Azpiri, muestra a uno de los personajes del cuento, el indio Presto Culcufura, montado en un caballo y manejando unas cuerdas, que serán las que apresen y secuestren al mayor de los chicos. (Figura 6-56).

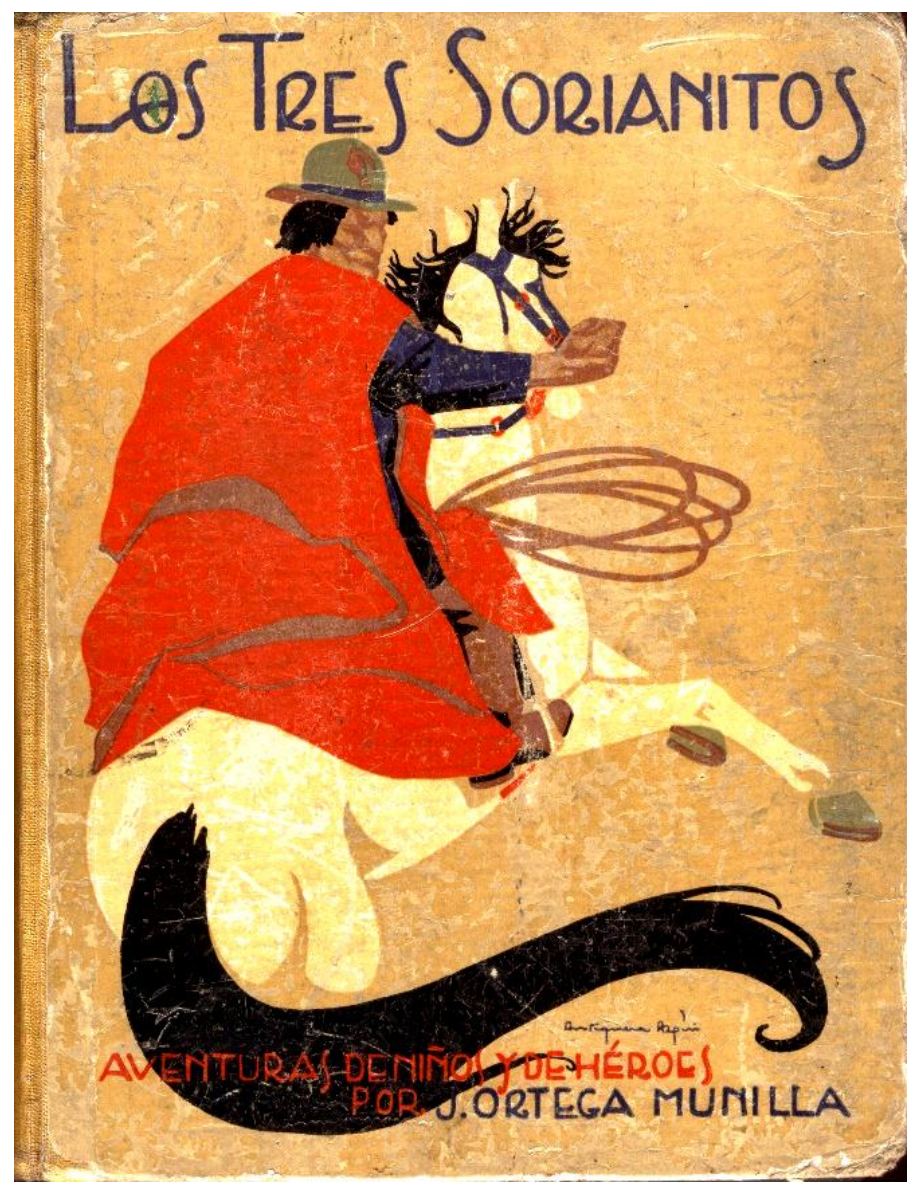

Fig. 6-56: Cubierta del libro Los tres sorianitos de Pedro Antequera Azpiri. Hijos de Santiago Rodríguez. 
Los dibujos de las guardas, también de Azpiri, representan el pueblo de Pareduelas-Albas, lugar de origen de los niños huérfanos. El cuento fue publicado en 1921, un año antes de la muerte del autor, y las ilustraciones están firmadas en 1920. Asimismo, en su interior encontramos treinta dibujos a color, algunos de ellos en blanco y negro; otros en blanco, negro y rojo; y cinco láminas a todo color relacionadas con el texto, sobre una cartulina a color. ${ }^{758}$ El libro está dedicado a Miguel Germán, su nieto, con el siguiente recordatorio:

Si te fatiga la lectura de este libro, serías el crítico esperado...Si acabas las aventuras de "Los tres sorianitos", no me importará el desdén de los cultos.

Cuentos de Pototo está escrito por Emiliano Ramírez Ángel, novelista y poeta, amigo y seguidor de Galdós. Cultivó la novela corta y el cuento, con gran maestría, obteniendo premios importantes como el "Mariano de Cavia" convocado por $A B C$. En 1919, ganó el concurso de cuentos de Blanco y Negro, con la obra Caperucita López. Colaboró en numerosas publicaciones como Los Contemporáneos, El Cuento Semanal, La Novela Corta, ABC, Blanco y Negro y Los Lunes de El Imparcial. ${ }^{759}$

El estilo narrativo en este cuento es sencillo, recorre el mundo infantil y mágico, a través de 17 historias, con un protagonista principal: un niño llamado Pototo. Sugiere en el prólogo que todos los relatos se deben y dedican a sus tres hijos. Los objetos se convierten en personajes animados sea el guante, el zapato, el pantalón, el caballito de madera y todos los animales. También salen a la luz lugares fantásticos y seres mitológicos como el señor Año, el País de azúcar, etc. Destaca la espontaneidad del narrador que, con temática diversa, aúna en su inventiva ingenuidad al mismo tiempo que ofrece al niño mensajes para la vida.

Las ilustraciones de Francisco López Rubio reafirman el mensaje, con trazos sencillos y el humor con el que resalta a los personajes animados, siendo reflejo la bella cubierta y portada del autor (figura 6-57), y las cuatro láminas interiores, a color, de los personajes de los cuentos. ${ }^{760}$

\footnotetext{
${ }^{758}$ Vid. Anexos 3.4.9; 3.4.10; 3.4.11; 3.4.12; 3.4.13; 3.4.22; 3.4.23; 3.4.24; 3.4.25.

${ }^{759}$ PASCUAL MARTÍNEZ, P. Op. cit., p. 732.

${ }^{760}$ Vid. Anexos 3.6.9; 3.6.10; 3.6.11.
} 

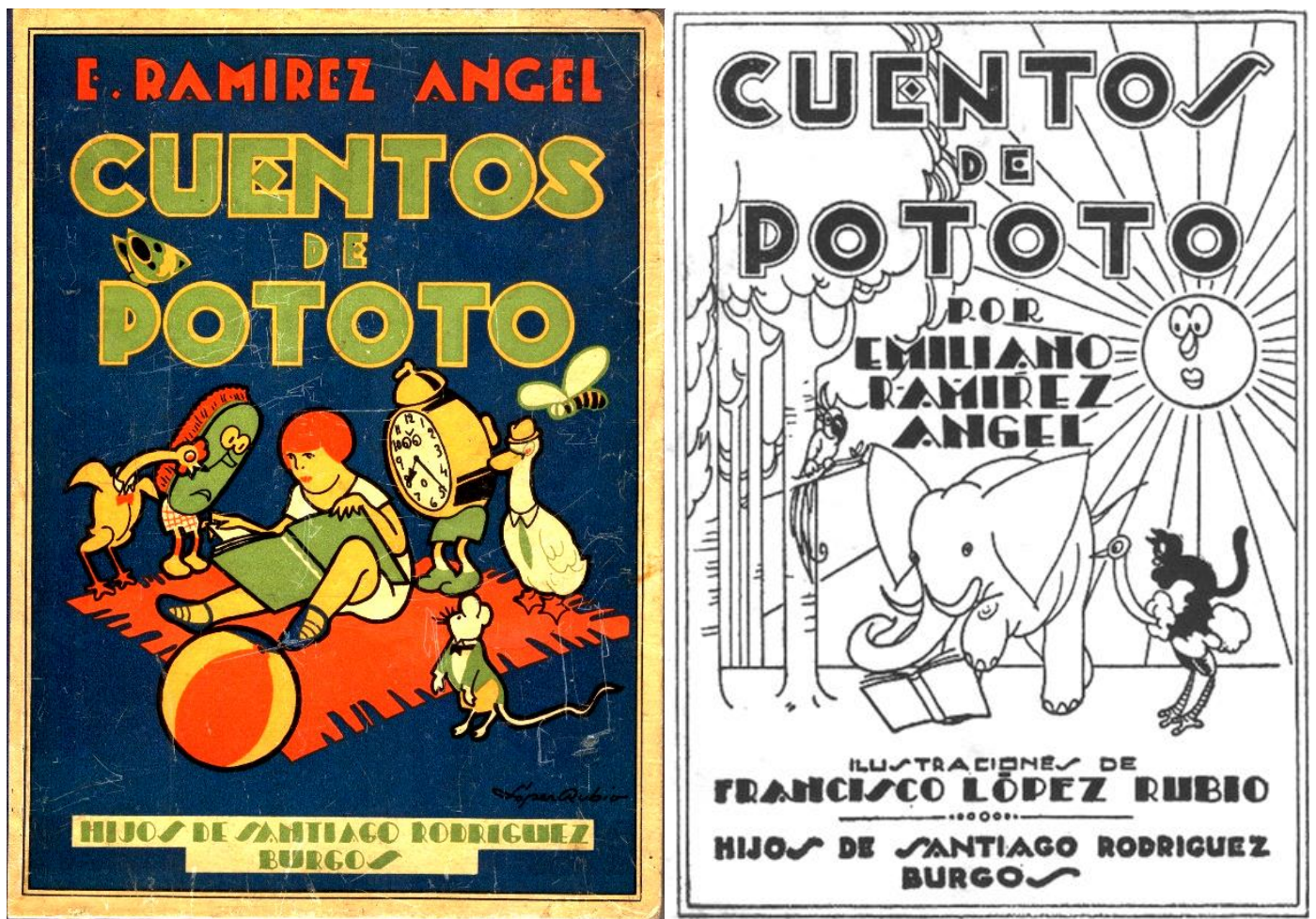

Fig. 6-57: Cubierta y portada de Cuentos de Pototo, ilustradas por Francisco López Rubio. Hijos de Santiago Rodríguez.

Cuentos para soñar está escrito por $\mathrm{M}^{\mathrm{a}}$ Teresa León. El prólogo de María Goyri, prima de la autora y esposa de Menéndez Pidal, expresa que, más que escribir libros especiales para los niños, es necesario escribir pensando en los niños. Así, muestra a la autora como madre y literata, con un mayor conocimiento del niño y que, por tanto, puede hacerle soñar con sus relatos. Y, en la dedicatoria, bajo el nombre de Tu Madre, describe bellamente el motivo de su narración:

Y era un día de nieve cuando al niño le regalaron el primer libro de cuentos. Desde entonces dejó el caballo y el aro, y casi olvidó la bicicleta.

El niño encontraba en su cabecita el poder de crear. Bebé, el antiguo bebé rubio y rosa soñaba.

Una briznita de inquietud brotaba en su alma. Las hadas, los gnomos, los gigantes, acompañaban su vida diaria.

Yo veía crecer su fantasía, afirmarse su personalidad. Para mi hijo iba inventado cuentos al volar de mi imaginación.

Hoy, en sus manos que tienen ya la tinta de colegial, dejo mi libro, lleno de amor a los viejos temas de mi infancia, avalorado por el arte de una compañera de juegos.

Para ti, mi pequeño de ojos negros, y para todos los niños que guste soñar. ${ }^{761}$

Organizada en un conjunto de 19 capítulos entrelazados con los personajes de los cuentos tradicionales, se adentra en el mundo mágico de

${ }^{761}$ LEÓN GOYRI, M. T. Cuentos para soñar. Burgos: Hijos de Santiago Rodríguez, 1928, p. 7. 
hadas, gnomos, ogros, pájaros encantados, etc. para hacer volar la imaginación y mantener el interés.

La protagonista es Nenasol, una niña que al comenzar el invierno va a patinar al Lago Verde. En su alocada carrera roza a un pino que se convierte en el hada Verdeniña que la acompaña y conduce al lago, escoltadas por un dragón. Llegadas al lago, el hada le cuenta cómo habían dejado de formar parte del mundo mágico de los adultos y niños, y cómo todas las hadas y seres mágicos se habían quedado en el Lago Verde.

Blancanieves, madrina de Nenasol, vendrá a buscarla para vivir una aventura donde conocerá a seres mágicos: la reina Titania y el rey Oyeron, Pulgarcito, el Pájaro Azul, el Hada Azul, Cenicienta, y toda clase de animales. Todo este despliegue mágico trata de conseguir que las hadas volviesen a ayudar a los hombres y jugar con los niños.

En la narración, introduce de manera original otras realidades: cómo se hicieron los juguetes de trapo, el nacimiento de Jesús, Papa Noël, etc. Mientras tanto, el discurso del relato va contando cómo la madre de Nenasol se queda en casa preocupada por su hija. Y, cuando el sueño se desvanece, vuelve a la realidad, a casa, y descubre que el alma del mundo está en el corazón de las madres, que son las hadas madrinas de todos los cuentos.

Rosario de Velasco ilustra, en total conexión con el texto, la cubierta donde refleja un mundo cambiante. Presenta un dibujo con rascacielos y chimeneas humeantes, e incluye la tradición literaria infantil con un gran pájaro donde están montados Nenasol y Pulgarcito. Las ilustraciones interiores retratan a la protagonista Nenasol como una muchacha moderna, de silueta estilizada y atuendo deportivo, con largas piernas y pelo corto recogido por una gorra de chico, alejada del estereotipo de los cuentos de hadas. Las ilustraciones, casi todas en blanco y negro, encajan a la perfección con el contenido del texto. ${ }^{762}$ Hay, también, varias láminas a color donde nos presenta personajes fantásticos: hadas, duendes, gnomos, dragones etc. ${ }^{763}$

Llama la atención cómo estas dos mujeres desde lo literario o lo estético, en posiciones políticas ${ }^{764}$ y sociales antagónicas, buscan dar un papel más activo a la mujer y romper los viejos moldes. Trataban de reclamar un nuevo lugar y encontrar un papel principal, que les correspondía por derecho propio, en la sociedad del momento o en la

\footnotetext{
762 Vid. Anexo 3.7.2; 3.7.3.

763 Vid. Anexo 3.7.1.

${ }^{764}$ Cuando se escribió el libro escrito en 1928, todavía no habían asumido su posicionamiento político: comunismo de $\mathrm{M}^{\mathrm{a}}$ Teresa León y falangismo de Rosario de Velasco.
} 
futura, aunque cuando se escribió el libro (1928) todavía no habían asumido un posicionamiento ideológico claro.

El Pájaro en la nieve y otros cuentos, de Armando Palacio Valdés, fue escrito y publicado hacia 1925 puesto que aparece en el Catálogo Recuerdo de 1925, siendo el último tomo de esta colección publicitado. En el mismo Catálogo, se mencionan personas y artículos de periódicos que nos hablan de dicha publicación. ${ }^{765}$ Muestra de ello son: ABC, El Liberal de Madrid, I.C.A.I. y Chiquitín, de Madrid; Decíamos Ayer, de Salamanca; El Puerto Rico Ilustrado, de San Juan de Puerto Rico; La Ciudad de Dios, de El Escorial; así como personas particulares como J. Francos Rodríguez, y E. Gómez de Baquero.

Un ejemplo del reconocimiento alcanzado lo encontramos en el artículo del periódico Puerto Rico Ilustrado donde se hace un gran elogio, tanto del autor e ilustrador como de la casa editorial.

Exigentes hasta la severidad para con los libros de enseñanza, no sabemos qué sea mejor en los editados por esta casa Hijos de Santiago Rodríguez si el texto de elegante y pulido lenguaje castizamente castellano, expurgado de ñonerías o disparates, o su magnífica presentación, de irreprochable factura y excelente material. ${ }^{766}$

La muy importante y progresista Casa Editorial Hijos de Santiago Rodríguez de Burgos, España, acaba de sumar un nuevo triunfo a los muchos conquistados en su larga vida difundidora de cultura con la publicación de un artístico tomo titulado El Pájaro en la nieve y otros cuentos, debido al glorioso escritor Armando Palacio Valdés, tan conocido y admirado por sus famosas novelas, en el mundo entero.

Esmeradamente impreso y encuadernado, con ilustraciones del afamado dibujante Echea, este hermoso libro está obteniendo un clamoroso éxito en todos los países de habla castellana... ${ }^{767}$

El libro tiene 91 páginas, y un índice al final incluyendo un añadido de 6 páginas, sin numeración, que hacen propaganda de dos de las bibliotecas: Biblioteca Rodríguez y Biblioteca Paz.

Se presenta en papel de excelente calidad, con tipografía grande y espaciada. Las ilustraciones, a plana entera, en blanco y negro y a color, de Echea $^{768}$-Enrique Martínez de Tejada y Echevarría-, intercaladas en el texto, refuerzan el contenido del cuento y por sí solas relatan el mismo.

El tomo está encuadernado en pasta dura, con lomo en tela de color combinada con la cubierta ilustrada por Echea, en varios colores, en la zona central. El autor y el título figuran en la parte superior; la editorial en la

\footnotetext{
${ }^{765}$ CATÁLOGO 1925, pp. 95-98.

766 Ibídem, p. 97. Hace referencia al periódico El Liberal de Madrid.

${ }^{767}$ Ibídem, p. 98. Hace referencia al periódico Puerto Rico Ilustrado, de San Juan de Puerto Rico, con el título "Un gran libro para la infancia".

768 Vid Anexo 3.5.
} 
inferior (figura 6-58). La contracubierta tiene el emblema de la editorial, a un solo color. Las guardas, delanteras y traseras, están ilustradas con dibujos de los personajes de algunos de los cuentos que forman parte del libro. La portada, en blanco y negro, incluye en varios tipos de letra el título, autor, ilustraciones y editorial, con un dibujo central sobre el personaje principal. Para darle más fuerza, indica que el autor pertenece a la Real Academia Española (Figura 6-58).
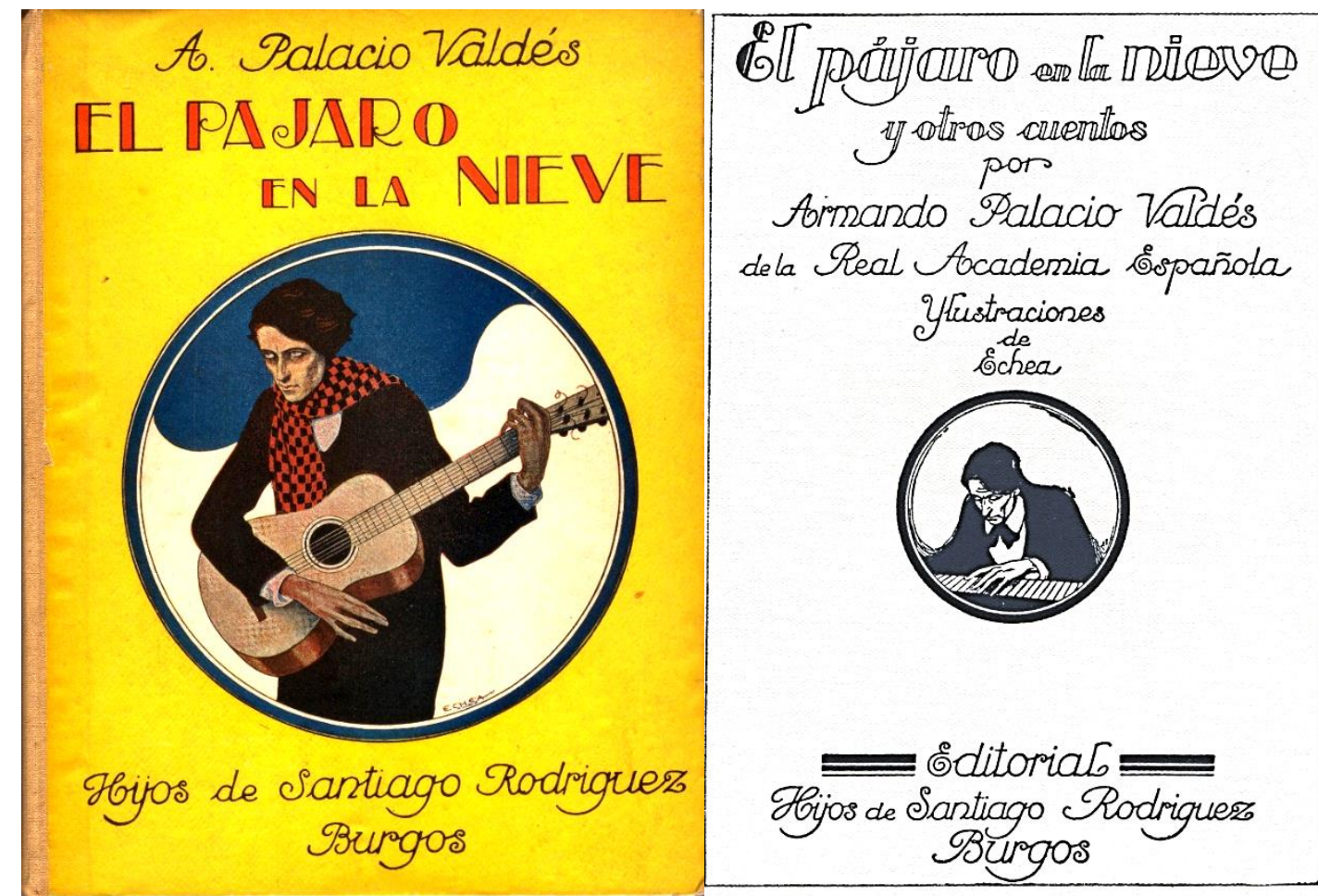

Fig. 6-58: Cubierta y portada de El pájaro en la nieve de Armando Palacio Valdés. Ilustraciones de Echea. Hijos de Santiago Rodríguez.

El argumento trata de un ciego de nacimiento, Juan, que se queda sólo a la muerte de su padre y consigue una plaza de organista en una de las iglesias de Madrid. Poco después, con los cambios políticos, le cesan y se va degradando su vida e ilusión por componer música, hasta su dulce muerte en un frío día de invierno, soñando el reencuentro con su hermano y familia de quienes nada sabía desde que éstos marcharon a América.

Describe, con gran fuerza narrativa, la realidad española del momento: la alternancia en el poder político de moderados y liberales, con cambios continuos en los puestos. Gracias a estos vaivenes políticos algunos acaban en la miseria, como a Juan; pero, la ilusión de un futuro mejor, enmarcada con la llegada de su hermano, encuadra esta realidad dentro de la utopía de su regeneración.

El cambio de Ministerio le sorprendió cuando aún no la había terminado. Ignoro si entraron los radicales, o los conservadores, o los constitucionales, pero entraron algunos nuevos. Juan no lo supo sino tarde y con daño. El nuevo 
Gabinete, pasados algunos días, juzgó que Juan era un organista peligroso para el orden público, y que desde lo alto del coro, en todos los registros del coro, le estaba haciendo una oposición verdaderamente escandalosa... buscándole un sustituto que en sus maniobras musicales ofreciese más garantías o fuese más adicto a las instituciones. ${ }^{769}$

Otro rasgo muy destacado del autor es el humor, con la evidente intención de distender la tensión dramática, tal como vemos en el texto anterior y como componente esencial de crítica social:

Pero se había reunido demasiada gente a su alrededor, y la autoridad temió que esto fuese causa de algún desorden, pues era cosa averiguada para los agentes de orden público que las personas que se reúnen en la calle a escuchar a un ciego demuestran por este hecho instintos peligrosos de rebelión, hostilidad contra las instituciones, una actitud, en fin, incompatible con el orden social y la seguridad del Estado... Es realmente consolador el ver con qué esmero procura la autoridad gubernativa que las vías públicas se hallen siempre limpias de ciegos que canten. ${ }^{770}$

También es un gran melómano, pues la música forma parte de su vida diaria y, por ello, en el cuento hace alusión constante.

Le habían enseñado lo único que los ciegos pueden aprender, la música...Pasaba las horas componiendo una gran misa de réquiem...empezó a cantar la romanza de tenor del primer acto de La Favorita...el aria del cuarto acto de La Africana, el Ave María de Gounod... ${ }^{771}$

Otro procedimiento utilizado por Palacio Valdés en esta obra son las pormenorizadas descripciones de los personajes individuales retratando su edad, aspecto, forma de ser, pensar, situación social y económica y su actividad profesional, lo que nos delatará su comportamiento en todo el relato. ${ }^{772}$ Éstas sirven para ayudan a reforzar el ambiente en que se mueven los personajes y explicar el comportamiento, según donde se desarrolla la acción, detallando el color, olor y estado de los objetos como imagen plástica y anímica del personaje.

Los únicos momentos felices del desdichado eran los que pasaba en oración en el ángulo de alguna iglesia solitaria. Oculto detrás de un pilar, aspirando los acres olores de la cera y la humedad, escuchando el chisporroteo de los cirios y el leve rumor de las plegarias de los pocos fieles distribuidos por las naves del templo, su

\footnotetext{
${ }^{769}$ PALACIO VALDÉS, A. El pájaro en la nieve. Burgos: Hijos de Santiago Rodríguez, p. 8.

${ }^{770}$ Ibídem, pp. 14-15.

${ }^{771}$ Ibídem, pp. 12-13.

772 GÓMEZ-FERRER MORANT, G. Teoría, práctica y técnicas narrativas en la obra de Armando Palacio Valdés [en línea]. Alicante: Biblioteca Virtual Miguel de Cervantes, 2009 [fecha de consulta 304-2013]. Disponible en: http://www.palaciovaldes.com/documentos p. 178

GARCÍA AVELLO, R. La sinfonía pastoral de Beethoven como fuente de inspiración literaria [en línea]. Entralgo, Laviana: Centro de Interpretación Armando Palacio Valdés [fecha de consulta 30-4-2013]. Disponible en: http://www.palaciovaldes.com/detalleEstudios
} 
alma inocente dejaba este mundo, que tan cruelmente le trataba, y volaba a comunicarse con Dios y su Madre Santísima. ${ }^{773}$

Contando cuentos, el penúltimo libro de esta biblioteca, es de la escritora Angélica Palma, hija del padre de la literatura peruana Ricardo Palma y difusora de la gran obra de su padre, por diversos países. ${ }^{774}$

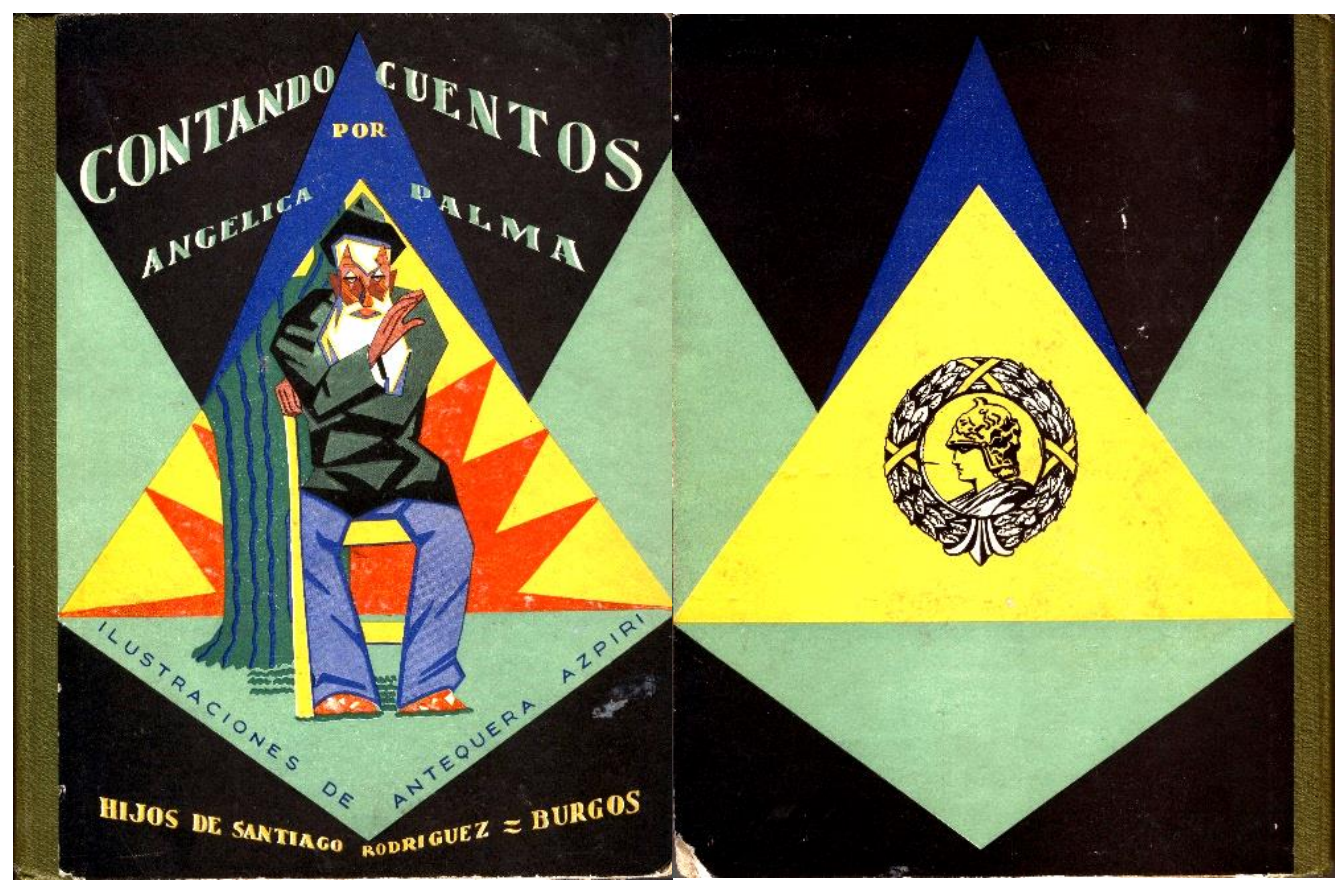

Fig. 6-59: Cubierta y contracubierta de Contando Cuentos de Angélica Palma ilustrado por Pedro Antequera Azpiri. Hijos de Santiago Rodríguez.

Sus narraciones, como nos señala $\mathrm{M}^{\mathrm{a}}$ Pía Sirvent de Luca, tienen una cierta afinidad con las de su padre, mezcla de historia y realidad, recordando el resurgir de Perú tras la guerra con Chile en 1879. No obstante, no podemos pensar en ella como una literata menor pues es reconocida como una gran comentarista, cronista y poeta de su tiempo, a la vez que también destaca en una faceta que aquí vamos a analizar: escritora de cuentos.

En una carta a su amiga, Blanca de los Ríos, le comenta su desconocimiento en negociaciones sobre temas editoriales. En esos momentos está en trato con la editorial burgalesa Hijos de Santiago Rodríguez para publicar algunos cuentos, en la misma colección, junto otros autores conocidos como Sofía Casanova y Armando Palacio Valdés. ${ }^{775}$

\footnotetext{
${ }^{774}$ SIRVENT DE LUCA, M. P. Angélica Palma: su vida y su obra (1878-1935). Tesis doctoral inédita, Universidad Complutense de Madrid, 2012. Disponible en: http://eprints.ucm.es/15286/.

${ }^{775}$ Ibídem, p. 276.
} 
El 9 de agosto de 1928, la editorial, dirigida entonces por Pascual Rodríguez, escribe a Angélica para informarle de la edición de un Catálogo general de todas sus publicaciones, con motivo de las singulares Exposiciones Iberoamericana de Sevilla y la Internacional de Barcelona, donde insertarían como en prensa su colección de cuentos, con un título original: "Cuentos para soñar". ${ }^{776}$ Finalmente, se produce una modificación y aparece como Contando cuentos, al tener ya impreso el rótulo en una obra de $\mathrm{M}^{\mathrm{a}}$ Teresa León.

Contando cuentos recoge una colección de once cuentos, con dedicatoria, introducción y epilogo. Algunos ya habían sido editados, como El niño que quería ser rey publicado por la revista Mundial, el 7 de septiembre de $1923 .{ }^{777}$

En la dedicatoria, "A los niños de mi idioma", se dirige a los destinatarios de su obra: los niños de ambas partes del océano. Para ella fue todo un reto, pues hemos de pensar que estos u otros cuentos los narraría de forma oral a sobrinos o hijos de amigos de España y Perú.

Para dar cohesión formal a todos los cuentos describe, en la introducción, a un señor de cabellos blancos y barba hasta el pecho; parecía un emperador viejo o un profeta como los de los cuadros de Historia Santa; referían que había viajado mucho, que había escrito libros y que sabía infinitas cosas. Sin duda, la referencia parece ser una clara alusión a su padre. La descripción continúa narrando que caminaba apoyado en un bastón y, allí en la playa, se sentaba en un butacón de mimbre con cojines, bajo la sombra de un toldo rayado, rodeado de sus nietos y de los amigos de sus nietos que le pedían que les contase cuentos (figura 6-60). Pero, en el final de su introducción, nos describe cómo, en un tono jocoso y desenfadado, recriminaba o aleccionaba a los que le escuchaban.

Complaciente narraba el anciano y mezclaba en la narración bromas y pullas a sus oyentes, que provocaban grande algazara.

Cuando veía rondar por allí chicuelos desarrapados, los llamaba a formar parte del corro. Si observaba que eran recibidos con despego, él, que nunca se enfadaba, se ponía furioso: -Oye, señoritingo - gritaba- o tú, madamita de la media almendra, si no te gusta tu vecino, te largas y la ida del humo; lo que es éste no se va; pues hombre, ;no faltaba más! ${ }^{778}$

\footnotetext{
${ }^{776}$ Ibídem, p. 277.

777 Ibídem, p. 276. Mundial fue una revista ilustrada peruana publicada en Lima (1920-1931).

${ }^{778}$ PALMA, A. Contando cuentos. Burgos: Hijos de Santiago Rodríguez, 1930, pp. 7-8.
} 


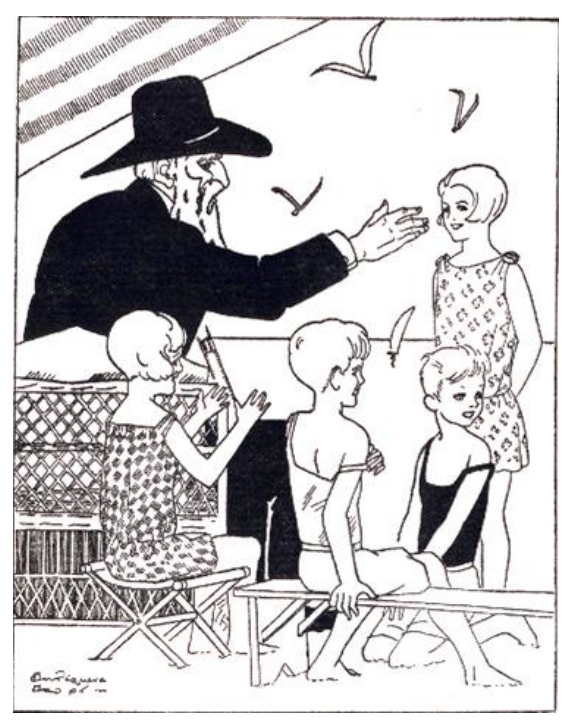

Fig. 6-60: Ilustración en blanco y negro sobre el lugar y personaje que narra los cuentos del libro Contando Cuentos por Pedro Antequera Azpiri.

Biblioteca Rodríguez. Hijos de Santiago Rodríguez.

Algunos cuentos de su tierra natal, como El sol por salir, se lo dedica a su sobrinito Vidal, nacido en la ciudad imperial de la leyenda, base argumental del cuento. Hace una bella descripción de la belleza y riqueza del país, recordando las creencias paganas de sus antiguos pobladores en el dios Sol, en paralelo con la vida cristiana.

-Si cuando seas mayor, te da por leer antiguallas, verás que hay muchas historias, como ésta que acabo de referiros, que parecen cuentos- respondió el abuelo. ${ }^{779}$

En el cuento Las dos voces nos narra dos mundos: el rural y el urbano; el paisaje y la belleza de los Andes, y el bullicio y las oportunidades de la ciudad, en boca de los niños Fortunata y Manuel. El cuento no deja un final diáfano, pero apuesta por la vida en la ciudad.

Y cansado de la soledad y del contacto exclusivo con la Naturaleza, Manuel regresó a la ciudad, a prepararse para la conquista futura;... Vosotros veréis a dónde le llevan esas ambiciones: a diputado, a gerente de un banco, a director de una fábrica iquién sabe! ${ }^{780}$

Recoge cuentos de su niñez, y los pone en boca de su mama Pancha, esa negra bonísima que nos cuidaba a mis hermanos y a mí. ${ }^{781}$ Describe la astucia y bondad de los personajes femeninos de dos historias donde se mezcla la realidad con el mundo fantástico de reyes y hadas. ${ }^{782}$ En otros,

\footnotetext{
779 Ibídem, p. 38.

${ }^{780}$ Ibídem, p. 120. El cuento incorpora varias palabras peruanas, que se explican al final del cuento.

781 Ibídem, p. 88.

${ }^{782}$ Ibídem, pp. 21-31; 88-99. Cuento de La tripita y Marisabidilla.
} 
siguiendo la tradición fantástica, los juguetes cobran vida, como en $\mathrm{La}$ suerte de los juguetes, pero con un fin moralista:

...los pobres juguetes no tienen voluntad y han de aguantar lo que se les haga con ellos. Nosotros merecemos en ocasiones los males que sufrimos y podemos hacer mucho por lograr el bien que deseamos, pues es muy cierto el adagio que dice: ayúdate y Dios te ayudará. ${ }^{783}$

De igual manera sucede en los cuentos de brujas y hechizos, como en La grulla, o de saltimbanquis, que engañan al pequeño Pipo, al igual que en Las aventuras de Pinocho.

En un último cuento, recoge y agrupa dos personajes: uno clásico del nonsense, como Peter Pan, y otro fantástico, como La Bella Durmiente. La acción transcurre en un diálogo desafiante entre dos mundos, dos historias $\mathrm{y}$ dos vidas, en el imperio de la fantasía donde todo es posible, aparentemente; pero, ni en ese mundo llegaron a entenderse estos dos espíritus pues, según la autora, estas cosas acaecen en el mundo de los cuentos...y también en el de la realidad.

En el epílogo, manifiesta un homenaje final a su padre, y a todos los grandes cuentistas europeos como los hermanos Grimm, Charles Perrault y James M. Barrie. Y, de la cultura del otro lado del Atlántico, sitúa varios cuentos de Rafael Pombo. ${ }^{784}$

$Y$ nos dirás también esos fantásticos

de hadas, bichos, gigantes y vestiglos

que a mí me gustan tanto:

Blanca de Nieve y la madrastra infame,

Caperucita Roja, los enanos,

la Cenicienta, Simón el bobito,

y Rinrín Renacuajo;

dirás de Barba Azul y la Mirringa

$y$ del festín a los señores gatos;

de Aladino y su lámpara asombrosa,

de Alí Babá y los cántaros;

del bravo Peter Pan, que a otros chiquillos

se llevaba volando

hasta Nunca-Jamás, aquella isla

de prodigioso encanta,

a donde él por el aire iba y venía

con espíritu eterno de muchacho,

que no quiso crecer ni volverse hombre

para no perder ese país soñado. ${ }^{785}$

\footnotetext{
${ }^{783}$ Ibídem, p. 45.

${ }^{784}$ Los cuentos de Rafael Pombo que recoge Angélica Palma son Mirringa Mirronga, Rinrín Renacuajo y Simón el bobito.

${ }^{785}$ Ibídem, p. 132. 
Finalmente, la conclusión de los cuentos recogidos de la tradición oral, los personaliza según el que va narrando:

$Y$ en esto, que es una verdad del tamaño de una catedral, se acabó el cuento de Periquito Sarmiento que volando, volando se lo llevó el viento. ${ }^{786}$

Colorín colorado, por hoy hemos terminado ${ }^{787}$.

Se casaron y fueron felicísimos. Por cierto que el día de la boda la más contenta era Toribia; me regaló tres caramelos: uno para Juan, otro para Pedro y otro para el que hable primero. ${ }^{788}$

Todas las ilustraciones de los diferentes cuentos, así como la cubierta y contracubierta, fueron realizadas por Pedro Antequera Azpiri ${ }^{789}$ (Figura 6-59).

CUADRO XVI: RELACIÓN DE LOS TÍTULOS DE LA BIBLIOTECA RODRÍGUEZ EN LOS CATÁLOGOS DE LA EDITORIAL HIJOS DE SANTIAGO RODRÍGUEZ.

\begin{tabular}{|l|l|l|}
\hline Títulos & $\begin{array}{l}\text { CATÁLOGO } \\
1925\end{array}$ & $\begin{array}{l}\text { CATÁLOGO } \\
1929\end{array}$ \\
\hline Los aventureros & $\mathrm{x}$ & $\mathrm{x}$ \\
\hline Viajes y Aventuras de una Muñeca española en Rusia & $\mathrm{x}$ & $\mathrm{x}$ \\
\hline Los tres Sorianitos & $\mathrm{x}$ & $\mathrm{x}$ \\
\hline El Pájaro en la nieve y otros cuentos & $\mathrm{x}$ & $\mathrm{x}$ \\
\hline Cuentos de Pototo & & $\mathrm{x}$ \\
\hline Cuentos para soñar & & $\mathrm{x}$ \\
\hline Contando cuentos & & $\mathrm{x}$ \\
\hline
\end{tabular}

Fuente: Catálogos de la Editorial Hijos de Santiago Rodríguez. Años 1925, 1929. Bibliotecas públicas y universitarias de España. CEINCE. Biblioteca Nacional de España. [Elaboración propia].

De esta misma Biblioteca se editó un último libro, en 1932, titulado Cuentos a mis nietos, de Carmen Karr, ilustrado por Rosario de Velasco.

Carmen Karr formó parte de la alta burguesía catalana, hija del ingeniero y vicecónsul de Francia, Eugéne Karr, y Emilia Alfonsetti, de origen italiano. Se dedicó al periodismo, a la literatura y a la composición de piezas teatrales. Formó parte de las nuevas corrientes sociales, por la mejora de la mujer y de la cultura femenina catalana, dentro de un reformismo de carácter social y católico. ${ }^{790}$

\footnotetext{
${ }^{786}$ Ibídem, p. 31. Cuento de La tripita.

${ }^{787}$ Ibídem, p. 38. Cuento El sol por salir.

${ }^{788}$ Ibídem, p. 52. Cuento Fifina.

${ }^{789}$ Vid. Anexos 3.4.2; 3.4.3; 3.4.4; 3.4.5; 3.4.6; 3.4.15; 3.4.16; 3.4.17; 3.4.18; 3.4.19; 3.4.20; 3.4.21.

${ }^{790}$ FABRI, A. Estudio de la cultura femenina según Carmen Karr, dentro del catolicismo social de principios del siglo XX [en línea]. Barcelona: Facultad de Teología de Cataluña, Revista Catalana de
} 
Asimismo, Carmen Karr creó y dirigió la revista Feminal, suplemento mensual para las mujeres, que se publicaba dentro del semanario Ilustración Catalana, entre los años 1907 y 1917; impartió cursos, en el Ateneo barcelonés, con otras escritoras y pedagogas; y dirigió el Pabellón de la Mujer en la Exposición Universal de 1929. En los años treinta fundó la Asociación Acción Femenina. ${ }^{791}$

La obra que escribió para la editorial Hijos de Santiago Rodríguez se despliega en siete cuentos: El Árbol de Navidad, El beso, La justicia del buen rey, La hilandera, El vestido de gemas, Raimundo el soñador, La retama bretona y El tapiz. En ellos aparecen muchos personajes típicos como princesas, reyes, hadas, gnomos, brujas y un sinfín de personajes religiosos y laicos que hilvanan unas historias divertidas donde los papeles, aunque previsibles, son frescos y sin moralizaciones.

Por otra parte, los dibujos de Rosario de Velasco muestran una evolución hacia dibujos más simples, con líneas más suaves, de formas redondeadas y con más detalles en toda la composición. (Figura 6-61).

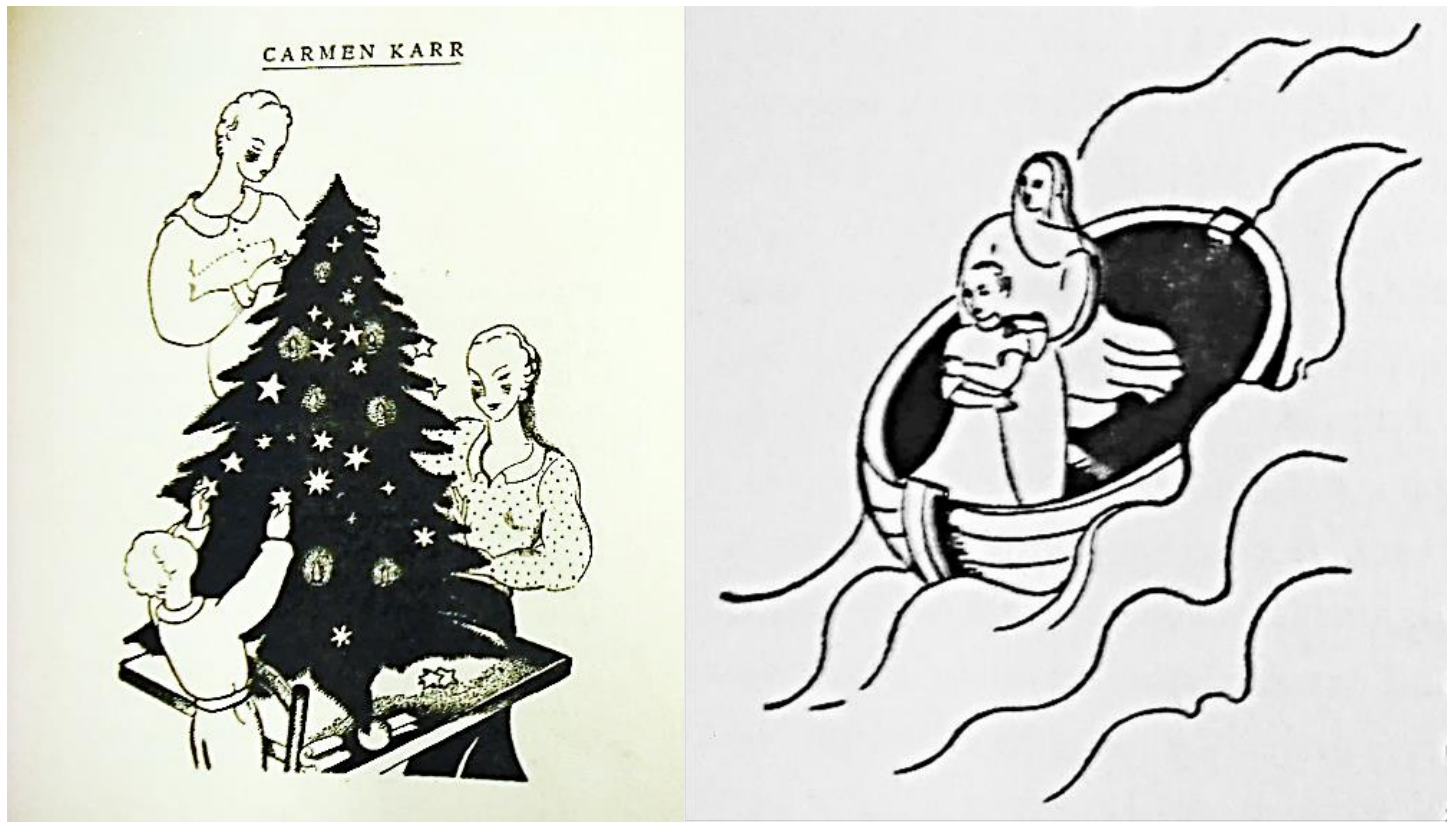

Fig. 6-61: Ilustraciones interiores de Rosario de Velasco en Cuentos a mis nietos. Hijos de Santiago Rodríguez. 1932.

Teología, vol. 30, 2005. [fecha de consulta 5 de febrero de 2015]. Disponible en: http://www.raco.cat/index.php/RevistaTeología/article/view/71483.

${ }^{791}$ PITARCH, D. Carmen Karr [en línea]. Asociación de escritores en lengua catalana [fecha de consulta 25-8-2014]. Disponible en: http://www.escriptors.cat/autors/karrc/pagina.php?id_sec=1631. 


\subsection{PERIÓDICO INFANTIL: ¿QUIERES SER MI AMIGO?}

Es curioso observar que la editorial, aparte de su función difusora de cultura, también realizó la impresión de un semanario infantil ilustrado pensado para la infancia.

La primera publicación de estas características que conocemos en España es La Gazeta de los niños ${ }^{792}$ de José y Bernabé Canga Argüelles, de finales del siglo XVIII (1789), impresa en el taller de Antonio Sancha. De carácter educativo y religioso, sin ilustraciones, intentaba que fuera lo más amena posible. En ella narran por medio de Pablo y Heliodoro, padres de Augusto, Carlos, Mariana, Amadeo, Félix y Carlota, las experiencias y sucesos vividos con sus hijos pequeños, en forma de diálogos, cuentos y anécdotas.

Ya en el prospecto, apunta que se trata de formar al hombre, desde los 9 años, y que ofrecemos en nuestro periódico, que se podría llamar La Enciclopedia de la Niñez, los últimos resultados de las fatigas de los sabios a todos los siguientes que nos han precedido...

Durante el siglo XIX surgen diversos periódicos infantiles, con finalidad educativa, según explica Mercedes Chevelet en su libro La prensa infantil en España desde el siglo XVIII hasta nuestros días. ${ }^{793}$ Según la autora, ya se considera al niño como lector asiduo, con unos intereses propios y concretos. También, en estas publicaciones se incluyen pasatiempos y juegos, e ilustraciones para apoyar los textos, alejándose del adoctrinamiento y centrándose más en el entretenimiento. El período más álgido de este género es a partir de la Restauración hasta 1917, cuando se crea la revista TBO.

A finales de siglo XIX, Hijos de Santiago Rodríguez decide publicar, todos los domingos a partir del 5 de enero de 1896, un semanario infantil ilustrado, bajo el título ¿Quieres ser mi amigo?, dirigido por Ángel Bueno. Según nos consta, sólo salen a la luz cinco números; un ejemplar del primer número se conserva en la Biblioteca Pública de Vitoria.

En la primera de las doce páginas nos señala, en la parte superior, la fecha 5 de Enero de 1896 y el número, Núm. I., para a continuación situar el título y subtítulo: ¿Quieres ser mi amigo? Semanario infantil ilustrado, junto con el nombre del director y los editores, con distinta tipografía. A

\footnotetext{
${ }^{792}$ CANGA ARGÜELLES, J. y B. La Gazeta de los Niños. Madrid: Librería de Sancha, 1798, 32 p. № I y III en la Biblioteca Nacional de España.

${ }_{793}$ CHIVELET, M. La prensa infantil en España: desde el siglo XVIII hasta nuestros días. Madrid: Fundación SM, 2009.
} 
partir de la media página inferior se explica que la dirección se sitúa en la calle de San Bernardo, núm. 75, de Madrid, y que la administración está en el Pasaje de la Flora, nº 12, librería de Burgos (Figura 6-52).

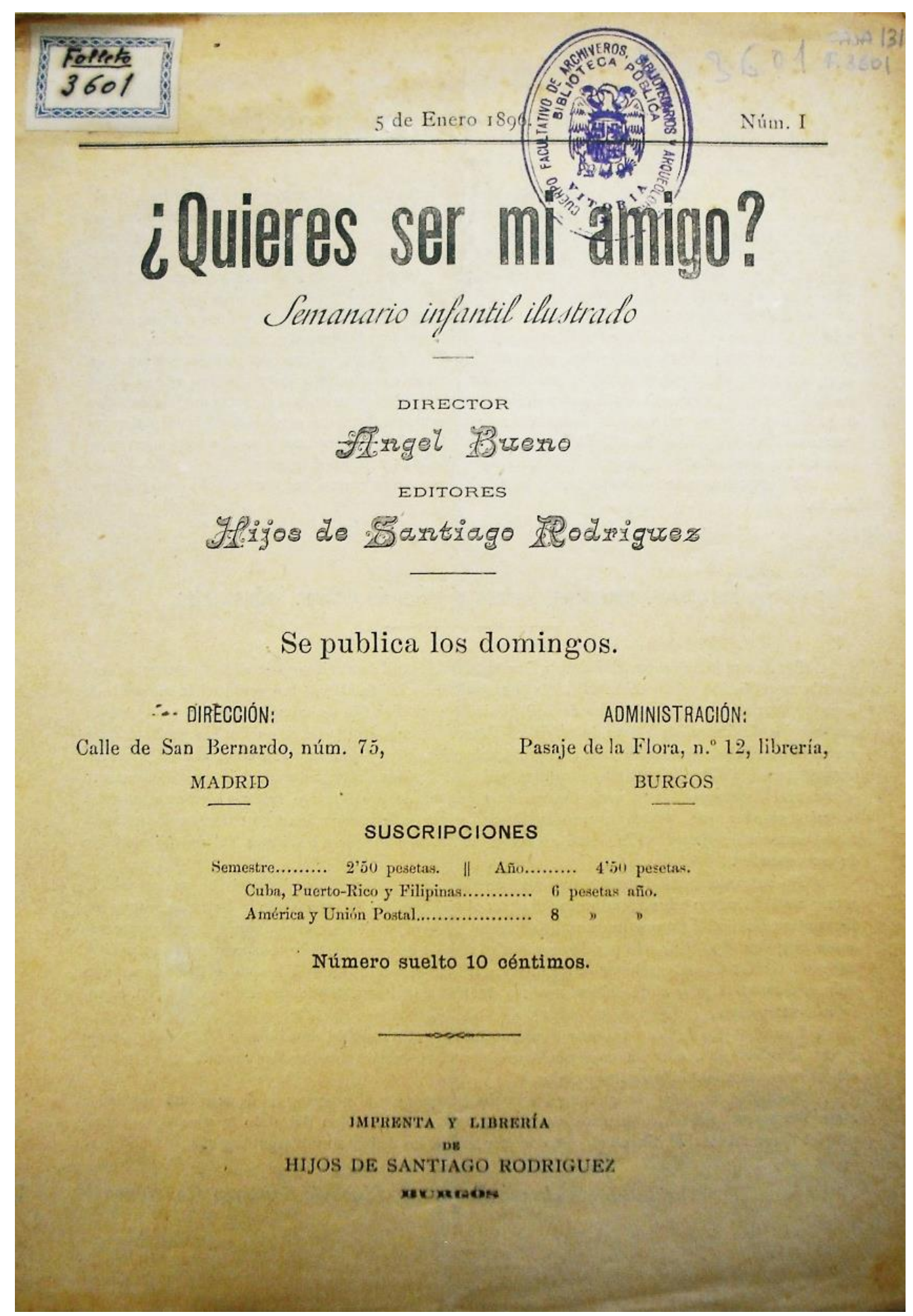

Fig. 6-62: Primera plana del Semanario infantil ilustrado ¿Quieres ser mi amigo? Número 1, 5 de enero de 1896. Hijos de Santiago Rodríguez. 
El número suelto costaba 0,10 pts. y se podían hacer suscripciones por semestre y año, siendo su valor de 2,50 y 4,50 pts., respectivamente. Si la suscripción era para Cuba, Puerto-Rico o Filipinas, la suscripción anual costaba 6 pts. y 8 pts. para América y Unión Postal.

En la segunda página, el director Ángel Bueno exhorta a los niños y jovencitos para que lo compren a fin de disfrutar y aprender, así como ganar los premios ofrecidos en varios concursos. También, anima a los maestros, padres y jefes de centros industriales en su difusión y compra, para servir "al Progreso y a la Humanidad", e insiste en que la publicación es amena y simpática, sin ser exclusiva para niños sino también para niñas.

No buscamos aquí directamente un beneficio material; nuestro deseo...educar, moralizar, ilustrar al niño en los países adonde la hermosa lengua de Cervantes se habla. Y porque puedan disfrutar del tal beneficio las clases populares, no sólo ponemos desde luego un tipo desusado por lo económico a suscripción y venta y rebajamos para escuelas y talleres o fábricas...realizaremos más tarde el ideal nuestro de abaratar hasta donde nos sea posible para popularizar más y más. Ángel Bueno. Hijos de Santiago Rodríguez. ${ }^{794}$

En la tercera página, encabeza una bonita ilustración de un niño rodeado de pájaros y plantas con el título del semanario y, en letras más grandes de lo normal, destaca el precio Solo cuesto 10 céntimos; debajo del dibujo vuelve a insistir en su baratura: Me venden los domingos, cuando tienes cuartos. Soy agradecido y te divertiré mucho enseñándote. ${ }^{795}$

En la cuarta página, aparece escrito el deseo de un feliz año 1896. Entre la cuarta y la quinta, proclama una exaltación de la Patria para todos los que van a la guerra de Cuba. En la sexta, presenta una poesía sobre la Noche de Navidad, de Ventura Ruiz Aguilera, y dos inventos: el fonógrafo y el glosógrafo.

En las siguientes páginas aparece impreso un Cuento de Reyes, que desarrolla el sueño de un niño, acerca de la guerra de Cuba, ensalzando como héroes a todos los que mueren defendiendo a su Patria. Está ilustrado, al comienzo y a mitad el cuento, por Teresa.

Además de pasatiempos, establece cuatro concursos mensuales para niños, tal como expresa el lema: trabajando para entreteneros, educaros e ilustraros. Se clasifican como concursos de escritura libre, de estudios (para el desarrollo de temas propios de asignaturas de escuela o instituto), de trabajos manuales y de juegos de imaginación (charadas, acertijos, logogrifos, anagramas, etc.).

\footnotetext{
${ }^{794}$ BUENO RODRÍGUEZ-ARIAS, A. ¿Quieres ser mi amigo? Semanario infantil ilustrado. Burgos: Hijos de Santiago Rodríguez, 5 enero de 1896, p. 2.

${ }^{795}$ Ibídem, p. 3.
} 
Aparte de estos concursos generales, se celebrarán dos extraordinarios cada semestre, sobre trabajos de traducción del francés, caligrafía y temas varios. Igualmente formula que aquellos trabajos premiados, de mérito, se insertarán en la revista; cuando sea excelente, se hará su retrato y una nota biográfica. Hace varias advertencias sobre la originalidad de los trabajos y, para evitar el engaño por la ayuda familiar, se reserva pedir al interesado que muestre sus habilidades y cualidades en la redacción.

Para participar, la editorial propondrá los temas de cada concurso. Los de Enero serán: de escritura libre, versará sobre Un articulillo a propósito de Navidad; el de estudios, Historia de José; de trabajos manuales, Descripción de una máquina de coser, Un dobladillo en tira estrecha de tela, y poco larga, Composición al lápiz de un episodio de guerra; y los de juegos de imaginación, Los correspondientes a los tres primeros números, estarán relacionados con los apartados anteriores. Para el concurso del 2 de febrero propone: Una fábula, en prosa o verso, en que intervengan el conejo, el loro y el ciervo y Un cuento sobre el proverbio: No la hagas, y no la temas.

Al final, en una última nota dirigida a la prensa, agradece la buena acogida e insta a todos en la labor de formar ciudadanos honrados, firmes en creencias sólidas, y nada expuestos por lo tanto a faltar a sus deberes por malos consejos de ignorantes o perversos. ${ }^{796} \mathrm{La}$ última página acaba de modo habitual con la propaganda de diversas empresas españolas y extranjeras.

${ }^{796}$ Ibídem, p. 11. 


\subsection{LIBROS ESCOLARES POR MATERIAS}

\subsubsection{Libros para la enseñanza de la Lengua}

En el Antiguo Régimen, el modelo de alfabetización se fijaba en la lectura y, cuando los niños leían de corrido y los padres podían pagar un dinero, se les enseñaba a escribir, aunque sólo a los varones. Para las niñas bastaba con el catecismo y las labores; la lectura era un aprendizaje no obligatorio que se daba, a petición de los padres, si la maestra tenía formación. ${ }^{797}$

Los materiales recurrentes para la enseñanza fueron silabarios, catones, abecedarios, cartillas, libros de lectura, etc., basados en métodos de aprendizaje por deletreo, silábico u orgánico, o mezcla de ambos. No nos detendremos en los materiales ni en los métodos ya que podemos obtener completa información en numerosas publicaciones. ${ }^{798}$

Son muchos los manuales para la enseñanza de la lengua encontrados en las bibliotecas o publicitados en los Catálogos de la editorial Hijos de Santiago Rodríguez. En el inventario, a la muerte del fundador, en la sección del almacén de la empresa, aparecen 1.500 catones de Seijas, y en menor cantidad otros catones como el de S. Casiano, o los silabarios de Flórez, Serrano, S. Antonio, García, Paluzíe, Pampliega y Hernando; y en la librería unos pocos ejemplares de algunos de ellos como el Catón de Seijas, o los silabarios de Serrano y Pampliega. ${ }^{799}$

A pesar de la relevancia de estos datos, no es posible conocer cuáles de ellos imprimían si bien la continuidad posterior de su impresión, en la editorial Hijos de Santiago Rodríguez, hace sospechar que su publicación

\footnotetext{
797 VIÑAO FRAGO, A. La lectura, del aprendizaje a las prácticas. En: V. INFANTES; F. LÓPEZ; J-F. BOTREL, dir. Historia de la edición y de la lectura en España 1472-1914. Madrid: Fundación Germán Sánchez Ruipérez, 2003.

798 VIÑAO FRAGO, A. Aprender a leer en el Antiguo Régimen: cartillas, silabarios y catones. En: A. ESCOLANO BENITO, dir. Historia ilustrada del libro escolar. Del Antiguo Régimen a la Segunda República. Madrid: Fundación Germán Sánchez Ruipérez, 1997, pp. 149-191; Alfabetización, lectura y escritura en el Antiguo Régimen (siglos XVI-XVIII). En: A. ESCOLANO BENITO, dir. Leer y escribir en España. Doscientos años de alfabetización. Madrid: Fundación Germán Sánchez Ruipérez, 1992, pp. 45-68; Alfabetización e Ilustración: difusión y usos de la cultura escrita. Revista de Educación, número extra 1, 1988, pp. 275-302; Leer y escribir. Historia de dos prácticas culturales. México: Fundación Educación, Voces y Vuelos, I.A.P., 1999; HERNÁNDEZ DÍAZ, J. M. Alfabetización y sociedad en la revolución liberal española. En: A. ESCOLANO BENITO, dir. Leer y escribir en España. Doscientos años de alfabetización. Op. cit., pp. 69-89; RUIZ BERRIO, J. La enseñanza de la lectura de la ilustración al liberalismo. En: A. ESCOLANO BENITO. Historia ilustrada del libro escolar en España. Del Antiguo Régimen a la Segunda República. Op. cit., pp. 193-227; ESCOLANO BENITO, A. dir. Leer y escribir en España. Doscientos años de alfabetización. Op. cit., pp. 13-44.; Tradición e innovaciones en los libros de iniciación a la lectura de la España de entresiglos. En: A. ESCOLANO BENITO, dir. Historia ilustrada del libro escolar en España. Del Antiguo Régimen a la Segunda República. Op. cit., pp. 229-254; BARTOLOMÉ MARTÍNEZ, B. Las bibliotecas públicas y la lectura. En: A. ESCOLANO, dir. Leer y escribir en España. Doscientos años de alfabetización. Op. cit., pp. 309-334.

${ }^{799}$ AHPBU. Sección Protocolos. Caja 9898, 23 de mayo de 1891. Vid. Anexo 2.4. Inventario de bienes a la muerte de Santiago Rodríguez Alonso.
} 
ya se realizaba desde el último tercio del siglo XIX. Algunos de los más conocidos pudieron ser: Silabario de San Antonio, arreglado por el orden más fácil y sencillo para aprender a leer; ${ }^{800}$ Libro Primero o Silabario, por D. Juan de la Cuesta Hernaiz; Abecedario y Silabario, por D. Antonio de la Iglesia, profesor de primera educación del número, de la Sociedad Patriótica de Valladolid, realizado con un sistema especial que facilita la instrucción de los niños con el mayor número de combinaciones ${ }^{801}$ Catón Cristiano y Doctrina Cristiana, de San Casiano, ilustrado con grabados; ${ }^{802}$ Libro Segundo, arreglado al de la Real Academia para aprender a leer por el método más fácil, corregido y aumentado con las Reglas de Urbanidad; ${ }^{803}$ y Catón Metódico de los Niños, por Seijas, con grabados e ilustraciones y encuadernado en pasta. ${ }^{804}$ (Figura 6-63).

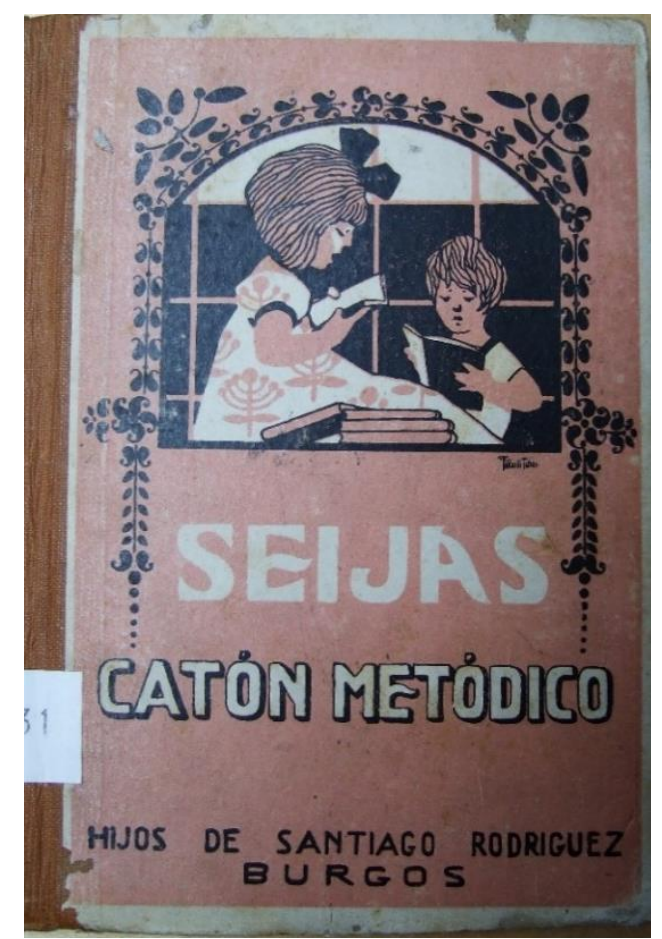

Fig. 6-63: Cubierta del Catón metódico de Seijas. La ilustración es de Fortunato Julián, donde observamos la figura femenina en primer plano y mayor que la masculina.

Biblioteca de la Diputación Provincial de Burgos.

\footnotetext{
${ }^{800}$ Catálogo 1908, p. 7; Catálogo 1917, p. 5.

${ }^{801}$ IGLESIA SERRANO, A. Abecedario y Silabario. Burgos: Hijos de Santiago Rodríguez. Catálogo 1908. Un tomo de $8^{\circ}$ de 16 páginas, impreso en elegantes y claros tipos, encuadernado en cartulina fuerte. 802 SAN CASIANO. Catón Cristiano y Doctrina Cristiana para uso de las escuelas. Burgos: Hijos de Santiago Rodríguez, Catálogo 1917. Edición en letra gruesa impresa e ilustrada con grabados, tomo en $8^{\circ}$ de 56 páginas, encuadernado en cartulina fuerte. Ver ilustración interior de Isidro Gil de una escuela donde aprovecha para poner el nombre de la editorial en una de las carpetas Anexo 3.2.31.

${ }^{803}$ Catálogo 1908 , p. 6.

${ }^{804}$ GONZÁLEZ SEIJAS, J. Catón Metódico de los Niños. Burgos: Hijos de Santiago Rodríguez. Según el Catálogo 1908 se presenta aumentado y corregido por Victoriano Hernando. Es una edición impresa con tipos gruesos y graduados, tomo en $8^{\circ}$ de 96 páginas encuadernado en pasta, con tapas al cromo y en colores. Vid. Anexo 3.2.25.
} 
Eduardo A. de Bessón, doctor en Jurisprudencia y catedrático del Instituto Provincial de Burgos, escribió un Método Nuevo para aprender a leer para las escuelas de niños y adultos. Aparece en el Catálogo de 1908 y en el inventario notarial, ${ }^{805}$ con 88 ejemplares en el almacén y tienda, aunque no se dispone de ejemplar alguno en las bibliotecas consultadas. ${ }^{806}$ Según el Catálogo, está aprobado por Real Orden y recomendado por la Autoridad Eclesiástica. Describe cómo el del Sr. Bessón se ha generalizado debido a sus especiales condiciones y lo sustenta con el argumento:

La base de este método consiste en no pasar nunca de una letra a otra sin conocerla de todos los modos que puede presentarse en la escritura usual. Esto hace que los niños, después de haber aprendido las letras, las conozcan y distingan hasta en el peor manuscrito y aprendan a leer con rapidez. ${ }^{807}$

Se completa este método con El Primer Libro de la Escuela, para perfeccionar la lectura, y le señala como aquel para conseguir enseñar a leer pronto y bien. Está escrito en forma nueva y es a la par que instructivo muy ameno. ${ }^{808}$

Para aprender a Leer, ${ }^{809}$ de Gerardo Rodríguez García, era un nuevo método del aprendizaje de la lectura basado en su larga experiencia práctica y en un conocimiento psicológico del niño. Configurado en dos tomos, el grado primero y segundo, se completa con el libro del maestro, Metodología didáctica de la lectura, donde el autor explica que su método no forma parte de la vieja rutina, ni del afán de introducir novedades, sino que facilita, de una forma fácil, rigorosa y completa, el aprendizaje de la lectura evitando los malos procedimientos que hacían que muchos se pasasen varios años enteros sabiendo leer a medias.

En los libros del primer grado se describe el método silábico estructurado en dos partes. En la primera, al principio, en la parte superior de la página presenta las vocales y consonantes (a, e, i, o, u, c, r, s, n, t, d, l, $\mathrm{g}$ ), de forma grande y separadas, y en la parte inferior, las mismas letras, en tamaño y orden diferente; después incluye todas las sílabas directas, e

\footnotetext{
${ }^{805}$ AHPBU. Sección Protocolos. Caja 9898, 23 de mayo de 1891.

${ }^{806}$ BESSÓN, E. A. de. Método nuevo para aprender a leer en las escuelas de niños y de adultos. $5^{\mathrm{a}}$ ed. Burgos: Imprenta y librería de Santiago Rodríguez Alonso, 1887. Un tomo está en la biblioteca Nacional "Miguel Obregón Lizano", en San José de Costa Rica. Ver trabajo del Dpto. de Investigación y bibliografía. Disponible en: http://www.sinabi.go.cr/biblioteca\%20digital/bibliografia/bibliografias/bib\%20libros\%20y\%20lectura\%2 0ii.pdf

${ }^{807}$ CATÁLOGO 1908, p. 7.

${ }^{808}$ BESSÓN, E. A. de. El Primer Libro de la Escuela. Burgos: Imprenta y librería de Santiago Rodríguez Alonso, 1890. Este libro estuvo editado por la imprenta y librería de Timoteo Arnaiz de Burgos desde 1868. Con el cierre de la misma Santiago Rodríguez se hizo con su impresión.

${ }^{809}$ RODRÍGUEZ GARCÍA, G. Para aprender a Leer. Grado primero. $2^{\mathrm{a}}$ edición. Burgos: Hijos de Santiago Rodríguez, 1918; Para aprender a Leer. Grado segundo. $5^{\text {a }}$ edición. Burgos: Hijos de Santiago Rodríguez, 1925.
} 
inversas; a continuación palabras enteras, introducidas progresivamente, de menor a mayor número de sílabas y de menor a mayor complejidad; seguidamente, de menor a mayor número de palabras en cada hoja, con más ilustraciones, y palabras más largas; y finalmente, se realiza un repaso de todo, con frases cortas. La segunda parte, con la misma disposición anterior, trata el resto de letras del abecedario (b, ll, h, ch, m, n, v, z, qu, p, $\mathrm{j}, \mathrm{f}, \mathrm{x}, \mathrm{k}$, ) y presenta el mismo proceso de dificultad, aunque intercala más frases. Las últimas cinco hojas contienen textos de carácter moralizante.

En el segundo grado continúa y completa el método, con series de ejercicios en los que sucesivamente se iban tratando las dificultades, de una a una y en varios grados, para introducir al niño en la lectura de pequeñas composiciones.

Es destacable que este nuevo método de lectura presenta ilustraciones a color, acompañando a las palabras, para despertar el interés y reforzar el aprendizaje de la lectura.

Para la enseñanza simultánea de la lectura y escritura, ${ }^{810}$ la editorial imprime un nuevo método, El Primer Vuelo, ${ }^{811}$ premiado en la Exposición Pedagógica de Bilbao en 1905, aprobado por el Consejo de Instrucción Pública -Real Orden de 5 de enero de 1909- y por la Autoridad eclesiástica. Contiene ejercicios de lectura y escritura, con variaciones progresivas.

\footnotetext{
${ }^{810}$ Ver: ESTEBAN, L. La academización de la escritura. Modelos e instrumentos para aprender a escribir en la España del siglo XIX y comienzos del XX. En: A. ESCOLANO BENITO. Historia Ilustrada. Del Antiguo Régimen a la Segunda República. Madrid: Fundación Germán Sánchez Ruipérez, 1997, pp. 315344.

${ }^{811}$ IZQUIERDO SÁIZ, V. El primer vuelo. Método para la enseñanza simultánea de la lectura y escritura, dividido en cuatro grados. $8^{\text {a }}$ edición. Burgos: Hijos de Santiago Rodríguez.
} 


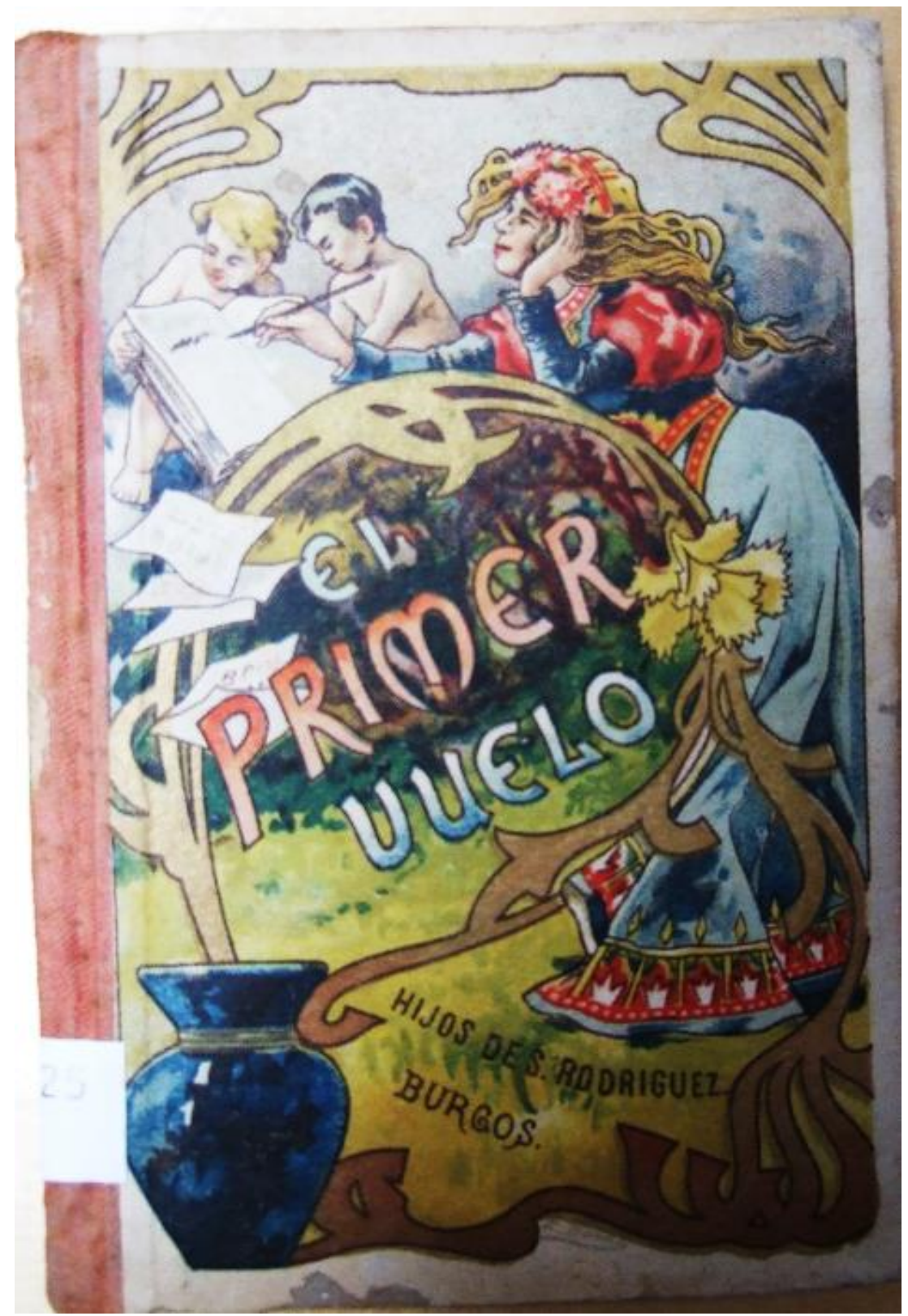

Fig. 6-64: Cubierta del libro El primer vuelo para la enseñanza simultánea de la lectura y escritura. Hijos de Santiago Rodríguez.

Ejemplar de la Biblioteca de la Diputación Provincial de Burgos.

El prólogo del nuevo método nos sugiere los pasos que debe darse:

$1^{\circ}$. El maestro escribe en el encerado algunas de las sílabas que componen la palabra de cada ejercicio, al mismo tiempo que las pronuncia clara y correctamente.

Repetición por el maestro y los discípulos de la sílaba escrita en el encerado.

Lectura por el maestro y el discípulo del anterior ejercicio, en el libro.

Esta misma lectura por el niño solo.

Lectura del tema y frases sueltas por el maestro (en el tercer grado serán los niños). 
La misma lectura por el niño.

$2^{\mathrm{o}}$ Escritura de palabras y frases (del libro u otras) que se le presentan en muestras.

Lectura de la plana copiada de estas muestras y comparación de una con otras.

$3^{\circ}$ Dictado, para escribir en la pizarra, de palabras y frases compuestas de elementos ya conocidos.

Y por último corrección ortográfica por el maestro.

Como ejercicios previos y preparatorios para las fases descritas deben realizarse:

A.- Trazado en el encerado y pizarra de líneas rectas y curvas, equidistantes y en distintas direcciones.

Lo mismo que lo anterior pero sobre papel, con lápiz enseñándole la postura de todas y cada una de las partes del cuerpo al escribir.

Trazado con pluma, palotes naturales y diagonales finas, en papel según su edad.

Trazado de palotes naturales, altos y bajos y curvas bajas, y altas.

B.- Pronunciación pura y correcta de las palabras.

División oral de las palabras en sílabas, deduciendo de esta su definición.

La base que sustenta este libro es la evolución y desarrollo natural de las letras y la repetición silábica como método único e insustituible. El profesor puede cambiar las muestras, siempre que figuren palabras que estén formadas por las letras que ya escribiera el discípulo; además, debe amoldarse a la inteligencia infantil alterando, muy levemente, la forma de algunas letras para facilitar la pronta terminación de su aprendizaje. Con las sílabas directas simples prepara el camino hacia las directas dobles, inversas y mixtas, y así, llegar leer cuentos.

El libro se completa con trece cuentos, cuatro narraciones y varios abecedarios, con distintos tipos de letras. Tiene un total de 172 páginas, encuadernado en cartón e ilustrado a color por Evaristo Barrio.

La editorial dispone de otras obras: Epítome de la Gramática de la Lengua Española, de Millán Orío y Millán, ${ }^{812}$ que aparece en todos los Catálogos estudiados; Compendio de Gramática castellana, de Herranz y Quirós, de los años 30; Primer curso de Lengua Española y Segundo curso de Lengua Española, de M. Peñín y Rubio, que aparece en los dos últimos Catálogos, de 1925 y 1929; y, un Compendio de Ortografía castellana que en doce capítulos desgrana la definición de ortografía, la división de las letras, algunas letras especiales, el acento o los signos de puntuación,

812 ORÍO Y RUBIO, M. Epítome de la gramática de la lengua española. $9^{\text {a }}$ edición. Burgos: Hijos de Santiago Rodríguez, 1900. 
guiones y abreviaturas, según las reglas de la Real Academia Española, escrito por Anselmo Salvá. Este último libro fue impreso en 1893, con 24 páginas, y encuadernado en cartulina fuerte. Sirvió de texto, en la enseñanza oficial, según Real Orden de 12 de febrero de $1906^{813}$ (Figura 6$65)$.

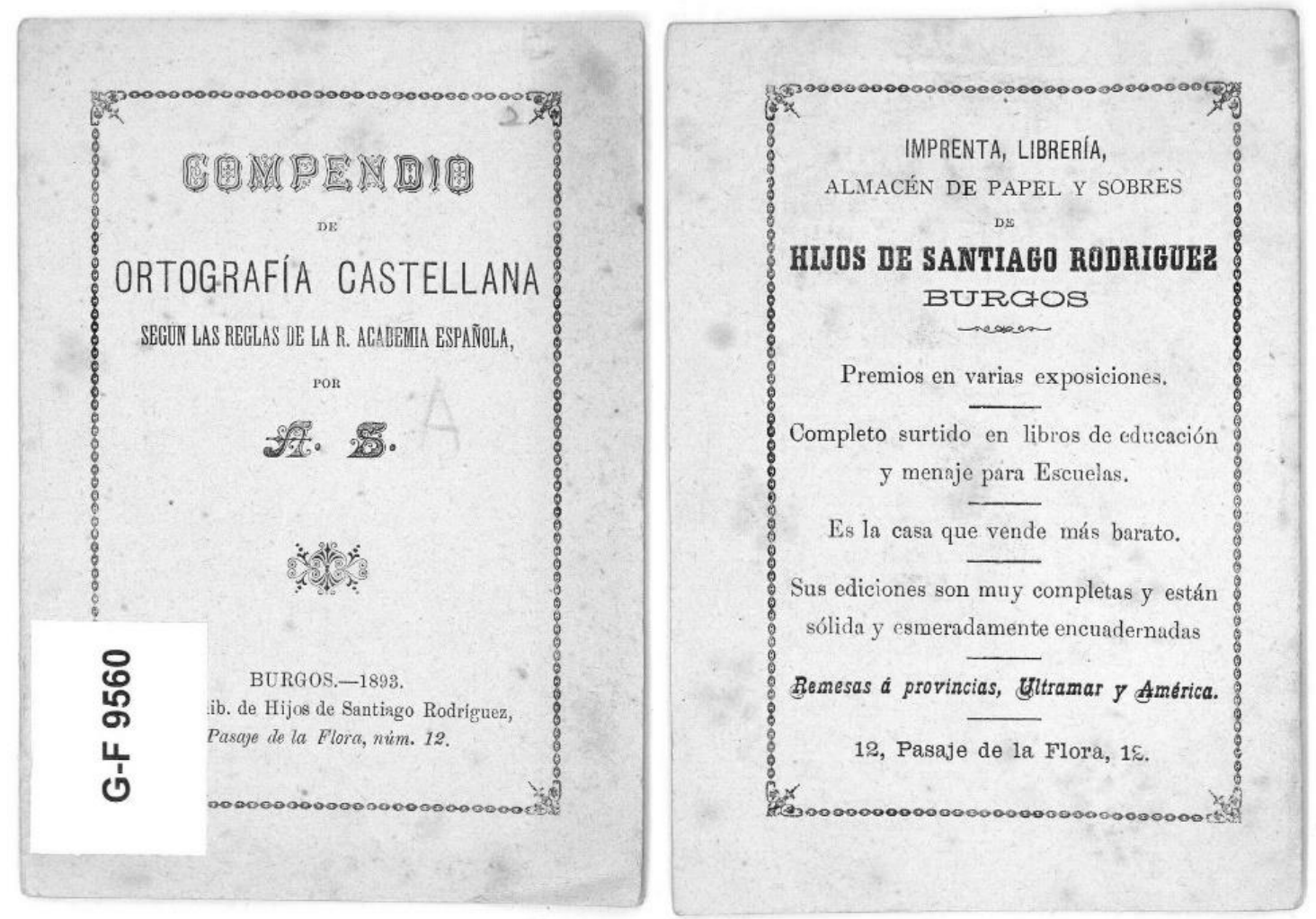

Fig. 6-65: Portada y contraportada del Compendio de Ortografía Castellana de Anselmo Salvá. Hijos de Santiago Rodríguez.

Ejemplar de la Biblioteca Digital de Castilla y León.

\section{Libros de lectura}

Si bien es cierto que la mayoría de los manuales de la enseñanza de la lectura formaban parte de la herencia de su padre, en esta nueva etapa empresarial aparecen otros libros. Son, propiamente, libros de lectura escolares que no forman parte de las Bibliotecas anteriormente descritas.

Son textos escritos en los últimos años del siglo XIX, y principios del $\mathrm{XX}$, que mantienen un anclaje religioso, acompañados con temas de índole moral y patriótica.

Mariano Rodríguez, buen conocedor de la situación de la enseñanza, supo ver que la introducción de nuevos métodos para el aprendizaje de la lectura era bastante difícil porque los maestros seguían utilizando las

${ }^{813}$ VILLALAÍN BENITO, J. L. Op. cit., T. III, p. 243. 
cartillas clásicas. Sin embargo, para afianzar esta instrucción se necesitaba abundante material. De ahí, resalta la importante labor editorial destinada a la escuela para reforzar el aprendizaje de la lectura.

La obra de lectura para niños y niñas, Para mi Hijo, ${ }^{814}$ escrita por Mateo Bustamante y aprobada por la Autoridad Eclesiástica, la forman una colección de narraciones morales. Están ordenadas según la dificultad lectora, incrementando el vocabulario y cambiando el tipo de letra, más grande al principio y paulatinamente más normalizada. Son cuentos cortos, amenos, en forma dialogada entre una madre y su hijo, a la hora de acostarse, en la que el hijo pide explicaciones o reconoce alguna enseñanza personal.

Aunque desconocemos el año de inicio, el primer libro del que tenemos referencias data de 1898, en una $2^{\text {a }}$ edición. En 1908 cuenta la $8^{a}$ edición, en 1917 llega a la $18^{\mathrm{a}}$, en 1925 a la $27^{\mathrm{a}}$, y en 1929 a la $30^{\mathrm{a}}$. Debido a su éxito continúa editándose hasta 1963 , con la $55^{\text {a }}$ edición. Desde sus inicios está ilustrado, tanto las cubiertas como el interior de cada una de las narraciones. Los ilustradores cambian según la época, desde Evaristo Barrio, Fortunato Julián, Rosario de Velasco, Julio Algora hasta Cristino Soravilla (Figura 6-66).

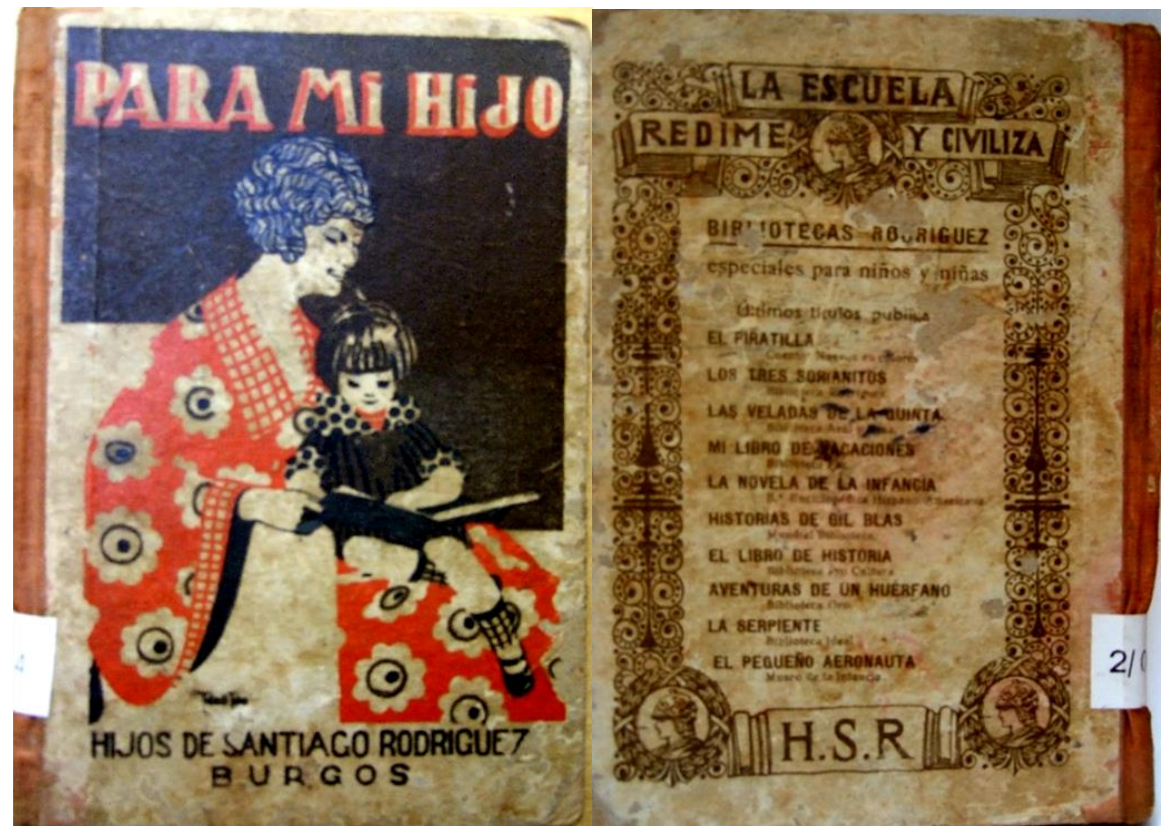

Fig. 6-66: Cubierta y contracubierta Para mi hijo.

Era habitual utilizar las contraportadas para publicitar las obras de la editorial más señaladas. Biblioteca de la Diputación Provincial de Burgos.

\footnotetext{
${ }^{814}$ BUSTAMANTE Y JUNQUERA, M. Para mi hijo. Libro primero de lectura para niñas y niños. $2^{\mathrm{a}}$ edición. Burgos: Hijos de Santiago Rodríguez, 1898, 152 p. El autor vende la propiedad intelectual en 1896. Vid. 2.1.17.
} 
Mateo Bustamante también escribió Lecturas Morales, libro que fue aprobado como de texto para las escuelas de primera enseñanza por Real Orden de 28 de marzo de $1882^{815}$ y por la Autoridad eclesiástica.

En la introducción nos relata cómo en la escuela el maestro, pensando en sus alumnos, ha confeccionado una colección de cuentos para que le recuerden, y los dictados sean más entretenidos; "más que para embellecer la letra y perfeccionar la ortografía os sirvan mis relatos para embellecer el alma y perfeccionar la conciencia. Es así como seréis honrados y respetados, y queridos por todos". 816

Contiene 24 lecturas donde la base principal de la educación es la moral fundada en la religión; si ésta falta, no puede haber sociedad bien ordenada.

La necesidad de inculcar en el alma tierna de los niños ideas sanas, sentimientos nobles y el amor a nuestros semejantes, es lo que ha animado al autor para hacer este precioso libro que es de gran valor para la lectura y uno de los mejores para educar el delicado corazón de los niños. ${ }^{817}$

Se desconoce el año de la $1^{\text {a }}$ edición aunque en el Catálogo de 1908 nos informa de la $9^{\mathrm{a}}$, notablemente corregida, en el de 1917 de la $13^{\mathrm{a}}$, en el de 1925 de la $17^{\mathrm{a}}$ y en el de 1929 de la $18^{\mathrm{a}}$. La correspondiente a la $10^{\mathrm{a}}$ edición tiene un tamaño de $16 \times 12 \mathrm{~cm}$. y 176 páginas, con numerosas ilustraciones de Evaristo Barrio. Está encuadernado en cartón con tela en el lomo. La cubierta está ilustrada a color por Evaristo Barrio donde figura una madre que está leyendo un libro a su hijo, en medio de la Naturaleza (Figura 6$67)$.

${ }^{815}$ VILLALAÍN BENITO, J. L. Op. cit., T. III, p. 63.

816 BUSTAMANTE Y JUNQUERA, M. Lecturas morales. Coleccionadas para los niños de ambos sexos. $10^{a}$ edición. Burgos: Hijos de Santiago Rodríguez, 1900, p. 5. El autor vende la propiedad intelectual de esta obra en 1896. Vid. 2.1.17.

${ }^{817}$ CATÁLOGO 1917, p. 18. 


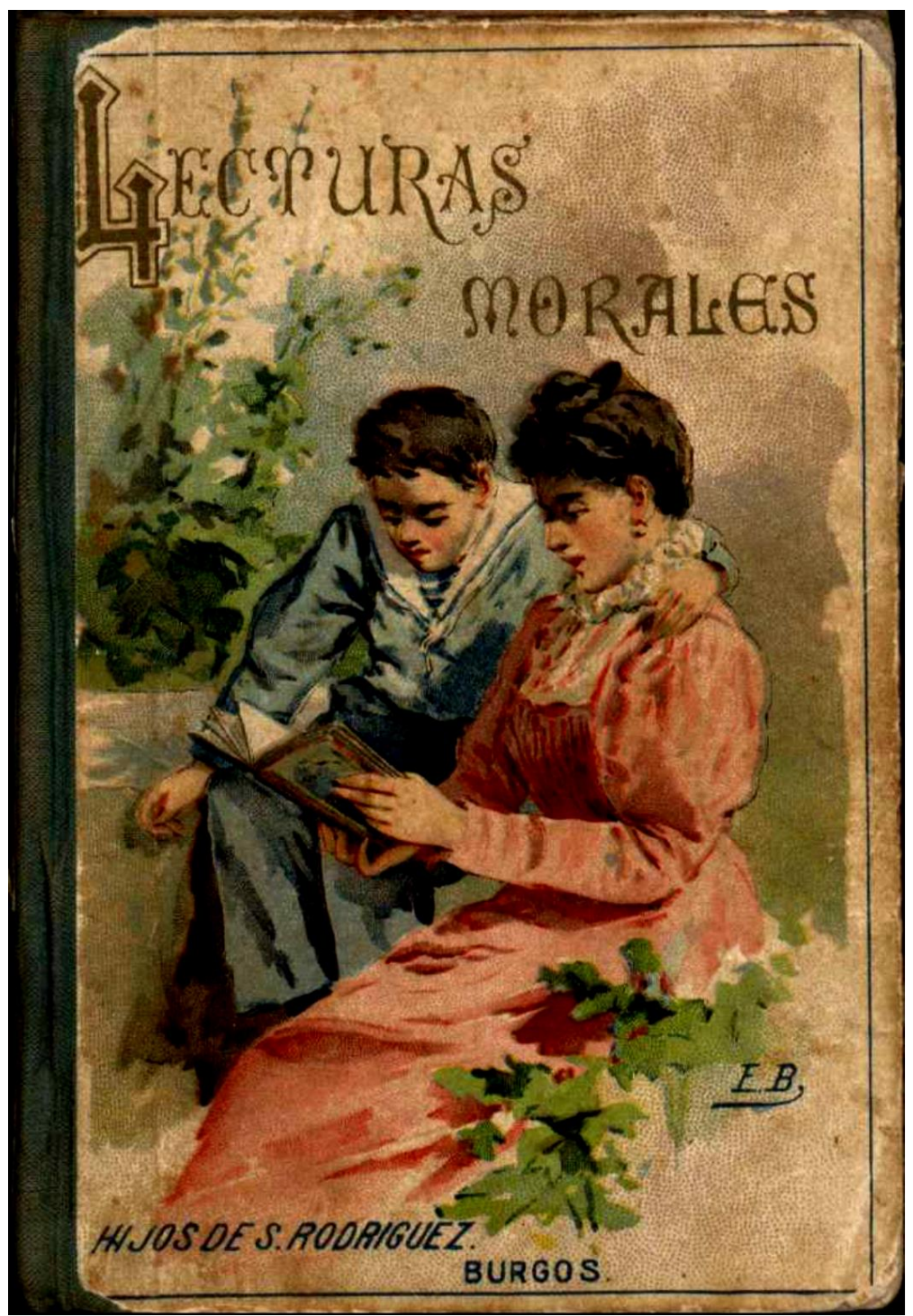

Fig. 6-67: Cubierta de Evaristo Barrio en Lectura Morales.

Hijos de Santiago Rodríguez. Biblioteca Digital de Castilla y León.

Viaje Infantil es un libro escrito por Mariano Rodríguez Miguel, publicado en enero de 1893 y aprobado por Real Orden de 29 de abril de 1893. ${ }^{818}$ También fue recomendado por la Autoridad eclesiástica y declarado de utilidad para las escuelas de $1^{\text {a }}$ enseñanza por el Consejo de Instrucción Pública de Burgos, el mismo año. ${ }^{819}$

Es un libro ampliamente editado y reformado hasta el año de 1963. Según la edición, cambia el número de páginas así como su tamaño. En el Catálogo de 1908 lo caracteriza de un tamaño de 16 x 11,8 cm. con 196 páginas. Está encuadernado en pasta, lomo de tela, con cubiertas en cromo e ilustraciones de Isidro Gil, quien lo firma en $1892,{ }^{820}$ realizadas en las litografías de Moliner y Rodríguez, en Burgos, y de Mateu, en Madrid. Las ilustraciones interiores, en blanco y negro, se deben a varios artistas:

\footnotetext{
${ }^{818}$ VILLALAÍN BENITO, J. L. Op. cit., T. III, p. 184.

${ }^{819}$ El Papa-Moscas. Año XVI, no 805, 28 de mayo de 1893, p. 3. Vid. Anexo 3.2.30.

${ }^{820}$ Vid. Anexo 3.2.23.
} 
Evaristo Barrio, Isidro Gil y Pedrero. Se registran un total de 21 ilustraciones de plana entera, la mayoría de ellas, y otras intercaladas en el texto (tamaño grande) o situadas en la parte superior, antes de cada apartado. Señala que la acogida ha sido tan favorable, en el magisterio español y americano, que la primera edición se agotó en un año con una tirada de 30.000 ejemplares.

En el Catálogo de 1917 y 1925 se publicita esta obra, con las mismas condiciones externas e internas, y menciona que va por la $16^{\mathrm{a}}$ y $24^{\mathrm{a}}$ edición, respectivamente. El Catálogo de 1929 expresa que se está preparando la $26^{a}$ edición, corregida y ampliada por Antonio J. Onieva, con datos más recientes acerca de los modernos inventos, e ilustrada por Fortunato Julián.

La prensa local refleja el éxito con las líneas publicadas en el periódico El Papa-Moscas:

Este nuevo libro irá a aumentar, con éxito seguramente, el catálogo de los muchos que la casa posee para material de escuelas.

El autor, que lo es D. Mariano Rodríguez, socio y gerente de referida casa, conocedor como el que más de las necesidades de las escuelas, y de los métodos más adecuados para enseñar con estímulo, aprovechamiento, ha sabido formar un libro de verdadero interés para los niños.

Las materias que trata, son: la locomotora, el telégrafo, el teléfono, el globo, el fonógrafo, la imprenta, la fotografía, la luz eléctrica, la navegación, el microscopio, el telescopio, el cristal, el barro, etc., están expuestos con gran suma de conocimientos científicos, y con la necesaria claridad, para que los niños deleitándose en la lectura, se instruyen y adquieren conocimientos generales de todo aquello que en la vida tenemos que utilizar.

Si a esto añadimos que la obrita está ilustrada con dibujos de los Sres. Barrio, Gil y Pedrero, representando lo más notable de cada aparato o máquina científica, fácilmente se comprenderá el valor que tiene para la educación escolar.

Felicitamos de todas veras al autor Sr. Rodríguez y a los inteligentes colaboradores, señores Barrio, Gil y Pedrero.

De venta en la librería de los Sres. Hijos de Santiago Rodríguez al precio de 0,80 pesetas..$^{821}$

Esta obra, Viaje Infantil, coincide en su contenido con Los grandes inventos de la Biblioteca Enciclopédica Hispano-Americana.

Destacamos la utilización de un lenguaje sencillo, ameno y cercano a la psicología infantil, que se observa en los diálogos que se establecen entre niño y padre. El niño, Santiaguito, hace comentarios de todo lo que le sorprende, con un sinfín de preguntas, cuenta emociones de forma espontánea, sin los anclajes de comportamiento estricto de un niño de 8 años de su época, y describe cómo adquiere estos conocimientos, por la

${ }^{821}$ El Papa-Moscas. Año XVI, no 786, 15 de enero de 1893, Burgos. 
observación directa e instrucción de un adulto, en este caso su padre. Este planteamiento metodológico supone un paso adelante frente al dogmatismo y moralismo del siglo que acaba.

Ejemplo de este pensamiento son frases que recogemos del libro que lleva al lector a tener una visión más global de la realidad, como $E l$ que puede y no viaja es un tonto y El viaje, hijo mío, es el bazar de la enseñanza.

Por otra parte al hablar sobre la imprenta nombra junto a libros clásicos como Cuentos de Schmid, de Andersen, Yo sabré leer, Ya sé leer, ${ }^{822} \mathrm{e}$ incluye otros de su propia editorial como El Previsor, Viaje Infantil. Es curioso observar que las obras extranjeras que propone ejemplifican dos tendencias alternativas de la literatura europea: Schmid como continuadora de la herencia moralizante y Andersen como referente del concepto romántico de la educación, donde la fantasía y la imaginación son elementos principales.

El Previsor, con el subtítulo de lecturas utilísimas sobre artes, oficios, carreras, etc., fue redactado por Antonio Álvarez Carretero, maestro de la Escuela Normal y Regente de la Escuela Práctica Superior de Burgos. También fue recomendado por la Junta Provincial de Instrucción Pública de Burgos para las escuelas de $1^{\mathrm{a}}$ enseñanza, ${ }^{823}$ aprobado por Real Orden de 8 de junio de $1880^{824}$ y por la Autoridad eclesiástica. Obtuvo premios en la Exposición de Zaragoza, en 1885, y en la Exposición Universal de Barcelona, de 1888.

El libro expone en dos partes, a modo de conversación, el diálogo de un maestro con dos de sus alumnos que dejan la escuela para dedicarse a un oficio, en dos partes.

La primera, de tipo filosófico, se desarrolla a través de un cierto monólogo donde el maestro explica y los alumnos reafirman lo que escuchan, aunque es un tanto imposible creer las preguntas que hacen los niños, supuestamente menores de diez años.

Algunos de los apartados pueden hacer ver el contenido de esta primera parte:

- Facultades y aspiraciones del espíritu.

- Necesidades humanas y su historia.

- División del trabajo.

- La riqueza. Fuentes de riqueza. Desarrollo necesario de las fuentes de riqueza.

- Elementos de producción.

${ }^{822}$ Es posible que se refiera al libro titulado Ya sé leer. Lecturas y escenas infantiles por un papá. París: Editorial Garnier Hermanos, [1870?]

${ }^{823}$ CATÁLOGO 1908, p. 16.

${ }^{824}$ VILLALAIN BENITO, J. L. Op. cit., T. III, p. 112. 
- Elección del trabajo.

La segunda parte, explica todas las ocupaciones y oficios, comenzando por la escuela. A continuación, y tras la visita de varios museos, les va especificando cada una de las carreras $^{825}$ y oficios existentes, con sus disposiciones oficiales vigentes.

En 1891, a los pocos meses de la muerte del fundador, se reimprime una nueva edición de la que nos da cuenta El Papa-Moscas:

Este libro es muy importante por las materias que abraza y las buenas condiciones que reúne para la enseñanza de la lectura.

Esto, unido a sus bonitos grabados esmerada impresión y elegante encuadernación, hace que figure entre los primeros de su clase.

Tiene además la ventaja de ser baratísimo, pues se vende en toda España a 1 pts. el ejemplar.

Tanto los dibujos como el cromo de la cubierta son debidos al lápiz del reputado artista D. Isidro Gil.

Está premiada esta obra en la Exposición de Zaragoza y en la Universal de Barcelona y además aprobada por Real Orden.

Agradecemos a los señores Hijos de Rodríguez la atención. ${ }^{826}$

La Biblioteca Pública de Burgos atesora un ejemplar de 1896, perteneciente a una $5^{a}$ edición, comentada como "Novísima Edición, corregida y aumentada".

\footnotetext{
${ }^{825}$ Ilustración de Isidro Gil a plana entera como introducción a la explicación de las diversas carreras y oficios. Anexo 3.2.29.

${ }^{826}$ El Papa-Moscas. Año XIV, no 712, 16 de agosto de 1891, p. 3.
} 


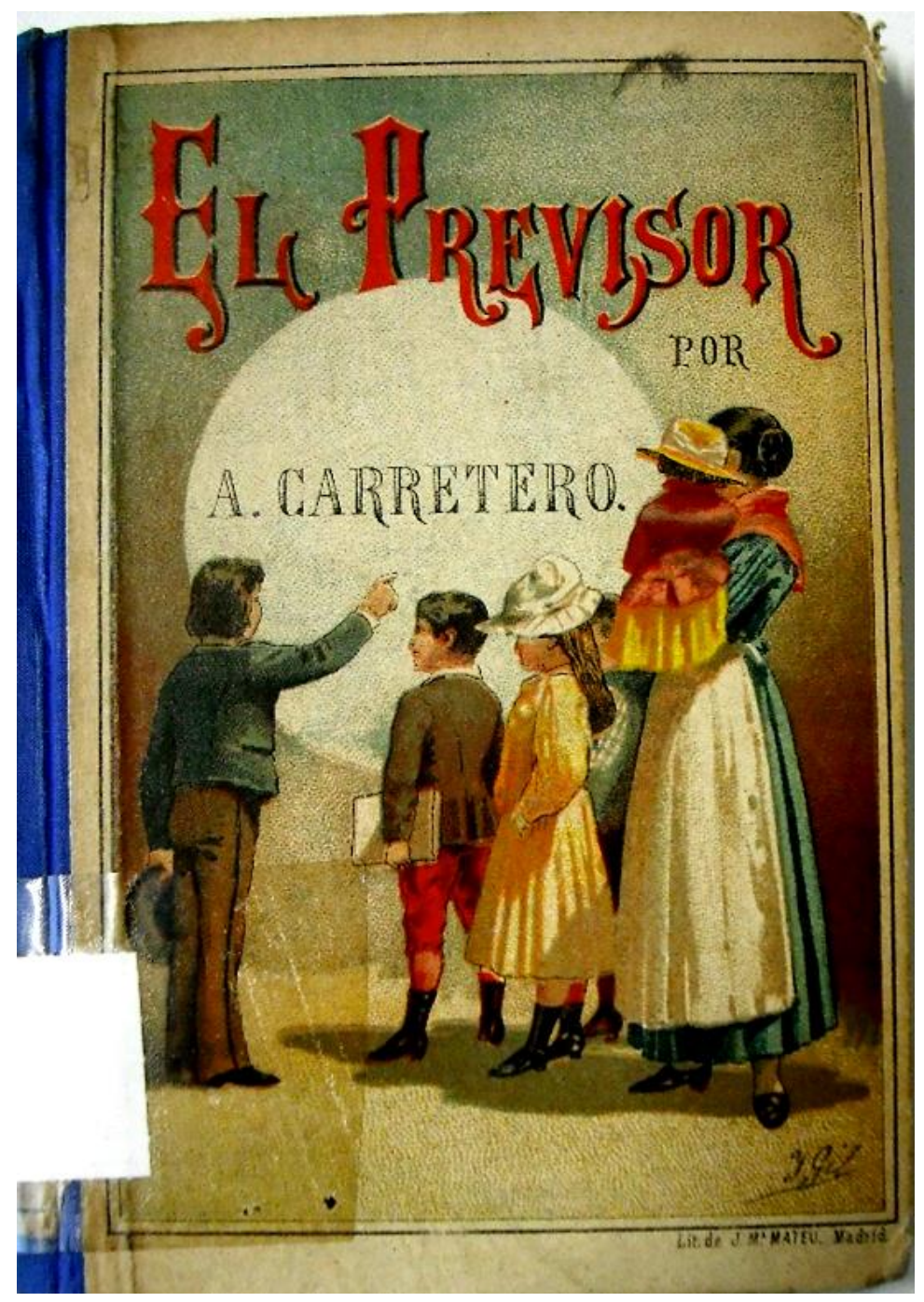

Fig. 6-68: Cubierta de Isidro Gil en el libro El Previsor. $5^{a}$ edición ilustrada. Hijos de Santiago Rodríguez. 1896. Ejemplar de la Biblioteca Pública de Burgos.

El Catálogo de 1908 informa que se han agotado siete numerosas ediciones y que se edita de nuevo con una nueva edición corregida y aumentada, por Ángel Bueno; el de 1917 indica que se editará la 9a edición; y el de 1925, no aporta ningún dato distinto. En el último de 1929 ya no aparece publicitado.

Según la edición, cambia el formato y el número de páginas. Encuadernado en pasta, con lomo en tela, e ilustrado a color por Isidro Gil (Figura 6-68). Tiene doce ilustraciones interiores en blanco y negro, de Isidro Gil y Evaristo Barrio.

Las lecciones del Padre es un libro escrito por Mariano Rodríguez Miguel y publicado en 1907, tal como anuncia el periódico El PapaMoscas: 
Hemos tenido el gusto de recibir y de guardar en nuestra biblioteca el libro Las lecciones del Padre, que el Sr. Rodríguez Miguel nos ha enviado. Encierra lecciones muy propias de la niñez, que recomendamos al profesorado. Se halla muy bien editado e ilustrada, con bellos dibujos del reputado artista Evaristo Barrio. ${ }^{827}$

El contenido es el mismo que edita bajo el nombre Alma y corazón, de la Biblioteca Enciclopédica Hispano-Americana, y comentado anteriormente. Fue declarado de utilidad para que sirviesen de texto en las escuelas de primera enseñanza, según la Real Orden de 20 de mayo de $1910{ }^{828}$ Se editó hasta 1962 con su $22^{a}$ edición reformada.

La obra La educación por la vista, de Ángel Bueno, impresa en 1907, con 221 páginas y más de 800 fotograbados, y encuadernada con tapas al cromo, fue declarada de utilidad como texto en las escuelas de primera enseñanza en la misma Real Orden que la obra anterior. Más que una obra de lectura puede considerarse como una auténtica enciclopedia. En el Catálogo de 1908, narra cómo el pedagogo D. Rufino Blanco la consideraba única en España por su mérito y utilidad. ${ }^{829} \mathrm{El}$ autor vende la propiedad intelectual por cincuenta pesetas, según registro notarial, ${ }^{830}$ y el precio de venta al público es muy económico pues cada ejemplar costaba 1,50 pts. y la docena 10 pesetas.

El ciudadano son lecturas manuscritas por Ángel Bueno, editado en agosto de 1897, según la información aparecida en El Papa-Moscas:

Hemos recibido un ejemplar de El Ciudadano, manuscrito de educación cívica que acaba de publicar esmeradamente los Sres. Hijos de Santiago Rodríguez. Es un librito muy útil y agradable y con esto está dicho todo.

No será difícil que haga la misma fortuna que los de su género publicados por la misma casa. ${ }^{831}$

La obra es un tratado de instrucción cívica y como tal nos lo describen los editores en el prólogo:

¡Nunca nos hemos ocupado en proporcionar semejante pasto intelectual, muy necesario en naciones libres, a los jóvenes estudiantes! El hombre nacido para vivir en sociedad, viviendo políticamente así reunidos en estados, necesita conocer sus derechos y deberes, dentro de tal forma de vida, para poder ser buen ciudadano. Sin inculcar estas ideas de instrucción cívica en sus hijos, los pueblos

\footnotetext{
${ }^{827}$ El Papa-Moscas. Año XXX, no 1610, 27 de octubre de 1907, p. 2.

${ }^{828}$ VILLALAÍN BENITO, J. L. Op. cit., T. III, p. 253. En dicha R.O. expresa que fue impresa en 1905, tiene 239 páginas con grabados.

${ }^{829}$ Catálogo 1908, p. 20.

${ }^{830}$ AHPBU. Sección protocolos. Caja no 11448, 14 de noviembre de 1907. Vid. Anexo 2.1.19.

${ }^{831}$ El Papa-Moscas. Año XX, no 1120, 1 de agosto de 1897, p. 3.
} 
declarados libres suelen convertirse en míseros esclavos de sí mismos, la patria suele no progresar ni aun ser feliz en su ignorancia. ${ }^{832}$

Ángel Bueno narra cómo un maestro es invitado a un pueblo de un discípulo suyo, Emilín, y que cada día al atardecer, debajo de una parra, se dedicará a charlar sobre Instrucción Cívica. Versa, con distinto tipo de letra manuscrita, sobre los siguientes temas institucionales: patria, familia, vida social en los pasados siglos, organización social moderna, representantes nacionales, poderes y administración del Estado, y sobre los diferentes ministerios. Al final, hace un resumen de todos los estamentos del Estado.

Es un libro de 168 páginas, encuadernado en pasta con lomo de tela e ilustrado a color por Evaristo Barrio (Figura 6-69). Las ilustraciones interiores fueron realizadas por el mismo autor, en blanco y negro.

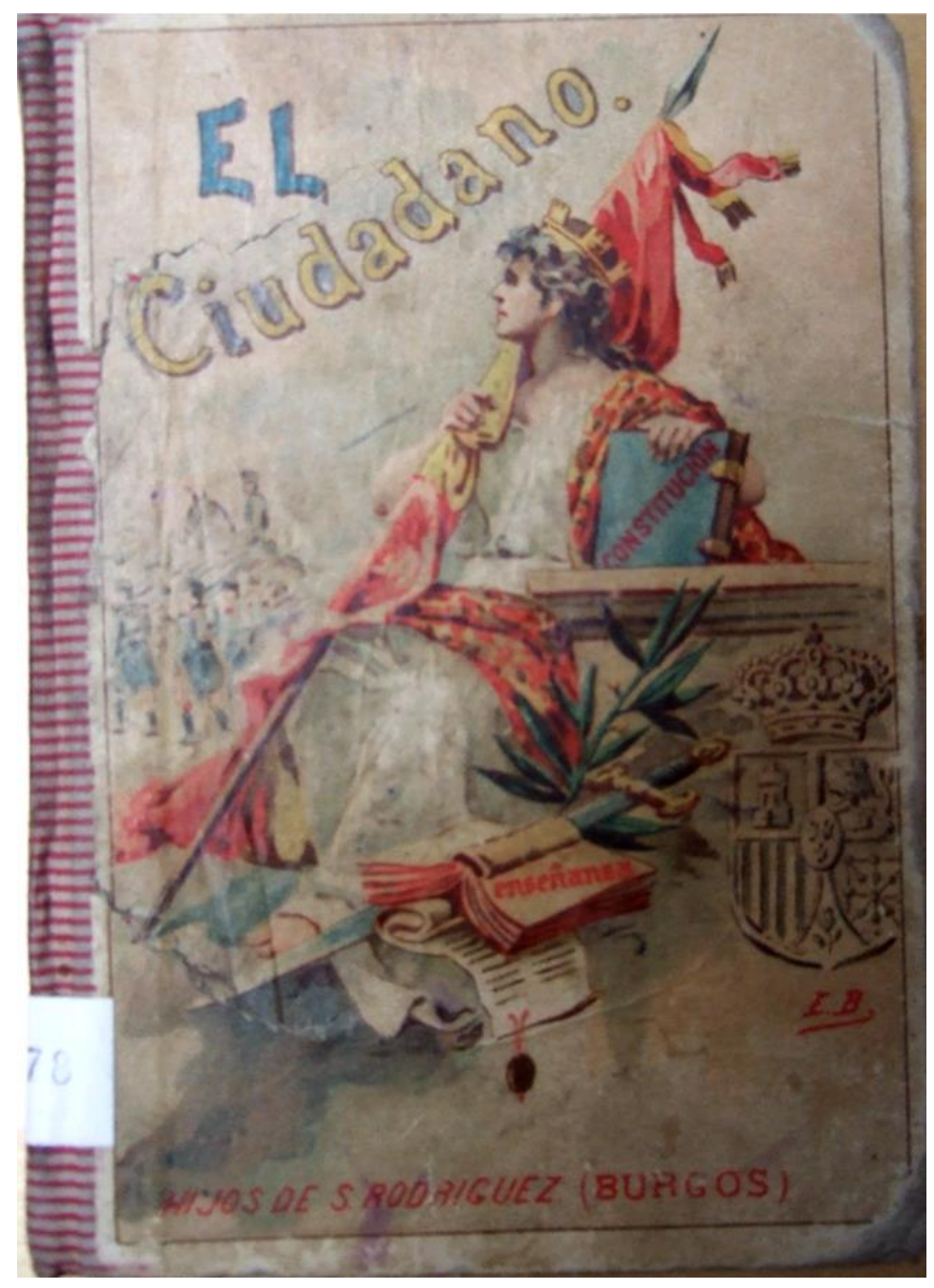

Fig. 6-69: Cubierta de Evaristo Barrio de la obra El Ciudadano.

Hijos de Santiago Rodríguez. Biblioteca de la Diputación Provincial de Burgos.

${ }^{832}$ BUENO RODRÍGUEZ-ARIAS, A. El Ciudadano. Burgos: Hijos de Santiago Rodríguez, 1897, pp. 56. 
Se conserva la $11^{\text {a }}$ edición de 1904. Los sucesivos catálogos presentan su reimpresión que alcanza la $17^{\mathrm{a}}$, en 1917 , la $25^{\mathrm{a}}$, en 1925 , y la $26^{\mathrm{a}}$, en 1929, como prueba de su éxito comercial. El Catálogo de 1904 apunta que en breve aparecerá una nueva edición, hecha con tipo común o redonda, con reformas en el texto para ajustarlo a las actuales divisiones vigentes en lo que se refiere a Municipios, Diputación y otros organismos recientemente creados. Para evitar confusiones o dudas esta nueva edición se titulará El Nuevo Ciudadano. Lecturas Cívicas, explicando que fue minuciosamente corregida por el autor, recientemente fallecido, como obra póstuma, y se edita como homenaje a su memoria.

Magdalena Santiago Fuentes escribió La Escuela y la Patria, lecturas manuscritas que narran, como maestra, escenas escolares. El argumento describe la vida de Malvina, hija de un director de una empresa de zarzuela que, debido a las extraordinarias dotes de su hija, desde muy pequeña forma parte de las obras artísticas llevadas al escenario. Al verla la Marquesa de Alcira se apiadó y quiso educarla en una escuela para niñas, aunque su mal comportamiento, debido a que quería ser artista, la llevó al ingreso como interna en el colegio. Allí, su carácter se dulcificó hasta llegar a ser maestra, aprobar una oposición y cuidar a su padre enfermo.

De alguna forma refleja su propia vida puesto que, al no poder acabar los estudios iniciados por la muerte prematura de su padre, reencontró su propio papel de educadora $\mathrm{y}$, a su vez, critica el papel que deben desempeñar las mujeres.

El tomo de 160 páginas está encuadernado en pasta dura, con ilustración a color de Evaristo Barrio (figura 6-70), y las interiores en blanco y negro. La litografía fue realizada por A. Moliner, de Burgos, con diferentes tipos de letras. En 1917 presentó la $15^{\text {a }}$ edición, en 1925 la 22ª y en 1929 la $24^{\mathrm{a}}$.

El 19 de noviembre de 1902 vende la propiedad intelectual a la editorial Hijos de Santiago Rodríguez de esta obra y de Novela de la infancia. Se realiza ante notario y, representada por D. Esteban Franco, tipógrafo y encuadernador, recibe la cantidad de 175 pts. ${ }^{833}$

${ }^{833}$ AHPBU. Sección Protocolos. Caja 11252, 19 de noviembre de 1902. Vid. Anexo 2.1.18. 


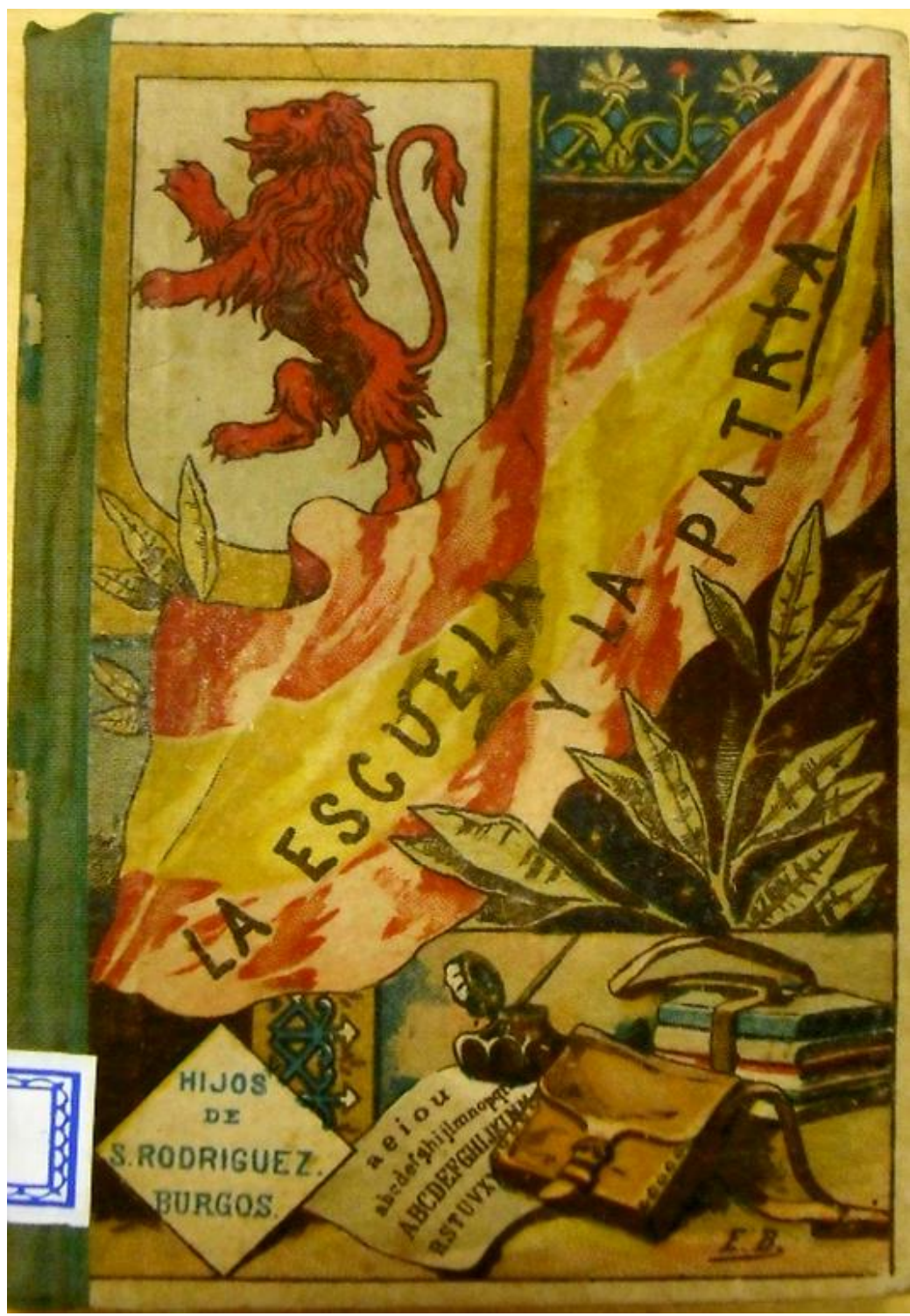

Fig. 6-70: Cubierta de Evaristo Barrio de La Escuela y la Patria. Hijos de Santiago Rodríguez.

Ejemplar de la Biblioteca Pública de Burgos.

Mi patria: lo que ha sido, lo que es y lo que puede ser España escrita por Gabino Enciso Villanueva, maestro de escuela nacional en Madrid, presenta a los niños un recorrido por todas y cada una de las provincias de España, mostrando su pasado y su presente. Se publicita en el Catálogo de 1917 , con un tamaño de 20 x $15 \mathrm{~cm}$. y 424 páginas, e ilustrada con 250 fotograbados.

El Ideal de una Niña es un libro de lectura para niñas escrito por el cronista de Burgos, Anselmo Salvá. Narra las excursiones de una maestra, los jueves por la tarde, por distintos lugares de una ciudad con un pequeño grupo de alumnas, según las notas obtenidas en los exámenes del sábado. En 16 capítulos aprovecha el autor para inculcar en las niñas los valores religiosos y morales para formar completas y acabadas madres de familia. 
El contenido del libro refleja el papel secundario de la mujer, limitándolo al ámbito familiar, como se puede apreciar en el siguiente fragmento:

A la mujer toca parte, la principal, en la obra que haya de producir aquellos resultados. Su influencia en la sociedad es vivísima, permanente e irresistible. Sus deficiencias en estos tiempos, tan adelantados para otras cosas, son notorias. Edúquese bien a la mujer, para que ella eduque después, por su medio o por otro, a la familia, e indirectamente en la sociedad, y se habrán sembrado los gérmenes de la felicidad de un pueblo.

A inculcar ideas, a suministrar conocimientos, a inspirar sentimientos y afectos para que la niña empiece a ser bien educada y la mujer llegue con su influencia, a ser buena educadora. ${ }^{834}$

El libro fue editado en 1897, encuadernado en pasta y lomo de tela, con ilustraciones en la cubierta e interiores de Evaristo Barrio. ${ }^{835}$

Cancionero de la Infancia es un libro formado por 60 composiciones poéticas para que los niños venzan sin esfuerzo las dificultades del verso. ${ }^{836} \mathrm{Su}$ autor, Lino González Ansótegui, expresa un contenido de carácter moral con la intención de estimular en los niños el amor a la verdad, al bien, al amor filial, a la caridad y la amistad. En la mayoría de las composiciones se percibe, claramente, un carácter religioso y patriótico. libro.

Para vosotros, niños, son principalmente los humildes versos contenidos en este

Con ellos, heme propuesto despertar en vuestros corazones el sentimiento del amor a Dios, a vuestros padres, a los hombres y a la patria. ${ }^{837}$

El libro tiene un tamaño de 16 x $12 \mathrm{~cm}$., con 170 páginas, y está encuadernado en pasta dura. La cubierta a color y las ilustraciones, a razón de una por cada composición, son de Evaristo Barrio, que vende sus derechos de propiedad a la editorial en 1907, por el precio de 40 pts. ${ }^{838}$

Al igual que las editoriales de su época, imprime libros referentes a obras y autores inmortales como el titulado Cervantes en la escuela, escrito por el licenciado en Filosofía y Letras, y maestro Normal, D. Acisclo Muñiz Vigo, con el propósito de vulgarizar el conocimiento de las obras de Cervantes, especialmente de El ingenioso hidalgo don Quijote de la

\footnotetext{
${ }^{834}$ El Papa-Moscas, Año XXI, no 1146, 30 de enero de 1898, p. 3.

${ }^{835}$ SALVÁ PÉREZ, A. El Ideal de una Niña. Burgos: Hijos de Santiago Rodríguez, 1898. Su autor vende la propiedad intelectual en noviembre de 1896, por lo que el libro señalado forma parte de reediciones posteriores. Vid. Anexo 2.1.17.

${ }^{836}$ CATÁlOGO 1908. Op. cit., p. 22.

837 GONZÁLEZ ANSÓTEGUI, L. Cancionero de la infancia: lecturas poéticas. Burgos: Hijos de Santiago Rodríguez, 1907, 170 p. Las palabras señaladas pertenecen a la dedicatoria que hace el autor al comienzo del libro.

${ }^{838}$ AHPBU. Sección protocolos. Caja 11448, 14 de noviembre de 1907.
} 
Mancha, incluyendo también algunos fragmentos de otras obras cervantinas para uso en las escuelas primarias.

Es de aplaudir el propósito de vulgarizar el conocimiento de las obras de Cervantes, especialmente de El ingenioso hidalgo don Quijote de la Mancha, llevando a la escuela primaria una adaptación de la inmortal novela y algunos fragmentos de otras obras del mismo celebrado autor, según lo dispuesto en el $n^{o}$ 11 de la real orden de 12 de octubre de 1912, y, por tanto, la citada obra, por su fin, por su contenido, por sus cualidades pedagógicas y hasta por sus condiciones materiales, parece recomendable, a fin de que pueda ser declarada útil para la enseñanza en las escuelas nacionales de instrucción primaria. [...]

Madrid, 21 de enero de 1916. Burell. Señor Director general de primera enseñanza. ${ }^{839}$

Hijos de Santiago Rodríguez publica la primera novela de $\mathrm{M}^{\mathrm{a}} \mathrm{Cruz}$ Ebro titulada La Niña, con el subtítulo Novela feminista. La portada fue realizada por el artista burgalés Fortunato Julián. ${ }^{840}$

La autora describe en 10 capítulos el paisaje gallego que pudo contemplar, durante su estancia en Pontevedra, cuando su padre fue Gobernador Civil de esta provincia. Es de señalar cómo la autora defiende el voto femenino, aun cuando todavía la mujer no lo tiene, y su derecho a intervenir en la vida pública y política. ${ }^{841}$

Se imprimieron, también, otras obras clásicas como Fábulas Literarias, tanto de Samaniego como de Iriarte. ${ }^{842}$ En el Catálogo de 1929 incluye las Fábulas de Julián Chave y Castilla y las Fábulas castellanas, selección realizada por Narciso Alonso Cortés.

En 1934, Josefina Bolinaga, premio Nacional de Literatura, escribe para la editorial Amanecer. Es un libro de lecturas amenas donde pretende no sólo instruir sino divertir a través de los relatos como La pastorcita rubia, El pájaro parlero, El ratoncito de oro, Sultán, Cuquillo, La cueva maldita, La Virgen de azúcar, Historia de un arbolito, Doña Perejil, La reinecita, La mariposa azul, El lobo-cordero, Quica la pastora, Cuento de Navidad y Sol de ocaso; son lecturas llenas de frescura e imaginación. La cubierta fue realizada por Fortunato Julián, lo mismo que las ilustraciones interiores. Este libro prolongó su edición más allá de 1960.

\footnotetext{
${ }^{839}$ VILLALAÍN BENITO, J. L. Op. cit., T. III, p. 305.

${ }^{840}$ El Papa-Moscas. Año IX, no 513, 10 de noviembre de 1918, p. 3.

${ }^{841}$ Para un mayor conocimiento de la autora leer el prólogo que sobre ella realizó Juan Carlos Estébanez en la edición del libro Memorias de una burgalesa de $\mathrm{M}^{\mathrm{a}}$ Cruz Ebro y publicado por el Instituto Municipal de Cultura del Ayuntamiento de Burgos.

${ }^{842}$ IRIARTE, T. de. Fábulas literarias. Burgos: Hijos de Santiago Rodríguez, 1897. SAMANIEGO, F. M. Fábulas en verso castellano. Burgos: Hijos de Santiago Rodríguez, 1898.
} 


\subsubsection{Geografia e Historia de España}

En esta sección hay dos autores que son los iconos de la editorial: en Geografía José Osés Larumbe, maestro de una escuela pública de Barcelona; y en Historia, Anselmo Salvá, cronista oficial de Burgos y miembro de la Real Academia de Historia.

José Osés Larumbe escribe otras obras para la editorial como El mejor tesoro, de la Biblioteca Oro, y Lo que puede la fe, de la Biblioteca Cuentos para Niños. Anselmo Salvá, autor prolífico, escribe muchas otras de carácter educativo y sobre la ciudad como Compendio de la ortografía castellana, Educación indirecta: ligeros apuntes, El ideal de una niña, Reglas de urbanidad para niños, Reglas de urbanidad para niñas, El día del Señor en Burgos, Las cortes de 1392 en Burgos, Remembranzas burgalesas, Tipos burgaleses y el Himno a Burgos.

Geografía para niños (primer grado) libro publicado en 1908, según el Catálogo del mismo año, está citado como $1^{\mathrm{a}}$ edición, aunque el más cercano encontrado pertenece a la $11^{\mathrm{a}}$ edición. El autor, José Osés Larumbe, describe su método de enseñanza, con preguntas y respuestas, donde la memoria es la principal facultad a desarrollar, sobre todo en niños más pequeños, y que una vez que tienen más dominado el lenguaje ya se pueden expresar sin sujeción a ellas. Esgrime como razón que los libros que no se basan en este método no tienen aceptación entre los maestros: "Es lo antiguo, es lo práctico, lo más fácil y sencillo y aún añadiremos que lo más racional". ${ }^{843}$ A pesar de ser conocedor de nuevas metodologías, aboga por la forma memorística, conceptual y racional, muy lejos de los grandes cambios que preconiza la psicología infantil del momento. Por ello advierte en el prólogo que no se extrañen encontrar una forma de confección antigua incrustada en un libro de confección moderna.

Está distribuido en varias partes:

- Nociones preliminares.

- Lecciones sobre Geografía física con varios apartados de parte sólida, la Tierra, parte líquida o agua y parte gaseosa o atmósfera.

- Parte política: razas humanas, la sociedad humana.

- Geografía descriptiva: Europa, España, Asia, África, América y Oceanía.

- Geografía astronómica.

${ }^{843}$ OSÉS LARUMBE, J. Geografía para niños (primer grado). Burgos: Hijos de Santiago Rodríguez, 1908, p. 4. 
En cada lección, después de las preguntas y respuestas, hay una Explicación del Maestro. Se trata de un pequeño esquema de posibles temas que incluyen reflexiones de orden moral y material.

He aquí, a modo de ejemplo, algunas de estas explicaciones sobre un tema:

Los elementos simples y compuestos. Átomo y molécula. Los cuatro elementos: aire, fuego, tierra y agua. Seres que viven en tres elementos. El fuego destruye todos los seres. El infierno. Ningún elemento puede subsistir por sí solo. El fuego se apaga sin aire. El agua no existe sin receptáculo y sin substancias. El aire no existe sin gases y los gases no se producen sin cuerpos. La Tierra no existe sin agua, sin aire y sin calor.

Reflexiones de orden moral: en los elementos se halla la vida y la muerte. La sabiduría de Dios resplandece en la manera de ser y de vivir de todos los seres.

Reflexiones de orden material: necesitamos conocer los elementos que ayudan y sostienen nuestra vida. ${ }^{844}$

Antes de cada lección hay una máxima personal que relaciona el tema con valores religiosos o patrióticos. Señalaremos algunos de ellos:

No basta ser bueno; es necesario ser instruido. ${ }^{845}$

Quien no se sobrecoge ante una tempestad, no está educado en el temor a Dios. ${ }^{846}$

El volcán es símbolo de la violencia de las pasiones humanas. ${ }^{847}$

No juzguéis a los hombres por el color de su piel; juzgarlos por el color de su conciencia. ${ }^{848}$

El Estado más fuerte es el más virtuoso. ${ }^{849}$

El libro, de unas 100 páginas, tamaño 16 x 11,8 cm, contiene ilustraciones de Isidro Gil y Evaristo Barrio, mapas de todos los continentes y uno de España, desplegable y a color.

Geografía para niños (segundo grado), del mismo autor, estudia en 36 lecciones todos los temas, pero no en forma de preguntas y respuestas sino en forma de definiciones que se completan en letra más pequeña. Incluye como novedad el método de los Deberes que recoge, según el autor, los deberes, de innovación francesa, pues los hacen todos los niños que saben escribir y en todas las asignaturas, tanto en escuelas numerosas como en pequeñas, en graduadas o unitarias, e incluso en días de vacaciones. Subraya que el deber es un ejercicio de recapitulación, de síntesis, de

\footnotetext{
${ }^{844}$ Ibídem, p. 8.

${ }^{845}$ Ibídem, p. 5.

${ }^{846}$ Ibídem, p. 28.

${ }^{847}$ Ibídem, p. 35.

848 Ibídem, p. 38.

${ }^{849}$ Ibídem, p. 42.
} 
reflexión e imaginativo, escrito por el niño en su propio lenguaje, con el auxilio del Dibujo cuando la lección lo admite o necesita recursos gráficos. ${ }^{850}$

Continúa explicando que el niño hace el ejercicio en un cuadernoborrador, en su casa, nunca en la escuela, y luego lo lleva al colegio donde se lo corrige su profesor con la nota correspondiente. Finalmente, el alumno lo pasa a un cuaderno de deberes con la fecha y la calificación. Afirma y propone como avance metodológico la inclusión de los deberes en cada tema.

La idea general que exponemos no es nuestra, pero sí lo son, sin copia ni plagio, los recursos con que la desarrollamos. ${ }^{851}$

Según el autor las ventajas de este nuevo método son:

1.- Los padres ven los adelantos en sus hijos.

2.- Se forman cuadernos de trabajos variados, desterrando el memorismo y la rutina.

3.- Aumentan los estímulos y el amor al trabajo y nace un concepto de los deberes sociales que ha de cumplir como futuro ciudadano.

Está distribuido como el de primer grado aunque amplia los contenidos e incluye los mismos apartados. Encuadernado con tapas al cromo, con la misma portada en el primer y segundo grado (figura 6-71), y con ilustraciones interiores de Evaristo Barrio, Isidro Gil y Manero, y otros desconocidos. Además, contiene un mapamundi con las alturas de las principales montañas y los mapas de Europa, Asia, África, América, Oceanía, todos ellos desplegables. Cuenta, además, con un apéndice con curiosidades geográficas, noticias históricas, viajes, descubrimientos, etc., ordenado por fechas. Presenta el mismo tamaño que el de primer grado, con 272 páginas. Las imágenes están realizadas en la Litografía de A. Moliner, en Burgos.

Vende el derecho de propiedad intelectual de ambas obras por el precio de 50 pesetas, el primer grado, y 75 pts., el segundo grado. ${ }^{852}$

${ }^{850}$ OSÉS LARUMBE, J. Geografía para niños (segundo grado). Burgos: Hijos de Santiago Rodríguez, 1917.

${ }^{851}$ Ibídem, p. 4.

${ }^{852}$ AHPBU. Sección protocolos. Caja 11448, 14 de noviembre de 1907. Vid. Anexo 2.1.19. 


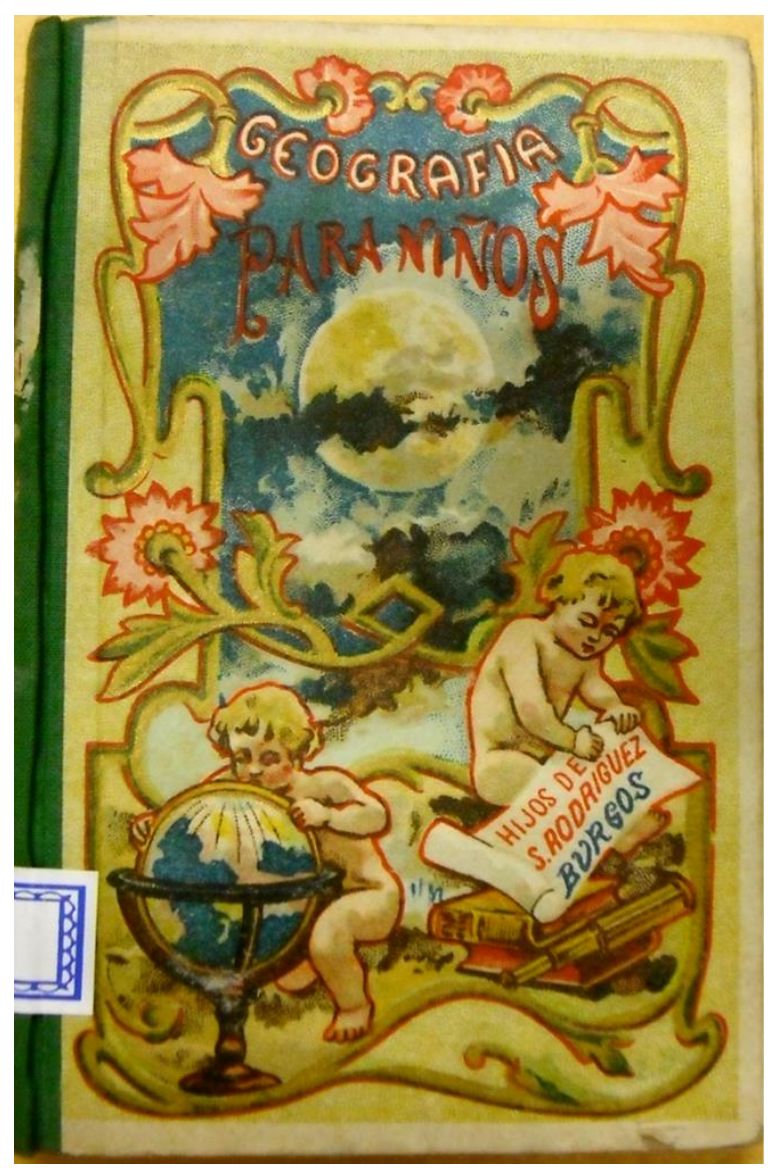

Fig. 6-71: Cubierta del libro Geografía para niños de José Osés Larumbe.

Hijos de Santiago Rodríguez. $11^{\mathrm{a}}$ edición.

Ejemplar de la Biblioteca de la Diputación Provincial de Burgos.

Para la Historia de España, Hijos de Santiago Rodríguez elige a Anselmo Salvá como autor principal y hace un desarrollo programático para este tipo de publicaciones. Con el título Resumen de Historia de España ${ }^{853}$ obra de 223 páginas con ilustraciones de Evaristo Barrio e Isidro Gil, ${ }^{854}$ se encuentran ejemplares de 1896 en una novísima edición ilustrada. La obra fue aprobada como texto en las escuelas de primera enseñanza por Real Orden de 8 de junio de $1898 .{ }^{855}$ De ella, conocemos que el autor Anselmo Salvá vende la propiedad intelectual en 1896. Ambos hechos, la aprobación y la venta, nos inducen a pensar en ediciones anteriores de la obra.

En las siguientes ediciones, se la nombra como Compendios, y aparece separada en grados en los diversos Catálogos; en el de 1908 nos coloca el segundo grado de Historia de España, con la $3^{\text {a }}$ edición, y el de $1^{\circ}$ grado lo

\footnotetext{
${ }^{853}$ VALLS MONTÉS, R. Historiografía escolar española. Siglos XIX-XXI. Madrid: UNED, 2007, p. 272. Hay un ejemplar de este libro, Resumen de la Historia de España, en la Biblioteca de Castilla La Mancha.

${ }^{854}$ Vid. Anexos $3.2 .21 ; 3.2 .22 ; 3.2 .23 ; 3.2 .24$.

${ }^{855}$ VILLLALAÍN BENITO, J. L. Op. cit., T. IIII, p. 209. Vid. Anexo 2.1.17. 
cita en prensa. Sin embargo, el de 1917 ya ofrece la $4^{\text {a }}$ edición, en ambos grados. En el Catálogo de 1925, del primer grado nos informa que está por la $7^{a}$ edición corregida y, curiosamente, publicita para el segundo grado y superior la $5^{\text {a }}$ edición reformada y entre paréntesis pone "en preparación". Entendemos, como se observa en el Catálogo de 1929, que se mantienen las anteriores ediciones y aparece una nueva como segundo grado y grado superior, corregida y ampliada por F. Y. A.

La obra Compendio de Historia de España, primer grado, está escrita en forma de preguntas y respuestas, y dividida por edades: Edad Antigua, Edad Media, La Reconquista $-1^{\circ}, 2^{\circ}, 3^{\circ}$ y $4^{\circ}$ período-, y Edad Moderna $-1^{\circ}$ y $2^{\circ}$ período-.

De esta obra Anselmo Salvá solicita que fuese señalada como libro para la enseñanza y se declara de utilidad según Real Orden de 4 de noviembre de 1915.

Es un compendio de nuestra historia, hecho con discreción y avalorado con cuadros sinópticos de los hechos y fechas principales de las tres edades, propios para facilitar el estudio y retener en la memoria los datos más culminantes acaecidos desde la antigüedad hasta nuestros días. ${ }^{856}$

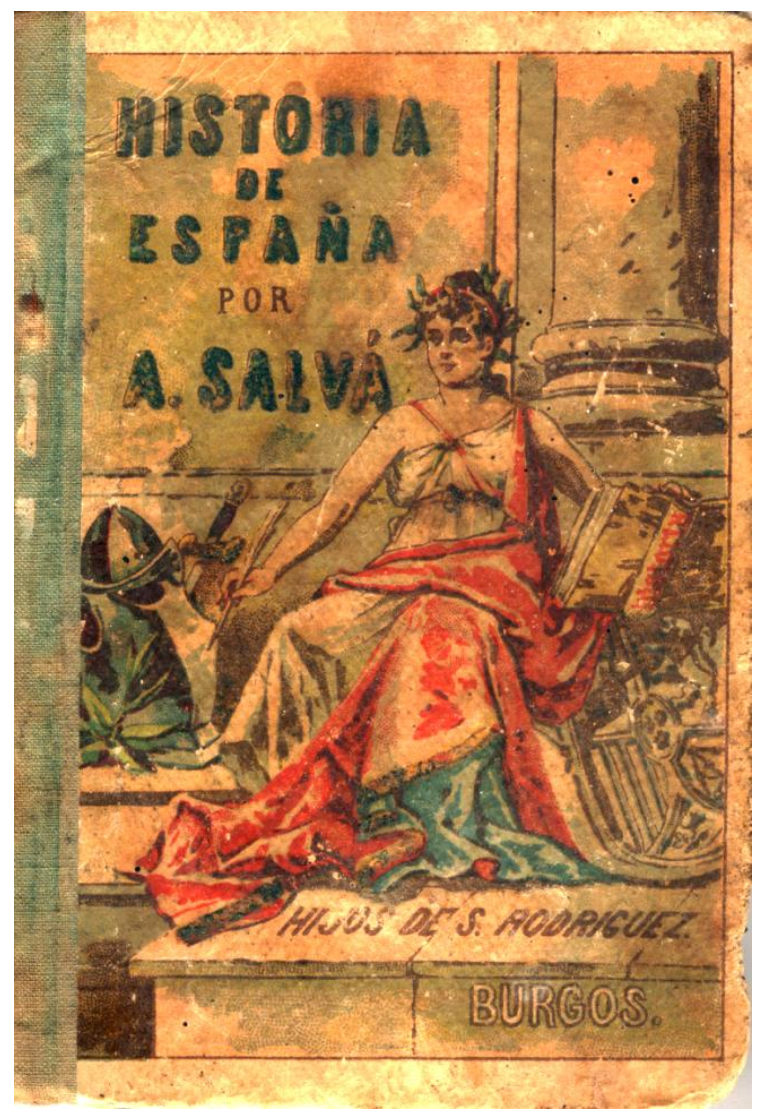

Fig. 6-72: Cubierta de la obra Historia de España, escrita por Anselmo Salvá. Hijos de Santiago Rodríguez.

${ }^{856}$ VILLLALAÍN BENITO, J. L. Op. cit., T. III, pp. 302-303. 
El libro del segundo grado lleva los mismos apartados que la de primer grado, pero de manera narrativa. Formado por 47 lecciones, en cada una inserta un resumen en pocas líneas con lo más sobresaliente de lo expuesto. Además, en algunas páginas añade e intercala pequeños trozos de diversas lecturas, donde se aportan detalles curiosos, y se completan con láminas de personajes, monumentos artísticos y hechos, incluyendo once mapas que ayudan a su estudio.

Mantiene las mismas ilustraciones interiores en todos los libros de Evaristo Barrio e Isidro Gil, así como la cubierta, a pesar que no figurar el nombre del autor.

En distintas bibliotecas se encuentra otro libro, Compendio de Historia de España, de Eudoro Casas y Arriola, profesor de la Escuela Normal Superior de maestros de Burgos. Fue una obra premiada en la Exposición escolar de Vitoria, en 1899, con Diploma de honor y con Diploma de Gran Premio en la Exposición Internacional de París en 1900. Obtuvo su aprobación como texto de segundo curso de las Escuelas Normales en la Real Orden de 14 de junio de 1895.

El ejemplar al que hemos tenido acceso, de la $3^{\text {a }}$ edición (1908), incluye todas las Edades y, al terminar cada época histórica, se agrega una lección sintetizando todo lo relativo a las instituciones políticas, civiles y religiosas. Es un libro de 332 páginas y muestra dos tipos de letras: grande para conceptos fundamentales y más pequeña para ideas secundarias.

Las ilustraciones de Evaristo Barrio son las mismas que en los libros de Anselmo Salvá aludidos anteriormente, y añade un conjunto de 16 láminas, intercaladas en el texto, en papel de mejor calidad, con dibujos de Pedrero. 


\subsubsection{Agricultura, Fisica, Química e Historia Natural}

El apartado que se describe está tomado del Catálogo de 1908 ya que en el R. D. de 26 de octubre de 1901, refrendado por el ministro Romanones, se incluían estas asignaturas en la primera enseñanza. Estaban configuradas como Nociones de Ciencias Físicas, Químicas y Naturales, y Agricultura. Teniendo en cuenta la estructura económico-social de la nación, anclada en lo agropecuario e industrias derivadas, el contenido disciplinar de Agricultura cobraba plena vigencia con la idea de mejorar las condiciones del campesino.

Hijos de Santiago Rodríguez edita una obra titulada, En el Campo, escrita por Ángel Bueno Rodríguez-Arias, con diferenciación en grados, según el nivel de los escolares a quienes se dirige.

En el Campo, primer grado, es un libro de 144 páginas, más el índice y 6 páginas de propaganda de la casa, cuya $3^{a}$ edición corresponde a 1908. Está encuadernado en pasta dura y lomo de tela. La portada ilustrada al cromo y oro, por Evaristo Barrio, muestra en un primer plano a un agricultor sobre un fondo con varias mujeres trabajando en el campo (Figura 6-73). La contraportada tiene el emblema de la editorial, realizada en la litográfica de Burgos, casa de A. Moliner. Las ilustraciones son abundantes y refuerzan las explicaciones del texto.

Ángel Bueno comenta que, en este primer grado, trata de esbozar los grandes problemas de la agricultura moderna, dejando para el segundo grado un mayor desarrollo de los mismos. Con ello incide en la importancia de su estudio para la regeneración agrícola, extensible al ámbito nacional, que debería ser dominado por los jóvenes.

La metodología que utiliza presenta la información, de forma clara y precisa, siguiendo el lema instruir deleitando y educar enseñando. Para ello presenta a dos niños, compañeros de estudios y de diferentes edades, donde César invita a Hipólito a veranear en una finca propiedad de sus padres. A través de ellos va explicando los distintos temas:

- La huerta. El hortelano y sus trabajos. Preparación del suelo. El semillero y otros cuidados. Clasificación de hortalizas. Alternancia de cosechas en las huertas.

- La planta. Alimentación de las mismas. Desarrollo, productos, multiplicación de las plantas. Recolección de cereales. El barbecho, la alternativa, el cultivo intermedio.

- Los riegos y el desagüe. Praderas, prados y conservación de forrajes.

- La oveja y el esquileo. La granja, el jardín y los frutales. El estiércol. Caballos, mulas, asnos, vacas, cerdos y gallinas. 
- El viñedo.

- Raíces y tubérculos: silos y graneros.

- Laboreo del suelo. Las siembras. El suelo y sus enmiendas.

- Atmósferas. Meteoros y climas.

Por último, acaba narrando la despedida de estos niños, y argumentan las variadas causas del éxodo del campo a la ciudad: el mal cultivo del mismo que lleva a una producción escasa, arruinando al labrador que debe acudir a prestamistas; cómo las familias ricas que poseen tierras viven en la ciudad, a espaldas de las mismas, educando a sus hijos en estudios que nada tienen que ver con la agricultura; y, también, el servicio militar que aleja a muchos jóvenes agricultores, sin que los gobiernos hayan hecho nada en su favor. No obstante, el autor muestra que está situación va cambiando algo, poco a poco, con libros sobre Agricultura, las exposiciones agrícolas, las casas de venta de maquinaria y abonos, las familias que visitan el campo y las asociaciones entre labradores, amparadas por ley. Al final de cada apartado se incluye un resumen de los temas tratados, en letra más pequeña. También señala en letra más grande y en negrita las palabras clave del tema, ayudando a su aprendizaje.

En el Campo, segundo grado, amplia las materias tratadas en el primer grado dando a conocer los procedimientos y adelantos más modernos para el cultivo de la tierra. Sigue el mismo esquema analítico que en el primer grado. Los dos amigos se han hecho adultos e Hipólito, consumado violinista, vuelve otra vez a la finca, con César, y se reencuentra con Luis, el hijo del labriego. César le explica que con la buena formación de Luis, en la Granja Agrícola de Castilla la Nueva, había conseguido mejoras en el rendimiento del campo y no seguir con las rutinas de sus padres. Además, el padre de César, regenera la situación escolar, paga a un nuevo maestro, compra libros apropiados y un terreno junto a la escuela, para experimentar los nuevos métodos. Por las noches, invitaba a los adultos a ampliar conocimientos, ve como paulatinamente se va incrementando el número de alumnos y como cada uno de ellos decide hacer un proyecto para mejorar todavía más esta situación.

Estos proyectos son los que describe Ángel Bueno en su libro, con los siguientes temas:

- Estudio de la planta.

- La atmósfera y su influencia en el cultivo.

- Estudio del suelo arable.

- Modos de beneficiar el suelo.

- Los abonos.

- Modos de cultivar los campos. 
- El cultivo extensivo.

- El cultivo intensivo.

- Cría de animales auxiliares del agricultor.

- Economía rural.

Es un libro de 432 páginas, con las mismas características que el del primer grado publicado en 1908.

La lectura de ambos libros precisa hacer dos aclaraciones:

- La primera, se refiere a que el autor da importancia al valor moral que nace de lo espiritual de este trabajo:

$Y$ que viviendo en el campo, parece que se vive en mayor unión con Dios y con la Naturaleza...A mi al menos, cuando en la soledad de la noche oigo esos ruidos misteriosos del campo, o cuando durante el día contemplo trabajando a todos tan contentos, pienso mucho más en el Supremo Hacedor...; y me parece que así como respiro mejor, estoy más animado para hacer el bien. ${ }^{857}$

- Y en una segunda, se advierte una visión muy optimista sobre la influencia de la enseñanza de la Agricultura en los trabajadores del campo. Aun siendo importante la instrucción, no lo son menos las mentalidades de propietarios y labriegos, por su tradicional inmovilismo, ni las políticas que se llevan a cabo.

La obra de Ángel Bueno En el campo, en su grado primero y segundo, se declara como obra de texto para las escuelas de primera enseñanza, según Real Orden de 20 de junio de 1913.

Ilmo. Sr.: En el expediente promovido por D. Mariano Rodríguez Miguel solicitando que se declare de utilidad para la enseñanza en las escuelas la obra titulada En el campo (grados primero y segundo), de la que es autor D. Ángel Bueno, la Sección primera del Consejo de Instrucción pública ha informado lo siguiente:

La Sección primera de este Consejo, en sesión celebrada el día 19 de abril último, con asistencia de los Sres. Labra, Presidente; Sanz Escartín, Bejarano, Groizard y Gómez de Baquero, emitió el siguiente dictamen:

Los libros de lecturas educativas y ordenadas sobre agricultura nacional (primero y segundo grado), de los que es autor D. Ángel Bueno, titulados En el campo, son unos buenos libros de lectura educativa, desarrollando en orden cíclico el estudio del campo y sus productos, con excelente plan, por todo lo que, a juicio de esta Sección, merecen ser declarados de utilidad como texto en las escuelas.

$Y$ S.M. el Rey (q. D. g.), conformándose con el preinserto informe, se ha servido resolver como en el mismo propone.

${ }^{857}$ BUENO RODRÍGUEZ-ARIAS, A. En el campo, primer grado. Burgos: Hijos de Santiago Rodríguez, 1908, pp. 132-133. 
De real orden lo digo a V.I. muchos años. Madrid, 20 de junio de 1913. Ruiz Giménez. Señor Director general de primera enseñanza. ${ }^{858}$

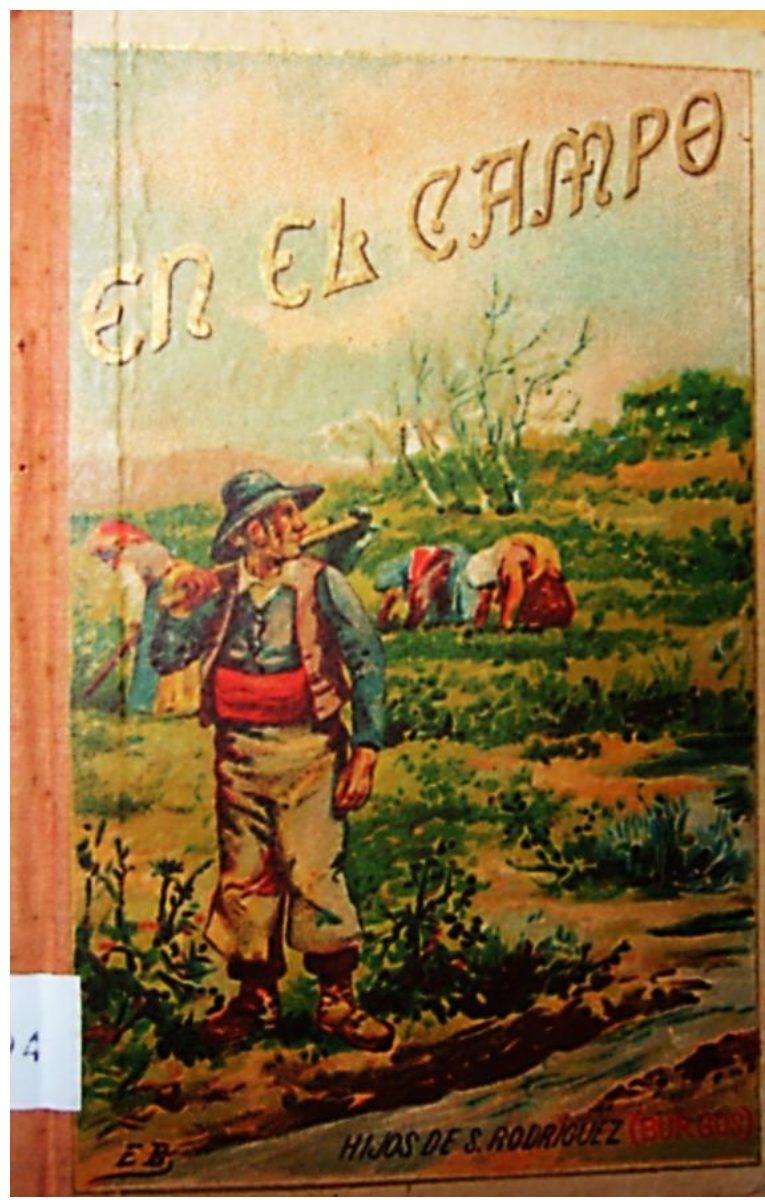

Fig. 6-73: Cubierta de Evaristo Barrio del libro En el campo.

Hijos de Santiago Rodríguez.

Ejemplar de la Biblioteca de la Diputación Provincial de Burgos.

Por otro lado, la editorial Hijos de Santiago Rodríguez publica otros textos para explicar las ciencias físico-químicas, como Páginas sobre Ciencias físicas y naturales, escrito por Juan Benejam Vives. Destacado maestro y pedagogo, cercano a algunos planteamientos de la Escuela Nueva y de la escuela activa, parte de las ideas de la Institución Libre de Enseñanza y del regeneracionismo. Estudia magisterio en Barcelona, abre una escuela privada y obtiene plaza de maestro elemental en su pueblo natal, Ciudadela, de Menorca ${ }^{859}$ Escribe este libro, según data el prólogo, en Ciudadela, en 1900. Sale publicado un año más tarde, según consta por un ejemplar de la Biblioteca Pública de Burgos, y en la prensa escrita. ${ }^{860}$

\footnotetext{
${ }^{858}$ VILLALAÍN BENITO, J. L. Op. cit., T. III, p. 281. Ver: Boletín Oficial del Ministerio de Instrucción pública y Bellas Artes de 15 de julio de 1913, nº 56, p. 8.

${ }^{859}$ Vid. VILAFRANCA MANGUÁN, Inés. Joan Benejam Vives (1846-1922): Un mestre menorquí a l'avantguarda pedagógica. Revista Catalana de Pedagogía, vol. 1, 2002, pp. 313-340. Disponible en: http://www.raco.cat/index.php/RevistaPedagogia/article/view/212297/282488.

${ }^{860}$ El Papa-Moscas. Año XXIV, no 1.303, 21 de abril de 1901, p. 3.
} 
En años sucesivos, según los Catálogos de la editorial, adapta esta obra a distintos grados de enseñanza, con la división en grado primero, medio y superior. Sólo el Catálogo de 1917 especifica el grado medio como en prensa y el no figurar en Catálogos sucesivos hace pensar que no llegó a publicarse.

Vende la propiedad intelectual de la obra a la editorial por el precio de 100 pts., en 1902, según escritura notarial. ${ }^{861}$ Se supone que, en años sucesivos, Hijos de Santiago Rodríguez adapta esta obra en distintos grados $\mathrm{y}$ con pequeñas diferencias.

El tomo Páginas sobre ciencias físicas y naturales: grado superior está encuadernado en pasta, con lomo en tela y cubierta ilustrada a todo color por Evaristo Barrio. Consta de 300 páginas, de 16,5 x 11,8 cm., con numerosos grabados de apoyo al texto, siendo la última utilizada para la propaganda de la editorial. Y, además, en cada bloque hay un dibujo alegórico de cada una de las ramas de las ciencias realizado por Evaristo Barrio, a plana entera.

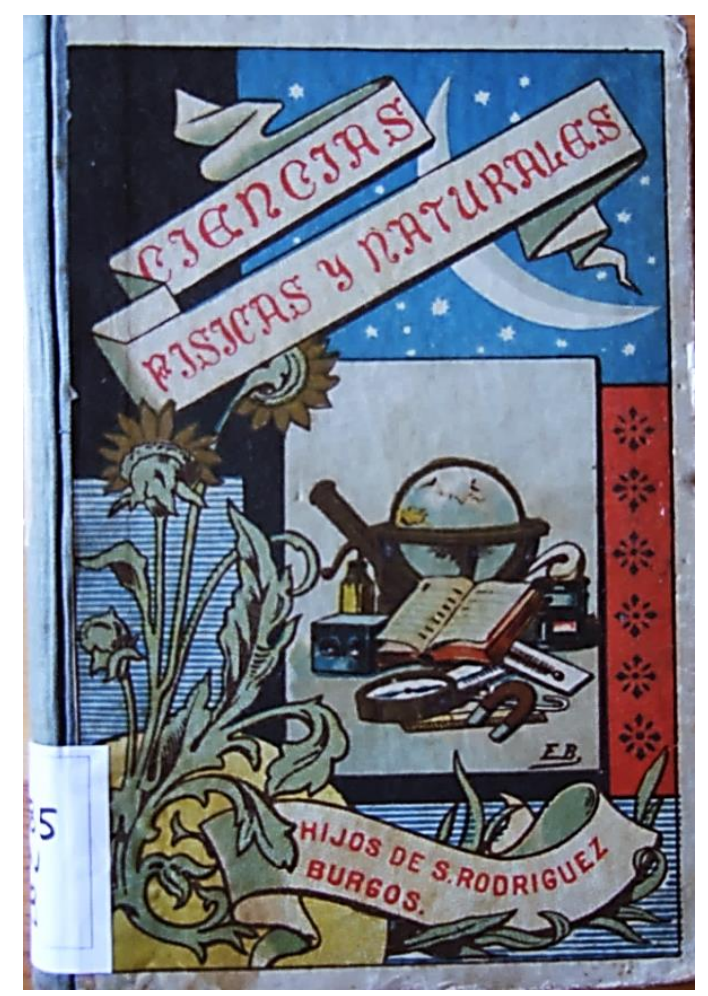

Fig. 6-74: Cubierta de Evaristo Barrio de Páginas sobre ciencias físicas y naturales. Grado superior. Hijos de Santiago Rodríguez. Ejemplar de la Biblioteca del CEINCE.

Esta obra sirve de texto en las escuelas, según Real Orden de 12 de febrero de $1906^{862}$ y refrendada en la Real Orden de 4 de noviembre de 1915.

\footnotetext{
${ }^{861}$ AHPBU. Sección Protocolos. Caja 11252, 19 de noviembre de 1902. Vid. Anexo 2.1.18.

${ }^{862}$ VILLALAÍN BENITO, J. L. Op. cit. T. III, p. 244.
} 
Ilmo. Sr.: En el expediente promovido por D. Juan Benejam, solicitando que el libro titulado Páginas sobre ciencias físicas y naturales se declare útil para la enseñanza, la Sección primera del Consejo de Instrucción pública ha informado lo siguiente:

Con ser el conocimiento de las ciencias físicas y naturales uno de los más importantes, si no se le desdeña en la generalidad de nuestras escuelas fuerza es reconocer que ocupa un lugar muy secundario, debido tal vez a la carencia, hasta ahora sentida, de libros escritos expresamente para niños, puesto que la mayoría de ellos se escribieron con un rigorismo científico, que en armonía con las inteligencias en formación.

Tal manera de escribir, que pudiera llamarse rutinaria, la desecha en absoluto el autor de Páginas sobre ciencias físicas y naturales, quien conocedor de la finalidad de la enseñanza práctica y de los obstáculos que impiden a las inteligencias infantiles la asimilación de cierta clase de conocimientos, recoge en su obra las sabias lecciones de la experiencia, presentando a los niños los asuntos en lenguaje claro y sencillo, prescindiendo de tecnicismos y definiciones, procurando cautivar la atención con la exposición de hechos y principios de que provienen en párrafos llenos de calor y amenidad, perfectamente asequibles a un despertar intelectual.

Al final de cada lección hace un resumen de la misma en forma sintética, fácil de confiar a la memoria.

En el curso de toda la obra estudia con un recto criterio analítico cuanto cae dentro del campo de acción de la física, de la química, de la mineralogía, botánica y zoología, empezando por la materia, sus propiedades, fenómenos, etc., dedicando a ello 64 capítulos, sin omitir nada de cuanto el progreso humano tiene catalogado hasta el día, y termina con dos capítulos dedicados al estudio del hombre en sus aspectos físico y fisiológico, condiciones todas que hacen a esta obra recomendable para que se leída por los niños de nuestras escuelas, con el fin de que se despierte e ellos el amor al estudio de ese gran libro llamado naturaleza, en cuyas páginas nos ofrece tantas y tan grandes enseñanzas, y puedan en su día contribuir a desterrar consuetudinarios perjuicios sobre hechos que tienen su origen en fenómenos naturales.

Por las condiciones expuestas, merece ser declarada útil para que sirva de texto en las escuelas nacionales.

Y S. M. el Rey (q. D. g.), conformándose con el preinserto dictamen, se ha servido resolver como en el mismo se propone.

De real orden lo digo a V.I. para su conocimiento y demás efectos. Dios guarde a V.I. muchos años. Madrid, 4 de noviembre de 1915. Andrade. Señor Director general de primera enseñanza. ${ }^{863}$

El prólogo titulado $A l$ que leyere expresa la convicción de que la enseñanza de las ciencias físicas y naturales no puede suprimirse de las escuelas pues están a la altura de la gramática y la aritmética. De hecho, hay más dificultades para enseñar análisis gramatical que para ofrecerles la evidencia de la mayor parte de los fenómenos físicos y naturales. Donde radican las dificultades es en la metodología, en la manera de presentarlos a los niños. El autor, aboga por conocer al niño y ofrecer los conocimientos

${ }^{863}$ Ibídem, p. 300-301. Ver: Boletín Oficial del Ministerio de Instrucción pública y Bellas Artes de 15 de julio de $1913, \mathrm{n}^{\circ} 56$, pp. 13-14. 
eliminando teorías y tecnicismos que le confunden, intentando en una serie de lecciones romper antiguos moldes para vaciar en troqueles nuevos aquellas ciencias. El libro lo forman un conjunto de lecciones con un resumen en cada una de ellas a fin de ayudar a una mejor comprensión de lo expuesto.

En las lecciones de Física trata sobre la materia y sus propiedades, la fuerza y sus caracteres, la presión de los líquidos, la presión del aire, el calor, las máquinas de vapor, meteoros, la luz, reflexión y refracción, los colores, los aparatos ópticos, los meteoros luminosos, el sonido su propagación, velocidad, la electricidad y sus aplicaciones, y el magnetismo. En las de química trata sobre la composición del aire, agua, el carbono, el hidrógeno, los óxidos, ácidos, sales y bases, y los metales u otros metaloides.

Páginas sobre ciencias físicas y naturales: primer grado es una adaptación para la escuela primaria del texto original del autor. Hemos accedido a una $4^{\mathrm{a}}$ edición de 1917 donde observamos el menor número de páginas, -116-, con letra más grande y reducción de apartados. El primero lo llama "Rudimentos de la Física", en Química trata prácticamente los mismos puntos aunque más sintéticamente y el apartado de Mineralogía lo cita como Historia Natural, en Botánica y Zoología simplifica los temas y en Zoología trata los mismos temas aunque sobre el ser humano sólo trata funciones de nutrición y de relación. Aporta ejemplos muy sencillos a la comprensión de los más pequeños y suprime las frases resumen después de los apartados. 


\subsubsection{Aritmética y Geometria}

\section{Aritmética}

Los textos de aritmética publicados por la editorial forman parte de los libros más antiguos, remontándose a los comienzos de la edición en la imprenta de Santiago Rodríguez Alonso.

Compendio de Aritmética, de Clemente Fernández, inspector de Primera Enseñanza en Burgos, y Jorge García de Medrano, director de la Escuela Normal Superior de Logroño, escriben este manual, aprobado para servir de texto en las Escuelas Normales, por R. O. de 5 de mayo de 1879. Fue publicado, inicialmente, en la Imprenta y Librería de Ricardo Martínez Merino de Logroño, ${ }^{864}$ así como por la imprenta de Nicolás Marcelino de Pamplona, en 1891.865

En 1888 tenemos constancia de su impresión en Burgos, por un ejemplar existente en la Imprenta y librería de Santiago Rodríguez Alonso (Figura 3-10). Está editado en cartulina a color, con 38 páginas, y es la $29^{a}$ edición, corregida y aumentada, lo cual indica la fuerte venta que tenía, más si cabe dado que ese mismo año aparece otro ejemplar que alcanza la $30^{\text {a }}$ edición.

\footnotetext{
${ }^{864}$ LINÉS ESCARDÓ, A. La matemática en La Rioja en el primer tercio del siglo XX y años de su entorno [en línea]. Comunicación impartida el 1 de noviembre de 1996 en el IER en III Simposio Julio Rey Pastor [fecha de consulta: 15-5-2014]. Disponible en http://dialnet.unirioja.es/descarga/articulo/110371.pdf

865 CENTRO DE DOCUMENTACIÓN DE LA CULTURA VASCA. Catálogo [en línea]. Vitoria: Fundación Sancho el Sabio [fecha de consulta 25-5-2013]. Disponible en: http://catalogo.fsanchosabio.es. 


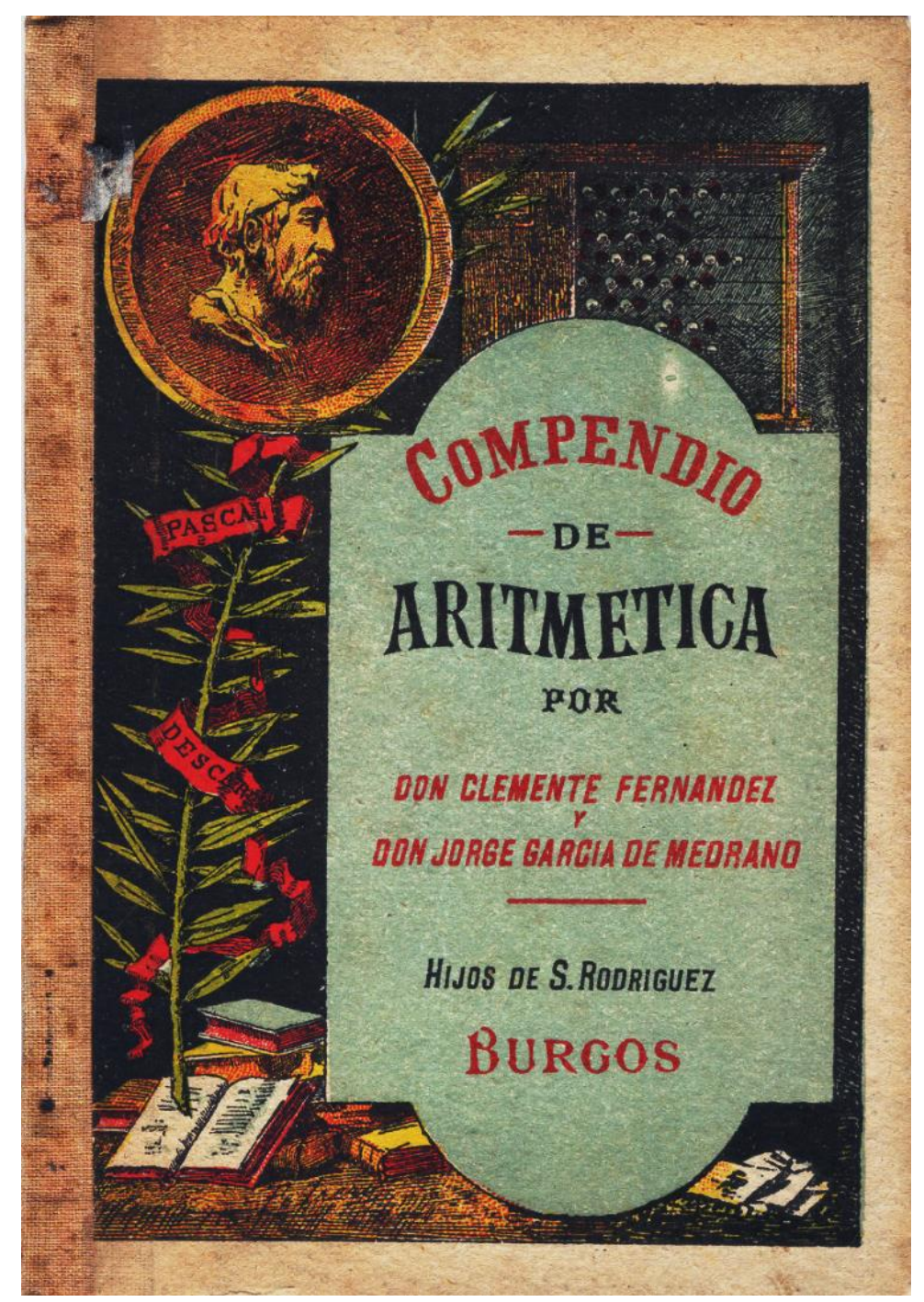

Fig. 6-75: Cubierta de Compendio de Aritmética.

Hijos de Santiago Rodríguez. 1907.

Biblioteca de la Diputación Provincial de Burgos.

Sin embargo, desconocemos cuántas ediciones se publicaban al año y el número de ejemplares de cada una de ellas. Este libro continúa con nuevos formatos y mantiene las mismas páginas; únicamente cambia la cubierta en pasta por otra al cromo, de Pedrero (Figura 6-75). En distintas bibliotecas de Castilla y León se encuentran publicaciones de este libro: 1903, 1907 y 1912 , en la $33^{\mathrm{a}}, 34^{\mathrm{a}}$ y $35^{\mathrm{a}}$ edición, respectivamente. Todas ellas de 38 páginas, más dos últimas con propaganda de la editorial.

El planteamiento metodológico corresponde al de preguntas teóricas con sus respuestas, incluyendo algunos ejemplos. La enseñanza, en esta época, estaba muy lejos de entender que cada área de conocimiento tenía su propia metodología. El aprendizaje tiene un carácter deductivo: se parte de los principios generales para llegar a la aplicación particular recogida en los 
ejemplos. Utiliza una sistematización lógica del saber, cerrado, sin valorar las experiencias infantiles.

Los temas que trata son los siguientes:

- Nociones preliminares sobre aritmética y numeración.

- Operaciones con números enteros.

- Quebrados ordinarios.

- Números decimales.

- Sistema métrico decimal.

- Medidas de longitud, capacidad y peso.

- Medidas de superficie o cuadradas.

- Medidas cúbicas o de volumen.

- Monedas.

- Aplicación de los decimales al sistema métrico.

- Tabla de las equivalencias entre las pesas y medidas métricas y las del antiguo sistema de Castilla.

- Medidas de Logroño que se diferencian de la de Castilla.

- Medidas de Navarra.

- Reducción de las pesas y medidas métricas a sus equivalentes del sistema antiguo y al contrario.

- Números denominados.

- Proporciones.

- Regla de tres, interés y compañía.

Con la unificación obligatoria de las equivalencias entre pesas y medidas, en la Restauración, se producen muchas resistencias. En esta obra observamos que junto a las medidas oficiales, adjunta las antiguas de Castilla. Además, incluye algunas equivalencias antiguas de las provincias de Logroño y Navarra. ${ }^{866}$

Vistos los contenidos, tenemos la impresión de estar ante un libro muy denso para los escolares de primera enseñanza, sin ilustraciones, e incluso con ejemplos de difícil comprensión para los niños.

Otro de los textos de aritmética, publicado por la editorial, es Nociones generales de Aritmética teórico-práctica, escrito por los mismos autores, si bien este manual ya había sido impreso anteriormente por imprentas riojanas, en $1843^{867}$ y en $1849 .{ }^{868}$ Se tiene constancia de la publicación, en

\footnotetext{
${ }^{866}$ Estos autores utilizaron el mismo texto impreso en Burgos, Logroño y Pamplona, lugares donde desarrollaron su labor docente.

${ }^{867}$ FERNÁNDEZ, C.; GARCÍA DE MEDRANO, J. Nociones generales de Aritmética teórico-práctica. Logroño: Imprenta de la Viuda de Brieva, 1843. Es un libro que encontramos en la Biblioteca del Instituto de Estudios Riojanos, en su fondo antiguo.

${ }^{868}$ FERNÁNDEZ, C; GARCÍA DE MEDRANO, J. Nociones generales de Aritmética teórico-práctica, Logroño: Imprenta de Domingo Ruiz, 1849. Este libro lo podemos encontrar en la Biblioteca Nacional de España, Hemeroteca Digital.
} 
la Imprenta y librería de Santiago Rodríguez Alonso en 1882, con la $14^{\mathrm{a}}$ edición, en 1912 con la $23^{\mathrm{a}}$, y en 1915 en su $24^{\mathrm{a}}$. Todos los ejemplares se componen de 95 páginas, lo cual nos hace suponer que se trataba del mismo contenido. Para ello, en la comparación entre un libro de 1849 con otro de 1915, y sin extensión de los detalles, se observa que contiene los mismos apartados y el mismo número de ejemplos ya que en muchos casos sigue utilizando el sistema antiguo de monedas, medidas y pesas.

En el prólogo de la $24^{\text {a }}$ edición, nos recuerda que:

El tratado se expone con bastante claridad y conocimiento cuanto se necesita saber en las escuelas de primera enseñanza...las Reales Ordenes de 6 de noviembre de 1852, y 5 de mayo de 1879, por las que el gobierno de S.M. se sirvió aprobarlas como libro de texto en las escuelas...y haber sido premiada con diploma de $1^{a}$ clase en la exposición logroñesa de 1880 es la mejor garantía de cuanto llevamos relacionado. ${ }^{869}$

Esta edición esta encuadernada en pasta dura y lomo de tela, con igual portada que Compendio de Aritmética. Es un libro árido que no tiene ilustraciones interiores, con ejemplos difíciles de comprender, así como la mezcla de todas las medidas.

Nociones generales de Aritmética teórico-práctica y Compendio de Aritmética siguen editándose hasta el primer tercio del siglo XX. A ellos se añaden otros publicados en una nueva colección titulada Nuevos Textos Escolares Rodríguez, atribuidos a la autoría de la editorial. Entre ellos se encuentran: Mis amigos los números. Periodo de iniciación, tomo de 40 páginas, profusamente ilustrado, con ejercicios de dibujo, de trabajo manual, etc.; Aritmética escolar. Grado elemental, de un centenar de páginas, con problemas y ejercicios gráficos muy sugestivos y amenos; y Aritmética escolar. Grado superior, de unas 300 páginas con multitud de problemas y ejercicios gráficos. ${ }^{870}$

También, en todos los Catálogos, nos encontramos con Tablas de Aritmética de las cuatro reglas, y Tablas de Reducción, de kilogramos a arrobas castellanas, de kilogramos a libras y de litros a cántaras, etc.

\section{Geometría}

La reforma de las matemáticas en estos primeros años de siglo, con los nuevos métodos y formas de aprendizaje lejos del método de preguntas y respuestas, se refleja en la obra de Félix Martí Alpera, con dos importantes

\footnotetext{
${ }^{869}$ FERNÁNDEZ, C.; GARCÍA DE MEDRANO, J. Nociones generales de Aritmética teórico-práctica. Burgos: Hijos de Santiago Rodríguez, 1915, p. 3.

${ }^{870}$ CATÁLOGO 1929, pp. 25-26.
} 
obras: Las Primeras Lecciones de Geometría (1908) y Nuevas Lecciones de Geometría, con aplicaciones al dibujo, a la agrimensura, a la arquitectura y al trabajo manual (1911), editadas en Hijos de Santiago Rodríguez y que, años más tarde, se declararán como libros de texto en las escuelas de primera enseñanza, según Real orden de 4 de noviembre de 1915.

Ilmo. Sr.: En el expediente promovido por D. Mariano Rodríguez solicitando que se declare útil para la enseñanza el libro titulado Nuevas lecciones de geometría con aplicaciones al dibujo, a la agrimensura, a la arquitectura y al trabajo manual, escrito por D. Félix Martí, la Sección primera del Consejo de Instrucción pública ha informado lo siguiente:

Este libro, con 38 lecciones, 12 problemas de estereometría, una tabla de pesos específicos y 298 grabados, forma una obra completa con Las primeras lecciones de geometría, grado elemental, del mismo autor:

Tanto en el nuevo trabajo como en el anteriormente informado por este Consejo, demuestra el autor su extraordinaria competencia al adaptarlo a la incipiente comprensión de los niños concurrentes a las escuelas primarias y hacerles comprender los difíciles principios que integran la geometría, en términos tales, que, por sí solos y sin auxilio ajeno, puedan hacer las necesarias aplicaciones de sus conocimientos sobre esta materia a la resolución de cuantas cuestiones concretas se les puedan presentar en el curso de la vida, no conformándose el autor con circunscribirlos exclusivamente a lo que pudiera llamarse material formal de la geometría, sino que extiende su acción a presentar ante los niños la resolución práctica de cuantos problemas son objeto especial de la agrimensura, dedicando varias páginas a la descripción de los diferentes órdenes arquitectónicos, especificando detalladamente todos y cada uno de los elementos que los integran.

El lenguaje empleado es, sin dejar de ser castizo, sencillo y comprensible por los niños; los ejercicios y problemas son adecuados, no sólo al principio del que se derivan, sino al término medio de las distintas graduaciones que en su desarrollo suele presentar la inteligencia infantil, y el alcance de la obra es serio, porque capacita al niño poniéndole en condiciones de resolver complejas cuestiones de geometría y agrimensura y aun de adquirir con su facilidad conocimientos de estas materias en un orden más elevado.

Por estas consideraciones es digna de ser declarada de utilidad para que sirva de texto en las escuelas nacionales.

Y S. M. el Rey (q. D. g.), conformándose con el preinserto dictamen, se ha servido resolver como en el mismo se propone.

De real orden lo digo a V.I. para su conocimiento y demás efectos. Dios guarde a V.I. muchos años. Madrid, 4 de noviembre de 1915. Andrade. Señor Director general de primera enseñanza. ${ }^{871}$

También, en esa misma orden se propone para las escuelas de primera enseñanza el libro del mismo autor, Las primeras lecciones de geometría.

\footnotetext{
${ }^{871}$ VILLALAÍN BENITO, J. L. Op. cit., T. III, pp. 299-300. Ver: Boletín Oficial del Ministerio de Instrucción pública y Bellas Artes de 14 de diciembre de 1915, nº 100, p. 13.
} 
Ilmo. Sr.: En el expediente sobre declaración de utilidad para la enseñanza del libro titulado Las primeras lecciones de geometría, escritas por D. Félix Martí, la Sección primera del Consejo de Instrucción pública ha informado lo siguiente:

Consta este libro de 25 lecciones, ilustradas con 197 grabados, varios problemas gráficos y multitud de ejercicios prácticos y trabajos manuales.

El autor revela un extraordinario conocimiento del desarrollo gradual de la inteligencia de los niños, y a ese conocimiento acomoda la exposición de los principios que sirven de fundamento a cada lección, empleando un lenguaje tan claro como sencillo, y fácilmente comprensible por los niños, prescindiendo por completo de definiciones que, por no comprenderlas, a ningún fin práctico los conducirían, y presentándoles al final de cada lección una serie de ejercicios prácticos, entre los cuales figuran además problemas gráficos y ejercicios de trabajos manuales que pudieran llamarse geométricos, y que, ejecutados por los niños, han de llevar a su ánimo la conciencia absoluta de la certeza de las verdades científicas contenidas en la lección de que forman parte.

El librito en cuestión es, en suma, uno de los mejores de su clase publicados hasta el día, y digno de ponerse en mano de los niños que concurren a las escuelas nacionales para que, por su medio, se instruyan en los principios de la geometría elemental.

Procede, en su consecuencia, declararlo de utilidad para poder servir de texto en las escuelas de primera enseñanza.

Y S. M. el Rey (q. D. g.), conformándose con el preinserto dictamen, se ha servido resolver como en el mismo se propone.

De real orden lo digo a V.I. para su conocimiento y demás efectos. Dios guarde a V.I. muchos años. Madrid, 4 de noviembre de 1915. Andrade. Señor Director general de primera enseñanza. ${ }^{872}$

Félix Martí Alpera fue uno de los maestros-directores más inquietos y avanzados de su época, impregnado de las ideas de la Escuela Nueva y de la Institución Libre de Enseñanza. Fue destituido y apartado de la escuela al finalizar la Guerra Civil, silenciado y marginado por la historia, no así sus obras. $^{873}$

El primer tratado se dirige a los alumnos de grado elemental, mientras que el segundo estaba dirigido a los alumnos de grado medio y superior. De ambos libros se harían múltiples reediciones.

En Las primeras lecciones de Geometría, obra con una bella portada, figura Geometría para Niños en la parte superior, en dorado, incluida en una cartela. A la derecha aparecen todo un conjunto de instrumentos de geometría: regla, escuadra, cartabón, esfera, compás, medidor de ángulos, etc., enlazados con una cinta y hojas de laurel a su alrededor.

${ }^{872}$ Ibídem, pp. 303-304.

873 Centro de Estudios sobre la Memoria Educativa (CEME/UMU). Exposición conmemorativa Félix Martí Alpera (1875-1946). Un maestro y la escuela de su tiempo [en línea]. [Fecha de consulta: 20 mayo 2014]. Disponible en: www.um.es/muvhe/felixmartialpera/ Es una página donde podemos recorrer una extensa biografía, todas sus obras, legado, movimiento asociativo, renovación curricular, la escuela graduada... 
Está encuadernado en pasta dura y lomo de tela forrado en papel, con el título del libro. Tiene 104 páginas, con un tamaño de 17,5 x $11 \mathrm{~cm}$. y está ilustrado con numerosos dibujos.

En el prólogo, dirigido a los niños, el autor les señala que todo lo que aprendan de geometrí, está no sólo en el libro pues el profesor les explicará otras muchas cuestiones, pero la mayor parte lo sabrán por deducción y observación directa.

El libro lo componen 25 lecciones, correspondientes a los contenidos siguientes:

Lección $1^{\text {a }}$ Definición.

$2^{\text {a }}$ Superficies.

$3^{\mathrm{a}}$ Líneas.

$4^{\text {a }}$ Posiciones de la línea recta.

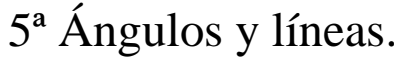

$6^{\mathrm{a}}$ Clases de ángulos.

$7^{\text {a }}$ Polígonos.

$8^{\text {a }}$ Triángulos.

$9^{\mathrm{a}}, 10^{\mathrm{a}}$ y $11^{\mathrm{a}}$ Cuadriláteros.

$12^{\text {a }}$ Circunferencia y círculo.

$13^{\mathrm{a}}$ Circunferencia y círculo

$14^{a}$ De otras curvas usuales (espiral, óvalo, elipse, huevo).

$15^{\mathrm{a}}, 16^{\mathrm{a}}$ y $17^{\mathrm{a}}$ Áreas.

$18^{\mathrm{a}}$ Poliedros regulares.

$19^{\text {a }}$ Poliedros irregulares.

$20^{\mathrm{a}}$ La pirámide

$21^{\text {a }}$ Cuerpos redondos.

$22^{\mathrm{a}}$ Cuerpos redondos: el cono.

$23^{\mathrm{a}}$ Cuerpos redondos: la esfera.

$24^{\mathrm{a}}$ Área de los cuerpos geométricos.

$25^{\text {a }}$ Volúmenes.

En la dedicatoria final a los profesores ${ }^{874}$ les indica que el libro es un instrumento útil para los alumnos, pero que sin las aclaraciones, preguntas y explicaciones de viva voz del maestro no tiene sentido. Por tanto, deben ampliar los ejercicios, problemas y trabajos manuales, ya que son sólo indicaciones iniciales pues dispone de un número limitado de páginas.

En cada lección, la palabra clave está impresa en negrita. La explicación parte de la realidad y después, en letra cursiva, explica la definición. Muchas definiciones se apoyan en dibujos adicionales, con un pie que añade explicaciones. Al final de cada lección hay 5 ó 6 ejercicios y

${ }^{874}$ MARTí ALPERA, F. Las primeras lecciones de Geometría. Burgos: Hijos de Santiago Rodríguez, 1908, p. 102. 
10 problemas gráficos, como este ejemplo: dividir una recta en dos partes iguales.

Hay ejercicios de trabajo manual:

- Plegado geométrico en papel.

- Hacer ángulos de $45^{\circ}$, de $30^{\circ}$.

- Recortado de un hexágono regular.

- Dividir una hoja en varias partes iguales.

- Hacer un sobre y una pajarita.

- Hacer un tejido con papel.

- Recortado geométrico.

- Hacer un filtro.

Figuran dibujos de aplicación como hacer una greca o varias clases de pavimentos, entre otros muchos. Tiene varios desarrollos de poliedros y otros 18 ejercicios, denominados Geometría mental, a base de preguntas, por ejemplo: ¿Cuál es el área de un ladrillo de forma cuadrada que tiene de lado 2 dm? ¿Cuántos ladrillos de éstos entrarán en un metro cuadrado?

Las lecciones se apoyan sobre objetos reales de la vida cotidiana, para luego dar la definición. Una muestra de ello es la lección segunda, expuesta a continuación:

\section{LECCIÓN $2^{\mathrm{a}}$}

1. Superficie.- Fijándonos en una caja, observamos que tiene seis costados o caras. Estas caras son la superficie de la caja. Superficie de un cuerpo es la cara o caras que limitan ese cuerpo.

2. Clases de superficie. Las superficies pueden ser de dos clases: superficies planas y superficies curvas.

3. Superficies planas. Las caras de una caja y las paredes del suelo de la clase son superficies planas. Plano o superficie plana es aquella a la cual se ajusta en todas direcciones una regla bien derecha.

4. Superficie curva. Una bola de billar, una pelota, una trompa, están limitadas por superficies curvas. Superficie curva es aquella a la cual no puede ajustarse una regla derecha. ${ }^{875}$

Nuevas Lecciones de Geometría es una obra escrita por Félix Martí Alpera, en 1911, continuadora de la anterior, Las Primeras Lecciones de Geometría, y correspondiente al grado segundo y tercero. Se señala en el prólogo que las exigencias editoriales, inspiradas sin duda en la economía de precio, disponen los dos grados en un volumen. Como aclaración, se

${ }^{875}$ Ibídem, p. 6. 
advierte que las lecciones compuestas en letra grande, corresponden al grado medio y que éstas, junto a las ampliaciones, son el grado superior.

Es un tomo de 204 páginas, encuadernado en pasta dura, con lomo de tela y cubierta ilustrada a color (Figura 6-76). En su interior aparecen múltiples ilustraciones que facilitan y ayudan en el aprendizaje. La litográfica está realizada en A. Moliner, de Burgos.

La estructura y ordenación de contenidos es la misma que podemos observar en cualquier texto de otras editoriales en la época:

- Geometría plana. Líneas. Ángulos. Polígonos. Triángulos. Cuadriláteros. Circunferencia y círculo. Áreas.

- Geometría del espacio. Poliedros regulares e irregulares. Dibujo de figura. Cuerpos redondos. Áreas de los cuerpos. Volúmenes. Órdenes arquitectónicos.

- Problemas de estereometría.

- Tablas de pesos específicos.

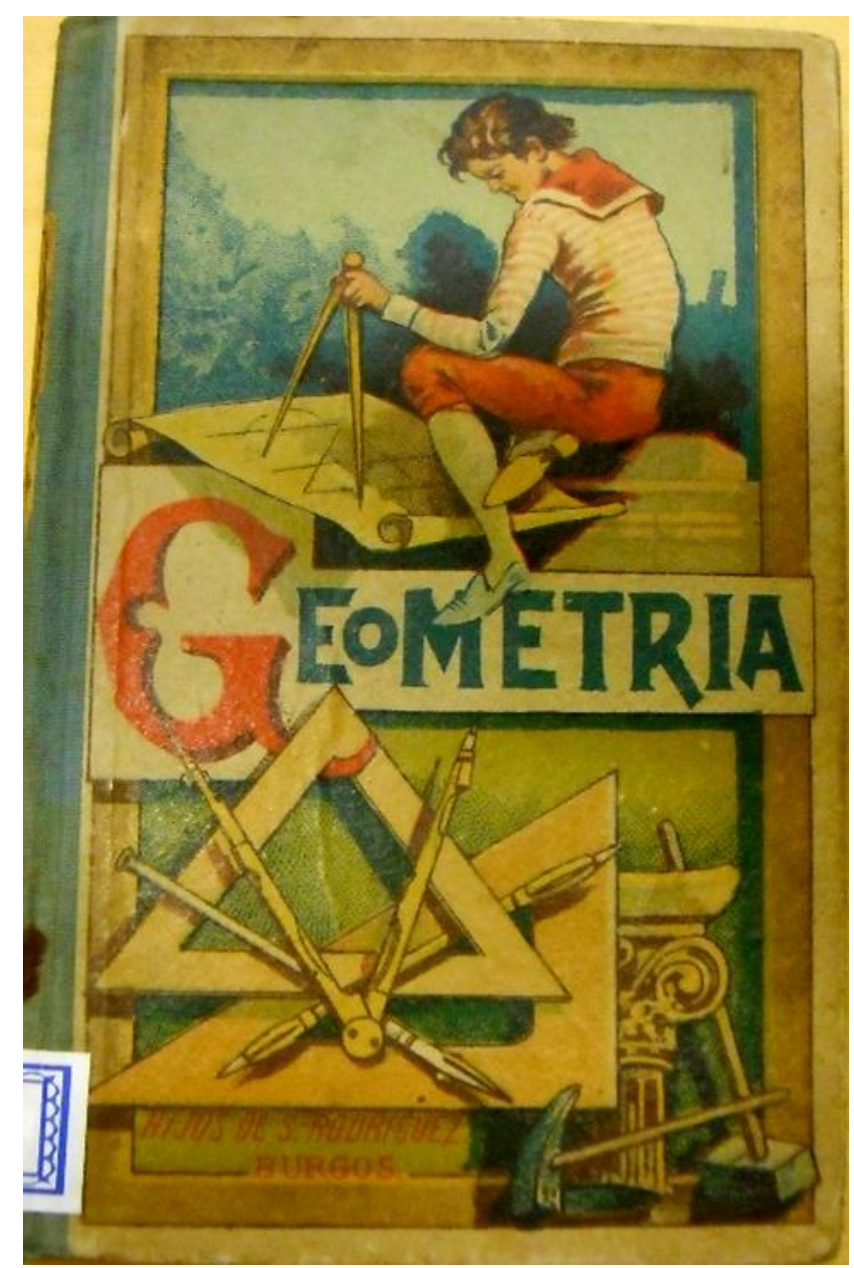

Fig. 6-76: Cubierta del libro Nuevas lecciones de Geometría.

Hijos de Santiago Rodríguez. Ejemplar de la Biblioteca de la Diputación Provincial de Burgos. 
Existen muchas diferencias con las nuevas publicaciones frente a los libros de aritmética que publicaba anteriormente la editorial. En primer lugar, los conocimientos ya no se imparten en forma de preguntas y respuestas sino por explicación de conceptos. Cada concepto, en letra negrilla para el grado medio, se explica según los nuevos planteamientos metodológicos de la Escuela Nueva en cuanto a claridad del lenguaje, accesible a los niños, y relacionándolo con ejemplos de la vida cotidiana. Por ejemplo, metodológicamente, para explicar qué es una superficie la editorial Calleja la define como conjunto de líneas puestas una tras otra, tocándose ${ }^{876}$ sin embargo en nuestro libro se señala:

Superficie.- Superficie, en general, es la extensión en dos dimensiones. En su parte exterior una caja, por ejemplo, tiene seis caras. Cada una de esas caras es una superficie. Las dimensiones de una superficie son la longitud o largo y la latitud o ancho. Una superficie no puede tener grueso. Si lo tuviera, sería un cuerpo. ${ }^{877}$

En otro ejemplo, sobre superficies planas y curvas, la definición se plasma como "superficie plana o plano es aquella a la cual se adapta en todas las direcciones una regla bien construida". ${ }^{878}$

Según los ejemplos expuestos, percibimos que el lenguaje es muy claro, sencillo y adaptado a los conocimientos de los niños, lo cual nos hace ver el estudio del autor sobre la mente infantil y la realidad de las aulas, así como el conocimiento de las nuevas metodologías. Al final de cada lección hay una propuesta de ejercicios que no son de memorización sino prácticos, sobre el tema tratado.

El apartado de grado superior, o ampliación como muestra el libro, sigue la misma línea de explicación con ejercicios y situaciones prácticas. Un ejemplo existente y viable del mismo es que cuando habla sobre líneas plantea trazarlas sobre el terreno por medio de jalones.

\footnotetext{
${ }^{876}$ CALLEJA, S. Geometría plana y del espacio. Madrid: Calleja, 1917, p. 7

${ }^{877}$ MARTÍ ALPERA, F. Nuevas Lecciones de Geometría. Burgos: Hijos de Santiago Rodríguez, 1911, p. 9.

${ }^{878}$ Ibídem, p. 10.
} 


\subsubsection{Urbanidad, Economia, Fisiologia e Higiene}

Tras la crisis del Antiguo Régimen, la configuración de la nueva sociedad liberal y el predominio de la burguesía consolida la instrucción de los nuevos ciudadanos, sujetos de derechos y deberes. Esta situación, lleva aparejada la necesidad de publicar normas de urbanidad para una mejor convivencia social.

Vista la oportunidad, la empresa Hijos de Santiago Rodríguez edita la obra Reglas de urbanidad para niños y niñas en 1891, referenciada por Hergueta. La componen dos volúmenes, de 40 y 48 páginas, escritas por Anselmo Salvá Pérez y diferenciadas por sexo. Están encuadernados y adornados con grabados y una cubierta artística al cromo ${ }^{879}$. En el Catálogo de 1908 figura la $6^{\text {a }}$ edición para las niñas, y $5^{\text {a }}$ para los niños; y en el de 1929 , la $13^{a}$ para niñas, y $10^{a}$ para niños. Estas obras son declaradas de utilidad como libros de texto en las escuelas de primera enseñanza, según Real Orden de 29 de abril de 1893.880

En los Catálogos se subraya que debido a sus excepcionales condiciones le han colocado entre los primeros de su clase y hoy se halla de texto en la mayor parte de las Escuelas de España y América. ${ }^{881}$ Llama la atención que, aunque separa las Reglas de Urbanidad en niños y niñas, en la publicidad de los Catálogos muestra lo que tanto un niño como una niña debe conseguir: trato benévolo, respetuoso, cariñoso y fino. En los últimos, de 1925 y 1929, sustituye la palabra "fino" por "cortés" para los niños y mantiene "fino" para las niñas.

De igual manera, publica El Amigo de los Niños del Abate Sabatier, traducido por Juan de Escoiquiz, y Tratado de las Obligaciones del hombre, del mismo traductor. Estos manuales están escritos en forma de lecciones, y se presentan como una guía moral para los niños. Añaden al final unas reglas de urbanidad y buena educación. Este tipo de obras las encontramos en otras editoriales de la época.

Por otra parte, la primera vez que se cita como asignatura Fisiología e Higiene, de manera concreta e independiente, entre las materias de enseñanza obligatoria en las escuelas primarias de todos los grados, se hace en el real decreto de 26 de octubre de 1901. Hasta entonces seguía vigente la Ley Moyano (1857) que aludía a "ligeras nociones de higiene doméstica”, aunque éstas quedaran como específicas para la enseñanza de

\footnotetext{
${ }^{879}$ CATÁLOGOS 1908, 1917, 1925, 1929.

${ }^{880}$ VILLALAÍN BENITO, J. L. Op. cit., T. III, p. 185.

${ }^{881}$ CATÁLOGO 1908. Op. cit., p. 52. No se han encontrado ningún ejemplar, pero se publicita en todos los Catálogos estudiados. En el Catálogo de 1908 se expresa que va por la $6^{a}$ edición y que son obras ilustradas por Isidro Gil y que tiene la cubierta a color.
} 
las niñas, junto con las labores propias del sexo y elementos de dibujo aplicados a esas mismas labores, ${ }^{882}$ ya que para los niños se incluía en los programas de historia natural.

Los libros sobre nociones de Fisiología e Higiene forman parte de la editorial desde los inicios de la imprenta Santiago Rodríguez.

El primer libro, de 1879, Catecismo de higiene y economía domésticas, precedido de unas nociones de fisiología para uso de las escuelas de niñas, que puede también servir para las aspirantes al título de Maestras de primera enseñanza, fue escrito por Antonio Álvarez Carretero, publicado por la Imprenta de Cariñena en Burgos ${ }^{883} \mathrm{y}$, pocos años más tarde, impreso en la Imprenta y librería de Santiago Rodríguez Alonso. Aunque no se sabe exactamente la fecha concreta, Domingo Hergueta, lo data en 1879, en la imprenta de Cariñena. El periódico El Papa-Moscas recoge el comentario de esta obra en 1880, la presenta como de nueva publicación e informa que su compra se puede efectuar en la librería de Santiago Rodríguez. ${ }^{884}$

Sí es seguro su publicación en 1884, en la Imprenta y librería de Santiago Rodríguez, bajo el mismo título Catecismo de higiene y economía domésticas, precedido de unas nociones de fisiología, con una $2^{\mathrm{a}}$ edición aumentada, con unas nociones de urbanidad en verso, y corregida la higiene por un licenciado en Medicina y cirugía de Burgos. Tiene 164 páginas, mide $16 \mathrm{~cm}$. de tamaño y está ilustrada. Lo mismo será la $3^{\mathrm{a}}$ edición que se publica en 1889. En 1896, con la $4^{\text {a }}$ edición, se cambia la palabra Catecismo del título, por Principios. Esta obra recibe premios en la Exposición Provincial de Burgos de 1882 y en la de Zaragoza de 1885.

En el inventario, a la muerte de Santiago Rodríguez, quedan 3.000 ejemplares valorados en 1 pts., cada uno, y otros 18 a 1,50 pts., lo cual hace pensar que la diferencia pecuniaria residía en la encuadernación.

El libro está organizado por el sistema de preguntas y respuestas sobre cada concepto fundamental. El texto de 1879 es un libro para uso en las escuelas de niñas; no así el de 1896, siendo recomendado por la Junta Provincial de Instrucción Pública de Burgos. Al comparar los textos de 1879 -imprenta de Cariñena- y de 1896 -editorial Hijos de Santiago Rodríguez- observamos que en el apartado de Fisiología, de1896, el texto explica y amplia todas las preguntas de conocimientos naturales incluyendo

\footnotetext{
${ }^{882}$ ALONSO MARAÑÓN, P. M. Notas sobre la Higiene como materia de enseñanza oficial en el siglo XIX [en línea]. Universidad de Salamanca: Revista Interuniversitaria, nº 6, 1987, pp. 22-41. [fecha de consulta 2-3-2013]. Disponible en: http://campus.usal.es/ revistas trabajo/index.php/02120267/article/viewFile/6734/6724

883 ÁlVAREZ CARRETERO, A. Catecismo de higiene y economía domésticas, precedido de unas nociones de fisiología para uso de las escuelas de niñas. Burgos: Imprenta de Cariñena, 1879, 157 p. La imprenta de Cariñena de Burgos fue fundada en 1850, y que Mariano Rodríguez la compró en 1913.

${ }^{884}$ El Papa-Moscas. Año III, no 122, 21 junio de 1880.
} 
preguntas de cada uno de los órganos que intervienen en el cuerpo humano, apartado que en años anteriores se incluía en Historia Natural. Además, la segunda parte sobre Higiene, de 1896, incluye una lección sobre diferencias individuales, con preguntas:

- ¿Los preceptos de la higiene pueden considerarse como generales?

- ¿Cuáles son estas diferencias individuales?

- ¿A qué llamamos temperamento?

- ¿Cuáles son los temperamentos?

- ¿Cuáles son los caracteres que determinan el sanguíneo?

- ¿Quiénes son los de temperamento linfático?

- ¿Cuáles son los caracteres que determinan el temperamento bilioso?

- ¿Qué personas tienen un temperamento nervioso?

- ¿Qué son idiosincrasias?

- ¿Qué es edad en un individuo?

- ¿En cuántas edades suele clasificarse la vida del hombre?

- ¿Cuántos sexos abraza la especie humana?

- ¿A qué llamamos herencia en higiene?

- ¿Qué es hábito?

- ¿A qué llamamos constitución?

Las respuestas corresponden a la tradición médica greco-romana que diferenciaba cuatro tipos, según las características personales: sanguíneo, melancólico, colérico y flemático, considerados como emanación del alma por la interrelación de los diferentes humores del cuerpo.

Las siguientes lecciones sobre Higiene -aire, luz, calor, electricidad, habitación, vestidos, alimentos, condimentos, bebidas, higiene de los sentidos, ejercicios, de las pasiones, enfermedades y accidentes, y botiquínsiguen la misma metodología de preguntas y respuestas, con algunos pequeños detalles. Así, se amplían algunas preguntas sobre la antigüedad de los preceptos de la higiene o sobre las distintas divisiones de los alimentos, y, curiosamente, incluye el baile. Como novedad, hay que registrar la lección "Terrenos, localidades y climas" que no consta en la edición de 1879.

La tercera parte, Economía Doméstica, se mantiene íntegra e idéntica en ambas ediciones. Si bien, en el último apartado de la edición de 1896, incluye unas nociones de urbanidad en verso.

Este libro lo encontramos encuadernado en tela y presenta ilustraciones interiores al comienzo de algunas lecciones, de Evaristo Barrio e Isidro Gil, relacionadas con el tema. ${ }^{885}$ Fue aprobado como libro de texto para la enseñanza de Higiene por Real Orden de 12 de mayo de 1888.

${ }^{885}$ Llama la atención, al igual que en otras colecciones, que al final del tema, si queda espacio libre, se completa con pequeños dibujos: una mujer regando, una niña con un pájaro, una mujer leyendo en un 


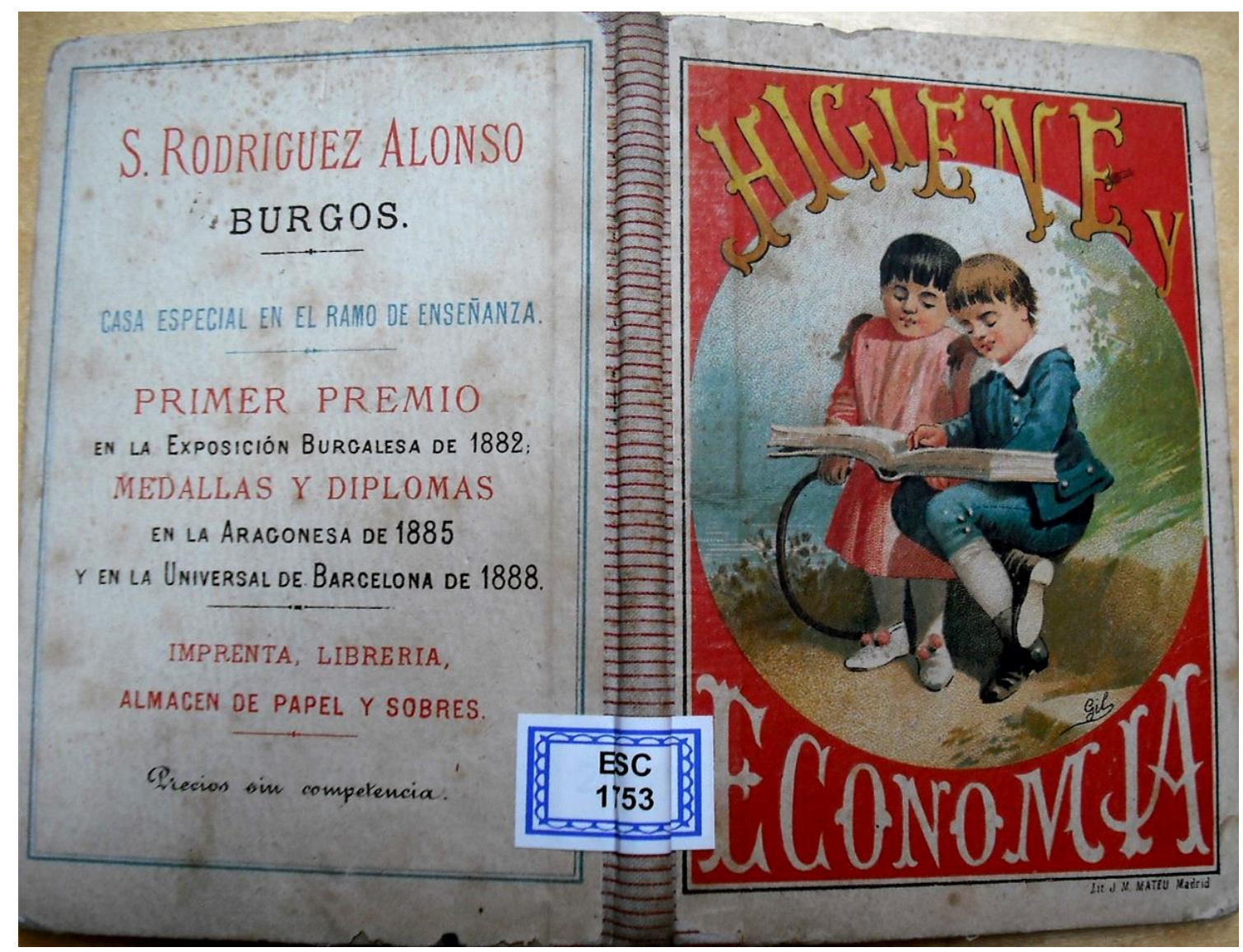

Fig. 6-77: Cubierta y contracubierta de Higiene y Economía Doméstica.

Hijos de Santiago Rodríguez. 1891.

Ejemplar de la Biblioteca de la Diputación Provincial de Burgos.

La hija del autor, Mariana, resume el libro de su padre, a petición del Sr. Rodríguez Alonso, con el objeto de poner en manos de niñas pequeñitas un extracto para que, cuando lleguen a su escuela, les sirva en el estudio de dicha asignatura. Higiene y economía, es el título de un libro fechado por la autora en 1890 y publicado en 1891, en la imprenta y librería de Santiago Rodríguez (figura 6-77). Más adelante, se cambiará el título por Resumen de Higiene y economía doméstica con la nueva empresa Hijos de Santiago Rodríguez.

En ambas ediciones las litografías son de distintas casas: la primera, corresponde a la Litografía de J. M. Mateu, de Madrid y, la segunda, a A. Moliner, de Burgos. Las ilustraciones son diferentes en su mayoría, pues sólo quedan tres de las impresas en las ediciones de su padre, aunque siguen siendo de Isidro Gil y Evaristo Barrio. ${ }^{886}$ Este libro fue aprobado

parque, un nido de pájaros, una mujer a caballo, una mujer cuidando el jardín, una máquina de tren, una parte de una ventana con un pájaro enjaulado y otro no.

${ }^{886}$ Cambian también los pequeños dibujos que se colocaban al final de la lección. Éstos son los siguientes: una mujer pintando, unos pájaros en una rama, una rana en bicicleta, la silueta de un niño tumbado, un señor pescando, un gato encima de la luna, un gato, un cazador con su perro, la silueta de la 
para la enseñanza de la Higiene, en la Real Orden de febrero de 1898, en las escuelas de enseñanza primaria. ${ }^{887}$

La casa editorial Hijos de Santiago Rodríguez edita libros sobre Fisiología, al aprobarse como asignatura obligatoria en las escuelas, a partir de 1901. Rogelio Francés y Gutiérrez escribe Fisiología e Higiene en dos tomos: Primer grado y grado medio, y otro como grado superior.

En el prólogo del primer tomo se insiste en la importancia de la asignatura, en que no se la relegue a un segundo plano, apoyando sus argumentos con palabras de Guillermo II de Alemania e insistiendo en su experiencia como Profesor.

La inteligencia del niño es rebelde a digerir conocimientos que se le suministren en calidad de mero recipiente de ideas ajenas, y que, por el contrario, se asimila con facilidad todo aquello que le hable a los sentidos, a la imaginación, al sentimiento; que le impresione y deleite: todo aquello que le incite a pensar y discurrir, a mostrarse, en fin, colaboradores de su próxima enseñanza. ${ }^{888}$

Supone un cambio fundamental en los presupuestos pedagógicos de la asignatura, rechazando el método memorístico. Su obra tiene tres apartados diferenciados:

- Una parte dedicada a la lectura: expone el tema de la lección.

- Otra parte destinada a la memoria. Resumen de cada lección para que el niño pueda aprender lo principal de ella con facilidad.

- Y una última, dedicada al profesor, compuesta de preguntas que a modo de conversación el profesor sostiene con su alumno y ampliará, según lo crea conveniente, y vea la asimilación de sus alumnos.

cabeza de una joven, flores y pájaros, una ardilla, la silueta de un niño y una niña, un mono, un conejo, etc.

${ }^{887}$ VILLALAÍN BENITO, J. L. Op. cit. T. III, p. 211.

${ }^{888}$ FRANCÉS GUTIÉRREZ, R. Fisiología e Higiene. Primer grado y grado medio. Burgos: Hijos de Santiago Rodríguez, $5^{\text {a }}$ edición, 1906, pp. 6-7. 


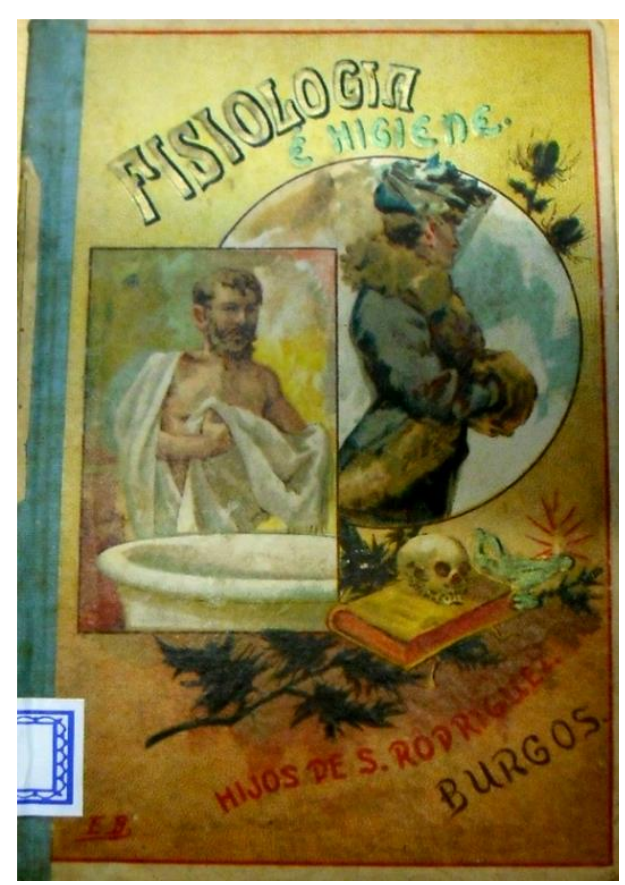

Fig. 6-78: Cubierta ilustrada por Evaristo Barrio de la obra Fisiología e Higiene. Hijos de Santiago Rodríguez. Ejemplar de la Biblioteca de la Diputación Provincial de Burgos.

El apartado de Fisiología centra las lecciones en las funciones de nutrición y de relación; en el de Higiene trata sobre la salud, el aire, el calor y la luz, la vivienda, el aseo y la limpieza, el vestido, el alimento, las bebidas, el ejercicio y el descanso. Sus numerosas ilustraciones son anatomías del ser humano y croquis explicativos de los temas tratados.

Es un libro de 116 páginas, con un tamaño de 17 x $11,5 \mathrm{~cm}$, encuadernado con una cubierta, en pasta dura y lomo de tela, ilustrada a todo color por Evaristo Barrio. La empresa que realizó la litografía fue S. Durá, de Valencia.

Sobre el último tratado de Fisiología e Higiene, de Rogelio Francés, subtitulado Veladas instructivas. Grado superior, no se ha encontrado ningún ejemplar en las distintas bibliotecas, a pesar de que Hergueta lo sitúa en la imprenta de Hijos de Santiago Rodríguez, en 1906. ${ }^{889}$

Rogelio Francés y Gutiérrez vende la propiedad intelectual de ambas obras a la editorial, en 1907; se valora en cincuenta pts. la correspondiente al primer grado y grado medio, y en 25 pts. Fisiología e Higiene (veladas instructivas). Grado superior ${ }^{890}$ En los demás Catálogos los presenta como "en prensa".

${ }^{889}$ HERGUETA MARTÍN, D. Op. cit., T. III, p. 239.

${ }^{890}$ Vid. Anexo 2.1.19. 


\subsubsection{Derecho}

El propio gerente y propietario de la editorial, Mariano Rodríguez Miguel, escribe un libro para la escuela primaria bajo el título de Nociones de Derecho o Derecho usual, como reza la portada de abril de 1906. La presentación del libro corre a cargo de su buen amigo Rogelio Francés y Gutiérrez y aparece reseñada en El Papa-Moscas:

Elegantemente editados por la conocida casa editorial de Hijos de Santiago Rodríguez de Burgos, acaba de ver la luz pública esta obrita, casi única en su género.

Su autor, D. Mariano Rodríguez es un entusiasta educador de la infancia, como lo tiene probado en el periódico y en el libro El viaje Infantil ha popularizado su nombre no solo por España, sino que también por América, pues difícilmente se encuentra escuela ni colegio en nuestra nación donde no se halle adoptado este hermoso libro de lectura, que de vivir lean con verdadero deleite.

Llevado este de su entusiasmo y de su infatigable laboriosidad, ha escrito un nuevo librito que destina a la enseñanza elemental de una asignatura que, siendo de los más indispensables en la vida, ha sido, no obstante una de los más olvidados en la enseñanza primaria.

El Sr. Rodríguez cree y piensa que la enseñanza del Derecho, en lo que tiene de elemental y aplicable a los usos generales de la vida, no es difícil llevarle a la escuela primaria; y que los niños puedan asimilarla desde que otras que se enseñan sin discusión: La Gramática, por ejemplo, y porque encierra tanto interés e importancia con esta; pues el hombre no puede dar un paso en la vida social sin que debe ser guiado por esa luz interior que se nos revela en nuestra misma conciencia. [...]

El estilo de las Nociones de Derecho revela al autor don Mariano Rodríguez en un lenguaje sencillo, persuasivo, interesante, en forma de conversaciones amenas propio de quien ha estudiado a fondo la génesis del desenvolvimiento de la inteligencia infantil y sabe compenetrarse con el sentir del niño. ${ }^{891}$

La obra tiene un total de 60 páginas, junto con el índice y una hoja de propaganda de la editorial. Su tamaño es de 17 x 11,5 cm., encuadernado en pasta dura, con lomo de tela e ilustrado a color por Evaristo Barrio. La litografía es realizada por A. Moliner, en Burgos. Las ilustraciones interiores, en blanco y negro, son de Evaristo Barrio e Isidro Gil. Los temas que trata son:

- La familia.

- El municipio.

- La Provincia.

- La Nación.

- La vida en familia, en el Municipio, en la Provincia y en la Nación.

- Servicios municipales, provinciales, nacionales.

${ }^{891}$ El Papa-Moscas, Año XXIX, no 1534, 8 de abril de 1906, p. 2. 
- Las Cortes.

- Las Leyes.

- Ministerio y Ministros.

- Administración del Estado.

- La Justicia.

- Ejército y Marina. ${ }^{892}$

La manera de presentar los contenidos se basa en una explicación de cada tema, seguido de un cuestionario sobre preguntas tratadas en el temario. Al igual que en otros libros, señala en negrilla las palabras clave del texto como ayuda a su fijación.

Aunque en todos los Catálogos estudiados nos informa de un segundo tomo en preparación, de segundo grado y grado superior, tenemos dudas de su publicación debido a la inexistencia de ejemplares en las bibliotecas consultadas.

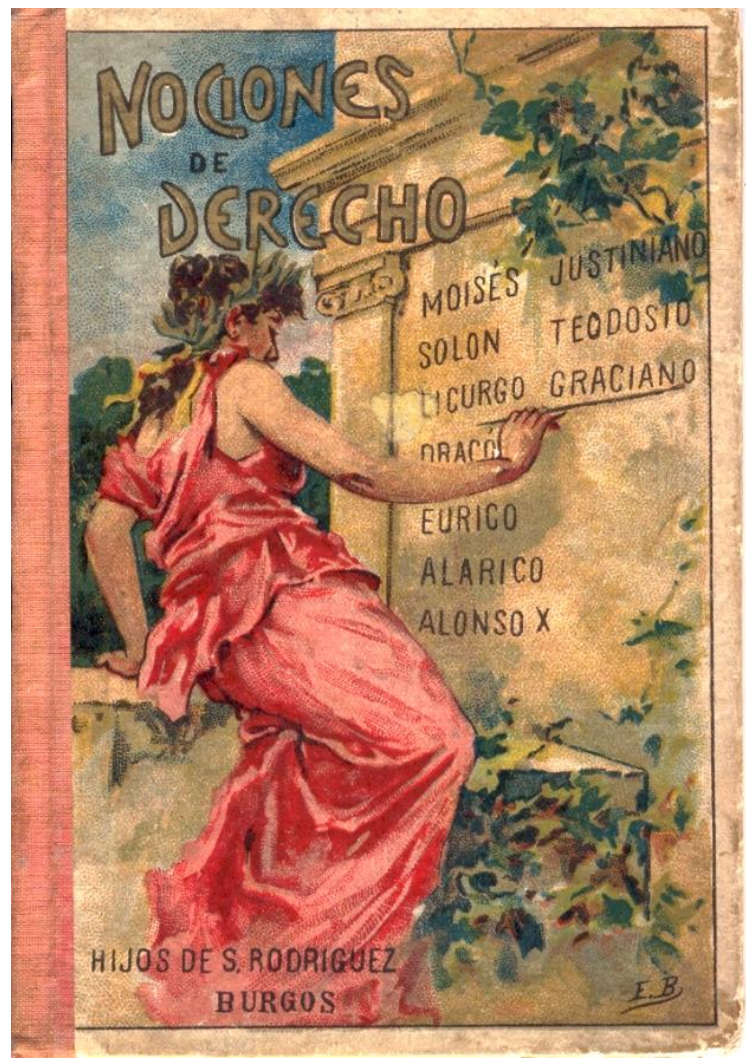

Fig. 6-79: Cubierta de Evaristo Barrio de la obra Nociones de derecho.

Hijos de Santiago Rodríguez. 1906.

Imagen cedida por Mercedes Rodríguez Plaza.

${ }^{892}$ RODRÍGUEZ MIGUEL, M. Nociones de derecho, primer grado. Burgos: Hijos de Santiago Rodríguez, 1906. 
LA EDITORIAL BURGALESA HIJOS DE SANTIAGO RODRÍGUEZ (1891-1936): ANÁLISIS DE LOS LIBROS ESCOLARES

\subsubsection{Dibujo}

No será hasta finales de los años 20 cuando aparece un manual de dibujo compuesto por siete cuadernos de un tamaño de $22 \times 20 \mathrm{~cm}$. A partir del cuaderno $4^{\circ}$, las imágenes están impresas en varias tintas. El precio de cada ejemplar, según el Catálogo de 1929, es de 0,50 pts. en los cinco primeros cuadernos, y de 0,75 pts. el $6^{\circ}$ y $7^{\circ}$. La colección completa cuesta 4 pts.

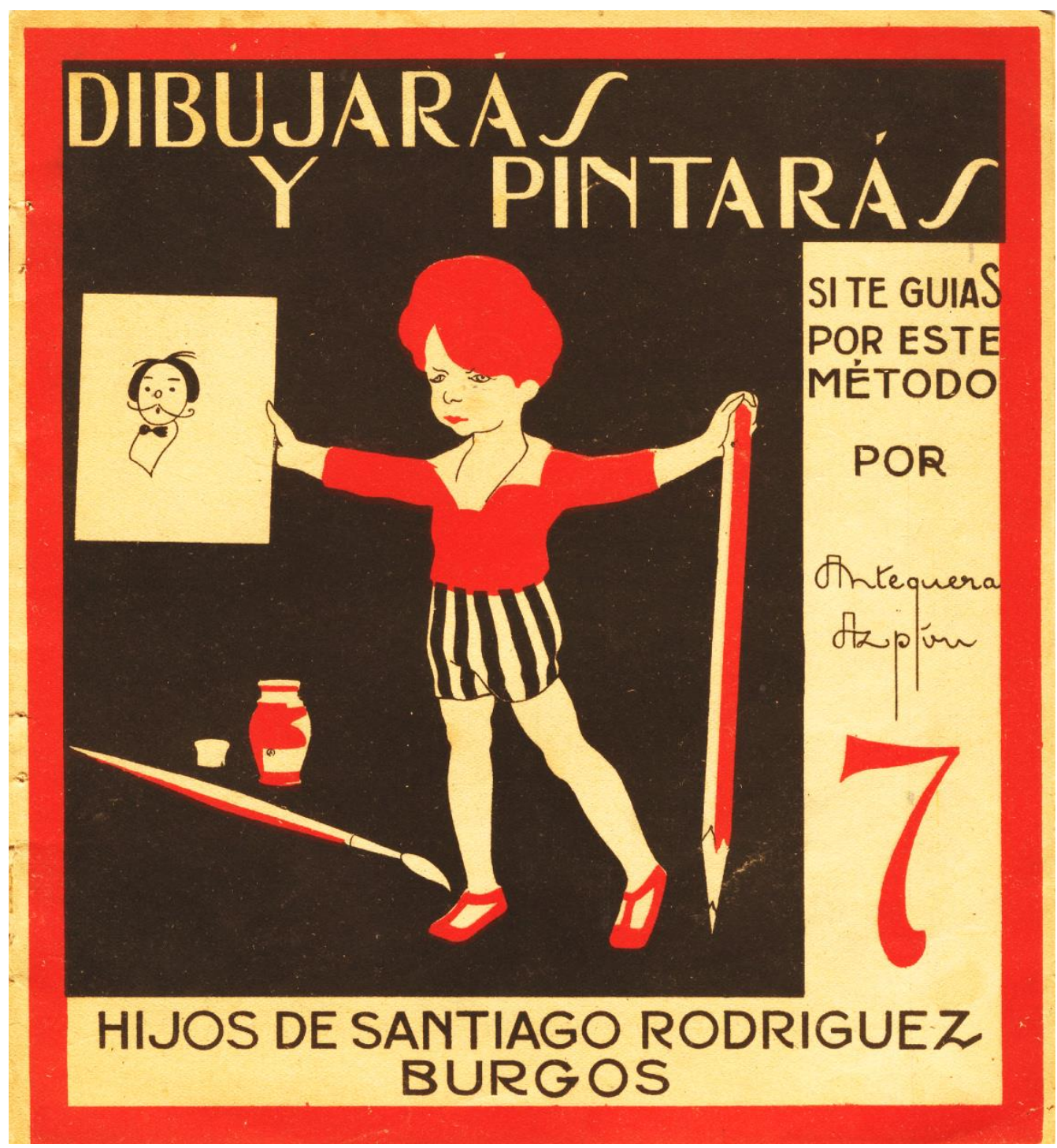

Fig. 6-80: Cubierta del método Dibujarás y pintarás de Pedro Antequera Azpiri. Cuaderno n 7 . Hijos de Santiago Rodríguez. 


\subsubsection{Historia Sagrada y Religión}

La Autoridad eclesiástica era la única que establecía los contenidos indiscutibles de la enseñanza religiosa. A ello se debe que se mantengan los mismos libros y autores en las distintas editoriales de la época como Calleja, Hernando, Bastinos etc. Las diferencias son pequeñas adaptaciones formales y reformas, en general de tipo organizativo, diseño, ilustración y maquetación del libro. ${ }^{893}$

La editorial publica los catecismos: Catecismo de la Doctrina cristiana, del P. Gaspar Astete, añadido y aumentado por D. Gabriel Menéndez de Luarca; Catecismo histórico o Compendio de la Historia Sagrada y de la Doctrina cristiana, del abad Fleury; y Catecismo de la Doctrina Cristiana, del P. Jerónimo Ripalda, y añadido por La Riva.

En todos ellos, el contenido está estructurado de la misma forma. En primer lugar, se presenta una parte que se denomina "Resumen de la doctrina cristiana, lo que debe saber un cristiano" que incluye la devoción a la Cruz, oraciones como el Padrenuestro y el Avemaría, los Mandamientos, etc. En segundo lugar, hay varias lecciones donde se expone los dogmas de la fe cristiana, con preguntas y respuestas que deben aprender de memoria. Y la parte tercera, se refiere a todo lo relativo a la Iglesia: mandamientos, sacramentos, pecados capitales, virtudes etc. Se completan estos apartados con varias oraciones, según las diferentes horas del día, y el modo de rezar el rosario y las letanías.

También se imprime un Catecismo del Arzobispado de Burgos, cuyo contenido coincide con la unión del Catecismo de Astete, aumentado con epígrafes aclaratorios; el Diálogo histórico del abad Fleury, corregido, y un conjunto de oraciones y cánticos. ${ }^{894}$

Festividades de la Iglesia es un libro que ya se imprimía en la Imprenta y librería de Santiago Rodríguez Alonso, ${ }^{895}$ y que continúa editándose en años posteriores. ${ }^{896}$ Trata de explicar el contenido dogmático de todas las fiestas religiosas y de los domingos en la liturgia, desde el primer domingo de Adviento hasta el $2^{\circ}$ después de Pentecostés, propuestos por el jesuita P.

\footnotetext{
${ }^{893}$ VIÑAO FRAGO, A. Religión en las aulas. Una materia controvertida. Madrid: Morata, 2014. Ver la primera parte que trata de la Religión desde comienzos del siglo XIX hasta la guerra civil.

${ }_{894}$ Para ampliar un mayor conocimiento del clero en Burgos ver la publicación de: ORTEGA GUTIÉRREZ, D. El mundo de las creencias y organización eclesiástica en Burgos. En: J. M. PALOMARES IBÁÑEZ, dir. Historia de Burgos (IV). Burgos: Caja de Burgos, 2005, v. II, pp. 805-858. ${ }^{895}$ MORAL, A. Festividades de la Iglesia. Burgos: Imprenta y librería de Santiago Rodríguez Alonso, 1888.

${ }^{896}$ Catálogos de la editorial Hijos de Santiago Rodríguez de 1908, 1917 y 1929 donde en este último nos pone que está en prensa, lo cual nos hace pensar en una nueva edición reformada.
} 
Croisset, y que Antonio Moral adapta para la escuela como profesor de primera enseñanza.

Por otra parte, además de los Catecismos, se editan varias obras de carácter religioso:

- Compendio de la Historia Sagrada y de la vida de Nuestro Señor Jesucristo, escrito por el padre Jean Nicolás Loriquet y cuya edición fue reformada por Mariano Rodríguez Miguel. ${ }^{897}$

- Un devocionario, titulado Devoción de los siete domingos de San José, editado en 1909, de 310 páginas. Se encuentra, un único ejemplar, en la biblioteca de la Universidad de Islas Baleares.

- Breve reseña histórica de la milagrosa imagen de Jesús Crucificado que se venera en el Real Monasterio de Palacios de Benaver, editado en 1899.

- El Día del Señor en Burgos, devocionario de Anselmo Salvá, editado en $1900 .^{898}$

- El Reinado Social del Sagrado Corazón de Jesús en las familias cristianas por el R.P. Ignacio de la Cruz Baños, de la Congregación de los Sagrados Corazones. ${ }^{899}$

- El Padre Nuestro de Fenelon: Historia religiosa, de Samuel-Henry Berthoud y traducido por Francisco Rodríguez Miguel, en dos ediciones. Una, de noviembre de 1896 y otra nueva de 1897, ilustrada por Evaristo Barrio y encuadernada con cubierta en colores. En el prólogo el traductor se lo dedica a su padre, D. Santiago, con un cariñoso recuerdo. En la Biblioteca de la Diputación Provincial de Burgos se conserva un ejemplar con dedicatoria del autor a D. Millán Orio, como agradecimiento a las correcciones aportadas.

\footnotetext{
${ }^{897}$ Existen ejemplares en diversas bibliotecas con ediciones de 1907, 1909 y 1910 con fotograbados y láminas a color y la cubierta a color realizada por Fortunato Julián.

898 [Anón.]. Breve reseña histórica de la milagrosa imagen de Jesús Crucificado que se venera en el Real Monasterio de Palacios de Benaver. Burgos: Hijos de Santiago Rodríguez, 1899. SALVÁ, Anselmo. El Día del Señor en Burgos. Burgos: Hijos de Santiago Rodríguez, 1900.

${ }^{899}$ CRUZ BAÑOS, I. de la R.P. El Reinado Social del Sagrado Corazón de Jesús en las familias cristianas. Burgos: Hijos de Santiago Rodríguez, 1917. Este libro se publicita en el periódico burgalés Tierra Hidalga. Año VII, nº 334, 2 de junio de 1918, p. 3.
} 


\subsubsection{Enciclopedias}

El modelo enciclopédico, difundido en Europa desde el siglo XVIII, se caracteriza por unir, en un solo volumen, todas las materias que un alumno debía aprender. En España se desarrolla más tarde, a principios del siglo XX, entre 1920 y 1960, fundamentalmente, tal vez debido al atraso social, económico, cultural y pedagógico.

Este compendio de conocimientos se distribuye en contenidos, por ciclos, que se constituyen en verdaderos sistemas didácticos y en referente obligado para maestros y alumnos.

Algunos libros, al incorporar diversas materias y variados conocimientos, se pueden considerar como precursores del modelo. Ejemplo de ello es la obra clásica, Juanito, de L. A. Parravicini, que Hijos de Santiago Rodríguez intituló Tesoro Escolar, traducida directamente del texto italiano por Ángel Bueno. Fue aumentada con Historia Sagrada, con Historia de España y con mayores conocimientos acerca de los inventos modernos, incluidos los últimos como el cinematógrafo y los rayos X..$^{900}$

La obra se presenta encuadernada en pasta, con tapas al cromo. Las ilustraciones interiores son numerosas, con más de 500 fotograbados de diferentes dibujantes -Gil, Barrio y Pedrero-, en blanco y negro. ${ }^{901} \mathrm{La}$ cubierta presenta a una niña mayor hablando a un niño pequeño, sobre el fondo de una población rural. La contracubierta es totalmente distinta a cuantas edita la casa puesto que no utiliza el emblema de la diosa Minerva, ni el lema de la editorial. A cambio, figuran dos ángeles: uno cuida el libro mientras el otro coloca unas cintas; en la parte superior reza el texto labor omnia vincit, y en la parte inferior, Rodríguez Burgos (Figura 6-81).

Se desconoce el número de ediciones realizadas ya que los Catálogos de 1925 y 1929 no ofrecen esta información. Los precios oscilan, desde 1 pts. en 1908 (9 pts. si se compran por docenas) hasta 1,90 pts. en 1929.

900 CATÁLOGO 1908. Op. cit., p. 14.

${ }^{901}$ BUENO RODRÍGUEZ-ARIAS, A. Tesoro Escolar. Burgos: Hijos de Santiago Rodríguez, 1902. 

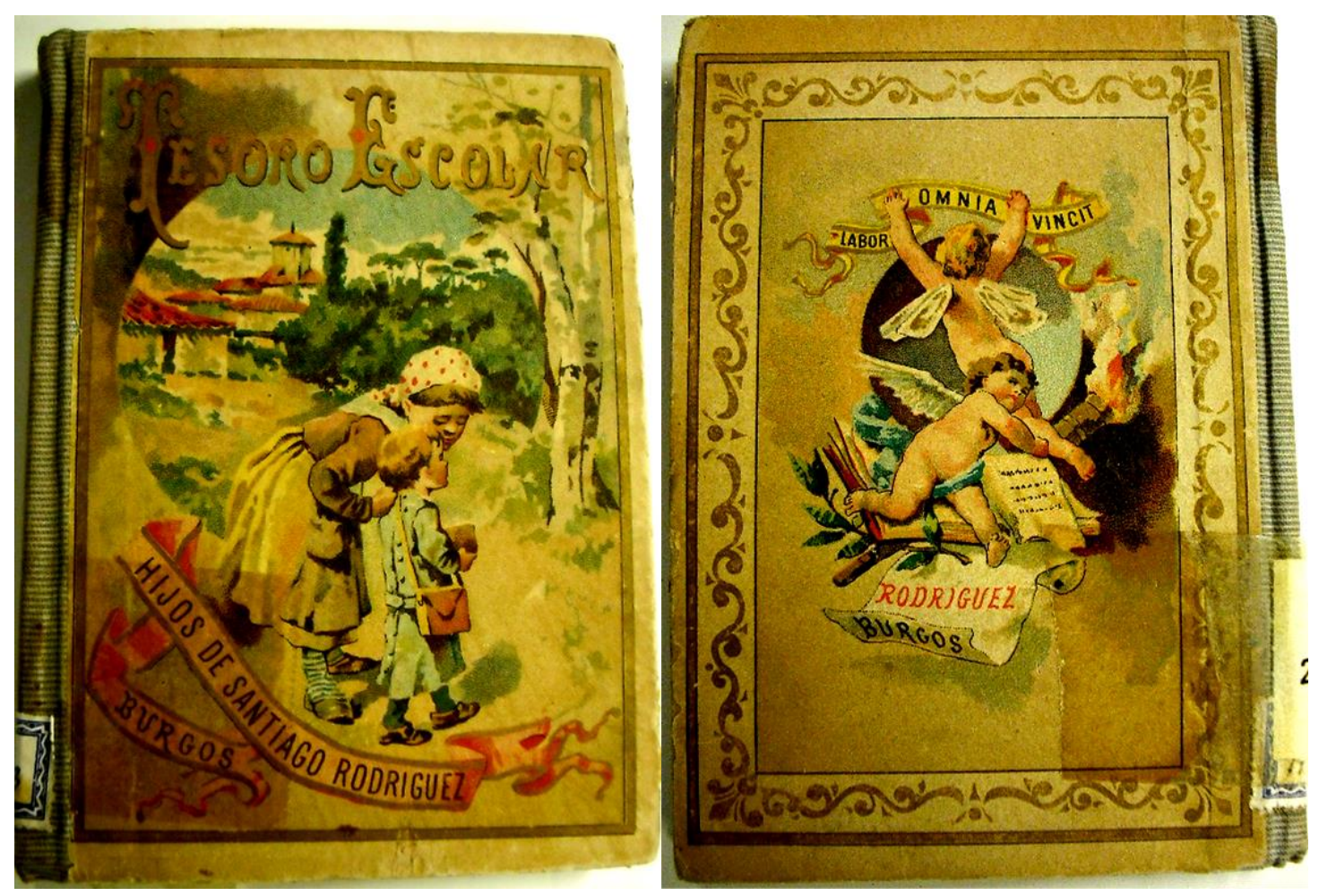

Fig. 6-81: Cubierta y contracubierta de Tesoro Escolar.

Hijos de Santiago Rodríguez.

Ejemplar de la Biblioteca Pública de Burgos.

El contenido de los capítulos, en forma de monólogo, explican aspectos sobre Geografía Física, Historia Natural, Física; sobre el Hombre, sus facultades, necesidades y deberes; sobre ocupaciones: artes mecánicas, bellas artes, ciencias, comercio y navegación; y por último, nos habla de los deberes de los niños, proponiendo los ejemplos modélicos de padres, maestros y curas, siguiendo los roles sociales de la época.

Observamos que este libro está publicitado en todos los Catálogos estudiados. Ahora bien, en los de 1925 y 1929 lo describe como una enciclopedia escolar lo suficientemente extensa para las primeras secciones. Sin duda, se componía de los contenidos principales, de la mayoría de las asignaturas de la primera enseñanza, aunque le falta el componente cíclico, propio de las enciclopedias.

En la misma línea, la editorial publicita Para saberlo todo. Para recordarlo todo ${ }^{902}$ como enciclopedia popular de la vida práctica. En el Catálogo de 1908 se anuncia como edición en prensa, encuadernada en tela inglesa con planchas en negro y oro, donde informa que contendrá todo lo publicado hasta ahora sobre Anatomía, Arquitectura, Aritmética, Biografía, Ciencias Físicas y Naturales, Cirugía, Comercio, Deberes de la sociedad,

902 RODRÍGUEZ-NAVAS, M. Para saberlo todo. Para recordarlo todo. $1^{\text {a }}$ ed. Burgos: Hijos de Santiago Rodríguez, 1911. 
Economía doméstica, Estadística, Fisiología, Fotografía, Geografía, Geometría, Historia, Medicina, Pesas y medidas, y cuyo autor será Eusebio Heras. Sin embargo, no será hasta octubre de $1910^{903}$ cuando aparezca publicada, y Manuel Rodríguez-Navas realice la labor de recopilación.

Las siguientes reediciones de las que hay constancia fueron a partir de 1914. ${ }^{904}$ En los Catálogos posteriores de 1925 y 1929 aparecen nuevas ediciones, con cambios en su estructura, en 6 secciones, con un mayor número de fotograbados y mapas a color. Fue encuadernada en tela inglesa, con planchas en negro y oro, y se vende al precio de 8 pts. en 1910, a 10 pts. en 1914, y a 25 pts. en 1925, en todas las librerías de España y América, según consta en los diferentes Catálogos en los que se publicita.

En su prólogo, recomienda la obra para consulta y estudio con el argumento de que las enciclopedias son símbolo de progreso.

En este tiempo, que podríamos llamar de las Enciclopedias, la utilidad de éstas, dada la rapidez con que se vive, es indiscutible. Por eso la Casa Rodríguez... gustó de marchar del brazo del Progreso animada por la importancia que a obras semejantes se han concedido en varias naciones extranjeras...por la amenidad (que les hace parecerse a un libro de entretenimiento) resulta un volumen recreativo como una obra de estudio y consulta útil..$^{905}$

Los lectores encontraban, en las primeras 170 páginas, un poco de todo: curiosidades, inventos, estadísticas, celebridades, divisas, horarios, comunicaciones... A continuación, desfilan los apartados de diversas materias: Arquitectura y Construcción; Historia (Universal, de España y de América); Literatura Universal: obras, autores, épocas e idiomas; Matemáticas; Ciencias físicas y Naturales, Fisiología, Medicina e Higiene; Comercio; Paremiología o Tratado expositivo de los refranes y proverbios; Juegos y sports; Economía doméstica; y vocabulario de tecnicismos. Finalmente, acaba con un índice de títulos y alfabético. Esta variedad, induce a pensar que más que un temario oficial, de cada una de las materias, presenta un conjunto de datos e informaciones para consulta.

El estudio de las enciclopedias escolares las entendemos como aquellas que responden a la idea de gradación paulatina de los contenidos de enseñanza, de forma sistemática y acumulativa, que se vertebran por razones pedagógicas y económicas. Algunos ejemplos se encuentran en Curso cíclico de primera enseñanza, de Porcel y Riera, en Enciclopedia

\footnotetext{
${ }^{903}$ La Voz de Castilla. Año I, no 108, 6 de noviembre de 1910, p. 2.

${ }^{904}$ La Voz de Castilla. Año V, no 323, 8 de noviembre de 1914, p. 2-3; El Papa-Moscas. Año XXXVII, ${ }^{\circ}$ $1.952,8$ de noviembre de 1914 , p. 3.

${ }^{905}$ RODRÍGUEZ-NAVAS, M. Op. cit., p. 5.
} 
cíclico-pedagógica, de Dalmau Carles, en Cursos graduados Ortiz y enEnciclopedia, de Calleja, entre otros. ${ }^{906}$

Hijos de Santiago Rodríguez publicita en el Catálogo de 1929, como en prensa, la Nueva Enciclopedia escolar, de Félix Martí Alpera, aunque no sale editada hasta 1930, el grado primero, y en años sucesivos los siguientes. Se divide en tres grados, según el método cíclico, con la enseñanza de todas las asignaturas, donde se incorporan los novedosos recursos didácticos y pedagógicos de la mano de Martí Alpera, quien ya los había aplicado en los nuevos libros escolares de aritmética y geometría de la editorial. Son tomos de 314, 584 y 934 páginas, correspondientes a los tres grados, respectivamente. Están encuadernados en pasta dura y lomo de tela, con la cubierta bellamente ilustrada por Fortunato Julián.

Cada enciclopedia debía ser usada durante dos años. Se recomendaba su utilización no antes de los 8 años y su aprovechamiento hasta los 14 años. También deja en manos del maestro la decisión de a quién corresponde pasar de año y de grado.

Las asignaturas o materias son agrupadas por razones didácticas ${ }^{907}$. Según el autor, se pretende facilitar la asociación, la articulación de las ideas y evitar que estén dispersos los conocimientos que deban estar totalmente enlazados. Las materias están englobadas en los siguientes apartados:

- Instrucción religiosa, moral y patriótica o cívica.

- Lengua Española.

- Aritmética.

- Geometría.

- Geografía.

- Historia de España.

- Conocimientos sobre la naturaleza. (Nociones de física, química, historia natural, fisiología e higiene).

Comienza el primer apartado con la instrucción religiosa, moral y patriótica, con todos los dogmas de la fe cristiana y escenas del Antiguo y Nuevo Testamento, oraciones y sacramentos. Los ejes moral-religioso y cívico-patriótico, sustentan los conocimientos. El núcleo moral es muy sencillo con temas como nuestros padres, los buenos modales, respeto a la

\footnotetext{
906 Agustín Escolano recoge sobre el tema aportaciones muy importantes. Ver: ESCOLANO BENITO, Agustín. Libros escolares para programas cíclicos. Epítomes, compendios y tratados. Las primeras enciclopedias. En: A. ESCOLANO BENITO, dir. Historia ilustrada. Del libro escolar en España. Del Antiguo Regimén a la Segunda República. Op. cit., pp. 425-448; Del imperio a la disolución de la enciclopedia. En: A. ESCOLANO BENITO, dir. Historia ilustrada. Del libro escolar en España. De la posguerra a la reforma educativa. Madrid: Fundación Germán Sánchez Ruipérez, 1998, p. 277-302. ${ }^{907}$ MARTÍ ALPERA, F. Nueva Enciclopedia Escolar. Burgos: Hijos de Santiago Rodríguez, 1930.
} 
vida de personas, animales y plantas, respeto a los bienes ajenos, amor a la verdad. El núcleo para la instrucción patriótica propone una lección de amor a la patria que se manifiesta en ser aplicados, limpios y generosos, así como en saludar con respeto a la bandera nacional, como señal o emblema de la nación.

En las distintas áreas -Lengua Española, Aritmética, Geometría y Geografía, Historia, Conocimientos sobre la naturaleza- se proponen explicaciones sencillas completadas con ejemplos de la vida cotidiana y, finalmente, dispone varios ejercicios, en algunos casos separados según el grado, excepto en Historia de España. Tiene numerosas ilustraciones relacionadas con los apartados tratados $\mathrm{y}$, en algunos de ellos, especifica cuáles son de $2^{\circ}$ año; y lo mismo para los ejercicios. El vocabulario utilizado está adaptado al nivel infantil.

El grado segundo está dividido en todas las asignaturas del plan de 1901: Instrucción religiosa, moral y cívica, Lengua Española, Aritmética, Geometría y trabajo manual, Geografía, Historia de España, Nociones de Física, Química, Historia Natural, Fisiología e Higiene. No presenta ejercicios en Geografía e Historia de España si bien se hace referencia a una parte práctica. En conocimientos sobre la naturaleza, además de ejercicios, hay un apartado dedicado a observaciones y experiencias.

En el grado tercero las asignaturas son: Instrucción religiosa, moral y cívica, Lengua Española, Aritmética, Geometría, Nociones de Física, Química, Historia Natural, Fisiología e Higiene, Geografía, e Historia de España. Todas las materias, excepto la Instrucción religiosa, moral y cívica, están formadas por una explicación, unos ejercicios y prácticas o experiencias según las mismas. 


\subsection{LIBROS DE ÁMBITO LOCAL Y PROVINCIAL}

La editorial Hijos de Santiago Rodríguez publica un Catálogo de obras referentes a Burgos y su provincia, titulado Bibliografía Burgalesa..$^{908}$

Es un boletín de 30 páginas, con varios apartados: obras referentes a Burgos y su provincia; Ediciones de Arte; Mapas de la provincia de Burgos; Tarjetas postales y vistas; y Autores Burgaleses. Está ordenado alfabéticamente por autores, tanto españoles como extranjeros. Coloca el autor y título, no así la editorial que lo publica, y señala el precio de dicha obra. Esta encuadernado en papel, con fotografías de vistas de la ciudad de Burgos, en la cubierta, y de la catedral de Burgos, en la contracubierta.

En los Catálogos generales no se describen los libros locales editados sobre Burgos y en Bibliografía Burgalesa no constan las obras publicadas por la editorial. El resultado nos lleva a rastrear tales obras en las diversas bibliotecas repartidas por todo el ámbito provincial, nacional e internacional.

De la catalogación ofrecida en páginas anteriores se desprende que las obras sobre Burgos se pueden agrupar en varias secciones: Libros acerca del conjunto histórico y artístico; libros sobre Burgos, ciudad y provincia; y libros para entidades oficiales.

\footnotetext{
${ }^{908}$ Hijos de Santiago Rodríguez. Bibliografía Burgalesa. Catálogo. Burgos: Hijos de Santiago Rodríguez, s/a. 


\subsubsection{Libros acerca del conjunto histórico y artístico}

En este grupo hay obras que tuvieron muchas ediciones sobre los grandes monumentos artísticos de Burgos: la Catedral, ${ }^{909}$ Monasterio de Silos, ${ }^{910}$ la Cartuja de Miraflores, ${ }^{911}$ Monasterio de Las Huelgas, ${ }^{912}$ Parroquia de San Gil. ${ }^{913}$ Y otras referidas a nuestra propia historia como: Burgos en las Comunidades de Castilla ${ }^{914}$, o Las Cortes de 1392 en Burgos. ${ }^{915}$

909 VV. AA. Catedral de Burgos: séptimo centenario de su fundación, 1221. Burgos: Hijos de Santiago Rodríguez, 1921, edición limitada.

DOTOR Y MUNICIO, A. (prólogo de Sr. Marceliano Santa María). La Catedral de Burgos: guía histórico-descriptiva. $2^{\text {a }}$ edición. Burgos: Hijos de Santiago Rodríguez, 1928. Su autor fue escritor e historiador sobre arte español, con monografías acerca de pintores, castillos y catedrales.

910 SERRANO, L. O.S.B., abad de Silos. El Real Monasterio de Santo Domingo de Silos (Burgos): su historia y tesoro artístico. Burgos: Hijos de Santiago Rodríguez, 1920.

${ }^{911}$ B. de A. La Cartuja de Miraflores. Burgos: Hijos de Santiago Rodríguez, 1899.

TARÍN y JUANEDA, F. La Real Cartuja de Miraflores: su historia y descripción. $1^{\mathrm{a}}$ edición. Burgos: Hijos de Santiago Rodríguez, 1896.

Francisco Tarín y Juaneda publica esta completa historia de la Cartuja con prólogo de Anselmo Salvà, cronista de la ciudad. Aunque fue abogado en Valencia, ya publicaba obras y apuntes históricos; dejó todo y vino a la Cartuja de Burgos como hermano lego, donde vivió más de 25 años, ejerciendo de cicerone mostrando las bellezas del templo.

912 El Real Monasterio de las Huelgas. Burgos: Hijos de Santiago Rodríguez, s/a. La obra, que se conserva en la Biblioteca Pública de Valladolid, consta de 5 páginas con un tamaño de $16 \mathrm{~cm}$.

En el Catálogo de 1929 aparece como obra en prensa y con el subtítulo de Nueva Guía históricodescriptiva. No tenemos ningún ejemplar y, por tanto, no podemos saber con exactitud si salió a la luz dicha publicación. No obstante, nos podemos remontar a una obra que hace referencia al Monasterio de las Huelgas, junto con la Catedral, la Cartuja y Hospital del Rey, de Leocadio Cantón Salazar, editada por Santiago Rodríguez en 1888, obra que encontramos en la Biblioteca Nacional de España, de 95 páginas.

913 BETOLAZA Y ESPARTA, G. Parroquia de San Gil de Burgos. Burgos: Hijos de Santiago Rodríguez, 1914. Gregorio Betolaza y Esparta era coadjutor de dicha parroquia.

Fue editada en marzo de 1914, describe las bellezas artísticas del Templo, aportando datos inéditos, sacados del Archivo de la Catedral y de los Archivos de la parroquia. Ilustra el libro unas fotografías del señor Dancausa Ibeas.

Existe otra obra de las mismas características y del mismo tema cuyo autor es Isidro Gil y fue editada por la casa Fournier. Se puede ver referencias de su edición en diversos periódicos de Burgos: El PapaMoscas. Año XXXVII, no 1.921, 29 de marzo de 1914, p. 3; La Voz de Castilla. Año V, no 289, 5 de abril de 1914, p. 2.

914 SALVÁ PÉREZ, A. Burgos en las Comunidades de Castilla. Burgos: Hijos de Santiago Rodríguez, 1895. Ver referencias sobre el mismo en El Papa-Moscas. Año XX. № 1.073, 8 de abril de 1897, p. 2.

El citado artículo hace un resumen sobre la sesión plenaria del Ayuntamiento de esa semana donde se discute sobre la subasta y el contrato de forma fraudulenta de la edición de dicho libro, tal como manifiesta el Sr. Arquiaga en contra de los demás ediles. También expresa que la cuenta ascendía a 2.880 pesetas y que la Casa cedió generosamente parte del importe, sin obligación alguna.

${ }^{2}$ SALVÁ PÉREZ, A. Las Cortes de 1392 en Burgos. Burgos: Hijos de Santiago Rodríguez, 1891. 


\subsubsection{Libros sobre burgos ciudad y provincia}

Varias obras de Anselmo Salvá se dedicaron a retratar la fisonomía burgalesa, como son Tipos burgaleses ${ }^{916}$ (1892) y Remembranzas burgalesas (1894). ${ }^{917}$ Fue un escritor, de pluma ágil y estilo directo, que describe las costumbres y los personajes de la ciudad, en las postrimerías del siglo XIX. También desempeñó la función de cronista de la ciudad de Burgos, de archivero municipal y miembro de la Real Academia de la Historia.

Isidro Gil escribe la obra Guía de Burgos y su provincia, de la que da cuenta el periódico El Papa-Moscas en una carta abierta de Ernesto Martínez, escrita desde Bilbao en marzo de 1913. En la misma ensalza la portada realizada por Marcelino Santa María, la policromía del escudo de la ciudad del decorador Arija y a la Casa editora Hijos de Santiago Rodríguez por la exquisita edición, así como por los numerosos dibujos y fotografías de su interior. ${ }^{918}$

Luis de Pablo Ibáñez escribe, en torno a los años 20, una guía titulada Burgos y su provincia: apuntes y notas para el visitante. Es una obra amplia con unas 150 páginas, con un plano de la ciudad y otro a color de la provincia, junto con fotograbados y fotografías de A. Vadillo.

También, de la provincia de Burgos, se publica la $1^{\text {a }}$ edición (1930) de la Nueva guía de Burgos y su provincia, de Pedro Díez Pérez. ${ }^{919}$ Éste, fue profesor auxiliar de la Sección de letras, en la Escuela Normal de Maestros de Burgos, y gran conocedor de la provincia.

Esta obra, también fue publicada por otras editoriales como Aldecoa, en Burgos, en 1927, con un texto refundido y ampliado por Eloy García de Quevedo, y la madrileña Hauser y Menet, en $1944 .{ }^{920}$

\footnotetext{
916 SALVÁ PÉREZ, A. Tipos burgaleses. Burgos: Hijos de Santiago Rodríguez, 1892. Aparece publicidad del mismo en el periódico El Papa-Moscas. Año XV, nº 742, 13 de marzo de 1892, p. 3.

917 SALVÁ PÉREZ, A. Remembranzas burgalesas. Burgos: Hijos de Santiago Rodríguez, 1892. Aparece publicidad en El Papa-Moscas. Año XVII, no 857, 27 de mayo de 1894, p. 2.

918 El Papa-Moscas. Año XXXVI, no 1.869, 30 de marzo de 1913, p. 2.

${ }^{919}$ DÍEZ PÉREZ, P. Nueva guía de Burgos y su provincia. Burgos: Hijos de Santiago Rodríguez, 1930.

${ }^{920}$ De ambas editoriales hay varios ejemplares en las diversas bibliotecas de España y digitalizado en la Biblioteca Digital de Castilla y León.
} 


\subsubsection{Libros para entidades oficiales}

La editorial publicaba documentos oficiales de las distintas secciones del Ayuntamiento: suministro del agua, ${ }^{921}$ estadística municipal, ${ }^{922}$ reglamento de las oficinas del Ayuntamiento, ${ }^{923}$ secretaría, ${ }^{924}$ beneficencia y mendicidad, ${ }^{925}$ impuestos, ${ }^{926}$ juegos florales $^{927}$ y Policía Urbana y Rural. ${ }^{928}$

De Hijos de Santiago Rodríguez se conservan algunos libros relacionados con la educación en Burgos, ${ }^{929}$ las memorias del Instituto provincial $^{930}$ y algunos de los discursos en las Escuelas Municipales, al terminar el curso. ${ }^{931}$

Asimismo, se editaron libros para registrar la contabilidad, la matrícula y la asistencia en las escuelas de primera enseñanza, ${ }^{932}$ así como memorándum para maestros, en los años 1914 y $1916 . .^{933}$

921 AYUNTAMIENTO DE BURGOS. Condiciones reglamentarias establecidas por la expresada compañía para el servicio de suministro de agua. Burgos: Hijos de Santiago Rodríguez, 1894.

AYUNTAMIENTO DE BURGOS. Contestación de la Compañía de Aguas de Burgos a la Memoria que la Comisión designada para el estudio de la municipalización del servicio de aguas. Burgos: Hijos de Santiago Rodríguez, 1930.

922 AYUNTAMIENTO DE BURGOS. Boletín de la Estadística Municipal de la ciudad de Burgos. Burgos: Hijos de Santiago Rodríguez, s/a. De periodicidad mensual, localizamos el $n^{\circ} 4$ (diciembre 1913).

923 AYUNTAMIENTO DE BURGOS. Reglamento para el servicio interior de las oficinas del Ayuntamiento de Burgos. Burgos: Hijos de Santiago Rodríguez, 1914, 50 p. En: AMBu se conserva una publicación de Hijos de Santiago Rodríguez sobre el reglamento para el servicio interior de las oficinas del Ayuntamiento con la sig. AD - 9401/ 22.

924 AMBu. Sigs. AD - 9401 / 4; AD - 9401 / 5; AD - 9401/6; AD - 9401 / 7; AD - 9401 / 8. Son publicaciones de la editorial sobre las memorias anuales de secretaría en los años 1906, 1907, 1908, 1914 y 1915 respectivamente.

925 DÍEZ-MONTERO, B. Consideraciones acerca de la beneficencia y mendicidad en Burgos. Burgos: Hijos de Santiago Rodríguez, 1904.

926 AYUNTAMIENTO DE BURGOS. Supresión del Impuesto de consumos. Burgos: Hijos de Santiago Rodríguez, 1906.

927 ANDRADE, B. M. Discurso leído el 4 de julio de 1902 en los Juegos florales en Burgos. Burgos: Hijos de Santiago Rodríguez, 1902.

928 AYUNTAMIENTO DE BURGOS. Bandos para el buen régimen y gobierno de todo lo concerniente a la Policía Urbana y Rural. Burgos: Hijos de Santiago Rodríguez, 1898.

${ }^{929}$ La publicación más antigua de la editorial que se conserva, de 1876, es el Resumen del estado que ha tenido el Instituto Provincial de $2^{a}$ Enseñanza de Burgos durante el año académico de 1875 a 1876, de 63 páginas, que fue leído por Eusebio Camarero García.

930 INSTITUTO PROVINCIAL DE SEGUNDA ENSEÑANZA DE BURGOS. Memoria acerca del estado del Instituto Provincial de Segunda Enseñanza de Burgos durante el curso escolar de 1891 a 1892. Burgos: Hijos de Santiago Rodríguez, 1892.

También se conservan los de los años: 1893, 1898, 1900, 1901, 1902, 1905, 1907, 1922, 1925.

${ }^{931}$ RUIZ YANGUAS, A. Discurso en la solemne distribución de premios a los niños y niñas de las Escuelas Municipales, el día 2 de julio de 1891. Burgos: Hijos de Santiago Rodríguez, 1891.

También se conservan los correspondientes al año 1897.

${ }^{932}$ HIJOS DE SANTIAGO RODRÍGUEZ. Libro registro de contabilidad y resúmenes de matrícula y asistencia media para uso de las escuelas públicas de primera enseñanza. Burgos: Hijos de Santiago Rodríguez, 1896. 
Otros libros hacen referencia a la educación en España:

- De la instrucción y la educación en España, de las industrias en general y de las clases productoras, de Francisco Ruiz Rubio.

- Una excursión pedagógica a Zaragoza, Barcelona y Valencia: del 27 de abril al 12 de mayo del año II de la República, escrita por maestros burgaleses.

- Males del Régimen en la primera enseñanza: remedios eficaces, debido al inspector de $1^{\mathrm{a}}$ enseñanza Juan Llenera.

- La "Unión Nacional de Maestros", de Hernán de la Puerta.

- El presupuesto de Instrucción pública para 1915. ${ }^{934}$

Igualmente, hallamos diversos libros de la Cámara de Comercio e Industria de Burgos, relacionados con informes de Secretaría o sobre Estatutos de la Asociación de Fomento de Turismo de Burgos, así como del Ateneo de Burgos, y en torno a la Cooperativa de Casas Baratas o acerca del Banco Regulador de Burgos; hay, incluso, ponencias sobre los ferrocarriles en Burgos. ${ }^{935}$

\footnotetext{
${ }^{933}$ GARCÍA ALÍA, J. Memorándum del maestro para 1914. Burgos: Hijos de Santiago Rodríguez, 1913. ${ }^{934}$ RUIZ DE LA PEÑA, F. De la instrucción y la educación en España, de las industrias en general y de las clases productoras. Burgos: Hijos de Santiago Rodríguez, 1907; AA. VV. Una excursión pedagógica a Zaragoza, Barcelona y Valencia: del 27 de abril al 12 de mayo del año II de la República. Burgos: Hijos de Santiago Rodríguez, 1932; LLENERA, Juan. Males del Régimen en la primera enseñanza: remedios eficaces. Burgos: Hijos de Santiago Rodríguez, 1931; PUERTA, Hernán de la. La "Unión Nacional de Maestros" y el presupuesto de Instrucción pública para 1915. Burgos: Hijos de Santiago Rodríguez, 1914.

935 CÁMARA OFICIAL DE COMERCIO E INDUSTRIA DE BURGOS. Algunos de los más importantes informes redactados por la Secretaría de la Cámara Oficial de Comercio e Industria de Burgos, y aprobados por esta corporación durante la vida legal del Pleno que cesó reglamentariamente en 31 de diciembre de 1927. Burgos: Hijos de Santiago Rodríguez, 1928; ASOCIACIÓN DEL FOMENTO DEL TURISMO DE BURGOS. Estatutos. Asociación del Fomento de Turismo de Burgos. Burgos: Hijos de Santiago Rodríguez, 1912; COOPERATIVA DE CASAS BARATAS (AUNÓS). Estatutos de la Cooperativa de Casas Baratas (Aunós). Burgos: Hijos de Santiago Rodríguez, 1929; SOCIEDAD ATENEO DE BURGOS. Reglamento. Burgos: Hijos de Santiago Rodríguez, 1924; AYUNTAMIENTO DE BURGOS. Reglamento para el régimen y gobierno del Banco Regulador de Burgos. Burgos: Hijos de Santiago Rodríguez, 1892; COMISIÓN BURGALESA DE INICIATIVAS FERROVIARIAS. El ferrocarril directo Madrid-Burgos. Burgos: Hijos de Santiago Rodríguez, 1932; CONGRESO NACIONAL DE INGENIERÍA. COMISIÓN BURGALESA DE INICIATIVAS FERROVIARIAS. Los ferrocarriles internacionales y la red peninsular. Burgos: Hijos de Santiago Rodríguez, 1919.
} 


\section{BALANCE DE LA INVESTIGACIÓN Y CONCLUSIONES}

En esta investigación hemos analizado la evolución de una editorial burgalesa Hijos de Santiago Rodríguez, desde sus orígenes hasta la Guerra Civil española. Señalamos los protagonistas principales con los matices, genialidades y aportaciones personales, políticas, culturales y comerciales que configuraron una editorial influyente y destacada.

Todo este legado se plasma en la obra editorial, en los libros y Bibliotecas escolares que estudiamos en un plano formal (materialidad, ilustraciones, tipos de bibliotecas) y de contenido (aspectos pedagógicos, cívicos y morales de los libros escolares y de lectura).

La dispersión y el desconocimiento de la localización de los ejemplares hicieron necesaria una catalogación para poder realizar su estudio. Ésta es una aportación necesaria e imprescindible de nuestra investigación.

La editorial contribuyó a configurar el entramado escolar con diversas metodologías, y un hacer educativo que se prolonga en una extensa época histórico-educativa en España. Señalamos tres periodos distintos, que corresponden a tres directores y momentos evolutivos diferentes:

- De 1850 a 1891, con la fundación y bajo la dirección de Santiago Rodríguez Alonso (1829-1891).

- De 1891 a 1925, dirigida por su hijo Mariano Rodríguez Miguel (1860-1925). Colabora su hermano Francisco (1868-1900). Se constituye como editorial bajo el nombre de Hijos de Santiago Rodríguez.

- De 1925 a 1935, bajo la dirección de Pascual Rodríguez

Escudero (1890-1935), del cual apenas se cuenta con datos biográficos.

De estos periodos apuntamos los hombres más notorios, Santiago y Mariano, que mantienen los siguientes hitos comunes para situar a la empresa en referente editorial:

1. En cuanto a la formación de ambos, comprendemos su interés por propuestas de cambios sociales a través de la educación al señalar sus datos biográficos fundamentales.

$\mathrm{Su}$ fundador, Santiago Rodríguez Alonso, nos descubre en la propia historia personal todo un proceso de cambio personal y social. La pertenencia de sus antepasados a unas élites estamentales de la villa de Isar, en el Antiguo Régimen, y la posible ruptura en la carrera de letrado de su padre con la llegada de la Guerra de la Independencia, nos lleva a situarlo como empleado público en Burgos. De él aprendió, en la sociedad liberal ya instaurada, la importancia de la educación al ofrecer a cada uno de sus hijos una educación diferente, acorde a sus capacidades, constituyendo su única y principal herencia. 
Santiago Rodríguez, una vez acabado el Bachiller de Artes en Burgos, en 1844, completa su formación en Madrid, de 1846 a 1850. Desconocemos las relaciones personales que se fraguaron en estas fechas, en la adquisición de los conocimientos, y las prácticas necesarias para su posterior negocio de librería e impresión.

Su hijo Mariano Rodríguez Miguel, nacido un 8 de diciembre de 1860, crece bajo los aires de La Gloriosa. Estudia en el Instituto Provincial de $2^{\text {a }}$ enseñanza de Burgos y aprende todas las tareas de la librería e imprenta de la mano de su mejor maestro y más cercano padre. Desde muy joven nace su vocación literaria, comienza su actividad escritora, en el periódico Cartas burgalesas, y la desarrolla en su propia empresa con la autoría y publicación de numerosos libros. Su hijo y sucesor, Pascual Rodríguez Escudero, continúa con los proyectos empresariales de su padre.

En todos, de forma autodidacta, fueron incorporando a sus ediciones todas las novedades educativas y pedagógicas de su época, expandiendo su radio de acción de la ciudad burgalesa a la provincia, y dan el salto al resto de las regiones españolas y naciones americanas, llegando a competir con ediciones extranjeras.

2. Sus inquietudes por mejorar y transformar la sociedad liberal les llevó a participar de forma activa en la vida política y social de Burgos, con algunas implicaciones a nivel nacional.

Santiago Rodríguez forma parte de la Corporación municipal como concejal, en los años 1865-66, 1869 -1871 y 1973. Participa en la Junta revolucionaria de Burgos, en fecha inmediata a Revolución de 1868, con propuestas unionistas, de talante más liberal-conservador que en el resto de la Nación.

Durante esta primera legislatura, Santiago Rodríguez Alonso se encarga de las comisiones de Paseos y Arbolado, Abastos y Personajes, junto con el alcalde. Sigue formando parte del Ayuntamiento durante el sexenio revolucionario, con aportaciones más abiertas a las ideas liberales. En este periodo coincide con el tumulto instigado por un sector fanático y ultraconservador del clero burgalés que origina el asesinato del gobernador civil que ejercía también el cargo de presidente de la Diputación Provincial, D. Isidoro Gutiérrez de Castro. Con la llegada de la Restauración de la monarquía borbónica se retira, por desengaños políticos y el fallecimiento de su esposa, en 1874.

Mariano Rodríguez sigue los pasos políticos de su padre presentándose al Consistorio, como independiente, al no fraguar otra candidatura proclamada por la Cámara de Comercio de Burgos. Participa en las legislaturas de 1899-1901 y 1901-1903. Vinculado al sector regeneracionista de Unión Nacional, suscita una controversia en el propio Ayuntamiento donde expresa la necesidad de dar soberanía al pueblo y de 
utilizar el Teatro Principal para dar mítines que sirviesen de propaganda a las ideas de progreso y civilización.

De la comisión de Instrucción Pública se percibe su preocupación por incorporar las nuevas ideas pedagógicas en las escuelas municipales. Intenta promover salidas escolares para conocer todos los aspectos de la vida social y cultural de la ciudad, pero choca con el ala más conservadora que veta sus proposiciones. Acaba su andadura municipal en 1903 y no se presenta en sucesivas elecciones; al igual que su padre decepcionado por el contexto político burgalés.

Al amparo de su padre se mueve en los principales círculos sociales de la incipiente burguesía empresarial burgalesa, perteneciendo a numerosas asociaciones económicas, culturales y sociales de la ciudad. Entre ellas, desempeñó las funciones de secretario de la Cámara de Comercio e Industria de Burgos, tres años después de su constitución, en marzo de 1887. Asiste, como representante por Burgos, a la reunión de la Junta del Círculo de la Unión Mercantil, en Madrid, en 1893, donde expone sus quejas por la falta de tratados de comercio con otros países, por las elevadas tarifas arancelarias, por la ley del Timbre, por la elevación de los cambios en la moneda y por el nuevo proyecto de tarifas para la contribución industrial.

Entra a formar parte en las Juntas Directivas de numerosas asociaciones locales de carácter benéfico dedicadas a la infancia, en asociaciones de tipo cultural y literario. La pertenencia a la Asociación del Turismo de Burgos le permite asistir al Congreso Internacional de Turismo, en Toulouse, como representante de la prensa local.

De forma tardía, Mariano Rodríguez y un grupo de periodistas burgaleses decidieron constituir, al amparo de la Asociación de la Prensa de Madrid, la Asociación de la prensa en Burgos, en 1916. Es elegido presidente hasta su fallecimiento en 1925 . Sus fines se centran en defender y mejorar los intereses, materiales y morales de la prensa periódica burgalesa y la protección de sus asociados, sean directores, redactores, colaboradores, corresponsales o administradores.

Participa y es elegido vicepresidente en el II Congreso Nacional de las Artes del Libro celebrado en Madrid en 1913, lo que nos hace pensar en una implicación mayor en círculos nacionales y extranjeros. Como dato significativo es de señalar el lugar privilegiado que ocupa en la mesa de presidencia por el cincuentenario del periódico El Imparcial.

$\mathrm{Su}$ amplia actividad enriquece y fortalece a la Casa editora al dar a conocer su gran labor editorial y adaptarse a los necesarios cambios para su mayor difusión. 
3. El éxito y desarrollo empresarial se comprende por un ensamblaje de ideas y realidades que se centraron en:

- Las señas de identidad de la editorial expresan y definen las motivaciones profundas, en alusión a la escuela y a los ideales de progreso y civilización, a través de su reconocible lema, La escuela redime y civiliza, completado con el icono de Minerva, diosa de la sabiduría, en clara referencia a la Gloriosa de la que Santiago Rodríguez fue un fiel entusiasta. Estos ideales alcanzan plena vigencia en el final de siglo, con los nuevos aires regeneracionistas que sitúan a la educación como el artífice del cambio social.

- Los orígenes hacen referencia a la Enseñanza. Santiago Rodríguez abre su librería en Burgos, en 1850, en la calle Laín Calvo número 12, en pleno centro urbano, comercial, social y educativo, ya que la mayoría de las escuelas elementales, tanto públicas como privadas, se sitúan en las cercanías. Burgos se convirtió en la capital de la provincia con el nuevo proceso de estructuración administrativa. Contaba con Audiencia y Capitanía General necesitadas de toda clase de materiales para el funcionamiento burocrático.

En sus inicios, para montar la imprenta aprovecha la incipiente industrialización del país, con mayores facilidades para el comercio, y la nueva estructuración de un sistema nacional de educación con la generalización de la instrucción pública. Compra su primera "Minerva" en 1874 y, cinco años más tarde, una nueva máquina tipográfica "modelo Bremer" para lanzarse de lleno a la impresión de todo tipo de documentos y libros escolares. En Burgos imprime numerosos periódicos como $E l$ Sereno, La Brújula, Cartas Burgalesas, El Almanaque de la Ilustración, El Papa-Moscas y El Anunciador Burgalés. La empresa, inaugurada con el nombre de Librería e Imprenta de Santiago Rodríguez se convierte en pionera, en pocos años, y se introduce en los mercados de España e Hispanoamérica con sus ediciones escolares.

El establecimiento comercial proporciona un lugar de encuentro para el Magisterio, al especializarse en textos de $\mathbf{1}^{\mathbf{a}}$ enseñanza, y obtener las últimas y mejores novedades. De esta forma, su librería se convierte en lugar de reunión para tertulias vespertinas de literatos y maestros de la ciudad.

Adquiere la propiedad de La Imparcialidad, periódico que fue el órgano de representación de las Asociaciones de Maestros de la provincia, en el que rezaba el subtítulo Revista de Primera Enseñanza. Al refundirse con otra revista, El Magisterio Burgalés, incluye numerosos trabajos pedagógicos y hace campaña en favor del bienestar moral y material de los maestros. 
Desde este periódico organiza todos los años los Certámenes Pedagógicos donde involucra a distintas asociaciones y a prohombres de la ciudad. Su importancia se ve reflejada por datos aportados en 1890 donde nos informa que atiende a unos 672 suscriptores, con una tirada de 700 ejemplares, y remite por correo unos 33.600 números anuales. Trabajan en el periódico cuatro redactores y dos empleados en la administración.

Mariano Rodríguez continúa como director y propietario del periódico, colabora en la continuidad de la Fiesta de la Enseñanza y premia a profesores y alumnos de las escuelas municipales de la ciudad y provincia. Anteriormente, su padre promovió los Certámenes Pedagógicos con el mismo objetivo.

La nueva empresa editorial, llamada Hijos de Santiago Rodríguez amplía el número de manuales escolares en las diferentes materias, realiza nuevas ediciones, e inicia colecciones de cuentos que genéricamente se apellidan Bibliotecas Rodríguez.

- Medios técnicos e inversión. Toda esta actividad empresarial hizo que en pocos años el local de la imprenta, compartido con la librería en la calle Laín Calvo $\mathrm{n}^{\mathrm{o}}$ 12, -Pasaje de la Flora- se quedase pequeño por lo que se traslada a otro lugar más amplio, sito en la zona del Paseo de los Cubos, en 1887. Compra una nueva Marinoni, de grandes dimensiones, que incorpora los últimos avances técnicos. En esos momentos, su hijo Mariano trabaja y dirige la empresa al mismo nivel que su padre.

Santiago Rodríguez forja una casa editorial pionera que invierte en maquinaria puntera, avalada con préstamos de banqueros burgaleses como Fernández Villa Hermanos. Se relaciona con numerosos libreros e impresores de toda España y realiza sus compras a la empresa madrileña Schomburg Caballero y Cía, que le suministra material especializado en imprenta, litografía y encuadernación. El papel lo obtiene del complejo industrial de la comarca de Tolosa, en Arza y Cía.

Tras la muerte del fundador en 1891, en una parte del inventario se consigna maquinaria de imprenta moderna: una Minerva de 1.000 pts., una Bremer de 6.750 pts. y una Marinoni de 5.000 pts., junto con máquinas para prensar, encuadernar y cortar, y un amplio conjunto de tipos, rayas, galeras, galerines etc., que se iguala con la editorial Hernando.

Mariano Rodríguez ve prioritario, en el sector editorial, el invertir en medios técnicos y locales. Esta necesidad se cubre gracias a la importante aportación económica de su mujer, Luisa Escudero Torres, que le permite trasladarse del local del Paseo de los Cubos a un emplazamiento más cercano y amplio, en la calle General Santocildes. Allí, dispone de un mayor número de máquinas de impresión; cuenta con la Bremer y amplía el número de Marinoni, de 1 a 4, en 1902. Posteriormente, nuevas demandas empresariales le obligan a mudarse a la calle Miranda, $\mathrm{n}^{\mathrm{o}} 11,13$ y 15, 
cuatro años más tarde. En años sucesivos adquiriere nuevas máquinas, con las más modernas innovaciones industriales: la nueva Victoria y una Planeta Tixia. Al no contar con maquinaria litográfica, proyecta, junto a los hermanos Moliner, en 1894, una empresa para la fabricación de naipes que le permite realizar las cubiertas a color de las nuevas Bibliotecas.

- La importancia editora se plasma en los premios obtenidos en diferentes exposiciones. Recibe la medalla de plata en la Exposición Provincial de Burgos, en 1882, medalla de bronce en la Exposición Nacional de Zaragoza, en 1885, y en la Universal de Barcelona, en 1888. Tras el cambio de siglo, sigue obteniendo premios en las distintas Exposiciones: medalla de plata en la Exposición Agrícola Industrial de Burgos, en 1902; un reconocimiento importante en la Exposición pedagógica internacional de Barcelona, en 1905; medalla de oro en la Exposición Internacional de Madrid, en 1907, al igual que en la Exposición Hispano-Francesa de Zaragoza, al año siguiente. La última participación tuvo lugar en la Exposición Universal del Centenario de Argentina, en Buenos Aires (1910), donde alcanza, también, la medalla de oro.

Estos premios están avalados por un crecimiento en la calidad de sus obras y por las estrategias comerciales publicitadas en los principales periódicos, en las contraportadas y últimas páginas de sus propios libros.

- Para la promoción y difusión, de sus obras utiliza los Catálogos, herramienta propagandística que envía, de forma gratuita, al colectivo de maestros, libreros y representantes de la editorial, en diversas ciudades españolas y americanas. Así, da a conocer las ediciones propias, las obras ajenas y la venta de material escolar. La propuesta comercial que distingue su producto enarbola su lema y símbolo, como prestigio de calidad editorial y reconocimiento de su imagen pedagógica.

Se presenta como marca editorial, especializada en libros escolares para la $1^{\mathrm{a}}$ enseñanza, de acuerdo con las orientaciones pedagógicas modernas, señalando que todos los textos son renovados y reformados, con nuevas ediciones puestas al día, frente a otras muchas editoriales que reimprimían obras publicadas anteriormente.

Otro sello inconfundible es la calidad técnica de sus ediciones, con textos de tipos muy claros, acompañadas de artísticas ilustraciones. Se diseña una marca e imagen distintiva, para muchas de las Bibliotecas, realizada por los principales ilustradores que colaboran con la Casa editorial.

Algunas de las estrategias comerciales de venta consisten en incentivar la compra de ejemplares, con la inclusión de papeletas para un sorteo, o descuentos, según el número de ejemplares adquiridos. También utiliza eslóganes para estimular la lectura, con imágenes originales y creativas. 
En el mismo inventario observamos que los precios más bajos, en la venta de libros escolares, los tienen las editoriales Calleja y Santiago Rodríguez Alonso, pues ambas pretenden favorecer el acceso a la cultura de las clases populares.

Sin embargo, Mariano Rodríguez tuvo que enfrentarse a varios problemas en el marco editorial, comunes a todos los editores, como el alto precio del papel, de las materias primas y de la maquinaria necesaria para la fabricación del libro. Tampoco ayudó el proteccionismo arancelario de la economía española, el cambio de moneda, la sobrevaloración de la peseta y la desprotección de la propiedad intelectual en América. Y además, las malas comunicaciones con los grandes centros no favorecieron su difusión. Con tal motivo, intentó mejorarlas con los principales pueblos de la provincia y ciudades próximas, para vender y promocionar sus productos.

En aquellos momentos la protección intelectual era un problema común a todas las editoriales españolas. Por ello, Mariano Rodríguez desde la Cámara de Comercio de Burgos hace llegar una instancia al Ministro de Fomento para pedir el cumplimiento con los países con los que España tenía tratados, extensible a todas las Repúblicas Americanas, al ser el potencial mercado más importante de libros en castellano.

A pesar de todas estas dificultades, se convierte en un ejemplo de la evolución editorial del conjunto del panorama nacional, donde se constatan los nuevos cambios educativos y el nacimiento de una floreciente literatura infantil. Ante esta nueva situación se unen importantes escritores e ilustradores que, por encima de ideas políticas y de pensamiento, hacen posible la creación de libros de una extraordinaria calidad literaria y artística.

El posterior y amplio desarrollo empresarial de postguerra marginó, de alguna manera, la calidad editorial de esta época.

Señaladas las biografías de los principales protagonistas y el recorrido empresarial, nos ocupamos de la producción editorial con el análisis y comentario de las obras editadas. Hemos tenido dificultades en la catalogación de los libros, debido a la gran dispersión de los ejemplares y a la inexistencia de un archivo propio de la editorial. Sus descendientes actuales conservan escasos datos y documentación.

Los libros consultados suponen una fuente de inestimable interés y valor documental. Son la herencia y el legado directo que dejaron los fundadores en cada época. Hemos analizado los aspectos relevantes del autor, ilustrador, contenido, estructura interna y externa, precios $\mathrm{y}$ propaganda editorial. 
Hecho el análisis de los fondos editoriales, de los libros escolares y de sus numerosas Bibliotecas, observamos su importante contribución en la erradicación del analfabetismo al facilitar el acceso a la lectura. La editorial fomenta la cultura literaria, en las franjas de niños y jóvenes de clases medias y bajas, con precios populares. Sorprende en este mismo sentido, el esfuerzo por actualizar la escuela y así mejorar la sociedad española. Sus libros escolares son aprobados como libros de texto en las escuelas y comprobamos la gran contribución a la literatura infantil de su época, con sus 18 Bibliotecas, en poco más de 40 años (1894-1935).

Tras el estudio de las Bibliotecas Rodríguez, una de sus creaciones estelares y más desconocidas, diferenciamos dos etapas bien definidas:

En la primera, desde finales del siglo XIX hasta la segunda década del XX, prima la edición de libros de tipo moralizante con títulos, autores, temática e ilustración, anclada en viejos moldes educativos, con algunas aportaciones novedosas.

Todas las Bibliotecas de esta etapa muestran las mismas características y tienen los mismos autores e ilustradores. Las diferencias formales en la presentación de los libros consisten en la variación del número de cuentos, en cada uno de los tomos, la temática, la encuadernación y la mejora litográfica.

La característica principal es el contenido moral de todas las obras, y se aprecia en todos los Catálogos editoriales al anunciarse estas Bibliotecas para premios, especificando que su lectura es amena de tipo moralizante. Ensalzan principios y modelos morales de la época: caridad, amor a los demás y a las buenas obras, obediencia, perdón, bondad, arrepentimiento, honradez, abnegación etc. Rechazan los vicios como la pereza, el orgullo, la envidia, la avaricia, etc., e impregnan un fuerte sentimiento religioso que amalgama todas las virtudes.

Otra característica singular detectada en estos libros es el protagonismo de niños y niñas, o adolescentes, pues proponen cualidades de superación personal dirigidas a una conversión moral y religiosa, o bien presentan a niños y niñas como prototipos de vicios, para conseguir su rechazo. En todos ellos, se enfatizan los roles propugnados por la sociedad burguesa de la época, donde también aparece la figura principal y enaltecida del maestro, pieza clave en el destino de este tipo de educación.

En sus cuentos se describen situaciones sociales, no para denunciarlas ni con la pretensión de cambiarlas como sucede en la literatura europea. Comenta la vida cotidiana, observada en realidades próximas, con una visión caritativa. 
Los personajes tienen nombre propio, al contrario que los protagonistas de los cuentos populares europeos designados por nombres genéricos o características adquiridas. ${ }^{936}$

Cabe destacar cómo algunos autores aprovechan el contexto geográfico burgalés, con alusiones toponímicas y referencias de lugares históricos, para contextualizar los cuentos. Otros autores invitan a viajar y conocer otros mundos a través de la imaginación.

La editorial selecciona autores muy conocidos de la literatura europea y española junto a otros autores locales, incluyendo a los propios gerentes. Entre los escritores más habituales encontramos a Carlos Frontaura, Manuel Ossorio Bernard, Christoph von Schmid, S.C. López, Juan Benejam Vives, Antonio Álvarez Carretero, Alfonso Pérez Nieva, Ángel Bueno Rodríguez-Arias, Mateo Bustamante, Diego Vidal, Isidro Gil, Agustín Ruiz Yanguas, Luis Villazul, Anselmó Salvá, Ángel Menoyo Portalés, Manuel Galán, Martín Domínguez Berrueta, Estanislao Maestre, Marcos Rafael Blanco-Belmonte, Marciano Zurita, Enrique de Bendito y Trujillo, Hilario Garzón Gutiérrez, Alfredo Garzón Antón, José Campo Moreno, José Osés Larumbe, Mariano Rodríguez Miguel y Francisco Rodríguez Miguel.

Es de destacar su elección literaria en la importante incorporación de mujeres escritoras -casi un tercio del total de autores de las Bibliotecas- que muestran sus inquietudes, sus cualidades literarias. En esta situación, hemos de subrayar que la elección llevaba aparejado enfrentarse a toda una serie de prejuicios, difíciles de superar, al alejarse del rol social de lo que se consideraba femenino. La mayoría de estas escritoras eran maestras o publicaban para periódicos infantiles.

Autoras como Magdalena Santiago Fuentes, su hermana Carmen, Mariana Álvarez Carretero, María Carbonell y Sánchez, Elpidia Rodríguez de Francés, Dolores Gonzalo Morón, Rosa Eguilaz de Parada, Encarnación Hidalgo Rey y Margarita Mayo escribieron uno o varios cuentos en las Bibliotecas. Remarcamos que, para la época, el hecho es muy novedoso al proponer la educación lectora igualitaria de las mujeres, sin hacer distinciones entre lecturas para niños y niñas, y reflejar una imagen de la feminidad fuera del contexto familiar, de la casa y del exclusivo cuidado de los hijos, pudiendo realizarse plenamente en un trabajo determinado por voluntad propia.

Subrayamos cómo la casa editora elige y apuesta por escritores conocedores y en contacto permanente con los niños, ya que la mayoría son maestros/as de escuelas primarias o de Escuelas Normales.

\footnotetext{
${ }^{936}$ En los cuentos tradicionales de Andersen y Perrault define sus nombres por su apariencia: Caperucita Roja, El gato con botas etc. o por cualidades posteriores como Cenicienta, Blancanieves...
} 
Los ilustradores más importantes de esta etapa son los burgaleses Evaristo Barrio, Isidro Gil Gabilondo, Luis Manero y Fortunato Julián. Adaptan similares planteamientos gráfico-estéticos: idealizan la realidad y refuerzan el texto escrito. Las cubiertas son a color, con el interior en negro $\mathrm{u}$ otro color.

Sin embargo, la temática que las Bibliotecas proponen nos muestra afinidades actuales: el cuento que enseña, los relatos de viajes, el amor a la naturaleza, los inventos y los descubrimientos de la ciencia. Cuentos para Niños, Museo de la Infancia, Biblioteca Ideal, Biblioteca Selecta y Biblioteca Oro, son Bibliotecas dedicadas a la presentación de cuentos moralizantes; la Biblioteca Hispano-Americana y Biblioteca Azul y Rosa ofrecen lecturas basadas en leyendas, cuentos y obras de la literatura nacional y europea; y la Biblioteca Pro-Cultura, Mundial Biblioteca y Biblioteca Popular de Medicina e Higiene tienen un carácter divulgativo sobre relatos de viajes, naturaleza, grandes autores de la literatura e históricos, descubrimientos de las ciencias, inventos, salud e higiene.

Se utilizan distintos tipos de encuadernación y técnicas de venta, según el público comprador. La mayoría de los libros se presentan en pasta dura y lomos en tela; los más sencillos en cartulina y con grapas, como la Biblioteca Cuentos para Niños y la Biblioteca Popular de Medicina e Higiene; y otros más lujosos, con lomo y puntas de tela, como la Biblioteca Azul y Rosa, la Biblioteca Enciclopédica Hispano-Americana, o completamente en tela como en la Mundial Biblioteca.

La segunda etapa, iniciada con los últimos años de vida de Mariano Rodríguez y el relevo en su hijo Pascual -segunda y tercera década del siglo $\mathrm{XX}$-, produce ediciones de libros de mayor calidad y belleza, con autores e ilustradores de las nuevas corrientes literarias y de los nuevos movimientos estéticos. Coincide con un cambio radical en la edición española, a la que se suma la casa Hijos de Santiago Rodríguez, con las últimas innovaciones técnico-gráficas. Aparecen nuevas colecciones adaptadas a los más pequeños, de pocas páginas, como Regalo de Reyes, Colección PapaMoscas y Cuentos Nuevos, en colores. Se busca el entretenimiento y se cuidan las historias, donde la ilustración adquiere un papel protagonista. El ejemplo de este cambio lo representa muy bien el ilustrador Pedro Antequera Azpiri que, al combinar los colores, define una novedosa concepción de los libros, con un nuevo lenguaje artístico para un lector moderno. Por su implicación en la causa republicana es relegado al olvido aunque puede igualar en talento a otros ilustradores de libros escolares como Penagos o Bartolozzi.

También se editan unos abecedarios para los más pequeños, ilustrados con cubierta de Pedro Antequera Azpiri y dibujos interiores de Fortunato 
Julián, que aplica los nuevos cánones estéticos para la colección más tardía, Cuentos de Ayer y de Hoy.

La editorial, con el mismo talante innovador y lejos de los estándares de cuentos al uso, publica en un formato original la Biblioteca Paz. En cada uno de los tomos hay una mezcla atrayente que reúne cuentos, leyendas, relatos, fábulas, literatura, geografía, biografías de hombres célebres, descubrimientos, inventos e historietas cómicas de humor realizadas por los mejores dibujantes de la época. Los propios títulos son sugestivos e incitan a la lectura, como Mi Libro de Navidad, Mi Libro de Año Nuevo, Mi Libro de Reyes, Mi Libro de Vacaciones, Mi Libro de Estampas y Cuentos, Mi Libro de Recreo, Mi Libro Bazar y Mi Libro Ideal. De esta manera, implican al niño en su propio proceso lector, no solo como poseedor del libro.

La última, Biblioteca Rodríguez, se presenta como la más selecta, de encomiable calidad destinada a los jóvenes, con autores consagrados en el mundo de la literatura como Manuel Linares Rivas, Sofía Casanova, Emiliano Ramírez Ángel, José Ortega Munilla, M ${ }^{\mathrm{a}}$ Teresa León, Armando Palacio Valdés, Angélica Palma y Carmen Karr. Los títulos de esta Biblioteca son: Los aventureros, Viajes y aventuras de una muñeca española en Rusia, Los tres sorianitos, El pájaro en la nieve y otros cuentos, Cuentos de Pototo, Cuentos para soñar, Contando cuentos y Cuentos a mis nietos.

Estos últimos autores formaron parte, en mayor o menor medida, del regeneracionismo de la cultura española. Entre ellos son significados José Ortíz Pinedo, Rafael Pombo, Pedro Díez Pérez, Ángel Menoyo Portalés, Augusto Riera, Ángel Arbeo, Ángel Martínez Zapater, Vicente M. de Murviedro y Pascual Rodríguez Escudero, hijo de Mariano Rodríguez.

Pero, sin duda, lo más original y destacado se sitúa en la ilustración con Francisco López Rubio, Pedro Antequera Azpiri, Emilio Ferrer, Gutiérrez Larraya, Fortunato Julián, Echea y Rosario de Velasco, autores de prestigio que colaboran con la editorial y promueven una nueva concepción de la ilustración, adaptada a la vanguardia estética e influenciada por el Modernismo. El estilo de figuras alargadas, con una línea precisa y clara, de fuertes contrastes en blancos, negros y rojos, evoluciona hacia una mayor simplicidad, con formas suaves y redondeadas. Estos autores colaboran con las principales publicaciones de la prensa nacional como Vida Nueva, El Sol, Blanco y Negro y Gente Menuda.

Las litografías fueron realizadas en la empresa fundada por Mariano Rodríguez y los hermanos Moliner, al principio. Después ordena los trabajos litográficos a A. Moliner y a la casa litográfica Fournier, en Burgos. Al aumentar la producción editorial busca otras casas litográficas como S. Durá en Valencia, o Mateu y Romillo en Madrid. 
En ambas etapas observamos la utilización de logotipos para muchas de las Bibliotecas, con imágenes que muestran a un niño y a una niña leyendo un libro, en un mismo plano de igualdad. Mantiene una política comercial de precios asequibles, para todos los públicos. Muestra de ello es que cada tomo de la primera Biblioteca, Cuentos para Niños, costaba 10 céntimos de peseta en 1894.

La editorial se involucra en un semanario infantil ilustrado, surgido en 1896 y publicado los domingos. Lleva por título ¿Quieres ser mi amigo?, y tuvo un corto recorrido temporal. Su precio, 10 céntimos de peseta, está pensado para comprarlo suelto o por suscripciones para España, Cuba, Puerto-Rico y Filipinas, y el resto de América. Insiste en su baratura incluyendo la frase "Me venden los domingos, cuando tienes cuartos. Soy agradecido y te divertirá mucho enseñándote”.

Su director Ángel Bueno exhorta a los niños, en el primer número, para que lo compren a fin de disfrutar, aprender y ganar premios con los concursos presentados. Anima a los padres, maestros y jefes de centros industriales para que difundan esta publicación que sirve "al progreso y a la Humanidad". Quizá, la dificultad de los mercados americanos y la situación de crisis en España motivaron su cierre.

Señalamos, como otro de los puntales de nuestro trabajo, el estudio los libros escolares de las diversas materias, siguiendo un itinerario disciplinar. A continuación, presentamos los de mayor éxito y relevancia editorial que responden a las características más notables.

- Lengua. Reedita libros para el aprendizaje de la lectura en la escuela, con numerosos silabarios y catones de autores como Seijas, D. Juan de la Cuesta Hernáiz, D. Antonio de la Iglesia y San Casiano, ya impresas por otras editoriales. Como novedad publica, del burgalés Eduardo A. de Bessón, Método Nuevo y El Primer Libro de la Escuela para aprender a leer. Y de Gerardo Rodríguez García la obra Para aprender a Leer, de primer y segundo grado, organizada siguiendo el método silábico y acompañada de un libro para el maestro, Metodología didáctica de la lectura. Es destacable de este nuevo método de lectura la presentación de numerosas ilustraciones a color acompañando a las palabras, para despertar el interés y mejorar este aprendizaje.

Para reforzar el aprendizaje de la lectura incorpora nuevos textos que llenan un vacío de mercado y edita un gran número de obras: Para mi Hijo y Lecturas Morales, de Mateo Bustamante; Viaje Infantil y Las lecciones del padre, de Mariano Rodríguez Miguel; El previsor: lecturas utilísimas sobre artes, oficios, carreras, etc., de Antonio A. Carretero; La educación por la vista y El ciudadano, de Ángel Bueno Rodríguez-Arias; La Escuela y la Patria, de Magdalena Santiago Fuentes; Cervantes en la escuela, de 
Acisclo Muñiz Vigo; El ideal de una niña, de Anselmo Salvá; Cancionero de la infancia, de Lino González Ansótegui; Mi patria, de Gabino Enciso Villanueva; La Niña: novela feminista, de $\mathrm{M}^{\mathrm{a}}$ Cruz Ebro; Fábulas literarias, de Samaniego, Iriarte, Juan Chave y Castilla; Fábulas castellanas, de Narciso Alonso Cortés; y Amanecer, de Josefina Bolinaga.

En otros apartados de la lengua encontramos un texto de 1893 sobre Ortografía, según las reglas de la RAE, de Anselmo Salvá. En la década de los años 20 se editan Primer curso de Lengua española y Segundo curso de Lengua española, para la enseñanza primaria, dos libros de M. Peñín y Rubio. Próximo a los años 30, se publica Compendio de Gramática castellana, de Herranz y Quirós.

- En Matemáticas observamos que, durante más de 50 años, se imprimen varios manuales de Aritmética, de Clemente Fernández y Jorge García de Medrano, basados en la repetición y memorización de definiciones y reglas, en la escritura de números, cantidades y operaciones. Se parte de conceptos generales para llegar a la aplicación particular con ejemplos. Sin apenas ilustraciones, son libros densos, de difícil comprensión para los niños pero de gran aceptación entre los maestros ya que cuentan con numerosas reediciones.

La edición de libros de Geometría (1911) se produce en momentos de renovación de la enseñanza. El maestro Félix Martí Alpera escribe dos obras: Primeras lecciones de geometría, correspondiente al primer grado, y Nuevas lecciones de geometría, al segundo y tercer grado. En cada lección la palabra clave se escribe en negrita, se explica a partir de ejemplos de la realidad acompañada de dibujos aclaratorios, con una definición final. Añade numerosos ejercicios, algunos con problemas gráficos y dibujos de aplicación junto con otro tipo de problemas denominados como "geometría mental".

- Geografía e Historia. José Osés Larumbe y Anselmo Salvá escriben los manuales escolares de estas materias. Ambos autores utilizan diferentes métodos dependiendo de los destinatarios. En los manuales de primer grado utilizan una metodología de aprendizaje a base de preguntas y respuestas de tipo memorístico y racional. Es un método tradicional, de unánime aceptación entre los maestros de escuelas elementales. Sin embargo, los maestros son resistentes a los nuevos aires pedagógicos, ${ }^{937}$ a pesar de los cambios que se perfilan en el ámbito educativo. En los siguientes grados, el contenido se expresa de forma narrativa, insertando resúmenes, añadiendo pequeñas lecturas

\footnotetext{
${ }^{937}$ Véase el prólogo de la obra: OSÉS LARUMBE, J. Geografía para niños: primer grado. Op. cit., p. 4, nota del autor. “...es lo más antiguo, es lo práctico, lo más fácil y sencillo y lo más racional”.
} 
con láminas de personajes y monumentos, hechos históricos, y un amplio conjunto de mapas.

- Agricultura, Ciencias físicas e Historia Natural. Son libros escritos por dos grandes maestros de $1^{\text {a }}$ enseñanza, Ángel Bueno y Juan Benejam y Vives, conocedores del niño y de la escuela, partidarios de las nuevas ideas pedagógicas europeas. Explican los conceptos, en forma de diálogo entre dos o más niños, o en forma narrativa, eliminando teorías y tecnicismos. Al final de cada apartado se incluye un resumen de los temas tratados, en letra más pequeña. Utiliza letra más grande, y en negrita, para aquellas palabras clave en el aprendizaje del tema. Estos libros contienen numerosas ilustraciones.

- Fisiología y la Higiene. Rogelio Francés y Gutiérrez escribe dos tomos sobre Fisiología e Higiene, separados en grados. Propone un cambio fundamental en la metodología: rechaza el sistema memorístico de preguntas y respuestas; aboga por un sistema de comprensión, a través de una lectura inicial del tema, donde se memoriza lo fundamental; y dispone, en una última parte, la conversación profesor-alumnos ampliable según la asimilación de contenidos. Se editaron otros manuales, entre ellos uno para niñas titulado Resumen de Higiene y Economía Doméstica de Mariana Álvarez Bollo Carretero, en 1890. En el título se vislumbra que es un resumen de la obra de su padre, Principios de Higiene y Economía Doméstica, editada para Escuelas Normales y Colegios Superiores. Además, ambas obras están basadas en el sistema de preguntas y respuestas. Estos dos últimos libros forman parte de la edición fundacional en la Imprenta y Librería de Santiago Rodríguez Alonso.

- Derecho. Mariano Rodríguez es autor y editor de un libro sobre Derecho, poco habitual en la enseñanza primaria. Está escrito en un lenguaje sencillo, en forma de conversaciones, señalando en negrilla las palabras clave de temas como la familia, el municipio, la provincia, la Nación, las Cortes, las leyes, la administración del Estado, la Justicia, el Ejército y la Marina.

- En Historia Sagrada y Religión los autores son los mismos en las diferentes editoriales. La organización y el contenido es idéntico: una primera parte explica el resumen de la doctrina cristiana; una segunda, lecciones sobre dogmas de la fe cristiana, con preguntas y respuestas de memoria; y una tercera referida a la Iglesia. Termina con oraciones, según las horas del día, rosario y letanías. 
- Las enciclopedias, compendios del saber, responden a la idea de organización y graduación de los contenidos de la enseñanza, tratados de forma sistemática. Comienzan a editarse, en la década de los años 30, de la mano de Félix Martí Alpera que incorpora los nuevos recursos pedagógicos y didácticos europeos. Posteriormente, tendrán una amplia aceptación en la educación de posguerra. Tuvo sus antecedentes, al igual que en otras editoriales, con la publicación de la obra Juanito de L.A. Parravicini, traducida por Ángel Bueno como Tesoro Escolar. Escrita en forma de monólogo, va tratando todos los temas escolares; los padres, el maestro y el cura son los modelos a imitar por los niños, siguiendo los roles sociales de la época.

El estudio de las Bibliotecas Rodríguez y de los libros escolares nos ha servido para mostrar la importante aportación educativa. Se ha pretendido abrir una puerta, un punto de partida para organizar todos los acontecimientos relacionados con la editorial y continuar ampliándolo con nuevas investigaciones.

Fuera del marco de investigación, se apuntan otras obras publicadas por la editorial por si fuesen de interés y objeto de estudio. Son de ámbito local y provincial que tratan del conjunto histórico-artístico burgalés. Aunque de menor interés pedagógico, también incluimos un amplio dossier de publicaciones, de carácter oficial, para las distintas entidades y sociedades burgalesas.

Este trabajo, abarca un amplio periodo histórico y educativo que refleja la discontinuidad social y política, acorde con la evolución de la editorial. Santiago Rodríguez a través de sus experiencias y en contacto permanente con el Magisterio inicia una editorial que va cristalizando en un mayor conocimiento y acercamiento a las bases educativas. Su hijo, Mariano Rodríguez consolida esta empresa con una buena inversión en adelantos técnicos y materiales, procedente de la herencia familiar, coincidiendo con la apertura económica, social y educativa, que favorecen las expectativas de una ampliación del negocio editorial. De esta manera, con una mirada innovadora y cercana al regeneracionismo, desecha los viejos anclajes educativos aunque mantiene sus raíces en contacto permanente con maestros y personas relacionadas con la cultura y la educación, siendo fiel al lema "La escuela redime y civiliza". Y todo ello en una ciudad donde los viejos moldes sociales, religiosos y de pensamiento apenas toleran los nuevos aires de modernidad, ilusión y dinamismo para crecer como ciudadanos. Pero a pesar de todo, se forjan los sólidos cimientos del emporio industrial. Quizá, por estas o similares razones, la editorial haya 
sido menos conocida y estudiada, al estar alejada de los principales centros editoriales.

Sin duda, el objetivo básico y primordial de la editorial consiste en proporcionar a los niños las herramientas necesarias para disfrutar leyendo, ofreciendo un libro atractivo, de calidad y del gusto infantil.

Llegados al final de este estudio, descubrimos que los objetivos que planteamos se han conseguido gracias a la extensa búsqueda en todos los archivos burgaleses y la información aportada por las fuentes hemerográficas, el análisis y organización de datos que nos han ayudado a situar los acontecimientos personales y la obra editorial en un contexto histórico-educativo. Sin embargo, a su vez, constatamos que existen vacíos documentales, lo cual dificulta una narración completa para recorrer y conocer toda la génesis editorial.

Proponemos algunas posibles vías de investigación surgidas de esta Tesis:

- Un rastreo en otros archivos nacionales podría aportar un mayor conocimiento para estudiar las relaciones con los movimientos culturales de la época, a nivel nacional e internacional.

- Estudiar las conexiones con otras editoriales coetáneas y poder realizar un análisis comparativo con editores escolares castellanos, como Hernando y Calleja, con los que guarda ciertos paralelismos.

- La continuidad editorial, centrada en la figura de Lucas Rodríguez Escudero e hijo de Mariano Rodríguez que la impulsó a ser una de las más importantes de España, en el período franquista.

- Completar una total catalogación editorial.

- Estudio de los escritores, en las distintas etapas editoriales, y sus conexiones con movimientos culturales de la Nación.

- Evolución, cambios y transformaciones en la ilustración de libros escolares en Hijos de Santiago Rodríguez.

- Correspondencia entre las líneas políticas y educativas, de distintos periodos, en relación con los contenidos de los libros escolares de la editorial.

- Estudio de los materiales escolares que aparecen en los Catálogos de la editorial.

- Aportaciones de la editorial en los proyectos de musealización educativa como CEME, MUPESA, CEINCE, CEMUPE, MUVHE. 


\section{FUENTES DOCUMENTALES Y ELECTRÓNICAS}

\subsection{CENTROS DE DOCUMENTACIÓN: ARCHIVOS Y BIBLIOTECAS}

\subsubsection{Archivos}

\subsubsection{Archivos Estatales}

\subsection{Archivos Históricos \\ Archivo Histórico Provincial de Burgos}

Sección de Protocolos:

Notarios:

José Antonio Calderón. (1752): Caja 7135.

Manuel García Puente (1787-1891): Caja 10015, 10016.

José Merino Vázquez (1827-1834): Caja 7311.

Rafael Pérez Romo (1808-1824): Caja 7254, 7434, 7254, 7255.

Francisco Villamudria (1804-1826): Caja 7327/1, 7327/2.

Agustín de Espinosa (1814-15; 1820-1851): Caja 7345, 7346, 7347, 7349, 7350, 7351/1, 7351/2, 7352, 7353/1, 7353/2, 7354, 7355, 7356, 7357, 7358, 7359, 7360, 7361, 7362, 7363, 7364, 7365, 7366, 7367, 7368, 7369, 7370, 7371, 7372, 7373, 7374, 7375, 7376, 7377, 7378.

Inocencio Moragas (1818-1823): Caja 7422/1, 7422/2, 7422/3, 7422/4, 7422/5, 7422/6, 7424, 7425, 7426, 7427, 7428, 7429.

Manuel Izquierdo (1840-1865): Caja 7600, 7603, 7604, 7605, 7606, 7607, 7608, 7609, 7610, 7611, 7612, 7613, 7614/1, 7614/2, 7615, 7616, 7617, 7618, 7619, 7620, 7621, 7622.

Domingo de Villafranca (1815-1857): Caja 7384, 7392, 7393, 7394, 7395, 7398.

Manuel Monterrubio (1819-1839): Caja 7434, 7435, 7436, 7437/1, 7437/2, 7438, 7439, 7440, 7441, 7442.

Valentín Díaz Güemes (1859-1862): Caja 8276/1, 8276/2, 8277/1, 8277/2. Joaquín Quintana (1884-1902): Caja 8288, 8905, 8906, 8907, 8909, 8911, 8913, 8914, 9902, 10758, 10881, 10930, 10962, 10995, 11047, 11088, 11126, 11174/1, 11229, 11244.

Francisco Saiz Moral (1896-1908): Caja 10997, 11051, 11082, 11124, $11171,11227,11249,11474$. 
Teódulo Santos y Santos (1895-1908): Caja 10964, 11003, 11040, 11086, 11121, 11168, 11224, 11253, 11295, 11332, 11369, 11408, 11448, 11478.

Felipe García (1828-1873): Caja 7478, 7513.

Francisco Bajo (1827-1850): Caja 7452.

Emeterio González (1846- 1859): Caja 7671, 7672, 7673, 7674, 7675, 7676, 7677, 7678, 7679, 7681, 7682, 7683, 7686, 7689, 7691.

Fernando Monterrubio (1860-1895): Caja 7715, 7716, 7717, 7718, 7719, 7721, 7722, 7723, 7725, 7726, 7727, 7730, 7732, 7735, 7737, 7740, 7742, 7813, 7752, 7755, 7758, 7761, 7764, 7767, 7769, 7771, 7777, 7780, 7783/1, 7783/2, 7788, 7794, 7799, 7804, 7808, 8918, 8922, 8925, 8926, 8927, 8928, 8934, 8939, 10754, 10883, 10928, 10956, 10957, 10958.

Tomás Jiménez (1853-1863): Caja 7907/1 y 2, 7908, 7909, 7910, 7911, 7913, 7915, 7917, 7921, 7924, 7931/1, 7933, 7943.

Cayetano García Santos (1849-1880): Caja 7817/1, 7818, 7819, 7820, 7821, 7823, 7833, 7836, 7840/1, 7843/1, 7847, 7852, 7857, 7862, 7867, 7872, 7877, 7882, 7886, 7887, 7889, 7890, 7892, 7894, 7895, 7898, 7899, 7901, 7903, 7905 .

Toribio Díaz y Díaz (1883-1892): Caja 8264, 8268, 8278/1 y 2, 8279, 8282, 8283, 8286, 8287.

Eugenio Arija (1849-1874): Caja 7524/1 y 2, 7525/1, 7526, 7527, 7528, $7529,7530,7531,7532,7533,7534 / 1$ у $2,7535 / 1$ у $2,7536,7537,7538$, $7539,7540 / 1$ y $2,7541,7542 / 1$ y $2,7543,7544,7545,7546,7547,7548 / 1$ y $2,7549,7550,7551,7553,7554,7555$.

Francisco de Paula Alonso Estébanez (1858-1880): Caja 8160, 8161/1 y 2, $8162,8165,8166,8167,8168,8169,8171,8172,8173,8177,8179,8181$, $8183,8185,8188,8191,8195,8197,8200,8202,8205,8208,8213,8217$, $8221,8226$.

José Comerzana (1853-1891): Caja 8013, 8014, 8015, 8016, 8017, 8032, $8034,8036,8037,8039,8041,8054,8055,8059,8063,8067,8070,8880$, 8887, 8889, 8891, 8895, 8899, 8903, 9906, 10882.

Manuel García Celis (1898-1908): Caja 11089, 11127, 11172, 11230, $11246,11480$.

Sección de Enseñanza:

Instituto Literario de Burgos. Signaturas: 593/3 y 593/4.

Colegio San Gil de Burgos. Cursos 1861-1865: Libro de Bachilleres $n^{\circ}$ 370.

Instituto de $2^{\mathrm{a}}$ Enseñanza de Burgos. Libro de matrículas: Signatura: 617/2, $617 / 3$. 


\section{Archivo Histórico Provincial de Segovia}

Sección Protocolos:

Notario:

Pío González García. (1815-1821). Caja 8833, 8835.

\subsection{Archivos Provinciales Municipales}

\section{Archivo de la Diputación Provincial de Burgos}

Catastro del Marqués de la Ensenada. Villa de Isar: Signatura 942, 943.

Libros de Actas de la Diputación Provincial: 1865, 1866, 1867, 1868, 1869, 1870, 1871, 1872, 1873, 1874, 1875, 1876.

\section{Archivo Municipal de Burgos}

Libros de Actas del Ayuntamiento de los años 1865-1874 y 1899-1903.

LA-501, LA-502, LA-503, LA-504, LA-505, LA-506, LA-507, LA-508, LA-509, LA-510, LA-535, LA-536, LA-537, LA-538, LA-539.

Padrones del vecindario:

PA-1 (1859), PA-2 (1859), PA-8 (1869-70), PA-9 (1871), PA-10 (1871), PA-11 (1871), PA-14 (1875), PA-29 (1886), PA- 36 (1890), PA-37 (1890), PA-60 (1892), PA-61 (1892), PA-82 (1894), PA-84 (1894), PA-85 (1894), PA-92 (1896), PA-93 (1896), PA-152 (1905), PA-153 (1905), PA-155 (1905), PA-156 (1905), PA-193 (1909), PA-196 (1911), PA-197 (1911), PA-248 (1915), PA-249 (1915), PA-266 (1917), PA-267 (1917), PA-268 (1917), PA-274 (1917), PA-275 (1917), PA-276 (1917), PA-277 (1917), PA-283 (1924), PA-287 (1924-1925), PA-303 y 312 (1930).

Expedientes consultados y ordenados por fechas:

Cuaderno cobratorio. Año 1820. Signatura C2-7-67.

Censo de población. Año 1821. Signatura 12-265.

Elecciones de alcaldes. Año 1821. Signatura 10-185.

Propietarios y renteros. Año 1821. Signatura C2-3-9/11.

Contribución al derecho de puertas. Año 1821. Signatura C2-5-15/2. 
Relación del $\mathrm{n}^{\circ}$ de habitantes de los distintos barrios de Burgos y $\mathrm{n}^{\mathrm{o}}$ de mozos sorteables para el reemplazo del ejército para el año 1822. Signatura 12-244.

Contribución de patentes. Año 1822: Signatura C2-8-8/4.

Lista de comerciantes en la cuarta clase de industrias para la contribución de patentes. Año 1822: Signatura C2-8/83.

Contribución de patentes. Año 1822-23: Signatura C2-8-8/10.

Administrador derechos de puertas de esta capital D. Santiago de Azuela. Años 1830-31: Signatura 9-567

Arriendo locales. Empresa Derechos de Puertas de Burgos. Año 1831: Signatura 11-404.

Lista de los mayores contribuyentes en el subsidio comercial. Año 1833: Signatura C2-5-9/1.

Lista de individuos de la Milicia Urbana de Burgos. Año 1834: Signatura C-79/19.

Instrucción sobre la contribución del subsidio industrial y de comercio. Año 1835: Signatura C3-2-2/6.

Mayores contribuyentes del año 1836: Signatura C2-8-10/8.

Vecinos de todos los barrios y pueblos de la provincia: Signatura C-74/18.

Listado general de varones de 16 a 54 años. Año 1836: Signatura C-44/11.

Contribución de paja y utensilios. Años 1836-1837: Signatura LI-665.

Lista de los 80 mayores contribuyentes del subsidio industrial y del comercio: Signatura C2-7-12/8.

Relación de casas para alojamientos de jefes y oficiales del Estado. Años 1836-39: Signatura 3-80; 3-19; 3-78; 3-103, 3-78.

Relación de contribuyentes del subsidio de comercio e industria. Año 1837: Signatura C2-9-12/22.

Relación de los contribuyentes que deben pagar en la ciudad la contribución extraordinaria de guerra. Años 1837-38: Signatura C2-9$12 / 18$.

Contribución extraordinaria de guerra y empréstito forzoso. Años 1837-38: Signatura LI-669-1837-1.

Índice de los contribuyentes a la contribución extraordinaria de guerra: Signatura LI-669-1837-2.

Contribución de 1837: Signatura LI-98-3.

Contribución por oficios: Signatura LI-98-5.

Contribución pagos especiales: Signatura LI-98-9.

Contribución extraordinaria de guerra. Años 1837-38: Signatura LI-98-2.

Contribución del subsidio de comercio e industria. Año 1837: Signatura LI98-80.

Borrador del vecindario de 1838: Signatura C-42/2.

Lista de contribuyentes. Año 1839: Signatura 10-60. 
Libro cobratorio de la contribución del subsidio de comercio e industria de 1840: Signatura LI-24; Año 1841: Signatura LI-612 y LI-613.

Relación de los diferentes industriales existentes en Burgos. Año 1842: Signatura 12-266.

Expediente de elecciones a Diputados a Cortes y propuesta de Senadores. Expediente de electores municipales. Año 1864: Signatura 10-35.

Elecciones a Diputados a Cortes y Provinciales. Lista electoral ultimada el 15 de mayo de 1864: Signatura 10-114.

Lista nominal de los mayores contribuyentes que han de componer el jurado en las elecciones de 1865-66: Signatura C-5-b-20.

Lista de electores por contribuyentes para cargos municipales. Año 1868: Signatura 10-193.

Adquisición de nicho en la galería baja del cementerio General Antiguo. Año 1868: Signatura 8-517.

Elecciones a Diputados a Cortes, correspondientes a los días 15, 16, 17 y 18 de enero de 1869: Signatura 10-191.

Actas y listas de electores que han formado parte para la elección de 5 concejales por el $1^{\circ}$ distrito, en los días 7,8 y 9 de diciembre de 1871: Signatura 10-52.

Expediente de Elecciones. Año 1873: Signatura 10-53.

Escrutinio general de Diputados a Cortes en las elecciones verificadas los días 10, 11, 12 y 13 de mayo de 1873: Signatura 10-114.

Permuta del nicho por la hornacina de la misma galería. Año 1874: Signatura 8-264.

Solicitud de Joaquín Pinilla para depositar piedra en el Paseo de la Ronda y petición de varios vecinos, Inocencio Gómez, Santiago Rodríguez, A. Sabater, F. Mendieta, prohibiendo esta actividad. Año 1887: Signatura 2281.

Memoria Anual de la Secretaría. Ejercicio 1906. Hijos de Santiago Rodríguez: Signatura AD-9401/4.

Memoria Anual de la Secretaría. Ejercicio 1907. Hijos de Santiago Rodríguez: Signatura AD-9401/5.

Reglamento provisional del nuevo cementerio. 1907. Hijos de Santiago Rodríguez: Signatura AD-9401/21.

Memoria Anual de la Secretaría: Ejercicio 1908. Hijos de Santiago Rodríguez: Signatura AD-9401/6.

Memoria Anual de la Secretaría. Ejercicio 1914. Hijos de Santiago Rodríguez: Signatura AD-9401/7.

Reglamento para el servicio interior de las oficinas del Ayuntamiento de Burgos. 1914. Hijos de Santiago Rodríguez: Signatura AD -9401/22.

Memoria Anual de la Secretaría. Ejercicio 1915. Hijos de Santiago Rodríguez: Signatura AD-9401/8. 
Himno Escolar "Burgos". Año 1926. Hijos de Santiago Rodríguez: Signatura AD-13451/12.

\section{Archivo Municipal de Isar. Burgos}

Libro de Hacienda de 1760.

Libro de Hacienda de 1794. (Incluye la entrada de nuevos vecinos y las rentas que pasaban a otros por fallecimiento y formaban parte de las fincas del Marqués de la Ensenada).

\subsubsection{Archivos Eclesiásticos}

\section{Archivo Diocesano de Burgos}

Libros de bautizados de la villa de Isar (1719-1896).

Libros de casados de la villa de Isar (1751-1851).

Libros de difuntos de la villa de Isar (1751-1919).

Libros de matrícula de la villa de Isar (1817-1851).

Libros de bautizados de la parroquia de San Gil (1778-1821), (1821-1848), (1849-1864), (1865-1877) y (1878-1891).

Libros de casados de la parroquia de San Gil (1811-1852), (1852-1875) y (1876-1886).

Libros de difuntos de la parroquia de San Gil (1852-1875).

Libros de bautizados de la parroquia de San Lesmes (1785-1835), (18351859), (1859-1876) y (1876-1893).

Libros de casados de la parroquia de San Lesmes (1816-1873) y (18731902).

Libros de difuntos de la parroquia de San Lesmes (1778-1865) y (18661903).

Libros de bautizados de la parroquia de San Lorenzo (1755-1802).

Libros de casados de la parroquia de San Lorenzo (1648-1847).

Libros de difuntos de la parroquia de San Lorenzo (1787-1836), (18361849).

Libros de bautizados de la parroquia de San Lorenzo en Villadiego (18171841).

Libros de difuntos de la parroquia de San Lorenzo en Villadiego (17871814), (1815-1851).

Libros de bautizados de la parroquia de San Nicolás de Burgos (17551851). 


\section{Archivo Diocesano de Segovia}

Libro de bautizados de la parroquia de Santa $\mathrm{M}^{\mathrm{a}}$ la Mayor de Ayllón (Libro $4^{\text {o }}$ de bautismos).

\section{Archivo de la parroquia de San Lesmes de Burgos}

Libros de casados (1902-1914), (1914-1921), (1921-1931) y (1932-1940).

Libros de defunciones (1916-1927) y (1927-1939).

\section{Archivo de la parroquia de San Gil de Burgos}

Libros de defunciones (1875-1889), (1889-1900), (1901-1914), (19141928), (1929-1939) y (1939-1948).

Libros de casados (1904-1917), (1917-1928) y (1928-1936).

\section{Archivo de la parroquia de San Lorenzo de Burgos}

Libros de defunciones (1881-1895).

\subsubsection{Archivos de organismos oficiales}

Fondos documentales de la Cámara de Comercio, Industria de Burgos

Correspondencia y Censo (1890-1910): Caja 517. Libro 1.

Censo electoral de contribuyentes a la Cámara de Comercio de Burgos en el año 1912: Caja 304. Carpeta 2.

Censo electoral de contribuyentes a la Cámara de Comercio de Burgos en el año 1914: Caja 304. Carpeta 3.

Censo electoral de contribuyentes a la Cámara de Comercio de Burgos en los años 1921-22: Caja 304. Carpeta 7.

Libro de Actas de las sesiones de la Cámara de Comercio de Burgos (18871996): Caja 517. Libro 2.

Libro de Actas de las sesiones de la Cámara de Comercio de Burgos (18971906): Caja 513. Libro 1.

Libro de Actas de las sesiones de la Cámara de Comercio de Burgos (19061912): Caja 513. Libro 2.

\subsubsection{Bibliotecas consultadas}

Biblioteca Pública de Burgos. 
Biblioteca Pública de Vitoria.

Biblioteca Pública de Valladolid.

Biblioteca Pública de Pamplona.

Biblioteca de la Diputación Provincial de Burgos.

Biblioteca del Archivo Municipal de Burgos.

Biblioteca Diocesana de Santo Domingo de Silos, Burgos.

Biblioteca Diocesana de San Pedro de Cardeña, Burgos.

Biblioteca del IES, Conde Diego Porcelos de Burgos.

Biblioteca de la Universidad de Burgos.

Biblioteca del Centro Internacional de la Cultura Escolar [CEINCE].

Biblioteca Nacional de España.

\subsection{FUENTES BIBLIOGRÁFICAS ESCRITAS}

\subsubsection{Prensa y publicaciones periódicas}

El Papa-Moscas, Burgos (1879-1895, 1897- 1920).

Diario de Burgos, Burgos (1902-1908).

El Pueblo, Burgos (1918-1921).

Guasa Viva, semanario festivo, Burgos (1913-1914).

La Verdad, Burgos (1893-1894).

La Voz de Castilla, Burgos (1910-1921).

Tierra Hidalga, Burgos (1916-1918).

La Fidelidad castellana, diario tradicionalista, Burgos (1888-1890).

El Heraldo de Castilla, Burgos (1880-1881).

El Noticiero Mercantil, Burgos (1880-1882).

Crónica de Burgos, Burgos (1879-1880).

La Brújula, Burgos (1890-1891).

\subsubsection{Publicaciones escritas de la editorial Hijos de Santiago Rodriguez}

ÁlVAREZ BOLLO CARRETERO, M. La viuda de Naín. Burgos: Hijos de Santiago Rodríguez. Biblioteca Selecta. s/a.

ÁlVAREZ BOLLO CARRETERO, M. Ferrús o el ermitaño del Abrojo. Burgos: Hijos de Santiago Rodríguez. Biblioteca Selecta, s/a.

ÁlVAREZ BOLlo CARRETERO, M. Dos primos célebres. Burgos: Hijos de Santiago Rodríguez. Biblioteca Selecta, s/a. 
ÁlVAREZ BOLLO CARRETERO, M. Resumen de Higiene y Economía doméstica. Burgos: Hijos de Santiago Rodríguez, 1890.

ÁlVAREZ CARRETERO, A. Una venta original. Burgos: Hijos de Santiago Rodríguez. Cuentos para Niños, s/a.

ÁLVAREZ CARRETERO, A. Siempre que puedas haz el bien. Burgos: Hijos de Santiago Rodríguez. Cuentos para Niños, s/a.

ÁlvareZ CARRETERO, A. El previsor. Burgos: Hijos de Santiago Rodríguez, 1896.

ÁlVAREZ CARRETERO, A. Principios de Higiene y Economía domésticas, precedido de unas nociones de fisiología. Burgos: Hijos de Santiago Rodríguez, 1896.

ANÓNIMO. Un amigo. Burgos: Hijos de Santiago Rodríguez. Regalo de Reyes, 1922.

ANÓNIMO. Gasparín. Burgos: Hijos de Santiago Rodríguez. Regalo de Reyes, 1922.

ANÓNIMO. Los tres amigos. Burgos: Hijos de Santiago Rodríguez. Cuentos para Niños, s/a.

ANTEQUERA AZPIRI, P. Patachín Patachán. Burgos: Hijos de Santiago Rodríguez. Colección Papa-Moscas, 1922.

ANTEQUERA AZPIRI, P. Rinconete y Cortadillo. Burgos: Hijos de Santiago Rodríguez. Colección Papa-Moscas, 1922.

ANTEQUERA AZPIRI, P. La larva y el águila. Burgos: Hijos de Santiago Rodríguez. Cuentos Nuevos en colores, s/a.

ART, G.; traducción y adaptación al castellano de la segunda edición francesa por Leoncio Urabayen. Para desarrollar nuestra memoria por la audición, la visión, la idea. Burgos: Hijos de Santiago Rodríguez, 1900.

ASTETE, G.; FLEURY, Cl.; AGUIRRE Y GARCÍA, G. M. Catecismo del arzobispado de Burgos: texto oficial de la Congregación de la Doctrina Cristiana. Burgos: Hijos de Santiago Rodríguez, 1907. 
B. DE A. La Cartuja de Miraflores. Burgos: Hijos de Santiago Rodríguez, 1899.

BENEJAM Y SAURA, J. La manta de lana. Burgos: Hijos de Santiago Rodríguez. Cuentos para Niños, s/a.

BENEJAM Y SAURA, J. El grumete. Burgos: Hijos de Santiago Rodríguez. Cuentos para Niños, s/a.

BENEJAM Y VIVES, J. Páginas sobre Ciencias Físicas y Naturales. Primer grado. Burgos: Hijos de Santiago Rodríguez, 1901.

BERTHOUD, traducido por F. RODRÍGUEZ MIGUEL. El padrenuestro de Fenelón: historia religiosa. Burgos: Hijos de Santiago Rodríguez, 1897.

BETOlAZA Y ESPARTA, G. Parroquia de San Gil de Burgos. Burgos: Hijos de Santiago Rodríguez, 1914.

BLANCO-BELMONTE, M. R. Pompas de Jabón. Burgos: Hijos de Santiago Rodríguez. Biblioteca Mundial, 1913.

BUENO RODRÍGUEZ-ARIAS, A. Moisés. Burgos: Hijos de Santiago Rodríguez. Biblioteca Selecta, 1920.

BUENO RODRÍGUEZ-ARIAS, A. A gran rey, mejor vasallo. Burgos: Hijos de Santiago Rodríguez. Cuentos para Niños, s/a.

BUENO RODRÍGUEZ-ARIAS, A. Emilín. Burgos: Hijos de Santiago Rodríguez. Cuentos para Niños, 1895.

BUENO RODRÍGUEZ-ARIAS, A. El Cristo yacente. Burgos: Hijos de Santiago Rodríguez. Cuentos para Niños, 1895.

BUENO RODRÍGUEZ-ARIAS, A. Felicidad en la buhardilla. Burgos: Hijos de Santiago Rodríguez. Cuentos para Niños, s/a.

BUENO RODRÍGUEZ-ARIAS, A. El divino infante. Burgos: Hijos de Santiago Rodríguez. Biblioteca Selecta, 1900.

BUENO RODRÍGUEZ-ARIAS, A. (coleccionados y traducidos). Cuentos Escogidos. Burgos: Hijos de Santiago Rodríguez. Biblioteca Enciclopédica Hispano-Americana, 1910. 
BUENO RODRÍGUEZ-ARIAS, A. Cuentos mexicanos. Burgos: Hijos de Santiago Rodríguez. Biblioteca Enciclopédica Hispano-Americana, 1905.

BUENO RODRÍGUEZ-ARIAS, A. Rafael. Burgos: Hijos de Santiago Rodríguez. Biblioteca Enciclopédica Hispano-Americana, 1901.

BUENO RODRÍGUEZ-ARIAS, A. Viejas memorias: Leyendas y tradiciones. Burgos: Hijos de Santiago Rodríguez. Biblioteca Enciclopédica Hispano-Americana, 1907.

BUENO RODRÍGUEZ-ARIAS, A. En el campo. Primer grado. Burgos: Hijos de Santiago Rodríguez, 1908.

BUENO RODRÍGUEZ-ARIAS, A. En el campo. Segundo grado. Burgos: Hijos de Santiago Rodríguez, 1908.

BUENO RODRÍGUEZ-ARIAS, A. El ciudadano: lecturas manuscritas. Burgos: Hijos de Santiago Rodríguez, 1900.

BUENO RODRÍGUEZ-ARIAS, A. dir. ¿Quieres ser mi amigo? Semanario infantil ilustrado. Burgos: Hijos de Santiago Rodríguez, 1896.

BUSTAMANTE y JUNQUERA, M. Lecturas morales, coleccionadas para los niños de ambos sexos. Burgos: Hijos de Santiago Rodríguez, 1900.

BUSTAMANTE Y JUNQUERA, M. La hija del desterrado. Burgos: Hijos de Santiago Rodríguez. Cuentos para Niños, 1895.

BUSTAMANTE Y JUNQUERA, M. Para mi hijo. Libro primero de lectura para niñas y niños. $2^{\mathrm{a}}$ edición. Burgos: Hijos de Santiago Rodríguez, 1898.

CAMPO MORENO, J. La corteza. Burgos: Hijos de Santiago Rodríguez. Cuentos para Niños, s/a.

CASANOVA, S. Viaje y aventuras de una muñeca española en Rusia. Burgos: Hijos de Santiago Rodríguez. Biblioteca Rodríguez, 1920.

CARAZO, A. ¿Quiere usted tener un buen embarazo? Burgos: Hijos de Santiago Rodríguez. Biblioteca Popular de Medicina e Higiene, 1918.

CARBONEL Y SÁNCHEZ, M. Las mariposas. Burgos: Hijos de Santiago Rodríguez. Cuentos para Niños, s/a. 
CARRO, S. ¿Quiere usted tener sano el estómago? Burgos: Hijos de Santiago Rodríguez. Biblioteca Popular de Medicina e Higiene, 1917.

CROISSET, P.; compendiadas por Antonio Moral. Festividades de la Iglesia. Burgos: Hijos de Santiago Rodríguez, 1897.

D’ARNEUIL, H. La curiosidad castigada. Burgos: Hijos de Santiago Rodríguez, s/a.

DÍEZ PÉREZ, P. Nueva guía de Burgos y su provincia. Burgos: Hijos de Santiago Rodríguez, 1930.

DOMÍNGUEZ BERRUETA, M. El libro de Historia. Burgos: Hijos de Santiago Rodríguez. Biblioteca Pro-Cultura, 1918.

DOMÍNGUEZ BERRUETA, M. El libro de Literatura. Burgos: Hijos de Santiago Rodríguez. Biblioteca Pro-Cultura, 1917.

DOMÍNGUEZ BERRUETA, M. Historias de D. Quijote. Burgos: Hijos de Santiago Rodríguez. Mundial Biblioteca, 1913.

DOMÍNGUEZ BERRUETA, M. Historias de la Historia. Burgos: Hijos de Santiago Rodríguez. Mundial Biblioteca, s/a.

DOTOR Y MUNICIO, A. (prólogo de Sr. Marceliano Santa María): La Catedral de Burgos: guía histórico-descriptiva. $2^{\mathrm{a}}$ edición. Burgos: Hijos de Santiago Rodríguez, 1928.

DUCREST DE ST-AUBIN, S. F. (Condesa de Genlis). Las veladas de la Quinta. Burgos: Hijos de Santiago Rodríguez. Biblioteca Azul y Rosa, 1916.

EBRO FERNÁNDEZ, M. C. La niña. Burgos: Hijos de Santiago Rodríguez, 1918.

EGUILAZ DE PARADA, R. El abrigo escocés. Burgos: Hijos de Santiago Rodríguez. Cuentos para Niños, s/a.

FERNÁNDEZ, Cl; GARCÍA DE MEDRANO, J. Compendio de aritmética. Burgos: Hijos de Santiago Rodríguez, 1907. 
FERNÁNDEZ, Cl.; GARCÍA DE MEDRANO, J. Nociones generales de aritmética teórico-práctica. Burgos: Hijos de Santiago Rodríguez, 1907.

FLEURY, Cl. Catecismo histórico o Compendio de la historia sagrada y de la doctrina cristiana. Burgos: Hijos de Santiago Rodríguez, 1895.

FOE, D. de. Aventuras de Robinson Crusoe. Burgos: Hijos de Santiago Rodríguez. Biblioteca Enciclopédica Hispano-Americana, 1904.

FRANCÉS Y GUTIÉRREZ, R. Fisiología e Higiene. Primer grado y grado medio. Burgos: Hijos de Santiago Rodríguez, 1906.

FRONTAURA Y VAZQUEZ, C. El abuelo y el nieto. Burgos: Hijos de Santiago Rodríguez. Cuentos para Niños, 1895.

FRONTAURA Y VAZQUEZ, C. Los hijos del Sr. Martín. Burgos: Hijos de Santiago Rodríguez. Cuentos para Niños, 1895.

GALÁN, M.; BUENO, A. El libro de la Naturaleza. Burgos: Hijos de Santiago Rodríguez. Biblioteca Pro-Cultura, 1918.

GARZÓN ANTÓN, A. El pastorcillo. Burgos: Hijos de Santiago Rodríguez. Cuentos para Niños, 1920.

GARZÓN GUTIÉRREZ, H. Amor filial. Burgos: Hijos de Santiago Rodríguez. Cuentos para Niños, s/a.

GARZÓN GUTIÉRREZ, H. El buen hermano. Burgos: Hijos de Santiago Rodríguez. Cuentos para Niños, s/a.

GARZÓN GUTIÉRREZ, H. Enriqueta. Burgos: Hijos de Santiago Rodríguez. Cuentos para Niños, 1920.

GIL GAVILONDO, I. La reina mora. Burgos: Hijos de Santiago Rodríguez. Cuentos para Niños, s/a.

GIL GABILONDO, I. Un genio. Burgos: Hijos de Santiago Rodríguez. Cuentos para Niños, 1895.

GIL MUÑIZ, A. España histórica y artística: (paisajes, tipos y costumbres): lecturas escolares escogidas. Burgos: Hijos de Santiago Rodríguez. Hispania Mater I, 1929. 
GIL MUÑIZ, A. España histórica y artística: (ciudades-museos, monumentos y narraciones heroicas): lecturas escolares escogidas. Burgos: Hijos de Santiago Rodríguez. Hispania Mater III, 1929.

GONZÁLEZ ANSÓTEGUI, L. Cancionero de la infancia: lecturas poéticas escritas para niños y niñas. Burgos: Hijos de Santiago Rodríguez, 1907.

GONZÁLEZ SEIJAS, J.; aumentado y corregido por Victoriano Hernando. Catón metódico de los niños. Burgos: Hijos de Santiago Rodríguez, 1900.

HIDALGO REY, E. La caída de la hoja. Burgos: Hijos de Santiago Rodríguez. Cuentos para Niños, 1900.

HIJOS DE SANTIAGO RODRÍGUEZ. Catálogo ilustrado. Burgos: Hijos de Santiago Rodríguez, 1908.

HIJOS DE SANTIAGO RODRÍGUEZ. Catálogo general ilustrado. Burgos: Hijos de Santiago Rodríguez, 1917.

HIJOS DE SANTIAGO RODRÍGUEZ. Catálogo. Edición publicada con ocasión del LXXV aniversario de la fundación de la casa. 1850-1925. Burgos: Hijos de Santiago Rodríguez, 1925.

HIJOS DE SANTIAGO RODRÍGUEZ. Catálogo general publicado con motivo de la Exposición Iberoamericana en Sevilla y de la Exposición Internacional de Barcelona. Burgos: Hijos de Santiago Rodríguez, 1929.

IZQUIERDO SAIZ, V. El primer vuelo: método para la enseñanza simultánea de la lectura y la escritura, dividido en cuatro partes. Burgos: Hijos de Santiago Rodríguez, 1909.

IRIARTE, T. de. Fábulas literarias. Burgos: Hijos de Santiago Rodríguez, s/a.

KARR ALFONSETTI C. Cuentos a mis nietos. Burgos: Hijos de Santiago Rodríguez. Biblioteca Rodríguez, 1932.

LAMPREAVE COMPAINS, M. Mi sendero: primer manuscrito para niños y niñas. Burgos: Hijos de Santiago Rodríguez, 1931.

LEÓN GOYRI, M. T. Cuentos para soñar. Burgos: Hijos de Santiago Rodríguez. Biblioteca Rodríguez, 1928. 
LEÓN GOYRI, M. T. La bella del mal amor. Burgos: Hijos de Santiago Rodríguez, 1930.

LINARES RIVAS, M. Los aventureros. Burgos: Hijos de Santiago Rodríguez. Biblioteca Rodríguez, 1919.

LÓPEZ, S. C. Aventuras de un huérfano. Burgos: Hijos de Santiago Rodríguez. Biblioteca Oro, s/a.

LÓPEZ DE REGO, J. ¿Quiere usted evitar las infecciones? Burgos: Hijos de Santiago Rodríguez. Biblioteca Popular de Medicina e Higiene, 1917.

MAESTRO, E. La Hija del Usurero. Burgos: Hijos de Santiago Rodríguez. Biblioteca Mundial, 1914.

MALOT, H. Flor de Aventuras. Burgos: Hijos de Santiago Rodríguez. Biblioteca Azul y Rosa, s/a.

MANÍN, J. Mikolán y Cía. Burgos: Hijos de Santiago Rodríguez. Cuentos Nuevos en colores, s/a.

MARTÍ ALPERA, F. Las primeras lecciones de Geometría. Burgos: Hijos de Santiago Rodríguez, 1911.

MARTÍ ALPERA, F. Nuevas Lecciones de Geometría. Burgos: Hijos de Santiago Rodríguez, 1911.

MARTÍ ALPERA, F. Nueva enciclopedia escolar H.S.R.: grado primero. Burgos: Hijos de Santiago Rodríguez, 1930.

MARTÍ ALPERA, F. Nueva enciclopedia escolar H.S.R.: grado segundo. Burgos: Hijos de Santiago Rodríguez, 1931.

MARTÍ ALPERA, F. Nueva enciclopedia escolar H.S.R.: grado tercero. Burgos: Hijos de Santiago Rodríguez, 1935.

MAYO, M. Tradiciones y leyendas de Toledo. Burgos: Hijos de Santiago Rodríguez. Biblioteca Mundial, 1926.

MÉNDEZ DE CUENCA, L.; IRIARTE T. de; SAMANIEGO F. M. Cuentos y fábulas. Burgos: Hijos de Santiago Rodríguez. Biblioteca Ideal, s/a. 
MENOYO PORTALÉS, A. El libro de viajes. Burgos: Hijos de Santiago Rodríguez. Biblioteca Pro-Cultura, 1917.

MENOYO PORTALÉS, A. Historias de Gil Blas. Burgos: Hijos de Santiago Rodríguez. Biblioteca Mundial, 1914.

MORAL, A. Festividades de la Iglesia. Burgos: Imprenta y librería de Santiago Rodríguez Alonso, 1888.

MUT, A. ¿Quiere usted tener sano el corazón? Burgos: Hijos de Santiago Rodríguez. Biblioteca Popular de Medicina e Higiene, 1917.

ORÍO Y RUBIO, M. Epítome de la gramática de la lengua española. 9a edición. Burgos: Hijos de Santiago Rodríguez, 1900.

ORTEGA MUNILLA, J. Los tres sorianitos. Burgos: Hijos de Santiago Rodríguez. Biblioteca Rodríguez, 1921.

OSÉS LARUMBE, J. El mejor tesoro. Burgos: Hijos de Santiago Rodríguez. Biblioteca Oro, s/a.

OSÉS LARUMBE, J. Lo que puede la fe. Burgos: Hijos de Santiago Rodríguez. Cuentos para Niños, s/a.

OSÉS LARUMBE, J. Geografía para niños. Primer grado. Burgos: Hijos de Santiago Rodríguez, 1900.

OSÉS LARUMBE, J. Geografía para niños. Segundo grado. Burgos: Hijos de Santiago Rodríguez, 1890.

OSSORIO Y BERNARD, M. La cuadratura del círculo. Burgos: Hijos de Santiago Rodríguez. Cuentos para Niños, 1895.

OSSORIO BERNARD, M. Presumir de hombre. Burgos: Hijos de Santiago Rodríguez. Cuentos para Niños, 1895.

OSSORIO BERNARD, M. Un héroe infantil. Burgos: Hijos de Santiago Rodríguez. Cuentos para Niños, 1895.

PALACIO VALDÉS, A. El pájaro en la nieve y otros cuentos. Burgos: Hijos de Santiago Rodríguez. Biblioteca Rodríguez, s/a. 
PALMA ROMÁN, A. Contando cuentos. Burgos: Hijos de Santiago Rodríguez. Biblioteca Rodríguez, 1930.

PARRAVICINI, L. A.; corregida y aumentada por Ángel Bueno. Tesoro escolar: obra elemental de educación escrita en italiano con el título de “Juanito”. Burgos: Hijos de Santiago Rodríguez, 1902.

PÉREZ NIEVA, A. La madre pequeñita. Burgos: Hijos de Santiago Rodríguez. Cuentos para Niños, 1895.

PÉREZ NIEVA, A. La tortilla de magia. Burgos: Hijos de Santiago Rodríguez. Cuentos para Niños, 1895.

RAMÍREZ ÁNGEL, E. Cuentos de Pototo. Burgos: Hijos de Santiago Rodríguez. Biblioteca Rodríguez, 1925.

RODRIGUEZ DE FRANCÉS, E. La tiranuela. Burgos: Hijos de Santiago Rodríguez. Cuentos para Niños, 1915.

RODRÍGUEZ GARCÍA, G. Para aprender a leer. Grado primero. Burgos: Hijos de Santiago Rodríguez, 1918.

RODRÍGUEZ GARCÍA, G. Para aprender a leer. Grado segundo. Burgos: Hijos de Santiago Rodríguez, 1925.

RODRÍGUEZ GARCÍA, G. Metodología Didáctica general. Burgos: Hijos de Santiago Rodríguez, 1898.

RODRÍGUEZ MIGUEL, F. Leal. Burgos: Hijos de Santiago Rodríguez. Cuentos para Niños, s/a.

RODRÍGUEZ MIGUEL, F. Trafalgar. Burgos: Hijos de Santiago Rodríguez. Cuentos para Niños, s/a.

RODRÍGUEZ MIGUEL, M. El vendedor de periódicos. Burgos: Hijos de Santiago Rodríguez. Cuentos para Niños, 1894.

RODRÍGUEZ MIGUEL, M. Pedro el avaricioso. Burgos: Hijos de Santiago Rodríguez. Cuentos para Niños, 1894

RODRÍGUEZ MIGUEL, M. Jesucristo sembrando el bien. Burgos: Hijos de Santiago Rodríguez. Biblioteca Selecta, 1920. 
RODRÍGUEZ MIGUEL, M. Alma y corazón. Burgos: Hijos de Santiago Rodríguez. Biblioteca Enciclopédica Hispano-Americana, 1905.

RODRÍGUEZ MIGUEL, M. Los grandes inventos. Burgos: Hijos de Santiago Rodríguez. Biblioteca Enciclopédica Hispano-Americana, 1902.

RODRÍGUEZ MIGUEL, M. Nociones de derecho. Primer grado. Burgos: Hijos de Santiago Rodríguez, 1906.

RODRÍGUEZ MIGUEL, M. Viaje Infantil. Burgos: Hijos de Santiago Rodríguez, 1893.

RODRÍGUEZ MIGUEL, M. Las lecciones del padre: educación moral y cívica. Burgos: Hijos de Santiago Rodríguez, 1905.

RODRÍGUEZ MIGUEL, M. La batalla campal. Burgos: Hijos de Santiago Rodríguez. Cuentos para Niños, s/a.

RODRÍGUEZ-NAVAS, M. Para saberlo todo, para recordarlo todo: enciclopedia del siglo XX. Burgos: Hijos de Santiago Rodríguez, 1911.

RUIZ YANGUAS, A. La venganza de las flores. Burgos: Hijos de Santiago Rodríguez. Cuentos para Niños, 1894.

SALIGNAC DE LA MOTHE [Fenelon], F. de (adaptación por Ángel Bueno Rodríguez). Aventuras de Telémaco. Burgos: Hijos de Santiago Rodríguez. Biblioteca Enciclopédica Hispano-Americana, 1902.

SALVÁ PÉREZ, A. Burgos en las Comunidades de Castilla. Burgos: Hijos de Santiago Rodríguez, 1895.

SALVÁ PÉREZ, A. Las Cortes de 1392 en Burgos. Burgos: Hijos de Santiago Rodríguez, 1891.

SALVÁ PÉREZ, A. Remembranzas burgalesas. Burgos: Hijos de Santiago Rodríguez, 1892.

SALVÁ PÉREZ, A. El Ideal de una Niña. Burgos: Hijos de Santiago Rodríguez, 1898.

SAlVÁ PÉREZ, A. Compendio de Historia de España. Primer grado. Burgos: Hijos de Santiago Rodríguez, 1910. 
SALVÁ PÉREZ, A. Compendio de Historia de España. Segundo grado y grado superior. Burgos: Hijos de Santiago Rodríguez, 1927.

SALVÁ PÉREZ, A. Compendio de ortografía castellana, según las reglas de la Real Academia Española. Burgos: Hijos de Santiago Rodríguez, 1893.

SALVÁ PÉREZ, A. Educación indirecta: ligeros apuntes. Burgos: Hijos de Santiago Rodríguez, 1898.

SALVÁ PÉREZ, A. Tipos burgaleses. Burgos: Hijos de Santiago Rodríguez, 1892.

SALVÁ PÉREZ, A. La suerte. Burgos: Hijos de Santiago Rodríguez, Cuentos para Niños, 1895.

SAMANIEGO, F. M. Fábulas en verso castellano. Burgos: Hijos de Santiago Rodríguez, s/a.

SANTIAGO FUENTES, C. Casa de muñecas. Burgos: Hijos de Santiago Rodríguez. Biblioteca Oro, s/a.

SANTIAGO FUENTES, M. El capricho de Susú. Burgos: Hijos de Santiago Rodríguez. Cuentos para Niños, [ca. 1915].

SANTIAGO FUENTES, M. La noche de Reyes. Burgos: Hijos de Santiago Rodríguez. Cuentos para Niños, s/a.

SANTIAGO FUENTES, M. La estrella de mar. Burgos: Hijos de Santiago Rodríguez. Cuentos para Niños, s/a.

SCHMIDT, S. Cristina y su corderito. Burgos: Hijos de Santiago Rodríguez. Biblioteca Oro, 1920.

SERRANO, L. [O.S.B.], abad de Silos: El Real Monasterio de Santo Domingo de Silos (Burgos): su historia y tesoro artístico. Burgos: Hijos de Santiago Rodríguez, 1920.

TAMAYO, B. ¿Quiere usted vivir muchos años?, lo que para conseguirlo debe hacerse. Burgos: Hijos de Santiago Rodríguez. Biblioteca Popular de Medicina e Higiene, 1914. 
TARÍN Y JUANEDA, F. La Real Cartuja de Miraflores: su historia y descripción. $1^{\text {a }}$ edición. Burgos: Hijos de Santiago Rodríguez, 1896.

URRACA A. REYERO, C. ¿Quiere usted conservar la vista? Burgos: Hijos de Santiago Rodríguez. Biblioteca Popular de Medicina e Higiene, 1914.

VIDAL, D. El nido y la choza. Burgos: Hijos de Santiago Rodríguez. Cuentos para Niños, 1895.

VV. AA. La tiranuela. Burgos: Hijos de Santiago Rodríguez. Museo de la Infancia, 1915.

VV. AA. Al borde del abismo. Burgos: Hijos de Santiago Rodríguez. Museo de la Infancia, 1906.

VV. AA. La cuenta del doctor. Burgos: Hijos de Santiago Rodríguez. Biblioteca Ideal, 1920.

VV. AA. El músico callejero. Burgos: Hijos de Santiago Rodríguez. Biblioteca Ideal, s/a.

VV. AA. La serpiente. Burgos: Hijos de Santiago Rodríguez. Biblioteca Ideal, s/a.

VV. AA. El niño en la tumba. Burgos: Hijos de Santiago Rodríguez. Biblioteca Ideal, s/a.

VV. AA. El cojito. Burgos: Hijos de Santiago Rodríguez. Biblioteca Ideal, s/a.

VV. AA. La hija del desterrado. Burgos: Hijos de Santiago Rodríguez. Biblioteca Ideal, 1919.

VV. AA. El mejor tesoro. Burgos: Hijos de Santiago Rodríguez. Biblioteca Oro, s/a.

VV. AA. ¿Quieres ser mi amigo? Burgos: Hijos de Santiago Rodríguez. Biblioteca Oro, s/a.

VV. AA. Mi libro de estampas y cuentos. Burgos: Hijos de Santiago Rodríguez. Biblioteca Paz, s/a. 
VV. AA. Mi libro bazar. Burgos: Hijos de Santiago Rodríguez. Biblioteca Paz, 1929.

VV. AA. Mi libro de Recreo. Burgos: Hijos de Santiago Rodríguez. Biblioteca Paz, 1926.

VV. AA. Mi libro de Año Nuevo. Burgos: Hijos de Santiago Rodríguez. Biblioteca Paz, 1920.

VV. AA. Mi libro de Reyes. Burgos: Hijos de Santiago Rodríguez. Biblioteca Paz, 1922.

VV.AA. Mi libro Ideal. Burgos: Hijos de Santiago Rodríguez. Biblioteca Paz, 1930.

VV. AA. Lee estos cuentos. Burgos: Hijos de Santiago Rodríguez. Cuentos de Ayer y de Hoy, s/a.

VV.AA.: Catedral de Burgos: séptimo centenario de su fundación, 1221. Burgos: Hijos de Santiago Rodríguez, 1921, edición limitada.

ZURITA, M. Historias de Zorrilla. Burgos: Hijos de Santiago Rodríguez. Biblioteca Mundial, 1914. 
LA EDITORIAL BURGALESA HIJOS DE SANTIAGO RODRÍGUEZ (1891-1936):

ANÁLISIS DE LOS LIBROS ESCOLARES

\subsection{FUENTES GRÁFICAS}

Las principales fuentes donde se obtuvieron todas las imágenes reproducidas en esta Tesis Doctoral se han extraído de:

- Del Archivo Municipal de Burgos en su sección gráfica.

- De los propios libros de la editorial.

- De los documentos, láminas y reproducciones aportadas por miembros de la familia de D. Santiago Rodríguez: Mercedes y Lucas Rodríguez Plaza. 


\subsection{FUENTES ELECTRÓNICAS}

ALONSO MARAÑ́́N, P. M. Notas sobre la Higiene como materia de enseñanza oficial en el siglo XIX [en línea]. Universidad de Salamanca: Revista Interuniversitaria, 6, 1987 [fecha de consulta 2-3-2013]. Disponible en: $\quad$ http://campus.usal.es/ revistas trabajo/index.php/02120267/article/viewFile/6734/6724

ARIZKUM CELA, A. La especialización industrial de Navarra en los orígenes de la industrialización, 1850-1936 [en línea]. Universidad Pública de Navarra [fecha de consulta 10-5-2013]. Disponible en: http://www.econ.unavarra.es/ arizkun/webs/hojaper/ESPNAV.html

ASENSIO GONZÁLEZ, R. La Estudiantina de la Escuela Superior de Maestras de La Laguna (Tenerife): 1921-1929. Estudio histórico y consideraciones [en línea]. TUNAE MUNDI. 2013 [fecha de consulta 1910-2014].

Disponible

en: http://tunaemundi.com/index.php/component/content/article/7-tunaemundicat/252-la-estudiantina-de-la-escuela-superior-de-maestras-de-la-lagunatenerife-1921-1929-estudio-historico-y-consideraciones

BADANELLI RUBIO, A.; OSSENBACH SAUTER, G. Hacer historia en la era digital: nuevas formas de acceso a las fuentes y de conservación del patrimonio histórico-educativo [en línea]. UNED [fecha de consulta 15-42013].

Disponible

en: http://dialnet.unirioja.es/descarga/articulo/2964256.pdf

BESSÓN, E. A. de. Método nuevo para aprender a leer en las escuelas de niños y de adultos [en línea]. $5^{\mathrm{a}}$ ed. Burgos: Imprenta y librería de Santiago Rodríguez Alonso, 1887, 63 p. [fecha de consulta 15-10-2013]. Disponible en:

http://www.sinabi.go.cr/biblioteca\%20digital/bibliografia/bibliografias/bib \%20libros\%20y\%20lectura\%20ii.pdf

BIBLIOTECA DIGITAL DE CASTILLA Y LEÓN [en línea]. Bibliotecas de Castilla y León [fecha de consulta 21-2-2013]. Disponible en: https://bibliotecadigital.jcyl.es/i18n/estaticos/contenido.cmd?pagina=estatic os/inicio.

BIBLIOTECA DIGITAL HISPÁNICA [en línea]. Biblioteca Nacional de España [fecha de consulta 12-2-2013]. Disponible en: 
http://www.bne.es/es/Catalogos/BibliotecaDigitalHispanica/Inicio/index.ht $\underline{\mathrm{ml}}$.

BIBLIOTECA NACIONAL "MIGUEL OBREGÓN LIZANO” [en línea]. Ministerio de Cultura, Juventud y Deportes. Sistema Nacional de Bibliotecas. San José. Costa Rica, 2008 [fecha de consulta 20-3-2013]. Disponible en: http://www.sinabi.go.cr/biblioteca\%20digital/bibliografia/bibliografias/bib \%20libros\%20y\%20lectura\%20ii.pdf

CATÁLOGO COLECTIVO DEL PATRIMONIO BIBLIOGRÁFICO [en línea]. Ministerio de Educación, Cultura y Deporte [fecha de consulta 15-12013]. Disponible en: http://gl.www.mcu.es/bibliotecas/MC/CCPB/

CENTRO DE DOCUMENTACIÓN DE LA CULTURA VASCA. Catálogo [en línea]. Vitoria: Fundación Sancho el Sabio [fecha de consulta 25-5-2013]. Disponible en: http://catalogo.fsancho-sabio.es

CENTRO DE ESTUDIOS SOBRE LA MEMORIA EDUCATIVA (CEME). Exposición conmemorativa Félix Martí Alpera (1875-1946). Un maestro y la escuela de su tiempo. [en línea]. Universidad de Murcia, 2010 [fecha de consulta 20 mayo 2014]. Disponible en: http://www.um.es/muvhe/felixmartialpera/

CRUZ QUINTÁS, J. M. "Algunos episodios biográficos de José Ortiz de Pinedo. Un escritor jaenés en el Madrid de la primera mitad del siglo XX". Elucidario: Semanario bio-bibliográfico Manuel Caballero Venzalá, 2007, [fecha de consulta: 15-1-2013]. Ver: dialnet.unirioja.es/descarga/articulo/2523266.pdf

FABRI, A. Estudio de la cultura femenina según Carmen Karr, dentro del catolicismo social de principios del siglo XX [en línea]. Barcelona: Facultad de Teología de Cataluña, Revista Catalana de Teología, 30, 2005. Disponible en: http://www.raco.cat/index.php/RevistaTeología/article/view

FERNÁNDEZ DE CANO, J. R. Álvarez Bollo Carretero, Mariana (1866-) [en línea]. La web de las biografías [fecha de consulta 17-9-2014]. Disponible en: http://www.mcnbiografias.com/appbio/do/show?key=carbonell-y-sanchez-maria

FERNÁNDEZ DE CANO, J. R. Carbonell y Sánchez, María (ss. XIX-XX) [en línea]. La web de las biografía [fecha de consulta 17-9-2014]. 
Disponible

en:

http://www.mcnbiografias.com/appbio/do/show?key=carbonell-y-sanchez-maria

Francisco López Rubio. Maestro de la línea clara [en línea]. Museo ABC. Madrid: 4 dic de 2012 a 20 de enero 2013 [fecha de consulta 18-8-2014]. Disponible en: http://museo.abc.es/exposicion.php?lang=es\&id=178

El dibujo de un maestro de la línea clara. Francisco López Rubio [en línea]. Granada: Centro de Exposiciones CajaGRANADA. Puerta Real. Del 24 de enero al 30 de marzo de 2014 [fecha de consulta 18-8-2014]. Disponible en: http://www.hoyesarte.com/evento/2014/01/maestro-de-lalinea-clara/

GARCÍA AVELLO, R. La sinfonía pastoral de Beethoven como fuente de inspiración literaria [en línea]. Entralgo, Laviana: Centro de Interpretación Armando Palacio Valdés [fecha de consulta 30-4-2013]. Disponible en: http://www.palaciovaldes.com/detalleEstudios.

GÓMEZ-FERRER MORANT, G. Teoría, práctica y técnicas narrativas en la obra de Armando Palacio Valdés [en línea]. Alicante: Biblioteca Virtual Miguel de Cervantes, 2009 [fecha de consulta 30-4-2013]. Disponible en: http://www.palaciovaldes.com/documentos p. 178

INSTITUTO PROVINCIAL DE SEGUNDA ENSEÑANZA "PRÁXEDES MATEO SAGASTA". Apuntes para la Historia. Personas y personajes [en línea]. Logroño [fecha de consulta 5-5-2013]. Disponible en: www.iessagasta.edurioja.org/elsagasta/archivo/personas_v.htm\#roca.

La norma ISO 690: 2010(E). Biblioteca de la Universidad de Alicante [en línea] [fecha de consulta 14-9-2013]. Disponible en: http://rua.ua.es/dspace/bitstream/10045/33984/1/Norma_ISO_Doctorado.p $\underline{\mathrm{df}}$

LERTXUNDI GALIANA, M. Retratos sobre la prisión. Pedro Antequera Azpiri y David Álvarez Flores [en línea]. San Sebastián: Koldo Mitxelena Kulturanea [fecha de consulta 14-4-2013]. Disponible en: https://kmk.gipuzkoakultura.net.

LINÉS ESCARDÓ, A. La matemática en La Rioja en el primer tercio del siglo XX y años de su entorno [en línea]. Comunicación impartida el 1 de noviembre de 1996 en el IER en III Simposio Julio Rey Pastor [fecha de consulta 15 mayo 2014].

Disponible en: http://dialnet.unirioja.es/descarga/articulo/110371.pdf. 
MARTÍNEZ RUS, A. Barcelona y Madrid ante el reto americano: Las expectativas de la industria del libro [en línea]. Universidad Complutense de Madrid [fecha de consulta 18-5-2013]. Disponible en: https://www.ucm.es/hcontemporanea/ana-martinez-rus

ONLINE COMPUTER LIBRARY CENTER [en línea]. The World's Largest Library Catalog [fecha de consulta 10-3-2013]. Disponible en: https://www.worldcat.org/.

PITARCH, D. Carmen Karr [en línea]. Asociación de escritores en lengua catalana [fecha de consulta 25-8-2014]. Disponible en: http://www.escriptors.cat/autors/karrc/pagina.php?id_sec=1631

REBIUM [en línea]. RED DE BIBLIOTECAS UNIVERSITARIAS [fecha de consulta 30-2-2013]. Disponible en: http://www.rebiun.org/Paginas/Inicio.aspx.

RUBIO CREMADES, E. Del montón. Retratos de sujetos que se ven en todas partes de Manuel Matoses. [en línea]. Universidad de Alicante. [fecha de consulta 20-5-1913]. Disponible en: http://dfelg.ua.es/romanticismo_espa\%C3\%B1ol_e_hispanoamericano/artic ulos/enrique/del_monton.pdf

SIRVENT de LUCA, M. P.. Angélica Palma: su vida y su obra (18781935) [en línea]. Madrid, Universidad Complutense de Madrid, 2012 [fecha de consulta 3-5-2013]. Disponible en: http://eprints.ucm.es/15286/

VILAFRANCA MANGUÁN, I. Joan Benejam Vives (1846-1922): Un mestre menorquí a l'avantguarda pedagógica. Revista Catalana de Pedagogía, vol. 1, 2002, pp. 313-340. Disponible en: http://www.raco.cat/index.php/RevistaPedagogia/article/view/212297/2824 $\underline{88}$ 


\subsection{BIBLIOGRAFÍA GENERAL}

ABELLÁN, J. L. Historia crítica del pensamiento español: de la gran guerra a la guerra civil española (1914-1939). Madrid: Espasa Calpe, 1991, tomo 5/III.

AGUILAR, M. Una experiencia editorial. Madrid: Aguilar, 1973.

ALCARAZ ABELLÁN, J.; RODRÍGUEZ MARRERO, H. Los perfiles de texto y la enseñanza de la historia (1857-1936). En: VII Symposium. Didáctica de las ciencias sociales. La investigación. Las Palmas: Centro Superior de Formación del Profesorado. Universidad de Las Palmas de Gran Canaria, 1995, pp. 391-400.

ALONSO CASTRO, M. P. Santiago Rodríguez Alonso: Perfil de un impresor con proyección editorial. Universidad de Burgos, [trabajo inédito para la obtención del Diploma de Estudios Avanzados], Departamento de Ciencias de la Educación de la Universidad de Burgos, 2004. [Ejemplar policopiado].

ÁLVAREZ DE ESCOSURA, S. Elementos de Aritmética. Madrid: Sucesores de Hernando, 1914.

ÁLVARO ESTRANCIANA, J. L.; MONGE LANZAS, I. La familia en los libros de texto de lectura infantil. Revista de Educación, 1984, 275, pp.7391.

ANELE. El Libro y la Escuela. Libro conmemorativo de la exposición. Biblioteca Nacional. Madrid: Asociación Nacional de Editores de Libros y Material de Enseñanza, 1992.

ARANGO GONZÁLEZ, M. P. Aspectos iconográficos de la prensa infantil española (1833-1923). Cuadernos de arte e iconografía, 1989, 4, pp. 234241.

ARNAU LOMBARTE, F. Cien años de evolución didáctica de una editorial: Los libros de Historia de España de Hijos de Santiago Rodríguez. de Burgos. Barcelona: Universidad de Barcelona, Tesis doctorales, Microficha 1060, 1991. 
AROSTEGUI, J. La investigación histórica: Teoría y método. Barcelona: Crítica, 1995.

ARNAUD, M. La mitología clásica. Madrid: Acento, 1996.

ATANASIO XARAMILlO, G. Guía o estado general de la Real Hacienda de España. Madrid: Imprenta de la Compañía, 1816.

BADANELLI RUBIO, A. M. Aproximación a un método de lectura e interpretación de imágenes en los manuales escolares. En: Etnohistoria de la escuela. XII Coloquio Nacional de Historia de la Educación. Burgos: [SEDHE]. Universidad de Burgos, 2003, pp. 333-342.

BATANAZ, L. La educación española en la crisis de fin de siglo. Los congresos pedagógicos. Córdoba: Diputación provincial, 1982.

BARRERA, C., ed. El periodismo español en su historia. Barcelona: Ariel, 2000.

BARTOLOMÉ MARTÍNEZ, B. Otras fuentes para la investigación histórico-pedagógica emanadas en espacios eclesiásticos desde la educación formal y no formal. En: J. RUIZ BERRIO, ed. La cultura escolar en Europa. Tendencias históricas emergentes. Madrid: Biblioteca Nueva, 2000, pp. 205-209.

BARTOLOMÉ MARTÍNEZ, B. Las bibliotecas públicas y la lectura. En: A. ESCOLANO, dir. Leer y escribir en España. Doscientos años de alfabetización. Madrid: Fundación Germán Sánchez Ruipérez, 1992, pp. 309-334.

BELTRÁN, F. El libro y la imprenta. Madrid: Librería Española y Extranjera, 1931.

BELLO, L. Viaje por las escuelas de Castilla y León. Valladolid: Ámbito, 1995.

BEST, J. W. Cómo investigar en educación. Madrid: Morata, 1972.

BRAVO VILLASANTE, C. Historia de la literatura infantil española. Madrid: Escuela Española D.L., 1985.

BRAVO-VILLASANTE, C. Ensayos de literatura infantil. Murcia: Universidad de Murcia, Secretariado de Publicaciones, 1989. 
BIZQUERRA, R. Métodos de investigación educativa. Barcelona: CEAC, 1989.

BOTREL, J.-F. Libros, prensa y lectura en la España del siglo XIX. Madrid: Fundación Germán Sánchez Ruipérez, 1993.

BUNGE, M. La investigación científica. Su estrategia y su filosofía. Barcelona: Ariel, 1976.

BURKE, P. (ed.). Formas de hacer Historia. Madrid: Alianza, 1993.

CALLEJA. S. Geometría plana y del espacio. Madrid: Calleja, 1917.

CANES, F. Sobre las características externas de los libros de texto escolares de finales del siglo XIX y comienzos del XX. En: El curriculum: historia de una mediación social y cultural. Granada: ICE Universidad de Granada, 1996, pp. 257- 264.

CANGA ARGÜELLES, J. y B. La Gazeta de los niños. Madrid: Librería de Sancha, 1798.

CAPEL SÁEZ, H.; SOLÉ MASIP, J.; URTEAGA, L. El libro de geografía en España, 1880-1939. Madrid: CSIC, 1988.

CAPITÁN DÍAZ, A. La educación en la Primera República Española. 1873. Valencia: Nau Llibres, 1982.

CAPITÁN DÍAZ, A. La educación en la España contemporánea. Barcelona: Ariel, 2000.

CARBONERO DOMINGO, J. Libros de una Edad de Plata (1910-1936). Valladolid: Junta de Castilla y León y Ayuntamiento de Valladolid, 2002.

CARDOSO, C. F. S. Introducción al trabajo de investigación histórica: Conocimiento, método e historia. Barcelona: Crítica, 1971.

CARRERAS PANCHÓN, A., coord. Guía para la elaboración de un trabajo científico. Bilbao: Cita, Publicaciones y Documentación, 1994.

CARRIÓN, M. Manual de Bibliotecas. Madrid: Fundación Germán Sánchez Ruipérez, 1993. 
CENDÁN PAZOS, F. Edición y comercio del libro español (1900-1972). Madrid: Editora Nacional, 1972.

CONGRESO CATÓLICO ESPAÑOL. Crónica del V Congreso Católico Español. Burgos: Imp. y Estereotipia de Polo, 1899.

COLOMER, T. Una literatura infantil y juvenil de calidad: el proyecto de un siglo. Boletín de la Institución Libre de Enseñanza. 2001, 42-43, pp. 131-152.

CÓRTAZAR, D. y J. Tratado de Aritmética. Madrid: Imprenta de Hernando, 1879.

CUESTA ESCUDERO, P. La escuela en la reestructuración de la sociedad española (1900-1923). Madrid: Siglo XXI, 1994.

CHARTIER, A. M.; HEBRARD, J. Discursos sobre la lectura (18801980). Barcelona: Gedisa, 1995.

CHARTIER, A. M.; HEBRARD, J. El libro como representación. Barcelona: Gedisa, 1992.

CHIVELET VILLARRUEL, M. La prensa infantil en España: desde el siglo XVIII hasta nuestros días. Madrid: Fundación SM, 2009, 365 p.

CHOPPIN, A.: Pasado y presente de los manuales escolares. En: J. RUIZ BERRIO, ed. La cultura escolar en Europa. Tendencias históricas emergentes. Madrid: Biblioteca Nueva, 2000, pp. 107-165.

DESVOIS, J. M. La prensa en España. Madrid: Siglo XXI de España Editores, 1977.

DÍAZ PLAJA, A. Historia del libro y de la imprenta. Barcelona: Teide, 1971.

DÍAZ PLAJA, A. El libro ayer, hoy y mañana. Barcelona: Salvat, 1974.

DURÁN Y SAMPERE, A. Centenario de la librería Bastinos 1852-1952. Editores y libreros de Barcelona. Barcelona: José Boch librero, 1952.

ECO, U. Cómo se hace una tesis. Técnicas y procedimientos de investigación, estudio y escritura. Barcelona: Gedisa, 1982. 
ESCOLANO BENITO, A. La investigación en Historia de la Educación en España. Tradiciones y nuevas tendencias. Revista de Ciencias de la Educación. 1993, 155, pp. 321-349.

ESCOLANO BENITO, A., dir. Historia de la Educación. Diccionario Anaya de Ciencias de la Educación. Madrid: Anaya, 1984-85, t. I.

ESCOLANO BENITO, A. La educación en la España contemporánea. Políticas educativas, escolarización y culturas pedagógicas. Madrid: Biblioteca Nueva, 2002.

ESCOLANO BENITO, A., dir. Leer y escribir. Doscientos años de alfabetización. Madrid: Fundación Germán Sánchez Ruipérez, 1992.

ESCOLANO BENITO, A., dir. Historia de la Educación. La educación contemporánea. Madrid: Diccionario, Anaya, 1985.

ESCOLANO BENITO, A., dir. Historia ilustrada del libro español. De los incunables al siglo XVIII. Madrid: Fundación Germán Sánchez Ruipérez, 1994.

ESCOLANO BENITO, A., dir. Historia ilustrada del libro español. De la posguerra a la reforma educativa. Madrid: Fundación Germán Sánchez Ruipérez, 1998.

ESCOLANO BENITO, A., dir. Historia Ilustrada del libro escolar en España. Del Antiguo Régimen a la Segunda República. Madrid: Fundación Germán Sánchez Ruipérez, 1997.

ESCOLANO BENITO, A. Tiempos y espacios para la escuela. Ensayos históricos. Madrid: Biblioteca Nueva, 2000.

ESCOLANO BENITO, A. El pensil de las niñas. La educación de la mujer. Invención de una tradición. Madrid: Edaf, 2001.

ESCOLANO BENITO, A. y HERNÁNDEZ DÍAZ, J. M. La memoria y el deseo. Cultura de la escuela y educación deseada. Valencia: Tirant Lo Blanch, 2002.

ESCOLAR SOBRINO, H., dir. Historia del libro español. Madrid: Gredos, 1998. 
ESCOLAR SOBRINO, H., dir. Historia ilustrada del libro español. De los incunables al siglo XVIII. Madrid: Fundación Germán Sánchez Ruipérez, 1993.

ESCOLAR SOBRINO, H., dir. Historia ilustrada del libro español. Los manuscritos. Madrid: Fundación Germán Sánchez Ruipérez, 1993.

ESCOLAR SOBRINO, H., dir. Historia ilustrada del libro español. La edición moderna. Siglos XIX y XX. Madrid: Fundación Germán Sánchez Ruipérez, 1996.

ESTEBAN MATEO, L. Los catálogos de librería y material de enseñanza como fuente iconográfica y literario-escolar. Historia de la Educación. 1997, 16, pp. 17-46.

FEDERACIÓN NACIONAL DE LAS ARTES DEL LIBRO. Boletín. Madrid: Imprenta de Antonio Marzo, San Hermenegildo, $\mathrm{n}^{\circ} 1$ al 14. Febrero de 1914 a marzo 1915.

FERNÁNDEZ Y CARDÍN, J. M. Elementos de matemáticas. Madrid: Imprenta Alejandro Gómez Fuentenebro. 1876.

FERNÁNDEZ DE CÓRDOBA Y CALLEJA, E. Saturnino Calleja y su editorial. Los cuentos de Calleja y mucho más. Madrid: Ediciones de la Torre, 2006.

GABRIEL, N. de. Los estados escolares como fuente histórico-educativa. Historia de la Educación. 1993-1994, 13-14, pp. 535-568.

GABRIEL, N. de. y VIÑAO, A., eds. La investigación histórico-educativa. Tendencias actuales. Barcelona: Ronsel, 1997.

GALINO, M. A. Pedagogía e historia. Madrid: Apis, Enciclopedia de la Nueva Educación, 1968.

GALLACH Y TORRAS, J. Medios prácticos para fomentar y activar el comercio de libros en España y activar el comercio de libros en España y entre la Península y las naciones americanas de origen español. En: Crónica de la I Asamblea de Libreros y Editores. Barcelona, 1909, p. 92.

GARCÍA MÍNGUEZ, J.; BEAS MIRANDA, M. Análisis histórico del libro de texto. En: J. GARCÍA y M. BEAS, comp. Libro de texto y 
construcción de materiales curriculares. Granada: Proyecto Sur, 1995, pp. 13-46.

GARCÍA GARRIDO, J. L. Sistemas Educativos de Hoy. Madrid: Dykinson, 1987.

GARCÍA PADRINO, J. Formas y valores: La ilustración infantil en España. Cuenca: Ediciones de la Universidad de Castilla La Mancha, 2004.

GARCÍA PUCHOL, J. Los textos escolares de $H^{a}$ en la enseñanza española (1808-1908). Análisis de su estructura y contenido. Barcelona: Universidad de Barcelona. 1993. p. 271.

GILI ROIG, G. Bosquejo de una política del libro. Barcelona: Gustavo Gili, 1944.

GÓMEZ RODRÍGUEZ DE CASTRO, F. Génesis de los sistemas educativos nacionales. Madrid: UNED, 1988.

GÓMEZ, A. L.; ROMERO MORANTE, J. Escuela para todos: conocimiento académico y geografía escolar en España. Santander: Servicio de Publicaciones de la Universidad de Cantabria, 2007.

GONZÁLEZ RODRÍGUEZ, C. Ideología y educación en los libros de lectura de la escuela primaria de la Restauración (1875-1902). Historia de la Educación, 1998, 17, pp. 233-249.

GUEREÑA, J.- L. Los manuales de urbanidad. En: El arte de saber estar. Enciclopedia práctica de buenas maneras y protocolo. Oviedo: Ediciones Nobel, 1998, v. 5, p. 295-315.

GUEREÑA, J.-L.; RUIZ BERRIO, J. y TIANA FERRER, A. eds. Historia de la educación en la España contemporánea. Diez años de investigación. Madrid: CIDE, 1994.

GUTIÉRREZ FLORES, J.; OBREGÓN GOYARROLA, F.; GUDÍN DE LA LAMA, E. y otros. Entre la espada y la pared. La represión del profesorado cántabro durante la Guerra civil y la postguerra. Santander: Asociación de Investigadores e Historiadores de la Guerra Civil y el Franquismo, 2011.

HAYMAN, J. L. Investigación y educación. Buenos Aires: Paidós, 1979. 
HERNÁNDEZ DÍAZ, J. M. Bibliografía pedagógica de Castilla y León (1808-1936). Salamanca: Colección Aguilafuente, 1993.

HERNÁNDEZ DÍAZ, J. M. La escuela primaria en Castilla y León. Estudios históricos. Salamanca: Amarú Ediciones, 1993.

HERNÁNDEZ DÍAZ, J. M. Alfabetización y sociedad en la revolución liberal española. En: A. ESCOLANO, dir. Leer y escribir en España. Doscientos años de alfabetización. Madrid: Fundación Germán Sánchez Ruipérez, 1992, pp.69-89.

INFANTES, V.; LÓPEZ F. y BOTREL J.-F., dirs. Historia de la edición y de la lectura en España, 1472-1914. Madrid: Fundación Germán Sánchez Ruipérez, 2003.

LIBRERÍA DE JUAN Y ANTONIO BASTINOS. Librería de Juan y Antonio Bastinos: Catálogo General. Barcelona: Imprenta de Jaime Jepús, 1877.

LÓPEZ YEPES, J. La aventura de la investigación científica. Guía del investigador y del director de investigación. Madrid: Síntesis, 1995.

MARTÍNEZ CUADRADO, M. La burguesía conservadora (1874- 1931). Madrid: Alianza Universidad, 1976.

MARTÍNEZ MARTÍN, J. A., dir. Historia de la edición en España (18361936). Madrid: Marcial Pons Editor, 2001.

MARTÍNEZ RUS, A. La política del libro y las ferias del libro de Madrid (1901-1936). Cuadernos de Historia Contemporánea. 2003, 25, pp. 217234.

MARTÍNEZ RUS, A. Barcelona y Madrid ante el reto americano: Las expectativas de la industria del libro. En: J. CATALÁN I VIDAL, J. A. MIRANDA y R. RAMÓN-MUÑOZ, dirs. Distritos y clusters en la europea del sur. Madrid: LID Editorial, 2011, pp. 81-100.

MARTÍNEZ MARTÍN, J.A.; MARTÍNEZ RUS, A y SÁNCHEZ GARCÍA, R. Los patronos del libro. Las asociaciones corporativas de editores y libreros. Gijón: Trea, 2004.

MARTÍNEZ CACHERO, J. M. ed. Antología del cuento español, 19001939. Madrid: Castalia, 1994. 
MEVES, CH. Los cuentos en la educación de los niños [traducción del alemán por J.C. Rodríguez Herranz]. Santander: Sal Terrae, 1978.

MOLERO PINTADO, A. En torno a la cultura escolar como objeto histórico. En J. RUIZ BERRIO ed. La cultura escolar en Europa. Tendencias históricas emergentes. Madrid: Biblioteca Nueva, 2000, pp. 223-228.

MOLINA NAVARRO G. 1874-1924. Libreros y editores de Madrid durante cincuenta años. Madrid: Imprenta Martín Herrera, 1924.

MORENO MARTÍNEZ, P. L.; SEBASTIÁN VICENTE, A. eds. Patrimonio y Etnografía de la escuela en España y Portugal durante el siglo XX. Murcia: Sociedad Española para el estudio del Patrimonio Histórico Educativo y Centro de Estudios sobre la Memoria Educativa [CEME] de la Universidad de Murcia, 2012.

MOTILLA SALAS, X.; GONZÁLEZ GÓMEZ, S. La utilización del grabado en El buen amigo. Periódico para la enseñanza de niños y adultos de Joan Benejam Vives. En: Actas del XVIII Coloquio de Historia de la Educación: Arte, literatura y educación. Vic: Universitat de VicUniversitat Central de Catalunya, 2015, pp. 409-423.

MUÑOZ OLIVARES, C. Los rincones de la vida. Mujeres comprometidas. Magdalena de Santiago-Fuentes. Cuenca: Diputación Provincial de Cuenca. Departamento de Publicaciones, 2004, 238 p.

NEGRÍN FAJARDO, O. y SOTO ARANGO, D. E. La metodología de la investigación histórico-educativa. Madrid: UNED, 1993.

OSSENBACH, G.; SOMOZA, M. y BADANELLI A. La Biblioteca Virtual Patre-Manes de textos escolares europeos y latinoamericanos: análisis de una experiencia. En: A. ESCOLANO BENITO, ed. La cultura material de la escuela. En el centenario de la Junta para la Ampliación de Estudios, 1907-2007. Actas de las II Jornadas de la Sociedad Española para el Estudio del Patrimonio Histórico Educativo [SEPHE]. Berlanga de Duero (Soria), CEINCE, 2007, pp. 327- 344.

OSSENBACH, G. La manualística escolar y la enseñanza de la Historia de la Educación. Cuadernos de Historia de la Educación, 2009, 6, pp. 41-51. 
OSSENBACH, G. Internet y museos pedagógicos. En: Actas del XII Coloquio Nacional de Historia de la Educación. Burgos: Universidad de Burgos, Sociedad Española de Historia de la Educación, [SEPHE], 2003, pp. 901-914.

OSSENBACH, G. y SOMOZA, M. Los manuales escolares como fuente para la Historia de la Educación. Madrid: UNED, 2001.

PALACIO ATARD, V. Nosotros, los españoles. Una breve historia de España. Barcelona: Editorial Planeta, 1991.

PALUZÍE, F. Catálogo de los libros y demás artículos de propiedad. Barcelona: Faustino Paluzíe, 1892.

PASCUAL MARTÍNEZ, P. Escritores y editores en la Restauración canovista (1875-1923). Madrid: Ediciones de la Torre, 1994, 2 vol.

PELEGRIN, A. Libro de Estampas. Almanaque de los niños 1800-1892. Madrid: Comunidad de Madrid-Consejería de Educación y Cultura, 1989.

PÉREZ GALÁN, M. La enseñanza en la II República Española. Revista de Educación. 2000, número extraordinario, pp. 317-332.

PUELLES BENÍTEZ, M. de; TIANA FERRER, A. El Proyecto MANES: una investigación histórica sobre los manuales escolares. Boletín de la Institución Libre de Enseñanza. 2003, 49-50, pp. 163-174.

RAMÍREZ GÓMEZ, C. Mujeres escritoras en la prensa andaluza del siglo XX (1900-1950). Sevilla: Universidad de Sevilla. Secretariado de Publicaciones, 2000, 404 p.

REYRE, J. (Abate Sabatier). Traducido por Juan de Escoiquiz. El amigo de los niños. Madrid: Saturnino Calleja (imp. de M. M. de los Ríos), 1884.

RUIZ BERRIO, J.; MARTÍNEZ NAVARRO, A.; COLMENAR, C. y CARREÑO, M. La editorial Calleja, un agente de modernización educativa en la Restauración. Madrid: UNED, Serie Proyecto MANES, 2002.

RUIZ BERRIO, J. Metodología de la investigación histórica de la educación. En: Educación actual. Problemas y técnicas. Madrid: Instituto de Pedagogía del CSIC-SEP, 1969, pp. 25-41. 
RUIZ BERRIO, J. La enseñanza de la lectura de la Ilustración al liberalismo. En: A. ESCOLANO dir. Historia ilustrada del libro escolar en España. Del Antiguo Régimen a la Segunda República. Madrid: Fundación Germán Sánchez Ruipérez, 1997, pp. 193-227.

RUIZ BERRIO, J. El método histórico en la investigación histórica de la educación. Revista Española de Pedagogía. 1976, 134, pp. 449-475.

RUIZ BERRIO, J. La cultura escolar en Europa. Tendencias históricas emergentes. Madrid: Biblioteca Nueva, S. L., 2000.

RUIZ-TILVE ARIAS, C. Libro para niños (1850-1950). Notas para una historia inacabada. Oviedo: KRK, 1996.

SÁNCHEZ GARCÍA, R. La edición de libros infantiles y juveniles. En: J. A. MARTÍNEZ MARTÍN, dir. Historia de la edición en España. Madrid: Marcial Pons, Historia, 2001, pp. 337-354.

SÁNCHEZ GARCÍA, R. Los catálogos y las señas de identidad editorial. En: J. A. MARTÍNEZ MARTÍN, ed. Historia de la edición en España 1836-1936. Madrid: Marcial Pons Editor, 2000, pp. 241-268.

SÁNCHEZ-MORATE Y MARTÍNEZ, J. F. Nuevo compendio de aritmética práctica: con el sistema métrico decimal y un método sencillo para resolver las cuestiones de la regla de tres, sin el auxilio de las proporciones. Madrid: Librería de Francisco F. Vila, 1867.

SÁNCHEZ VIGIL, J. M. Calpe. Paradigma editorial (1918-1925). Gijón: Ediciones Trea, 2005.

SEÑÁN Y VELÁZQUEZ J. Guía general del estado de la Real Hacienda de España. Madrid: Imprenta de Vega y Compañía, 1817.

TEJADA, M. Aritmética al alcance de los niños. Barcelona: Librería de Juan y Antonio Bastinos, 1881.

TORRIJOS, M. La infanta Doña Teresa. Madrid: Imprenta de Ginés Hernández y Artés, 1857.

TIANA FERRER, A. El proyecto MANES y la investigación histórica sobre los manuales escolares (siglos XIX y XX). Historia de la Educación, 2000, 19, pp. 179-194. 
TIANA FERRER, A. La investigación histórico-educativa actual. Enfoques y métodos. Madrid: UNED, 1988.

TIANA FERRER, A. El libro escolar, reflejo de las intenciones políticas e influencias pedagógicas. Madrid: UNED, 2000.

TORRES RAMÍREZ, I., coord. Las fuentes de información. Madrid.: Síntesis, 1999.

TUÑON DE LARA, M. Por qué la Historia. Barcelona: Salvat, 1981.

TUÑON DE LARA, M. Medio siglo de cultura española 1885-1936. Madrid: Tecnos, 1970.

TURÍN, Y. La educación y la escuela en España de 1874 a 1902. Madrid: Aguilar, 1967.

VALERO DE TORNOS, J. España en fin de siglo. Madrid: Romero, Impresor, T. II, 1896.

VALLÍN Y BUSTILLO, A. F. Aritmética para niños. Madrid: Librería de Hernando, 1878.

VALLS MONTÉS, R. Historiografía escolar española. Siglos XIX-XXI. Madrid: UNED, 2007.

VÍCTOR DE PAREDES, A. Institución y origen del arte de la imprenta y reglas generales para los componedores. Madrid: Crotalón, 1984.

VIÑAO FRAGO, A. Aprender a leer en el Antiguo Régimen: cartillas, silabarios y catones. En A. ESCOLANO, dir. Historia ilustrada del libro escolar en España. Del Antiguo Régimen a la Segunda República. Madrid: Fundación Germán Sánchez Ruipérez, 1997, pp. 149-191.

VIÑAO FRAGO, A. Religión en las aulas. Una materia controvertida. Madrid: Morata, 2014.

VIÑAO FRAGO, A. Textos escolares y didácticos. En: V. INFANTES; F. LÓPEZ ; J.-F. BOTREL. Historia de la edición y la lectura en España, 1472-1914. Madrid: Fundación Germán Sánchez Ruipérez, 2003, pp. 400407. 
VIÑAO FRAGO, A. Tiempos escolares, tiempos sociales. La distribución del tiempo y del trabajo en la enseñanza primaria en la escuela (18381936). Barcelona: Ariel, 1998.

VIÑAO FRAGO, A. El libro escolar. En: J. A. MARTÍNEZ MARTÍN (dir.). Historia de la edición en España. Madrid: Marcial Pons, 2001, pp. 309-336.

VIÑAO FRAGO, A. Las prácticas escolares de lectura y su aprendizaje. En: J. A. MARTÍNEZ MARTÍN, dir. Historia de la edición en España. Madrid: Marcial Pons, 2001, pp. 417-43.

VIÑAO FRAGO, A. Leer y escribir. Historia de dos prácticas culturales. México: Fundación Educación, voces y vuelos, I.A.P., 1999.

VIÑAO FRAGO, A. La lectura, del aprendizaje a las prácticas. En: V. INFANTES; LÓPEZ, F.; BOTREL, J.-F., dir. Historia de la edición y de la lectura en España 1472-1914. Madrid: Fundación Germán Sánchez Ruipérez, 2003, pp. 642-648.

VIÑAO FRAGO, A. Alfabetización e Ilustración: difusión y usos de la cultura escrita. Revista de Educación. 1988, número extraordinario sobre La educación en la Ilustración española, pp. 275-302

VILLALAIN BENITO, J. L. Manuales escolares en España. Tomo I. Legislación (1812-1839). Madrid: U.N.E.D., 1997.

VILlALAIN BENITO, J. L. Manuales escolares en España. Tomo II. Libros de texto autorizados y censurados (1833-1874). Madrid: U.N.E.D., 1999.

VILLALAIN BENITO, J. L. Manuales escolares en España. Tomo III. Libros de texto autorizados y censurados (1874-1939). Madrid: U.N.E.D., 2002.

YEVES, C. Programa de primera enseñanza. Aritmética. Madrid: Imprenta de Alejandro Gómez Fuentenebro, 1872. 


\subsection{BIBLIOGRAFÍA SOBRE BURGOS}

ALBARELLOS BERROETA, J. Efemérides burgalesas. Burgos: Imprenta del Diario de Burgos, 1918.

ALBERDI ELOLA, L. Breverías burgalesas. Burgos: Ayuntamiento de Burgos, Imprenta Aldecoa, 1969.

ALBERDI ElOLA, L. El Teatro Principal. Burgos: Ayuntamiento de Burgos, 1979.

ALMUIÑA FERNÁNDEZ C. y otros. Liberalismo y caciquismo (siglo XIX). En: J. VALDEÓN, dir. Historia de Castilla y León. Valladolid: Ámbito, v. 9, 1985-1986.

ALMUIÑA FERNÁNDEZ, C. La burguesía burgalesa y su proyección regionalista desde mediados del siglo XIX a 1936. En: Actas del Congreso de Historia de Burgos, MC aniversario de la Ciudad 884-1984. Valladolid: Junta de Castilla y León, 1987, pp. 545-583.

BUITRAGO Y ROMERO, A. Guía general de Burgos. Madrid: Aribau, 1876.

CÁMARA MORAL, M. Hoy, como ayer. Crónica de los acontecimientos vividos en Burgos entre 1898 y 1914. Burgos: Estudio Euroláser, 2002

CÁMARA MORAL, M. Hoy, como ayer. Los avatares regionalistas y otros hechos que conmovieron a la sociedad burgalesa entre 1915 y 1918. Burgos: Estudio Euroláser, 2006.

CÁMARA MORAL, M. Hoy, como ayer. La pérdida de la inocencia: Burgos, 1919-1923. Burgos: Estudio Euroláser, 2006.

CÁMARA MORAL, M. Hoy, como ayer. Las claves ocultas: Burgos, 1924-1927. Burgos: Estudio Euroláser, 2007.

CÁMARA MORAL, M. Hoy, como ayer. De la Dictadura a la República: Burgos, 1928-1931. Burgos: Estudio Euroláser, 2007.

CÁMARA MORAL, M. Hoy, como ayer. Burgos republicano: una reflexión (1932-1935). Burgos: Estudio Euroláser, 2009. 
CAMARERO BULLÓN, C. Burgos y el Catastro de Ensenada. Burgos: Caja de Ahorros Municipal de Burgos, 1989.

CARASA SOTO, P. Pauperismo y revolución burguesa (Burgos, 17501900). Valladolid: Universidad de Valladolid, 1978.

CARMONA URAN, G. Historia de las viejas rúas burgenses. Burgos: Aldecoa, 1954.

CASTRILLEJO IBÁÑNEZ, F. La desamortización de Madoz en la provincia de Burgos (1855-1869). Valladolid: Universidad de Valladolid, 1978.

CRESPO REDONDO, J. Evolución demográfica de la ciudad de Burgos en el siglo XIX. Estructura económica e inmigración hasta 1857. En: Actas del Congreso de Historia de Burgos: MC aniversario de la ciudad 884-1984. Valladolid: Junta de Castilla y León, 1987, pp. 723- 781.

DE LA CRUZ, V. BURGOS Libros e imprentas. Burgos: Caja de Ahorros Municipal, 1988.

DELGADO VIÑAS, C. Clase obrera, burguesía y conflicto social. Burgos 1883-1936. Valladolid: Universidad de Valladolid, 1993.

EBRO, M. C. Memorias de una burgalesa (1885-1931). Burgos: Instituto Municipal de Cultura, Ayuntamiento de Burgos, 2004.

FERNÁNDEZ SANCHA, A. Burgos en torno a 1900. En: VV.AA. Burgos. Siglo XX. Burgos: Cámara Oficial de Comercio e Industria de Burgos, 2001, pp. 25-65.

FERNÁNDEZ SANCHA, A. La evolución de la ciudad. Burgos 19001936. En: VV.AA. Burgos. Siglo XX. Burgos: Cámara Oficial de Comercio e Industria de Burgos, 2001, pp. 69-107.

FERNÁNDEZ SANCHA, A. y SANZ QUINTANA, J. M. Cultura burguesa, cultura popular y cultura obrera en el Burgos de la Restauración (1875-1931). En: Historia Contemporánea de Burgos. Burgos: Diario 16, v. III, 1993, pp. 999-1010.

GARCÍA DE QUEVEDO Y CONCELLÓN, E. Libros burgaleses de memorias y noticias. Burgos: Imprenta del Monte Carmelo, 1931. 
GARCÍA RÁMILA, I. El Salón de Recreo: cien años de una vida social, rectilínea, amable y eficiente. Burgos: Hijos de Santiago Rodríguez, 1975.

GARCÍA RÁMILA, I. Bibliografía burgalesa. Burgos: Aldecoa, 1961.

GONZÁLEZ, N. Burgos la ciudad marginal de Castilla. Burgos: Aldecoa, 1958.

HERGUETA MARTÍN, D. La imprenta en Burgos y su provincia (14751920), Ejemplar mecanografiado. Copia digital. Valladolid: Junta de Castilla y León. Conserjería de Cultura y Turismo, 2009-2010, 4 v.

IGLESIAS ROUCO, L. S. Burgos en el siglo XIX, arquitectura $y$ urbanismo (1813 -1900). Valladolid: Universidad de Valladolid, 1979.

IGLESIAS ROUCO, L. S., coord. Protagonistas burgaleses del siglo XX. Burgos: Diario de Burgos, 2 v, 2000-2002.

LIGA DE CONTRIBUYENTES DE BURGOS. Boletín de la Liga de Contribuyentes de Burgos. Burgos: Impr. Timoteo Arnaiz, 1876-1880.

LÓPEZ MATA, T. Burgos durante el período constitucional de 1820 a 1823. Boletín de la Institución Fernán González. 1966-1967, T. XVII, pp. 113-119.

LÓPEZ SAIZ, I. y OREJÓN, A. Demografía burgalesa. Burgos: inédito, mecanografiado, 1950. Copia digital: IMC del Ayuntamiento de Burgos, 2011

MADOZ, P. Diccionario Geográfico-Estadístico-Histórico de España y sus posesiones de Ultramar. Valladolid: Ámbito, facsímil, 1984.

MANERO, F. La industria en Castilla y León. Valladolid: Ámbito, 1983.

MARTÍNEZ AÑIBARRO Y RIBES, M. Intento de un diccionario biográfico y bibliográfico de autores de la provincia de Burgos. Valladolid: Junta de Castilla y León, 1993.

MONJE MATÉ, C. La industria del libro en Burgos durante el siglo XX. En: L. S. IGLESIAS ROUCO, coord. Protagonistas burgaleses del siglo XX. Burgos: Diario de Burgos, 2002, v. I, pp. 145-150. 
ORTEGA BARRIUSO, F. Breve historia de la ciudad de Burgos. Burgos: Asociación de Libreros de Burgos, 1998.

ORTEGA BARRIUSO, F. Diccionario de la cultura de Burgos. Burgos. Siglo XX. Burgos: Dossoles, 2001.

ORTEGA BARRIUSO, F. Burgos. Memoria de una ciudad. Burgos: Aldecoa, 2009.

MORENO PEÑA, J. L. Gran propiedad rústica en Burgos. Burgos: Caja de Ahorros Municipal de Burgos, 1992.

ORTEGA GUTIÉRREZ, D., GIL-PERALTA ANTOLÍN, E. y CASTRILLO LARA L. La Cámara de Comercio e Industria de Burgos (1887-1897). El tránsito del ruralismo a la industrialización. Burgos: Cámara de Comercio e Industria, 1987.

PEÑA PÉREZ, F. J.; PAYO HERNANZ, R. J., coords. Historia del Comercio de Burgos. Burgos: Federación de Empresarios de Comercio de Burgos, 2005.

PALOMARES IBÁNEZ, J. M., dir. Historia de Burgos (IV). Burgos: Caja de Burgos, 2006.

PÉREZ MANRIQUE, J. C. Prensa periódica en Burgos durante el siglo XIX. Burgos: Aldecoa, 1996.

PÉREZ MANRIQUE, J. C. El Papa-Moscas, 1878-1898. En: Actas del Congreso de Historia de Burgos: MC aniversario de la ciudad 884-1984. Valladolid: Junta de Castilla y León, 1987, pp. 621-632.

SALVÁ PÉREZ, A. Burgos a vuela pluma. Burgos: Imprenta de la Revista de Provincias, 1889.

SANCHEZ DIANA, J. M. Burgos en la guerra de la independencia: la ciudad y los guerrilleros. Hispania, 1970, 116, pp. 515-569.

SANTAMARTA REGUERA, J. La enseñanza primaria en Burgos (18751931). Burgos: Universidad de Burgos, 2000.

SÁNCHEZ DOMINGO, R. Historia de Isar. Cámara de los Manrique. Burgos: Excma. Diputación Provincial de Burgos, 2012. 
SERRANO GARCÍA, R. La revolución de 1868 en la ciudad de Burgos: la actuación de la Junta Revolucionaria y de la Corporación Municipal. En: Actas del Congreso de Historia de Burgos: MC aniversario de la ciudad 884-1984. Valladolid: Junta de Castilla y León, 1987, pp. 613-621.

SIERRA Y GIL DE LA CUESTA, J. Visitas reales al Burgos romántico 1875-1931. Burgos: Excma. Diputación Provincial de Burgos. Temas burgaleses 2, 1987.

SOTO CARMONA, A. Estudio comparativo de la fuerza de trabajo en Burgos, 1860-1930. En: Actas del Congreso de Historia de Burgos: MC aniversario de la ciudad 884-1984. Burgos: Junta de Castilla y León, 1978, pp. 811-823.

TUÑÓN DE LARA, M. Medio siglo de cultura española 1885-1936. Madrid: Tecnos, 1970.

VILLOTA GIL-ESCOIN, P. Burgos durante el bienio progresista (185456). Aproximación a una época conflictiva. En: Actas del Congreso de Historia de Burgos: MC aniversario de la ciudad 884-1984. Valladolid: Junta de Castilla y León, 1978, pp. 587-608.

VV.AA. La colección fotográfica de Juan Antonio Cortés (1.851-1.944). La memoria entre las hojas. Burgos: Instituto Municipal de Cultura y Turismo del Ayuntamiento de Burgos, 2010.

ZAPARAÍN YÁNEZ, M. J. Diseño gráfico y encuadernación. En: L. S. IGLESIAS ROUCO, dir. Protagonistas burgaleses del Siglo XX. Burgos: Diario de Burgos, 2000, v. I, pp. 153-160. 
ANEXOS 

1.1.ÁRBOL GENEALÓGICO: FAMILIA DE D. SANTIAGO RODRÍGUEZ ALONSO 


\section{1.- ÁRBOL GENEALÓGICO: FAMILIA DE D. SANTIAGO RODRÍGUEZ ALONSO}

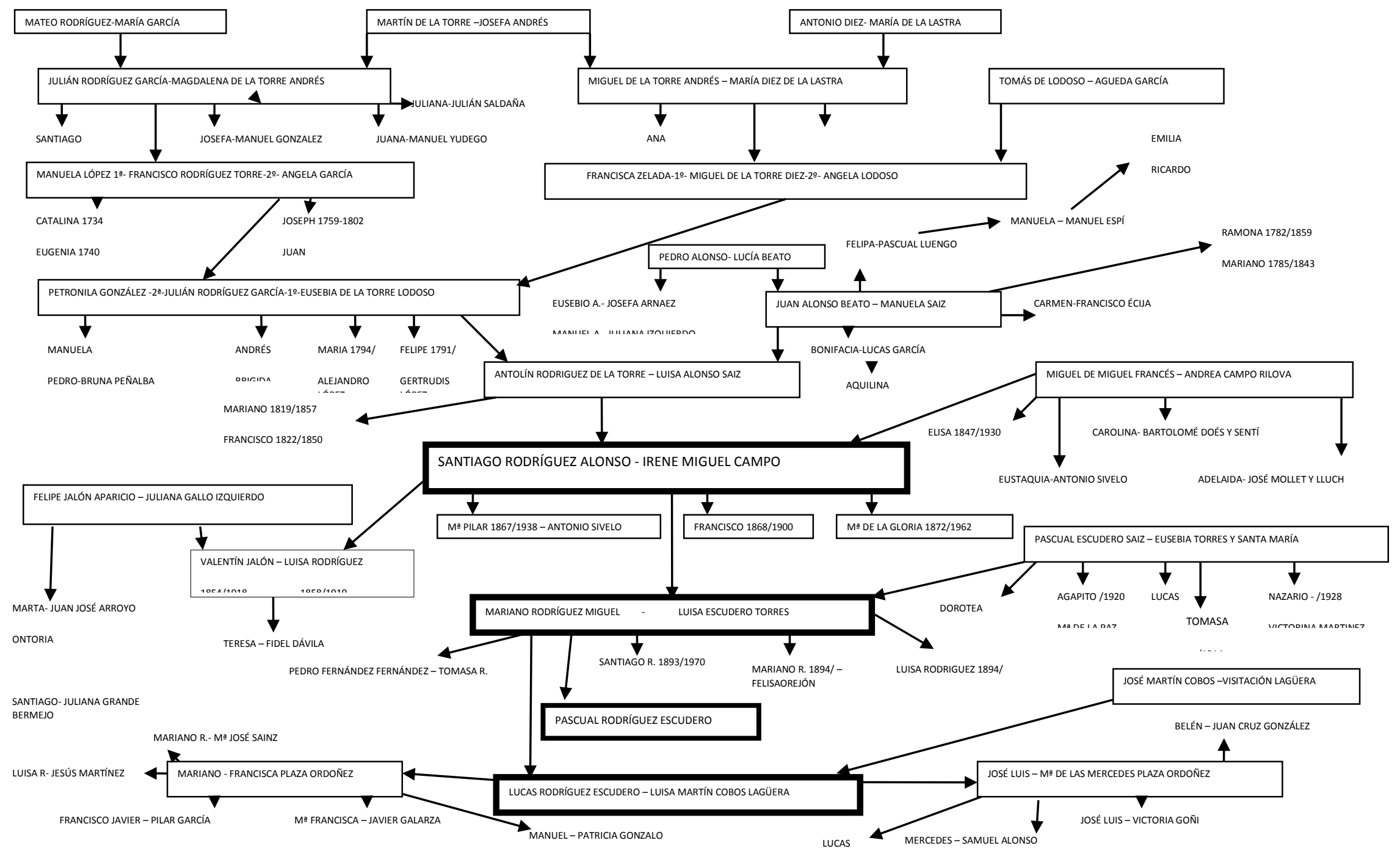

Fuente: Archivo Diocesano del Arzobispado de Burgos. [Elaboración propia]. 


\subsection{DOCUMENTOS NOTARIALES}

Se han recogido todos aquellos documentos importantes en el devenir de los acontecimientos de la familia o de la empresa editorial, y se transcribe la parte fundamental de la escritura que contiene la información relevante, excluyendo en algunos casos, la terminología notarial.

1. Escritura de fianza a favor de la Real Hacienda otorgada por D. Antolín Rodríguez y D ${ }^{a}$ Luisa Alonso en Ayllón -Segovia-, el 14 de junio de 1817.

2. Poder de D. Bernabé Mateo a D. Antolín Rodríguez, en Ayllón Segovia-, el 2 de agosto de 1819.

3. Poder otorgado por Isidro Vicente y Francisco Benito, vecinos de Fuentearmegil a D. Antolín Rodríguez y a D. Francisco Navas, vecinos de la villa de Ayllón -Segovia- para presentarse ante el Sr. Juez de $1^{\text {a }}$ instancia y realizar gestiones pertinentes.

4. Arrendamiento de una casa a D. Antolín Rodríguez y consorte a favor de $\mathrm{D}^{\mathrm{a}}$ Manuela Laredo, en Burgos el 20 de abril de 1831.

5. Arrendamiento de una casa a D. Antolín Rodríguez y consorte a favor de D. Florentín Izquierdo, en Burgos 8 de mayo de 1833.

6. Escritura de fianza de D. Antolín Rodríguez y consorte, vecinos de la ciudad de Burgos a favor de la Excelentísima Sra. Marquesa, viuda de la Rambla, por su apoderamiento el 7 de diciembre de 1832.

7. Testamento de D. Antolín Rodríguez y $\mathrm{D}^{\mathrm{a}}$ Luisa Alonso en Burgos el 8 de agosto de 1834 .

8. Sustitución en la suerte de soldado de D. Santiago Rodríguez Alonso, el 26 de febrero de 1849.

9. Mariano Rodríguez Alonso, apoderado del Sr. Marqués de la Rambla, 1853. 
10. Poder notarial de $\mathrm{D}^{\mathrm{a}}$ Luisa Alonso a favor de su hijo D. Dámaso Rodríguez para que cobre la pensión de su madre, como viuda de empleado de las puertas de la ciudad.

11. Testamento de $\mathrm{D}^{\mathrm{a}}$ Luisa Alonso, el 18 de octubre de 1858.

12. Recepción de la novicia $\mathrm{D}^{\mathrm{a}}$ Ramona Alonso en la comunidad de Religiosas de San José de Burgos, el 31 de marzo de 1862.

13. Poder de D. Santiago Rodríguez a D. José Ortega, procurador de Alicante para litigar contra su hermano D. Dámaso Rodríguez, por deudas, el 11 de marzo de 1868.

14. Poder de D. Santiago Rodríguez Alonso a su hijo Mariano Rodríguez Miguel para que le represente en todos los asuntos de la Casa Editorial, el 19 de diciembre de 1884.

15. Testamento de D. Santiago Rodríguez Alonso, el 6 de abril de 1891.

16. Escritura de Sociedad "Hijos de Santiago Rodríguez".

17. Escritura de cesión de propiedad literaria por D. Anselmo Salvá, D. Mateo Bustamante y D. Esteban Franco en representación de varios autores, a favor de los Sres. Hijos de Santiago Rodríguez, el 20 de noviembre de 1896.

18. Escritura de cesión de propiedad literaria por D. Arsenio Herreros Martínez y D. Esteban Franco en representación de varios autores a favor de los Sres. Hijos de Santiago Rodríguez, el 19 de noviembre de 1902.

19. Escritura de cesión de propiedad literaria por D. Agapito Escudero Torres y D. José García Alía en representación de varios autores a favor de los Sres. Hijos de Santiago Rodríguez, el 14 de noviembre de 1907. 
1. Escritura de fianza a favor de la Real Hacienda otorgada por D. Antolín Rodríguez y $D^{\text {a }}$ Luisa Alonso en Ayllón -Segovia-, el 14 de junio de 1817.

Escritura de fianza a favor de la Real Hacienda otorgada por D. Antolín Rodríguez y $\mathrm{D}^{\mathrm{a}}$ Luisa Alonso, su mujer vecinos de esta villa.

En la villa de Ayllón a 14 de junio de 1817 ante mí el Escribano del número y testigos que al final se presentarán aparecieron D. Antolín Rodríguez y $\mathrm{D}^{\mathrm{a}}$ Luisa Alonso su mujer, vecinos de ella y precedida la venia y licencia que para estos casos el derecho impone que ha sido pedida, concedida y aceptada entre el uno y el otro, de cuya petición, concesión y aceptación yo el notario doy fe dijeron que hallándose empleado el referido D. Antolín en el destino de veredero de la Administración de Rentas Estancadas de esta villa y pueblos de su partido, para surtir de tabacos a los mismos y recaudar sus productos [...] para cumplir puntualmente con lo mandado en el Real Reglamento expedido en el particular y demás órdenes que se le han comunicado presenta la fianza a favor de la Real Hacienda hasta la suma de tres mil reales de vellón siendo en fincas para la responsabilidad de dicho su destino, al efecto autorizando a la Ordenanza de la villa de Isar, pueblo de su natural, solicitando se le recibiere información para acreditar que las fincas señaladas para la fianza eran suyas y le corresponden por legítimos títulos, libre de toda carga y que su valor en el día de hoy, es de tres mil reales las cuales quedan sujetas a dicha fianza dando en ello información que justifique de la forma más legal que la citada información para documentar la escritura al Administrador principal de las mismas rentas del Partido de Aranda de Duero al que está agregada la citada villa y cuyo original me la entregan a mí el escribano para que la misma la incorpore en ella la que recibí y que en su literalidad es la siguiente:

\section{Aquí la información:}

Y para que el otorgamiento de dicha escritura de fianza tenga debido efecto, otorgan y declaran que las fincas contenidas en la información son suyas propias y les pertenecen por ciertos y legítimos títulos que se hallan en los sitios con las cabidas y linderos que se expresan, que están libres de toda carga perpetua y salen las cantidades en que están tasadas y así lo expresan en debida forma e hipotecan para la responsabilidad de dicho destino de veredero, de modo que no las pueda cambiar, dividir ni enajenar a comunidad ni persona alguna y caso de que lo hicieran ha de ser suelo de ningún valor y efecto por quedar desde este otorgamiento ligados con toda 
preferencia y antelación a favor de la Hacienda para que pueda reclamar dichas fincas aunque se hallen en poder de terceros [...] quedando hipotecadas y los bienes que en adelante adquieran $[\ldots]$

Y asimismo $D^{a}$ Lucía Alonso renuncia a la ley 61 que dice que la mujer no puede ser fiadora de su marido y que cuando se obligan de mancomun en uno o en diversos contratos quede obligada a menos que lo justifique que la deuda se convirtió en su utilidad y provecho [...]

Otorgamos y firmamos a quienes yo el notario doy fe conozco, siendo testigos, Josef Valles, Germán García y Clemente Alonso, vecinos de dicha villa.

Firman: El notario D. Pío González García, Antolín Rodríguez y Luisa Alonso. 


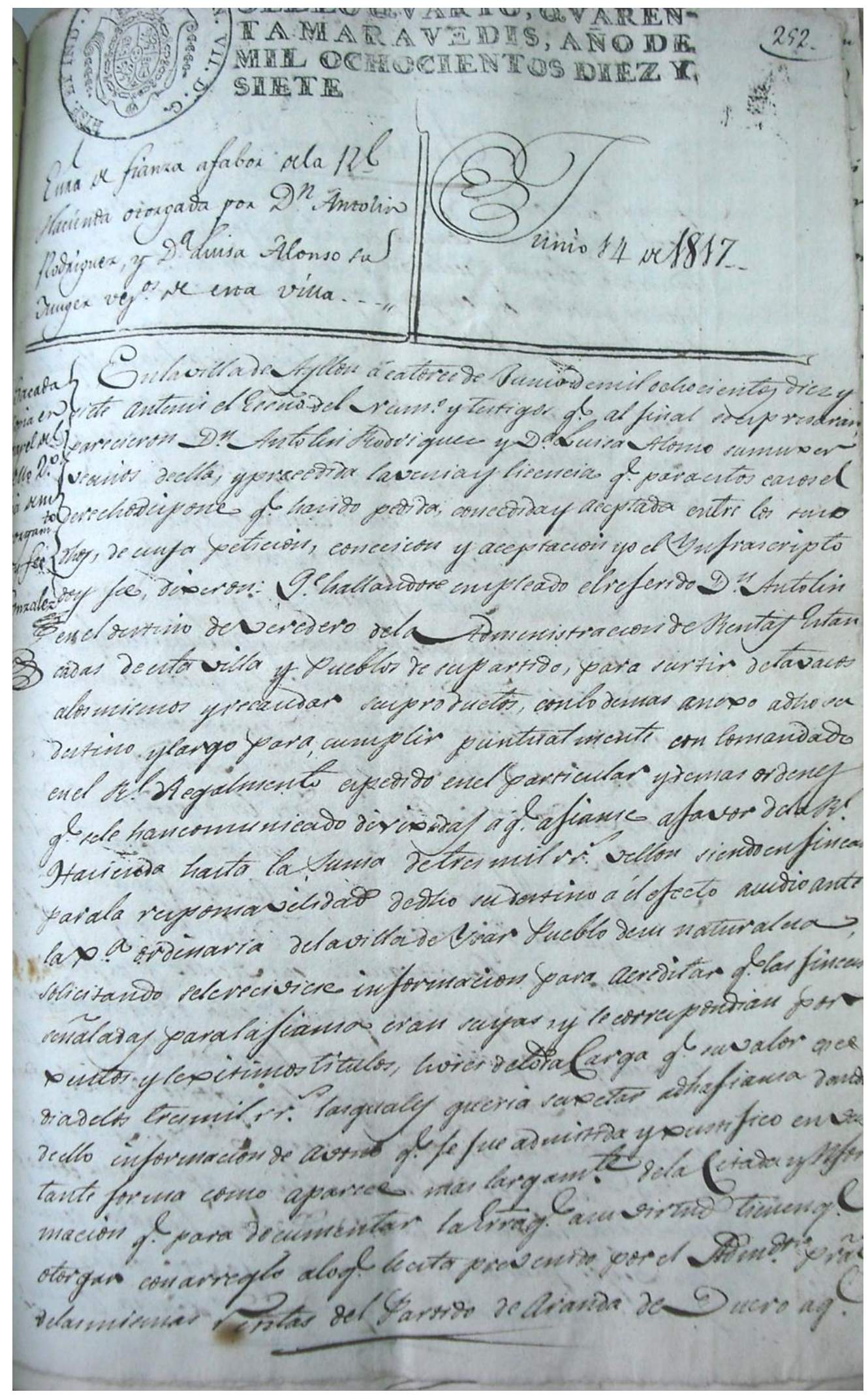

Fig.: 1

Escritura de fianza a favor de la Real Hacienda otorgada por D. Antolín Rodríguez y D Luisa Alonso. Ayllón.

Archivo Histórico de Segovia. 1917, p. 1 de 3. 
LA EDITORIAL BURGALESA HIJOS DE SANTIAGO RODRÍGUEZ (1891-1936): ANÁLISIS DE LOS LIBROS ESCOLARES

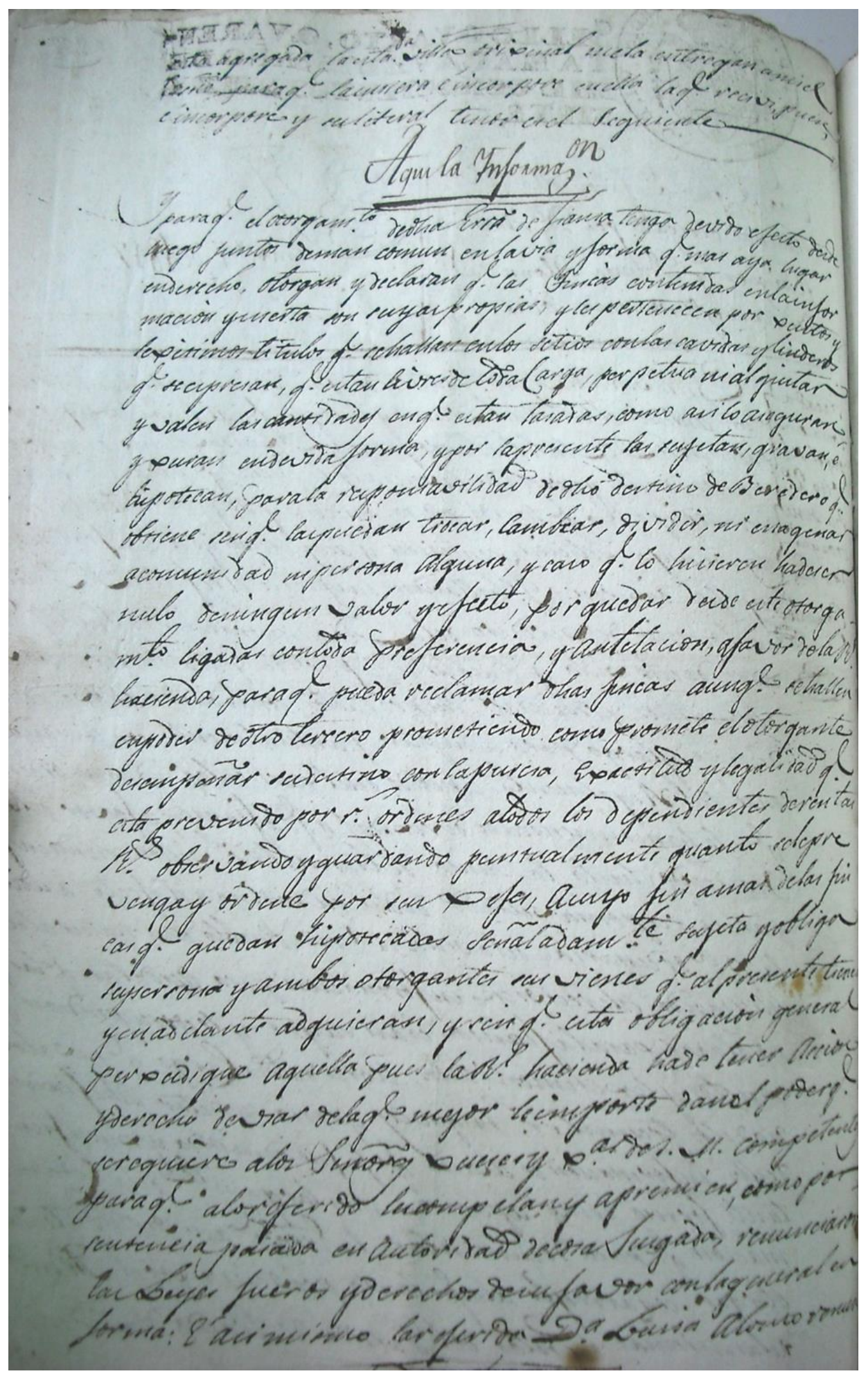

Fig.: 2

Escritura de fianza a favor de la Real Hacienda otorgada por D. Antolín Rodríguez y D Luisa Alonso. Ayllón.

Archivo Histórico de Segovia. 1917, p. 2 de 3. 


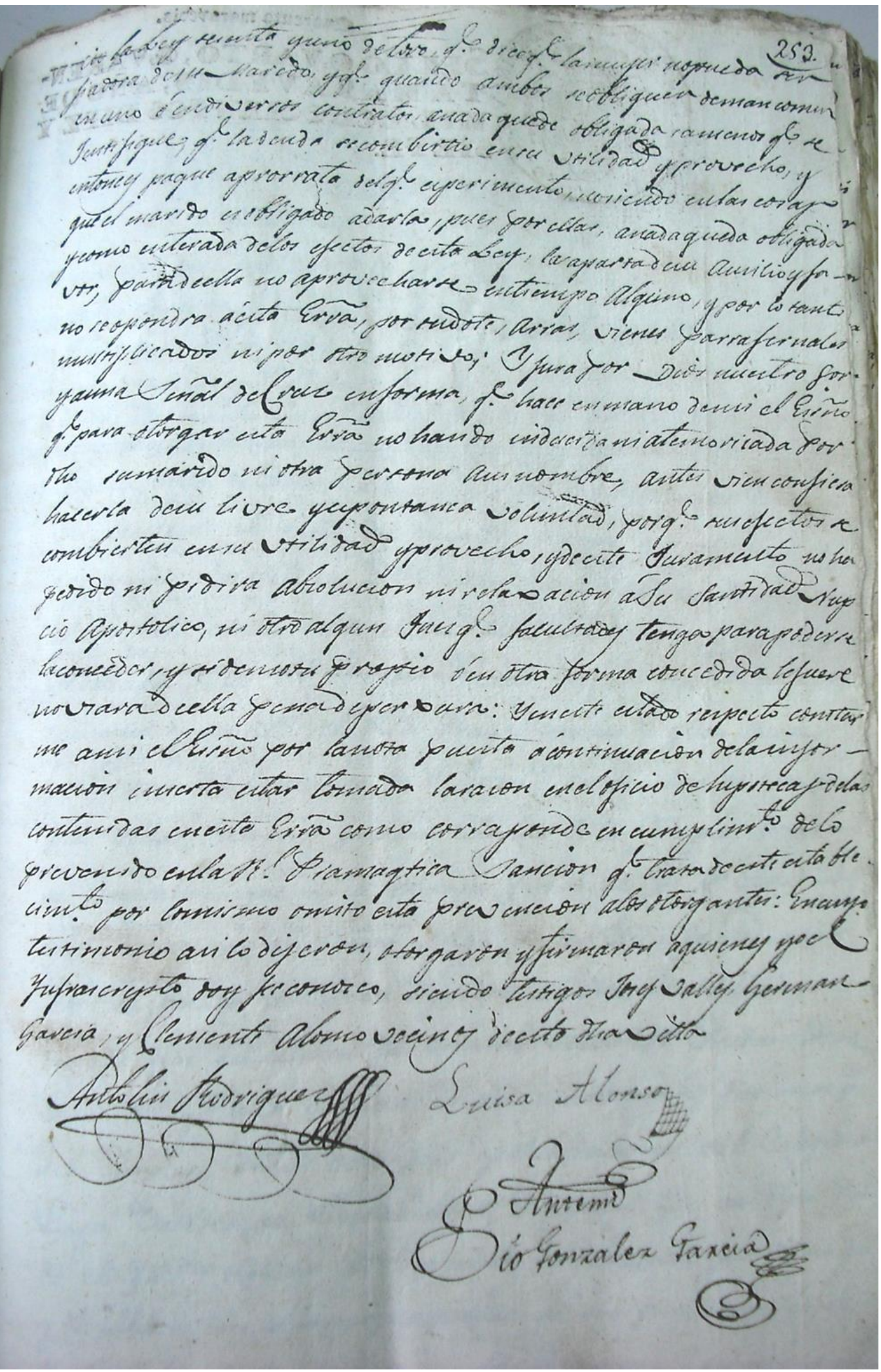

Fig.: 3

Escritura de fianza a favor de la Real Hacienda otorgada por D. Antolín Rodríguez y Da Luisa Alonso. Ayllón.

Archivo Histórico de Segovia. 1917, p. 3 de 3. 


\section{Poder de D. Bernabé Mateo a D. Antolín Rodríguez, en Ayllón - Segovia-, el 2 de agosto de 1819.}

Poder otorgado por Bernabé Mateo vecino de la villa de Fuentelcésped a Don Antolín Rodríguez vecino de esta villa. (Se transcribe la parte nuclear del poder que se refiere a D. Antolín Rodríguez, padre del fundador de la casa editorial).

En la villa de Ayllón a dos de agosto de mil ochocientos diecinueve ante mí el escribano del Número y testigo que al final se expresaron por dicho Bernabé Mateo vecino de Fuentelcésped, estante al presente en esta referida villa y dijo que estando como está a su cargo el abasto del ramo de vinos de la oficina pública de la misma a consecuencia de la postura y remate que se celebró en su persona conforme a lo dispuesto por S.M en la Real orden expedida en el particular que trata de la estancación de dicho género; mediante lo cual y guiándose por la justicia y Ayuntamiento de esta propia villa dar distinto sentido que el verdadero a las condiciones que se estamparon y bajo de las que se hizo dicho remate se aprobó por la Intendencia y se celebró las oportunas escrituras se le quiere compeler al pago de las cantidades vencidas por lo ofrecido con destino a que sirva para la Real Contribución en beneficio de esta villa sin hacerle la debida rebaja hasta que hizo efecto la aprobación del indicado remate y entró después en quieta y pacífica posesión de abastecer de dichos vinos lo que se verificó en el día de 6 de abril por lo que le precisa usar de su derecho y de las acciones conducentes a fin de que se consiga ya que se tiene que ausentar a su pueblo como labrador a la recolección de mieres por ser el tiempo más crítico para ello desde luego en la vía y forma que más haya lugar en derecho: otorga y confiere todo su poder cumplido el que se requiera sea necesario y debe velar, amplio general y sin limitación alguna a Don Antolín Rodríguez vecino de esta villa y fiel veredero de la Administración de Rentas Reales de ella y su partido [...]

Firman: El notario D. Pío González García y Bernabé Mateo. 


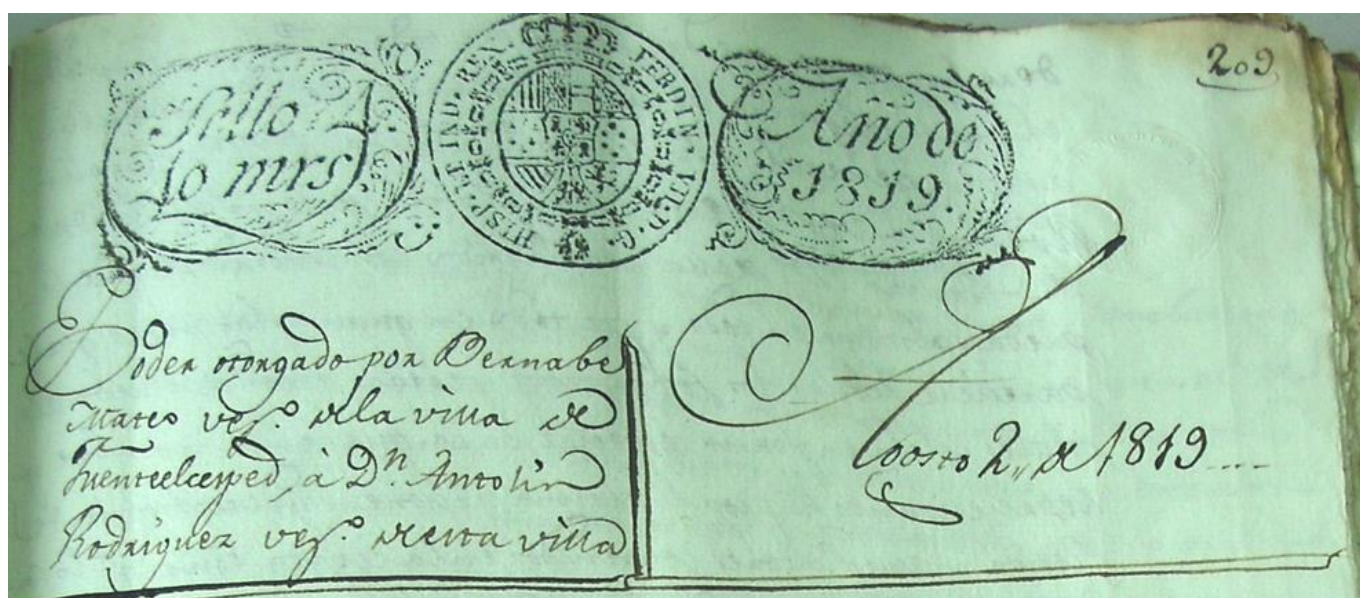

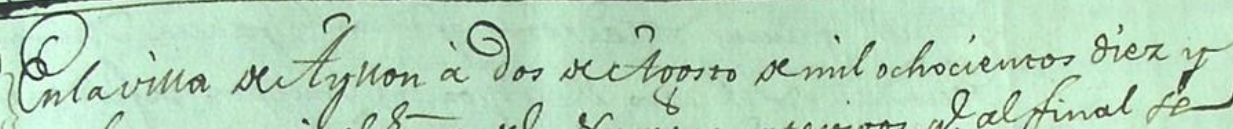

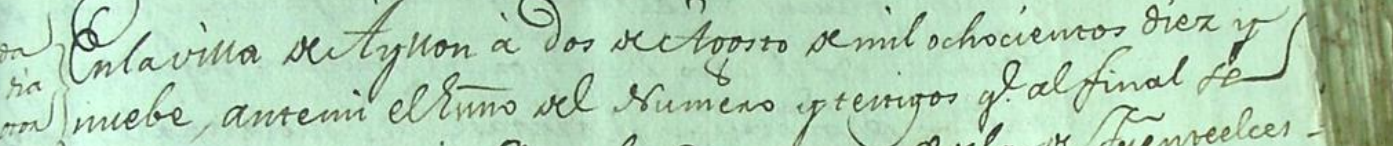

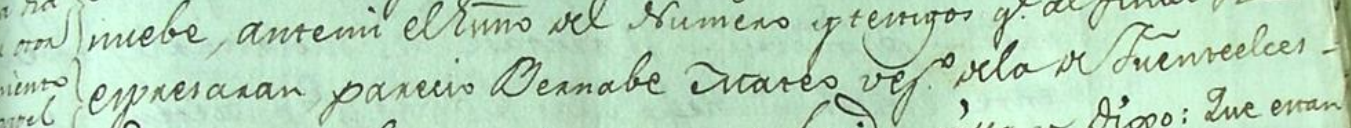
tons det, evante alpresente en ena referida viua y Dioso: Lwe evan iny do coms evra anu cango el Abano orl ramo rvinos sela ofici.

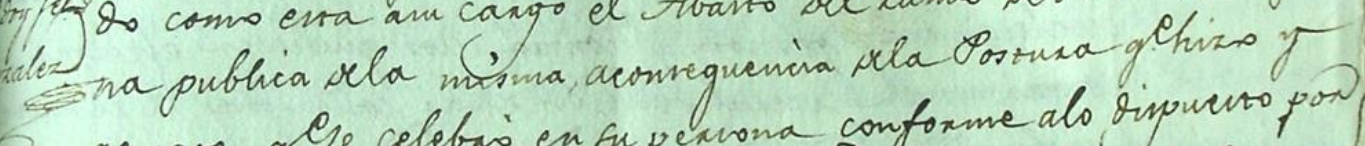
xemare ge celebis en fu perrona conforme alo oimuento pon

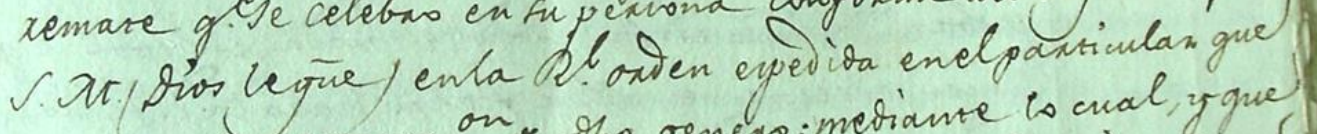
tava red entancy. on tho genexs; metiante is cual, yque,

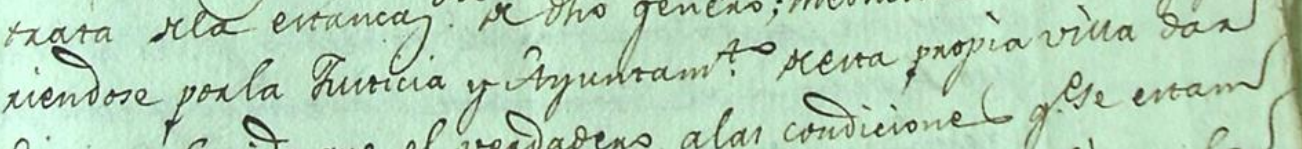

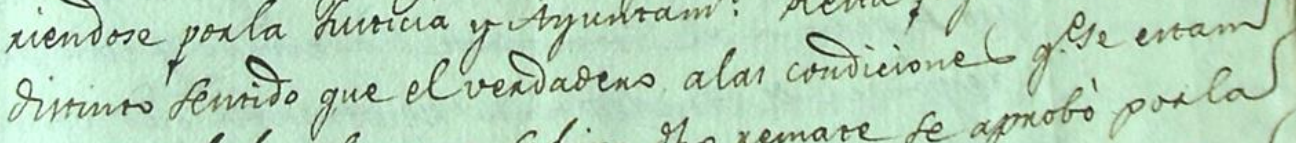
paron ybafo relar gue fehizo tho xumare fe aprobo poxld Trvent a celebis la opontuna enxa fle guiene compelex

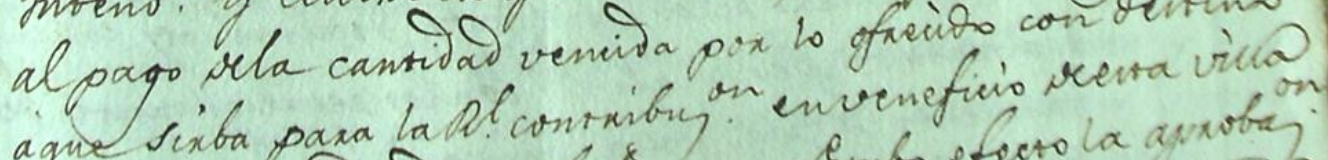

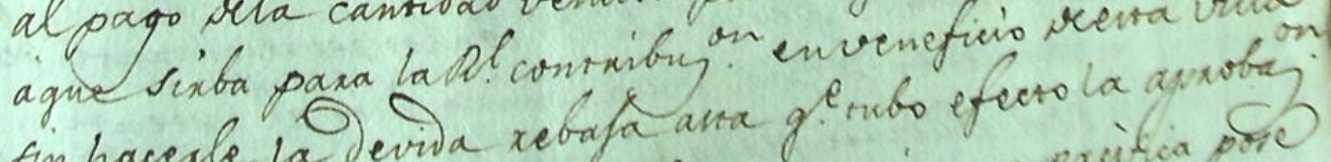
fin hacenle la deviva xebafa ana ge paricia pos

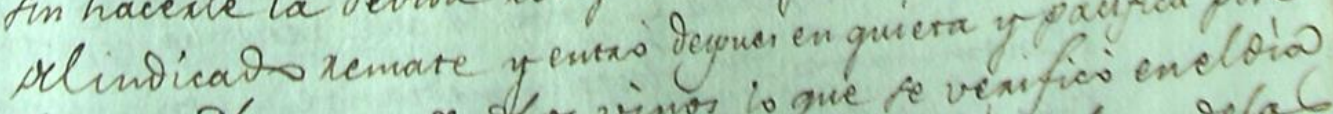

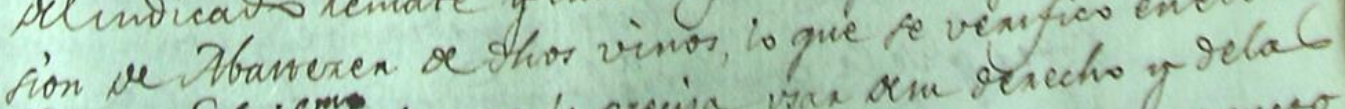

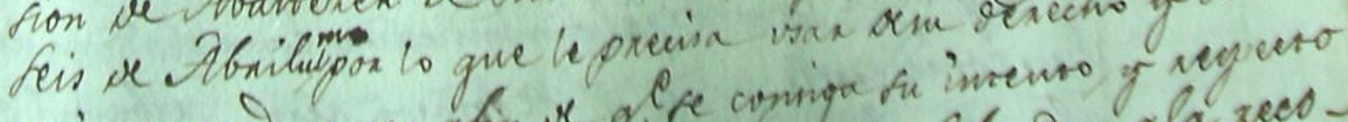

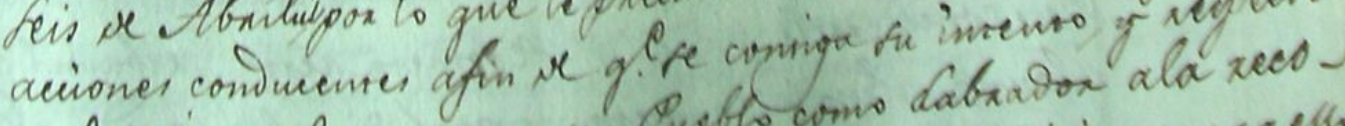

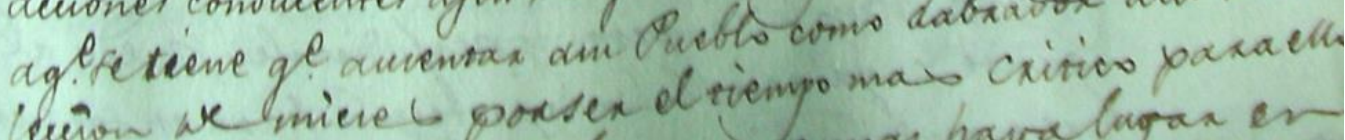

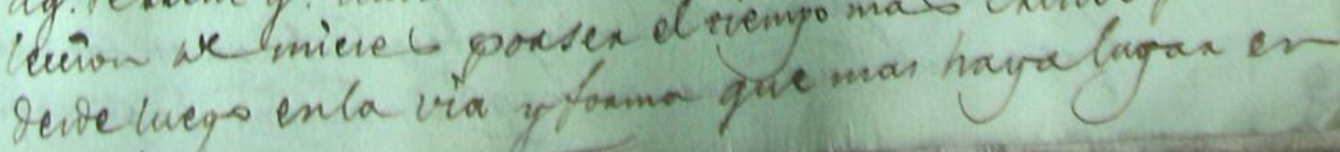

Fig.: 4

Poder otorgado por Bernabé Mateo a Don Antolín Rodríguez en Ayllón. Archivo Histórico de Segovia. 1819, p. 1 de 3. 


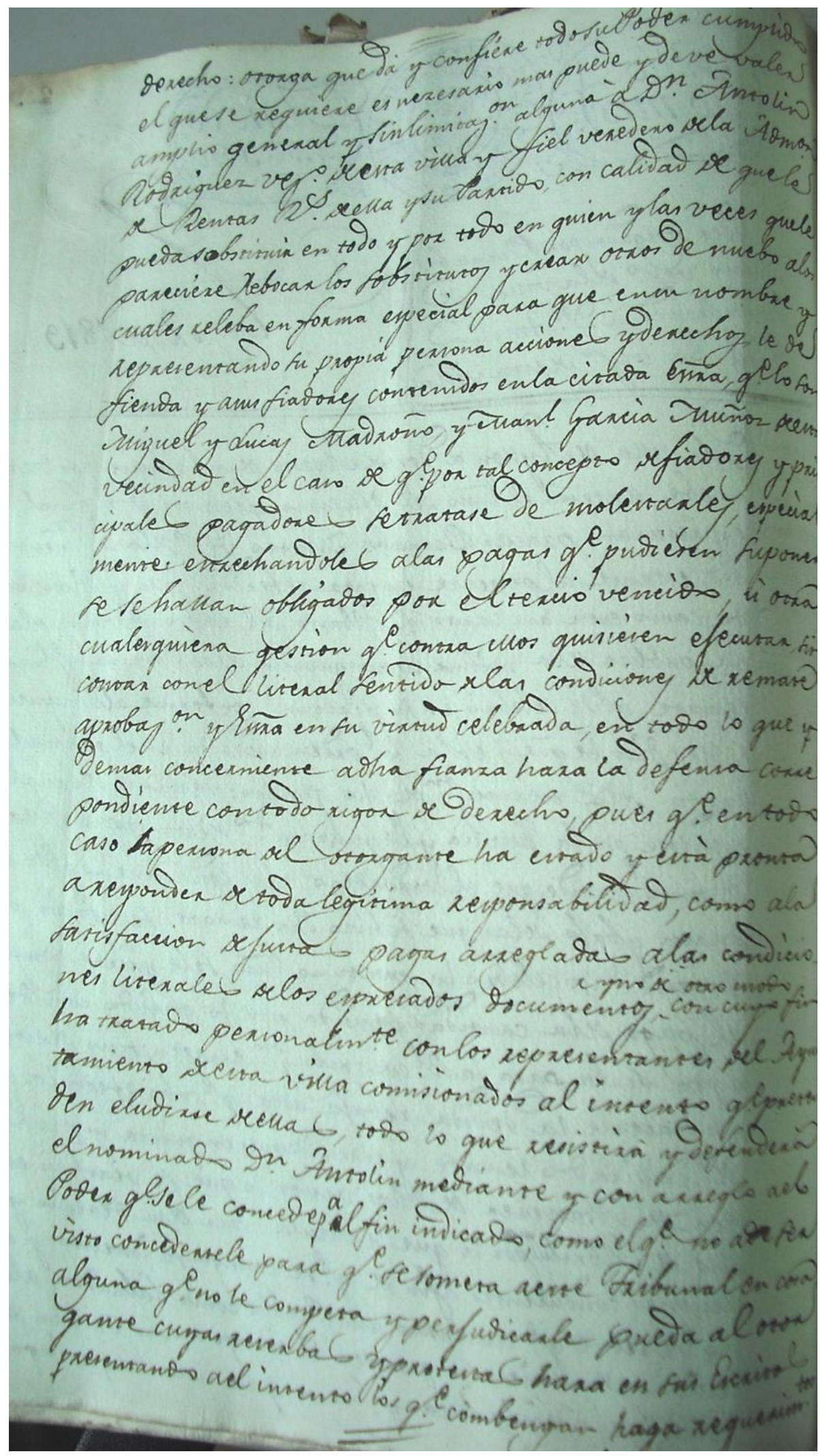

Fig.: 5

Poder otorgado por Bernabé Mateo a Don Antolín Rodríguez en Ayllón. Archivo Histórico de Segovia. 1819, p. 2 de 3. 


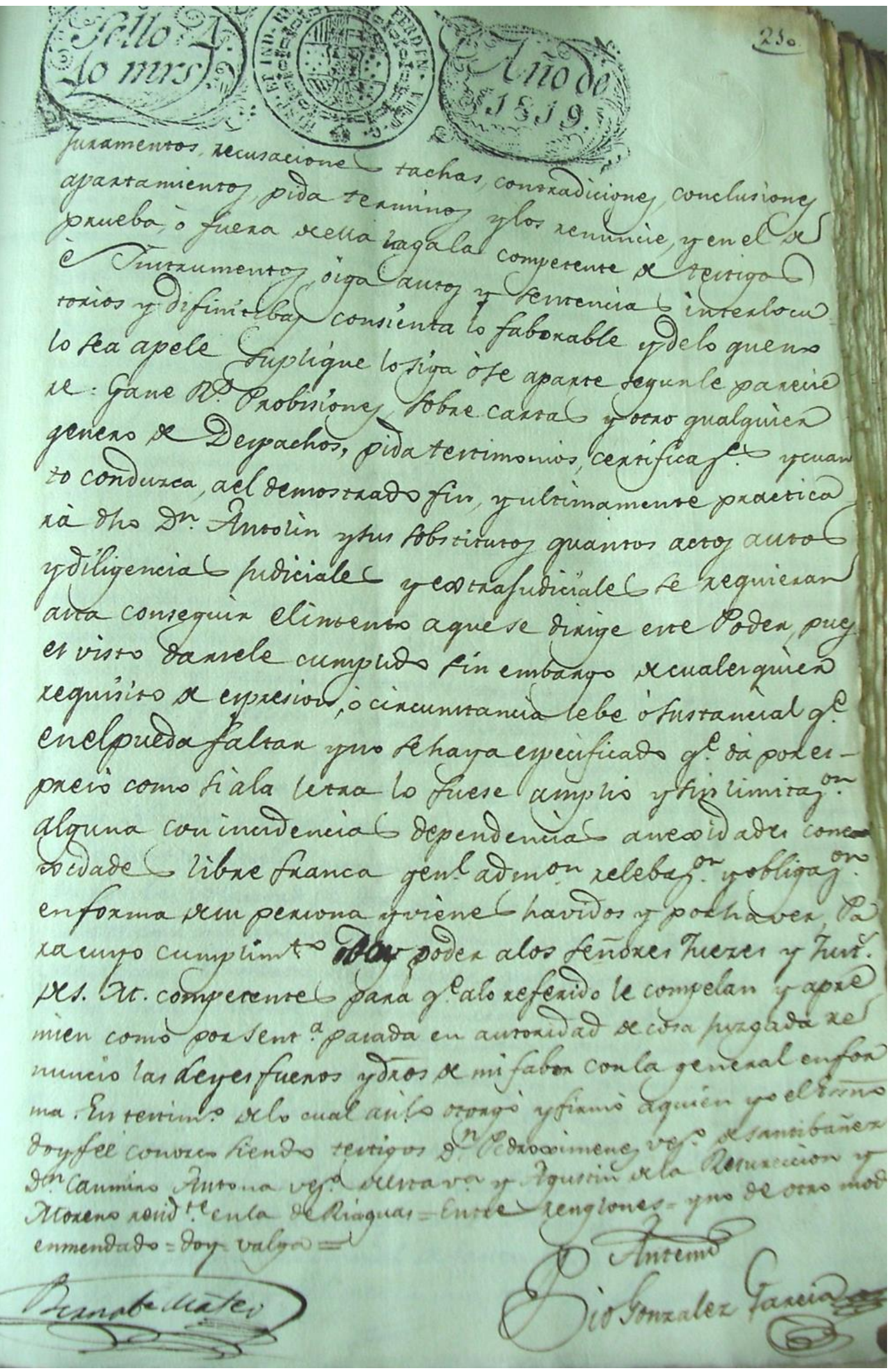

Fig.: 6

Poder otorgado por Bernabé Mateo a Don Antolín Rodríguez en Ayllón. Archivo Histórico de Segovia. 1819, p. 3 de 3. 


\section{Poder otorgado por Isidro Vicente y Francisco Benito, vecinos de} Fuentearmegil a D. Antolín Rodríguez y a D. Francisco Navas, vecinos de la villa de Ayllón -Segovia- para presentarse ante el Sr. Juez de $\mathbf{1}^{\text {a }}$ instancia y realizar gestiones pertinentes.

En la villa de Ayllón a treinta y uno de marzo de mil ochocientos veintiuno ante mí el escribano y testigos que al final se expresarán parecieron Isidro Vicente y Francisco Benito vecinos de la villa de Fuentearmengil de este partido y dijeron que aventuras recientes ocurridas en la noche del seis del coincidente de dicha vecindad del que salieron heridos Fernando Andrés y Santiago Esteban, este vecino y aquel residente en ella se formó la competente causa de oficio por el alcalde Constitucional de esta villa en averiguación del autor o autores de dichas heridas a este Juzgado de $1^{\mathrm{a}}$ instancia y suponiéndolos a los relacionantes, cómplices se les condujo presos a esta cárcel Nacional y después de varios días de arresto se les puso en libertad bajo fianza por lo que y para hacer ver su inculpabilidad y reclamar los prejuicios y daños que se les ha causado no pudiendo menos de depurar persona que lo practique en su nombre en este juzgado a efecto desde luego en la vía y forma que nos haya lugar [...] juntos insolidum otorgan y dan y confieren todo su poder cumplido el que se requiere... amplio general y sin limitación alguna a Don Antolín Rodríguez vecino de esta propia villa persona de nuestra satisfacción y confianza en calidad de que ante el Sr. Juez de $1^{\text {a }}$ instancia de esta villa y su partido y demás Tribunales competentes pida la entrega de autos y que con vista de ella se les absuelvan y den por libres a los otorgantes de la criminalidad por la que se les imputa y que se les abonen los gastos, daños y perjuicios que se le ha seguido haciendo las demás provisiones... a cuyo fin el presente D. Antolín y sus sustitutos [...]

Firman: El notario D. Pío González García, Isidro Vicente y el testigo Juan de Pedro. 


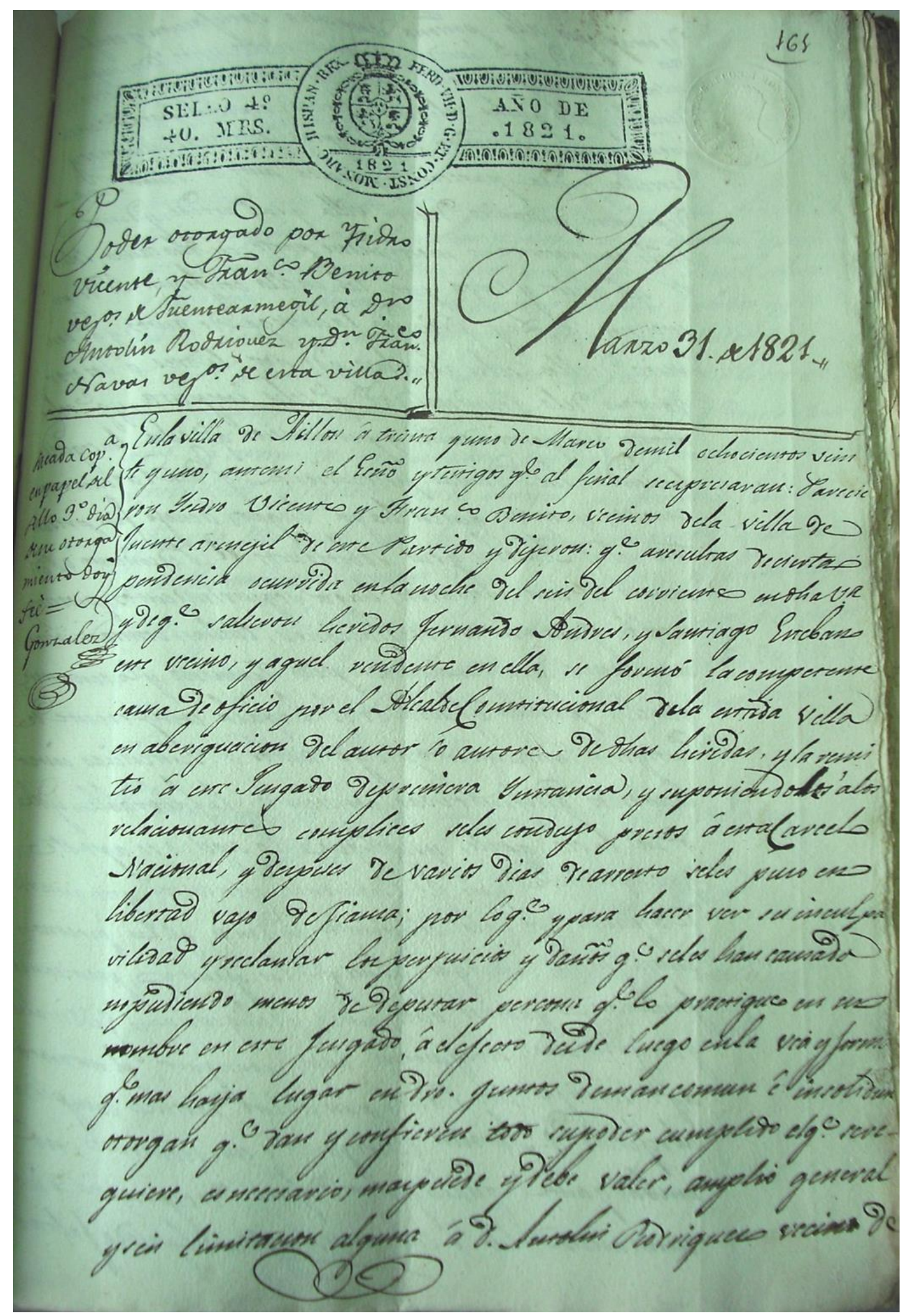

Fig.: 7

Poder otorgado a Don Antolín Rodríguez para pedir al Juez de $1^{\mathrm{a}}$ instancia la entrega de autos y pida la absolución de los otorgantes. Ayllón.

Archivo Histórico de Segovia.1821, p. 1 de 3. 
LA EDITORIAL BURGALESA HIJOS DE SANTIAGO RODRÍGUEZ (1891-1936): ANÁLISIS DE LOS LIBROS ESCOLARES

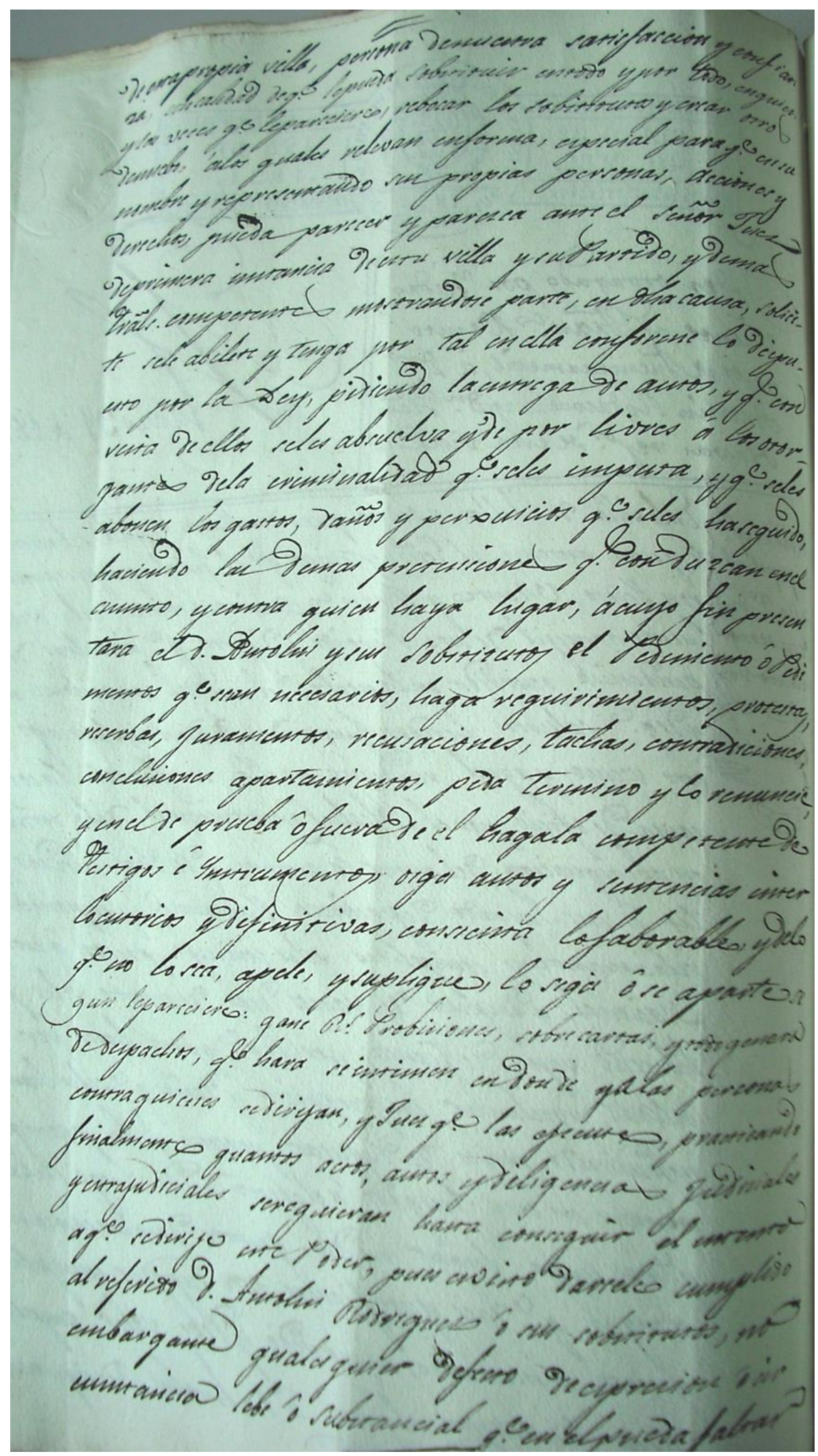

Fig.: 8

Poder otorgado a Don Antolín Rodríguez para pedir al Juez de $1^{a}$ instancia la entrega de autos y pida la absolución de los otorgantes. Ayllón.

Archivo Histórico de Segovia.1821, p. 2 de 3. 


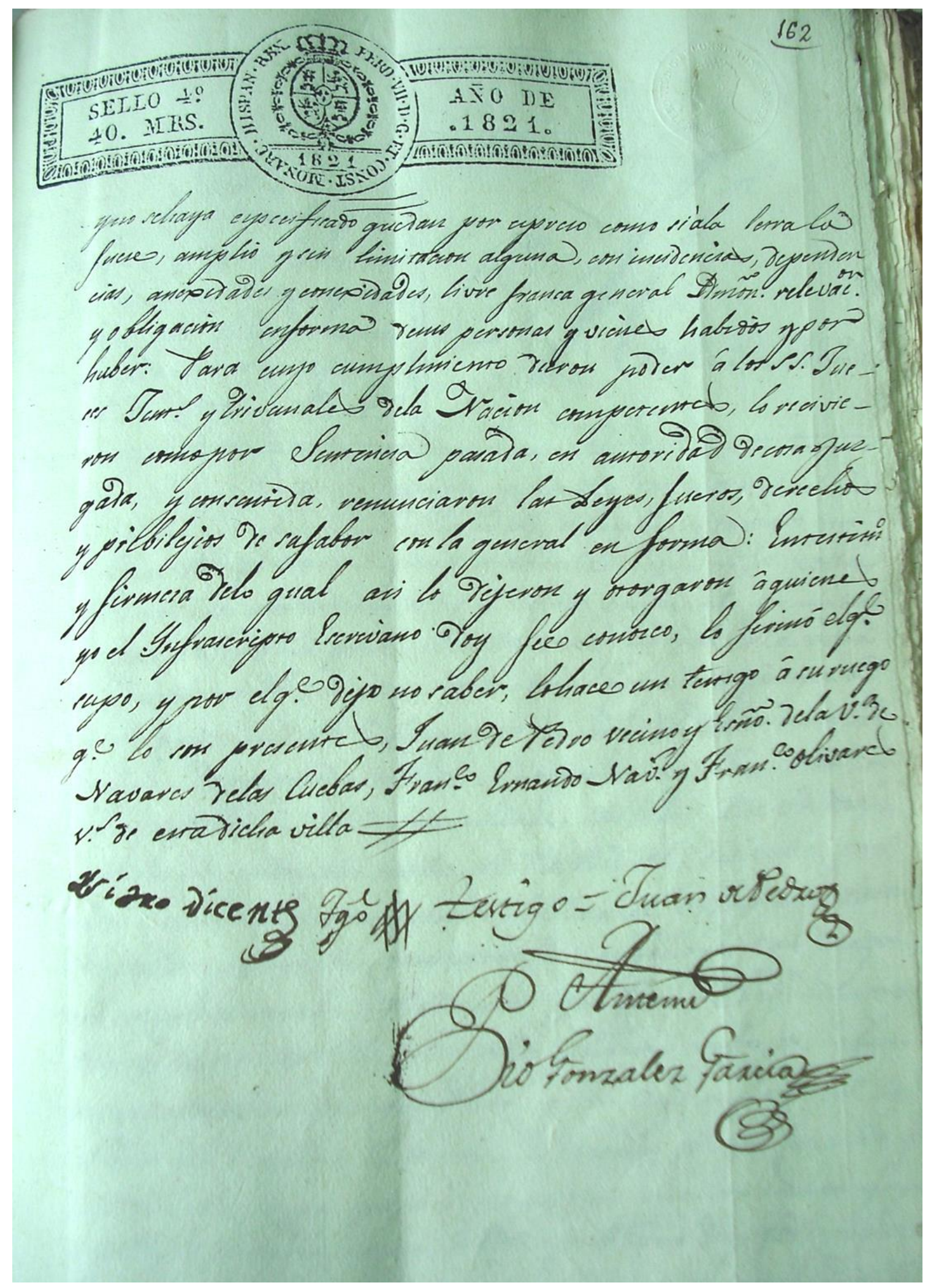

Fig.: 9

Poder otorgado a Don Antolín Rodríguez para pedir al Juez de $1^{\mathrm{a}}$ instancia la entrega de autos y pida la absolución de los otorgantes. Ayllón.

Archivo Histórico de Segovia.1821, p. 3 de 3. 


\section{Arrendamiento de una casa a D. Antolín Rodríguez y consorte a favor de $D^{a}$ Manuela Laredo, en Burgos el 20 de abril de 1831.}

Arrendamiento de una casa a D. Antolín Rodríguez y consorte a favor de $\mathrm{D}^{\mathrm{a}}$ Manuela Laredo, todos vecinos de esta ciudad.

Sépase por esta pública escritura de arrendamiento, vienen como nosotros D. Antolín Rodríguez y $\mathrm{D}^{\mathrm{a}}$ Luisa Alonso marido y mujer legítimos vecinos de esta ciudad de Burgos, premisa entre nosotros la venia licencia y consentimiento marital...otorgamos: que tomamos en renta $y$ arrendamiento de $\mathrm{D}^{\mathrm{a}}$ Manuela Laredo, convecina una casa que la pertenece con el número diez y seis por tiempo y espacio de tres años que empezamos a correr y contarse desde el día 24 de junio del año corriente y de ser fin en otro tal día del que vendrá de mil ochocientos treinta y cuatro por la renta en cada uno de mil ciento cuarenta reales vellón en moneda sonante y contante usual y corriente y no en otra especie papel moneda creada y crearse pueda, puesto al vencimiento de cada uno de los plazos que se estipularan y por cuenta y riesgo en la casa y poder de la nominada $\mathrm{D}^{\mathrm{a}}$ Manuela Laredo o de la persona que legítimamente en esta dicha ciudad la represente, pagados por medios años, siendo la primera paga y en ella quinientos setenta y cinco reales para el mismo día veinte y cuatro de junio del año corriente y en el que hemos de entrar a habitar dicha casa y se da adelantada por vía de fianza y se ha de seguir hasta que se firme el arriendo y por consecuencia la segunda paga ha de ser y en ella otros quinientos setenta y cinco para el día 24 de diciembre de este mismo año corriente y así sucesivamente hemos de ir haciendo las demás pagas hasta la conclusión de los tres años convenidos y pasados algunos de los plazos convenidos o estipulados sin así haberlo cumplido queremos ser ejecutados por esta escritura y que a nuestra costa puedan enviar persona a la cobranza al sitio o lugar donde nosotros y nuestros bienes seamos habidos por la cual pagaremos por sus salarios a razón de quinientos maravedíes por cada un día de los que la tal cobranza se detuviere y ocupare incluso los de caminos contados estos al respecto de siete leguas y por otros salarios y demás costas que se invoquen que dejamos[...] y además de cuanto en dicha escritura de observar, guardar y cumplir las condiciones siguientes:

$1^{\circ}$ que durante los tres años de este arrendamiento hemos de traer dicha casa bien cuidada y administrada conservando todo lo que haya en ella de puertas, ventanas con sus cerraduras y llaves y cristales en el modo y forma que nos sea entregada para lo cual nos será dado por la $\mathrm{D}^{\mathrm{a}}$ Manuela un inventario de todo ello para cuando nos hayamos de salir de dicha casa hacer la entrega con su cuenta y razón y si algo faltare serlo de nuestra cuenta. 
$2^{\circ}$ que dicha casa no la hemos de poder subarrendar en el todo ni en parte sin expresa licencia por escrito del dueño.

$3^{\circ}$ en este arrendamiento no se comprende la oficina que en dicha casa está destinada para cuadra quedando a el libro uso de la mencionada $\mathrm{D}^{\mathrm{a}}$ Manuela o de la persona que legítimamente la pueda representar para lo cual teniendo la puerta principal de dicha casa dos llaves, tendrá la $\mathrm{D}^{\mathrm{a}}$ Manuela la una para la entrada y salida de dicha cuadra.

$4^{\circ}$ que pasados los tres años de arrendamiento no quisiésemos seguir con dicha casa dos meses antes de la conclusión llevará de requerimiento al dueño y lo mismo si tuviéramos que continuar para otorgar nueva escritura haciéndolo en igual forma para con nosotros sino gustase que sigamos con ella.

$5^{\circ}$ que si siguiésemos con mencionada casa algún año más de los tres sin que preceda dicho requisito de requerimiento por el o los que fueren hemos de pagar la misma renta y observar las mismas condiciones que si fuese por esta escritura. Al cumplimiento de todo obligamos nuestras personas y bienes presentes y futuros bajo el competente poderío de justicias y... leyes de nuestro fuero con la general en forma y a mayor abundamiento yo la $\mathrm{D}^{\mathrm{a}}$ Luisa Alonso renuncio la sesenta y uno... y demás de mi sexo de cuyos efectos he sido enterada por el notario presente: juro en legal forma no quebrantar este contrato [...] Lo otorgamos y lo firmamos así, siendo testigos D. Santiago Casero, D. Manuel Arnaiz y D. Manuel Gutiérrez vecinos de esta ciudad de Burgos, en ella a 20 de abril de 1831 de que yo el notario doy fe y del conocimiento de los otorgantes y testigos.

Firmado por el notario Agustín de Espinosa, Antolín Rodríguez y Luisa Alonso. 
LA EDITORIAL BURGALESA HIJOS DE SANTIAGO RODRÍGUEZ (1891-1936): ANÁLISIS DE LOS LIBROS ESCOLARES

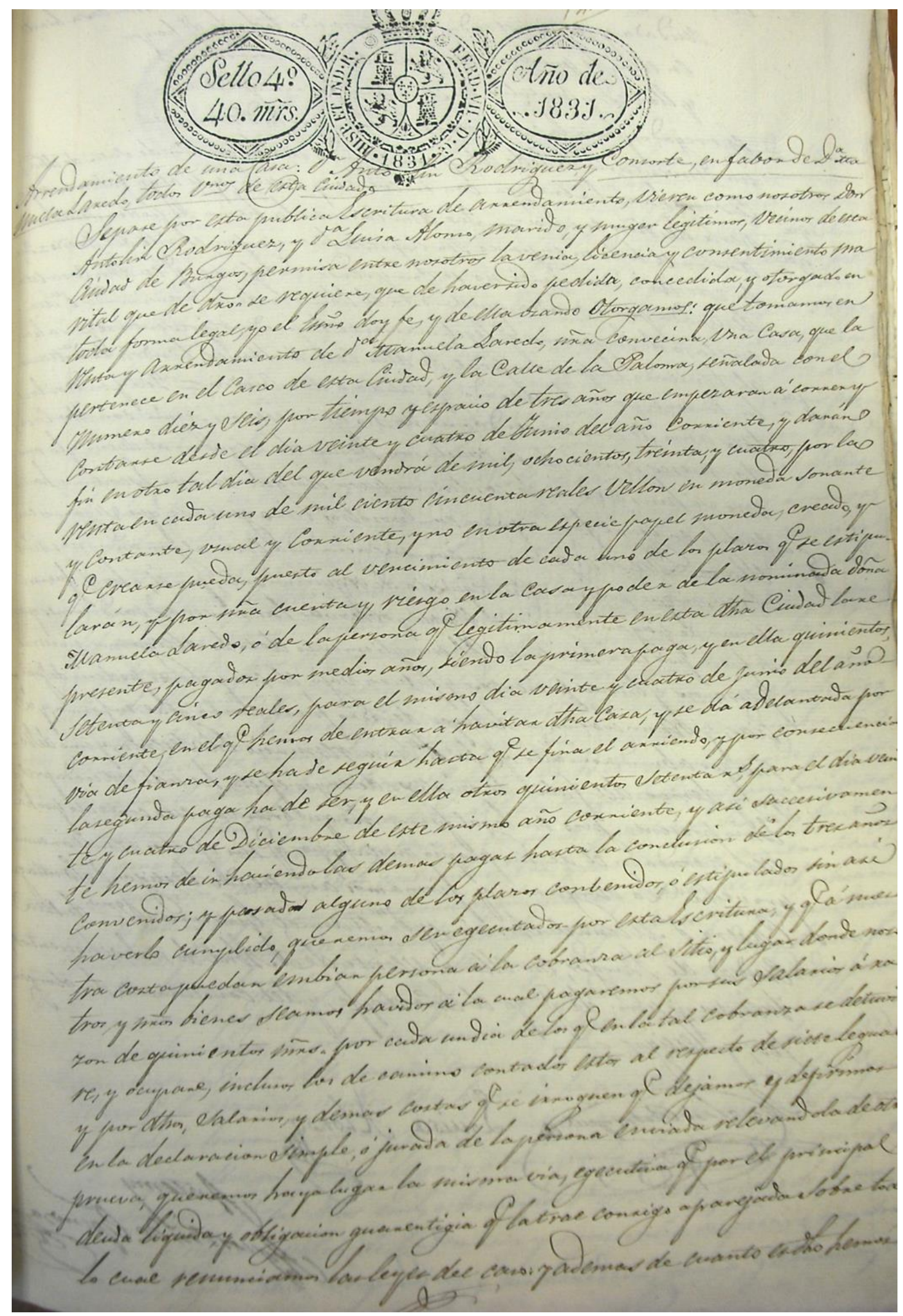

Fig.: 10

Arrendamiento de una casa a D. Antolín Rodríguez y consorte a favor de $\mathrm{D}^{\mathrm{a}}$ Manuela Laredo. Calle La Paloma ${ }^{\circ}$ 16. Burgos.

Archivo Histórico Provincial de Burgos. 1931, p. 1 de 2. 


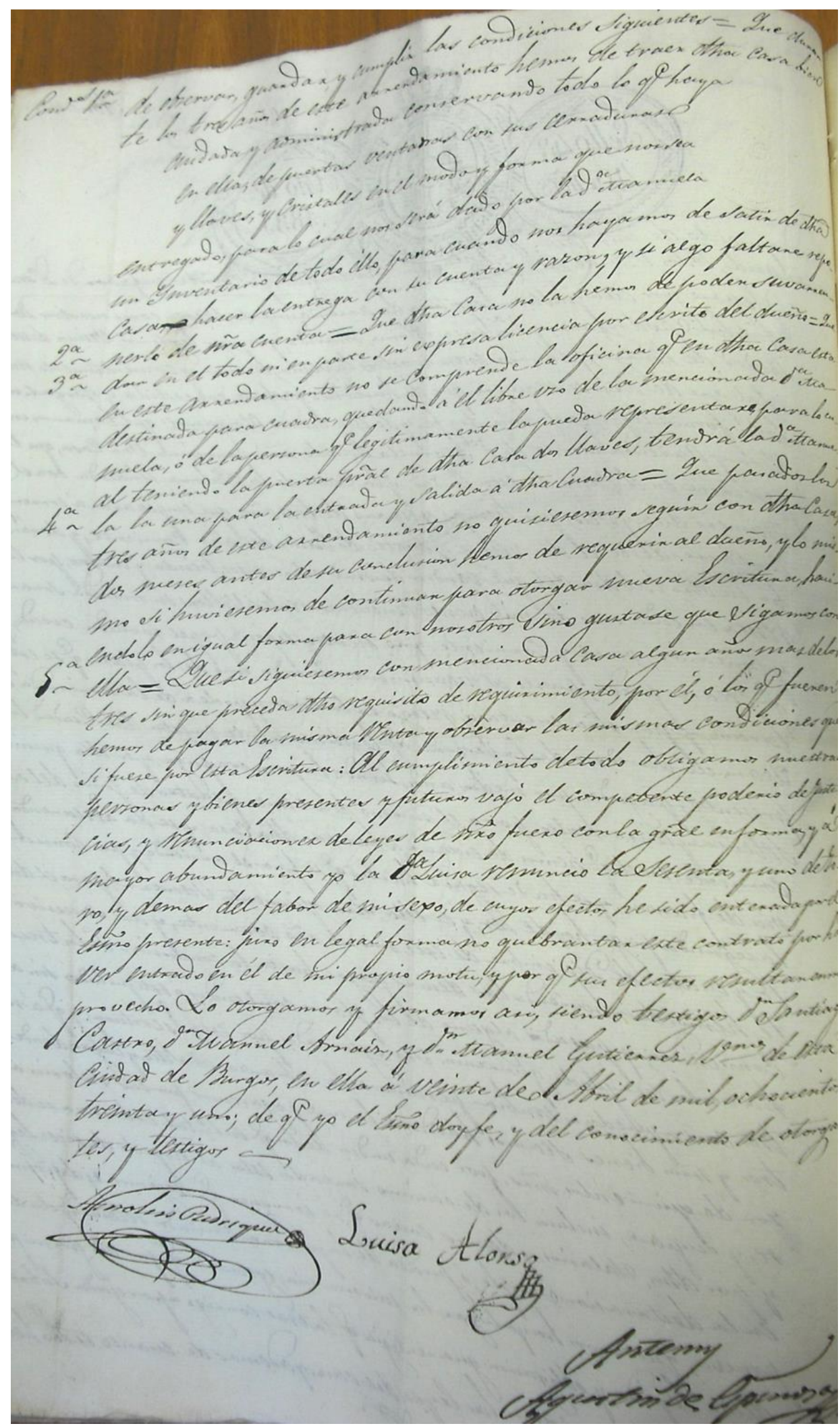

Fig.: 11

Arrendamiento de una casa a D. Antolín Rodríguez y consorte a favor de $\mathrm{D}^{\mathrm{a}}$ Manuela Laredo. Calle La Paloma ${ }^{\circ} 16$. Burgos.

Archivo Histórico Provincial de Burgos. 1931, p. 2 de 2. 


\section{Arrendamiento de una casa a D. Antolín Rodríguez y consorte a favor de D. Florentín Izquierdo, en Burgos 8 de mayo de 1833.}

Sépase por esta pública escritura vieren como nosotros D. Antolín Rodríguez y $\mathrm{D}^{\mathrm{a}}$ Luisa Alonso marido y mujer legítimos vecinos de esta ciudad de Burgos, entre nosotros y para lo cual di licencia y consentimiento de que de uno a otra y de otra a uno se requiera sea concedida y otorgada en toda forma legal de que el presente escrito certifica y de ella usando otorgamos que tomamos y recibimos en renta y arrendamiento del señor D. Florentín Izquierdo vecino de la villa de Reinosa la casa en que al presente vivamos y que $\mathrm{D}^{\mathrm{a}}$ Manuela Laredo vecina y del comercio que fue de esta ciudad sita en la casa de ella y a la calle de la Paloma señalada con el diez y seis por tiempo y espacio de seis años y la renta en cada cinco de ellos de mil doscientas cincuenta reales de vellón pagado en metálico y con exclusión de todo papel moneda creado o que se pueda crear por medios años a seiscientas veinticinco reales por cada uno, cuyos seis años entran a correr y contarse desde el día veinticuatro de junio del corriente siendo la paga de un medio año anticipada por razón de fianza y bajo esta conformidad la primera para dicho día de San Juan de Junio y en ella los seiscientos veinticinco reales y la segunda y otro igual cantidad para el día de Navidad también de esta año y así sucesivamente las demás pagas hasta la conclusión de este arrendamiento [...] Verificado por el que sean y las costas a que podamos dar lugar ha de poder repetir contra nuestros bienes por la vía sumaria ejecutada y todo lo que sea en derecho se hará.

Hemos de guardar y cumplir las condiciones siguientes: que los seis años de duración de este arrendamiento hemos de traer bien cuidada la casa hacer el mejor uso de ella y no poder subarrendarla en el todo si en parte, licencia por cuenta del dueño y en otro caso aunque nos de poder para desahuciar en la citada casa

Que el dueño y sin ninguna responsabilidad es árbitro para poder ceder la casa cuando le acomode. Que al fin de los seis años debe responder de todos los efectos que comprende el inventario formado en este día de enseres de la casa.... Antes del arrendamiento y no quisieren seguir ocupando le hemos de requerir al dueño para que busque nuevos inquilinos y lo mismo ha de hacer el para con nosotros si no gusta que sigamos habitándola y si lo hiciésemos sin proceder este requisito hemos de pagar el tiempo que sea de esta escritura sin ningún descuento. Con cuyas condiciones que se han de guardar y cumplir religiosamente y según que ellas son y así tomamos y recibimos de leyes de nuestro fuero con la general en forma yo la $\mathrm{D}^{\mathrm{a}}$ Luisa renuncio la ley sesenta y uno y las demás de mi sexo que me pudieran ser útiles juro en toda forma legal no quebrantar este contrato como hecho de mi propio mutuo y porque sus efectos se conviertan en mi provecho. Lo otorgamos así y firmamos en 
Burgos a ocho de mayo de mil ochocientos treinta y tres siendo testigos Diego Álvarez, D. Manuel García Salazar y Don Gregorio Merino vecinos aquellos y naturales y residente este en ella de que yo el escribano doy fe y del conocimiento de los testigos y otorgantes.

Firmado por el notario D. Agustín de Espinosa y Antolín Rodríguez

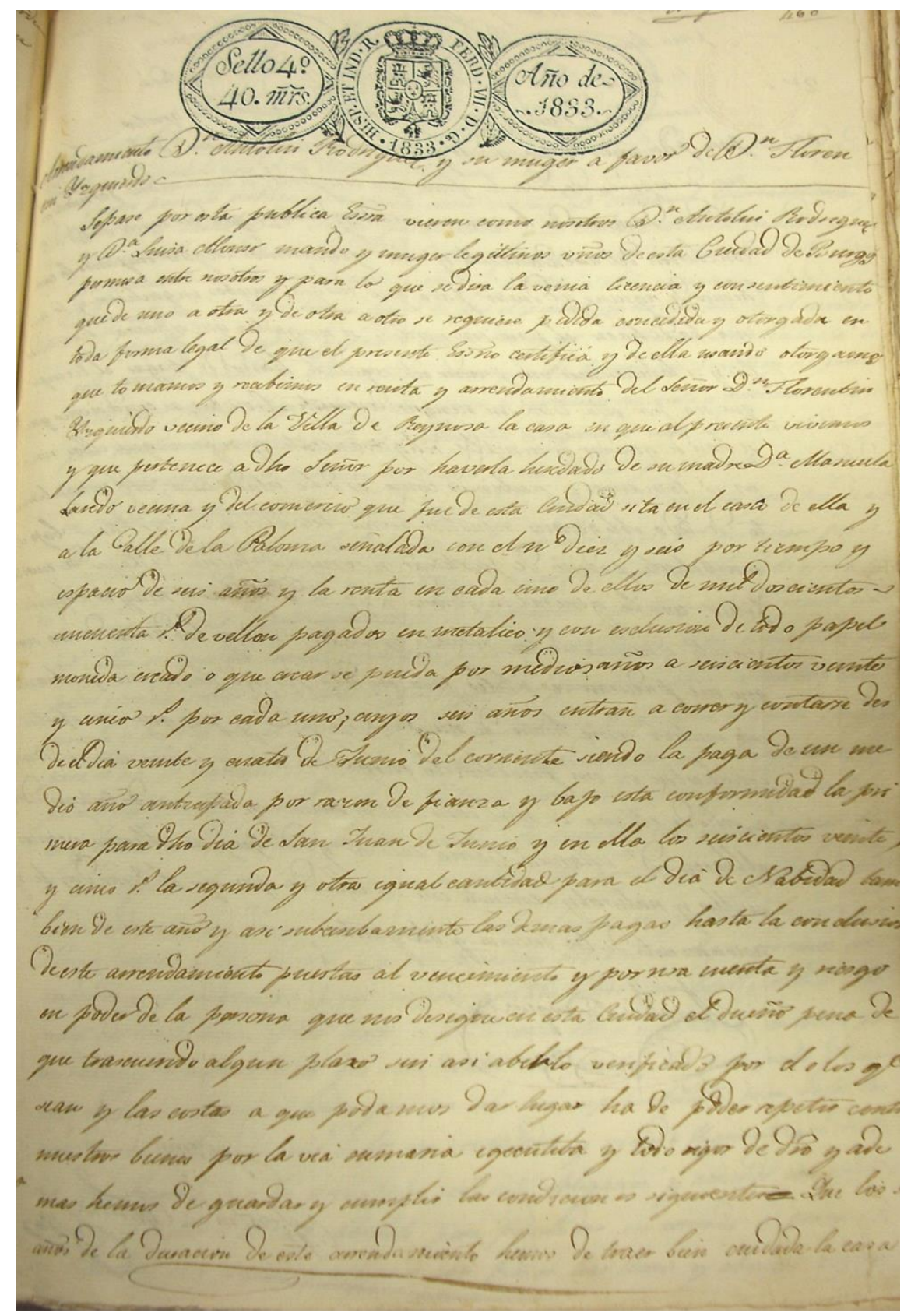

Fig.: 12

Arrendamiento de una casa a D. Antolín Rodríguez y consorte a favor de D. Florentín Izquierdo. Calle La Paloma $\mathrm{n}^{\mathrm{o}} 16$. Burgos.

Archivo Histórico Provincial de Burgos. 1833, p. 1 de 2. 


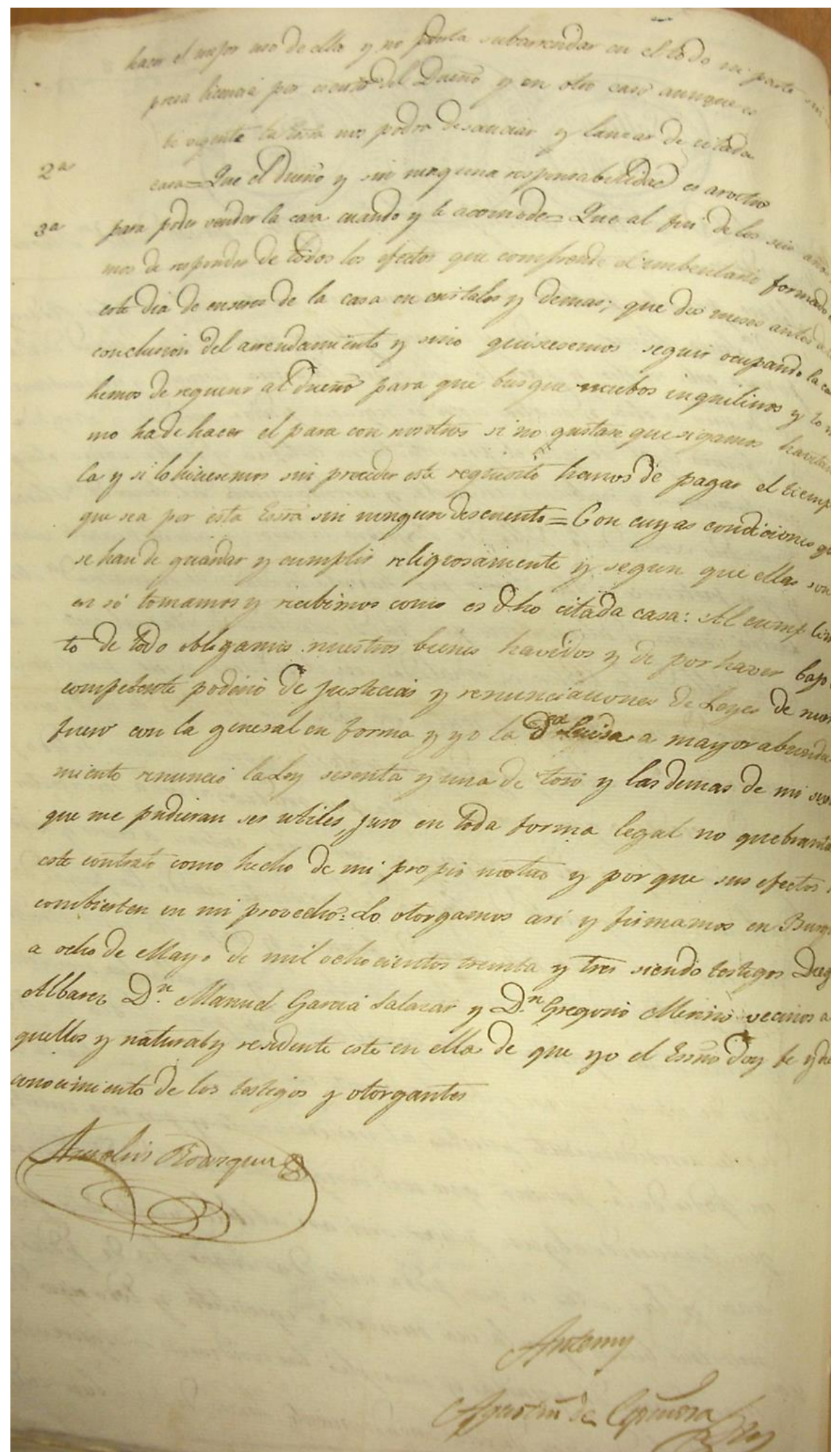

Fig.: 13

Arrendamiento de una casa a D. Antolín Rodríguez y consorte a favor de D. Florentín Izquierdo. Calle La Paloma ${ }^{\circ} 16$. Burgos.

Archivo Histórico Provincial de Burgos. 1833, p. 2 de 2. 


\section{Escritura de fianza de D. Antolín Rodríguez y consorte, vecinos de la ciudad de Burgos a favor de la Excelentísima Sra. Marquesa, viuda de la Rambla, por su apoderamiento el 7 de diciembre de 1832.}

Escritura de fianza D. Antolín Rodríguez Alonso y su consorte vecinos de esta ciudad a favor de la Excelentísima Sra. Marquesa viuda de la Rambla.

Sépase para esta pública escritura de obligación y fianza en forma como nosotros D. Antolín Rodríguez y $\mathrm{D}^{\mathrm{a}}$ Luisa, marido y mujer legítimos, vecinos de esta ciudad de Burgos con licencia y consentimiento que de uno a otro y de otra a otro, se requiera, pedida, concedida y otorgada en toda forma legal de que yo, el presente escribano certifico, otorgamos que nos obligamos a administrar, regir y gobernar, todos los bienes, fincas rusticas y urbanas que en esta ciudad y fuera de ella de la Excma. Sra. Marquesa viuda de la Rambla, vecina de la ciudad de Úbeda, como madre tutora y curadora de su menor hijo D. Bernardo de Orozco, actual marqués del mismo título, cuyo encargo confió al Sr. coronel D. Lorenzo Fernández, teniente coronel mayor, del regimiento de Caballería, quinto de la Albuera que guarnece al presente en esta ciudad de Burgos con la cláusula de que le pudiese sustituir en quien fuera de su agrado caso de tener que salir de esta capital, según que caso así, pues aparece en el citado poder fechado y otorgado para dicha excelentísima señora, en citada ciudad de Úbeda, a veinte de noviembre del corriente año, fidelidad de Bonifacio de la Quadra escribano público y del número de aquella ciudad y como que el Señor D. Lorenzo Fernández no puede contar con ninguna seguridad de permanencia en esta capital por el servicio que está prestando en la milicia, le ha sustituido en este día y testimonio del presente escribano para los mismos fines y efectos que le ha sido conferido las resultas y poniéndole en ejecución por la aceptación hecha de su encargo, obligamos todos nuestros bienes, créditos y acciones presentes y futuras a administrar, regir y gobernar bien y fielmente todos los predios rústicos y urbanos que en esta ciudad y fuera de ella pertenecen a v. e. en el concepto que responde por su Marquesado de la Rambla percibir sus rentas, dar cuenta con pago de ellas, como y cuando se le ordene, ayudando de los mejores aumentos y requerimientos del Estado, para su ejecución y costas y el más exacto cumplimiento además de la obligación que en general tenemos hechos de todos nuestros bienes, créditos y acciones presentes y futuras, que reiteramos ponemos para expresadas hipotecas dejo:

Hipotecas: Lo primero unas tierras en términos de la villa de Isar, al que dicen Carresetillo de seis celemines de sembradura al poco más o menor que surca por las aguas, cierzo, arroyo, solano y abrigo, tierras de beneficia.

Otra en término de la misma villa y al que dicen La redondilla de ocho celemines de sembradura que surca el cierzo con otra del Convento de 
Monjas de Palacios y al abrigo con otra de Joaquín López vecino de dicha villa.

Otra adonde dicen La Lengua término de la propia villa de siete celemines de sembradura que surca por las aguas, cierzo, solano, camino y por regañón con otra de D. Vicente Oyuelos vecino de esta ciudad.

Cuyas tres fincas son propias de mí el Antolín Rodríguez, están libres y me corresponden con otras en la citada villa de Isar por herencia de mis padres, las cuales no vendemos, cambiaremos ni llegaremos a otra deuda, ni fianza que está mientras esté a nuestro cargo la administración al que dejamos sea hecha y si lo hiciésemos sobre nosotros sea nulo sin ningún efecto ni valor, hemos de caer e incurrir en las penas...los que prometen uno y hacen otro...cumplimiento de cuanto es dicho obligamos nuestras personas y bienes habidos y por haber bajo el competente poderío de justicias y renunciaciones de leyes de nuestro fuero con la general en forma y yo la Luisa Alonso juro en toda forma legal no quebrantar este contrato como hecho de mi voluntad libre y para que sus efectos se conviertan en mi provecho: Lo otorgamos así y lo firmamos siendo testigos D. Manuel Gutiérrez, D. Ángel de Chomereal y D. Santiago Rozas vecinos de esta ciudad a quienes ya los señores otorgantes yo el notario doy fe conozco y lo firmo en Burgos a 7 de diciembre de mil ochocientos treinta y dos y de estar prevenido que de esta escritura y dentro de la ley marca se ha de tomar razón en el oficio de hipotecas del partido a que están efectos los relacionados

Firmado por el notario D. Agustín de Espinosa y D. Antolín Rodríguez. 


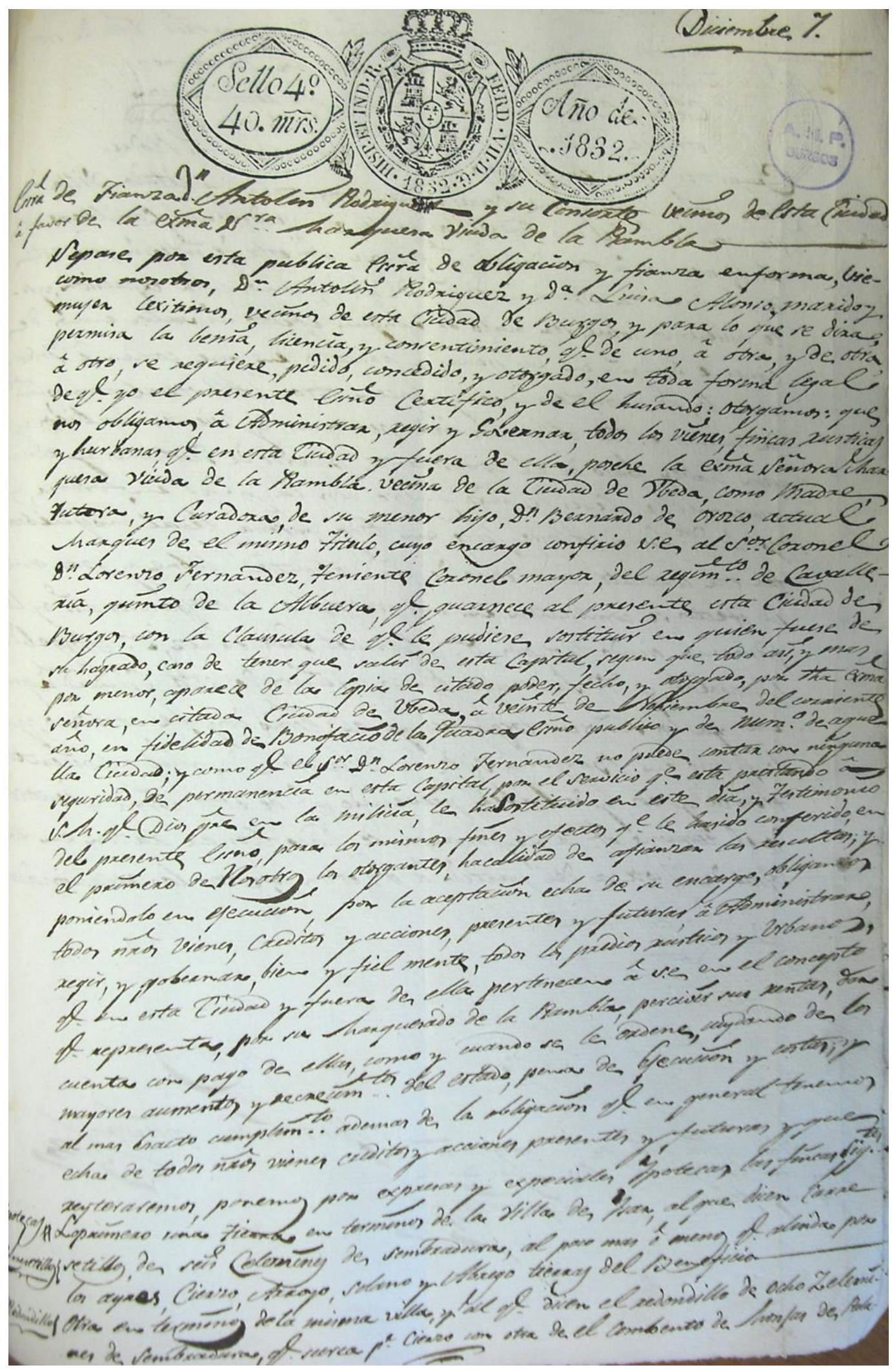

Fig.: 14

Escritura de fianza D. Antolín Rodríguez Alonso y su consorte vecinos de esta ciudad a favor de la Excelentísima Sra. Marquesa viuda de la Rambla.

Archivo Histórico de Burgos. 1832, p. 1 de 2. 


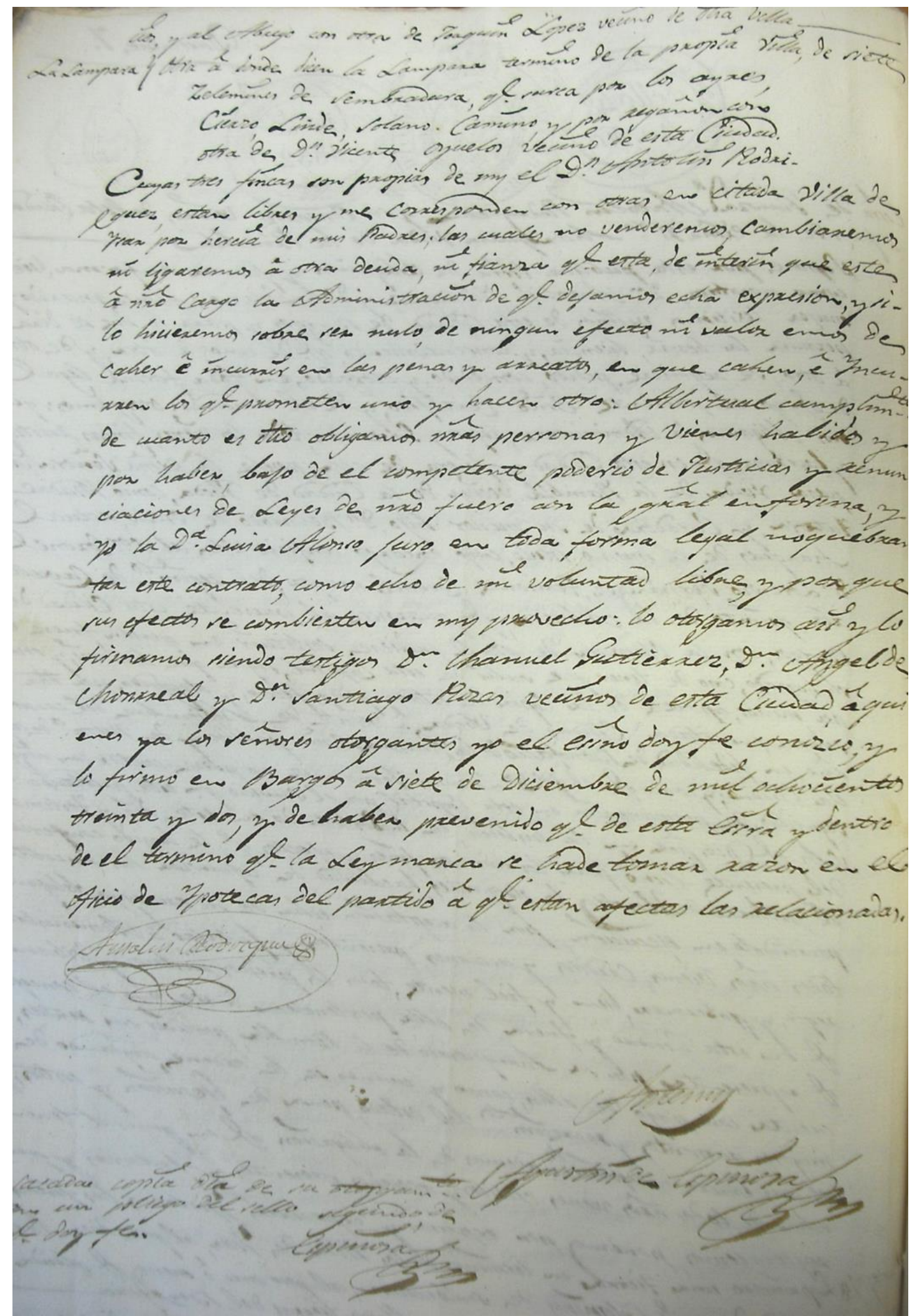

Fig.: 15

Escritura de fianza D. Antolín Rodríguez Alonso y su consorte vecinos de esta ciudad a favor de la Excelentísima Sra. Marquesa viuda de la Rambla.

Archivo Histórico de Burgos. 1832, p. 2 de 2. 


\section{Testamento de D. Antolín Rodríguez y $\mathrm{D}^{\mathrm{a}}$ Luisa Alonso en Burgos el 8 de agosto de 1834.}

Testamento de D. Antolín Rodríguez y $\mathrm{D}^{\mathrm{a}}$ Luisa Alonso su mujer vecinos de esta ciudad de Burgos.

En el nombre de Dios todo poderoso amén: notario y público sea a todos los que la presente letra de testamento viesen y leyeren como nosotros D. Antolín Rodríguez hijo habido y procreado en legítimo matrimonio de los señores $\mathrm{D}$. Julián y $\mathrm{D}^{\mathrm{a}}$ Eusebia de la Torre ya difuntos vecinos que fueron de la villa de Isar y $\mathrm{D}^{\mathrm{a}}$ Luisa Alonso marido y mujer legítimos vecinos de esta ciudad de Burgos hija con igual legitimidad de D. Juan y de $D^{a}$ Manuela Sáez ya difunta vecina de esta fue de esta ciudad hallándonos por la infinita misericordia en sana salud y entendimiento general de que el presente escrito dan fe creyendo y confesando en los altos e inefables misterios de la Santísima Trinidad, Padre, Hijo y Espíritu Santo, tres personas en uno verdaderamente son distintos tienen unos mismos atributos y componen un solo Dios verdadero y en todos los demás misterios y confiesa en nuestra madre la Iglesia Católica, Apostólica, Romana y de cuya buena fe y verdadera creencias hemos vivido bajo la misma pensamos morir y vivir como nuestra hasta la hora de la muerte para cuando esta llegue tener dispuestos las cosas temporales y que no nos anteponen nuestras almas en carrera de salvación otorga nuestro testamento y para el mejor acierto ponemos para nuestra intercesora y medianera a la Reina Santísima de los Ángeles, madre de Dios y Señora nuestra, consagrados de nuestros nombres, cuanta devoción y demás de la corte celestial y fieles de estos poderosos auxilios y bajo el unísono consejo lo hacemos y otorgamos en el modo y manera siguientes.

Lo primero encomendamos nuestras almas a Dios nuestro señor que les crió de la nada y redimió con tomar realizó de su sangre los cuerpos a la tierra donde fueron formados y a veces adornados a disposición del supremo sean sepultados en el lugar santo de nuestra parroquia de San Gil y que en ellas y por su Cabildo de señores curas, se nos hagan con día de entierro, otro de honras y durante los oficios fúnebres se celebren por el alma de cada uno, cuatro misas rezadas, pagándose las limosnas y por cada una de ella un escudo de vellón.

Mandamos que nos asistan con la cera y sufragios de regla de las cofradías de que somos hermanos que se nombre la Bula de Difuntos y florín de San Juan, que se cumplan las mandas pías forzosas y paguen los demás impuestos que se puedan imponer en esta clase y que se cubran nuestras sepulturas los días festivos y que diga la misa del año siguiente en el de mi fallecimiento. 
Mandamos que se celebren doscientas misas rezadas con la limosna de cuatro escudos de vellón por cada una de ellas, los ciento cincuenta por alivio de nuestras almas y penitencias mal cumplidas y las cincuenta restantes por los de nuestras obligaciones, advirtiendo que después de dar a la parroquia la tercera parte de estas misas las restantes queremos que se celebren en los conventos de Padres Dominicos, Franciscanos y Carmelitas de esta ciudad y sus religiosos.

Declaramos que nos hallamos casados según disposiciones de nuestra Santa Madre la Iglesia y que en este matrimonio y hasta el presente tenemos cinco hijos, que lo son D. Mariano, D. Francisco, Da Ramona, D. Santiago y D. Dámaso Rodríguez Alonso constituidos en la menor edad.

Mandamos que se cobre y pague religiosamente todo cuanto nos sea debido y nosotros podamos deber legítimamente estándose y pasándose por nuestros apuntes y libro de gobierno.

Mando yo la Luisa Alonso que las alhajas de mi adorno de cuello, orejas y manos así como las ropas de mi uso interior y exterior se distribuyan y repartan con toda igualdad entre las hijas que pueden dejar y si sola uno esta se lo llevaría todo, por vía de legado y manda particular y a los que sean y pueden les ruego que me encomiende a Dios.

Mandamos usando de las facultades que la ley nos dispensa a nuestro hijo menor D. Dámaso Rodríguez Alonso el remanente del quinto, de todos aquellos bienes, créditos y acciones y si este falleciere antes de tomar estado o llegase a tomarle quedando constituidas en la menor edad nuestra hija Ramona Rodríguez Alonso queremos que recaiga en esta, y por lo tanto y desde ahora y para entonces esto, le legamos otro quinto y remanente de nuestros bienes, créditos y acciones como en que nuestro hijo y su hermano el susodicho Dámaso y que nos encomiende a Dios.

En uso de la misma ley yo el susodicho D. Antolín Rodríguez nombro por Protectora, casadora y legítima administradora de las personas y bienes de mis hijos menores a su madre la susodicha Luisa Alonso en forma de finanzas y en su defecto a nuestro hermano D. Mariano Alonso y a este y a D. Julián López vecinos de esta ciudad para testamentarios y contadores con todas las facultades que para el mejor desempeño de este encargo necesiten.

Cumplido y pagado que sea este nuestro testamento así como todos los demás bienes, créditos y acciones que podemos dejar y el que nos sea debido nombramos e instituimos por nuestros y universales herederos a nuestros hijos habidos y que podemos haber y procrear en nuestro actual y legítimo matrimonio para que con la bendición de Dios y la nuestra la hagan herederos y disfruten y les rogamos que nos encomienden a Dios.

Por el presente y sin temor, revocamos, anulamos y damos y dejamos sin ningún efecto ni velar otro cualquiera testamento codicilo o poder para testar que con antelación a este podamos tener hecho por escrito o de 
palabra que ninguno sino el que queremos que valga ni haya fe ni juicio ni fuera de él, así lo otorgamos y firmamos en esta ciudad de Burgos en ella a ocho de agosto de mil ochocientos treinta y cuatro siendo testigos llamados y pagados a nuestra instancia D. Ángel de Honreal, D. Jacinto Fernández y D. Antonio Ruiz vecinos de ella y a los otorgantes doy fe conozco.

Firmado por el notario D. Agustín de Espinosa y por D. Antolín Rodríguez y Da Luisa Alonso. 
LA EDITORIAL BURGALESA HIJOS DE SANTIAGO RODRÍGUEZ (1891-1936): ANÁLISIS DE LOS LIBROS ESCOLARES

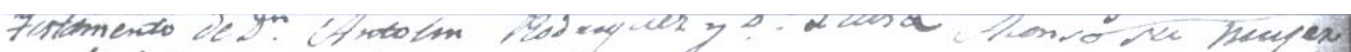

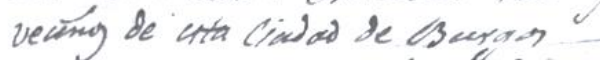

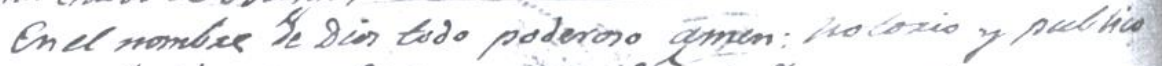

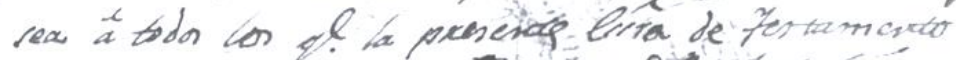

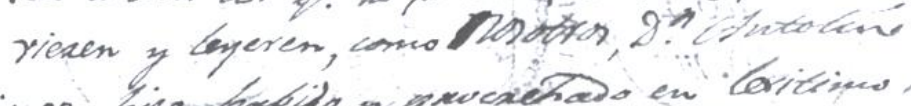

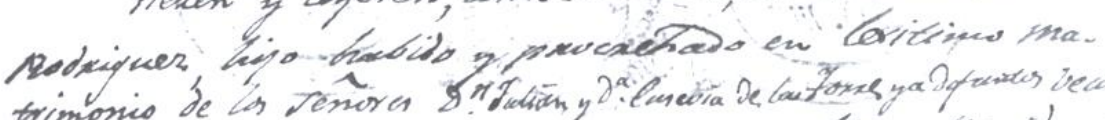

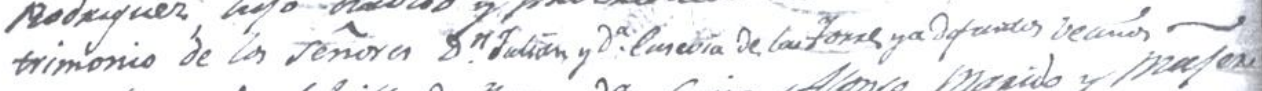

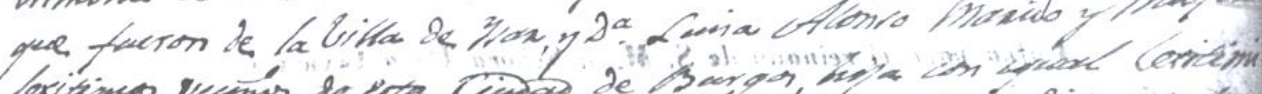

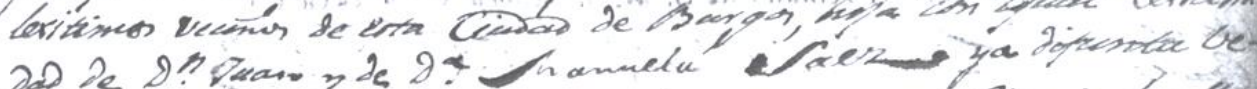

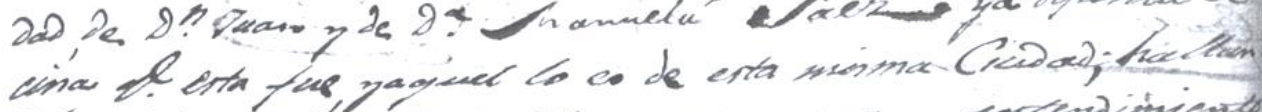

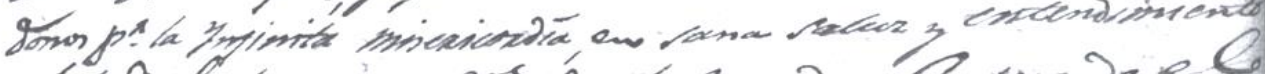

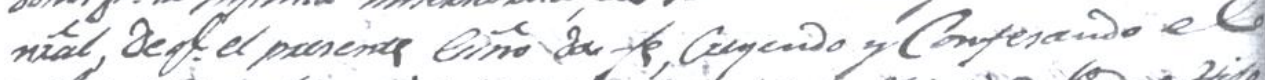

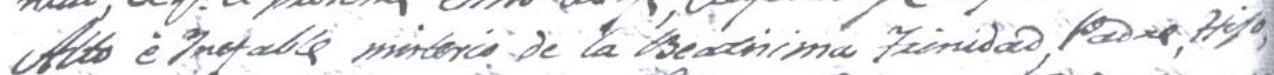

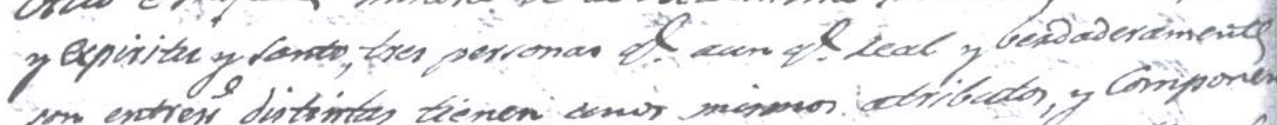

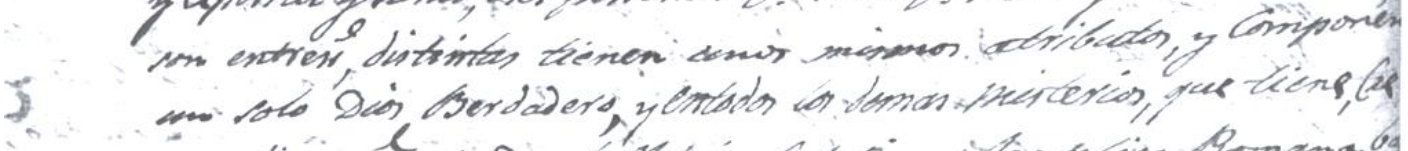

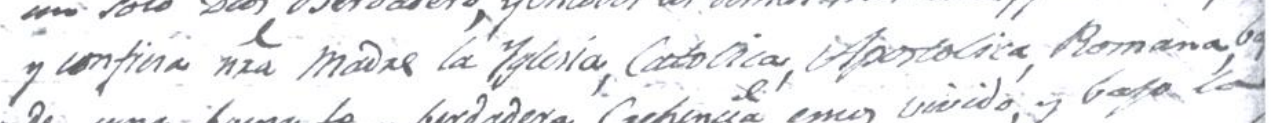

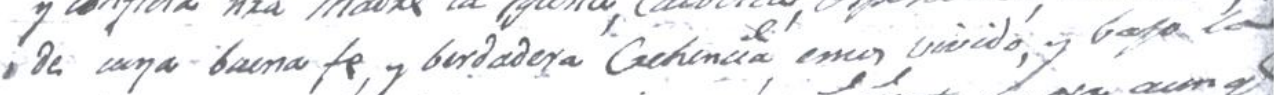

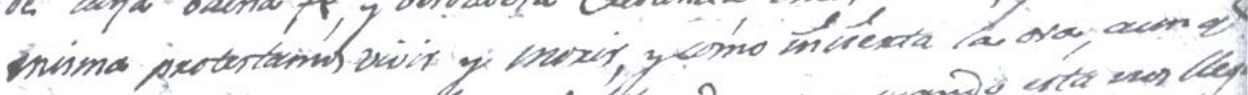

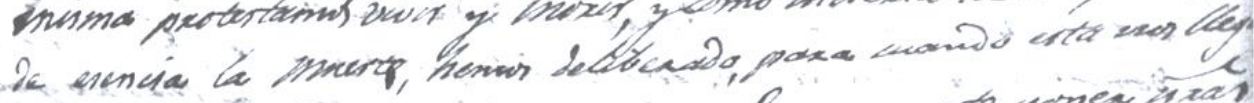

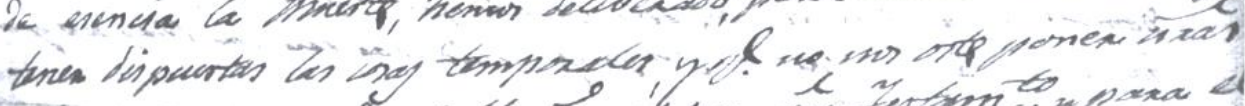

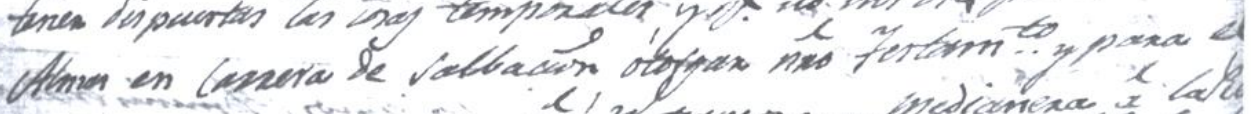

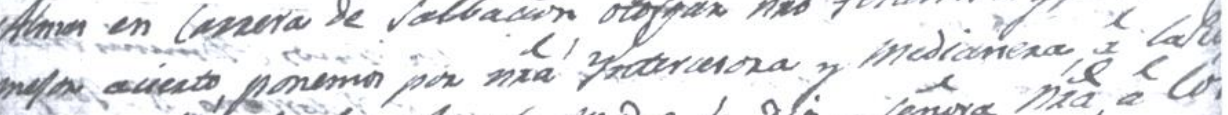

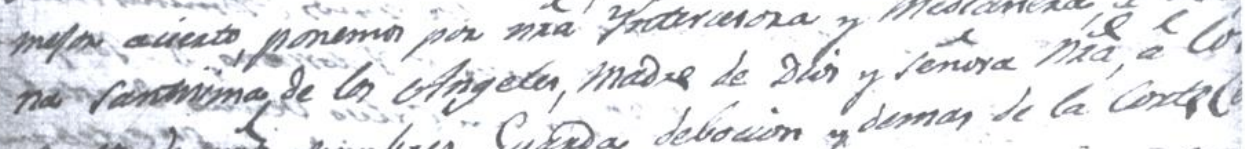

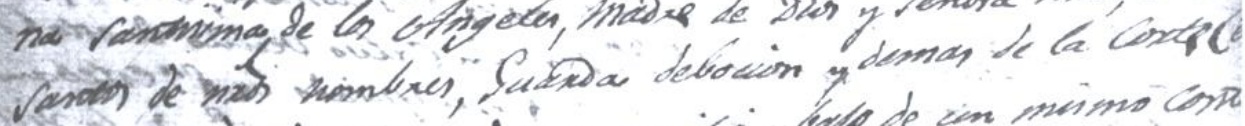

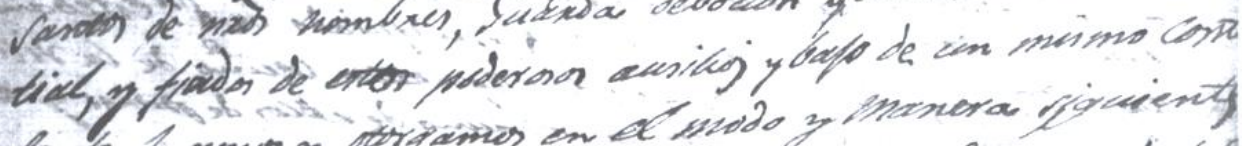

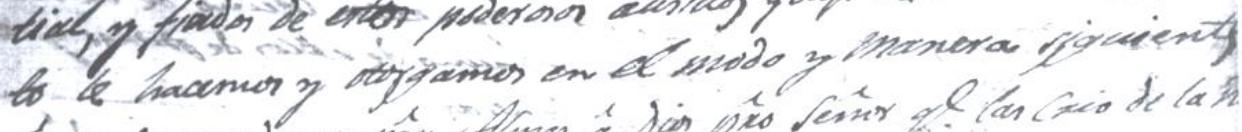

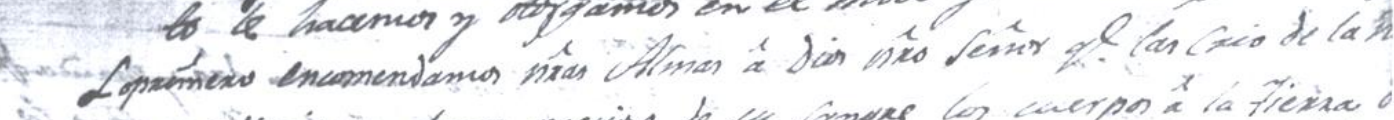

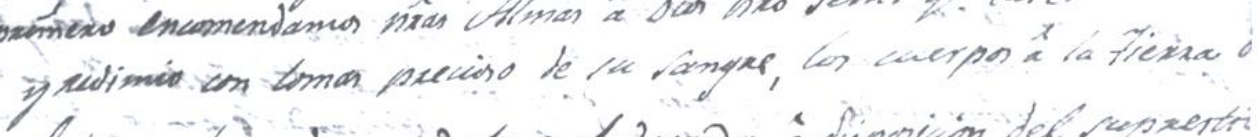

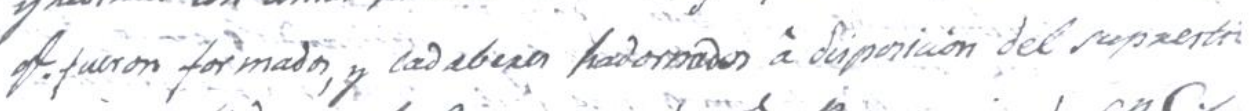

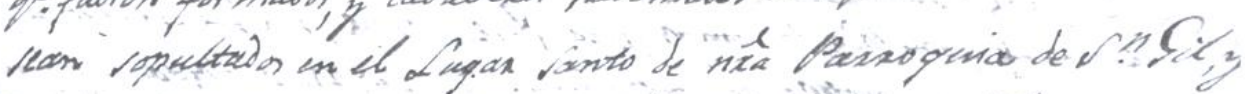

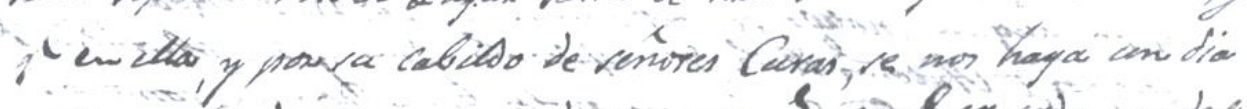

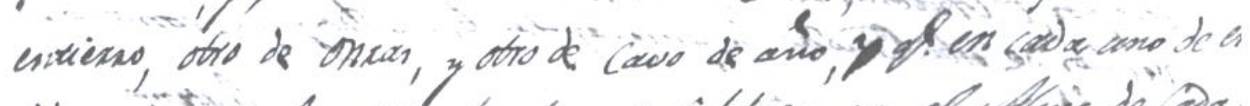

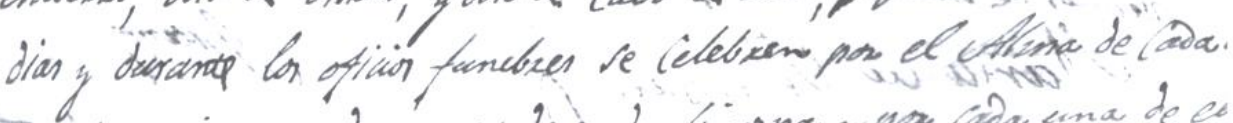

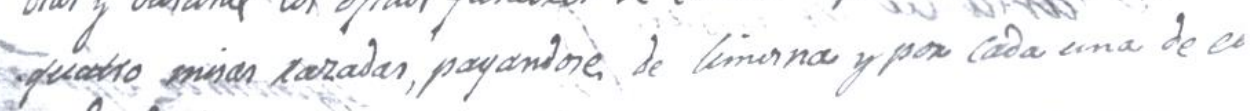
i soln do sellesis.

Fig.: 16

Testamento de D. Antolín Rodríguez y $\mathrm{D}^{\mathrm{a}}$ Luisa Alonso. Archivo Histórico de Burgos. 1834, p. 1 de 3. 


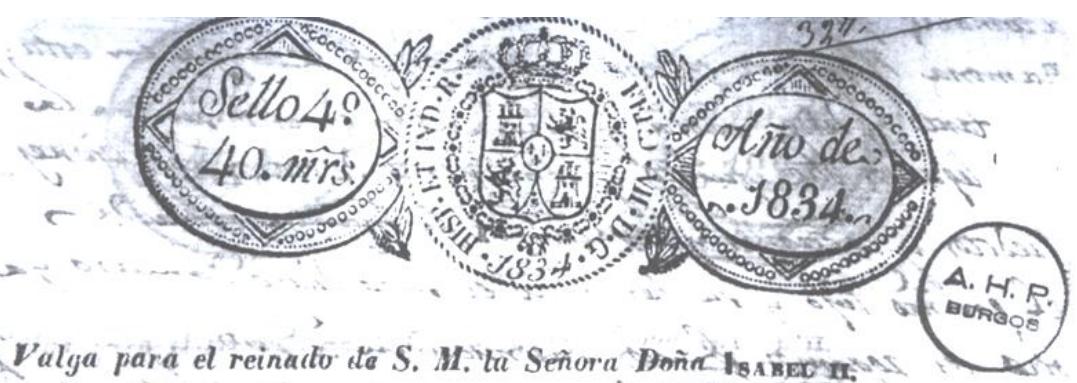

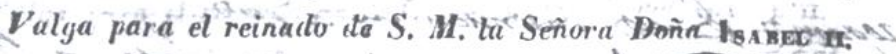

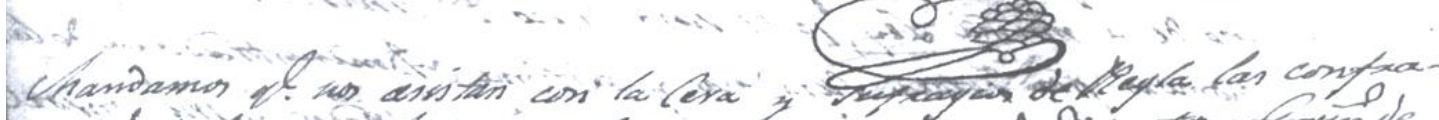

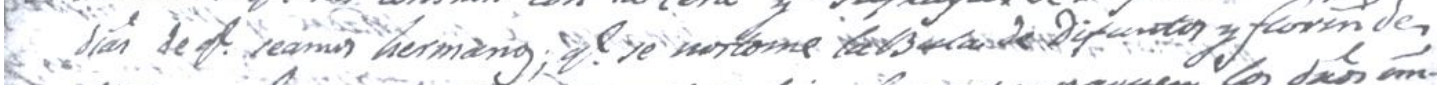

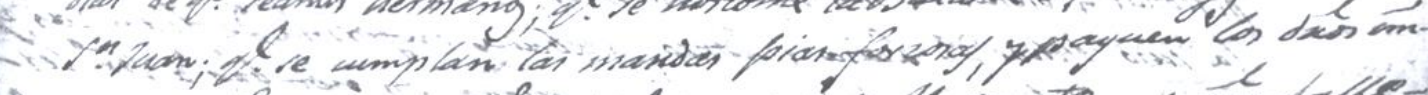

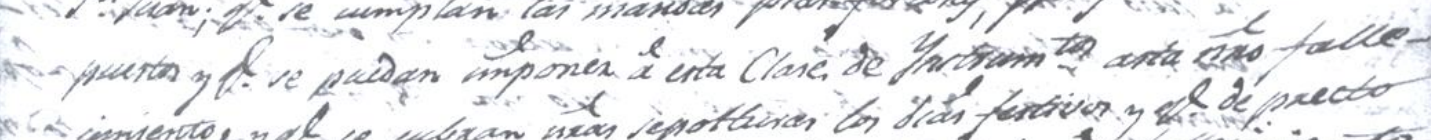

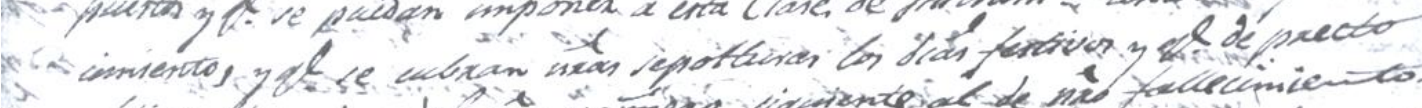

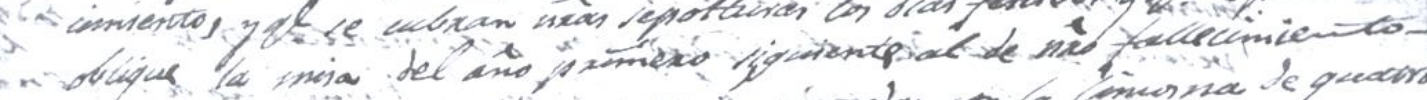

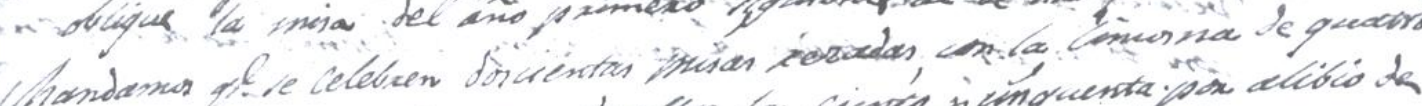

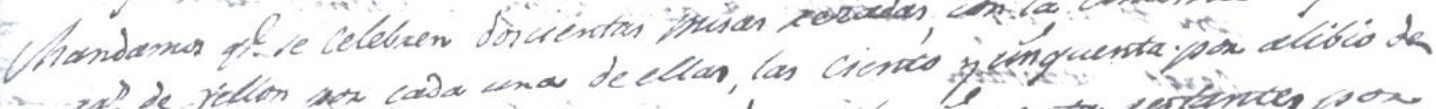

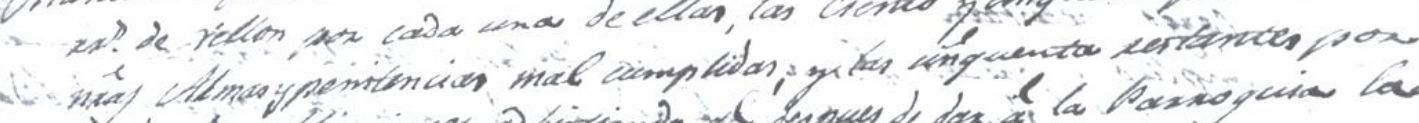

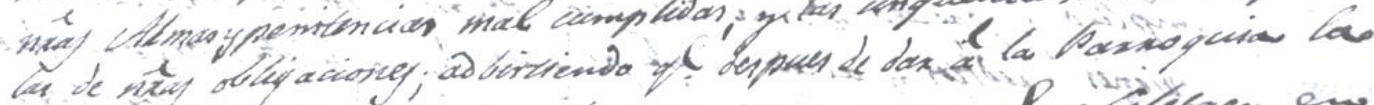

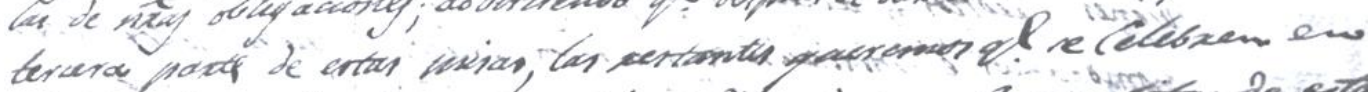

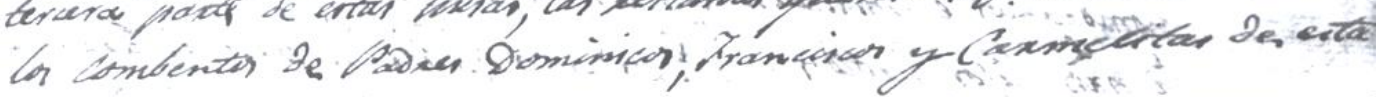

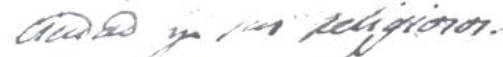

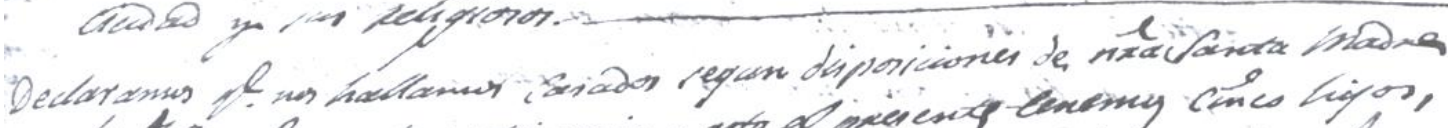

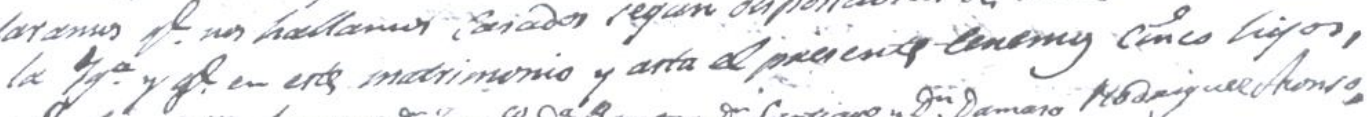

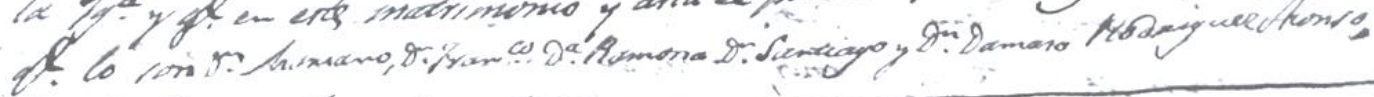
Contituitor en la moies has

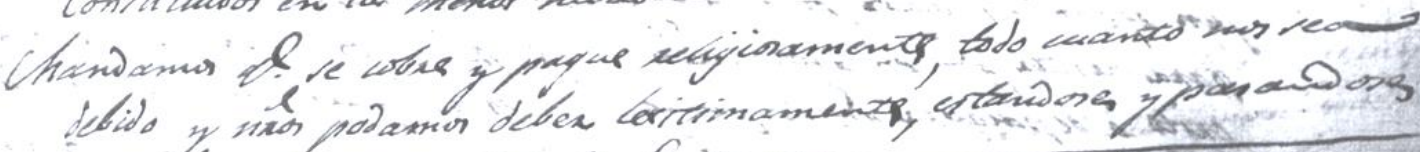

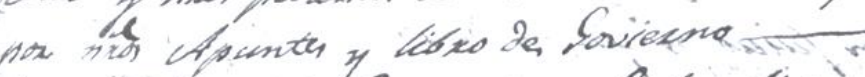

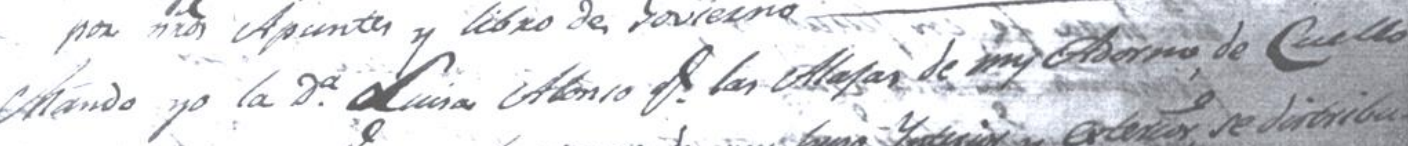

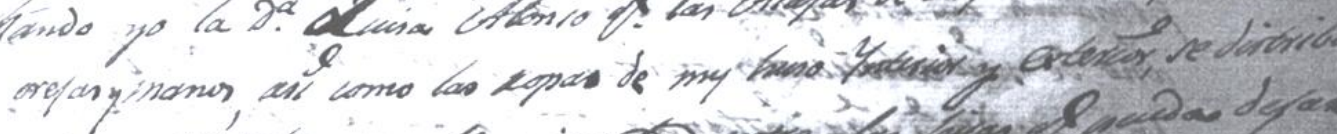

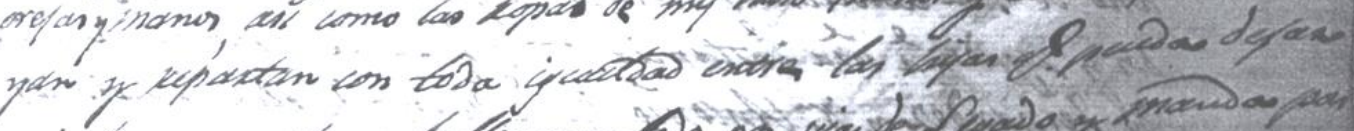

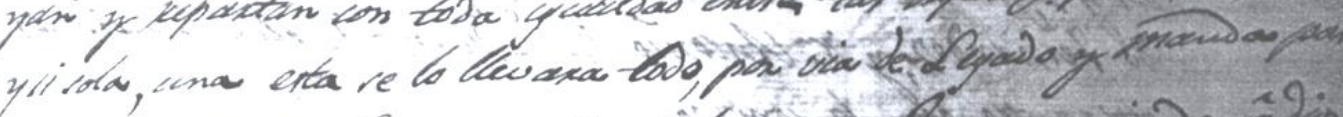

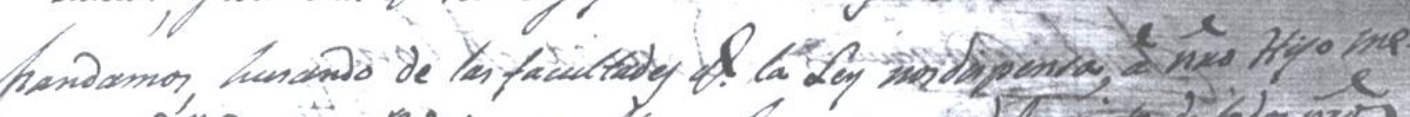

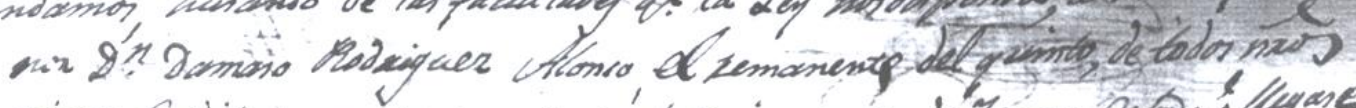

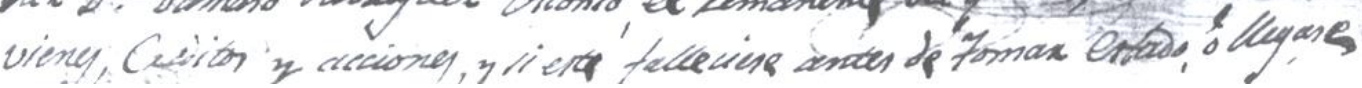

Fig.: 17

Testamento de D. Antolín Rodríguez y Da Luisa Alonso. Archivo Histórico de Burgos. 1834, p. 2 de 3. 


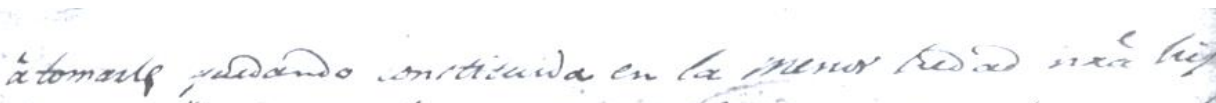

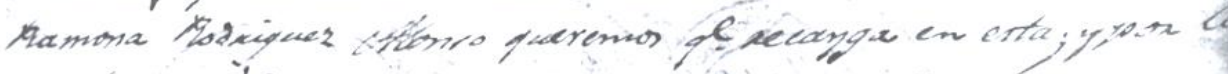

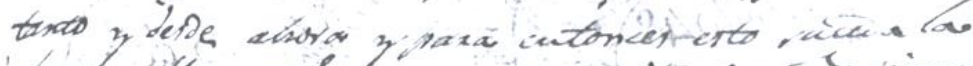

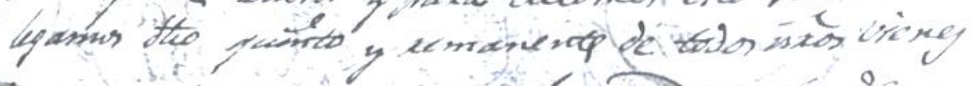

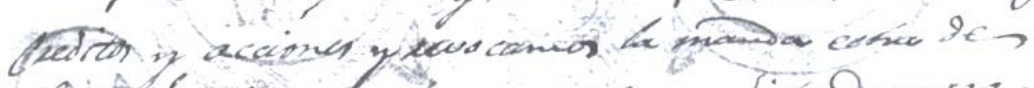

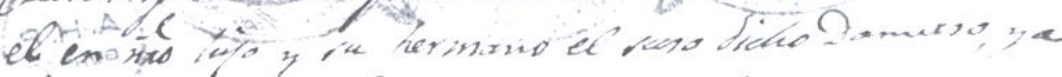

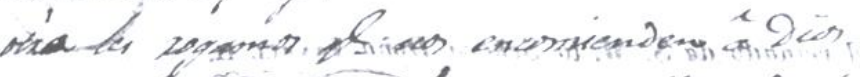

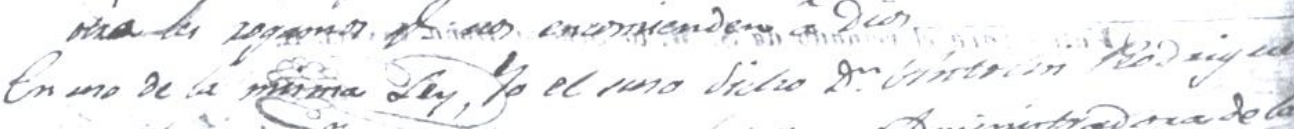

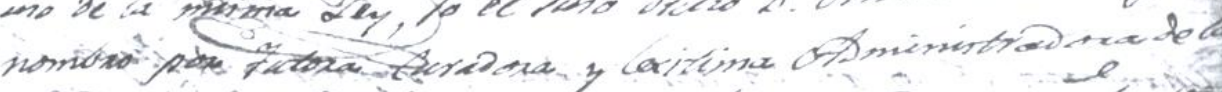

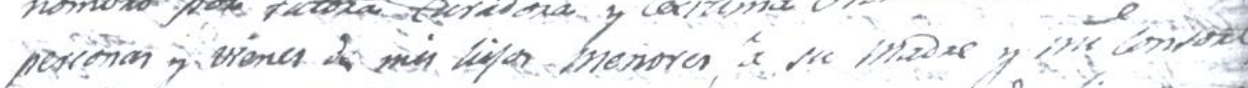

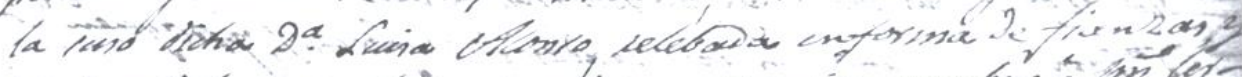

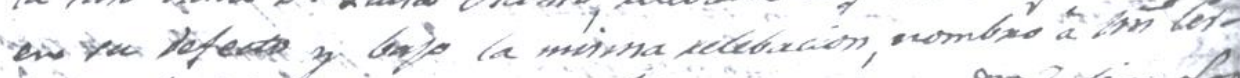

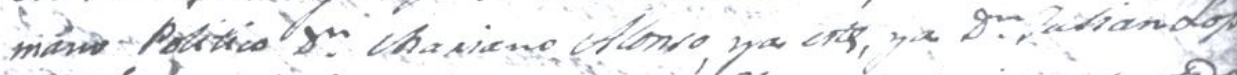

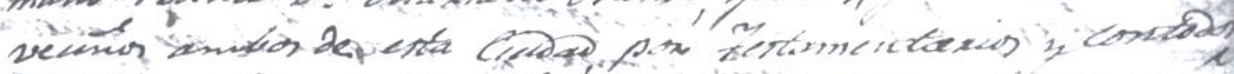

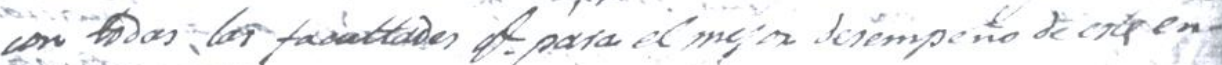
cangs, necositari

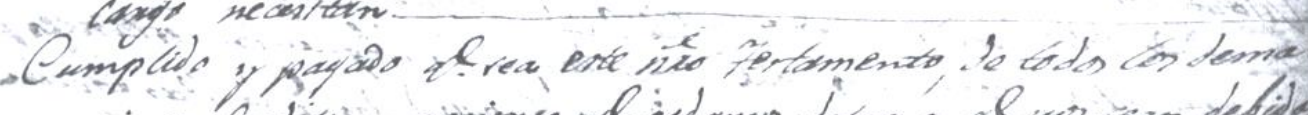

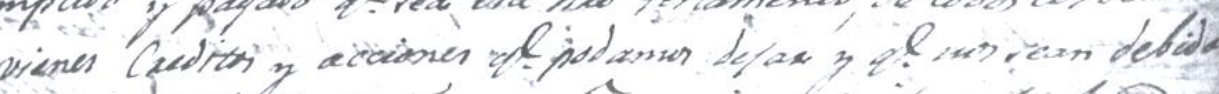

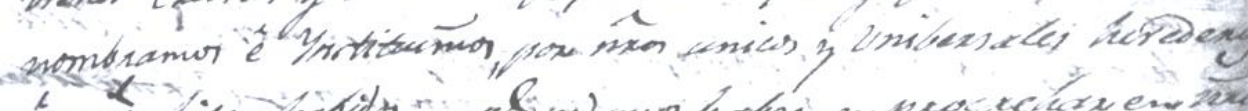

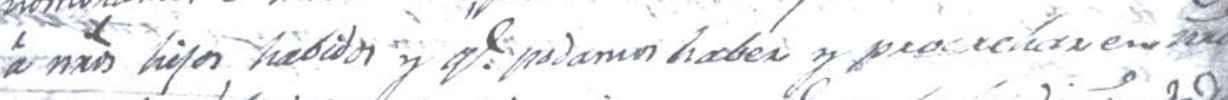

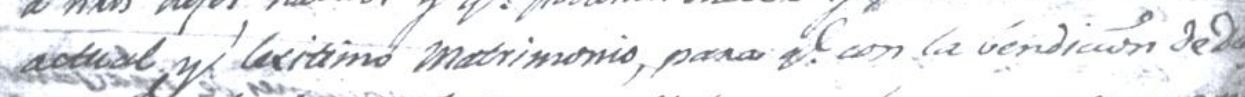

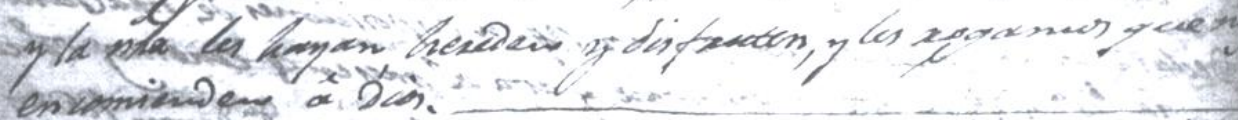

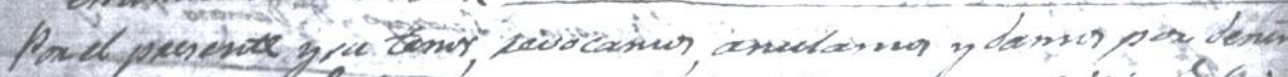

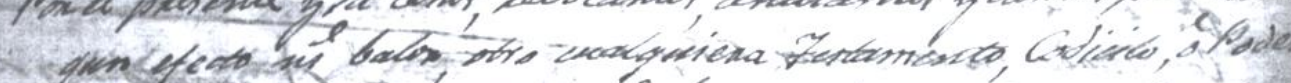

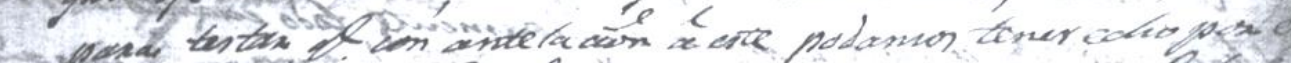

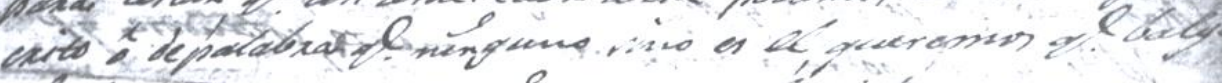

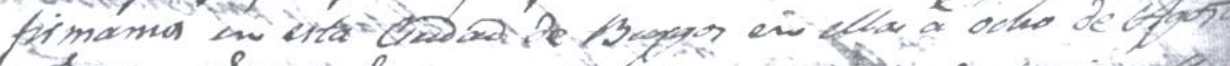

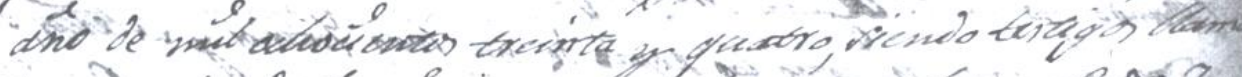

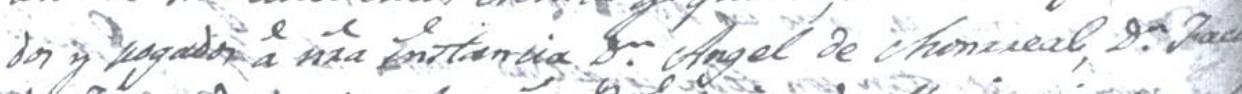

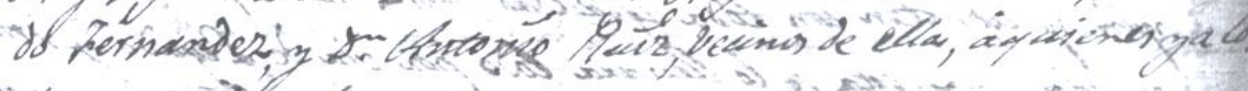

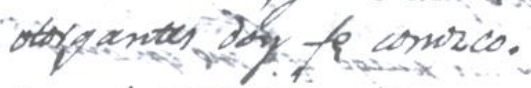

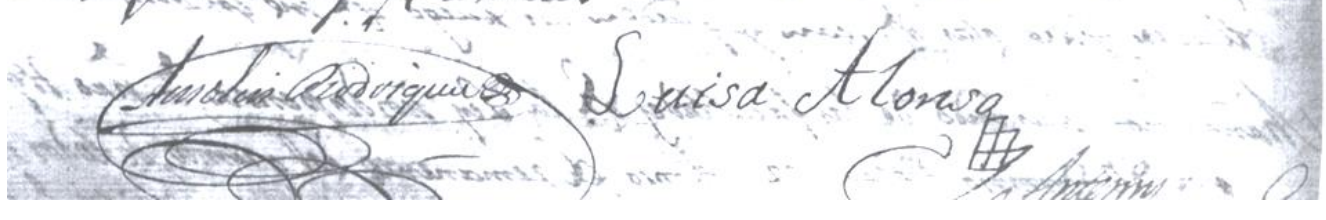

Fig.: 18

Testamento de D. Antolín Rodríguez y Da Luisa Alonso. Archivo Histórico de Burgos. 1834, p. 3 de 3. 


\section{Sustitución en la suerte de soldado de D. Santiago Rodríguez Alonso, el 26 de febrero de 1849.}

Documento notarial de sustitución en la suerte de soldado de D. Santiago Rodríguez Alonso.

En la ciudad de Burgos a veintiséis de febrero de mil ochocientos cuarenta y nueve ante mí el escribano de su número y testigos que se expresarán, Lorenzo Medina, soltero natural de Villalmanzo usando el consentimiento que para formalizar este instrumento obtuvo de su padre Francisco, vecino de dicho pueblo que se halla presente dijo: que tiene convenido con D. Mariano Rodríguez vecino de esta ciudad el sustituir la suerte de soldado que a D. Santiago Rodríguez, hermano del D. Mariano le ha cabido en el último sorteo, celebrado en esta capital, con calidad de que el indicado D. Mariano le ha de satisfacer y satisfará seis mil reales en metálico, de esta forma; los mil de presente tan luego como ingrese en caja a razón de setecientos catorce con diez maravedíes, en cada uno de ellos, pero si antes de finalizar los siete años, muriese el Lorenzo, si se inutilizare, entonces el D. Mariano entregará inmediatamente y en una sola partida la cantidad que adeudare, de los seis mil reales mencionados, ya sea al Lorenzo o a su legítimo representante y tan luego como aquel sea licenciado por haber servido los siete años en la milicia o por cualquier otra razón se dará el D. Mariano, además de los reales citados un vestido completo de paisano, conjunto de chaqueta, chaleco y pantalón, camisa, sombrero y zapatos, aquella de paño pardo[...]

Nota: queda cancelada esta escritura por haber recibido el Lorenzo Medina los seis mil reales, vestido que la misma expresa, su atención a haber obtenido la licencia absoluta, para que conste lo firma en Burgos a ocho de enero de mil ochocientos cincuenta y cinco. Lorenzo Medina. 
LA EDITORIAL BURGALESA HIJOS DE SANTIAGO RODRÍGUEZ (1891-1936): ANÁLISIS DE LOS LIBROS ESCOLARES

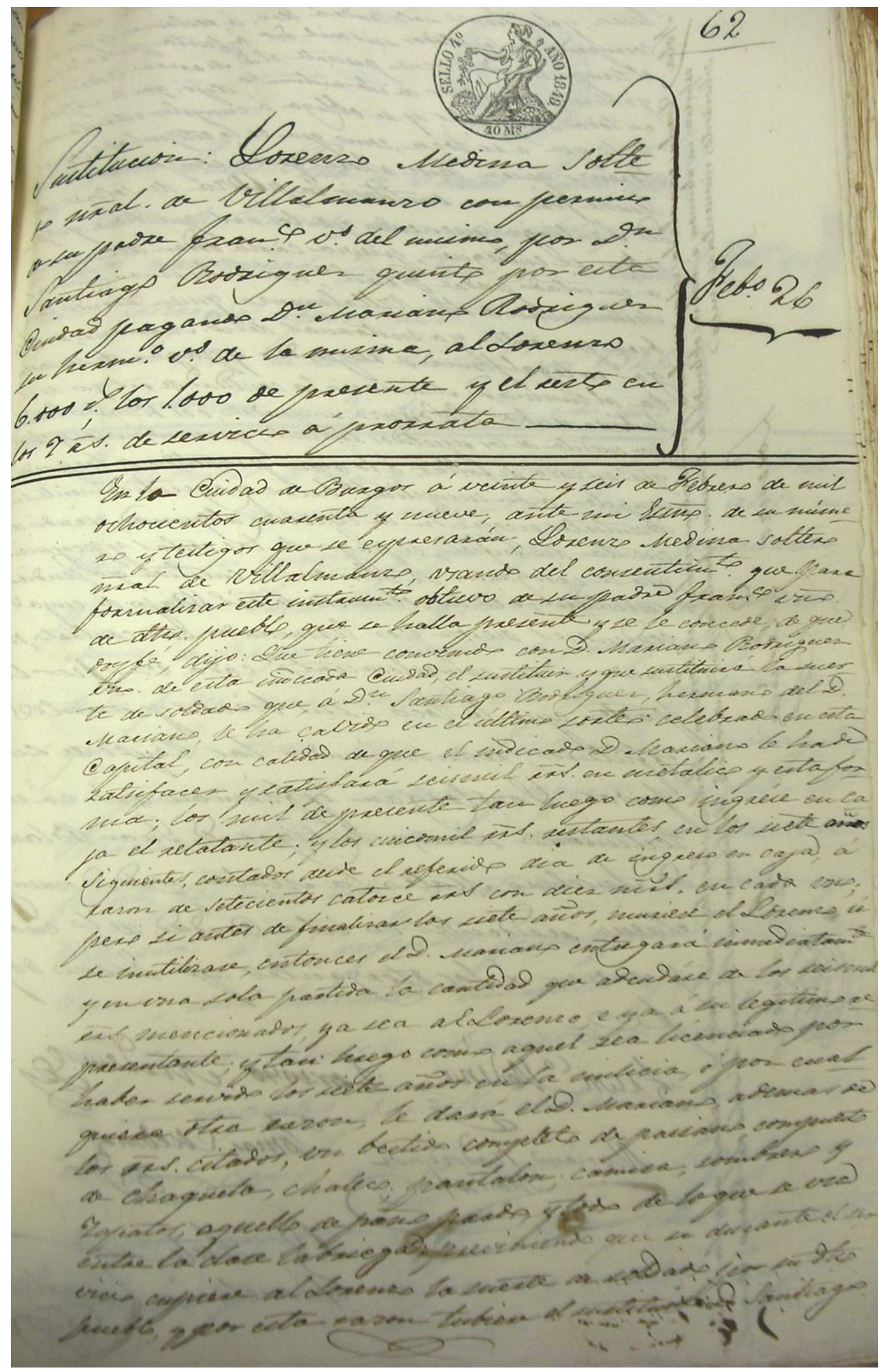

Fig.: 19

Sustitución por fianza de 6.000 reales de la suerte del soldado que recayó sobre D. Santiago Rodríguez Alonso.

Archivo Histórico Provincial de Burgos. 1849, p. 1 de 2. 


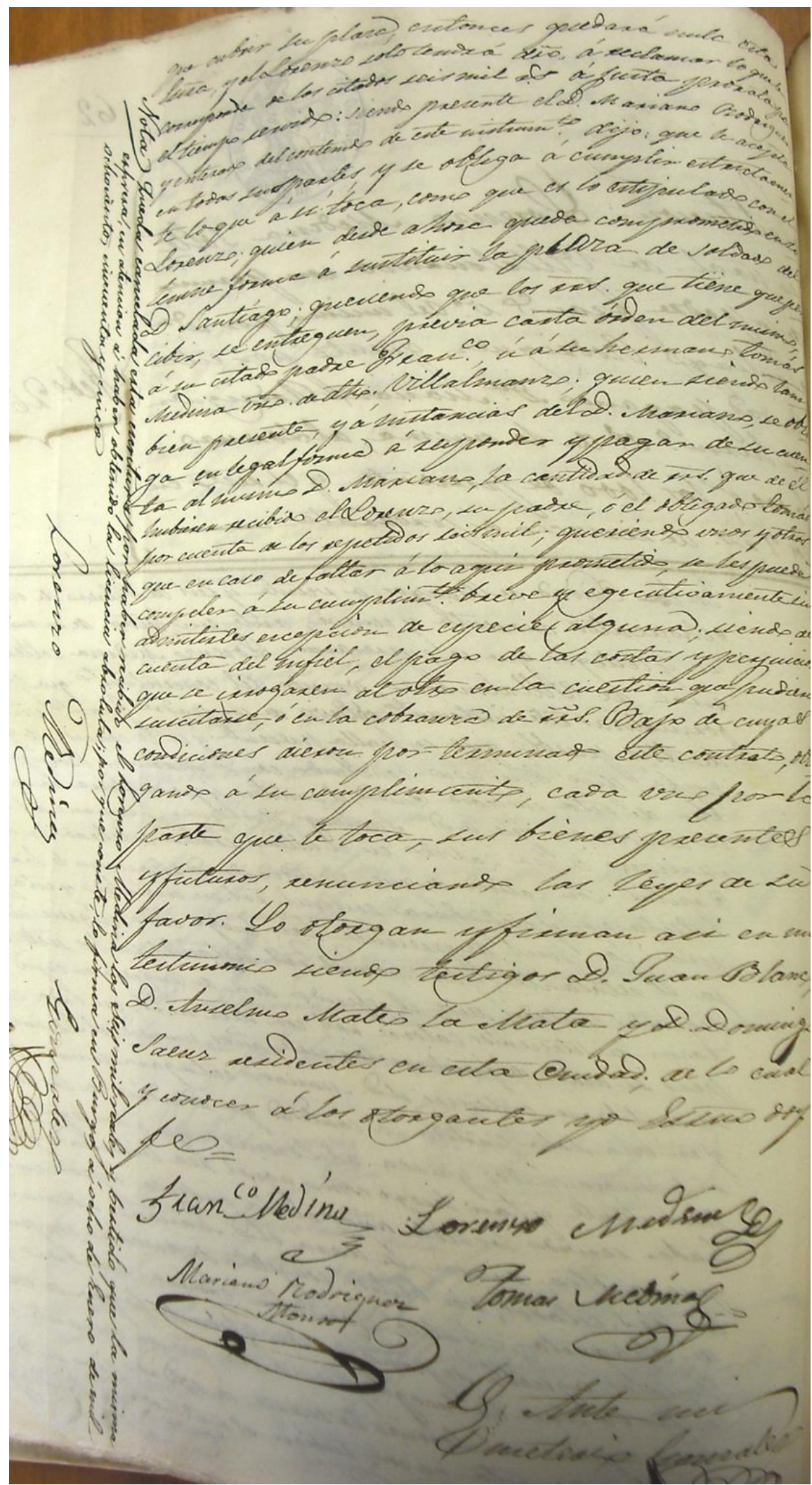

Fig.: 20

Sustitución por fianza de 6.000 reales de la suerte del soldado que recayó sobre D. Santiago Rodríguez Alonso. Archivo Histórico Provincial de Burgos. 1849, p. 2 de 2. En el margen izquierdo queda cancelada la escritura por la obtención de la licencia absoluta en 1855. 
LA EDITORIAL BURGALESA HIJOS DE SANTIAGO RODRÍGUEZ (1891-1936): ANÁLISIS DE LOS LIBROS ESCOLARES

9. Mariano Rodríguez Alonso, apoderado del Sr. Marqués de la Rambla, 1853.

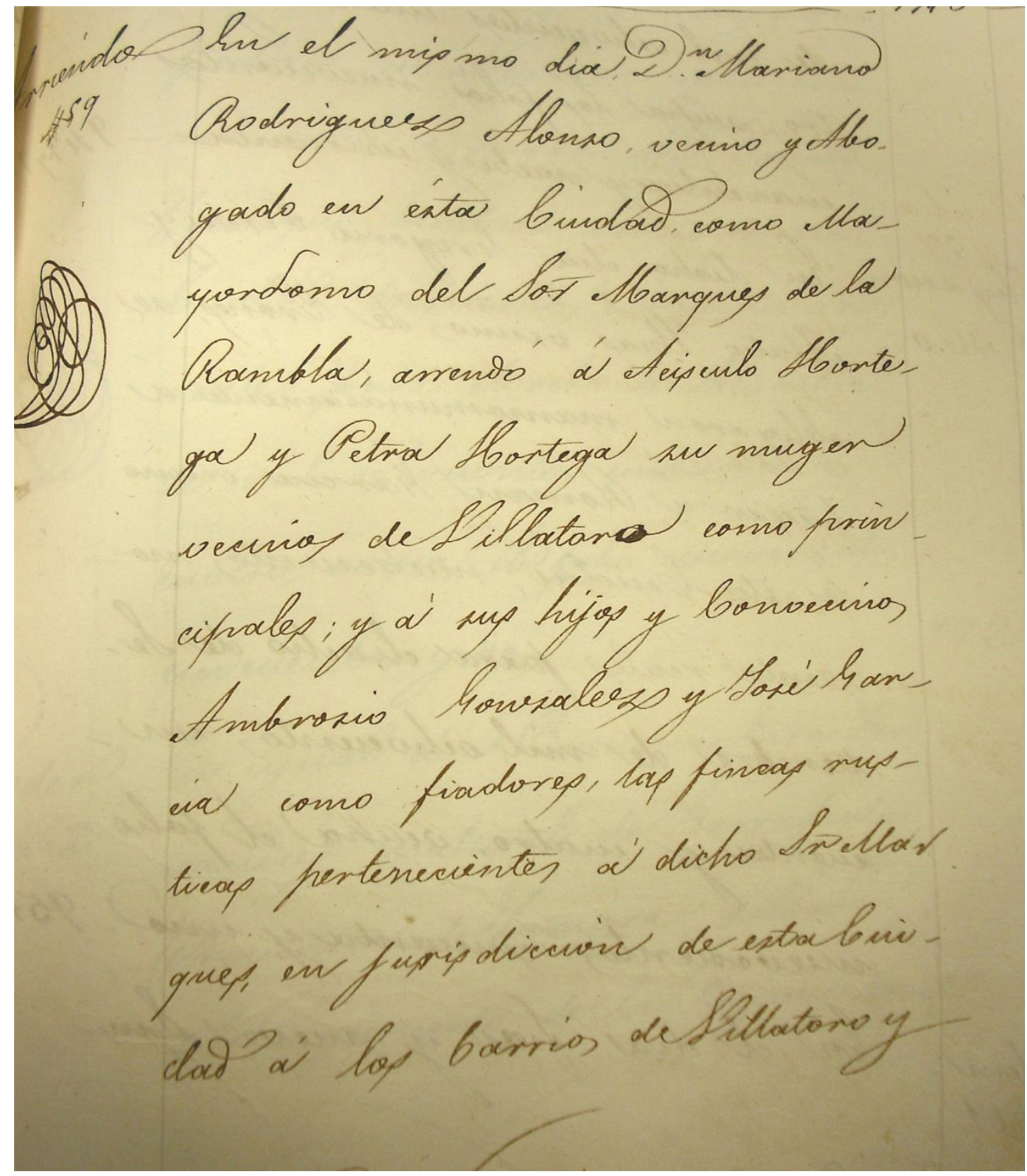

Fig.: 21

A la muerte de D. Antolín Rodríguez, su hijo Mariano Rodríguez Alonso, continúa como apoderado del Sr. Marqués de la Rambla. Archivo Histórico Provincial de Burgos. 1853. 


\section{Poder notarial de $D^{a}$ Luisa Alonso a favor de su hijo D. Dámaso Rodríguez para que cobre la pensión de su madre, como viuda de empleado de las puertas de la ciudad.}

Poder de $\mathrm{D}^{\mathrm{a}}$ Luisa Alonso, viuda vecina de esta ciudad a favor de su hijo D. Dámaso Rodríguez, soltero residente en ella para cobrar cantidad menor de 5.000 reales.

En la ciudad de Burgos a dieciséis de marzo de mil ochocientos cincuenta y cinco ante mí el Escribano de su número y testigos que se expresarán pareció $\mathrm{D}^{\mathrm{a}}$ Luisa Alonso, viuda, vecina de la misma a quien doy fe conozco y dijo que confiere el poder necesario en derecho a su hijo D. Dámaso Rodríguez, soltero residente en ella, para que cobre de la Administración principal de Hacienda de esta dicha ciudad la pensión que tiene como viuda de D. Antolín Rodríguez, empleado que fue en las puertas de la misma capital, importante una suma menor de 5.000 reales otorgando al efecto las conducentes cartas de pago que tendrán la misma validez que si se expidiera por la Sra. otorgante, pues el poder que para lo dicho se requiere y demás incidentes o dependiente en cualquiera manera, ese mismo da al nominado D. Dámaso Rodríguez sin restricción con cláusula impresa de relevación en forma, obligando al cumplimiento de cuanto se hiciere en virtud de este poder sus bienes en general presentes y futuros conforme a derecho. Lo otorga así y firmo siendo testigos D. Fermín Aranzana Pérez, D. Julián Martínez Medina y D. Gregorio Guinea vecinos y residentes en esta ciudad.

Firman: El notario D. Emeterio González y D ${ }^{\mathrm{a}}$ Luisa Alonso. 
LA EDITORIAL BURGALESA HIJOS DE SANTIAGO RODRÍGUEZ (1891-1936): ANÁLISIS DE LOS LIBROS ESCOLARES

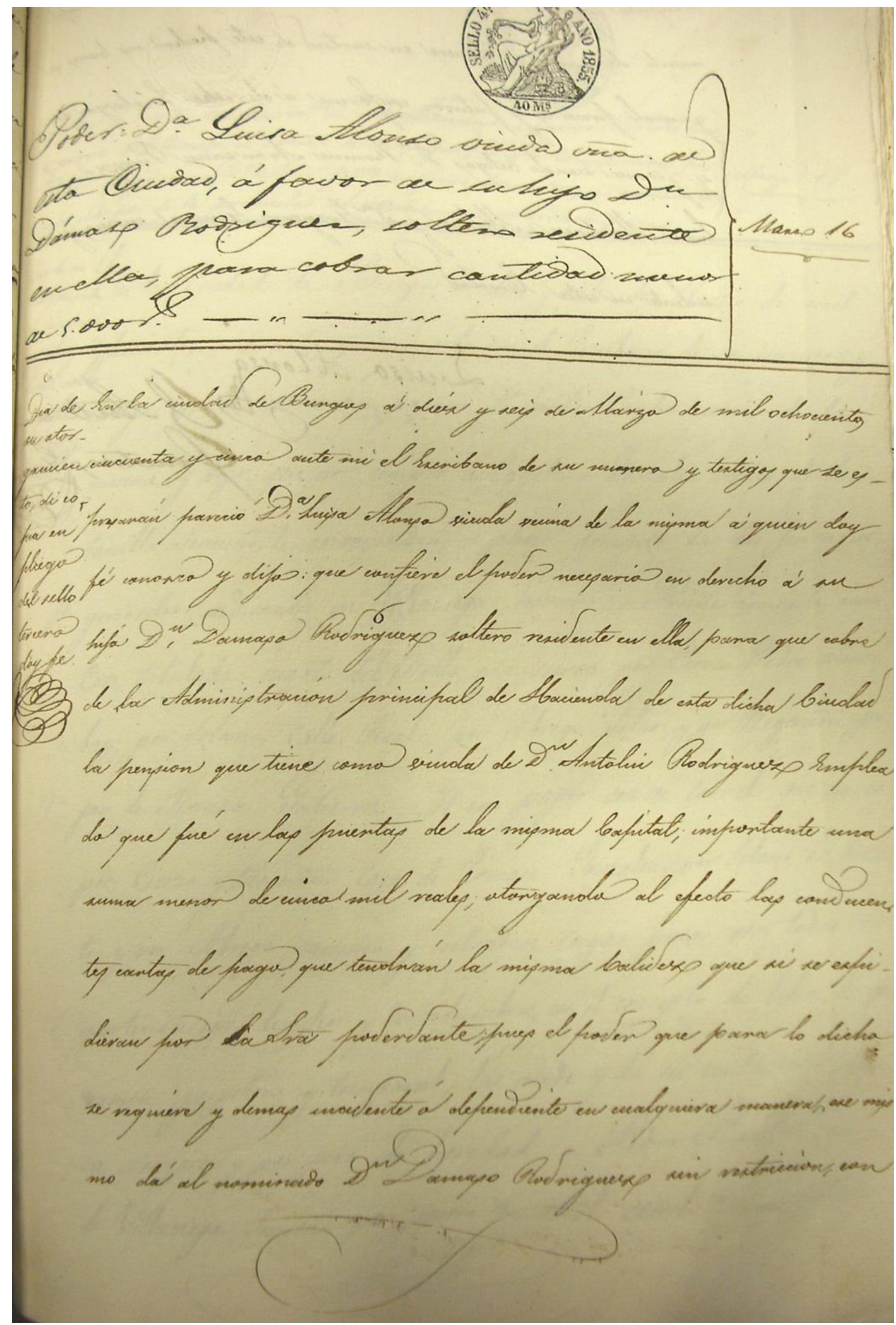

Fig.: 22

Poder de $\mathrm{D}^{\mathrm{a}}$ Luisa Alonso a favor de su hijo D. Dámaso Rodríguez, para que cobre de la Administración principal de Hacienda de esta ciudad, la pensión como viuda de D. Antolín Rodríguez, empleado en las puertas de la ciudad. Archivo Histórico Provincial de Burgos. 1855, p. 1 de 2. 


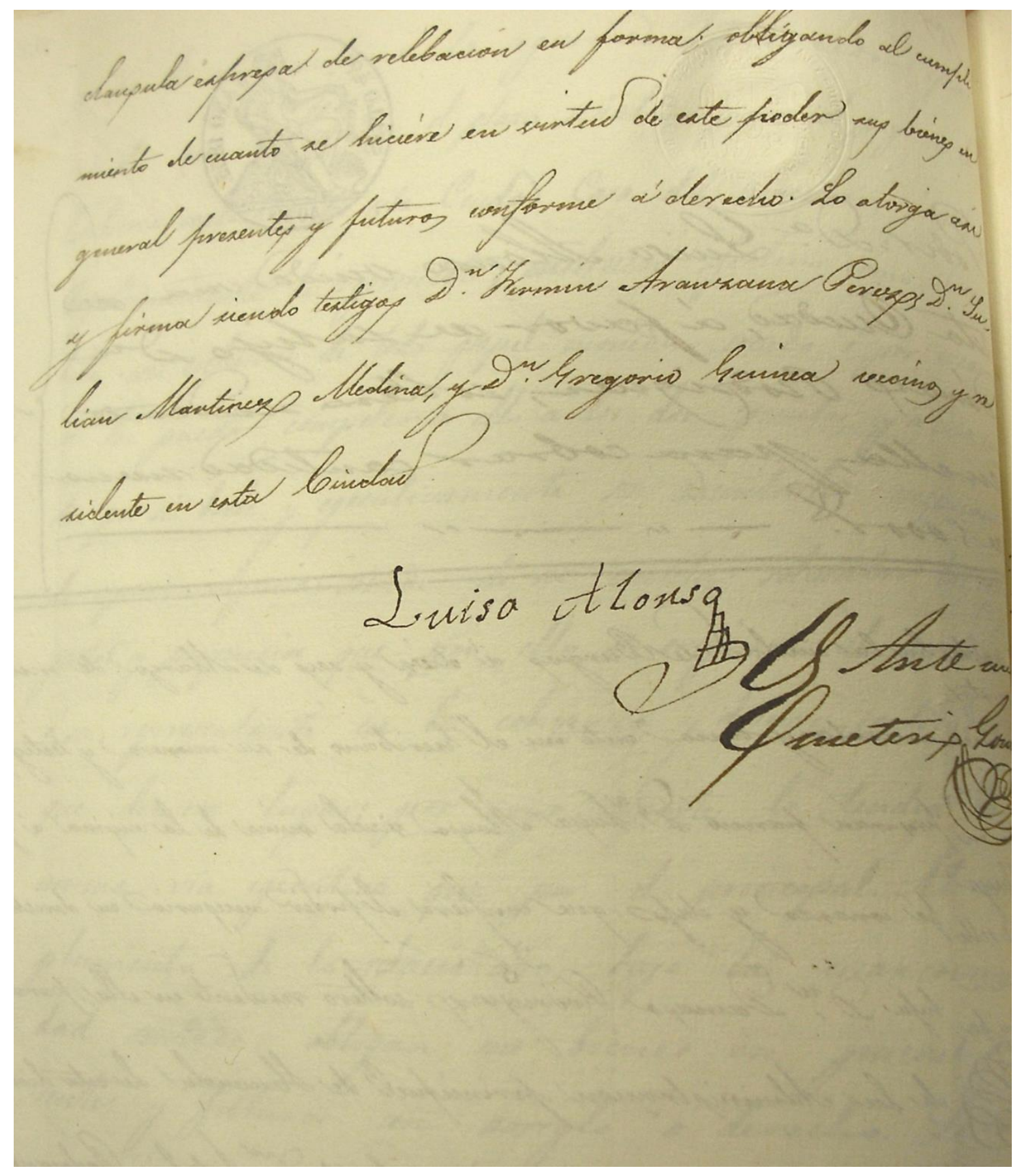

Fig.: 23

Poder de $\mathrm{D}^{\mathrm{a}}$ Luisa Alonso a favor de su hijo D. Dámaso Rodríguez, para que cobre de la Administración principal de Hacienda de esta ciudad, la pensión como viuda de D. Antolín Rodríguez, empleado en las puertas de la ciudad. Archivo Histórico Provincial de Burgos. 1855, p. 1 de 2. 


\section{Testamento de $D^{\text {a }}$ Luisa Alonso, el 18 de octubre de 1858.}

Testamento de Luisa Alonso viuda vecina de esta ciudad. In Dei nomine Amén.

En la ciudad de Burgos a diez y ocho de octubre de mil ochocientos cincuenta y ocho, ante mí el Escribano de su número y testigos que se expresarán, $\mathrm{D}^{\mathrm{a}}$ Luisa Alonso viuda y vecina de ella, dijo que es hija legítima de D. Juan y $\mathrm{D}^{\mathrm{a}}$ Manuela Saiz difuntos vecinos que fueron de esta población; que se halla en su sano juicio y cabal entendimiento con una salud regular, que cree y confiesa el misterio de la Santísima Trinidad y los demás de Nuestra Santa Madre la Iglesia C.A.R. bajo cuya creencia ha vivido y piensa morir en ella, ordena su testamento bajo los auxilios de la Virgen María y demás santos del cielo en la forma siguiente.

Primeramente encomienda su alma a Dios nuestro Señor y el cuerpo a la tierra; el cual hecho cadáver sea amortajado y sepultado en la forma que acordaran sus hijos, a cuya voluntad se le harán también entierro honras y cabo de año, celebrándose las misas que los mismos acordaren; que todo lo que pase quiere se ejecute en la forma que sus dichos hijos dispongan.

Declara haber estado casada en primeras y únicas nupcias con D. Antolín Rodríguez en cuyo matrimonio procrearon diferentes hijos de los cuales viven hoy $\mathrm{D}^{\mathrm{a}}$ Ramona, D. Santiago y D. Dámaso Rodríguez y Alonso; éste y la $\mathrm{D}^{\mathrm{a}}$ Ramona solteros mayores de edad y el D. Santiago casado, quien tiene recibidos por cuenta a su haber seis mil quinientos reales según consta de recibo sin que los otros dos hayan recibido cosa alguna.

También declara que al fallecer su otro hijo D. Mariano Rodríguez Alonso dejó por caudal suyo propio veinte y cuatro mil reales, disponiendo que el tercio de ellos lo percibieron por vía de mejora su hermana $\mathrm{D}^{\mathrm{a}}$ Ramona y sin embargo de que su disposición no fue escrita y en este extremo solo afectaba los derechos de legitima que como a madre correspondían a los testadores según las leyes, quiere y es su voluntad que sea respetada la dicha mejora deduciéndose después de su muerte los ocho mil reales que sobra sobre los veinte y cuatro mil citados reconoce pertenecer a su referida hija $\mathrm{D}^{\mathrm{a}}$ Ramona a quien sin perjuicio de la anterior declaración mejora en el tercio y quinto de sus bienes para proteger en la situación de infortunio en que pudiera quedar, rogándole que se recuerde de su anciana madre en sus oraciones.

Para cumplir este su testamento nombra por sus albaceas con el doble carácter de contadores y partidor a D. Julián González y D. Francisco Orai, éste presbítero, ambos vecinos de esta ciudad y caso de no hallarse en ella el D. Julián cuando muera la testadora nombra en su lugar a D. Jorge de la Riba y Herrera vecino de Poza facultándoles para que junta o 
solidariamente se apoderen de los bienes que dejare, vendiendo pública y privadamente los necesarios para cumplir cuanto deja otorgado, haciendo por si mismo y extra judicialmente el inventario, tasación cuenta y partición correspondiente cuyo encargo les durará el año legal y más tiempo que necesitaren pues se les prorroga.

Cumplido y pagado que sea este su testamento del remanente de todos sus bienes derechos $\mathrm{y}$ acciones nombre e instituye por los únicos $\mathrm{y}$ universales herederos a sus nominados hijos $D^{a}$ Ramona, D. Santiago y D. Dámaso Rodríguez Alonso para que les hagan y hereden por iguales partes con la bendición de Dios y la suya.

Por el presente revoca y anula cuantas disposiciones testamentarias haya otorgado antes de ahora en cualquier manera queriendo que ninguna valga sino esta que acaba de otorgar y que firma con los testigos D. Juan Rodríguez y D. Juan Albonoz y D. Elías González vecinos de esta ciudad, de los cuales conoce a la otorgante yo el Escribano doy fe y de tener forma por la ley pena de nulidad.

Firmado por el notario D. Emeterio González, Luisa Alonso y los testigos. 
LA EDITORIAL BURGALESA HIJOS DE SANTIAGO RODRÍGUEZ (1891-1936): ANÁLISIS DE LOS LIBROS ESCOLARES

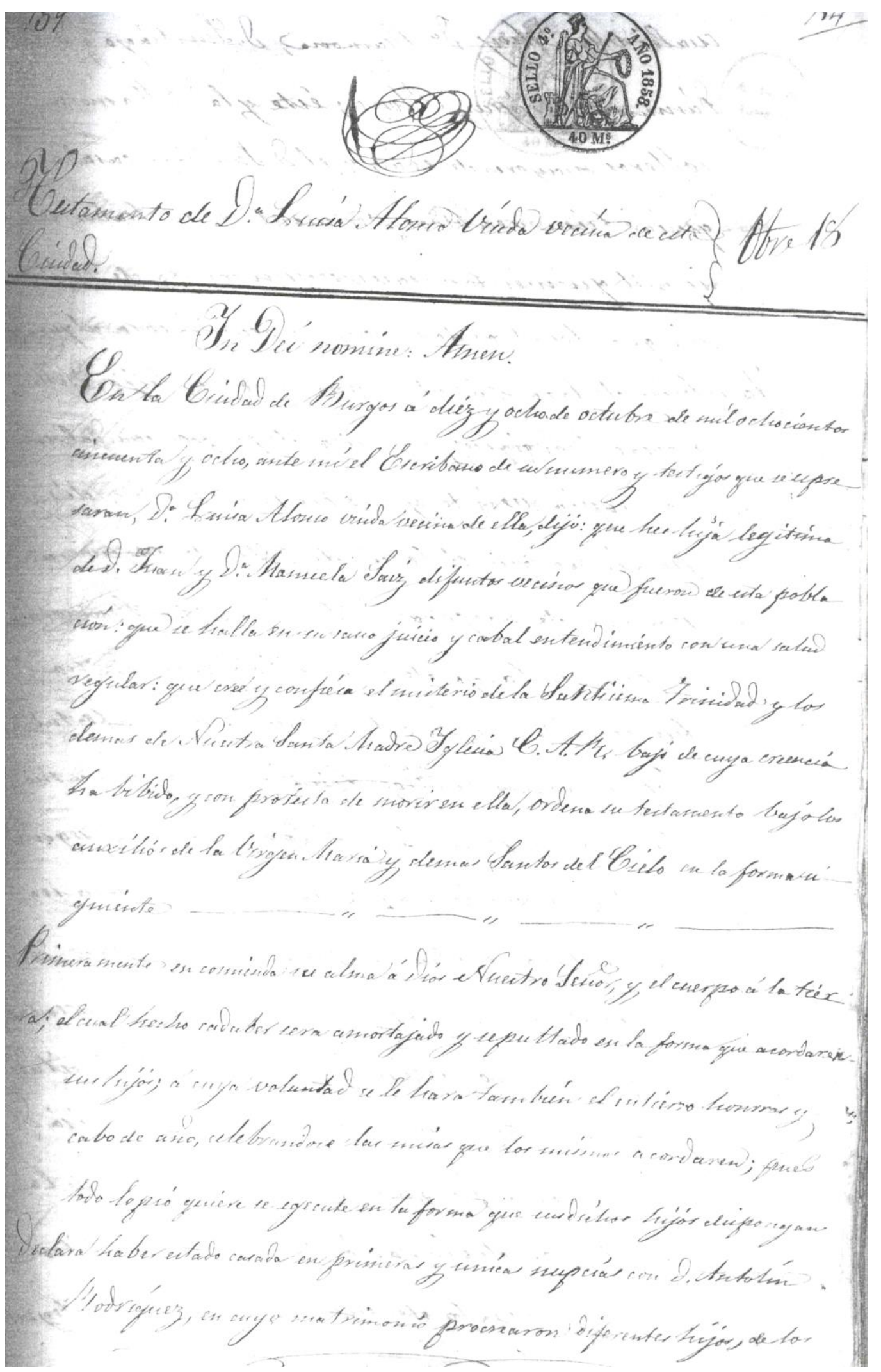

Fig.: 24

Testamento de Luisa Alonso.

Archivo Histórico Provincial de Burgos. 1858, p. 1 de 4. 


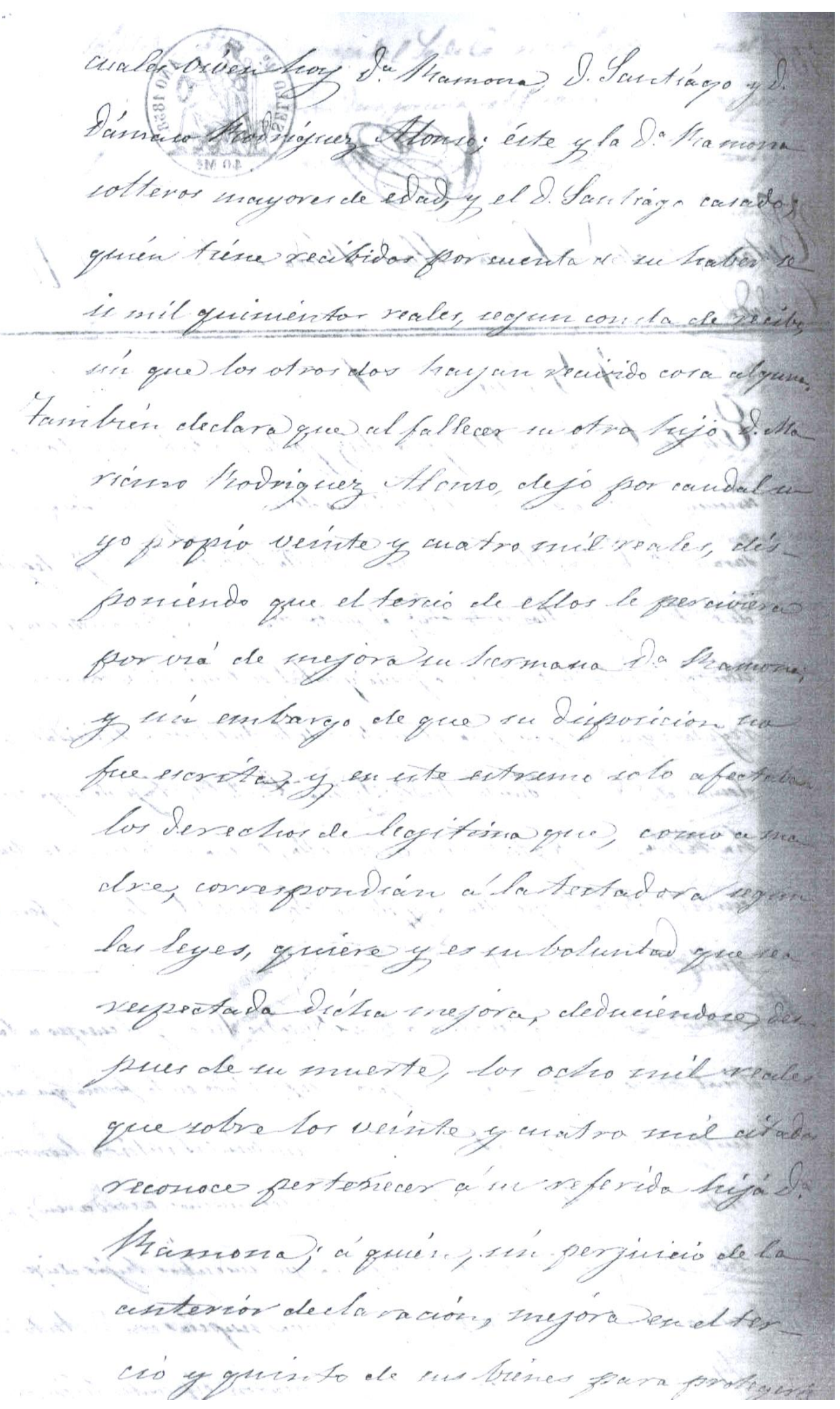

Fig.: 25

Testamento de Luisa Alonso.

Archivo Histórico Provincial de Burgos. 1858, p. 2 de 4. 
LA EDITORIAL BURGALESA HIJOS DE SANTIAGO RODRÍGUEZ (1891-1936): ANÁLISIS DE LOS LIBROS ESCOLARES

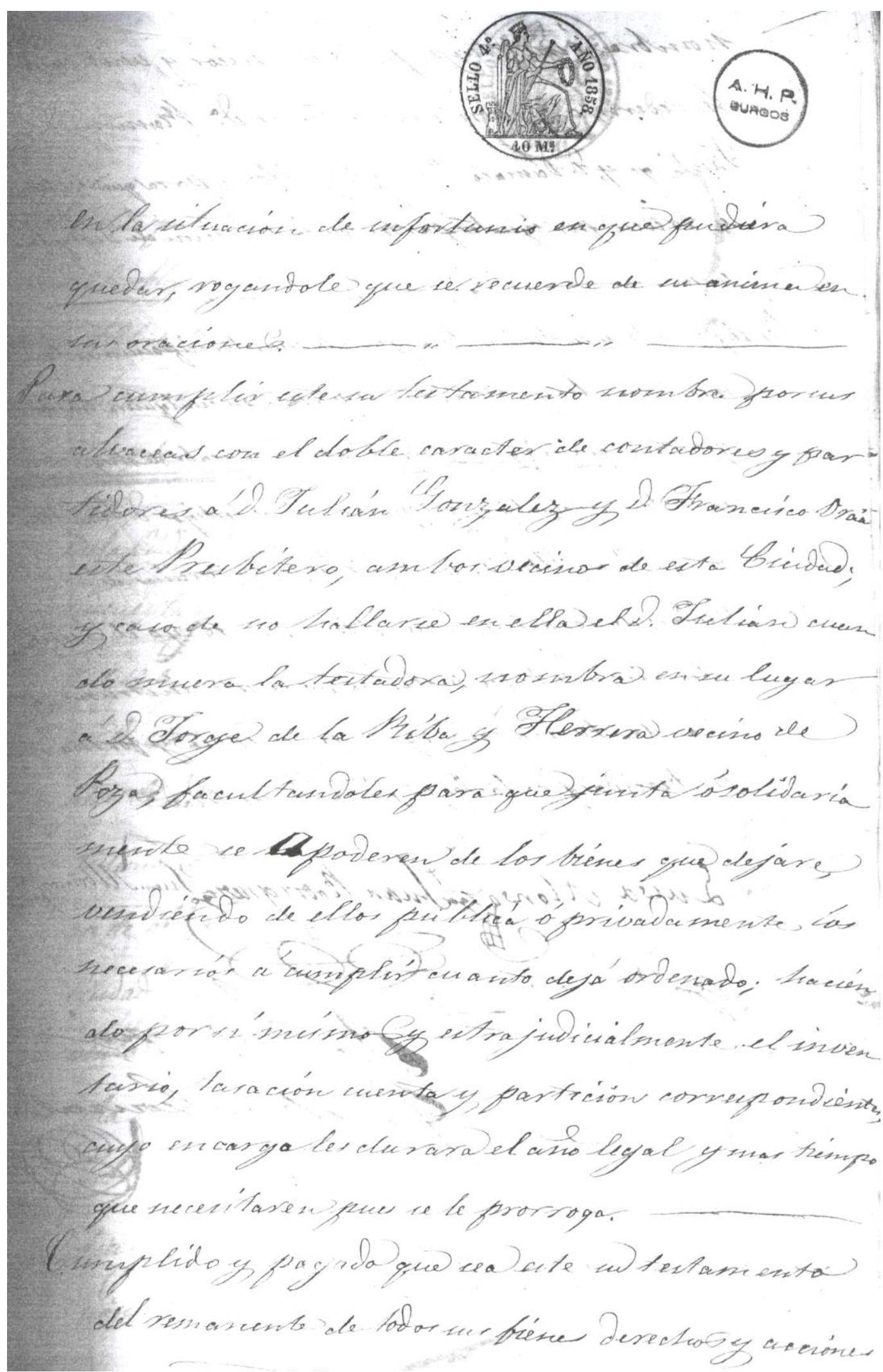

Fig.: 26

Testamento de Luisa Alonso.

Archivo Histórico Provincial de Burgos. 1858, p. 3 de 4. 


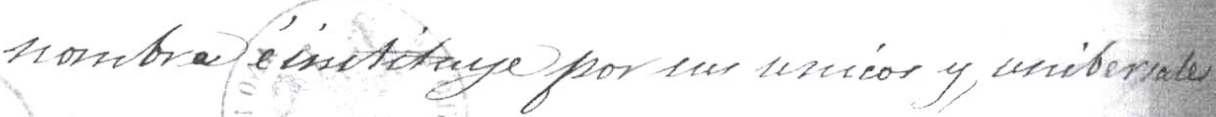

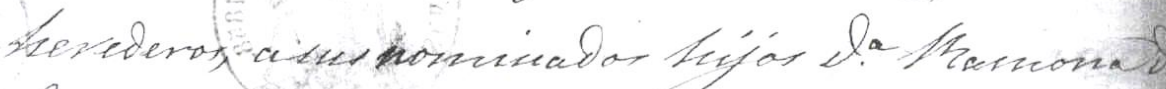

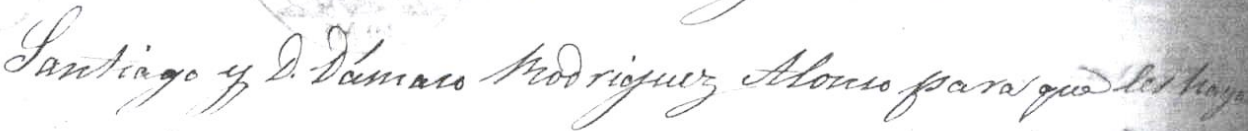

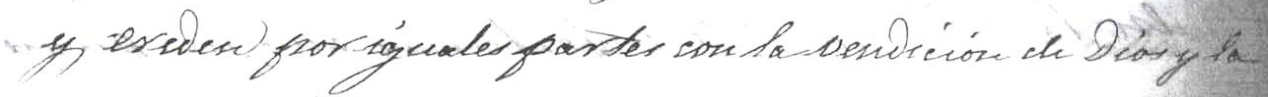

Sucal

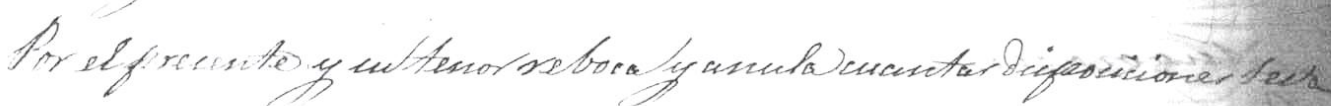

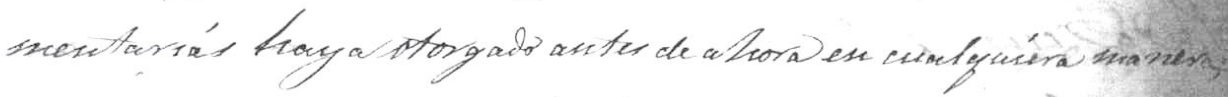

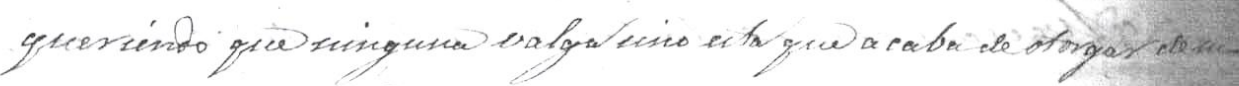

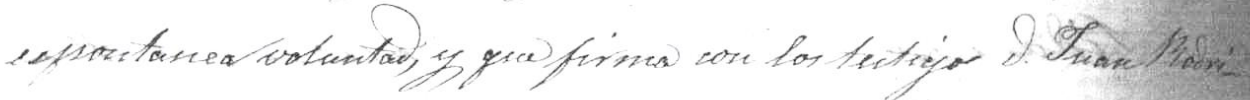

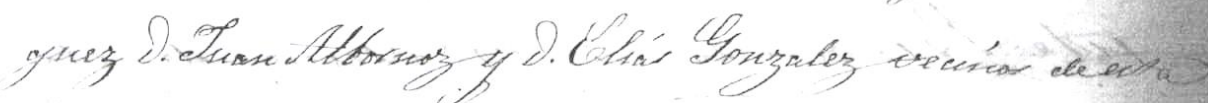

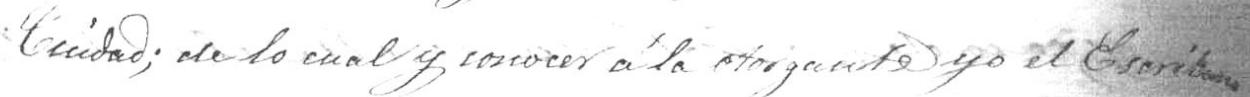

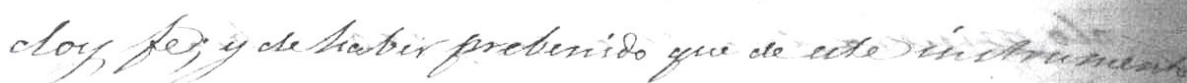

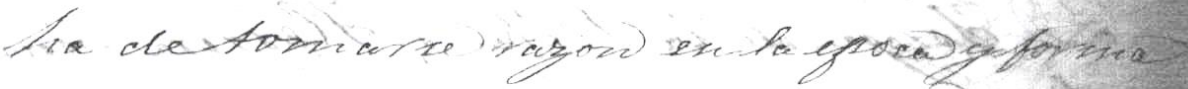

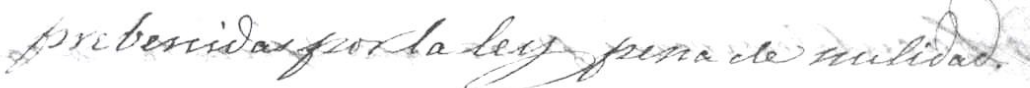

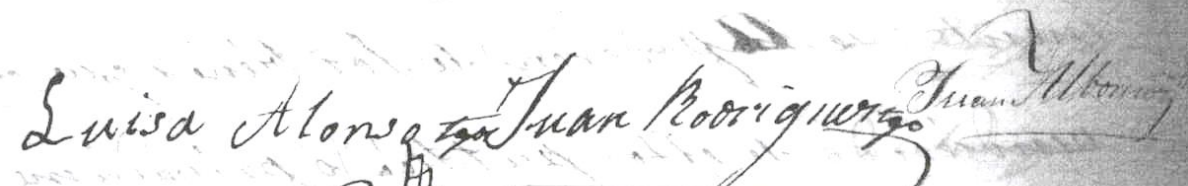
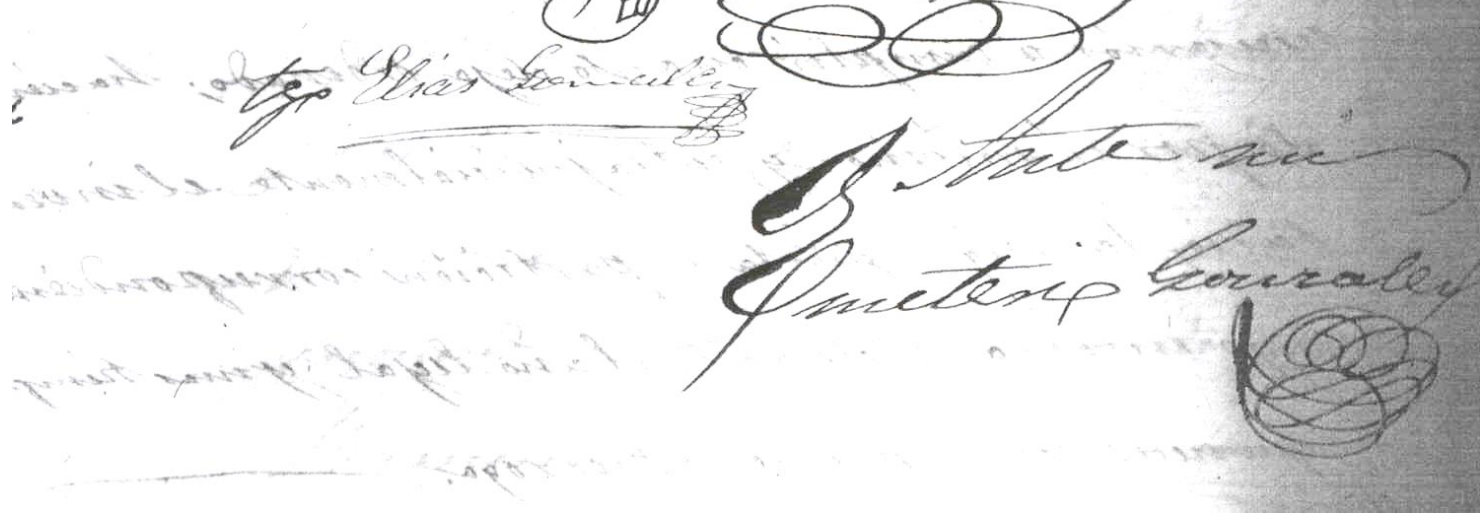

Fig.: 27

Testamento de Luisa Alonso.

Archivo Histórico Provincial de Burgos. 1858, p. 4 de 4. 


\section{Recepción de la novicia $D^{a}$ Ramona Alonso en la comunidad de Religiosas de San José de Burgos, el 31 de marzo de 1862.}

Recepción de monjas de coro, voz y voto de la comunidad de Religiosas de San José en esta ciudad de la novicia $D^{a}$ María Ramona y Rodríguez Alonso natural de esta capital, mayor de edad por quien se entrega en dote de la misma, a dicha Comunidad quince mil reales bajo las bases que establece el Concordato de mil ochocientos cincuenta y uno en su artículo treinta.

En la ciudad de Burgos y su Monasterio de Religiosas de San José de la misma, extramuros de ella, a treinta y uno de marzo de mil ochocientos sesenta y dos ante mí el escribano de su número y testigos que expresarán $\mathrm{D}^{\mathrm{a}}$ María Ramona y Rodríguez Alonso, novicia en el mismo, natural de esta capital, mayor de edad, hija legítima de D. Antolín y Luisa Alonso, difuntos, vecinos que fueron también de esta capital, y dijo: que sintiéndome con verdadera vocación de religiosa, solicita la entrada y entre de novicia de este indicado Monasterio, donde lleva el tiempo necesario de ejercicios para su profesión, a cuyo fin ha solicitado y obtenido licencia del Ordinario Diocesano habiéndose instruido sobre el particular expediente gubernativo en el Tribunas Eclesiástico ante el Notario Mayor D. Juan José de Labiano del cual resulta la entrega de quince mil reales en efectivo metálico hecha por $\mathrm{D}^{\mathrm{a}}$ María Ramona según disposición del artículo treinta del Concordato Novísimo para los fines indicados en el mismo y en conformidad a lo último dispuesto por el Excmo. Sr. Cardenal de esta Diócesis en su instrucción relativa a la admisión de novicias en los conventos de su arzobispado insertos en el Boletín Eclesiástico del mismo, fecha de veinte de marzo de mil ochocientos cincuenta y ocho que aproximándose el día de la profesión conforme a lo dispuesto en el Santo Concilio de Trento de su espontánea voluntad y en la forma que más haya lugar en derecho, otorga: que desde ahora para cuando se verifique su profesión y desde ella y para siempre renuncia a favor de su Sres. hermanos D. Santiago y D. Dámaso Rodríguez Alonso, a ambos por iguales partes, todos los bienes, derechos que puedan corresponderle y le correspondan en lo sucesivo bien por herencia, o bien por otro cualquier concepto y lo cede todo en sus referidos señores hermanos por este contrato interviene es irrevocable dándoles amplia facultad para que verificada su profesión, no antes, dispongan a su arbitrio de cuantas pertenencias le correspondan, que se da por satisfecha de todo en haber paterno y materno y de cuanto pudiera corresponderle por otros conceptos, renunciando al efecto, las leyes que puedan favorecerla [...] D Juana Pardo de Terán, Da Saturnino Luzuriago, $\mathrm{D}^{\mathrm{a}}$ Tomasa Ángulo López, abadesa y priora y consiliaria respectivamente del mismo por si y a nombre de las enfermas, ausentes y venideras por 
quienes presenta canción de que estarán y pasarán por el contenido de este instrumento confiesan haber recibido de la ya citada $\mathrm{D}^{\mathrm{a}}$ María Ramona los reales referidos por dote de la misma según consta del expediente obrante en la Notaría del expresado Sr. de Lebiano manifestando que de mutua conformidad, reciben a aquella por religiosa de coro, voz y voto en este convento desde ahora por el día en que se verifique su profesión y bajo de las reglas y estatutos de este convento, prometiendo a la novicia $\mathrm{D}^{\mathrm{a}}$ María Ramona que le serán guardadas las consideraciones y preeminencias que a las demás religiosas de su clase; obligando cada una de las partes comprendidas en este instrumento por la que así tocan sus bienes propios y los de la Comunidad en general al cumplimiento del mismo, con renuncia de las leyes de su favor y en beneficio de restitución ni integramos.

Lo otorgan y así firmaron las que dejaron saber a los testigos que fueron D. Nicolás Porres y D. Felipe García vecinos y residentes respectivamente en esta ciudad, en todo lo cual y conoce a los señores otorgantes yo el escribano doy fe.

Firmado por el notario D. Valentín Díaz Güemes, Ramona Rodríguez Alonso y todas las religiosas de la comunidad y los testigos. 
LA EDITORIAL BURGALESA HIJOS DE SANTIAGO RODRÍGUEZ (1891-1936): ANÁLISIS DE LOS LIBROS ESCOLARES

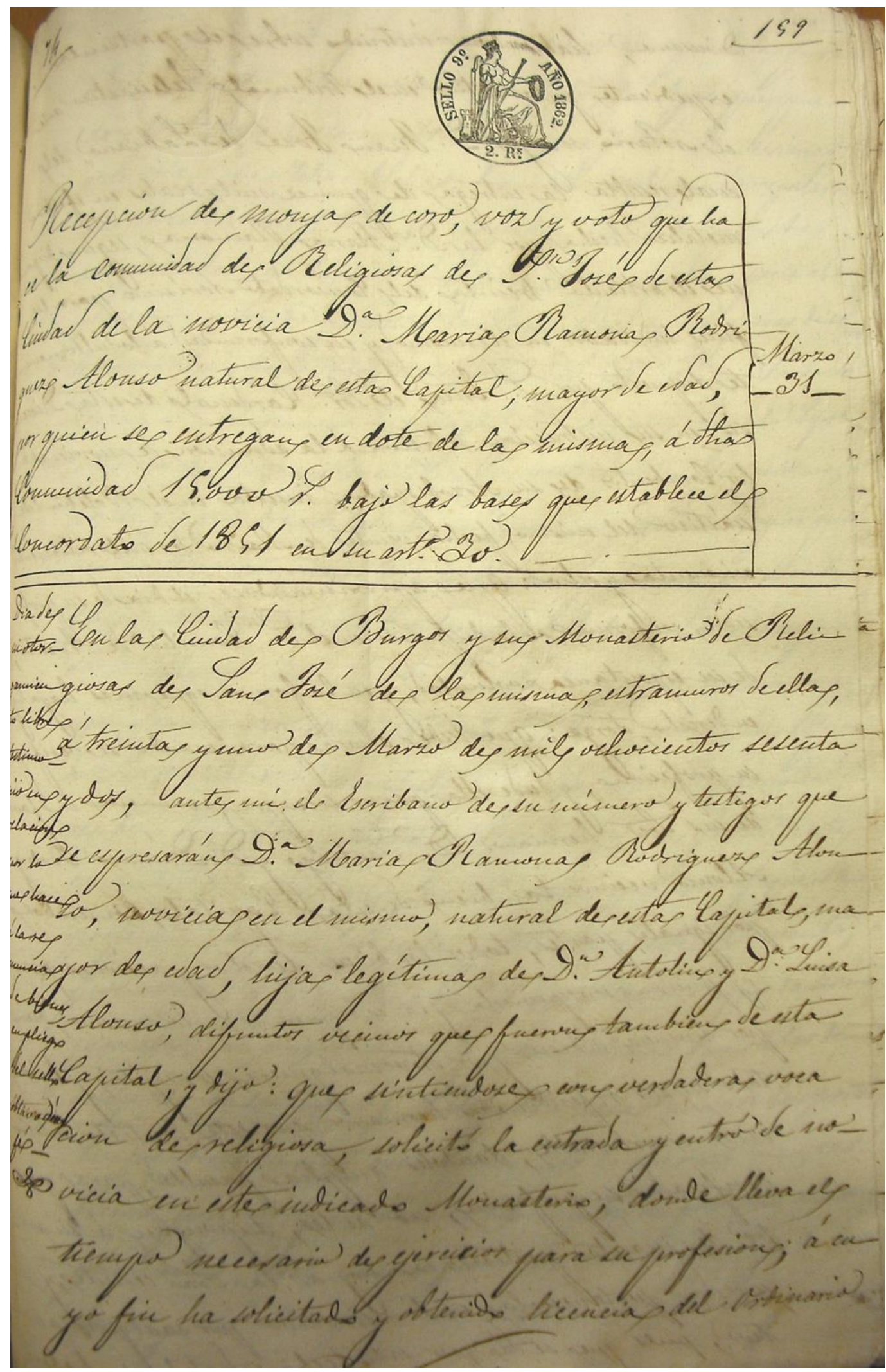

Fig.: 28

Entrada como religiosa a la comunidad de religiosas de San José en Burgos, de la novicia Da María Ramona Rodríguez Alonso. Archivo Histórico de Burgos. 1862, p. 1 de 4. 


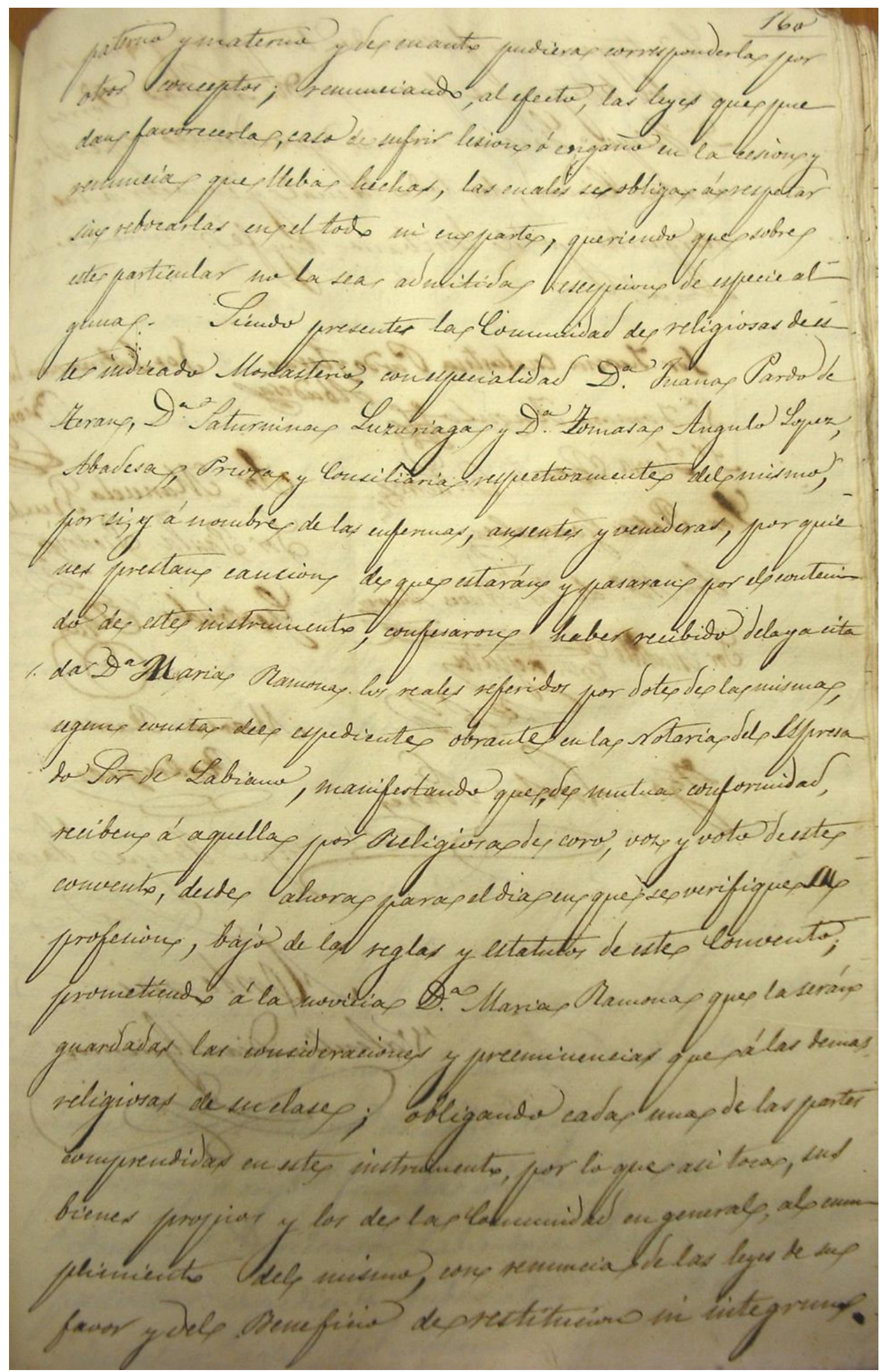

Fig.: 29

Entrada como religiosa a la comunidad de religiosas de San José en Burgos, de la novicia Da María Ramona Rodríguez Alonso. Archivo Histórico de Burgos. 1862, p. 2 de 4. 


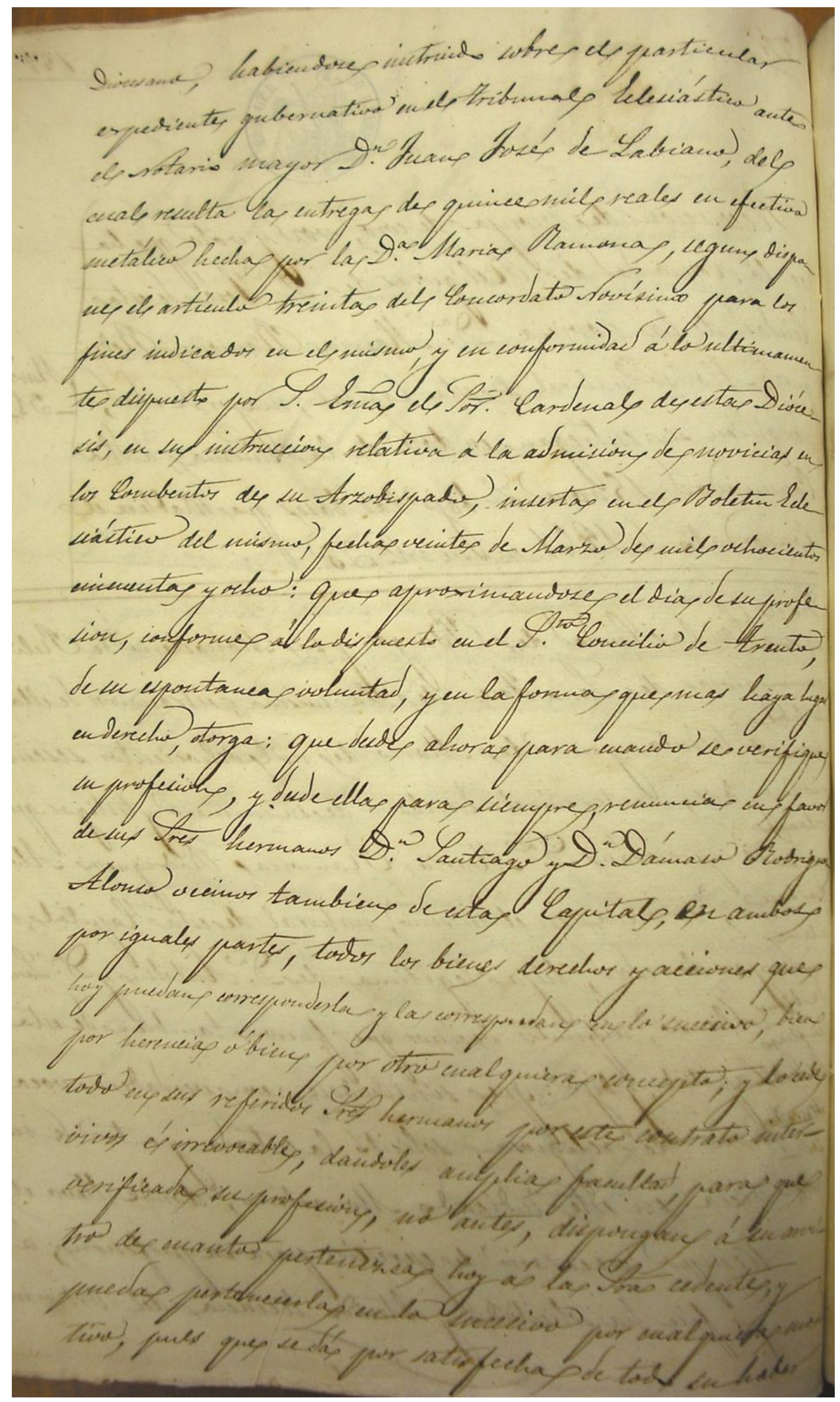

Fig.: 30

Entrada como religiosa a la comunidad de religiosas de San José en Burgos, de la novicia Da María Ramona Rodríguez Alonso. Archivo Histórico de Burgos. 1862, p. 3 de 4. 


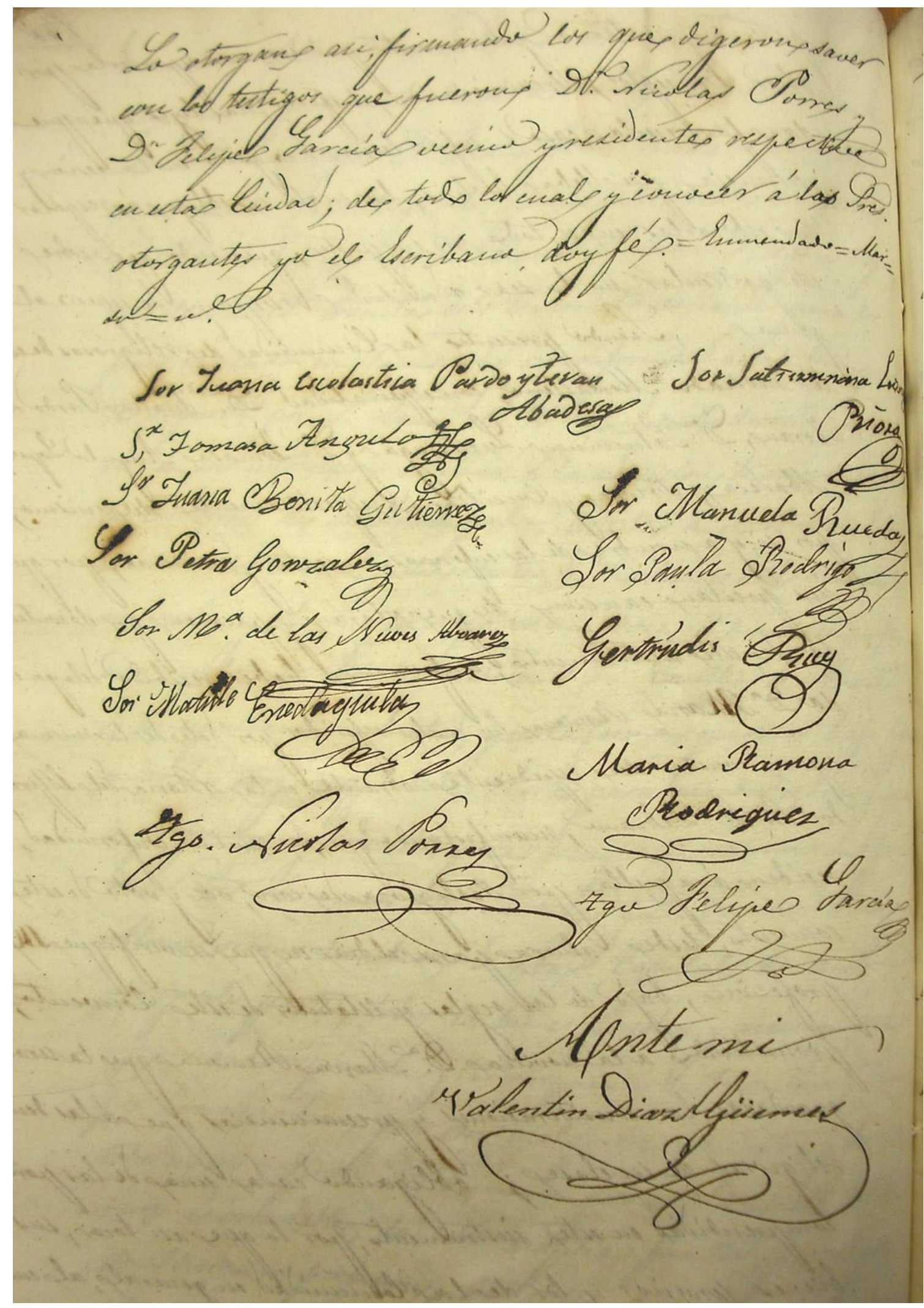

Fig.: 31

Entrada como religiosa a la comunidad de religiosas de San José en Burgos, de la novicia Da María Ramona Rodríguez Alonso. Archivo Histórico de Burgos. 1862, p. 4 de 4. 


\section{Poder de D. Santiago Rodríguez a D. José Ortega, procurador de Alicante para litigar contra su hermano D. Dámaso Rodríguez, por deudas, el 11 de marzo de 1868.}

DON SANTIAGO RODRÍGUEZ ALONSO a Don José Ortega procurador en Alicante para litigar.

En la ciudad de Burgos a once de marzo de 1868 ante mi Fernando Monterrubio vecino de esta ciudad y Notario de su colegio, presentes los testigos que nombraré, comparece Don Santiago Rodríguez Alonso de treinta y ocho años de edad, del comercio, vecino de esta ciudad de cuyo conocimiento, profesión y vecindad doy fe y asegurando hallarse en el pleno uso de los derechos civiles y con la capacidad legal para otorgar este instrumento dice: que su hermano Don Dámaso, empleado y residente en Alicante, le es en deber cierta cantidad procedente de entregas en metálico que le ha hecho y pagos también en metálico hechos por cuenta suya para cuya cobranza ha deliberado autorizar una persona de su confianza mediante no serle posible verificarlo por sí propio y al efecto [...] Otorga: que da y confiere todo su poder cumplido... a Don José Ortega procurador del juzgado y vecino de Alicante...reclame a Don Dámaso Rodríguez Alonso las cantidades que es en deber al Señor otorgante para lo cual le comunicará las noticias y antecedentes precisos por medio de la correspondencia particular y si por los medios de armonía no pudiese conseguir la cobranza la demandará por el juicio o juicios que procede con arreglo a derecho proveyéndose en su uso del certificado o certificados que fueren menester ante el Tribunal que pueden ocurrir el Señor otorgante en aquella capital y su partido autoriza al expresado procurador Don José Ortega Miralles con toda su amplitud celebrando al efecto juicios de conciliación y verbales, presentando escritos, pedimentos y documentos que tenga por convenientes haciendo pruebas justificaciones de toda clase oyendo las providencias que se dicten de las cuales consentirá las favorables $[\ldots]$

Testigo: Don Julián de Vegas y Jacinto Díaz

Firmado por el notario D. Fernando Monterrubio y D. Santiago Rodríguez Alonso. 


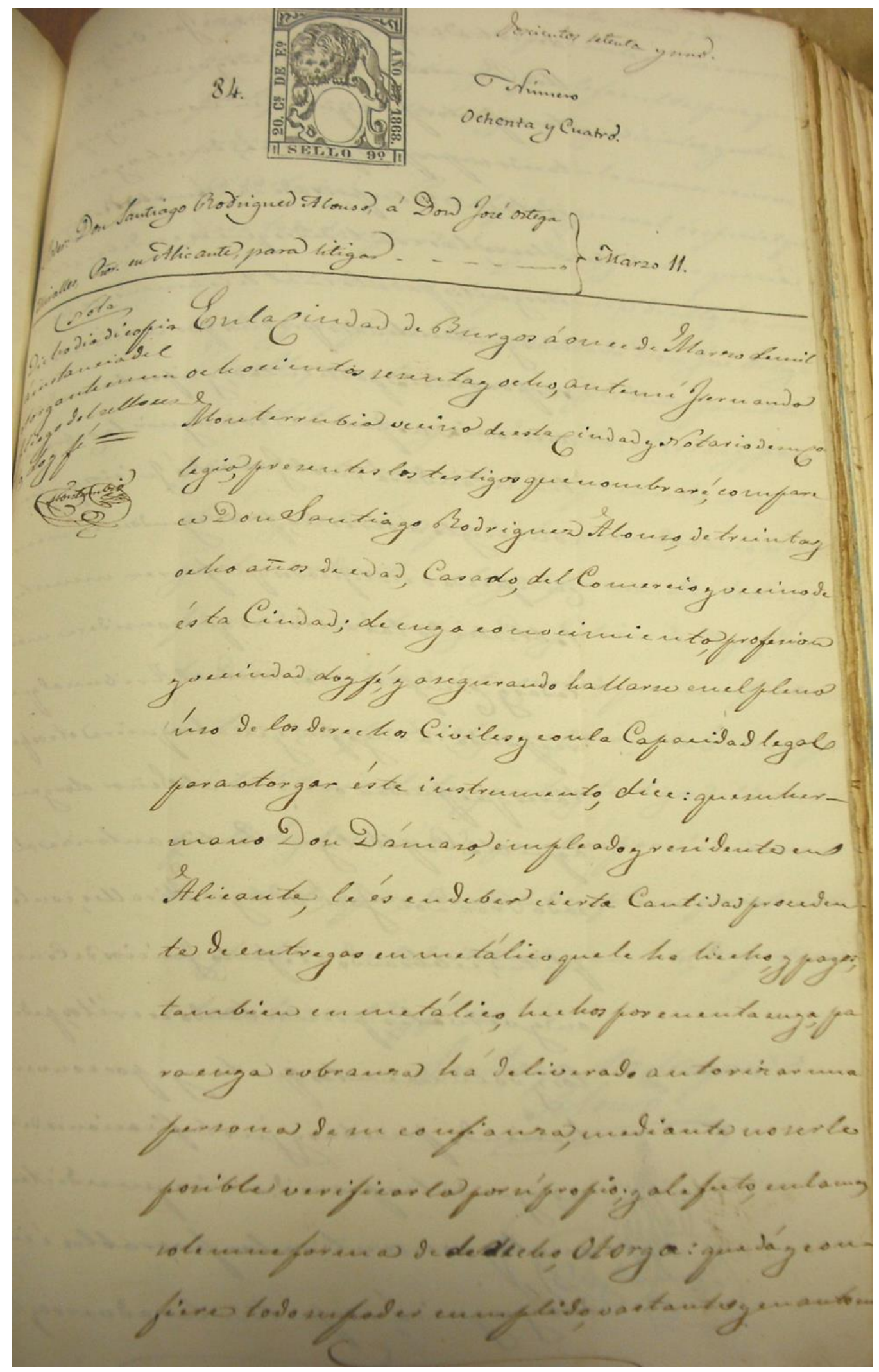

Fig.: 32

Poder para litigar de D. Santiago Rodríguez Alonso a D. José Ortega, procurador de Alicante para litigar en contra de su hermano Dámaso por deudas. Archivo Histórico Provincial de Burgos. 1868, p. 1 de 3. 


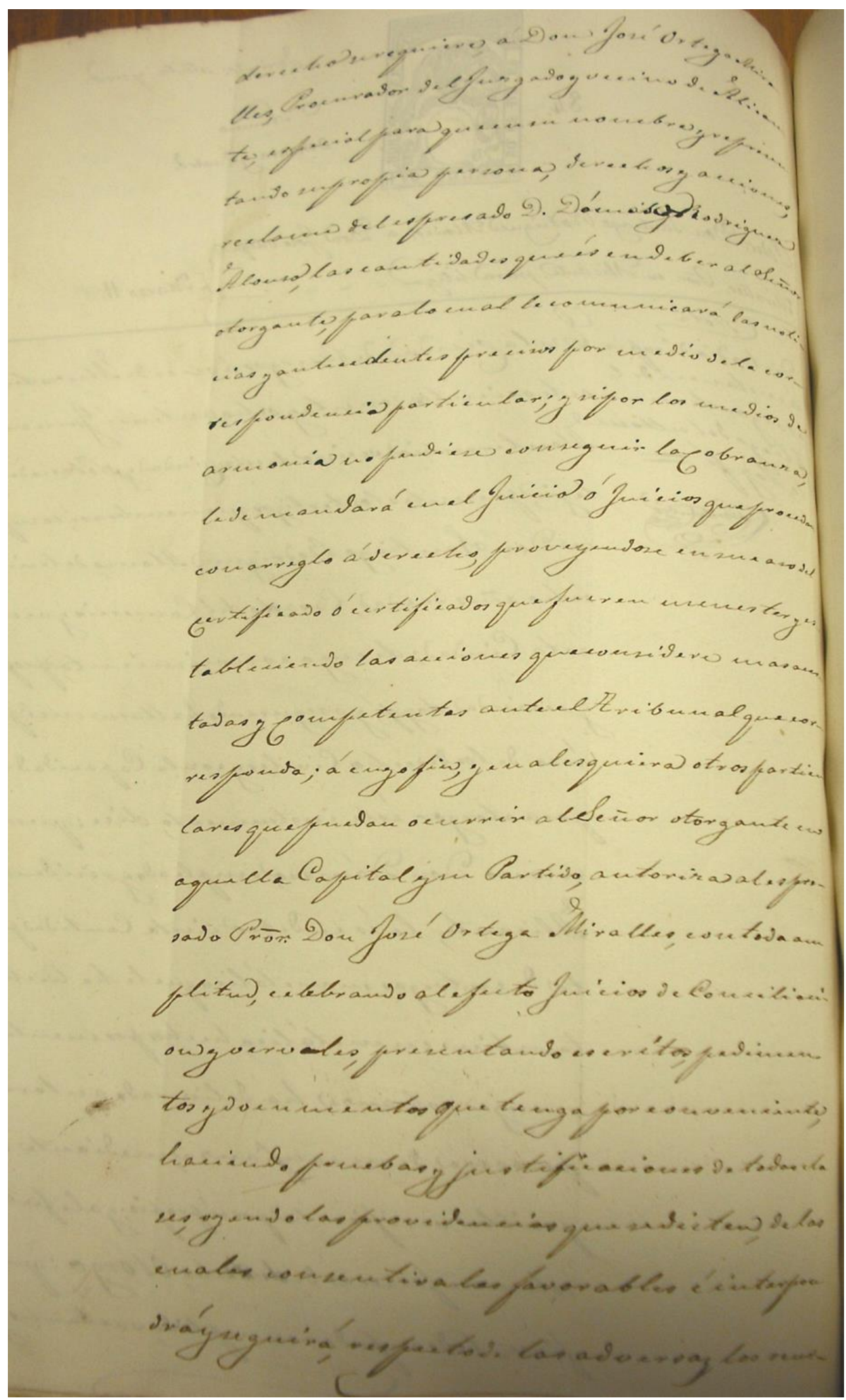

Fig.: 33

Poder para litigar de D. Santiago Rodríguez Alonso a D. José Ortega, procurador de Alicante para litigar en contra de su hermano Dámaso por deudas. Archivo Histórico Provincial de Burgos. 1868, p. 2 de 3. 


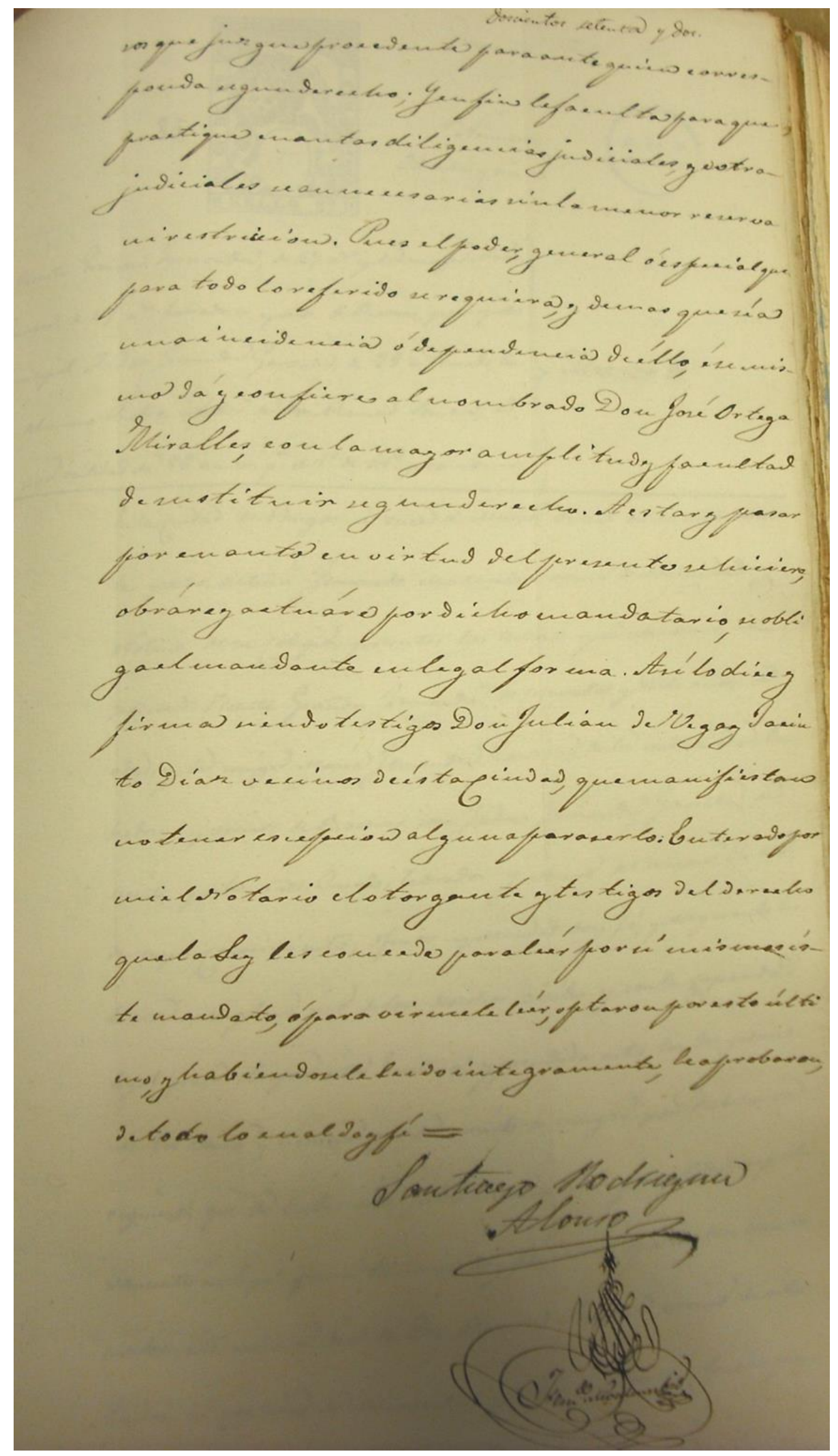

Fig.: 34

Poder para litigar de D. Santiago Rodríguez Alonso a D. José Ortega, procurador de Alicante para litigar en contra de su hermano Dámaso por deudas. Archivo Histórico Provincial de Burgos. 1868, p. 3 de 3. 


\section{Poder de D. Santiago Rodríguez Alonso a su hijo Mariano Rodríguez Miguel para que le represente en todos los asuntos de la Casa Editorial, el 19 de diciembre de 1884.}

Poder: D. Santiago Rodríguez Alonso a su hijo Mariano Rodríguez Miguel para que le represente en todos los asuntos de la Casa.

En la ciudad de Burgos a diecinueve de diciembre de mil ochocientos ochenta y cuatro ante mí D. Fernando Monterrubio vecino de la misma y notario de su Colegio presentes los testigos que nombraré comparecen: Don Santiago Rodríguez Alonso de cincuenta y cinco años de edad, viudo, comerciante y vecino de esta ciudad, según cédula personal que me exhibe y expedida con fecha dieciséis del presente mes y número trescientos sesenta y cuatro de séptima clase, el cual tiene a mi juicio la capacidad legal necesaria para celebrar este instrumento y dice: que con el fin de que los asuntos y negocios comerciales de su casa no sufran entorpecimiento ni alteración alguna y mereciéndole una ilimitada confianza su hijo Mariano ha resuelto autorizarle para que represente en toda clase de actos que pudieran ocurrirle y en que el Sr. otorgante tenga un interés directo o indirecto o se precise su intervención por cualquier concepto y a efectos con la más solemne forma de derecho otorga: que autoriza con el poder más amplio especial o general que por derecho se requiera al expresado su hijo Don Mariano Rodríguez Miguel, soltero, mayor de edad y que vive en su compañía para que le represente en todos los asuntos de su casa comercial del mismo modo que podía hacerlo por sí propio el Sr. otorgante si éste se hallare enfermo o ausente aunque no fuera de la población, de modo que podrá hacer compras, ventas o intervenir en todos los negocios del comercio con inclusión de los giros de letras, pagarés y otros efectos públicos, aceptar, endosar o pagar los mismos documentos, otorgar contratos públicos y privados, ejecutar en fin todos cuantos actos y diligencias requieran la marcha regular y acostumbrada de la casa en términos de que por falta de algún particular imprevisto se le ponga obstáculo alguno en el ejercicio de este cometido porque al efecto erige desde ahora a su citado hijo D. Mariano en su misma personalidad y aprueba y ratifica cuantos actos ejercite a nombre del Sr. otorgante; y si por cualquier caso o motivo fuera necesario parecer en juicio, le autoriza también para que de respuesta en todos los actos de conciliación con avenencia o sin ella y en los juicios verbales y en actos de todas las clases, así civiles como criminales de jurisdicción voluntaria y gubernativa que pueda ocurrirle en los Tribunales de justicia y en las Oficinas del Estado, la provincia o el municipio, pudiendo en su virtud presentar instancias escritas y documentos, hacer pruebas, oír providencias y practicar cuantas diligencias judiciales o extrajudiciales sean necesarias sin reserva ni 
restricción alguna, pues el poder general o especial que para todo lo referido se requiera y demás que sea una incidencia o dependencia de ello, ese mismo da y confiere a su citado hijo D. Mariano Rodríguez Miguel con la mayor amplitud y facultades $[\ldots]$

Firmado por el notario D. Fernando Monterrubio, D. Santiago Rodríguez y dos testigos.

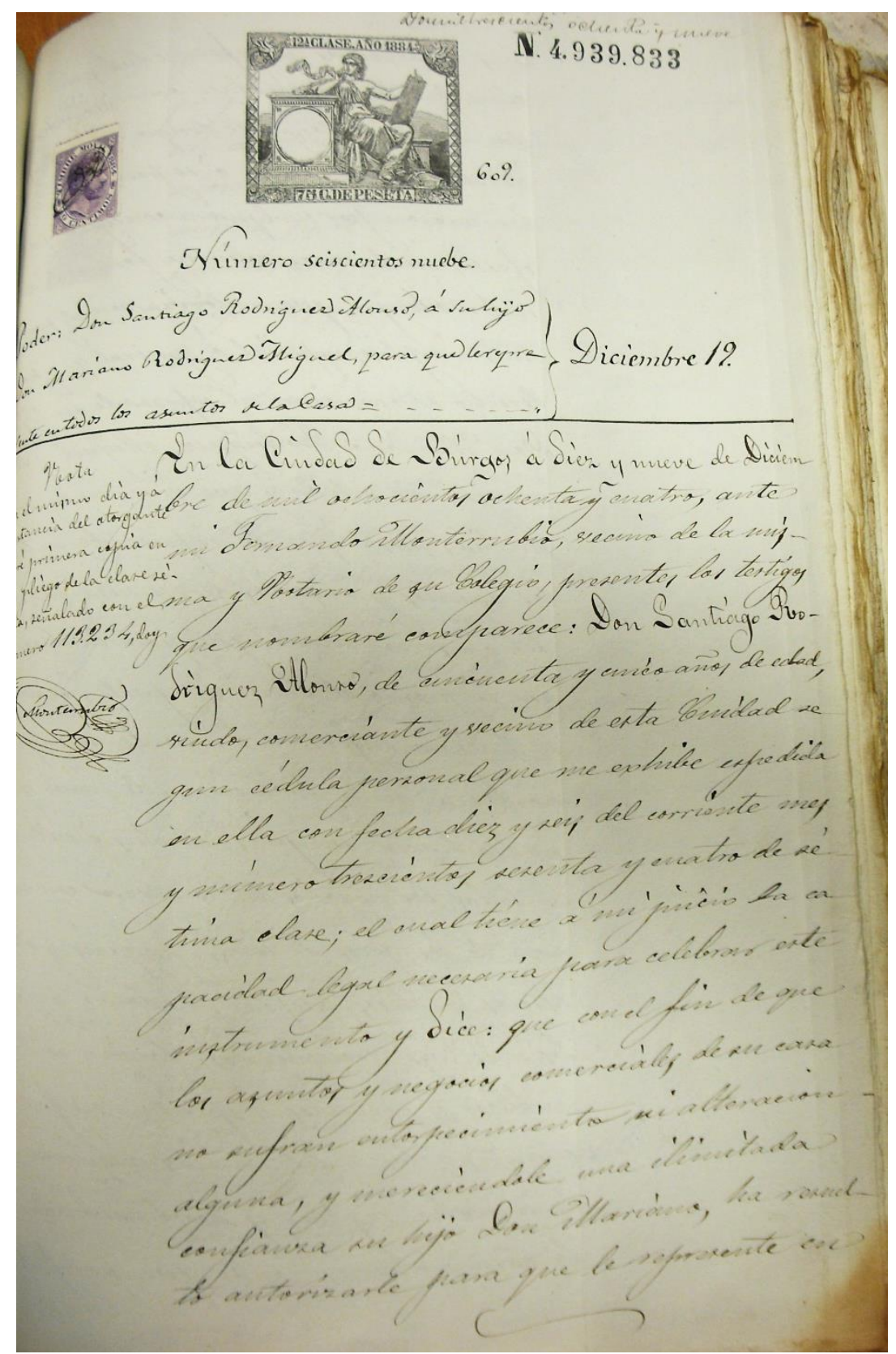

Fig.: 35

Poder de D. Santiago Rodríguez Alonso a favor de su hijo, Mariano Rodríguez Miguel para que le represente en todos los asuntos.

Archivo Histórico Provincial de Burgos. 1884, p. 1 de 4. 


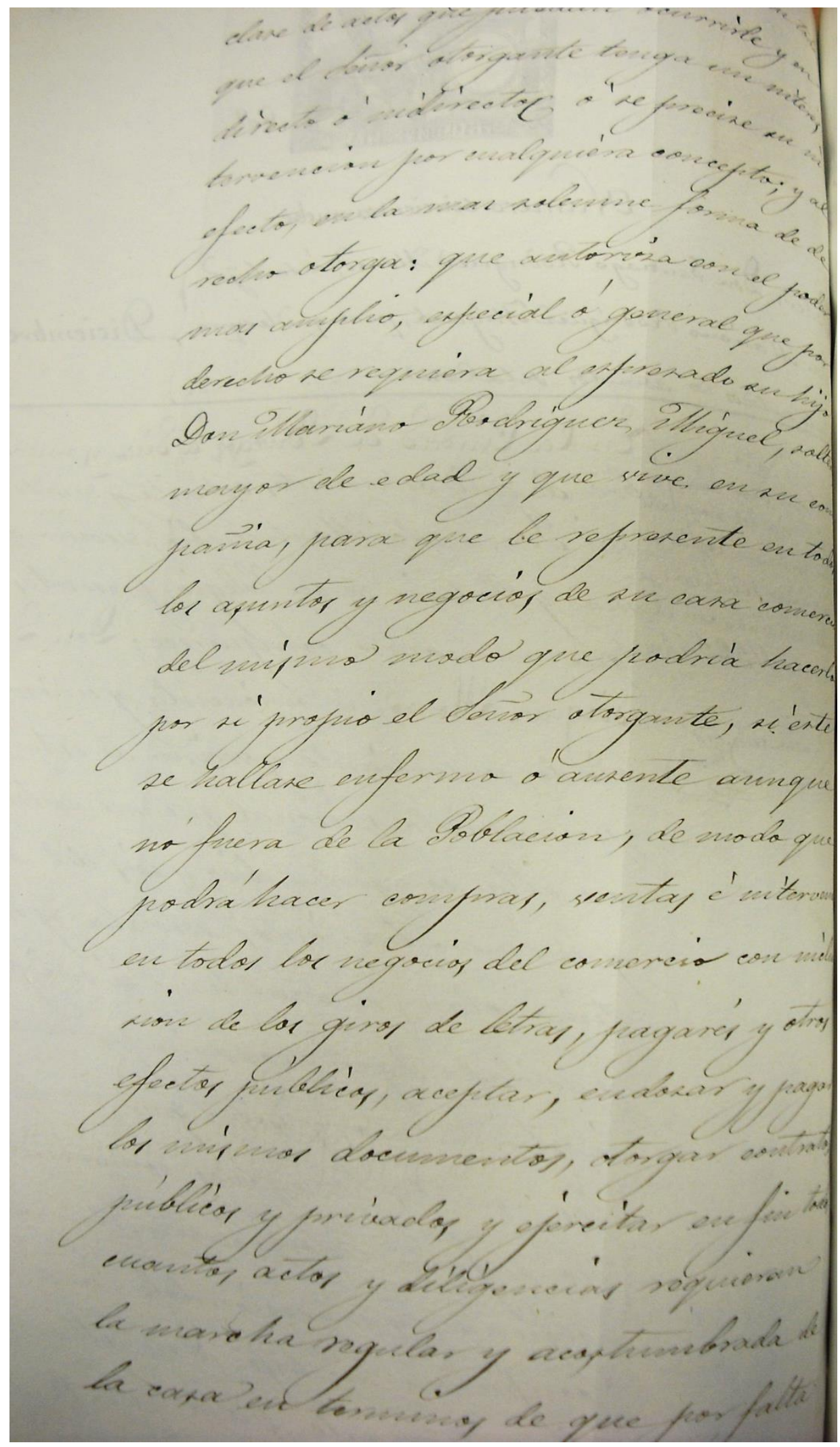

Fig.: 36

Poder de D. Santiago Rodríguez Alonso a favor de su hijo, Mariano Rodríguez Miguel para que le represente en todos los asuntos.

Archivo Histórico Provincial de Burgos. 1884, p. 2 de 4. 


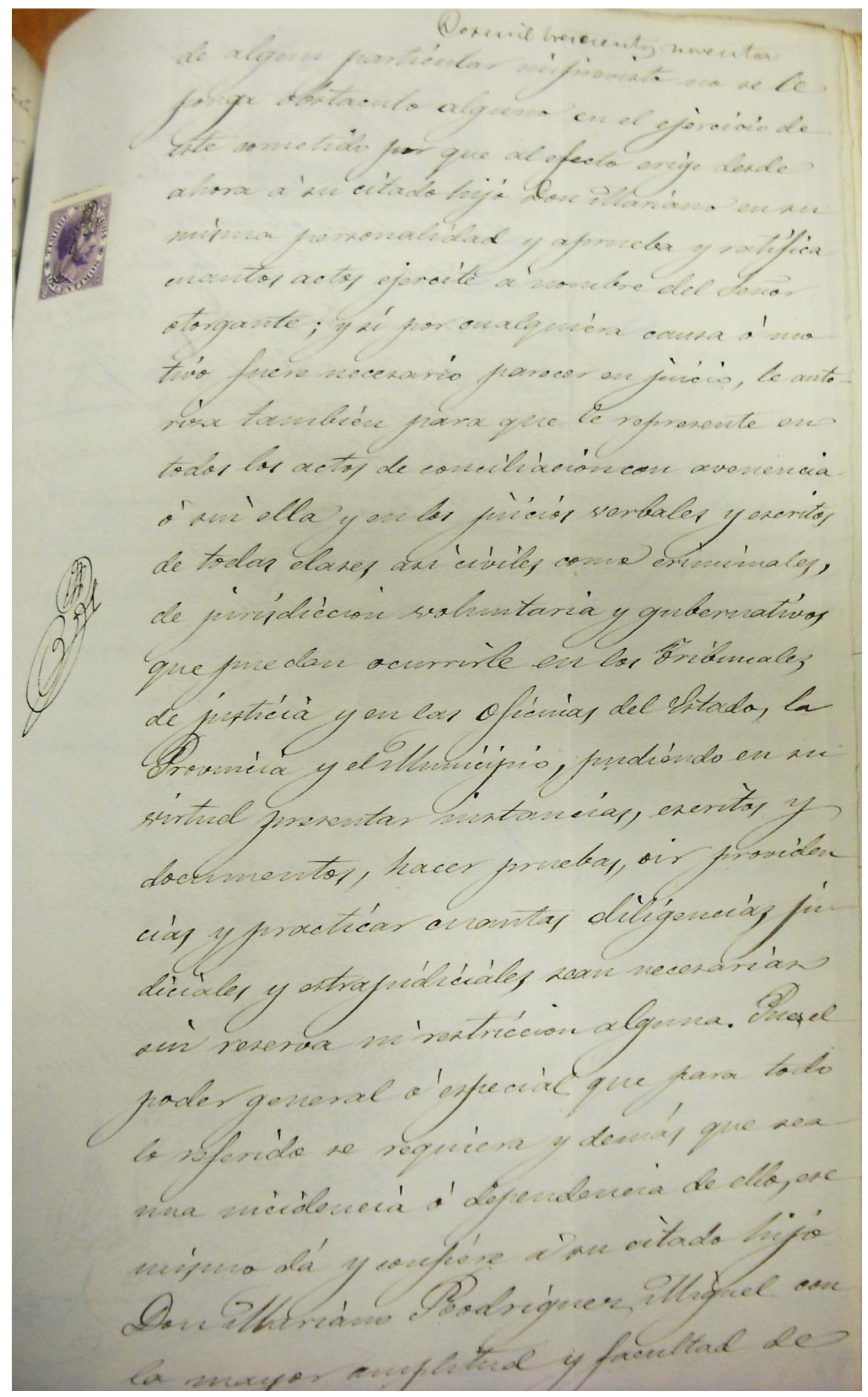

Fig.: 37

Poder de D. Santiago Rodríguez Alonso a favor de su hijo, Mariano Rodríguez Miguel para que le represente en todos los asuntos.

Archivo Histórico Provincial de Burgos. 1884, p. 3 de 4. 


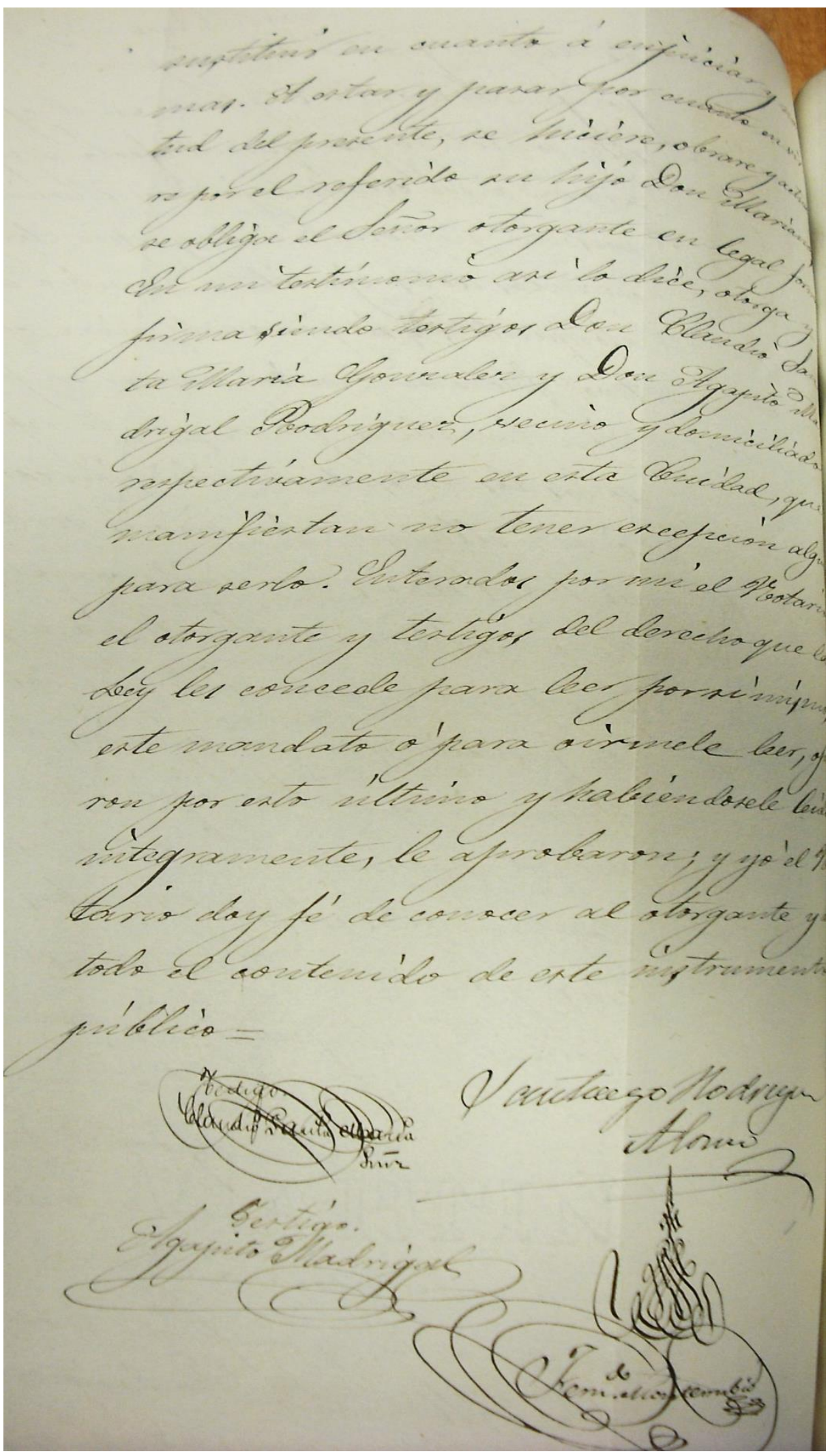

Fig.: 38

Poder de D. Santiago Rodríguez Alonso a favor de su hijo, Mariano Rodríguez Miguel para que le represente en todos los asuntos.

Archivo Histórico Provincial de Burgos. 1884, p. 4 de 4. 


\section{Testamento de D. Santiago Rodríguez Alonso, el 6 de abril de 1891.}

Testamento de D. Santiago Rodríguez Alonso.

En la ciudad de Burgos a las cinco de la tarde del día seis de abril de mil ochocientos noventa y uno, ante mi Fernando Monterrubio, vecino de la misma y Notario de su colegio presentes los testigos que comparece Don Santiago Rodríguez Alonso, de sesenta años de edad, viudo, comerciante, natural y vecino de esta ciudad, según cédula personal que me exhibe expedida en ella con fecha once de agosto última y número cuarenta, de séptima clase, hijo de Don Antolín y $\mathrm{D}^{\mathrm{a}}$ Luisa, difuntos, vecinos que fueron de esta ciudad, el cual hallándome algo delicado de salud pero en su juicio con capacidad legal necesaria para testar dice: Que deseando formalizar su última voluntad otorgan el presente testamento abierto en la forma contenida en las cláusula siguientes:

Porque he vivido, vive y pretende vivir y morir en el seno de la Religión C.A.R.

Deja a la voluntad de sus hijos y testamentarios la disposición de entierro, funerales y demás sufragios que hayan de verificarse por sufragio de su alma.

Quiere que se paguen las mandas pías forzosas que estuvieren vigentes al tiempo de su fallecimiento.

Declara haber estado casado legítimamente en primeras y únicas nupcias con $\mathrm{D}^{\mathrm{a}}$ Irene Miguel y Campo, de cuyo matrimonio tiene cinco hijos llamados D ${ }^{a}$ Luisa, D. Mariano, $D^{a}$ María del Pilar, D. Francisco y D ${ }^{a}$ María de la Gloria de los cuales los dos últimos son menores de edad en cuya virtud nombra por tutor de los mismos a D. Valentín Jalón y Gallo por el D. Francisco y a D. Mariano hijo del testador para Da María de la Gloria relevada de toda fianza por merecerles ambos la misma e ilimitada confianza.

Es su expresa voluntad que teniendo recibidas algunas cantidades sus hijos casados $\mathrm{D}^{\mathrm{a}}$ Luisa, D. Mariano se iguale con los mismos a los otros tres adjudicándoles en su oportunidad la suma equivalente según aparecerá de los apuntes que el testador lleva en sus libros.

Lega y manda la cantidad de dos mil pesetas a su hermana política $\mathrm{D}^{\mathrm{a}}$ Elisa Miguel y Campos que vive en su compañía y la recomienda muy particularmente a sus hijos para que la atiendan y no la abandonen durante sus días por sus especiales circunstancias.

Instituye y nombra por sus únicos y universales herederos de todos sus bienes, acciones y derechos presentes y futuros a sus referidos cinco hijos: $\mathrm{D}^{\mathrm{a}}$ Luisa, D. Mariano, $\mathrm{D}^{\mathrm{a}}$ María del Pilar, D. Francisco y $\mathrm{D}^{\mathrm{a}}$ María de la 
Gloria Rodríguez y Miguel por iguales partes para que los hayan y hereden con la bendición de Dios y la suya.

Declara que sus dos hijos D. Mariano y D. Francisco aunque no se hallan en sociedad con el otorgante, trabajan e intervienen en todos los asuntos de la casa por un estipendio que les tiene asignado el Señor otorgante y que les tiene satisfechos constantemente hasta el día sin atraso de ningún género lo que manifiesta para que se tenga presente en su oportunidad.

Para cumplir y pagar este su testamento y lo en él contenido nombra por sus albaceas testamentarios y contadores a sus dos hijos legítimo y político respectivamente D. Mariano Rodríguez y D. Valentín Jalón y a su convecino D. Agapito Escudero Torres, a los tres juntos y a cada uno in solidum con todas las facultades más amplias para que luego de su fallecimiento y sin intervención alguna judicial cumplan todo cuanto deja dispuesto $[\ldots]$

Y por el presente revoca, anula y cancela todo testamento o disposición anterior al presente y que es el que quiere se guarde, cumpla y aplique en la forma más legal y solemne que tenga lugar en derecho. En mi testimonio así lo dice otorga y firma habiendo tenido en un solo acto y en presencia de los tres testigos idóneos que ven, entienden y conocen al testador y lo son D. Nicolás Rey Redondo, D. Nazario Escudero y Torres y D. Hilarión Garzón Gutiérrez, vecinos de esta ciudad que manifiestan no tener acepción alguna para serlo. Enterados por mí el Notario, los señores otorgantes y testigos del derecho que la ley les concede para leer por sí mismo este testamento o para oírmele leer, optaron por esta última y habiéndose leído íntegramente le aprobaron manifestando el testador estar conforme con todos y cada una de las cláusulas y yo el Notario doy fe al conocer al señor otorgante y testigos, de haberse cumplido las disposiciones expresadas en la sección general del capítulo primero del vigente código civil y de todo el contenido de este instrumento público.

Firmado por el notario D. Fernando Monterrubio, D. Santiago Rodríguez Alonso y tres testigos, Nicolás Rey, Nazario Escudero e Hilarión Garzón. 


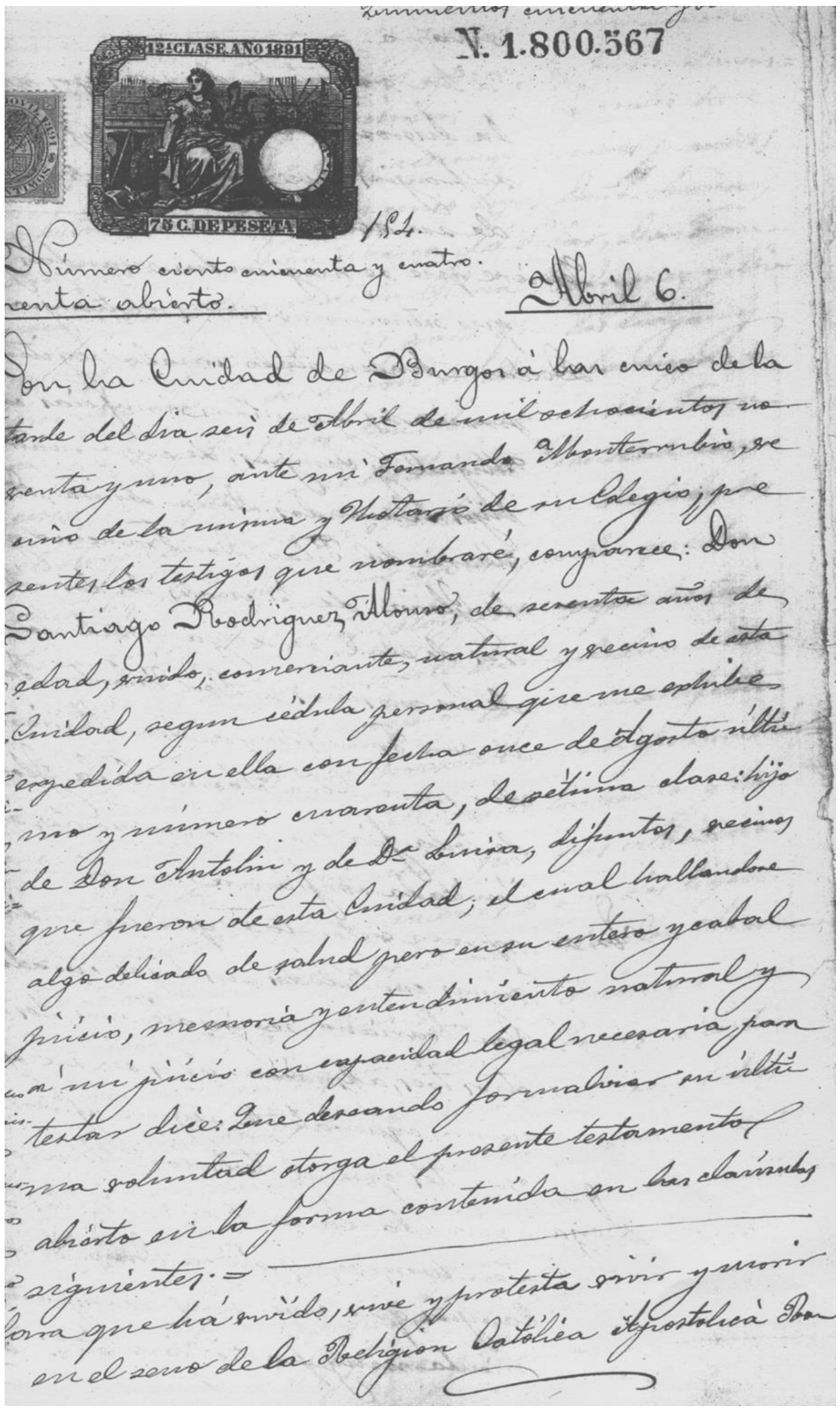

Fig.: 39

Testamento de D. Santiago Rodríguez Alonso.

Archivo Histórico Provincial de Burgos. 6 de abril de 1891, p. 1 de 4. 
LA EDITORIAL BURGALESA HIJOS DE SANTIAGO RODRÍGUEZ (1891-1936): ANÁLISIS DE LOS LIBROS ESCOLARES

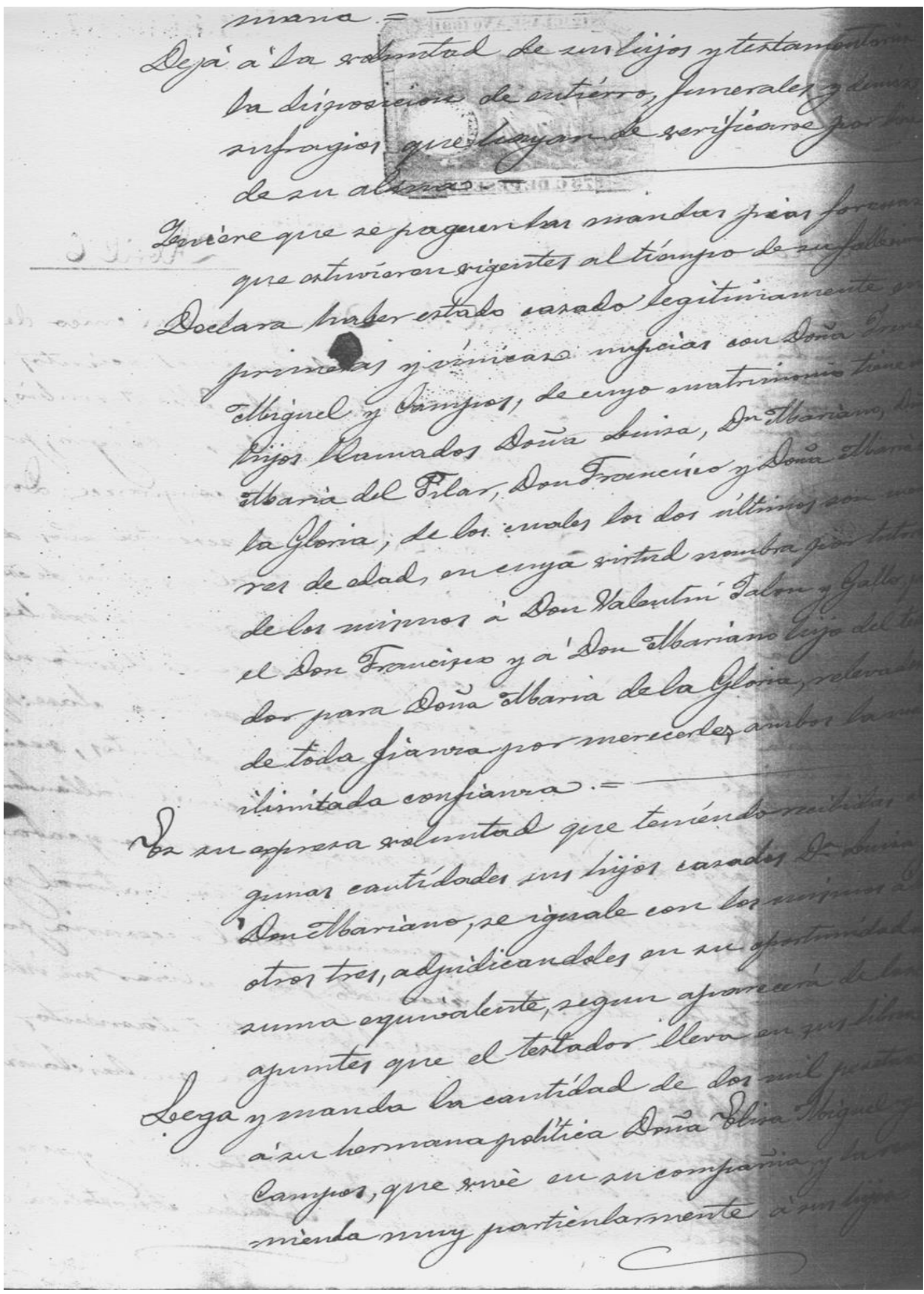

Fig.: 40

Testamento de D. Santiago Rodríguez Alonso.

Archivo Histórico Provincial de Burgos. 6 de abril de 1891, p. 2 de 4. 


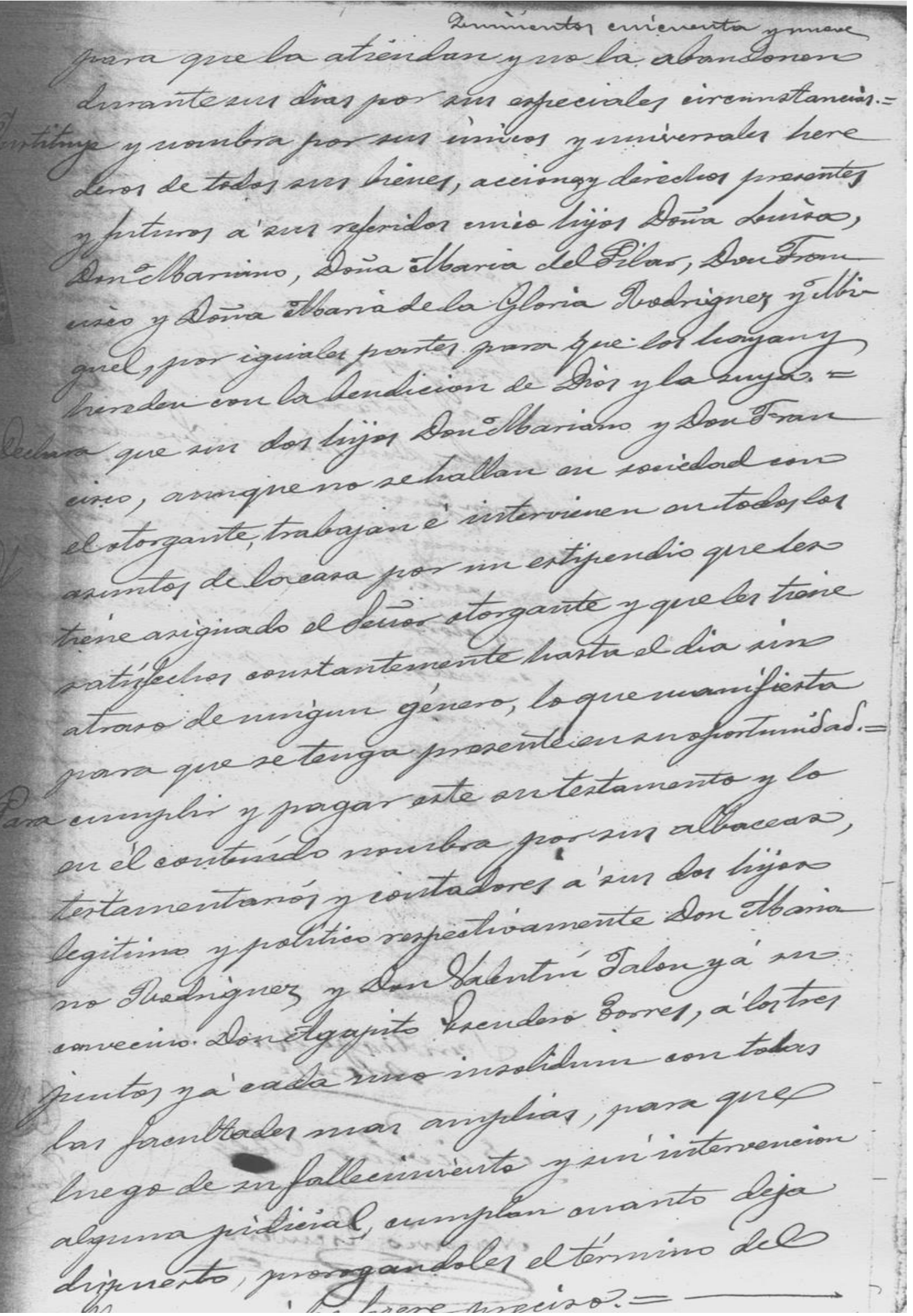

Fig.: 41

Testamento de D. Santiago Rodríguez Alonso.

Archivo Histórico Provincial de Burgos. 6 de abril de 1891, p. 3 de 4. 
LA EDITORIAL BURGALESA HIJOS DE SANTIAGO RODRÍGUEZ (1891-1936): ANÁLISIS DE LOS LIBROS ESCOLARES

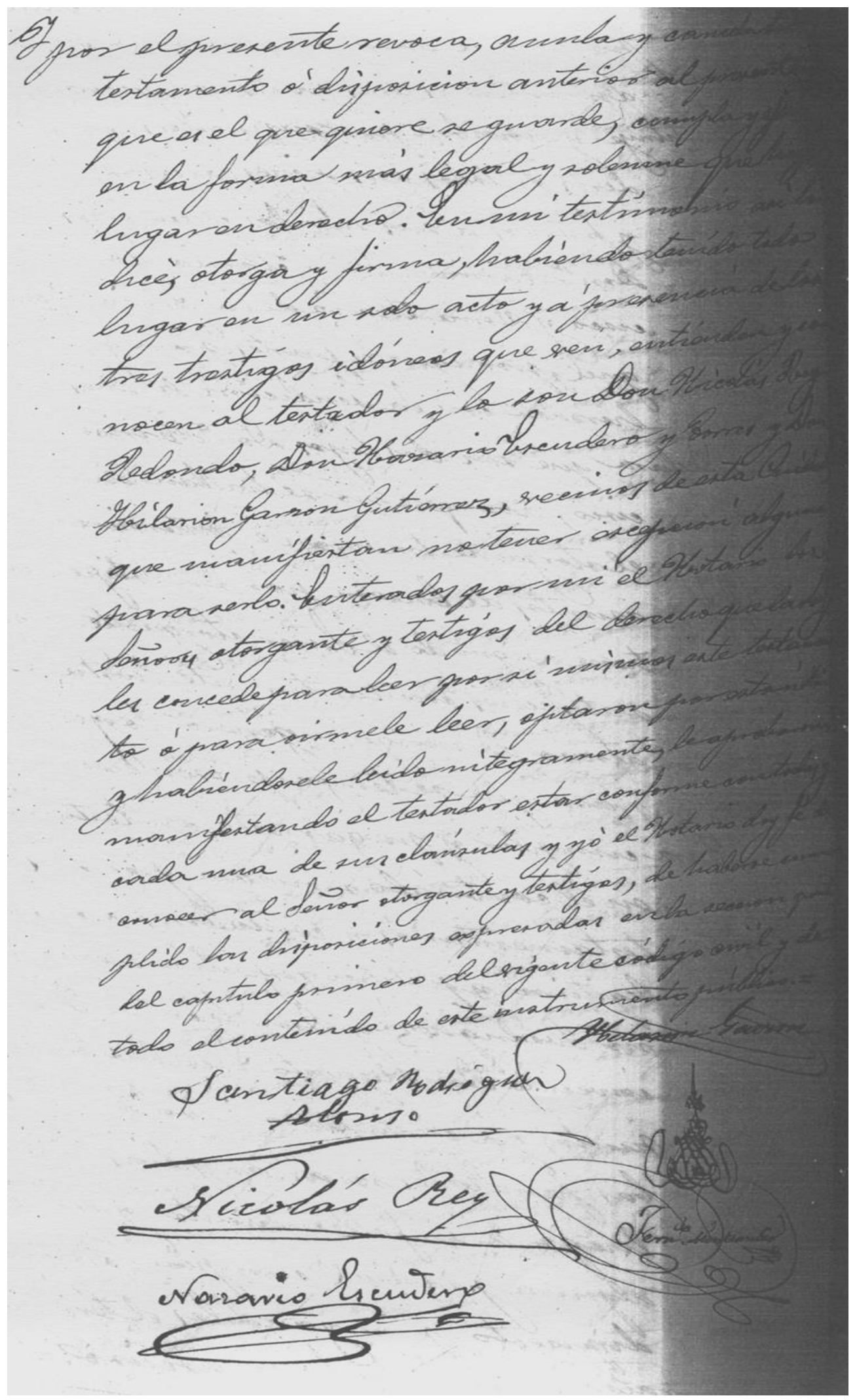

Fig.: 42

Testamento de D. Santiago Rodríguez Alonso.

Archivo Histórico Provincial de Burgos. 6 de abril de 1891, p. 4 de 4. 


\section{Escritura de Sociedad "Hijos de Santiago Rodríguez".}

\section{Escritura de Sociedad titulada "Hijos de Santiago Rodríguez"}

En la ciudad de Burgos a veinte y tres de Junio de mil ochocientos noventa y uno, ante mí Fernando Monterrubio, vecino de la misma y Notario de su colegio, presentes los testigos que nombraré comparecen: Don Mariano, Don Francisco, Doña María del Pilar y Doña María de la Gloria Rodríguez Miguel, hermanos, de edad, respectivamente de treinta y uno, veinte y dos, veinte y uno y diez y siete años, casado el primero y solteros los demás, comerciantes los dos varones y dedicados a las labores de su sexo las dos hembras, todos vecinos y domiciliados en esta ciudad según cédulas personales que me exhiben expedidas en ella con las respectivas fechas de veinte y ocho de octubre, once, quince y once de Agosto últimos y números respectivamente doscientos ochenta y seis, de sétima clase, trescientos cuarenta y cinco, trescientos cuarenta y cuatro y trescientos cuarenta y seis, de undécima clase; y Don Valentín Jalón y Gallo de treinta y seis años, casado, Secretario de Sala y propietario y vecino de esta ciudad, según cédula personal que también me exhibe expedida con fecha veinte y dos de septiembre último y número ciento noventa y seis, de sétima clase, éste último como legítimo representante de su esposa Doña Luisa Rodríguez Miguel, todos los cuales tienen a mi juicio la capacidad legal necesaria para celebrar este instrumento y al efecto me presentan en este acto el certificado que acredita la autorización del consejo de familia a los menores Don Francisco y Doña María de la Gloria y que copiada a la letra dice así:

(Aquí el certificado)

Concuerda el certificado inserto literalmente con su original que queda unido a este registro para documentarlo e insertar en sus traslados, de que doy fe y a que me remita, y en su consecuencia todos los señores comparecientes de su acuerdo y en conformidad manifiestan que:

$1^{\circ}$ A consecuencia del fallecimiento de su Señor padre Don Santiago Rodríguez Alonso vecino que fue de esta ciudad, ocurrido en ella el día nueve de abril próximo pasado, procedieron a la formulación de las oportunas operaciones testamentarias que aprobadas judicialmente por auto de cinco del corriente mes, fueron protocolizadas en mi registro corriente de escrituras públicas con fecha seis del mismo bajo el número de orden doscientos cincuenta y dos, resultando de las mismas, haberse adjudicado a cada uno de los comparecientes Don Mariano y Don Francisco Rodríguez Miguel la quinta parte de los bienes, derechos y acciones, que constituían el Establecimiento mercantil e industrial que giraba en esta plaza bajo la denominación de "Santiago Rodríguez Alonso" compuesto de imprenta, almacén de papel y objetos de escritorio correspondiendo las otras tres 
quintas partes a sus hermanas Doña Luisa, Doña María del Pilar y Doña María de la Gloria Rodríguez Miguel.

$2^{\circ}$ Que con tal motivo celebraron diferentes conferencias para el examen del pensamiento que a todos dominaba sobre la conveniencia de constituir una sociedad que además de honrar a la memoria de su buen padre, continuase funcionando en la misma forma que giraba durante su vida y habiendo merecido la aprobación de personas competentes con inclusión del consejo de familia protector y tutores de los dos citados menores, han resuelto fundar una sociedad y empresa industrial y de comercio que teniendo por objeto la continuación del que su Señor padre giraba, comprenda las bases meditadas y discutidas que consideran han de contribuir al interés de todos; y en consecuencia otorgan la presente escritura de fundación de la sociedad regular colectiva solamente por los dos hermanos Don Mariano y Don Francisco Rodríguez Miguel y conforme a las siguientes bases:

La compañía mercantil e industrial regular colectiva que se constituye tendrá su domicilio en esta ciudad y girará bajo la razón social "Hijos de Santiago Rodríguez" y se dedicará al comercio de librería, papelería y objetos de escritorio, y a la industria de imprenta, reputándose continuadora del establecimiento expresado "Santiago Rodríguez Alonso".

\section{$2^{\circ}$}

Los dos socios citados aportan al fondo común la cantidad de diez mil pesetas que forman un total de veinte mil que es lo que constituye el capital social:

$3^{\circ}$

La gestión y administración de la compañía y el uso de la firma social, se encomienda al socio Don Mariano Rodríguez Miguel:

$4^{\circ}$

En los casos de ausencia, enfermedad o cualquiera otro impedimento de este, podrá usar el de la firma el socio Don Francisco Rodríguez Miguel, quedando facultados uno y otro en sus respectivos casos para cuantas gestiones requieran los negocios de la sociedad en su curso ordinario.

$5^{\circ}$

Cada uno de los dos socios percibirá anualmente para sus gastos particulares la cantidad de mil doscientas pesetas abonadas por el socio gerente. El Señor Don Mariano Rodríguez percibirá además como sueldo que se le señala por la gestión y administración de la compañía y de cuantos asuntos tenga relación con la misma la cantidad anual de cuatro mil pesetas y el Don Francisco por el mismo concepto y por el trabajo ordinario que ha de prestar constantemente en los negocios de la compañía la cantidad de mil pesetas anuales abonables una y otra por meses. 
$6^{\mathrm{o}}$

Anualmente y en el mes de Junio se formará el balance general que prescribe el artículo treinta y siete del colegio del comercio y se pondrá de manifiesto por quince días, para que los socios puedan enterarse de la marcha de la sociedad.

$7^{\mathbf{o}}$

El cincuenta por ciento de las utilidades que resulten en cada año, se distribuirá con igualdad entre los dos socios, reservándose el cincuenta por ciento restantes como aumento del capital social de la compañía.

$8^{\circ}$

Si en la liquidación anual que se practique resultara que había pérdida o baja del capital o los productos o ganancias, no llegaron en proporción a la cantidad retirada, se bajará a cada socio una cantidad proporcional de la asignada para sus gastos así como de los sueldos.

$9^{\circ}$

La duración de la compañía será de diez años a contar desde la fecha del otorgamiento de esta escritura.

$10^{\circ}$

Caso de fallecimiento de cualquiera de los socios sus herederos adquirirán los mismos derechos que aquellos tenían en la sociedad que continuará con estos:

\section{$11^{\circ}$}

A la liquidación de la sociedad, sea cualquiera la causa porque termine se distribuirá con igualdad entre los dos socios el haber social que resultare en la proporción igual o aproximada a efectos y en metálico que existiere, y en la misma proporción responderán de las pérdidas si las hubiere:

$12^{\circ}$

Ninguno de los socios podrá ceder, donar, vender ni permutar su participación en la sociedad a persona extraña a ésta.

$13^{\circ}$

Todas las dudas o diferencias que puedan surgir con motivo de los asuntos de la sociedad, así como por la inteligencia y aplicación de las cláusulas, se resolverán por un Tribunal de comerciantes de la plaza, que será designada uno por cuenta de los socios colectivos, dirimiendo la discordia caso de haberla, por otro designado por los dos comerciantes. El fallo o resolución de este Tribunal será obligatorio para ambos socios:

$3^{\circ}$ Que para complemento de esta escritura y en virtud de la autorización del consejo de familia que anteriormente se han mencionado, los comparecientes Doña María del Pilar y Doña María de la Gloria Rodríguez Miguel y Don Valentín Jalón y Gallo en representación de su esposa Doña Luisa Rodríguez Miguel deseando coadyuvar al mejor resultado de las sociedades que por esta escritura constituyen sus hermanos, 
Don Mariano y Don Francisco dejan a título de imposición de la sociedad "Hijos de Santiago Rodríguez", los bienes, derechos y acciones que constituyen la quinta parte por cada uno del establecimiento mercantil e industrial que fue de su finado Señor padre Don Santiago Rodríguez Alonso y le ha sido adjudicada en las operaciones testamentarias al principio mencionadas, representando un capital de quince mil seiscientas veinte y ocho pesetas cada quinta parte cuyas tres cuartas partes de imposición quedan afectas a las pérdidas y utilidades que la sociedad tenga, de modo que las tres imponentes tendrán derecho a la quinta parte cada uno de las utilidades de la sociedad, percibiendo anualmente el cincuenta por ciento de estos y reservándose el otro cincuenta por ciento al igual que los socios como aumento del capital.

Mensualmente entregará el socio gerente a cada uno de los tres imponentes la cantidad de cien pesetas como adelanto de las utilidades les puedan corresponder y si hubiere pérdidas se disminuirá la entrega menguada en justa proporción a aquellos:

El balance que anualmente forme la sociedad se pondrá de manifiesto por treinta días con los comprobantes necesarios a los imponentes o a sus legítimos representantes:

Los expresados señores Doña María del Pilar y Doña María de la Gloria Rodríguez Miguel y Don Valentín Jalón podrá retirar cuando lo tengan por conveniente la imposición que hacen en la sociedad en cuyo caso se hará inventario y se entregará a cada uno de los imponentes que lo soliciten el valor en metálico a que ascienda la quinta parte del haber de la sociedad "Hijos de Santiago Rodríguez" incluso las partes impuestas en el tiempo en que cada uno retire su imposición, para lo cual avisará con seis meses de anticipación. El pago de esta quinta parte se hará en cinco años contados desde que se haga la petición, si en otra cosa no convinieran los interesados.

Durante los cinco años percibirá el imponente que se retire el cinco por ciento del capital que en aquella fecha le corresponda, descontándose las entregas que se le fueron haciendo y no tendrá derecho a las utilidades. Caso de retirarse dos de los imponentes a un mismo tiempo percibirá cada uno el cincuenta por ciento en las épocas y plazos determinados.

Bajo cuyas bases formalizan la presente escritura que se obligan a guardar y cumplir en todas sus partes con arreglo a derecho, quedando advertidos por mí el Notario de la obligación que tienen que presentar la primera copia de estas escrituras en la oficina de liquidación del impuesto para satisfacer el que corresponda a la Hacienda Pública, dentro del término legal, sin cuyo requisito además de incumplir en las responsabilidades reglamentarias no podrá admitirse en ningún Tribunal ni oficina así lo dicen, otorgan, firman siendo testigos Don Patricio Tobar y 
Don Agapito Madrigal Rodríguez vecino y domiciliado respectivamente en esta ciudad que manifiestan no tener excepción alguna para serlo.

Enterado por mí el Notario los señores otorgantes y testigos de derecho que la ley les concede para leer por sí mismo esta escritura o para oírmelo leer, optaron por esta última y habiéndosele leído íntegramente, lo aprobaron y yo el Notario doy fe de conocer a los señores otorgantes y de todo el contenido de este instrumento público y en comprobación lo signo y firmo a continuación.

Firmado por el notario D. Fernando Monterrubio, todos los hijos varones y solteros de D. Santiago Rodríguez -Mariano, Francisco, $\mathrm{M}^{\mathrm{a}}$ del Pilar, $\mathrm{M}^{\mathrm{a}}$ de la Gloria- y D. Valentín Jalón como marido de $\mathrm{D}^{\mathrm{a}}$ Luisa Rodríguez Miguel y dos testigos. 
LA EDITORIAL BURGALESA HIJOS DE SANTIAGO RODRÍGUEZ (1891-1936): ANÁLISIS DE LOS LIBROS ESCOLARES

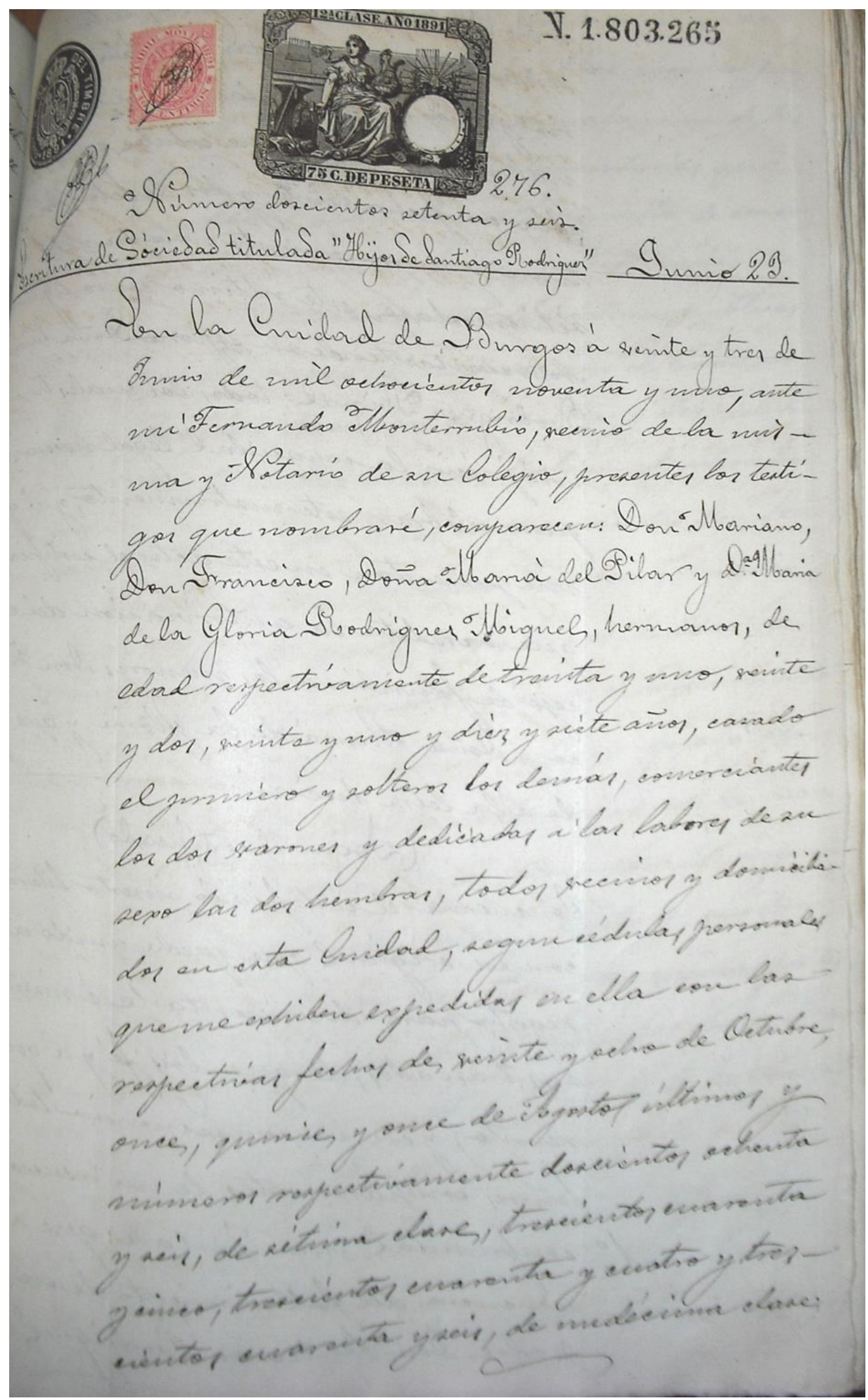

Fig.: 43

Escritura de sociedad Hijos de Santiago Rodríguez. Archivo Histórico Provincial de Burgos. 23 de junio de 1891, p. 1 de 13. 


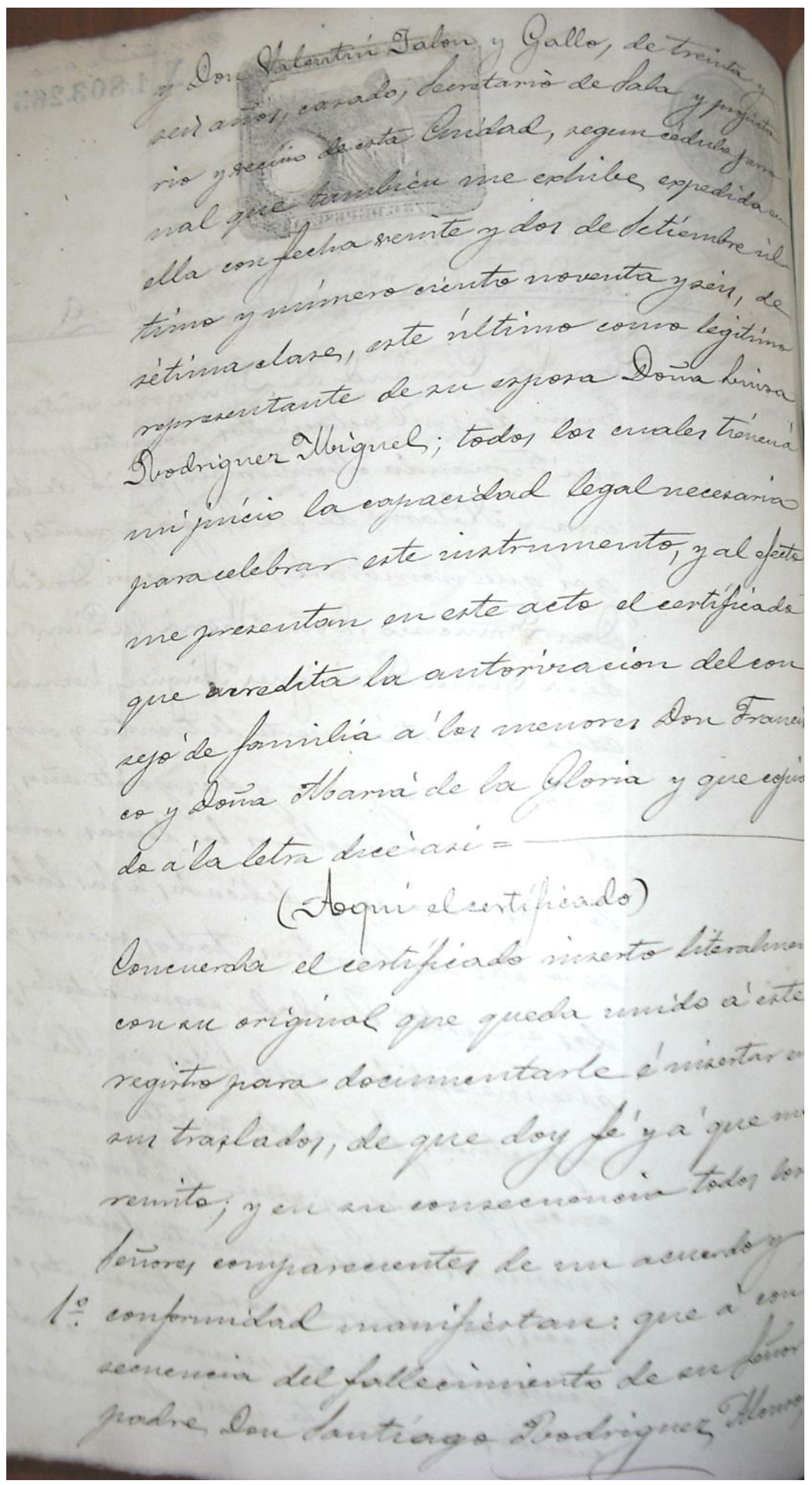

Fig.: 44

Escritura de sociedad Hijos de Santiago Rodríguez.

Archivo Histórico Provincial de Burgos. 23 de junio de 1891, p. 2 de 13. 


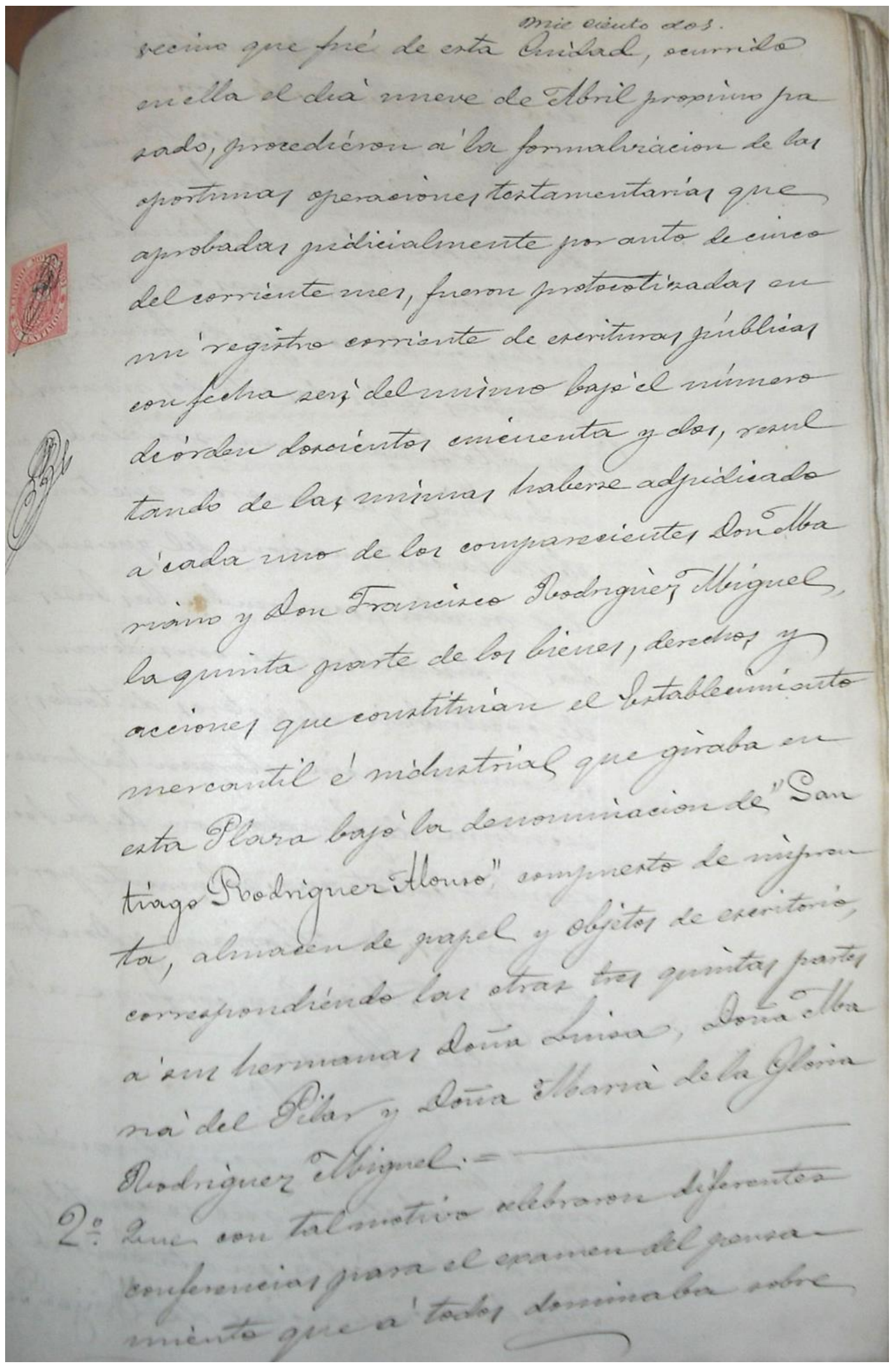

Fig.: 45

Escritura de sociedad Hijos de Santiago Rodríguez.

Archivo Histórico Provincial de Burgos. 23 de junio de 1891, p. 3 de 13. 


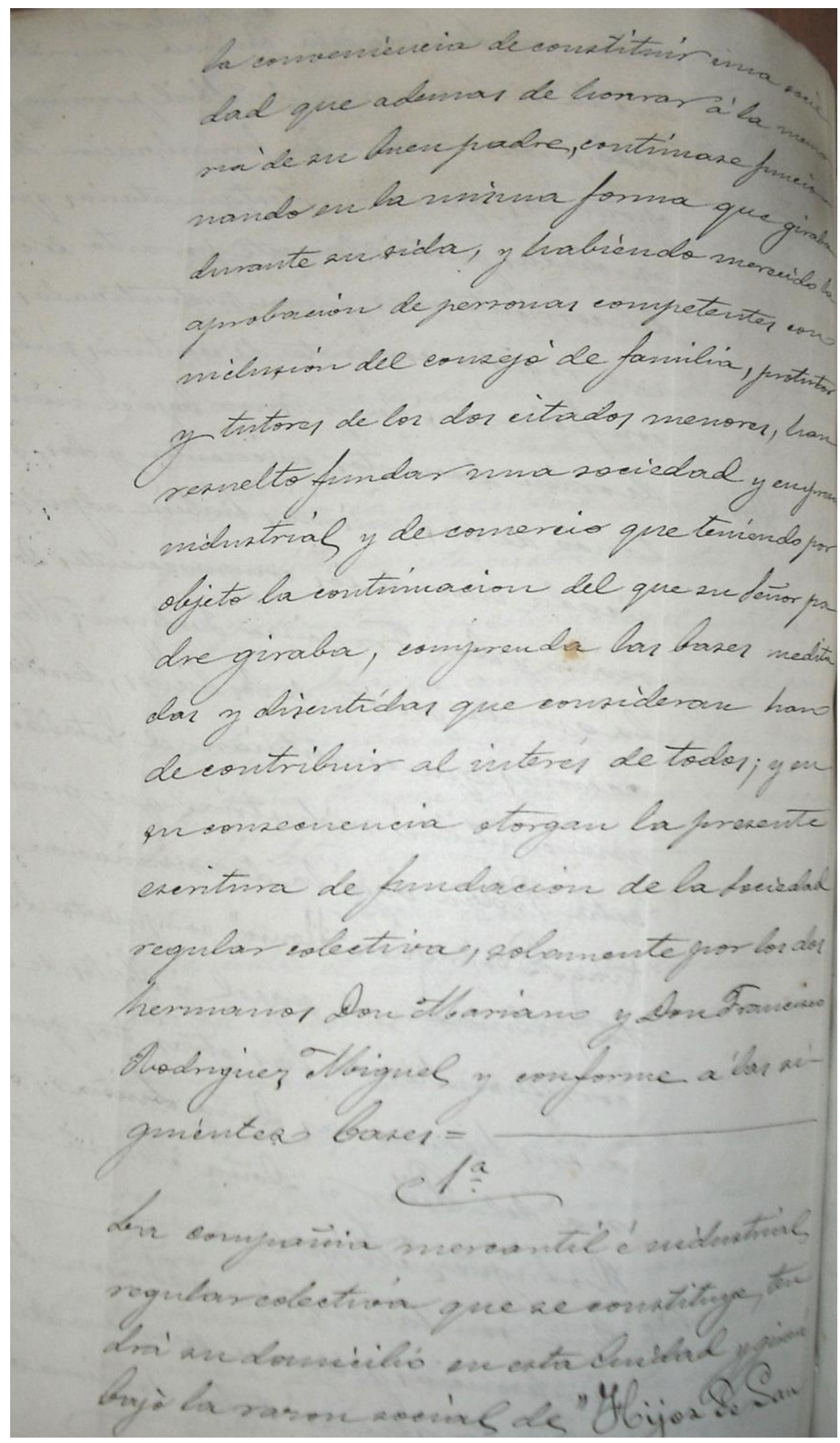

Fig.: 46

Escritura de sociedad Hijos de Santiago Rodríguez.

Archivo Histórico Provincial de Burgos. 23 de junio de 1891, p. 4 de 13. 
LA EDITORIAL BURGALESA HIJOS DE SANTIAGO RODRÍGUEZ (1891-1936): ANÁLISIS DE LOS LIBROS ESCOLARES

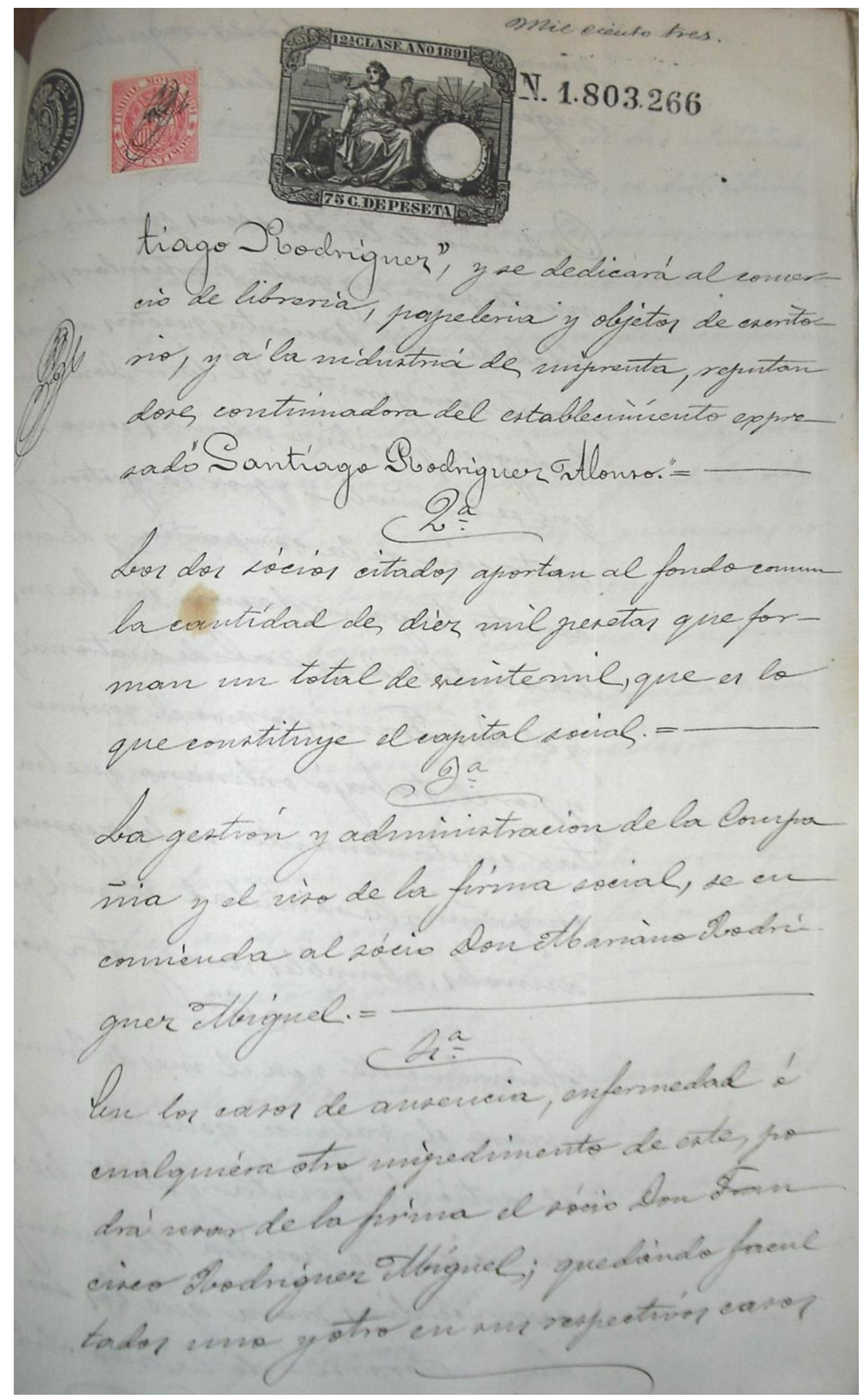

Fig.: 47

Escritura de sociedad Hijos de Santiago Rodríguez.

Archivo Histórico Provincial de Burgos. 23 de junio de 1891, p. 5 de 13. 


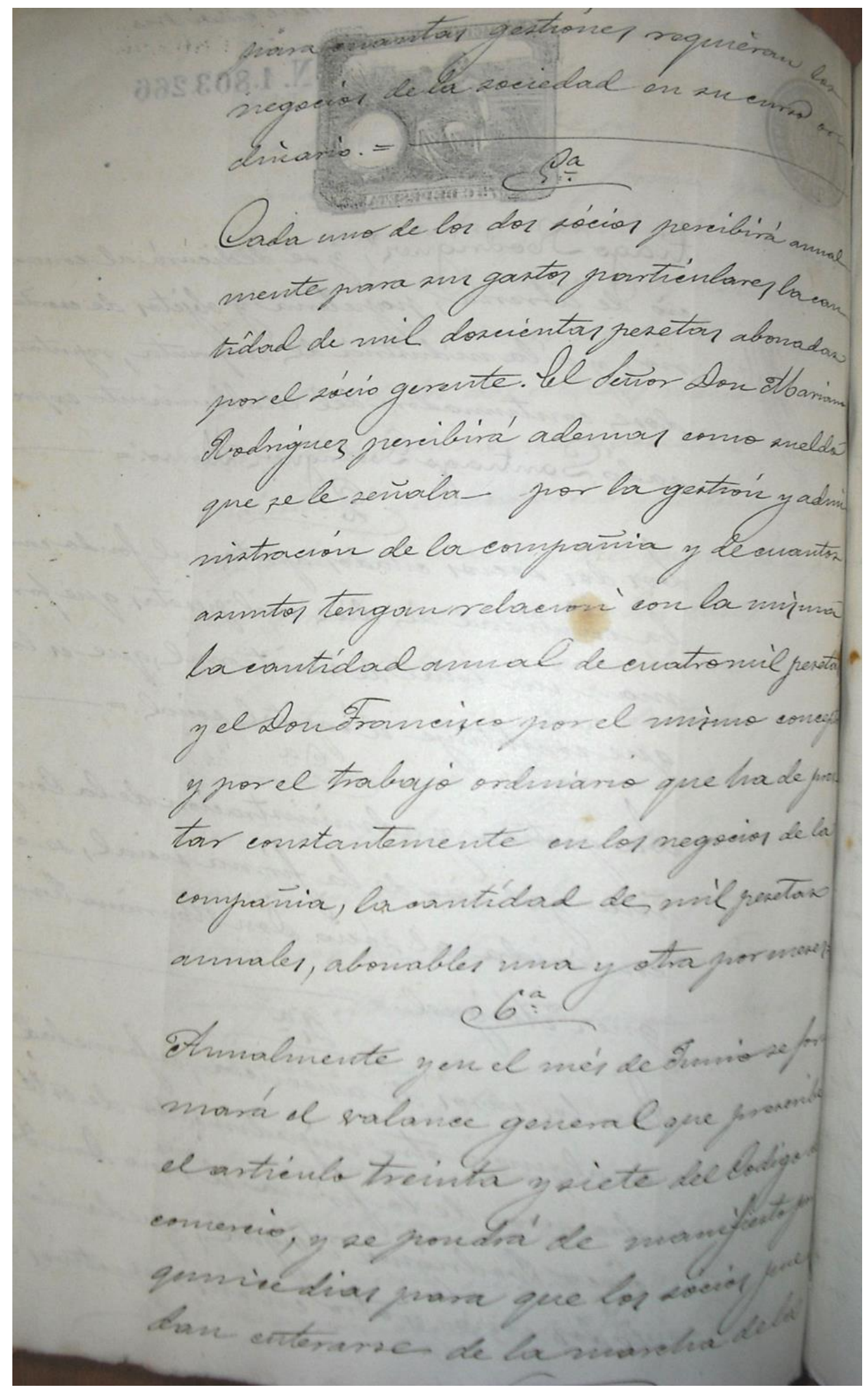

Fig.: 48

Escritura de sociedad Hijos de Santiago Rodríguez. Archivo Histórico Provincial de Burgos. 23 de junio de 1891, p. 6 de 13. 


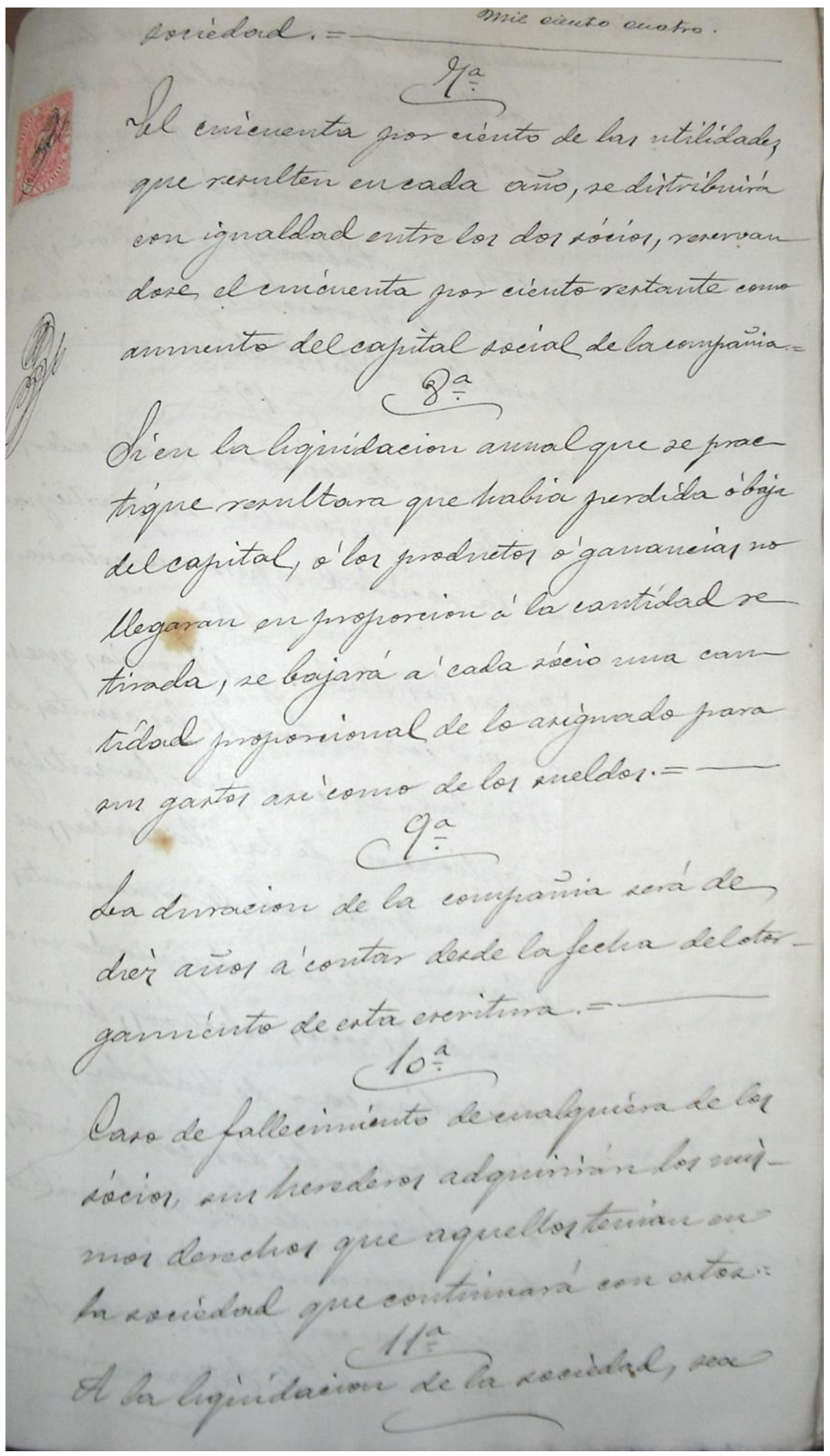

Fig.: 49

Escritura de sociedad Hijos de Santiago Rodríguez.

Archivo Histórico Provincial de Burgos. 23 de junio de 1891, p. 7 de 13. 


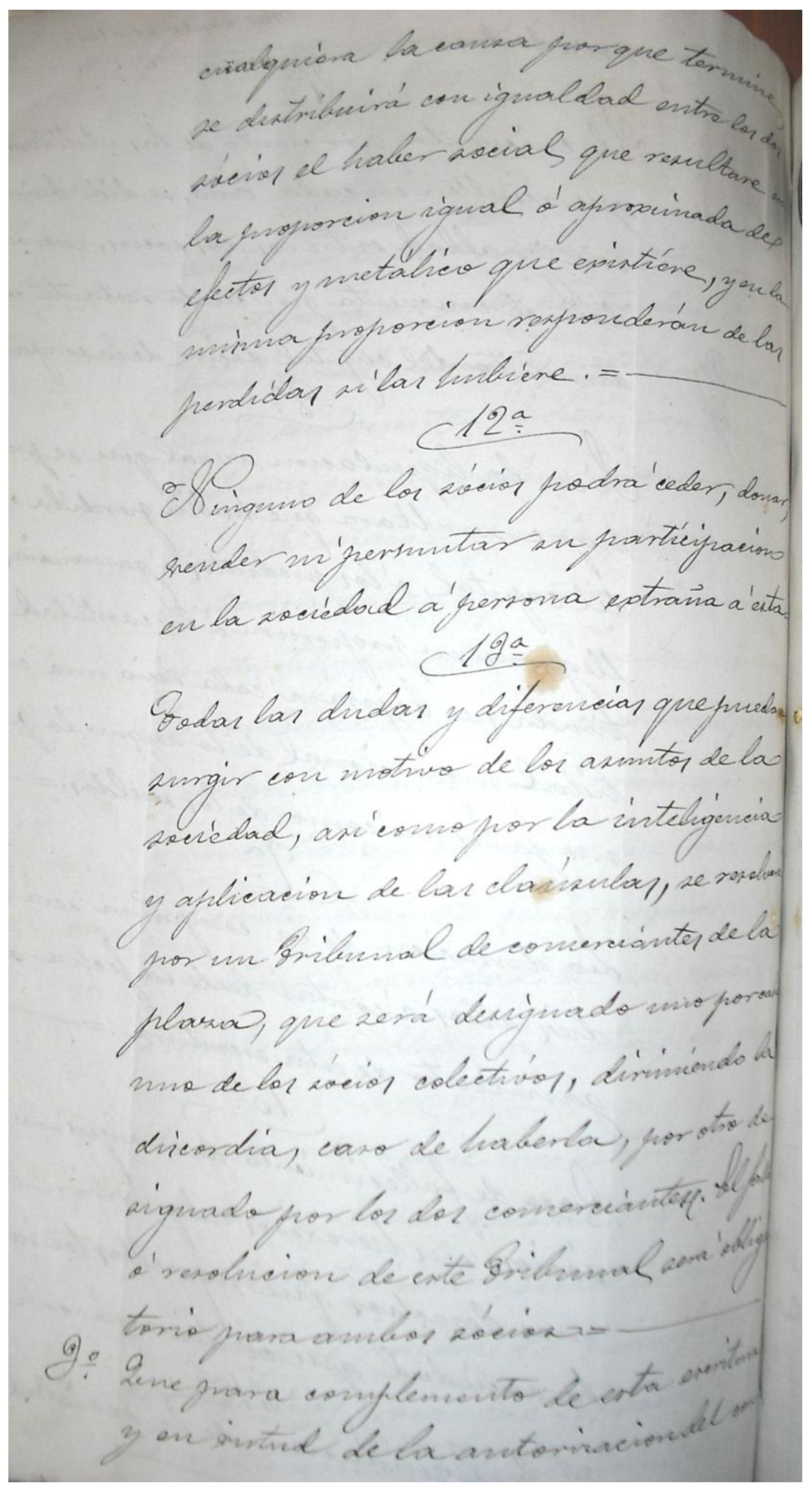

Fig.: 50

Escritura de sociedad Hijos de Santiago Rodríguez.

Archivo Histórico Provincial de Burgos. 23 de junio de 1891, p. 8 de 13. 
LA EDITORIAL BURGALESA HIJOS DE SANTIAGO RODRÍGUEZ (1891-1936): ANÁLISIS DE LOS LIBROS ESCOLARES

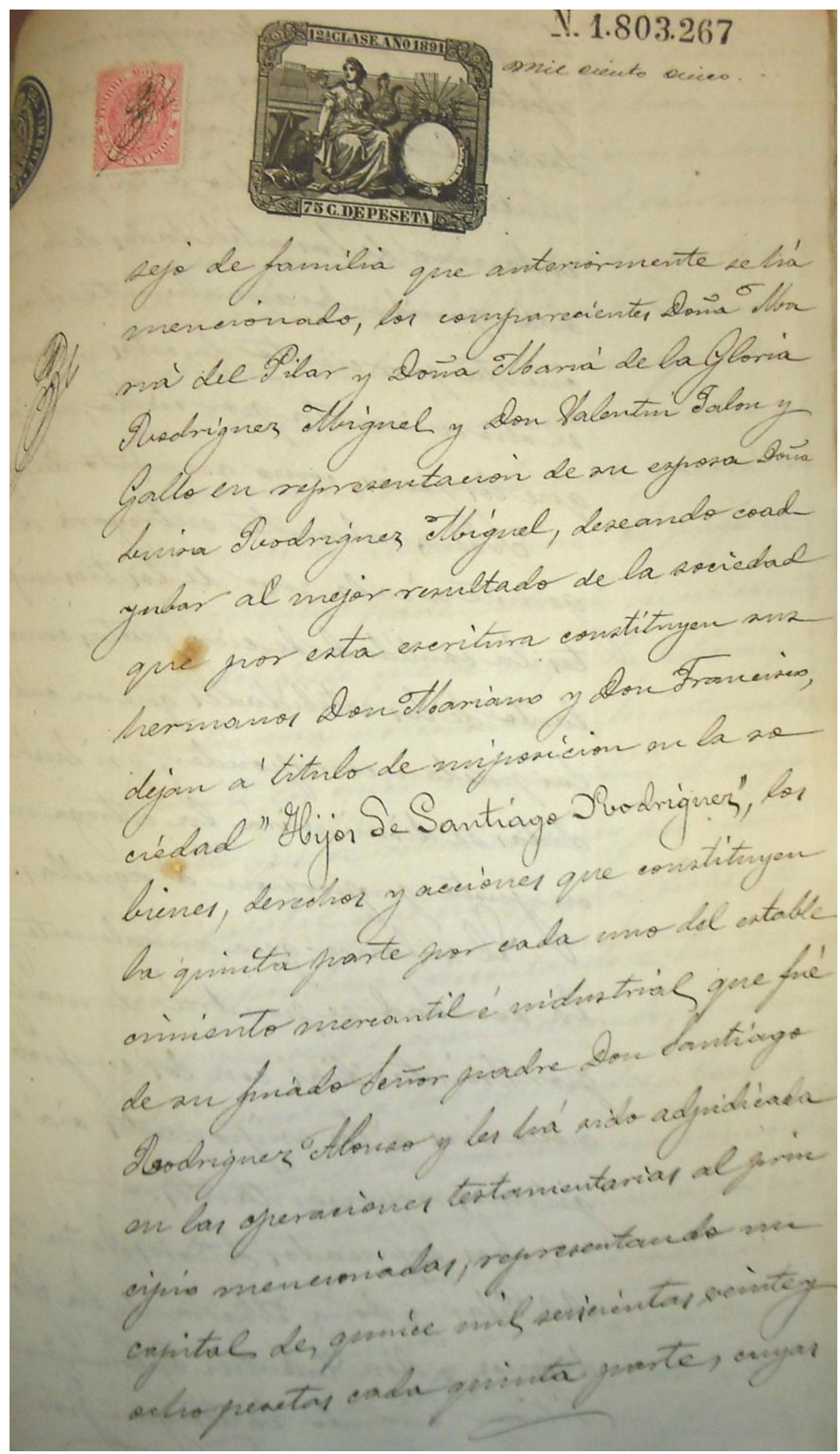

Fig.: 51

Escritura de sociedad Hijos de Santiago Rodríguez. Archivo Histórico Provincial de Burgos. 23 de junio de 1891, p. 9 de 13. 


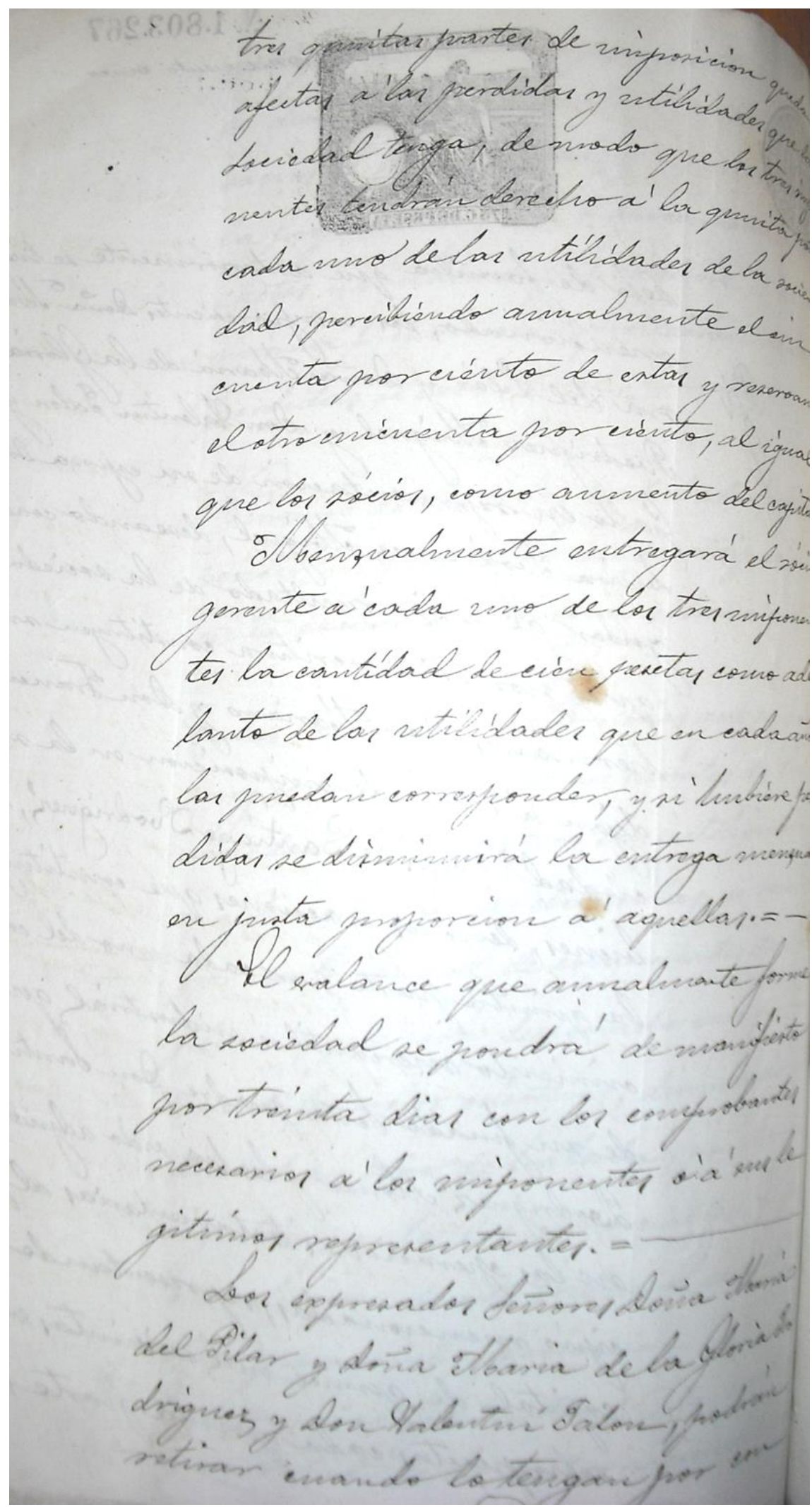

Fig.: 52

Escritura de sociedad Hijos de Santiago Rodríguez.

Archivo Histórico Provincial de Burgos. 23 de junio de 1891, p. 10 de 13. 


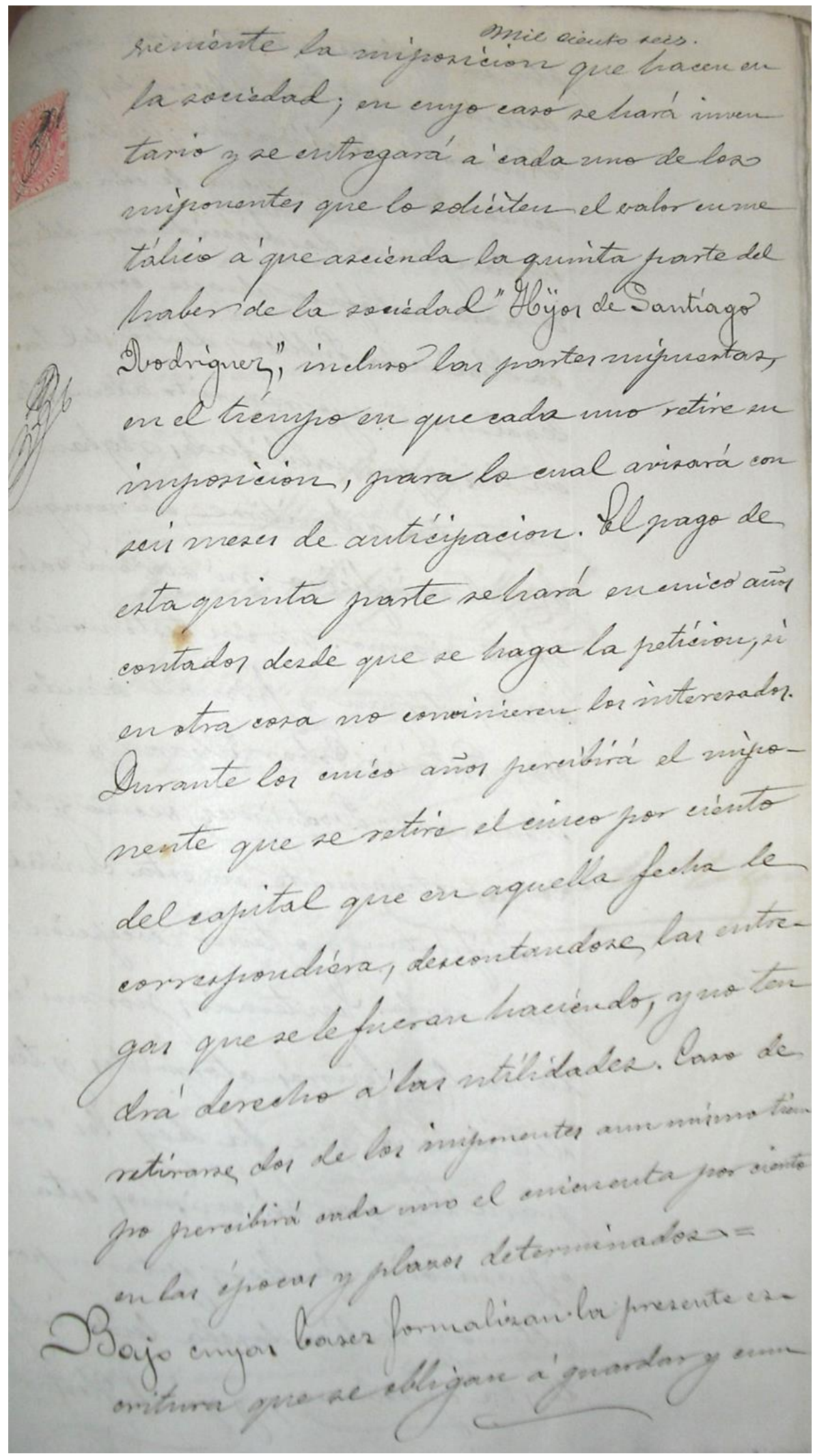

Fig.: 53

Escritura de sociedad Hijos de Santiago Rodríguez.

Archivo Histórico Provincial de Burgos. 23 de junio de 1891, p. 11 de 13. 


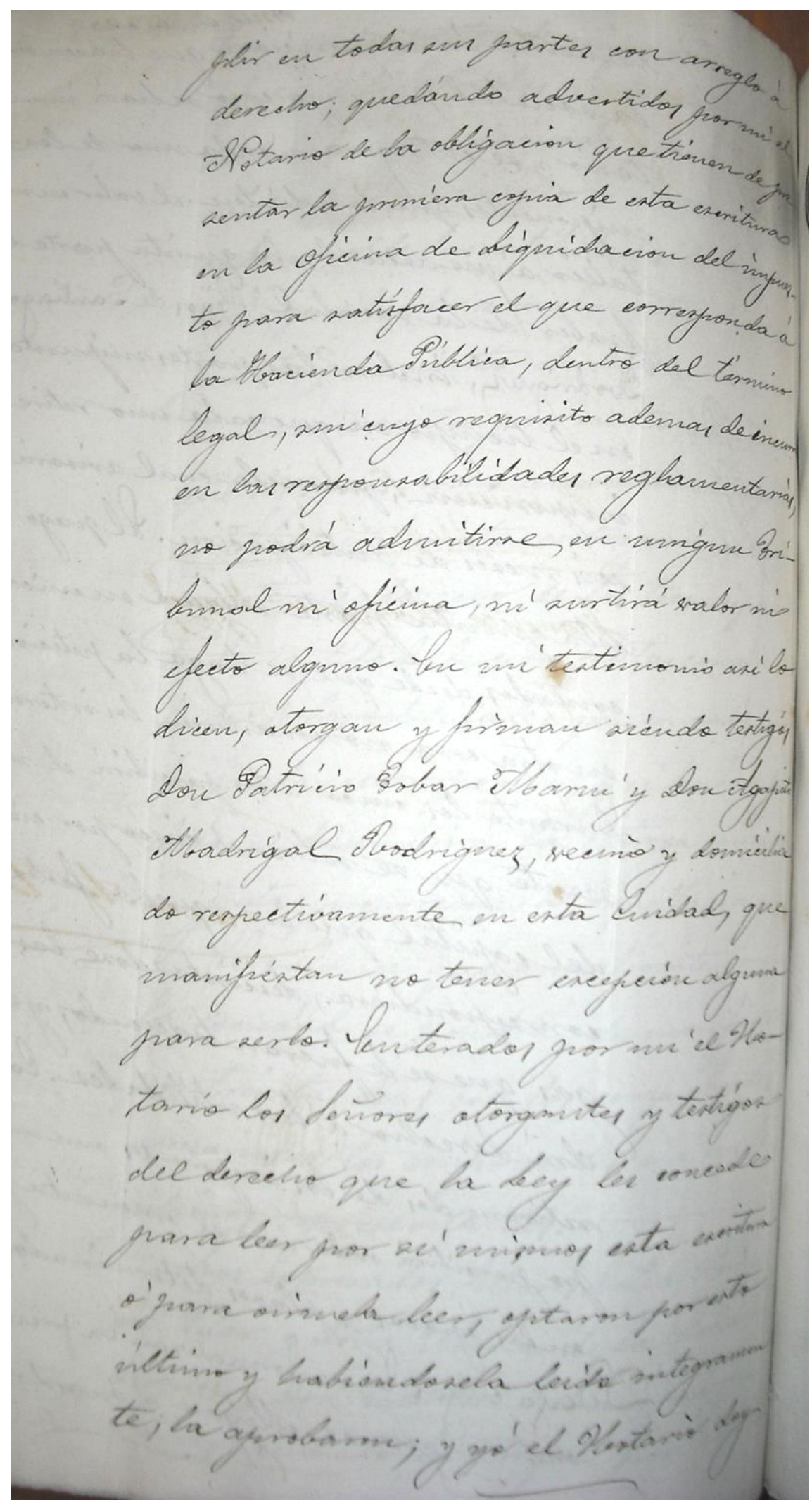

Fig.: 54

Escritura de sociedad Hijos de Santiago Rodríguez.

Archivo Histórico Provincial de Burgos. 23 de junio de 1891, p. 12 de 13. 
LA EDITORIAL BURGALESA HIJOS DE SANTIAGO RODRÍGUEZ (1891-1936): ANÁLISIS DE LOS LIBROS ESCOLARES

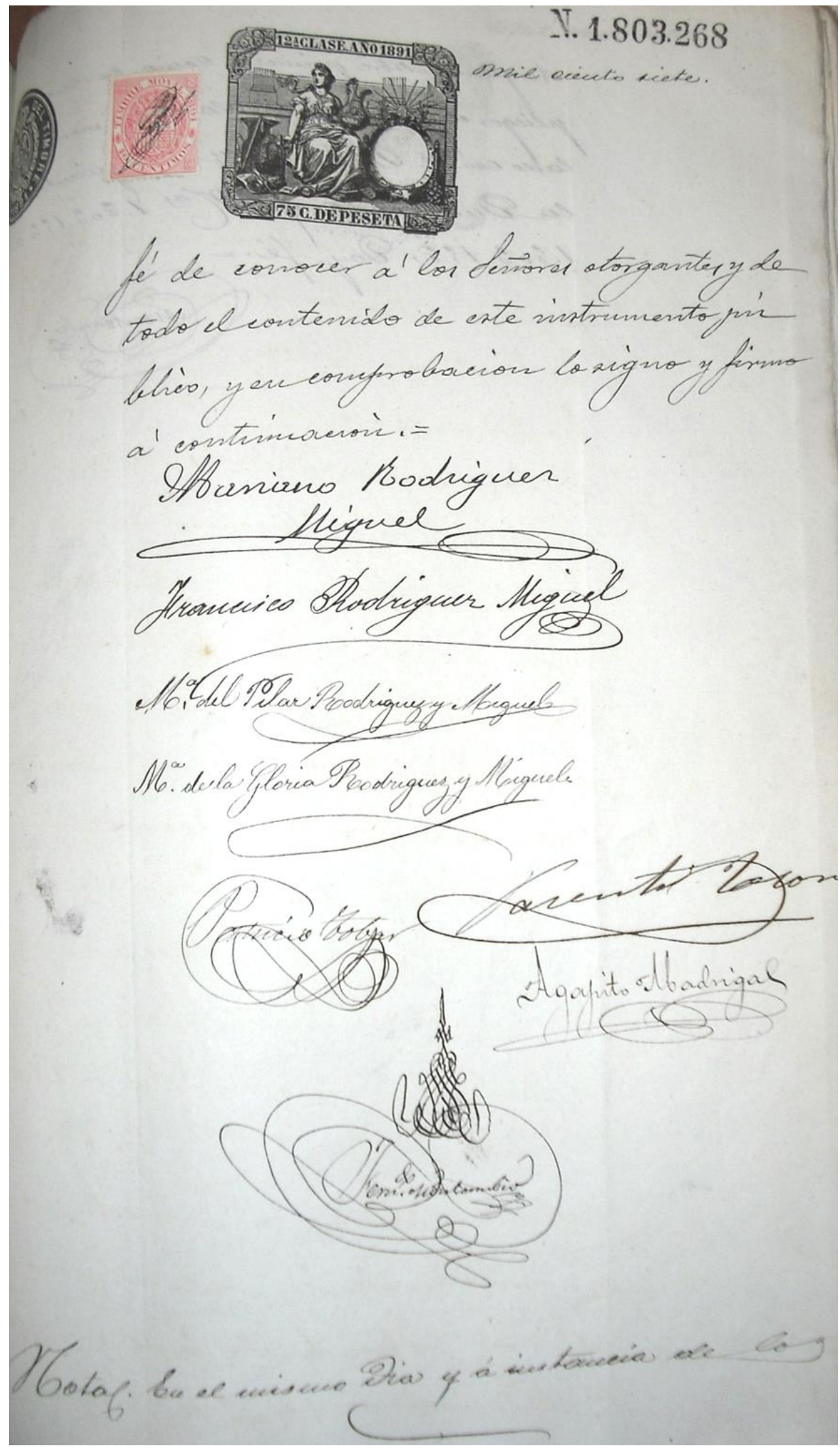

Fig.: 55

Escritura de sociedad Hijos de Santiago Rodríguez.

Archivo Histórico Provincial de Burgos. 23 de junio de 1891, p. 13 de 13. 


\section{Escritura de cesión de propiedad literaria por D. Anselmo Salvá, D. Mateo Bustamante y D. Esteban Franco en representación de varios autores, a favor de los Sres. Hijos de Santiago Rodríguez, el 20 de noviembre de 1896.}

Cédula de propiedad literaria por Don Anselmo Salvá a los Sres. de Hijos de Santiago Rodríguez.

En la ciudad de Burgos en veinte de noviembre de mil ochocientos noventa y seis ante mi Teódulo Santos y Santos notario de su Ilustre Colegio con vecindad en ella y de los testigos que se dirán:

Comparecen

Don Anselmo Salvá Pérez mayor de cuarenta años, casado, Archivero de este Excmo. Ayuntamiento, vecino de esta ciudad con cédula personal de octava clase número siete mil seiscientos cincuenta y dos expedida en quince de septiembre último.

Don Mateo Bustamante Junquera de sesenta y ocho años, casado, empleado vecino de esta ciudad con cédula personal de décima clase número nueve mil novecientos tres expedida en primero de octubre de este año.

Don Esteban Franco del Río de cuarenta y tres años de edad, casado, tipógrafo vecino de esta ciudad con cédula personal de octava clase número novecientos quince expedida el veintiocho de julio último.

Y Don Mariano Rodríguez Miguel de treinta y siete años, casado del comercio vecino de esta ciudad con cédula personal de séptima del número once mil noventa y dos expedida en quince de octubre de este año.

Los cuatro señores comparecientes aseguran hallarse en el pleno goce de sus derechos civiles y en aptitud legal a su juicio para otorgar esta escritura de venta de propiedad literaria y en su virtud:

Manifiestan

Primero: Que el Don Anselmo Salvá y Don Mateo Bustamante concurren a este acto por su propio derecho, el Don Esteban Franco en representación de los Sres. Don Carlos Frontaura, Don Alfonso Pérez Nieva, Don Diego Vidal Fernández, Don Ángel Bueno Rodríguez-Arias, Don Manuel Ossorio Bernal y Don Miguel Medina y Fernández vecinos de Madrid según lo acredita en el acto con la copia del mandato otorgado a su favor en Madrid el día catorce de julio último ante el Notario Don Gregorio Santos la cual queda unida al final de esta escritura para (unirla) en sus copias.

Y el Don Mariano Rodríguez concurren a este acto como socio gerente de la sociedad comercial con domicilio en esta ciudad que gira bajo la razón de "Hijos de Santiago Rodríguez" cuya circunstancia acredita con la copia primera de la escritura su constitución que fue otorgada en esta 
ciudad el día 23 de junio de 1891 ante el Notario de ella Don Fernando Monterrubio la cual se inscribió en el Registro mercantil de esta provincia en la hoja número treinta y cinco, libro cuarto provisional de sociedades folio diez con fecha catorce de diciembre del mismo año y en cuyo documento aparecen las cláusulas que a la letra dicen así:

$1^{\circ}$ La compañía mercantil industrial regular colectiva que se constituye tendrá su domicilio en esta ciudad y girará bajo la razón social de "Hijos de Santiago Rodríguez" y se dedicará al comercio de librería, papelería y objetos de escritorio y a la industria de imprenta reputándose continuadora del establecimiento expresado Santiago Rodríguez Alonso.

$2^{\circ}$ La gestión y administración de la compañía y el uso de la firma social se encomienda al socio Don Mariano Rodríguez Miguel.

Lo relacionado es cierto y lo escrito corresponde a la letra con referida escritura que rubricada con la mía devolví al señor compareciente.

Segundo: Que el compareciente Don Esteban Franco manifiestan que su representado Don Carlos Frontaura le pertenecen de pleno dominio por ser autor de ellos los tres libros de cuentos titulados el "Abuelo y el Nieto", cuentos "Paseando a la verdad" y "Los hijos del Sr. Martín".

Que a su representado Don Alfonso Pérez Nieva le corresponde en pleno dominio por ser su autor los libros de cuentos titulados "La madre Chiquita" y la "Tortilla de Magia".

Que a su representado Don Manuel Ossorio Bernard le corresponde en pleno dominio por ser su autor los libros de cuentos titulados "Un héroe infantil" "La ambición" "La cuadratura del Círculo" y "Presumir de hombre".

Igualmente corresponde a su representado Don Miguel Medina otro libro de cuentos titulado "El castillo del Águila negra" del cual es autor.

Que también corresponde a su representado Don Ángel Bueno las obras siguientes de las cuales es autor "Cristo yacente" "Emilín" "La primera comunión", "El ciudadano", "Historias de Méjico" "El tesoro de las Escuelas" "Resumen de Geografia" y "Nociones de Geometría".

Tercero: Que al correspondiente Don Anselmo Salvá le corresponde en pleno dominio por ser su autor las obras tituladas "El ideal de una niña" "La suerte" "Resumen de Historia de España"

Cuarto: Al compareciente Don Mateo Bustamante les corresponde en pleno dominio por ser su autor las obras tituladas "La Hija del desterrado" "Para mi hijo" y "Lecturas Morales".

Quinto:

Venta: Que el Don Esteban Franco vende a los Sres. Hijos de Santiago Rodríguez la propiedad literaria de las obras que pertenecen a sus representados en la forma siguiente. Los del Sr. Frontaura en la cantidad de treinta pesetas, las del Sr. Nieva en la cantidad de veinticinco pesetas, la del Sr. Vidal en la cantidad diez pesetas, la del Sr Ossorio en la cantidad de 
treinta pesetas. Las del Sr. Medina en la cantidad de cinco pesetas y las del Sr. Bueno en la cantidad de ciento cincuenta pesetas que (juntas) suman todas la cantidad de doscientas cincuenta pesetas.

Que el Sr. Anselmo Salvá también vende las obras de que es autor ya relacionadas a la Sociedad comercial de Sres. Hijos de Santiago Rodríguez por el precio de setenta y cinco pesetas y en igual forma el de Don Mateo Bustamante vende a los citados Sres. Rodríguez sus tres obras descritas por el precio de cincuenta pesetas cuyas ventas en junto forman la suma de trescientas setenta y cinco pesetas que en este acto entregaron los Sres Rodríguez al Sr. Franco doscientos cincuenta por las obras de sus representados, al Sr. Salvá setenta y cinco pesetas por las suyas y al Sr. Bustamante las cincuenta restantes por las suyas, por lo que les otorgan cartas de pago en forma y en virtud le transfieren todos los derechos que correspondan a las referidas obras en virtud de la ley de propiedad intelectual de día de enero de mil ochocientos setenta y nueve.

Sexto.

Advertencias legales

$1^{\circ}$ Advertí yo el Notario a los Sres. otorgantes que la copia primera de esta escritura se va inscribir en el Registro intelectual así como las obras descritas para los efectos de los artículos treinta y tres y siguientes de la ley de propiedad intelectual antes referida.

$2^{\circ}$ Que referida copia se debe presentar en la oficina de liquidación de derechos reales para satisfacer el que devengan bajo las multas establecidas en el Reglamento vigente en cuyos requisitos no se podrá inscribir en el mencionado Registro.

Séptimo:

Aceptación

El compareciente Don Mariano Rodríguez en nombre de la Sociedad que representa Sres. Hijos de Santiago Rodríguez acepta esta escritura y sus efectos y las partes contratantes se obligan a su cumplimiento en lo que a cada uno incumbe con arreglo a derecho bajo pena de pago de costas y perjuicios si no lo verificasen.

Octavo:

Otorgamiento

En mi testimonio así lo otorgan y firman con los testigos presentes al acto Don Isidro García Terradillos, Don Restituto Martínez Sáez vecinos y residentes en esta ciudad y (sin excepción) legal para serlo.

Leída íntegramente esta escritura por mí el Notario a instancia de los Sres. otorgantes y testigos los primeros manifestaron su conformidad y los segundos de quedar enterados.

Del contenido de este instrumento público y del conocimiento de los Sres. otorgantes yo el Notario doy fe, lo signo y firmo: 
Firmado por el notario D. Teódulo Santos y Santos, D. Mariano Rodríguez Miguel, D. Mateo Bustamante, D. Anselmo Salvá, D. Restituto Martínez y D. Isidro García Terradillos.

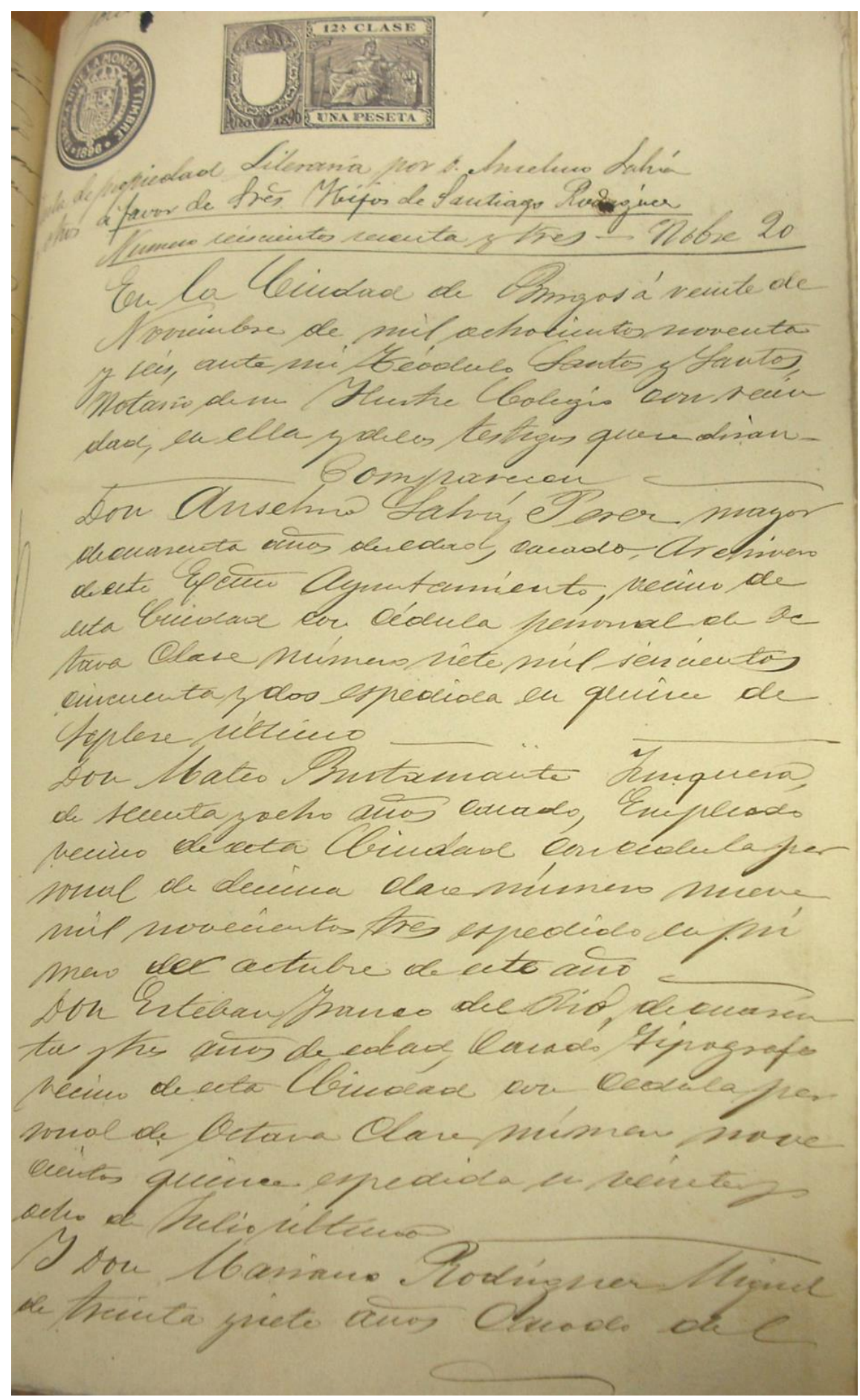

Fig.: 56

Cesión de propiedad intelectual de Anselmo Salvá, Mateo Bustamante, Carlos Frontaura, Alfonso Pérez Nieva, Ángel Bueno Rodríguez-Arias, Miguel Medina y Manuel Ossorio y Bernard a favor de Hijos de Santiago Rodríguez. Archivo Histórico Provincial de Burgos. 1896, p. 1 de 8. 


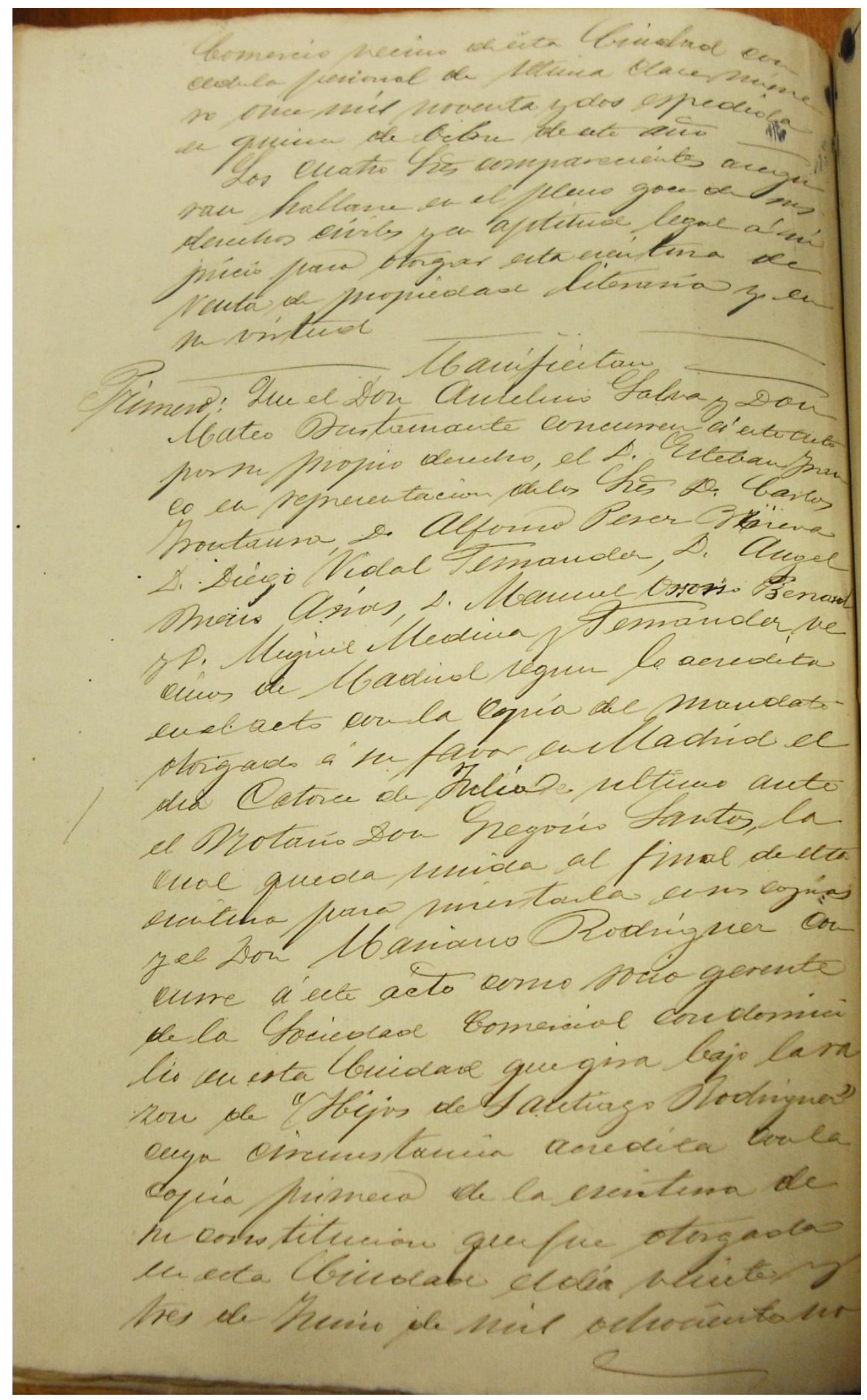

Fig.: 57

Cesión de propiedad intelectual de Anselmo Salvá, Mateo Bustamante, Carlos Frontaura, Alfonso Pérez Nieva, Ángel Bueno Rodríguez-Arias, Miguel Medina y Manuel Ossorio y Bernard a favor de Hijos de Santiago Rodríguez. Archivo Histórico Provincial de Burgos. 1896, p. 2 de 8. 


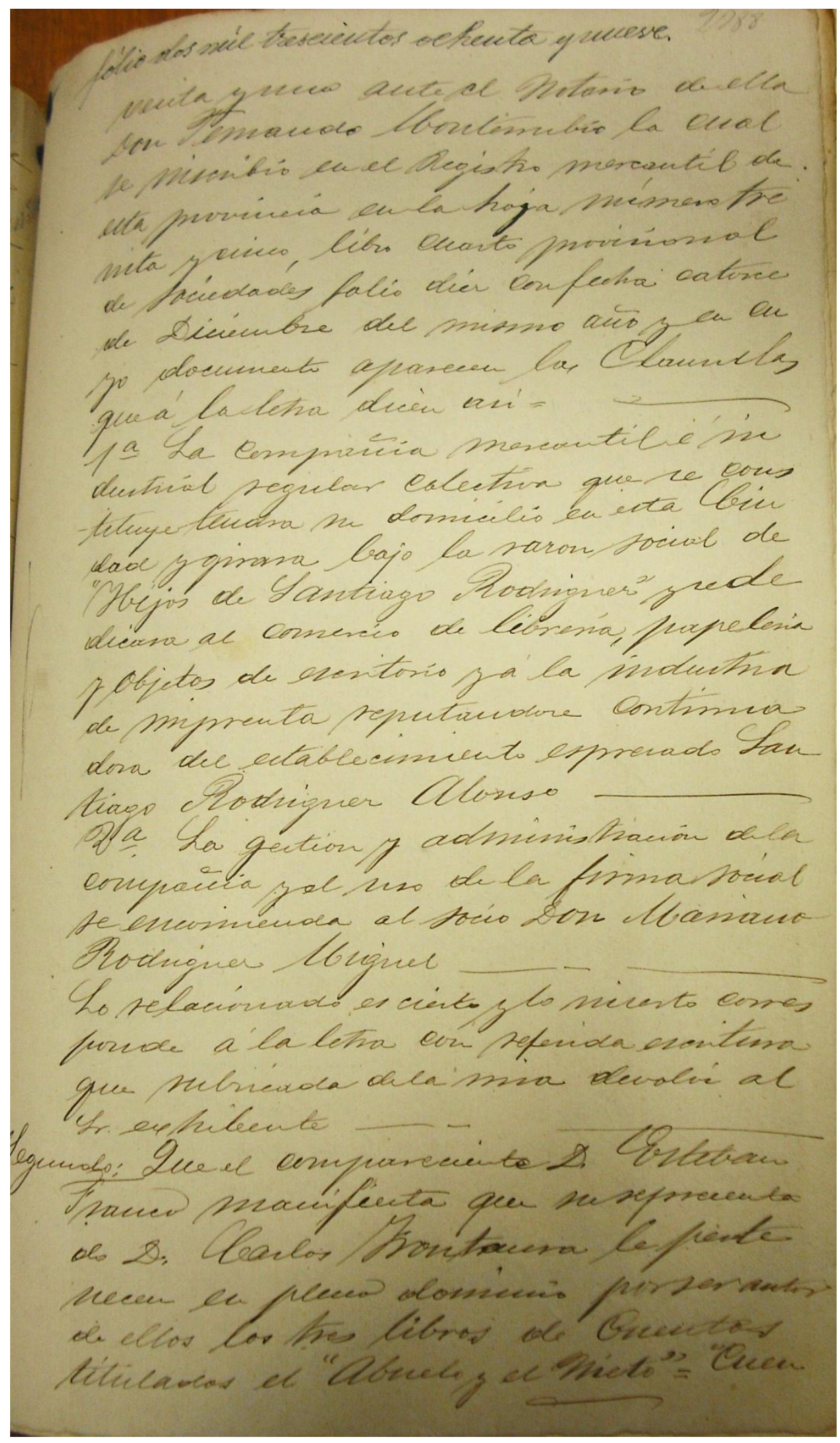

Fig.: 58

Cesión de propiedad intelectual de Anselmo Salvá, Mateo Bustamante, Carlos Frontaura, Alfonso Pérez Nieva, Ángel Bueno Rodríguez-Arias, Miguel Medina y Manuel Ossorio y Bernard a favor de Hijos de Santiago Rodríguez. Archivo Histórico Provincial de Burgos. 1896, p. 3 de 8. 


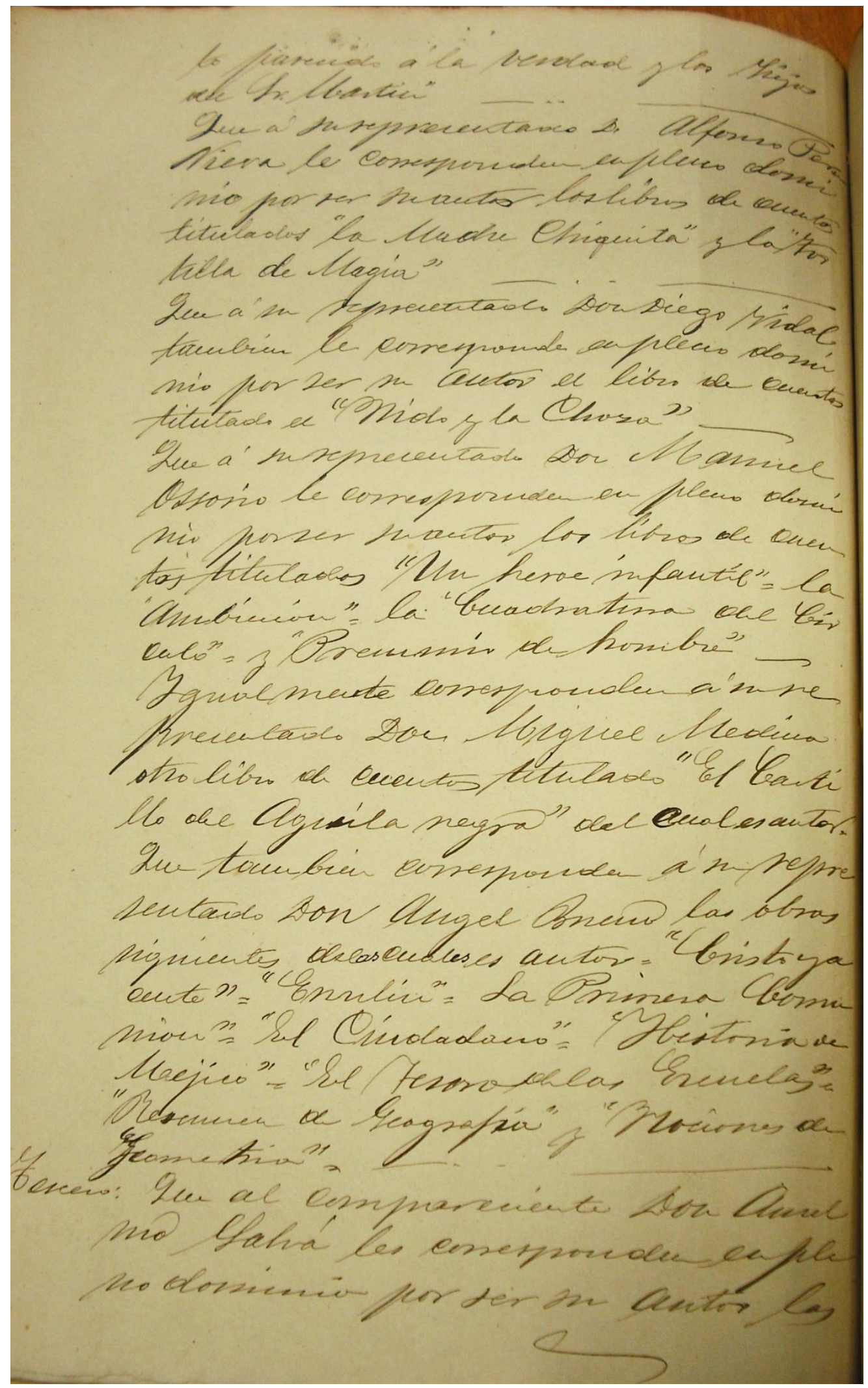

Fig.: 59

Cesión de propiedad intelectual de Anselmo Salvá, Mateo Bustamante, Carlos Frontaura, Alfonso Pérez Nieva, Ángel Bueno Rodríguez-Arias, Miguel Medina y Manuel Ossorio y Bernard a favor de Hijos de Santiago Rodríguez. Archivo Histórico Provincial de Burgos. 1896, p. 4 de 8. 
LA EDITORIAL BURGALESA HIJOS DE SANTIAGO RODRÍGUEZ (1891-1936): ANÁLISIS DE LOS LIBROS ESCOLARES

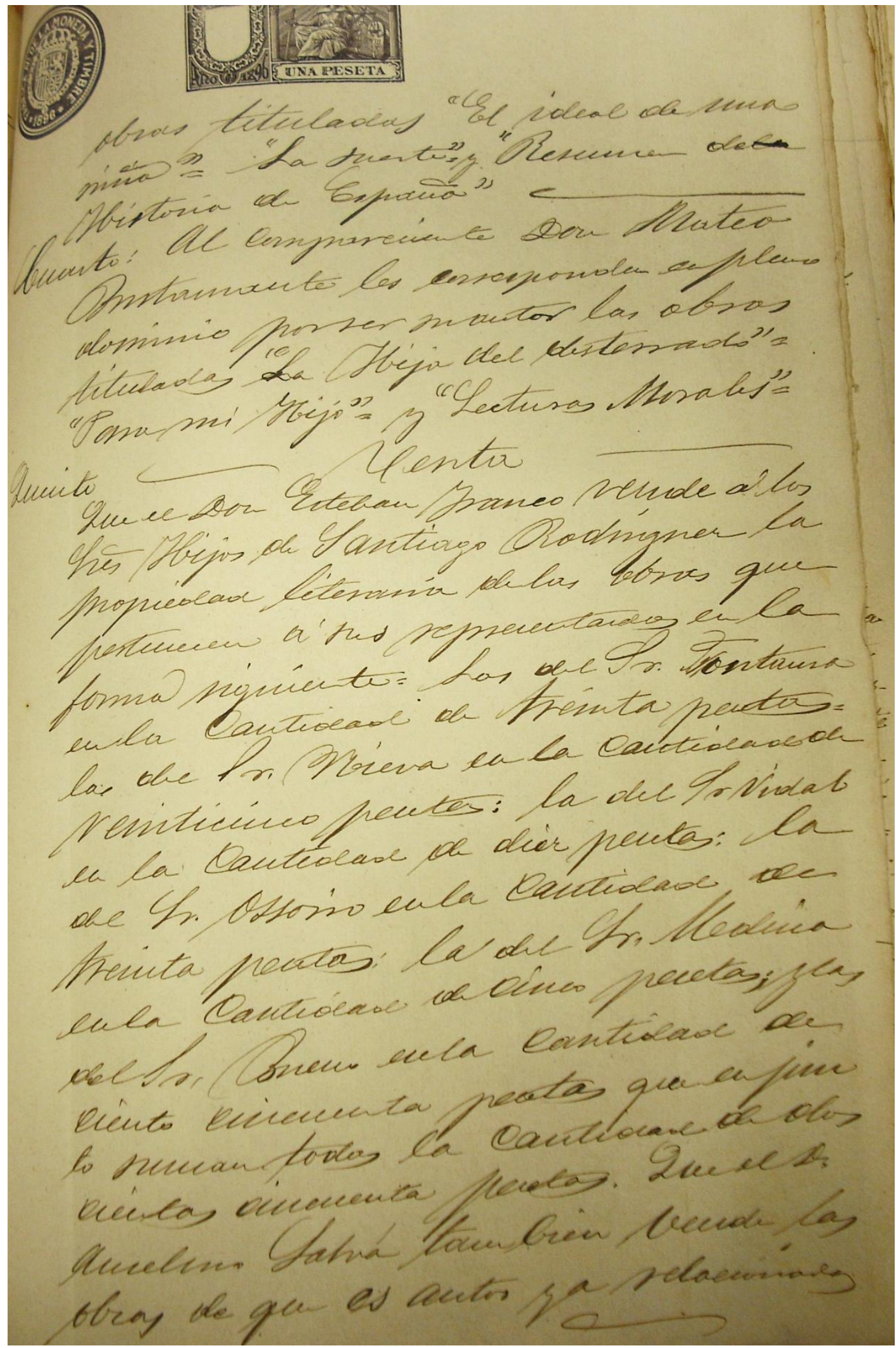

Fig.: 60

Cesión de propiedad intelectual de Anselmo Salvá, Mateo Bustamante, Carlos Frontaura, Alfonso Pérez Nieva, Ángel Bueno Rodríguez-Arias, Miguel Medina y Manuel Ossorio y Bernard a favor de Hijos de Santiago Rodríguez. Archivo Histórico Provincial de Burgos. 1896, p. 5 de 8. 


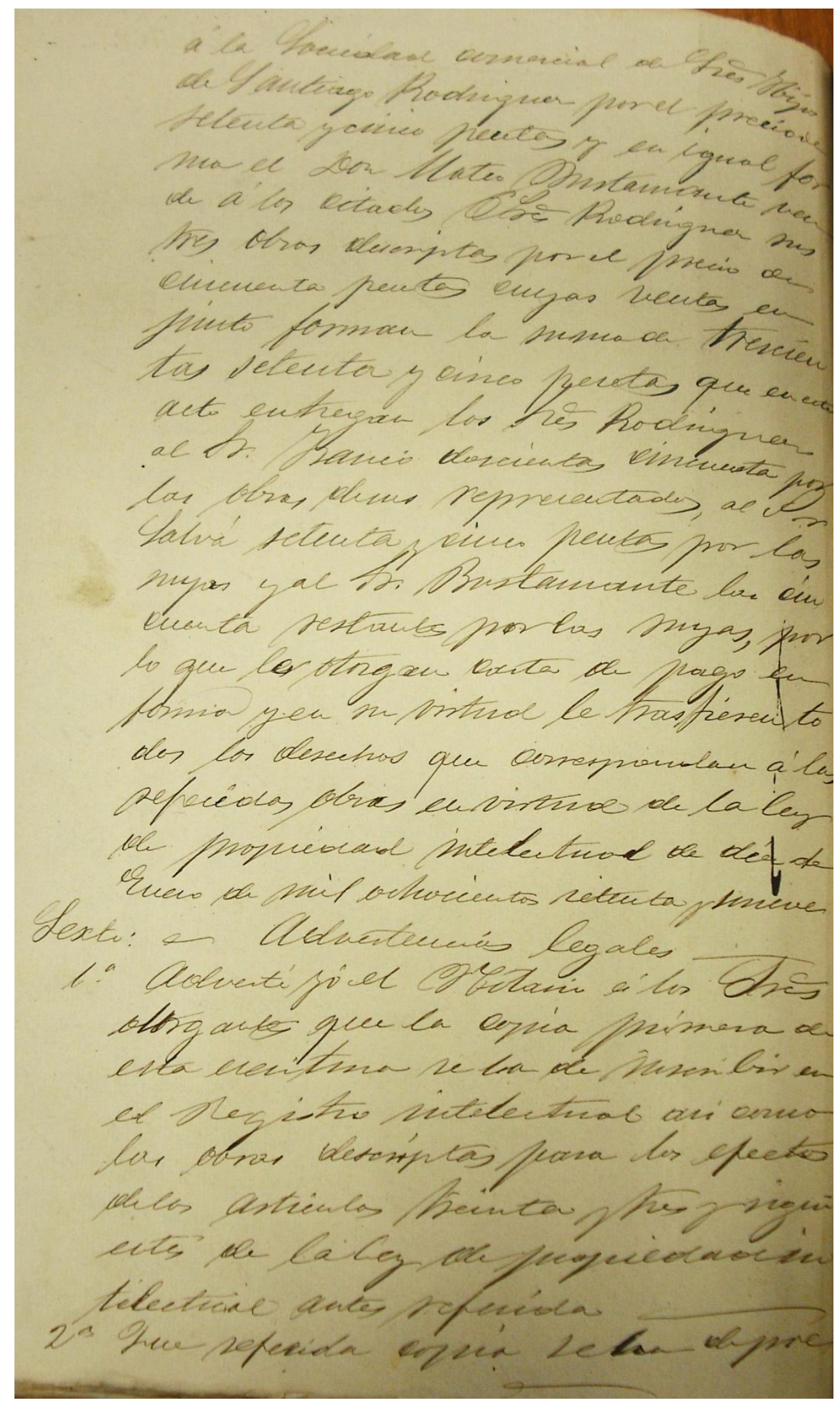

Fig.: 61

Cesión de propiedad intelectual de Anselmo Salvá, Mateo Bustamante, Carlos Frontaura, Alfonso Pérez Nieva, Ángel Bueno Rodríguez-Arias, Miguel Medina y Manuel Ossorio y Bernard a favor de Hijos de Santiago Rodríguez. Archivo Histórico Provincial de Burgos. 1896, p. 6 de 8. 


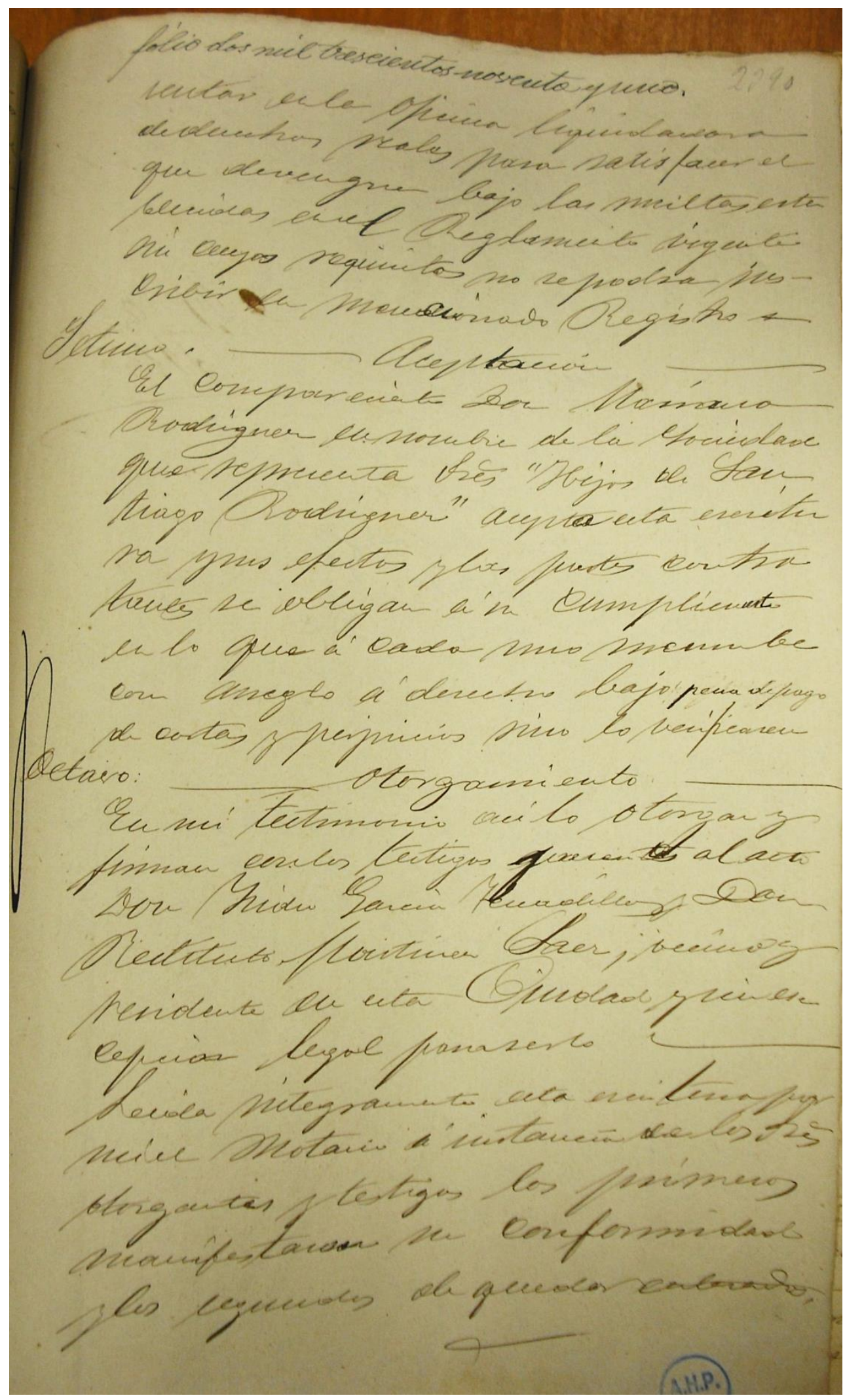

Fig.: 62

Cesión de propiedad intelectual de Anselmo Salvá, Mateo Bustamante, Carlos Frontaura, Alfonso Pérez Nieva, Ángel Bueno Rodríguez-Arias, Miguel Medina y Manuel Ossorio y Bernard a favor de Hijos de Santiago Rodríguez. Archivo Histórico Provincial de Burgos. 1896, p. 7 de 8. 


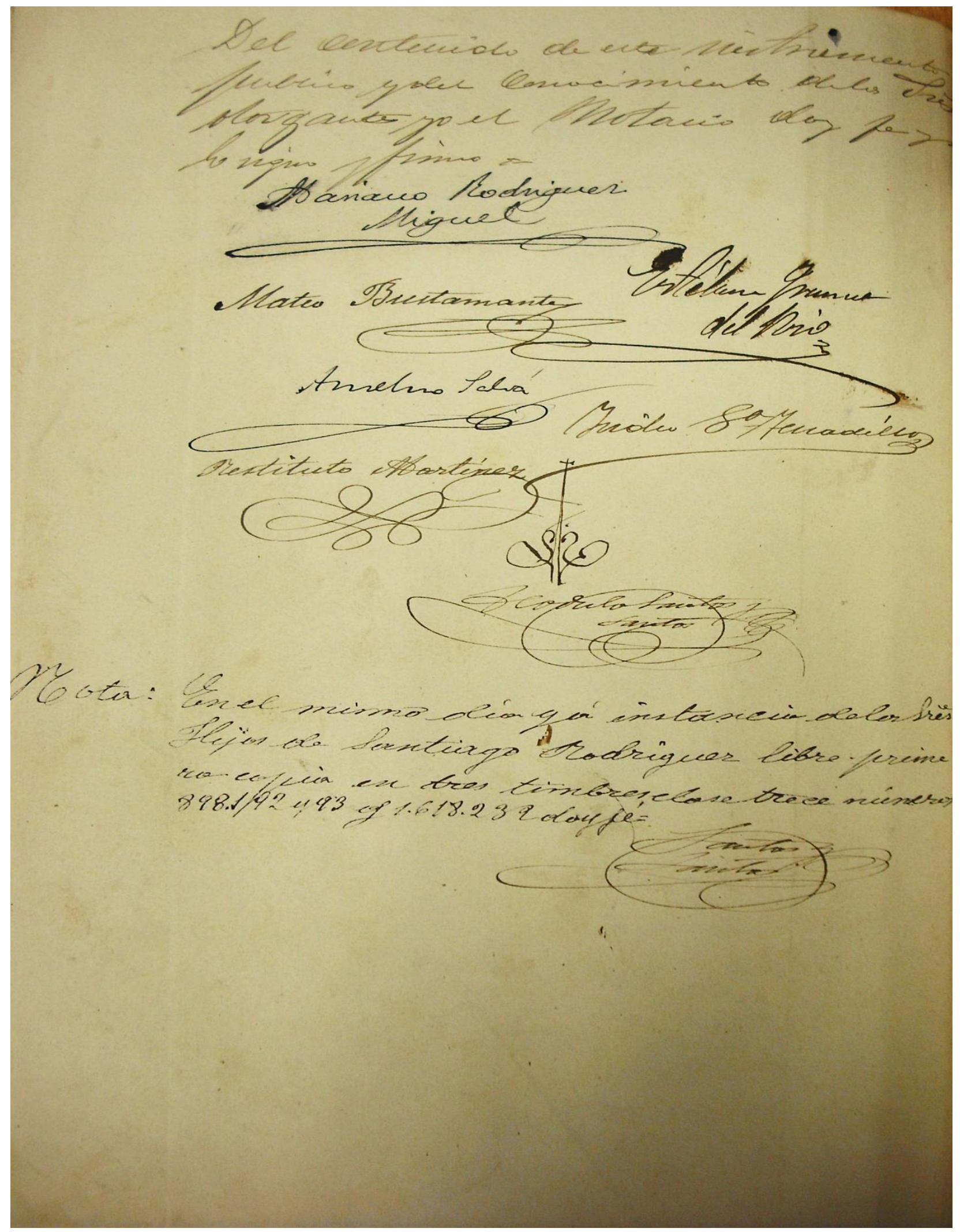

Fig.: 63

Cesión de propiedad intelectual de Anselmo Salvá, Mateo Bustamante, Carlos Frontaura, Alfonso Pérez Nieva, Ángel Bueno Rodríguez-Arias, Miguel Medina y Manuel Ossorio y Bernard a favor de Hijos de Santiago Rodríguez. Archivo Histórico Provincial de Burgos. 1896, p. 8 de 8. 


\section{Escritura de cesión de propiedad literaria por D. Arsenio Herreros Martínez y D. Esteban Franco en representación de varios autores a favor de los Sres. Hijos de Santiago Rodríguez, el 19 de noviembre de 1902.}

En la ciudad de Burgos a diez y nueve de noviembre de mil novecientos dos ante mi Teódulo Santos y Santos, Notario del Ilustre Colegio de esta capital con vecindad en ella y de los testigos que se dirán:

Comparecen -

De una parte: Don Arsenio Herreros Martínez de sesenta y un años de edad, casado, comerciante, vecino de esta ciudad con cédula personal de sexta clase número siete mil noventa y dos expedida en dos de Julio último.

Don Esteban Franco del Río, de cuarenta años, casado, encuadernador, vecino de esta ciudad con cédula personal de novena clase número cinco mil seiscientos, expedida en veinte de junio último.

Y de otra: Don Mariano Rodríguez Miguel de cuarenta y tres años, casado, del comercio, vecino de esta ciudad, con cédula personal de séptima clase número seis mil novecientos treinta y siete expedida en dos de julio último.

Los tres señores comparecientes se encuentran en pleno goce de sus derechos civiles y con capacidad legal necesaria a mi juicio para otorgar esta escritura de venta de propiedad literaria y en su virtud:

Manifiestan:

Primero: Que Don Arsenio Herreros concurre a este acto en nombre y representación de Don Juan Benejam Vives según lo acredita con la copia del mandato que a la letra dice así:

Poder: Número trescientos sesenta y siete: En La Ciudadela de Menorca a veintisiete de noviembre de mil novecientos, ante mi el Sr. don Antonio Anglada y Bonet, notario del Colegio de las Baleares, con vecindad y residencia en esta ciudad, comparece:

Don Juan Benejam Vives, casado, profesor de instrucción primaria, mayor de edad, de este vecindario y después de comprobar sus circunstancias de filiación con las que consta en su cédula personal de clase novena expedida por esta Alcaldía el cuatro del próximo pasado octubre bajo el número mil noventa y dos, hallándose a mi juicio con la capacidad legal necesaria para otorgar esta escritura, libre y espontáneamente dice: que confiere poder especial tan amplio y general cual en derecho sea necesario a favor de Don Arsenio Herreros, vecino de la ciudad de Burgos, para que representando la personalidad, derechos y acciones del Sr. otorgante ceda y venda a "Hijos de Santiago Rodríguez", razón social en la misma ciudad de Burgos, el libro titulado "Páginas de Ciencias físiconaturales" que el Sr. otorgante ha escrito y lo cede y vende por el precio que estime conveniente, que recibirá o declarará haber recibido el principal, 
firmándole la correspondiente escritura con los requisitos y cláusulas legales para surtir los efectos dispuestos por la legislación vigente en la materia a fin de que el comprador pueda sacar el título de propiedad y hacer valer todos los derechos que le corresponden en virtud de la cesión y venta que se le hiciere. En la expresada conformidad se obliga el propio Don Juan Benejam Vives a estar y pasar bajo la consiguiente responsabilidad, por lo que se ejecute en virtud de esta escritura que otorga firmando con los testigos, Don José Meoll Vidal y Don Francisco Jalort Pour, de este vecindario, después de haberle leído a uno y otros íntegramente y advirtiéndoles de su derecho de hacerlo por sí; de todo lo cual, del conocimiento, profesión y vecindad del Señor otorgante doy fe.

\section{Firmas}

Es copia de la matriz número trescientos sesenta y siete de mi protocolo corriente que expido para que el señor poderante en este pliego clase séptima número 0038.575 y en Ciudadela día de la fecha: Está signado. Don Antonio Anglada: Los infrascritos Notarios del Colegio de las Baleares Distrito Notarial de Mahón. Legalizamos el signo, firma y rústica que antecede del Notario Dr. D. Antonio Anglada. Mahón veintinueve de noviembre de mil novecientos. Hay un signo: Miguel Alanor: Hay otro signo Francisco Andreu y Pass. Hay un sello de legalizar que dice: colegio Notarial de las Baleares.

Que el Don Esteban Franco concurre a este acto en representación de Doña Magdalena Fuentes Soto según lo acredita con la copia del mandato que a la letra dice así:

Poder: Número treinta y seis. En la ciudad de Sigüenza a veintiocho de abril de mil novecientos uno, ante mí Francisco Pastor Cabellos, Notario del Ilustre Colegio de Madrid de este distrito, vecino de esta ciudad y testigos que se expresarán comparece: Doña Magdalena Fuentes Soto, vecina de Huesca, con cédula personal clase novena número nueve expedida en diez y ocho de diciembre último por el agente Manuel Lafuente, residente accidentalmente en esta ciudad de estado soltera, maestra, de veintisiete años de edad: tiene a mi juicio la capacidad legal necesaria para formalizar esta escritura de mandato y otorga: que confiere poder amplio bastante cuanto por derecho se requiere a favor de Don Esteban Franco, mayor de edad, vecino de Burgos facultándole para que en representación de la otorgante venda a "Hijos de Santiago Rodríguez" vecinos también de Burgos la propiedad del libro titulado "La Escuela y la Patria" y la de otro libro para premios escritos por la otorgante siendo por tanto de su propiedad exclusiva pertenencia cuya venta y cesión la verifique por el precio que estime conveniente, formalizando para ello la escritura o documento que sea procedente con todas las cláusulas y requisitos establecidos en derecho separándose por tanto la otorgante del 
derecho y propiedad que sobre los dichos libros por ella escritos y por lo tanto única dueña de ellos y autora tiene en la actualización: Pues el poder que para todo ello y lo incidente se necesite, ese mismo confiere al referido Don Esteban Franco y se obliga en forma a su cumplimiento: Así lo otorga la referida señora Doña Magdalena Fuentes Soto, en presencia de los testigos Manuel de Luis López y Raimundo Aparicio Galvacio, vecinos de esta ciudad, que manifiestan no tener excepción: Y enterados todos de su derecho para leerlo por sí, al que renunciaron, se lo leí y lo ratifica la señora otorgante, firmando con los testigos: Y del conocimiento de todos y de todo lo referido yo el Notario doy fe: Magdalena Santiago Fuentes: Manuel de Ruiz. Raimundo Aparicio: Signado: Franco Pastor: Rúbricas. Es primera copia literal de su matriz que autorizada por mi, queda en mi protocolo corriente a que me remito y en cuyo otorgamiento he sido presente con los testigos. Y en fe de ello, a requerimiento de la otorgante, la signo y firmo en este pliego clase séptima número 0007071, dejando nota en Notaría: Legalización: Don Gumersindo González Miranda: Notario del Ilustre Colegio de Madrid en este Distrito vecino de esta ciudad con el visto bueno del Sr. Juez de Primera Instancia de la misma a falta de otro Notario en la localidad. Legalizo el signo, firmo y rúbrica anterior de Don Franco Pastor Cabellos, mi compañero Notario con residencia en esta ciudad: Dada y sellada con el de nuestro Colegio en Sigüenza a veintiséis de abril de mil novecientos uno. Visto bueno. El Juez de $1^{\text {a }}$ Instancia Federico Baudin. Hay un signo. Gumersindo González Miranda. Hay un sello de legalizaciones.

Y el Don Mariano Rodríguez Miguel concurre a este acto como socio Gerente de la Sociedad Comercial con domicilio en esta ciudad que gira bajo la razón "Hijos de Santiago Rodríguez" cuya circunstancia acredita con la copia de la escritura de su constitución y que fue otorgada en esta ciudad el día veintitrés de junio de mil ochocientos noventa y uno ante el Notario de ella Don Fernando Monterrubio la cual se inscribió en el Registro Mercantil de esta provincia en la hoja número treinta y cinco, libro cuarto provisional de sociedades, folio diez, con fecha catorce de diciembre del mismo año y en cuyo documento aparecen las cláusulas que a la letra dice así:

$1^{\circ}$. La Compañía Mercantil Industrial regular colectiva que se constituye tendrá su domicilio en esta ciudad y girará bajo la razón social de "Hijos de Santiago Rodríguez" y se dedicará al comercio de librería, papelería y objetos de escritorio y a la industria de imprenta, reputándose continuadora del Establecimiento expresado Santiago Rodríguez Alonso.

$2^{\circ}$ La gestión y administración de la Compañía y el uso de la firma social se encomienda al socio Don Mariano Rodríguez Miguel. 
Lo relacionado es cierto y lo inserto corresponde a la letra con los documentos de su razón que rubricados de la mía devolví a los señores exhibientes y a que me remito.

Segundo: Que el compareciente Don Arsenio Herreros, manifiesta que su representado don Juan Benejam Vives, le pertenece en pleno dominio por ser autor de él, el libro titulado "Páginas de ciencias físico-naturales".

Tercer: Que el compareciente Don Arsenio Franco manifiesta que a su representada Doña Magdalena Fuentes, le pertenecen en pleno dominio por ser autora de ellos, el libro titulado "La Escuela y la Patria" y otro titulado para premios titulado "La novela de la Infancia".

Cuarto: Venta

Que el Don Arsenio Herreros vende a los Señores Hijos de Santiago Rodríguez" la propiedad literaria de la obra que pertenece a su representado en la cantidad de cien pesetas.

Que el Don Esteban Franco también vende la propiedad de las obras que pertenecen a su representada Doña Magdalena Fuentes a la sociedad Comercial "Hijos de Santiago Rodríguez" por el precio de ciento setenta y cinco pesetas que a este acto entrega el Sr. Rodríguez al Sr. Herreros las cien pesetas por la obra de su representado y el Sr. Franco las ciento setenta y cinco pesetas por las obras de su representado, por lo que le otorgan carta de pago en forma y en su virtud transfiere todos los derechos que correspondan a referidas obras en virtud de la Ley de propiedad intelectual de diez de enero de mil ochocientos setenta y nueve.

Quinto: Yo el Notario hice a los Sres. otorgantes las advertencias legales correspondientes a este contrato.

Sexto: Aceptación.

El compareciente Don Mariano Rodríguez en nombre de la sociedad que representa "Hijos de Santiago Rodríguez" acepta esta escritura y sus efectos y las partes contratantes se obligan a su cumplimiento en lo que a cada uno incumbe con arreglo a derecho, bajo pena de pago de costas y perjuicios si no lo verificasen.

En mi testimonio así lo otorgan y firman con los testigos presentes a Don Isidro García Terradillos y Don Restituto Martínez Sáez de esta vecindad y sin excepción legal para serlo.

Leída íntegramente esta escritura por mí el Notario a instancia de los Sres. otorgantes y testigos, los primeros manifestaron su conformidad y los segundos quedaron enterados del contenido de este instrumento público y del conocimiento de los Sres. otorgantes. Yo el Notario doy fe y lo signo y lo firmo.

Firmado por el notario D. Teódulo Santos y Santos, D. Mariano Rodríguez Miguel, D. Restituto Martínez, D. Esteban Franco, D. Arsenio Herreros y D. Isidro Gil. 
LA EDITORIAL BURGALESA HIJOS DE SANTIAGO RODRÍGUEZ (1891-1936): ANÁLISIS DE LOS LIBROS ESCOLARES

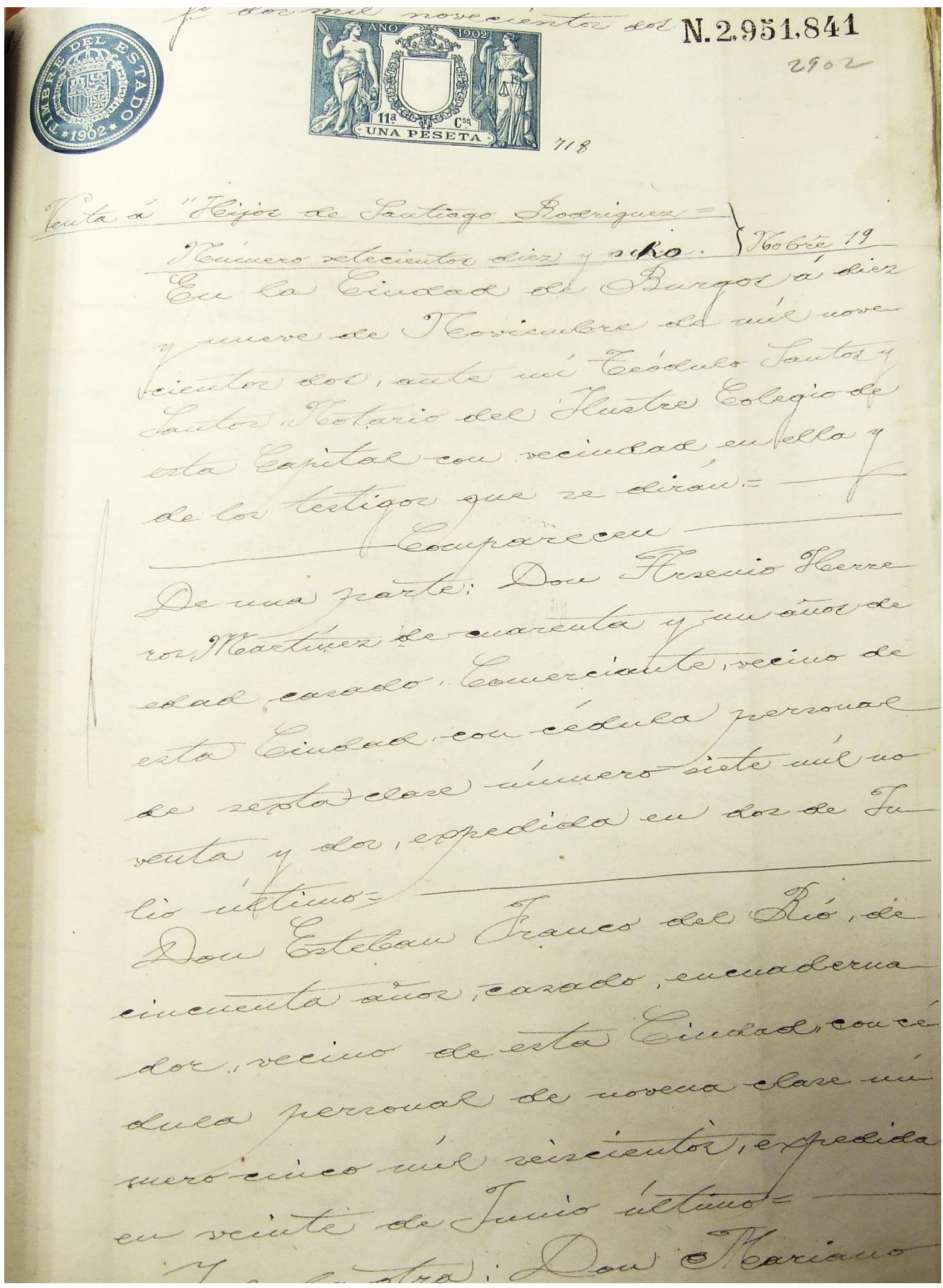

Fig.: 64

Venta de propiedad intelectual de D. Juan Benejam Vives y Da Magdalena Fuentes Soto a favor de Hijos de Santiago Rodríguez.

Archivo Histórico Provincial de Burgos. 1902, p. 1 de 12. 


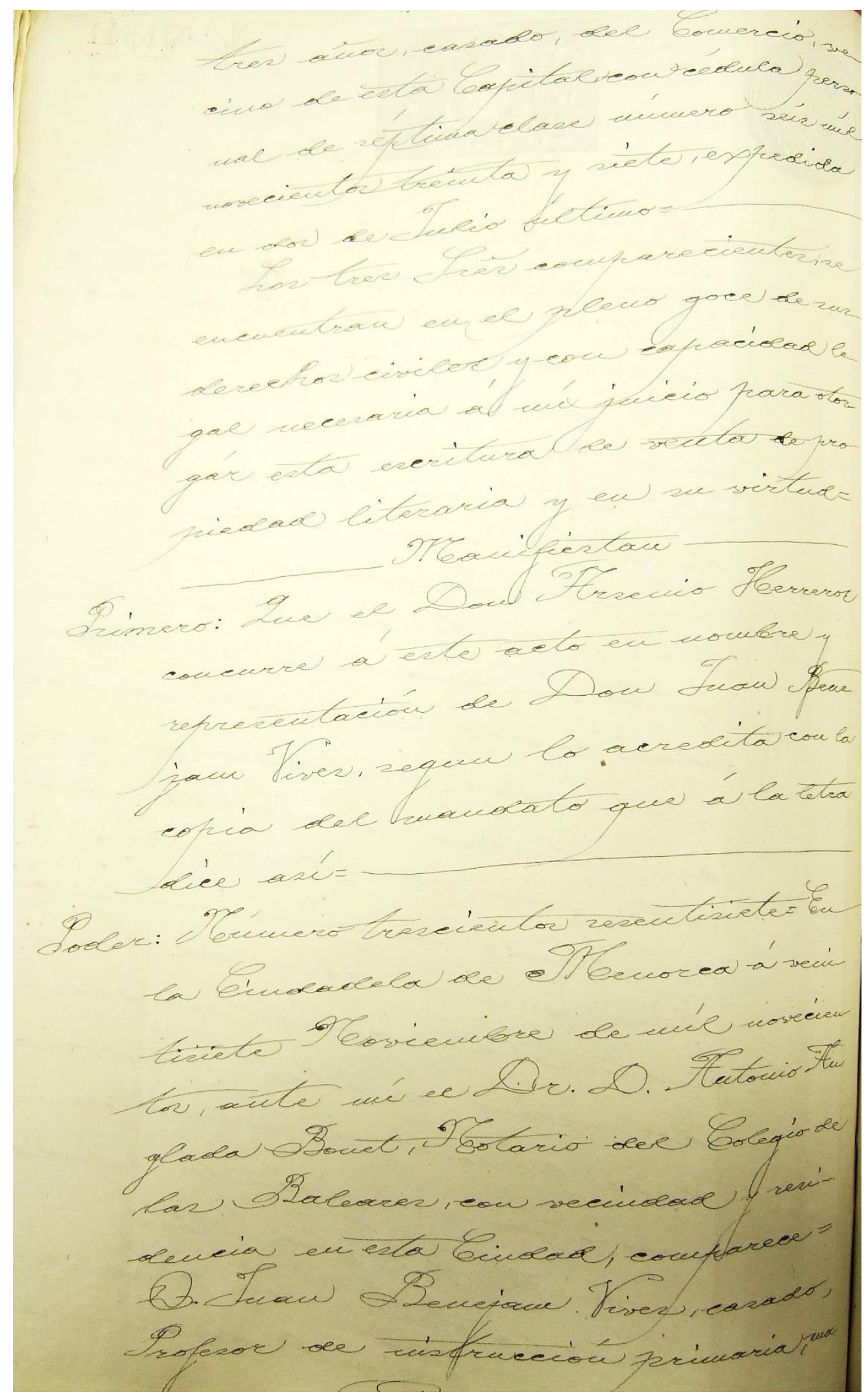

Fig.: 65

Venta de propiedad intelectual de D. Juan Benejam Vives y Da Magdalena Fuentes Soto a favor de Hijos de Santiago Rodríguez.

Archivo Histórico Provincial de Burgos. 1902, p. 2 de 12. 
LA EDITORIAL BURGALESA HIJOS DE SANTIAGO RODRÍGUEZ (1891-1936): ANÁLISIS DE LOS LIBROS ESCOLARES

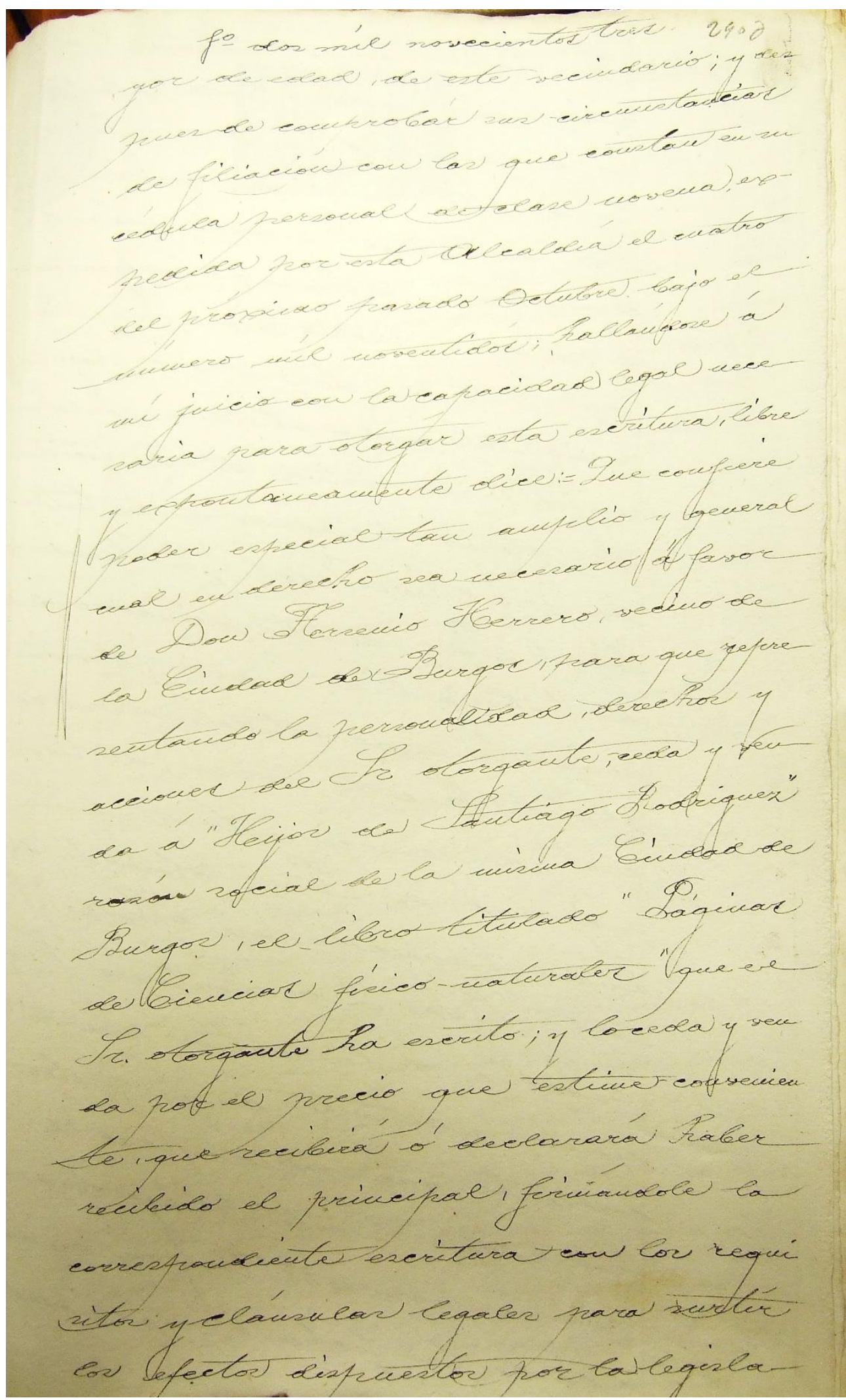

Fig.: 66

Venta de propiedad intelectual de D. Juan Benejam Vives y Da Magdalena Fuentes Soto a favor de Hijos de Santiago Rodríguez.

Archivo Histórico Provincial de Burgos. 1902, p. 3 de 12. 


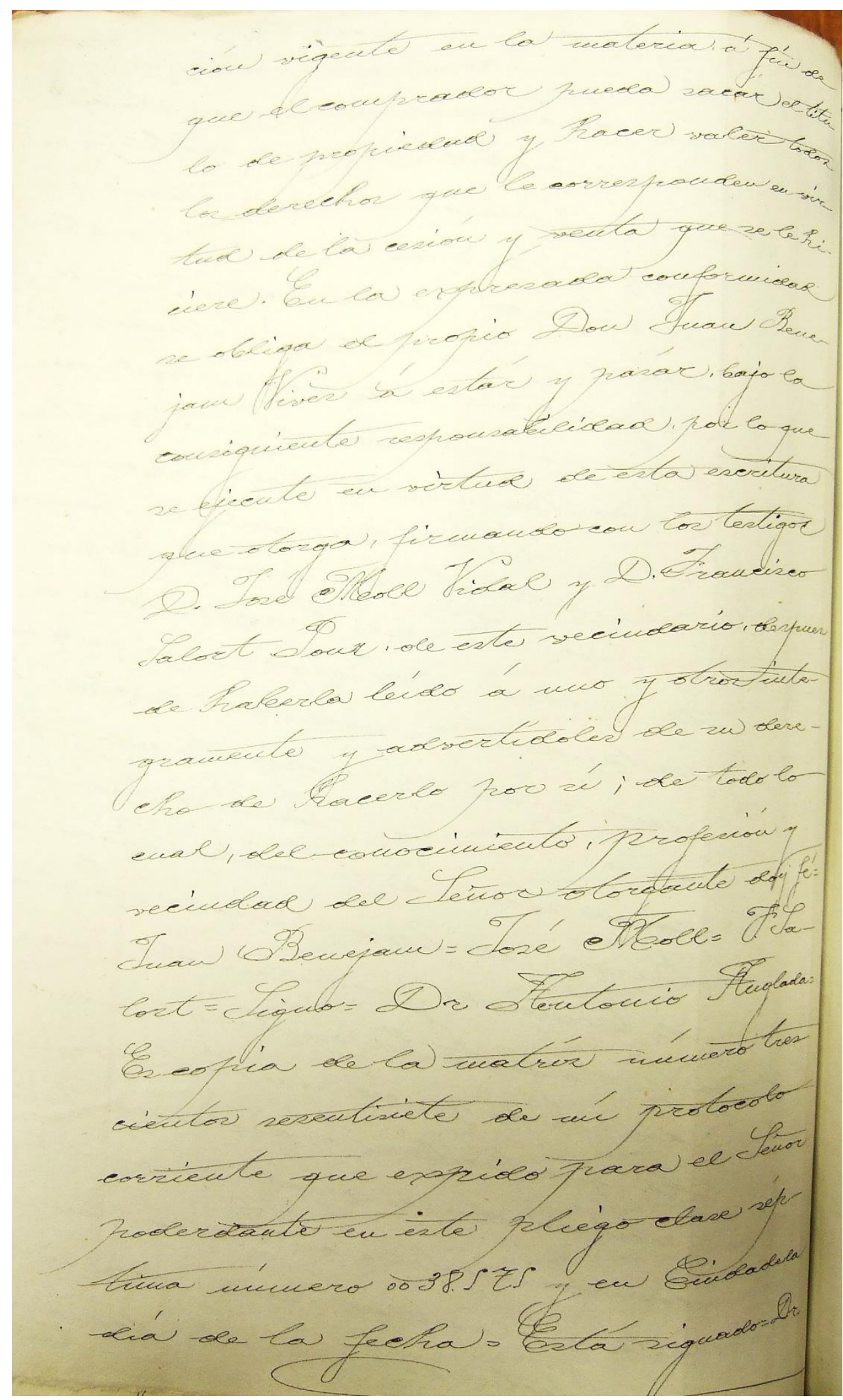

Fig.: 67

Venta de propiedad intelectual de D. Juan Benejam Vives y Da Magdalena Fuentes Soto a favor de Hijos de Santiago Rodríguez.

Archivo Histórico Provincial de Burgos. 1902, p. 4 de 12. 
LA EDITORIAL BURGALESA HIJOS DE SANTIAGO RODRÍGUEZ (1891-1936): ANÁLISIS DE LOS LIBROS ESCOLARES

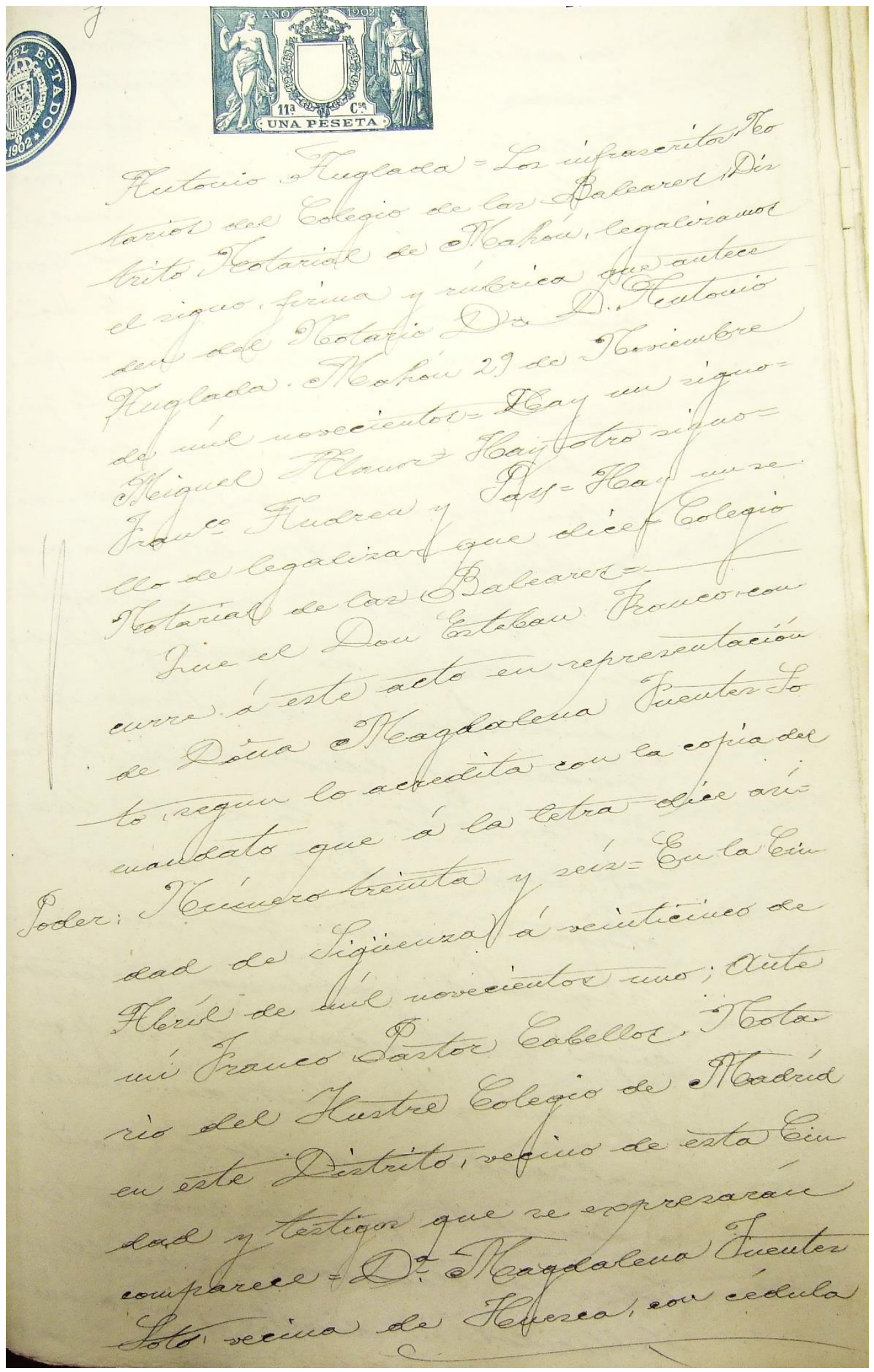

Fig.: 68

Venta de propiedad intelectual de D. Juan Benejam Vives y Da Magdalena Fuentes Soto a favor de Hijos de Santiago Rodríguez.

Archivo Histórico Provincial de Burgos. 1902, p. 5 de 12. 


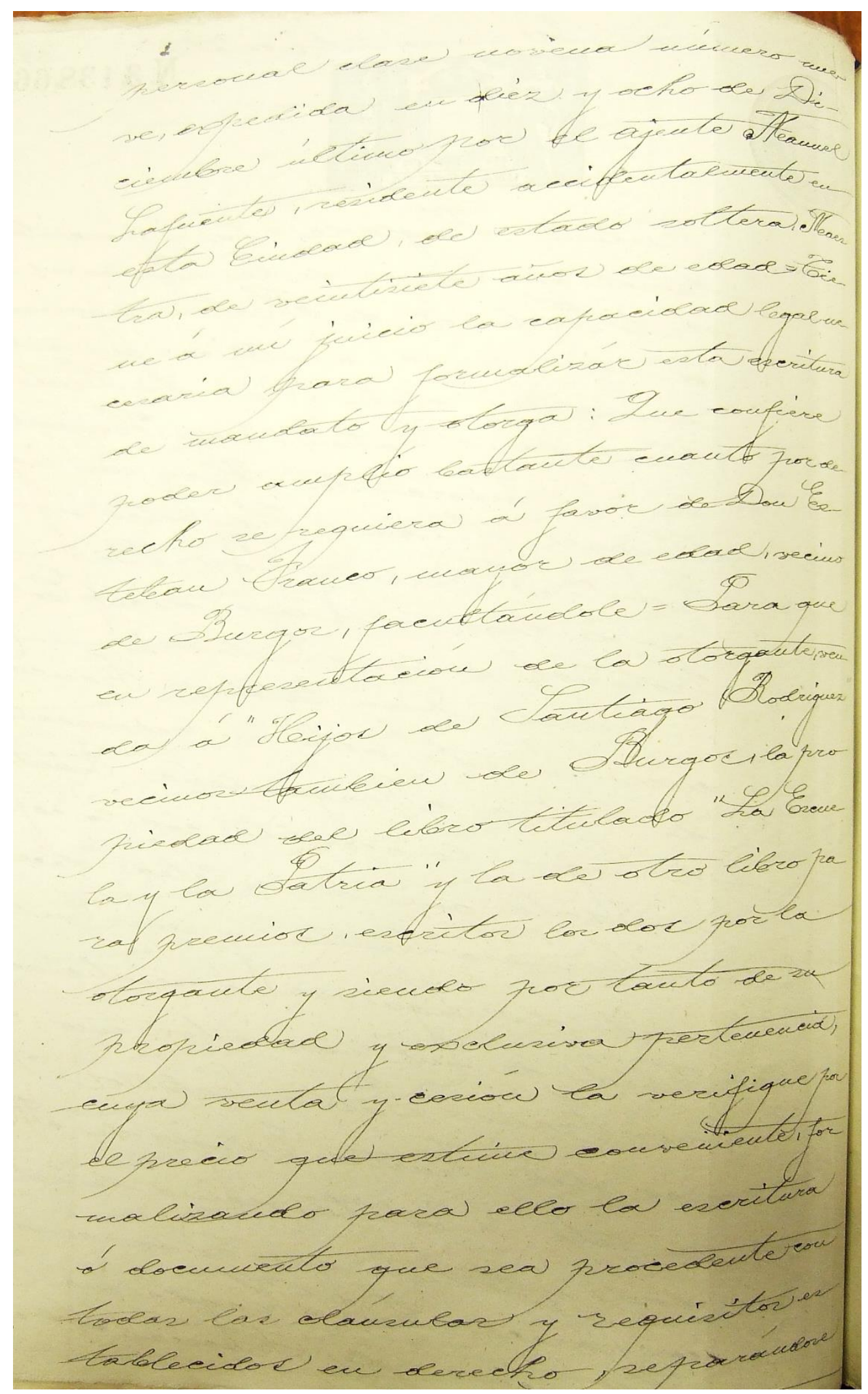

Fig.: 69

Venta de propiedad intelectual de D. Juan Benejam Vives y Da Magdalena Fuentes Soto a favor de Hijos de Santiago Rodríguez.

Archivo Histórico Provincial de Burgos. 1902, p. 6 de 12. 
LA EDITORIAL BURGALESA HIJOS DE SANTIAGO RODRÍGUEZ (1891-1936): ANÁLISIS DE LOS LIBROS ESCOLARES

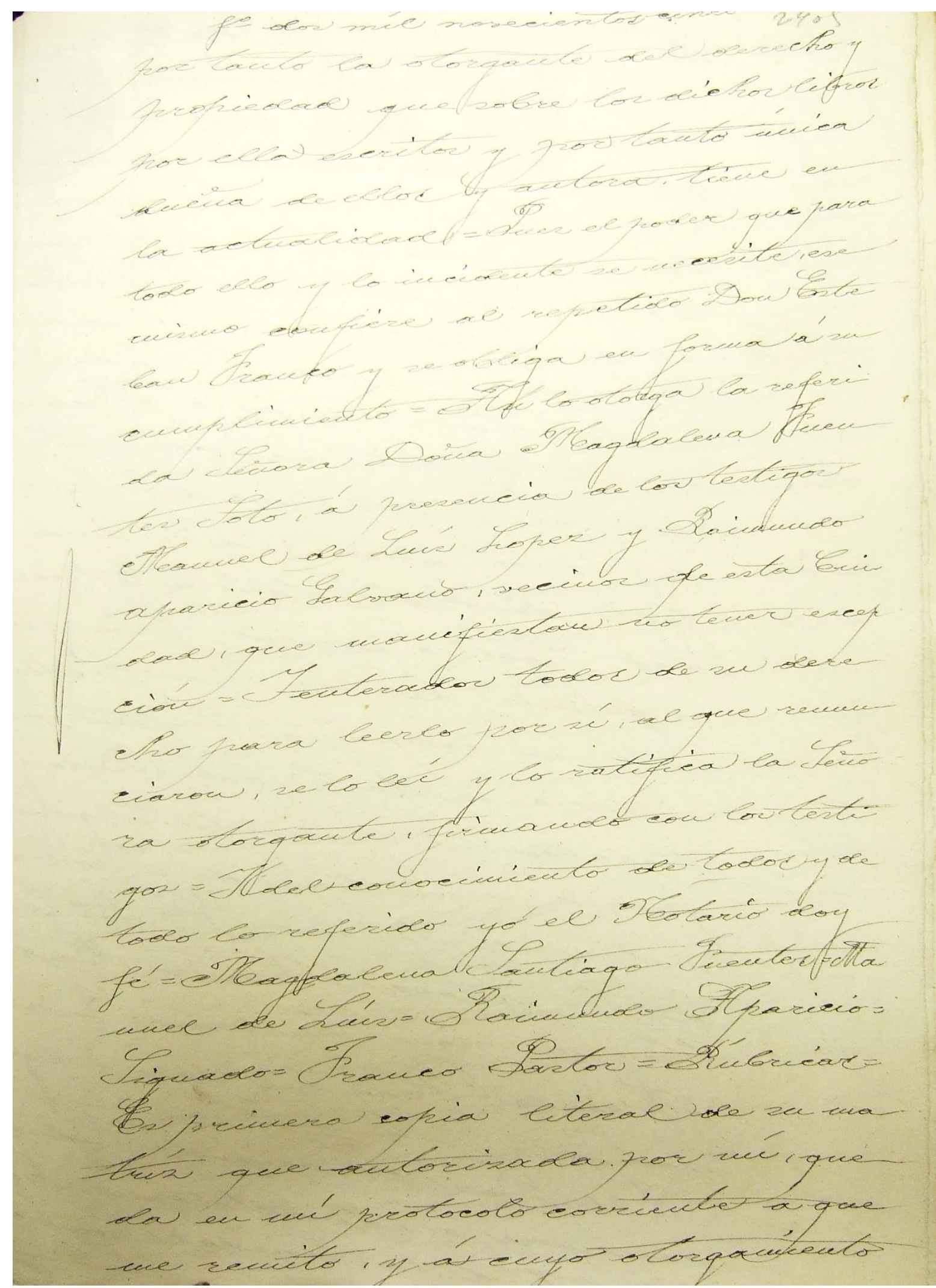

Fig.: 70

Venta de propiedad intelectual de D. Juan Benejam Vives y Da Magdalena Fuentes Soto a favor de Hijos de Santiago Rodríguez.

Archivo Histórico Provincial de Burgos. 1902, p. 7 de 12. 


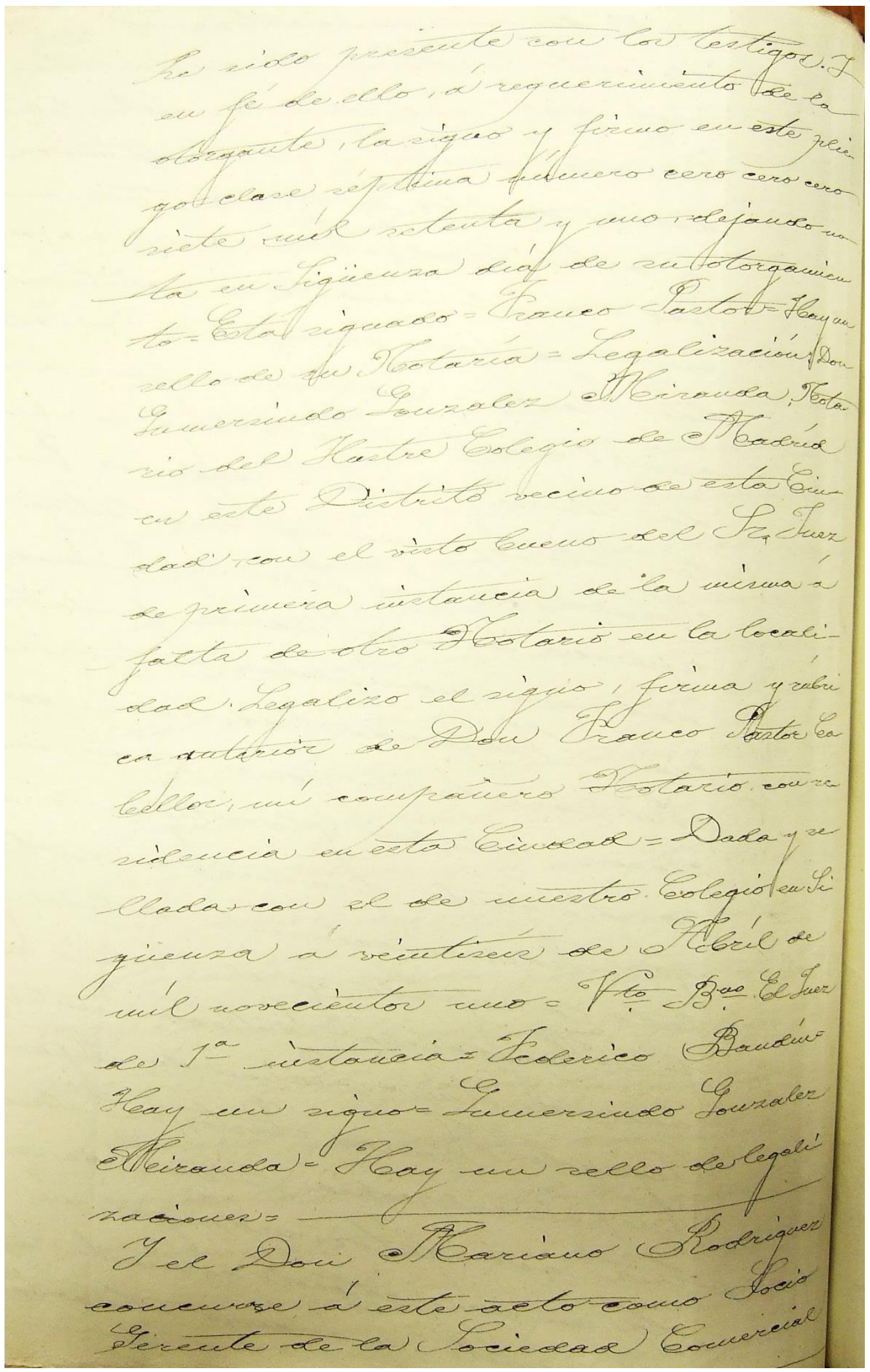

Fig.: 71

Venta de propiedad intelectual de D. Juan Benejam Vives y Da Magdalena Fuentes Soto a favor de Hijos de Santiago Rodríguez.

Archivo Histórico Provincial de Burgos. 1902, p. 8 de 12. 
LA EDITORIAL BURGALESA HIJOS DE SANTIAGO RODRÍGUEZ (1891-1936): ANÁLISIS DE LOS LIBROS ESCOLARES

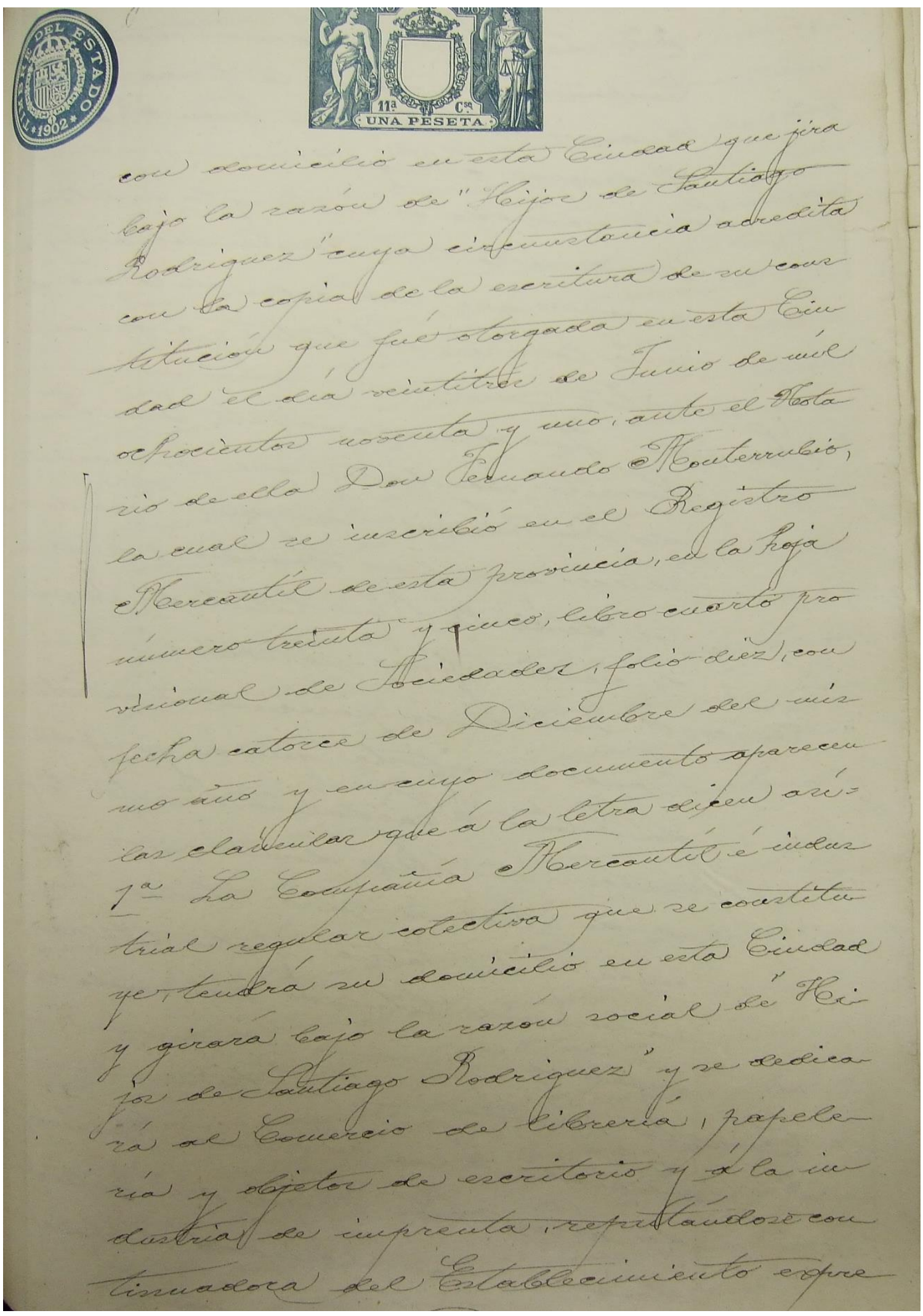

Fig.: 72

Venta de propiedad intelectual de D. Juan Benejam Vives y Da Magdalena Fuentes Soto a favor de Hijos de Santiago Rodríguez.

Archivo Histórico Provincial de Burgos. 1902, p. 9 de 12. 


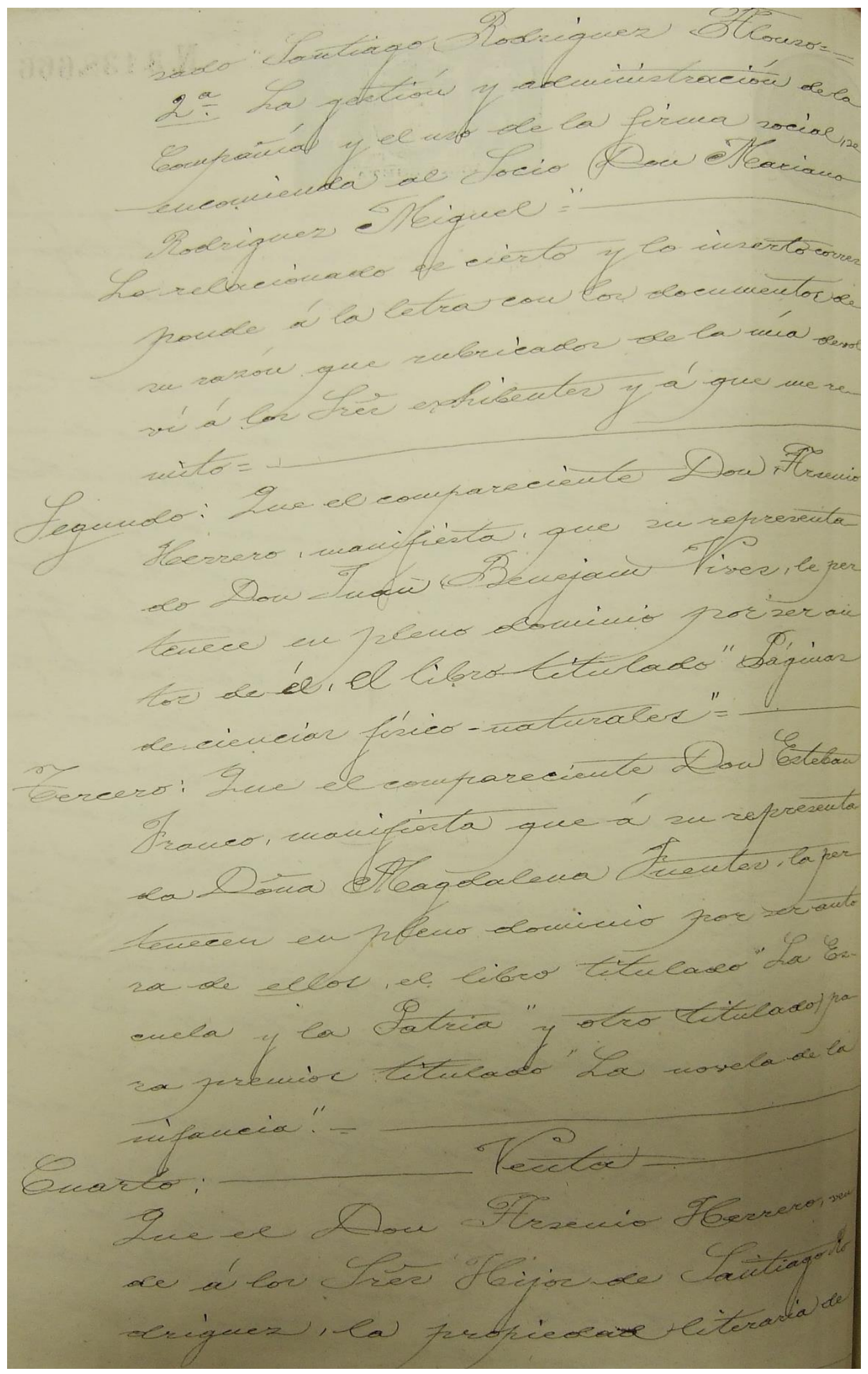

Fig.: 73

Venta de propiedad intelectual de D. Juan Benejam Vives y Da Magdalena Fuentes Soto a favor de Hijos de Santiago Rodríguez.

Archivo Histórico Provincial de Burgos. 1902, p. 10 de 12. 


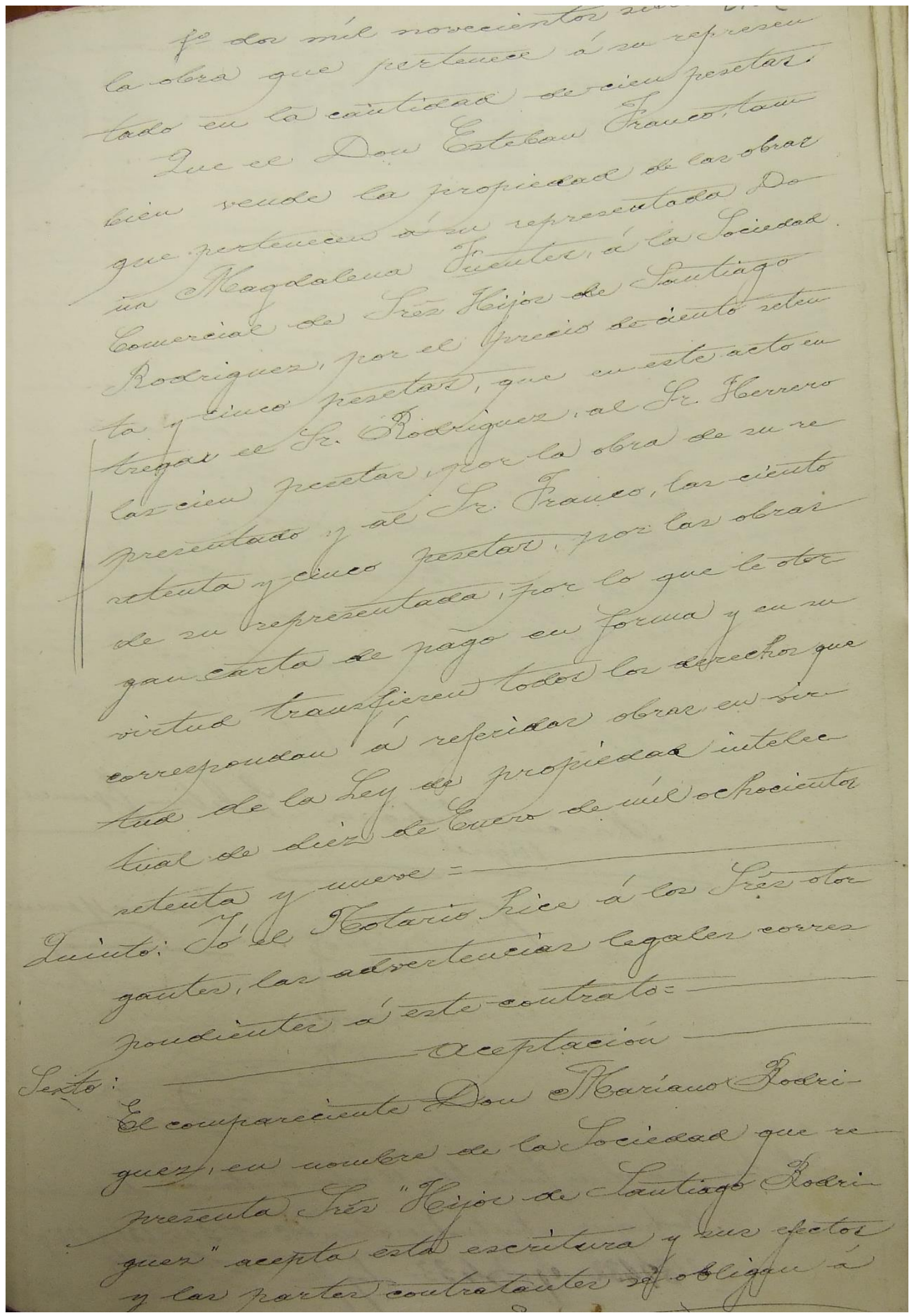

Fig.: 74

Venta de propiedad intelectual de D. Juan Benejam Vives y Da Magdalena Fuentes Soto a favor de Hijos de Santiago Rodríguez.

Archivo Histórico Provincial de Burgos. 1902, p. 11 de 12. 


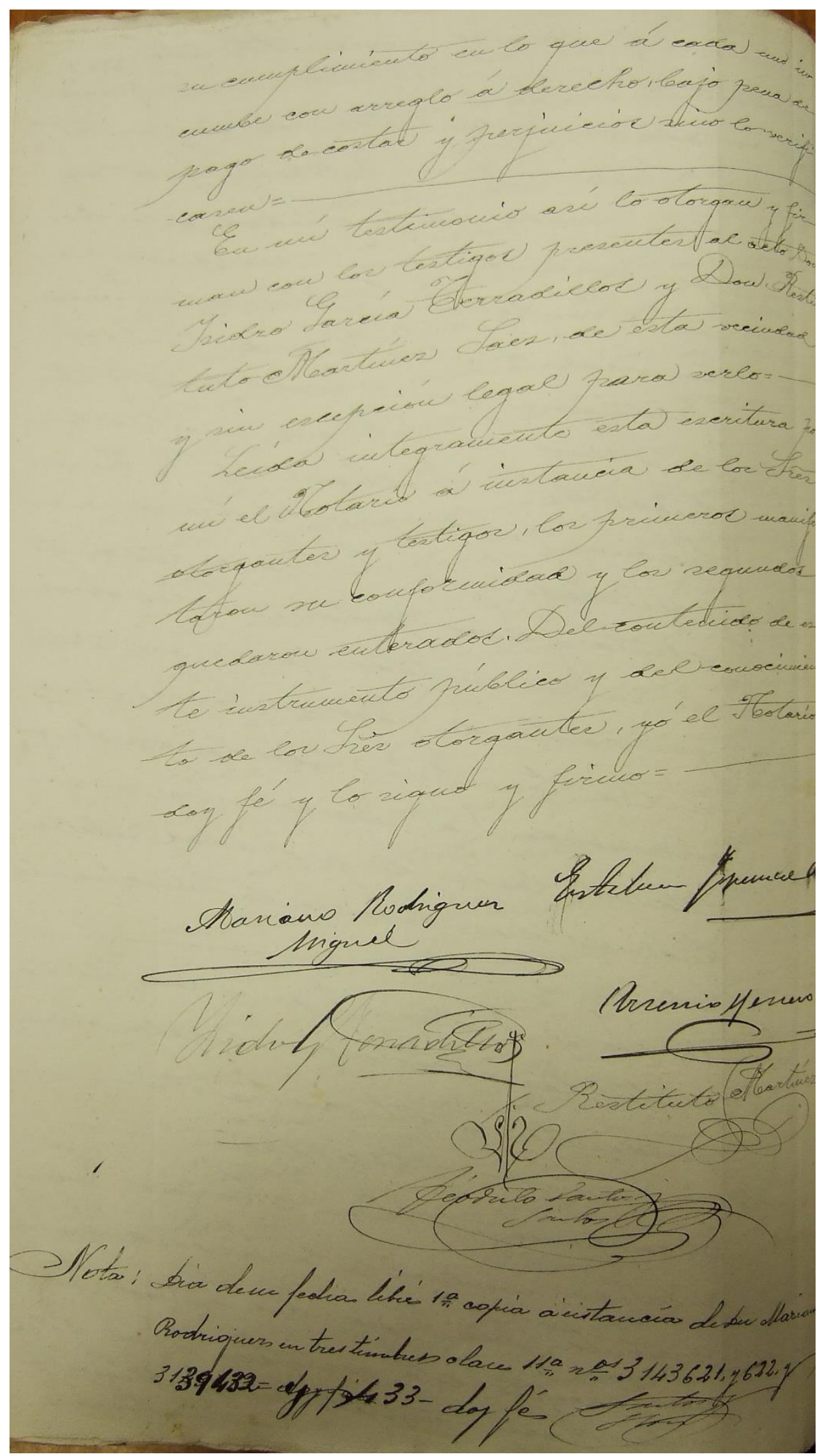

Fig.: 75

Venta de propiedad intelectual de D. Juan Benejam Vives y Da Magdalena Fuentes Soto a favor de Hijos de Santiago Rodríguez.

Archivo Histórico Provincial de Burgos. 1902, p. 12 de 12. 


\section{Escritura de cesión de propiedad literaria por D. Agapito Escudero Torres y D. José García Alía en representación de varios autores a favor de los Sres. Hijos de Santiago Rodríguez, el 14 de noviembre de 1907.}

Venta a los Sres. Hijos de Santiago Rodríguez.

En la ciudad de Burgos a catorce de noviembre de mil novecientos siete ante mi Teódulo Santos y Santos, Notario del Ilmo. colegio de esta Capital con ejercicio y vecindad en la misma y de los testigos que se dirán:

Comparece:

De una parte Don Agapito Escudero Torres, mayor de edad, viudo, propietario, vecino de Burgos, exhibe y recoge su cédula personal de séptima clase número doscientos setenta y ocho expedida en esta ciudad a ocho de agosto de mil novecientos siete.

Don José García Alía, mayor de edad, casado, escribiente, vecino de Burgos, exhibe y recoge su cédula personal de undécima clase número dos mil cuatrocientos uno, expedida el veinte y seis de julio de mil novecientos siete.

De otra Don Mariano Rodríguez Miguel mayor de edad, casado, del comercio vecino de esta ciudad, exhibe y recoge su cédula personal de séptima de número cuatrocientos cincuenta y cinco expedida en esta capital a veinte y dos de octubre de este corriente.

Los dichos Señores comparecientes se hallan en el pleno goce de sus derechos civiles y en capacidad legal a mi juicio para otorgar esta escritura de compraventa de propiedad literaria.

Exponen:

Primero: Que Don Agapito Escudero Torres concurre a este acto en su nombre y por cuenta de Don Juan José Osés y Larrumbe según lo acredita con la copia del mandato otorgado a su favor y que a la letra dice así:

Poder: Número trescientos setenta y nueve. En la ciudad de Barcelona a siete de agosto de mil novecientos siete ante mi Don Manuel Borrás y Palau, abogado, licenciado en Derecho Administrativo y Notario del Ilmo. Colegio del territorio de Barcelona con residencia en la Capital y los testigos que al final se nombrarán. Comparece Don Juan José Osés y Larrumbe mayor de edad, casado, profesor de instrucción primaria y vecino de esta ciudad domiciliado actualmente según manifiesta en la calle de Mierva del distrito de Gracia número siete provista de cédula personal que se exhibe de clase octava número novecientos treinta y cuatro expedida a quince de junio del año último. Y asegurando tener a mi juicio el Sr. compareciente la capacidad legal necesaria para este acto, dice: que da y confiere poder especial, cumplido y lo bastante como se requiera y sea necesario a Don Agapito Escudero vecino de Burgos para que en su 
nombre y representación del Sr. otorgante pueda vender a los Señores Hijos de Santiago Rodríguez", editores, de dicha ciudad de Burgos el derecho de propiedad intelectual que le corresponde de la obra Geografía para niños, primer y segundo grado por el precio de cincuenta pesetas el primero y setenta y cinco pesetas el segundo grado que puede cobrar al contado y a dicho fin celebra el oportuno contrato de venta con todas las cláusulas y requisitos que consideren firmando los documentos y escrituras públicas y privadas que sean precisas sin limitación. Por su parte el Sr. Otorgante tiene por firme y válido todo cuanto fuere obrado por su mandatario escriturado en este poder y no impugnarlo a tiempo alguno. Así lo otorga siendo presentes por testigos Don Francisco de Paula Haro y Pagés y Don José Villagrasa y Manet de esta vecindad, a quienes y al Sr. otorgante he leído íntegramente, después de enterados por el Notario del derecho que la ley les concede para leerlo por si mismos y de conocer al señor otorgante su profesión y vecindad, después firman con los testigos y de todo lo demás contenido en este instrumento público, yo el Notario autorizante doy fe. Juan José Osés Larrumbe. F. de P. Haro. Jose Vilagrasa. Manuel Borrás de Palau rubricado. Concuerda con el original que bajo el número al principio, protocolo corriente de escritura pública a que me remito. Doy fe.

Firmo copia de este pliego de la clase séptima. Firmo y rubrico en Barcelona a veintiuno de agosto de mil novecientos siete. Manuel Borrás y de Palau. Hay un sello en tinta de la Notaria del Ilustre Colegio de la Audiencia de Barcelona con residencia en esta capital.

Dicho Don Agapito Escudero concurre en nombre por cuenta de Don Ángel Bueno Rodríguez según lo acredita con la primera copia del mandato otorgada a su favor y que a la letra dice así:

Poder: En la villa de Madrid a quince de junio de mil novecientos siete ante mi José Toral y Sagrista, abogado, notario del Ilustre Colegio de esta capital con vecindad y residencia en la misma.

Comparece: Don Ángel Bueno Rodríguez Arias, mayor de edad, soltero, de esta vecindad en domicilio en la casa número quince en la calle Moinas que todo resulta de la cédula de novena clase que exhibe obrado en diecisiete de mayo último...Juzgo que el señor compareciente con la capacidad legal necesaria... para otorgar esta escritura de mandato y en su virtud expone:

Que por convenir así a sus intereses confiere poder especial...a Don Agapito Escudero Torres, mayor de edad, y vecino de Burgos para que en su nombre y representación del mandante y sin reserva ni limitación alguna pueda practicar la siguiente venta a los editores de la misma ciudad "Hijos de Santiago Rodríguez" de pleno dominio en los derechos de edición, traducción y colección, las obras de que es autor, por los precios que se expresa a saber "Educación por la vista", cincuenta pesetas: "Nociones de agricultura", primero y segundo grado, de sesenta pesetas, "Rafael" 
(cuentos fantásticos), a cuarenta pesetas, "Leyendas y tradiciones", en la misma cantidad que la anterior, "José" o el Leñador, "El divino Infante", "Moisés" y "La suerte del Justo" en veinticinco pesetas cada una, "Para los niños", "Cuentos franceses", "Cuentos árabes", "Leyendas Bíblicas" y "Cuentos Egipcios" en precio total de doscientas pesetas o sea de cincuenta pesetas cada una, cuyo precio recibirá el mandatario al contado o confesará haber recibido, otorgando y firmando en ambos casos los correspondientes recibos y cartas de pago, así como cuantos documentos públicos y privados sean necesarios a los fines del presente poder. Así lo otorga en presencia de los testigos instrumentales Don Julio Vivar Almuzana y Don José Huixa y Bonet, mayores de edad, sin excepción legal para ser tales testigos según aseguran. Leída por mí a todos por mi deseo esta escritura íntegra después de advertirles del derecho que tienen para leerla por sí mismos manifiestan quedar enterados de ello prestando su asentimiento y firmándola con los testigos. Yo el Notario doy fe de que conozco al Señor otorgante y de todo lo contenido en este instrumento público. Ángel Bueno y José Huixa, Julio Vivar. Licenciado José Toral todos en rúbrica. Es primera copia.

Madrid a quince de enero de mil novecientos siete.

Referido Don Agapito Escudero Torres también concurre en nombre por cuenta de Don Rogelio Francés Gutiérrez, mayor de edad, casado, profesor y vecino de Gijón, con cédula de clase octava número veinte mil ochocientos noventa y ocho expedida en aquella villa el quince de mayo último. Tiene a mi juicio capacidad legal para otorgar esta escritura y dice: Que confiere poder a Don Aga, según lo acredita en la copia del mandato otorgando a su favor el cual a la letra dice así.

Poder: En Gijón a catorce de enero de mil novecientos siete ante mi Santiago Urias, Notario y vecino de esta villa comparece, Don Rogelio Francés Gutiérrez, mayor de edad, casado, profesor y de esta vecindad con cédula de octava número veinte mil ochocientos noventa y ocho expedida en esta villa el quince de mayo último. Tiene a mi juicio capacidad legal para otorgar esta escritura y dice: Que confiere poder a Don Agapito Escudero y Torres, mayor de edad, viudo, propietario y vecino de Burgos para que en nombre del otorgante vende a la Señores Hijos de Santiago Rodríguez", casa editorial de dicha ciudad de Burgos la propiedad de las obras tituladas "Fisiología e Higiene", primer grado y grado medio y "Fisiología e Higiene, segundo grado", en precio la primera de cincuenta pesetas y la segunda de veinticinco, que recibirá al contado y de cuyas obras es autor otorgando a tal efecto las escrituras y documentos que proceden. Son testigos Don Benito Conde y García y Mauro Entrialgo de esta vecindad y sin tacha legal a los cuales el otorgante leí esta escritura y les advierto que la pueden leer por sí. Firman todos y yo el Notario doy fe de conocer al otorgante y de todo lo contenido en este instrumento público. Rogelio Francés Gutiérrez. Benito Conde. Mauro Entrialgo. Signado 
Santiago Urias, concede con su original número cincuenta y cuatro de mi protocolo corriente, y para el otorgante doy esta primera copia en Gijón el día de su fecha. Signado Santiago Urias. Hay un sello de la Notaria...

Que Don José García Alía concurre en nombre y por cuenta de Don Lino González y González Ansótegui según lo acredita con la copia del mandato otorgada a su favor y que a la letra dice así:

Poder: Número treinta y uno. En la ciudad de Palencia a catorce de enero de mil novecientos siete ante mi Don Aniano Masa, abogado en ejercicio y Notario con residencia y vecindad en ella del mismo distrito y del Ilustre Colegio Territorial de Valladolid comparece: Don Lino González y González Ansótegui de cuarenta años de edad, casado, profesión empleado y vecino de esta capital provisto de cédula personal librada en ella por el Recaudador con el número seis mil setecientos once de octava el treinta de junio último...confiere poder...a Don José García Alía, mayor de edad y vecino de esta ciudad de Burgos cuyas demás circunstancias ignora, facultándole para que en nombre y representación del Sr. otorgante venda a los Señores "Hijos de Santiago Rodríguez" de la citada ciudad de Burgos la propiedad del libro titulado "Cancionero de la Infancia" de que es autor el compareciente transmitiéndoles cuantos derechos por la ley le corresponde en el precio de cuarenta pesetas cuya cantidad confirma el apoderado haberles recibido ya en su poder en efecto y formulando a favor de los mismos la oportuna escritura pública con todos los requisitos necesarios para su inscripción en el Registro de la Propiedad Intelectual. Palencia a catorce de enero de mil novecientos siete. El juez de $1^{\mathrm{a}}$ instancia Víctor García Alonso.

Segundo:

Que el compareciente Don Agapito Escudero Torres manifiesta que a su representado Don Juan José Osés Larrumbe el derecho de propiedad intelectual de las obras "Geografía para niños, primer y segundo grado".

Dicho Don Agapito manifiesta que a su representado Don Ángel Bueno Rodríguez Arias le pertenece el pleno dominio de modo absoluto incluso con los derechos de edición, traducción y colección de las obras de que es autor y son las siguientes: "Educación por la vista" "Nociones de agricultura" primer y segundo grado, "Rafael" (cuentos fantásticos), "Leyendas y tradiciones", "José o el Soñador" "El divino Infante", "Moisés" y "La suerte del Justo", "Para los niños", "Cuentos franceses", "Cuentos árabes", "Leyendas Bíblicas" y "Cuentos Egipcios"

Referido Don Agapito manifiesta que su representado Don Rogelio Francés Gutiérrez le pertenece la propiedad de las obras tituladas, "Fisiología e Higiene", primer grado y grado medio y "Fisiología e Higiene", segundo grado", por ser autor de ella. 
Tercero: Que el compareciente Don José García Alía manifiesta que a su representado Don Lino González y González Ansótegui le pertenece en pleno dominio por ser autor del libro titulado "Cancionero de la Infancia".

Cuarto: Venta.

Que Don Agapito Escudero Torres en virtud de las facultades conferidas y en nombre de los principales, vende a la Sociedad Mercantil "Hijos de Santiago Rodríguez" que compra la propiedad literaria de las obras ya relacionadas y que pertenecen a los señores representados en la forma siguiente:

Las de Don Juan José Osés Larrumbe en la cantidad de ciento veinte y cinco pesetas. Las de Don Ángel Bueno y Rodríguez Arias en la cantidad de cuatrocientas noventa pesetas y la de Don Rogelio Francés y Gutiérrez en la cantidad de setenta y cinco pesetas, cuyas tres sumas hace la de seiscientas noventa pesetas.

Que Don José García Alía en nombre y representante de su principal vende a la referida Sociedad mercantil "Hijos de Santiago Rodríguez" que compra la propiedad literaria de la obra ya relacionada que pertenece a su representado Don Lino González y González Ansótegui por la cantidad de cincuenta pesetas que el Sr. García Alía confiesa que su principal tiene ya recibida antes de ahora a su satisfacción y el compareciente Don Mariano Rodríguez Miguel en nombre de la Sociedad que representa entrega en este acto al Seños Escudero Torres las seiscientas noventa pesetas por las obras de sus representados en buenas monedas corrientes a presencia de los testigos y del Notario: dicho señor Escudero Torres y García Alía otorgan carta de pago en forma a dicha Sociedad y en su virtud le transfieren todos los derechos que correspondan a las obras en virtud de la Ley de propiedad intelectual de diez de enero de mil ochocientos setenta y nueve.

Quinto: Y yo el Notario hice de palabra a los Señores otorgantes las oportunas advertencias legales correspondientes a este contrato de los cuales quedan enterados; y que la copia primera de esta escritura se ha de inscribir en el Registro Intelectual y así como las obras transcritas para los efectos de los artículos treinta y dos y siguientes de la Ley de propiedad intelectual antes referida.

Sexto: Aceptación.

El compareciente Don Mariano Rodríguez Miguel en nombre de la Sociedad que regenta "Hijos de Santiago Rodríguez" acepta esta escritura y sus efectos y las partes contratantes se obligarán a su cumplimiento con arreglo a derecho.

Otorgamiento.

Es mi testimonio así lo dicen y otorgan y firman los Señores comparecientes con los testigos presentes al acto Don Isidro García Tornadillos y Don Andrés González de la Fuente vecinos y domiciliados respectivamente en esta ciudad y sin excepción legal para serlo. 
Leída íntegramente esta escritura por mí el Notario a instancias de los Señores otorgantes y testigos, los mismos manifestaron conformidad y los testigos quedaron enterados del contenido de este instrumento público del conocimiento, profesión y vecindad de los Señores comparecientes y de que se hallan extendido en cuatro pliegos timbrados, clase undécima, serie $\mathrm{B}$, números, un millón setenta y tres mil ciento ochenta y cuatro, ciento ochenta y siete y ciento noventa y quinientos catorce mil noventa y seis. Yo el notario doy fe, lo signo y firmo.

Firmado por el notario D. Teódulo Santos y Santos, Hijos de Santiago Rodríguez, José García Alía, Agapito Escudero, Andrés Gonzáles e Isidro Gil. 


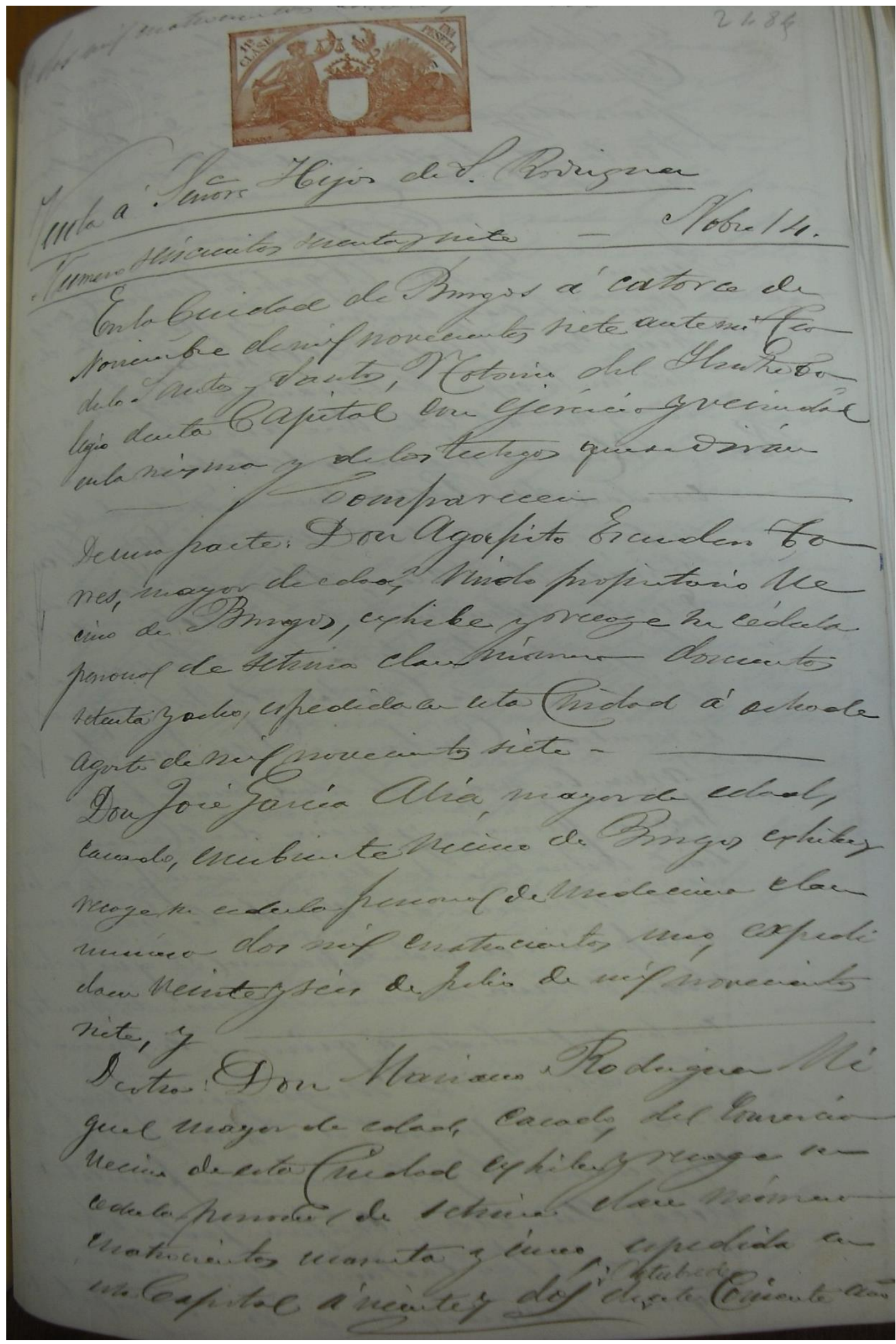

Fig.: 76

Venta de propiedad intelectual de D. Ángel Bueno Rodríguez-Arias, D. Rogelio Francés Gutiérrez, D. Lino González y González Ansótegui, D. Juan José Osés Larrumbe a favor de Hijos de Santiago Rodríguez.

Archivo Histórico Provincial de Burgos. 1907, p. 1 de 14. 


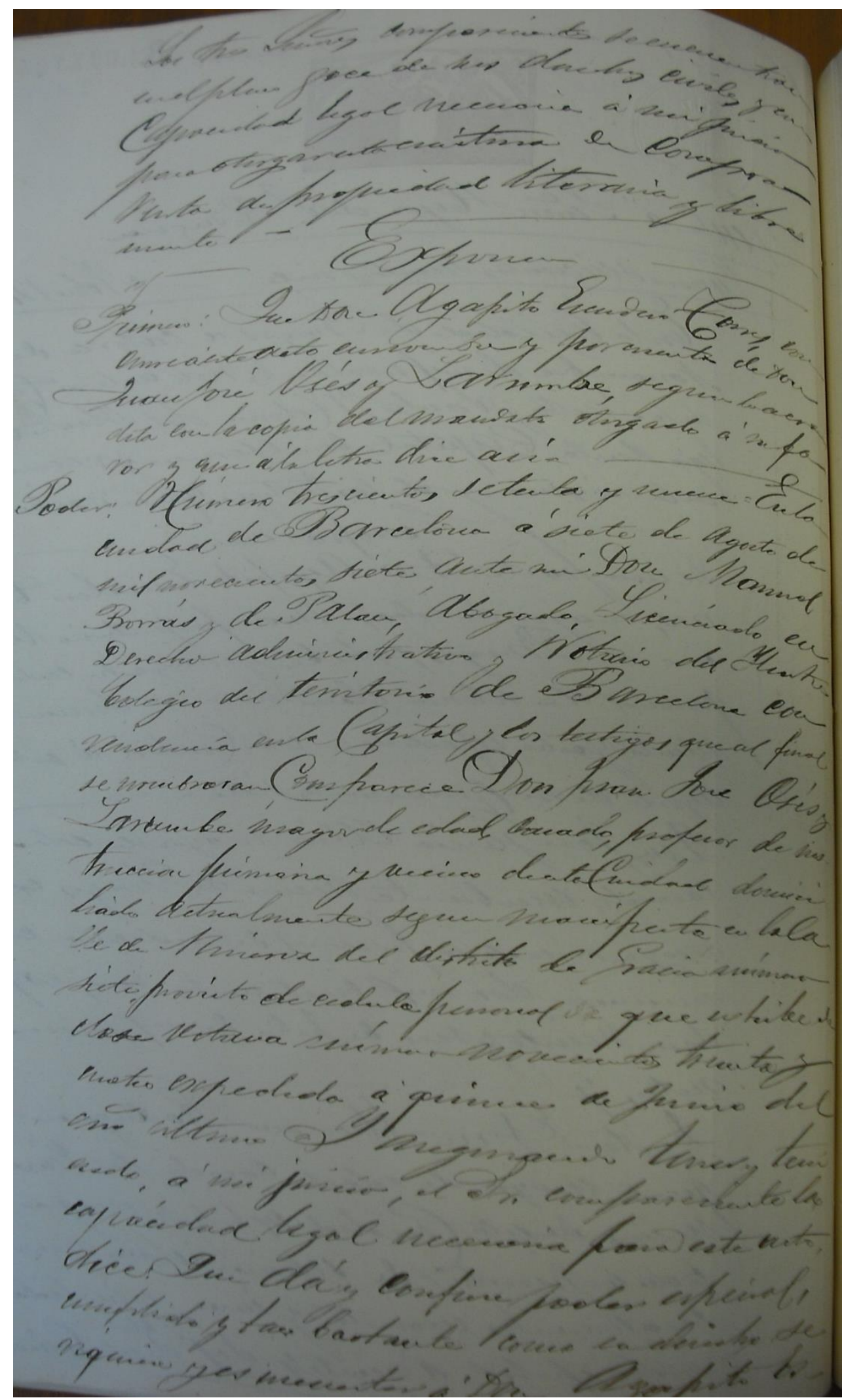

Fig.: 77

Venta de propiedad intelectual de D. Ángel Bueno Rodríguez-Arias, D. Rogelio Francés Gutiérrez, D. Lino González y González Ansótegui, D. Juan José Osés Larrumbe a favor de Hijos de Santiago Rodríguez.

Archivo Histórico Provincial de Burgos. 1907, p. 2 de 14. 


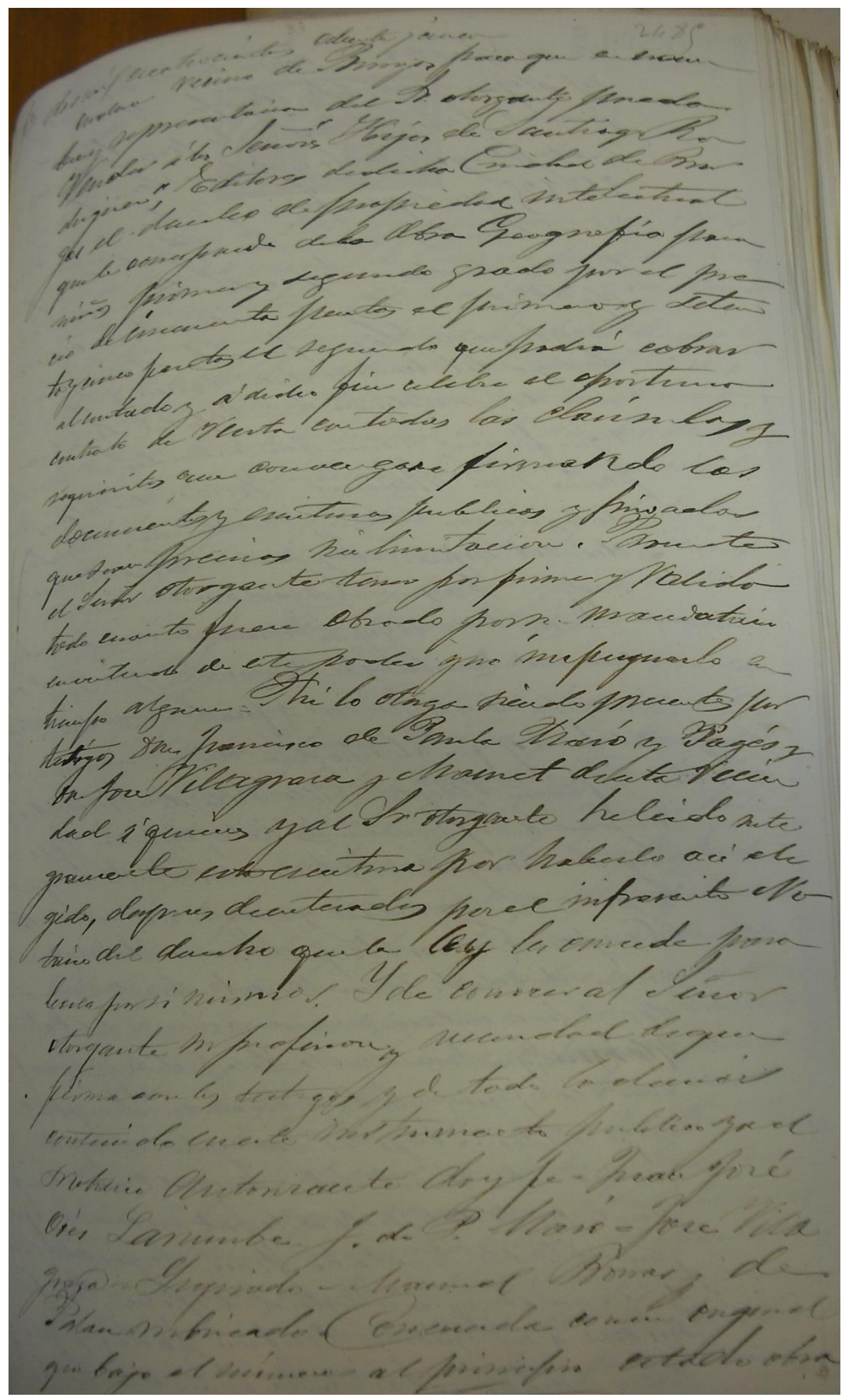

Fig.: 78

Venta de propiedad intelectual de D. Ángel Bueno Rodríguez Arias, D. Rogelio Francés Gutiérrez, D. Lino González y González Ansótegui, D. Juan José Osés Larrumbe a favor de Hijos de Santiago Rodríguez.

Archivo Histórico Provincial de Burgos. 1907, p. 3 de 14. 


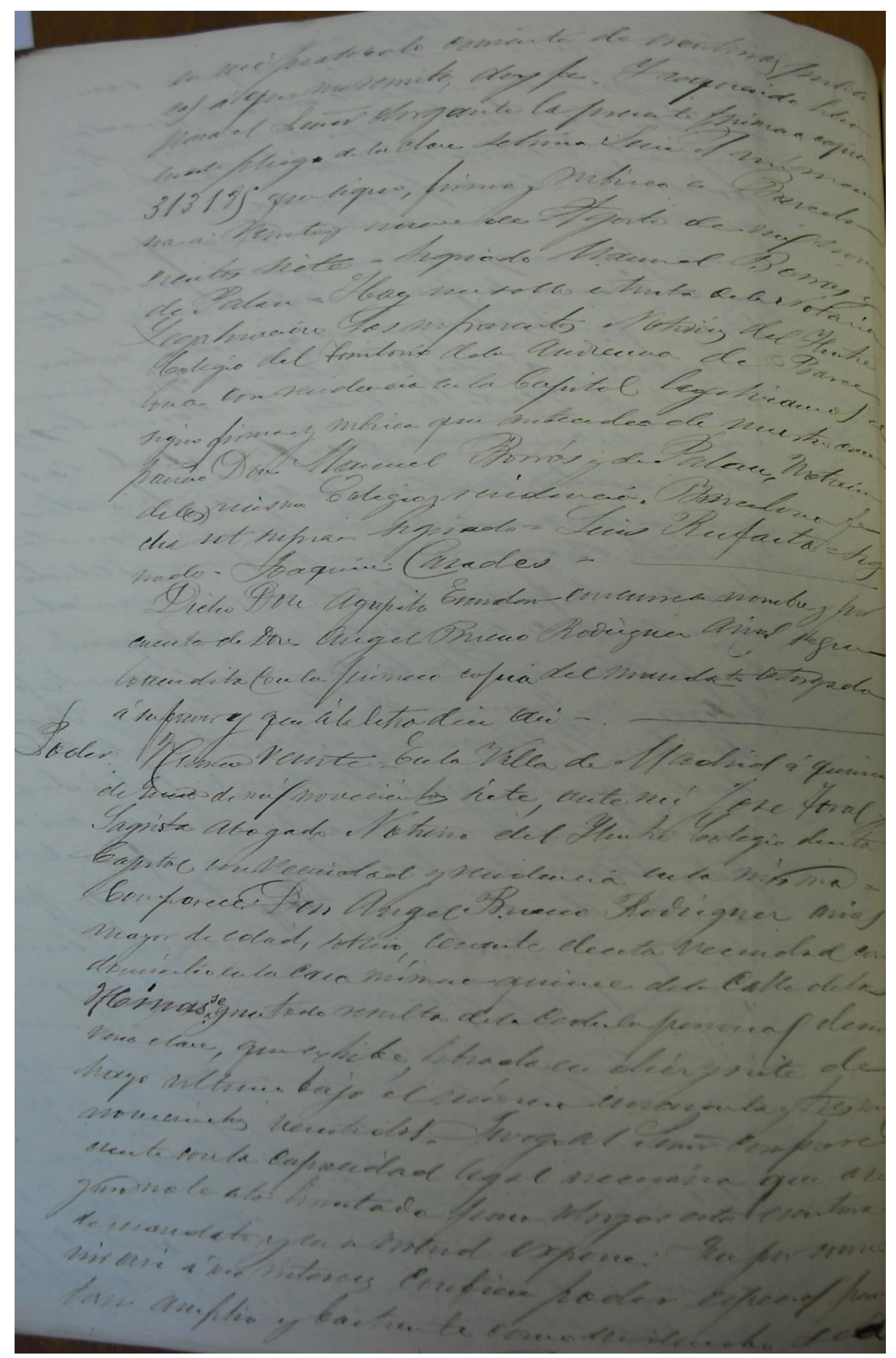

Fig.: 79

Venta de propiedad intelectual de D. Ángel Bueno Rodríguez-Arias, D. Rogelio Francés Gutiérrez, D. Lino González y González Ansótegui, D. Juan José Osés Larrumbe a favor de Hijos de Santiago Rodríguez.

Archivo Histórico Provincial de Burgos. 1907, p. 4 de 14. 


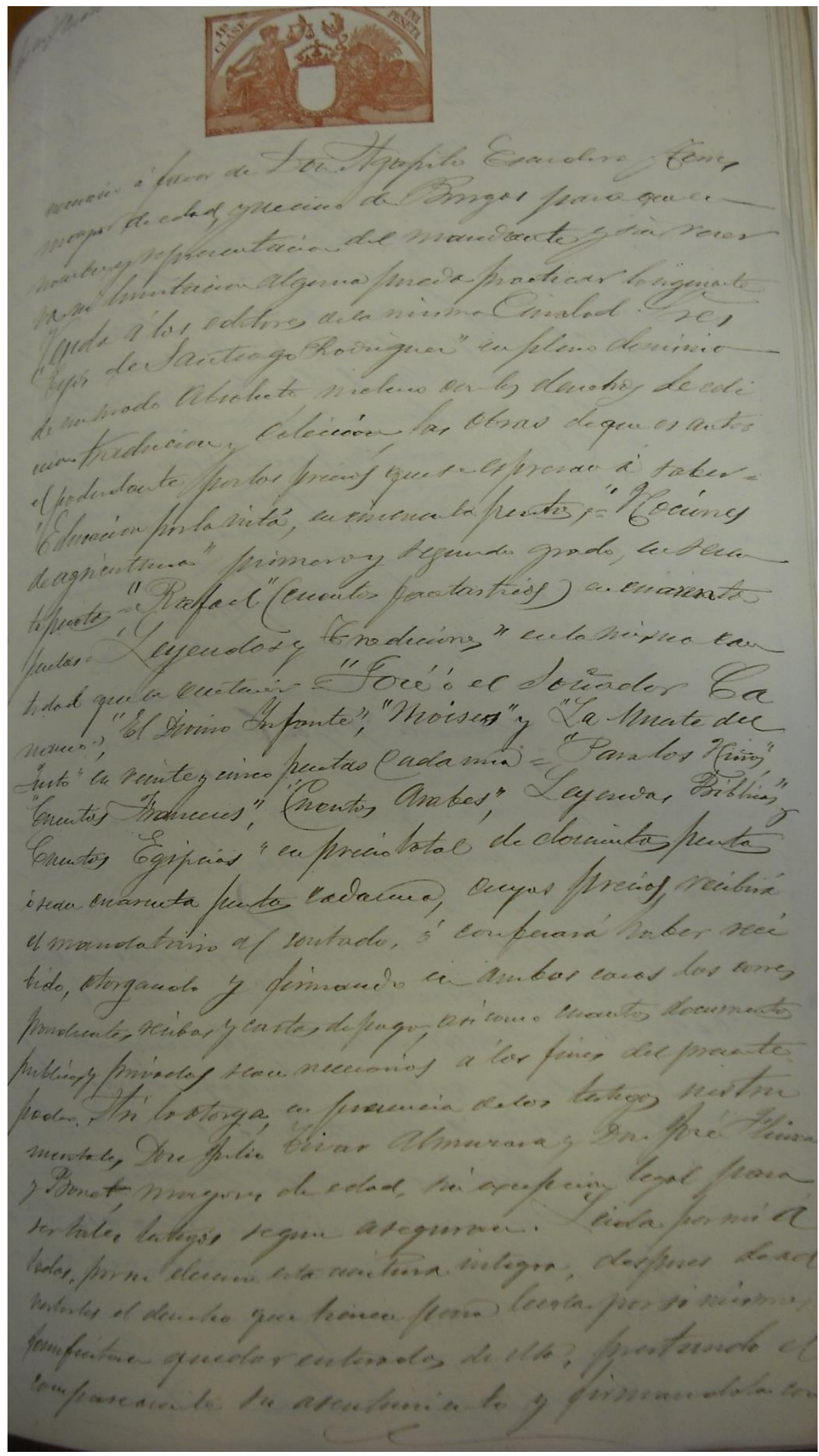

Fig.: 80

Venta de propiedad intelectual de D. Ángel Bueno Rodríguez-Arias, D. Rogelio Francés Gutiérrez, D. Lino González y González Ansótegui, D. Juan José Osés Larrumbe a favor de Hijos de Santiago Rodríguez.

Archivo Histórico Provincial de Burgos. 1907, p. 5 de 14. 


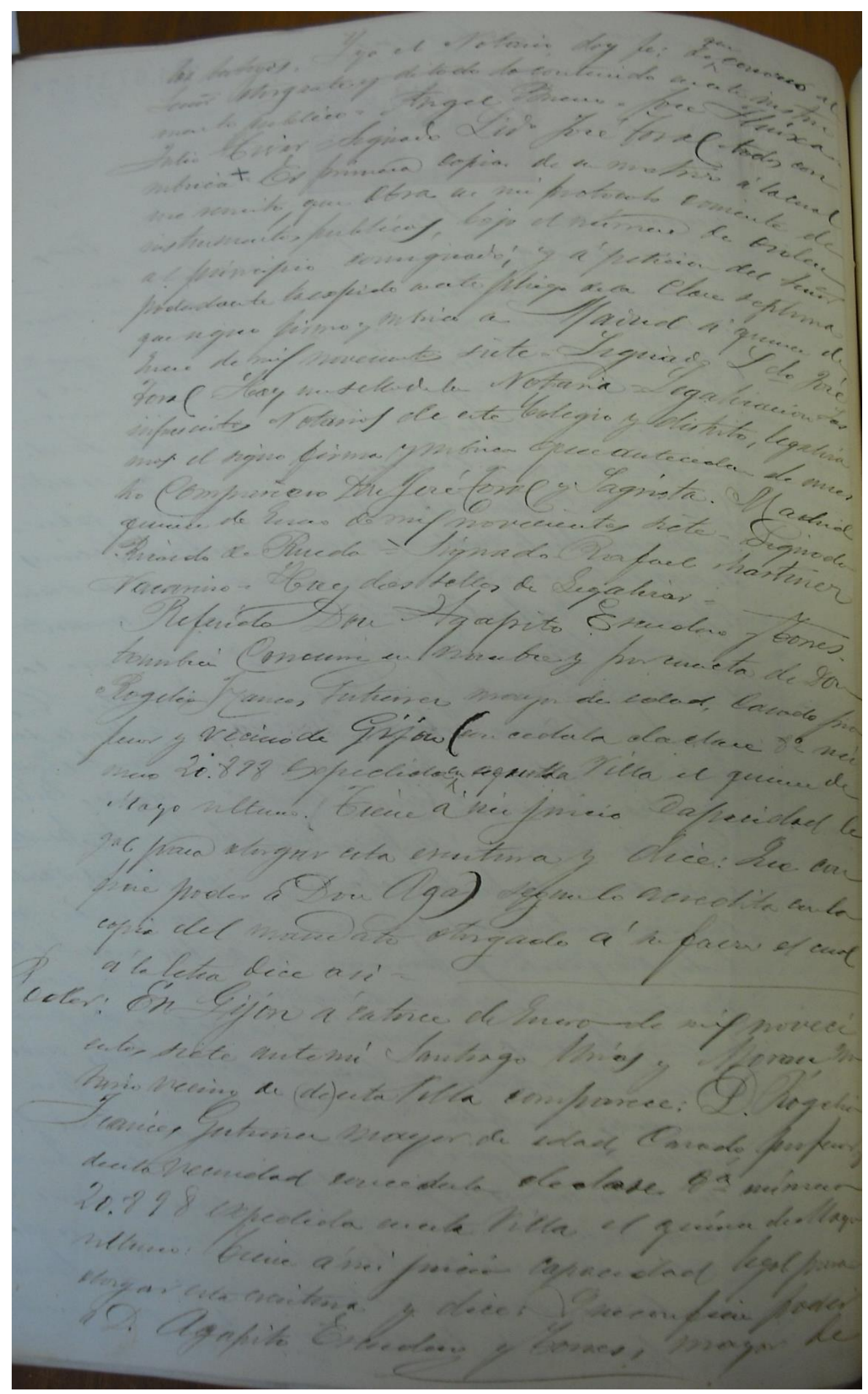

Fig.: 81

Venta de propiedad intelectual de D. Ángel Bueno Rodríguez-Arias, D. Rogelio Francés Gutiérrez, D. Lino González y González Ansótegui, D. Juan José Osés Larrumbe a favor de Hijos de Santiago Rodríguez.

Archivo Histórico Provincial de Burgos. 1907, p. 6 de 14. 


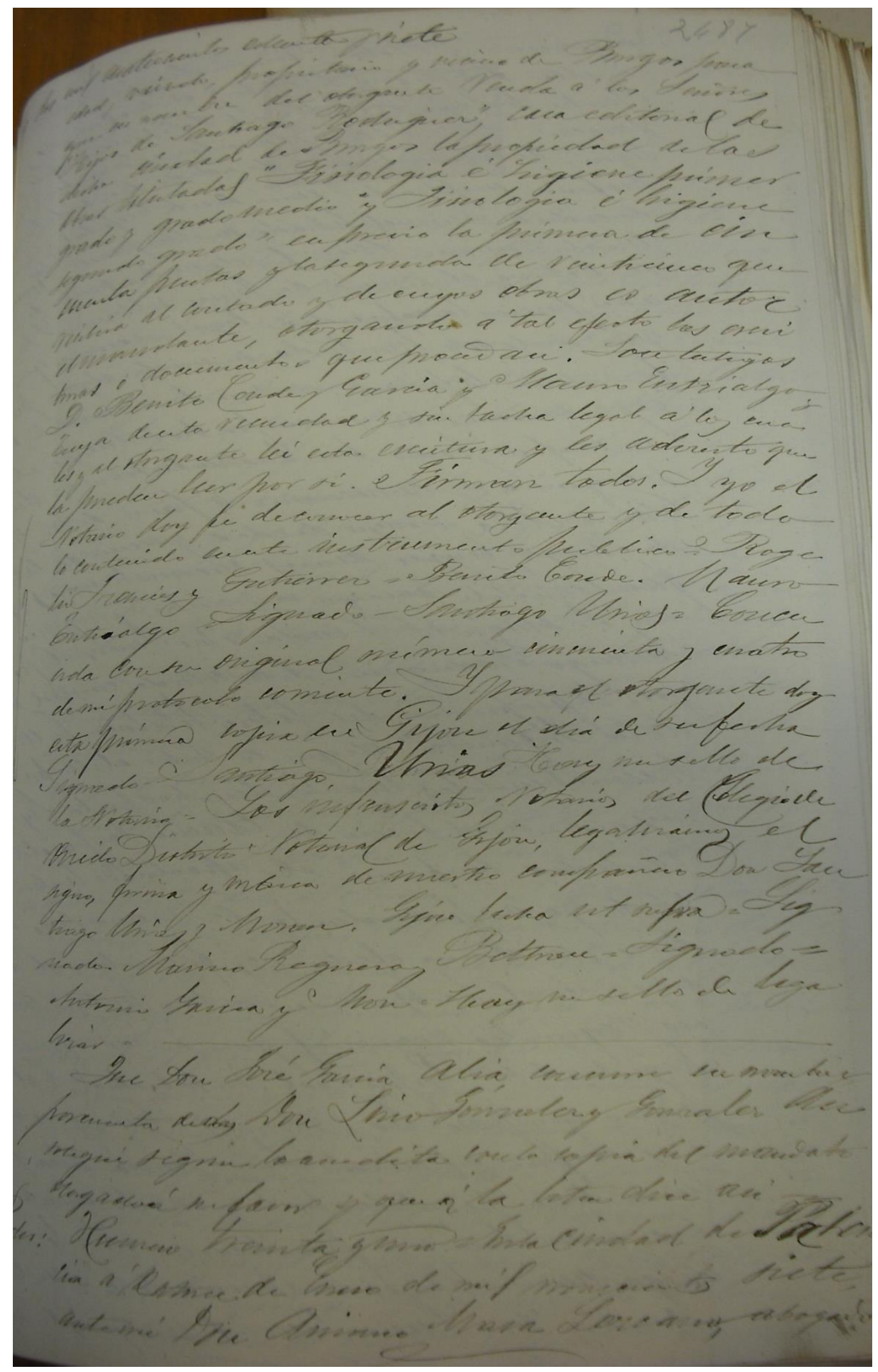

Fig.: 82

Venta de propiedad intelectual de D. Ángel Bueno Rodríguez-Arias, D. Rogelio Francés Gutiérrez, D. Lino González y González Ansótegui, D. Juan José Osés Larrumbe a favor de Hijos de Santiago Rodríguez.

Archivo Histórico Provincial de Burgos. 1907, p. 7 de 14. 


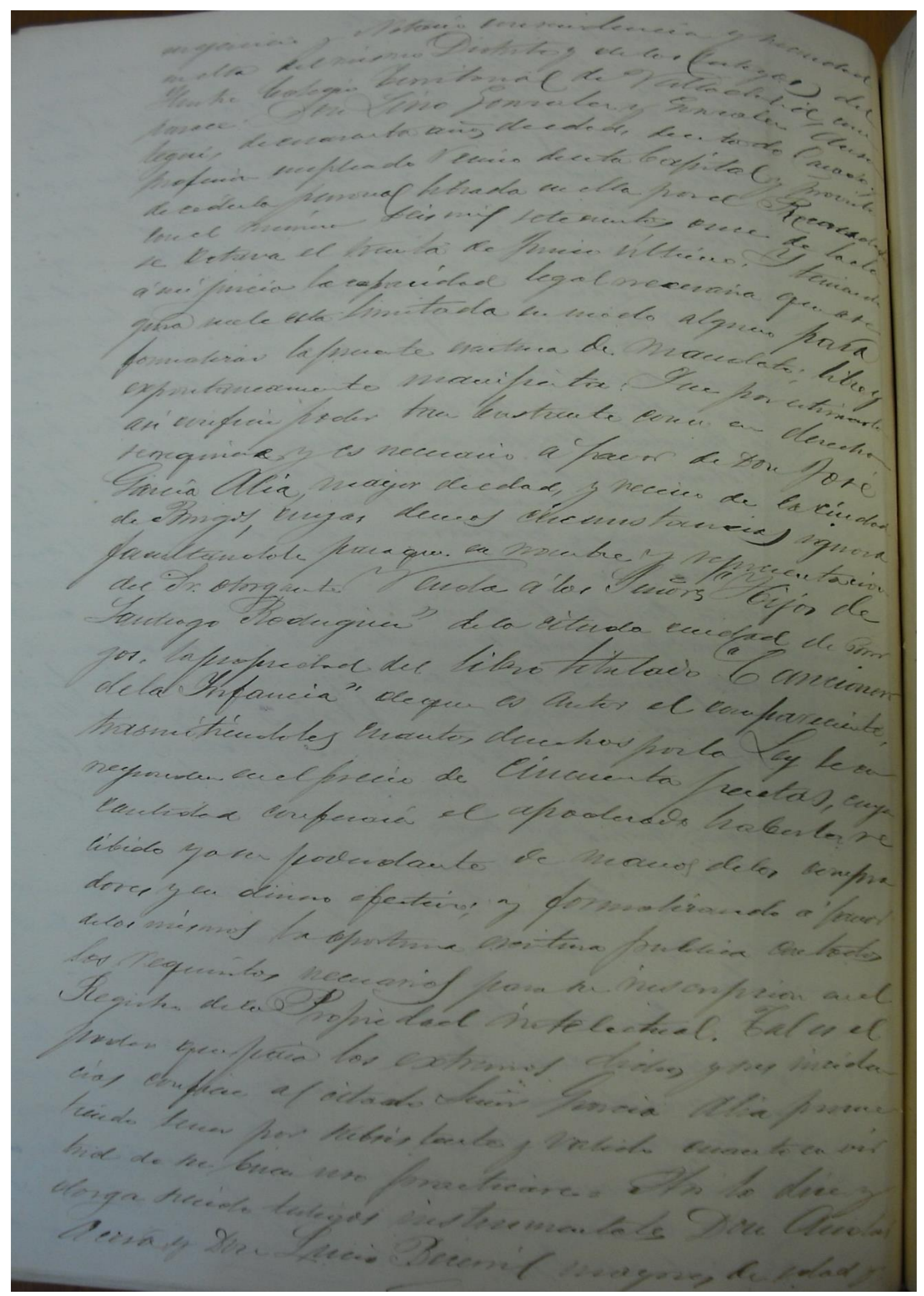

Fig.: 83

Venta de propiedad intelectual de D. Ángel Bueno Rodríguez-Arias, D. Rogelio Francés Gutiérrez, D. Lino González y González Ansótegui, D. Juan José Osés Larrumbe a favor de Hijos de Santiago Rodríguez.

Archivo Histórico Provincial de Burgos. 1907, p. 8 de 14. 


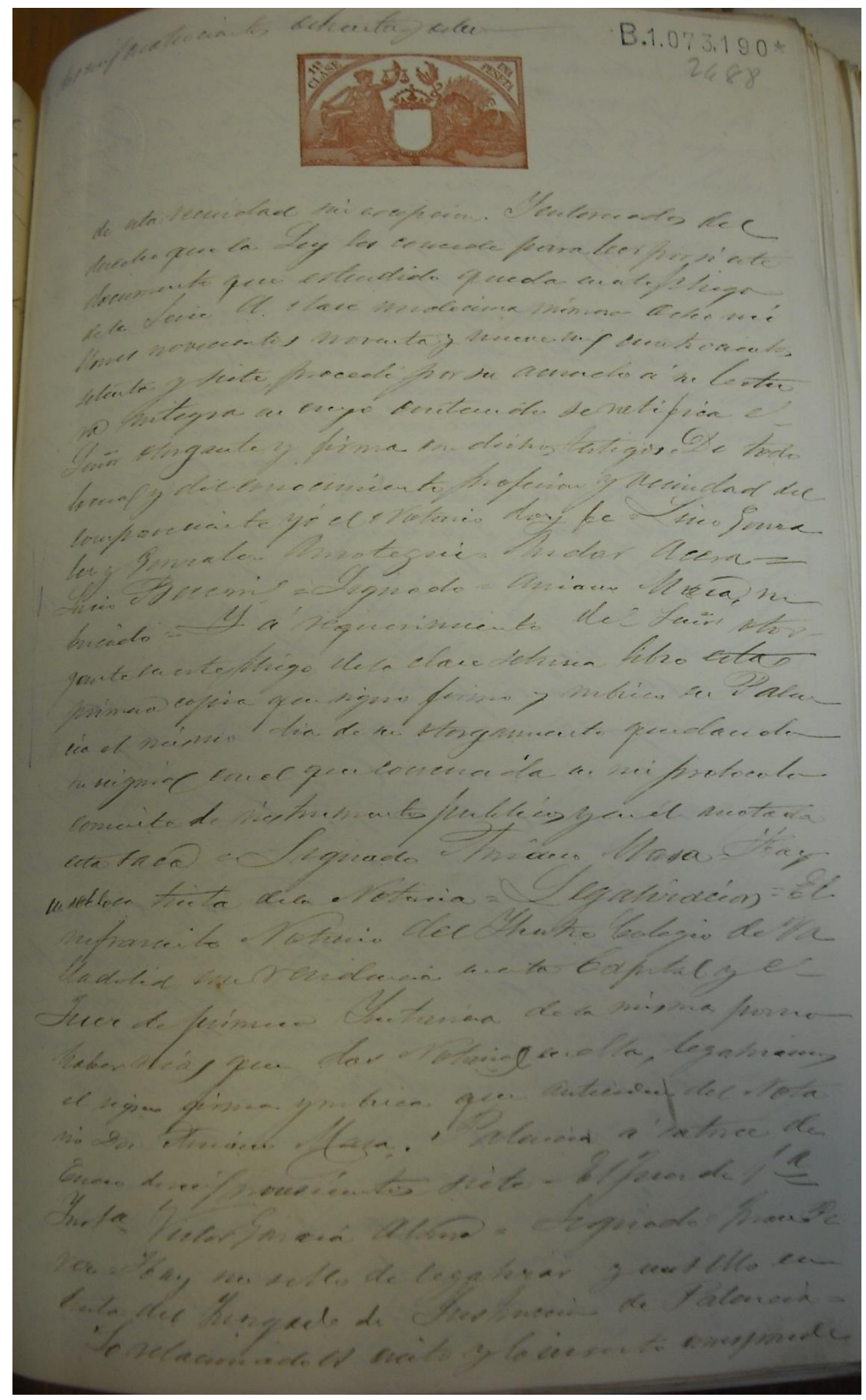

Fig.: 84

Venta de propiedad intelectual de D. Ángel Bueno Rodríguez-Arias, D. Rogelio Francés Gutiérrez, D. Lino González y González Ansótegui, D. Juan José Osés Larrumbe a favor de Hijos de Santiago Rodríguez.

Archivo Histórico Provincial de Burgos. 1907, p. 9 de 14. 


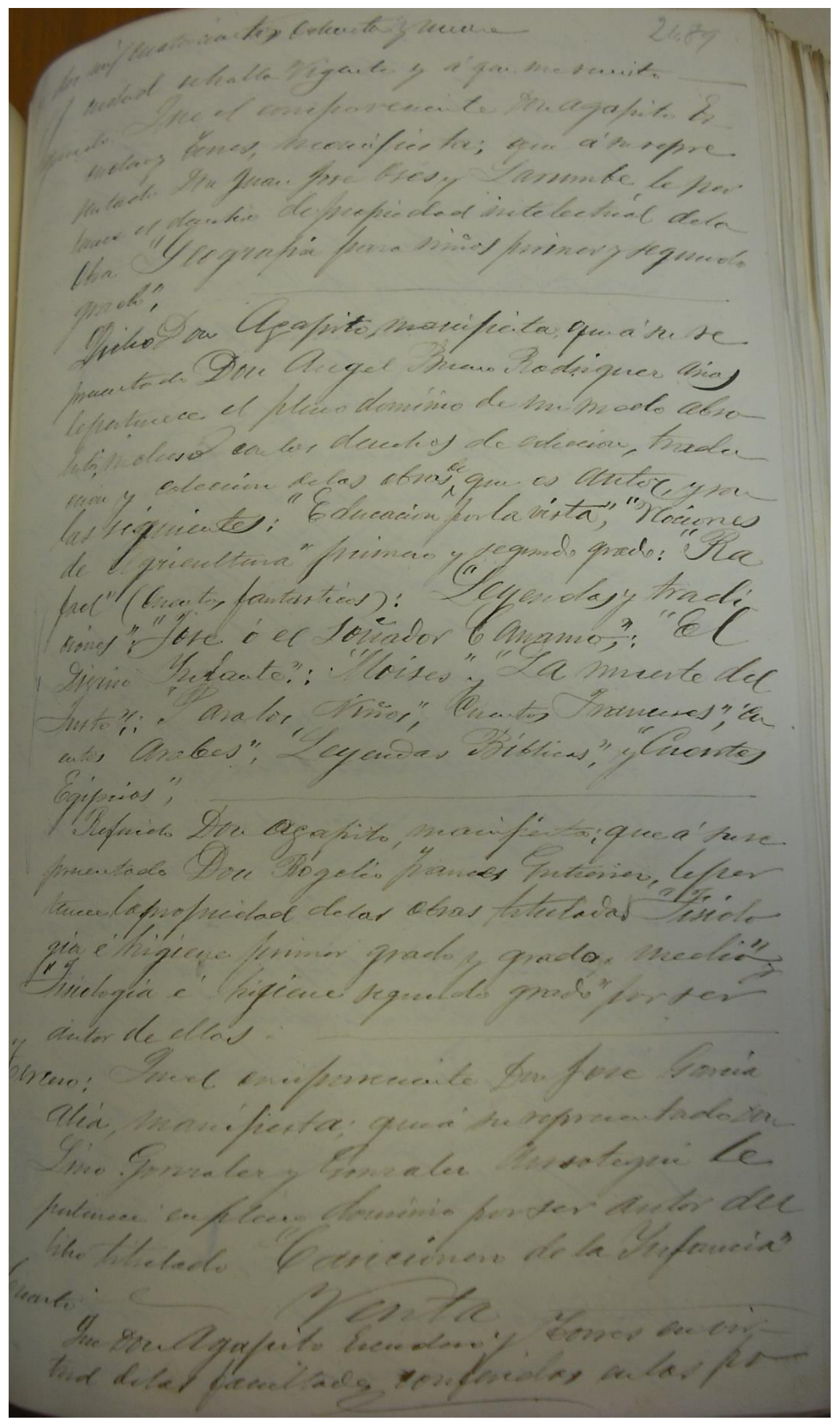

Fig.: 85

Venta de propiedad intelectual de D. Ángel Bueno Rodríguez-Arias, D. Rogelio Francés Gutiérrez, D. Lino González y González Ansótegui, D. Juan José Osés Larrumbe a favor de Hijos de Santiago Rodríguez.

Archivo Histórico Provincial de Burgos. 1907, p. 10 de 14. 


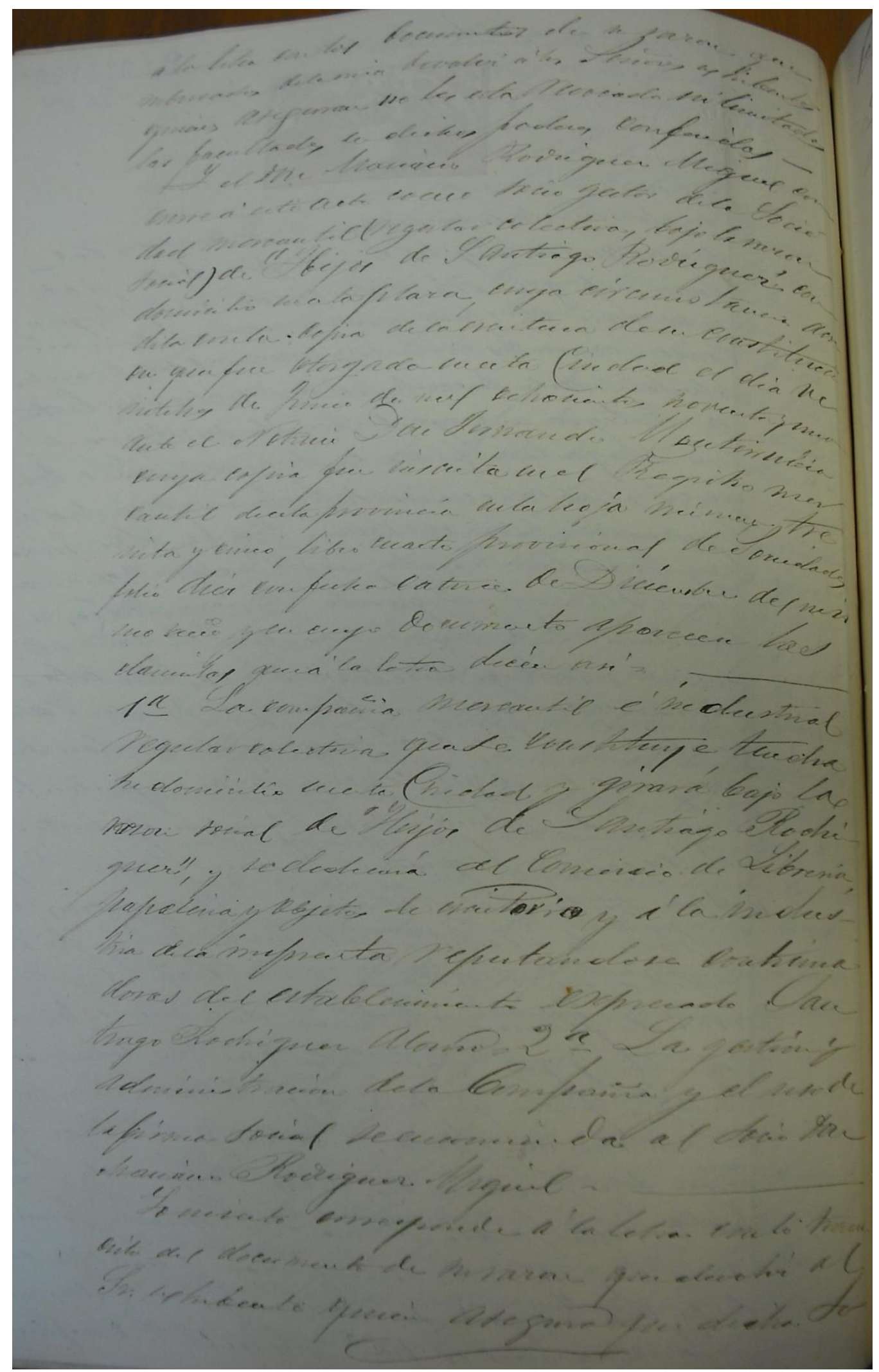

Fig.: 86

Venta de propiedad intelectual de D. Ángel Bueno Rodríguez-Arias, D. Rogelio Francés Gutiérrez, D. Lino González y González Ansótegui, D. Juan José Osés Larrumbe a favor de Hijos de Santiago Rodríguez.

Archivo Histórico Provincial de Burgos. 1907, p. 11 de 14. 


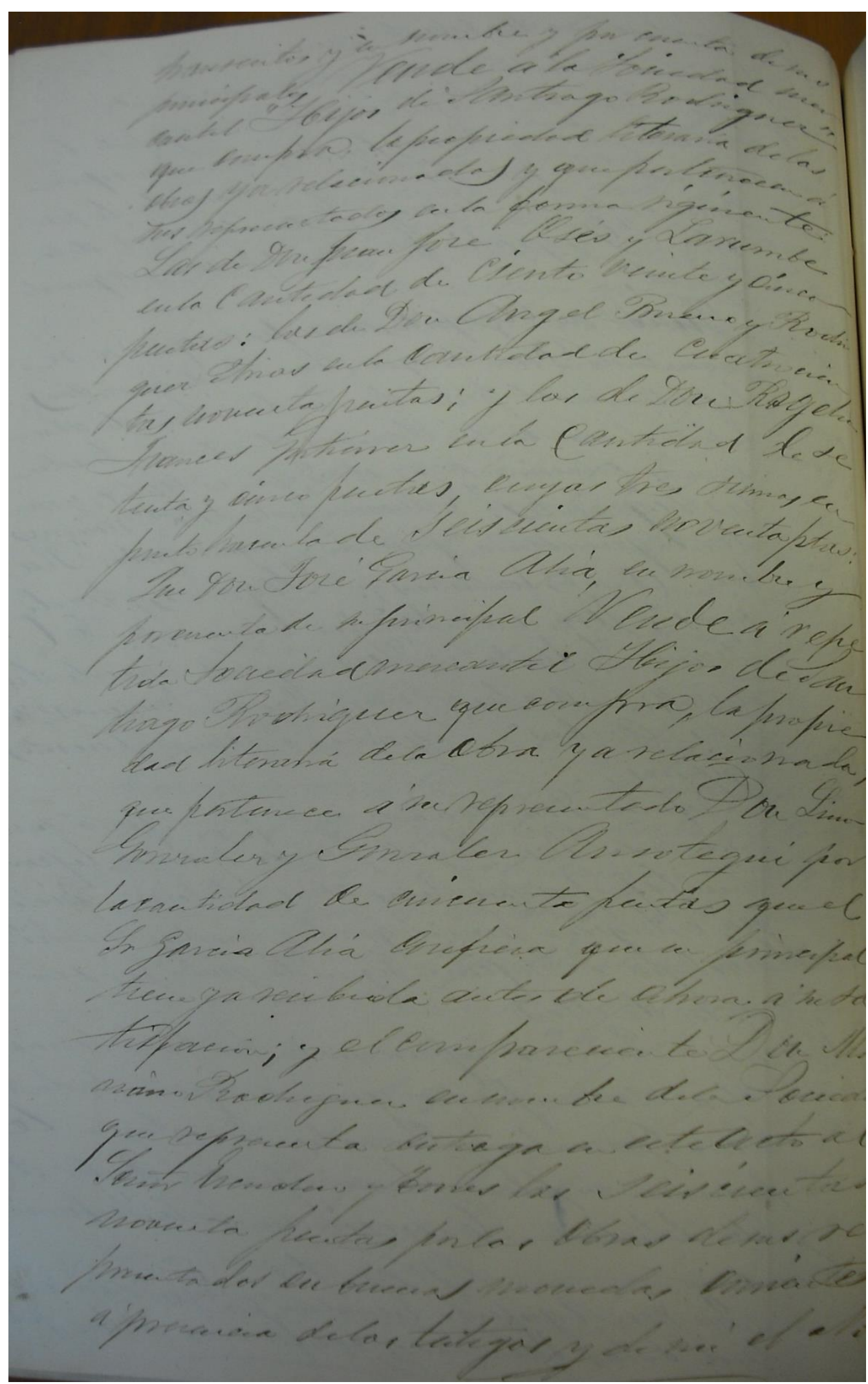

Fig.: 87

Venta de propiedad intelectual de D. Ángel Bueno Rodríguez-Arias, D. Rogelio Francés Gutiérrez, D. Lino González y González Ansótegui, D. Juan José Osés Larrumbe a favor de Hijos de Santiago Rodríguez.

Archivo Histórico Provincial de Burgos. 1907, p. 12 de 14. 


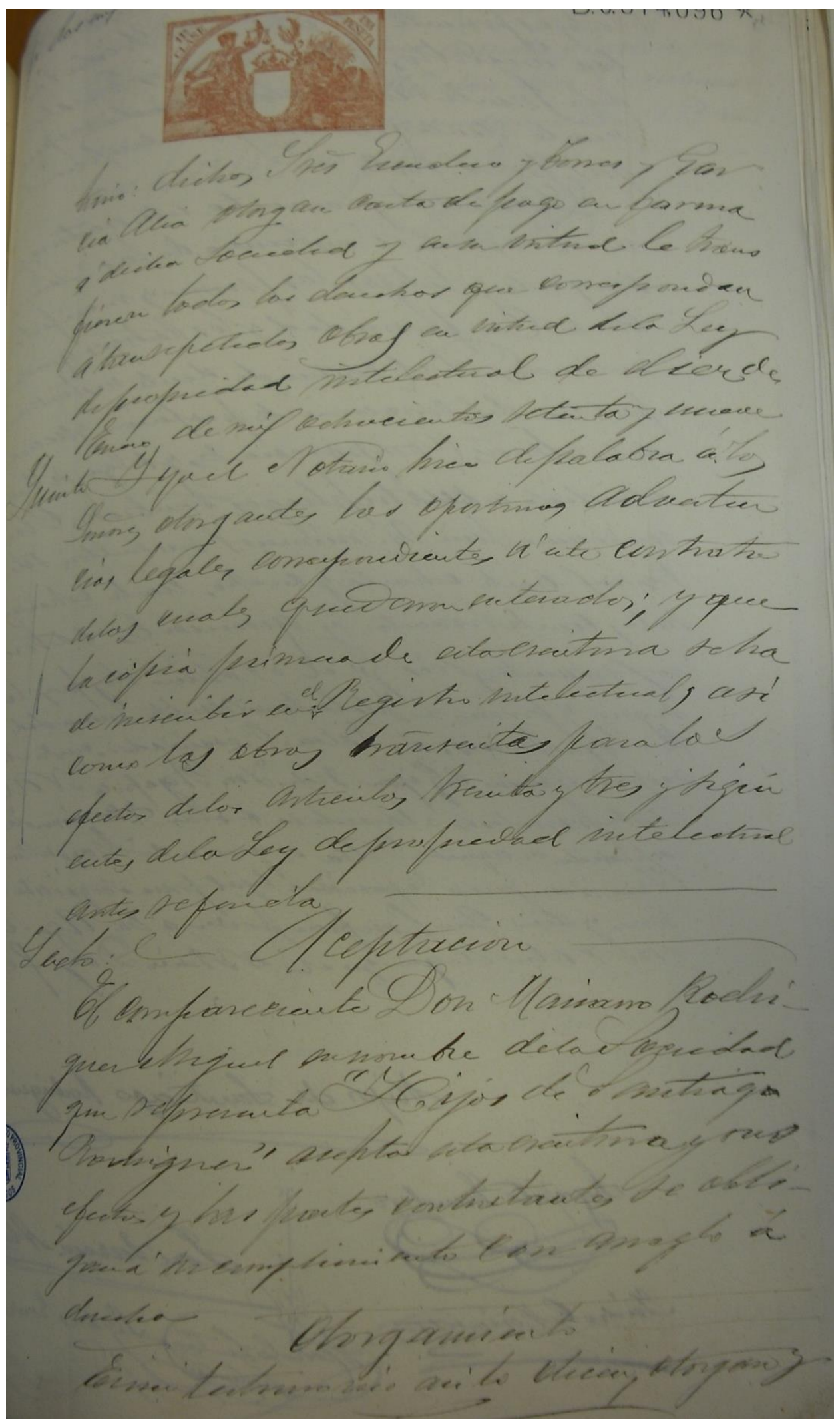

Fig.: 88

Venta de propiedad intelectual de D. Ángel Bueno Rodríguez-Arias, D. Rogelio Francés Gutiérrez, D. Lino González y González Ansótegui, D. Juan José Osés Larrumbe a favor de Hijos de Santiago Rodríguez.

Archivo Histórico Provincial de Burgos. 1907, p. 13 de 14. 


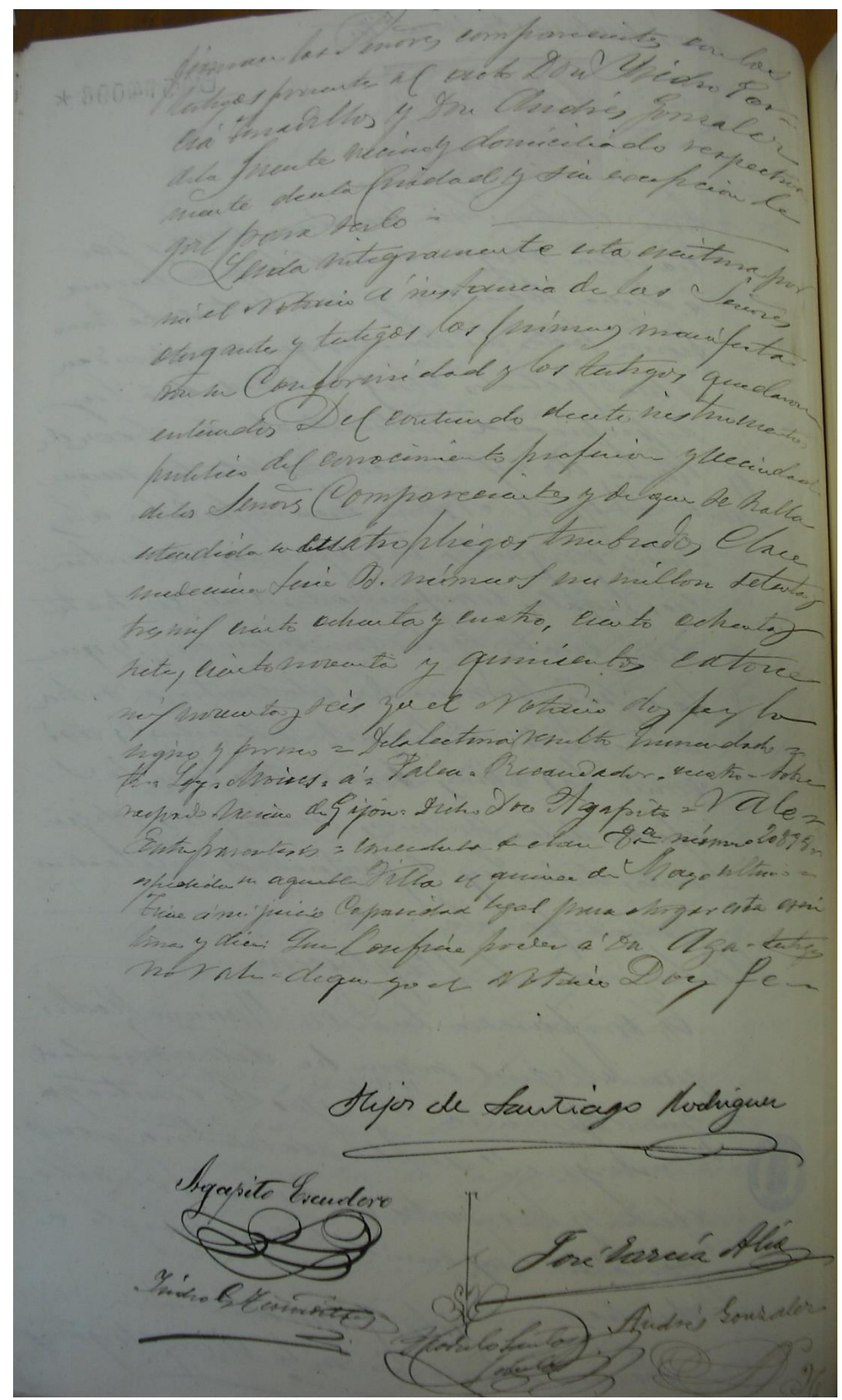

Fig.: 89

Venta de propiedad intelectual de D. Ángel Bueno Rodríguez-Arias, D. Rogelio Francés Gutiérrez, D. Lino González y González Ansótegui, D. Juan José Osés Larrumbe a favor de Hijos de Santiago Rodríguez.

Archivo Histórico Provincial de Burgos. 1907, p. 14 de 14. 


\subsection{DOCUMENTOS DIOCESANOS}

Se han recogido las actas sobre nacimientos, -recogidas en las partidas de bautismo-, matrimonios y defunciones de las personas más relevantes en la genealogía de la familia Rodríguez y se transcribe modificando a la actual grafía, suprimiendo las partes que pertenecen a la nomenclatura de las partidas diocesanas o a expresiones de la época.

1. Acta literal de bautismo en Isar de Julián Rodríguez García.

2. Acta literal de bautismo en Isar de Eusebia de la Torre Lodoso, nacida el 14 de agosto de 1769.

3. Acta literal de matrimonio en Isar de Julián Rodríguez García y de Eusebia de la Torre Lodoso, el 14 de octubre de 1787.

4. Acta literal de bautismo en la parroquia San Lesmes de Burgos de Francisco Rodríguez Alonso, nacido entre el 6 y 7 de enero de 1822.

5. Acta literal de bautismo en la parroquia de San Lesmes de Burgos de Ramona Rodríguez Alonso, nacida el 4 de agosto de 1827.

6. Acta literal de bautismo en la parroquia de San Lesmes en Burgos de Dámaso Rodríguez Alonso, nacido el 11 de diciembre de 1831.

7. Acta literal de bautismo en la Iglesia parroquial de San Gil en Burgos de Luisa Rodríguez Miguel, nacida el 28 de noviembre de 1858.

8. Acta literal de bautismo en la Iglesia parroquial de San Lesmes en Burgos de Luisa Escudero Torres, nacida el 19 de agosto de 1861.

9. Acta literal de bautismo en la Iglesia parroquial de San Gil en Burgos de María del Pilar Rodríguez Miguel, nacida el 17 de octubre de 1867.

10.Acta literal de bautismo en la Iglesia parroquial de San Gil en Burgos de Francisco Rodríguez Miguel, nacido el 10 de septiembre de 1868.

11.Acta literal de bautismo en la Iglesia parroquial de San Gil en Burgos de María de la Gloria Rodríguez Miguel, nacida el 10 de enero de 1872. 
12.Acta literal de bautismo en la Iglesia parroquial de San Lesmes en Burgos de Tomasa Eusebia Rodríguez Escudero, nacida el 26 de septiembre de 1889.

13. Acta literal de bautismo en la Iglesia parroquial de San Lesmes en Burgos de Pascual Rodríguez Escudero, nacido el 29 de diciembre de 1890.

14.Acta literal de bautismo en la Iglesia parroquial de San Lesmes en Burgos de Santiago Rodríguez Escudero, nacido el 29 de diciembre de 1890.

15.Acta literal de defunción en la Iglesia parroquial de San Gil en Burgos de D. Santiago Rodríguez Alonso, el 9 de abril de 1891.

16. Acta literal de defunción en la Iglesia parroquial de San Gil en Burgos de D. Francisco Rodríguez Miguel, el 17 de noviembre de 1900 .

17. Acta literal de bautismo en la Iglesia parroquial de San Gil en Burgos de Santiago Rodríguez Escudero, nacido el 17 de noviembre de 1893.

18. Acta literal de bautismo en la Iglesia parroquial de San Gil en Burgos de Mariano Rodríguez Escudero, nacido el 1 de noviembre de 1894.

19.Acta literal de bautismo en la Iglesia parroquial de San Gil en Burgos de Lucas Rodríguez Escudero, nacido el 3 de diciembre de 1895.

20.Acta literal de defunción en la Iglesia parroquial de San Gil en Burgos de D. Mariano Rodríguez Miguel, el 17 de mayo de 1925. 


\section{Acta literal de bautismo en Isar de Julián Rodríguez García.}

En la villa de Isar a seis del mes de julio del año de mil setecientos sesenta y nueve, yo D. Francisco de la Peña, cura y beneficiado en ella, bauticé solemnemente y puse los santos óleos a Julián hijo legítimo de Francisco Rodríguez y Ángela García, vecinos de esta villa. Nació el día 4 de este mes y año, a las tres de la tarde, poco más o menos. Le di por abogado a San Fermín. Fue su padrino D. Andrés de la Torre, presbítero, medio racionero en esta villa. Fueron sus abuelos paternos, Julián Rodríguez y Magdalena de la Torre, vecinos de esta nominada villa y los maternos, Pedro García Pardo y Cathalina Blanco, vecinos de Hornillos del Camino, siendo testigos Gabriel Rodríguez y Gabriel López. Firmó el que supo y firmé yo en esta dicha villa, día, mes y año.

Firmado por D. Francisco de la Peña y D. Andrés de la Torre.

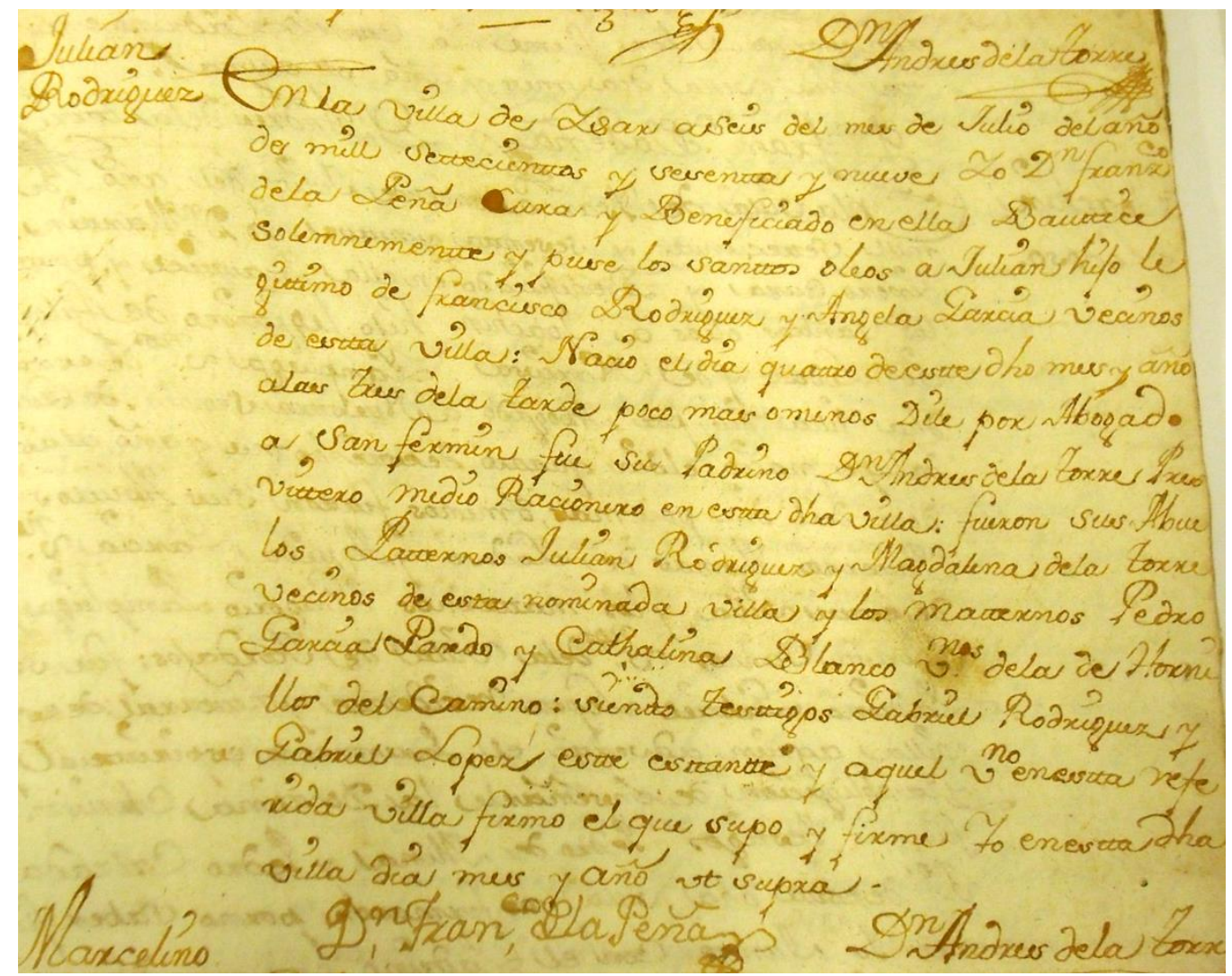

Fig.: 90

Acta literal de bautismo de Julián Rodríguez García, hijo de Francisco Rodríguez Torre y Ángela García. Archivo Diocesano de Burgos. Isar (4-7-1769). 


\section{Acta literal de bautismo en Isar de Eusebia de la Torre Lodoso, nacida el 14 de agosto de 1769.}

En la villa de Isar a diecisiete del mes de agosto del año de mil setecientos sesenta y nueve, yo D. Martín Tigero, cura y beneficiado en ella, bauticé solemnemente y puse los santos óleos a Eusebia hija legítimo de Miguel de la Torre y de Agueda Lodoso, vecinos de esta villa. Nació el día 14 de este mes y año, a las nueve de la mañana, poco más o menos. Le di por abogado a San Lorenzo. Fue su padrino D. Andrés de la Torre, presbítero, medio racionero en esta villa. Fueron sus abuelos paternos, Miguel de la Torre y María Díez, vecinos de esta nominada villa y los maternos, Tomás de Lodoso y Ángela García, siendo testigos Simón de Lodoso y Manuel Saiz. Firmó el que supo y firmé yo en esta dicha villa, día, mes y año.

Firmado por D. Martín Tigero y D. Andrés de la Torre.

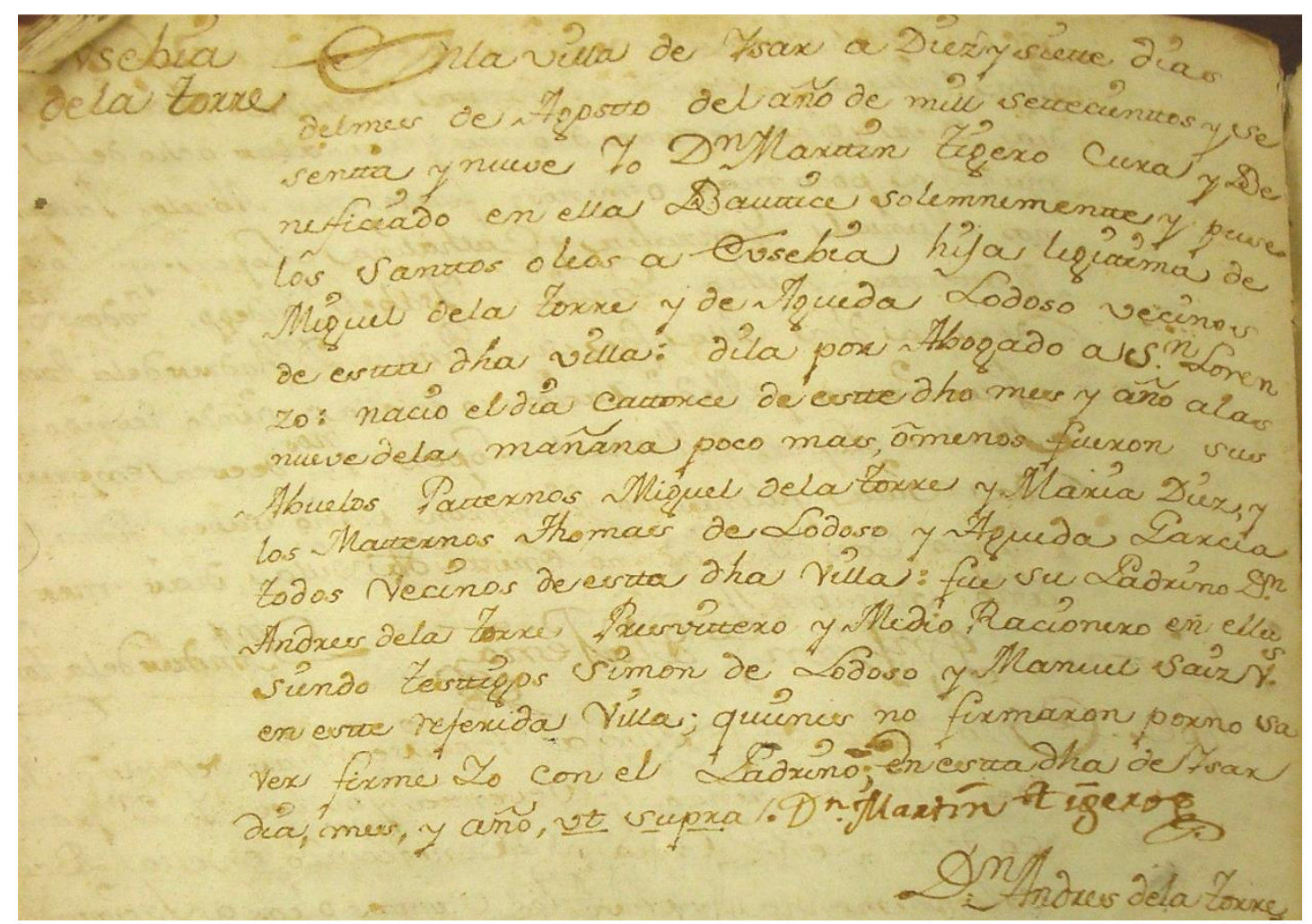

Fig.: 91

Acta literal de bautismo de Eusebia de la Torre, hija de Miguel de la Torre Diez y Agueda Lodoso. Archivo Diocesano de Burgos. Isar (14-8-1769). 


\section{Acta literal de matrimonio en Isar de Julián Rodríguez García y de Eusebia de la Torre Lodoso, el 14 de octubre de 1787.}

En la villa de Isar a catorce del mes de octubre de mil setecientos ochenta y siete yo D. Martín Tigero, cura beneficiado en la parroquia de San Martín, desposé y casé a D. Julián Rodríguez, hijo legítimo de Francisco Rodríguez y de Ángela García, ya difuntos, y a Eusebia de la Torre, hija legítima de Miguel de la Torre, ya difunto, y de Águeda Lodoso, todos vecinos en esta villa, habiendo precedido las tres Canónicas moniciones que manda el Concilio Tridentino y no haber resultado impedimento que el de ser parientes en $2^{\circ}$ grado con tercero de consanguinidad dispensado por nuestro Santísimo Papa Pío VI, para lo que se me dio licencia por los Sres. Provisores de este Arzobispado. Los examiné y lo hallé suficientes en la Doctrina Cristiana. Recibieron los Santos Sacramentos de Penitencia y Eucaristía. Fueron testigos Fulgencio Lodoso e Ildefonso López, vecinos de esta villa de los cuales firmó el que supo y yo en fe de ello.

Firmado por D. Martín Tigero y Ildefonso López. 
Culian Rodxi Lnlavilla de Ysax a Catoxce doias deelmes de ouz, y Cusebia Ochubue del ano de milsetecientos ochenta y Sieze delatoxxe Yo An thaxintigexo Cuxa Beneficiado en la Saxus quial de Sane Maxtin de ella despose, Case, y vele in facie eclerie pox paíabxas de pxesente que hacen vexdadexo Sacxamento de Mathimonis a Iulian Rodxiouez hijo legitimo de trancéses Rodxiou. ez y de Angela. Saxcia ya difuntos, y a luscbia de la torxe hi: leoitima de Miguel de la Toxa ya ditunio, y de Atgueda dodoso to dor verinor de esta Villa; haviendo prece dido las bes Canonicas mo da el Concileo Tuidentino yno ha niciones que manda vex xesultado otwo impedionento, que el desex paxien - ties en Segundo oxado con texcexo de Consanouina dad dispensado pox nuestro Sant: $p$ po sexts, paxa lo quesemedis licencia pox $S^{\text {res }}$ Provisoxes de este Axzobispado: Los exsamine ylos halle Sufieierte enla Doctaina Chxistiana: Xeciviezon los Santos Sa cxamentos de lenitencia, y Cucharastia: fueron test gos fulgenció Lodoso, y Yteforisodopez vecinos de esta villa delos quales lofixmo el que suposy is enft de ello fra utsupra $=$ Dnvartirs ligsxog

Fig.: 92

Acta literal de matrimonio de Julián Rodríguez García,

y Eusebia de la Torre. Archivo Diocesano de Burgos. Isar (4-7-1769). 


\section{Acta literal de bautismo en la parroquia San Lesmes de Burgos de Francisco Rodríguez Alonso, nacido entre el 6 y 7 de enero de 1822.}

En la Iglesia parroquial de la ciudad de Burgos (San Lesmes, extramuros de la ciudad) a veintiuno de enero de mil ochocientos veintidós, yo D. Felipe Arribas, cura de la misma, bauticé solemnemente a un niño hijo legítimo de Antolín Rodríguez y Luisa Alonso, vecinos de esta ciudad y él natural de Isar y ella de dicha ciudad. Le puse por nombre Francisco de Paula. Dijeron haber nacido entre seis y siete de la misma. Abuelos paternos, Julián Rodríguez y Eusebia de la Torre, ya difunta, vecina del referido pueblo de Isar. Abuelos maternos, Juan Alonso y Manuela Sáez, ya difunta, vecinos de esta ciudad. Fueron sus padrinos D. Francisco Écija, sargento del Batallón Ligero de Bailén y $\mathrm{D}^{\mathrm{a}}$ Carmen Alonso, a quienes les advertí del parentesco espiritual y demás obligaciones. Fueron testigos, Pascual Luengo, sargento del referido Batallón de Bailén y Mariano Alonso, quien lo firmó.

Firmado por D. Felipe Arribas, D. Francisco Écija, D. Pascual Luengo, D. Mariano Alonso y $\mathrm{D}^{\mathrm{a}}$ Carmen Alonso. 

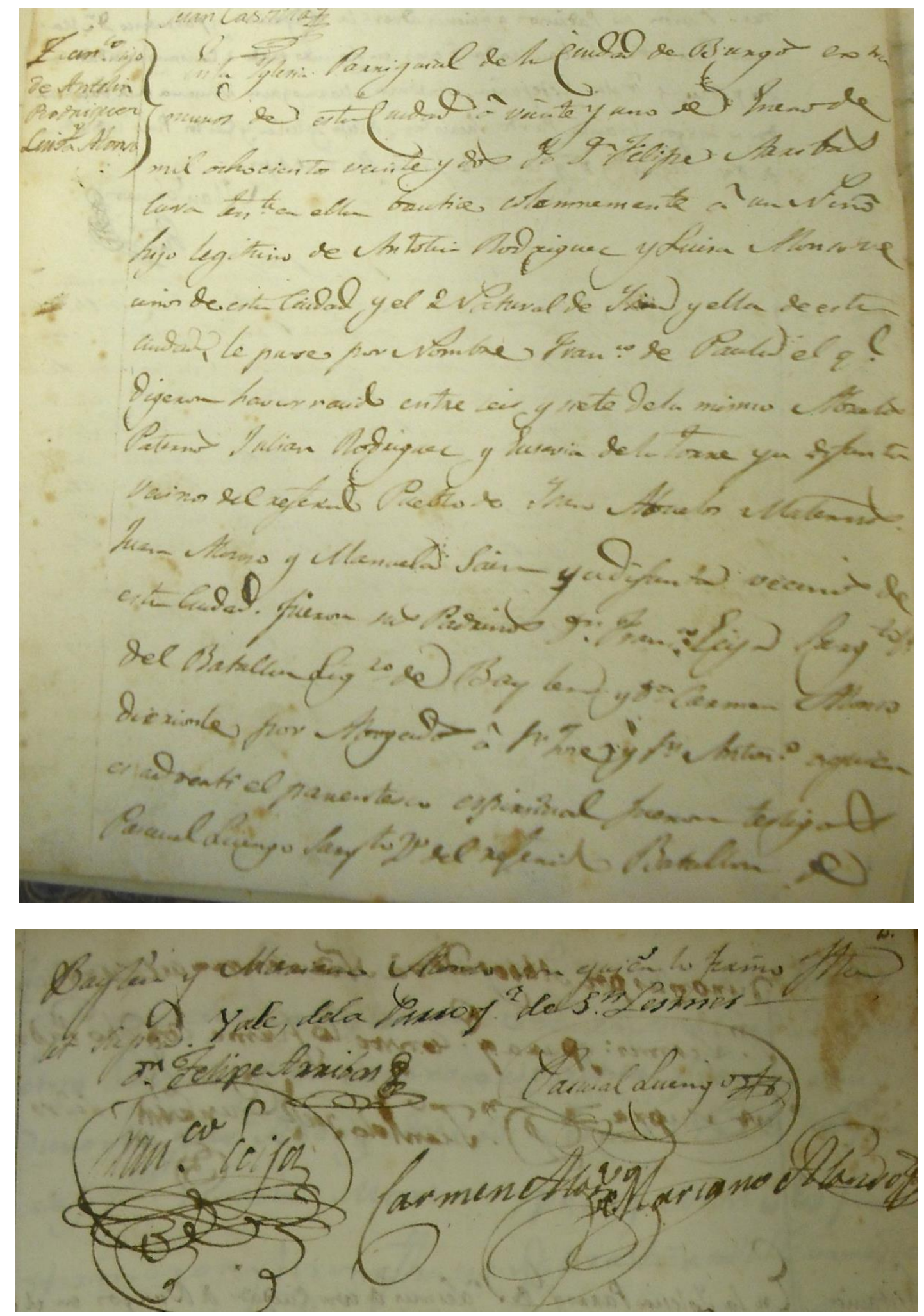

Fig.: 93

Acta literal de bautismo de Francisco Rodríguez Alonso, hijo de Antolín Rodríguez y Luisa Alonso.

Archivo Diocesano de Burgos. (21-1-1822). 


\section{Acta literal de bautismo en la parroquia de San Lesmes de Burgos de Ramona Rodríguez Alonso, nacida el 4 de agosto de 1827.}

En la Iglesia parroquial de San Lesmes extramuros de la ciudad de Burgos a 5 días del mes de agosto de mil ochocientos veintisiete, yo el cura de esta parroquia, bauticé solemnemente en la pila bautismal según el Ritual Romano a una niña que nació ayer a cuatro días del mes y año a las dos de la mañana, poco más o menos a quien puse por nombre Ramona y di por sus abogados a Nuestra Sra. de las Nieves y San Lesmes. Es hija legítima de D. Antolín Rodríguez, natural de la villa de Isar y de Luisa Alonso, natural de esta ciudad, vecina en ella. Abuelos paternos, Julián Rodríguez y Eusebia de la Torre, ésta difunta, vecinos de la villa de Isar. Maternos, Juan Alonso y Manuela Sáez, ya difunta, vecinos de esta ciudad.

Fueron sus padrinos, Mariano Alonso y María Alonso, sus tíos a quienes advertí el parentesco espiritual y demás obligaciones y testigo dicho padrino y Vicente Pardo y por verdad y que conste lo firmo con el que supo.

Firmado por D. José Antonio Ruiz, D. Mariano Alonso y D. Vicente Pardo. 


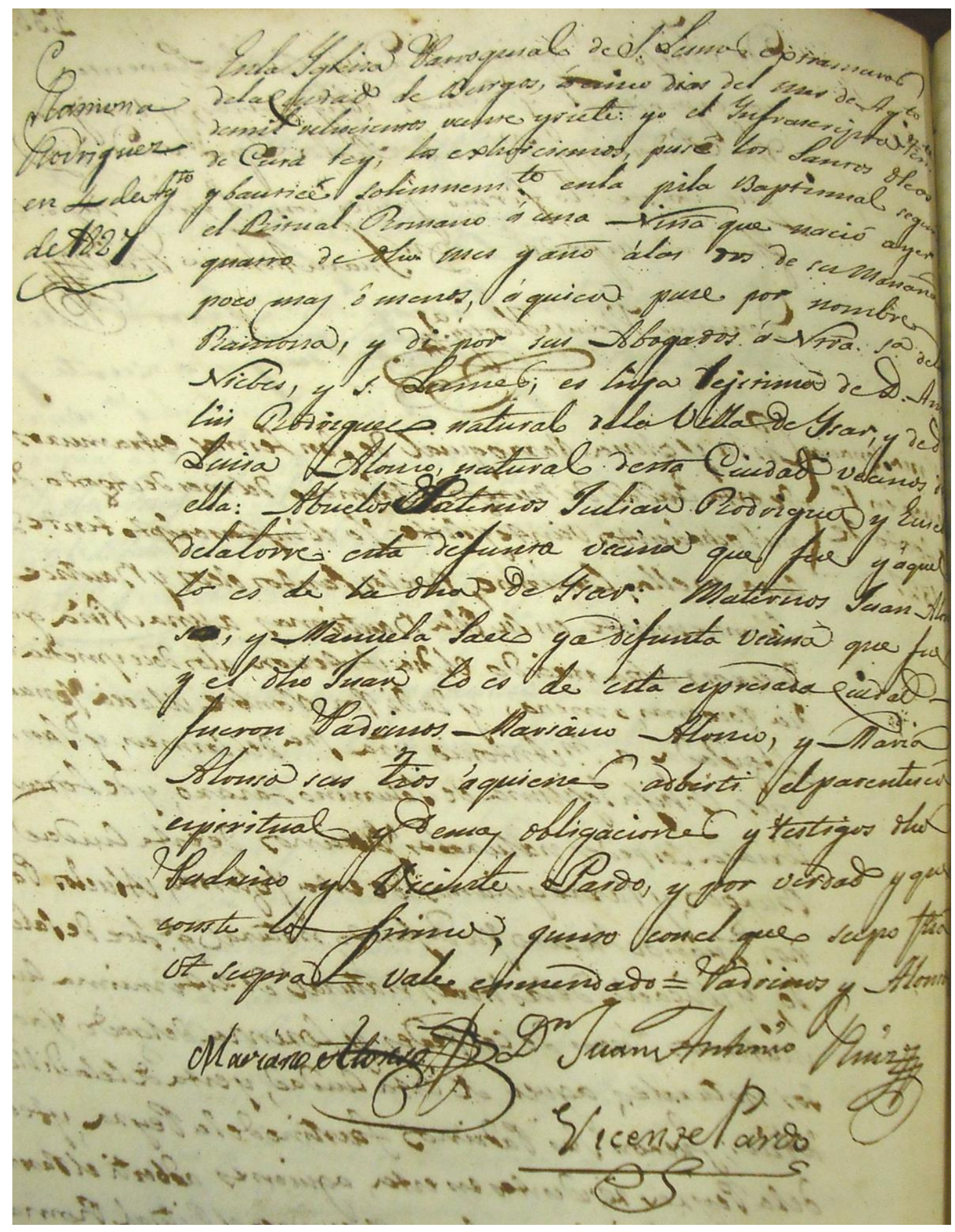

Fig.: 94

Acta literal de bautismo de Ramona Rodríguez Alonso, hija de Antolín Rodríguez y Luisa Alonso. Archivo Diocesano de Burgos. (4-8-1827). 
6. Acta literal de bautismo en la parroquia de San Lesmes en Burgos de Dámaso Rodríguez Alonso, nacido el 11 de diciembre de 1831.

En la Iglesia parroquial de San Lesmes extramuros de la ciudad de Burgos a doce de diciembre de mil ochocientos treinta y uno, yo el cura de la misma bauticé solemnemente a un niño a las tres de la mañana del día once del corriente a quien puse por nombre Dámaso y dieron por abogado a Nuestra Sra. del Carmen, S. José y San Lesmes. Es hijo legítimo de D. Antolín Rodríguez y $\mathrm{D}^{\mathrm{a}}$ Carmen Alonso, vecinos y parroquianos de ésta y natural éste de la villa de Isar y aquella de ésta.

Abuelos paternos, Julián Rodríguez y Eusebia de la Torre, ya difunta, vecinos de Isar y naturales del mismo; maternos Juan Alonso y Manuela Sáez, ya difunta, vecinos que lo es y a aquella lo fue, naturales éste de Burgos y aquella de Medina de Pomar. Fueron sus padrinos Juan Alonso, abuelo del bautizado y Aquilina García, prima del bautizado.

Fueron sus testigos, dichos padrinos y Pascual Luengo habiendo advertido a los padrinos las obligaciones y parentesco espiritual que contrajeron y para que conste, lo firmo.

Firmado por D. Benito Nieto y D. Pascual Luengo. 


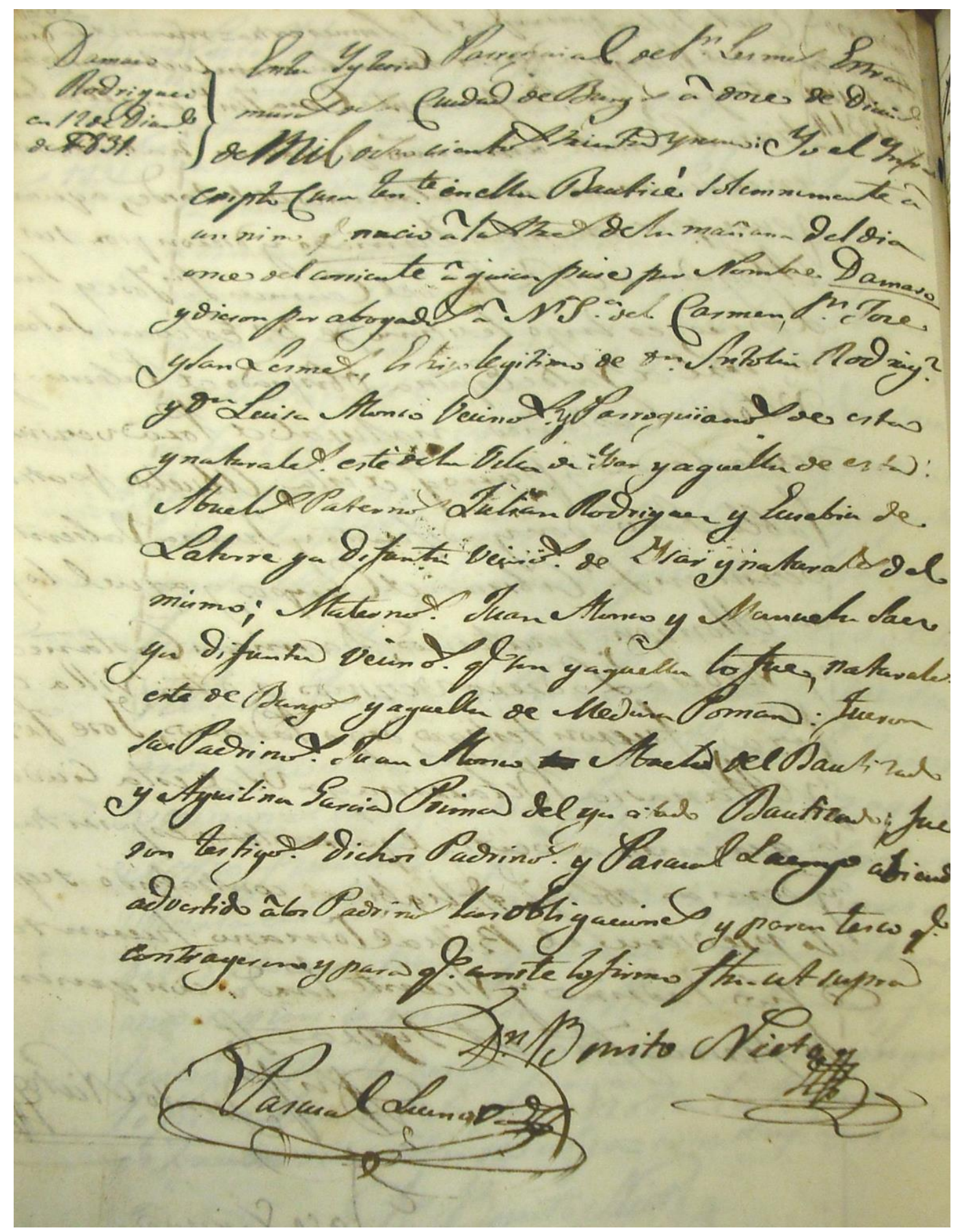

Fig.: 95

Acta literal de bautismo de Dámaso Rodríguez Alonso, hijo de Antolín Rodríguez y Luisa Alonso.

Archivo Diocesano de Burgos. (12-12-1831). 


\section{Acta literal de bautismo en la Iglesia parroquial de San Gil en} Burgos de Luisa Rodríguez Miguel, nacida el 28 de noviembre de 1858.

En la Iglesia parroquial de San Gil de esta ciudad de Burgos, el día primero de diciembre de mil ochocientos cincuenta y ocho, yo D. Dámaso del Castillo, beneficiado de la Sta. Iglesia metropolitana de ésta de Burgos, habiendo obtenido licencia de D. Fernando Linage, coadjutor de la expresada de San Gil, bauticé solemnemente a una niña que nació el día veintiocho de noviembre del mismo año, a las diez y media de la noche, a quien puse los nombres de Luisa Esperanza Gregoria Andrea, hija legítima de D. Santiago Rodríguez y $\mathrm{D}^{\mathrm{a}}$ Irene Miguel, natural y vecino de ésta de Burgos y feligreses de esta Iglesia.

Abuelos paternos, D. Antolín Rodríguez, natural de Isar y $\mathrm{D}^{\mathrm{a}}$ Luisa Alonso de ésta de Burgos; maternos D. Miguel de Miguel, natural de Villadiego y $\mathrm{D}^{\mathrm{a}}$ Andrea del Campo que lo es de Sasamón.

Fueron padrinos, su abuelo materno D. Miguel de Miguel y Da Adelaida Miguel, tía de la bautizada. Se le dio por abogada a Nuestra Sra. la Virgen María. Fue testigo, Fernando Esteban, quien lo firmó.

Firmado por D. Fernando Linage, D. Dámaso del Castillo y D. Fernando Esteban. 


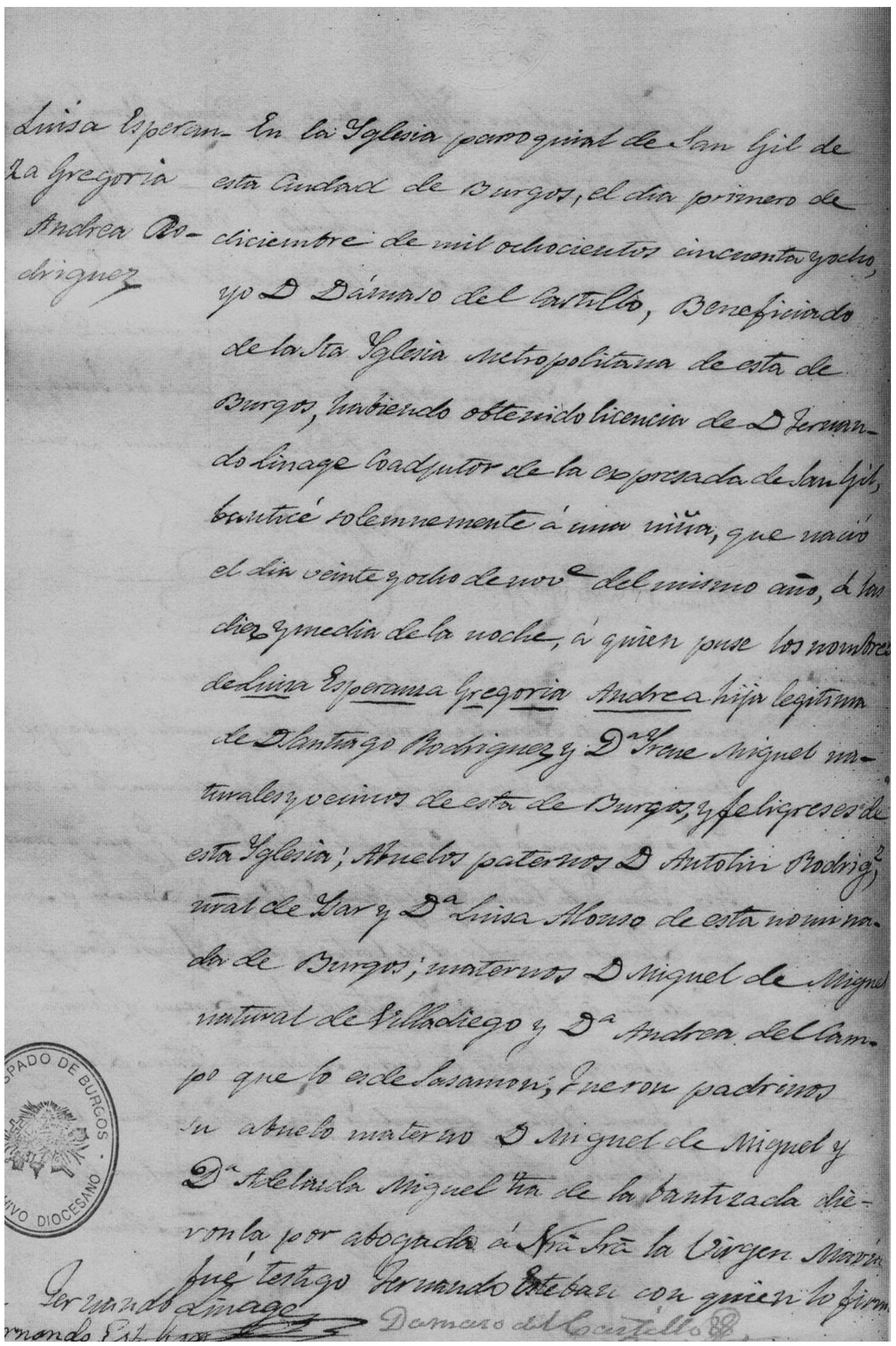

Fig.: 96

Acta literal de bautismo de Luisa Esperanza Gregoria Andrea Rodríguez Miguel, hija de D. Santiago Rodríguez Alonso e D ${ }^{\mathrm{a}}$ Irene Miguel del Campo. Archivo Diocesano de Burgos. (28-11-1858). 


\section{Acta literal de bautismo en la Iglesia parroquial de San Lesmes en Burgos de Luisa Escudero Torres, nacida el 19 de agosto de 1861.}

Luisa Jacinta Benita Escudero y Torres hija legítima de D. Pascual y D ${ }^{a}$ Eusebia el 19 de agosto de 1861.

En la ciudad de Burgos, diócesis y provincia de la misma, a veinte del mes de agosto del año de mil ochocientos sesenta y uno, yo D. Antonino Hortigüela y Sáez, cura beneficiado de esta iglesia parroquial de San Lesmes, bauticé solemnemente en ella una niña que según declaración de su familia nació ayer nueve a las doce de la mañana. Le puse por nombre Luisa Jacinta Benita y le di por abogada a Nuestra Sra. de Gracia, S. José y S. Lesmes. Es hija legítima de legítimo matrimonio de D. Pascual Escudero, maestro de obras y de $\mathrm{D}^{\mathrm{a}}$ Eusebia Torres, naturales y vecinos de esta ciudad en la feligresía de esta iglesia. Abuelos paternos, D. Lesmes Escudero y $\mathrm{D}^{\mathrm{a}}$ Francisca Saiz, difuntos y naturales que fueron, ésta del pueblo de Modúbar de Sancibrián en esta provincia y aquel de esta de Burgos, de la que fueron vecinos; maternos D. Jacinto Torres, y $\mathrm{D}^{\mathrm{a}}$ Juliana Santamaría naturales y vecinos de esta referida ciudad; fueron sus padrinos D. Benito Jiménez Torres, natural de Almería de estado casado y Visitador General de la Casa del Excmo. Duque de Frías y vecino de Madrid y Teresa Casado, tía de la bautizada de estado viuda y natural de Gamonal a quienes advertí el parentesco espiritual y obligaciones que contrajeron, siendo testigo A. Gómez, sacristán de esta iglesia. Y para que conste autoriza la presente partida.

Firmado por D. Antonino Hortigüela Sáez. 


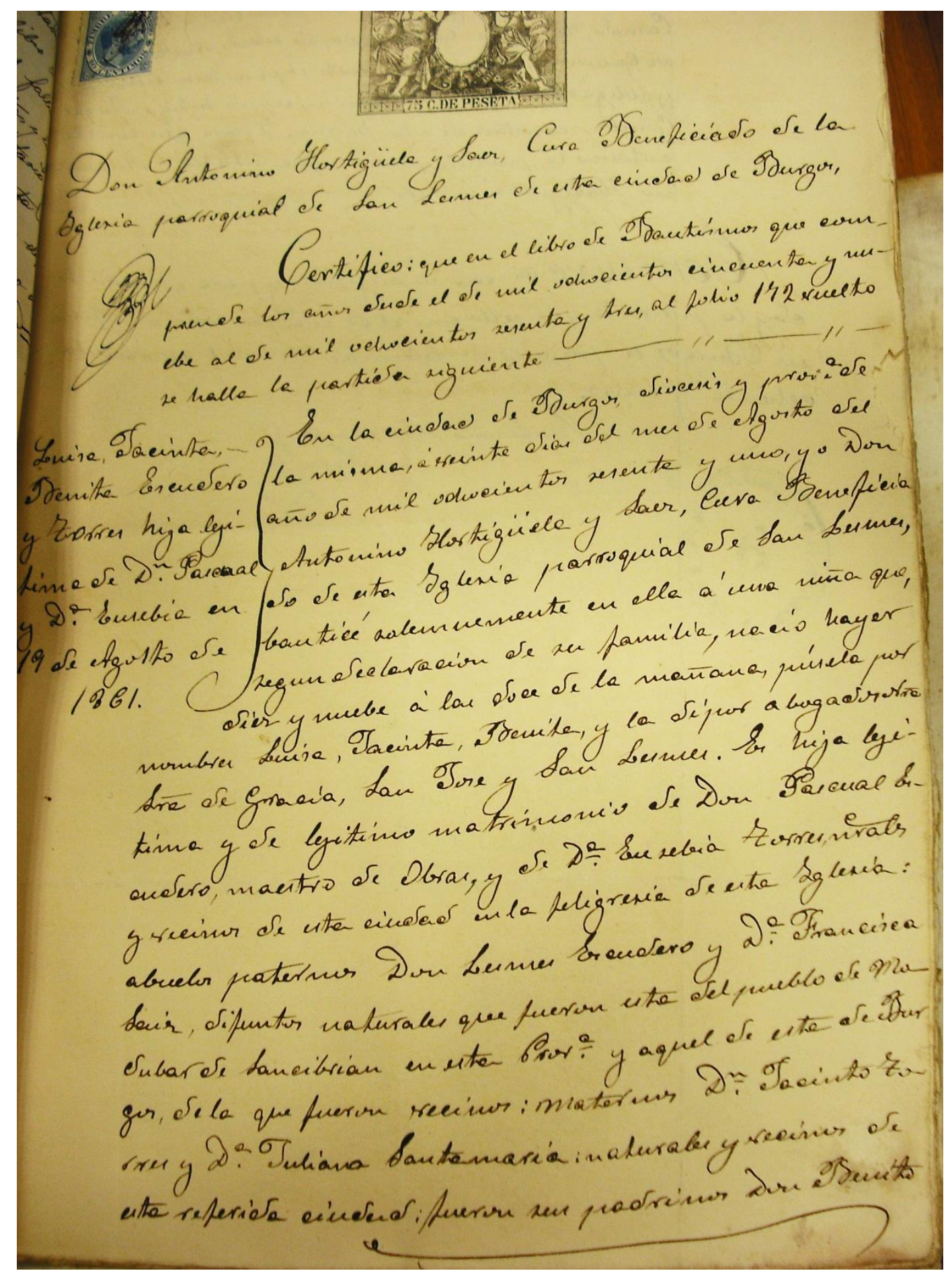

Fig.: 97

Acta de certificación de la partida de bautismo de $\mathrm{D}^{\mathrm{a}}$ Luisa Escudero Torres, hija de D. Pascual Escudero Saiz y Da Eusebia Torres Santamaría.

(19-8-1961). Archivo Histórico Provincial de Burgos, p. 1 de 2. 


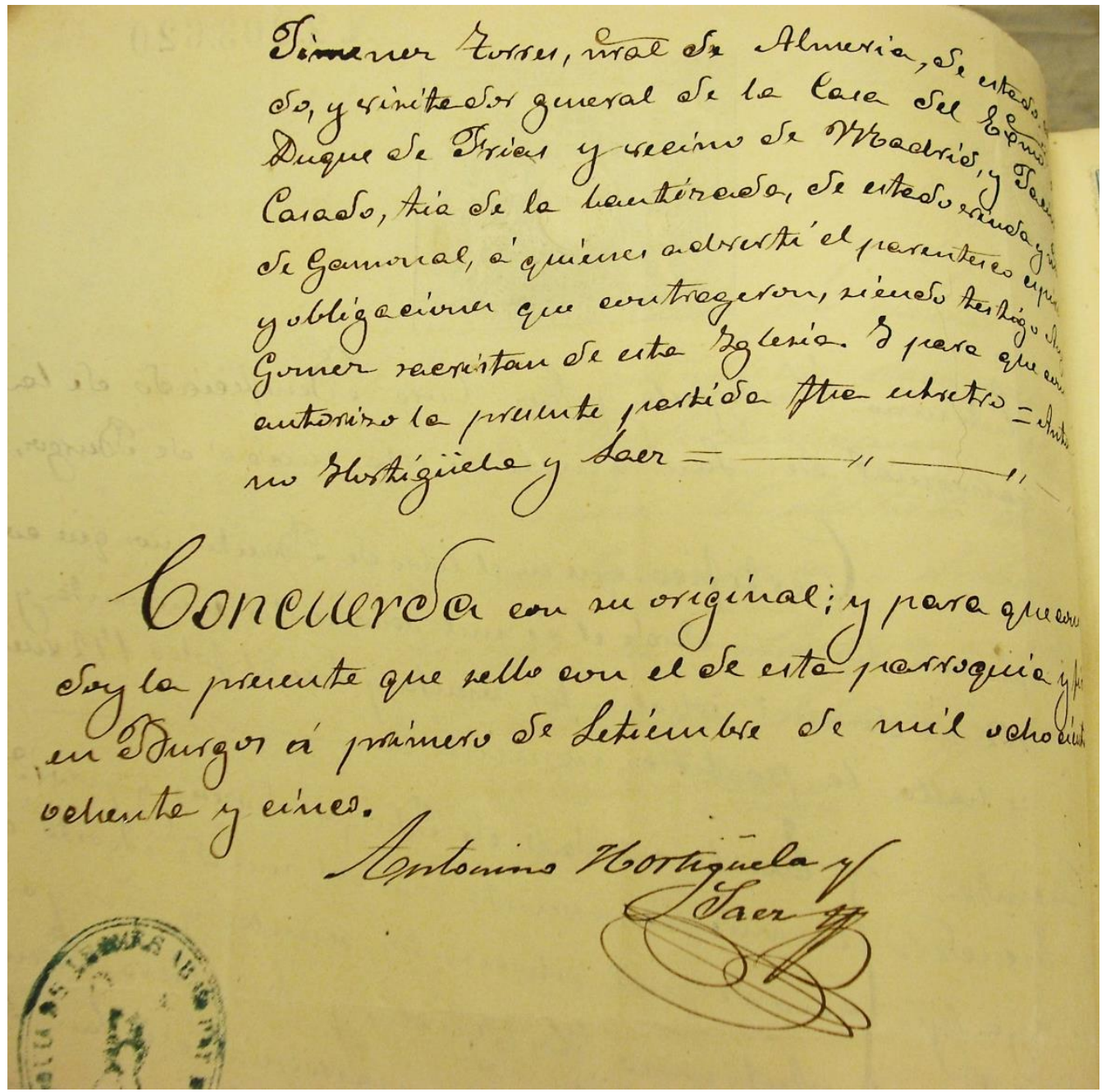

Fig.: 98

Acta de certificación de la partida de bautismo de $\mathrm{D}^{\mathrm{a}}$ Luisa Escudero Torres, hija de D. Pascual Escudero Saiz y Da Eusebia Torres Santamaría.

(19-8-1961). Archivo Histórico Provincial de Burgos, p. 2 de 2. 


\section{Acta literal de bautismo en la Iglesia parroquial de San Gil en Burgos de María del Pilar Rodríguez Miguel, nacida el 17 de octubre de 1867.}

En la ciudad de Burgos, Diócesis y Provincia de la misma a diecinueve días del mes de octubre del año de mil ochocientos sesenta y siete, yo D. Fernando Linage, cura propio de esta Iglesia parroquial de San Gil, bauticé solemnemente en ella a una niña que según declaración de sus padres, nació el día diecisiete de dicho mes y año a la nueve y media de la mañana. Púsele por nombre María del Pilar Eduvigis, y la di por abogada a Nuestra Sra. la Virgen María, con el título de las Mercedes, San Ramón y San Gil. Es hija legítima y de legítimo matrimonio de D. Santiago Rodríguez, natural y vecino de esta ciudad, de ocupación librero y encuadernador y de $\mathrm{D}^{\mathrm{a}}$ Irene Miguel de la misma naturaleza y vecindad.

Abuelos paternos, D. Antolín Rodríguez y $\mathrm{D}^{\mathrm{a}}$ Luisa Alonso, difuntos, naturales y vecinos de esta ciudad; maternos D. Miguel de Miguel y $\mathrm{D}^{\mathrm{a}}$ Andrea Campo, naturales el primero de Villadiego y la segunda de Sasamón.

Fueron sus padrinos D. Miguel Sivelo, soltero natural y vecino de la misma, de ocupación estudiante, primo de la bautizada y Luisa Rodríguez, hermana de la bautizada.

Firmado por D. Fernando Linage y D. Miguel Sivelo.

Margen izquierdo: Se casó en esta parroquia el once de agosto de mil novecientos nueve con D. Antonio Sivelo.

Firmado por D. Basilio Olalla Gonzalo 


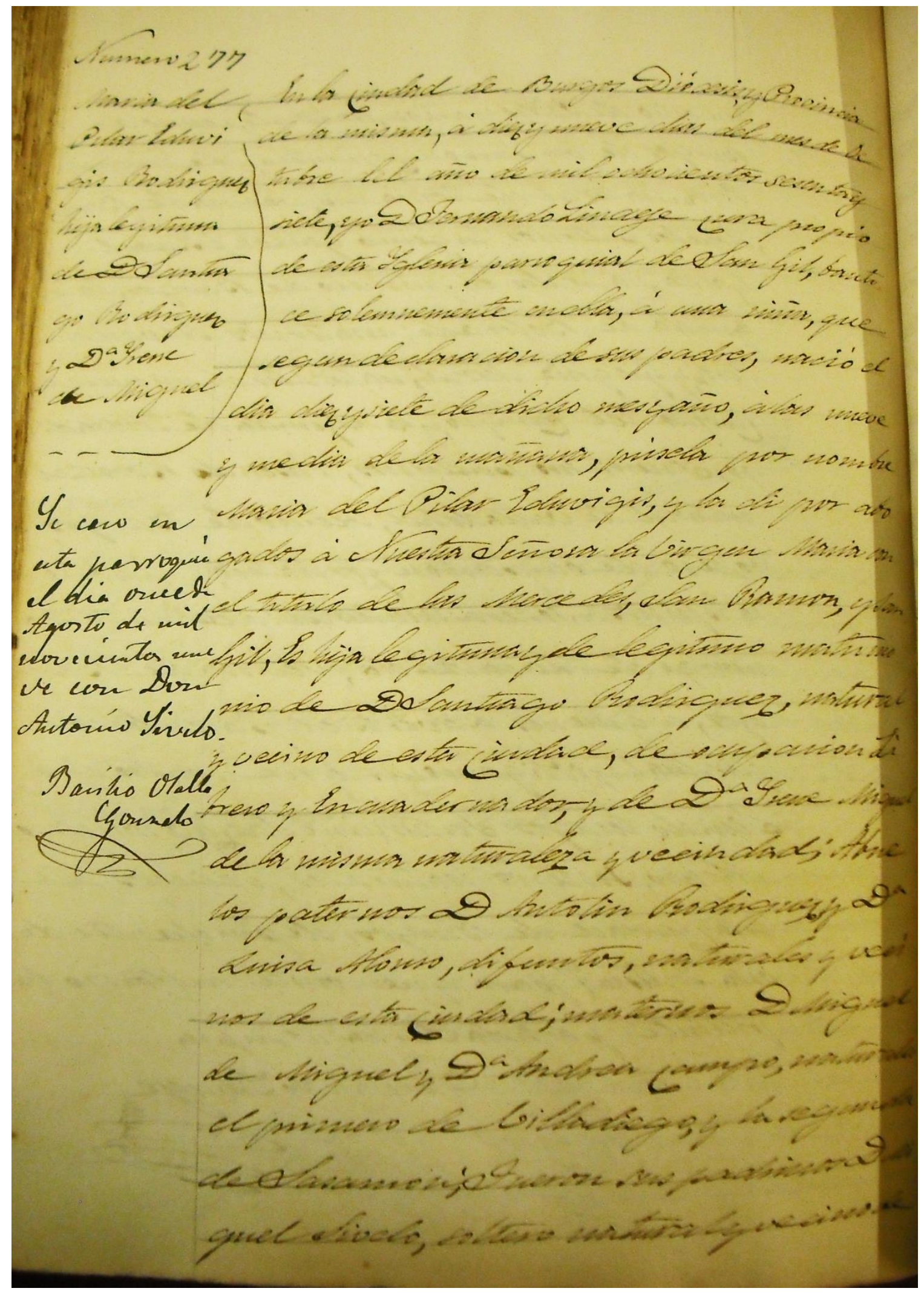

Fig.: 99

Acta literal de bautismo de Pilar Eduvigis, hija de Santiago Rodríguez Alonso e Irene Miguel y Campo. Archivo Diocesano de Burgos. (17-10-1867).

En el margen izquierda hace referencia a su matrimonio con Antonio Sivelo (9-8-1909). 


\section{Acta literal de bautismo en la Iglesia parroquial de San Gil en Burgos de Francisco Rodríguez Miguel, nacido el 10 de septiembre de 1868.}

En la ciudad de Burgos, Diócesis y Provincia de la misma a ocho días del mes de febrero del año de mil ochocientos sesenta y nueve, yo D. Fernando Linage, cura propio de esta Iglesia parroquial de San Gil, exorcicé, catequicé y puse los santos óleos a un niño, el cual por hallarse en inminente peligro de muerte, bauticé en casa el día diez de septiembre de mil ochocientos sesenta y ocho a las ocho de la mañana.

Es hijo legítimo y de legítimo matrimonio de D. de D. Santiago Rodríguez, natural y vecino de esta ciudad, de ocupación del comercio y de $\mathrm{D}^{\mathrm{a}}$ Irene Miguel de la misma naturaleza y vecindad. Según declaración de sus padres nació el diez de septiembre de mil ochocientos sesenta y ocho a las ocho de la mañana.

Púsele por nombre Francisco Nicolás de Tolentino y le di por abogada a la Purísima Virgen María, con el título de las Mercedes, San Ramón y San Gil.

Abuelos paternos, D. Antolín Rodríguez y $\mathrm{D}^{\mathrm{a}}$ Luisa Alonso, difuntos, naturales y vecinos de esta ciudad; maternos D. Miguel de Miguel y $\mathrm{D}^{\mathrm{a}}$ Andrea Campo, naturales el primero de Villadiego y la segunda de Sasamón.

Fueron sus padrinos para el bautismo privado D. Miguel Delgado, natural y vecino de Burgos, de estado casado y ocupación cirujano y para ésta solemne ceremonia, D. Miguel Sivelo, natural y vecino de la misma, de estado soldado, de ocupación militar y $\mathrm{D}^{\mathrm{a}}$ Luisa Rodríguez, natural y vecina de Burgos, de estado soltera, hermana del bautizado y el padrino, primo, a quienes advertí las obligaciones que contrajeron. Siendo testigos D. Saturnino Sáez y Francisco Alonso, solteros, naturales y vecinos de esta ciudad. Y para que conste autorizo la presente partida.

Firmado por Fernando Linage. 
LA EDITORIAL BURGALESA HIJOS DE SANTIAGO RODRÍGUEZ (1891-1936): ANÁLISIS DE LOS LIBROS ESCOLARES

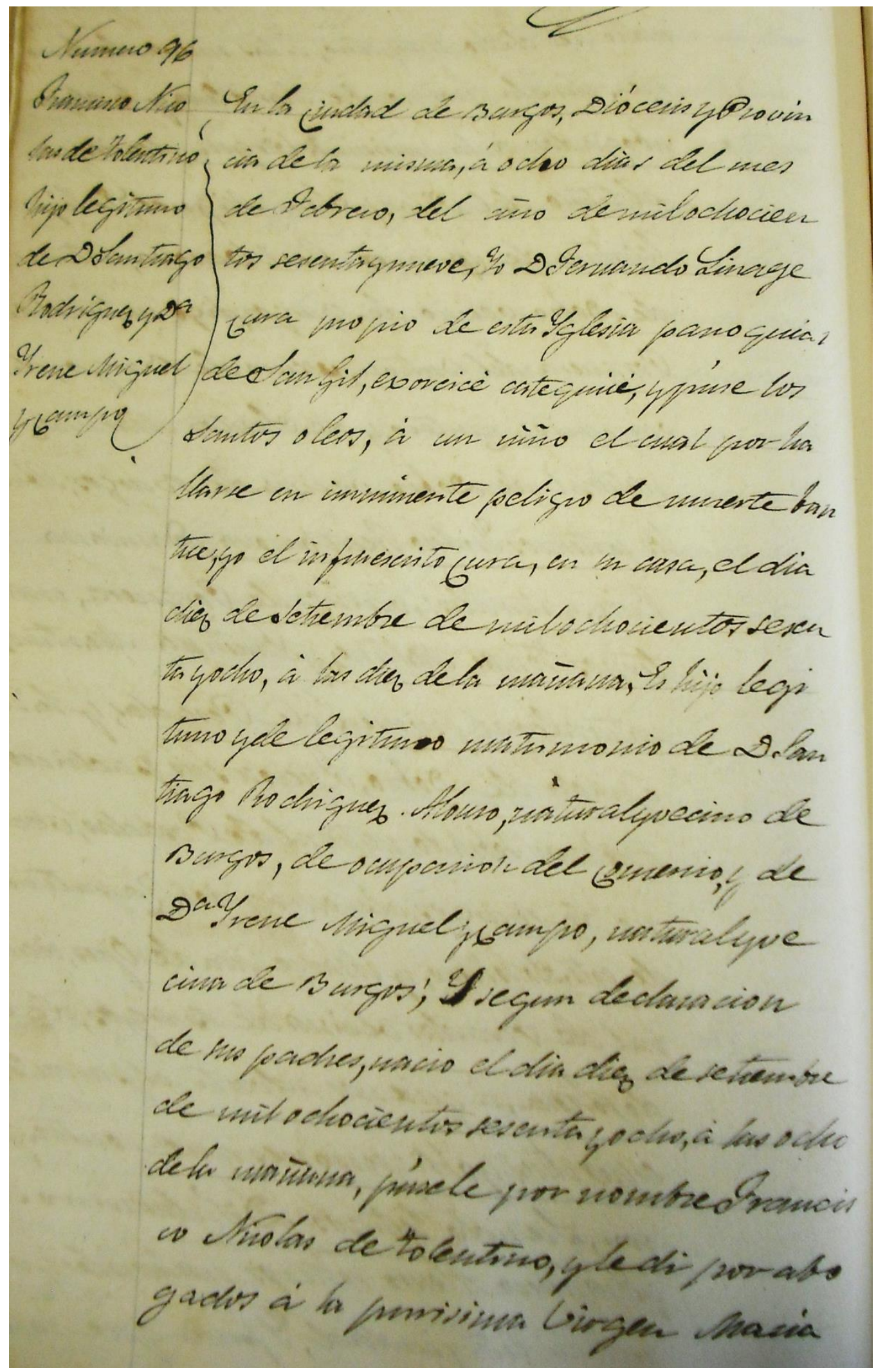

Fig.: 100

Acta literal de bautismo de Francisco Nicolás de Tolentino, hijo de D. Santiago Rodríguez Alonso e $\mathrm{D}^{\mathrm{a}}$ Irene Miguel y Campo.

Archivo Diocesano de Burgos. (10-9-1868), p. 1 de 2. 


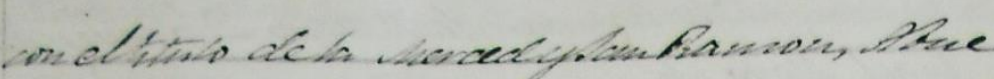

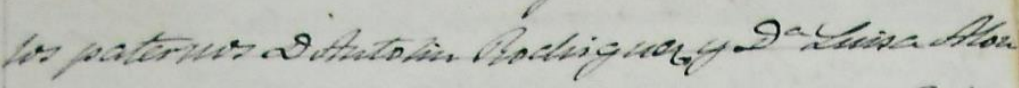

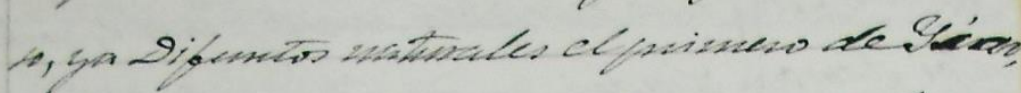

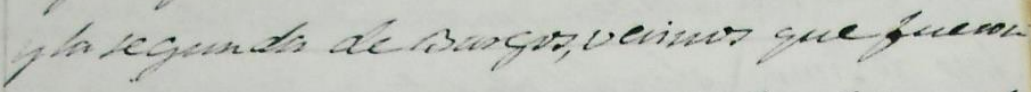

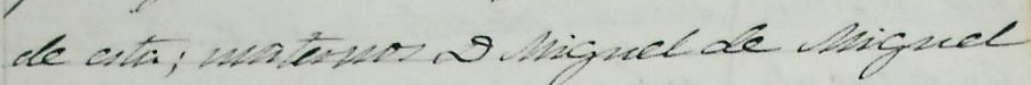

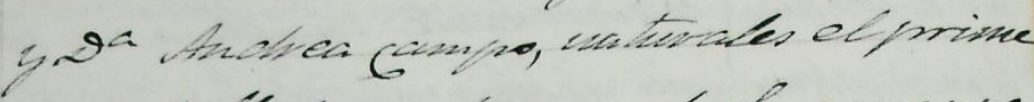

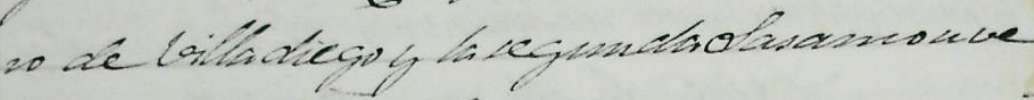

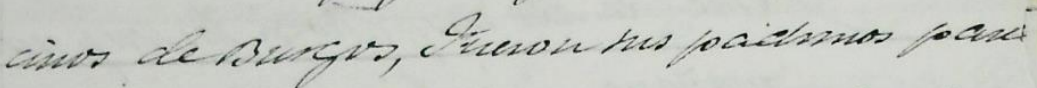

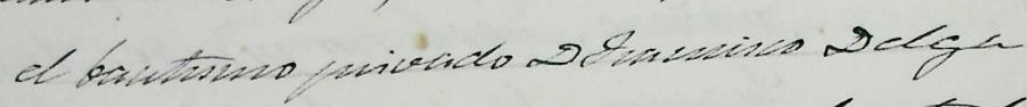
do, witraly weimede 3 ungios, de ertade

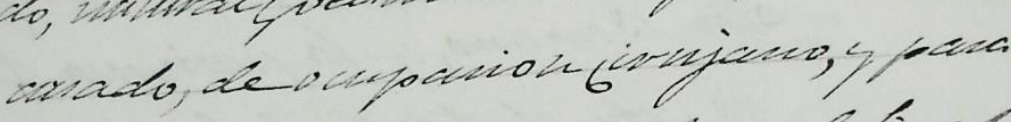

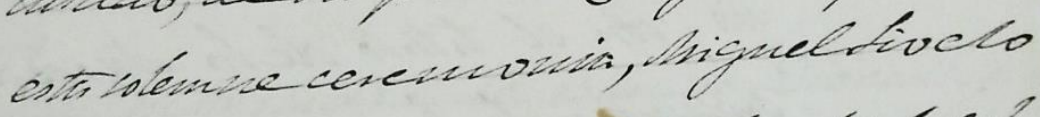

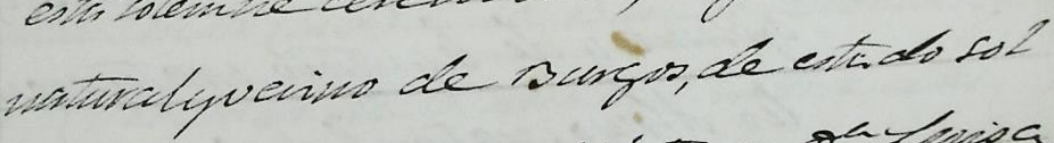

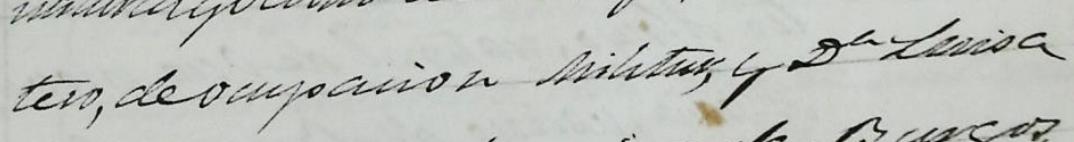

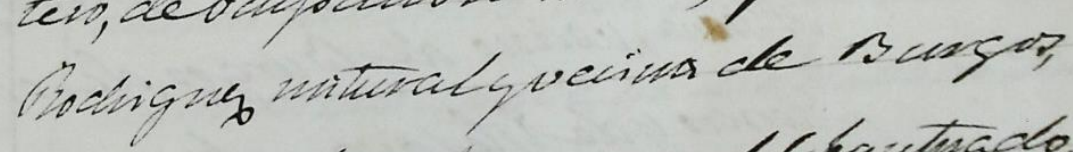

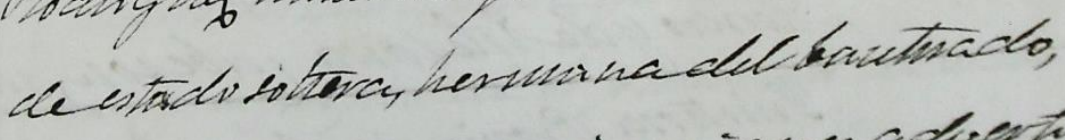

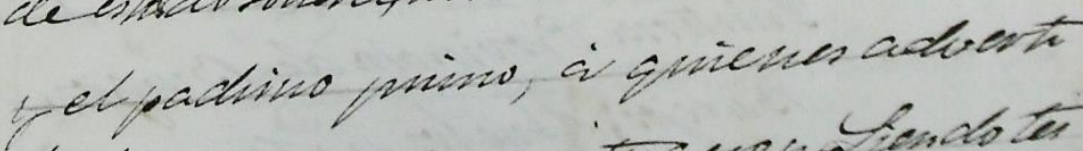

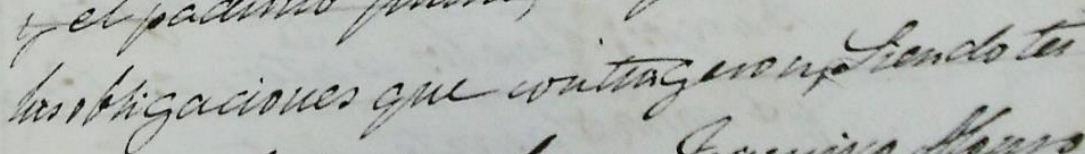

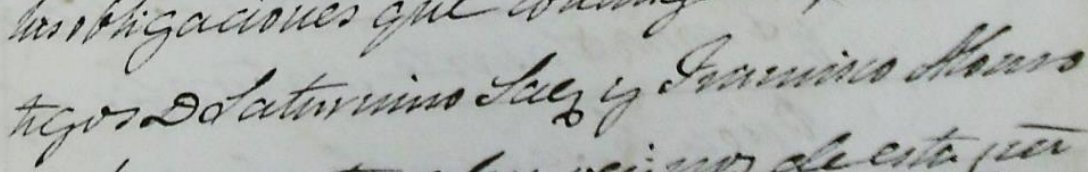

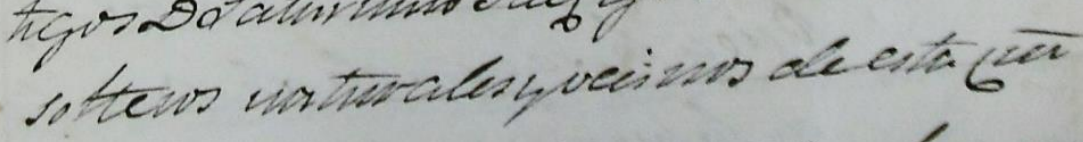

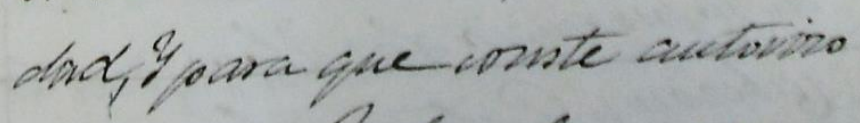

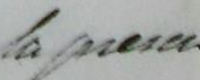

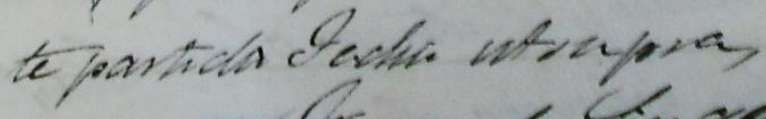

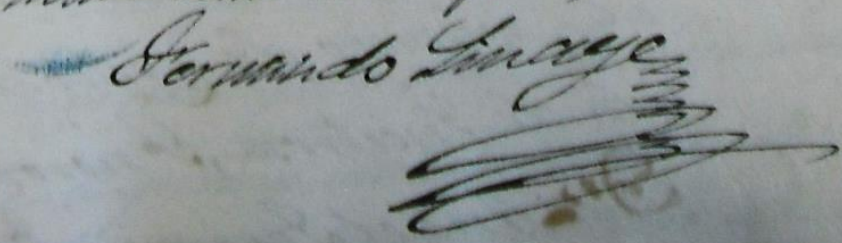

Fig.: 101

Acta literal de bautismo de Francisco Nicolás de Tolentino, hijo de D. Santiago Rodríguez Alonso y D ${ }^{\mathrm{a}}$ Irene Miguel y Campo.

Archivo Diocesano de Burgos. (10-9-1868), p. 2 de 2. 


\section{Acta literal de bautismo en la Iglesia parroquial de San Gil en Burgos de María de la Gloria Rodríguez Miguel, nacida el 10 de enero de 1872.}

En la ciudad de Burgos a trece días del mes de enero del año de mil ochocientos setenta y dos, yo Fernando Linage, cura propio de esta Iglesia parroquial de San Gil Abad de la misma, bauticé solemnemente en ella a una niña que según declaración de sus padres nació el día diez del corriente mes a las seis de la mañana. Púsele por nombre María de la Gloria Nicanora y le dí por abogada a la Purísima Concepción de Nuestra Sra., San José y San Gil Abad. Es hija legítima y de legítimo matrimonio de D. de D. Santiago Rodríguez, natural y vecino de esta ciudad, de ocupación comerciante y de $\mathrm{D}^{\mathrm{a}}$ Irene Miguel natural y vecina de Burgos.

Abuelos paternos D. Antolín Rodríguez y $\mathrm{D}^{\mathrm{a}}$ Luisa Alonso, naturales el primero de Isar en esta provincia y la segunda de Burgos, ya difuntos. Y maternos D. Miguel de Miguel y $\mathrm{D}^{\mathrm{a}}$ Andrea del Campo, natural el primero de Villadiego, la segunda de Sasamón, ambos pueblos de esta provincia. Fueron sus padrinos D. Antonio Sivelo, natural de La Coruña, vecino de Valladolid, de estado casado, comisario de Guerra y $\mathrm{D}^{\mathrm{a}}$ Elisa Miguel natural y vecina de Burgos y de estado soltera a quienes advertí las obligaciones que contrajeron. Siendo testigos D. Saturnino Sáez, natural y vecino de Burgos y Miguel Gutiérrez, natural y vecino de Burgos, dependiente de la misma. Y para que conste autorizo la presente partida.

Firmado por Fernando Linage. 

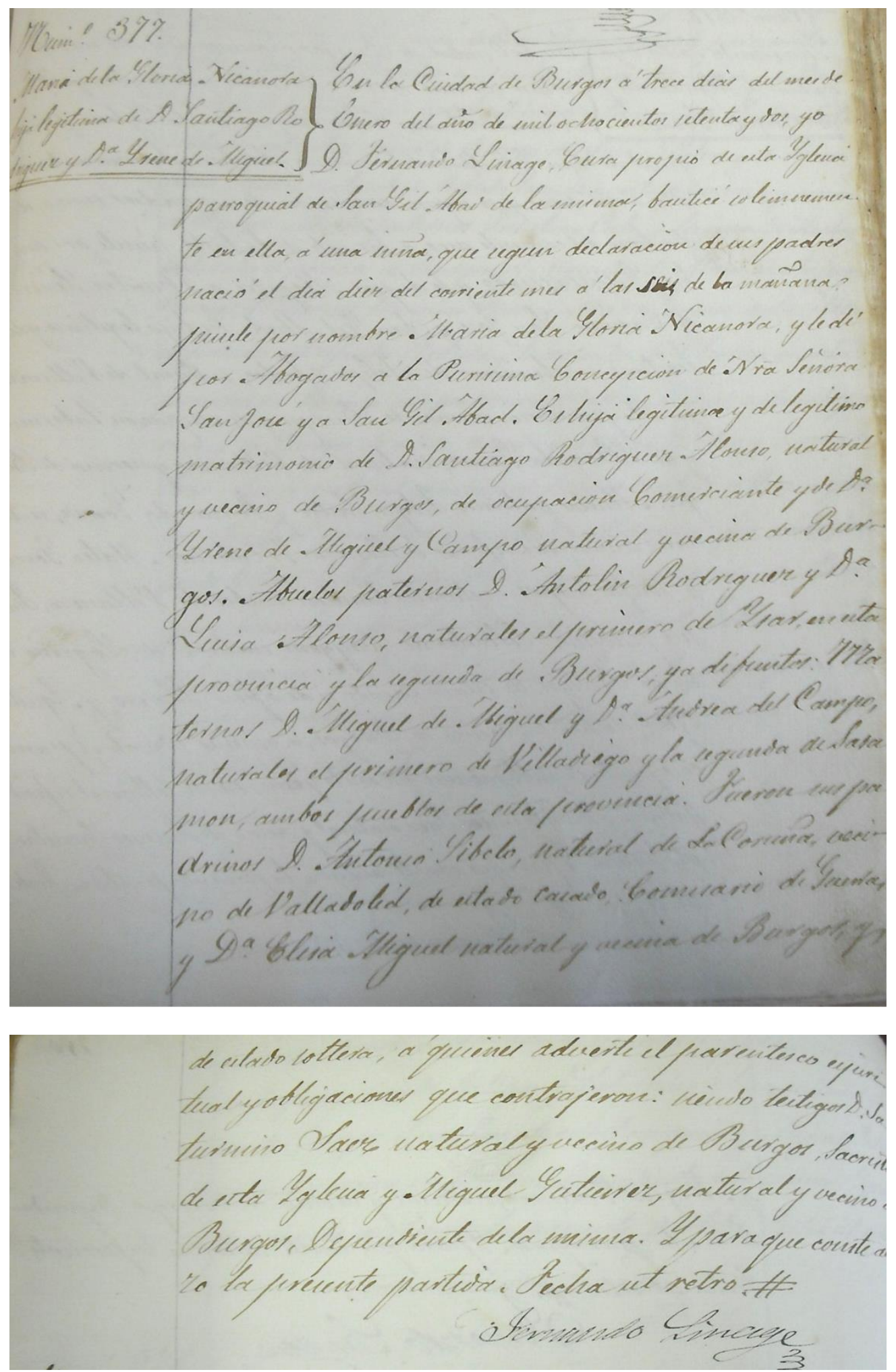

Fig.: 102

Acta literal de bautismo de $\mathrm{M}^{\mathrm{a}}$ de la Gloria Nicanora, hija de D. Santiago Rodríguez Alonso y Da Irene Miguel y Campo. Archivo Diocesano de Burgos. (10-1-1872). 


\section{Acta literal de bautismo en la Iglesia parroquial de San Lesmes en Burgos de Tomasa Eusebia Rodríguez Escudero, nacida el 26 de septiembre de 1889.}

En la ciudad de Burgos, Diócesis y Parroquia de la misma a del mes de octubre de mil ochocientos ochenta y nueve, yo D. Enrique Hernando y Villandiego, cura ecónomo en esta parroquia de San Lesmes, bauticé solemnemente en ella a una niña que según declaración del abuelo nació el día___de octubre último a las de la . Se la puso por nombre Tomasa Eusebia y por abogada S. José y S. Lesmes. Es hija legítima de D. Mariano Rodríguez y $\mathrm{D}^{\mathrm{a}}$ Luisa Escudero. Abuelos paternos D. Santiago Rodríguez y $\mathrm{D}^{\mathrm{a}}$ Irene Miguel; maternos D. Pascual Escudero, difunto, y $\mathrm{D}^{\mathrm{a}}$ Eusebia Torre. Fueron sus padrinos el abuelo y $\mathrm{D}^{\mathrm{a}}$ Tomasa Escudero, todos naturales y vecinos de esta capital, advirtiéndoles a dichos padrinos las obligaciones que contraían. Siendo testigos el padrino y Lesmes Pérez. Para que conste autorizo la siguiente partida.

Firmado D. Fernando Hernando.

Margen izquierda:

La niña Tomasa Eusebia Rodríguez Escudero a que se refiere esta partida de bautismo, fue bautizada en esta iglesia del uno al seis de octubre de mil ochocientos ochenta y nueve, sin que pueda precisarse el día por ignorarle los padres, y nació según declaración firmada que conservo del padre, un veintiséis de septiembre de dicho año a las doce de la noche, habiendo sido su padrino, no el abuelo como expresa la partida sino su tío D. Lucas Escudero.

Lo que con autorización del Ministro y Sr. Provisor de esta Arzobispado se consigna para suplir las deficiencias y equivocaciones de dicha partida.

Burgos, 21 de febrero de 1901.

Licenciado Tiburcio Peña. 


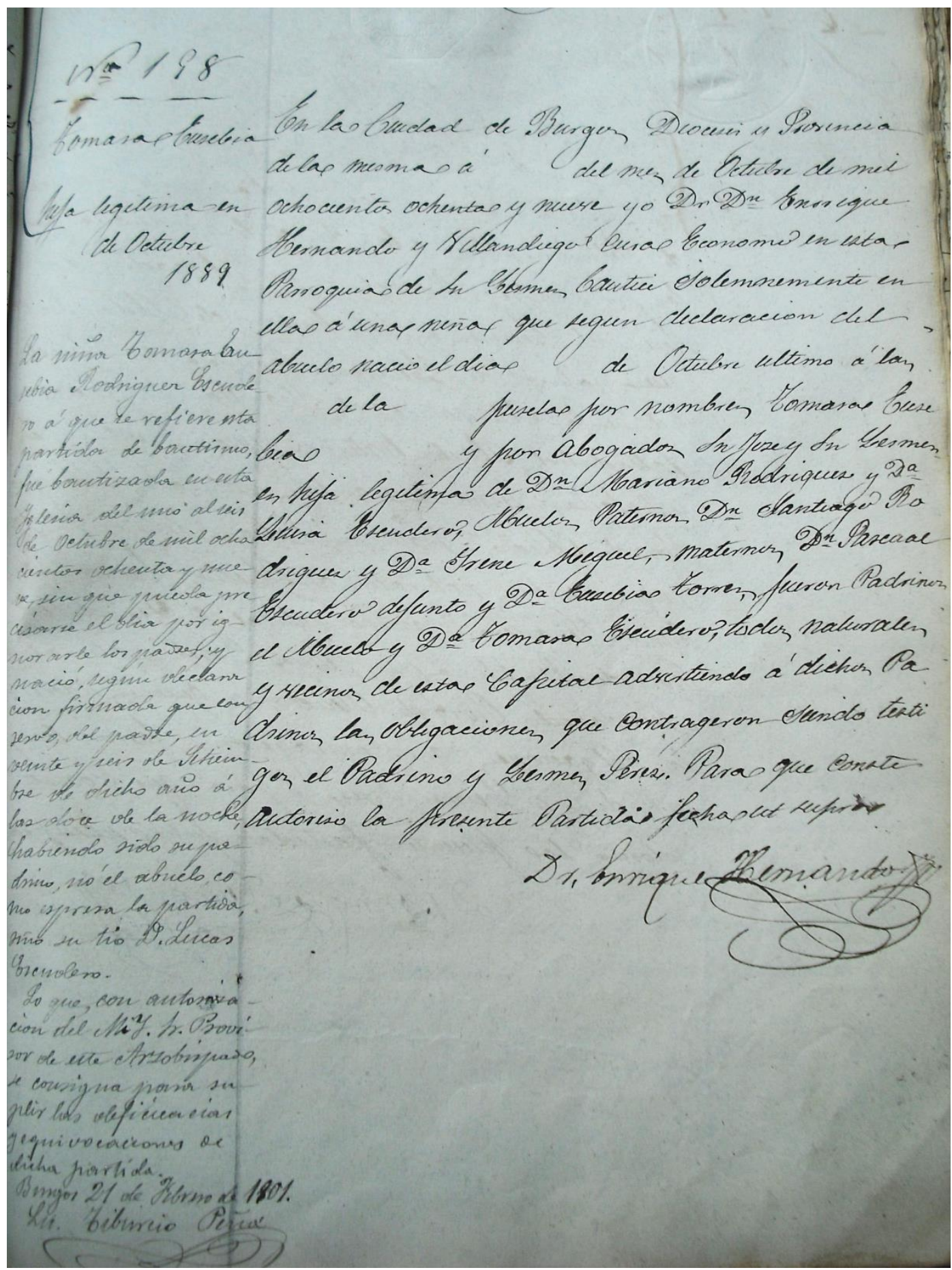

Fig.: 103

Acta literal de bautismo de Tomasa Rodríguez Escudero, hija de D. Mariano Rodríguez Miguel y Da Luisa Escudero y Torres. Archivo Diocesano de Burgos. (26-9-1889). 


\section{Acta literal de bautismo en la Iglesia parroquial de San Lesmes en Burgos de Pascual Rodríguez Escudero, nacido el 29 de diciembre de 1890.}

En la ciudad de Burgos, Diócesis y Parroquia de la misma a veinticuatro días del mes de enero de mil ochocientos noventa y uno, yo D. Benito Peña, cura ecónomo en esta parroquia de San Lesmes, bauticé solemnemente en ella a una niño que según declaración de los padres nació el día veintinueve de diciembre próximo pasado a las siete de la tarde. Se la puso por nombre Pascual y por abogados a S. José y S. Lesmes. Es hijo legítima y de legítimo matrimonio de D. Mariano Rodríguez Miguel, natural y vecino de Burgos del comercio de libros y de $D^{a}$ Luisa Escudero Torres, natural y vecina de esta ciudad. Abuelos paternos D. Santiago Rodríguez y $D^{\mathrm{a}}$ Irene Miguel; maternos D. Pascual Escudero, difunto, y D ${ }^{\mathrm{a}}$ Eusebia Torre. Fueron sus padrinos D. Agapito Escudero Torres, viudo e industrial y $\mathrm{D}^{\mathrm{a}}$ Tomasa Escudero, soltera, natural y vecina de Burgos.

Les advertí el parentesco espiritual y las obligaciones que contrajeron, siendo testigos Lesmes Pérez Martínez y Lesmes Pérez Bedoya, naturales de esta repetida ciudad, sacristán y estudiante respectivamente. Para que conste autorizo la siguiente partida.

Firmado por Benito de la Peña. 


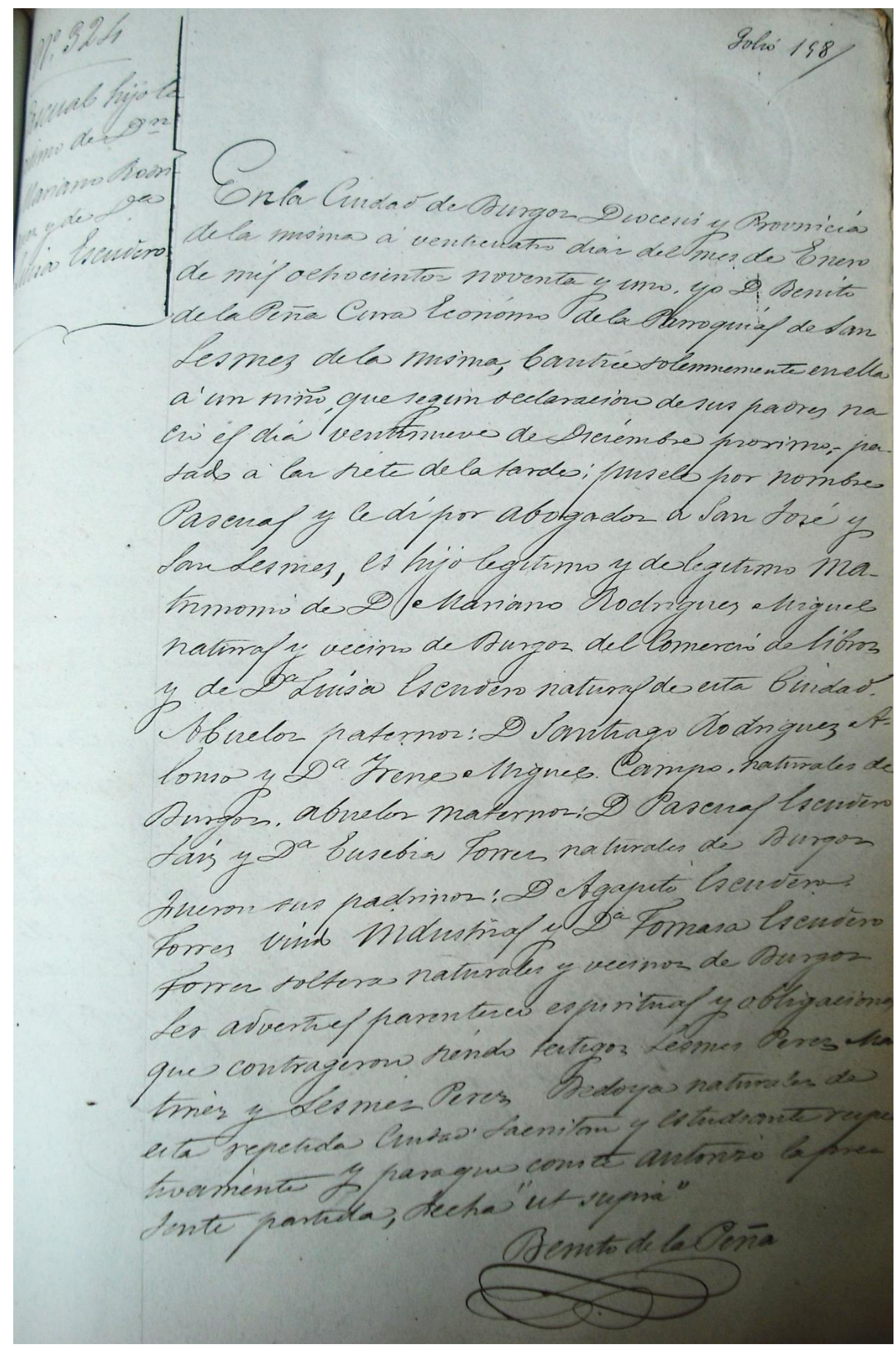

Fig.: 104

Acta literal de bautismo de Pascual Rodríguez Escudero, hijo de D. Mariano Rodríguez Miguel y Da Luisa Escudero y Torres.

Archivo Diocesano de Burgos. (29-12-1890). 


\section{Acta literal de bautismo en la Iglesia parroquial de San Lesmes en Burgos de Santiago Rodríguez Escudero, nacido el 29 de diciembre de 1890.}

En la ciudad de Burgos, Diócesis y Parroquia de la misma a veinticuatro días del mes de enero de mil ochocientos noventa y uno, yo D. Benito Peña, cura ecónomo en esta parroquia de San Lesmes, bauticé solemnemente en ella a una niño que según declaración de los padres nació el día veintinueve de diciembre próximo pasado a las siete de la tarde. Se la puso por nombre Santiago y por abogados a S. José y S. Lesmes. Es hijo legítimo y de legítimo matrimonio de D. Mariano Rodríguez Miguel, natural y vecino de Burgos, comerciante y de $\mathrm{D}^{\mathrm{a}}$ Luisa Escudero Torres, natural y vecina de esta ciudad. Abuelos paternos D. Santiago Rodríguez Alonso y $\mathrm{D}^{\mathrm{a}}$ Irene Miguel, vecinos de Burgos él y ambos de esta ciudad naturales; maternos D. Pascual Escudero Sáez, y D ${ }^{a}$ Eusebia Torre de Santa María, naturales de Burgos. Fueron sus padrinos D. Agapito Escudero Torres, viudo e industrial y $\mathrm{D}^{\mathrm{a}}$ Tomasa Escudero, soltera, natural y vecina de Burgos.

Les advertí el parentesco espiritual y las obligaciones que contrajeron, siendo testigos Lesmes Pérez Martínez y D. Mariano Miegimolle, naturales y vecinos de esta repetida ciudad. Para que conste autorizo la siguiente partida.

Firmado D. Benito de la Peña. 


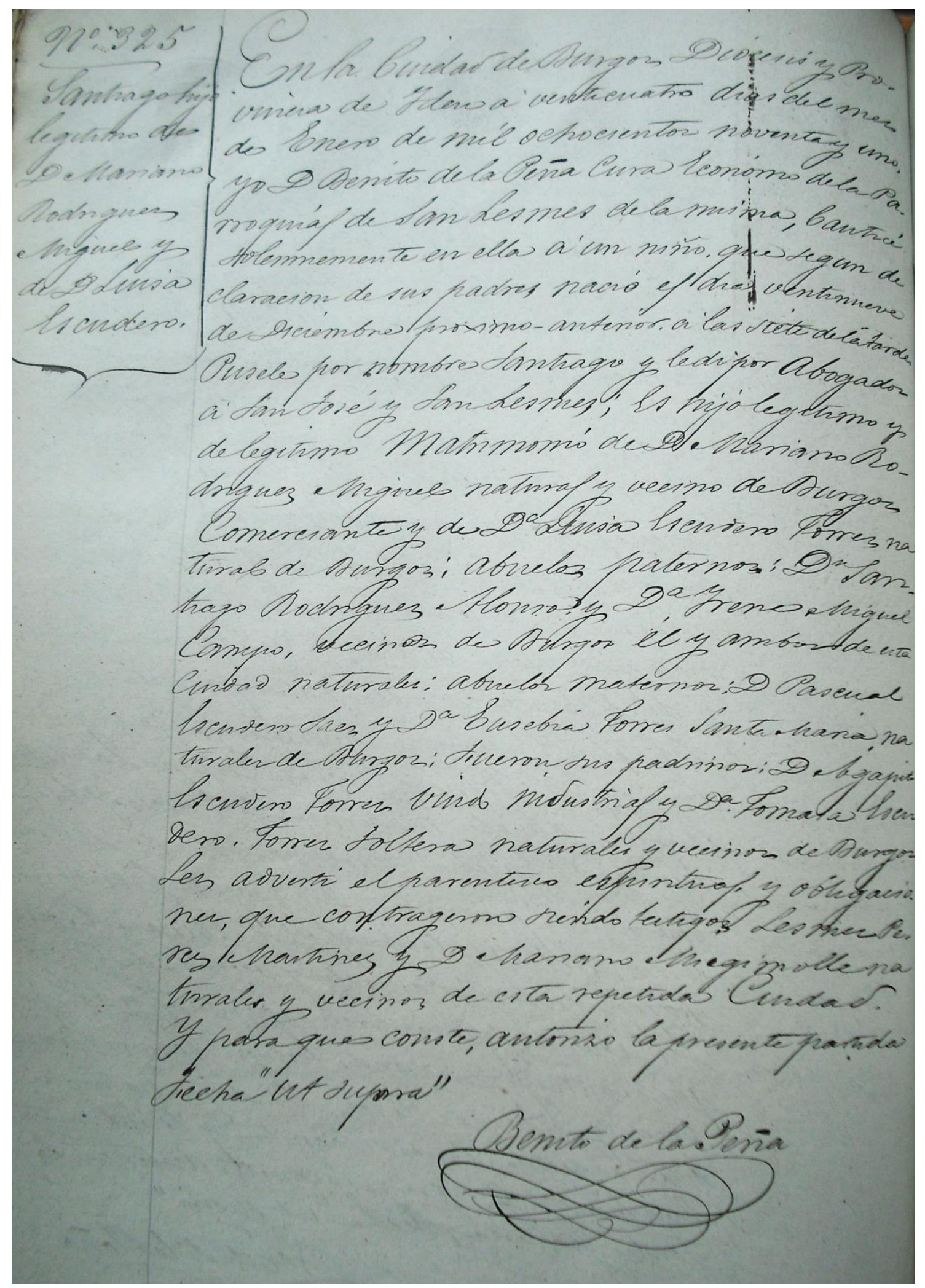

Fig.: 105

Acta literal de bautismo de Santiago Rodríguez Escudero, hijo de D. Mariano Rodríguez Miguel y D ${ }^{a}$ Luisa Escudero y Torres.

Archivo Diocesano de Burgos. (29-12-1890). 


\section{Acta literal de defunción en la Iglesia parroquial de San Gil en Burgos de D. Santiago Rodríguez Alonso, el 9 de abril de 1891.}

Santiago Rodríguez, viudo de Da Irene Miguel.

En la ciudad de Burgos a diez días del mes de abril del año de mil ochocientos noventa y uno, yo el licenciado D. Tiburcio Peña, cura canónico de la Iglesia parroquial de San Gil Abad de la misma, mandé dar sepultura en el cementerio público de ella al cadáver de D. Santiago Rodríguez Alonso, natural y vecino de Burgos, feligresía de San Gil de sesenta y dos años de edad, de estado viudo de $\mathrm{D}^{\mathrm{a}}$ Irene Miguel de Miguel, natural y vecina que fue también de esta ciudad e hijo legítimo de D. Antolín Rodríguez y $\mathrm{D}^{\mathrm{a}}$ Luisa Alonso, naturales el primero de Isar y la segunda de Burgos.

Murió el día anterior de una lesión de corazón a las ocho y diez minutos bajo testamento que otorgó ante D. Fernando Monterrubio, notario público de esta ciudad. Deja cinco hijos llamados, Luisa, Mariano, $\mathrm{M}^{\mathrm{a}}$ Pilar, Francisco y $\mathrm{M}^{\mathrm{a}}$ de la Gloria.

Recibió los Santos Sacramentos de la Penitencia, Sagrado Viático y Extremaunción y se le hizo entierro de $1^{\text {a }}$ clase con Cruz de Recomendación y acompañamiento del Cabildo hasta el cementerio con asistencia además del Cabildo de la Parroquia de San Esteban.

Tuvo dos días de honras y misas de letra abierta. Y para que conste autorizo la presente.

Firmado Lic. Tiburcio Peña. 


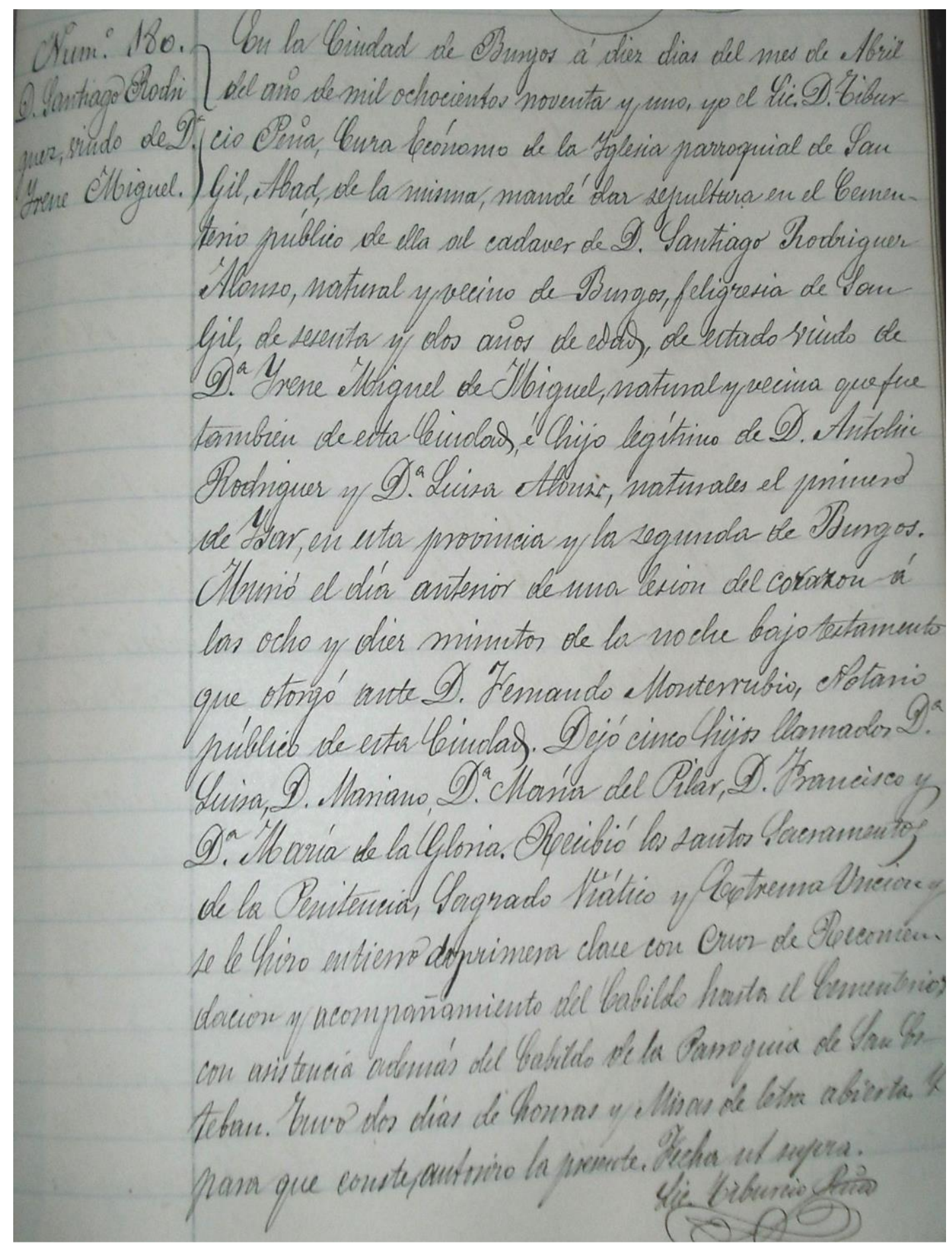

Fig.: 106

Acta literal de defunción de D. Santiago Rodríguez Alonso.

Archivo Parroquial de San Gil. (9-4-1891). 


\section{Acta literal de defunción en la Iglesia parroquial de San Gil en Burgos de D. Francisco Rodríguez Miguel, el 17 de noviembre de 1900.}

D. Francisco Rodríguez, hijo de D. Santiago y de D ${ }^{\mathrm{a}}$ Irene de Miguel.

En la ciudad de Burgos a dieciocho de noviembre del año de mil novecientos, yo D. Basilio Olalle Gonzalo, cura propio de la parroquia de San Gil Abad de la misma, mandé dar sepultura en el cementerio público de ella al cadáver de D. Francisco Rodríguez, soltero, natural y vecino de esta ciudad, de edad de treinta y un años e hijo legítimo de D. Santiago Rodríguez y de $\mathrm{D}^{\mathrm{a}}$ Irene de Miguel de la misma naturaleza. Murió de pulmonía el día anterior a las once de la mañana después de recibir los Santos Sacramentos de Penitencia, Sagrado Viático y Extremaunción. Otorga testamento ante D. Teódulo Santos, notario público de esta ciudad. Se le hizo entierro de $3^{\text {a }}$ clase con Cruz de Recomendación y acompañamiento del Cabildo hasta el cementerio con un día de honra. Y para que conste autorizo la presente.

Firmado Basilio Olalle Gonzalo. 
$\therefore 1136$

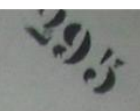

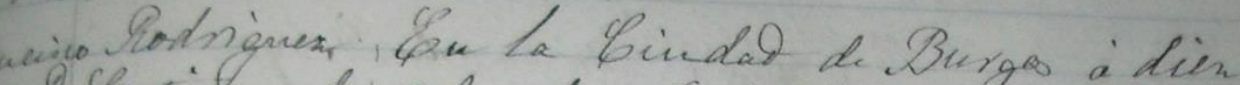

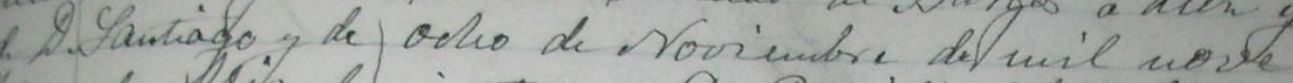

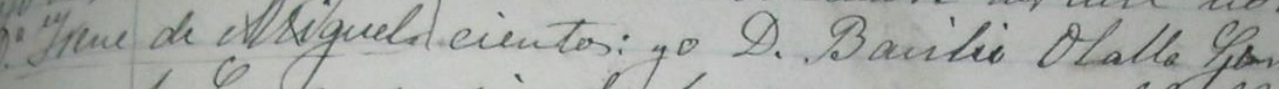
- Euta lasui de

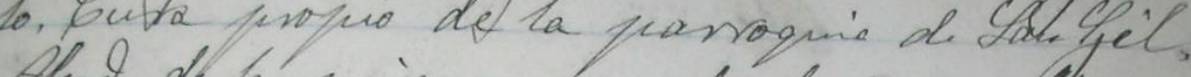

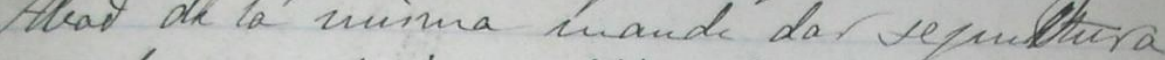
en el cencisterio futoleco de efla al cadarer

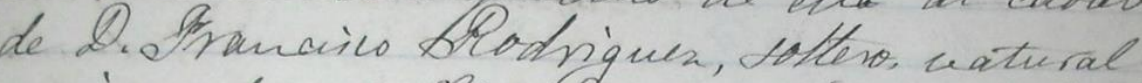

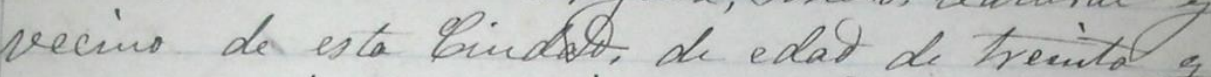

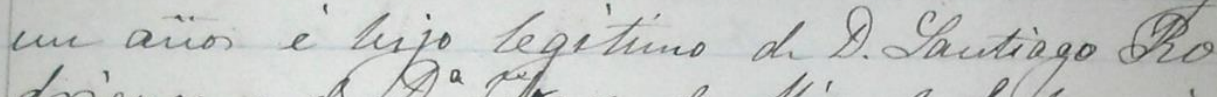

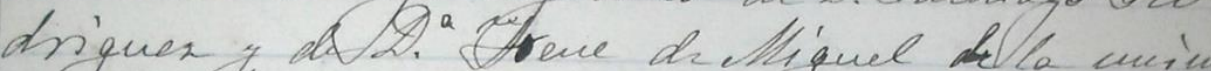

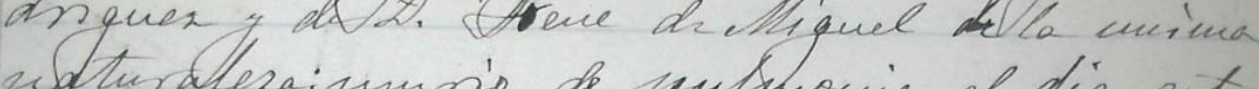

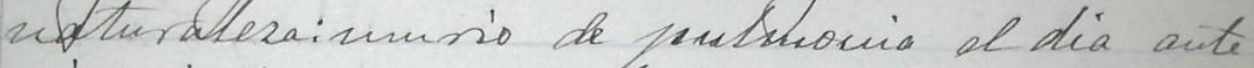

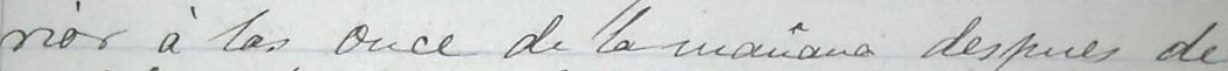

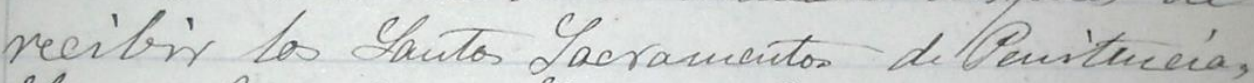

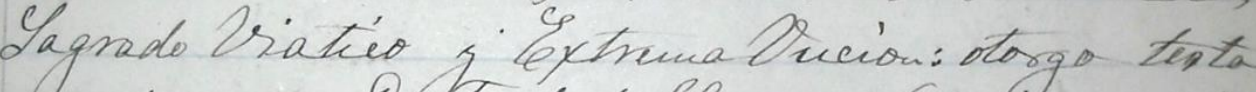

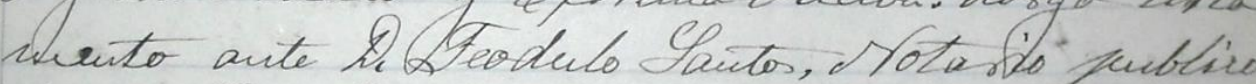

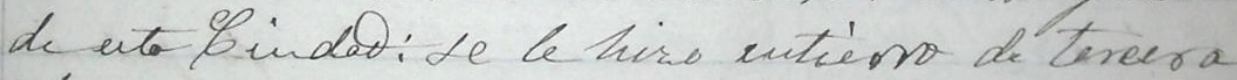

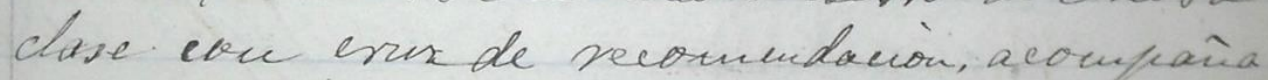

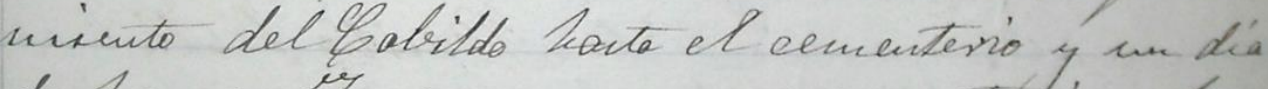

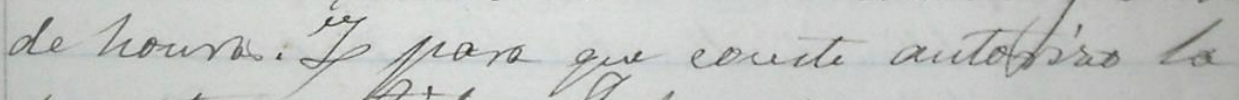

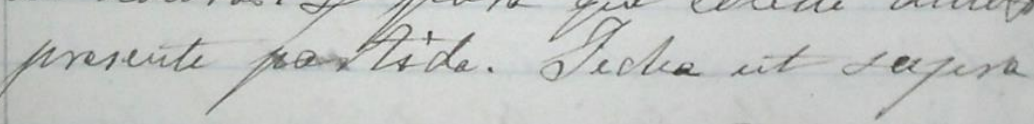

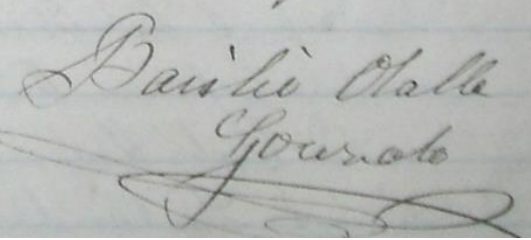

Fig.: 107

Acta literal de defunción de D. Francisco Rodríguez Miguel. Archivo de la parroquia de San Gil. (17-11-1900). 


\section{Acta literal de bautismo en la Iglesia parroquial de San Gil en Burgos de Santiago Rodríguez Escudero, nacido el 17 de noviembre de 1893.}

Santiago, hijo de Mariano Rodríguez y Luisa Escudero.

En la ciudad de Burgos, Diócesis y Parroquia de la misma a veintiocho días del mes de noviembre de mil ochocientos noventa y tres, yo D. Tiburcio Peña, cura ecónomo de la Iglesia parroquial de San Gil Abad, bauticé solemnemente en ella a un niño que según declaración de los padres nació el día diecisiete de dicho mes y año a las seis de la mañana. Se le puso por nombre Santiago y por abogados a la Virgen del Carmen y a S. José. Es hijo legítimo y de legítimo matrimonio de D. Mariano Rodríguez Miguel, de profesión comerciante y de $\mathrm{D}^{\mathrm{a}}$ Luisa Escudero Torres, ambos naturales y vecinos de esta ciudad de Burgos y feligreses de esta de San Gil Abad. Abuelos paternos D. Santiago Rodríguez Alonso y Da Irene Miguel, los dos difuntos y vecinos de esta ciudad naturales; maternos D. Pascual Escudero Sáez, y $D^{a}$ Eusebia Torre también difuntos y naturales de esta ciudad. Fueron sus padrinos D. Lucas Escudero Torres, de ocupación maestro de obras y $\mathrm{D}^{\mathrm{a}}$ Tomasa Escudero Torres, los dos solteros, naturales y vecinos de Burgos, tíos de la bautizada a quienes advertí el parentesco espiritual y las obligaciones que contrajeron, siendo testigos D. Saturnino Sáez, casado y José Manzanedo, solteros, naturales y residentes de esta ciudad y dependientes de esta parroquia. Para que conste autorizo la siguiente partida.

Firmado Lic. Tiburcio Peña. 

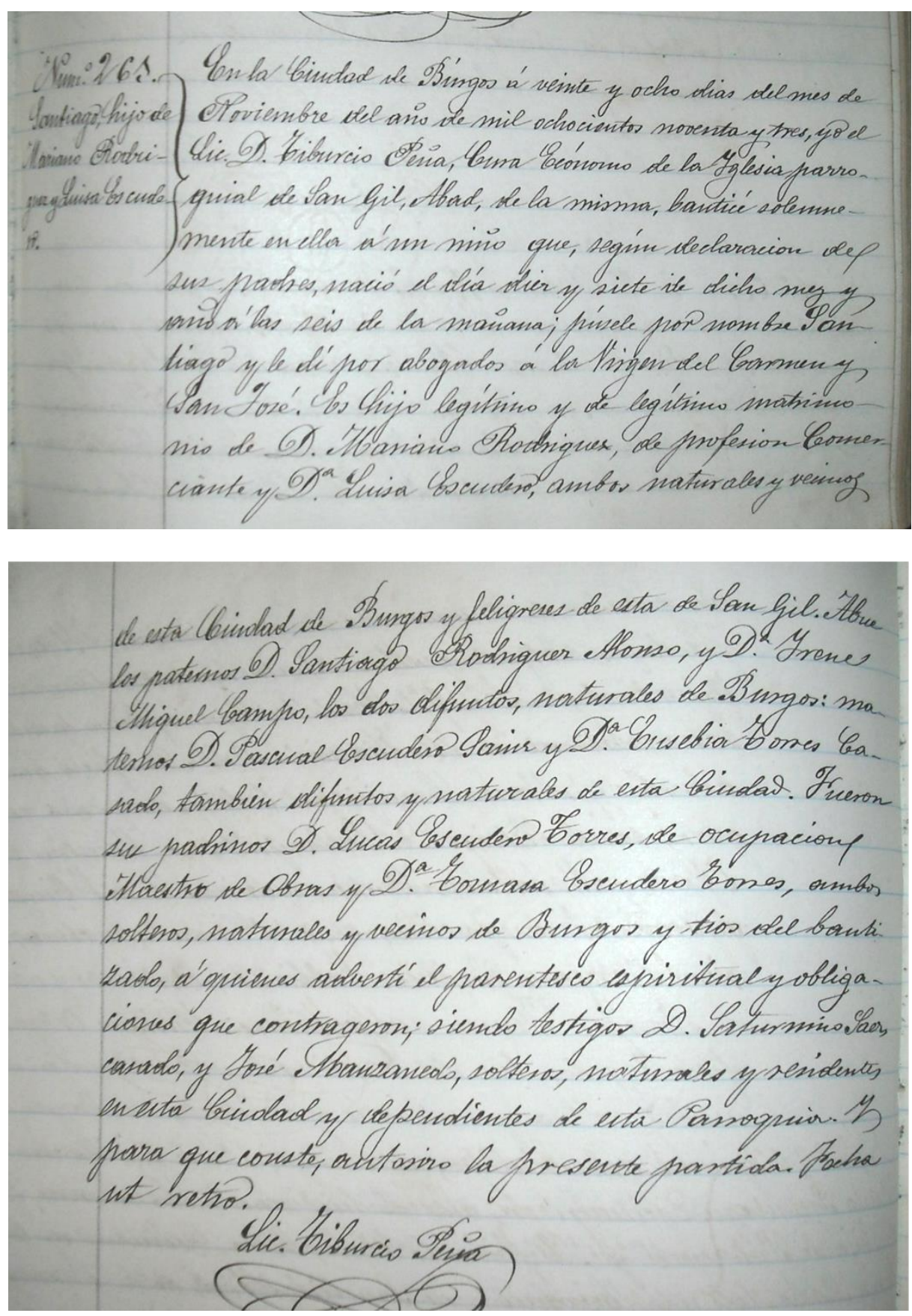

Fig.: 108

Acta literal de bautismo de D. Santiago Rodríguez Escudero.

Archivo parroquial de San Gil. (17-11-1893). 


\section{Acta literal de bautismo en la Iglesia parroquial de San Gil en Burgos de Mariano Rodríguez Escudero, nacido el 1 de noviembre de 1894.}

Mariano, hijo de Mariano Rodríguez y Luisa Escudero.

En la ciudad de Burgos, a siete días del mes de noviembre de mil ochocientos noventa y cuatro, yo el lic. D. Tiburcio Peña, cura propio, digo ecónomo de la Iglesia parroquial de San Gil Abad, bauticé solemnemente en ella a un niño que según declaración de los padres nació el día uno de dicho mes y año a las cuatro de la mañana. Se le puso por nombre Mariano Santos y le di por abogados a Nuestro Sra. la Virgen del Carmen y a S. José. Es hijo legítimo y de legítimo matrimonio de D. Mariano Rodríguez Miguel, de ocupación comerciante y de $\mathrm{D}^{\mathrm{a}}$ Luisa Escudero Torres, ambos naturales y vecinos de esta ciudad de Burgos y feligreses de esta parroquia. Abuelos paternos D. Santiago Rodríguez Alonso y D ${ }^{\mathrm{a}}$ Irene Miguel Campo, ya difuntos y vecinos de Burgos; maternos D. Pascual Escudero Sáez, y Da Eusebia Torres Santamaría, también difuntos y naturales de esta ciudad. Fueron sus padrinos D. Lucas Escudero Torres, de oficio industrial y $\mathrm{D}^{\mathrm{a}}$ Tomasa Escudero Torres, los dos solteros, naturales y vecinos de Burgos, tíos de la bautizada a quienes advertí el parentesco espiritual y las obligaciones que contrajeron, siendo testigos D. Saturnino Sáez, casado y Ángel Pablo, soltero, naturales y residentes de esta ciudad y dependientes de esta parroquia. Para que conste autorizo la siguiente partida.

Firmado Lic. Tiburcio Peña.

En el margen izquierdo:

Contrajo matrimonio en la parroquia de San Pedro y San Felices de esta capital el día veintinueve de octubre de mil novecientos veinte con Felisa Orejón Hernando, siendo testigos D. Jacobino de la Virgen del Carmen y Don Luis Martínez Ariz-Navarreta.

Firmado por el Lic. G. Betolaza. 


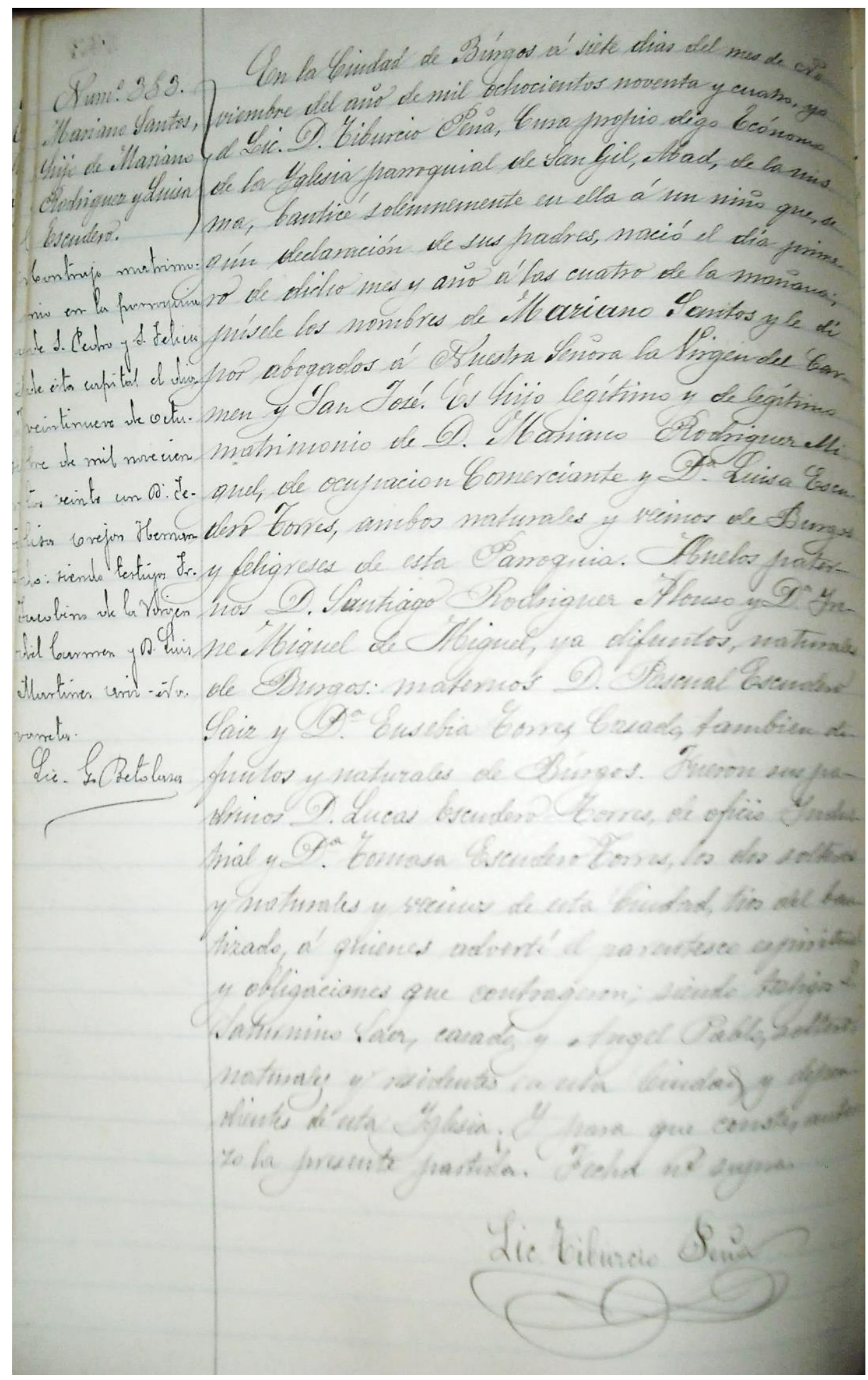

Fig.: 109

Acta de bautismo de Mariano Santos Rodríguez Escudero. Archivo parroquial de San Gil. (1-1-1894). 


\section{Acta literal de bautismo en la Iglesia parroquial de San Gil en Burgos de Lucas Rodríguez Escudero, nacido el 3 de diciembre de 1895.}

Lucas Francisco, hijo legítimo de D. Mariano Rodríguez y de D ${ }^{a}$ Luisa Escudero.

En la ciudad de Burgos a seis de diciembre de mil ochocientos noventa y cinco, yo D. Basilio Olalla Gonzalo, cura propio de la parroquia de San Gil Abad de la misma, bauticé solemnemente en ella a un niño que según declararon sus padres, nació el día tres del presente mes a las cinco de la mañana. Le puse por nombre Lucas Francisco y di por abogado a Nuestra Sra. del Carmen y a San José. Es hijo legítimo del legítimo matrimonio de D. Mariano Rodríguez y D $D^{a}$ Luisa Escudero. Abuelos paternos D. Santiago Rodríguez y $\mathrm{D}^{\mathrm{a}}$ Irene Miguel, difuntos y maternos D. Pascual Escudero y $\mathrm{D}^{\mathrm{a}}$ Eusebia Torres, también difuntos. Fueron su padrinos D. Lucas Escudero y $\mathrm{D}^{\mathrm{a}}$ Tomasa Escudero, solteros a quienes les advertí del parentesco espiritual y demás obligaciones que habían contraído y testigos D. Saturnino Sáez, sacristán de esta iglesia y Ángel Pablo, soltero y dependiente de la misma, todos son o fueron vecinos de esta ciudad y naturales de la misma. Y para que conste autorizo la presente partida.

Firmado por D. Basilio Olalla Gonzalo.

En el margen izquierdo:

Contrajo matrimonio en la parroquia de San Pedro y San Felices el 3 de diciembre de 1924 con Da Luisa Martín Lagüera, natural de Madrid.

Firmado: A. Miguel. 


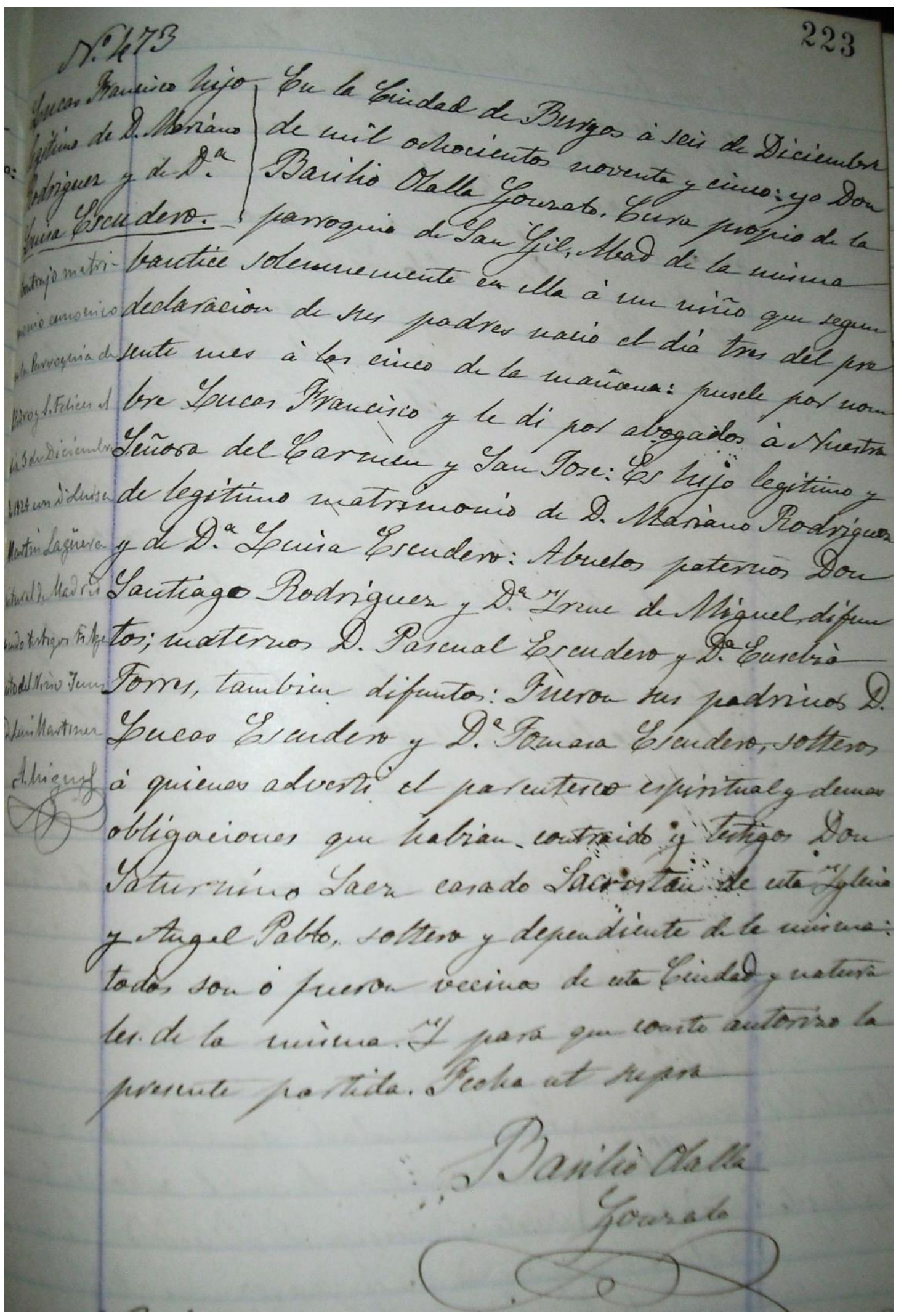

Fig.: 110

Acta literal de bautismo de D. Lucas Francisco Rodríguez Miguel. Archivo parroquial de San Gil. (3-12-1895). 


\section{Acta literal de defunción en la Iglesia parroquial de San Gil en Burgos de D. Mariano Rodríguez Miguel, el 17 de mayo de 1925.}

Mariano Rodríguez Miguel, esposo de $\mathrm{D}^{\mathrm{a}}$ Luisa Escudero Torre.

En la ciudad de Burgos, capital de la provincia y Arzobispado a dieciocho de mayo de mil novecientos veinticinco, yo presbítero D. Aureliano Miguel Gutiérrez, cura Regente de la Parroquia de San Gil Abad de la misma, previos los requisitos en derecho necesarios, mandé dar sepultura eclesiástica en el cementerio de San José de Della al cadáver de D. Mariano Rodríguez Miguel que falleció a los sesenta y cinco años de edad de muerte natural a consecuencia de neoplastia maligna del estómago, el día anterior y a las diez de la noche en la calle Laín Calvo número doce. Se le ha dado entierro con acompañamiento y un funeral de primera clase y cruz de recomendación. Era natural de esta ciudad e hijo legítimo de D. Santiago Rodríguez Alonso y $\mathrm{D}^{\mathrm{a}}$ Irene Miguel Campo, naturales de esta ciudad. En el acto del fallecimiento se hallaba casado con $\mathrm{D}^{\mathrm{a}}$ Luisa Escudero y Torres, natural de esta ciudad, en cuyo matrimonio deja siete hijos llamados, Tomasa, Pascual, Santiago, Mariano, Lucas, Luisa y Pilar. Recibió los Santos Sacramentos de Penitencia, Sagrado Viático y Extremaunción y no se haya otorgado testamento y para que así conste autoriza la presente partida.

Firmado por D. Aureliano Miguel. 


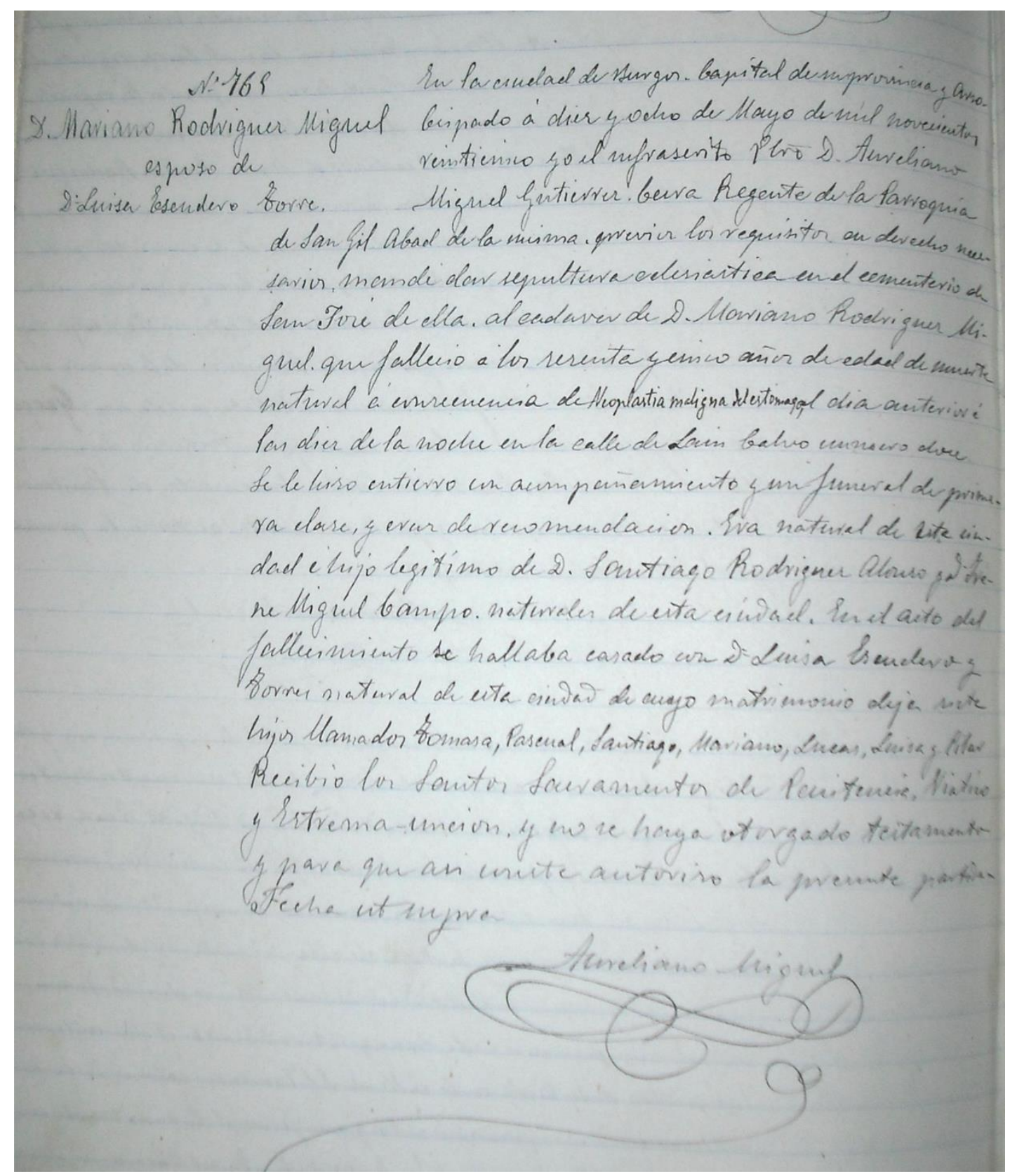

Fig.: 111

Acta de defunción de D. Mariano Rodríguez Miguel.

Archivo de la parroquia de San Gil. (15-5-1925). 


\subsection{DOCUMENTOS HEMEROGRÁFRICOS}

1. Inauguración del estreno de maquinaria tipográfica en la librería e imprenta de Santiago Rodríguez Alonso.

2. Las Imprentas burgalesas. Hijos de Santiago Rodríguez. Diario de Burgos, 11 de julio de 1902.

3. Las Bibliotecas Rodríguez. Periódico El Pueblo, 27 de diciembre de 1919.

4. Bibliografía. Periódico Guasa Viva, 9 de noviembre de 1913.

5. Artículo breve de opinión de Mariano Rodríguez Miguel sobre su visión de Burgos. Periódico Guasa Viva, 28 de junio de 1914.

6. Expositores burgaleses. Diario de Burgos, 1 de diciembre de 1908. 
1. Inauguración del estreno de maquinaria tipográfica en la librería e imprenta de Santiago Rodríguez Alonso.

(La fotografía está ampliada para una mejor visión y se encuentra en la página 3 en el cuadrante inferior derecha).

El Viernes por la noche tuvimos el gusto de asis. tir, prévia y gilantemente invitados por el $\mathrm{Sr}$. Rodriguez Alonso, al estreno de la máquina de imprimir, que ha traido de Lóndres y que pone al servicio del público. Es de forma esbelta, bien construida y alcanza las últimas innovaciones conocidas. El papel se coloca con facilidad y economia de tiempo, y tiene la ventaja de poderla parar cuando conviene, en todo 6 en parte, $y$ en el momento en que se desea.

A nuestra vista se hizo un cartel concebido en los siguientes términos:

\section{SANTIAGORODRIGUEZ Y ARONSO}

\section{BALUDA}

A SES COMTARERROS DR INDUSTRIA

$\mathrm{Y}$

DEDAQ

EL PRIMER TRABAJO TIPOGRÁFIGO DE SU MAQOUINA BREMNER

\section{A LA GIUDAD DE:BURGOS,}

Y EN SU REPRESENTACION A LA

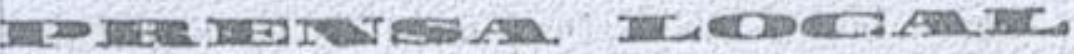

Felicitamos al Sr. Rodriguez, y le deseamos felices resultados, á la par que agradecemos su galantería para con la Prensa.

Fig.: 113

Periódico El Papa-Moscas, 18 de septiembre de 1879.

Inauguración de nueva maquinaria de imprimir de la Imprenta y librería Santiago Rodríguez Alonso. 


\section{Las industrias burgalesas. Hijos de Santiago Rodríguez. Diario de Burgos, 11 de julio de 1902.}

\section{Las industrias burgalesas}

\section{HIJOS DE SANTIAGO RODRÍGUEZ}

Imprenta y librería

Cuando, los que dependemos del Estado y al mismo tiempo nos dedicamos al emborronamiento de cuartillas, recibimos un pliego concebido, poco más o menos, en los siguientes términos: "Su Majestad el Rey (q. D. g.), ha tenido a bien trasladar a usted a tal punto" (aquí la voluntad del supremo), la primera investigación es averiguar quién o quiénes pueden ser las ruedas centrales del reloj literario, alrededor de las que podemos girar.

Y al ser esta humilde persona trasladada desde Valladolid a Burgos, el resultado que obtuvo de aquellas indagaciones fue saber que aquí, la vida literaria, prensa, iniciativas de donde podían partir, era de la casa "Hijos de Santiago Rodríguez".

Tratándose de Burgos, donde desgraciadamente la vida literaria no está a la altura de otras capitales, me supuso encontrar una modesta librería con media docena de obras de texto, alguna que otra suscripción al Blanco y Negro y unas cuantas novelas de 4 real la entrega.

Bien pronto pude convencerme de lo contrario: Murillo en Madrid, $\mathrm{Fe}$ en Sevilla, Aguilar y Ortega en Valencia, Nuevo en Valladolid, Montaner en Barcelona, y en una palabra, el catálogo de buenos editores de España, tenía en Burgos un nombre, "Hijos de Santiago Rodríguez", que podía figurar en primera línea, sin desmerecer ni un átomo de aquellas importantes casas y aun superando a alguna de ellas.

Y aquí es de justicia, rendir un cariñoso tributo, un sentido recuerdo, a la figura creadora de la actual casa, al honrado burgalés D. Santiago Rodríguez, padre de los actuales propietarios, que dedicado desde sus primeros años a la vida industrial y defensor acérrimo de la enseñanza, fundara, allá por el año 1846, la actual librería, siendo entusiasta propagandista de las ideas pedagógicas, demostrando en diversos certámenes aquí celebrados la instalación de una escuela modelo en la Exposición de Burgos en el año 1882, la fundación del órgano del magisterio La Imparcialidad y tantos otros que pudieran citarse.

Los desvelos de tan laborioso industrial repercuten en nuestros días, y tras la elegante instalación que en la Exposición actual presentan sus hijos se ve la figura del cariñoso padre y del obrero honrado que no queriendo 
más premios que los de su trabajo rechazó la cruz de Carlos III que el gobierno le concediera en 1874 por su conducta como concejal y diputado.

Ocupa la citada instalación el primer espacio a la derecha en la sección de Artes Industriales y consta de dos cuerpos:

En el de la parte superior se ve en el centro un precioso cartel a tres colores y debajo una elegante lámina, también a tricolor, que por la limpieza de sus tintas y esmero en la estampación, compite con los trabajos de los mejores revistas ilustradas, tales como Blanco y Negro y que seguramente será de estos trabajos el primero ejecutado en provincias.

A los lados dos nombres dos rombos con una selecta selección de grabados y debajo dos rodelas en las que informa de perfectísimos trabajos de impresión, tarjetas en varias tintas y purpurinas, cartas comerciales B.L.M. y facturas llamando especialmente la atención un resguardo de la Azucarera Burgalesa hecho en papel vitela y tirado a dos tintas.

En el cuerpo de la parte inferior y a forma de pupitre, se ve, esparcida con gran gusto, numerosa colección de libros de enseñanza, editados por la casa Rodríguez, colección de cuentos para niños, ilustrados con artísticos fotograbados y encuadernados con elegantes y alusivas tapas al cromo; de dichos cuentos hay hasta 55 títulos, viéndose también el "Museo de la Infancia" y la "Biblioteca enciclopédica hispano americana" que pueden competir con las principales casas editoriales nacionales y extranjeras.

En el establecimiento de los "Hijos de Santiago Rodríguez" está instalado en la calle Laín Calvo, esquina al Pasaje de la Flora y es el centro de reunión de literatos, hombres de ciencia y cuantos se dedican al cultivo de las letras.

Allí, además de un riquísimo surtido de menaje para escuelas, se vende toda clase de obras científicas y literarias, estando montado a tan gran altura, que obra que se publique es presentada a los pocos días en el escaparate de los "Hijos de Santiago Rodríguez", no habiendo, por tanto, retraso alguno en su "Catálogo bibliográfico".

La imprenta se halla instalada en la calle del General Santocildes, estando al frente el entendido regente D. Juan Calvo. En ella hay cuatro máquinas sistema Marinoni doble y Bremer, guillotinas, prensas y cuanto se necesita para el arte tipográfico, además de un riquísimo surtido en caracteres de letra y clichés, hasta el punto de pasar de 3.000 el número de éstos en fotograbado.

El catálogo en que anuncian sus publicaciones de educación y enseñanza y el material escolar, tiene 1.349 artículos diferentes.

Con tales elementos, puede editarse toda clase de trabajos, pudiendo citarse como modelos últimamente publicados, las obras de Salvá y la Historia de la Cartuja, de Tarín. 
En dicha casa se han editado diversos periódicos: además de la Imparcialidad, se imprimió el Papa Moscas, El Sereno, La Brújula y otros varios.

Además de la numerosa venta en Burgos, exporta a todas las repúblicas americanas en gran escala.

Ha obtenido el primer premio en la Exposición burgalesa de 1882; medalla y diploma en la aragonesa de 1885, en la de Barcelona de 1888 y en la Pedagógica de Valladolid.

Hoy figura al frente el laborioso e inteligente industrial D. Mariano Rodríguez, que además representa en el Ayuntamiento la segunda tenencia de alcaldía.

M. DE ABAJO. 


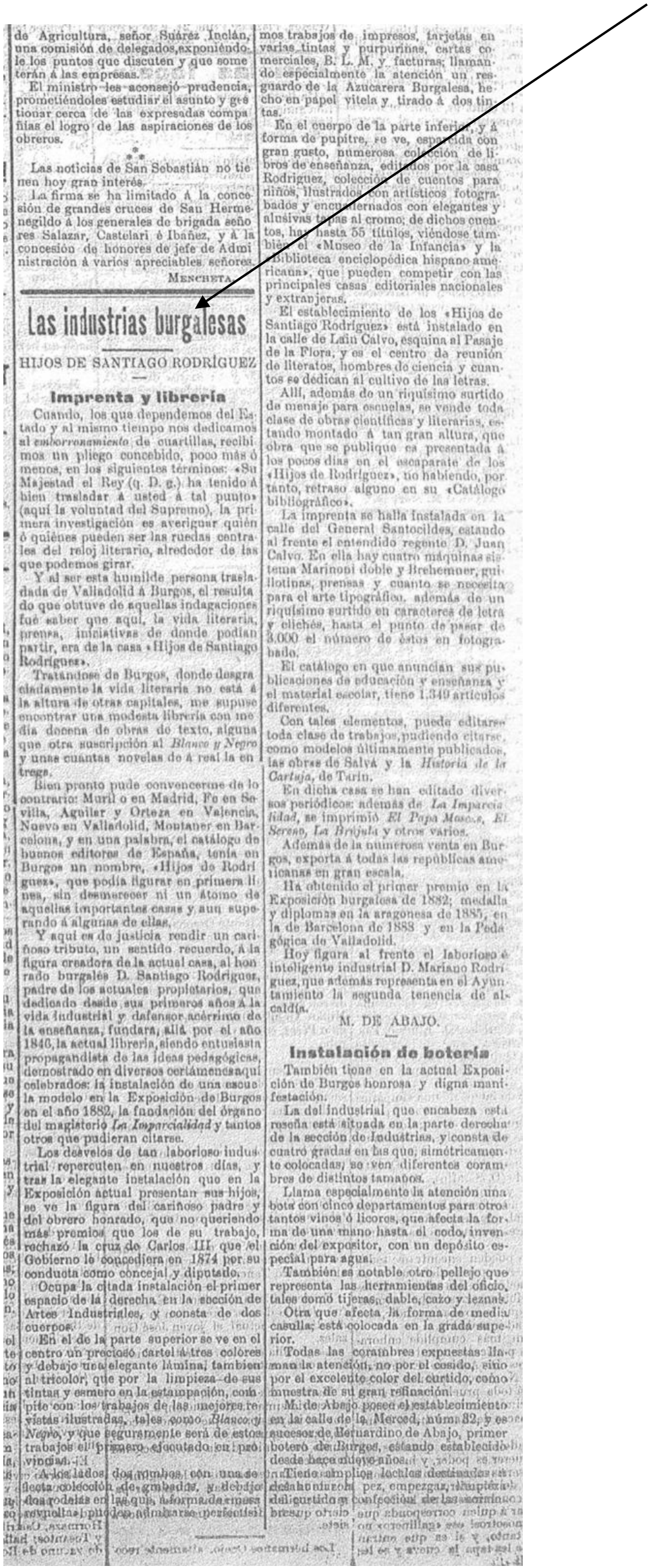

Fig.: 114

Diario de Burgos, 11 de julio de 1902. 


\section{Las Bibliotecas Rodríguez. Periódico El Pueblo, 27 de diciembre de 1919.}

El Pueblo: semanario democrático escribió un artículo sobre las bibliotecas de la Casa editorial Hijos de Santiago Rodríguez el 27 de diciembre de 1919.

\section{LAS BIBLIOTECAS RODRÍGUEZ}

Hora es ya de que prestemos alguna atención a las varias e interesantes publicaciones aparecidas últimamente para pasto de las jóvenes inteligencias, de los pequeños lectorcillos.

Abandonando por un momento los temas serios y sesudos, internémonos por los bellos países de ensueño, por las deliciosas y no menos atrayentes páginas de esta literatura genuinamente infantil.

En España, desgraciadamente, no se ha generalizado todavía suficientemente la culta y delicada costumbre, arraigada hace ya tiempo en otros países más adelantados, de conceptuar el libro como objeto predilecto para regalo a los muchachos, muy especialmente en los días de Navidad, Año Nuevo y Reyes.

Pero poco a poco, y gracias a los trabajos de algunas casas editoriales, los padres que verdaderamente se interesan por la educación de sus hijos, van relegando al olvido aquellos juguetes y cachivaches, casi siempre inútiles y de pasajero solaz, dando preferencia a estos tomitos que en manos de los incipientes y curiosos lectorcillos constituyen, a no dudarlo, el más preciado y positivo pasatiempo.

La ventaja del libro bueno y bien hecho es indiscutible: se desarrolla en el muchacho el gusto a la lectura y al estudio, aprende mil y mil cosas provechosas, se recrea en las bellas descripciones y conmovedores relatos, aprecia la belleza de los dibujos y grabados y todo ello contribuye poderosamente a que insensiblemente vaya desarrollando sus facultades intelectuales, su gusto y sus aficiones.

$\mathrm{Y}$ esto viene a cuento porque hasta nosotros llegan algunos tomos de las interesantes y sugestivas bibliotecas que la casa editorial Hijos de Santiago Rodríguez, de Burgos, ha publicado últimamente.

Son tantas y todas tan bonitas que nos limitaremos a consignar aquí el nombre de algunas de aquellas colecciones: la "Biblioteca Paz", cuyo primer tomo, titulado "Mi Libro de Navidad" es de lo más original, sugestivo y variado que para niños puede hacerse; la "Biblioteca ProCultura" en cuyos tomos se tratan materias tan interesantes como "El Libro de Historia", "El Libro de la Naturaleza", "El Libro de Literatura", "El Libro de Viajes"; los deliciosos “Álbums Infantiles", abecedarios que serán el encanto de los pequeños y con los cuales aprenderán los primeros 
balbuceos del idioma, deleitándose con los atractivos y chispeantes dibujos de que están cuajados; y, finalmente la artística y magnífica "Biblioteca Rodríguez" para la juventud, alarde de buen gusto y en la que colaboran los más prestigiosos literatos y artistas contemporáneos.

Muchas otras bibliotecas tienen publicadas esta conocida casa, desde cuentos del más ínfimo precio hasta tomos lujosísimos, que constituyen soberbios regalos y en todos ellos campea la amenidad junto al interés, las enseñanzas provechosas con la más sana moral.

Sinceramente felicitamos a la casa Rodríguez que, con sus publicaciones infantiles, da una nota de alta cultura nacional y de moderna orientación hacia la educación de los niños de hoy, los hombres del porvenir.

Por ello aconsejamos a los padres de familia visiten en estos días la exposición de libros infantiles que la citada casa Rodríguez tiene instalada, y en ella podrán adquirir aquellos que sean más de su agrado, como obsequio duradero y de gran utilidad para sus hijos, no solo en nuestro preciado idioma, sino también en francés e inglés para los niños que estudien estos idiomas. 
LA EDITORIAL BURGALESA HIJOS DE SANTIAGO RODRÍGUEZ (1891-1936): ANÁLISIS DE LOS LIBROS ESCOLARES

\section{LAS BIBLIOTECAS RODRIGUEZ}

Hora es ya de que prestemos algu. na atención a las varias e interesant publicaciones aparecidas últim»mente para pasto do las jóvenes inteligencias, de los pequeños lectorcillos.

Abandonando por un momento los tomas serios y sesudos, internémonos por los bellos países de ensueño, por las deliciosas y no menos atrayenter páginas de esta lit эratura genuin̨. mente infantil.

En España, desgraciadamente, no se ha generalizado toda vía suficiante. mente la culta y delicada costumbre, arraigada hace ya tiempo en otros países más adelantados, de conceptuar el libro como objeto predilecto par. regalo a los muchachos, muy espe. cialmente en los días de Navidad, A ño Nuøvo y Rayes.

Pero poco a poco, y gracias a los trabajos de algun 9 s casas editoriales, los padres que verdadoramente se interesan por la educacióa de sus hijos, van relegands al olvido aque. llos juguetes y cachibaches, casi siempre inútiles y do pasajero solaz, dando preferencia a estos tomitos que on manos de los incipientes y curiosss lectorcillos constituyen, a ro dudarlo, el más preciado y positivo pasationpo.

La ventaja del libro bueno $y$ bien hecho as indiscutible: s9 desarrolla on el muchacho ol gusto a la lectura y al estudio, aprendo mil y mil cosas pro. vechosas, se recrea on las bellas dos cripciones y conmovedores relates, aprecia la belleza de los dibujos y grabados y todo ello contribuye podo. rosamente a que insansiblemente vaya desarrollando sus facultades intelec. tuales, su gusto y sus a ficiones.

Y esto viene a cuento porque hasta nosotros llegan algunos tomos do $\mathrm{li}_{\mathrm{g}}$ interesantes y sugestivas bibliotecs que la casa editorial Hijos de Santiago Rodriguez, de Burgos, ha publicado últimamente.

Son tantas y todas $\tan$ bonitas que nos limitaremos a consignar aqui el nombre do algunas de aquellas coleo ciones: la «Biblioteca Paz, cuyo primer tomo, titulado $4 \mathrm{Mi}$ Libro de Navidad, es de lo más original, sugestivo y variado que para niñós puede hacerse; la iBiblioteca Pro Cultura, on cuyos tomos se tratan materias tan interesantes como \& ? Libro de Historia ‘, «El Libro de la

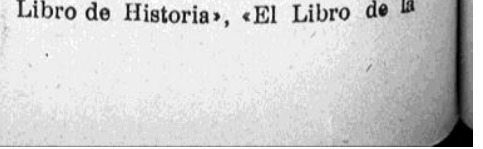

Vaturaleza", El Libro de Literatu ra, "El Libro de Viajes"; los deliciosos albums Infantiles", abecedarios que serán el encant's de los pequeñosy que serán elencantenderá lo prim con los cuales apistán los primgros balbucaos del idioma, deleitándose con los atractivos $y$ chispeantes dibu. jos de que están cuajados; y, finalmento la artística y magnífica "Biblioteca Rodríguez» para la juventud, nlarde di buon gusto y en la que colaboran los más prestigiusos liter tos y artistas contem poráa eos.

Muchas otras bibliote as tiene publicadas esta conocida cass, deste cuentos del más ínfimo precio hasta tomos lujosísimos, gus constituyen soberbios regalos y en todos ellos cam pea la amenidad junto al interés, las enseñanzas provechosas con la más sana mural.

Sincoramente fulicitamos a la casa Rodriguez que, con sus publicaciones infantiles, da una nota de alta cu'tura nacional y de moderna orisntación hacia la educación do los niños de hoy, los hombres del purvenir.

Por ello acons jamos a los padres de familia visiten en estos días la exposición de libros infantiles que la citada casa Rodríguez tiene instalada, yen ella podrán adquirir aquellos que sean más de su agrado, como ob. sequio duradero y de gran utilidad para sus hijos, no solo en nuastro pro ciado idioma, sin 6 también en francés o inglés para los niños que estudien estos idiomas.

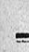

Fig.: 115

Las Bibliotecas Rodríguez en la editorial Hijos de Santiago Rodríguez. El Pueblo, 27 diciembre 1919. 


\section{Bibliografía. Periódico Guasa Viva, 9 de noviembre de 1913.}

Guasa Viva: semanario festivo comenta el agradecimiento por el envío de la nueva publicación de "Mundial Biblioteca", de la editorial Hijos de Santiago Rodríguez que constituye la primera obra de dicha colección y nos relata la inauguración de nueva maquinaria.

\section{Bibliografía}

Hemos enriquecido nuestra escogida Biblioteca con dos ejemplares de la obra "Historias de Don Quijote", que los señores Hijos de Santiago Rodríguez han tenido la atención de enviarnos.

Da la maldita casualidad de que tanto don Domingo M. Berrueta, autor del libro, como D. Evaristo Barrio, ilustrador de la obra, y hasta el propio D. Quijote, son amigos nuestros, y, por tan triste motivo, nos vemos imposibilitados de romper en su honor el parche del bombo.

Otro dato nos acontece con los editores Sres. Hijos de Santiago Rodríguez, y así, únicamente diremos que los dos ejemplares recibidos conservan la huella de la rica baba que se nos ha deslizado al contemplar aquellos magníficos fotograbados a dos tintas y doble tono, y aquella lujosa y exquisita presentación de toda la obra.

Este es el primer volumen de la serie "Mundial Biblioteca" que en la citada casa se edita y si para muestra un botón, seguros estamos de que no habrá persona de buen gusto que no desee lucir toda la botonadura.

Don Quijote, Apeles, Gutenberg y nosotros estamos satisfechos.

Nuestra enhorabuena, distinguidos amigos.

Aunque no sea cosa de bibliografía, conste que hemos visto la Biblia de cosas gráficas y por eso se lo vamos a colocar a ustedes en esta sección.

Los señores Hijos de Santiago Rodríguez, nos invitaron el pasado viernes a presenciar el funcionamiento de unas nuevas máquinas que han instalado en sus hermosos talleres: Una minerva "Victoria", que ha de proporcionarles victorias sin cuento, y una "Planeta", que es de lo mejorcito que hemos visto en el ídem.

Admiramos también, entre otras cosas, una magnífica "Bremen" inglesa, que lleva trabajando la friolera de 39 otoños sin detrimento de sus férreas morbideces.

Esta es la primera inglesa entradita en años que ha conseguido arrancarnos cuatro piropos.

Los talleres de los señores Hijos de Rodríguez son un museo de verdaderas joyas tipográficas, y nos felicitamos muy mucho de contar en Burgos con industriales que tan alto ponen el nombre de nuestra querida ciudad. 
Don Mariano Rodríguez, con exquisita amabilidad, obsequió a sus numerosos y distinguidos invitados con sabroso moka, riquísimas brevas y bebestibles de varias clases.

Y conste que a cierto colega también les cayó su correspondiente breva, aunque no lo ha dicho.

\section{Q DA EA NIVA}

-El pasado martes marcho á Pradoluengo rel êputado provincial D. Fsorentino Markínez Mingo.

- Ha regresado de sus posesiones, S. A. el Príncipe de Covarrubias, D. Enrique Cecilia de la Morena.

Sea bienvenido el ilustre viajero $\mathrm{y}$ buen amigo.

\section{Hoticias yarias}

Despuéz de brillantes y arriesgados ejercicios se ha licenciado en Medicina y Cirugía, nuestro muy querido amigo $D$. Isidro Cameno.

Reciba el nuevo médico la más cordial enhorabuena.

- Según nuestro estimado colega eNuevo Mundos ha sido nombrado gobernador civil de Barcelona el ilustrado abcgado de esta capital D. Benito M. Andrade.

Sea enhorabuena.

- Ha sido destinado á Larache nuestro estimado amigo el oficial segundo de Intendencia D. José Sañudo de Madrazo.

- Nuestro estimado compañero en la prensa D. José Celma, redactor dè «El Nervión», de Bilbao, se encuentra en Burgos pasando una temporada.

- También se encuentra entre nogotros, dis frutando una licencia de 40 días, por enfermo el joven alumno de la Acsdemia de Iofantería D. Victorino Sáez y Sáez.

\section{Una boda}

El pasado miércoles y en el oratorio parti. cular de casa de la novia, se celebró el matrimonio del distinguido joven D. Pascual Moliner Escudero y la encantadora señorita Consuelo Pérez del Molino.

Los novios á quienes deseamos inacabable luna de miel, marcharon á Valladolid, Madrid y otras poblaciones.

то́то.

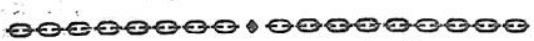

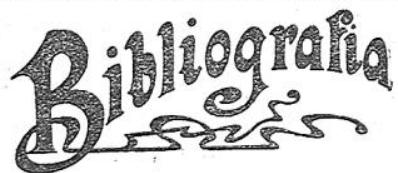

Hemos enriquecido nuestra escogida Biblioteca con dos ejemplares de la obra $e$ Historias de Don Quijote», que los señores Hijos de Santiago Rodríguez han tenido la atención de en. viarnos.

Dá la maldita casualidad de que tanto don Domingo M. Berrueta, autor del libro, como
D. Evaristo Barrio, ilustrador de ia obre, $y$ hasta el propio D. Qiijote, son amigos nuestros, y, por tan triste motivo, nos vemos imposibilitados de rompar en su honor el parche del bombo.

Otro tanto nos acontece con los editores Sres. Hijos de Santiago Rudrígu: z, y at í, únicamente diremos qne los dos ejemplares ricibidos conservan la huella de la rica baba que se nos ha deslizido al contemplar aquellos magniflcos fotograbados á dos tintas y doble tono, y aquella lajosa y exquisita presentación de toda la obra.

Este es el primer volamen de la serie "Mundial Bibliotecas que en la citada casa se edit?, y si para muestra basta un botón, seguros estamos de que no habrá percona de buen gusto que no desie lucir toda la botonadua.

Dor Qu jote, Apeles, Guttenbarg y cosotroe, estamos satisfechos.

Nuestra enhorabuena, distinguidos amigos. $\therefore$

Aunque no sea cosa de bibliografía, conste que hemos visto la biblia de cosas gráficas y por eso se lo vamos á culocar á natż a 3 en esta sección.

Los señores Hijos de Santiago Rodríguez, nos invitaron el pasado viernes $\{$ presenciar el funcionamiento de unas nusvas máquinas que han instalacio en sus hermosos talleres: Una minerva "Victoria», que ha de proporcionarles victorias sin cuento, $\mathrm{y}$ una sPlaneta s, que es de lo mejorcito que hemos visto en el ídem.

Admiramos también, entre otras cosas, una magníflca $₫$ Brement inglesa, que lleva traba jando la friolera de 39 otoños sin detrimento de sus férreas morbideces.

Esta es la primera ingless entradita en años que ha conseguido arrancarnos cuateo piropos.

Ios talleres de los señores Hijos de Rodríguez son un museo de verdaderas joyas tipo: gráficas, y nos felictamos muy mucho de contar en Burgos con industriales que tan alto ponen el nombre de nuestra querida ciudad.

Don Mariano Rodríguez, con exquisita amabilidad, obsequiơ á sus numerosos y distingnidos invitados con sabroso moka, riquísimas brevas y bebestibles de varias clases.

Y conste que á cierto colega también les cayó su correspondiente breva, aunque no lo ha dicho.

\footnotetext{
GONOZIN - GONOZÍN - GONOSÁN Contra la blenorragia. Lismuy discreto en su uso y hace desaparecer el tluju en pocos dias.
}

D. renta on todis tas fapracios.

Fig.: 116

Nuevas máquinas y nuevos ejemplares en la editorial Hijos de Santiago Rodríguez.

Guasa Viva, 9 de noviembre de 1913. 


\section{Artículo breve de opinión de Mariano Rodríguez Miguel sobre su} visión de Burgos. Periódico Guasa Viva, 28 de junio de 1914.

El periódico Guasa Viva: semanario festivo publica en cada uno de sus números opiniones de miembros destacados burgaleses sobre cómo ven a Burgos. Mariano Rodríguez escribe lamentándose de las dificultades que tienen todos aquellos que tienen iniciativas para mejorar la situación de la ciudad.

\section{9.}

Silos burgaleses nos quisiéramos y protegiésemos, como deben quererse y protegerse los que en el mismo suelo racieron; si pusiéramos en él aplauso y en el estímulo todo el calor que en la crítica y la censura empleamos sería más fecunda la labor de los que trabajan y llegarían a sazón algunas buenas iniciativas que muleren en flor.

Por ser como somos, esta Burgos como estả.

\section{Marianò Rodríguez Migicel.}

Director de "La Impar cialidad"

25 Junio: 1914.

Fig.: 117

Opinión de Mariano Rodríguez Miguel sobre Burgos.

Guasa Viva, Año 2 n 67, 28 junio 1914, p. 9. 


\section{Expositores burgaleses. Diario de Burgos, 1 de diciembre de 1908.}

\section{Expositores burgaleses.}

$\mathrm{El}$ arte de imprimir tiene en Burgos un brillante pasado; los impresores, un abolengo ilustre.

A los pocos años de inventarse la imprenta, Burgos rivalizaba con Alemania: en el Museo Británico, y considerados como joyas hay ejemplares impresos en Burgos en el año 1485, entre éstos un ejemplar de "Glosas de las coplas de Mingo Repulgo".

En la Biblioteca provincial hay ejemplos curiosísimos: "El libro de albaitería" (veterinaria) por el burgalés Francisco Reina, que en la página 49 habla ya de la circulación de la sangre, cuando aún no había nacido Harvey, a quien se concede el honor de haberla descubierto.

Esta obra fue impresa en Burgos el año 1564.

La traducción del "Dante", por don Pedro Villegas, impresa en Burgos en 1515 .

La Crónica del "Famoso Caballero Cid Ruiz-Díaz Campeador", impresa en Burgos, con una portada preciosa, en 1592.

Obras artísticas, admirables, prueban el adelanto de los impresores de Burgos y el gusto artístico y literario de sus vecinos.

En siglos posteriores no decayó y entre las muestras de buen gusto y riqueza de los artistas impresores de nuestra ciudad recuerdo las "Ordenanzas del Excmo. Ayuntamiento de Burgos, cuya impresión, año 1625 , y dibujos, son verdaderas joyas.

Ya en tiempos actuales, todos hemos conocido la imprenta de D. Timoteo Arnaiz, de legendario recuerdo como alcalde de Burgos; la del señor Polo, gran latino, excelente humanista, autor de varias obras en este Instituto, y que elevó su arte al sacerdocio, por el cuidado y esmero con que llevaba a cabo sus trabajos, que no necesitaban nunca ser corregidos; la antiquísima de los señores Villanueva, continuada de padres a hijos; la de Cariñena, y otras que no recordamos.

No llegaba a tanto D. Santiago Rodríguez, al que todos los cincuentones recordamos con cariño.

Activo, laborioso, trabajador, fundó su establecimiento de librería hacia mediados del siglo pasado. Era un buen tipo de castellano viejo, del genuino burgalés.

Su físico parecía exigir la cota de malla y el casco de los escuderos del Cid, pero su aspecto de guerrero era desmentido por su simpática mirada y agradabilísimo trato; alegre, dicharachero, amigo y conmilitón de los buenos burgaleses Lorencito Rincón, Sarachu Marrón, Los Roscones, Los Cármenes y tantos otros que recuerdo con gusto, porque con su alegría y 
graciosas bromas animaban a este querido Burgos, que si de algo peca es de serio y tristón.

Santiago Rodríguez, gran trabajador, sin temor a competencias, con tantos y tan buenos impresores, fue extendiendo su modesta librería; empezó por hacer tarjetas, más tarde, a su industria de librero y almacenista de papel y objetos de escritorio, añadió editar obras de primera enseñanza, a cuya especialidad tenía gran cariño.

A este fin y compró una máquina "Bremen", de gran tamaño; lanzado ya en este camino, ensanchó su esfera de acción y llegó a figurar un burgalés entre los editores españoles.

Por sus iniciativas y seriedad en los negocios, su nombre fue respetado en el comercio y consiguió ser premiado con diploma y medallas en las Exposiciones de 1882, 1885 y en las de Barcelona de 1888.

He tenido el placer de dedicar este recuerdo a la memoria del buen Santiago, no sólo por afecto, sino porque creo que en Burgos se padece la enfermedad del olvido para con sus hijos, y creo también que ya es hora de que todos, y aprovechando todas las ocasiones, vayamos haciendo justicia a los que poco a poco, en silencio y con modestia, hacen culto, simpático y agradable el nombre de Burgos, y poco a poco también contribuyen a que nuestra ciudad sea conocida y respetada.

Fallecido don Santiago, heredó su industria y actividad su hijo Mariano, simpático burgalés, que es vocal necesario en todas las juntas ya asociaciones en las que se trate de hacer algo por Burgos.

Mariano Rodríguez, de tal modo ha ensanchado la esfera de acción de su casa, que hoy su razón social es conocida en España y en primera fila como casa editora y muy especialmente entre las que se dedican al ramo de la primera enseñanza.

Su casa tiene amplios talleres, cuatro grandes máquinas, que funcionan movidas por electricidad; hace toda clase de trabajos tipográficos y edita obras, propiedad de la casa Hijos de Santiago Rodríguez.

En España y América son conocidísimas las obras de los señores Rodríguez, y las medallas de oro en la Exposición Internacional de Madrid y en la actual de Zaragoza han sancionado la labor meritísima de una industria burgalesa.

F. Cecilia. 


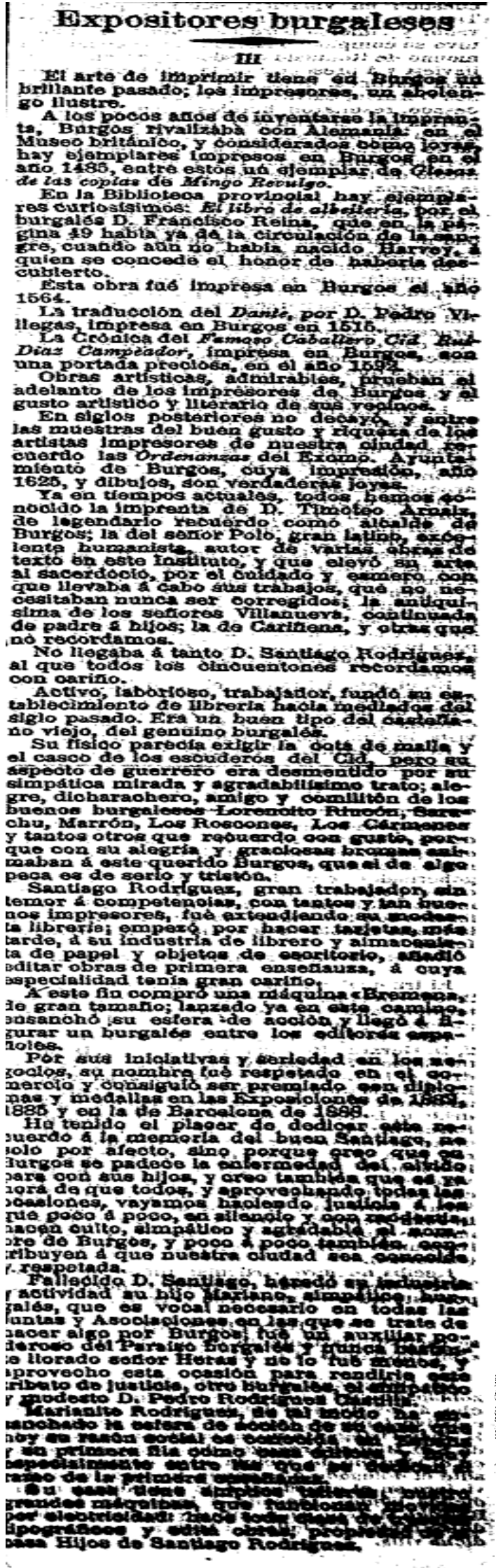

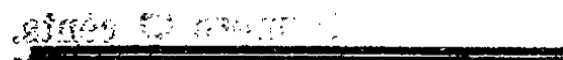

Dì Espata y América son conociałsimes ing obras de las señores Rodriguez, y las medalises de oro en is Exposicion Internaecionalde Madrid y en la actual de Zaragoza hair sameionado is itbor meritisima de una induotria bergalesa.

F. Caciuls.

Fig.: 118

Diario de Burgos, 1 de diciembre de 1908. 


\subsection{DOCUMENTOS NECROLÓGICOS}

Necrología de la figura de D. Santiago Rodríguez Alonso en el libro de Juan Valero de Tornos España en fin de siglo, segundo tomo, 1896.

La obra es una crónica con referencias históricas, artísticas, industriales de cada provincia, incluyendo apuntes biográficos, empresas y fábricas de cada provincia en el final del siglo XIX. Además contiene los estudios relativos a la España musical por el Conde de Morphy; la España jurídica por Francisco Silvela, la España política descrita por Emilio Castelar y la España literaria por Luis Ruiz Contreras.

En las páginas 108 a 110, nos relata una biografía en forma de necrología del fundador de la casa Editorial burgalesa, añadiendo un artículo muy significativo después del fallecimiento del anterior sobre la nueva empresa Hijos de Santiago Rodríguez.

\section{SANTIAGO RODRIGUEZ ALONSO}

\section{NECROLOGIA}

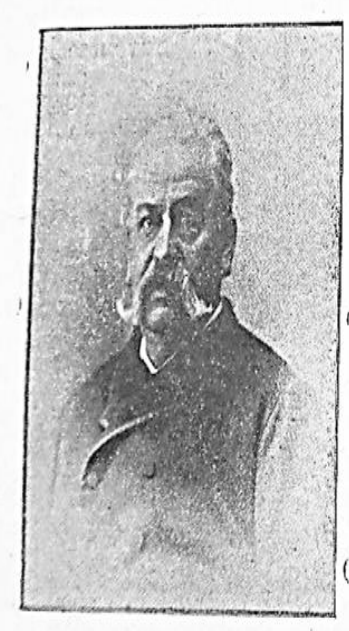

Dou Santiago Bodríguez Alouso

Nació nuestro biografiado en Burgos el 25 de Julio de 182 y estudió en la misma capital la segunda ensen̂anza, obteniend, el grado de Bachiller en artes en el año 1844; pero en verde seguir una carrer'a científica ó literaria, abandonó las aulas emprendió con fé y entusiasmo su vida industrial, para la y manifestaba inteligencia y dotes poco comunes, realizando bien pronto las ideas y empresas que su pensamiento le indicara

Después de haber adquirido en Madrid durante los años 1846 al 50 los conocimientos y práctica indispensables, regresó á Burgos y fundó su librería y hoy casa editorial de primer orden y de gran importancia. Desde el primer momento mani. festó tal estimación por la enseñanza, por la educación y por el Nagisterio, que no se dió momento de reposo hasta ver en su establecimiento todo cuanto de más notable, más nuevo y más útil existía entonces para dicho ramo. Libros, menaje, aparatos de todo ofreció á los dignos maestros de la provincia.

Como no podía menos de suceder, dado el cariño que el seî́or Rodríguez profesaba á todo lo que con la ensen̂anza se re-

lacionara, era uno de los propagandistas más activos de las nuevas ideas pedagógicas de suitiempo. Los diferentes certámenès pedagógicos que con brillante resultado se Lan celebrado en Bur-

Fig.: 119

Necrología de D. Santiago Rodríguez Alonso.

España fin de siglo. Juan Valero de Tornos. 1896.

Biblioteca Pública de Navarra. 
ros, deben al Sr. Rodriguez su sxito, pues adomás do contribuir con sus trabajos ó iniciativas, regalaba para premios valiosisimos libros y animaba í todo el mundo á entrar en tan nobles campainas.

peseoso do servir más emmplidamente í los intereses de la enseînanya, adquirió la propiedad de la revista profesional La . Imparciatidad, quo ya de antigno se publieaba on la ciudad del Citl,

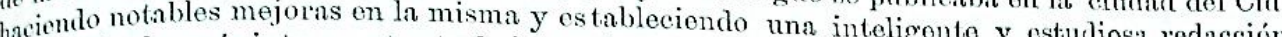
que publica los más interesantes trabajos pedigógicos, a la vez que sostiene las campañas mís enérgicas en fivor del bienestar moral y material de los maestros. En gran parte so le debo que sea esta la única provincia de Espnña que tiene satisfechas todas las atenciones de enseíanza.

En 1852 celobrose en Burgos una Exposición provincial, en donde el Sr. Rodríguez instaló una escuela modelo, por lo que obturo el premio de honor.

Desde su establecimiento, que iba perfeccionando de día on día, y sin abandonar un momento su industria, en li que era peritísimo, hizo grandes favores á todo aquel que se ncercaba í pedir su proteceión, sin que nunca hiciera alarde do ello, sucediendo lo mismo con los que contribuyó á la prosperidad de la industria y el comercio burgalés. Essto hizo que por una gran votación fuese elegido Concejal del Municipio en 1864, habiendo formado parte de tan respetable Corporación, con pequeî́os intervalos, hasta el año 1874, que fuó nombrado Diputado provincial por el distrito de Burgos-Sedano.

La conducta noble y patriótica que nuestro biografiado siguió en ambas Corporaciones, el interés que por todos los asuntos se tomaba y lo bien que se portó como representante del pueblo, hizo que se le concediera en Julio de 1874 la cruz de Carlos III, que rechazó, pues dijo que no queria más honores y recompensas que los quo su trabajo le proporcionara.

Hermoso rasgo que prueba la humildad del Sr. Rodríguez.

Desgracias de familia y desengaños políticos hicieron que el Sr. Rodríguez se retirara de la rida pública y se dedicase con mayor empeño í su negocio, que entonces adquirió mayor desarrollo, con el establecimiento de una imprenta, con todos los adelantos, en 1879. Inauguró sus trabajos tipogáficos, tirando un precioso cartel en el que nuestro biografiado dedicaba su primer trabajo á la ciudad de Burgos, y en su representación á la prensa local como prueba del gran cariño que profesaba al pueblo que le vió nacer.

Ensanchando su negocio continuó hasta el año 1891, en que una cruel enfermedad le arrebató la vida cuando más le sonreía el porvenir y cuando iba recogiendo el fruto de su largo trabajo, dejando en el mayor desconsuelo á su distinguida familia y numerosos amigos. Su muerte fué sentidisima en la capital de Castilla, y en particular por el Mragisterio burgalés, á quien tantos favores debia.

Entonces la prensa local dió cuenta de la imponente manifestación de duelo celebrada con motivo de su entierro, y la consagrada al interesante ramo de la enseńanza publicó la biografia de este querido y popular industrial, verdadero hijo del trabajo y verdadero antor de su bienestar y de su buen nombre, rindiendo así justo homenaje al que por mís de un concepto era acreedor de él.

\section{IMPPEENTA Y LIBBEERIA DE LOS HIJOS DE SANTIAGO RODRíGUEZ}

No es Burgos de las poblacionos que su industria y comercio hacen más ruido ni se extienden Pero no por eso deja de tener establecimientos que, por su importancia $y$ crédito, pueden competir con los primeros do España.

Entre éstos, pocos por desgricia, se cuental la imprenta y libreria de que nos vamos á ocupar.

Herederos los Sres padre, lo que hnco que continúe la cnsa en la misma forma y con el mismo crédito que cuando vivía su fundador, á quien yn homos biografiado.

La librerín estí muy bien servida, y on ella so enouentra oompleto surtido on obras de Medicina, Derecho, Cienoins y literarias: pero lo que más ouenta, $y$ on lo que más puede competir con

las primeras de Españn, es en el ramo de onseñanza, al que con verdadero amor se dedica. All se hallan cuantas novedndes pedngógicas se oonocen, y ol surtido

Fig.: 120

Necrología de D. Santiago Rodríguez Alonso. España fin de siglo. Juan Valero de Tornos. 1896.

Biblioteca Pública de Navarra. 
110

ESPAÑA EN FIN DE STGLO

las es tan selecto y abundante que, al tener ocasión de visitar dicho establecimiento, nos pare

cia mentira que no fuese más conocido, contribuyendo a ello la suma modestia de sus posedores.

El Magisterio y la enseñanza tienen en esta casa un completo y acabado Museo y una com.

pleta y acabada Biblioteca.
Cansa asombro ver los libros, los objetos varios, los utensilios y la abundancia do todo

Canto han reunido los Hijos de Santingo Rodriguez, que allí se halla cuanto de más eleganto más lujoso y más artístico se desee.

Pero si al visitar la libreria sufrimos agradable sorpresa, no fuó menos la que experiment mos al penetrar en el establecimien to tipográfico.

Fundado, como ya hemos dicho, en 1879 , con todos los adelantos modernos, se halla estable cido en un espacioso local: consta de tres grandes máquinas de los sistemas Brenmer y Marino con una pequeña Minerva, además de las guillotinas y prensas destinadas á cortar y satinon papel. En ellas se tiran admirablemente, con limpieza completa en la tirada, con tipos nuer el preciosos y con una estampación perfecta, numerosos libros de enseñanza que acreditan y establecimiento.

Las ediciones pueden competir con las de Madrid y Barcelona, y en ellas se ven grabados cromos y viñetas, sin disputa alguna, de lo más artístico quo se ha publicado $\mathrm{y}$ que se puede exigir.

Una de las muchá pruebas que podíamos dar de la importancia de la casa que nos ocupa, es el numeroso y entendido personal que sostiene

Come no podía menos de suceder á una casa de las condiciones de ésta, cuenta con varios premios que por sus buenos trabajos y grandes adelantos ha alcanzado. En 1882 obtuvo el premio de honor por la instalación de una escuela modelo, y medalla de plata por los trabajos tipográ ficos en la Exposición provincial celebrada en dicho año; medalla de bronce en la regional gonesa celebrada en 1885 en Zaragoza, por las obras de enseňanza presentadas; seis del mismo metal en la universal de Barcelona de 1888, por varios conceptos relacionados todos con su negocio; y últimamente, en la Exposición pedagógica celebrada en Valladolid en 1894, obturo gra diploma por las varias obras de enseñanza de su propiedad.

Fig.: 121

Necrología de D. Santiago Rodríguez Alonso. España fin de siglo. Juan Valero de Tornos. 1896.

Biblioteca Pública de Navarra.

\section{SANTIAGO RODRÍGUEZ ALONSO}

\section{NECROLOGÍA}

Nació nuestro biografiado en Burgos el 25 de Julio de 1829, y estudió en la misma capital de segunda enseñanza, obteniendo el grado de Bachiller en artes en el año 1844; pero en vez de seguir una carrera científica o literaria, abandonó las aulas y emprendió con fe y entusiasmo su vida industrial, para la que manifestaba inteligencia y dotes poco comunes, realizando bien pronto las ideas y empresas que su pensamiento le indicara.

Después de haber adquirido en Madrid durante los años 1846 al 50 los conocimientos y práctica indispensables, regresó a Burgos y fundó su librería y hoy casa editorial de primer orden y de gran importancia. Desde el primer momento manifestó tal estimación por la enseñanza, por la educación y por el Magisterio, que no se dio momento de reposo hasta ver en su establecimiento todo cuanto de más notable más nuevo y más útil 
existía entonces para dicho ramo. Libros, menaje, aparatos de todo ofreció a los dignos maestros de la provincia.

Como no podía menos de suceder, desde el cariño que el señor Rodríguez profesaba a todo lo que con la enseñanza se relacionara, era uno de los propagandistas más activos de las nuevas ideas pedagógicas de su tiempo.

Los diferentes certámenes pedagógicos que con brillante resultado se han celebrado en Burgos, deben al Sr. Rodríguez su éxito, pues además de contribuir con sus trabajos e iniciativas, regalaba para premios valiosísimos libros y mimaba a todo el mundo a entrar en tan nobles campañas.

Deseoso de servir más cumplidamente a los intereses de la enseñanza, adquirió la propiedad de la revista profesional La Imparcialidad, que ya de antiguo se publicaba en la ciudad del Cid, haciendo notables mejoras en la misma y estableciendo una inteligente y estudiosa redacción que publica los más interesantes trabajos pedagógicos, a la vez que sostiene las campañas más enérgicas en favor del bienestar moral y material de los maestros. En gran parte se le debe que sea ésta la única provincia de España que tiene satisfechas todas las atenciones de enseñanza.

En 1882 se celebró en Burgos una Exposición provincial, en donde el Sr. Rodríguez instaló una escuela modelo, por lo que obtuvo el premio de honor.

Desde su establecimiento, que iba perfeccionando día a día y sin abandonar un momento su industria, en la que era peritísimo, hizo grandes favores a todo aquel que se acercaba a pedir su protección, sin que nunca hiciera alarde de ello, sucediendo lo mismo con lo que contribuyó a la prosperidad de la industria y el comercio burgalés. Esto hizo que por una gran votación fuese elegido concejal del Municipio en 1864, habiendo formado parte de tan respetable Corporación, con pequeños intervalos, hasta el año 1874, que fue nombrado Diputado provincial por el distrito de Burgos-Sedano.

La conducta noble y patriótica que nuestro biografiado siguió en ambas Corporaciones, el interés que por todos los asuntos se tomaba y lo bien que se portó como representante del pueblo, hizo que se le concediera en Julio de 1874 la cruz de Carlos III, que rechazó, pues dijo que no quería más honores y recompensas que los que su trabajo le proporcionara.

Hermoso rasgo que prueba la humildad del Sr. Rodríguez.

Desgracias de familia y desengaños políticos hicieron que el Sr. Rodríguez se retirara de la vida pública y se dedicase con mayor empeño a su negocio, que entonces adquirió mayor desarrollo, con el establecimiento de una imprenta, con todos los adelantos, en 1879. Inauguró sus trabajos tipográficos, tirando un precioso central en el que nuestro biografiado dedicaba su primer trabajo en la ciudad de Burgos, y en su representación a 
la prensa local como prueba del gran cariño que profesaba al pueblo que le vio nacer.

Ensanchando su negocio continuó hasta el año 1891, en que una cruel enfermedad le arrebató la vida cuando más le sonreía el porvenir y cuando iba recogiendo el fruto de su largo trabajo, dejando con el mayor desconsuelo a su distinguida familia y numerosos amigos. Su muerte fue sentidísima en la capital de Castilla, y en particular por el Magisterio burgalés, a quien tantos favores debía.

Entonces la prensa local dio cuenta de la imponente manifestación de duelo celebrada con motivo de su entierro, y la consagrada al interesante ramo de la enseñanza publicó la biografía de este querido popular industrial, verdadero hijo del trabajo y verdadero autor de su bienestar y de su buen nombre, rindiendo así justo homenaje al que por más de un concepto era acreedor de él.

\section{IMPRENTA Y LIBRERÍA DE LOS HIJOS DE SANTIAGO RODRÍGUEZ}

No es Burgos de las poblaciones que su industria y comercio hacen más ruido ni se extienden a mayores distancias. Pero no por eso deja de tener establecimientos que, por su importancia y crédito, pueden competir con los primeros de España.

Entre éstos, pocos por desgracia, se cuenta la imprenta y librería de que nos vamos a ocupar.

Herederos los Sres. Rodríguez de un honrado apellido, según la huella que fiel les trazara su padre, lo que hace que continúe la casa en la misma forma y con el mismo crédito que cuando vivía su fundador, a quien ya hemos biografiado.

La librería está muy bien servida, y en ella se encuentra completo surtido en obras de Medicina, Derecho, Ciencias y literarias: pero la que más cuenta, y en lo que más puede competir con las primeras de España, es en el ramo de enseñanza, al que con verdadero amor se dedica.

Allí se hallan cuantas novedades pedagógicas se conocen, y el surtido de menaje para escuelas es tan selecto y abundante que, al no tener ocasión de visitar dicho establecimiento, nos parecía mentira que no fuese más conocido, contribuyendo a ello la suma modestia de sus poseedores.

El Magisterio y la enseñanza tienen en esta casa un completo y acabado Museo y una completa y acabada Biblioteca.

Causa asombro ver los libros, los objetos varios, los utensilios y la abundancia de todo cuanto han reunido los Hijos de Santiago Rodríguez, que allí se halla cuanto de más elegante más lujoso y más artístico se desee.

Pero si al visitar la librería sufrimos agradable sorpresa, no fue menos la que experimentamos al penetrar en el establecimiento tipográfico. 
Fundado, como ya hemos visto, en 1879, con todos los adelantos modernos, se halla establecido en un espacioso local: consta de tres grandes máquinas de los sistemas Brenmer y Marinoni, con una pequeña Minerva, además de las guillotinas y prensas destinadas a cortar y satinar el papel. En ellas se tiran admirablemente, con limpieza completa en la tirada, con tipos nuevos y preciosos y con una estampación perfecta, numerosos libros de enseñanza que acreditan al establecimiento.

Las ediciones pueden competir con las de Madrid y Barcelona, y en ellas se ven grabados, cromos y viñetas, sin disputa alguna, de lo más artístico que se ha publicado y que se puede exigir.

Una de las muchas pruebas que podíamos dar de la importancia de la casa que nos ocupa, es el numeroso y entendido personal que sostiene.

Como no podía menos de suceder a una casa de las condiciones de ésta, cuenta con varios premios que por sus buenos trabajos y grandes adelantos ha alcanzado. En 1882 obtuvo el premio de honor por la instalación de una escuela modelo, y medalla de plata por los trabajos tipográficos en la Exposición provincial celebrada en dicho año; medalla de bronce en la regional aragonesa celebrada en 1885 en Zaragoza, por las obras de enseñanza presentadas; seis del mismo metal en la universal de Barcelona en 1888, por varios conceptos relacionados todos con su negocio; y últimamente, en la Exposición pedagógica celebrada en Valladolid en 1894, obtuvo gran diploma por las varias obras de enseñanza de su propiedad. 


\subsection{INVENTARIO DE LA LIBRERÍA E IMPRENTA DE SANTIAGO RODRÍGUEZ EN 1891}

Todo el inventario de la empresa Imprenta y librería de Santiago Rodríguez fue dividido en varios apartados, se han seleccionado aquellos datos que interesan al estudio como son por una parte el activo en caja y sobre todo el material en almacén o en tienda, así como la maquinaria de la imprenta y los saldos deudores y acreedores para conocer la dotación empresarial.

En cuanto al material de almacén y de tienda se ha centrado en los libros tanto escolares como literarios, dejando sin transcribir todo el amplio material en papel y escolar, sobres, de escritorio, así como otros útiles de tipo administrativo, religioso o de uso corriente.

\section{Activo en caja al fallecimiento de D. Santiago Rodríguez Alonso.}

Activo

Reales Pesetas

Caja: Existencias en la misma en efectivo.

$10.000 \quad 2.500$ 
LA EDITORIAL BURGALESA HIJOS DE SANTIAGO RODRÍGUEZ (1891-1936): ANÁLISIS DE LOS LIBROS ESCOLARES

Inventario de libros en el almacén.

\begin{tabular}{|c|c|c|c|}
\hline & ALMACÉN & $\begin{array}{l}\text { Precio en } \\
\text { Reales por } \\
\text { unidad }\end{array}$ & $\begin{array}{l}\text { Precio de } \\
\text { los } \\
\text { ejemplares }\end{array}$ \\
\hline 3000 & Higiene por Carretero & 1 & 3.000 \\
\hline 1500 & Catones por Seijas & 0,20 & 300 \\
\hline 200 & Amigos de los niños (en rama) & 0,40 & 800 \\
\hline 320 & Guía de Burgos por Buitrago & 6 & 1.920 \\
\hline 1000 & $\begin{array}{l}\text { Historia de la Instrucción Pública en } \\
\text { España }\end{array}$ & 9 & 9.000 \\
\hline 100 & $\begin{array}{l}\text { Historia de la Instrucción Pública en } \\
\text { España (pasta) }\end{array}$ & 10 & 1.000 \\
\hline 175 & Geografía por Rives (rama) & 10 & 1.750 \\
\hline 6000 & $\begin{array}{l}\text { Tablas de reducción de arrobas a } \\
\text { kilos }\end{array}$ & 0.1 & 600 \\
\hline 10000 & Cubiertas de Higiene al cromo & & \\
\hline 26 & Ejemplares Iris del cristiano & 6,29 & 163 \\
\hline 34 & Ejemplares Kempis & 3,5 & 119 \\
\hline 9 & Ejemplares Devocionario & 6,25 & 56,25 \\
\hline 13 & $\begin{array}{l}\text { Ejemplares Manual de los PP. } \\
\text { Jesuitas }\end{array}$ & & 13 \\
\hline 11 & Ejemplares Camino Recto & 4,5 & 49,5 \\
\hline 16 & $\begin{array}{l}\text { Ejemplares Visitas al Sto. } \\
\text { Sacramento(letra grande) }\end{array}$ & 3,5 & 56 \\
\hline 35 & $\begin{array}{lll}\text { " } " ~ & \text { (letra } \\
\text { pequeña) } & & \end{array}$ & 3,79 & 142,4 \\
\hline
\end{tabular}




\begin{tabular}{|c|c|c|c|}
\hline 60 & Ejemplares Ejercicio cotidiano & 1,5 & 90 \\
\hline 37 & Ejemplares Semana Santa & 2,5 & 92,5 \\
\hline 23 & Cuentas apuntadas & & 23 \\
\hline 35 & $\begin{array}{l}\text { Ejemplares Ancora de Salvación } \\
\text { grandes }\end{array}$ & 7,25 & 213,75 \\
\hline 18 & $\begin{array}{l}\text { Ejemplares Ancora de Salvación } \\
\text { canto dorado }\end{array}$ & 12 & 216 \\
\hline 13 & $\begin{array}{l}\text { Ejemplares Ancora de Salvación } \\
\text { canto broche }\end{array}$ & 16 & 208 \\
\hline 100 & $\begin{array}{l}\text { Ejemplares Ancora de Salvación } \\
\text { pequeña }\end{array}$ & 5 & 500 \\
\hline 9 & $\begin{array}{l}\text { Ejemplares Ancora de Salvación } \\
\text { canto dorado }\end{array}$ & 7 & 63 \\
\hline 2 & $\begin{array}{l}\text { Ejemplares Ancora de Salvación } \\
\text { canto broche }\end{array}$ & 11,25 & 22,50 \\
\hline 92 & Ejemplares Devoto feligrés & 3,71 & 195 \\
\hline 12 & Ejemplares Ejercicio cotidiano (piel) & 2 & 24 \\
\hline 12 & $\begin{array}{l}\text { Ejemplares Oficio Divino (canto } \\
\text { dorado y borla) }\end{array}$ & & 12 \\
\hline 12 & Ejemplares Iris del Cristiano & & 12 \\
\hline 12 & Ejemplares Hora Divina & & 4 \\
\hline 12 & Ejemplares Lirio Celestial & & 2 \\
\hline 12 & $\begin{array}{l}\text { Ejemplares Maneras de catequizar a } \\
\text { los nuevos fieles }\end{array}$ & & 1 \\
\hline 12 & Ejemplares Domingos de S. Luis & & 0,50 \\
\hline 12 & Ejemplares Regla de la vida & & 0,50 \\
\hline 2 & Ejemplares El nuevo amante de la & 0,75 & \\
\hline
\end{tabular}


LA EDITORIAL BURGALESA HIJOS DE SANTIAGO RODRÍGUEZ (1891-1936):

ANÁLISIS DE LOS LIBROS ESCOLARES

\begin{tabular}{|c|c|c|c|}
\hline & Virgen & & \\
\hline 12 & $\begin{array}{l}\text { Ejemplares Ancora niño. Canto y } \\
\text { broche }\end{array}$ & & 96 \\
\hline 1 & $\begin{array}{l}\text { Ejemplares El secretario de los } \\
\text { amantes }\end{array}$ & & 3 \\
\hline 56 & $\begin{array}{l}\text { Ejemplares Semana Santa grande } \\
\text { pasta }\end{array}$ & 2 & 112 \\
\hline 12 & $\begin{array}{l}\text { Docenas de Ancora de Salvación } \\
\text { niños }\end{array}$ & 24 & 360 \\
\hline 36 & Cuadernos Aritmética Paluzíe & & 36 \\
\hline 20 & Tesoro de la Infancia Ortega y Trías & 1,5 & 30 \\
\hline 24 & Manual de Sacristanes & 1,25 & 30 \\
\hline 14 & Geografía de Lara & & 14 \\
\hline 36 & El necesario para saber comprar & & 36 \\
\hline 20 & El arte en todas sus manifestaciones & & 20 \\
\hline 25 & Fábulas de Hartzenbusch & 2 & 50 \\
\hline 225 & Catecismos largos Paluzíe cartulina & & 100 \\
\hline 10 & Higiene doméstica Monlan & 3 & 30 \\
\hline 30 & Lecciones de Aritmética González & & 30 \\
\hline 40 & Método para aprender a leer Naharro & 1,25 & 50 \\
\hline 40 & Estilo general de cartas & 2 & 80 \\
\hline 288 & Catecismos Paluzíe (cartulina) & 0,25 & 18 \\
\hline 42 & Festividades de la Iglesia de Moral & 2 & 84 \\
\hline 59 & Lecciones de mundo Guerrero & 2 & 118 \\
\hline 10 & Jerusalén González Alfaro & 1,5 & 15 \\
\hline
\end{tabular}




\begin{tabular}{|c|c|c|c|}
\hline 12 & Guía de la Mujer & & 52,50 \\
\hline 60 & $\begin{array}{l}\text { Ejemplares Martínez de la Rosa } \\
\text { resma }\end{array}$ & & \\
\hline & Colecciones de Aritmética & & 45 \\
\hline & Galán & & 8 \\
\hline & De los Papas & 3 & 12 \\
\hline 2 & $\begin{array}{l}\text { Colecciones Historia de España } \\
\text { negro }\end{array}$ & 26 & 52 \\
\hline 1 & “ $\quad$ Artes y Oficios & & 40 \\
\hline 4 & Colección de Tablas & 28 & 112 \\
\hline 3 & $\begin{array}{l}\text { Colección de Historia Sagrada } \\
\text { pequeña }\end{array}$ & 80 & 240 \\
\hline 2 & $\begin{array}{l}\text { Colección de Historia Sagrada } \\
\text { González }\end{array}$ & 90 & 180 \\
\hline 1 & $\begin{array}{l}\text { Colección de Historia Sagrada } \\
\text { grande }\end{array}$ & & 160 \\
\hline 1 & Colección de Historia de España & & 104 \\
\hline 28 & Historia de España Álvarez & 3,21 & 91 \\
\hline 108 & Ejemplares Obligaciones del hombre & 0,5 & 54 \\
\hline 83 & Ejemplares Aritmética de $\mathrm{J}$ & & 40 \\
\hline 68 & Ejemplares Cartillas Olivan & 1,50 & 103 \\
\hline 11 & Ejemplares Cuadernos Avendaño & 2,5 & 27,50 \\
\hline 45 & $\begin{array}{l}\text { Ejemplares Religión y Moral Flórez } \\
\text { (cartoné } 2^{\mathrm{a}} \text { ) }\end{array}$ & & 98 \\
\hline 56 & $\begin{array}{l}\text { Ejemplares Método racional } \\
\text { completo }\end{array}$ & 17,5 & 79.5 \\
\hline
\end{tabular}


LA EDITORIAL BURGALESA HIJOS DE SANTIAGO RODRÍGUEZ (1891-1936): ANÁLISIS DE LOS LIBROS ESCOLARES

\begin{tabular}{|c|c|c|c|}
\hline 50 & Ejemplares Obras de Yeves & & 75 \\
\hline 81 & $\begin{array}{l}\text { Ejemplares Prontuario de Pedagogía } \\
\text { Carretero }\end{array}$ & 1 & 81 \\
\hline 72 & Ejemplares Fleuri (cartulina) $2^{a}$ & 0,8 & 48 \\
\hline 62 & Ejemplares Historia Sagrada láminas & & 62 \\
\hline 61 & $\begin{array}{l}\text { Ejemplares Manuscrito religión y } \\
\text { moral Valle }\end{array}$ & & 61 \\
\hline 63 & Ejemplares Silabario Flórez $2^{\mathrm{a}}$ parte & 0.56 & 35,28 \\
\hline 19 & $\begin{array}{l}\text { Ejemplares Amigo de los niños } \\
\text { (rústica) }\end{array}$ & 0.5 & 9,5 \\
\hline 15 & Ejemplares Catón cristiano & 0.6 & 9 \\
\hline 21 & Ortografía Salazar & 1,5 & 31,5 \\
\hline 1900 & Tablas & 0,06 & 76 \\
\hline 70 & Catecismos Paluzíe & 0.12 & 35 \\
\hline 32 & Historia Sagrada Rosado & & 68 \\
\hline 73 & Silabario Serrano (papel) & 0,04 & 3,72 \\
\hline 139 & Silabario Larrea & 0.4 & 5,56 \\
\hline 100 & Programas $2^{\circ}$ año francés & 1 & 100 \\
\hline 83 & Programas $1^{\circ}$ año francés & 1 & 83 \\
\hline 117 & Programas Historia de España & 1 & 117 \\
\hline 53 & Programas de Historia Universal & 1 & 53 \\
\hline 24 & $\begin{array}{l}\text { Ejemplares Diálogo del Fleuri } \\
\text { (papel) }\end{array}$ & 0,1 & 2,4 \\
\hline 131 & Ejemplares Historia Sagrada $1^{a}$ serie & & 98,21 \\
\hline 8 & Ejemplares Diccionario de la niñez & & 8 \\
\hline
\end{tabular}




\begin{tabular}{|c|c|c|c|}
\hline & Carrillo & & \\
\hline 26 & Ejemplares Españoles célebres & & 26 \\
\hline 95 & Ejemplares Aritmética & & 100 \\
\hline 46 & $\begin{array}{l}\text { Ejemplares Lecciones familiares } \\
\text { Guerrero }\end{array}$ & & 33,12 \\
\hline 46 & Ejemplares Historia Sagrada $2^{\mathrm{a}}$ serie & 0,75 & 34,5 \\
\hline 36 & Ejemplares Educador de las niñas & 2 & 72 \\
\hline 67 & Ejemplares Aritmética García & & 67 \\
\hline 18 & Ejemplares Higiene Carretero & 1,5 & 34,5 \\
\hline 40 & $\begin{array}{l}\text { Ejemplares Prontuario Aritmética } \\
\text { Pastor }\end{array}$ & & 80 \\
\hline 21 & Ejemplares Catón de S. Casiano & 0,60 & 13,8 \\
\hline 28 & Ejemplares Fábulas de Samaniego & 0,50 & 14 \\
\hline 86 & $\begin{array}{l}\text { Ejemplares Fábulas de Samaniego } \\
\left(\text { cartulina } 2^{\text {a }} \text { ) }\right.\end{array}$ & & 27 \\
\hline & Ejemplares Cartilla agraria Prieto & 1,8 & 92,5 \\
\hline 88 & $\begin{array}{l}\text { Ejemplares El Sacramento de la } \\
\text { Penitencia }\end{array}$ & 1 & 88 \\
\hline 38 & Ejemplares Urbanidades Ollero & 1 & 38 \\
\hline 26 & Ejemplares Aritmética de Valle & 1 & 26 \\
\hline 24 & Ejemplares Geografía Morante papel & 1,4 & 28 \\
\hline 122 & Ejemplares Urbanidad de niños & 0,5 & 61 \\
\hline 50 & $\begin{array}{l}\text { Ejemplares Apuntes de } \mathrm{H}^{\mathrm{a}} \text { Sagrada } \\
\text { Fernando }\end{array}$ & 1 & 50 \\
\hline 190 & $\begin{array}{l}\text { Ejemplares Urbanidad niños } \\
\text { cartulina }\end{array}$ & 0,50 & 95 \\
\hline
\end{tabular}


LA EDITORIAL BURGALESA HIJOS DE SANTIAGO RODRÍGUEZ (1891-1936): ANÁLISIS DE LOS LIBROS ESCOLARES

\begin{tabular}{|c|c|c|c|}
\hline 80 & Ejemplares Antiguo Testamento & 0,50 & 40 \\
\hline 35 & $\begin{array}{l}\text { Ejemplares Método práctico } \\
\text { Pampliega }\end{array}$ & 0,50 & 17,50 \\
\hline 94 & $\begin{array}{l}\text { Ejemplares Diálogo de Fleuri } \\
\text { cartulina }\end{array}$ & 0,16 & 8,64 \\
\hline 10 & Ejemplares Cuentas apuntadas & & 8 \\
\hline 144 & Ejemplares Cartilla Benito papel & & 100 \\
\hline 98 & Ejemplares Higienes de Ollero & 2 & 196 \\
\hline 736 & Ejemplares Tablas de sumas & 0,04 & 37,4 \\
\hline 57 & Ejemplares cuadernos Araujo & 2 & 114 \\
\hline 47 & $\begin{array}{l}\text { Ejemplares Catecismo Astete } \\
\text { (cartulina) }\end{array}$ & 1,21 & 58 \\
\hline 124 & $\begin{array}{l}\text { Ejemplares Programa Geografía } \\
\text { Rives }\end{array}$ & & 124 \\
\hline 100 & Ejemplares Religión y Moral Flores & 1,75 & 175 \\
\hline 86 & Ejemplares Epítomes & 2 & 172 \\
\hline 59 & Ejemplares Naharro & 1,21 & 68,75 \\
\hline 132 & Ejemplares Catón de S. Casiano & 0,60 & 79,2 \\
\hline 42 & $\begin{array}{l}\text { Ejemplares Lecturas Morales } \\
\text { Bustamante }\end{array}$ & 1,70 & 63 \\
\hline 400 & Ejemplares Silabarios Pampliega & 0,11 & 44 \\
\hline 280 & Ejemplares Silabarios Serrano & 0,04 & 12 \\
\hline 25 & Ejemplares Fleuri & & 12,5 \\
\hline 150 & Ejemplares Libro $2^{\circ}$ (cartulina) & 0,24 & 36 \\
\hline 150 & Ejemplares Ortografía Acard & 2,75 & 415,21 \\
\hline
\end{tabular}




\begin{tabular}{|c|c|c|c|}
\hline 78 & $\begin{array}{l}\text { Ejemplares Catón metódico } \\
\text { González }\end{array}$ & 0,40 & 31,20 \\
\hline 40 & Ejemplares Manuales García & 0,75 & 30 \\
\hline 88 & Ejemplares Método Besson & & 70 \\
\hline 350 & Ejemplares Silabario Florez $3^{\mathrm{a}}$ parte & 0,52 & 182 \\
\hline 201 & $\begin{array}{l}\text { Ejemplares Silabario S. Antonio } \\
\text { (papel) }\end{array}$ & 0,04 & 8,01 \\
\hline $\operatorname{lin}$ & $\begin{array}{l}\text { Ejemplares Silabario Serrano } \\
\text { (cartulina) }\end{array}$ & 0,75 & 108 \\
\hline 121 & Ejemplares Silabario García & 0,12 & 14,52 \\
\hline 13 & Ejemplares Aritmética Hernando & & \\
\hline 50 & $\begin{array}{l}\text { Ejemplares Tratado obligaciones del } \\
\text { hombre }\end{array}$ & 0,50 & 25 \\
\hline 80 & Ejemplares Silabario Paluzie & 0,60 & 48 \\
\hline 1425 & Resumen de Higiene en resma & 1 & 1425 \\
\hline 1000 & Catecismo Ripalda & 0,1075 & 107,50 \\
\hline 200 & Calonge Historia Sagrada & 2,25 & 450 \\
\hline 165 & Libros de contabilidad & 3 & 495 \\
\hline 14 & $\begin{array}{l}\text { Cuaderno de Olmos, Aranda, Valle } \\
1^{\mathrm{a}} \text { y } 2^{\mathrm{a}} \text { parte }\end{array}$ & 16 & 72 \\
\hline 51 & Cuadernos de Aranda & 1,25 & 63,75 \\
\hline 51 & Cuadernos de Valle $1^{\mathrm{a}}$ y $2^{\mathrm{a}}$ parte & 1,5 & 76,50 \\
\hline 800 & Amigo de los niños (rústica) & 0,33 & 264 \\
\hline 500 & Amigo de los niños (cartulina) & 0,46 & 230 \\
\hline 320 & Fleuri (rústica) & 0,30 & 69 \\
\hline
\end{tabular}


LA EDITORIAL BURGALESA HIJOS DE SANTIAGO RODRÍGUEZ (1891-1936): ANÁLISIS DE LOS LIBROS ESCOLARES

\begin{tabular}{|c|c|c|c|}
\hline 69 & Silabario Soriano en cartulina & 9,25 & 619,71 \\
\hline 500 & Libro segundo en cartulina & 0,20 & 100 \\
\hline 474 & Obligaciones del Hombre (cartulina) & 0,2 & 100 \\
\hline 5 & Silabario Serrano (papel) & 1,50 & 27,5 \\
\hline 6 & Silabario García & 15 & 90 \\
\hline 296 & Método práctico Carrera (cartulina) & 0,91 & 211 \\
\hline 4,5 & Silabario Hernando & 28 & 126 \\
\hline \multirow[t]{3}{*}{460} & Catón Seijas (cartulina) & 0,28 & 119 \\
\hline & Prólogo del Fleuri (cartulina) & 0,16 & 128 \\
\hline & Texto explicativo Menchaca & 0,75 & 867,25 \\
\hline \multirow[t]{8}{*}{5} & Silabarios S. Antonio (papel) & 9 & 45 \\
\hline & Silabarios S. Antonio cartulina & 12 & 42 \\
\hline & $\begin{array}{l}\text { Nociones de Aritmética (cartulina, } \\
\text { rústica) }\end{array}$ & 0,12 & 42 \\
\hline & Cuadernos de reducción & 0,09 & 34,02 \\
\hline & Catón de S. Casiano (cartulina) & 0,25 & 282,50 \\
\hline & Procedimiento enseñanza Abad & & 100 \\
\hline & Texto explicativo & & 14 \\
\hline & Urbanidades Marqueri & & 100 \\
\hline 8 & Economía & 2 & 18 \\
\hline 6 & Aritmética Fontova y López & 1,50 & 9 \\
\hline 16 & Pedagogía Carretero (rústica) & 2 & $112 ?$ \\
\hline 28 & Manuales García & 0,75 & 19,75 \\
\hline 28 & Método práctico por Naharro & 1,25 & 35 \\
\hline
\end{tabular}




\begin{tabular}{|c|c|c|c|}
\hline 1000 & Fábulas Samaniego (cartoné) & 0,76 & 760 \\
\hline 51 & Fábulas Miguel & 3 & 153 \\
\hline 9 & Fábulas Iriarte & 1,25 & 11,25 \\
\hline 17 & Fábulas Raeza & 2,50 & 42,50 \\
\hline 25 & Fábulas Iriarte & 1 & 25 \\
\hline 15 & Fábulas Regulón & 2,50 & 37,50 \\
\hline 200 & Páginas de la Infancia (cartoné) & 2,25 & 450 \\
\hline 10 & Fábulas Calleja & 0,80 & 8 \\
\hline 161 & Juanitos Hernando & 2,50 & 412,50 \\
\hline 24 & Juanito Valle & 2,75 & 66 \\
\hline 31 & Juanito Rosado & 2,50 & 82,50 \\
\hline 8 & Juanito Torrente & 4,25 & 34 \\
\hline 374 & Martínez de la Rosa & 2,10 & 791,7 \\
\hline 72 & Hernany & 4 & 288 \\
\hline 126 & Cuentos morales Vidal “ & 2,50 & 289,8 \\
\hline 3 & La educación de las niñas “ & 6,50 & 19,50 \\
\hline 18 & $\begin{array}{l}\text { Libro de las niñas por P. San Juan } \\
\text { (cartulina) }\end{array}$ & 2,75 & 49,50 \\
\hline 14 & Catecismos Calleja & & 1,50 \\
\hline 107 & Libro de Oro (cartoné) & 2,75 & 321,75 \\
\hline 3 & Conjugaciones Salazar (cartoné) & 2 & 6 \\
\hline 100 & Cuentos del pastor & 2,98 & 298 \\
\hline 109 & Espejo de las niñas & 2,21 & 307,19 \\
\hline 22 & Mosaico literario & 3 & 66 \\
\hline
\end{tabular}


LA EDITORIAL BURGALESA HIJOS DE SANTIAGO RODRÍGUEZ (1891-1936): ANÁLISIS DE LOS LIBROS ESCOLARES

\begin{tabular}{|c|c|c|c|}
\hline $95 ?$ & Libro de los Deberes & 2,63 & 249,85 \\
\hline 40 & El amigo de las niñas & 2 & 80 \\
\hline 64 & El Evangelio de los niños & 2,50 & 160 \\
\hline 9 & El Trovador de los niños & 2,50 & 22,50 \\
\hline 61 & Mentor de los niños (cartoné) & 4,50 & 274.50 \\
\hline 25 & Marco Valladolid & 6 & 150 \\
\hline 95 & " $\quad$ Paris & 4,5 & 427,10 \\
\hline 15 & El Sendero de la Virtud " & 2 & 30 \\
\hline 48 & Ejemplos morales & 2 & 96 \\
\hline 23 & El libro de los Párvulos “ & 3 & 69 \\
\hline 15 & Rueda & 4,25 & 63,75 \\
\hline 165 & Jerusalén & 1,50 & 281,71 \\
\hline 99 & La florista infancia & 1,75 & 175,25 \\
\hline 12 & Leyendas católicas & & 24 \\
\hline 70 & Albores de la infancia & 1,75 & 122,50 \\
\hline 400 & Catón Seijás & 0,50 & 200 \\
\hline 13 & D. Quijote & 6 & 78 \\
\hline 52 & Obligaciones del hombre “ & 0,80 & 31.60 \\
\hline 100 & Pedagogía Carretero & 3 & 300 \\
\hline 200 & Higienes & 1,50 & 300 \\
\hline 53 & Método nuevo Bessón & 0,50 & 26,50 \\
\hline 141 & Libro Segundo $\quad$ (cartoné) & 0,50 & 70,50 \\
\hline 52 & Lecturas morales & 1,54 & 80,58 \\
\hline 96 & Festividades de la Iglesia (cartoné) & 2 & 19,2 \\
\hline
\end{tabular}




\begin{tabular}{|c|c|c|c|}
\hline 12 & Industria y Comercio Rosado & 2,50 & 30 \\
\hline 10 & Ramillete poético (cartoné) & 2 & 20 \\
\hline 8 & Tratado de economía & & 12 \\
\hline & Manuales García & 1,25 & 45 \\
\hline 100 & Ciencia de la mujer & 2 & 20 \\
\hline 18 & El faro de las niñas & 1,75 & 26,25 \\
\hline 22 & Tratado de Industria & 3 & 66 \\
\hline 9 & Ordinario de la Misa & 2 & 18 \\
\hline 6 & Felicitaciones & 2 & 12 \\
\hline 9 & La Aurora del Pensamiento “ & 6 & 54 \\
\hline 9 & Historia Natural Morate & 3 & 27 \\
\hline 12 & Abecedario de la Virtud " " & 3 & 36 \\
\hline 6 & $\begin{array}{l}\text { Manual completo de las niñas } \\
\text { (cartoné) }\end{array}$ & 6 & 36 \\
\hline 13 & Narraciones bíblicas (cartoné) & 3 & 39 \\
\hline 43 & Plutarco & 2,75 & 118,25 \\
\hline 11 & Luz de la Infancia & 3 & 33 \\
\hline 14 & La madre de familia & 3 & 42 \\
\hline 78 & Los deberes de los niños “ & 2 & 156 \\
\hline 16 & Manual de Sacristanes (grandes) & 9 & 144 \\
\hline 74 & Manual de Sacristanes (pequeños) & 5 & 185 \\
\hline 12 & “ $\quad$ (cartulina) & 1,25 & 15 \\
\hline 17 & Tesoro del Artesano (cartoné) & 2,75 & 156,75 \\
\hline 7 & Catecismos explicados Claret (pasta) & 1,25 & 36,75 \\
\hline
\end{tabular}


LA EDITORIAL BURGALESA HIJOS DE SANTIAGO RODRÍGUEZ (1891-1936): ANÁLISIS DE LOS LIBROS ESCOLARES

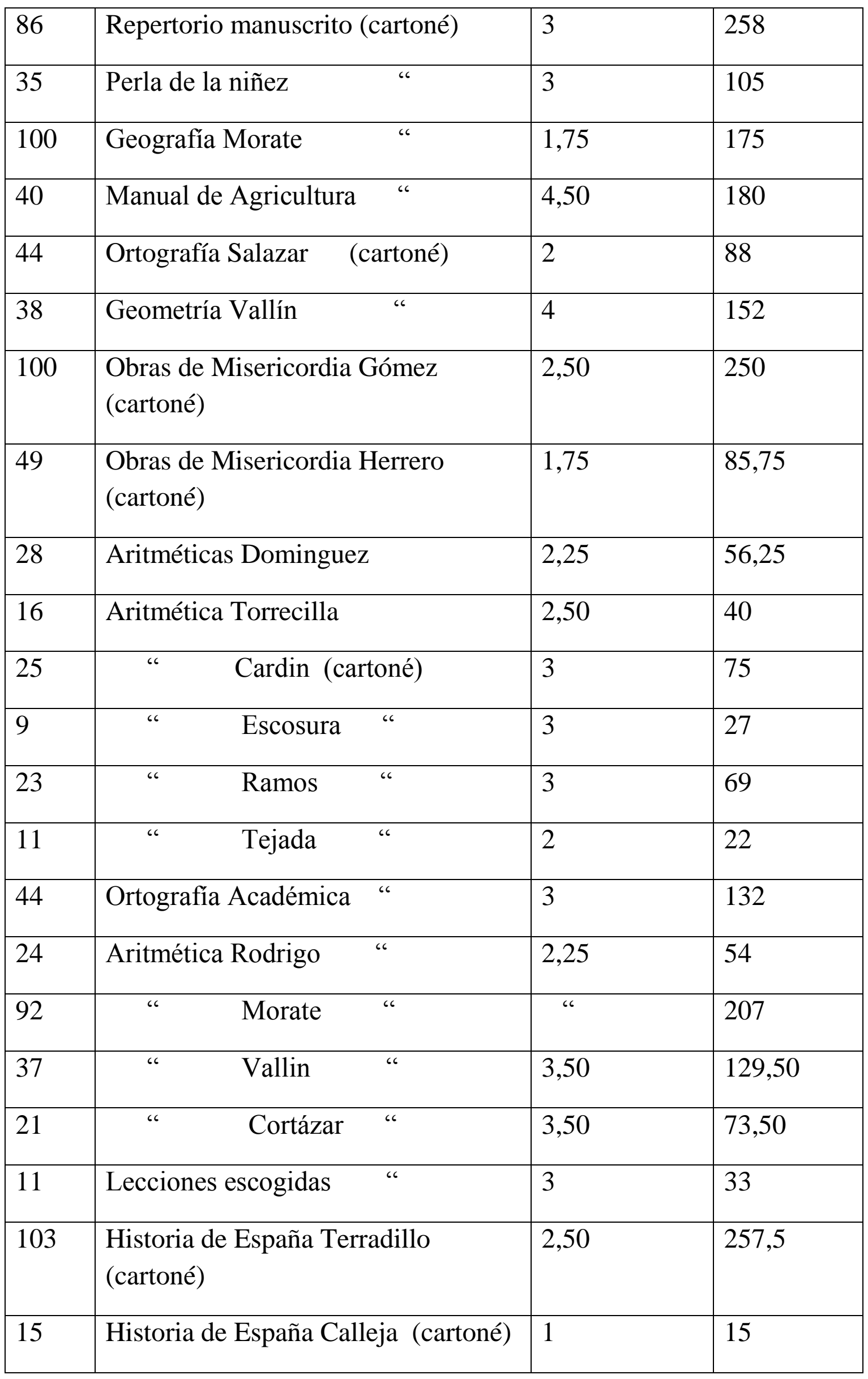




\begin{tabular}{|c|c|c|c|}
\hline 117 & $\begin{array}{l}\text { Historia de España González Alfaro } \\
\text { (cartoné) }\end{array}$ & 2,25 & 263,25 \\
\hline 18 & $\begin{array}{l}\text { Historia de España Sanz } \\
\text { (cartoné) }\end{array}$ & 3,25 & 58,50 \\
\hline 6 & $\begin{array}{l}\text { Historia de España Férriz } \\
\text { “ }\end{array}$ & 2 & 12 \\
\hline 11 & “ $\quad$ Guillen & 3 & 33 \\
\hline 93 & $\begin{array}{l}\text { Historia de España Morate } \\
\text { ، }\end{array}$ & 1,75 & 162,75 \\
\hline 5 & $\begin{array}{l}\text { Historia de España Florez } \\
\text { “ }\end{array}$ & 2 & 10 \\
\hline 42 & $\begin{array}{l}\text { Gramática Miguel } \\
\text { “ }\end{array}$ & 3 & 126 \\
\hline 52 & $\begin{array}{l}\text { Epitomes } \\
\text { ، }\end{array}$ & 2,40 & 124.80 \\
\hline 54 & $\begin{array}{l}\text { Gramática Herranz } \\
\text { “ }\end{array}$ & 2,25 & 126,90 \\
\hline 13 & $\begin{array}{l}\text { Compendio Gramática Académica } \\
\text { “ }\end{array}$ & 4,50 & 58,50 \\
\hline 12 & $\begin{array}{l}\text { Epitomes Morate } \\
\text { ، }\end{array}$ & 2,80 & 27,60 \\
\hline 45 & $\begin{array}{l}\text { Historia Sagrada Hernando } \\
\text { ، }\end{array}$ & & 67,50 \\
\hline 53 & ، $\quad$ “ $\quad$ Guillen & 3,5 & 185,50 \\
\hline 29 & texto explicativo & 3 & 87 \\
\hline 625 & Loriquet & 0,70 & 437,50 \\
\hline
\end{tabular}


LA EDITORIAL BURGALESA HIJOS DE SANTIAGO RODRÍGUEZ (1891-1936): ANÁLISIS DE LOS LIBROS ESCOLARES

\begin{tabular}{|c|c|c|c|}
\hline & "6 & & \\
\hline \multirow[t]{2}{*}{500} & $\begin{array}{l}\text { Amigos de los niños } \\
\text { “ }\end{array}$ & & \\
\hline & $\begin{array}{l}\text { Guía del ama de casa } \\
\text { (cartoné) }\end{array}$ & 3 & 225 \\
\hline 56 & Aritmética Yeves & 2 & 112 \\
\hline 48 & Gramática “ & 2 & 96 \\
\hline \multirow[t]{5}{*}{ '2 } & Geometría “ & 2 & 206 \\
\hline & $\begin{array}{l}\text { Historia de España “ } \\
\text { “ }\end{array}$ & 2 & 102 \\
\hline & $\begin{array}{l}\text { Ortografía práctica “ } \\
\text { “ }\end{array}$ & 4,50 & 18 \\
\hline & Mentor de las niñas “ & 4,50 & 171 \\
\hline & ، $، \quad$ de los niños “ & 3,75 & 71,25 \\
\hline 50 & Geografías & 2 & 100 \\
\hline \multirow[t]{3}{*}{29} & Historia Sagrada “ & 2 & 58 \\
\hline & $\begin{array}{l}\text { Juanitos Paluzie } \\
\text { “ }\end{array}$ & 2,25 & 252 \\
\hline & Fleuris Paluzie & 0,75 & 19,50 \\
\hline 27 & $\begin{array}{l}\text { Geografía iluminada Paluzie } \\
\text { (cartoné) }\end{array}$ & 3,75 & 101,25 \\
\hline 24 & $\begin{array}{l}\text { Geografía negro Paluzie } \\
\text { (cartoné) }\end{array}$ & 3,25 & 78 \\
\hline 7 & Geografía grandes “ & 6 & 42 \\
\hline
\end{tabular}




\begin{tabular}{|c|c|c|c|c|}
\hline & " & & & \\
\hline 21 & económicas Paluzíe & & 1,80 & 37,80 \\
\hline 26 & $\begin{array}{l}\text { Escritura y lenguaje Paluzíe } \\
\text { “ }\end{array}$ & & & 166,4 \\
\hline & “ “ $\quad\left(3^{\circ}\right.$ cuaderno $)$ “ & & 1,30 & 59,80 \\
\hline 29 & “ $"\left(2^{\circ}\right.$ cuaderno $) “$ & & 2,25 & 65,50 \\
\hline 35 & “ $"\left(1^{\circ}\right.$ cuaderno $) "$ & & 2,25 & 78,75 \\
\hline 14 & ¿ o la Educación “ & “" & 3,75 & 52,50 \\
\hline 28 & Historia de España “ & “" & 3,25 & 91 \\
\hline 38 & Geometría & "“ & 2,25 & \\
\hline 18 & Gramáticas & “ & 2,25 & 40,50 \\
\hline & Atlas de Geografía “ & “" & 7,50 & 187,50 \\
\hline 8 & El amigo de los niños “ & “" & & 8 \\
\hline 7 & $\begin{array}{l}\text { Biografía Reyes de España “ } \\
\text { “ }\end{array}$ & & 3 & 21 \\
\hline 10 & Blasones españoles & “ & 4 & 40 \\
\hline 6 & Boletín infantil & “" & 3 & 18 \\
\hline 36 & Historia de España económica & & 3,25 & 117 \\
\hline 22 & Impresiones y lenguaje & " & 6 & 132 \\
\hline 23 & $\begin{array}{l}\text { Aritmética Paluzíe } \\
\text { (cartón) }\end{array}$ & & 2,75 & 63,25 \\
\hline 37 & Sagrada [Bellera] & “6 & 2,75 & 101,75 \\
\hline
\end{tabular}


LA EDITORIAL BURGALESA HIJOS DE SANTIAGO RODRÍGUEZ (1891-1936): ANÁLISIS DE LOS LIBROS ESCOLARES

\begin{tabular}{|l|l|l|l|}
\hline 18 & Misceláneas “ & 3,25 & 58,50 \\
\hline 82 & Guía del Artesano “ & 2,75 & 225,50 \\
\hline 14 & Gramática Morate “ & 2,75 & 38,50 \\
\hline 800 & Higienes Carretero pequeños cartón & 1,50 & 1200 \\
\hline 12 & El consejero de las niñas & 2,25 & 27 \\
\hline 150 & Programas Geografía Rives & 1 & 150 \\
\hline
\end{tabular}

Fuente: Inventario notarial de los bienes de la empresa Imprenta y Librería Santiago Rodríguez Alonso. [Elaboración propia]

Inventario de libros en la tienda.

\begin{tabular}{|l|l|l|l|}
\hline \multicolumn{1}{|c|}{} & \multicolumn{1}{|c|}{ Tienda } & & \\
\hline 8 & Diccionario Latino-español París & 28 & \\
\hline 10 & Diccionario francés Salva & 15 & 224 \\
\hline 10 & Diccionarios español Campano & 16 & 150 \\
\hline 4 & [Cocinero] europeo & 14 & 160 \\
\hline 1 & Obra festivas y satíricas & & 96 \\
\hline 1 & Luchas del siglo & & 48 \\
\hline 1 & [ilegible] & & 8 \\
\hline 1 & Historia de la Literatura & & 16 \\
\hline 1 & Los compañeros de & & 16 \\
\hline 1 & El vizconde de Fragelonne & & 16 \\
\hline 1 & Historia de los franceses & & \\
\hline
\end{tabular}




\begin{tabular}{|c|c|c|c|}
\hline 1 & El rey de las montañas & & 8 \\
\hline 1 & Aventuras de un misántropo & & 8 \\
\hline 1 & Francisco de Bretaña & & 8 \\
\hline 1 & La Pagana & & 8 \\
\hline 1 & $\mathrm{D}^{\mathrm{a}}$ Mercedes de Castilla & & 8 \\
\hline 2 & Veinte años después & 16 & 32 \\
\hline 2 & Gil Blas & 16 & 32 \\
\hline & $\begin{array}{l}\text { Hay varias obras de tipo religioso: } \\
\text { Ángel, Áncoras, Luz Divina, Tierra } \\
\text { para los niños, Mujer Católica, } \\
\text { Libros de memorias, Semana Santa, } \\
\text { Divinamente, Kempis... }\end{array}$ & & \\
\hline 2 & Los tres mosqueteros & 16 & 32 \\
\hline 16 & Diccionario español-latino & 26 & 264 \\
\hline- & Historia universal & & 600 \\
\hline 1 & Diccionario Gregorio & & 120 \\
\hline 1 & Viajeros modernos & & 44 \\
\hline 1 & Imitación a Cristo & & 146 \\
\hline 2 & Samaniego Fábulas & 40 & 80 \\
\hline 1 & Cuentos de Boccaccio & & 77 \\
\hline 1 & Divina comedia & & 42 \\
\hline 2 & Robinson & 42 & 84 \\
\hline 1 & La hija de Corcés & & 36 \\
\hline 1 & Gil Blas de Santillana & & 32 \\
\hline 1 & La moral en acción & & 26 \\
\hline
\end{tabular}


LA EDITORIAL BURGALESA HIJOS DE SANTIAGO RODRÍGUEZ (1891-1936):

ANÁLISIS DE LOS LIBROS ESCOLARES

\begin{tabular}{|c|c|c|c|}
\hline 1 & Novelas selectas & & \\
\hline 5 & Lirio celestial & 4 & 20 \\
\hline 6 & Historia universal & 18 & 108 \\
\hline 1 & Diccionario de jurisprudencia & & 20 \\
\hline 1 & El Heroísmo & & 8 \\
\hline 1 & Historia Universal & & 25 \\
\hline 6 & Higiene de Monlau & 22 & 132 \\
\hline 1 & Abecedario ilustrado & & 4 \\
\hline 1 & Cuentos de Grimm & & 14 \\
\hline 1 & Biblioteca Selecta & & 14 \\
\hline 1 & Doce reales de prosa & & 25 \\
\hline 1 & Guía de París & & 4 \\
\hline 1 & La generación de Garnier & 22 & 132 \\
\hline 2 & Aventuras de Robinson & 12 & 24 \\
\hline 2 & Obras de Espronceda & 14 & 28 \\
\hline 72 & [Rústico Bertobelo] & 4 & 288 \\
\hline 1 & Nuevas confidencias & & 8 \\
\hline 1 & Dudas y tristezas & & 6 \\
\hline 9 & Manual de juegos de sociedad & 4 & 36 \\
\hline 1 & Diccionario de Estrada & & 8 \\
\hline 1 & Educación de la juventud & & 4 \\
\hline- & Novena de la Virgen & & 5 \\
\hline 1 & Las mujeres Karr & & 8 \\
\hline 1 & Biblioteca de la juventud & & 4 \\
\hline
\end{tabular}




\begin{tabular}{|c|c|c|c|}
\hline 13 & Biblioteca de la mujer & 2 & 26 \\
\hline 5 & Biblioteca infantil & & 5 \\
\hline 2 & Ya sé leer & 18 & 36 \\
\hline 1 & Robinson Crusoe & & 26 \\
\hline 2 & Animales salvajes & 20 & 40 \\
\hline 2 & Cuentos de Perrault & 25 & 50 \\
\hline 53 & Un libro para los niños & 0,5 & 106 \\
\hline 20 & Explicación de los niños & 4 & 80 \\
\hline 63 & Comedias infantiles & & 63 \\
\hline 10 & El aniversario & 2 & 20 \\
\hline 1 & Juan el despreciado & & 2 \\
\hline 2 & Yo sabré leer & 22 & 44 \\
\hline 2 & Álbums de Historia Natural & 9 & 18 \\
\hline 1 & La hechicera enana & & 4 \\
\hline 1 & Alegrías Infantiles & & 2 \\
\hline 1 & Diccionario castellano & & 34 \\
\hline 2 & Diccionarios & 24 & 48 \\
\hline 6 & Oficio de la virgen & 4 & 24 \\
\hline 1 & Prácticas para visitar a enfermos & & 5 \\
\hline 1 & Despertador eucarístico & & 5 \\
\hline 1 & La esperanza del cristiano & & 5 \\
\hline 1 & Comulgador general & & 6 \\
\hline 4 & Pequeño Lavalle & 4 & 16 \\
\hline 5 & Oraciones de Granada & 5 & 25 \\
\hline
\end{tabular}


LA EDITORIAL BURGALESA HIJOS DE SANTIAGO RODRÍGUEZ (1891-1936):

ANÁLISIS DE LOS LIBROS ESCOLARES

\begin{tabular}{|c|c|c|c|}
\hline 2 & Granada meditación & 5 & 10 \\
\hline 1 & Ejercicios espirituales & & 5 \\
\hline 1 & Ejercicios cotidianos & & 3 \\
\hline 3 & Ramillete de flores & 3 & 9 \\
\hline 1 & Camino del cielo & & 2 \\
\hline 3 & Devocionario de semana santa & 2 & 6 \\
\hline 3 & Devocionario de semana santa & 1 & 3 \\
\hline 1 & Reflexiones piadosas & & 4 \\
\hline 1 & Aurora del cristiano & & 4 \\
\hline 1 & Diamante diurno & & 5 \\
\hline 1 & Horas diurnas & & 20 \\
\hline 1 & Finezas de María & & 3 \\
\hline 1 & Semana Santa & & 4 \\
\hline 2 & canto dorado & 12 & 24 \\
\hline 2 & “6 & 5 & 10 \\
\hline 2 & de salvación grande & 7,25 & \\
\hline 4 & pequeño & 8 & 32 \\
\hline 3 & Camino recto & 9 & 18 \\
\hline 3 & Ancora de salvación pequeño & 5,5 & 17,5 \\
\hline 3 & Kempis imitación de Cristo & 3,75 & 11,25 \\
\hline 2 & Devoto feligrés & 3,75 & 7,50 \\
\hline 11 & Ejercicio cotidiano & 1,25 & 13,5 \\
\hline 22 & Devocionario Calleja pequeño & 1 & 22 \\
\hline 13 & Ejercicio cotidiano París & 1,25 & 16,25 \\
\hline
\end{tabular}




\begin{tabular}{|c|c|c|c|}
\hline 1 & Mes de María & & 1 \\
\hline 16 & Aritmética por José Martínez & 2,50 & 40 \\
\hline 8 & " Arroyo & 1,50 & 12 \\
\hline 2 & Geometría Paluzíe & 2,25 & 4,50 \\
\hline 4 & Historia sagrada Loriquet & 1 & 4 \\
\hline 2 & Historia natural Paluzíe & 4 & 8 \\
\hline 10 & Escritura y lenguaje Paluzíe & 6,25 & 62,50 \\
\hline 1 & Historia de España “ & & 3,25 \\
\hline 3 & Pedagogía Carretero & 3 & 9 \\
\hline 2 & Higienes “ & 2 & 4 \\
\hline 2 & Previsor " " & 2 & 4 \\
\hline 3 & Resumen de Higiene Carretero & 1 & 3 \\
\hline 2 & Cuentos morales Vidales & 2,5 & 5 \\
\hline 2 & Páginas de la infancia Terradillo & 2,25 & 4,5 \\
\hline 1 & Nociones de Aritmética & 1,75 & 12,25 \\
\hline 2 & Historia Sagrada Rosado & 3 & 6 \\
\hline 17 & Epítomes R. Academia & 1,8 & 30,6 \\
\hline 3 & Martínez de la Rosa & 2,1 & 6,3 \\
\hline 2 & El Evangelio de los niños & 2,5 & 5 \\
\hline 7 & Prontuario de ortografía Acad & 2,75 & 19,25 \\
\hline 1 & Libro de los deberes & & 2,7 \\
\hline 10 & Compendio Aritmética & 1 & 10 \\
\hline 3 & Historia de España Terradillo & 2,5 & 7,5 \\
\hline 4 & Gramáticas de Herrán & 2,25 & 9 \\
\hline
\end{tabular}


LA EDITORIAL BURGALESA HIJOS DE SANTIAGO RODRÍGUEZ (1891-1936): ANÁLISIS DE LOS LIBROS ESCOLARES

\begin{tabular}{|c|c|c|c|}
\hline 2 & Espejo de la niñez & 2,25 & 4,5 \\
\hline 1 & Naharro & & 1,25 \\
\hline 2 & Blasones españoles & 3 & 6 \\
\hline 4 & Guía del artesano & 2,25 & 9 \\
\hline 3 & Historia Sagrada Calonge & 2,75 & 8,25 \\
\hline 2 & Jerusalén & 1,5 & 3 \\
\hline & Método Naharro & 0,5 & 3 \\
\hline 12 & Silabario Pampliega & & 1,25 \\
\hline 8 & Manuales García & 0,75 & 6 \\
\hline 5 & Catón Seijas & 0,5 & 2,5 \\
\hline 1 & Historia Sagrada & & 1 \\
\hline & Método nuevo de Besson & & 3 \\
\hline 5 & Cartilla agraria & 1,5 & 7,5 \\
\hline 9 & Silabarios Serrano & & 1 \\
\hline 1 & Rives Geografía & & 14 \\
\hline 2 & Sánchez Casado Geografía & 19 & 38 \\
\hline 1 & Historia de España & & 16 \\
\hline 2 & Historia Universal & 16 & 32 \\
\hline 4 & “ $\quad$ Natural & 9 & 36 \\
\hline 3 & 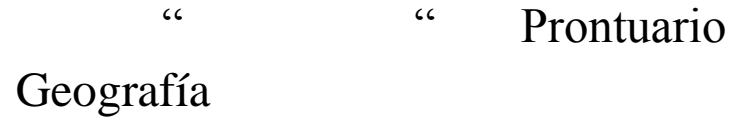 & 6 & 18 \\
\hline 12 & Santos Lecciones de Agricultura & 11 & 132 \\
\hline 3 & Pedagogía & 19 & 57 \\
\hline 8 & Vallín Geometría & 23 & 184 \\
\hline
\end{tabular}




\begin{tabular}{|c|c|c|c|}
\hline 3 & " Aritmética y algebra & 26 & 69 \\
\hline 1 & Gramática francesa & & 24 \\
\hline 1 & Salinas Algebra & & 24 \\
\hline 2 & Rivero Legislación de $1^{\mathrm{a}}$ enseñanza & 22 & 44 \\
\hline 2 & Ferrer & 26 & 52 \\
\hline 1 & Rouche Geometría & & 48 \\
\hline 2 & Rico [ilegible] & 40 & 80 \\
\hline 11 & La llave del idioma francés & & \\
\hline 1 & Pereda Historia Natural & & 48 \\
\hline 2 & Atlas Geografía & 28 & 56 \\
\hline 2 & Problemas & 8 & 16 \\
\hline 2 & Historia de España Cortes & 6 & 12 \\
\hline 1 & Curso de Topografía militar & & 14 \\
\hline 5 & Prontuario de Geografía & 6 & 30 \\
\hline 1 & Geometría Vicent & & 26 \\
\hline 6 & Aritmética Cardín & 13 & 78 \\
\hline 7 & Algebra & 15 & 105 \\
\hline 3 & Geometría “ & 17 & 51 \\
\hline 1 & Tablas de logaritmos & & 18 \\
\hline 8 & Geometría Vallín & 26 & 138 \\
\hline 3 & Elementos de Trigonometría & 8 & 24 \\
\hline 1 & Lecciones de Geometría & & 30 \\
\hline 1 & Aritmética & & 15 \\
\hline 1 & Algebra & & 25 \\
\hline
\end{tabular}


LA EDITORIAL BURGALESA HIJOS DE SANTIAGO RODRÍGUEZ (1891-1936):

ANÁLISIS DE LOS LIBROS ESCOLARES

\begin{tabular}{|c|c|c|c|}
\hline 1 & Geometría analítica Serret & & 36 \\
\hline 1 & Geometría Giménez & 2 & 10 \\
\hline 4 & Cortázar & 18 & 72 \\
\hline 2 & Trigonometría “ & 17 & 34 \\
\hline 2 & Pedagogía Liberato Guerra & 10 & 20 \\
\hline 8 & Algebra Cortázar & 17 & 136 \\
\hline 1 & Curso elemental de Topografía & & 28 \\
\hline 2 & Aritmética de Vallejo & 26 & 52 \\
\hline 2 & Atlas Geográfico Paluzíe pequeño & 4 & 8 \\
\hline 1 & Autores selectos latinos & & 34 \\
\hline 1 & Gramática latina Torres & & 10 \\
\hline 3 & “ $\quad$ castellana Salazar & 8 & 24 \\
\hline 1 & Retórica Terradillos & & 11 \\
\hline 1 & Geografía & & 24 \\
\hline 1 & Gramática latina & & 17 \\
\hline 9 & Física Ramos & 18 & 90 \\
\hline 1 & " $\quad$ " $\quad$ rústica & & 16 \\
\hline 1 & Química Ramos & 18 & 72 \\
\hline 2 & Programa grado elemental Carretero & 2 & 4 \\
\hline 2 & $\begin{array}{l}\text { Programa Religión y moral } \\
\text { Carretero }\end{array}$ & 3 & 6 \\
\hline 2 & Programa Gramática Orio & 2 & 4 \\
\hline 5 & Tratado de Lectura Avendaño & 5,5 & 27,5 \\
\hline 2 & Barrasa & 3 & 6 \\
\hline
\end{tabular}




\begin{tabular}{|c|c|c|c|}
\hline 2 & Programa de Geometría & 3 & 6 \\
\hline 1 & $\begin{array}{l}\text { Programa de Religión y moral } \\
\text { Olmos }\end{array}$ & & 6 \\
\hline 7 & Antología y caligrafía & 2 & 14 \\
\hline 8 & $\begin{array}{l}\text { Tratado de Ontología y caligrafía } \\
\text { Barroso }\end{array}$ & 13 & 105 \\
\hline 3 & $\begin{array}{l}\text { Tratado de industria y comercio } \\
\text { Cardeña }\end{array}$ & 13 & 39 \\
\hline 1 & Física y Química Morate & & 26 \\
\hline 1 & Aritmética Bajo Ibáñez & & 16 \\
\hline 1 & Pedagogía Avendaño & & 20 \\
\hline 10 & Diálogos y poesías Zabala & 4 & 40 \\
\hline 1 & Discursos y disertaciones & & 16 \\
\hline 1 & Instrucción y enseñanza Avendaño & & 14 \\
\hline 3 & Dirección de los maestros Yeves & & \\
\hline 4 & Estudio sobre la enseñanza Yeves & 10 & 40 \\
\hline 1 & Diálogos y disertaciones & & 12 \\
\hline 1 & Tratado de lectura Avendaño & & 9 \\
\hline 1 & Discursos por Zabala & & 10 \\
\hline 1 & Resumen de Historia General Castro & & 40 \\
\hline 1 & Tratado elemental Física General & & 40 \\
\hline 1 & Pedagogía Alcántara & & 24 \\
\hline 1 & Manual de educación de párvulos & & 28 \\
\hline 12 & Arte de esgrimir el sable & 7 & 84 \\
\hline 7 & Doctrina cristiana La Cerda & 8 & 56 \\
\hline
\end{tabular}


LA EDITORIAL BURGALESA HIJOS DE SANTIAGO RODRÍGUEZ (1891-1936):

ANÁLISIS DE LOS LIBROS ESCOLARES

\begin{tabular}{|c|c|c|c|}
\hline 1 & Manual de Urbanidad Carreño & & 4 \\
\hline 2 & Elementos de Psicología Monlau & 10 & 20 \\
\hline 1 & Tablas de logaritmos & & 10 \\
\hline 8 & Método de Ahn y claves & 16 & 108 \\
\hline 4 & Gramática francesa & 4 & 16 \\
\hline 1 & “ Naharro & & 12 \\
\hline 4 & Tesoro del sacerdote & 28 & 112 \\
\hline 1 & Matemáticas Vallejo & & 6 \\
\hline 3 & Gramática francesa & 26 & 78 \\
\hline 2 & Vocabulario de versiones francesas & 6 & 12 \\
\hline 1 & Diccionario francés Taboada & & 20 \\
\hline 1 & La descendencia del hombre & & 48 \\
\hline 1 & Diccionario francés & & 50 \\
\hline 3 & Atlas Geografía Bustillo & 7 & 21 \\
\hline 1 & Justicia militar & & 12 \\
\hline 2 & Gramática francesa & 36 & 72 \\
\hline 1 & Gramática inglesa & & 20 \\
\hline 3 & Gramática francesa Chautreau & & 16 \\
\hline 1 & Teneduría de libros Castaño & & 12 \\
\hline 3 & Traducción del alemán & 10 & 30 \\
\hline 1 & Diccionario etimológico & & 8 \\
\hline 1 & Montemayor aritmética & & 10 \\
\hline 1 & Elementos de fisiología Casas & & 4 \\
\hline 3 & Problemas por Malgorri & 8 & 24 \\
\hline
\end{tabular}




\begin{tabular}{|c|c|c|c|}
\hline 1 & Elementos agricultura Blanco & & 20 \\
\hline 1 & Dramas líricos Calderón & & 4 \\
\hline 1 & Teoría de la lectura & & 3 \\
\hline 1 & Manual del Sistema Métrico & & 7 \\
\hline 1 & Ortografía Flórez & & 3 \\
\hline 3 & Sistemas de enumeración & 2 & 6 \\
\hline 1 & La gran economía de las familias & & 2 \\
\hline 1 & Problemas de matemáticas & & 3 \\
\hline 2 & Gramática francesa & 8 & 16 \\
\hline 3 & Claves de temas Chautreaux & 3 & 9 \\
\hline 1 & Historia de España Serrano & & 6 \\
\hline 1 & Manual de Mineralogía & & 2 \\
\hline 1 & Historia de la conquista de & & 8 \\
\hline 1 & Disposición gramatical Miguel & & 2 \\
\hline 1 & Historia de España por Carrillo & & 10 \\
\hline 1 & Caligrafía para Castilla & & 4 \\
\hline 1 & Caligrafía francesa & & 8 \\
\hline 1 & Historia de España Alonso & & 4 \\
\hline 3 & Curso de pronunciación francesa & 3 & 9 \\
\hline 1 & Historia de España Alonso & & 4 \\
\hline 3 & Cálculo mercantil Valle & 10 & 30 \\
\hline 1 & Arte militar Zabala & & 8 \\
\hline 1 & Diccionario greco-latino & & 16 \\
\hline 1 & Tratado de metalurgia por La Cruz & & 8 \\
\hline
\end{tabular}


LA EDITORIAL BURGALESA HIJOS DE SANTIAGO RODRÍGUEZ (1891-1936):

ANÁLISIS DE LOS LIBROS ESCOLARES

\begin{tabular}{|c|c|c|c|}
\hline 2 & Elementos de Geografía & 14 & 28 \\
\hline 1 & Reducción de libras a francos & & 5 \\
\hline 3 & Los Estuardos por Chateaubraux & 2 & 6 \\
\hline 1 & Concilio de Trento & & 4 \\
\hline 1 & Historia evangélica 2 tomos & & 10 \\
\hline 2 & El padre nuestro explicado & 6 & 12 \\
\hline 5 & Autores latinos & 5 & 25 \\
\hline 5 & Cartas de Abelardo y Eloísa & & 5 \\
\hline 6 & Elementos de matemáticas Vallín & 6 & 36 \\
\hline 3 & Nuestro maestro español & 6 & 18 \\
\hline 1 & Sermones & & 4 \\
\hline 1 & Gramática Taboada & & 4 \\
\hline 1 & Ejercicios ortográficos franceses & & 3 \\
\hline 4 & Tratado de anatomía & 40 & 160 \\
\hline 2 & $\begin{array}{l}\text { Manual de conversación francés- } \\
\text { inglés }\end{array}$ & 20 & 40 \\
\hline 5 & Manera de catequizar Granada & 1 & 5 \\
\hline 4 & Diccionario latino & 15 & 60 \\
\hline 3 & Ejercicios de lectura francesa & 5 & 15 \\
\hline 1 & Guía Políglota & & 4 \\
\hline 1 & Diccionario inglés-francés & & 16 \\
\hline 9 & Discursos & & \\
\hline 3 & Diccionario francés-español Salvá & 15 & 45 \\
\hline 30 & Gramática francesa Instituto & 6 & 180 \\
\hline
\end{tabular}




\begin{tabular}{|c|c|c|c|}
\hline 3 & Historia de Francia & 2 & 6 \\
\hline 2 & Manual de correspondencia francesa & 6 & 12 \\
\hline 1 & Filosofía González & & 12 \\
\hline 9 & Libros Gury 2 tomos & 68 & 612 \\
\hline 15 & Libros Gramática & 4 & 60 \\
\hline 5 & “ Cosmología & 36 & 180 \\
\hline 1 & “ cólera morbo & & 2 \\
\hline 1 & " de la contabilidad & & 32 \\
\hline 1 & “ $\quad$ Ley del jurado Pacheco & & 40 \\
\hline 3 & Higiene y saneamiento de población & 14 & 42 \\
\hline 1 & $\begin{array}{l}\text { Historia de la instrucción pública en } \\
\text { España }\end{array}$ & & 10 \\
\hline 1 & $\begin{array}{l}\text { Comentario de legislación } \\
\text { hipotecaria }\end{array}$ & & 8 \\
\hline 1 & La Esmeralda por Víctor Hugo & & 16 \\
\hline 4 & Manual de Teneduría de libros & 13 & 52 \\
\hline 6 & Constitución de la Monarquía & 1 & 6 \\
\hline 1 & $\begin{array}{l}\text { Manual de lo contencioso Abella } \\
\text { rústica }\end{array}$ & & 30 \\
\hline 2 & $\begin{array}{l}\text { Manual de lo contencioso " } \\
\text { holandesa }\end{array}$ & 36 & 72 \\
\hline 1 & Código civil & & 15 \\
\hline 1 & Legislación de minas & & 24 \\
\hline 3 & Legislación de España & 15 & 45 \\
\hline 1 & Partición de herencia & & 15 \\
\hline
\end{tabular}


LA EDITORIAL BURGALESA HIJOS DE SANTIAGO RODRÍGUEZ (1891-1936):

ANÁLISIS DE LOS LIBROS ESCOLARES

\begin{tabular}{|c|c|c|c|}
\hline 1 & $\begin{array}{l}\text { Programa de aspirante a la } \\
\text { judicatura }\end{array}$ & & 2 \\
\hline 1 & Agricultura elemental & & 38 \\
\hline 2 & Práctica criminal & 7,5 & 15 \\
\hline 3 & Cuadernos del código & 3 & 9 \\
\hline 1 & Manual de policía urbana & & 15 \\
\hline 1 & Ley de enjuiciamiento civil & & 9 \\
\hline 1 & Manual del secretario & & 38 \\
\hline 1 & Id de los juzgados municipales & & 38 \\
\hline 1 & Id de apremios & & 30 \\
\hline 1 & Tratado de sanidad & & 30 \\
\hline 1 & Manual de desamortización & & 7,5 \\
\hline 2 & Tratado de lo contencioso & 36 & 72 \\
\hline 1 & Tratado de cálculos Rodera & & 36 \\
\hline 1 & Derecho internacional & & 12 \\
\hline 1 & Instrumentos públicos & & 38 \\
\hline 1 & $\begin{array}{l}\text { Ley y reglamento de Administración } \\
\text { provincial }\end{array}$ & & 9 \\
\hline 2 & $\begin{array}{l}\text { Procedimiento y reclamación } \\
\text { administrativa }\end{array}$ & 4,5 & 9 \\
\hline 1 & Expropiación forzosa & & 12 \\
\hline 2 & Tablas de reducción recíproca & 6 & 12 \\
\hline 6 & Ley del Jurado & 1,5 & 9 \\
\hline 2 & Ley electoral de Diputados & 4,5 & 9 \\
\hline 1 & Ley de lo criminal y del Jurado & & 15 \\
\hline
\end{tabular}




\begin{tabular}{|c|c|c|c|}
\hline 2 & Manual de consumos & 4,5 & 9 \\
\hline 1 & Ley de aguas & & 4,5 \\
\hline 3 & Lógica $\quad$ Mendivil & 10 & 30 \\
\hline 2 & Cosmología & 10 & 20 \\
\hline 3 & Ontología & 10 & 30 \\
\hline 2 & Psicología & 10 & 20 \\
\hline 2 & Theodicea & 10 & 20 \\
\hline 3 & Lógica y ontología “ & 30 & 90 \\
\hline 8 & Gramática Académica grande & 15 & 120 \\
\hline 10 & La cocinera moderna & 12 & 120 \\
\hline 15 & Programa $1^{\circ}$ curso francés & 1 & 15 \\
\hline 4 & Programa $2^{\circ}$ curso francés & 1 & 4 \\
\hline 6 & " $\quad$ de geografía & 1 & 6 \\
\hline 2 & “ $\quad$ de Historia de España & 1 & 2 \\
\hline 1 & “ $\quad$ de aritmética & & 4 \\
\hline 7 & “ $\quad$ Historia Universal & 1 & 7 \\
\hline 1 & latín $1^{\circ}$ año & & 2 \\
\hline 4 & Gramática Carrillo & 7 & 28 \\
\hline 3 & Código Civil Gral. & 14 & 42 \\
\hline 3 & Copiadores cartas & 9 & 27 \\
\hline 2 & Manual de quintas & 15 & 30 \\
\hline 1 & Manual de cédulas personales & & 3 \\
\hline 4 & Ley provincial & 3 & 12 \\
\hline 1 & Formación del censo general & & 3 \\
\hline
\end{tabular}


LA EDITORIAL BURGALESA HIJOS DE SANTIAGO RODRÍGUEZ (1891-1936):

ANÁLISIS DE LOS LIBROS ESCOLARES

\begin{tabular}{|c|c|c|c|}
\hline 2 & Manual de caza & 6 & 12 \\
\hline 1 & $\begin{array}{l}\text { Manual de caza } \\
\text { holandesa }\end{array}$ & & 8 \\
\hline 2 & Código penal militar & 9 & 18 \\
\hline 1 & Manual de fiscales & & 15 \\
\hline 1 & Manual de Registro civil & & 6 \\
\hline 1 & Ley de régimen militar & & 9 \\
\hline 1 & Leyes civiles de España & & 24 \\
\hline 3 & Código civil $3^{\circ}$ tomo & 15 & 45 \\
\hline 2 & $\begin{array}{l}\text { Ley de enjuiciamiento criminal } \\
\text { holandesa }\end{array}$ & 18 & 36 \\
\hline 2 & $\begin{array}{l}\text { Ley de enjuiciamiento civil } \\
\text { holandesa }\end{array}$ & 18 & 36 \\
\hline 2 & $\begin{array}{l}\text { Ley de enjuiciamiento civil } \\
\text { med. }\end{array}$ & 15 & 30 \\
\hline 2 & $\begin{array}{l}\text { Ley de enjuiciamiento criminal } \\
\text { “ }\end{array}$ & 15 & 30 \\
\hline 2 & Manual del timbre & 6 & 12 \\
\hline 1 & Código de comercio & & 15 \\
\hline 2 & Manual de & 6 & 12 \\
\hline 5 & Ley de expropiación forzosa & 3 & 15 \\
\hline 2 & Manuales judiciales & 4,5 & 9 \\
\hline 1 & Manual del Jurado & & 4,5 \\
\hline 2 & Manual de pesetas & 7,5 & 15 \\
\hline 1 & Legislación de minas & & 9 \\
\hline
\end{tabular}




\begin{tabular}{|c|c|c|c|}
\hline 2 & Leyes electorales & 3 & 6 \\
\hline 2 & Código penal & 4,5 & 9 \\
\hline 5 & Ley municipal & 3 & 15 \\
\hline 1 & Código civil & & 12 \\
\hline 3 & Manual de elecciones & 3 & 9 \\
\hline 4 & Formulario $\mathrm{p}^{\mathrm{o}}$ función de faltas & 3 & 12 \\
\hline 3 & Impuestos de derechos reales & 4,5 & 13,5 \\
\hline 1 & Manual de la contribución territorial & & 15 \\
\hline 1 & Formulario & 24 & 48 \\
\hline 1 & Ley de Jurado & & 9 \\
\hline 2 & Manuales de Hacienda municipal & 15 & 30 \\
\hline 1 & Manual de Alcaldes & & 15 \\
\hline 1 & Manual de policía urbana & & 15 \\
\hline 1 & Manual de ayuntamientos & & 7,5 \\
\hline 1 & $\begin{array}{l}\text { Ley de Aguas } \\
\text { holandesa }\end{array}$ & & 12 \\
\hline 1 & Ley de aguas & & 9 \\
\hline 1 & $\begin{array}{l}\text { Manual de montes } \\
\text { holandesa }\end{array}$ & & 9 \\
\hline 1 & Diccionario derecho civil & & 12 \\
\hline 3 & Manual de apremios & 9 & 27 \\
\hline 1 & Manual de desahucio & & 9 \\
\hline 1 & Expropiación forzosa & & 14 \\
\hline 1 & Contratos administrativos & & 18 \\
\hline
\end{tabular}


LA EDITORIAL BURGALESA HIJOS DE SANTIAGO RODRÍGUEZ (1891-1936):

ANÁLISIS DE LOS LIBROS ESCOLARES

\begin{tabular}{|c|c|c|c|}
\hline 1 & Procedimientos de apremios & & 6 \\
\hline 1 & Ley de alcoholes & & 6 \\
\hline 2 & $\begin{array}{l}\text { Manual de administración de } \\
\text { Hacienda }\end{array}$ & 4,5 & 9 \\
\hline 4 & Ley municipal & 3 & 12 \\
\hline 1 & Biblioteca judicial & & 9 \\
\hline 5 & Ley electoral & 3 & 15 \\
\hline 1 & Ley orgánica & & 7,5 \\
\hline 1 & Manual de reglamento civil & & 6 \\
\hline 3 & Veladas del obrero & 3 & 9 \\
\hline 1 & Historia de España & & 36 \\
\hline 1 & Historia de Jovellanos & & 20 \\
\hline 8 & Catecismo & 8 & 24 \\
\hline 1 & Los Santos Padres & & 10 \\
\hline 1 & Del Ebro al Tíber & & 6 \\
\hline 3 & Tratado de Hidrografía & 2 & 6 \\
\hline 1 & Gilberto y Matilde & & 3 \\
\hline 1 & Tratado de perfección & & 6 \\
\hline 3 & La madre & 5 & 15 \\
\hline 2 & El insecto & 5 & 10 \\
\hline 3 & El libro de los oradores & 6 & 18 \\
\hline 37 & Comedias encuadernadas & 2 & 74 \\
\hline 5 & Estudios y disertaciones & 6 & 30 \\
\hline 3 & Historia natural Gaspar & 2 & 6 \\
\hline
\end{tabular}




\begin{tabular}{|c|c|c|c|}
\hline 6 & Agricultura & 2 & 12 \\
\hline 1 & Manual del viajero & & 3 \\
\hline 1 & Geografía estadística & & 3 \\
\hline 1 & Manual de lectura & & 3 \\
\hline 1 & Manual del añil & & 3 \\
\hline 1 & Manual de geografía & & 3 \\
\hline 1 & Manual del aceite & & 3 \\
\hline 2 & Manual de mecánica & 3 & 6 \\
\hline 1 & Manual del capitalista & & 3 \\
\hline 2 & La Dama de las Camelias & 3 & 6 \\
\hline 8 & Verdadero Evangelio del pueblo & 0,5 & 4 \\
\hline 20 & La voz en el desierto & 2 & 40 \\
\hline 2 & Pensamiento & 4 & 8 \\
\hline 2 & Manual del tresillo & 6 & 12 \\
\hline 1 & Melonar de Madrid & & 4 \\
\hline 1 & Historia del Credo & & 5 \\
\hline 4 & Método de enseñanza & 3 & 12 \\
\hline 8 & Sendero de la vida & 2 & 16 \\
\hline 3 & La cocina perfeccionada & 3 & 9 \\
\hline 1 & La cocina moderna & & \\
\hline 5 & $\begin{array}{l}\text { Manual de sacristanes } \\
\text { grandes }\end{array}$ & 8 & 40 \\
\hline 2 & pequeños & 5 & 15 \\
\hline
\end{tabular}


LA EDITORIAL BURGALESA HIJOS DE SANTIAGO RODRÍGUEZ (1891-1936): ANÁLISIS DE LOS LIBROS ESCOLARES

\begin{tabular}{|c|c|c|c|}
\hline 3 & Maro & 5 & 15 \\
\hline 2 & El Educador de los niños & 6 & 12 \\
\hline 1 & La Ley de Dios & & 2 \\
\hline 2 & La Aurora del pensamiento & 1 & 2 \\
\hline 30 & Explicaciones láminas Mendivil & 1 & 30 \\
\hline 10 & Tesoro de las niñas & 2 & 20 \\
\hline 6 & Ciencia de la mujer & 3 & 18 \\
\hline 6 & Floresta de la infancia & 2 & 12 \\
\hline 7 & Juego del tresillo & 2 & 14 \\
\hline 3 & Religión de Balmes & 3 & 9 \\
\hline 3 & Compendio gramática $\quad$ Salazar & 3 & 9 \\
\hline 1 & Método $1^{\circ}$ aprender a leer & & 1 \\
\hline 4 & El ajedrez & 4 & 16 \\
\hline 3 & Lecciones familiares $\quad$ Guerrero & 2 & 6 \\
\hline 6 & Manual de agricultura & 4,5 & 27 \\
\hline 20 & Programa $H^{a}$ Sagrada & 0,5 & 10 \\
\hline 8 & Aritmética & 2,5 & 20 \\
\hline 5 & Estilo de cartas & 3 & 15 \\
\hline 2 & Conjugación de verbos & 3 & 6 \\
\hline 3 & Geografía & 2 & 6 \\
\hline 11 & Urbanidades en verso & 0,5 & 5,5 \\
\hline 1 & Manual completo $\mathrm{p}^{\circ}$ las niñas & & 5,5 \\
\hline 1 & $\begin{array}{l}\text { Cuaderno } 4^{\circ} \\
\text { Avendaño }\end{array}$ & & 2 \\
\hline
\end{tabular}




\begin{tabular}{|c|c|c|c|}
\hline 6 & Páginas de la virtud & 2 & 12 \\
\hline 1 & Perla práctica & 3 & 15 \\
\hline 1 & La mujer sensata $\quad$ Balmes & & 2 \\
\hline 3 & El libro de los deberes & 3 & 9 \\
\hline 3 & Guía del ama de casa & 3 & 9 \\
\hline 2 & Ciencia de la mujer & 2 & 4 \\
\hline 5 & $\begin{array}{l}\text { Historia Sagrada } \\
\text { Rosado }\end{array}$ & 2 & 10 \\
\hline 6 & $\begin{array}{l}\text { Ortografía } \\
\text { Salazar }\end{array}$ & 1,5 & 9 \\
\hline 3 & Cuentos del Pastor & 4 & 12 \\
\hline 6 & Perla práctica & 3 & 18 \\
\hline 4 & Perla de la niñez & 3 & 12 \\
\hline 1 & Libro de oro por Perala & & 2 \\
\hline 2 & Cuentos morales & 2,5 & 5 \\
\hline 2 & Ejemplos morales & 2,5 & 5 \\
\hline 3 & Mentor de los niños & 3 & 9 \\
\hline 3 & Mentor de las niñas & 3 & 9 \\
\hline 10 & Varias obras de Yeves & 1,5 & 15 \\
\hline 5 & $\begin{array}{l}\text { Programa de Geografía } \\
\text { Yeves }\end{array}$ & 1,5 & 7,5 \\
\hline 10 & $\begin{array}{l}\text { Geometrías } \\
\text { Yeves }\end{array}$ & 1,5 & 24 \\
\hline 3 & $\begin{array}{l}\text { Obras satíricas y festivas } \\
\text { Quevedo }\end{array}$ & 4 & 12 \\
\hline
\end{tabular}


LA EDITORIAL BURGALESA HIJOS DE SANTIAGO RODRÍGUEZ (1891-1936):

ANÁLISIS DE LOS LIBROS ESCOLARES

\begin{tabular}{|c|c|c|c|}
\hline 2 & Derecho Administrativo & 4 & 8 \\
\hline 1 & Fabricación del aguardiente & & 11 \\
\hline 1 & Examen de la vida de Jovellanos & & 2 \\
\hline 1 & Apuntes contemporáneos & & 6 \\
\hline 3 & La comedia de nuestro tiempo & 80 & 240 \\
\hline 1 & Olozaga y su tiempo & & 20 \\
\hline 1 & Biblioteca de autores españoles & & 8 \\
\hline 1 & Año cristiano Mayo & & 8 \\
\hline 1 & Vida de Pío IX & & 1 \\
\hline 1 & Los mártires de Chateaux & & 8 \\
\hline 1 & Diccionario de la niñez & & 2 \\
\hline 1 & De 1820 al 1824 & & 2 \\
\hline 1 & Melonar de Madrid & & 2 \\
\hline 1 & Calderón de la Barca & & 4 \\
\hline 1 & Estudios histórico políticos & & 4 \\
\hline 2 & Sentir y soñar & 2 & 4 \\
\hline 1 & Procedimiento político & & 2 \\
\hline 1 & El polvillo verde & & 1 \\
\hline 1 & Biblioteca & & 10 \\
\hline 1 & Año científico & & 4 \\
\hline 1 & La condesa de Bahou & & 2 \\
\hline 1 & Enciclopedia popular & & 3 \\
\hline 1 & Las trece noches de Carmen & & 2 \\
\hline 1 & Al montón & & 2 \\
\hline
\end{tabular}




\begin{tabular}{|c|c|c|c|}
\hline 1 & Piezas festivas & & 2 \\
\hline 1 & El buen tesorero & & 2 \\
\hline 1 & La desheredada & & 16 \\
\hline 1 & Habitante del planeta & & 4 \\
\hline 1 & Los postergados & & 4 \\
\hline 1 & Cuatro millones & & 4 \\
\hline 1 & $\mathrm{El} 4^{\circ}$ podio & & 8 \\
\hline 1 & El padre Mariana & & 6 \\
\hline 1 & Conflictos y tribulaciones & & 12 \\
\hline 1 & Matrimonio adúltero & & 2 \\
\hline 1 & Los hijos del desierto & & 2 \\
\hline 1 & Vista & & 4 \\
\hline 1 & Madrid por fuera & & 4 \\
\hline 1 & Capítulos de un libro & & 4 \\
\hline 1 & España & & 4 \\
\hline 1 & Constantinopla & & 6 \\
\hline 6 & Guía de Burgos & 4 & 24 \\
\hline 1 & Arquitectura legal & & 20 \\
\hline 1 & Retrato histórico & & 6 \\
\hline 1 & Rima contemporánea & & 4 \\
\hline 1 & La vida de Madrid & & 8 \\
\hline 8 & Pardo Bazán & 6 & 48 \\
\hline 1 & Roma por Catalina & & 27 \\
\hline 2 & La lucha por la existencia & 8 & 16 \\
\hline
\end{tabular}


LA EDITORIAL BURGALESA HIJOS DE SANTIAGO RODRÍGUEZ (1891-1936):

ANÁLISIS DE LOS LIBROS ESCOLARES

\begin{tabular}{|c|c|c|c|}
\hline 1 & Vida moderna & & 6 \\
\hline 1 & Enriqueta & & 6 \\
\hline 1 & Obras de Bécquer & & 24 \\
\hline 1 & tela & & 44 \\
\hline 1 & Redención del esclavo & & 16 \\
\hline 1 & Códice diplomático & & 8 \\
\hline 1 & El libro de una madre & & 4 \\
\hline 1 & Venganza de mujer & & 1 \\
\hline 2 & Los viajeros modernos & 4 & 8 \\
\hline 1 & Tratado de antropología & & 3 \\
\hline 1 & El caballero de rompe y rasga & & 14 \\
\hline 1 & Arquitectura & & 24 \\
\hline 2 & Cuentos de Perrault & 40 & 80 \\
\hline 1 & Reflexiones de asuntos políticos & & 1 \\
\hline 1 & Máximas eternas & & 2 \\
\hline 3 & Cantares flamencos & 2 & 6 \\
\hline 1 & Sendas opuestas & & 2 \\
\hline 1 & El Secretario de familia & & 2 \\
\hline 3 & Tesoro del arte jabonero & 8 & 24 \\
\hline 1 & Horario en España & & 16 \\
\hline 1 & El Solitario y su tiempo & & 16 \\
\hline 2 & Lucas & 12 & 24 \\
\hline 1 & Perlas literarias & & 4 \\
\hline 1 & Sainetes de D. Ramón de la Cruz & & 6 \\
\hline
\end{tabular}




\begin{tabular}{|c|c|c|c|}
\hline 1 & Responsabilidad moral & & 2 \\
\hline 1 & Tarifa de aguardientes y vino & & 1 \\
\hline 1 & La perfecta casada & & 2 \\
\hline 1 & Manual de la caña de azúcar & & 2 \\
\hline 1 & Guía de Alba de Tormes & & 2 \\
\hline 1 & El diablo cojuelo & & 2 \\
\hline 1 & La familia de Fernanda & & 1 \\
\hline 1 & Dolores de Campoamor & & 1 \\
\hline 1 & Las serpientes & & 1 \\
\hline 1 & Tierra del Infierno & & 1 \\
\hline 1 & El Talismán de Juan Soldado & & 3 \\
\hline 1 & Novísimo ramillete de felicitaciones & & 3 \\
\hline 1 & Ecos del alma & & 4 \\
\hline 1 & Calabazas y cabezas & & 2 \\
\hline 1 & Bernardo Palises & & 2 \\
\hline 1 & Las triquinas & & 2 \\
\hline 1 & Diccionario inglés especial & & 6 \\
\hline 3 & Teoría de la inmortalidad & 2 & 6 \\
\hline 1 & Higiene del alma & & 4 \\
\hline 1 & Homenaje poético & & 3 \\
\hline
\end{tabular}

Fuente: Inventario notarial de los bienes de la empresa Imprenta y Librería Santiago Rodríguez Alonso. [Elaboración propia]. 
LA EDITORIAL BURGALESA HIJOS DE SANTIAGO RODRÍGUEZ (1891-1936):

ANÁLISIS DE LOS LIBROS ESCOLARES

Inventario de maquinaria, material y papel en la imprenta.

1 Máquina Minerva

4.000

reales

1 Máquina Bremen

27.000

reales

1 Máquina Marinoni

20.000

reales

1 Máquina para trepar

reales

1. Máquina para prensar

reales

1 Máquina para cortar

2.000

reales

Tipos, rayas, tintes y demás material

reales

Cajas, galeras, galerines, mesas y demás

reales

277 resmas de papel de diversos tamaños y calidades

5.746 reales

ALMACÉN: $180.921,72$ reales $=45.230,43$ pts .

TIENDA: $66.077,10$ reales $=16.519,28$ pts.

IMPRENTA: 115.192 reales $=28.798$ pts .

AJUAR DE CASA: 26.000 reales $=6.500$ pts.

TOTAL: 99.547,71 pts. 
Lista de los deudores y sus cantidades a la muerte de D. Santiago Rodríguez Alonso.

\begin{tabular}{|l|l|}
\hline SALDOS DEUDORES & PTS. \\
\hline Aureliano Ruiz Cabrera & 60 \\
\hline Germán Pérez & 89,88 \\
\hline Darío Rahola & 267,26 \\
\hline Uceda Hermanos & 260,75 \\
\hline Mata y Martín & 15 \\
\hline Diputación de Salamanca & 254 \\
\hline Rafael Terol & 94,41 \\
\hline Manuel Ma Ramón & 101,50 \\
\hline Cosme Urueta & 25 \\
\hline José Pérez & 64,50 \\
\hline Guillermo Vélez & 9,85 \\
\hline Eusebio Chamizo & 25,62 \\
\hline José [Vigón] & 51 \\
\hline Francisco Góngora & 184,63 \\
\hline Tadeo Calomarde & 182 \\
\hline Julio Subiran & 34,75 \\
\hline José M. Ramos & 13,72 \\
\hline Felipe G. de los Ríos & 16,25 \\
\hline José Camarero & \\
\hline Eugenio Rámila & 180 \\
\hline
\end{tabular}


LA EDITORIAL BURGALESA HIJOS DE SANTIAGO RODRÍGUEZ (1891-1936): ANÁLISIS DE LOS LIBROS ESCOLARES

\begin{tabular}{|c|c|}
\hline Pérez y Gónzalez & 39,91 \\
\hline Gregorio Rueda & 1000 \\
\hline Tireo Arroyo & 30 \\
\hline Viuda de Sierra & 80 \\
\hline Eliodoro Mendivil & 100 \\
\hline Francisco Gel & 13,20 \\
\hline Julián Lobo & 43,14 \\
\hline Isidoro Gallego & 108,75 \\
\hline Eduardo A. de Besson & 500 \\
\hline José Pardo & 123 \\
\hline Ramón Moreno & 199,95 \\
\hline Sr. Crespo & 6 \\
\hline Manuel Samperio & 4 \\
\hline Viuda de J. Fontanel & 17,85 \\
\hline Catalina González & 45 \\
\hline Manuel Cotarelo & 31,25 \\
\hline Lorenzo Pérez & 13,18 \\
\hline Manuel Abarca & 122,33 \\
\hline Leopoldo Rodríguez & 79,50 \\
\hline Mateo de las Heras & 204,26 \\
\hline Pablo Rodríguez & 28,95 \\
\hline Antero Concha & 482,25 \\
\hline Francisco Pérez & 90,71 \\
\hline José Ballesteros & 137,75 \\
\hline
\end{tabular}




\begin{tabular}{|l|l|}
\hline Julián [Horciano] & 96,25 \\
\hline Manuel R. Cabrera & 914,05 \\
\hline Eloy Ugalbe & 127,13 \\
\hline Manuel Urban & 70,25 \\
\hline Juan Presa & 74,79 \\
\hline Eusebio Pinedo & 170,19 \\
\hline Baldomero Campano & 74,50 \\
\hline José Iglesias & 110,50 \\
\hline Pascual G. Hernández & 22,51 \\
\hline Pedro Garcés & 153,70 \\
\hline Saturnino Peña & 19,50 \\
\hline Victoriano del Campo & 36,50 \\
\hline Ascensión Sintra & 114,80 \\
\hline Elías M. de León & 162 \\
\hline Julián de Miguel & 10,79 \\
\hline Ricardo M. Merino & 101,55 \\
\hline Eloy Pérez & 133,13 \\
\hline Nicolás Pérez Román & 130,89 \\
\hline Antonio [Egumola] & 57,11 \\
\hline Antonio [Sientes] & 19,25 \\
\hline Bernardo Fabregues & 118 \\
\hline Felipe A. Peláez & 138 \\
\hline José Ma Gastaca & \\
\hline Blas González & 130 \\
\hline
\end{tabular}


LA EDITORIAL BURGALESA HIJOS DE SANTIAGO RODRÍGUEZ (1891-1936): ANÁLISIS DE LOS LIBROS ESCOLARES

\begin{tabular}{|c|c|}
\hline Viuda de Villamil & 77,50 \\
\hline Maximiliano Carrera & 60,75 \\
\hline Francisco Rodrigo & 10 \\
\hline Roca Bren & 1499,13 \\
\hline Ceferino Reci & 20,05 \\
\hline Santiago Alonso & 44 \\
\hline Viuda de Berned & 150,99 \\
\hline Blas Pérez & 162,75 \\
\hline Francisco R. Morote & 29,80 \\
\hline Francisco Patiño & 6,99 \\
\hline Francisco Fons & 77,45 \\
\hline Dámaso Rodríguez & 1104 \\
\hline Rojas hermanos & 9 \\
\hline [Jonfer] Pérez & 105,63 \\
\hline León Villen & 1013 \\
\hline Antonio Palacios & 500 \\
\hline Juan M. Nieto & 60 \\
\hline Eusebio Revilla & 193,59 \\
\hline Claudio Alva & 74,75 \\
\hline Pascual Boz & 37,50 \\
\hline Rafael Camis & 163,43 \\
\hline Francisco L. Munain & 154,10 \\
\hline Antonio Quesada & 336,60 \\
\hline Viuda de L. Arias & 228 \\
\hline
\end{tabular}




\begin{tabular}{|l|l|}
\hline Antonio J. Bastinos & 2,08 \\
\hline José Soto & 185,40 \\
\hline Juan Espla & 822,65 \\
\hline Herederos de Miñón & 175,25 \\
\hline Miguel Barro Pérez & 229 \\
\hline Vicente Tejero & 170,41 \\
\hline Eusebio Fernández & 300 \\
\hline Fernando Meléndez & 100,15 \\
\hline Andrés C. Ciriano & 182,15 \\
\hline Francisco Delgado & 50,16 \\
\hline Luis Montero & 152,88 \\
\hline Viuda de Pérez & 86,75 \\
\hline Joaquín J. Vélez & 12,25 \\
\hline M. Galban & 62,97 \\
\hline Camilo de Blas & 12,74 \\
\hline León Velasco & 2089,31 \\
\hline Policarpo & 184,50 \\
\hline Pedro Velasco & 1874,62 \\
\hline Salón de Recreo & 466,25 \\
\hline Isidoro Hernández & 289,80 \\
\hline Méndez hermanos & 5,18 \\
\hline A. Lynn Luc de Moris & \\
\hline Francisco Iglesias & 28,08 \\
\hline Viuda de Pablo & \\
\hline
\end{tabular}


LA EDITORIAL BURGALESA HIJOS DE SANTIAGO RODRÍGUEZ (1891-1936): ANÁLISIS DE LOS LIBROS ESCOLARES

\begin{tabular}{|l|l|}
\hline Blanco hermanos & 76 \\
\hline Pedro M. Luelmo & 7,20 \\
\hline Melchor Zenzarren & 66,64 \\
\hline Francisco Castro & 9,23 \\
\hline Anselmo Pérez y Compañía & 16 \\
\hline Carlos Guzmán & 302,34 \\
\hline Antonio A. Carretero & 175 \\
\hline Diputación de León & 100 \\
\hline Rodolfo Díaz & 47,50 \\
\hline Francisco Jornet & 580,43 \\
\hline Clemente Fernández & 130,50 \\
\hline Hijos de Ildefonso Diez & 38,75 \\
\hline Santos del Campo & 77,25 \\
\hline Francisco Jiménez & 5,68 \\
\hline Ceferino Larca & 105,70 \\
\hline Vicente Cuello & 48,50 \\
\hline Epifanio Salazar & 252,94 \\
\hline Víctor Asenjo & 64,25 \\
\hline Vicente González & 79,58 \\
\hline José Pérez Botella & 193,98 \\
\hline Ildefonso Manzano & 89,69 \\
\hline Ambrosio Vicente & 12,40 \\
\hline Luis G. Hernández & \\
\hline Francisco Galban & \\
\hline
\end{tabular}




\begin{tabular}{|l|l|}
\hline Viuda de Castilla & 313,75 \\
\hline Francisco López & 67,79 \\
\hline Julián Fernández & 73,75 \\
\hline José M. López & 454,02 \\
\hline Inocencio M. Palacios & 515,67 \\
\hline Vicente Álvarez & 172,88 \\
\hline Miguel Soto & 244,17 \\
\hline Juan P. Requena & 511,98 \\
\hline Yarto Jiménez & 1474,16 \\
\hline Francisco Martínez Giménez & 67,50 \\
\hline Viuda de Porto & 18,25 \\
\hline José R. Paratolia & 349 \\
\hline Esteban Navas & 104,84 \\
\hline Nicolás L. Miñón & 427,03 \\
\hline Viuda de P. Pascual & 803 \\
\hline Manuel Galán & 121,05 \\
\hline Fernando López Toral & 49,75 \\
\hline Tomás Campans & 253,38 \\
\hline Generoso Montero & 92,21 \\
\hline J. M. Paez & 28 \\
\hline Galo Nuñez & 10,50 \\
\hline José Erice & 92,55 \\
\hline Rafael G & \\
\hline Buenaventura González & \\
\hline
\end{tabular}


LA EDITORIAL BURGALESA HIJOS DE SANTIAGO RODRÍGUEZ (1891-1936): ANÁLISIS DE LOS LIBROS ESCOLARES

\begin{tabular}{|l|l|}
\hline R. Constantino Terol & 100 \\
\hline Asensio Torregrosa & 236 \\
\hline Francisca Robles & 86,97 \\
\hline Francisco Losa & 116 \\
\hline Manuel Tamargo & 239,50 \\
\hline Viuda de J.P. Galán & 113,20 \\
\hline Antonio José Torres & 189 \\
\hline Victoriano Palencia & 181,25 \\
\hline Diego Guerrero & 152,75 \\
\hline Manuela Ales & 135,50 \\
\hline Guillermo Barrero & 109,99 \\
\hline [Linazaroso] hermanos & 149,25 \\
\hline Ramón García Díaz & 104,50 \\
\hline Casto Pérez Pozo & 75,50 \\
\hline Vega y Montilla & 238,54 \\
\hline Emilio Palacios & 105,50 \\
\hline A. Castellanos y hermanos & 76,50 \\
\hline José Vidal & 202,05 \\
\hline Raimundo Sánchez & 69,50 \\
\hline Antolín Serrano & 19,75 \\
\hline Ezequiel de Castro & 35,25 \\
\hline Alejo Hernández & 827,85 \\
\hline Clodomiro Díaz & 196,98 \\
\hline Juan López & \\
\hline
\end{tabular}




\begin{tabular}{|l|l|}
\hline Galo Barrutia & 1777,37 \\
\hline Basilia Gallego & 90 \\
\hline
\end{tabular}

Fuente: Inventario notarial de los bienes de la empresa Imprenta y Librería Santiago Rodríguez Alonso. [Elaboración propia]

TOTAL: $37.413,68$ pts.

Maestros deudores: 2.086 pts.

Cuentas a cobrar: $8.627,51$ pts.

Deudores de La Imparcialidad 200 pts.

Ajuar de almacén y tienda: 800 pts.

SUMA TOTAL DEL ACTIVO: 148.674,90 pts.

Lista de los acreedores y sus cantidades a la muerte de D. Santiago Rodríguez Alonso.

\begin{tabular}{|l|l|}
\hline SALDOS ACREEDORES & PTS \\
\hline Espasa y Compañía & 27 \\
\hline Montaner y Simón & 489,18 \\
\hline Sucesores de J.M. Fabre & 219,59 \\
\hline Julio Cenzano & 2 \\
\hline Crespo y Compañía & 1129,42 \\
\hline Viuda e Hijos de Subirana & 61,57 \\
\hline
\end{tabular}


LA EDITORIAL BURGALESA HIJOS DE SANTIAGO RODRÍGUEZ (1891-1936): ANÁLISIS DE LOS LIBROS ESCOLARES

\begin{tabular}{|l|l|}
\hline Hachette y Compañía & 65,20 \\
\hline Garnier Hermanos & 312,50 \\
\hline Pedro Alma & 1020.67 \\
\hline Cándido Velasco & 13 \\
\hline J. José Laborde & 126,47 \\
\hline L. Turgis et Fils & 4,85 \\
\hline M. H. Huber & 35,38 \\
\hline Jaime Pirfol & 127,85 \\
\hline García Quintano & 8,65 \\
\hline Marciano Murillo & 7,90 \\
\hline Grote y Schulz & 100 \\
\hline El Liberal & 566 \\
\hline El Imparcial & 205 \\
\hline Domingo Sar & 7,25 \\
\hline Victoriano Cuevas & 32,12 \\
\hline Manuel Diez & 45,42 \\
\hline Schomburg Caballero y Compañía & 1097,22 \\
\hline Fernández Villa Hermanos & $12,413,65$ \\
\hline Agustín Puebla & 100,96 \\
\hline E. Gutiérrez y Compañía & 1242,74 \\
\hline Arza y Compañía & \\
\hline Saturnino Calleja & \\
\hline Faustino Paluzie & \\
\hline L. Rivas y Compañía & \\
\hline
\end{tabular}




\begin{tabular}{|l|l|}
\hline Manuel Rosado & 441,52 \\
\hline Dolores Flórez & 106,13 \\
\hline Manes y Compañía & 60,65 \\
\hline Eugenio Sobrino & 250 \\
\hline Baldomero Ollo & 835,75 \\
\hline José Villaseca & 1192,98 \\
\hline Juan Gili & 123 \\
\hline R. (ilegible) & 232,80 \\
\hline Sebastián Maltrana & 179 \\
\hline Amadeo Cros & 31,88 \\
\hline Pedro Uranga & 732,02 \\
\hline Emilio Lannois & 206,46 \\
\hline Hijos de Rodríguez & 46 \\
\hline Viuda de Fuentenebro & 68,20 \\
\hline Berasaluce y Barrena & 1060 \\
\hline Dorao Hermanos & 240,38 \\
\hline Ramón L. Jalcon & 194,26 \\
\hline Laroche Foubert & 48,10 \\
\hline John Dickison & 780,65 \\
\hline Viuda de Cuesta & 716,55 \\
\hline Viuda de Hernando & 59,68 \\
\hline Viuda de Orallo & 1500 \\
\hline Viuda de Rodríguez & \\
\hline J. Matheu y Compañía & \\
\hline
\end{tabular}


LA EDITORIAL BURGALESA HIJOS DE SANTIAGO RODRÍGUEZ (1891-1936): ANÁLISIS DE LOS LIBROS ESCOLARES

\begin{tabular}{|c|c|}
\hline Victorino Suarez & 80,91 \\
\hline Juan A. Sánchez & 260 \\
\hline San Pedro y compañía & 1674,50 \\
\hline Hijos de J. Pastor & 71,91 \\
\hline Fernando Jé & 30,32 \\
\hline Ponte y compañía & 10 \\
\hline Wilhelm Leniere & 757,60 \\
\hline Manuel Recarte & 13 \\
\hline Francisco Serrano & 18 \\
\hline Pascual Torras & 349,60 \\
\hline Manuel Abellá & 99,60 \\
\hline Saenz de Jubera Hermanos & 625,77 \\
\hline Wenceslao Guarro & 132 \\
\hline J.M. Paullard & 214,30 \\
\hline José Gil y Hernando & 418,80 \\
\hline A. Baench Fils & 175 \\
\hline J. Levy y Compañía & 133,65 \\
\hline Israel et Fils & 591,16 \\
\hline A. Bethencourt e Hijos & 36,80 \\
\hline Montaner y Simon & 489,18 \\
\hline Nicolás Mayo & 12,20 \\
\hline Abelardo J. de Carlos & 134,39 \\
\hline Compañía transatlántica & 56,67 \\
\hline Elisa de Miguel y Campo & 1500 \\
\hline
\end{tabular}


CUENTAS A PAGAR: 6.710,84 Pts.

LETRAS A PAGAR EN CIRCULACIÓN: 6.989,25 pts.

Resumen total y activo de la nueva empresa Hijos de Santiago Rodríguez.

IMPORTE EL ACTIVO: 148.674,90 pts.

IMPORTE EL PASIVO: $\quad 52.646,81$ pts.

CAPITAL LÍQUIDO: $\quad 96.028,09$ pts.

LIQUIDACIÓN:

El caudal hereditario en el inventario representa la cantidad de 96.028,09 pts.

BAJAS:

FUNERALES: $885,47 \mathrm{pt}$.

LEGADO DE ELISA MIGUEL: 2.000 pts.

LEGADO DE Mª PILAR RODRÍGUEZ MIGUEL: 5.000 pts.

LEGADO DE FRANCISCO RODRÍGUEZ MIGUEL: 5.000 pts.

LEGADO DE Mª DE LA GLORIA RODRÍGUEZ MIGUEL: 5.000 pts. 
LA EDITORIAL BURGALESA HIJOS DE SANTIAGO RODRÍGUEZ (1891-1936):

ANÁLISIS DE LOS LIBROS ESCOLARES

Los legados de los tres hermanos son para igualar con los casados, Mariano y Luisa, en su condición de solteros.

\section{RESUMEN FINAL:}

Caudal hereditario: $96.028,09$ pts.

Bajas: $\quad 17.885,47$ pts.

CAPITAL LÍQUIDO: 78.142,62 pts. 


\subsection{EVARISTO BARRIO (ZARAGOZA, 1841-BURGOS 1924)}

3.1.1. Ilustración de la cubierta del cuento A gran rey mejor vasallo de la Biblioteca Cuentos para Niños.

3.1.2. Ilustraciones interiores del cuento A gran rey mejor vasallo de la Biblioteca Cuentos para Niños.

3.1.3. Ilustración de la cubierta del cuento Lo que puede la fe de la Biblioteca Cuentos para Niños.

3.1.4. Ilustraciones interiores del cuento Lo que puede la fe de la Biblioteca Cuentos para Niños.

3.1.5. Ilustración de la cubierta del cuento El buen hermano de la Biblioteca Cuentos para Niños.

3.1.6. Ilustraciones interiores del cuento El buen hermano de la Biblioteca Cuentos para Niños.

3.1.7. Ilustración de la cubierta del cuento La manta de lana de la Biblioteca Cuentos para Niños.

3.1.8. Ilustraciones interiores del cuento La manta de lana de la Biblioteca Cuentos para Niños.

3.1.9. Ilustración de la cubierta del cuento Batalla campal de la Biblioteca Cuentos para Niños.

3.1.10. Ilustraciones interiores del cuento Batalla campal de la Biblioteca Cuentos para Niños.

3.1.11. Ilustración de la cubierta del cuento El capricho de Susú de la Biblioteca Cuentos para Niños.

3.1.12. Ilustraciones interiores del cuento Batalla campal de la Biblioteca Cuentos para Niños.

3.1.13. Ilustración de la cubierta del cuento El grumete de la Biblioteca Cuentos para Niños. 
3.1.14. Ilustraciones interiores del cuento El grumete de la Biblioteca Cuentos para Niños.

3.1.15. Ilustración de la cubierta del cuento El grumete de la Biblioteca Cuentos para Niños.

3.1.16. Ilustraciones interiores del cuento El pastorcillo de la Biblioteca Cuentos para Niños.

3.1.17. Ilustración de la cubierta del cuento El pequeño aeronauta de la Biblioteca Cuentos para Niños.

3.1.18. Ilustraciones interiores del cuento El pequeño aeronauta de la Biblioteca Cuentos para Niños.

3.1.19. Ilustración de la cubierta del cuento El vendedor de periódicos de la Biblioteca Cuentos para Niños.

3.1.20. Ilustraciones interiores del cuento El vendedor de periódicos de la Biblioteca Cuentos para Niños.

3.1.21. Ilustración de la cubierta del cuento Emilín de la Biblioteca Cuentos para Niños.

3.1.22. Ilustraciones interiores del cuento Emilín de la Biblioteca Cuentos para Niños.

3.1.23. Ilustración de la cubierta del cuento Enriqueta de la Biblioteca Cuentos para Niños.

3.1.24. Ilustraciones interiores del cuento Enriqueta de la Biblioteca Cuentos para Niños.

3.1.25. Ilustración de la cubierta del cuento Siempre que puedas haz bien de la Biblioteca Cuentos para Niños.

3.1.26. Ilustraciones interiores del cuento Siempre que puedas haz bien de la Biblioteca Cuentos para Niños.

3.1.27. Ilustración interior del cuento Felicidad en la buhardilla de la Biblioteca Cuentos para Niños.

3.1.28. Ilustraciones interiores del cuento $\mathrm{La}$ noche de Reyes de la Biblioteca Cuentos para Niños. 
3.1.29. Ilustración interior del cuento Pedro el avaricioso de la Biblioteca Cuentos para Niños.

3.1.30. Ilustraciones interiores del cuento Al borde del abismo de la Biblioteca Museo de la Infancia.

3.1.31. Ilustración interior del cuento El músico callejero de la Biblioteca Ideal.

3.1.32. Ilustración de la cubierta del libro Dos primos célebres de la Biblioteca Selecta.

3.1.33. Ilustración interior del libro Ferrús el ermitaño de la Biblioteca Selecta.

3.1.34. Ilustración interior del libro Flor de Aventuras de la Biblioteca Azul y Rosa (I).

3.1.35. Ilustración interior del libro Flor de Aventuras de la Biblioteca Azul y Rosa (II).

3.1.36. Ilustraciones interiores del libro Pompas de jabón de la Mundial Biblioteca.

3.1.37. Ilustraciones interiores del libro ¿Quieres ser mi amigo? de la Biblioteca Oro.

3.1.38. Ilustración de la cubierta Aventuras de un huérfano de la Biblioteca Oro.

3.1.39. Ilustración de la cubierta La tiranuela de la Biblioteca Museo de la Infancia.

3.1.40. Ilustración de la cubierta de Aventuras de Telémaco de la Biblioteca Enciclopédica Hispano-Americana.

3.1.41. Ilustración de la cubierta de Rafael de la Biblioteca Enciclopédica Hispano-Americana. 
LA EDITORIAL BURGALESA HIJOS DE SANTIAGO RODRÍGUEZ (1891-1936): ANÁLISIS DE LOS LIBROS ESCOLARES

3.1.1. Ilustración de la cubierta del cuento A gran rey mejor vasallo de la Biblioteca Cuentos para Niños.

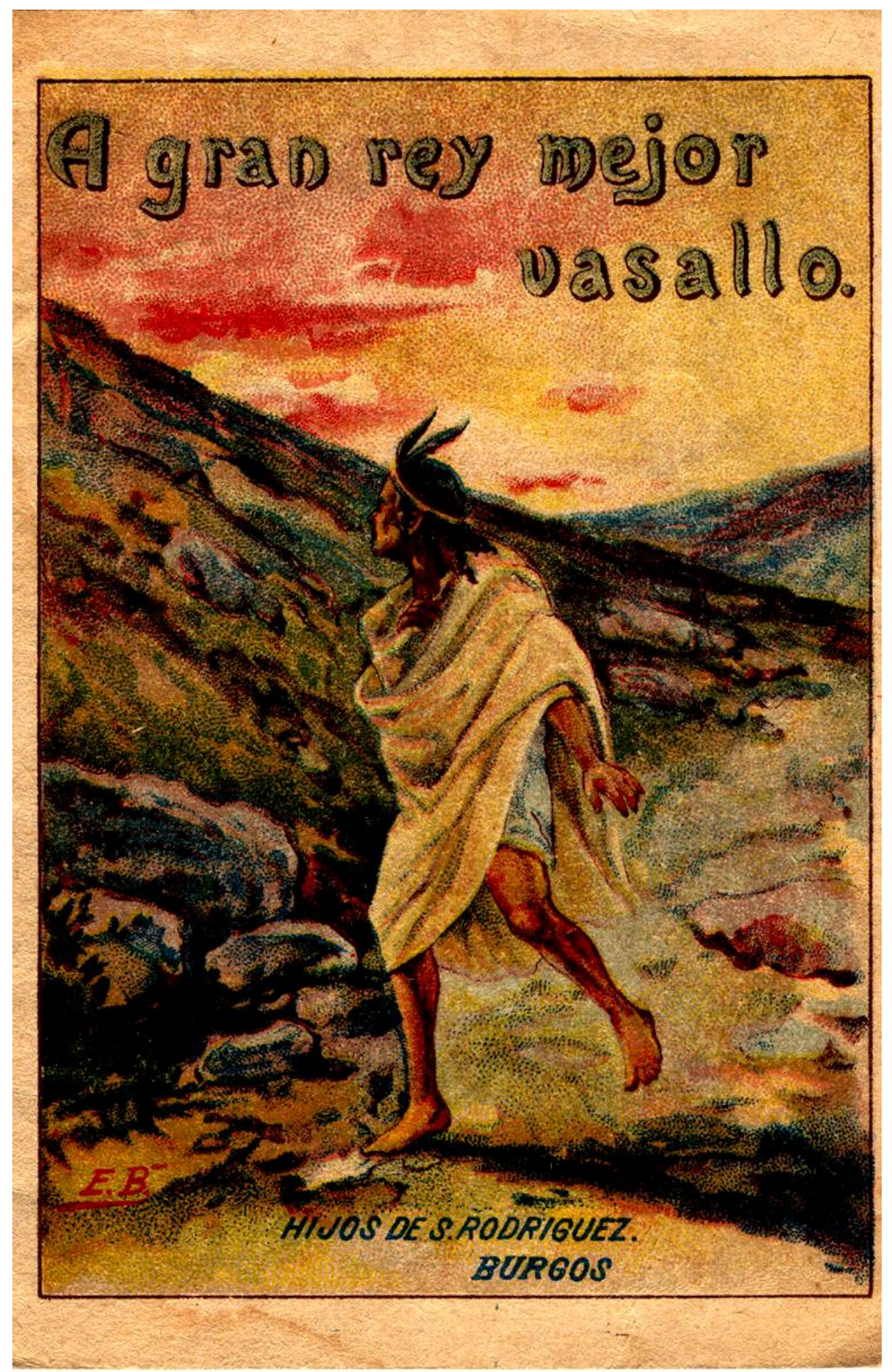

Fig: 1

Cubierta a color del cuento A gran rey mejor vasallo de la Biblioteca Cuentos para Niños. Hijos de Santiago Rodríguez. 
3.1.2. Ilustraciones interiores del cuento A gran rey mejor vasallo de la Biblioteca Cuentos para Niños.
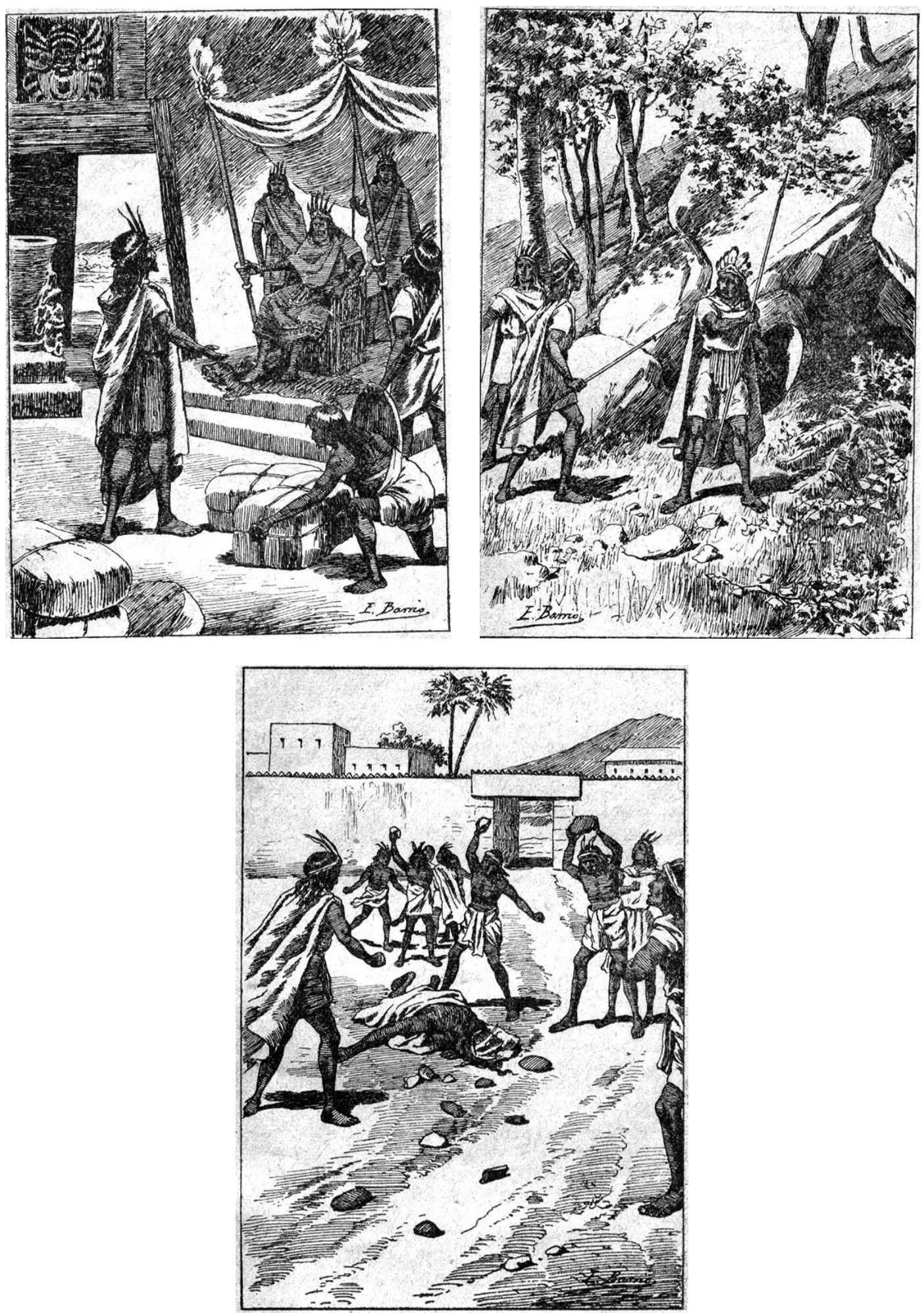

Fig.: 2

Ilustraciones interiores del cuento A gran rey mejor vasallo de la Biblioteca Cuentos para Niños. Hijos de Santiago Rodríguez. 
LA EDITORIAL BURGALESA HIJOS DE SANTIAGO RODRÍGUEZ (1891-1936): ANÁLISIS DE LOS LIBROS ESCOLARES

3.1.3. Ilustración de la cubierta del cuento Lo que puede la fe de la Biblioteca Cuentos para Niños.

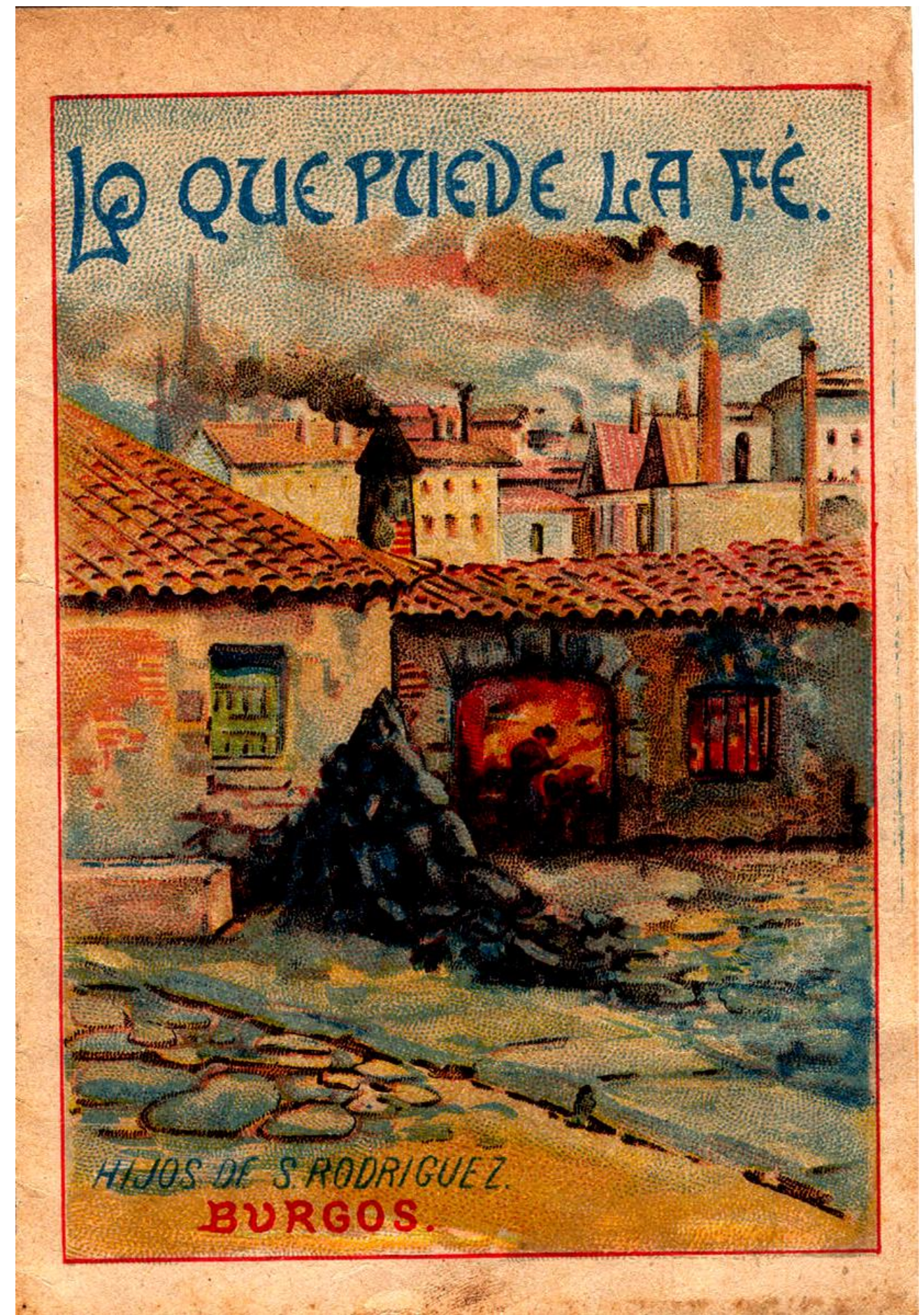

Fig: 3

Cubierta a color del cuento Lo que puede la fe de la Biblioteca Cuentos para Niños. Hijos de Santiago Rodríguez. 
3.1.4. Ilustraciones interiores del cuento Lo que puede la fe de la Biblioteca Cuentos para Niños.
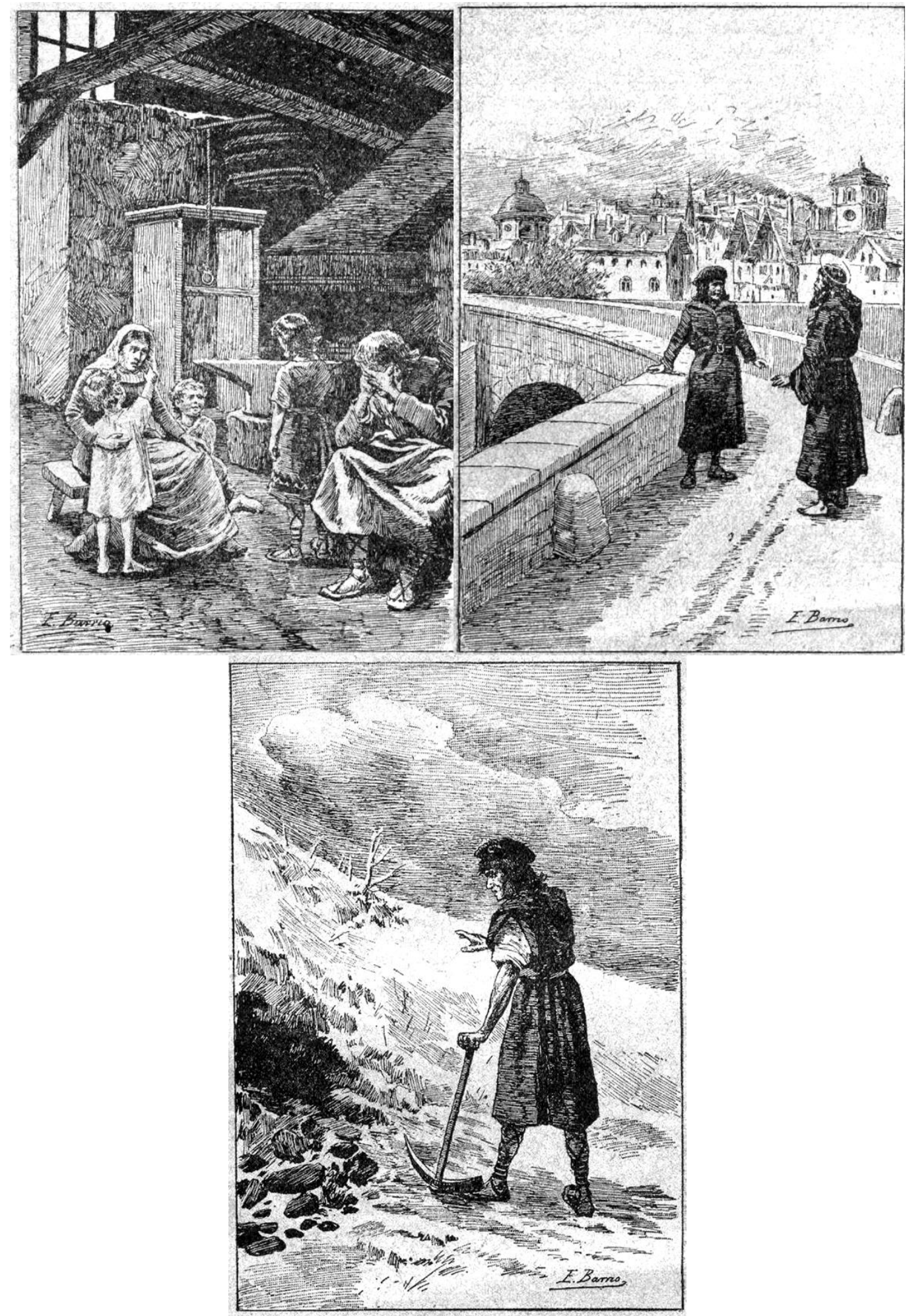

Fig.: 4

Ilustraciones interiores del cuento Lo que puede la fe de la Biblioteca Cuentos para Niños. Hijos de Santiago Rodríguez. 
LA EDITORIAL BURGALESA HIJOS DE SANTIAGO RODRÍGUEZ (1891-1936): ANÁLISIS DE LOS LIBROS ESCOLARES

3.1.5. Ilustración de la cubierta del cuento El buen hermano de la Biblioteca Cuentos para Niños.

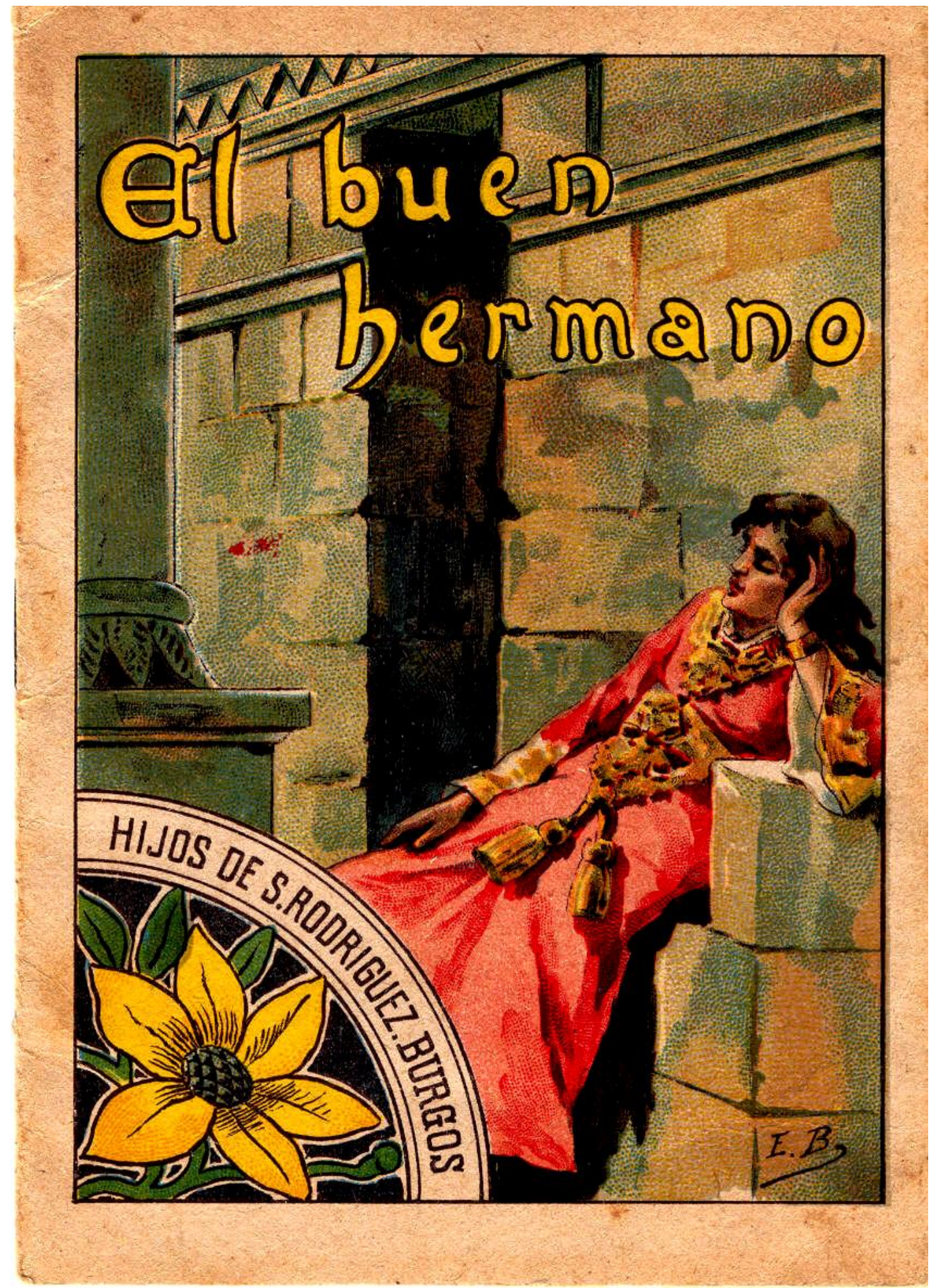

Fig: 5

Cubierta a color del cuento El buen hermano de la Biblioteca Cuentos para Niños. Hijos de Santiago Rodríguez. 
3.1.6. Ilustraciones interiores del cuento El buen hermano de la Biblioteca Cuentos para Niños.
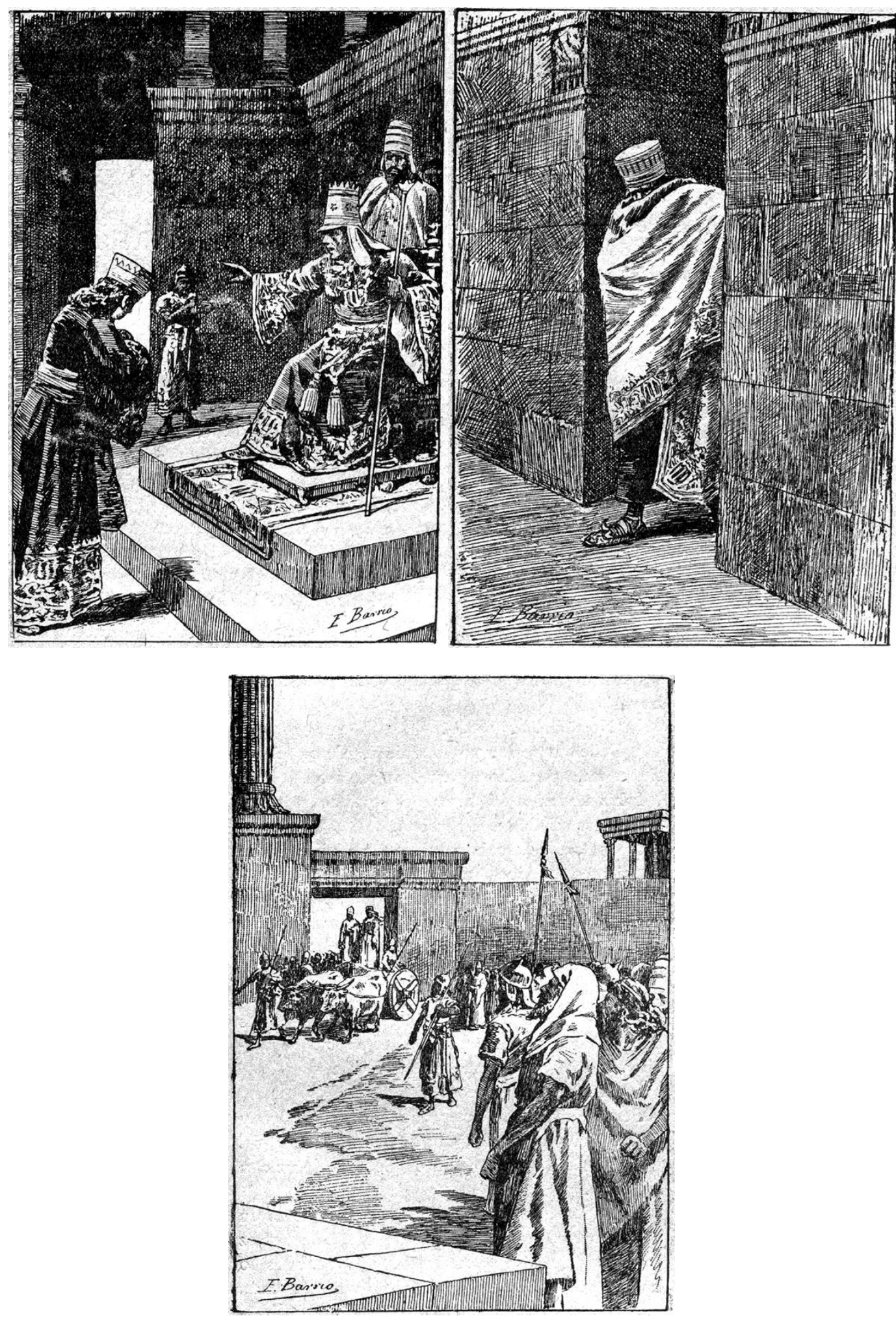

Fig.: 6

Ilustraciones interiores del cuento El buen hermano de la Biblioteca Cuentos para Niños. Hijos de Santiago Rodríguez. 
LA EDITORIAL BURGALESA HIJOS DE SANTIAGO RODRÍGUEZ (1891-1936): ANÁLISIS DE LOS LIBROS ESCOLARES

3.1.7. Ilustración de la cubierta del cuento La manta de lana de la Biblioteca Cuentos para Niños.

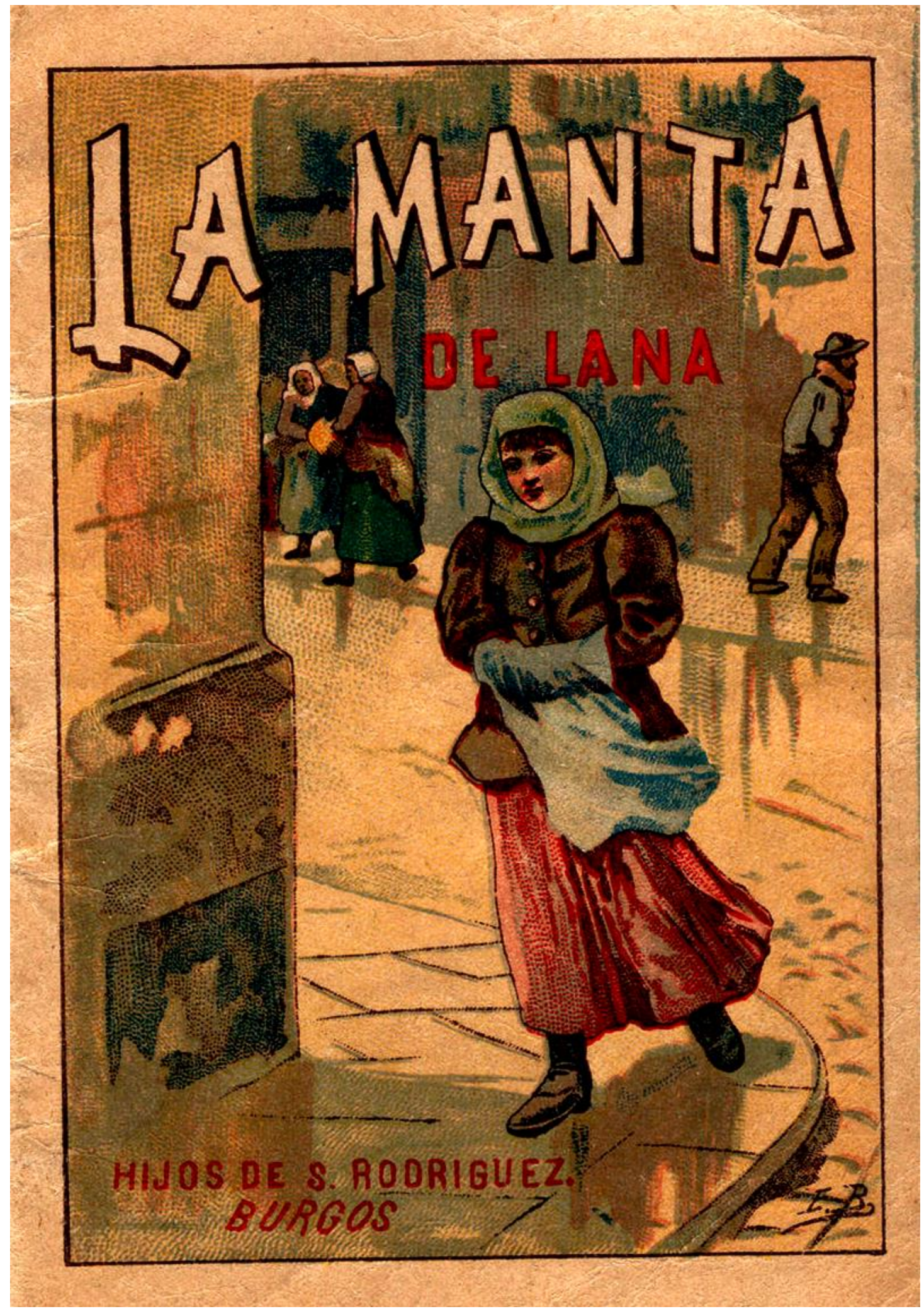

Fig: 7

Cubierta ilustrada del cuento La manta de lana de la Biblioteca Cuentos para Niños. Hijos de Santiago Rodríguez. 
3.1.8. Ilustraciones interiores del cuento La manta de lana de la Biblioteca Cuentos para Niños.
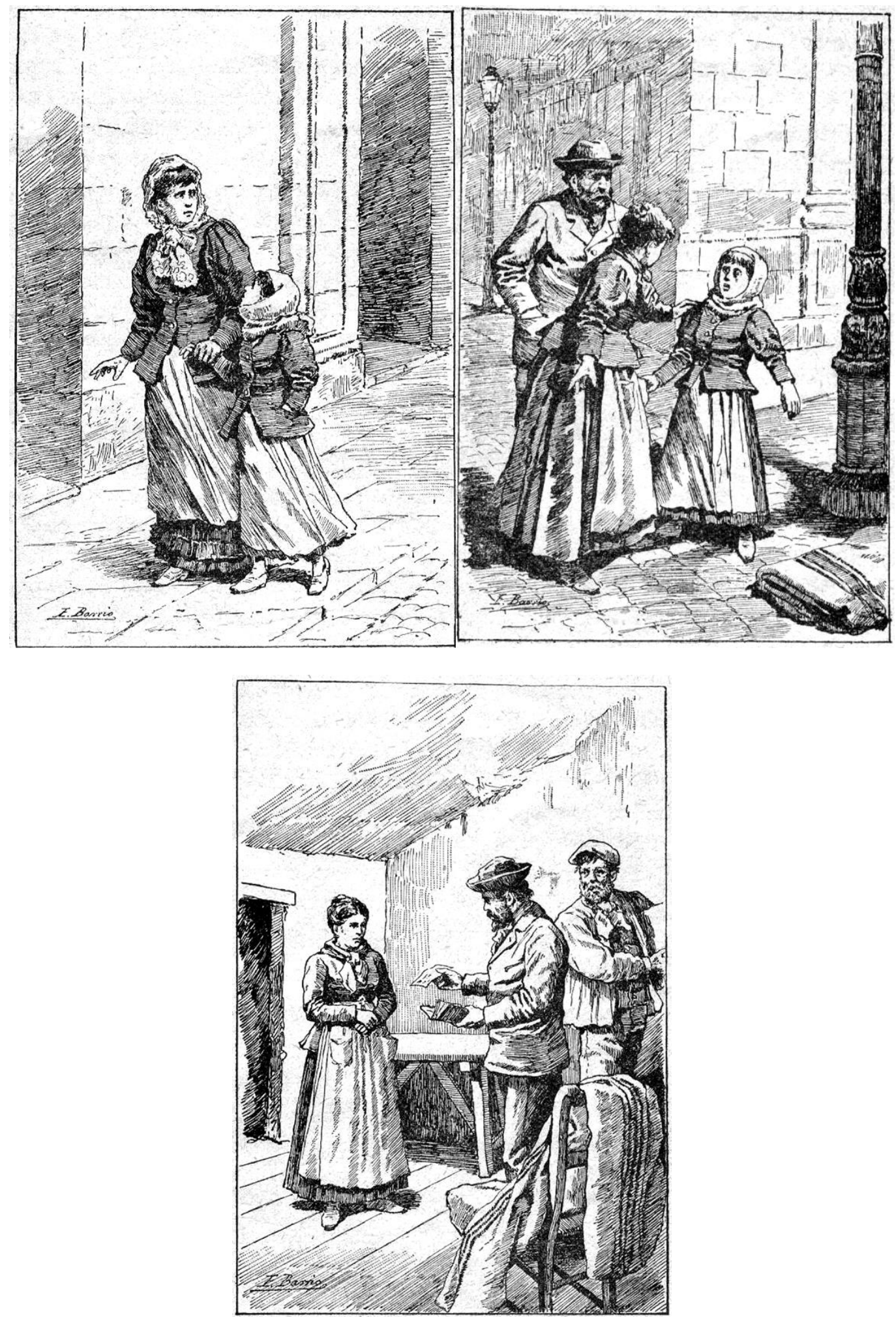

Fig.: 8

Ilustraciones interiores del cuento La manta de lana de la Biblioteca Cuentos para Niños. Hijos de Santiago Rodríguez. 
LA EDITORIAL BURGALESA HIJOS DE SANTIAGO RODRÍGUEZ (1891-1936): ANÁLISIS DE LOS LIBROS ESCOLARES

3.1.9. Ilustración de la cubierta del cuento Batalla campal de la Biblioteca Cuentos para Niños.

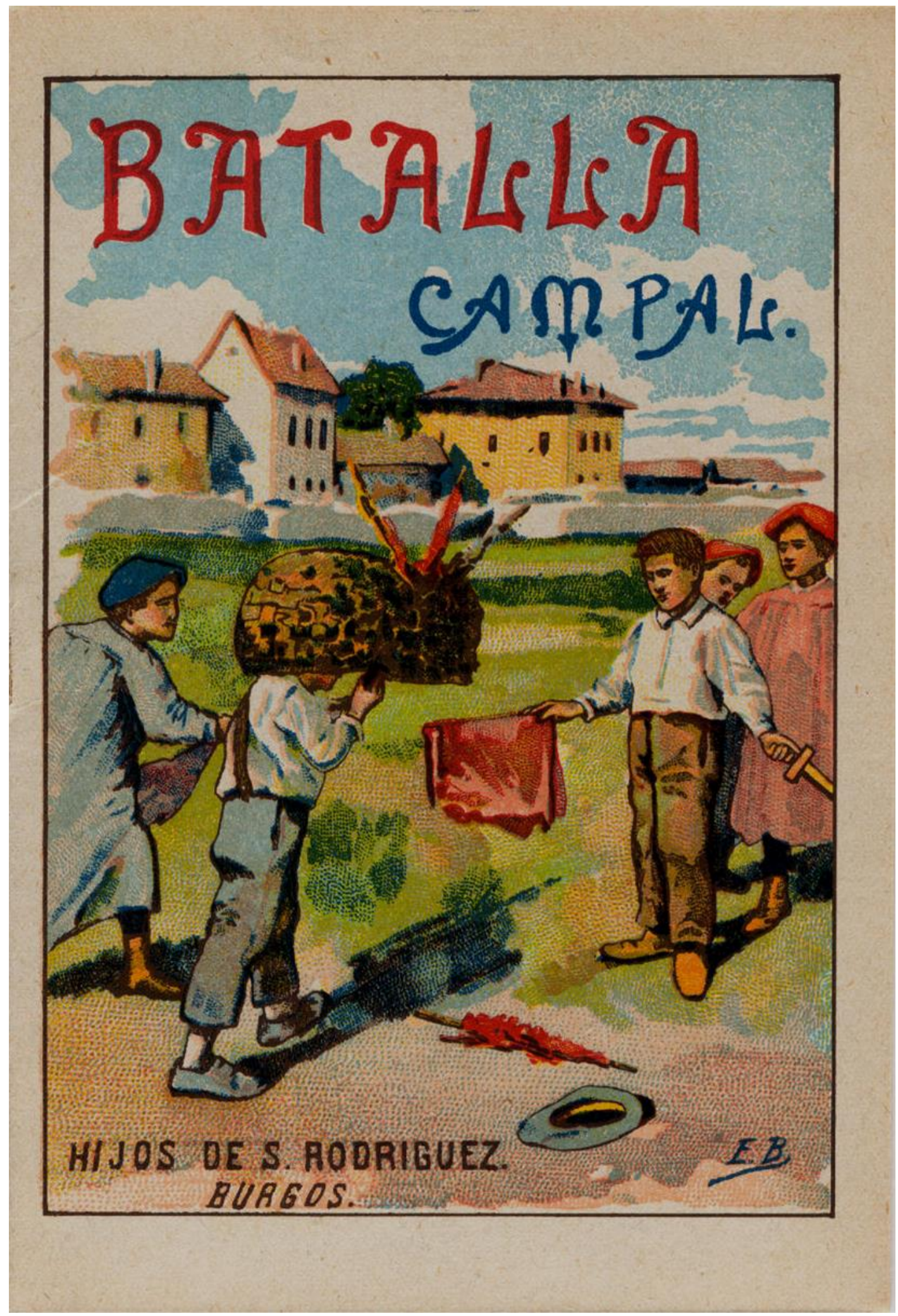

Fig.: 9

Cubierta ilustrada del cuento Batalla campal de la Biblioteca Cuentos para Niños. Hijos de Santiago Rodríguez. 
3.1.10. Ilustraciones interiores del cuento Batalla campal de la Biblioteca Cuentos para Niños.
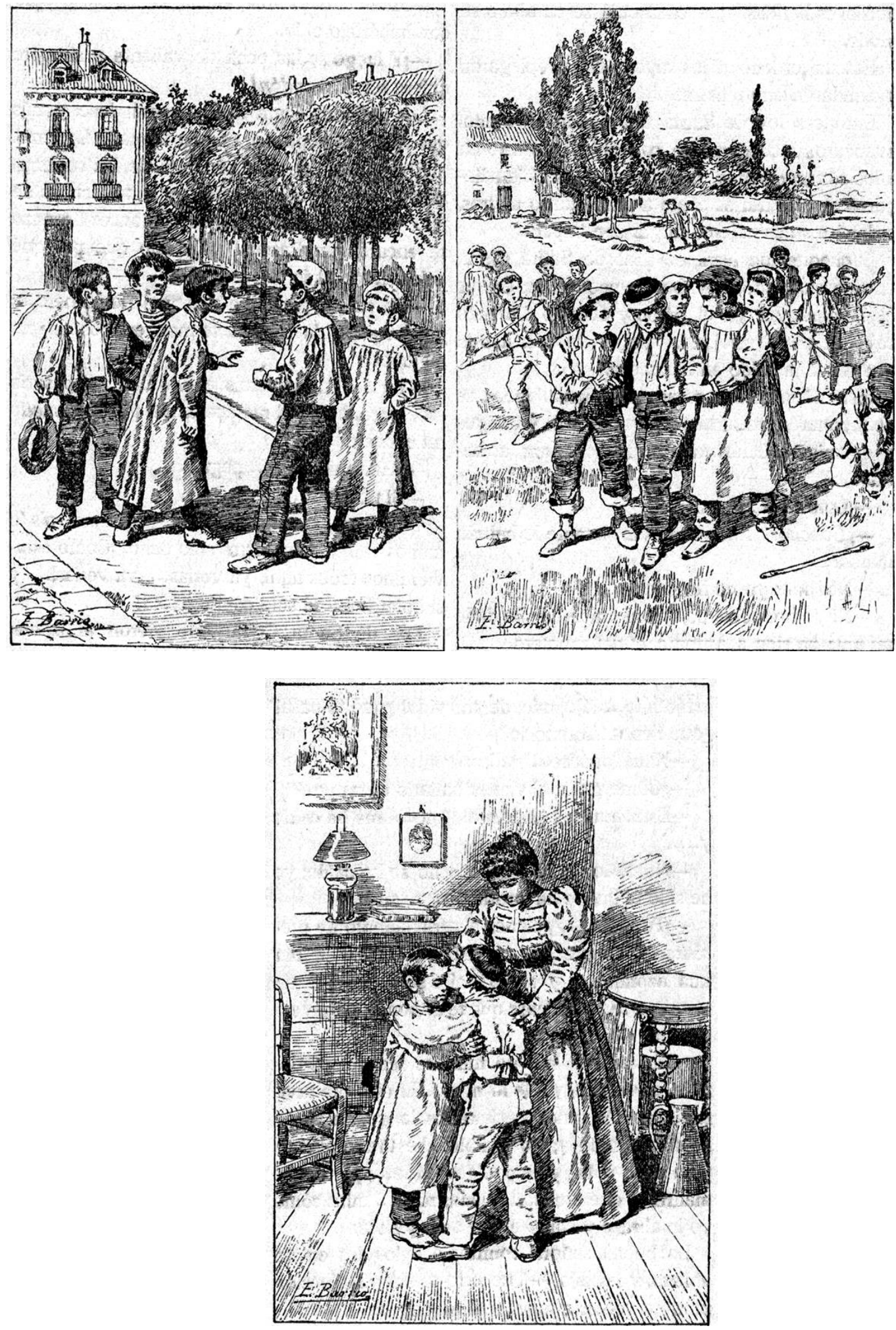

Fig.: 10

Ilustraciones interiores del cuento Batalla campal de la Biblioteca Cuentos para Niños. Hijos de Santiago Rodríguez. 
LA EDITORIAL BURGALESA HIJOS DE SANTIAGO RODRÍGUEZ (1891-1936): ANÁLISIS DE LOS LIBROS ESCOLARES

3.1.11. Ilustración de la cubierta del cuento El capricho de Susú de la Biblioteca Cuentos para Niños.

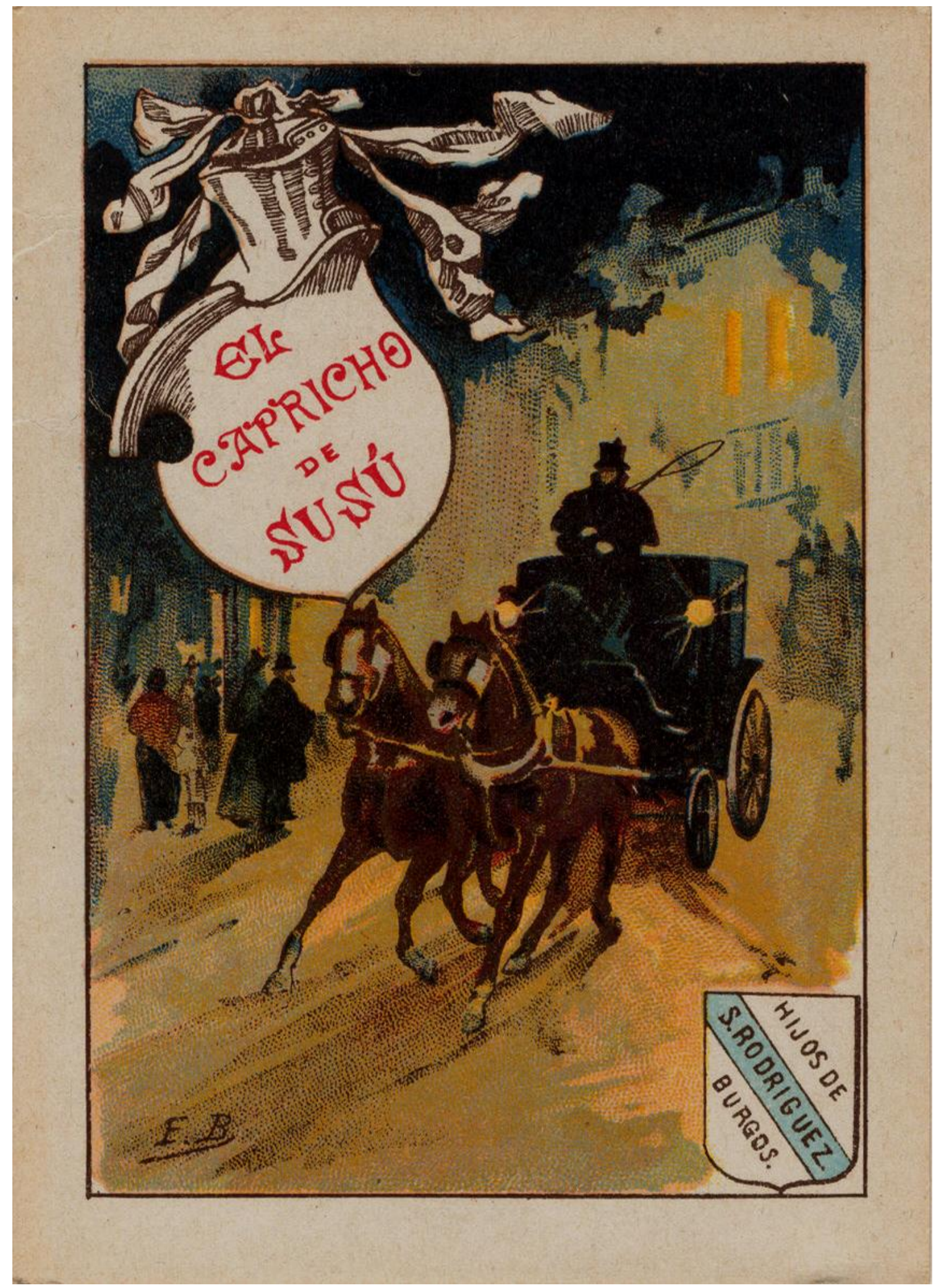

Fig.: 11

Cubierta ilustrada del cuento El capricho de Susú de la Biblioteca Cuentos para Niños. Hijos de Santiago Rodríguez. 
3.1.12. Ilustraciones interiores del cuento Batalla campal de la Biblioteca Cuentos para Niños.
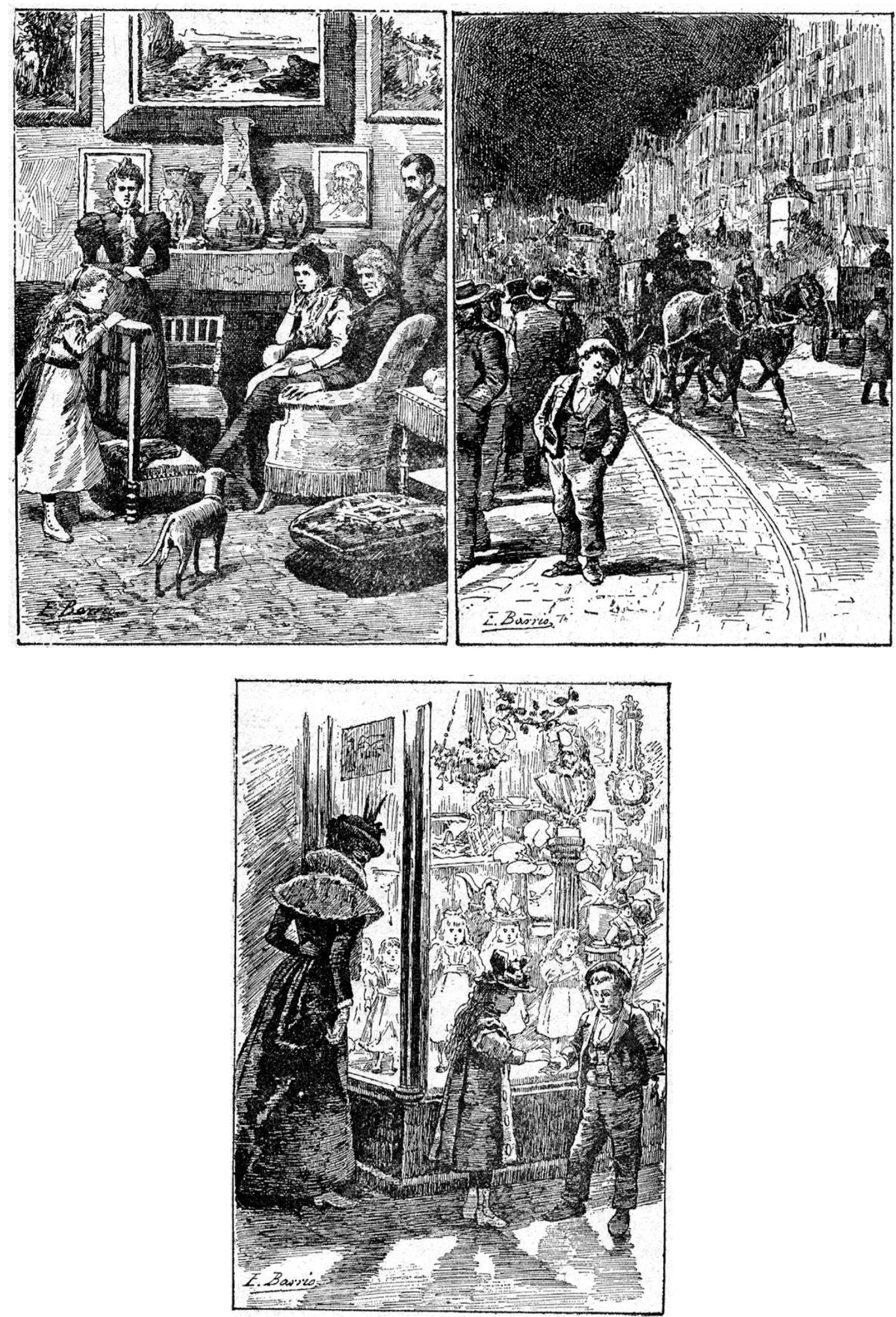

Fig.: 12

Ilustraciones interiores del cuento El capricho de Susú de la Biblioteca Cuentos para Niños. Hijos de Santiago Rodríguez. 
LA EDITORIAL BURGALESA HIJOS DE SANTIAGO RODRÍGUEZ (1891-1936): ANÁLISIS DE LOS LIBROS ESCOLARES

3.1.13. Ilustración de la cubierta del cuento El grumete de la Biblioteca Cuentos para Niños.

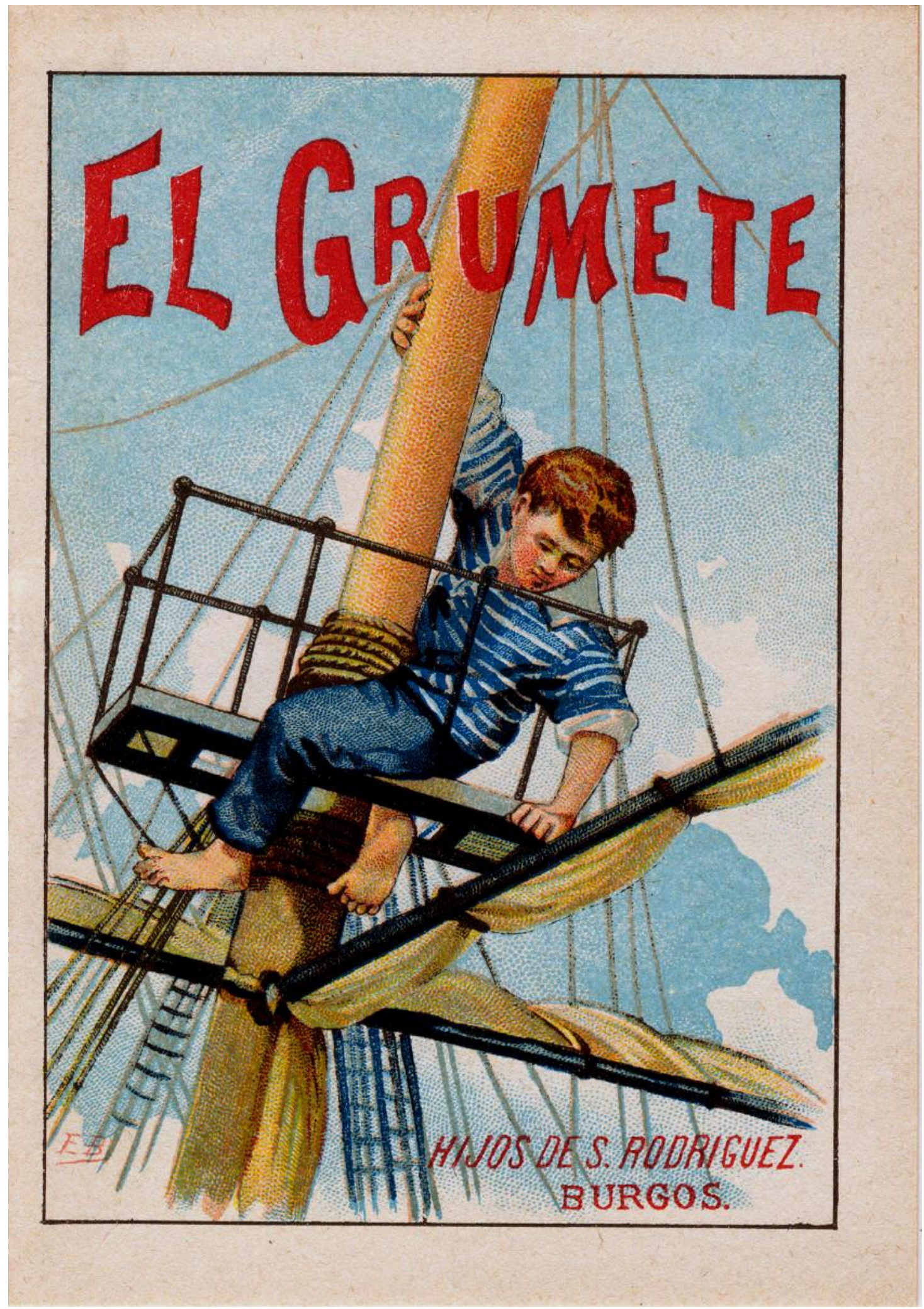

Fig.: 13

Cubierta ilustrada del cuento El grumete de la Biblioteca Cuentos para Niños. Hijos de Santiago Rodríguez. 
3.1.14. Ilustraciones interiores del cuento El grumete de la Biblioteca Cuentos para Niños.
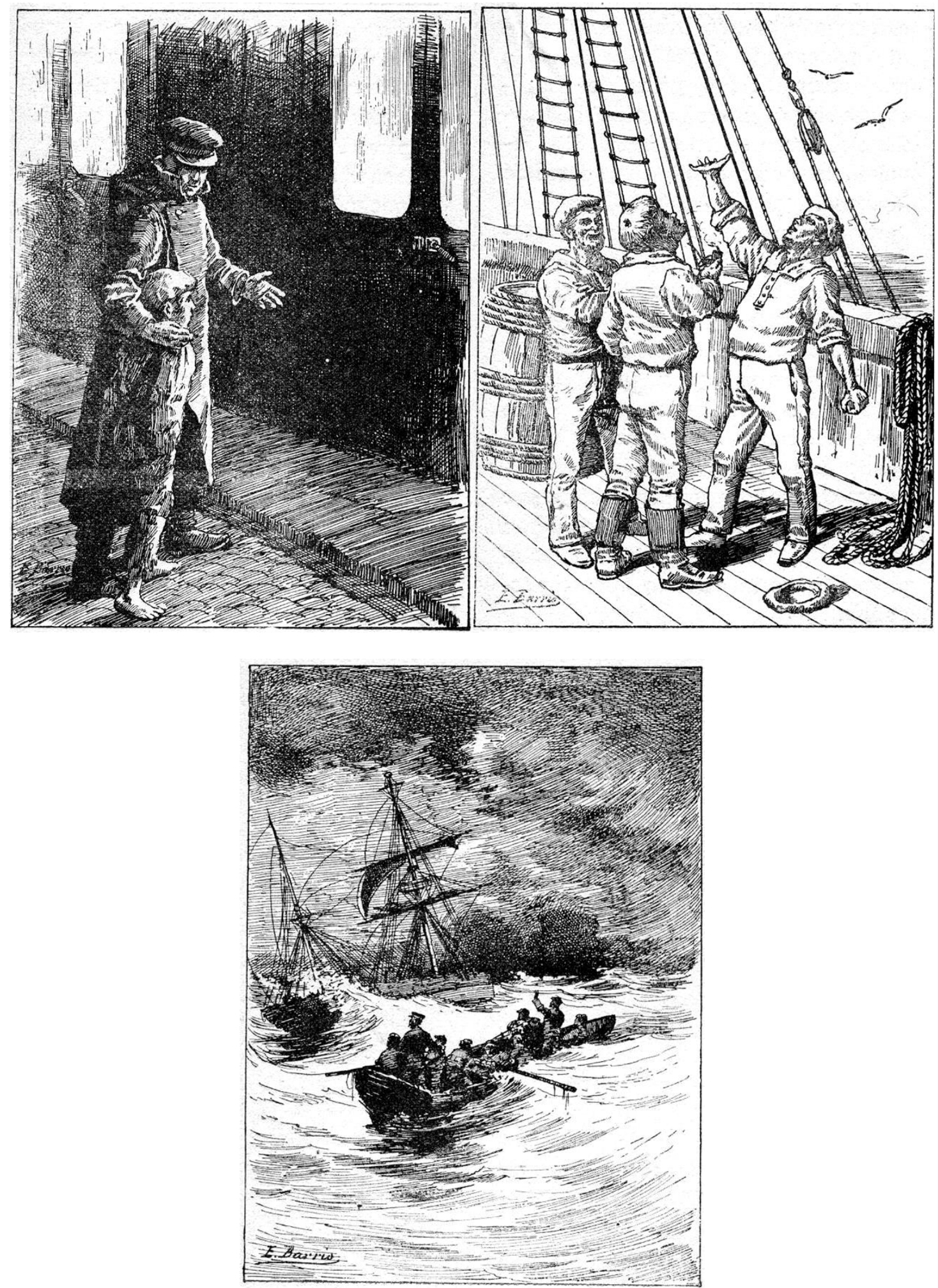

Fig.: 14

Ilustraciones interiores del cuento El capricho de Susú de la Biblioteca Cuentos para Niños. Hijos de Santiago Rodríguez. 
LA EDITORIAL BURGALESA HIJOS DE SANTIAGO RODRÍGUEZ (1891-1936): ANÁLISIS DE LOS LIBROS ESCOLARES

3.1.15. Ilustración de la cubierta del cuento El grumete de la Biblioteca Cuentos para Niños.

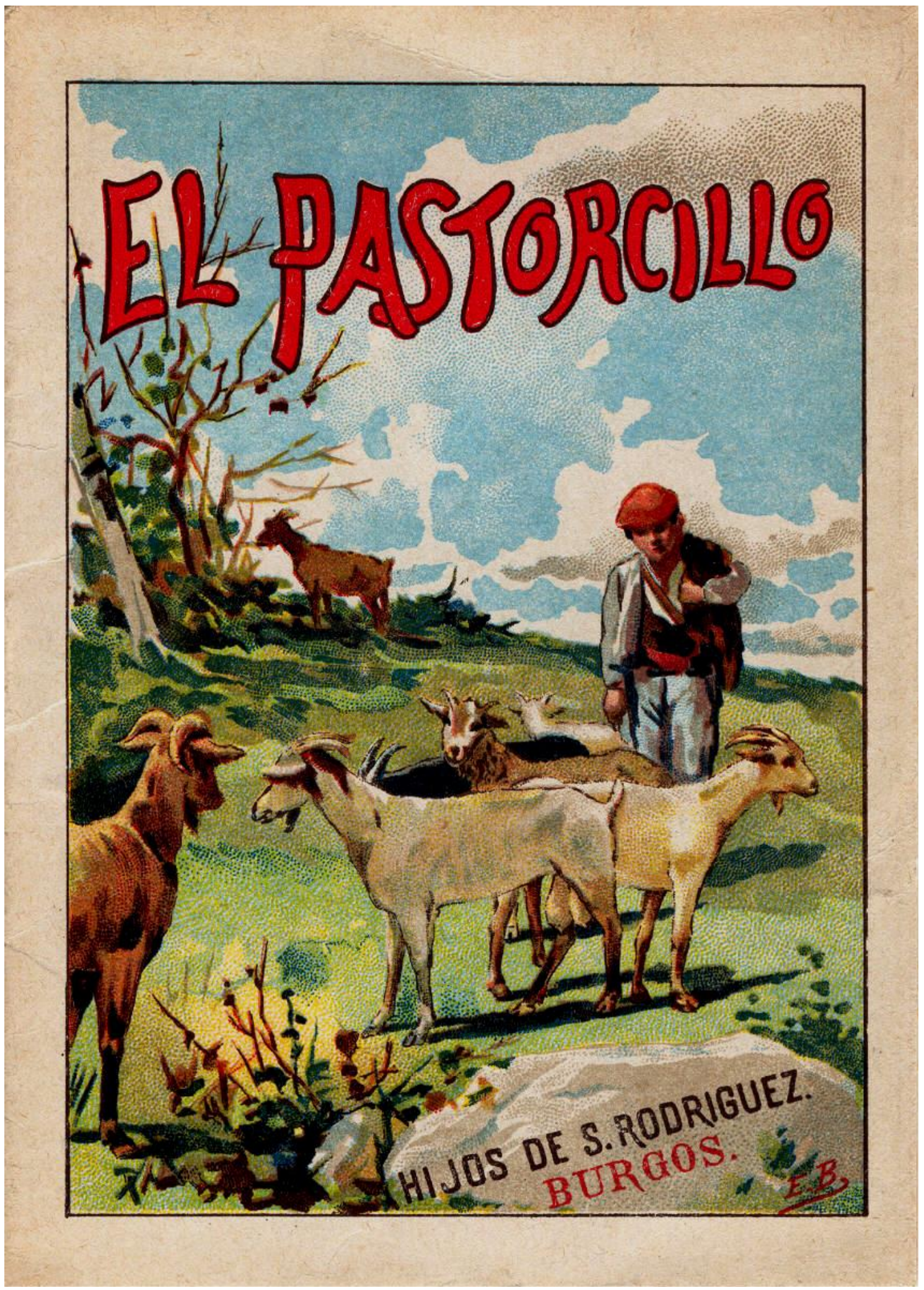

Fig.: 15

Cubierta ilustrada del cuento El pastorcillo de la Biblioteca Cuentos para Niños. Hijos de Santiago Rodríguez. 
3.1.16. Ilustraciones interiores del cuento El pastorcillo de la Biblioteca Cuentos para Niños.
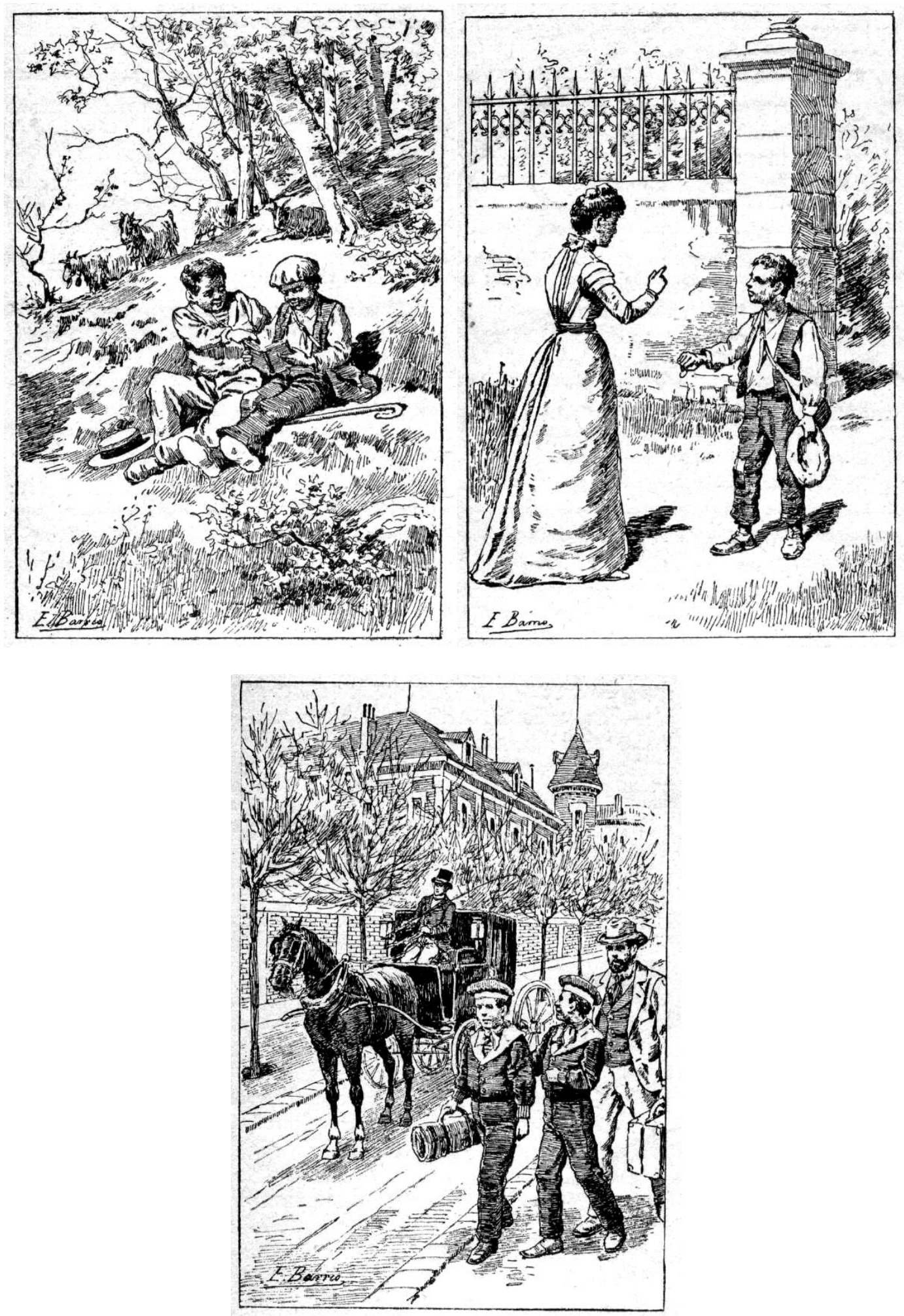

Fig.: 16

Ilustraciones interiores del cuento El pastorcillo de la Biblioteca Cuentos para Niños. Hijos de Santiago Rodríguez. 
LA EDITORIAL BURGALESA HIJOS DE SANTIAGO RODRÍGUEZ (1891-1936): ANÁLISIS DE LOS LIBROS ESCOLARES

3.1.17. Ilustración de la cubierta del cuento El pequeño aeronauta de la Biblioteca Cuentos para Niños.

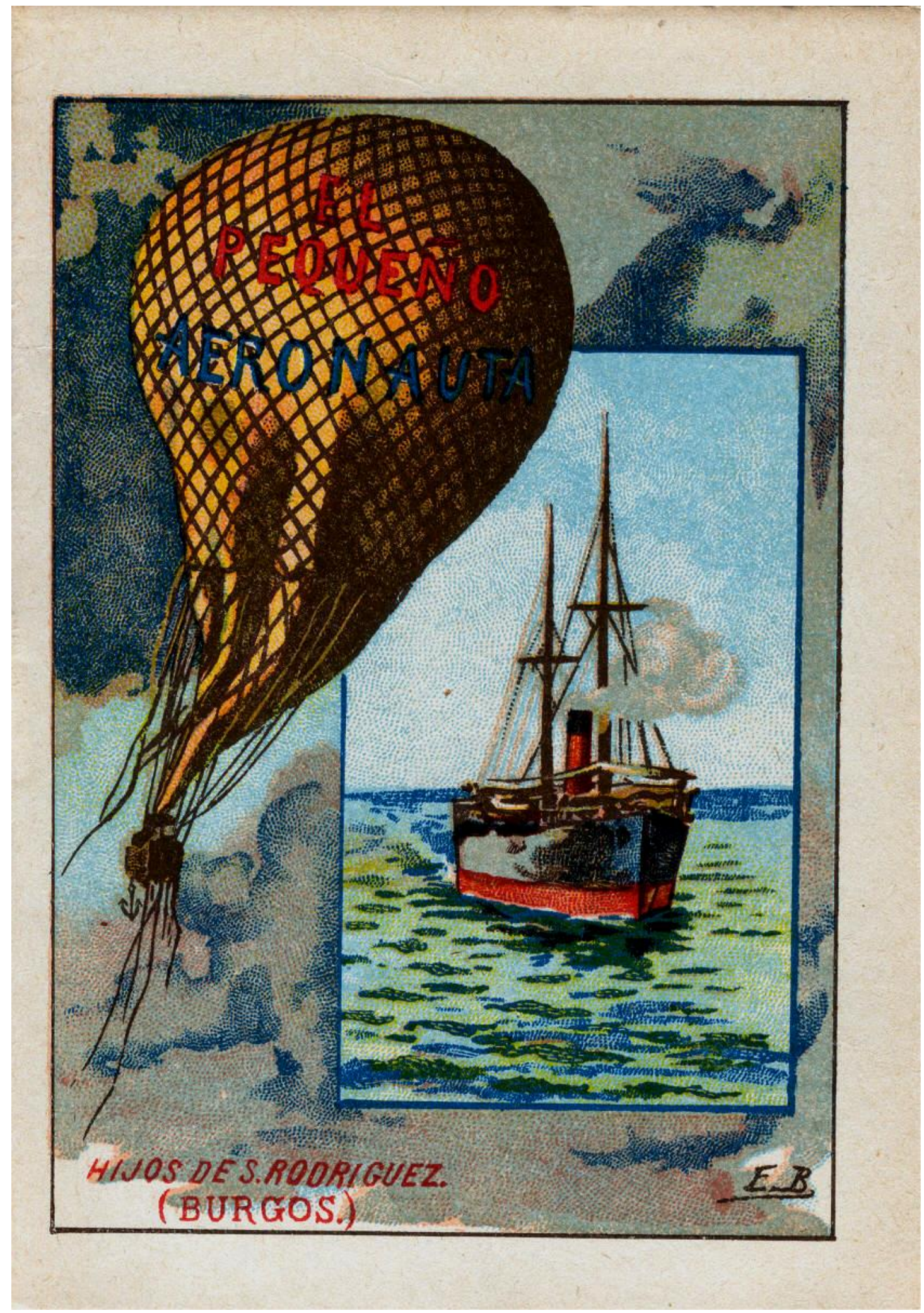

Fig.: 17

Cubierta ilustrada del cuento El pequeño aeronauta de la Biblioteca Cuentos para Niños. Hijos de Santiago Rodríguez. 
3.1.18. Ilustraciones interiores del cuento El pequeño aeronauta de la Biblioteca Cuentos para Niños.
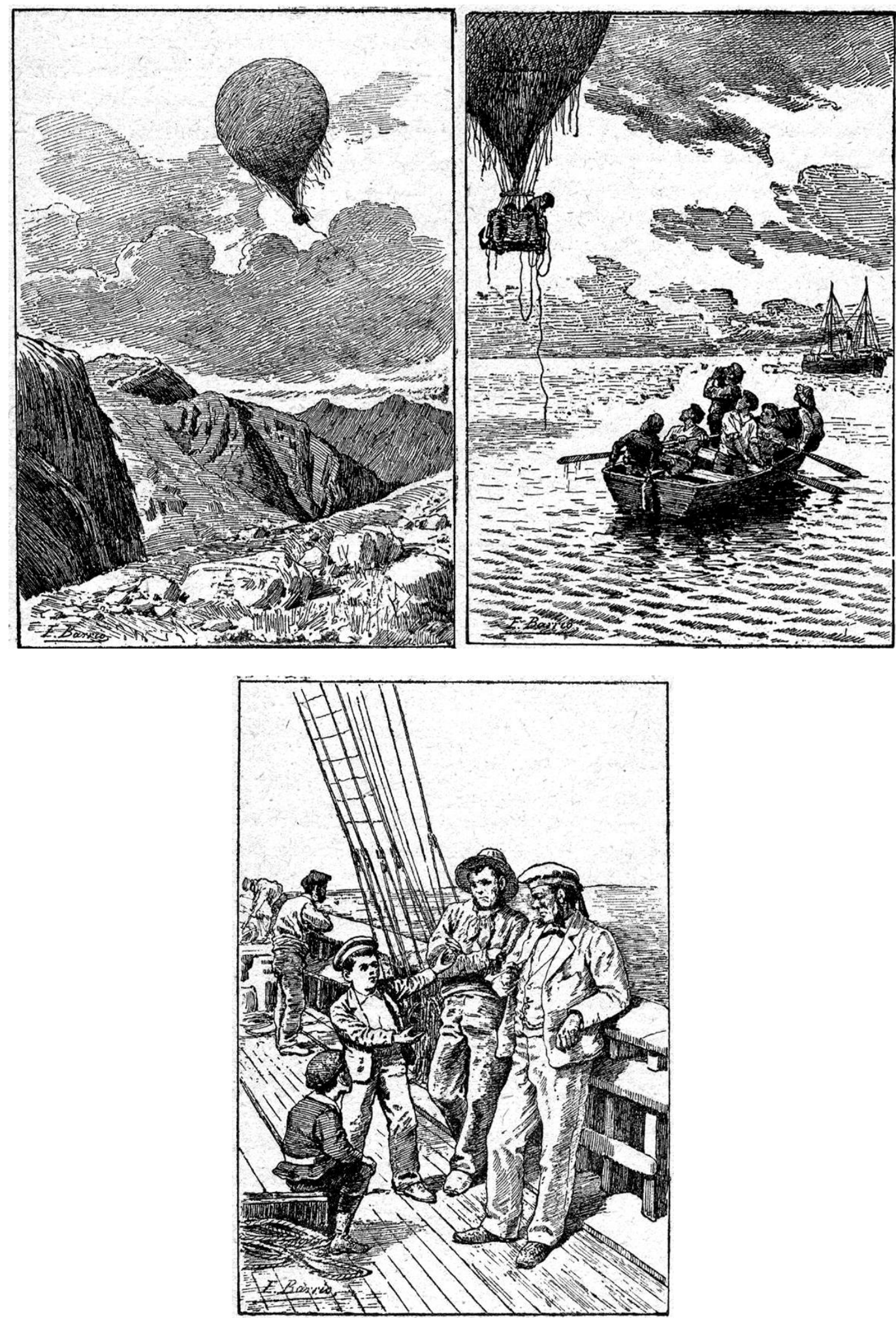

Fig.: 18

Ilustraciones interiores del cuento El pequeño aeronauta de la Biblioteca Cuentos para Niños. Hijos de Santiago Rodríguez. 
LA EDITORIAL BURGALESA HIJOS DE SANTIAGO RODRÍGUEZ (1891-1936): ANÁLISIS DE LOS LIBROS ESCOLARES

3.1.19. Ilustración de la cubierta del cuento El vendedor de periódicos de la Biblioteca Cuentos para Niños.

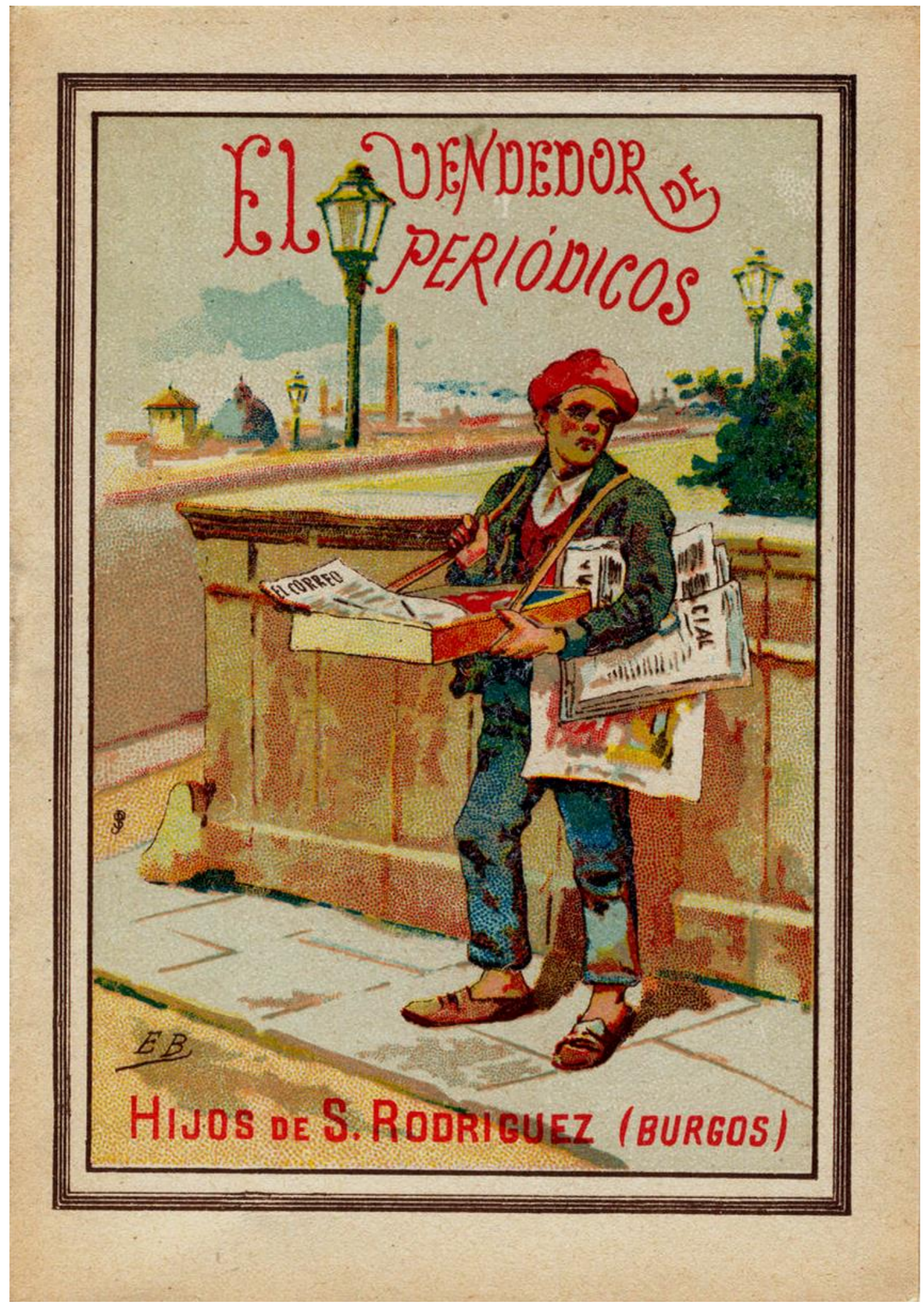

Fig.: 19

Cubierta ilustrada del cuento El vendedor de periódicos de la Biblioteca Cuentos para Niños. Hijos de Santiago Rodríguez. 
3.1.20. Ilustraciones interiores del cuento El vendedor de periódicos de la Biblioteca Cuentos para Niños.
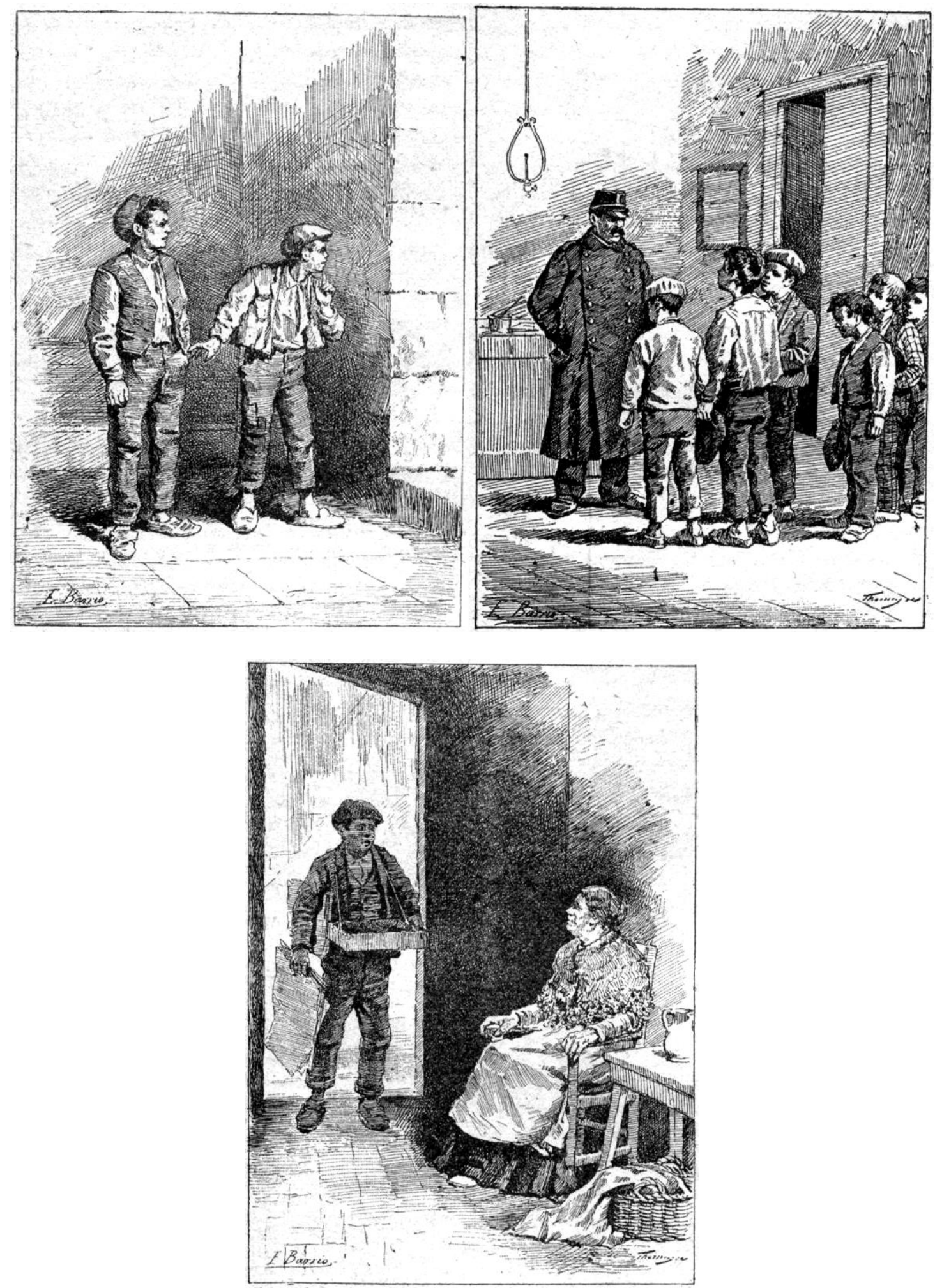

Fig.: 20

Ilustraciones interiores del cuento El vendedor de periódicos de la Biblioteca Cuentos para Niños. Hijos de Santiago Rodríguez. 
LA EDITORIAL BURGALESA HIJOS DE SANTIAGO RODRÍGUEZ (1891-1936): ANÁLISIS DE LOS LIBROS ESCOLARES

3.1.21. Ilustración de la cubierta del cuento Emilín de la Biblioteca Cuentos para Niños.

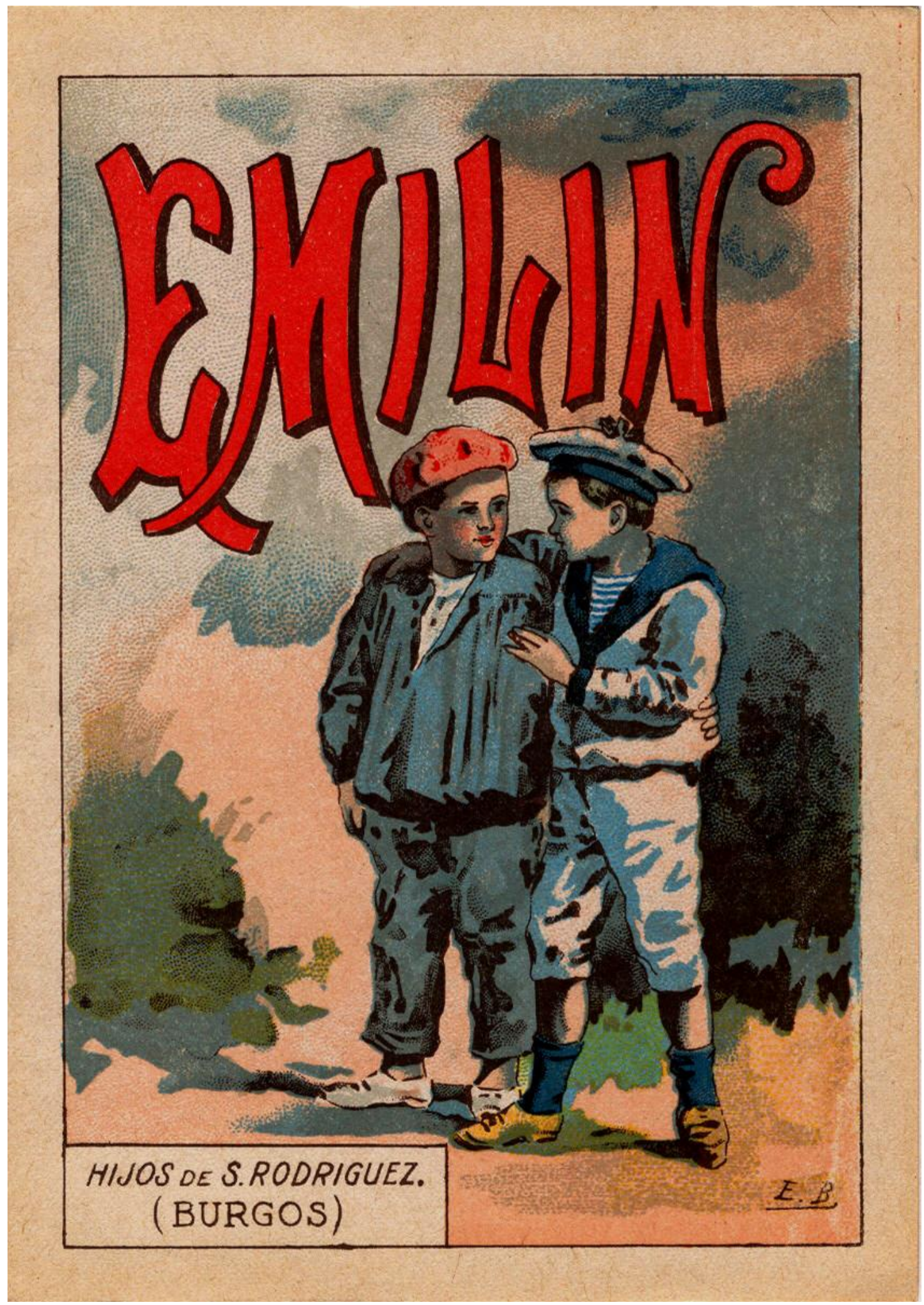

Fig.: 21

Cubierta ilustrada del cuento Emilín de la Biblioteca Cuentos para Niños. Hijos de Santiago Rodríguez. 
3.1.22. Ilustraciones interiores del cuento Emilín de la Biblioteca Cuentos para Niños.
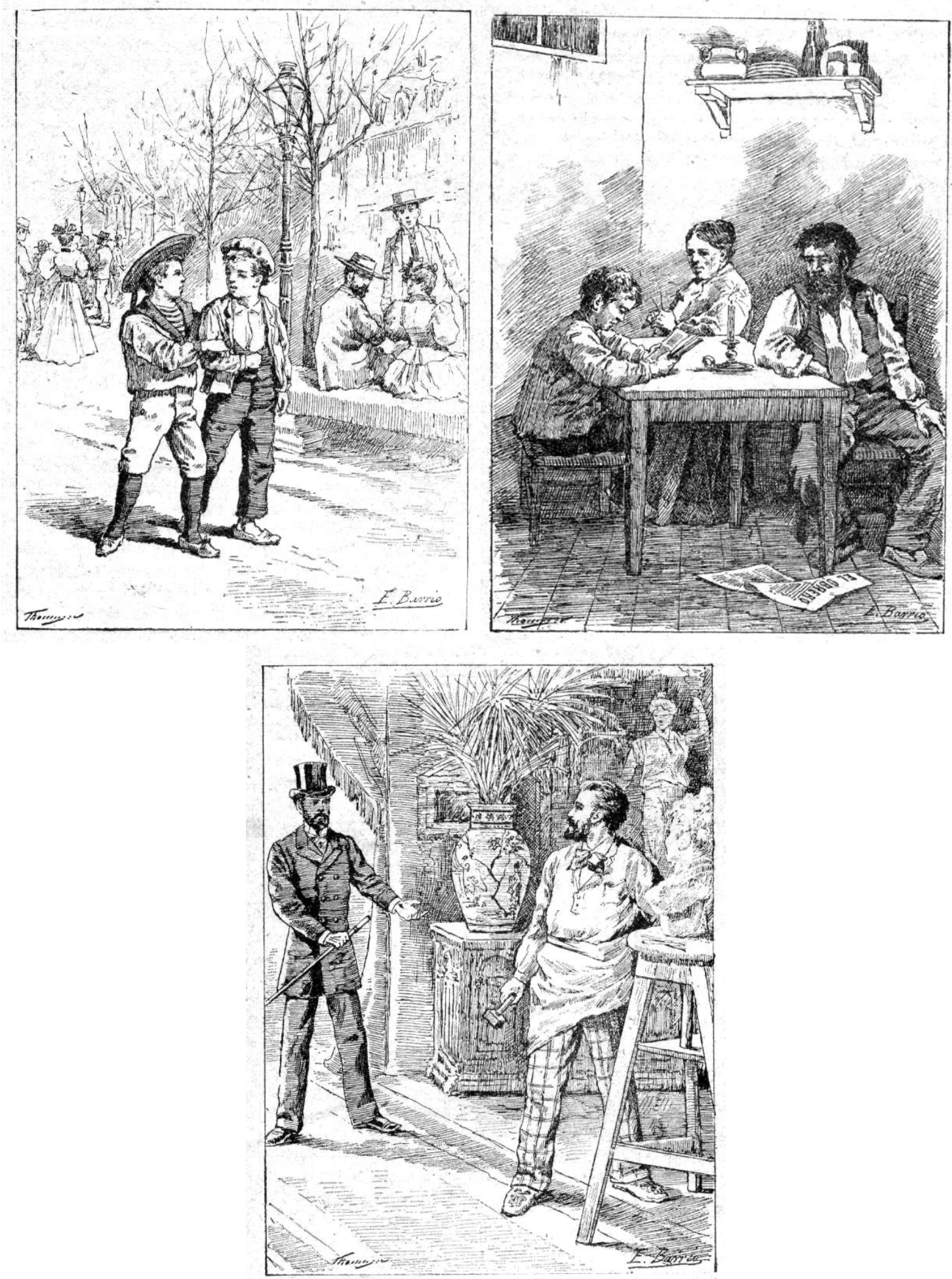

Fig.: 22

Ilustraciones interiores del cuento Emilín de la Biblioteca Cuentos para Niños. Hijos de Santiago Rodríguez. 
LA EDITORIAL BURGALESA HIJOS DE SANTIAGO RODRÍGUEZ (1891-1936): ANÁLISIS DE LOS LIBROS ESCOLARES

3.1.23. Ilustración de la cubierta del cuento Enriqueta de la Biblioteca Cuentos para Niños.

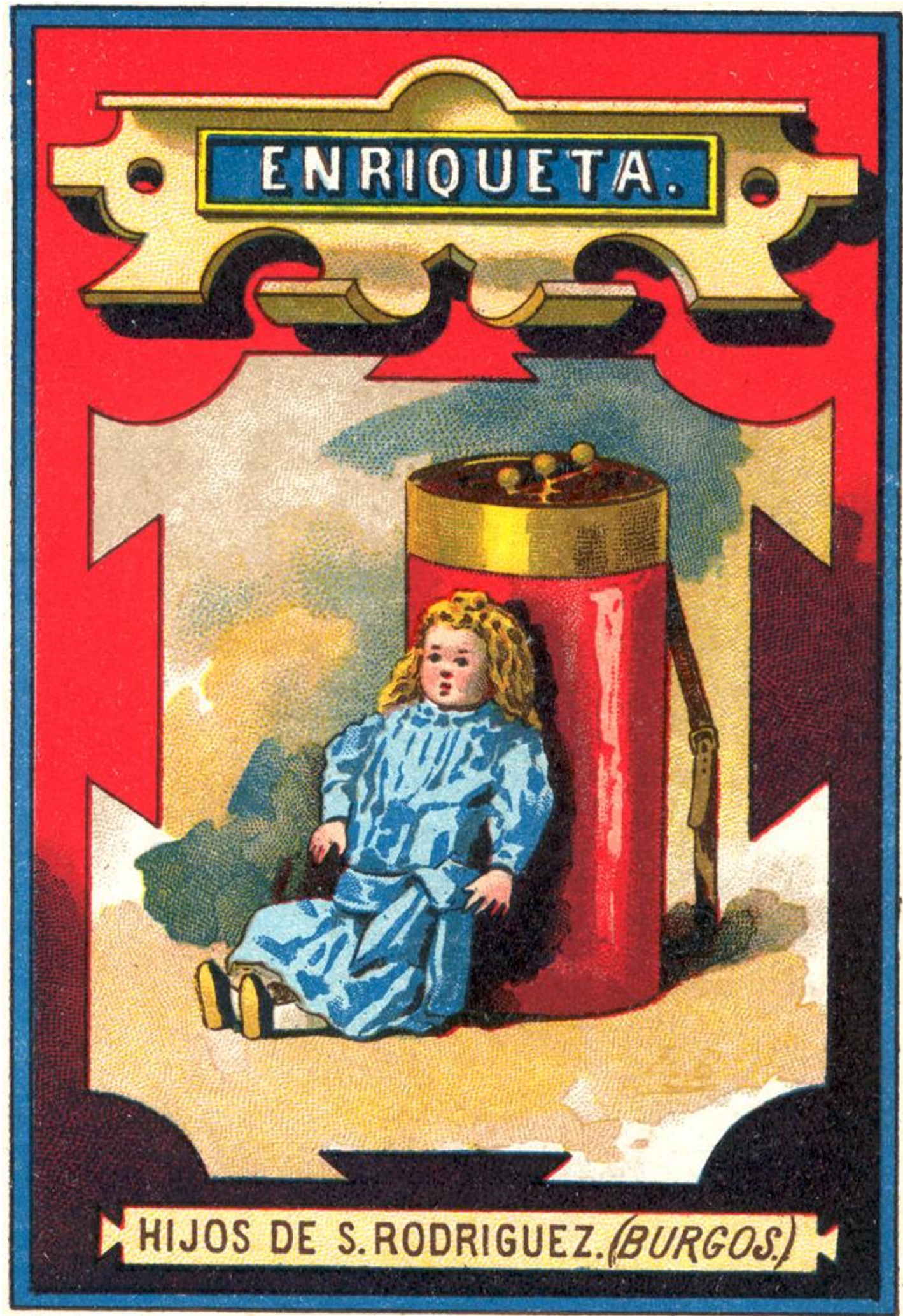

Fig.: 23

Cubierta ilustrada del cuento Enriqueta de la Biblioteca Cuentos para Niños. Hijos de Santiago Rodríguez. 
3.1.24. Ilustraciones interiores del cuento Enriqueta de la Biblioteca Cuentos para Niños.
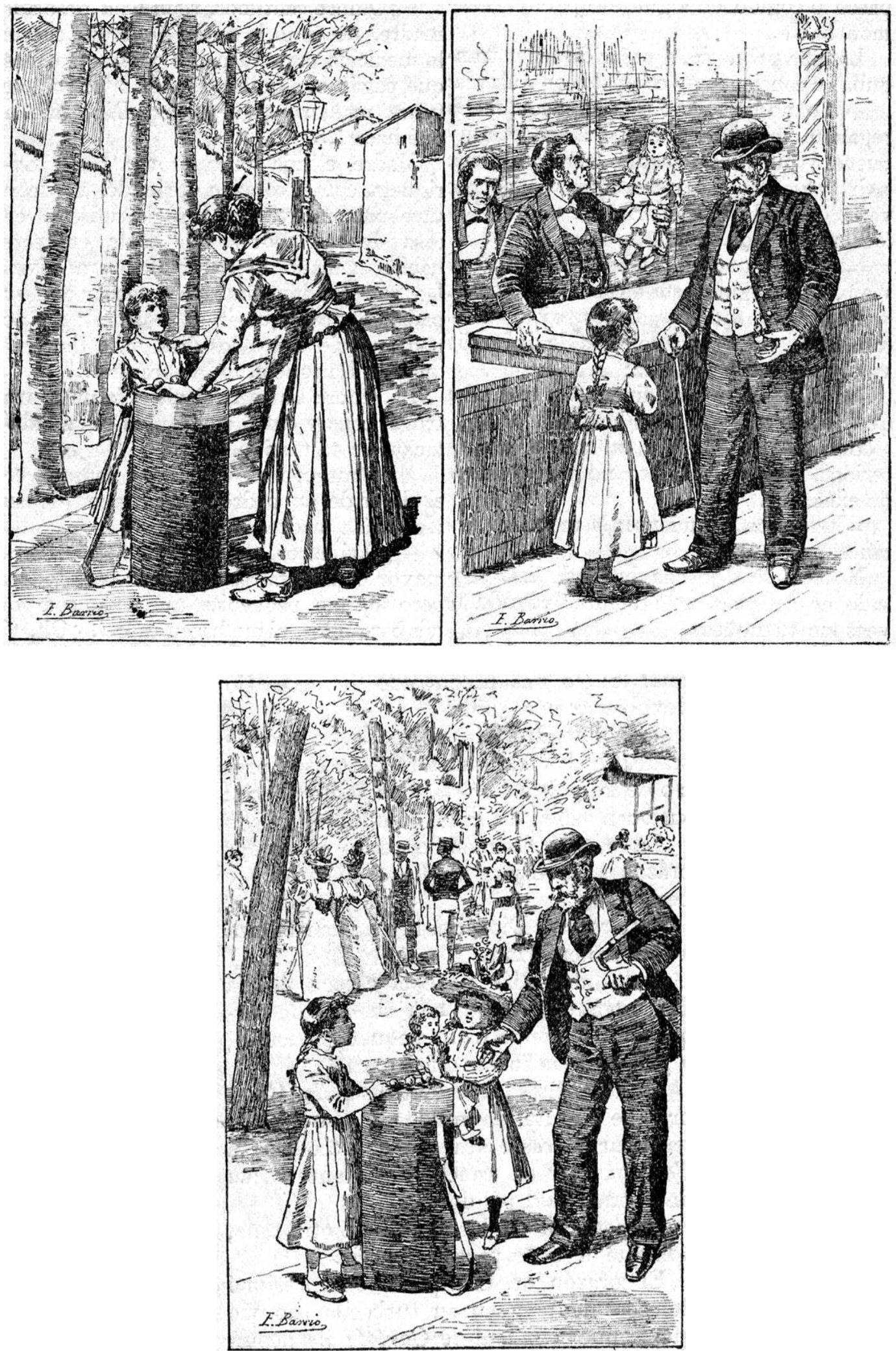

Fig.: 24

Ilustraciones interiores del cuento Enriqueta de la Biblioteca Cuentos para Niños. Hijos de Santiago Rodríguez. 
LA EDITORIAL BURGALESA HIJOS DE SANTIAGO RODRÍGUEZ (1891-1936): ANÁLISIS DE LOS LIBROS ESCOLARES

3.1.25. Ilustración de la cubierta del cuento Siempre que puedas haz bien de la Biblioteca Cuentos para Niños.

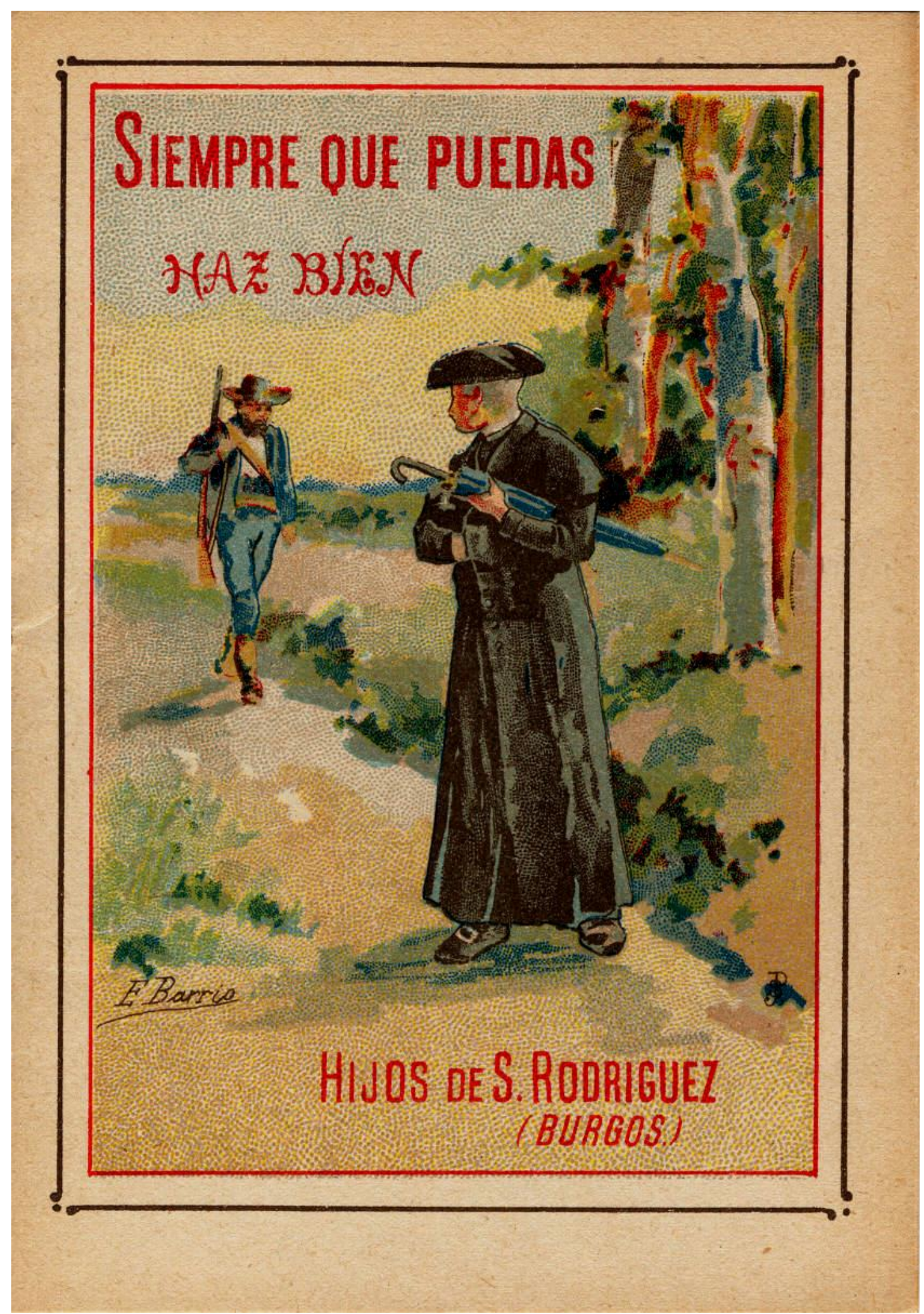

Fig.: 25

Cubierta ilustrada del cuento Siempre que puedas haz bien de la Biblioteca Cuentos para Niños. Hijos de Santiago Rodríguez. 
3.1.26. Ilustraciones interiores del cuento Siempre que puedas haz bien de la Biblioteca Cuentos para Niños.
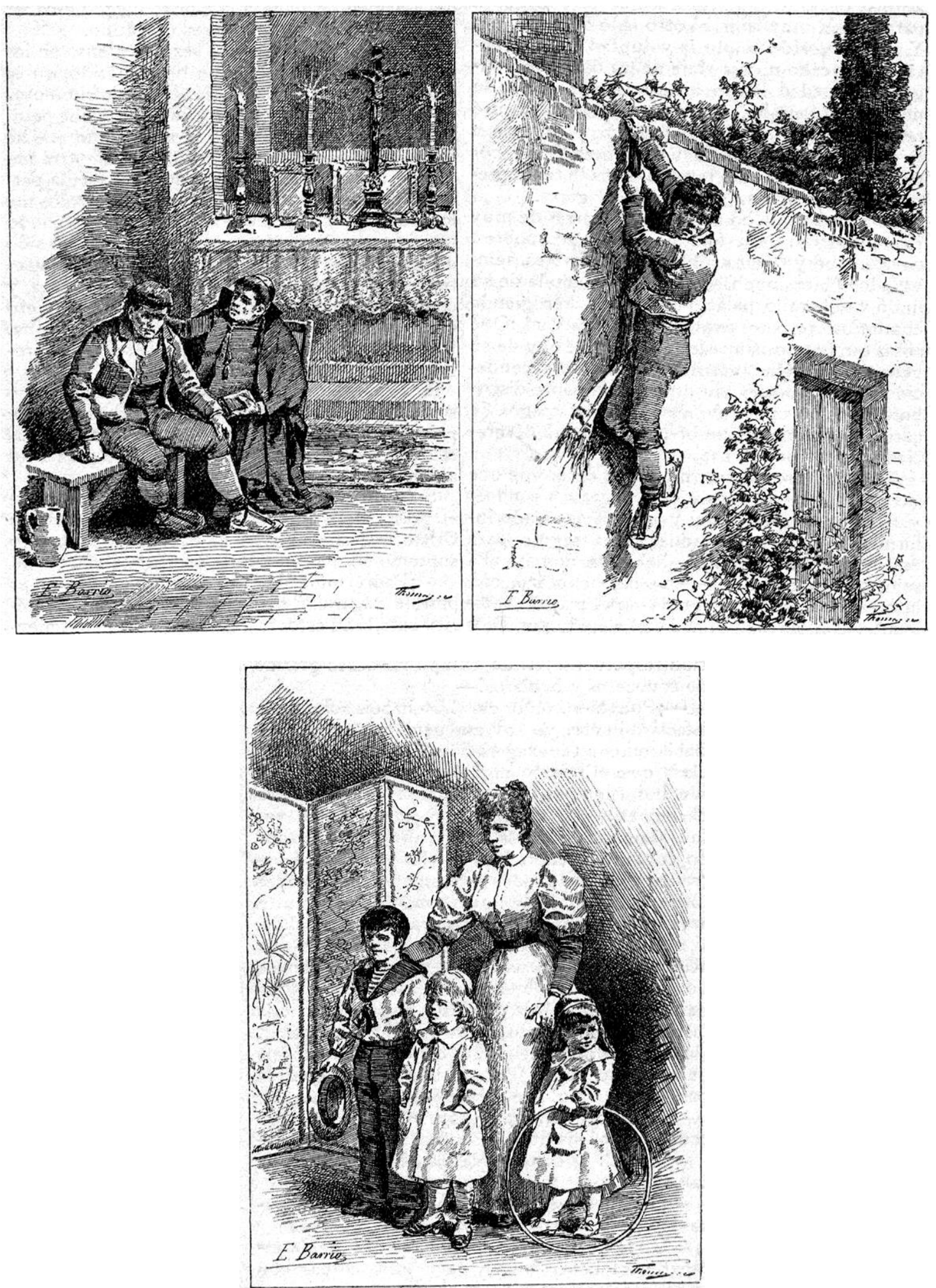

Fig.: 26

Ilustraciones interiores del cuento Siempre que puedas haz bien de la Biblioteca Cuentos para Niños. Hijos de Santiago Rodríguez. 
LA EDITORIAL BURGALESA HIJOS DE SANTIAGO RODRÍGUEZ (1891-1936): ANÁLISIS DE LOS LIBROS ESCOLARES

3.1.27. Ilustraciones de la cubierta e interiores del cuento Felicidad en la buhardilla de la Biblioteca Cuentos para Niños.
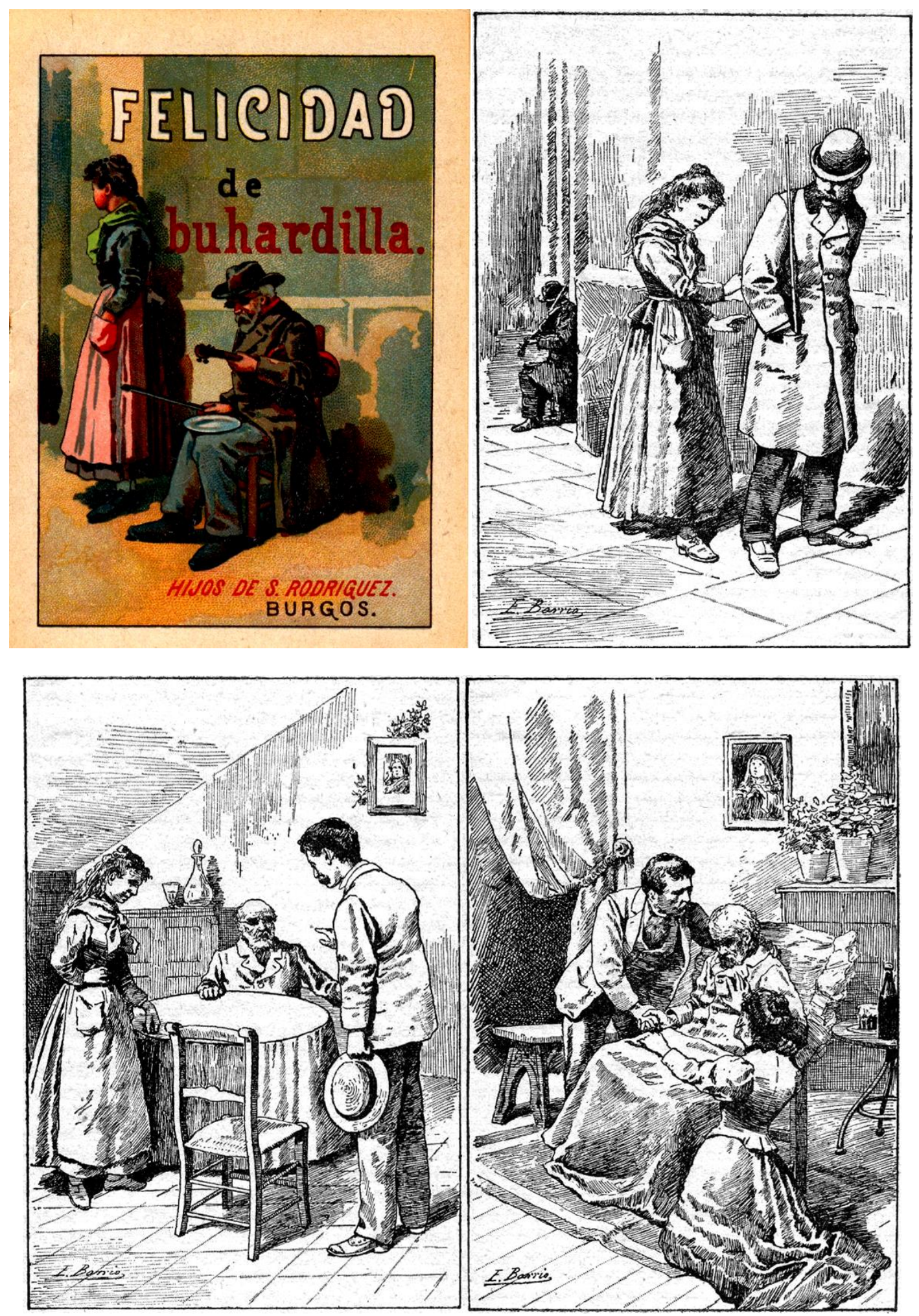

Fig.: 27

Ilustraciones del cuento Felicidad en la buhardilla.

Biblioteca Cuentos para Niños. Hijos de Santiago Rodríguez. 
3.1.28. Ilustraciones interiores del cuento $L a$ noche de Reyes de la Biblioteca Cuentos para Niños.
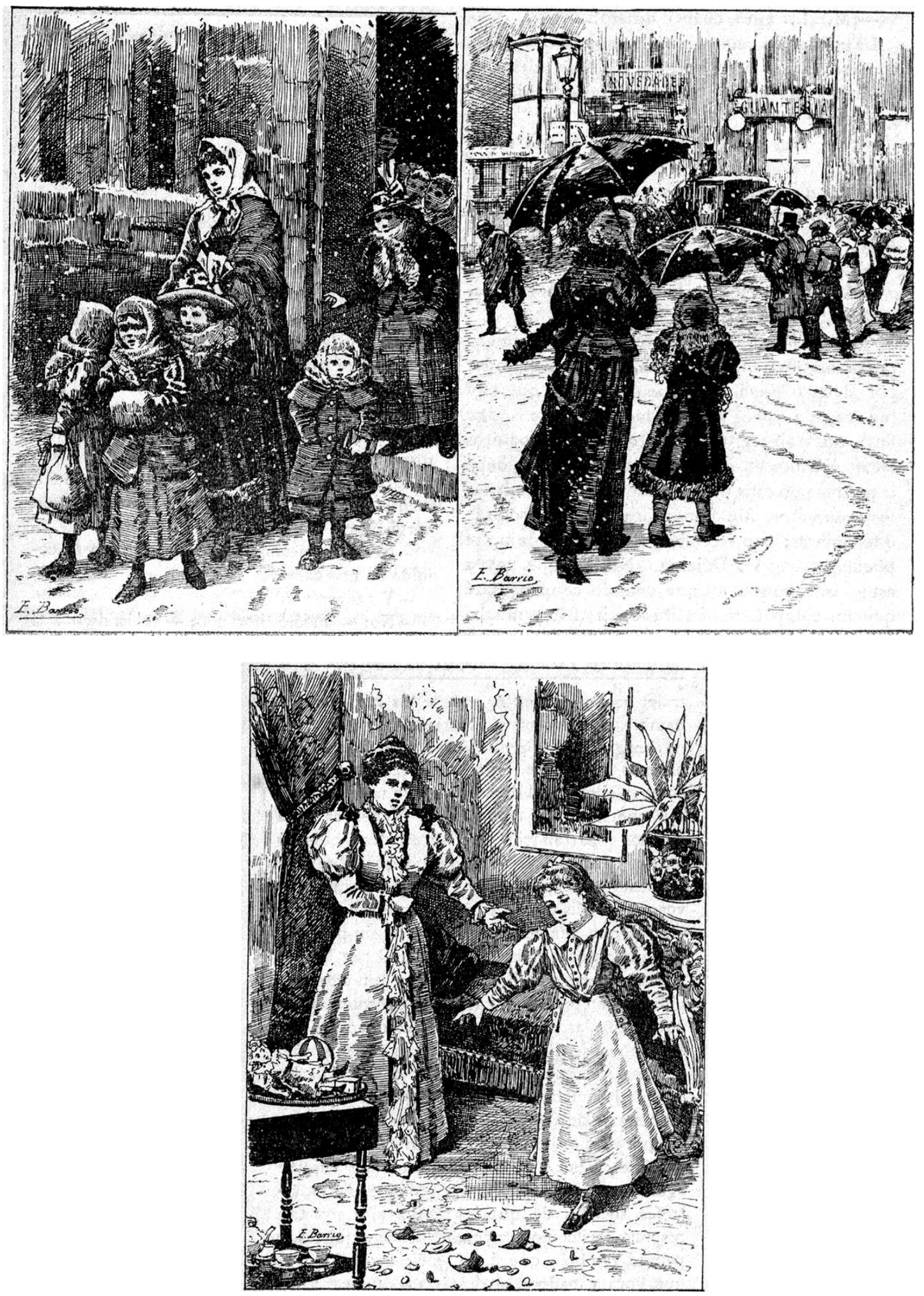

Fig.: 28

Ilustraciones interiores a plana entera del cuento La noche de Reyes Biblioteca Cuentos para Niños. Hijos de Santiago Rodríguez. 
LA EDITORIAL BURGALESA HIJOS DE SANTIAGO RODRÍGUEZ (1891-1936): ANÁLISIS DE LOS LIBROS ESCOLARES

3.1.29. Ilustración interior del cuento Pedro el avaricioso de la Biblioteca Cuentos para Niños.
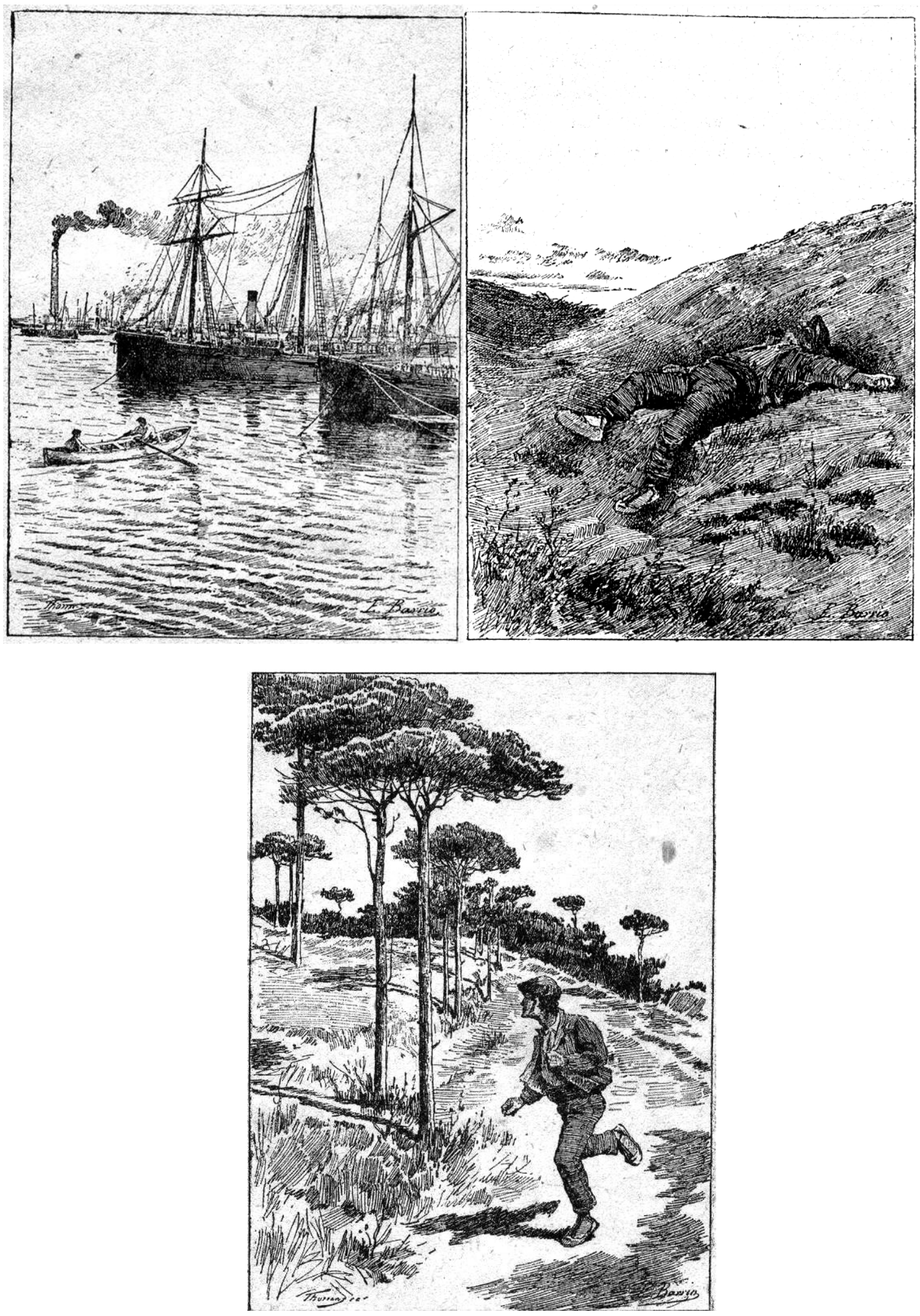

Fig.: 29

Ilustraciones interiores a plana entera del cuento Pedro el avaricioso. Biblioteca Cuentos para Niños. Hijos de Santiago Rodríguez. 
3.1.30. Ilustraciones interiores del cuento Al borde del abismo de la Biblioteca Museo de la Infancia.
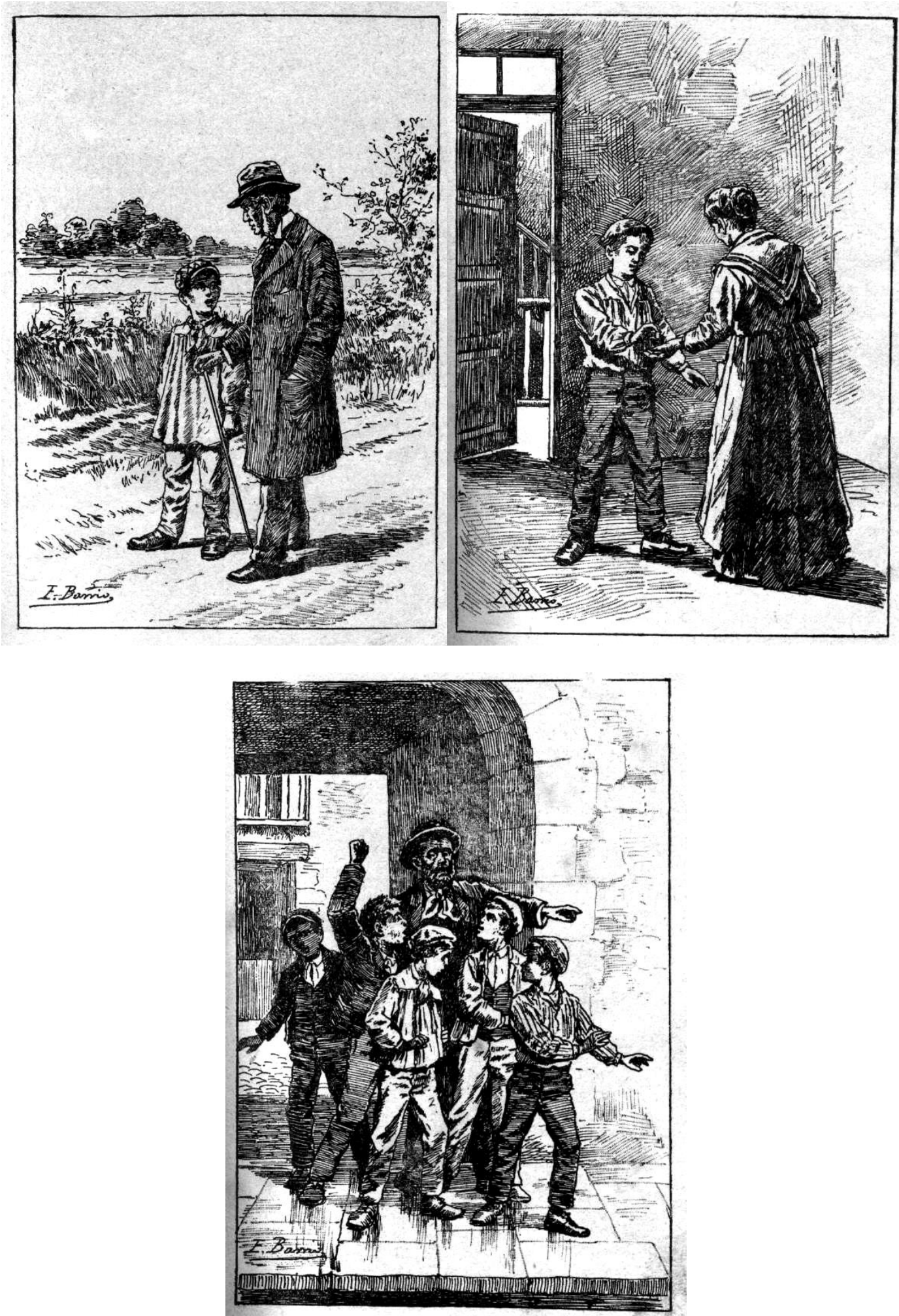

Fig.: 30

Ilustraciónes interiores a plana entera del cuento Al borde del abismo. Biblioteca Cuentos para Niños. Hijos de Santiago Rodríguez (Parte 1). 
LA EDITORIAL BURGALESA HIJOS DE SANTIAGO RODRÍGUEZ (1891-1936): ANÁLISIS DE LOS LIBROS ESCOLARES
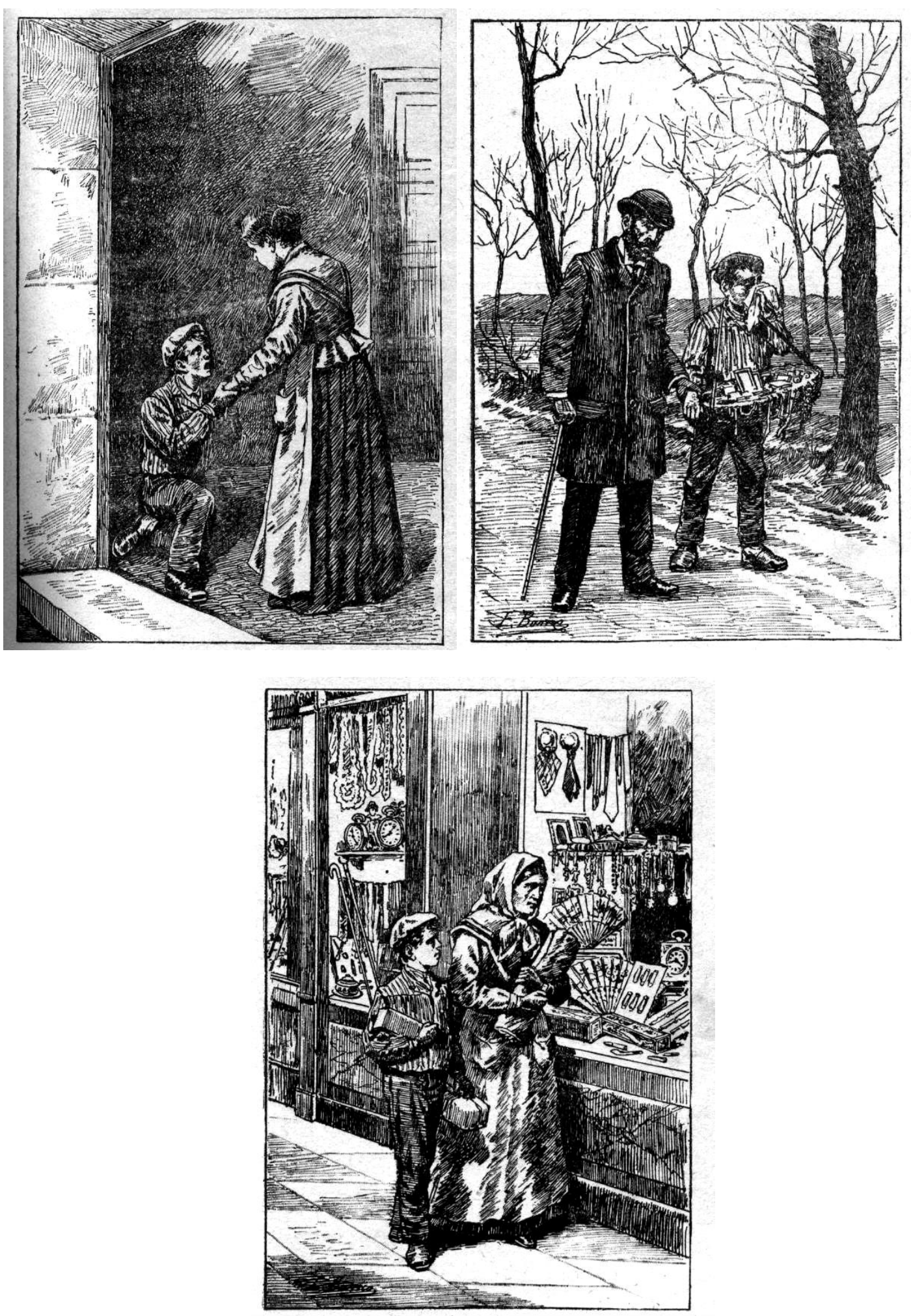

Fig.: 30

Ilustraciónes interiores a plana entera del cuento Al borde del abismo. Biblioteca Cuentos para Niños. Hijos de Santiago Rodríguez (Parte 2). 
3.1.31. Ilustración interior del cuento El músico callejero de la Biblioteca Ideal.

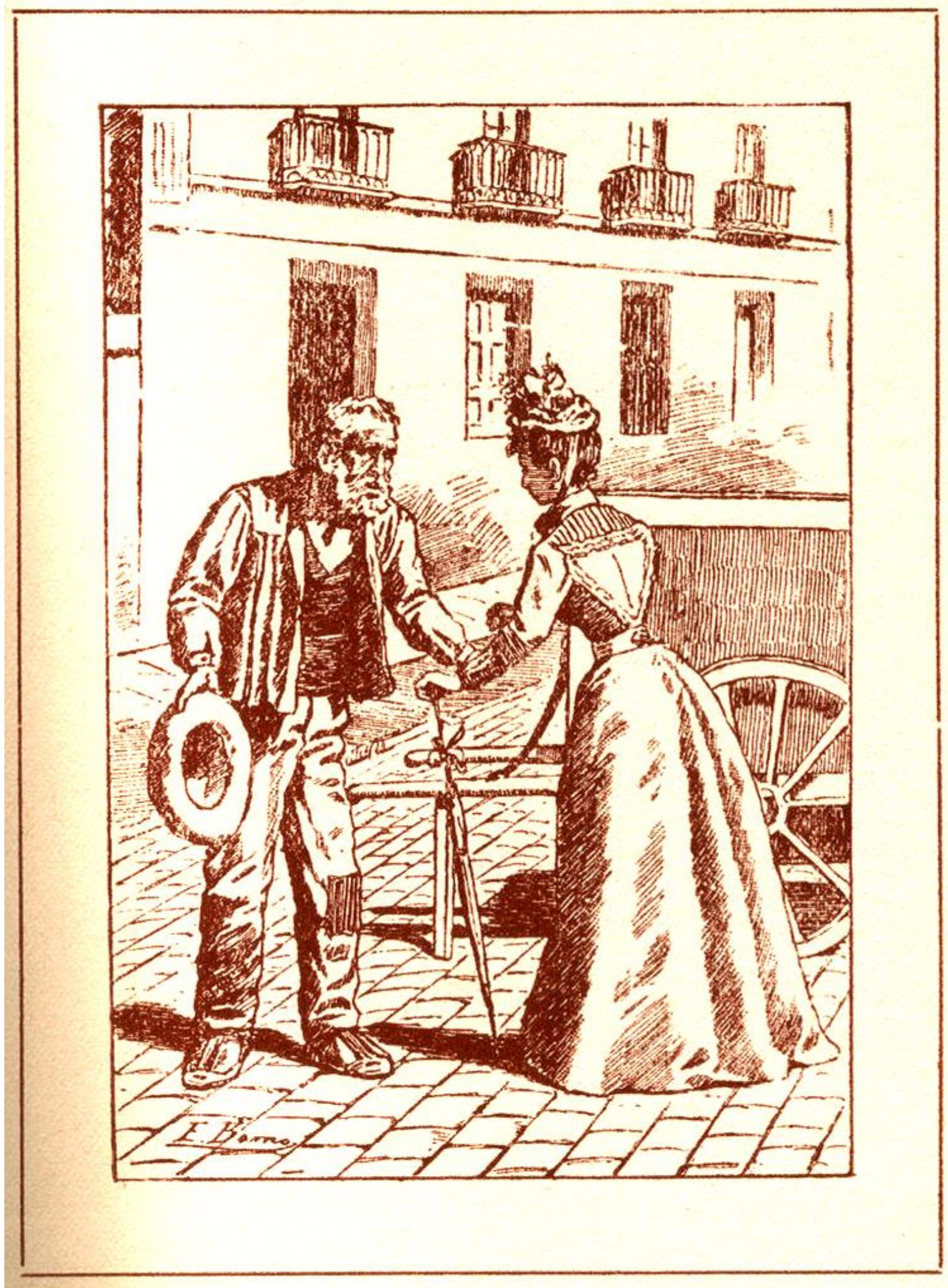

Fig.: 31

Ilustración interior a plana entera del cuento El músico callejero. Biblioteca Ideal. Hijos de Santiago Rodríguez. 
LA EDITORIAL BURGALESA HIJOS DE SANTIAGO RODRÍGUEZ (1891-1936): ANÁLISIS DE LOS LIBROS ESCOLARES

3.1.32. Ilustración de la cubierta del libro Dos primos célebres de la Biblioteca Selecta.

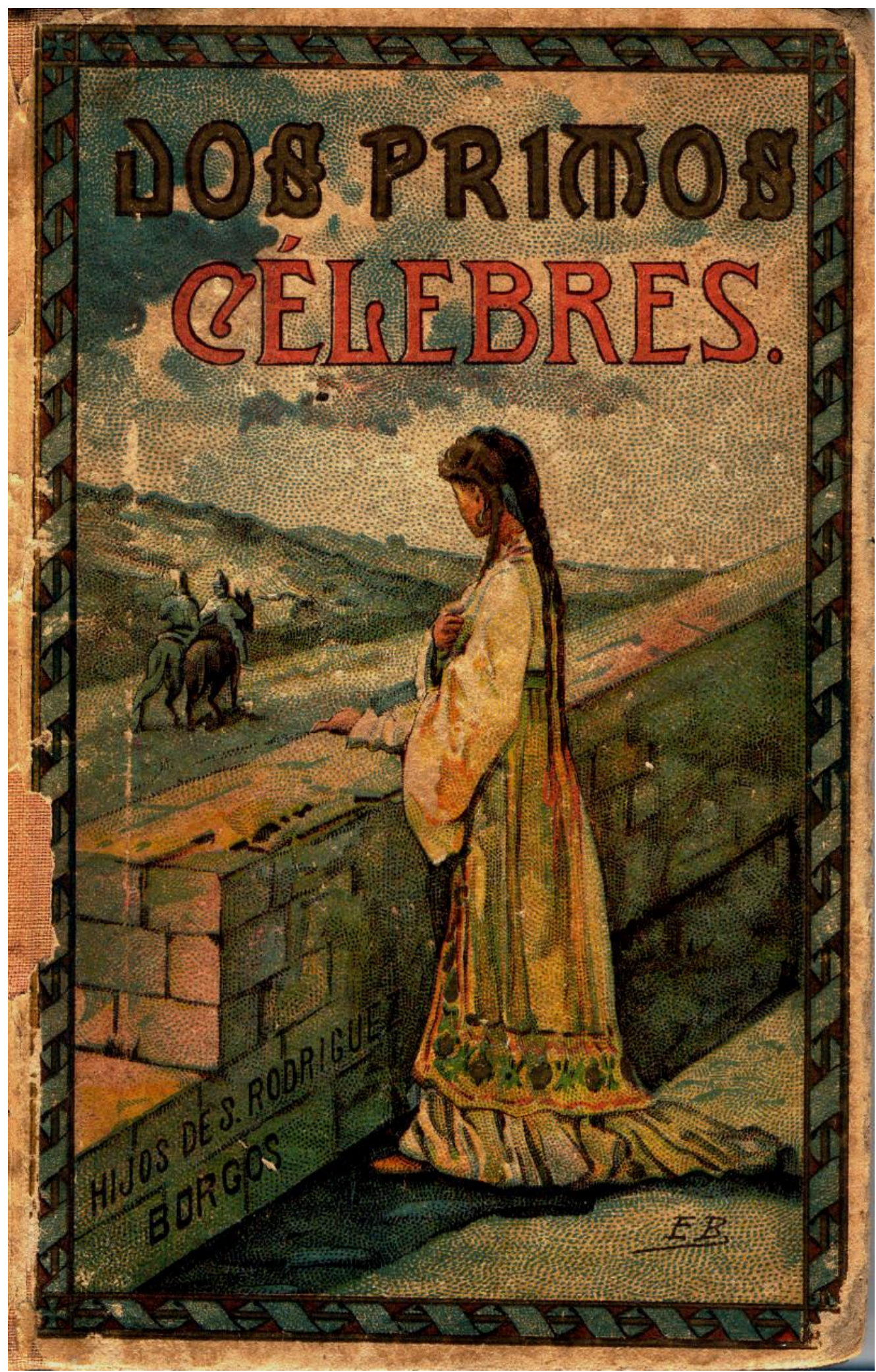

Fig.: 32

Cubierta del libro Dos primos célebres. Biblioteca Selecta. Hijos de Santiago Rodríguez. 
3.1.33. Ilustración interior del libro Ferrús el ermitaño de la Biblioteca Selecta.

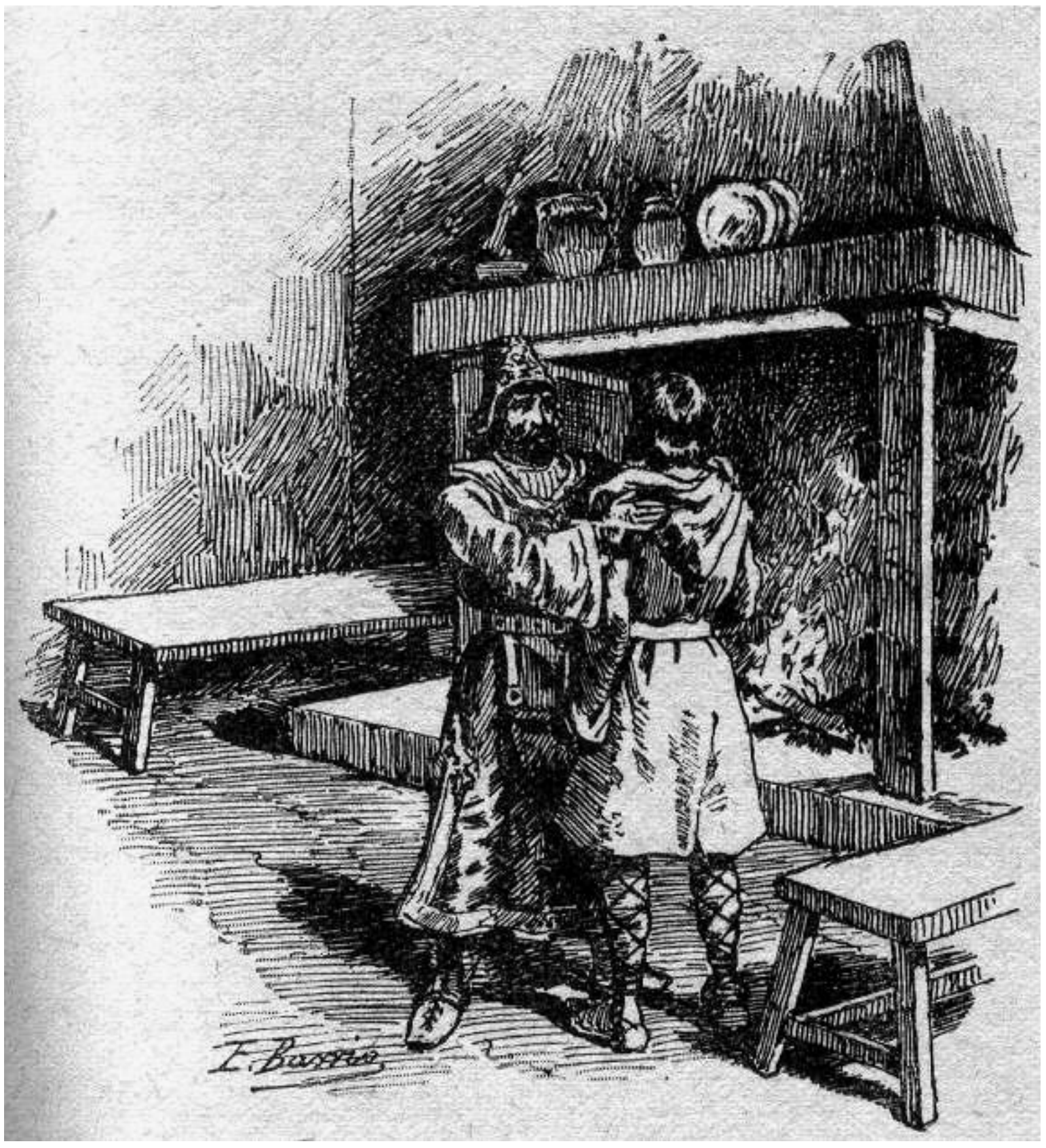

Fig.: 33

Ilustración interior del libro Ferrús el ermitaño.

Biblioteca Selecta. Hijos de Santiago Rodríguez. 
LA EDITORIAL BURGALESA HIJOS DE SANTIAGO RODRÍGUEZ (1891-1936): ANÁLISIS DE LOS LIBROS ESCOLARES

3.1.34. Ilustración interior del libro Flor de Aventuras de la Biblioteca Azul y Rosa (I).

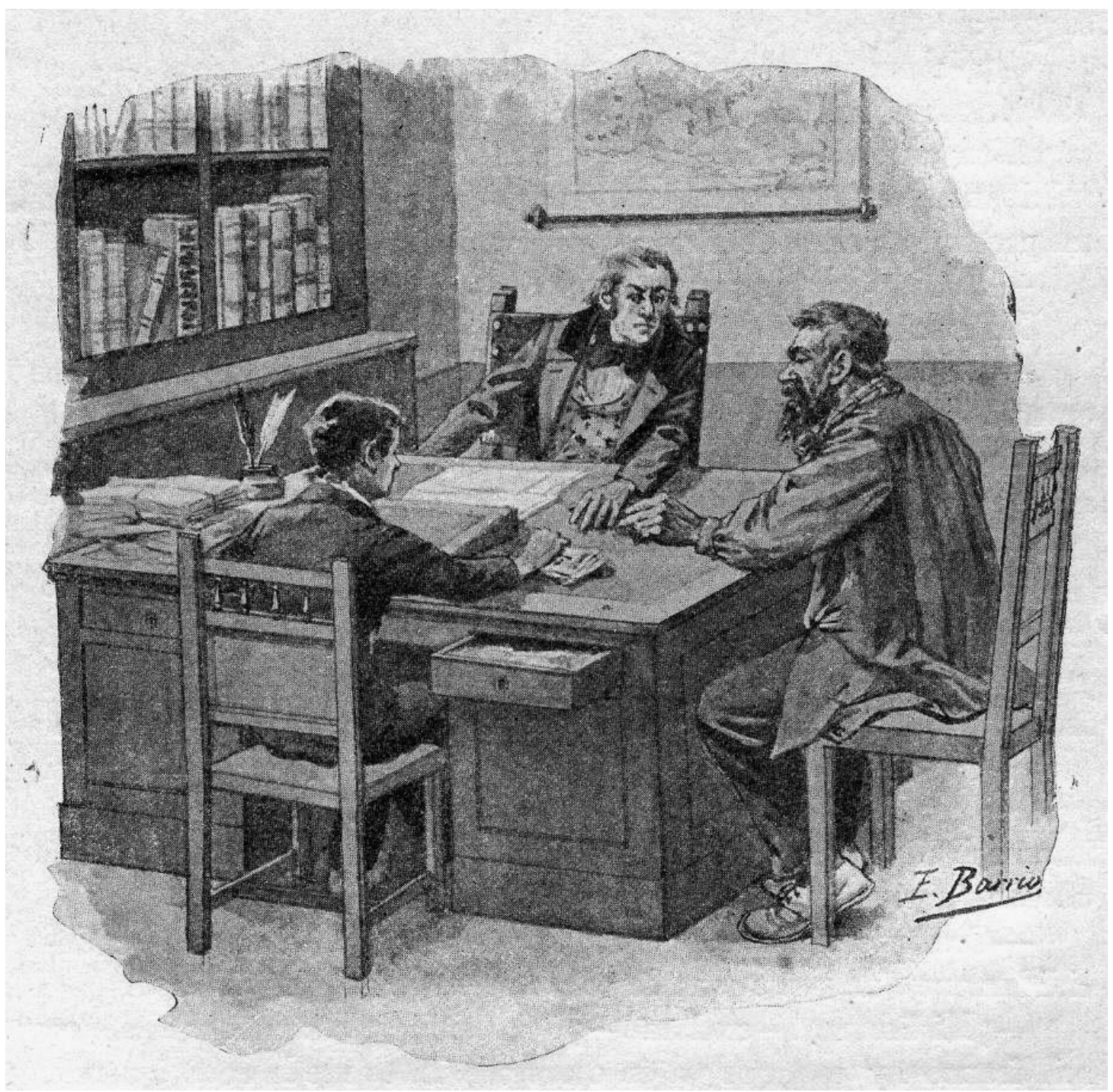

Fig.: 34

Ilustración interior del libro Flor de aventuras.

Biblioteca Azul y Rosa. Hijos de Santiago Rodríguez. 
3.1.35. Ilustración interior del libro Flor de Aventuras de la Biblioteca Azul y Rosa (II).

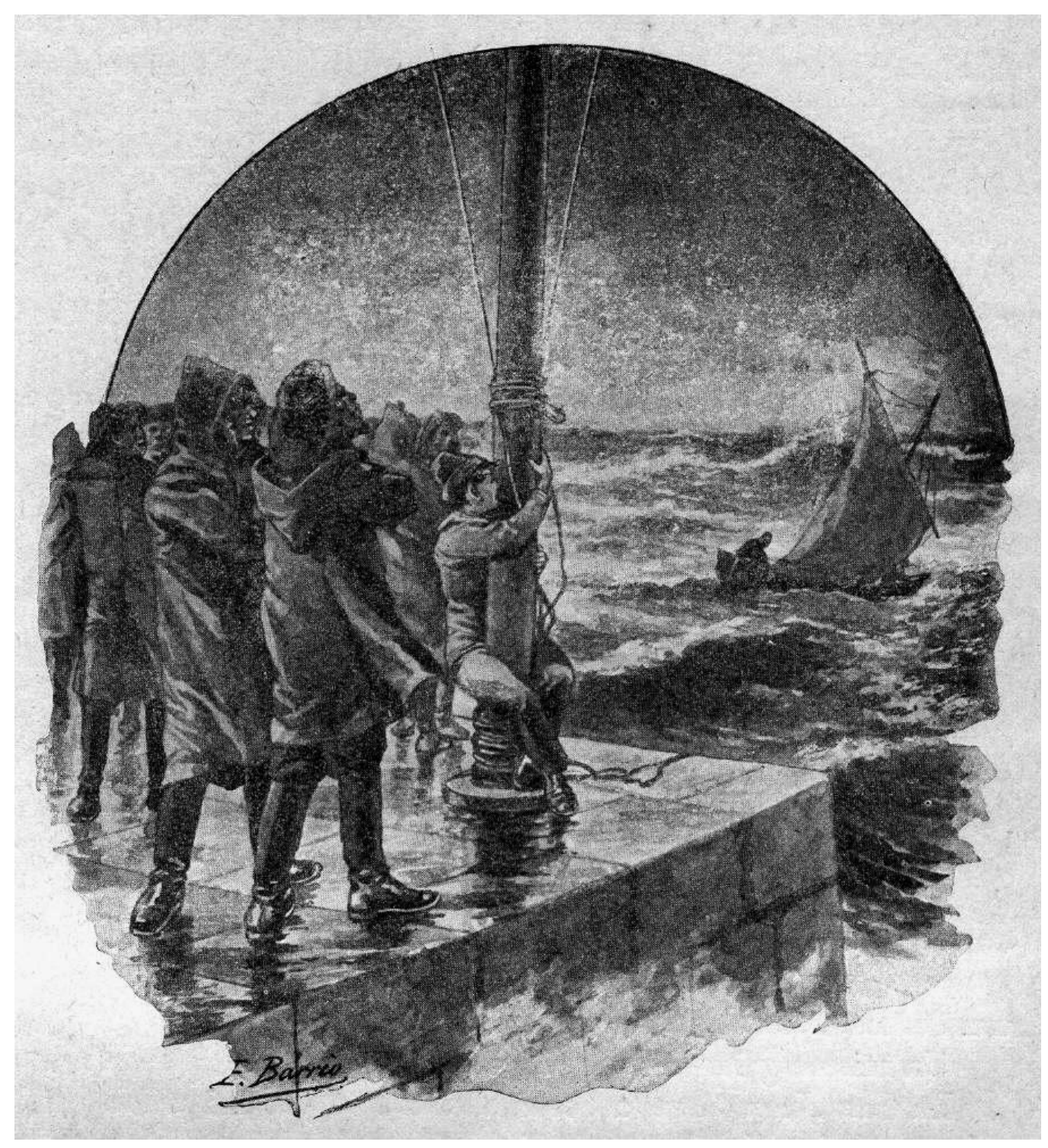

Fig.: 35

Ilustración interior del cuento Flor de aventuras.

Biblioteca Azul y Rosa. Hijos de Santiago Rodríguez. 
LA EDITORIAL BURGALESA HIJOS DE SANTIAGO RODRÍGUEZ (1891-1936): ANÁLISIS DE LOS LIBROS ESCOLARES

3.1.36. Ilustraciones interiores del libro Pompas de jabón de la Mundial Biblioteca.
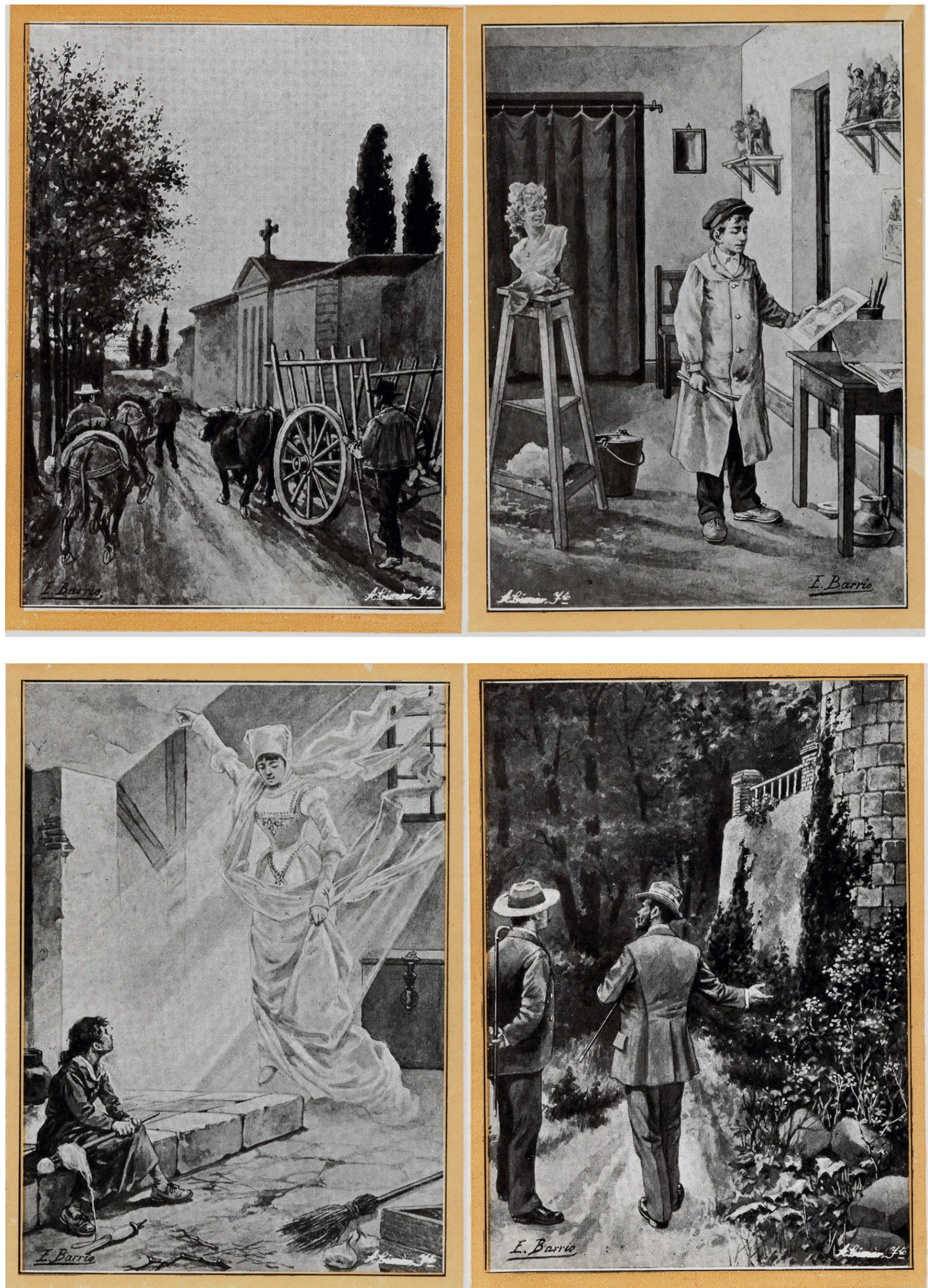

Fig.: 36

Ilustraciones interiores a plana entera del libro Pompas de jabón. Mundial Biblioteca. Hijos de Santiago Rodríguez. 
3.1.37. Ilustraciones interiores del libro ¿Quieres ser mi amigo? de la Biblioteca Oro.
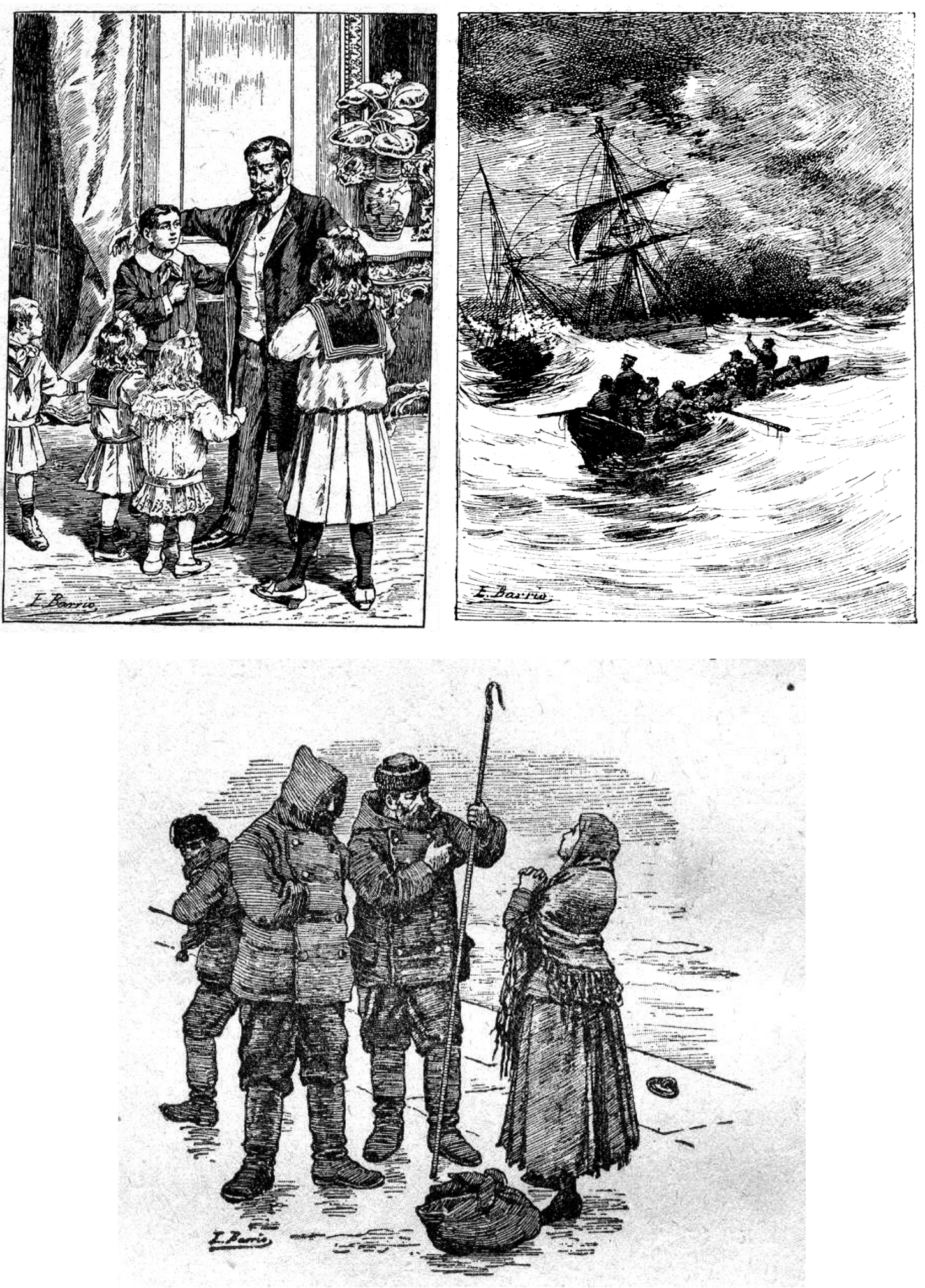

Fig.: 37

Ilustraciones interiores del libro ¿Quieres ser mi amigo? Biblioteca Oro. Hijos de Santiago Rodríguez. 
LA EDITORIAL BURGALESA HIJOS DE SANTIAGO RODRÍGUEZ (1891-1936): ANÁLISIS DE LOS LIBROS ESCOLARES

3.1.38. Ilustración de la cubierta Aventuras de un huérfano de la Biblioteca Oro.

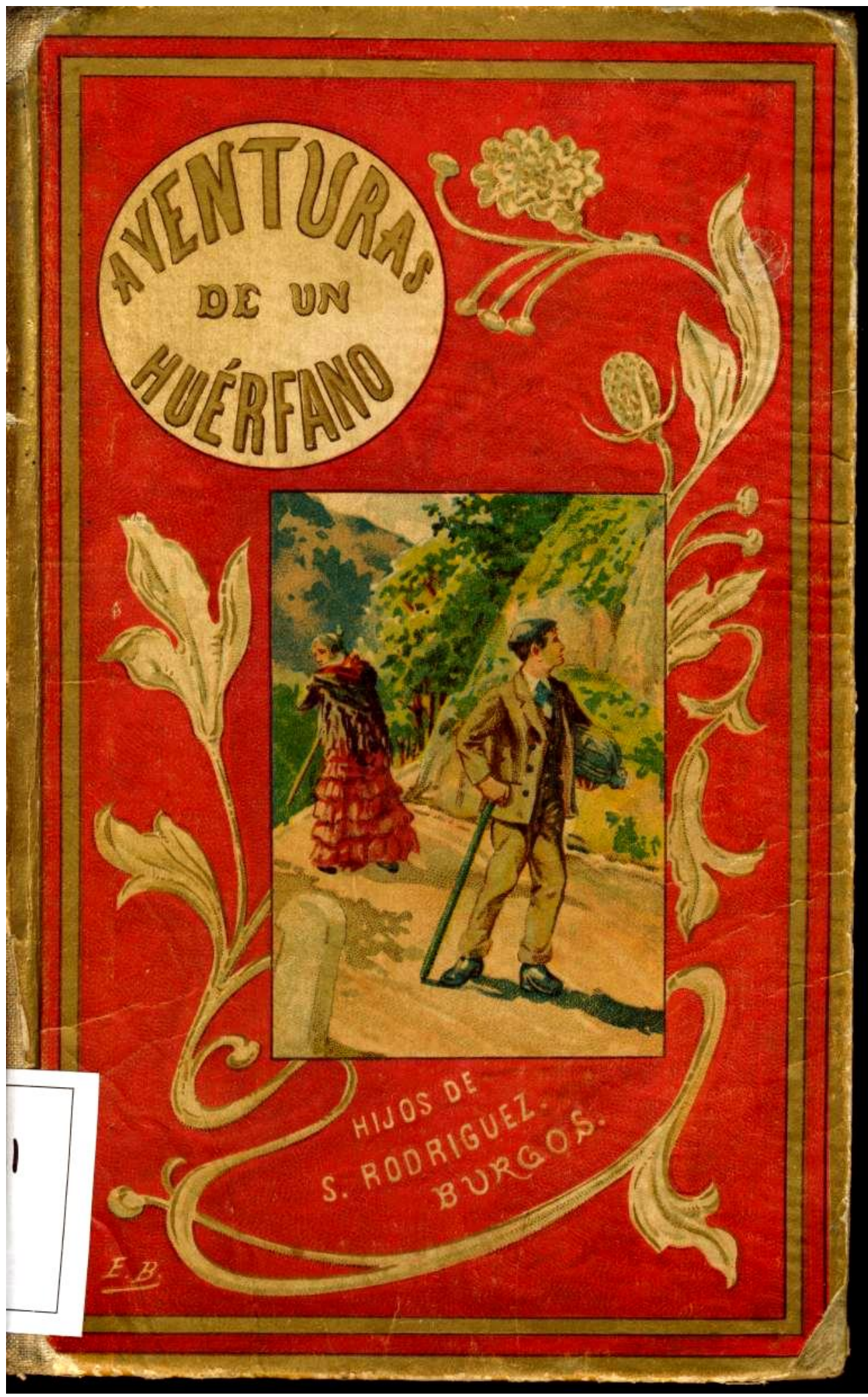

Fig.: 38

Ilustración a color de la portada Aventuras de un huérfano de la Biblioteca Oro. Hijos de Santiago Rodríguez. Ejemplar del CEINCE. 
3.1.39. Ilustración de la cubierta La tiranuela de la Biblioteca Museo de la Infancia.

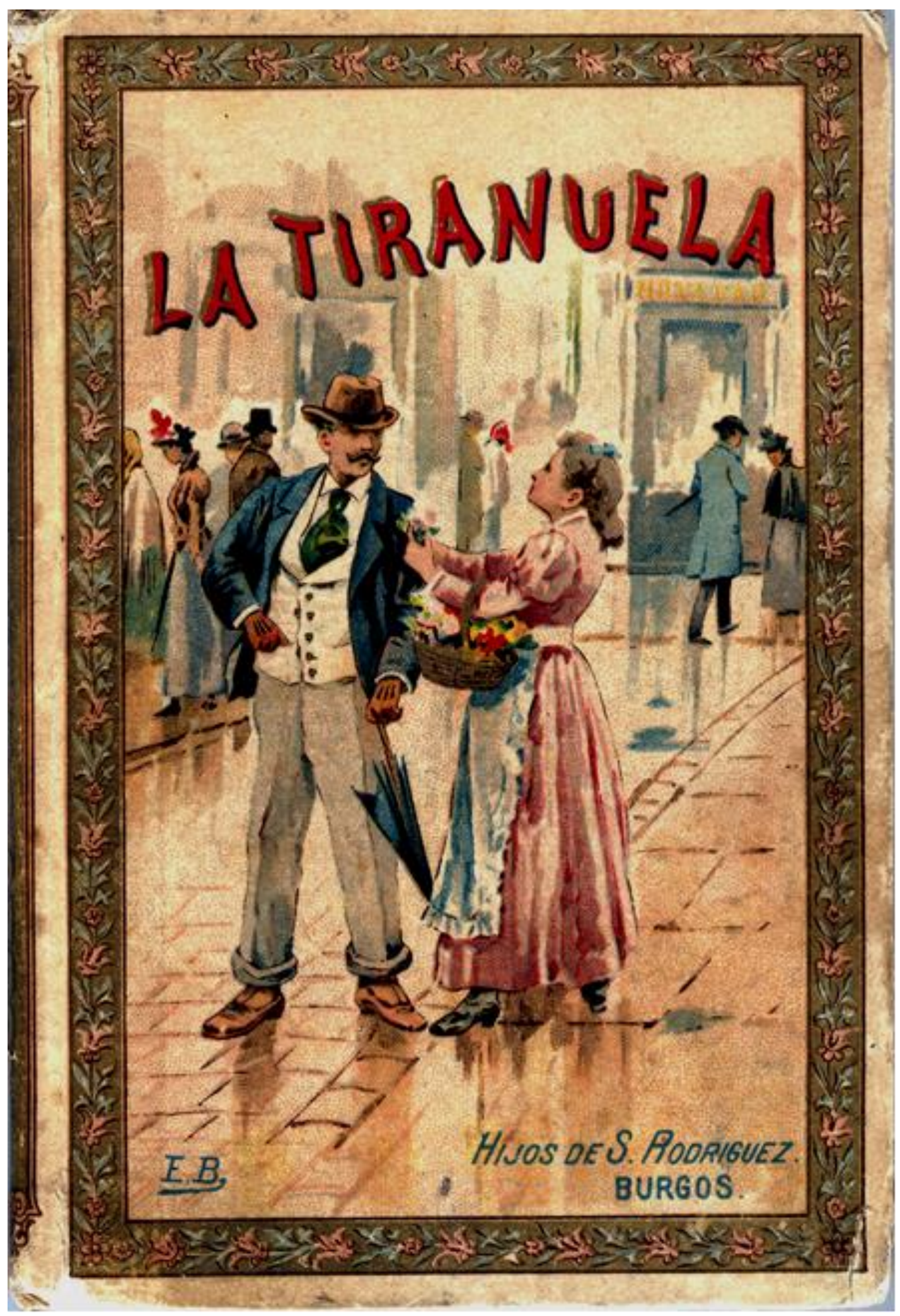

Fig.: 39

Cubierta del libro La tiranuela de la Biblioteca Museo de la Infancia. Hijos de Santiago Rodríguez. 1899. 
LA EDITORIAL BURGALESA HIJOS DE SANTIAGO RODRÍGUEZ (1891-1936): ANÁLISIS DE LOS LIBROS ESCOLARES

3.1.40. Ilustración de la cubierta de Aventuras de Telémaco de la Biblioteca Enciclopédica Hispano-Americana.

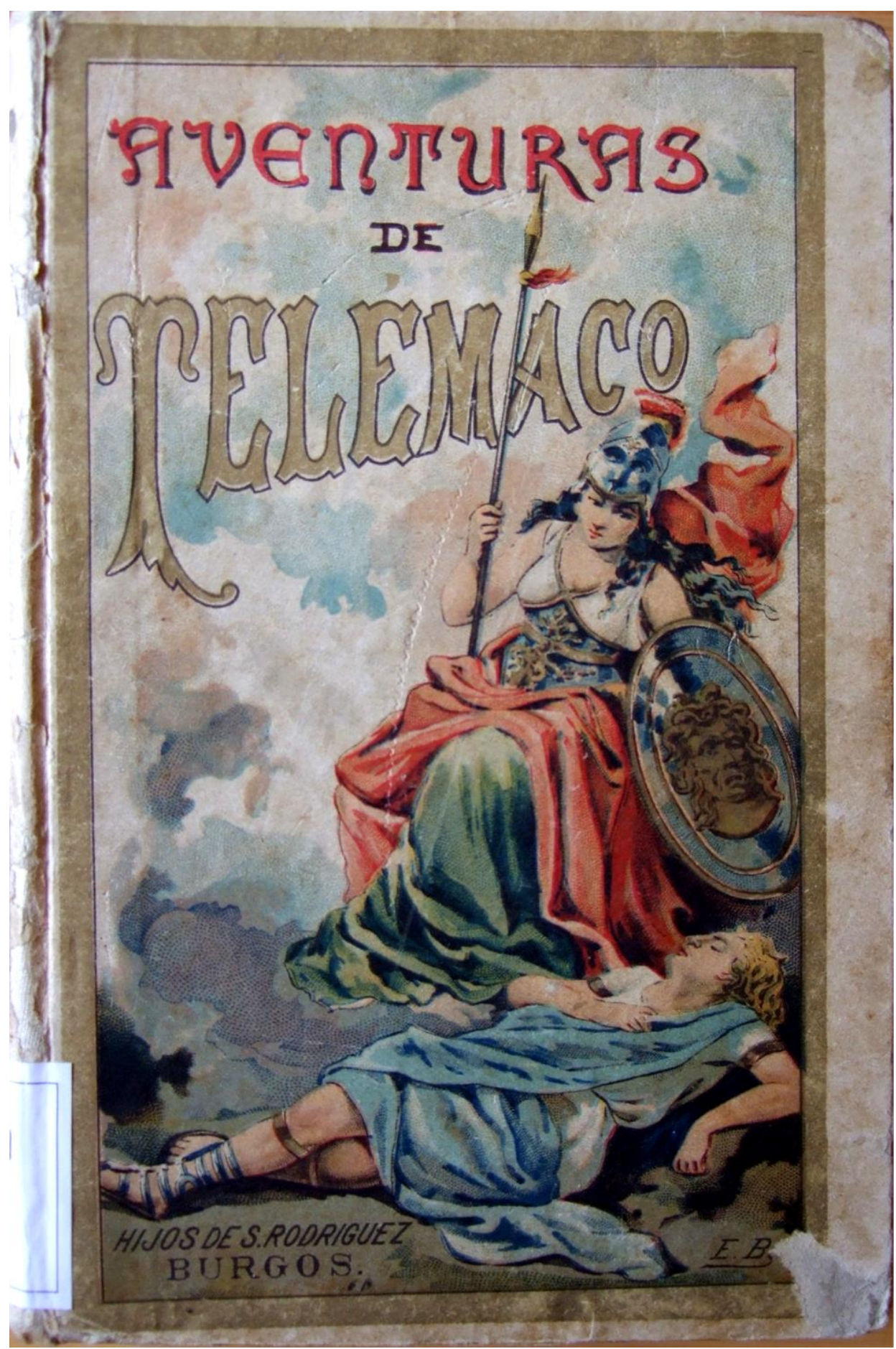

Fig.: 40

Cubierta a color de la obra Aventuras de Telémaco de la Biblioteca Enciclopédica Hispano-Americana. Hijos de Santiago Rodríguez. 1902.

Ejemplar del CEINCE. 
3.1.41. Ilustración de la cubierta de Rafael de la Biblioteca Enciclopédica Hispano-Americana.

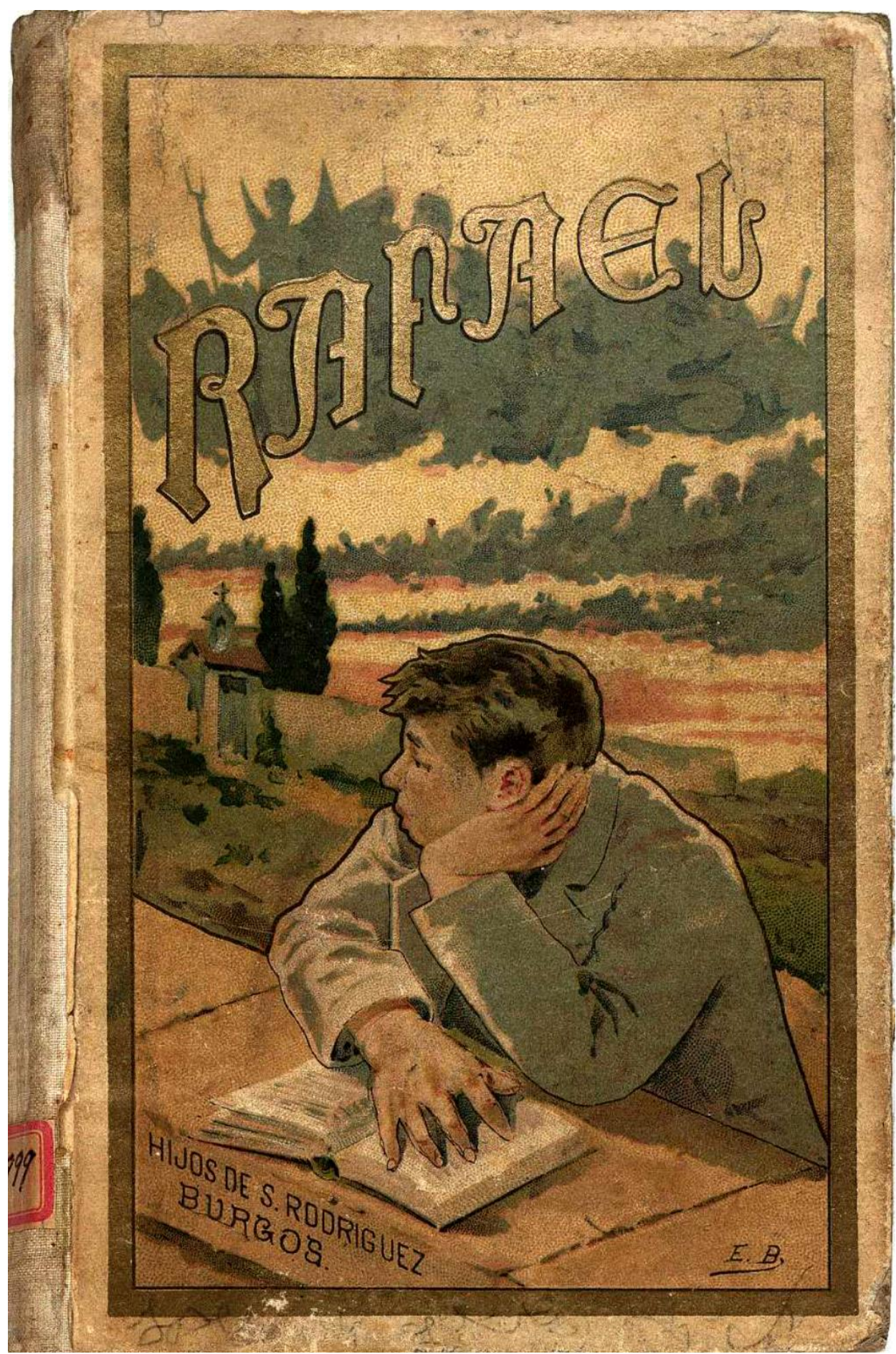

Fig.: 41

Cubierta a color de la obra Rafael de la Biblioteca Enciclopédica Hispano-Americana. Ejemplar de la Biblioteca Digital de Castilla y León. 
3.2.ISIDRO GIL GABILONDO (AZCOITIA, GUIPUZCOA, 1840-BURGOS 1917)

3.2.1. Ilustración de la cubierta del cuento El miedo de la Biblioteca Cuentos para Niños.

3.2.2. Ilustraciones interiores del cuento El miedo de la Biblioteca Cuentos para Niños.

3.2.3. Ilustración de la cubierta del cuento La curiosidad de la Biblioteca Cuentos para Niños.

3.2.4. Ilustraciones interiores del cuento La curiosidad castigada de la Biblioteca Cuentos para Niños.

3.2.5. Ilustración de la cubierta del cuento La estrella del mar de la Biblioteca Cuentos para Niños.

3.2.6. Ilustraciones interiores del cuento La estrella del mar de la Biblioteca Cuentos para Niños.

3.2.7. Ilustración de la cubierta del cuento La venganza de las flores de la Biblioteca Cuentos para Niños.

3.2.8. Ilustraciones interiores del cuento La venganza de las flores de la Biblioteca Cuentos para Niños.

3.2.9. Ilustración de la cubierta del cuento Leal de la Biblioteca Cuentos para Niños.

3.2.10. Ilustraciones interiores del cuento Leal de la Biblioteca Cuentos para Niños.

3.2.11. Ilustración de la cubierta del cuento Morir por la patria de la Biblioteca Cuentos para Niños.

3.2.12. Ilustraciones interiores del cuento Morir por la patria de la Biblioteca Cuentos para Niños.

3.2.13. Ilustración de la cubierta del cuento Un genio de la Biblioteca Cuentos para Niños. 
3.2.14. Ilustraciones interiores del cuento Un genio de la Biblioteca Cuentos para Niños.

3.2.15. Ilustración de la cubierta del libro ¿Quieres ser mi amigo? de la Biblioteca Oro.

3.2.16. Ilustración interior de El Libro de los viajes de la Biblioteca ProCultura.

3.2.17. Ilustración interior del cuento La cabaña del credo del libro El mejor tesoro de la Biblioteca Oro.

3.2.18. Ilustración interior del cuento Mundo, demonio y carne del libro El mejor tesoro de la Biblioteca Oro.

3.2.19. Ilustraciones interiores del cuento El cazador de gorriones del libro El mejor tesoro de la Biblioteca Oro.

3.2.20. Ilustraciones interiores del cuento La mensajera del libro El mejor tesoro de la Biblioteca Oro.

3.2.21. Ilustración interior del libro Historia de España (I).

3.2.22. Ilustración interior del libro Historia de España (II).

3.2.23. Ilustración interior del libro Historia de España (III).

3.2.24. Ilustración interior del libro Historia de España (IV).

3.2.25. Cubierta del libro Viejas memorias: leyendas y tradiciones universales de la Biblioteca Enciclopédica Hispano-Americana.

3.2.26. Ilustraciones de las carátulas de distintas leyendas en la obra Viejas memorias: leyendas y tradiciones universales de la Biblioteca Enciclopédica Hispano-Americana.

3.2.27. Ilustraciones interiores sobre distintas leyendas en la obra Viejas memorias: leyendas y tradiciones universales de la Biblioteca Enciclopédica Hispano-Americana.

3.2.28. Cubierta a color del libro Cristina y su corderito de la Biblioteca Oro. 
LA EDITORIAL BURGALESA HIJOS DE SANTIAGO RODRÍGUEZ (1891-1936):

ANÁLISIS DE LOS LIBROS ESCOLARES

3.2.29. Cubierta de la obra Viaje Infantil escrita por Mariano Rodríguez Miguel.

3.2.30. Ilustración interior a plana entera como introducción en la explicación de las diversas carreras del libro El previsor de Antonio Álvarez Carretero.

3.2.31. Ilustración interior del libro Catón Metódico de los Niños para el aprendizaje de la lectura. 
3.2.1. Ilustración de la cubierta del cuento El miedo de la Biblioteca Cuentos para Niños.

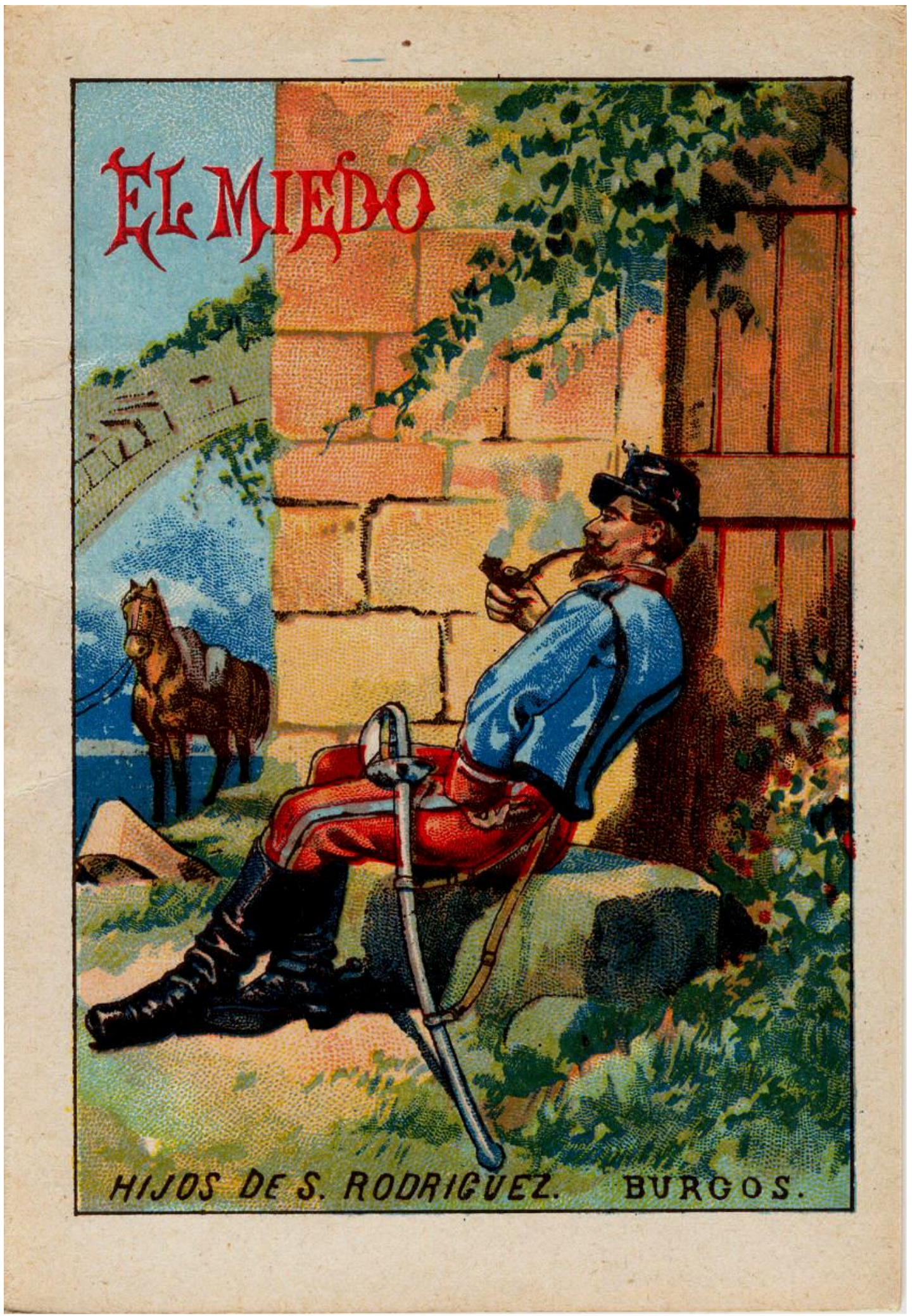

Fig.: 42

Cubierta a color del cuento El miedo de la Biblioteca Cuentos para Niños. Hijos de Santiago Rodríguez. 
LA EDITORIAL BURGALESA HIJOS DE SANTIAGO RODRÍGUEZ (1891-1936): ANÁLISIS DE LOS LIBROS ESCOLARES

3.2.2. Ilustraciones interiores del cuento El miedo de la Biblioteca Cuentos para Niños.
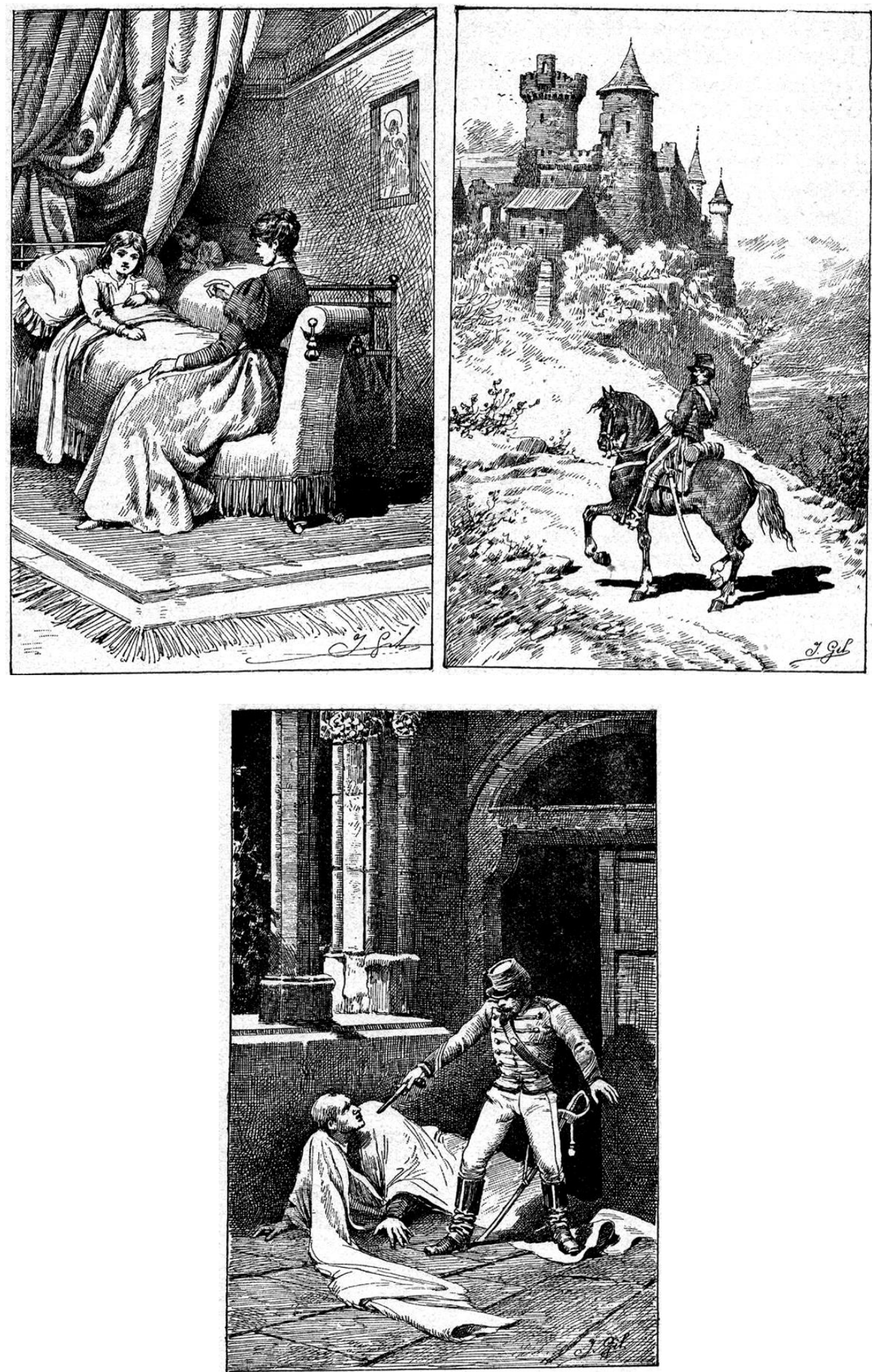

Fig.: 43

Ilustraciones interiores del cuento El miedo de la Biblioteca Cuentos para Niños. Hijos de Santiago Rodríguez. 
3.2.3. Ilustración de la cubierta del cuento La curiosidad de la Biblioteca Cuentos para Niños.

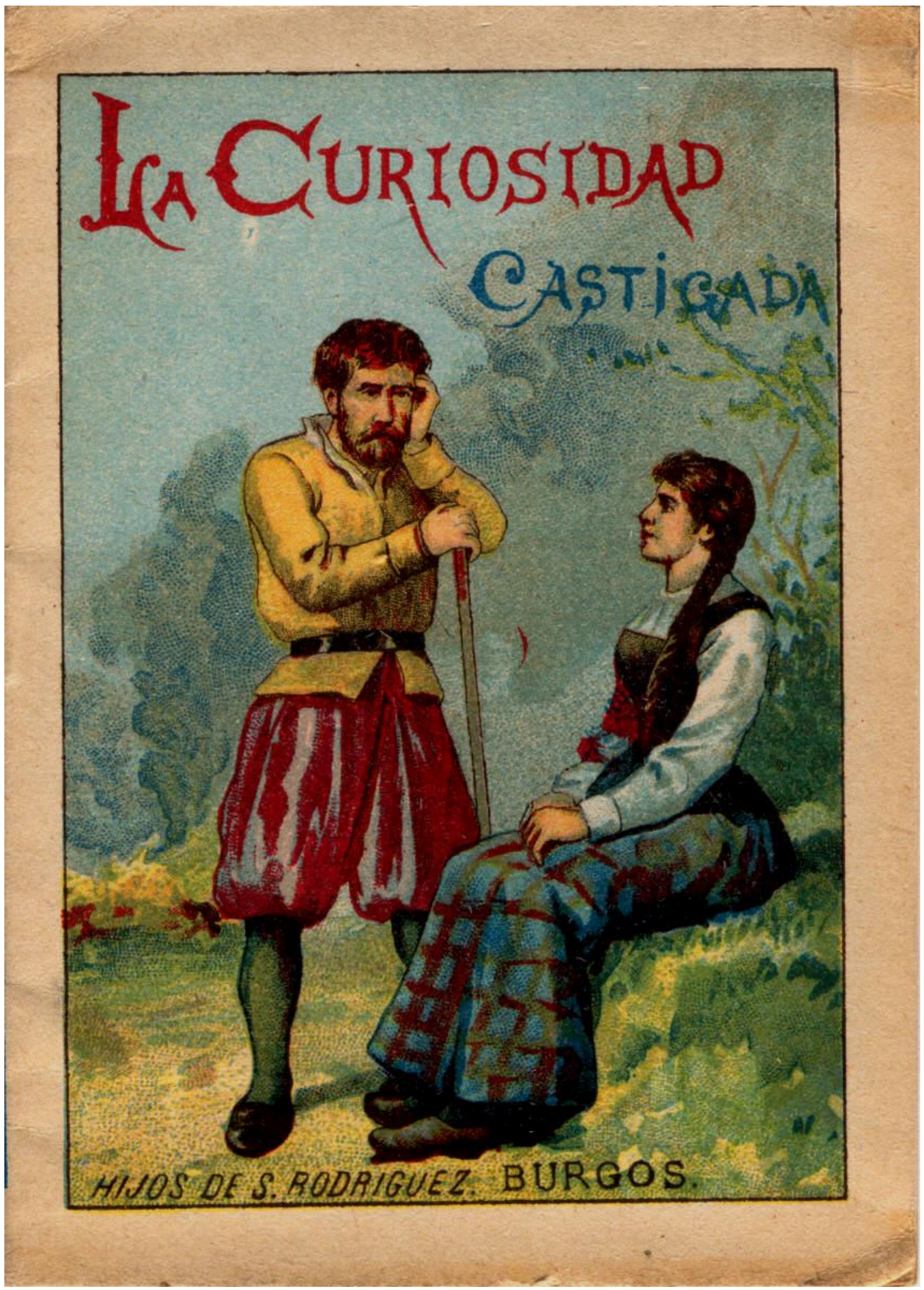

Fig.: 44

Cubierta a color del cuento La curiosidad castigada de la Biblioteca Cuentos para Niños. Hijos de Santiago Rodríguez. 
LA EDITORIAL BURGALESA HIJOS DE SANTIAGO RODRÍGUEZ (1891-1936): ANÁLISIS DE LOS LIBROS ESCOLARES

3.2.4. Ilustraciones interiores del cuento La curiosidad castigada de la Biblioteca Cuentos para Niños.
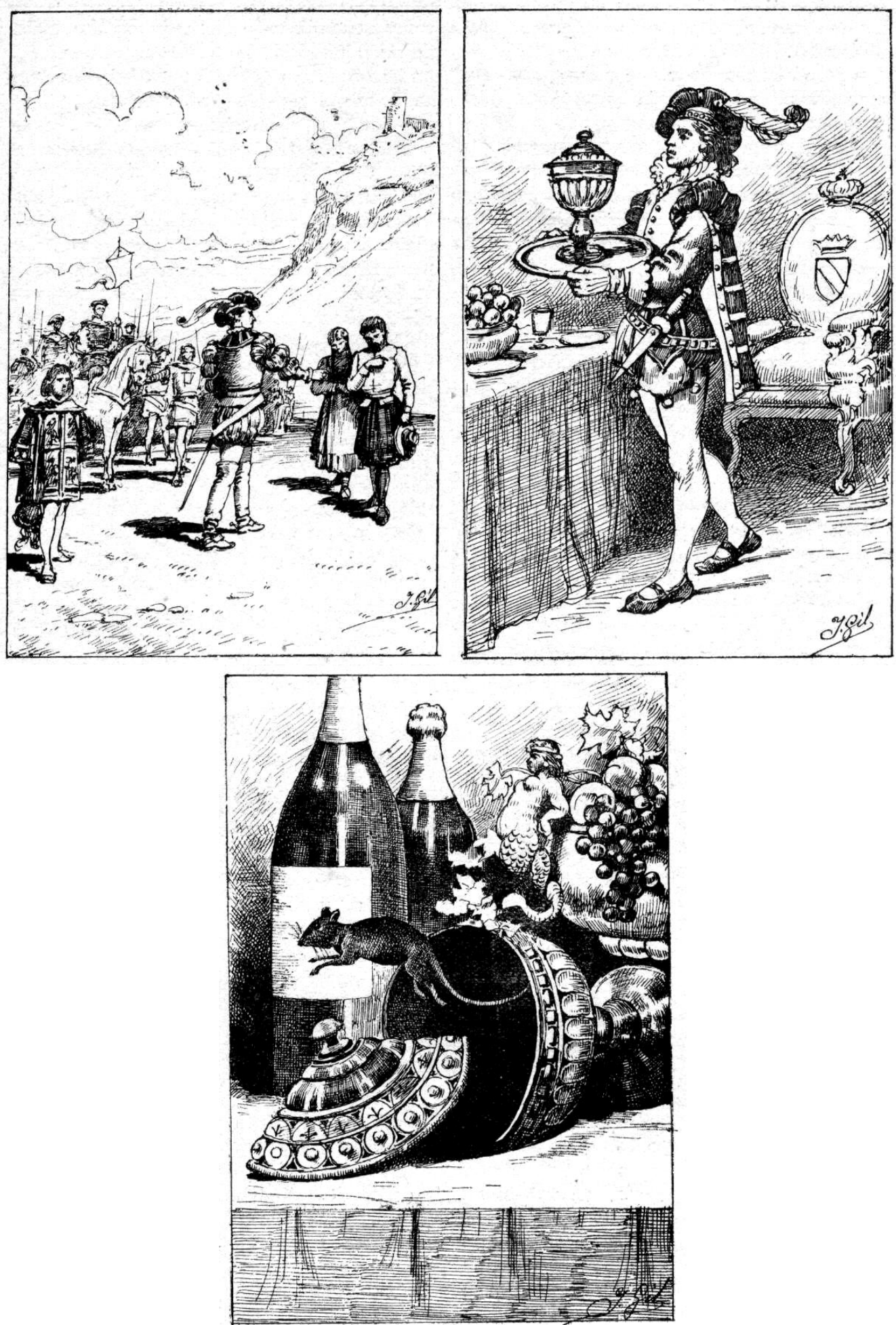

Fig.: 45

Ilustraciones interiores del cuento La curiosidad castigada de la Biblioteca Cuentos para Niños. Hijos de Santiago Rodríguez. 
3.2.5. Ilustración de la cubierta del cuento La estrella del mar de la Biblioteca Cuentos para Niños.

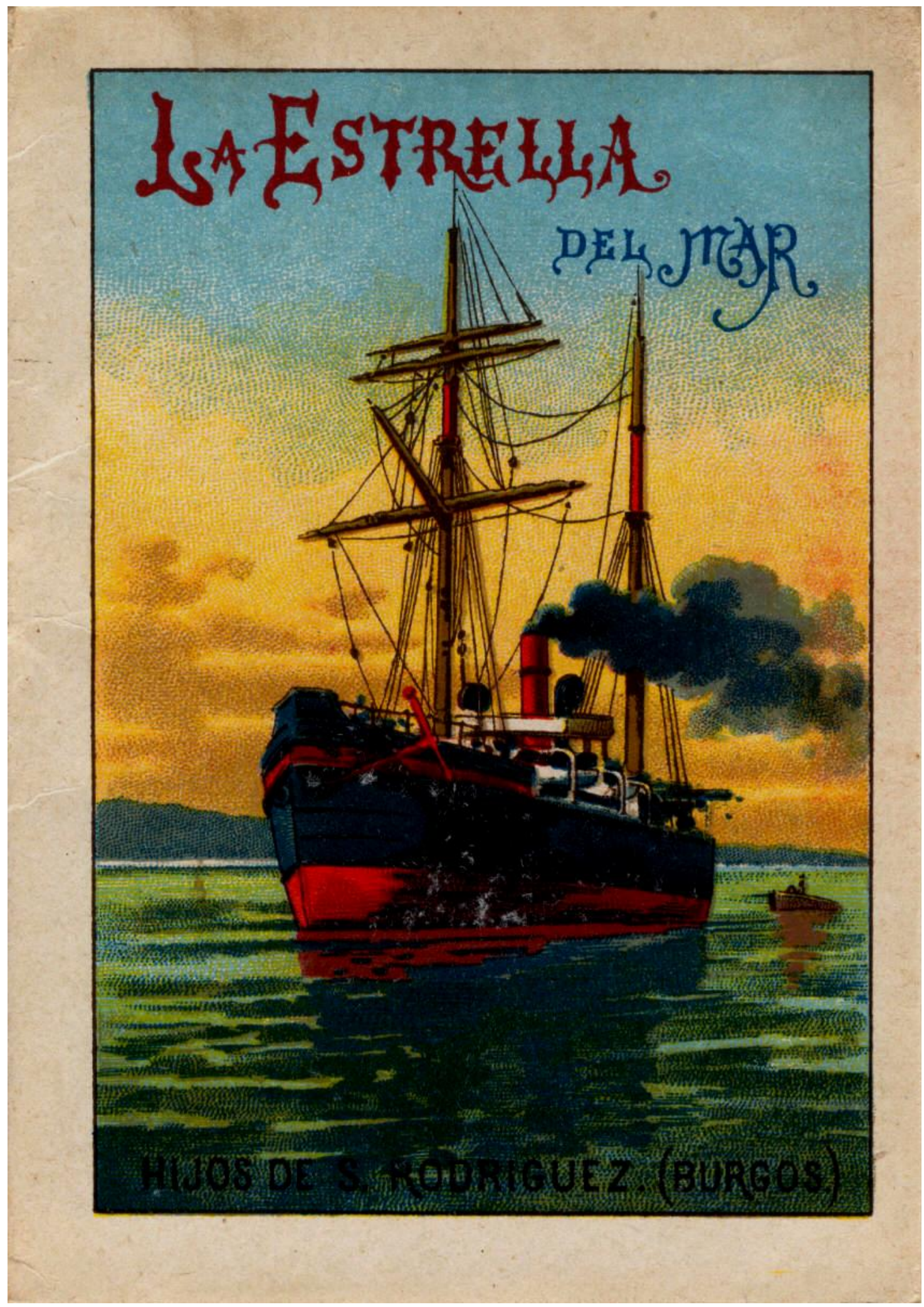

Fig.: 46

Cubierta a color del cuento La estrella del mar de la Biblioteca Cuentos para Niños. Hijos de Santiago Rodríguez. 
LA EDITORIAL BURGALESA HIJOS DE SANTIAGO RODRÍGUEZ (1891-1936): ANÁLISIS DE LOS LIBROS ESCOLARES

3.2.6. Ilustraciones interiores del cuento La estrella del mar de la Biblioteca Cuentos para Niños.
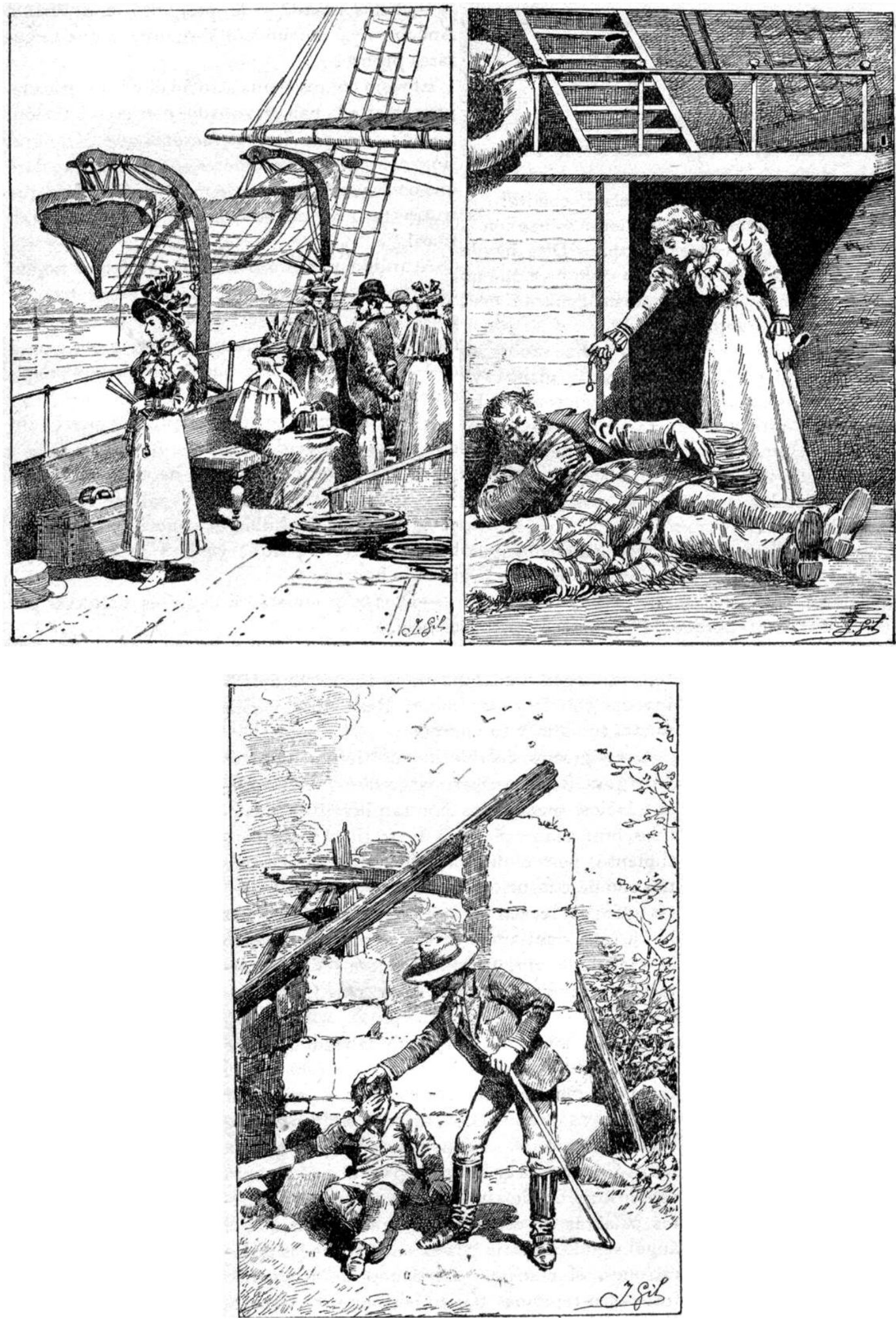

Fig.: 47

Ilustraciones interiores del cuento La estrella del mar de la Biblioteca Cuentos para Niños. Hijos de Santiago Rodríguez. 
3.2.7. Ilustración de la cubierta del cuento La venganza de las flores de la Biblioteca Cuentos para Niños.

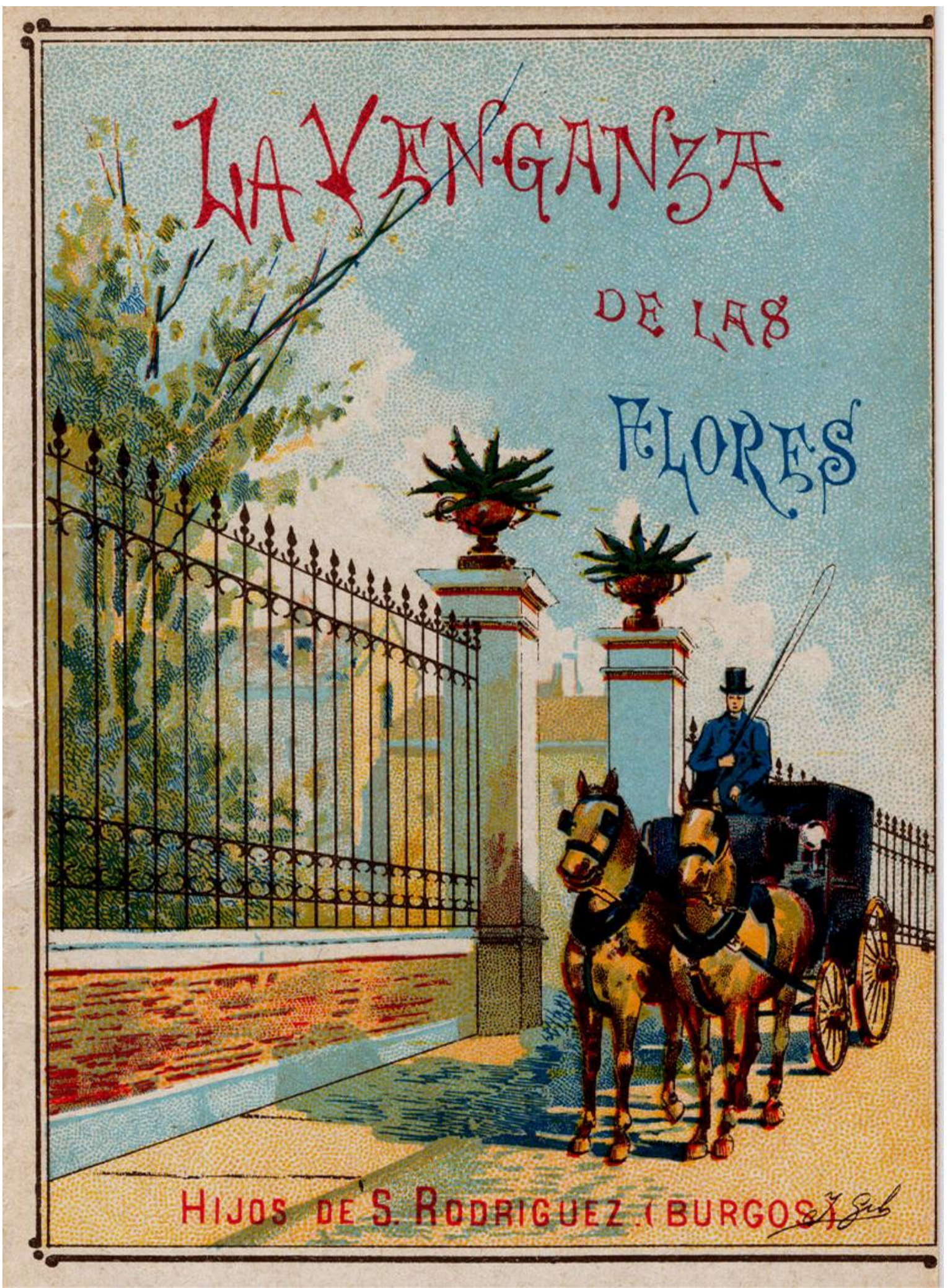

Fig.: 48

Cubierta a color del cuento La venganza de las flores de la Biblioteca Cuentos para Niños. Hijos de Santiago Rodríguez. 
LA EDITORIAL BURGALESA HIJOS DE SANTIAGO RODRÍGUEZ (1891-1936): ANÁLISIS DE LOS LIBROS ESCOLARES

3.2.8. Ilustraciones interiores del cuento La venganza de las flores de la Biblioteca Cuentos para Niños.
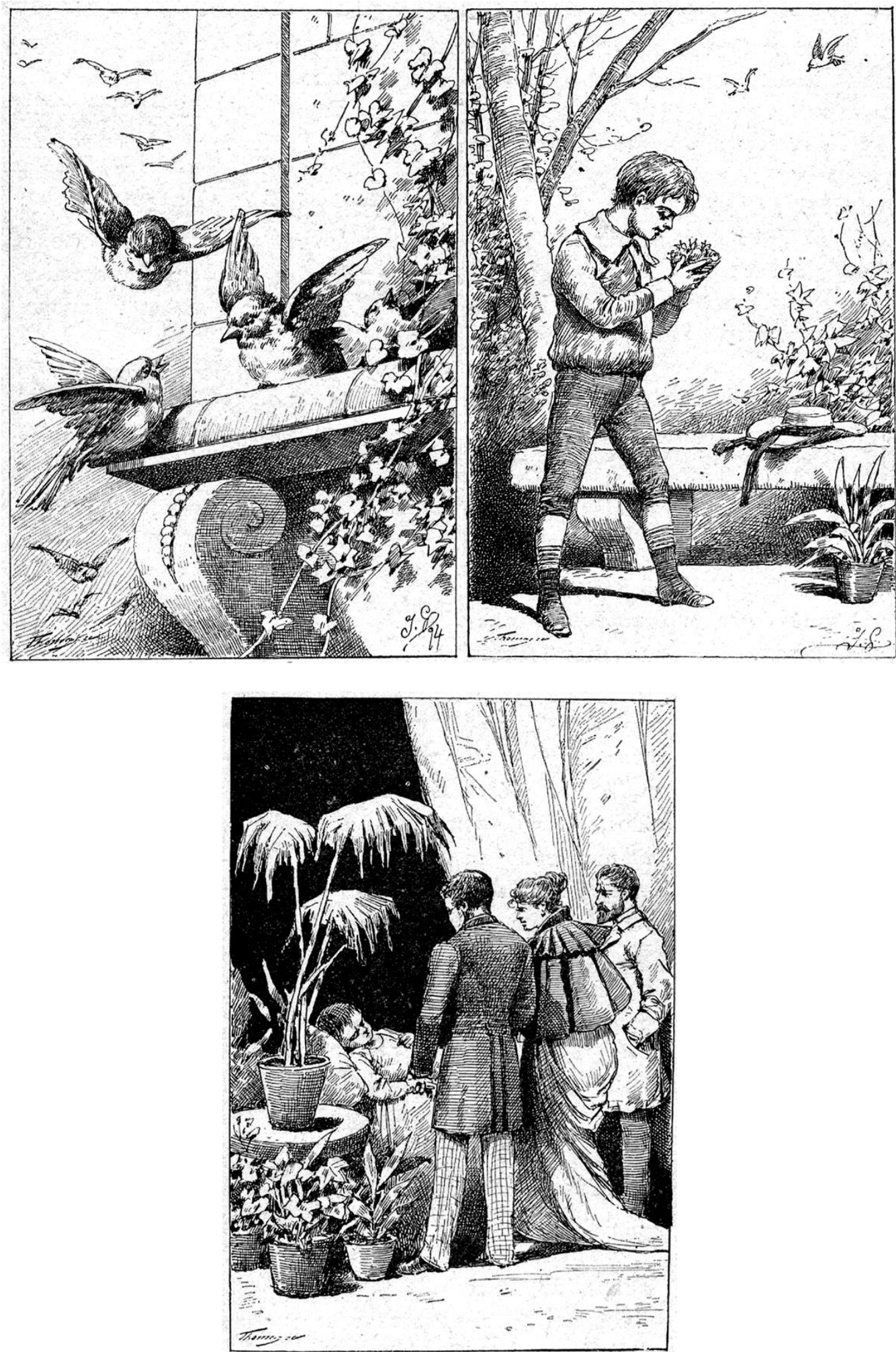

Fig.: 49

Ilustraciones interiores del cuento La estrella del mar de la Biblioteca Cuentos para Niños. Hijos de Santiago Rodríguez. 
3.2.9. Ilustración de la cubierta del cuento Leal de la Biblioteca Cuentos para Niños.

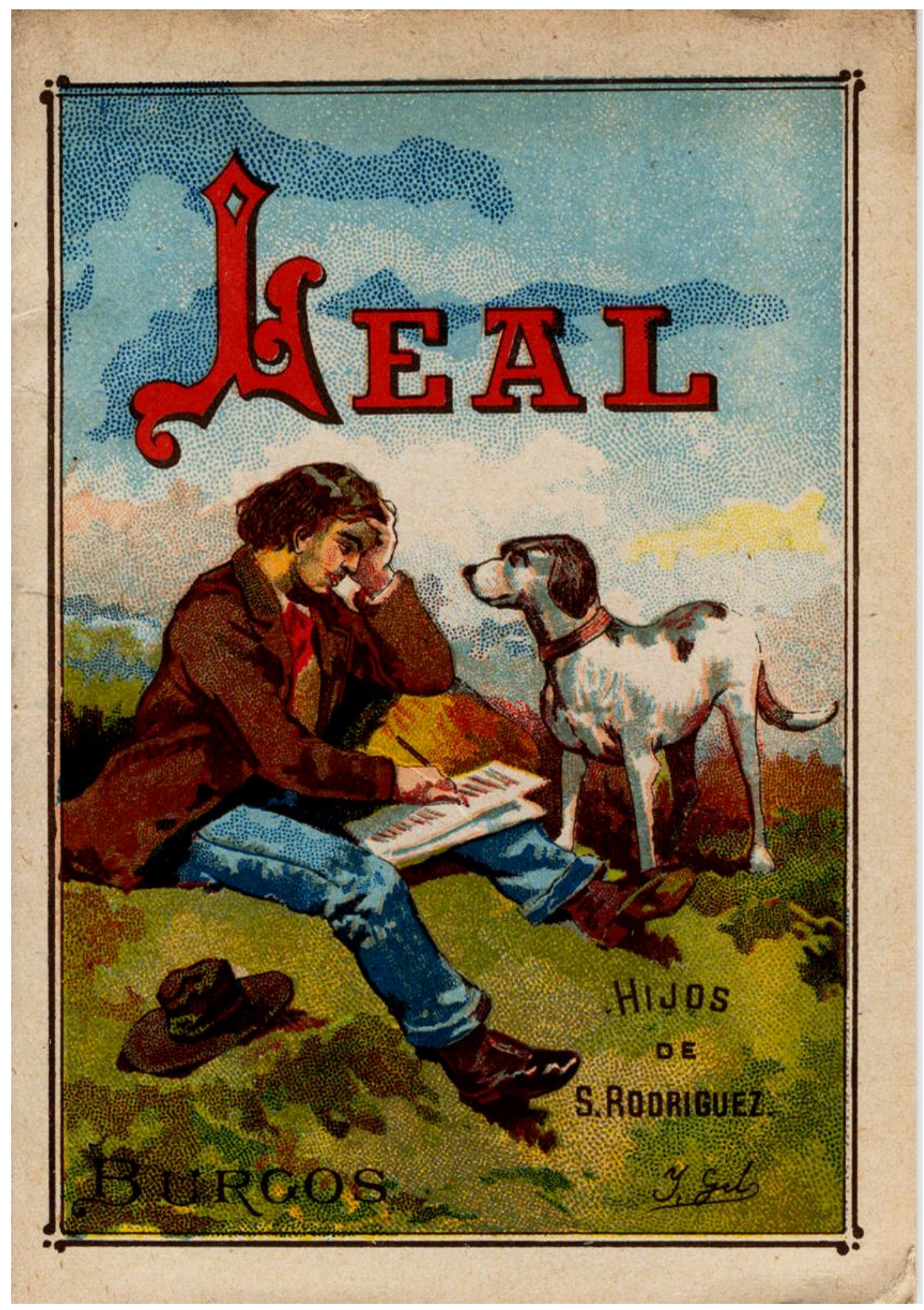

Fig.: 50

Cubierta a color del cuento Leal de la Biblioteca Cuentos para Niños. Hijos de Santiago Rodríguez. 
LA EDITORIAL BURGALESA HIJOS DE SANTIAGO RODRÍGUEZ (1891-1936): ANÁLISIS DE LOS LIBROS ESCOLARES

3.2.10. Ilustraciones interiores del cuento Leal de la Biblioteca Cuentos para Niños.
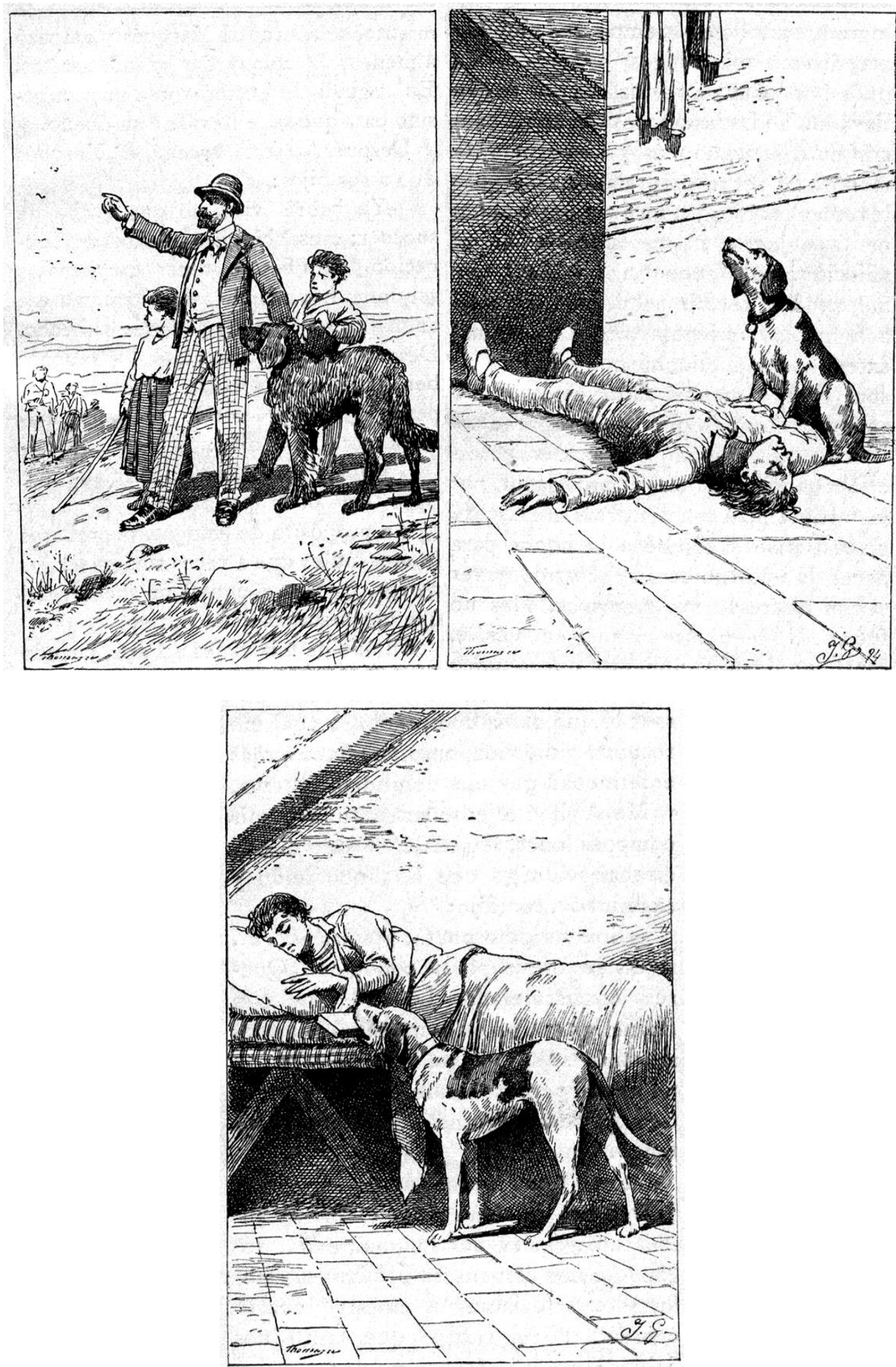

Fig.: 51

Ilustraciones interiores del cuento Leal de la Biblioteca Cuentos para Niños. Hijos de Santiago Rodríguez. 
3.2.11. Ilustración de la cubierta del cuento Morir por la patria de la Biblioteca Cuentos para Niños.

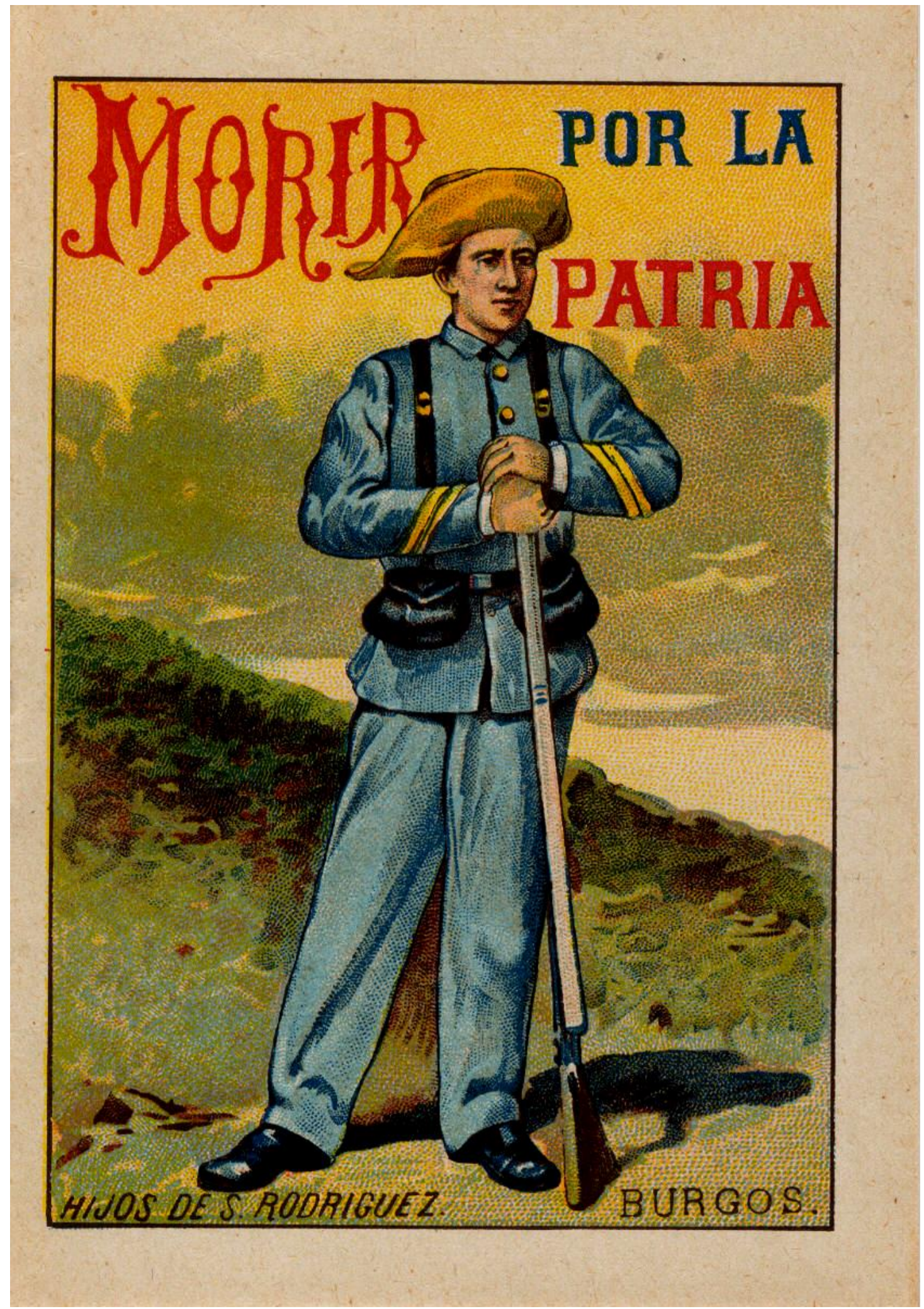

Fig.: 52

Cubierta a color del cuento Morir por la patria de la Biblioteca Cuentos para Niños. Hijos de Santiago Rodríguez. 
LA EDITORIAL BURGALESA HIJOS DE SANTIAGO RODRÍGUEZ (1891-1936): ANÁLISIS DE LOS LIBROS ESCOLARES

3.2.12. Ilustraciones interiores del cuento Morir por la patria de la Biblioteca Cuentos para Niños.
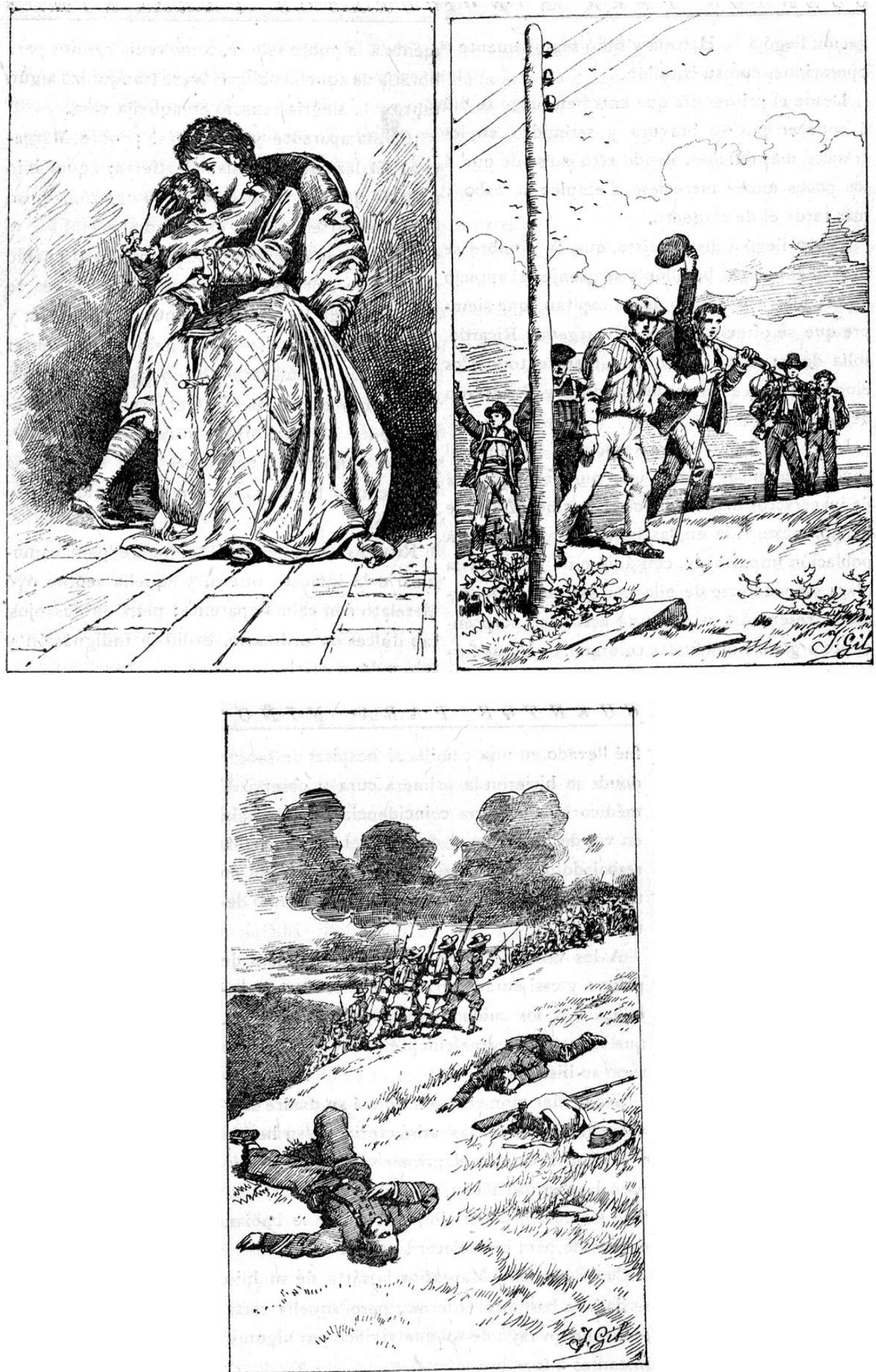

Fig.: 53

Ilustraciones interiores del cuento Morir por la patria de la Biblioteca Cuentos para Niños. Hijos de Santiago Rodríguez. 
3.2.13. Ilustración de la cubierta del cuento Un genio de la Biblioteca Cuentos para Niños.

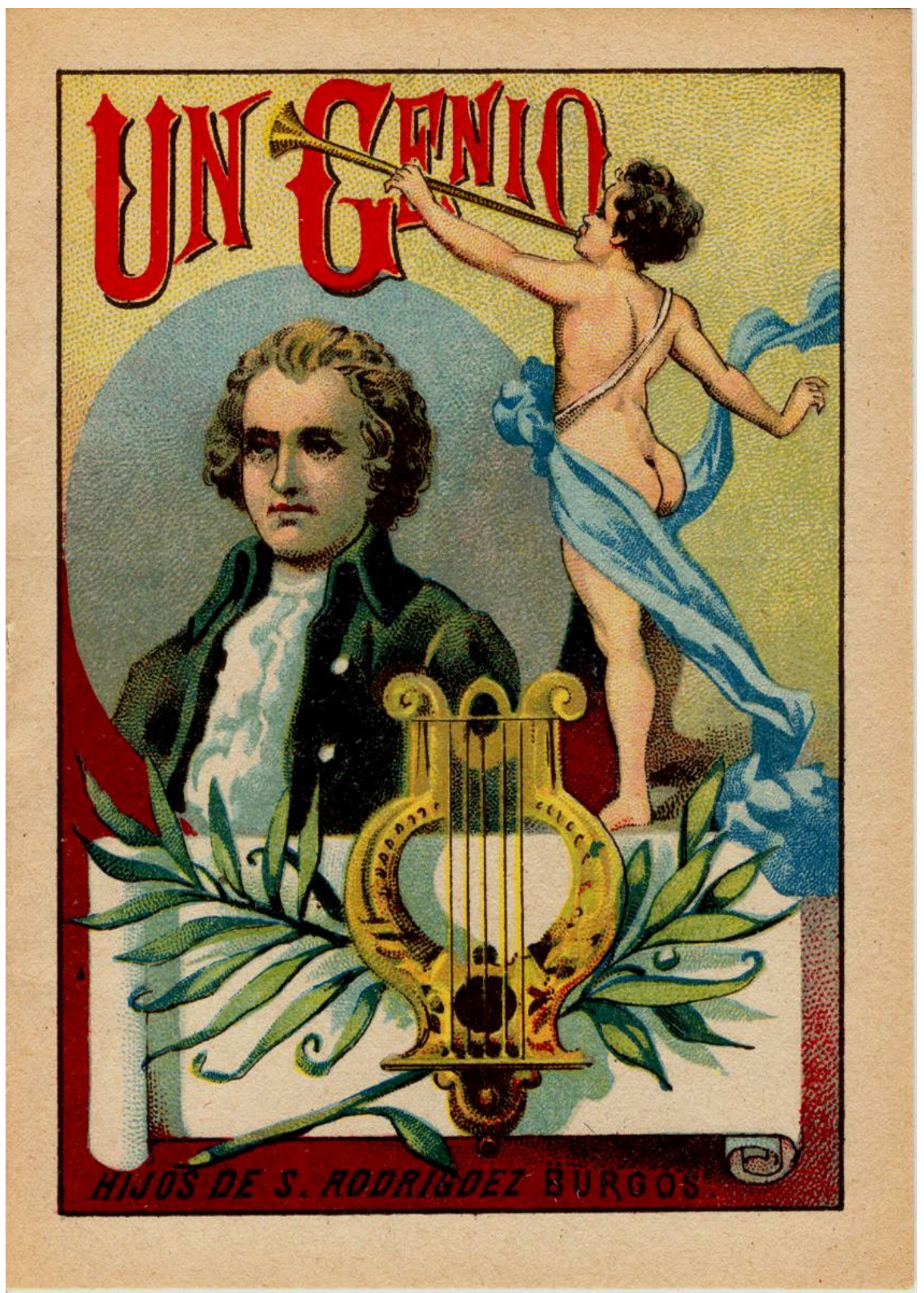

Fig.: 54

Cubierta a color del cuento Un genio de la Biblioteca Cuentos para Niños. Hijos de Santiago Rodríguez. 
LA EDITORIAL BURGALESA HIJOS DE SANTIAGO RODRÍGUEZ (1891-1936): ANÁLISIS DE LOS LIBROS ESCOLARES

3.2.14. Ilustraciones interiores del cuento Un genio de la Biblioteca Cuentos para Niños.
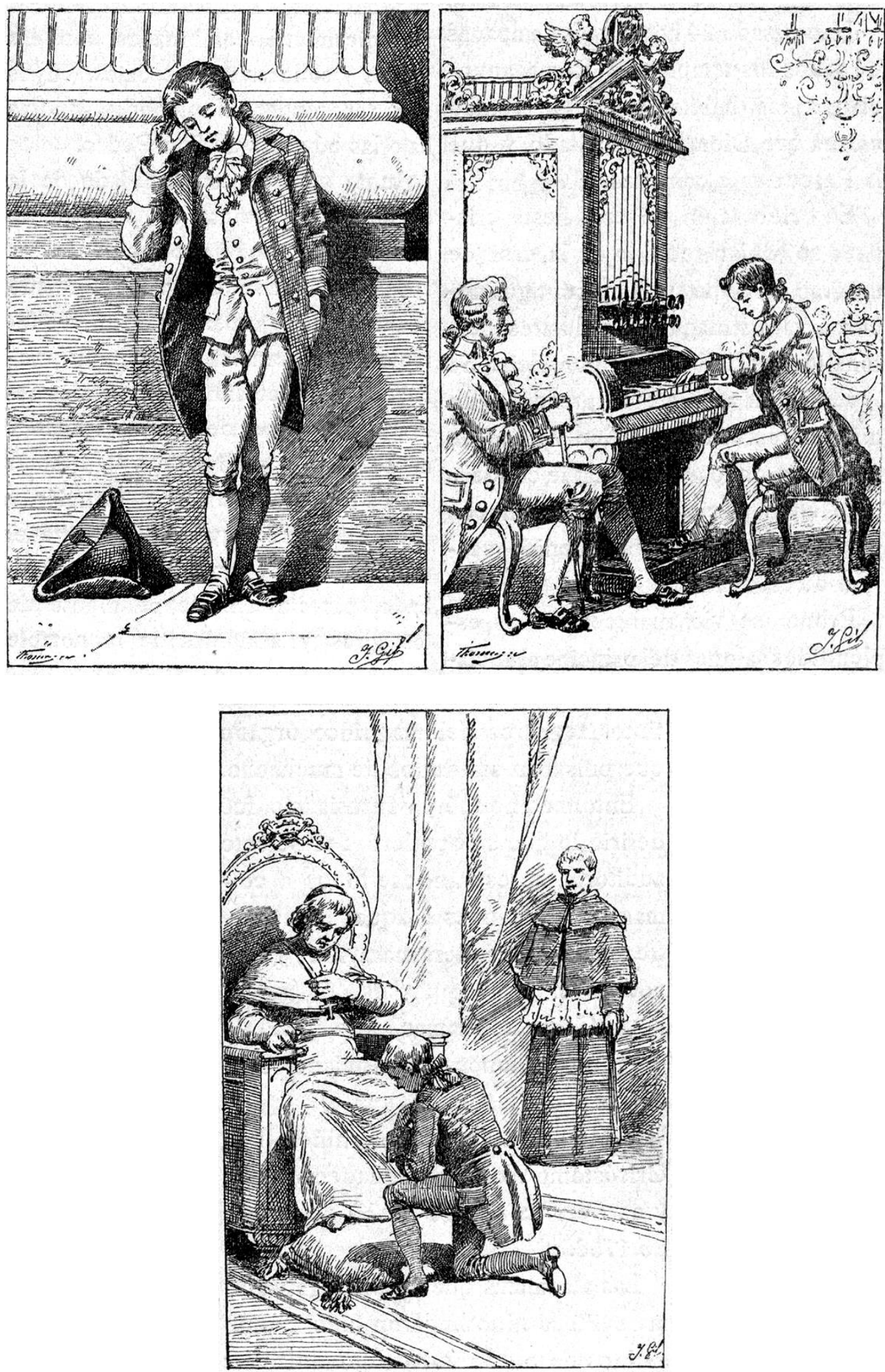

Fig.: 55

Ilustraciones interiores del cuento Un genio de la Biblioteca Cuentos para Niños. Hijos de Santiago Rodríguez. 
3.2.15. Ilustración de la cubierta del libro ¿Quieres ser mi amigo? de la Biblioteca Oro.

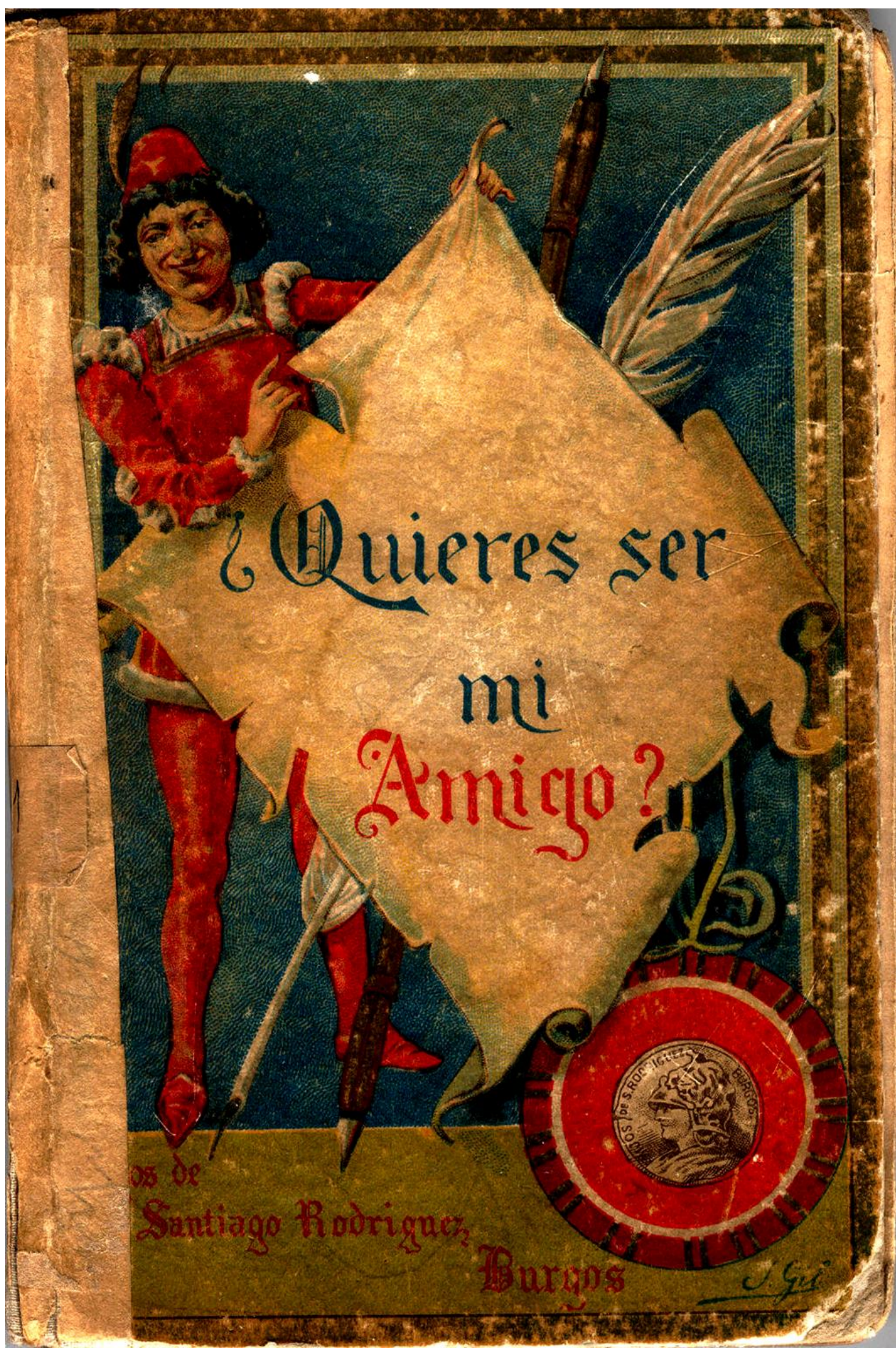

Fig.: 56

Cubierta del libro ¿Quieres ser mi amigo?

Biblioteca Oro. Hijos de Santiago Rodríguez. 
LA EDITORIAL BURGALESA HIJOS DE SANTIAGO RODRÍGUEZ (1891-1936): ANÁLISIS DE LOS LIBROS ESCOLARES

3.2.16. Ilustración interior de El Libro de los viajes de la Biblioteca ProCultura.

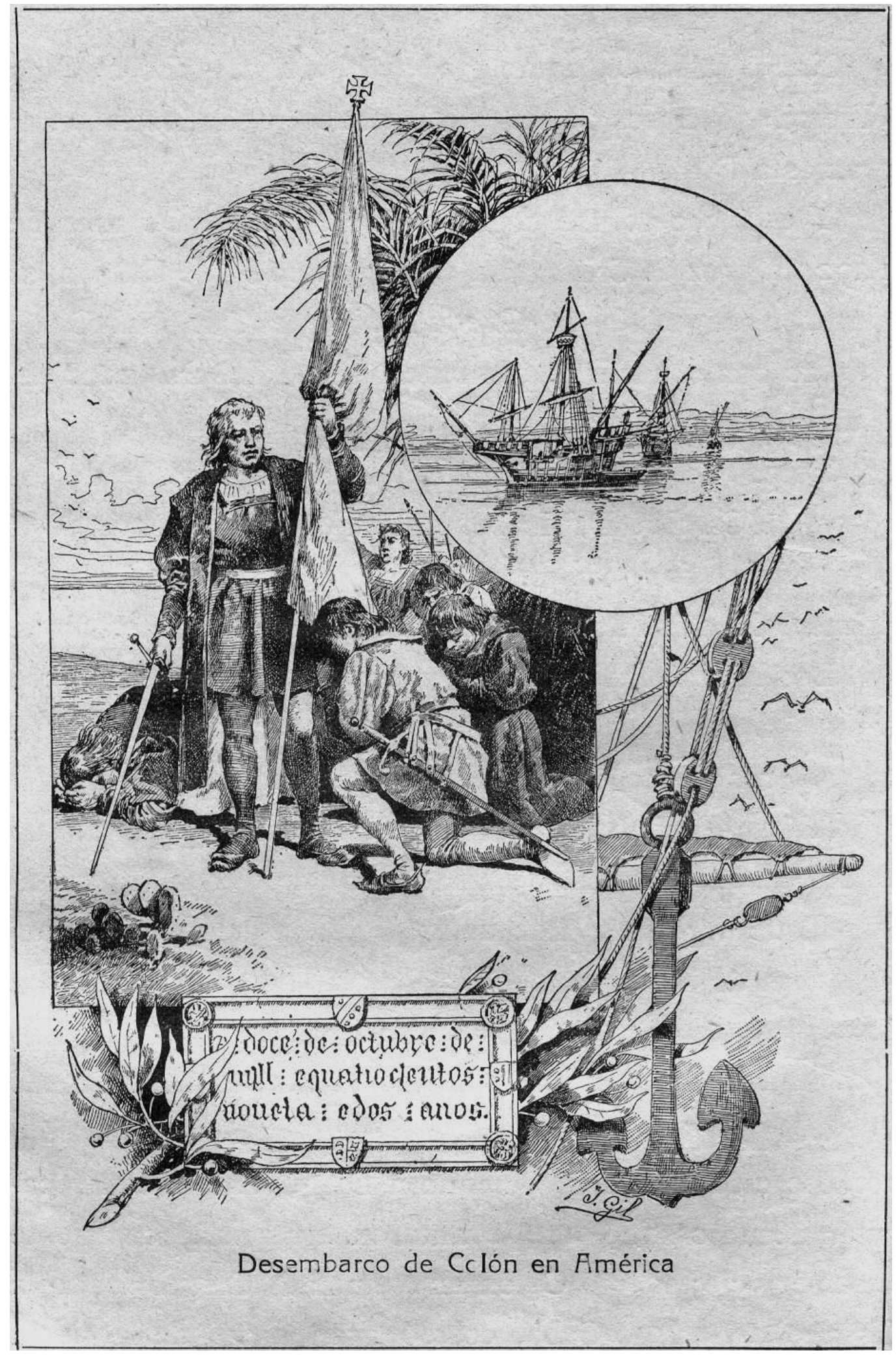

Fig.: 57

Ilustración interior a plana entera de El Libro de Viajes.

Biblioteca Pro-Cultura. Hijos de Santiago Rodríguez. 
3.2.17. Ilustración interior del cuento La cabaña del credo del libro El mejor tesoro de la Biblioteca Oro.

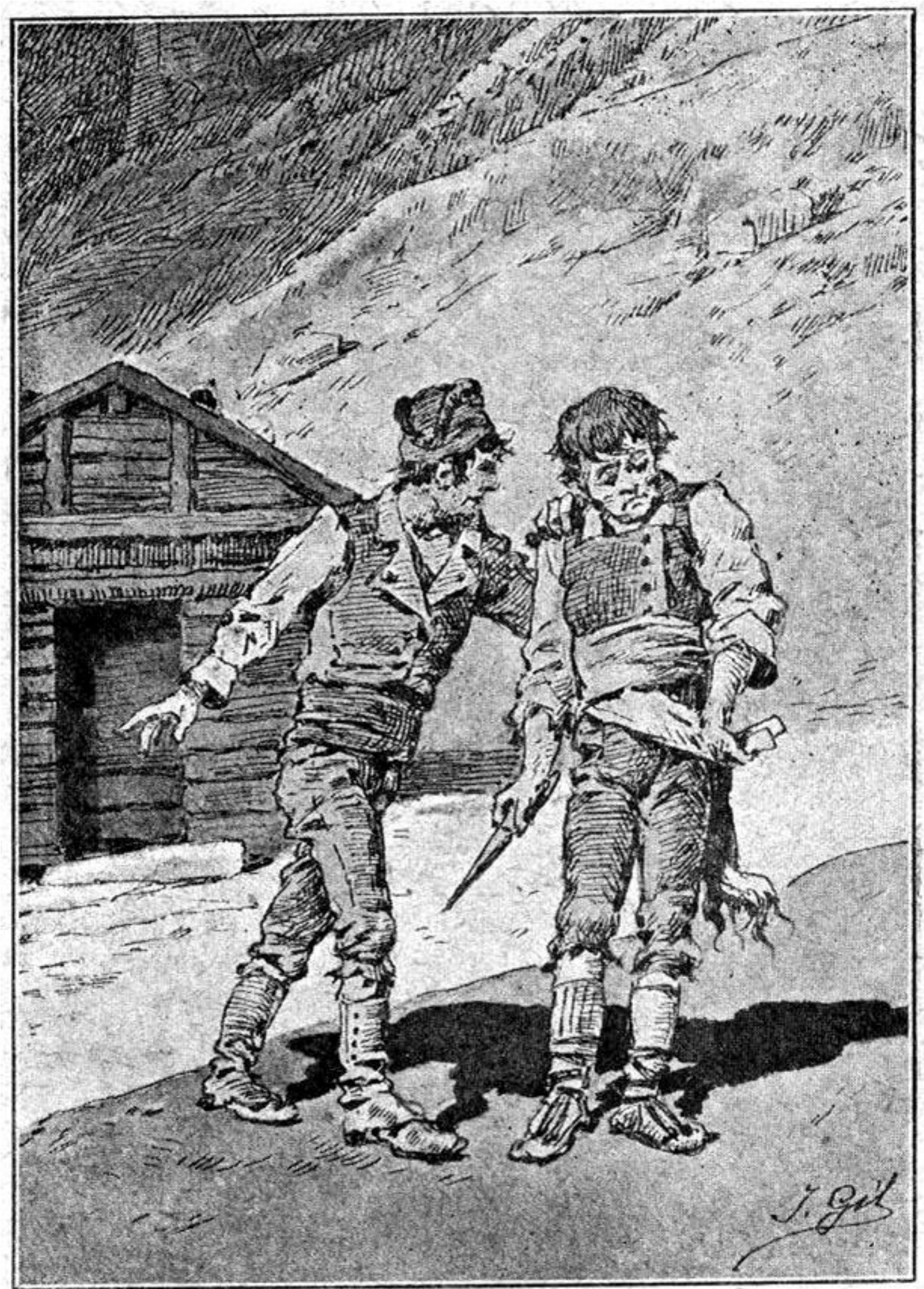

Fig.: 58

Ilustración interior a plana entera del cuento La cabaña del credo del libro El mejor tesoro. Biblioteca Oro. Hijos de Santiago Rodríguez. 
LA EDITORIAL BURGALESA HIJOS DE SANTIAGO RODRÍGUEZ (1891-1936): ANÁLISIS DE LOS LIBROS ESCOLARES

3.2.18. Ilustración interior del cuento Mundo, demonio y carne del libro El mejor tesoro de la Biblioteca Oro.

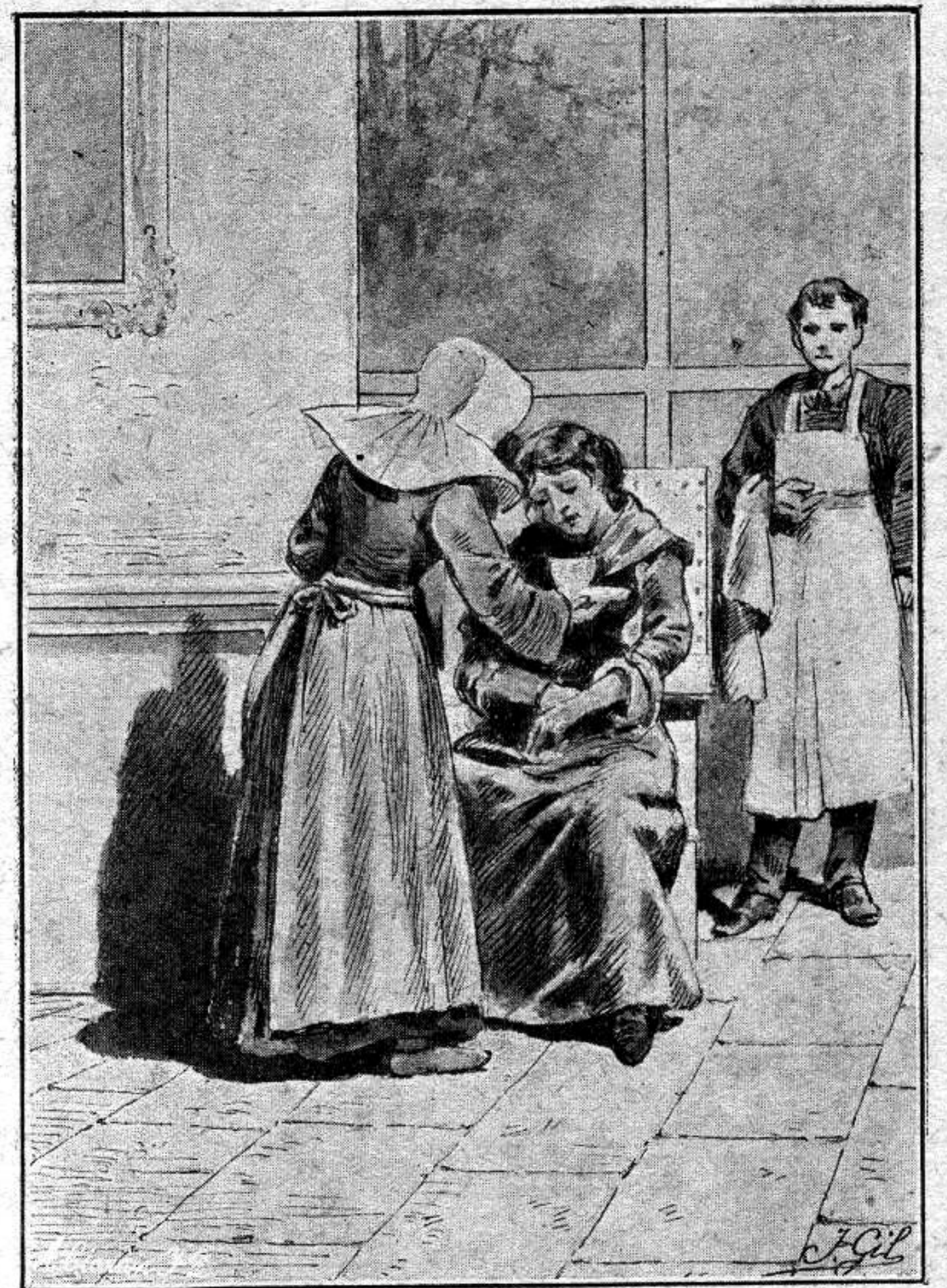

Fig.: 59

Ilustración interior a plana entera del cuento Mundo, demonio y carne del libro El mejor tesoro. Biblioteca Oro. Hijos de Santiago Rodríguez. 
3.2.19. Ilustraciones interiores del cuento El cazador de gorriones del libro El mejor tesoro de la Biblioteca Oro.
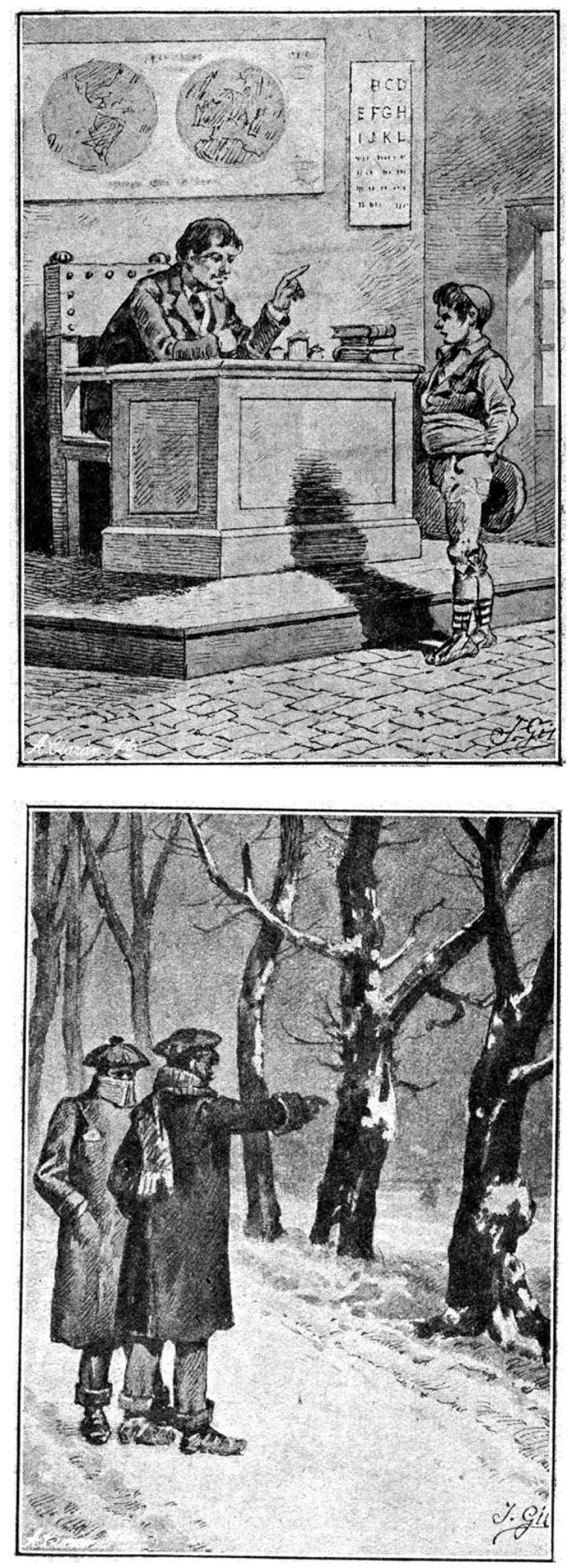

Fig.: 60

Ilustraciones interiores a plana entera del cuento El cazador de gorriones del libro El mejor tesoro. Biblioteca Oro. Hijos de Santiago Rodríguez. 
LA EDITORIAL BURGALESA HIJOS DE SANTIAGO RODRÍGUEZ (1891-1936): ANÁLISIS DE LOS LIBROS ESCOLARES

3.2.20. Ilustraciones interiores del cuento La mensajera del libro El mejor tesoro de la Biblioteca Oro.
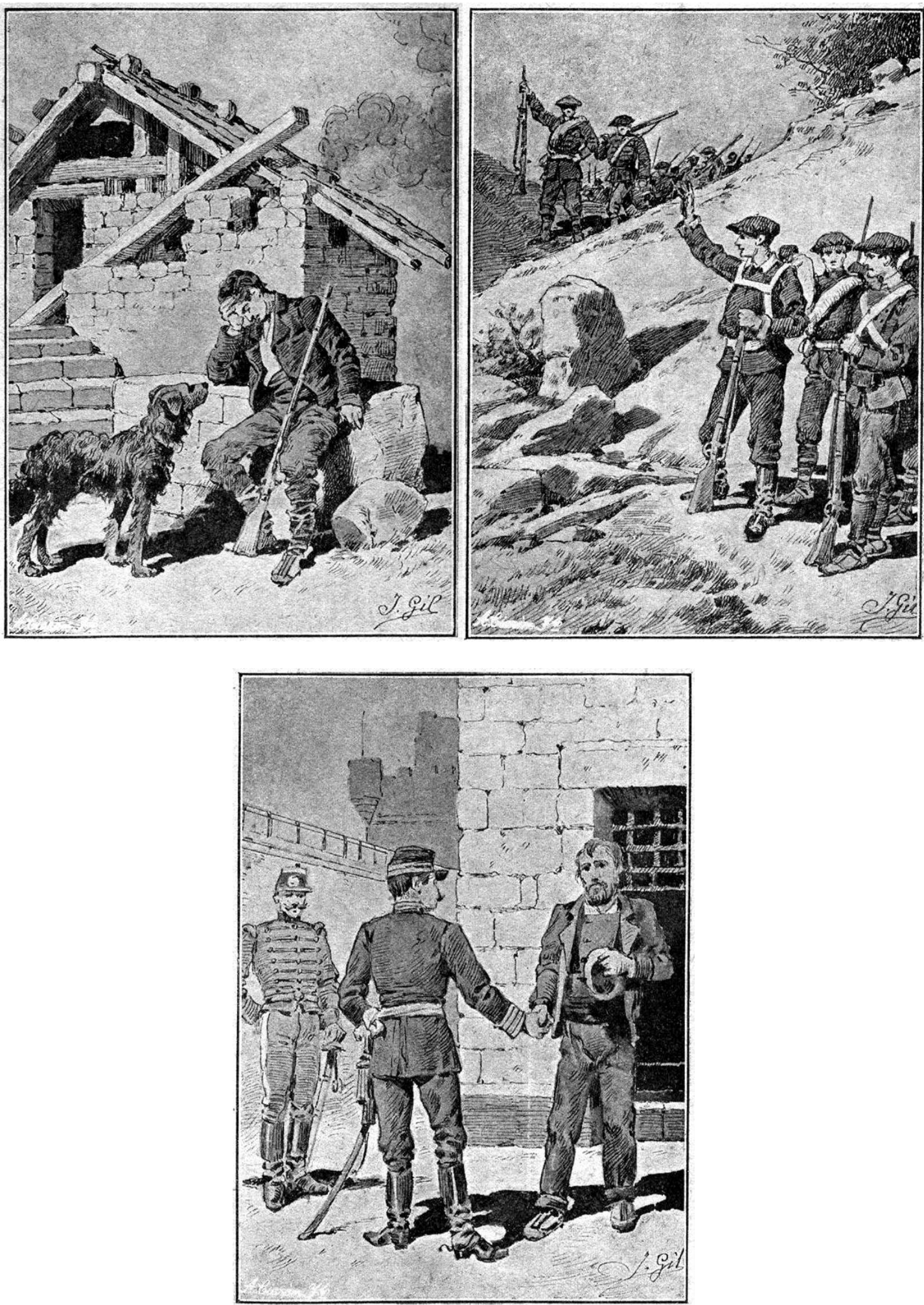

Fig.: 61

Ilustraciones interiores a plana entera del cuento La mensajera del libro El mejor tesoro. Biblioteca Oro. Hijos de Santiago Rodríguez. 
3.2.21. Ilustración interior del libro Historia de España (I).

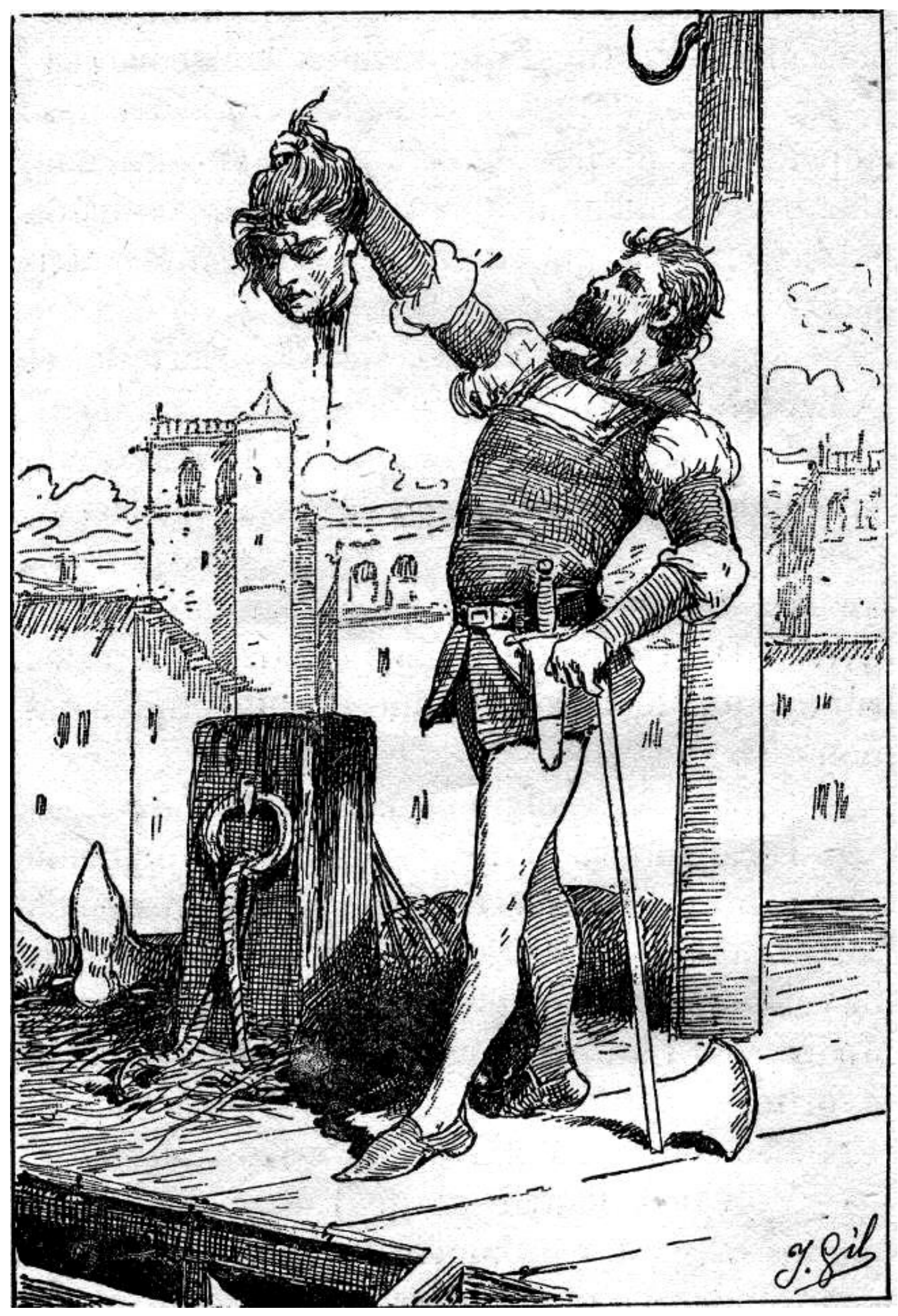

Fig.: 62

Ilustración interior del libro Historia de España sobre la muerte de D. Álvaro de Luna. Hijos de Santiago Rodríguez. 
LA EDITORIAL BURGALESA HIJOS DE SANTIAGO RODRÍGUEZ (1891-1936): ANÁLISIS DE LOS LIBROS ESCOLARES

3.2.22. Ilustración interior del libro Historia de España (II).

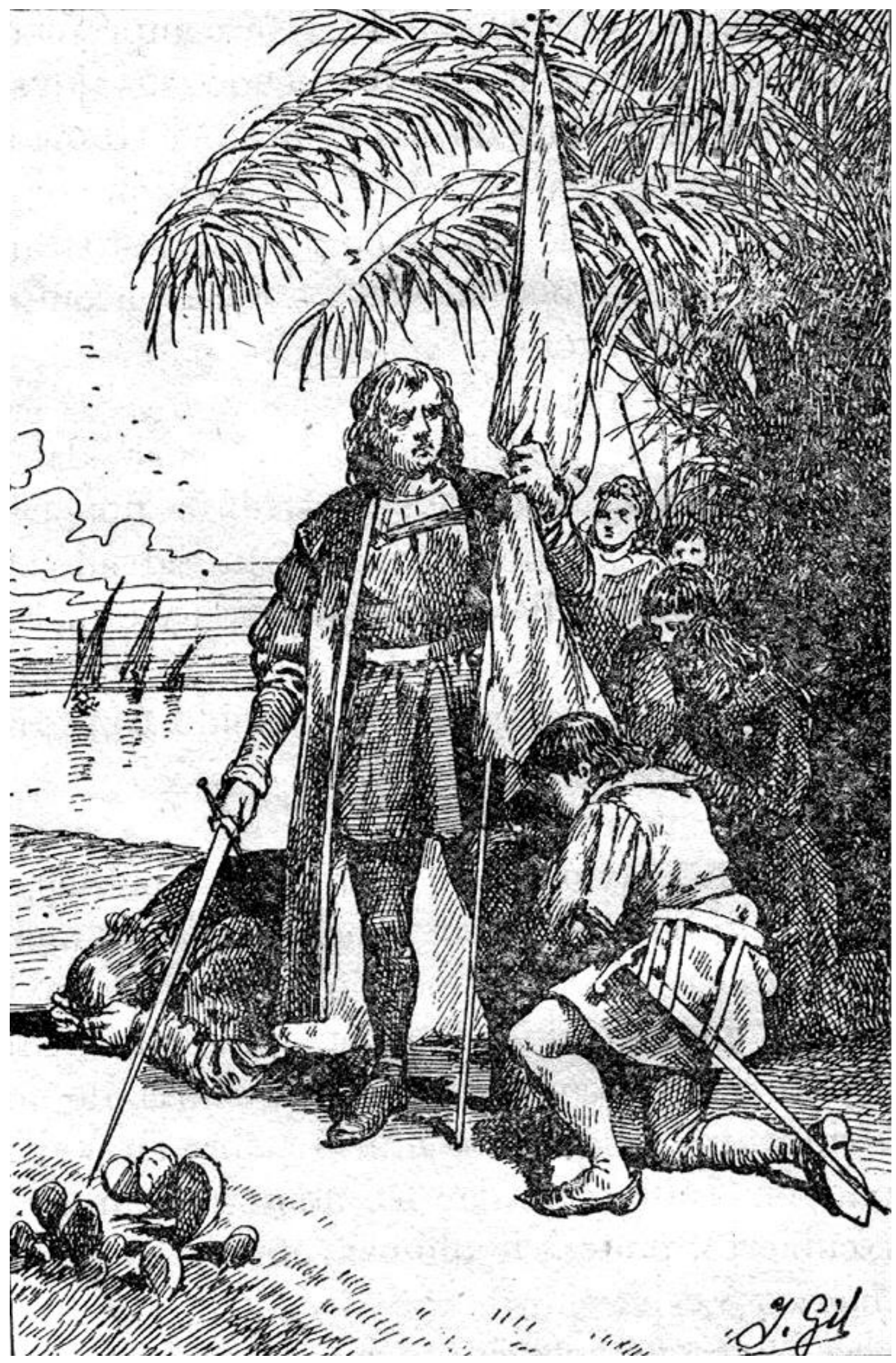

Fig.: 63

Ilustración interior del libro Historia de España donde ilustra el descubrimiento de América. Hijos de Santiago Rodríguez. 
3.2.23. Ilustración interior del libro Historia de España (III).

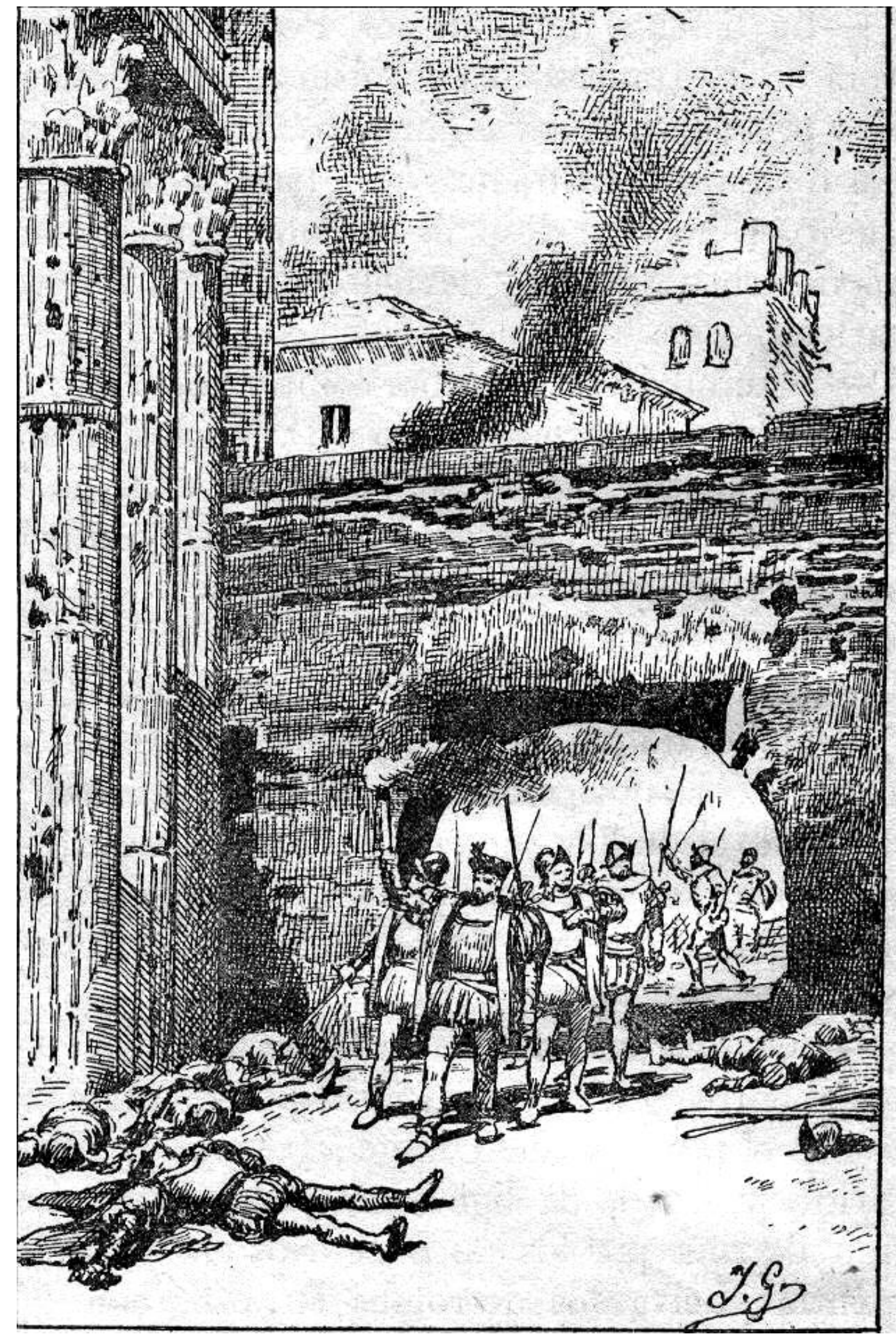

Fig.: 64

Ilustración interior del libro Historia de España sobre el "saco de Roma" ocurrido el 6 de mayo de 1527 por tropas alemanas y españolas de Carlos I. Hijos de Santiago Rodríguez. 
LA EDITORIAL BURGALESA HIJOS DE SANTIAGO RODRÍGUEZ (1891-1936): ANÁLISIS DE LOS LIBROS ESCOLARES

3.2.24. Ilustración interior del libro Historia de España (IV).

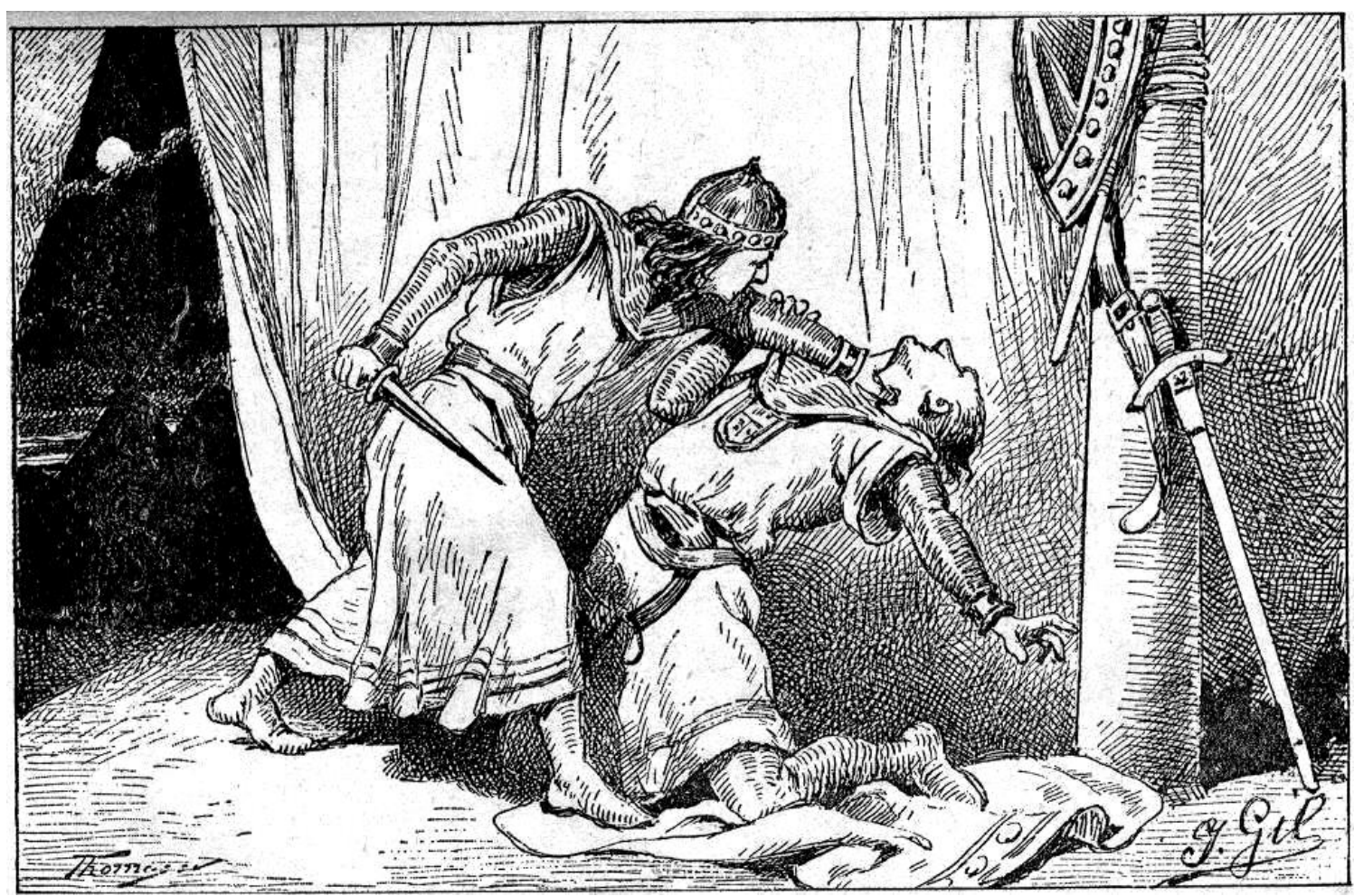

Fig.: 65

Ilustración interior del libro Historia de España sobre la muerte de Pedro I el Cruel. Hijos de Santiago Rodríguez. 
3.2.25. Cubierta del libro Viejas memorias: leyendas y tradiciones universales de la Biblioteca Enciclopédica Hispano-Americana.

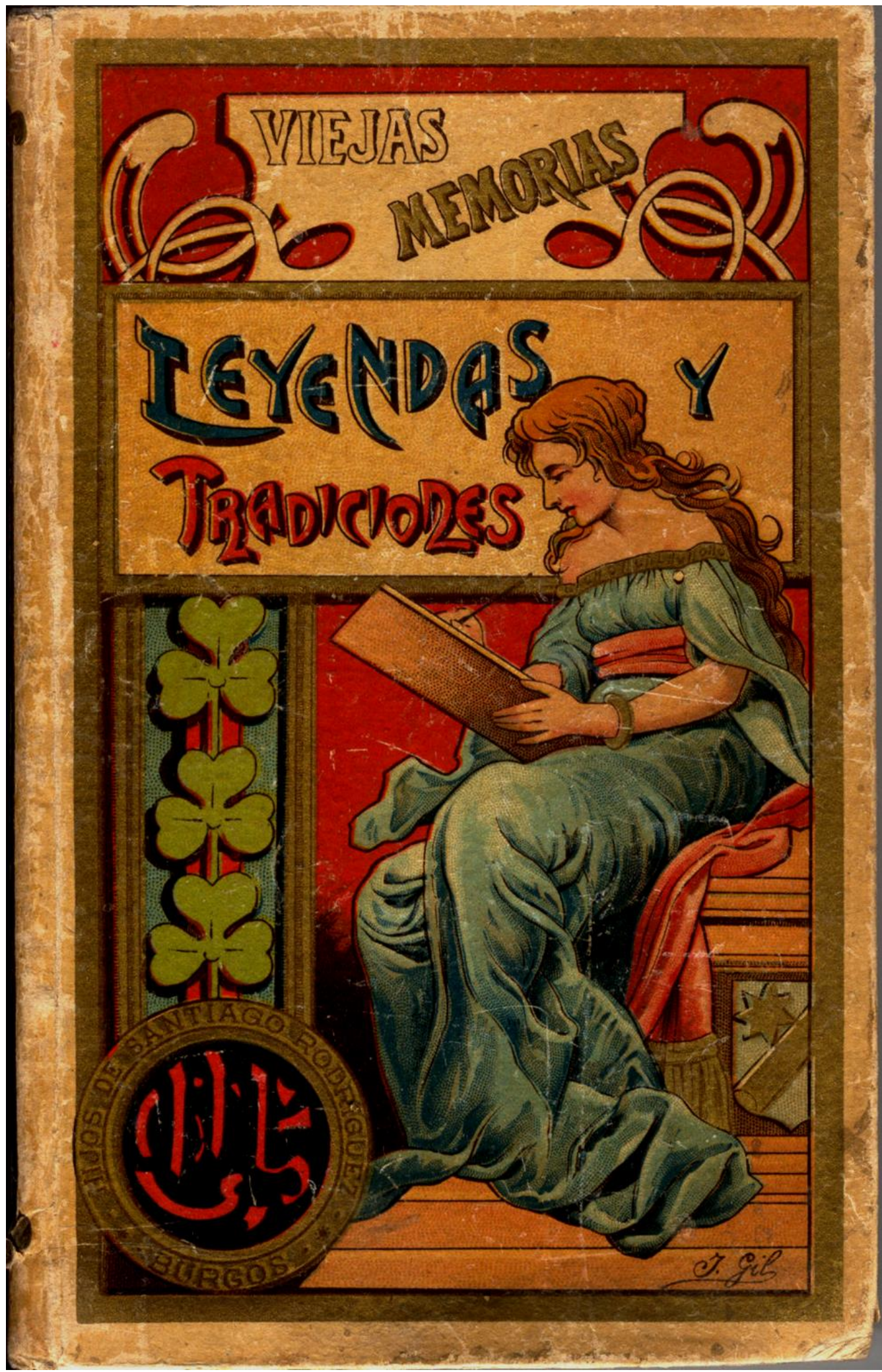

Fig.: 66

Cubierta de Isidro Gil del libro Viejas memorias: leyendas y tradiciones universales de la Biblioteca Enciclopédica Hispano-Americana. Hijos de Santiago Rodríguez. 
LA EDITORIAL BURGALESA HIJOS DE SANTIAGO RODRÍGUEZ (1891-1936): ANÁLISIS DE LOS LIBROS ESCOLARES

3.2.26. Ilustraciones de las carátulas de distintas leyendas en la obra Viejas memorias: leyendas y tradiciones universales de la Biblioteca Enciclopédica Hispano-Americana.
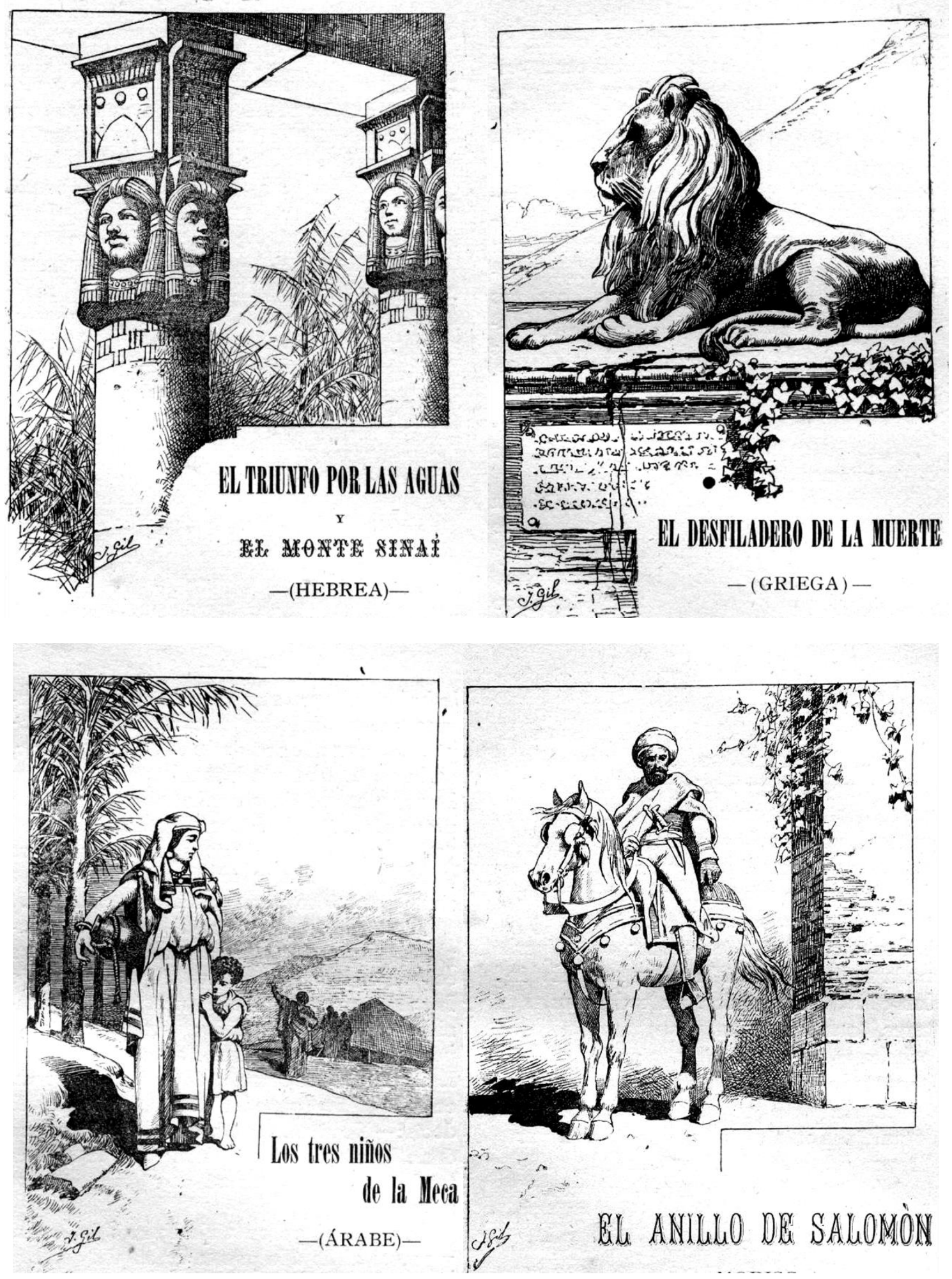

Fig.: 67

Isidro Gil ilustra cada una de las leyendas en el libro Viejas memoria: leyendas y tradiciones universales de la Biblioteca Enciclopédica Hispano-Americana. Hijos de Santiago Rodríguez. 
3.2.27. Ilustraciones interiores sobre distintas leyendas en la obra Viejas memorias: leyendas y tradiciones universales de la Biblioteca Enciclopédica Hispano-Americana.
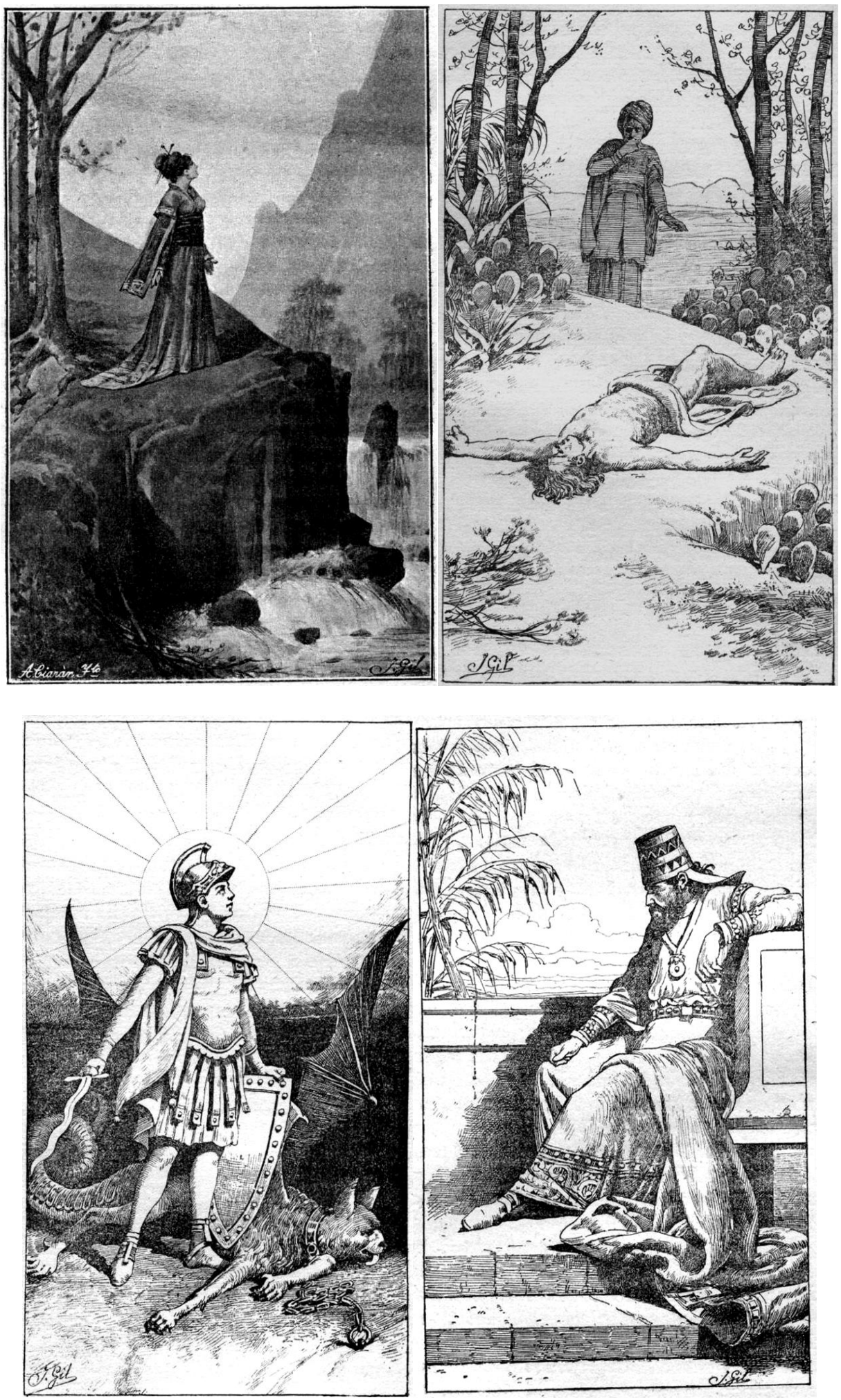
LA EDITORIAL BURGALESA HIJOS DE SANTIAGO RODRÍGUEZ (1891-1936): ANÁLISIS DE LOS LIBROS ESCOLARES
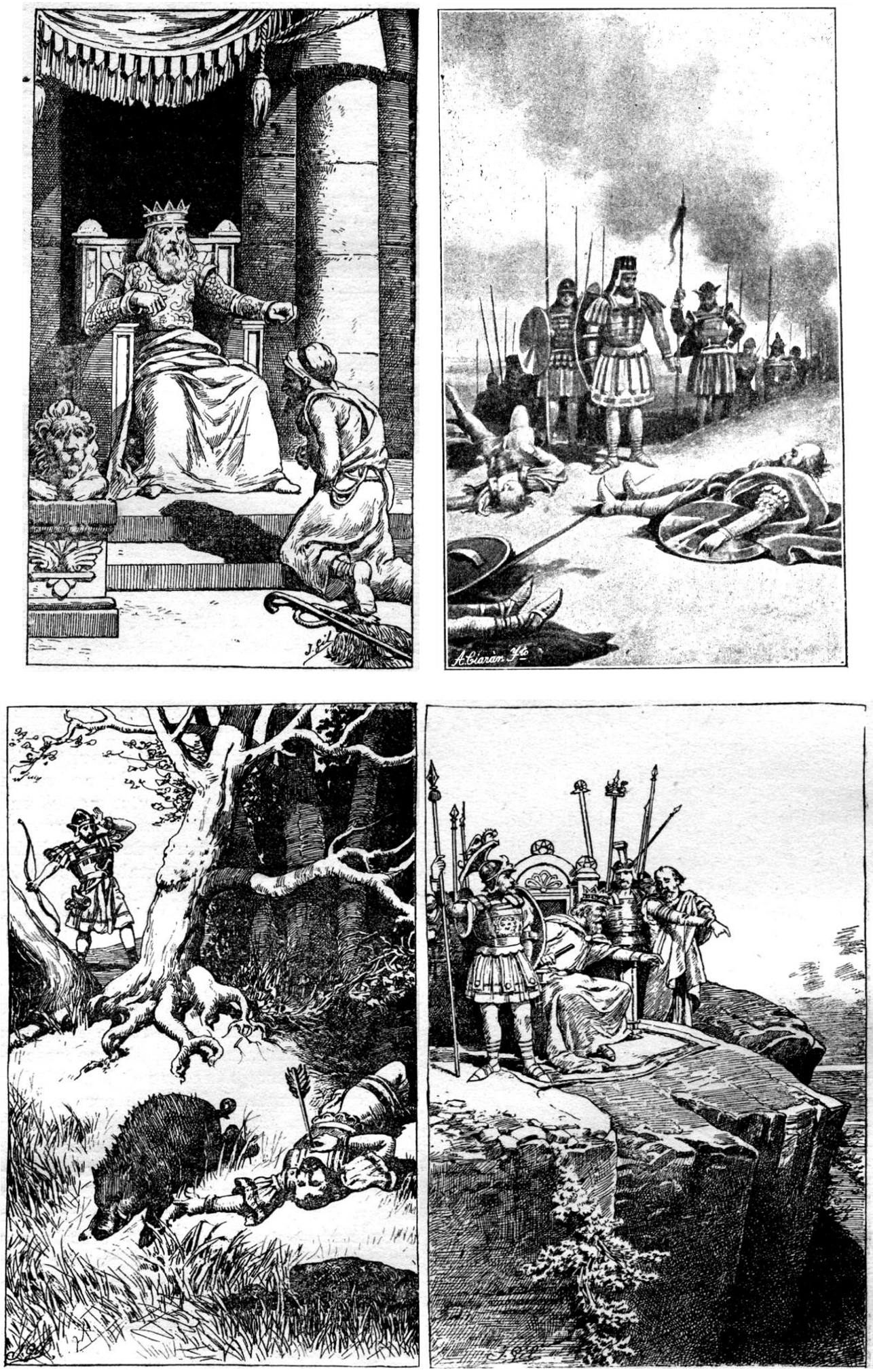

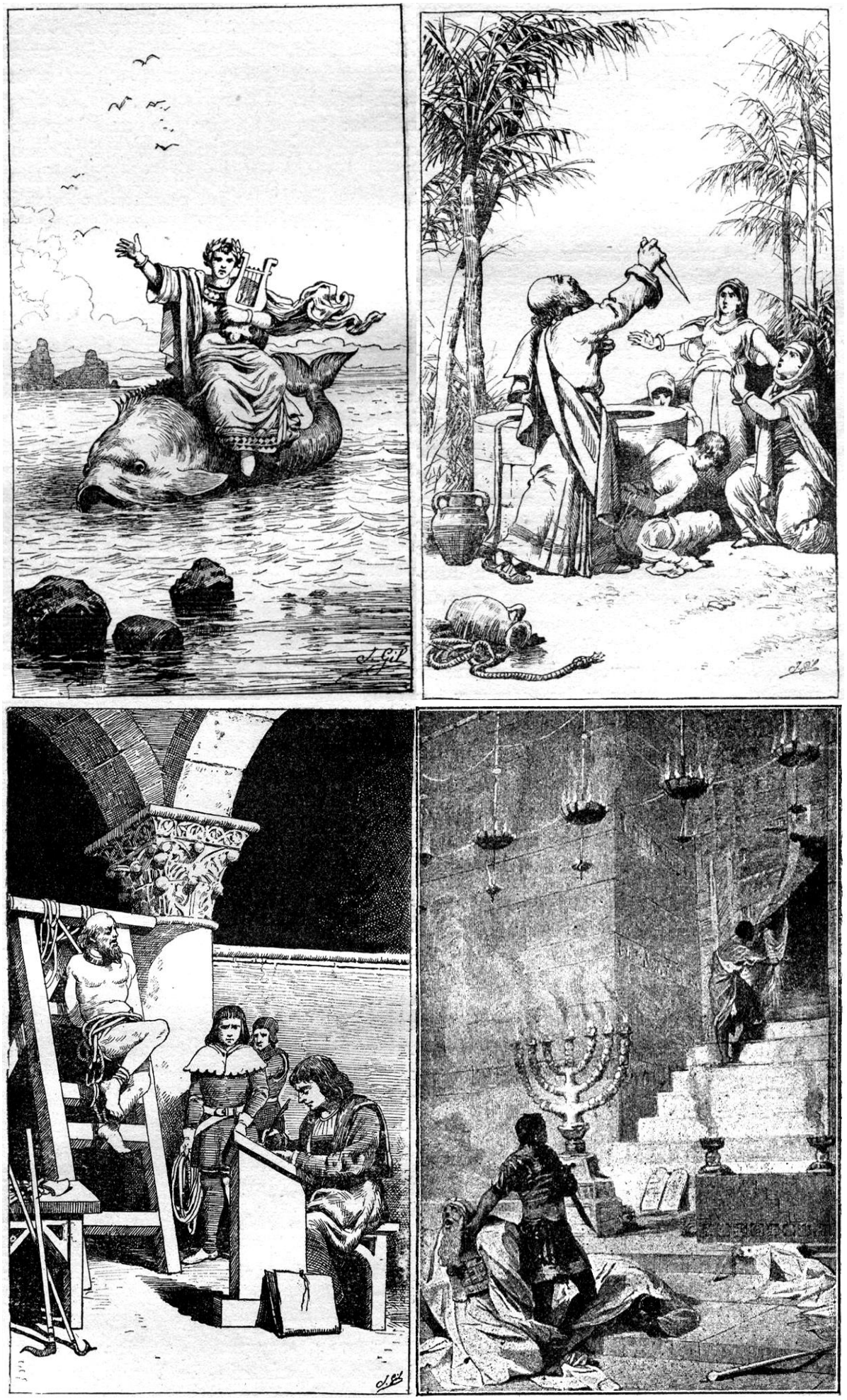

Fig.: 68

Ilustraciones interiores en blanco y negro de Isidro Gil en las distintas leyendas en la obra Viejas memorias: leyendas y tradiciones universales de la Biblioteca Enciclopédica Hispano-Americana. Hijos de Santiago Rodríguez. 
LA EDITORIAL BURGALESA HIJOS DE SANTIAGO RODRÍGUEZ (1891-1936): ANÁLISIS DE LOS LIBROS ESCOLARES

3.2.28. Cubierta a color del libro Cristina y su corderito de la Biblioteca Oro.

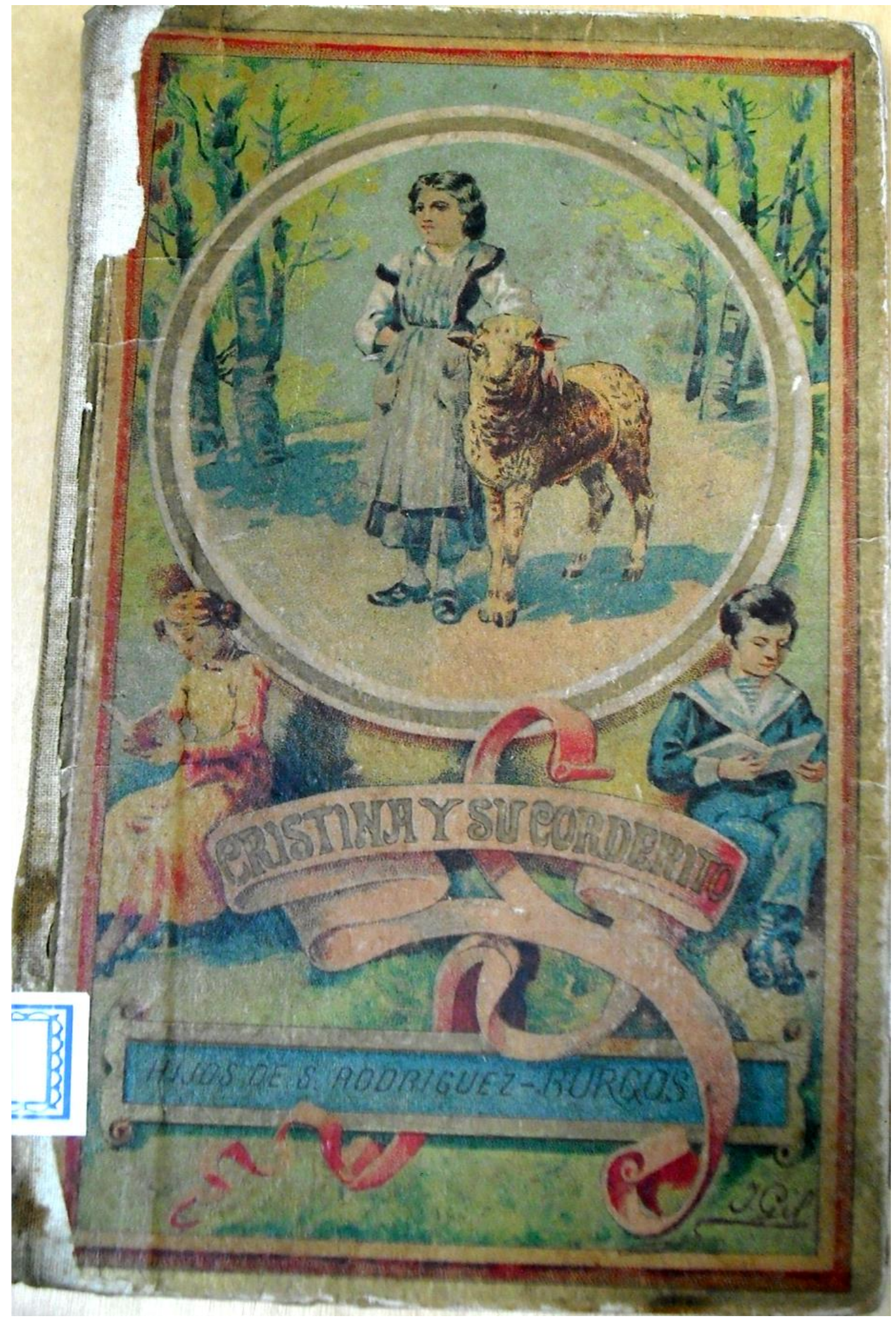

Fig.: 69

Cubierta a color de Cristina y su corderito de la Biblioteca Oro. Hijos de Santiago Rodríguez. Ejemplar del CEINCE. 
3.2.29. Cubierta de la obra Viaje Infantil escrita por Mariano Rodríguez Miguel.

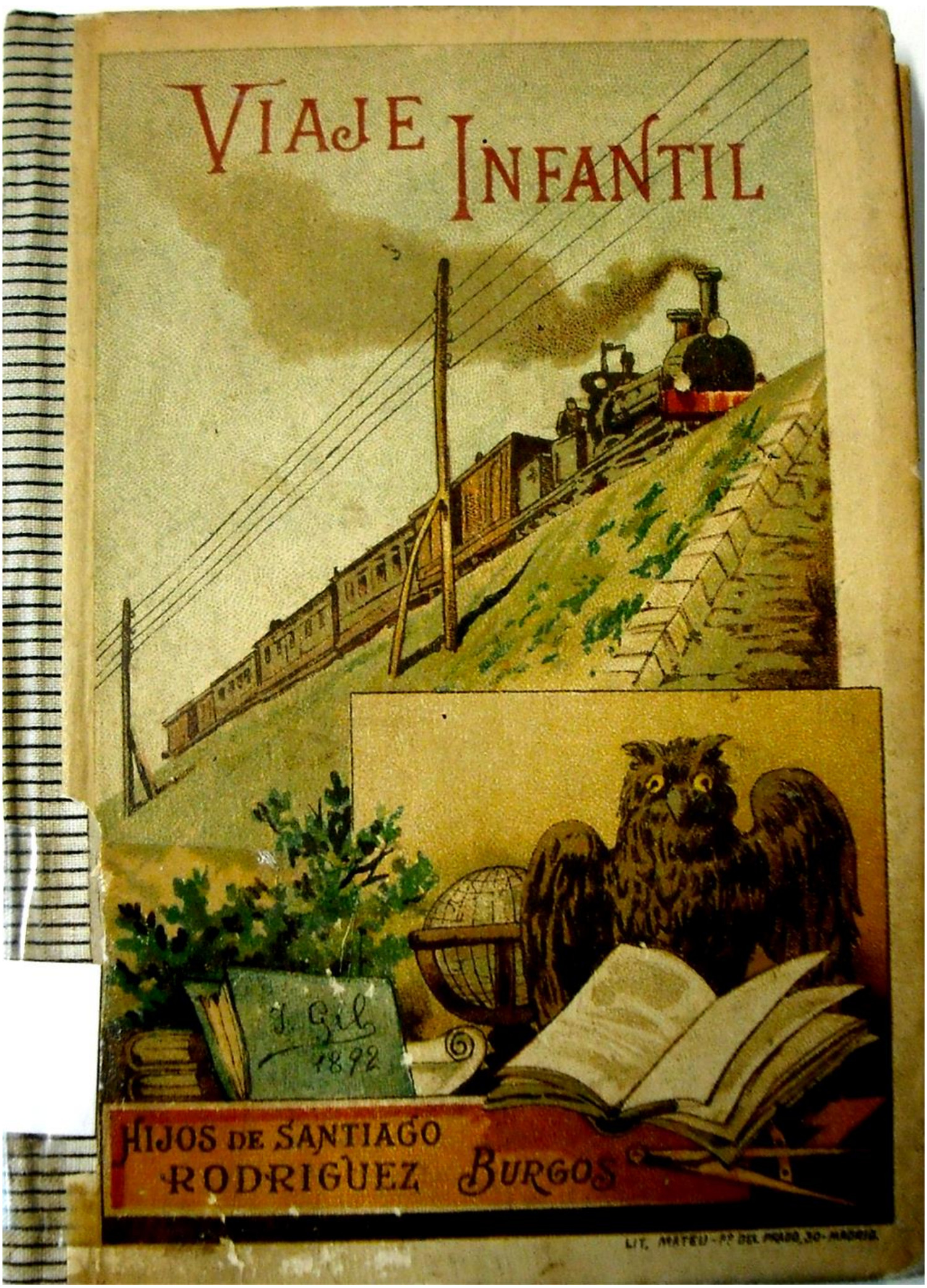

Fig.: 71

Cubierta de Isidro Gil en 1892 para la obra de Mariano Rodríguez Miguel Viaje Infantil. Hijos de Santiago Rodríguez. Ejemplar de la Biblioteca Pública de Burgos. 
LA EDITORIAL BURGALESA HIJOS DE SANTIAGO RODRÍGUEZ (1891-1936): ANÁLISIS DE LOS LIBROS ESCOLARES

3.2.30. Ilustración interior a plana entera como introducción en la explicación de las diversas carreras del libro El previsor de Antonio Álvarez Carretero.

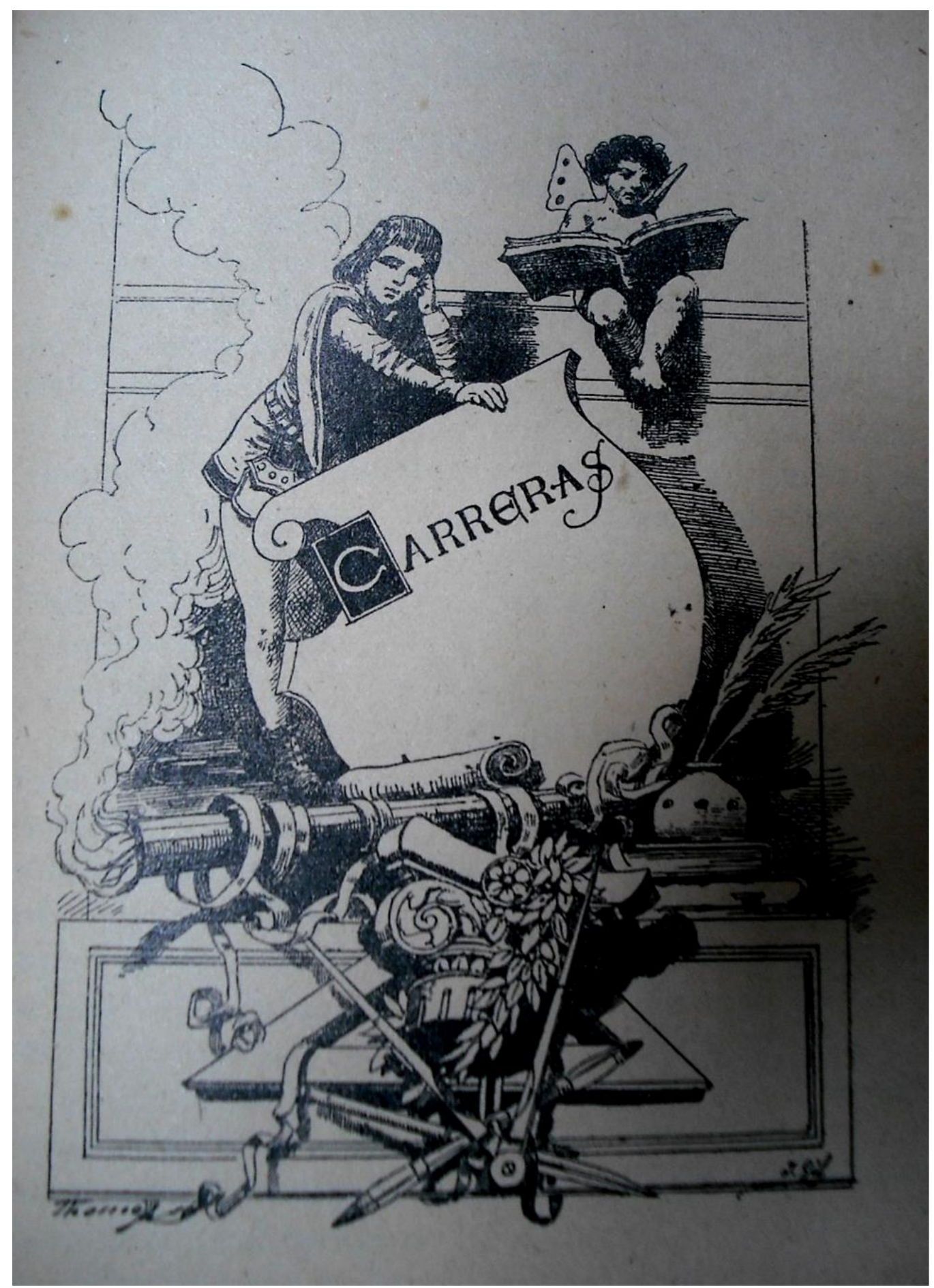

Fig.: 70

Ilustración de Isidro Gil como introducción a la explicación de las diversas carreras del libro El previsor de Antonio Álvarez Carretero.

Hijos de Santiago Rodríguez.

Ejemplar de la Biblioteca de la Diputación Provincial de Burgos. 
3.2.31. Ilustración interior del libro Catón Metódico de los Niños para el aprendizaje de la lectura.

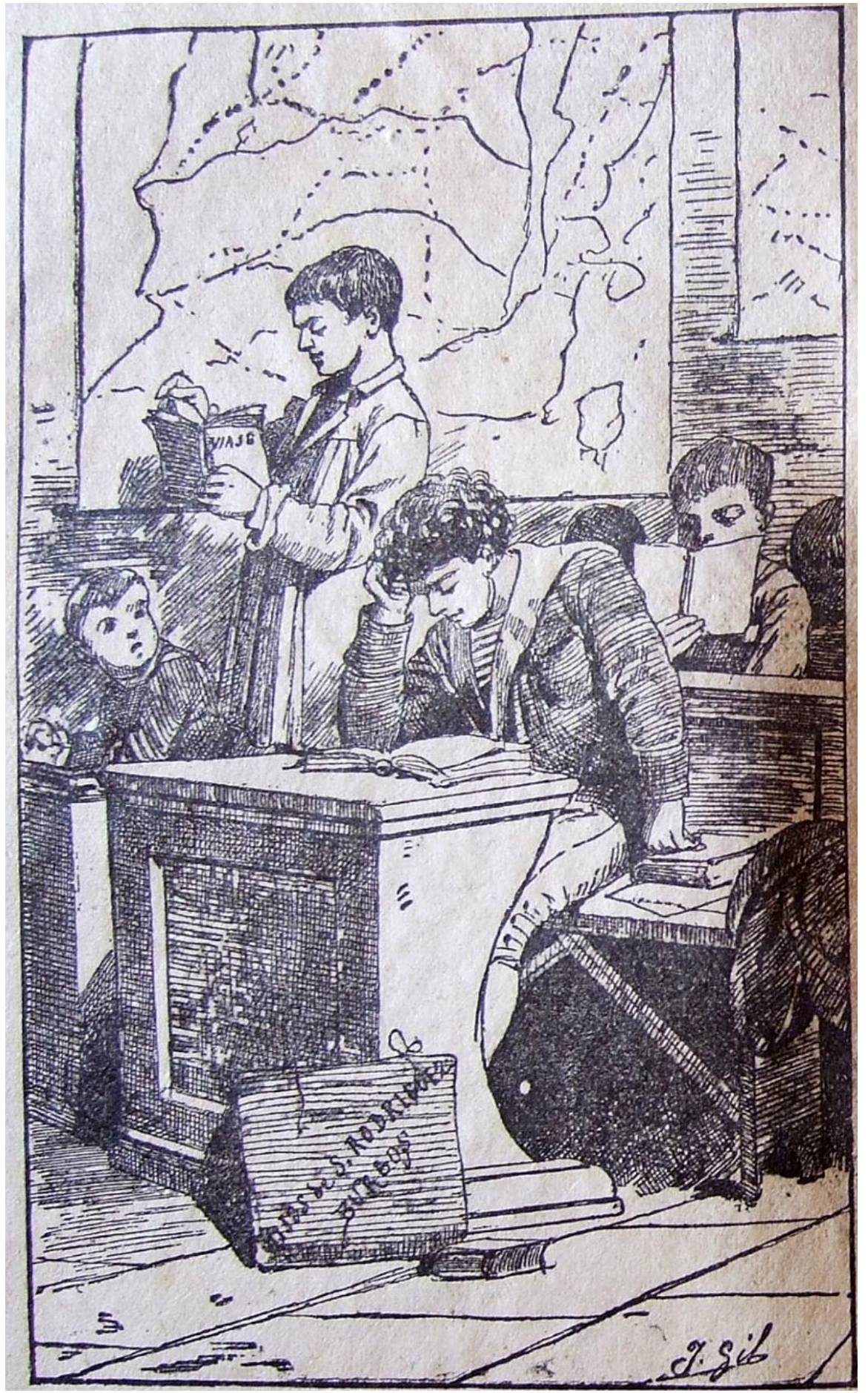

Fig.: 72

Ilustración de la parte posterior a la portada del libro Catón Metódico de los Niños escrito por José González Seijas. Es curioso ver cómo presenta en primer plano el nombre de la editorial y la lectura de uno de los libros que empieza por Viaje se pueda referir al libro de Viaje Infantil escrito por el gerente de la empresa.

Hijos de Santiago Rodríguez. 
LA EDITORIAL BURGALESA HIJOS DE SANTIAGO RODRÍGUEZ (1891-1936):

ANÁLISIS DE LOS LIBROS ESCOLARES

3.3. FORTUNATO JULIÁN (BURGOS 1891-1972)

3.3.1. Ilustración de la cubierta del cuento Presumir de hombre de la Biblioteca Cuentos para Niños.

3.3.2. Ilustración de la cubierta del cuento Presumir de hombre de la Biblioteca Cuentos para Niños.

3.3.3. Ilustración interior a color de Mi Libro Bazar de la Biblioteca Paz.

3.3.4. Ilustraciones interiores en blanco y negro de Mi Libro Bazar de la Biblioteca Paz.

3.3.5. Ilustración interior a color en Mi Libro de Navidad de la Biblioteca Paz.

3.3.6. Ilustración interior del cuento El príncipe que conquistó un mundo y el que se contentó con menos del libro Lee estos cuentos de la Biblioteca Cuentos de Ayer y de Hoy.

3.3.7. Ilustración interior del cuento El sueño de Juan del libro Lee estos cuentos de la Biblioteca Cuentos de Ayer y de Hoy.

3.3.8. Ilustración interior en forma de viñeta Para ser fuerte, ejercita tus músculos de Mi Libro de Navidad de la Biblioteca Paz.

3.3.9. Ilustración interior en forma de viñeta titulada Cómo se fabrican los coches Ford en Mi Libro de Estampas y Cuentos de la Biblioteca Paz.

3.3.10. Ilustración de la portada del cuento La sombra del maestro de Mi Libro de Año Nuevo de la Biblioteca Paz.

3.3.11. Ilustración inicial del cuento ¡Año Nuevo! del Mi Libro de Año Nuevo de la Biblioteca Paz.

3.3.12. Ilustraciones interiores del cuento Los pájaros azules de Mi Libro de Navidad de la Biblioteca Paz.

3.3.13. Cubierta ilustrada del El libro de la naturaleza de la Biblioteca ProCultura. 
3.3.14. Ilustraciones en blanco y negro sobre Las hazañas del valeroso Cid Rodrigo Díaz de Vivar el Campeador en Mi libro bazar de la Biblioteca Paz.

3.3.15. Ilustración infantil en blanco y negro en el índice de Mi libro de Navidad de la Biblioteca Paz.

3.3.16. Ilustración del cuento La moza de los gansos escrito por los hermanos Grimm en Mi Libro de estampas y cuentos. Biblioteca Paz.

3.3.17. Ilustraciones del cuento de Grimm Flor de Agavanzo en Mi libro de estampas y cuentos de la Biblioteca Paz.

3.3.18. Ilustración del cuento de Grimm El hermanito y la hermanita en $M i$ libro de Estampas y cuentos de la Biblioteca Paz.

3.3.19. Cubierta ilustrada de Las maravillosas aventuras de un cascanueces: el juguete animado de la Biblioteca Oro.

3.3.20. Ilustraciones interiores del libro Maravillosas aventuras de un cascanueces: el juguete animado de la Biblioteca Oro.

3.3.21. Cubierta ilustrada a todo color de la Biblioteca Paz, Mi Libro Ideal.

3.3.22. Ilustraciones interiores a pluma sobre la Exposición IberoAmericana en Sevilla de 1929 presentadas en el Mi Libro Ideal de la Biblioteca Paz.

3.3.23. Ilustración sobre el CXXV aniversario de Andersen. 
LA EDITORIAL BURGALESA HIJOS DE SANTIAGO RODRÍGUEZ (1891-1936): ANÁLISIS DE LOS LIBROS ESCOLARES

3.3.1. Ilustración de la cubierta del cuento Presumir de hombre de la Biblioteca Cuentos para Niños.

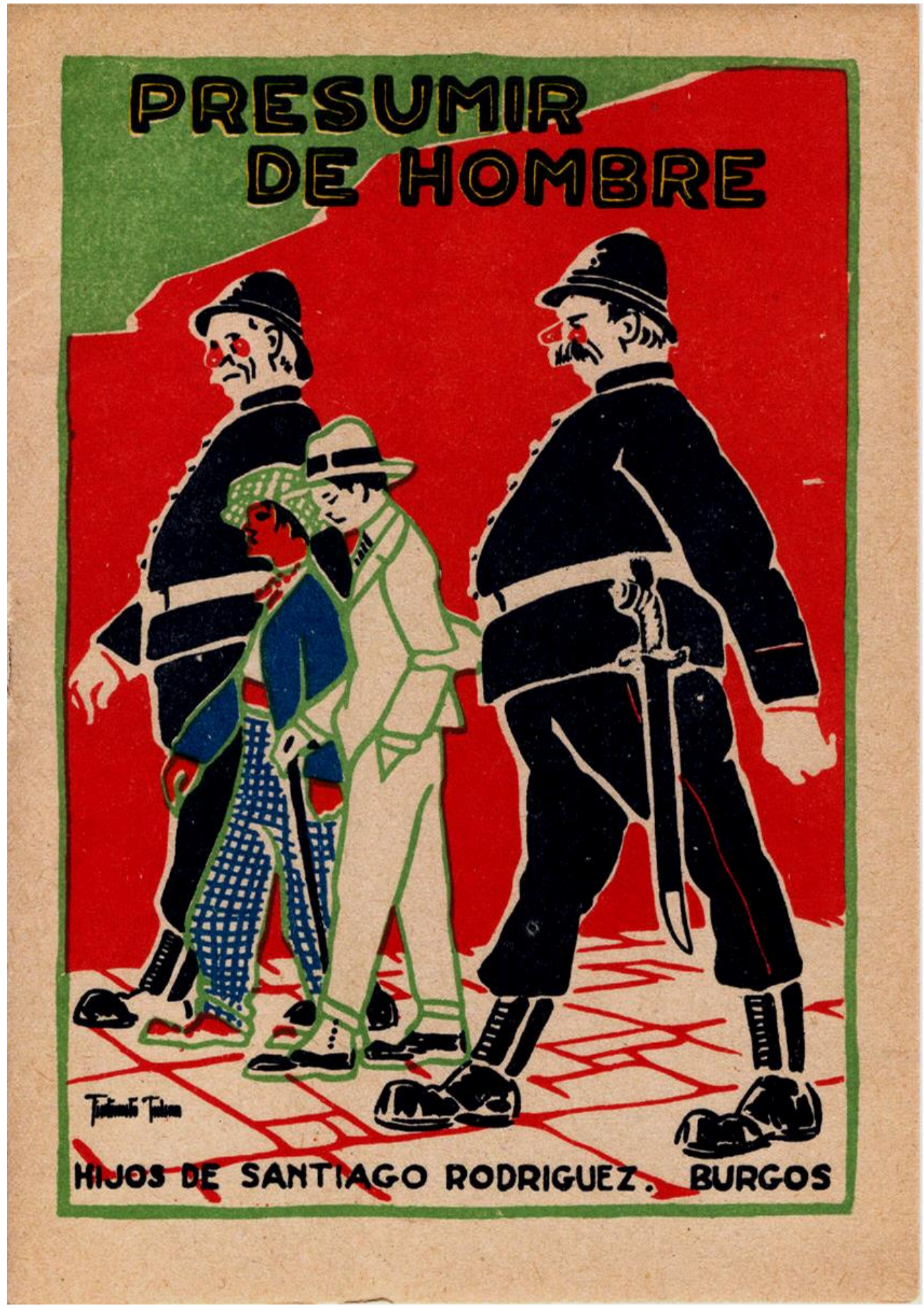

Fig.: 75

Cubierta a color del cuento Presumir de hombre de la Biblioteca Cuentos para Niños. Hijos de Santiago Rodríguez. 
3.3.2. Ilustración de la cubierta del cuento La noche de Reyes de la Biblioteca Cuentos para Niños.

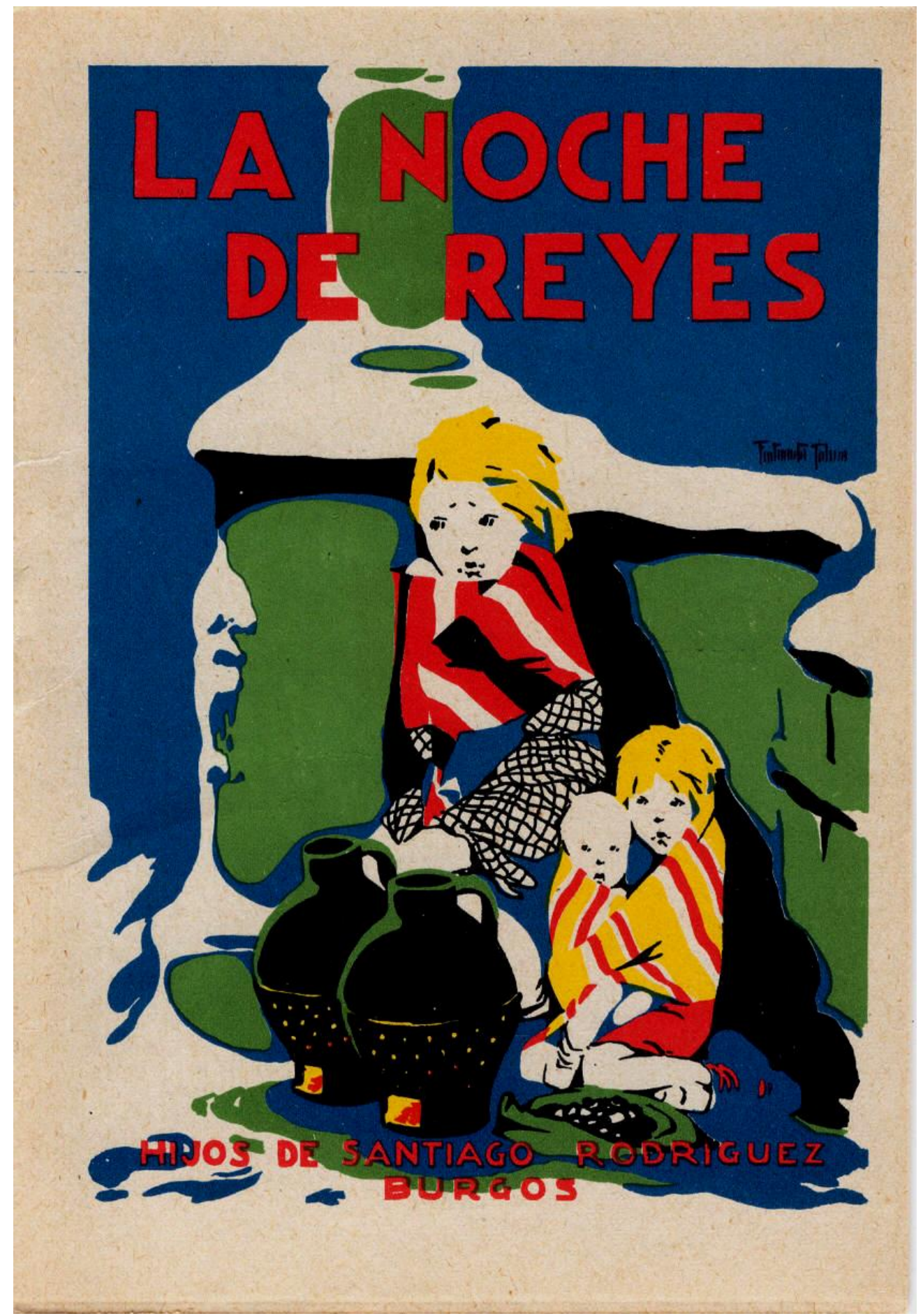

Fig.: 76

Cubierta a color del cuento La noche de Reyes de la Biblioteca Cuentos para Niños. Hijos de Santiago Rodríguez. 
LA EDITORIAL BURGALESA HIJOS DE SANTIAGO RODRÍGUEZ (1891-1936): ANÁLISIS DE LOS LIBROS ESCOLARES

3.3.3. Ilustración interior a color de Mi Libro Bazar de la Biblioteca Paz.

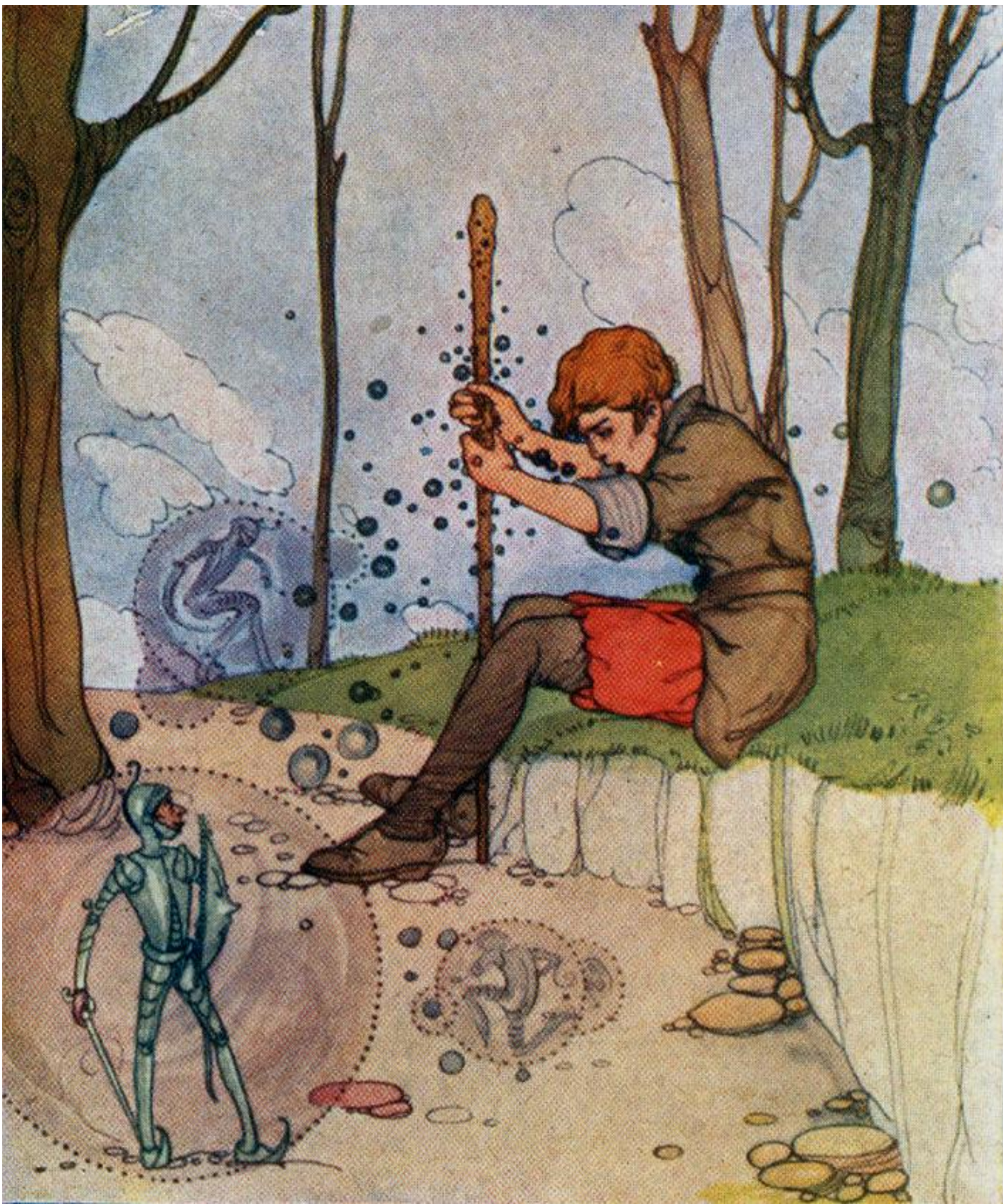

Fig.: 77

Ilustración interior a color de Mi Libro Bazar.

Biblioteca Paz. Hijos de Santiago Rodríguez. 
3.3.4. Ilustraciones interiores en blanco y negro de Mi Libro Bazar de la Biblioteca Paz.
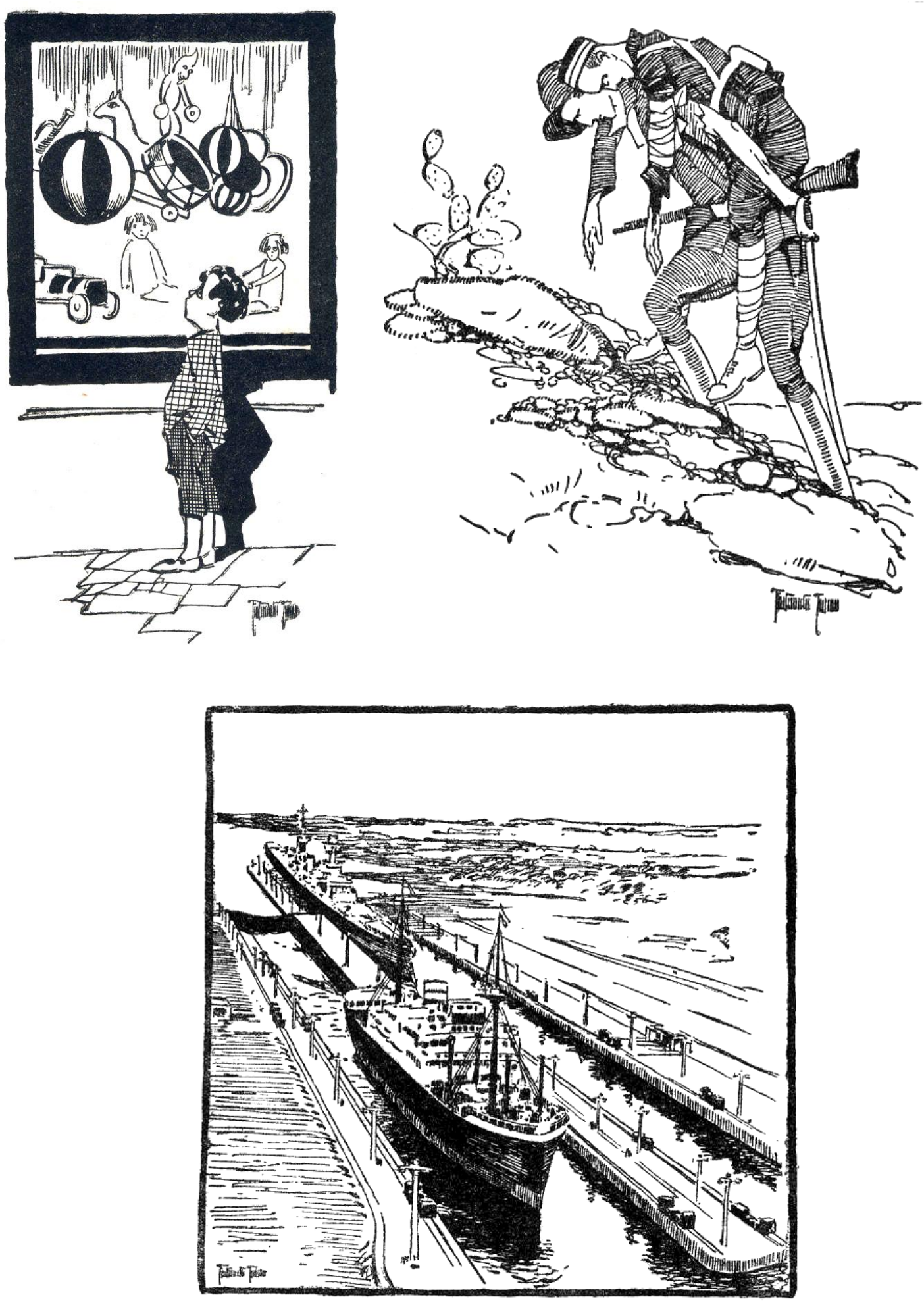

Fig.: 78

Ilustraciones interiores de Mi Libro Bazar.

Biblioteca Paz. Hijos de Santiago Rodríguez. 
LA EDITORIAL BURGALESA HIJOS DE SANTIAGO RODRÍGUEZ (1891-1936): ANÁLISIS DE LOS LIBROS ESCOLARES

3.3.5. Ilustración interior a color en Mi Libro de Navidad de la Biblioteca Paz.

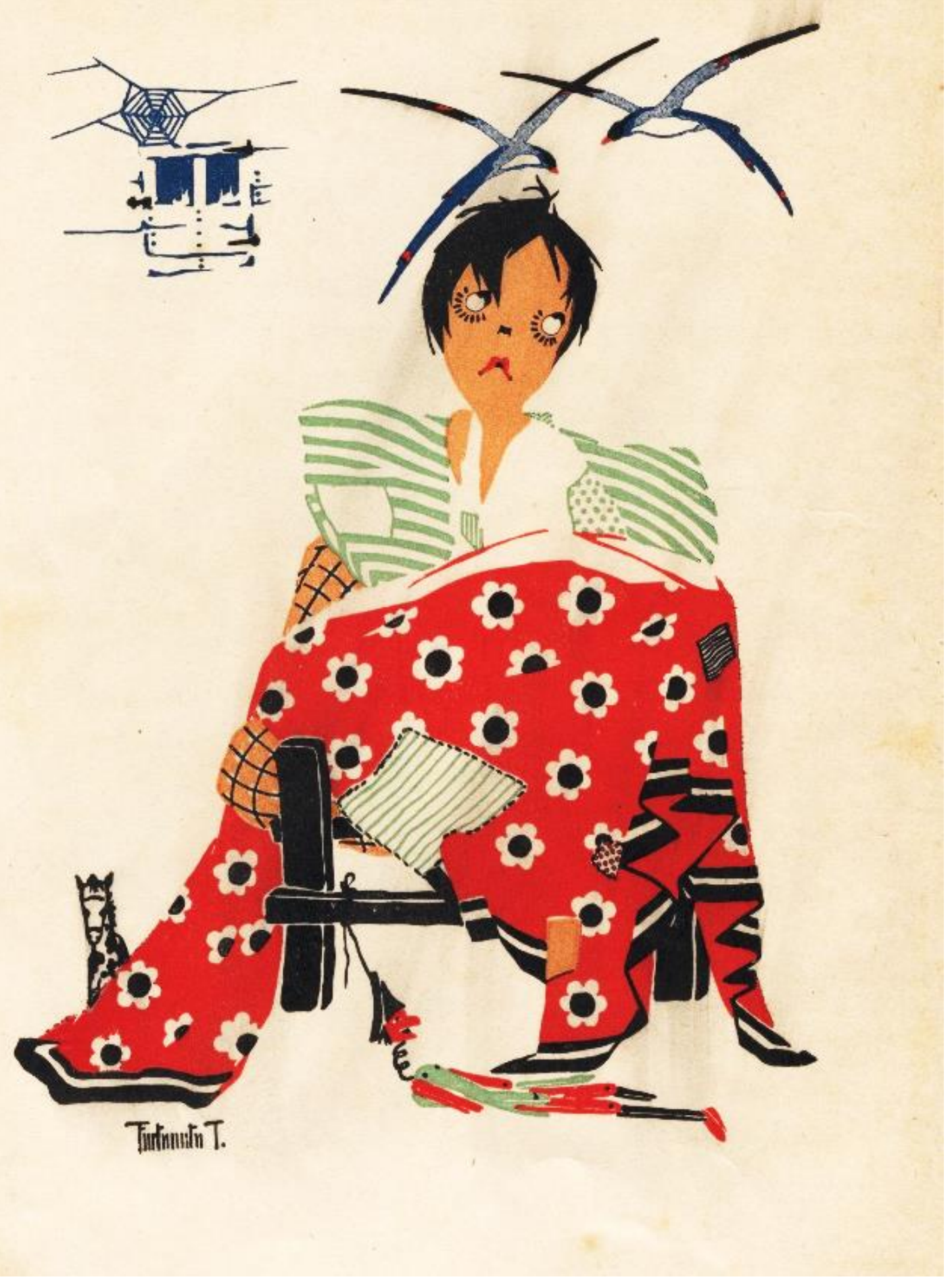

Fig.: 79

Ilustración interior a color de Fortunato Julián en Mi Libro de Navidad.

Biblioteca Paz. Hijos de Santiago Rodríguez. 
3.3.6. Ilustración interior del cuento El príncipe que conquistó un mundo y el que se contentó con menos del libro Lee estos cuentos de la Biblioteca Cuentos de Ayer y de Hoy.

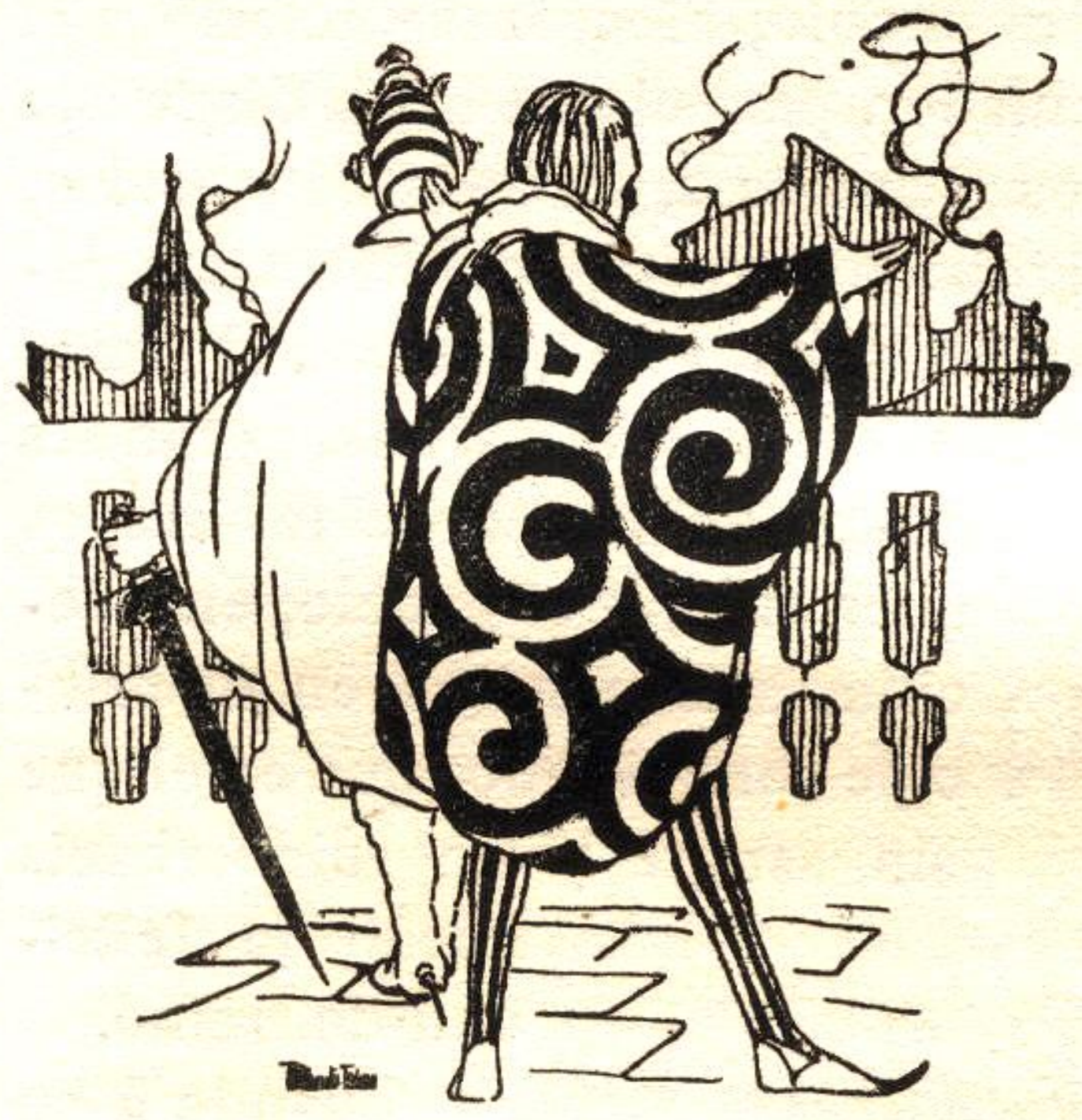

Fig.: 80

Ilustración interior del libro Lee estos cuentos.

Biblioteca Cuentos de Ayer y de Hoy.

Hijos de Santiago Rodríguez. 
3.3.7. Ilustración interior del cuento El sueño de Juan del libro Lee estos cuentos de la Biblioteca Cuentos de Ayer y de Hoy.

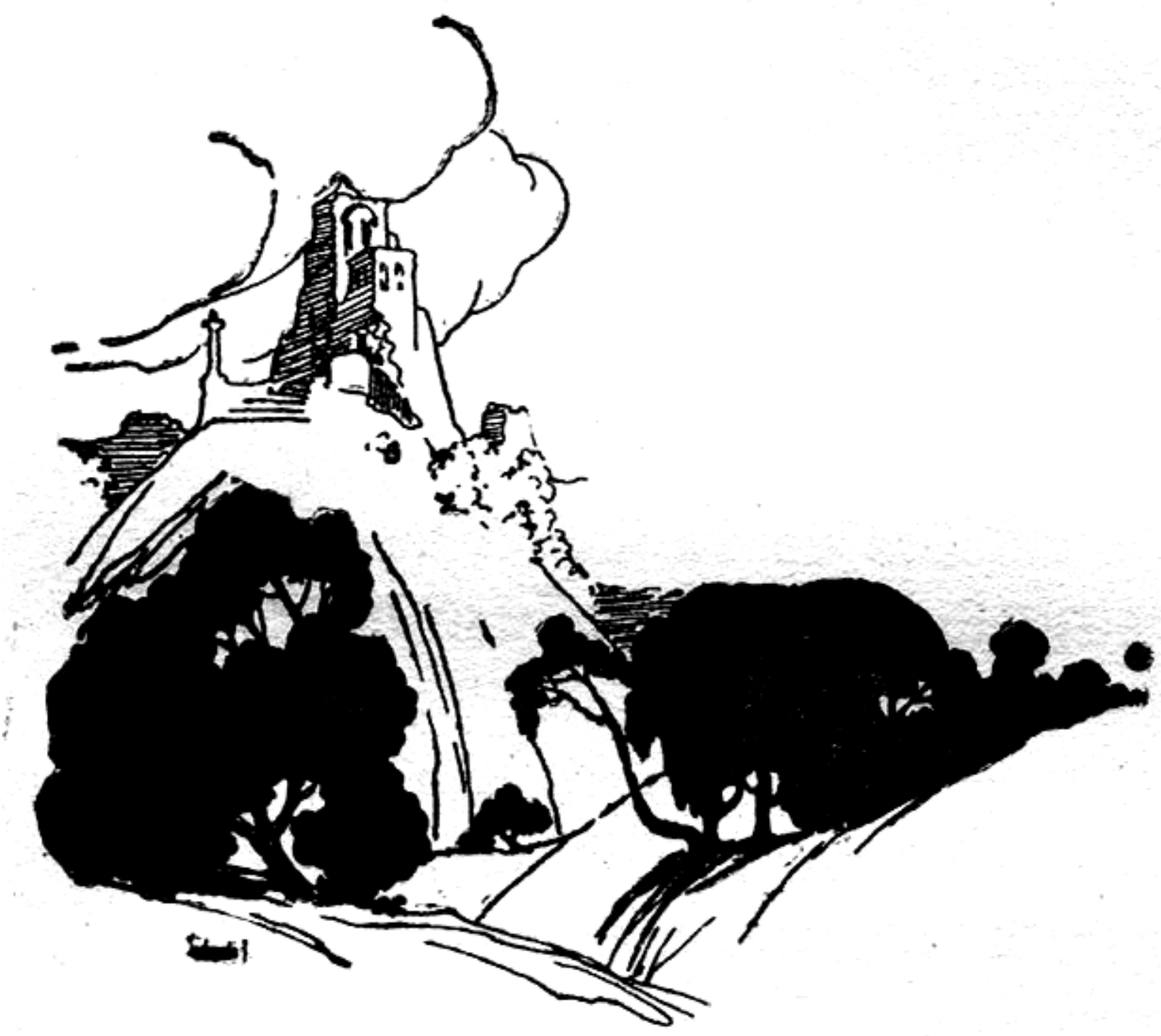

Fig.: 81

Ilustración interior del cuento El sueño de Juan del libro Lee estos cuentos. Biblioteca Cuentos de Ayer y de Hoy. Hijos de Santiago Rodríguez. 
3.3.8. Ilustración interior en forma de viñeta Para ser fuerte, ejercita tus músculos de Mi Libro de Navidad de la Biblioteca Paz.
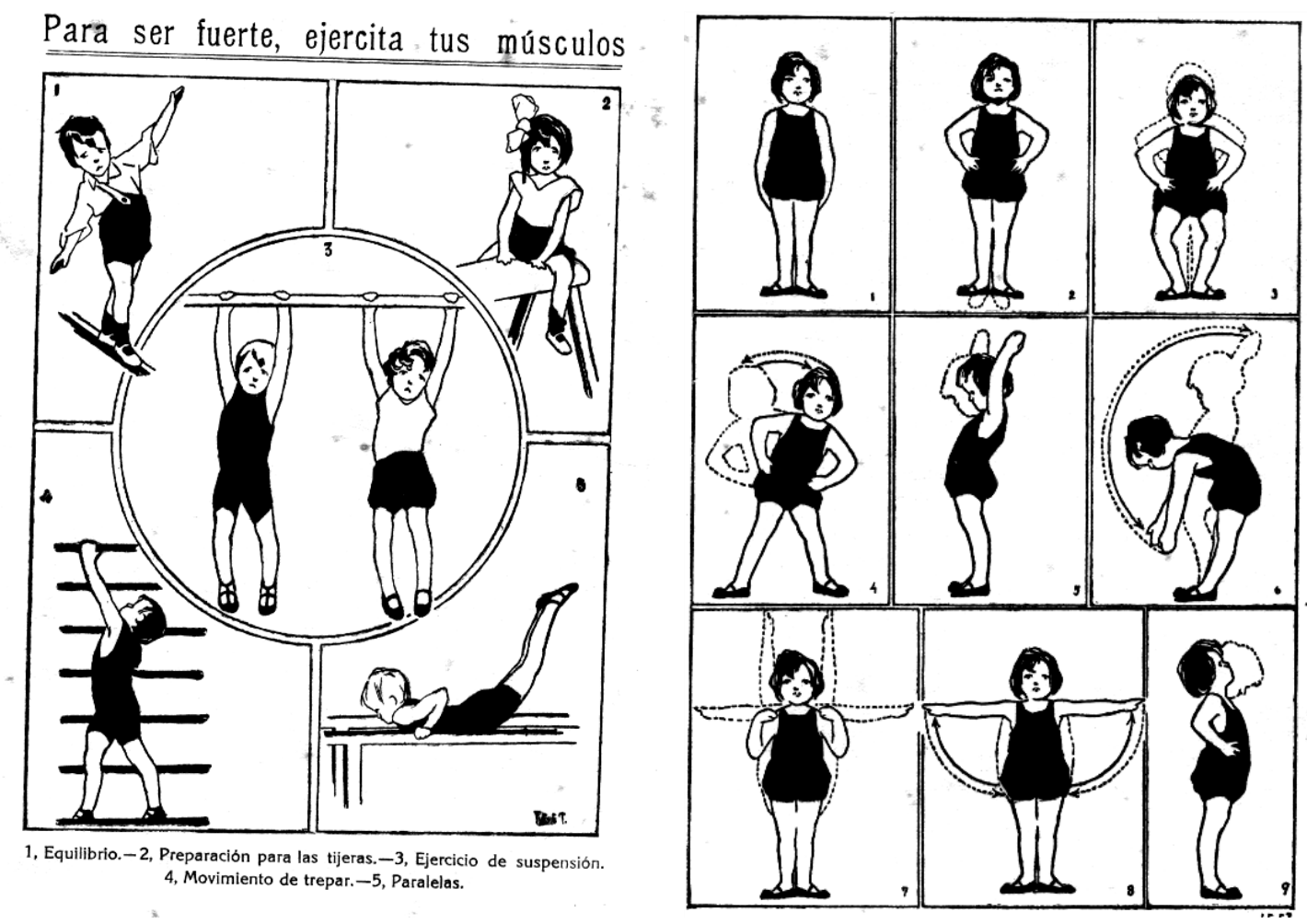

Fig.: 84

Ilustración interior en forma de viñeta Para ser fuerte, ejercita tus músculos del libro Mi Libro de Navidad. Biblioteca Paz.

Hijos de Santiago Rodríguez. 
3.3.9. Ilustración interior en forma de viñeta titulada Cómo se fabrican los coches Ford en Mi Libro de Estampas y Cuentos de la Biblioteca Paz.

\section{CÓMO SE FABRICAN LOS COCHES ,FORD,}
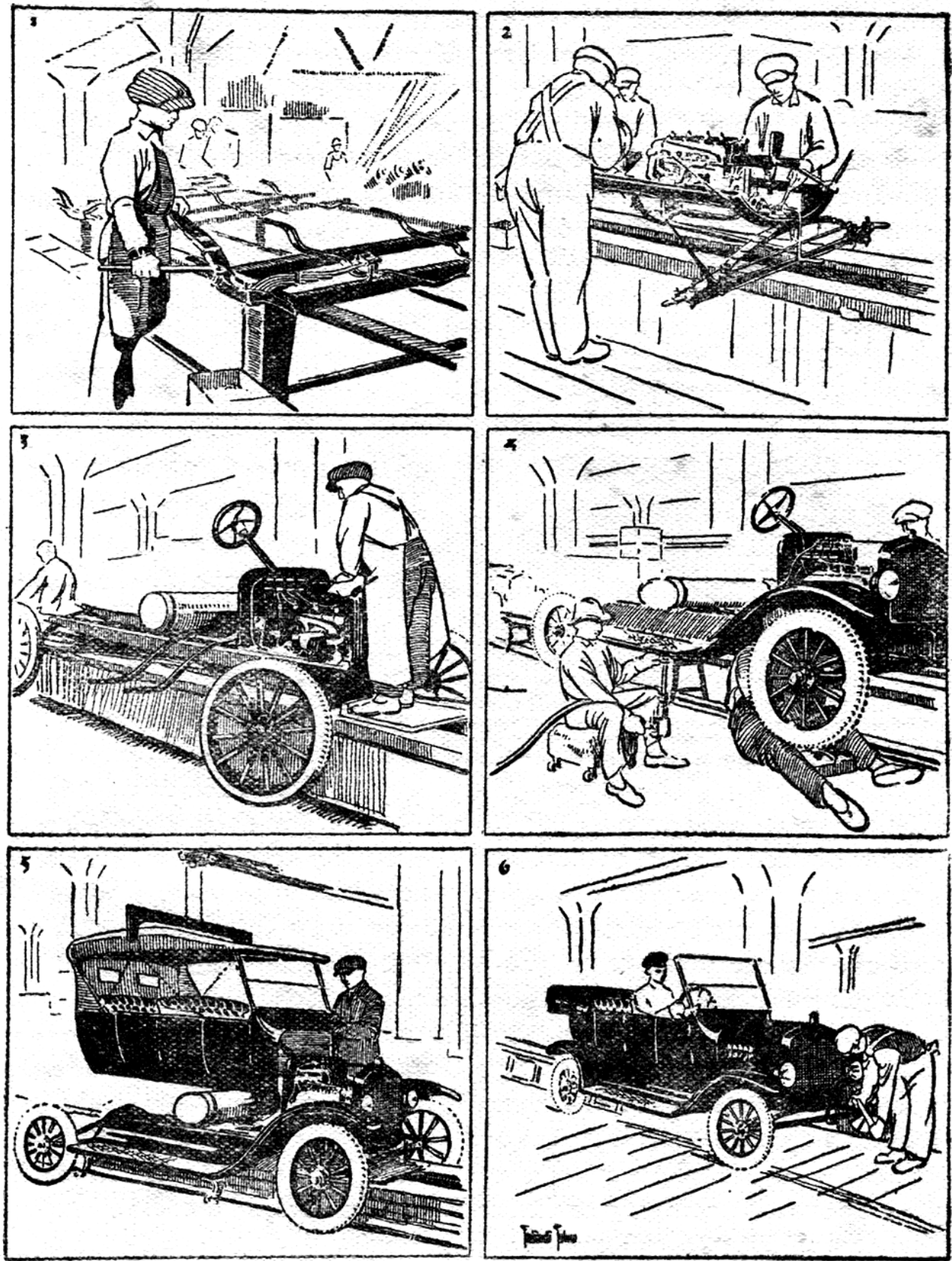

1. El chassís o armazón del coche llega frente al obrero encargado de colocar los resortes de suspensión. Esta es la primera fase del montafe - 2. Montando el motor, que es el corazón del automóvil. - 3. Colocación del radiador -4 . Montando los guardabarros y estríbos -5 . Colocando la carrosserie. Esta llega conducida por un transportador aéreo y en pocos minutos queda coloeada sobre el chassis ya completo. - 6 . El conductor esta ya frente al volante. Un obrero, antes de que el coche salga de la fábrica para realizar las pruebas, examina el buen funcionamfento de los faros. $\mid \mathrm{El}$ coche está terminadol

Fig.: 85

Ilustración interior en forma de viñeta sobre cómo se fabricaban los coches Ford. Mi Libro de Estampas y Cuentos. Biblioteca Paz.

Hijos de Santiago Rodríguez. 
3.3.10. Ilustración de la portada del cuento La sombra del maestro de Mi

Libro de Año Nuevo de la Biblioteca Paz.

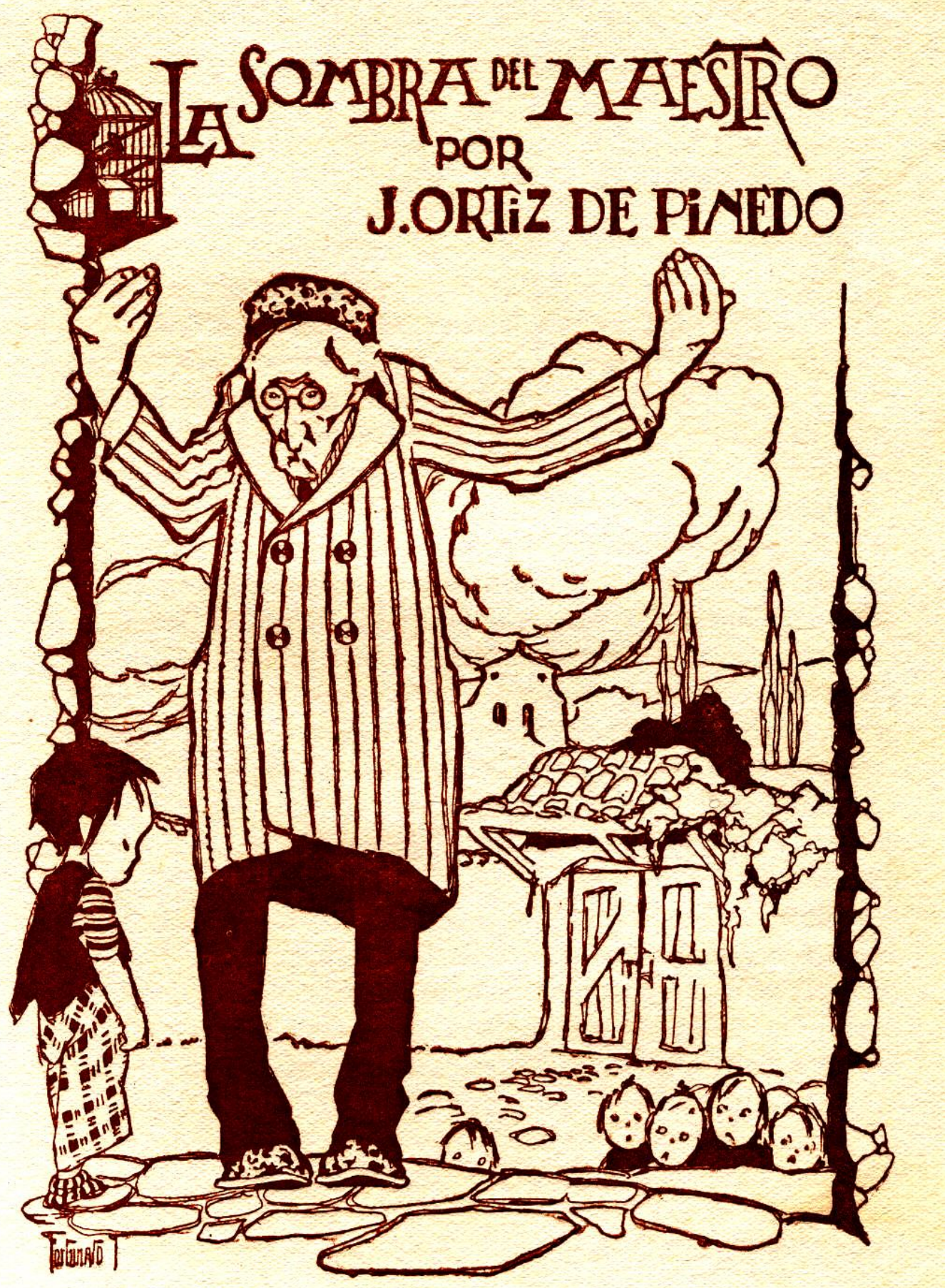

Fig.: 86

Ilustración interior del cuento La sombra del maestro.

Mi Libro de Año Nuevo. Biblioteca Paz. Hijos de Santiago Rodríguez. 
LA EDITORIAL BURGALESA HIJOS DE SANTIAGO RODRÍGUEZ (1891-1936):

ANÁLISIS DE LOS LIBROS ESCOLARES

3.3.11. Ilustración inicial del cuento ;Año Nuevo! del Mi Libro de Año Nuevo de la Biblioteca Paz.

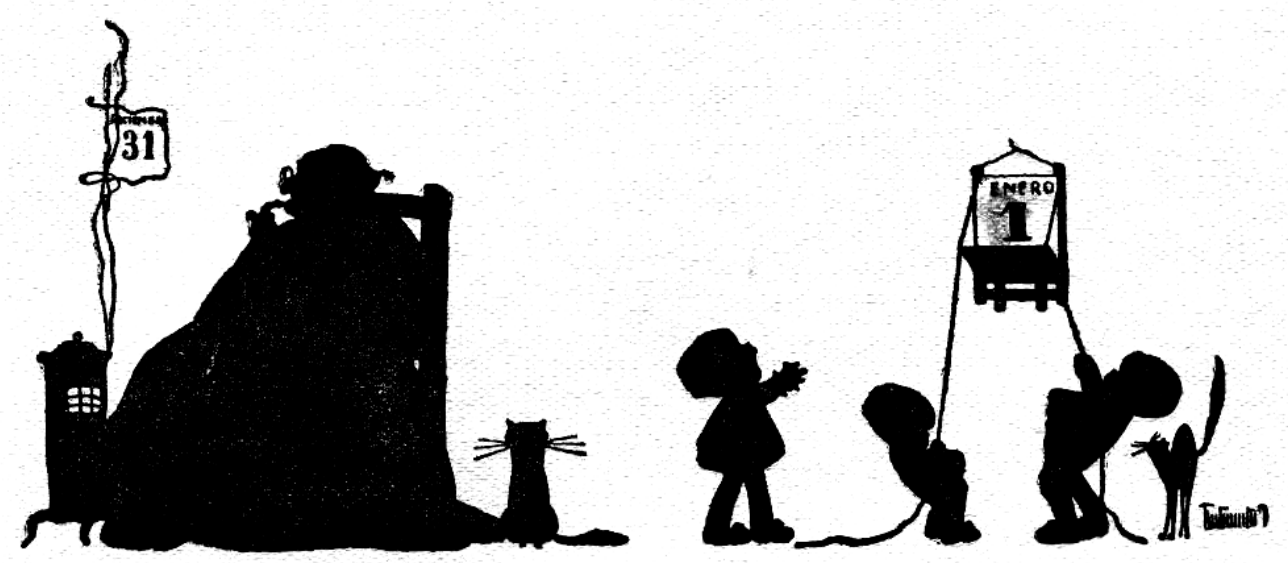

Fig.: 87

Ilustración inicial del cuento iAño Nuevo! en Mi Libro de Año Nuevo. Biblioteca Paz. Hijos de Santiago Rodríguez. 
3.3.12. Ilustraciones interiores del cuento Los pájaros azules de Mi Libro de Navidad de la Biblioteca Paz.
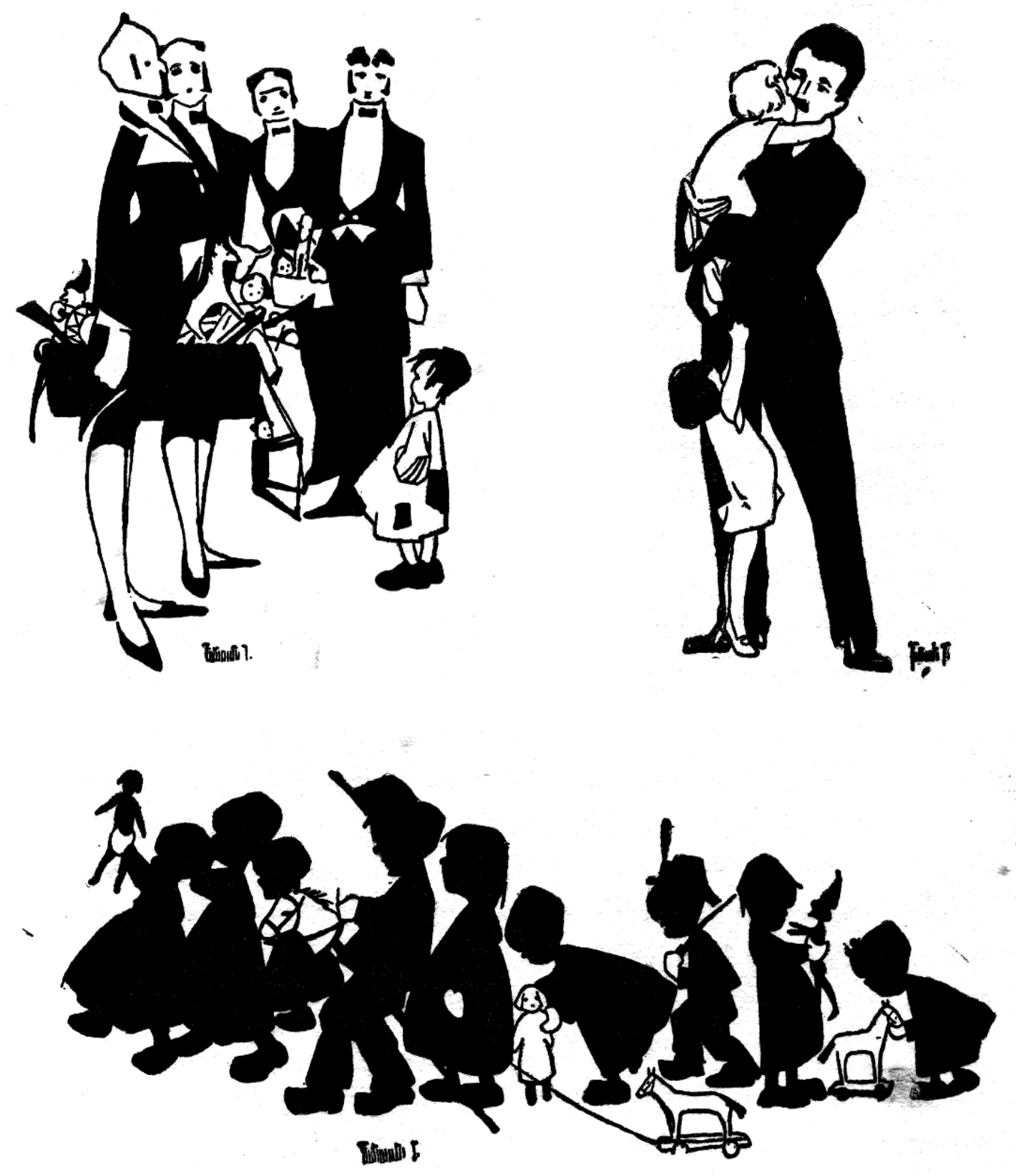

Fig.: 88

Ilustraciones interiores del cuento Los pájaros azules en Mi Libro de Navidad. Biblioteca Paz. Hijos de Santiago Rodríguez. 
LA EDITORIAL BURGALESA HIJOS DE SANTIAGO RODRÍGUEZ (1891-1936): ANÁLISIS DE LOS LIBROS ESCOLARES

3.3.13. Cubierta ilustrada del El libro de la naturaleza de la Biblioteca ProCultura.

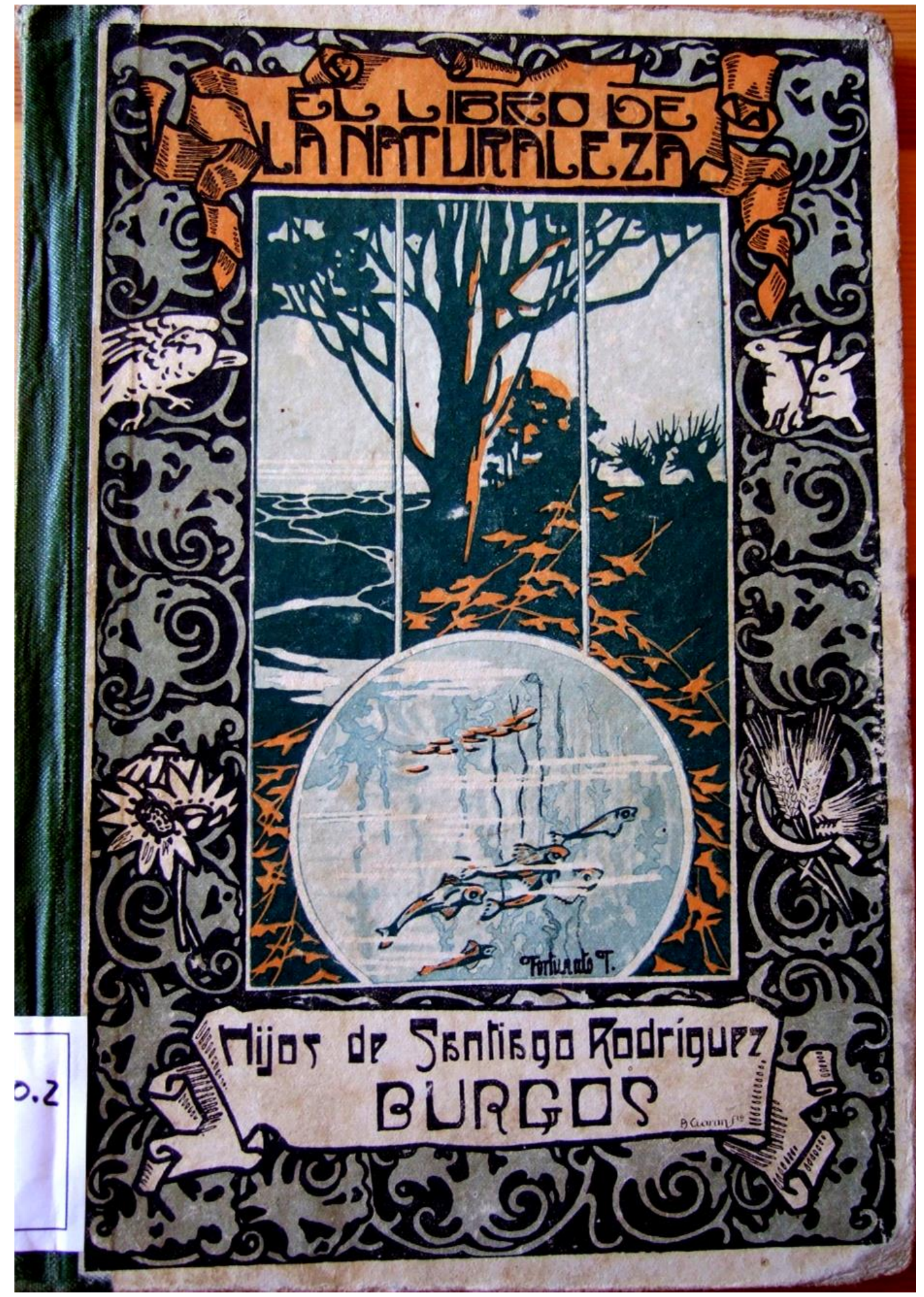

Fig.: 89

Cubierta ilustrada por Fortunato Julián de la obra El Libro de la naturaleza de la Biblioteca Pro-Cultura. Burgos. Hijos de Santiago Rodríguez.

Ejemplar del CEINCE. 
3.3.14. Ilustraciones en blanco y negro sobre Las hazañas del valeroso Cid Rodrigo Díaz de Vivar el Campeador en Mi libro bazar de la Biblioteca Paz.
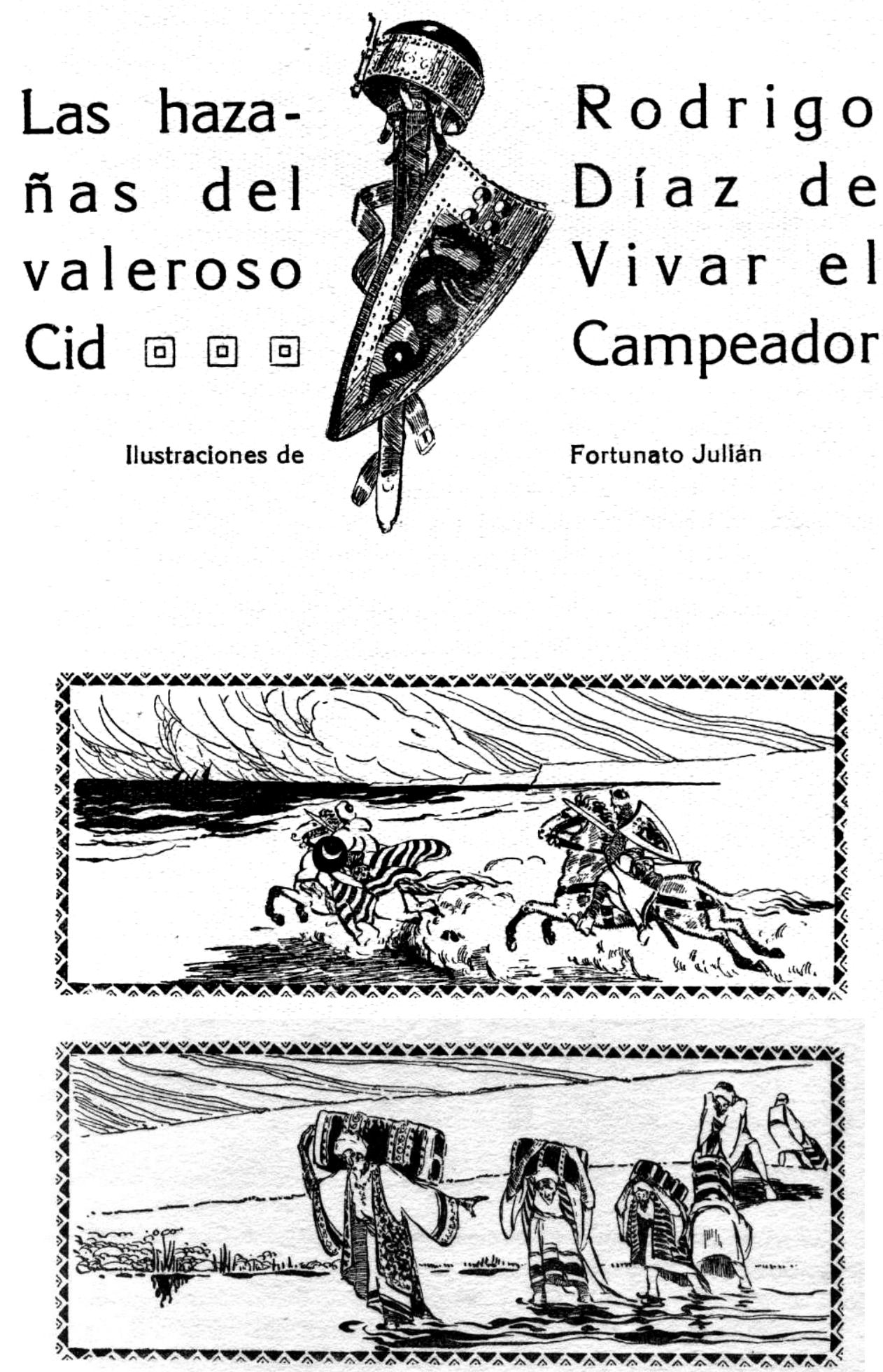
LA EDITORIAL BURGALESA HIJOS DE SANTIAGO RODRÍGUEZ (1891-1936): ANÁLISIS DE LOS LIBROS ESCOLARES
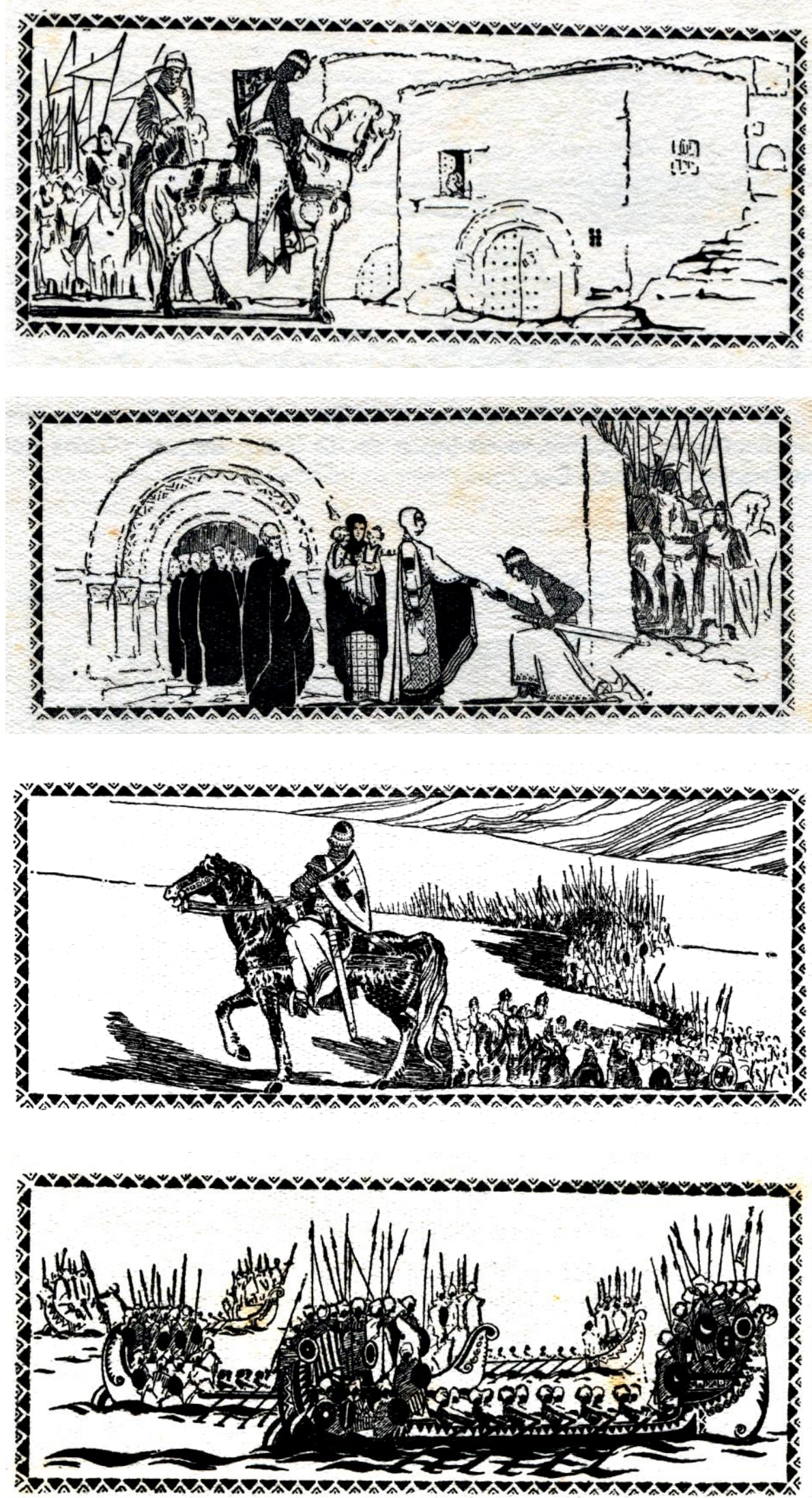

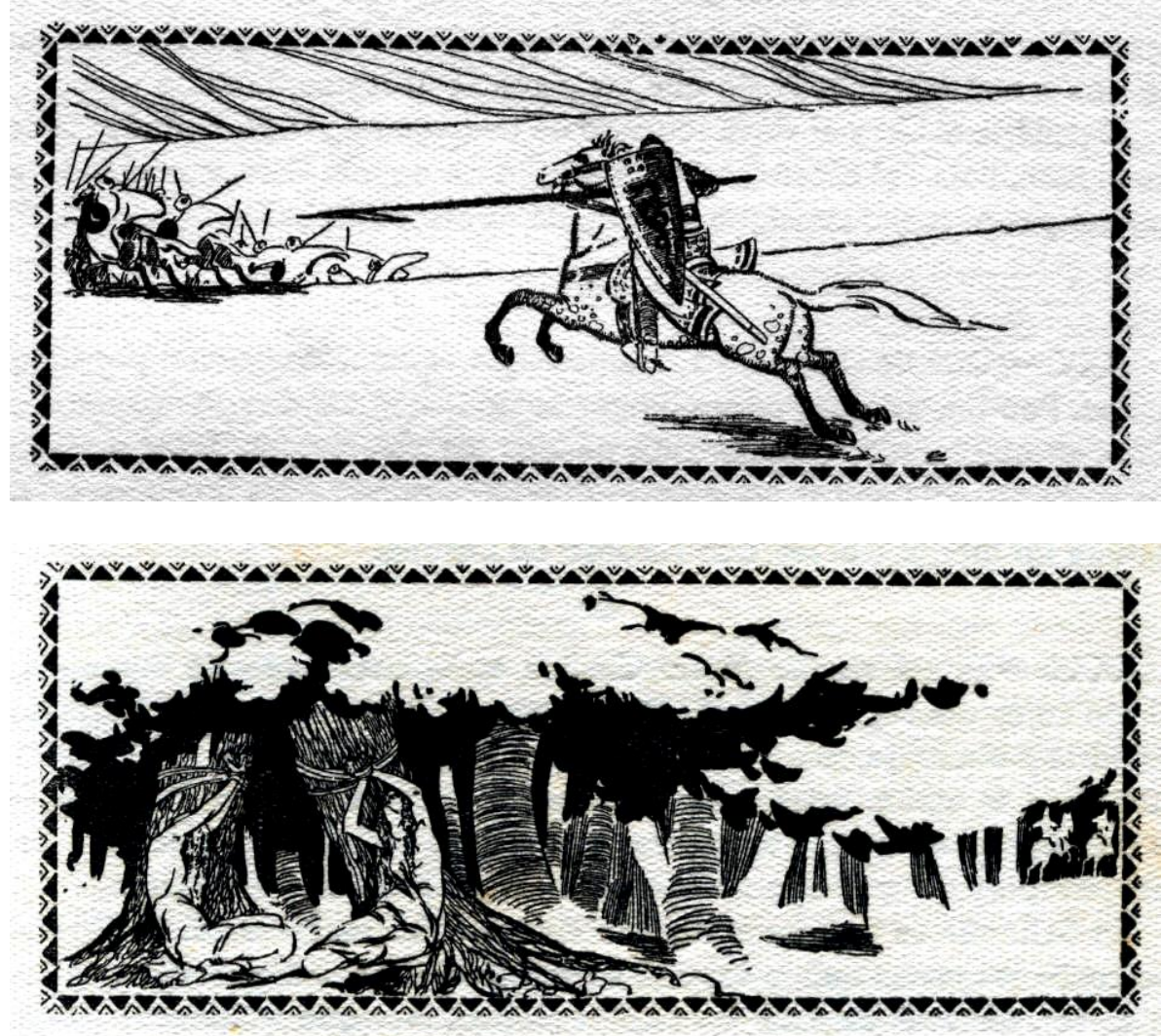

Fig.: 90

Ilustraciones de Las hazañas del valeroso Cid Rodrigo Díaz de Vivar el Campeador en Mi libro bazar. Biblioteca Paz. Hijos de Santiago Rodríguez. 
3.3.15. Ilustración infantil en blanco y negro en el índice de Mi libro de Navidad de la Biblioteca Paz.

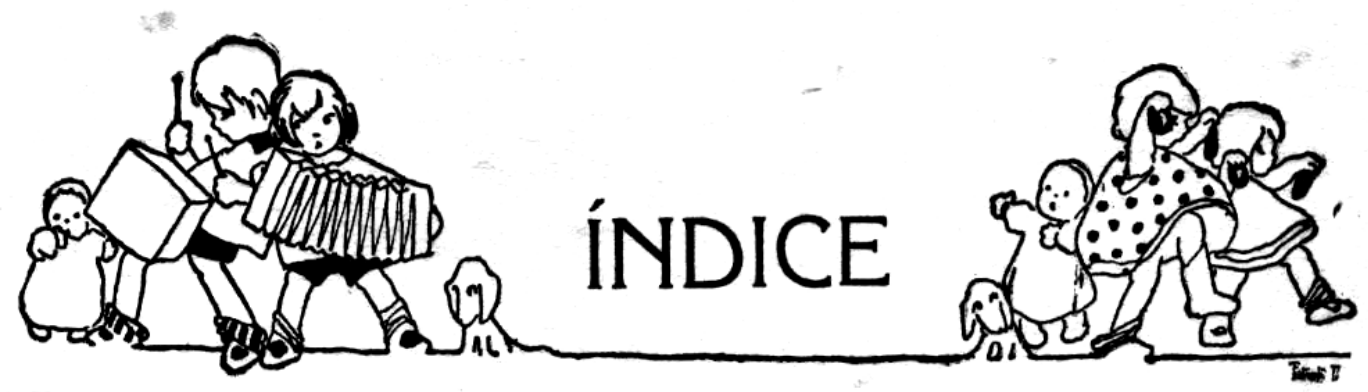

Fig.: 91

Ilustración infantil en el índice de Mi libro de Navidad. Biblioteca Paz.

Hijos de Santiago Rodríguez.

3.3.16. Ilustración del cuento La moza de los gansos escrito por los hermanos Grimm en Mi Libro de estampas y cuentos. Biblioteca Paz.

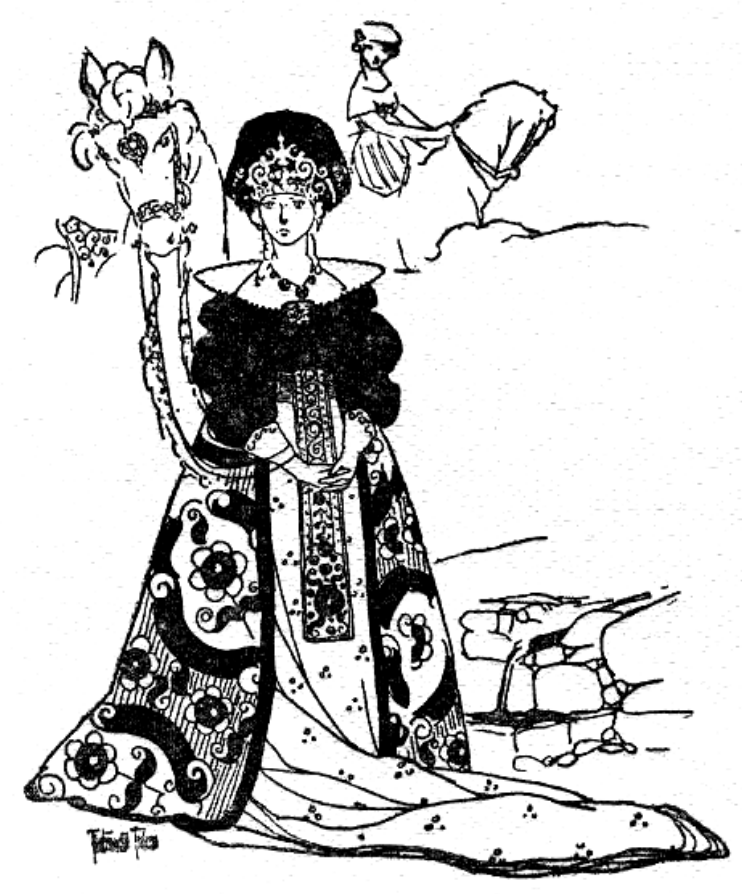

Fig.: 92

Ilustración en blanco y negro La moza de los gansos de Mi Libro de estampas y cuentos. Biblioteca Paz. Hijos de Santiago Rodríguez. 
3.3.17. Ilustraciones del cuento de Grimm Flor de Agavanzo en Mi libro de estampas y cuentos de la Biblioteca Paz.
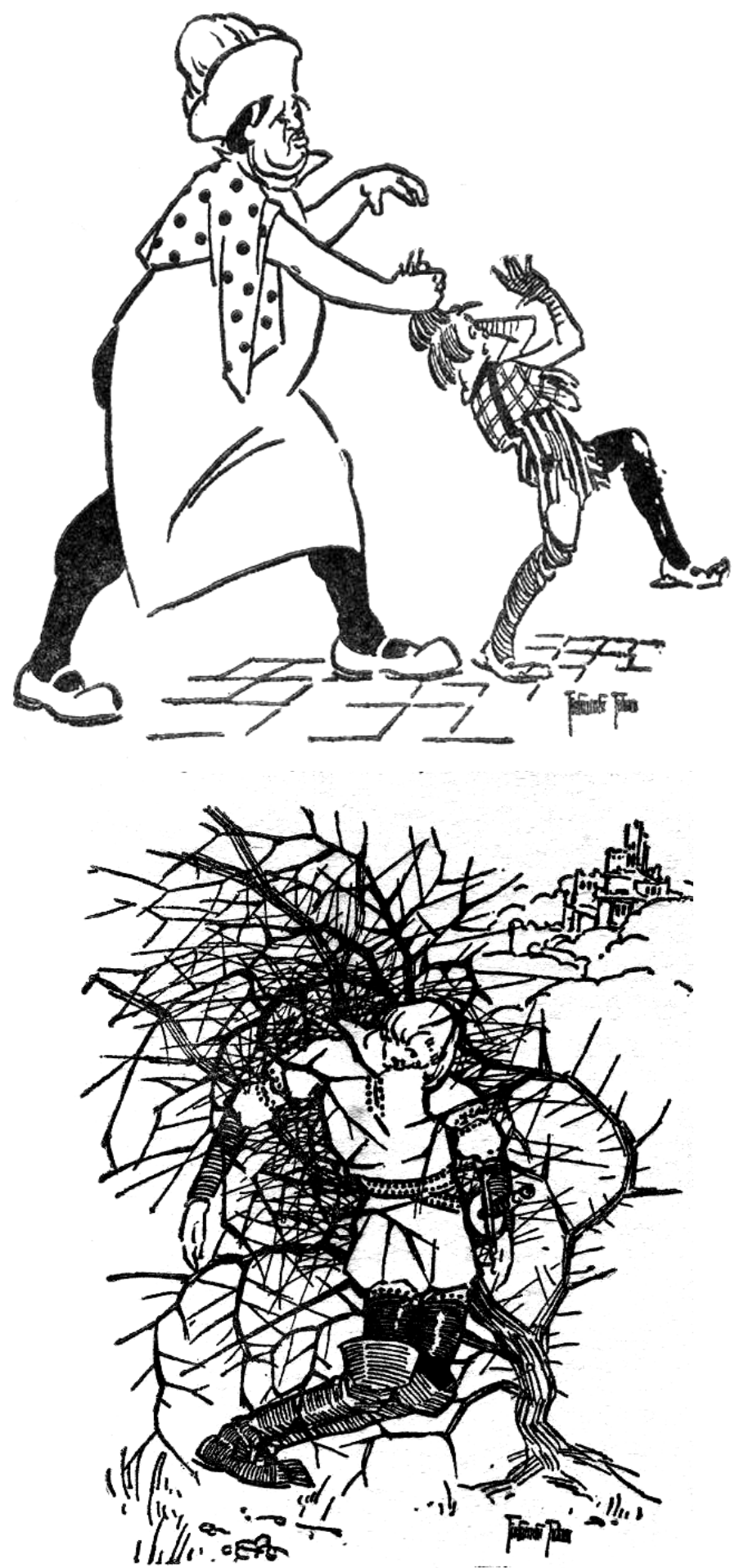

Fig.: 93

Ilustraciones del cuento Flor de Agavanzo en Mi libro de estampas y cuentos de la Biblioteca Paz. Hijos de Santiago Rodríguez. 
3.3.18. Ilustración del cuento de Grimm El hermanito y la hermanita en Mi libro de Estampas y cuentos de la Biblioteca Paz.

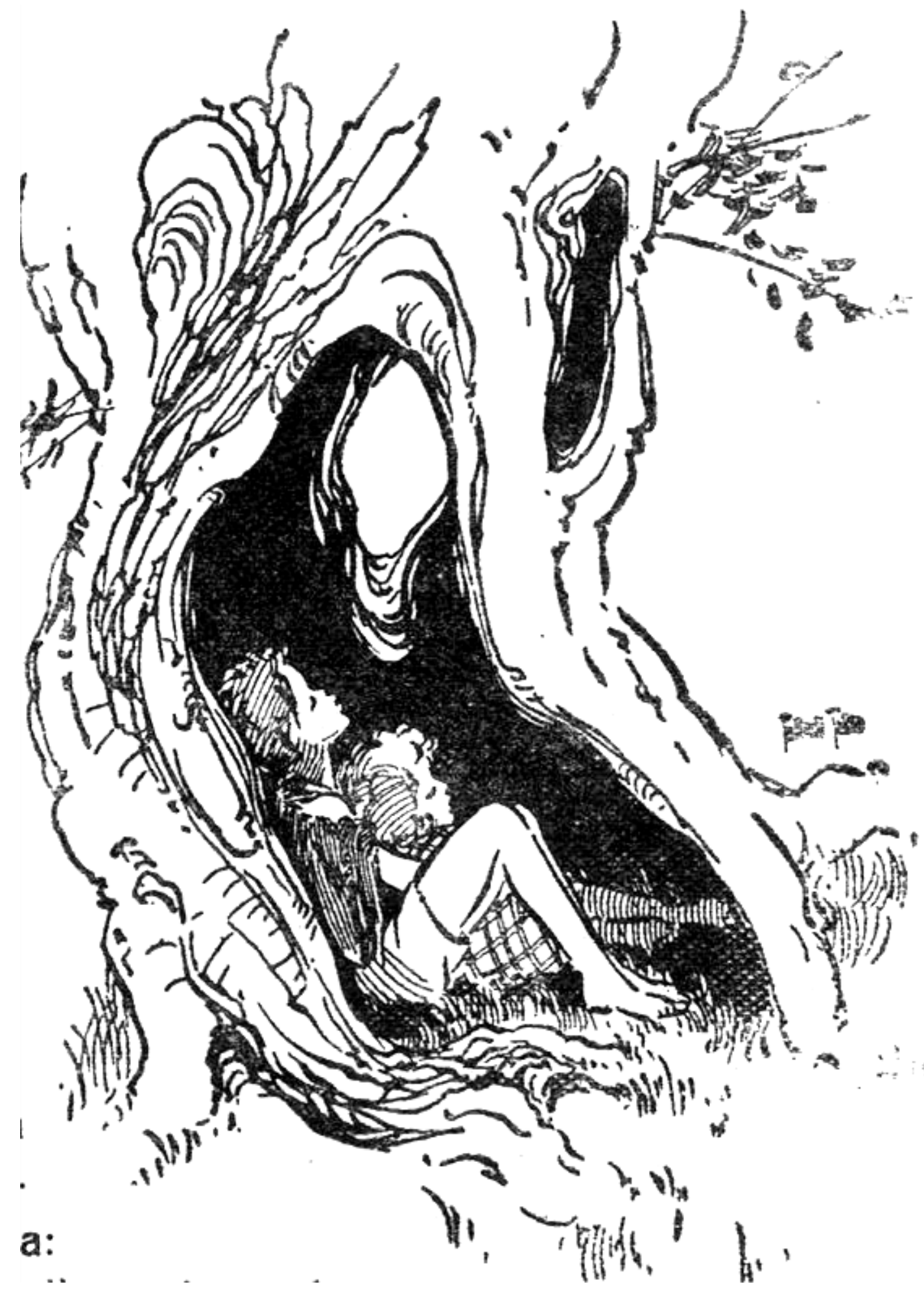

Fig.: 94

Ilustración del cuento de Grimm El hermanito y la hermanita en Mi libro de Estampas y cuentos de la Biblioteca Paz. Hijos de Santiago Rodríguez. 
3.3.19. Cubierta ilustrada de Las maravillosas aventuras de un cascanueces: el juguete animado de la Biblioteca Oro.

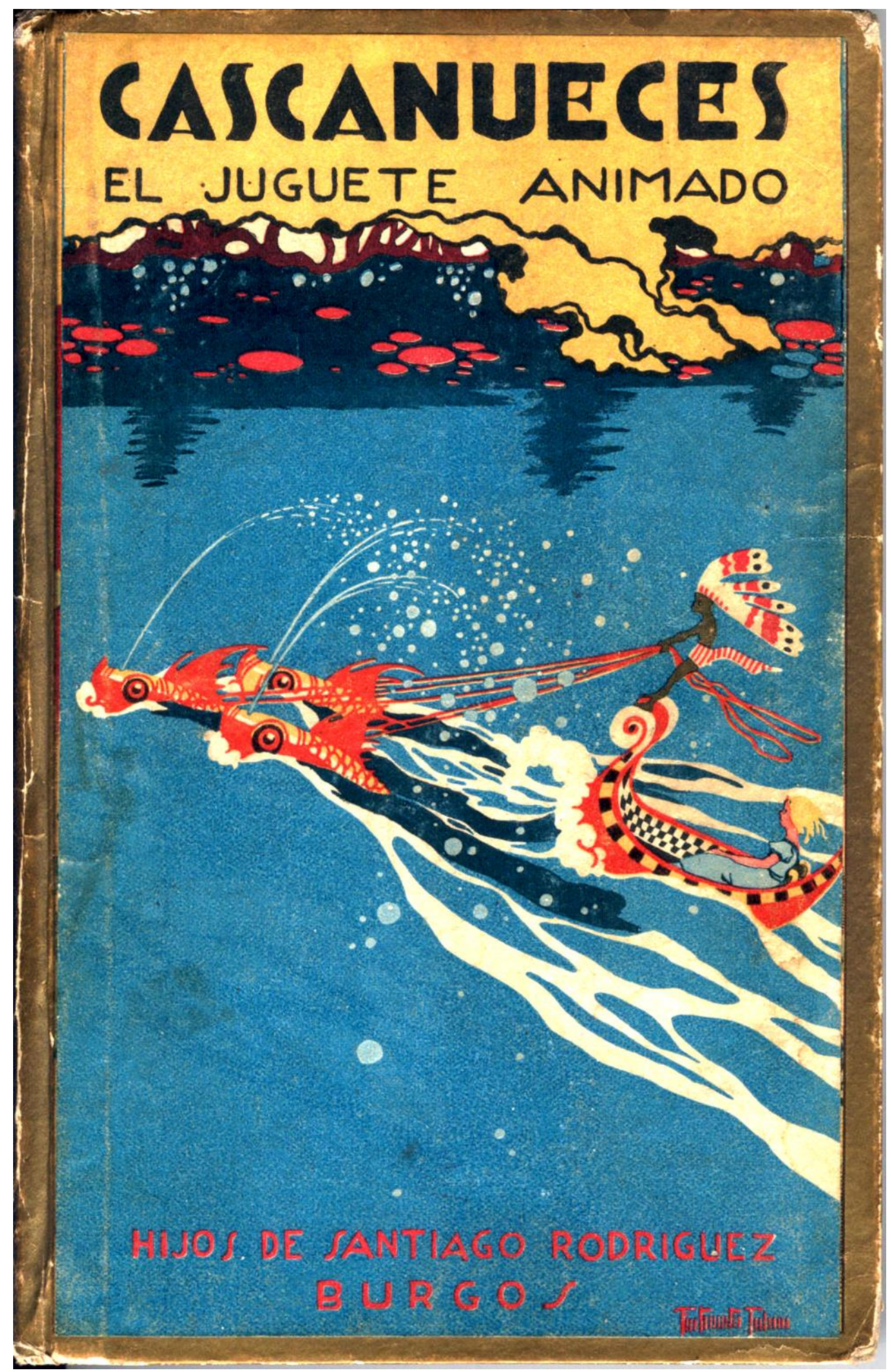

Fig.: 95

Cubierta ilustrada del libro Maravillosas aventuras de un cascanueces: el juguete animado. Biblioteca Oro. Hijos de Santiago Rodríguez. 
3.3.20. Ilustraciones interiores del libro Maravillosas aventuras de un cascanueces: el juguete animado de la Biblioteca Oro.
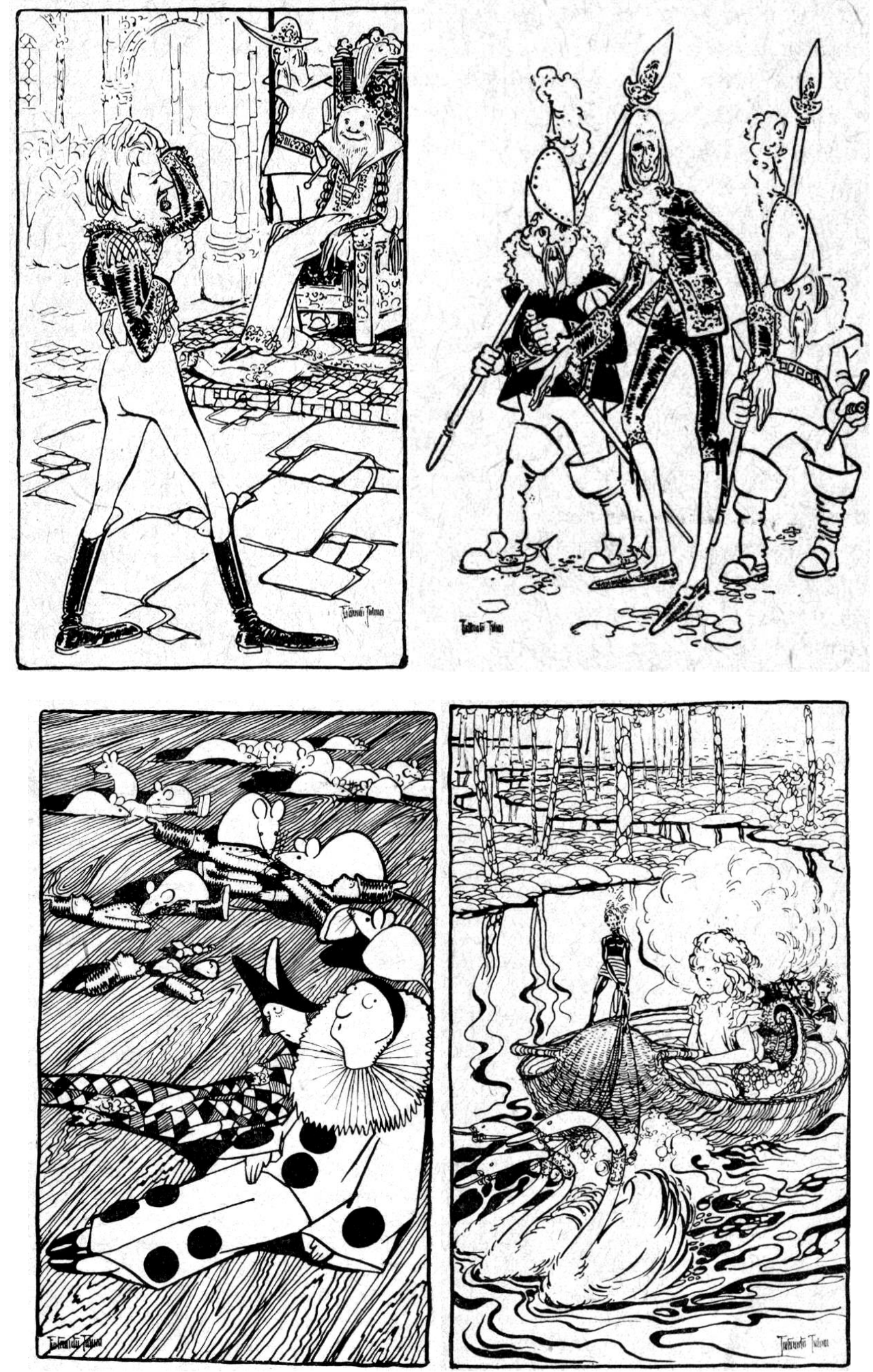

Fig.: 96

Ilustraciones interiores en blanco y negro del libro de la Biblioteca Oro Maravillosas aventuras de un cascanueces: el juguete animado. Hijos de Santiago Rodríguez. 
3.3.21. Cubierta ilustrada a todo color de la Biblioteca Paz, Mi Libro Ideal.

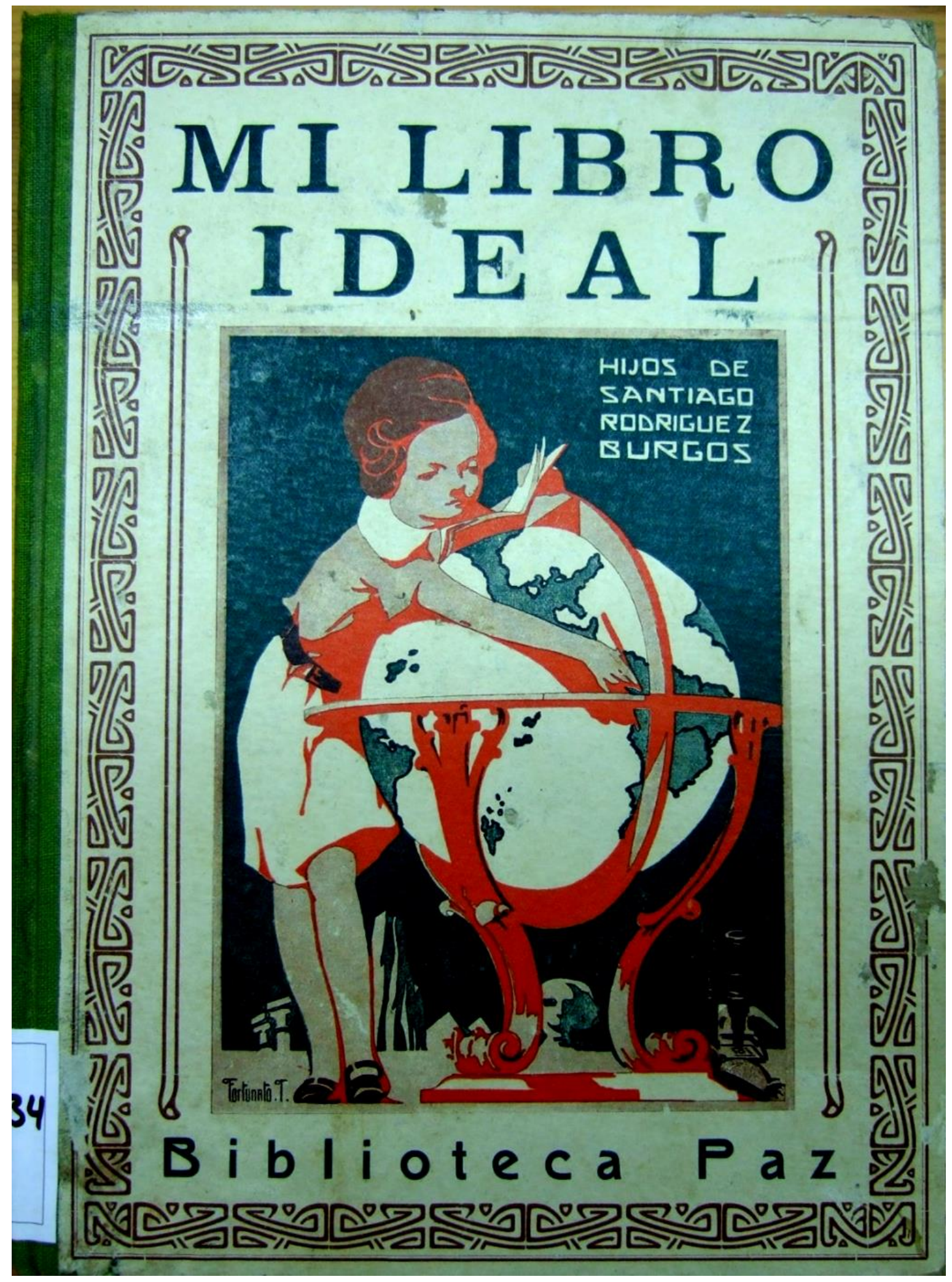

Fig.: 97

Cubierta ilustrada de la Biblioteca Paz, Mi Libro Ideal. Burgos. Hijos de Santiago Rodríguez. 1933. Ejemplar del CEINCE. 
3.3.22. Ilustraciones interiores a pluma sobre la Exposición IberoAmericana en Sevilla de 1929 presentadas en el Mi Libro Ideal de la Biblioteca Paz.
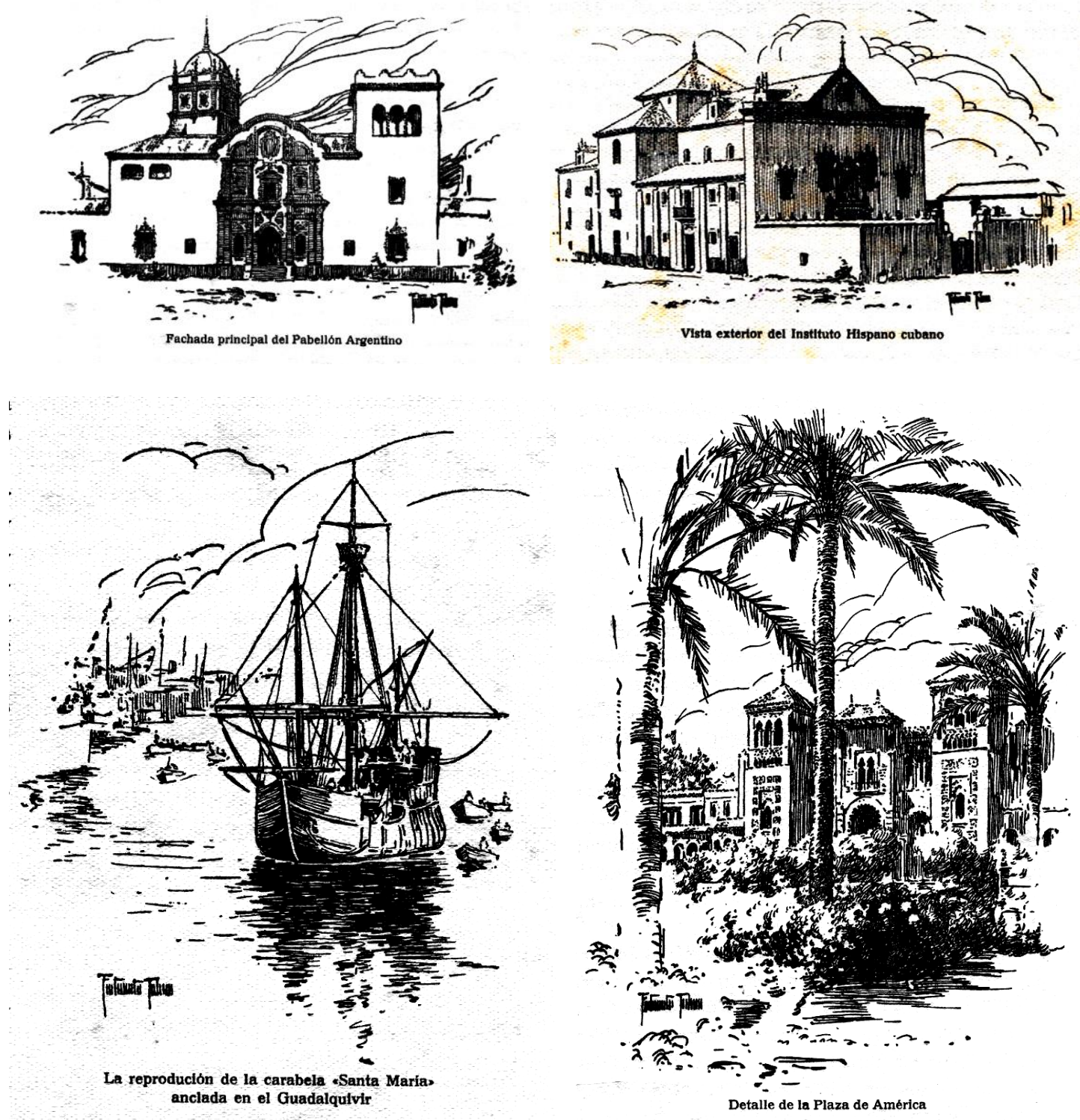

Fig.: 98

Ilustraciones interiores a pluma de la Exposición Ibero-Americana de Sevilla. Mi libro ideal. Biblioteca Paz. Hijos de Santiago Rodríguez. 
3.3.23. Ilustración sobre el CXXV aniversario de Andersen.

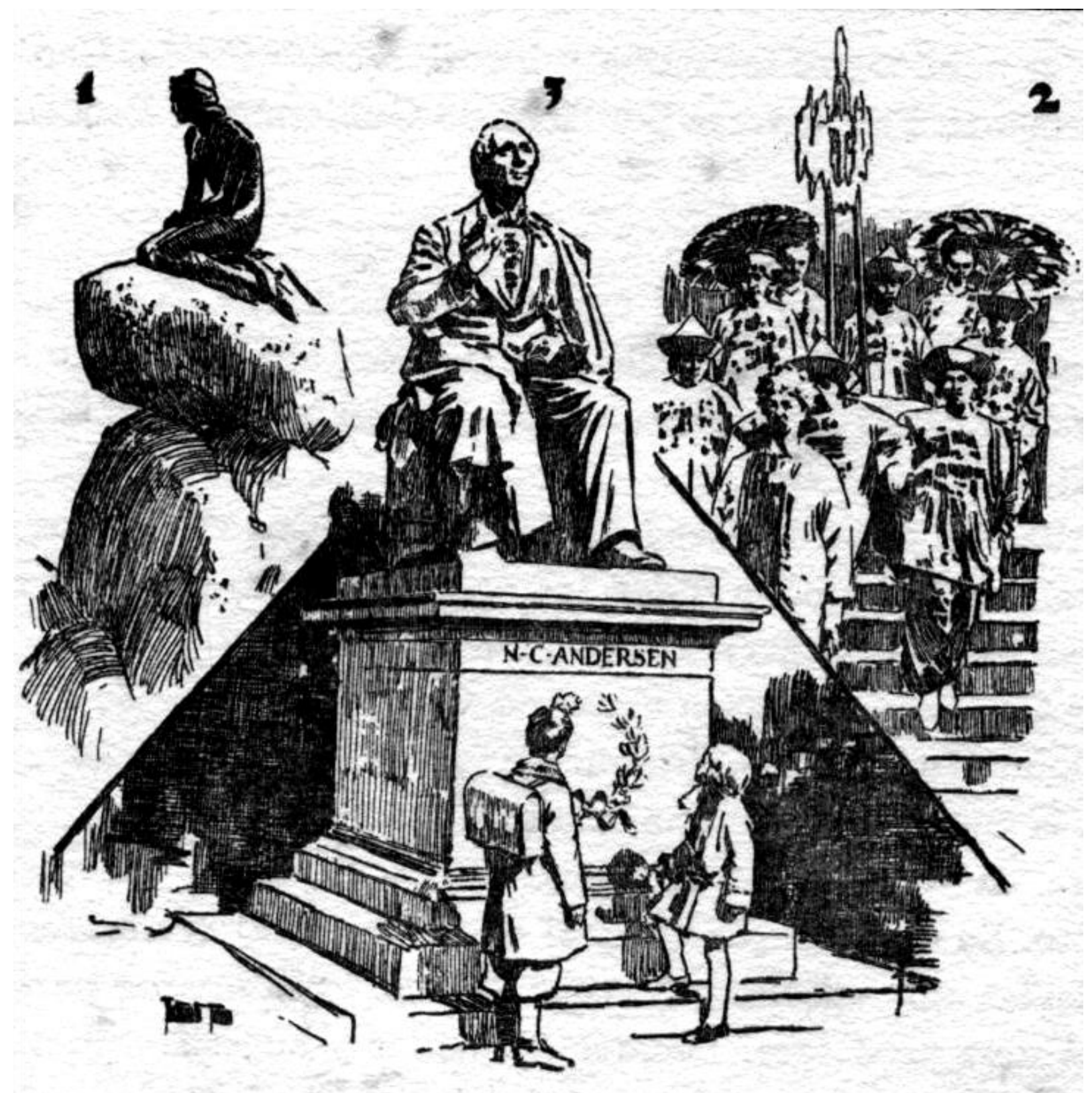

Fig.: 99

Ilustración sobre el CXXV aniversario de Andersen con el símbolo de la sirenita y el monumento que la ciudad hizo al famoso cuentista danés, al igual que algunos de los personajes creados por dicho autor.

Biblioteca Paz. Mi Libro Ideal. Hijos de Santiago Rodríguez. 


\subsection{PEDRO ANTEQUERA AZPIRI (MADRID 1892-1975)}

3.4.1. Tira cómica de Mi Libro de Estampas y Cuentos de la Biblioteca Paz.

3.4.2. Ilustración a color del cuento El niño que quería ser rey que forma parte del libro Contando Cuentos de la Biblioteca Rodríguez.

3.4.3. Ilustración a color del cuento La tripita que forma parte del libro Contando Cuentos de la Biblioteca Rodríguez.

3.4.4. Ilustración a color del cuento La grulla que forma parte del libro Contando Cuentos de la Biblioteca Rodríguez.

3.4.5. Ilustración a color del cuento La aventura de Pipo que forma parte del libro Contando Cuentos de la Biblioteca Rodríguez.

3.4.6. Ilustración a color del cuento Las discusiones fantásticas que forma parte del libro Contando Cuentos de la Biblioteca Rodríguez.

3.4.7. Ilustración interior a color del libro La larva y el águila de la Biblioteca Cuentos Nuevos en Colores.

3.4.8. Ilustraciones interiores a color del libro Mikolán y Cía de la Biblioteca Cuentos Nuevos en Colores.

3.4.9. Ilustración interior a color del libro Los tres sorianitos de la Biblioteca Rodríguez (I).

3.4.10. Ilustración interior a color del libro Los tres sorianitos de la Biblioteca Rodríguez (II).

3.4.11. Ilustración interior a color del libro Los tres sorianitos de la Biblioteca Rodríguez (III).

3.4.12. Ilustración interior a color del libro Los tres sorianitos de la Biblioteca Rodríguez (IV).

3.4.13. Ilustración interior a color del libro Los tres sorianitos de la Biblioteca Rodríguez (V).

3.4.14. Ilustración interior bicolor del libro Patachín Patachán de la Biblioteca Colección Papa-Moscas. 
3.4.15. Ilustración interior en blanco y negro del cuento El niño que quería ser rey del libro Contando Cuentos de la Biblioteca Rodríguez.

3.4.16. Ilustración interior en blanco y negro del cuento La tripita del libro Contando Cuentos de la Biblioteca Rodríguez.

3.4.17. Ilustración interior en blanco y negro del cuento El Sol por salir, del libro Contando Cuentos de la Biblioteca Rodríguez.

3.4.18. Ilustración interior en blanco y negro del cuento Fifina del libro Contando Cuentos de la Biblioteca Rodríguez.

3.4.19. Ilustración interior final en blanco y negro del cuento Fifina del libro Contando Cuentos de la Biblioteca Rodríguez.

3.4.20. Ilustración interior final en blanco y negro del cuento Con pautas torcidas renglones derechos del libro Contando Cuentos de la Biblioteca Rodríguez.

3.4.21. Ilustración interior en blanco y negro del Epílogo del libro Contando Cuentos de la Biblioteca Rodríguez.

3.4.22. Ilustración interior en blanco y negro del libro Los tres sorianitos de la Biblioteca Rodríguez.

3.4.23. Ilustraciones interiores bicolor del libro Los tres sorianitos de la Biblioteca Rodríguez (I).

3.4.24. Ilustraciones interiores bicolor del libro Los tres sorianitos de la Biblioteca Rodríguez (II).

3.4.25. Ilustraciones interiores bicolor del libro Los tres sorianitos de la Biblioteca Rodríguez (III).

3.4.26. Ilustración en blanco y negro del libro Mikolán y Cía de la Biblioteca Cuentos Nuevos en Colores.

3.4.27. Ilustración interior en blanco y negro de Mi Libro de Estampas y Cuentos de la Biblioteca Rodríguez.

3.4.28. Ilustración infantil en blanco y negro de Mi Libro de Estampas y Cuentos de la Biblioteca Paz. 
LA EDITORIAL BURGALESA HIJOS DE SANTIAGO RODRÍGUEZ (1891-1936):

ANÁLISIS DE LOS LIBROS ESCOLARES

3.4.29. Ilustraciones interiores en blanco y negro del libro Patachín Patachán de la Biblioteca Colección del Papa-Moscas.

3.4.30 Ilustraciones sobre dibujos del natural en la Exposición Internacional de Barcelona en 1929 realizados para la editorial Hijos de Santiago Rodríguez en Mi Libro Ideal de la Biblioteca Paz. 
3.4.1. Tira cómica de Mi Libro de Estampas y Cuentos de la Biblioteca Paz.

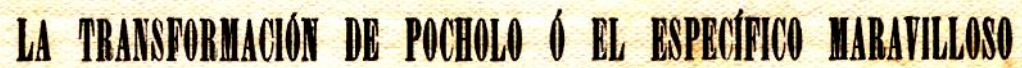
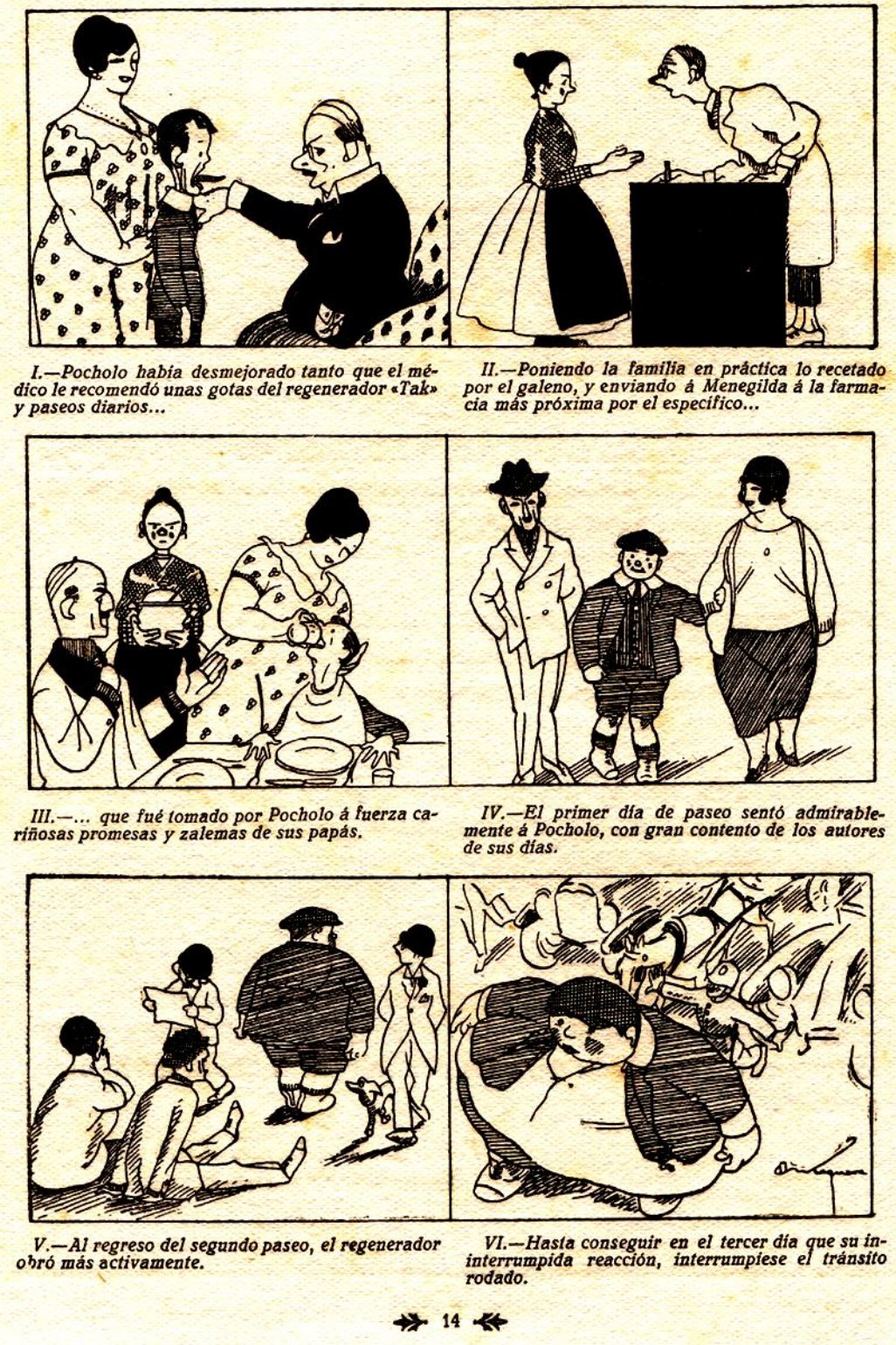

Fig.: 100

Tira cómica del libro Mi Libro de Estampas y Cuentos.

Biblioteca Paz. Hijos de Santiago Rodríguez. 
LA EDITORIAL BURGALESA HIJOS DE SANTIAGO RODRÍGUEZ (1891-1936): ANÁLISIS DE LOS LIBROS ESCOLARES

3.4.2. Ilustración a color del cuento El niño que quería ser rey que forma parte del libro Contando Cuentos de la Biblioteca Rodríguez.

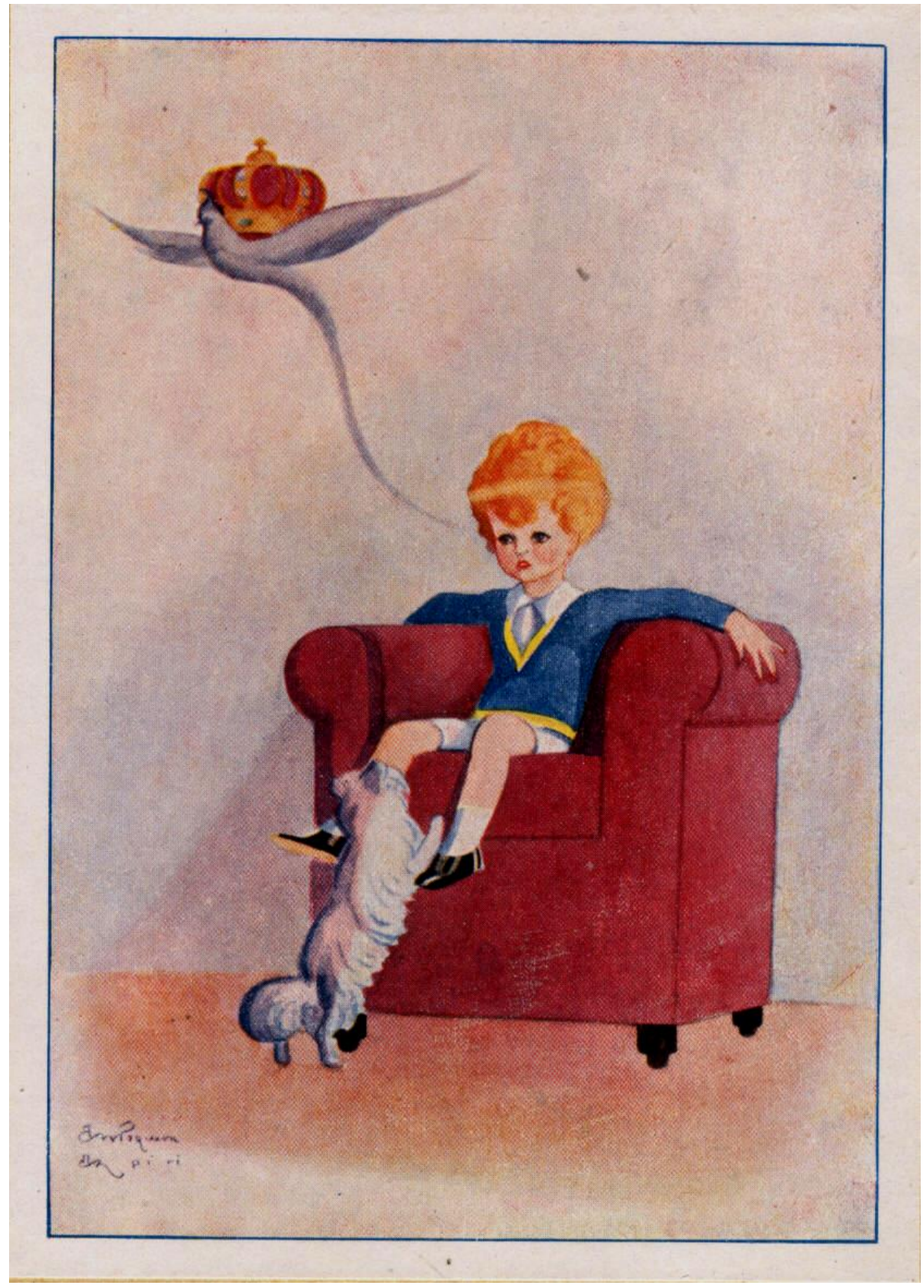

Fig.: 101

Ilustración del cuento El niño que quería ser rey del libro Contando cuentos. Biblioteca Rodríguez. Hijos de Santiago Rodríguez. 
3.4.3. Ilustración a color del cuento La tripita que forma parte del libro Contando Cuentos de la Biblioteca Rodríguez.

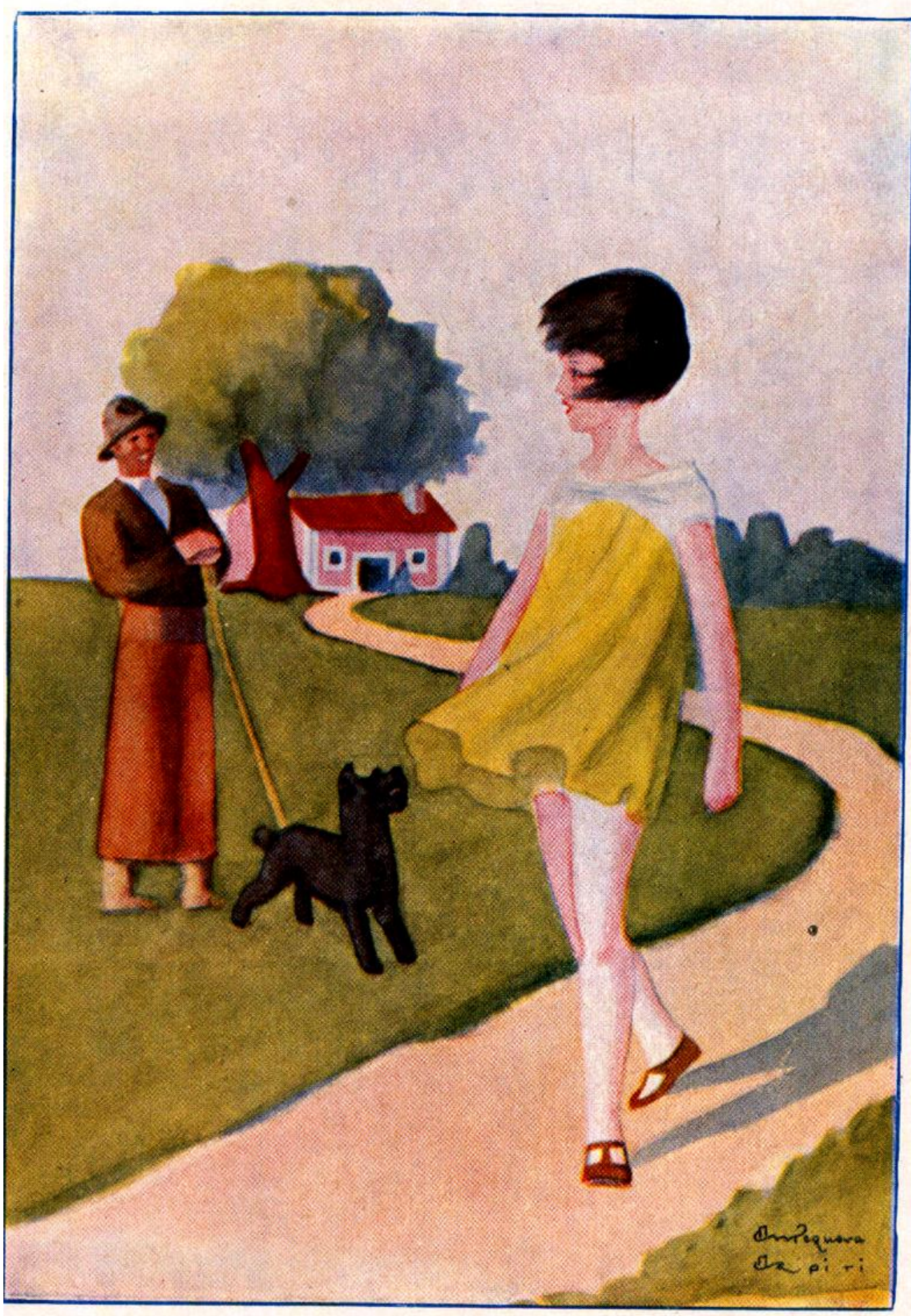

Fig.: 102

Ilustración del cuento La tripita del libro Contando Cuentos.

Biblioteca Rodríguez. Hijos de Santiago Rodríguez. 
LA EDITORIAL BURGALESA HIJOS DE SANTIAGO RODRÍGUEZ (1891-1936): ANÁLISIS DE LOS LIBROS ESCOLARES

3.4.4. Ilustración a color del cuento La grulla que forma parte del libro Contando Cuentos de la Biblioteca Rodríguez.

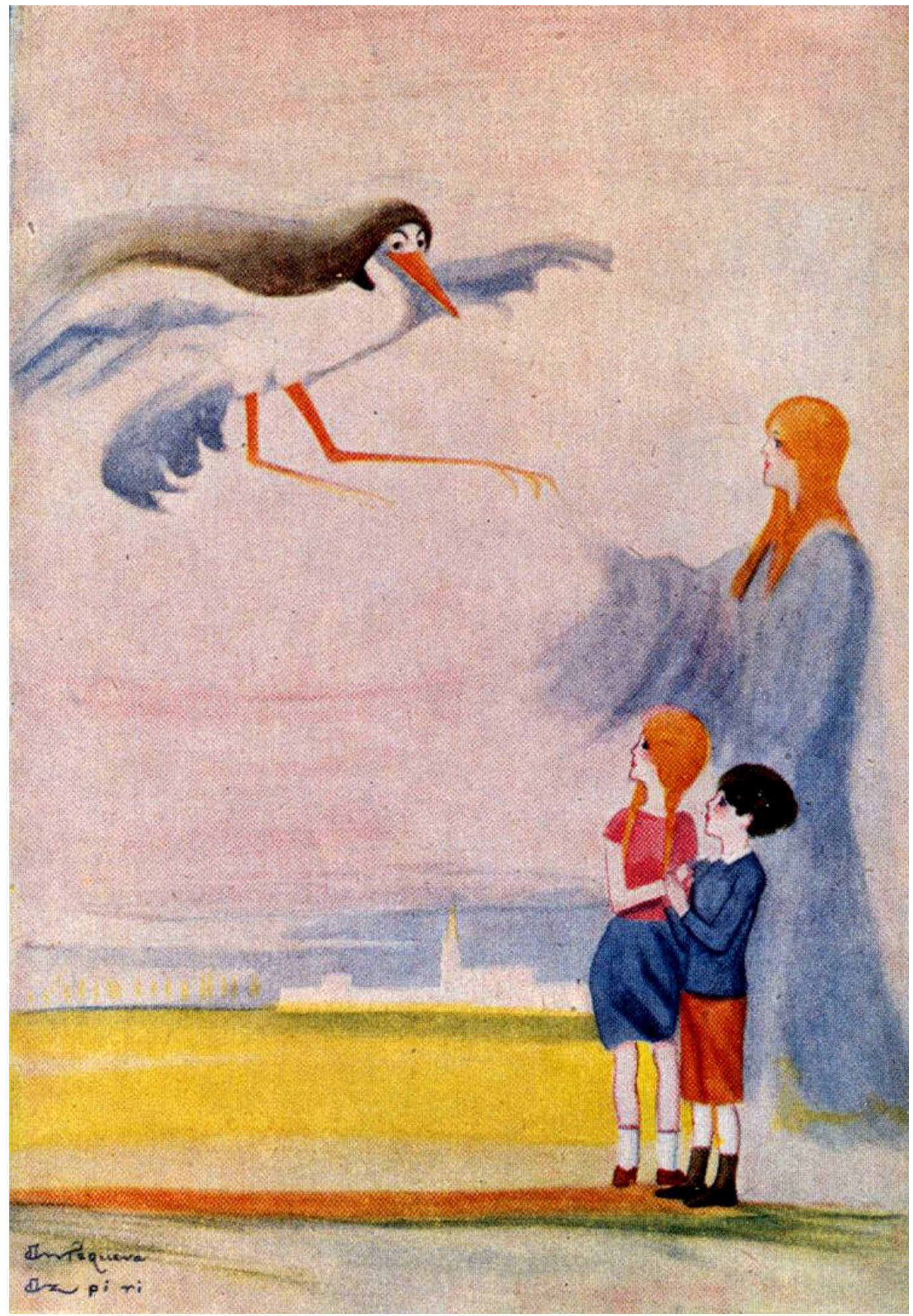

Fig.: 103

Ilustración del cuento La grulla del libro Contando Cuentos. Biblioteca Rodríguez. Hijos de Santiago Rodríguez. 
3.4.5. Ilustración a color del cuento La aventura de Pipo que forma parte del libro Contando Cuentos de la Biblioteca Rodríguez.

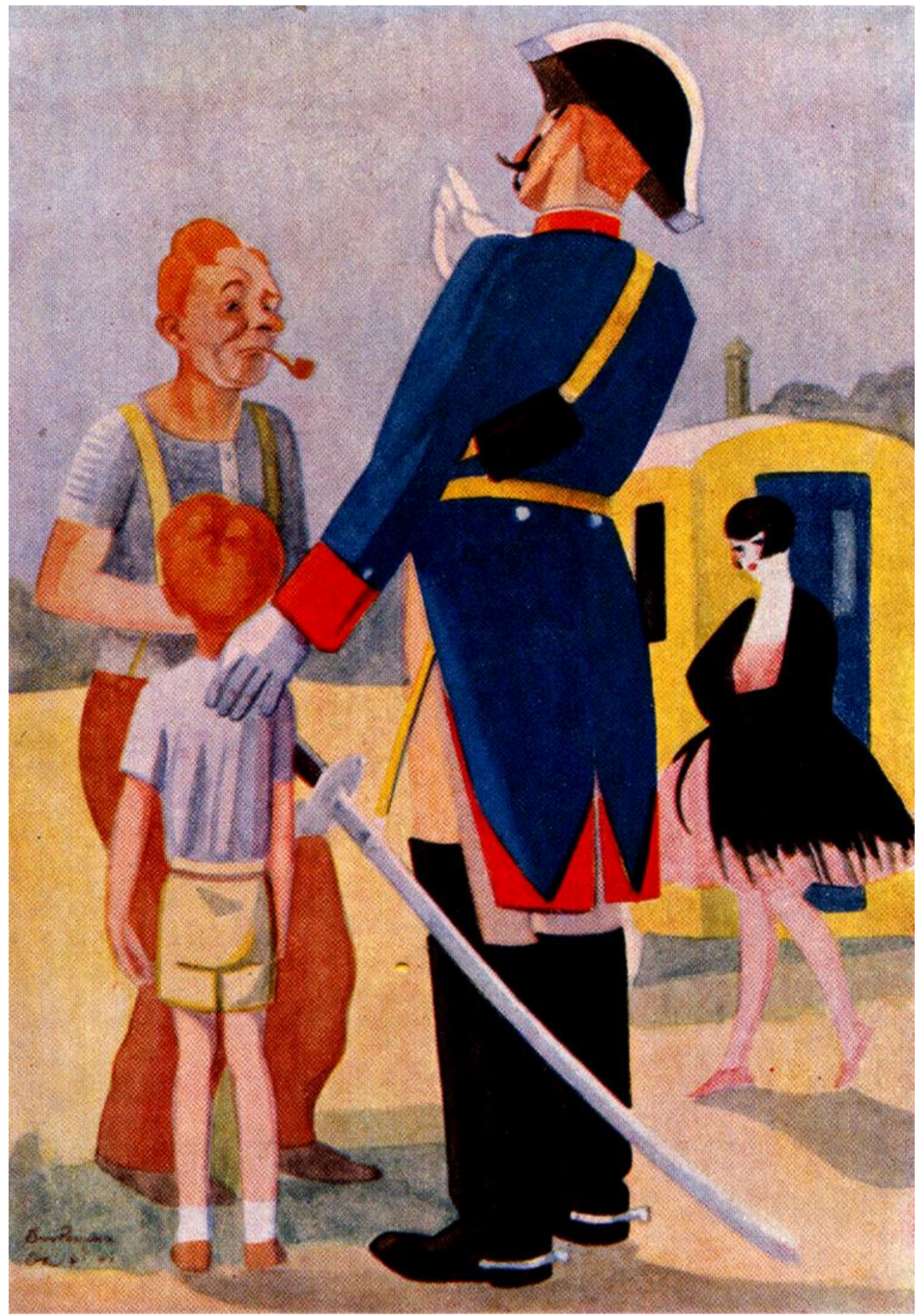

Fig.: 104

Ilustración del cuento La aventura de Pipo del libro Contando Cuentos. Biblioteca Rodríguez. Hijos de Santiago Rodríguez. 
LA EDITORIAL BURGALESA HIJOS DE SANTIAGO RODRÍGUEZ (1891-1936): ANÁLISIS DE LOS LIBROS ESCOLARES

3.4.6. Ilustración a color del cuento Las discusiones fantásticas que forma parte del libro Contando Cuentos de la Biblioteca Rodríguez.

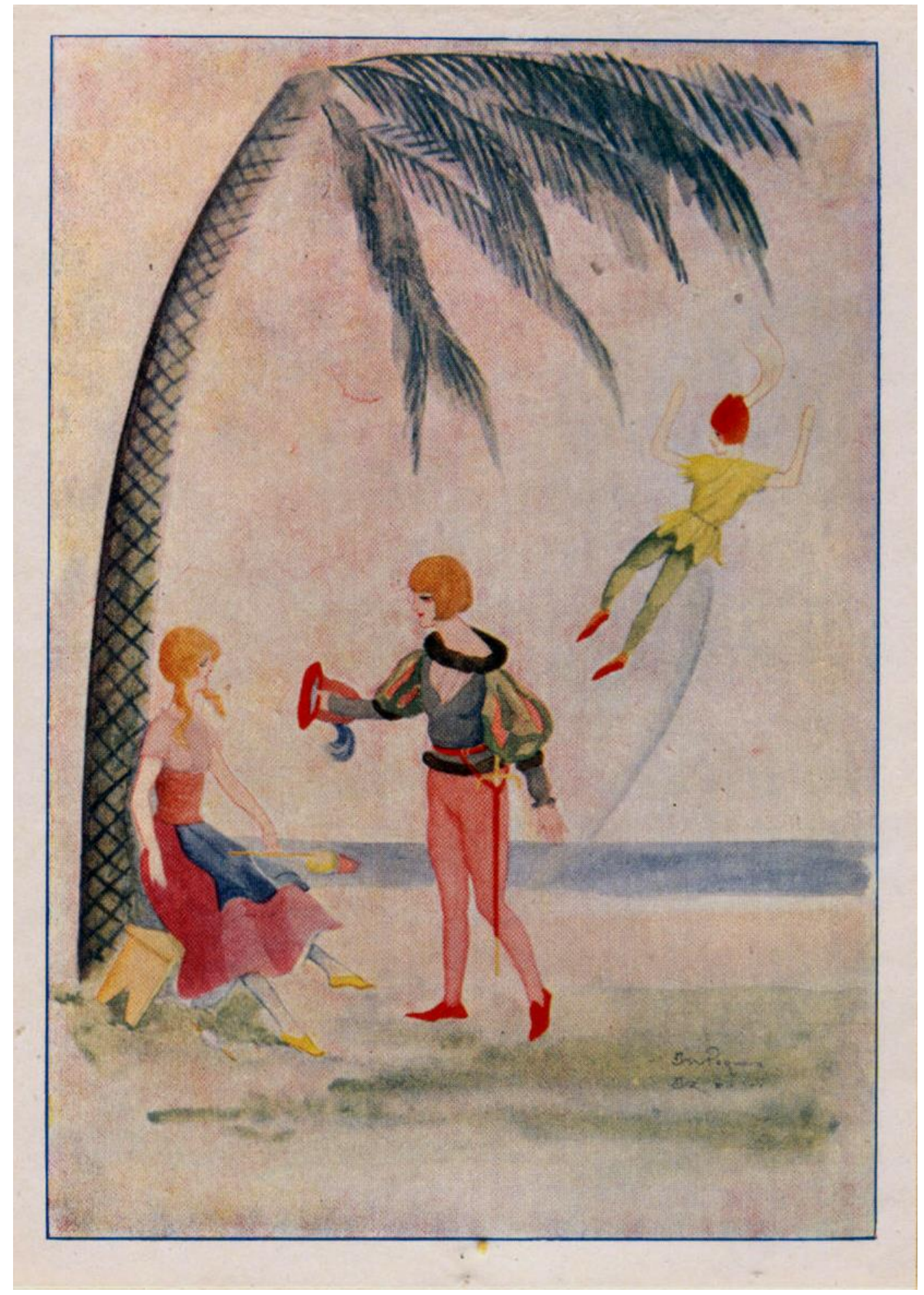

Fig.: 105

Ilustración del cuento Las discusiones fantásticas del libro Contando Cuentos. Biblioteca Rodríguez. Hijos de Santiago Rodríguez. 
3.4.7. Ilustración interior a color del libro La larva y el águila de la Biblioteca Cuentos Nuevos en Colores.

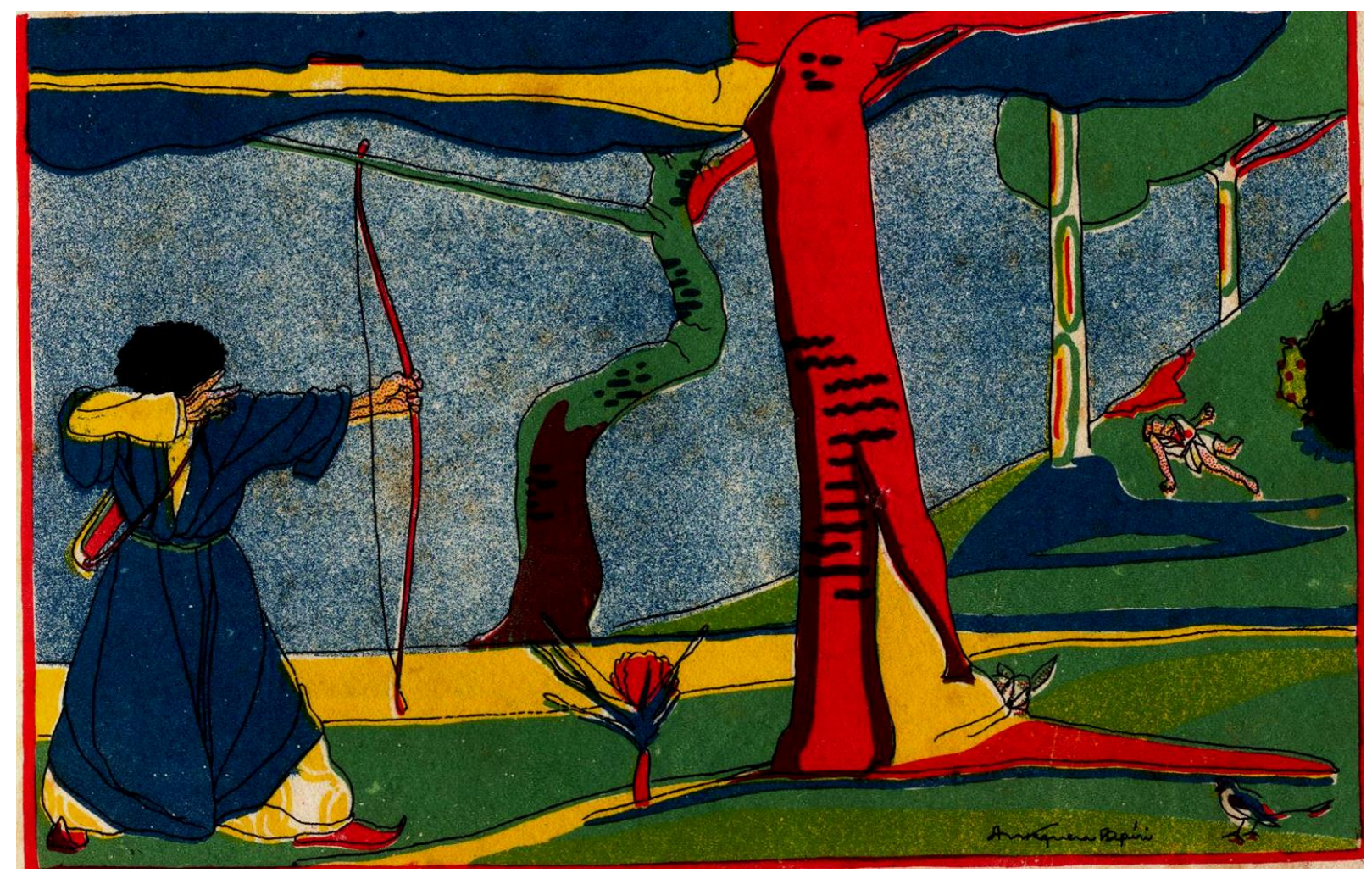

Fig.: 106

Ilustración interior del libro La larva y el Águila.

Biblioteca Cuentos Nuevos en Colores. Hijos de Santiago Rodríguez. 
LA EDITORIAL BURGALESA HIJOS DE SANTIAGO RODRÍGUEZ (1891-1936): ANÁLISIS DE LOS LIBROS ESCOLARES

3.4.8. Ilustraciones interiores a color del libro Mikolán y Cía de la Biblioteca Cuentos Nuevos en Colores.
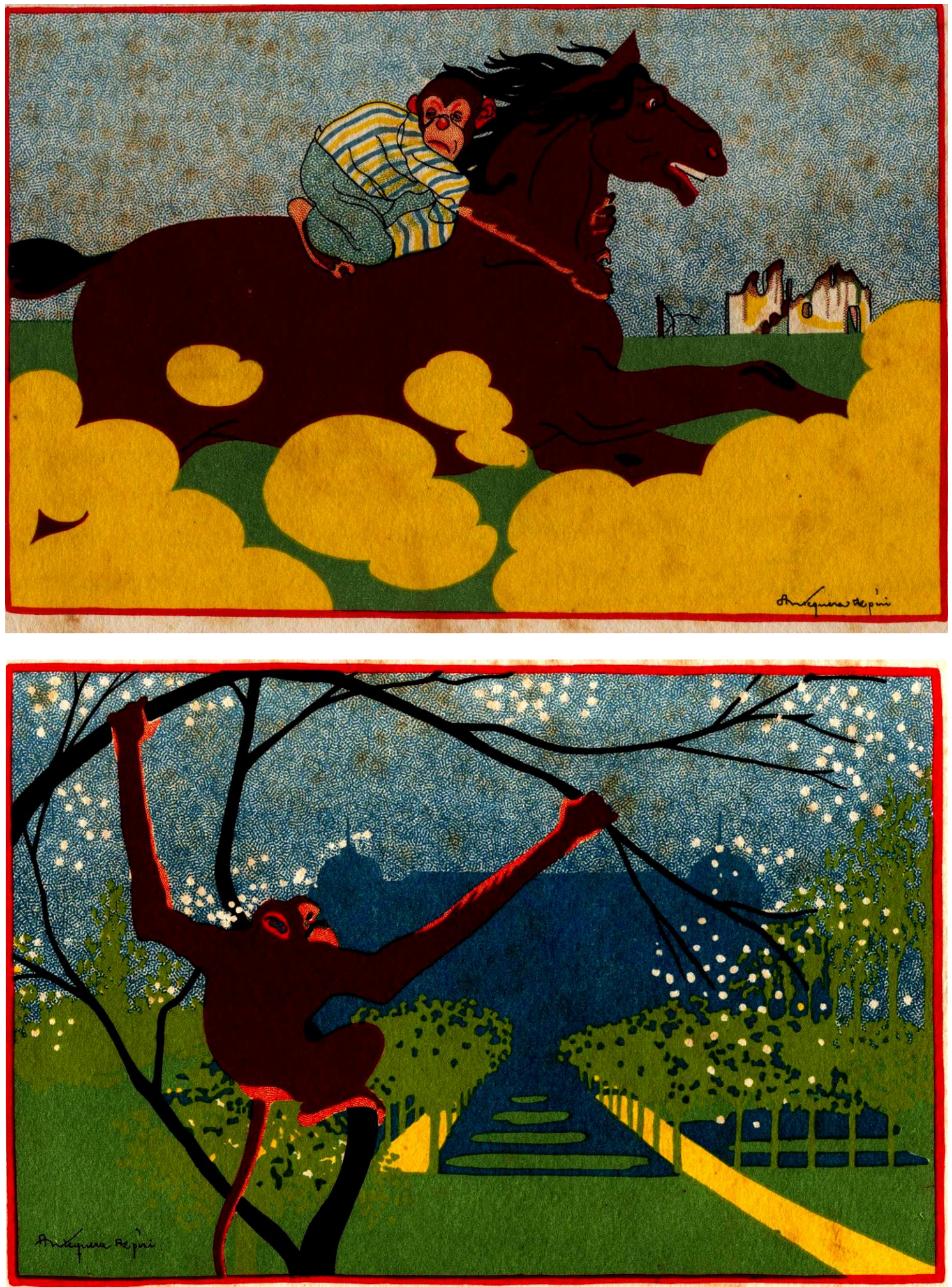

Fig.: 107

Ilustraciones interiores del libro Mikolán y Cía. Biblioteca Cuentos Nuevos en Colores. Hijos de Santiago Rodríguez. 
3.4.9. Ilustración interior a color del libro Los tres sorianitos de la Biblioteca Rodríguez (I).

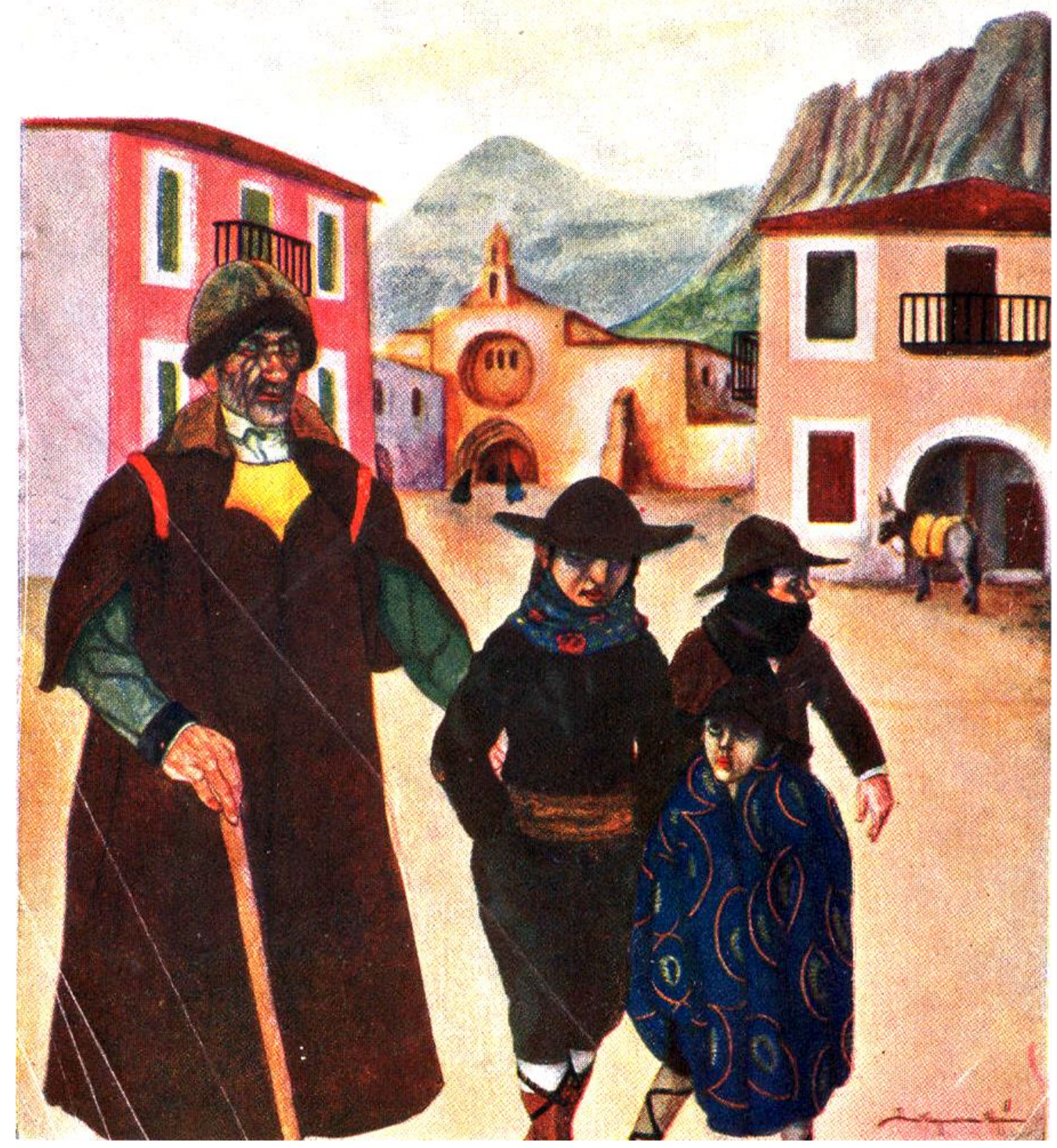

Fig.: 108

Ilustración a color interior del libro Los tres sorianitos.

Biblioteca Rodríguez. Hijos de Santiago Rodríguez. 
LA EDITORIAL BURGALESA HIJOS DE SANTIAGO RODRÍGUEZ (1891-1936): ANÁLISIS DE LOS LIBROS ESCOLARES

3.4.10. Ilustración interior a color del libro Los tres sorianitos de la Biblioteca Rodríguez (II).

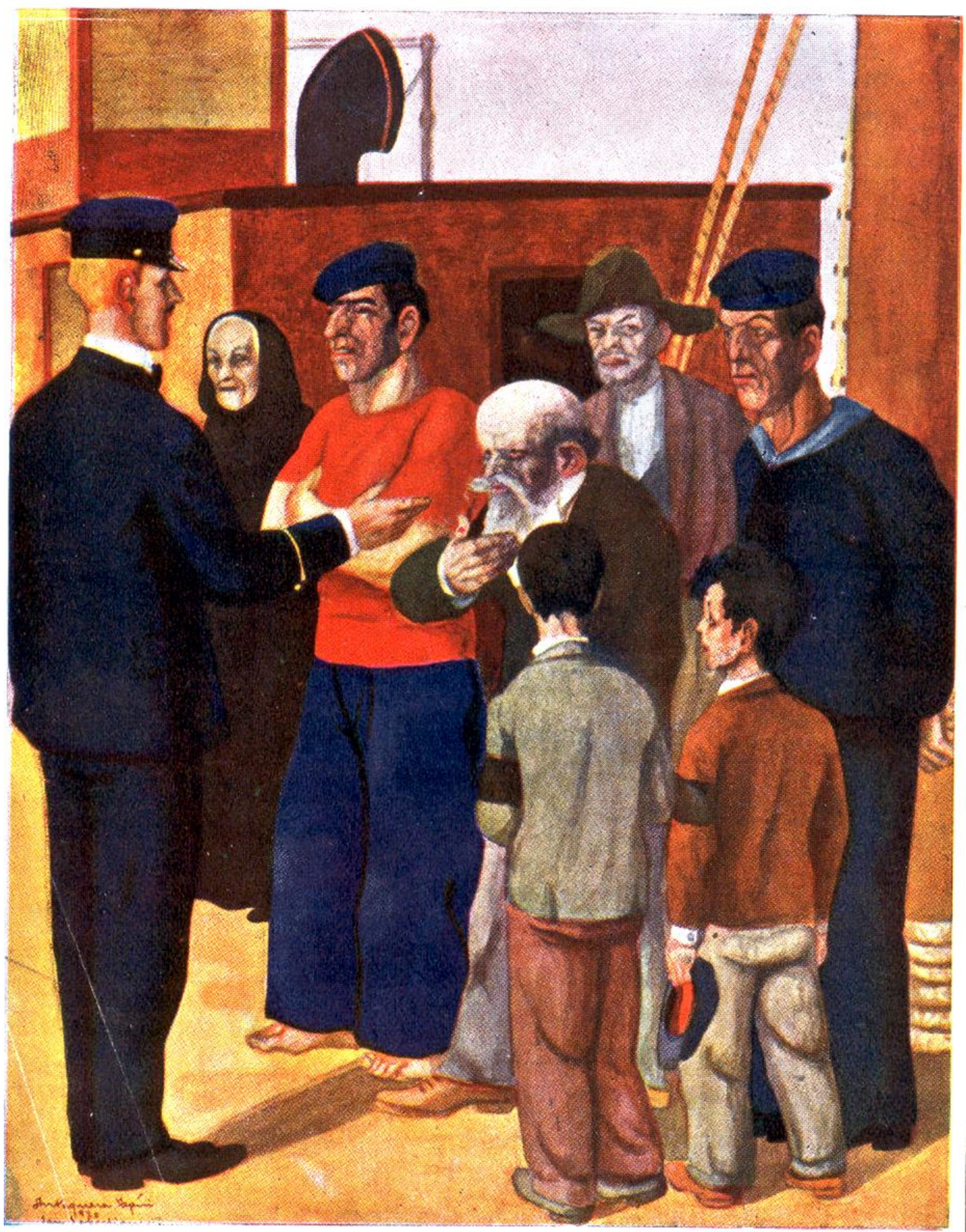

Fig.: 109

Ilustración interior del libro Los tres sorianitos.

Biblioteca Rodríguez. Hijos de Santiago Rodríguez. 
3.4.11. Ilustración interior a color del libro Los tres sorianitos de la Biblioteca Rodríguez (III).

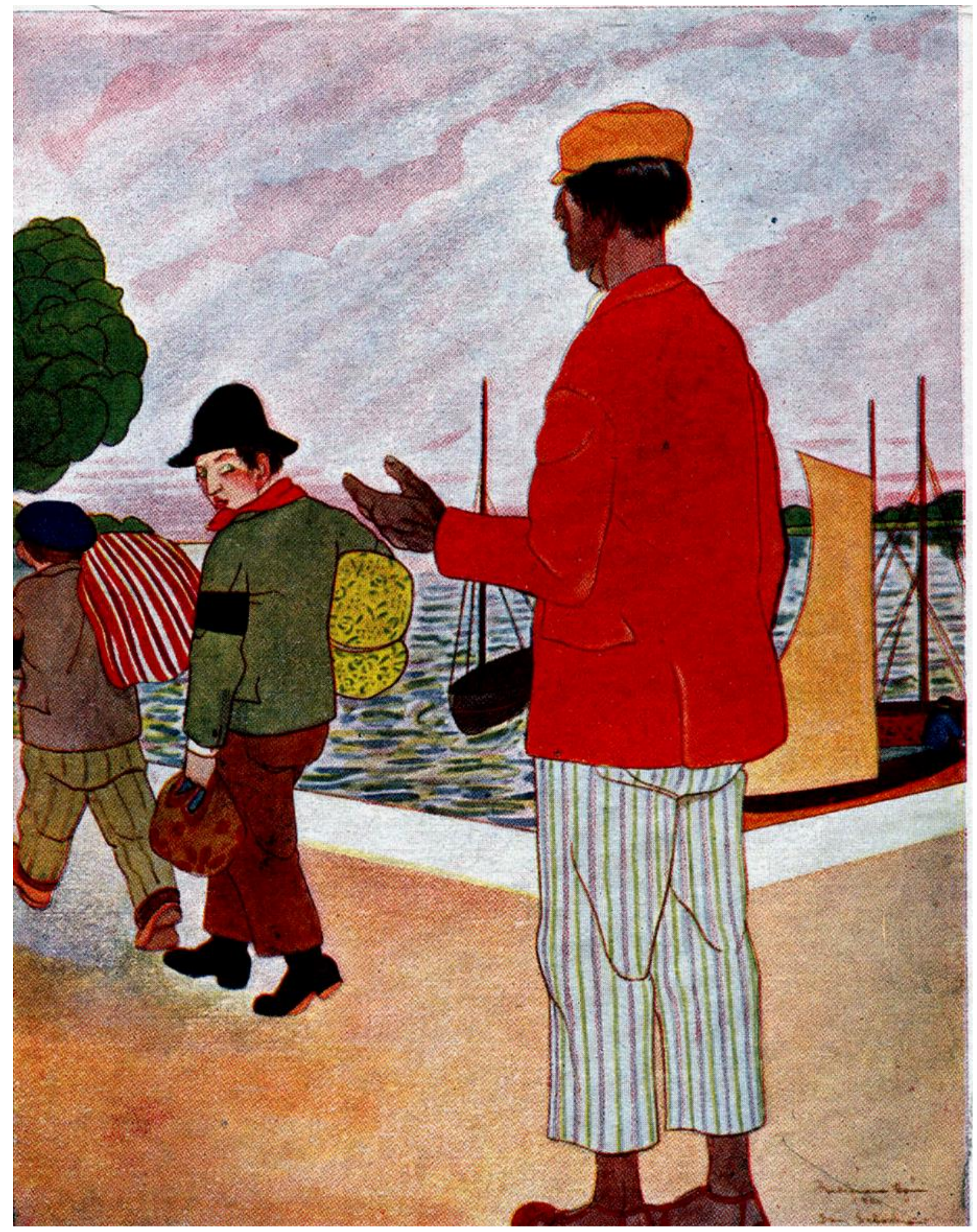

Fig.: 110

Ilustración interior del libro Los tres sorianitos.

Biblioteca Rodríguez. Hijos de Santiago Rodríguez. 
LA EDITORIAL BURGALESA HIJOS DE SANTIAGO RODRÍGUEZ (1891-1936): ANÁLISIS DE LOS LIBROS ESCOLARES

3.4.12. Ilustración interior a color del libro Los tres sorianitos de la Biblioteca Rodríguez (IV).

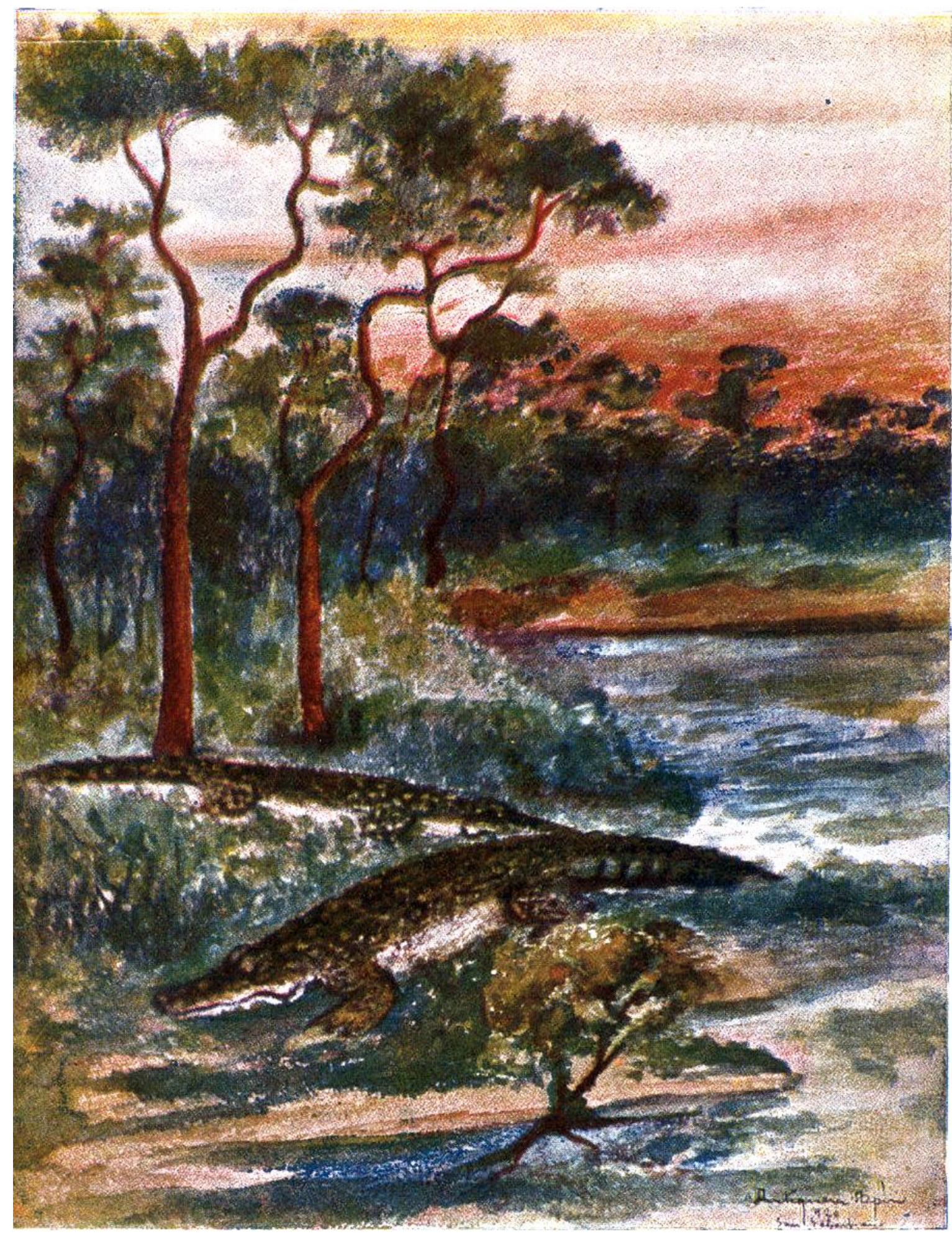

Fig.: 111

Ilustración interior del libro Los tres sorianitos.

Biblioteca Rodríguez. Hijos de Santiago Rodríguez. 
3.4.13. Ilustración interior a color del libro Los tres sorianitos de la Biblioteca Rodríguez (V).

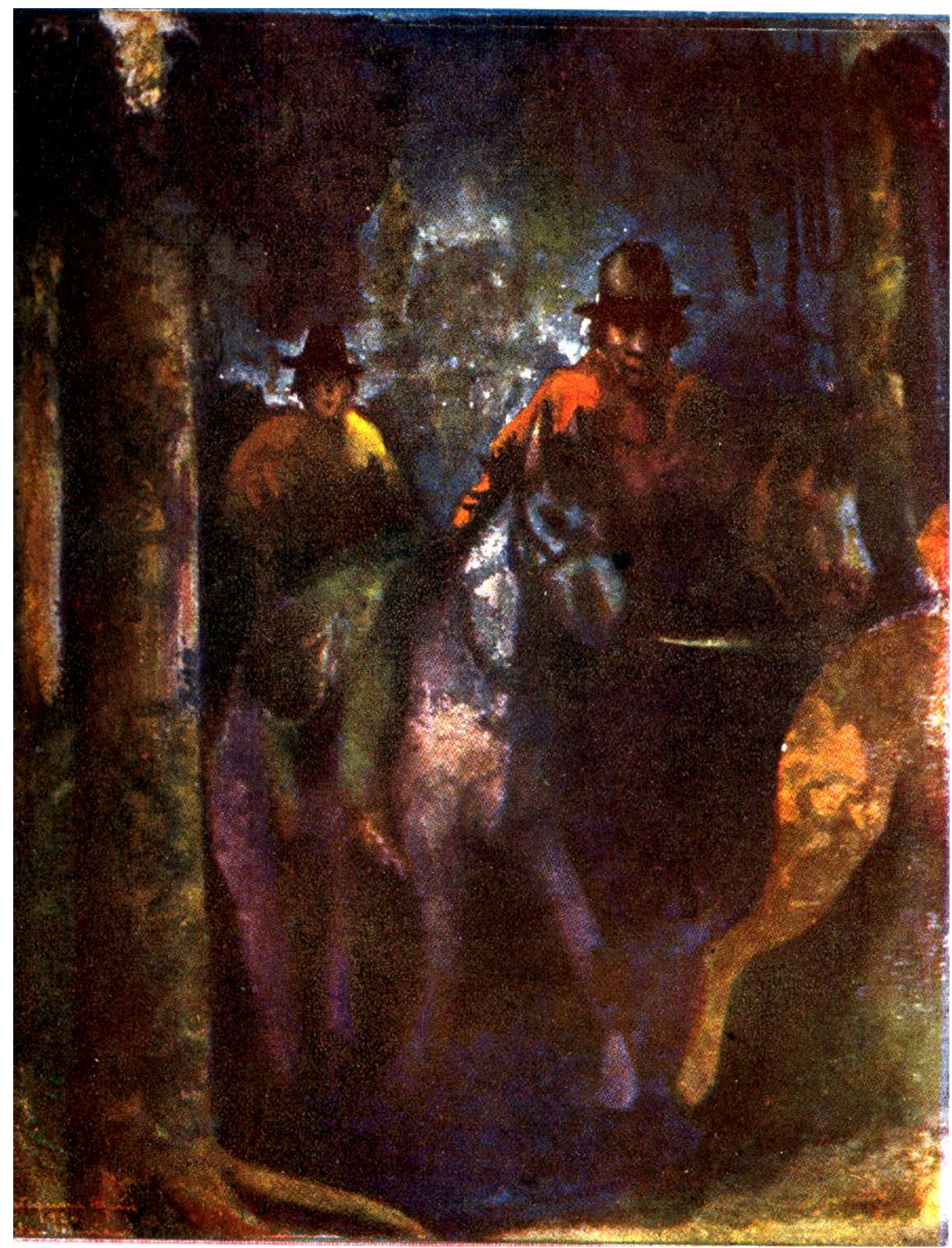

Fig.: 112

Ilustración interior del libro Los tres sorianitos.

Biblioteca Rodríguez. Hijos de Santiago Rodríguez. 
LA EDITORIAL BURGALESA HIJOS DE SANTIAGO RODRÍGUEZ (1891-1936): ANÁLISIS DE LOS LIBROS ESCOLARES

3.4.14. Ilustración interior bicolor del libro Patachín Patachán de la Biblioteca Colección Papa-Moscas.

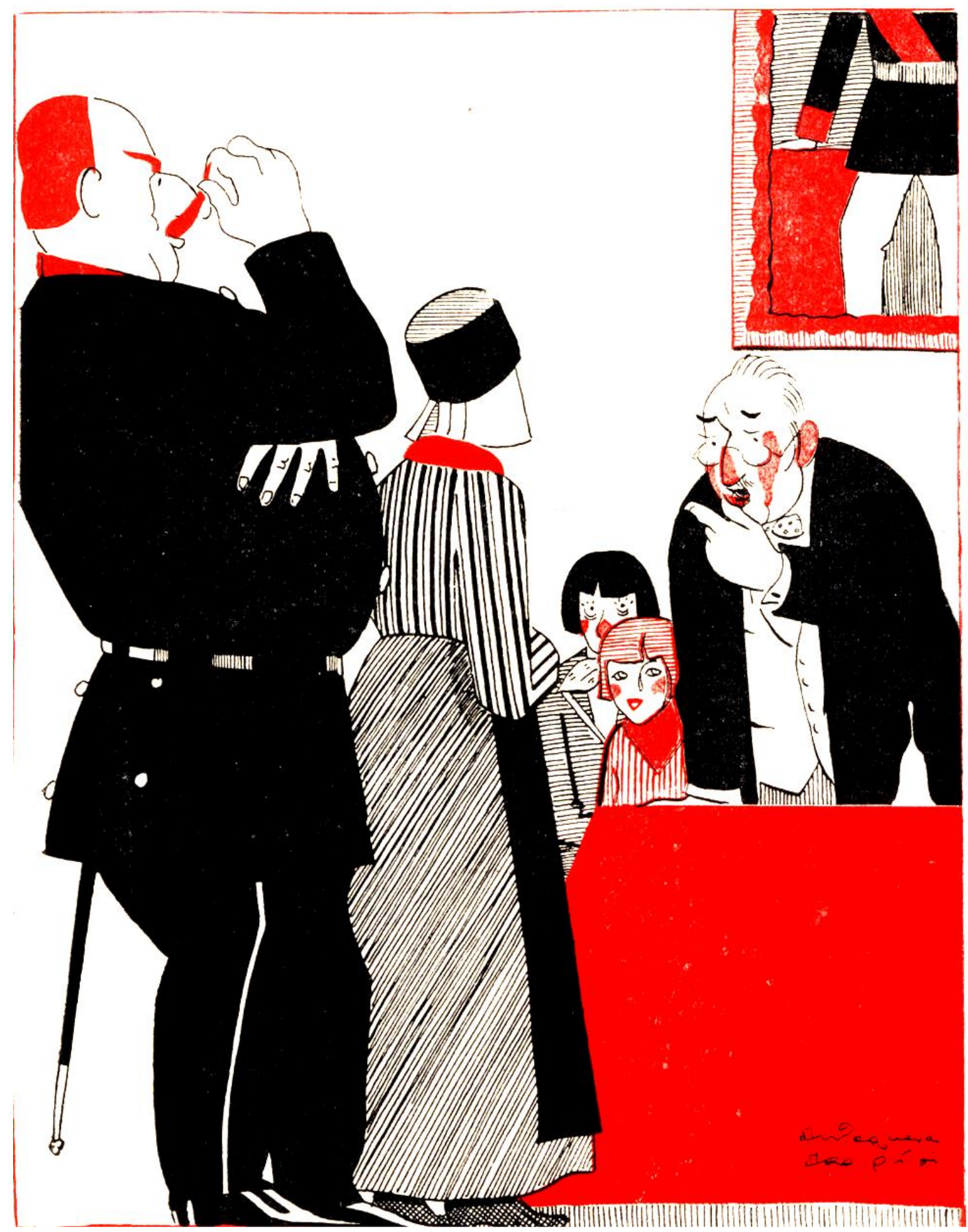

Fig.: 113

Ilustración interior del libro Patachín Patachán.

Biblioteca Colección Papa-Moscas. Hijos de Santiago Rodríguez. 
3.4.15. Ilustración interior en blanco y negro del cuento El niño que quería ser rey del libro Contando Cuentos de la Biblioteca Rodríguez.

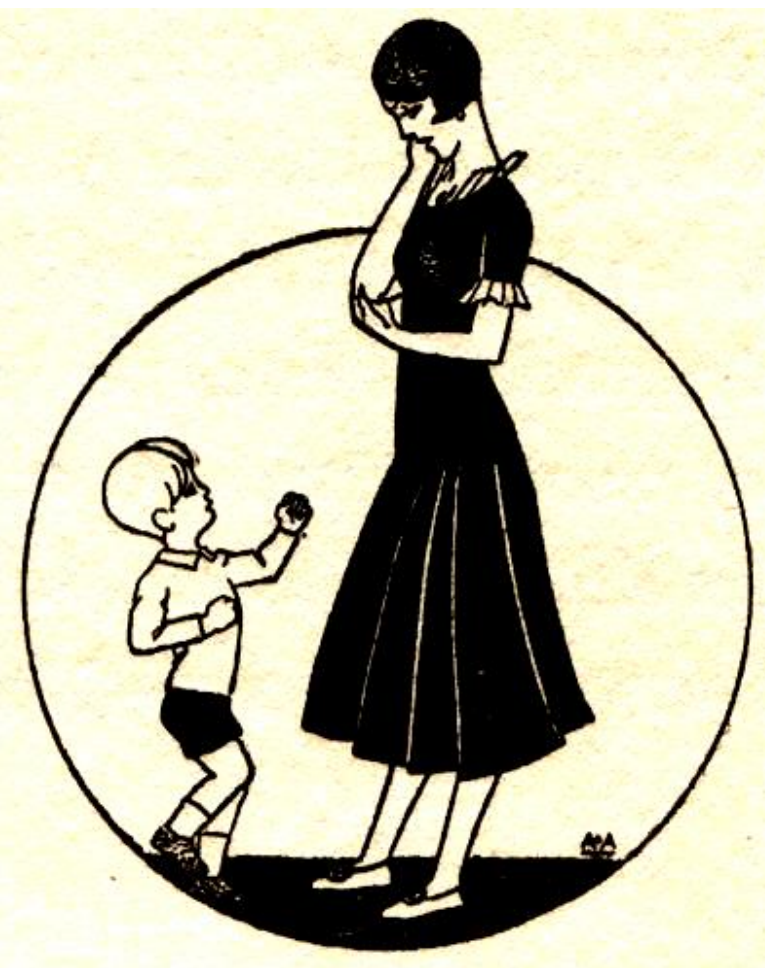

Fig.: 114

Ilustración interior del cuento El niño que quería ser rey del libro Contando Cuentos. Biblioteca Rodríguez. Hijos de Santiago Rodríguez.

3.4.16. Ilustración interior en blanco y negro del cuento La tripita del libro Contando Cuentos de la Biblioteca Rodríguez.

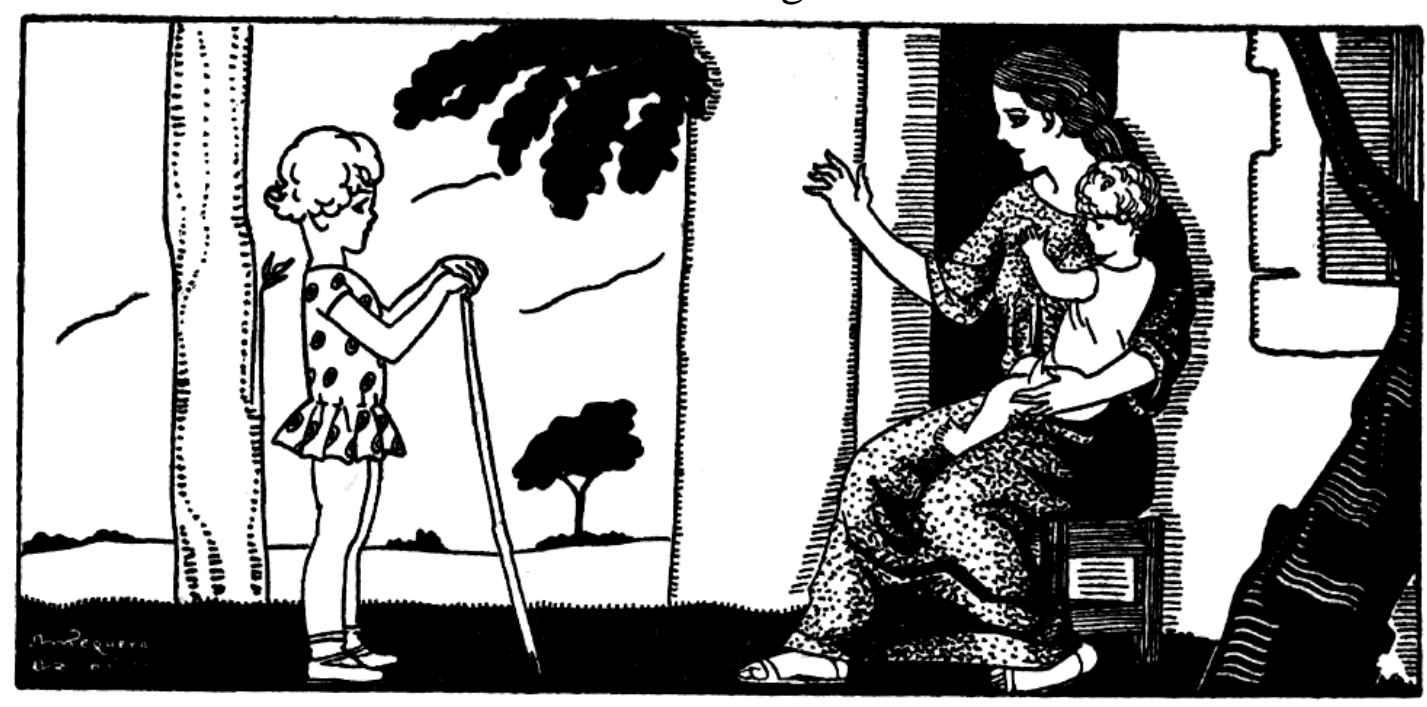

Fig.: 115

Ilustración interior del cuento La tripita del libro Contando Cuentos. Biblioteca Rodríguez. Hijos de Santiago Rodríguez. 
3.4.17. Ilustración interior en blanco y negro del cuento El Sol por salir, del libro Contando Cuentos de la Biblioteca Rodríguez.

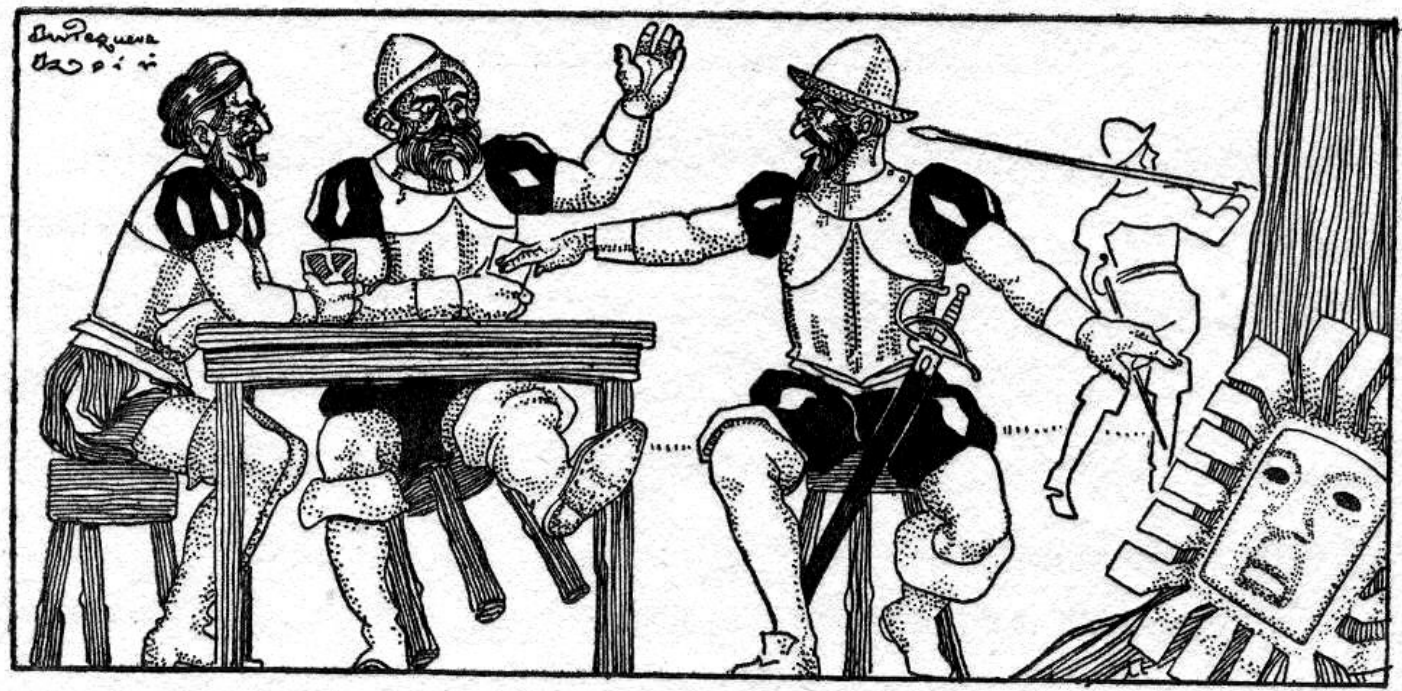

Fig.: 116

Ilustración interior del cuento El Sol por salir del libro Contando Cuentos. Biblioteca Rodríguez. Hijos de Santiago Rodríguez.

3.4.18. Ilustración interior en blanco y negro del cuento Fifina del libro Contando Cuentos de la Biblioteca Rodríguez.

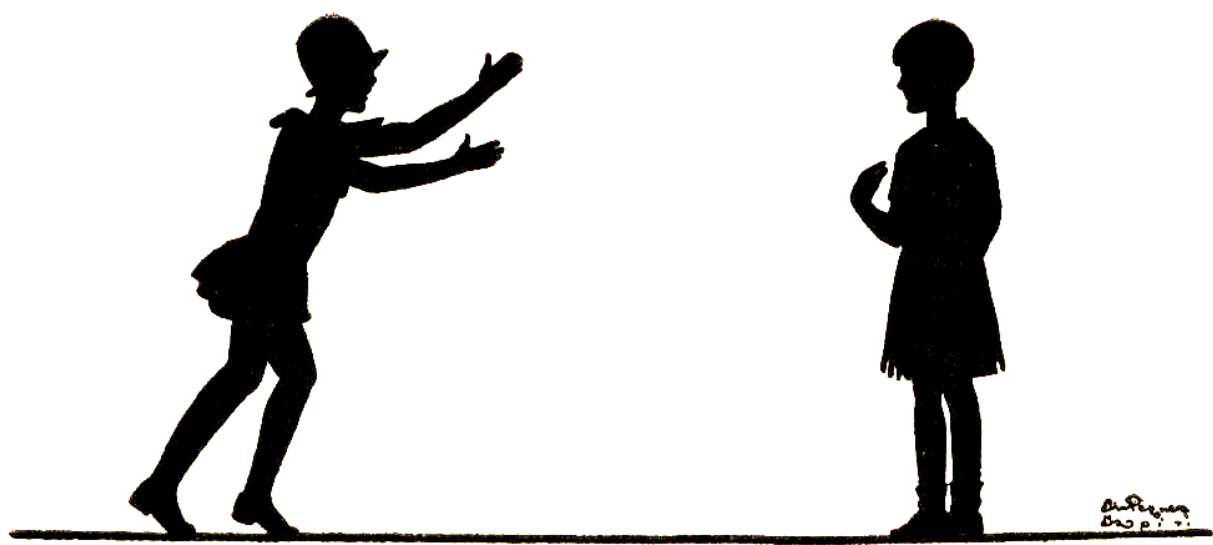

Fig.: 117

Ilustración interior del cuento Fifina del libro Contando Cuentos. Biblioteca Rodríguez. 
3.4.19. Ilustración interior final en blanco y negro del cuento Fifina del libro Contando Cuentos de la Biblioteca Rodríguez.

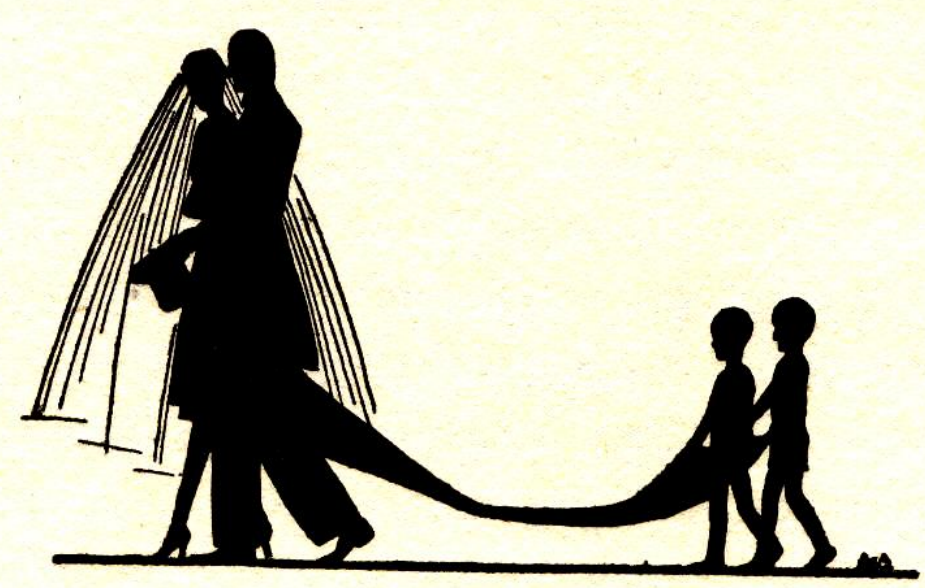

Fig.: 118

Ilustración interior final del cuento Fifina del libro Contando Cuentos. Biblioteca Rodríguez. Hijos de Santiago Rodríguez.

3.4.20. Ilustración interior final en blanco y negro del cuento Con pautas torcidas renglones derechos del libro Contando Cuentos de la Biblioteca Rodríguez.

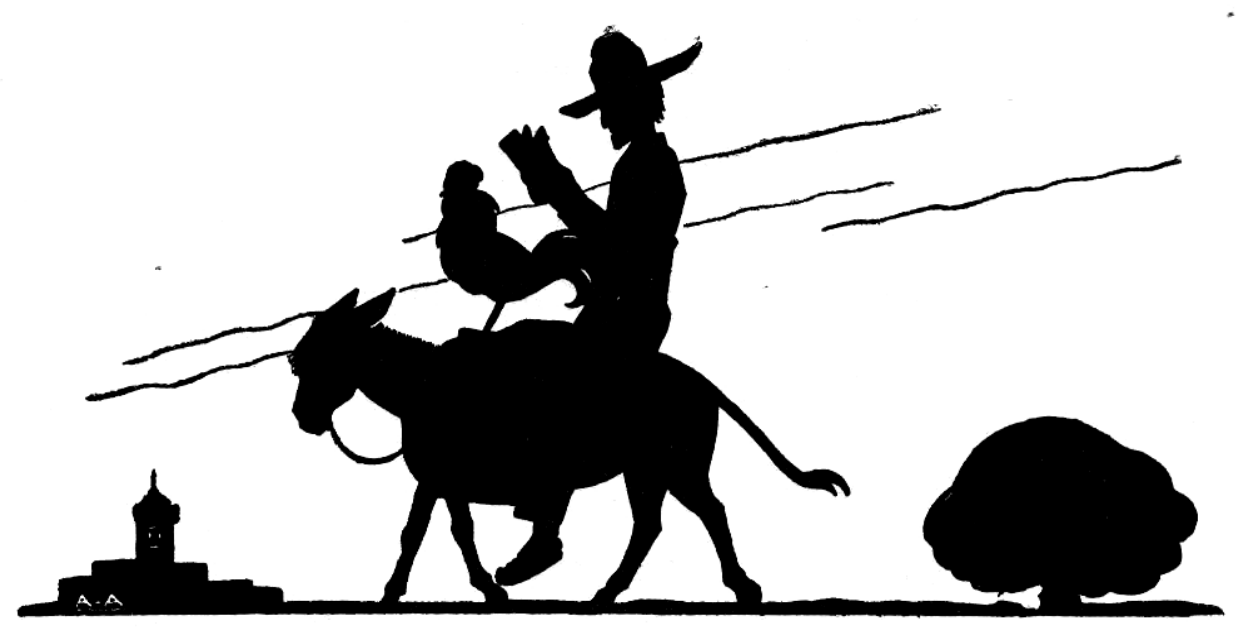

Fig.: 119

Ilustración interior del cuento Con pautas torcidas renglones derechos libro Contando Cuentos. Biblioteca Rodríguez. Hijos de Santiago Rodríguez. 
3.4.21. Ilustración interior en blanco y negro del Epílogo del libro Contando Cuentos de la Biblioteca Rodríguez.

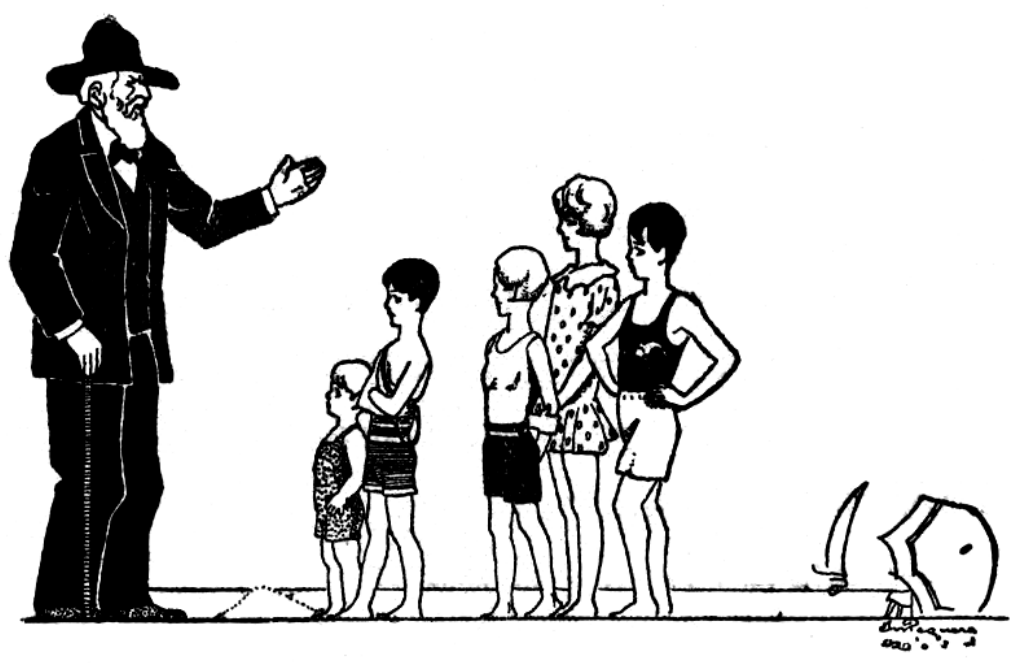

Fig.: 120

Ilustración interior del Epílogo del libro Contando Cuentos. Biblioteca Rodríguez. Hijos de Santiago Rodríguez.

3.4.22. Ilustración interior en blanco y negro del libro Los tres sorianitos de la Biblioteca Rodríguez.

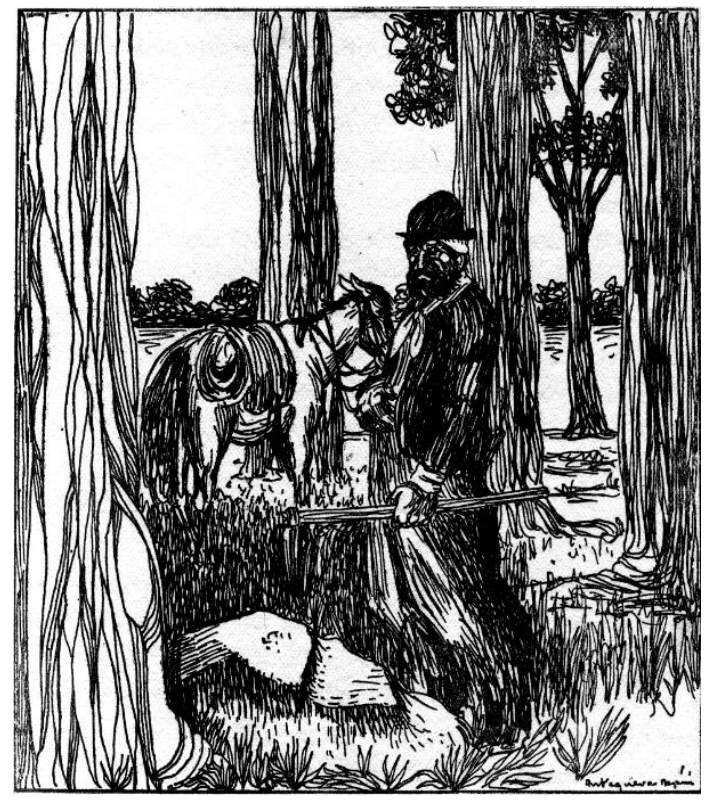

Fig.: 121

Ilustraciones interiores del libro Los tres sorianitos. Biblioteca Rodríguez. Hijos de Santiago Rodríguez. 
3.4.23. Ilustraciones interiores bicolor del libro Los tres sorianitos de la Biblioteca Rodríguez (I).
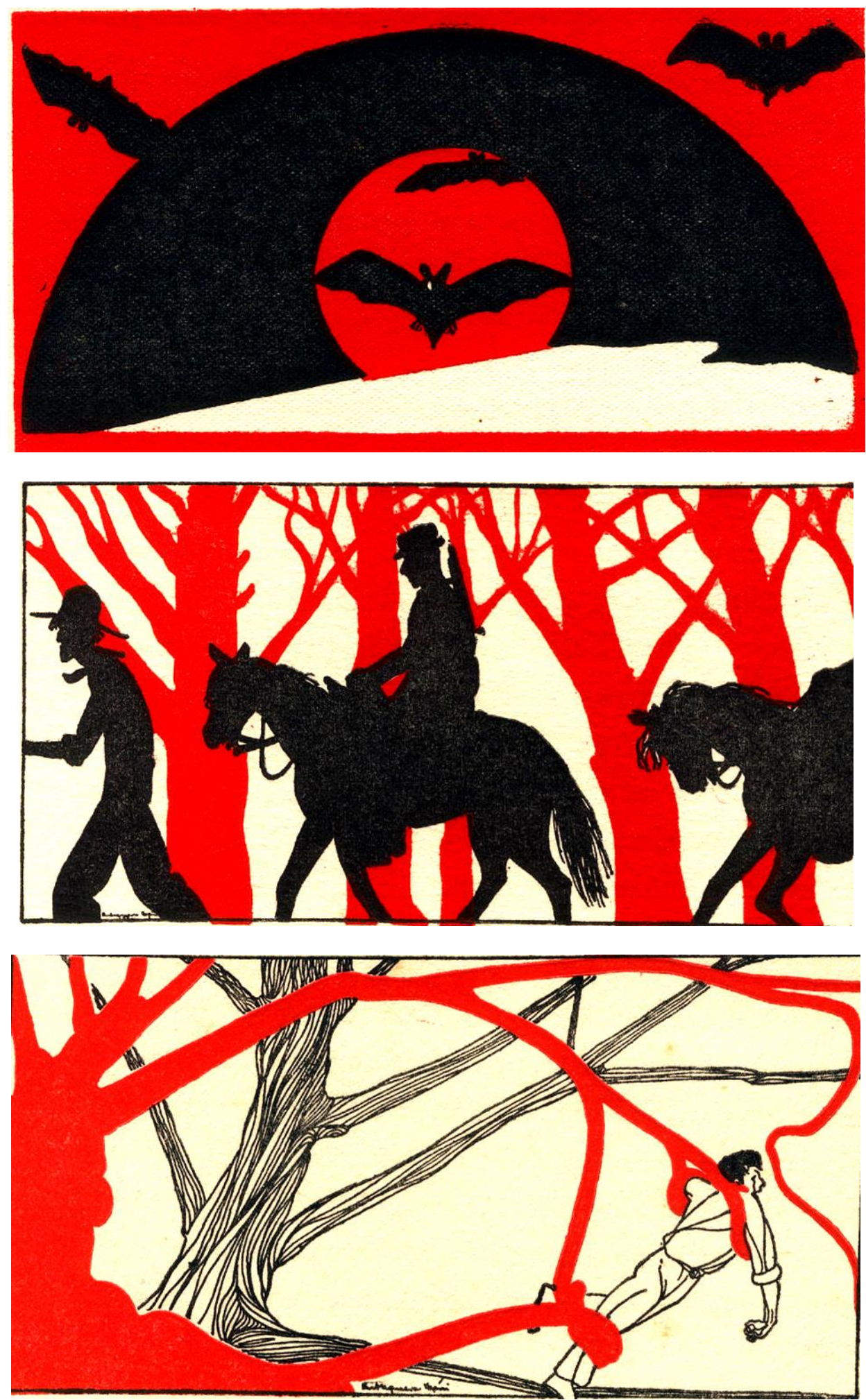

Fig.: 122

Ilustraciones interiores del libro Los tres sorianitos. Biblioteca Rodríguez. Hijos de Santiago Rodríguez. 
LA EDITORIAL BURGALESA HIJOS DE SANTIAGO RODRÍGUEZ (1891-1936): ANÁLISIS DE LOS LIBROS ESCOLARES

3.4.24. Ilustraciones interiores bicolor del libro Los tres sorianitos de la Biblioteca Rodríguez (II).
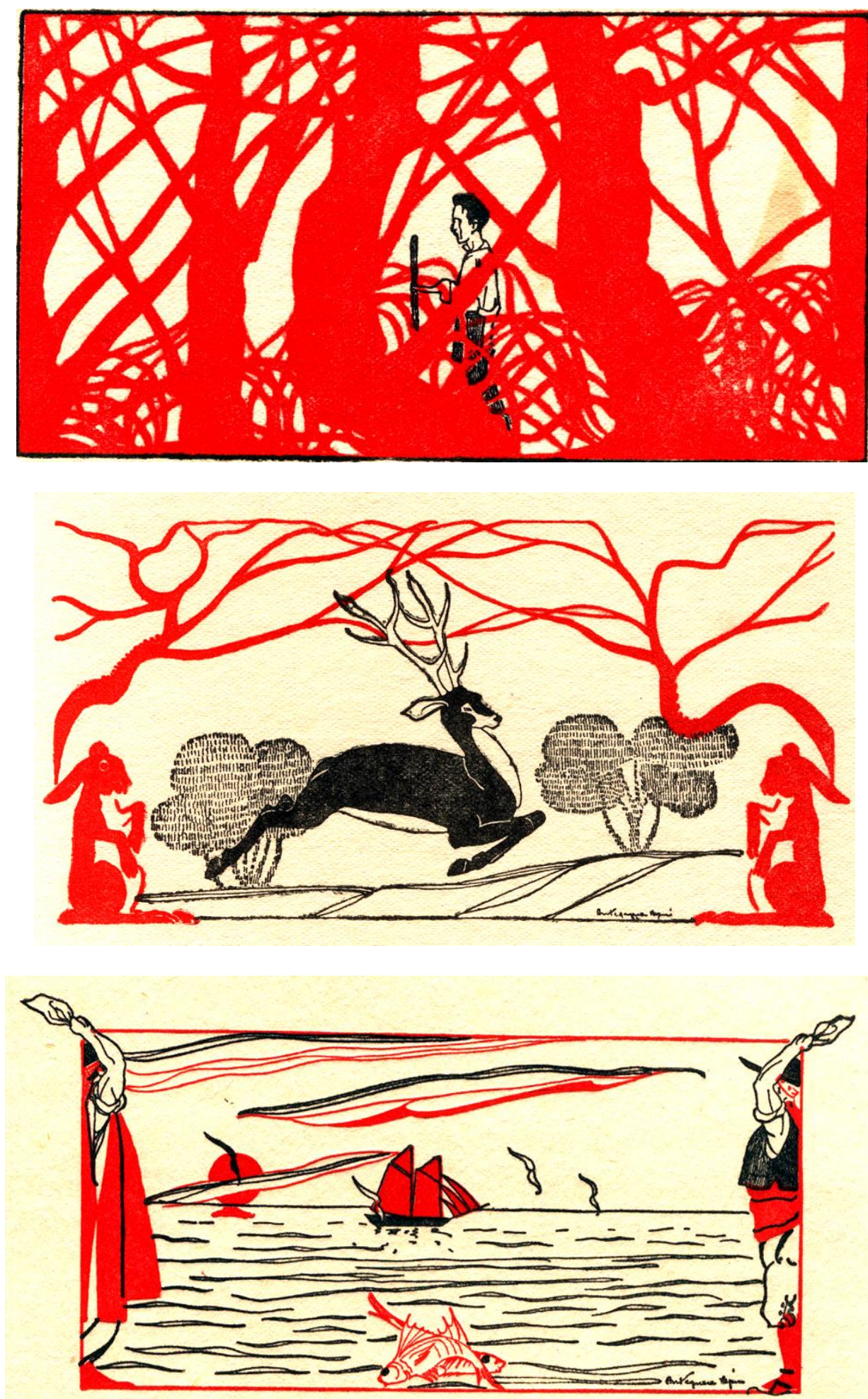

Fig.: 123

Ilustraciones interiores del libro Los tres sorianitos. Biblioteca Rodríguez. Hijos de Santiago Rodríguez. 
3.4.25. Ilustraciones interiores bicolor del libro Los tres sorianitos de la Biblioteca Rodríguez (III).
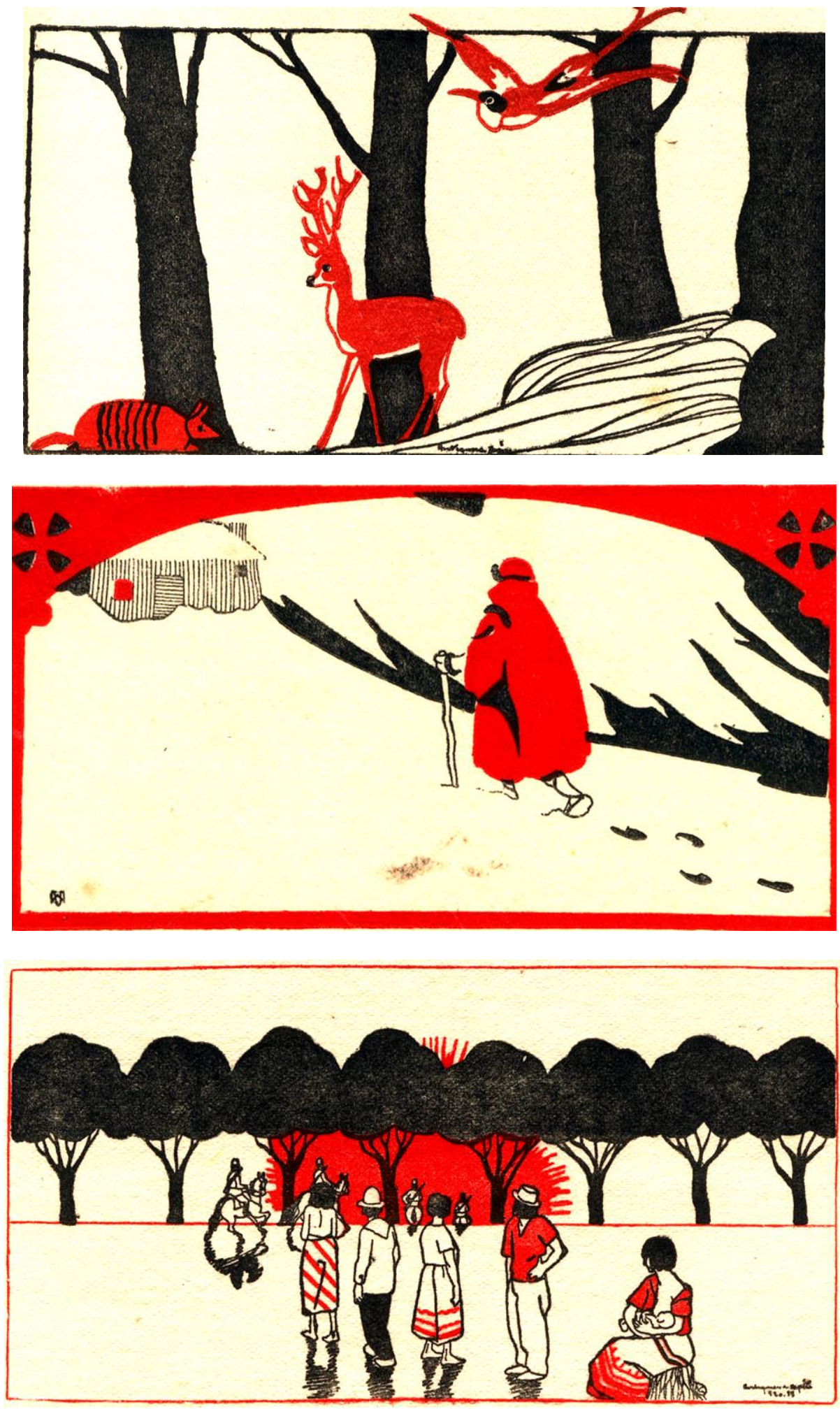

Fig.: 124

Ilustraciones interiores del libro Los tres sorianitos. Biblioteca Rodríguez. Hijos de Santiago Rodríguez. 
3.4.26. Ilustración en blanco y negro del libro Mikolán y Cía de la Biblioteca Cuentos Nuevos en Colores.

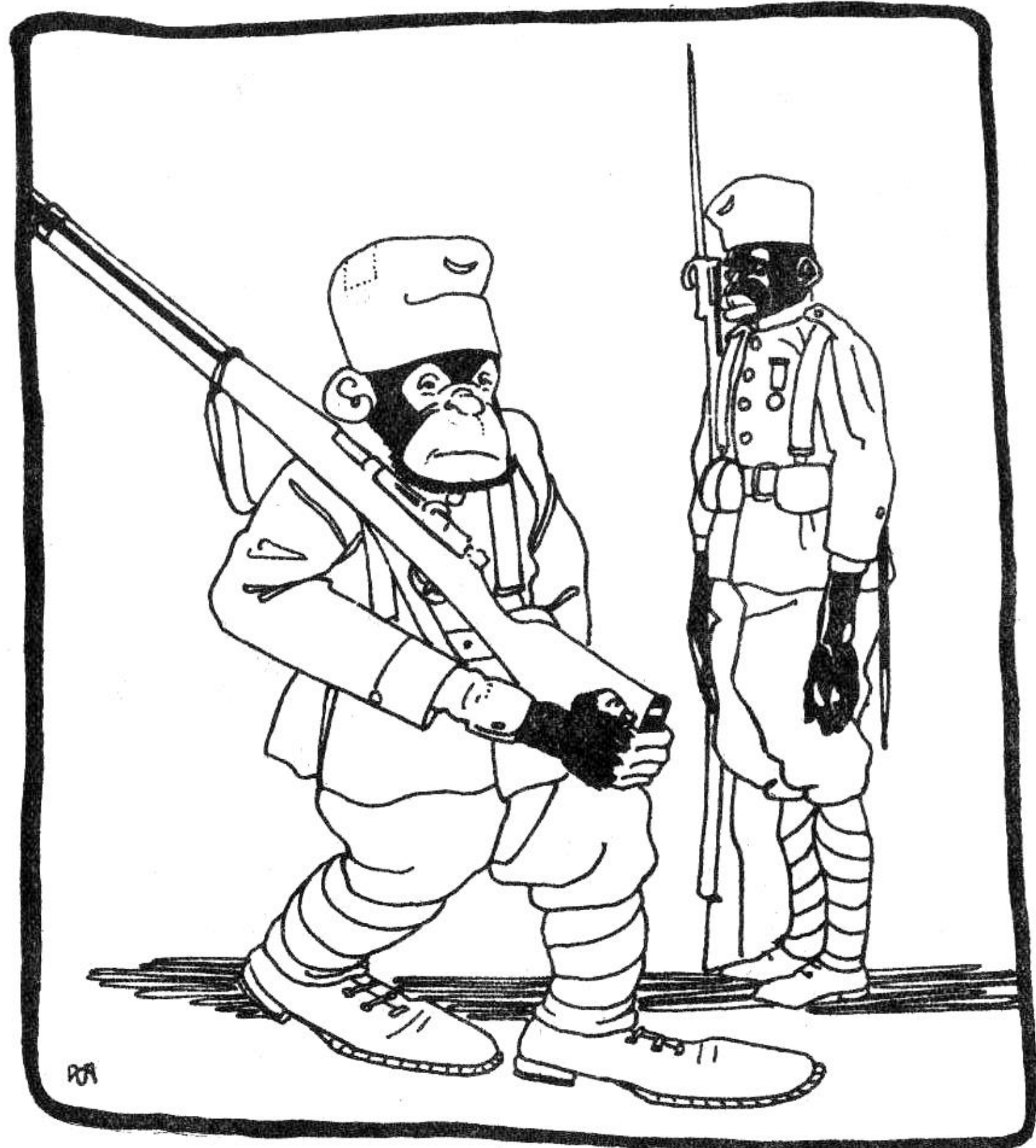

Fig.: 125

Ilustración interior del libro Mikolán y Cía.

Biblioteca Cuentos Nuevos en Colores. Hijos de Santiago Rodríguez. 
3.4.27. Ilustración interior en blanco y negro de Mi Libro de Estampas y Cuentos de la Biblioteca Rodríguez.

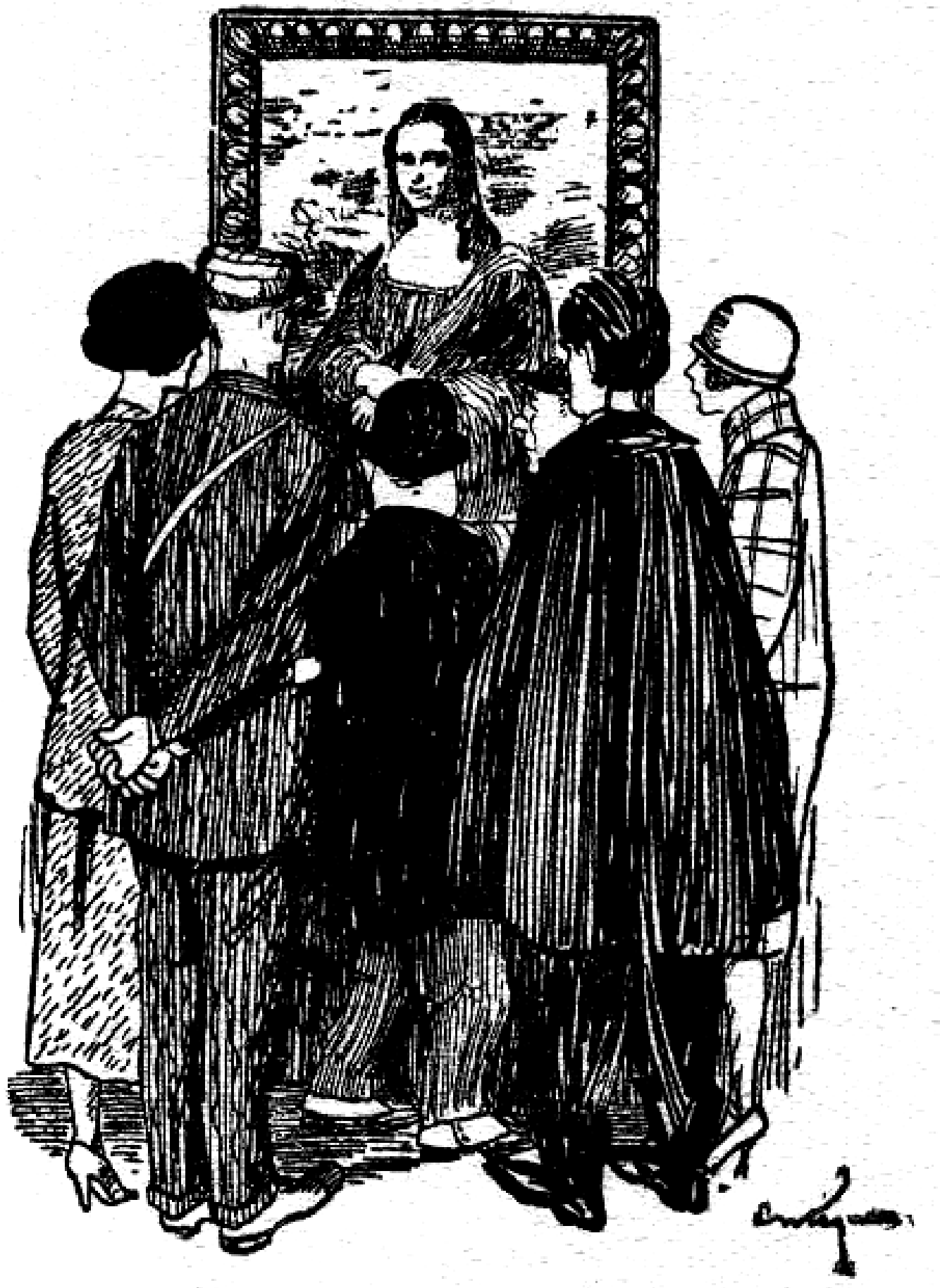

Fig.: 126

Ilustración interior de Mi Libro de Estampas y Cuentos.

Biblioteca Paz. Hijos de Santiago Rodríguez. 
3.4.28. Ilustración infantil en blanco y negro de Mi Libro de Estampas y Cuentos de la Biblioteca Paz.

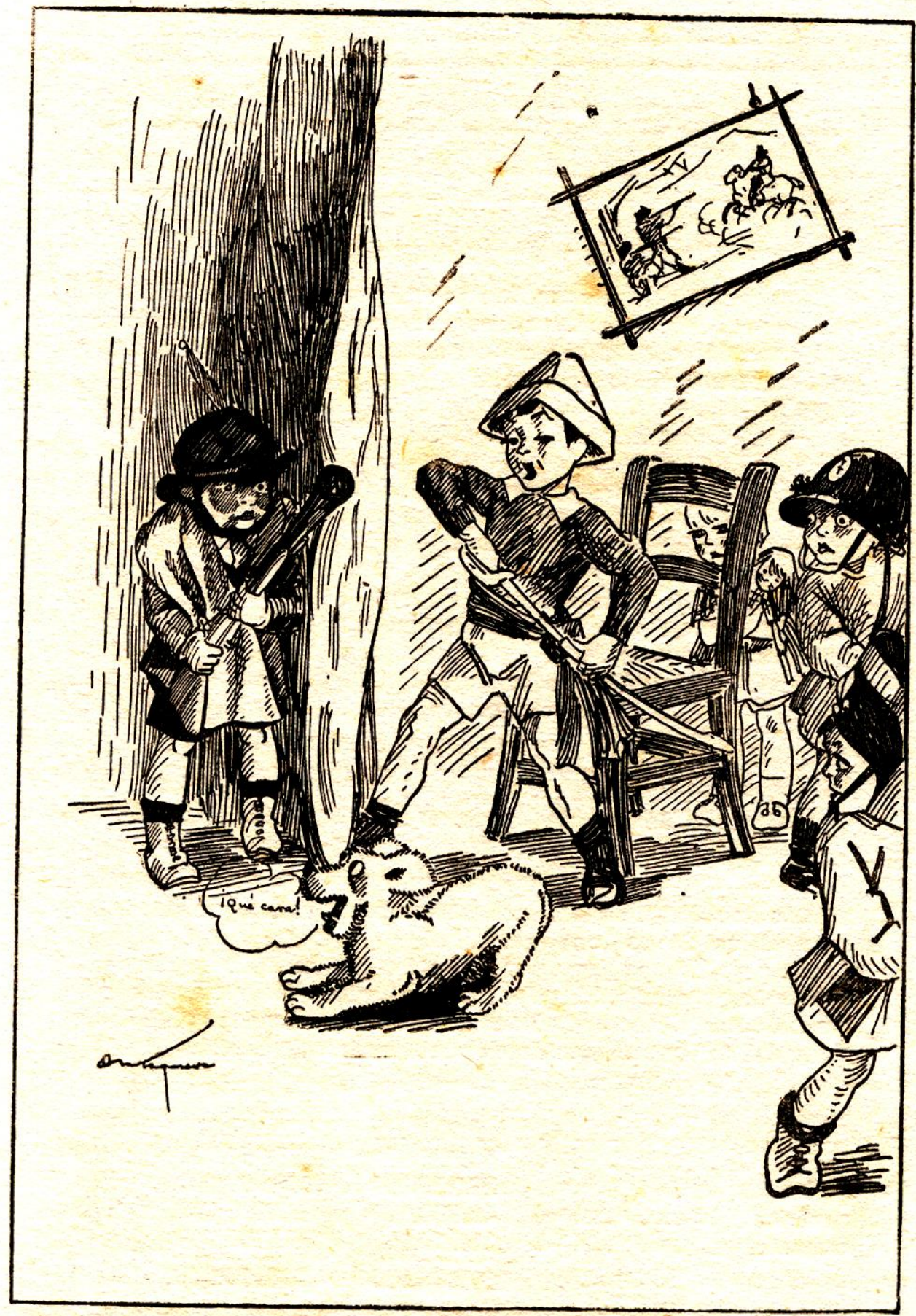

El capitán «Sin miedow.-iA ver, «Candelas», date preso!

«Candelas» entre dientes.- Te advierto que si me das con el sable como ayer, te aarreo».

Fig.: 127

Ilustración interior del libro Mi Libro de Estampas y Cuentos. Biblioteca Paz. Hijos de Santiago Rodríguez. 
3.4.29. Ilustraciones interiores en blanco y negro del libro Patachín Patachán de la Biblioteca Colección del Papa-Moscas.
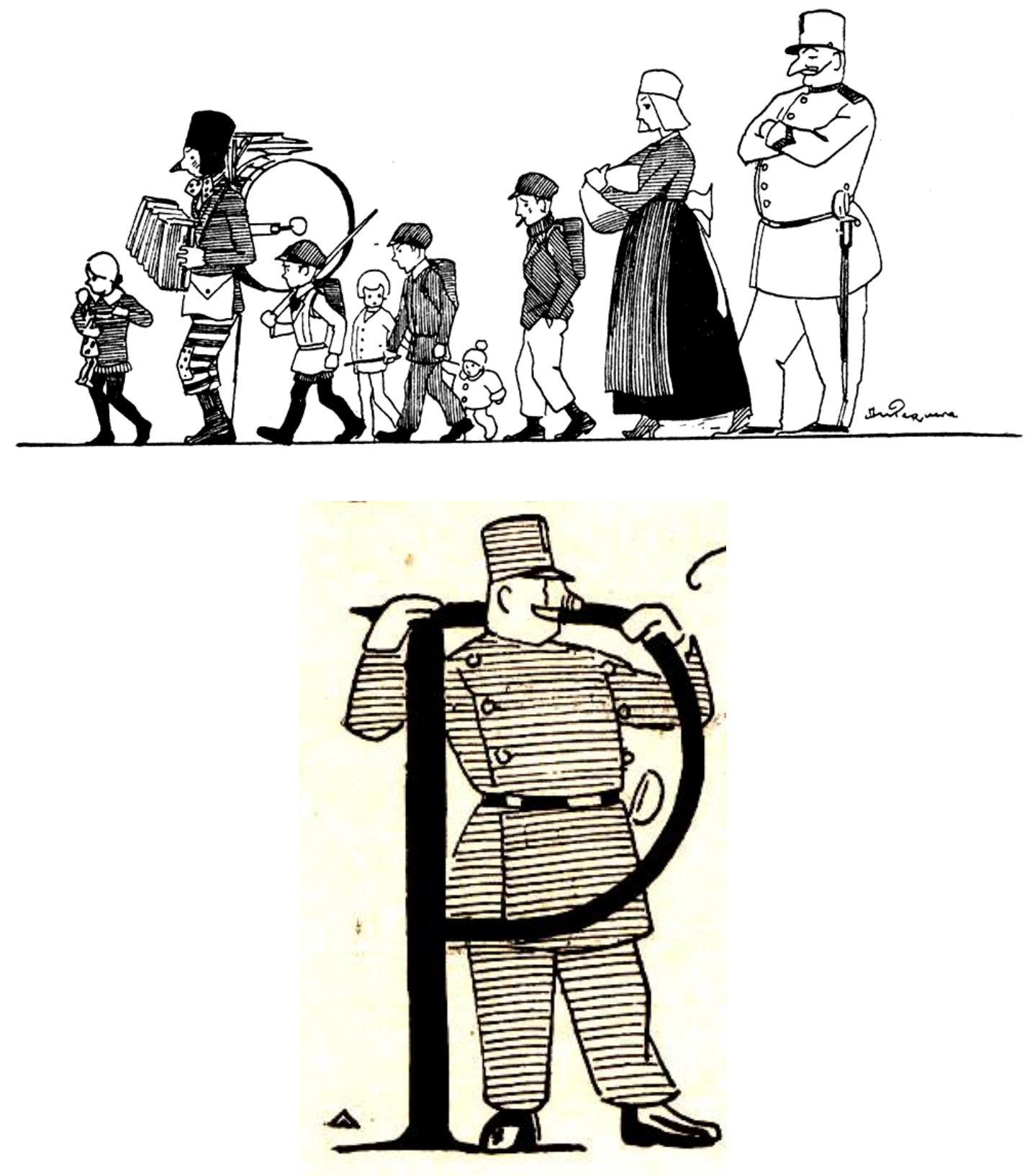

Fig.: 128

Ilustraciones interiores del libro Patachín Patachán. 
3.4.30 Ilustraciones sobre dibujos del natural en la Exposición Internacional de Barcelona en 1929 realizados para la editorial Hijos de Santiago Rodríguez en Mi Libro Ideal de la Biblioteca Paz.

\section{En la}

\section{Exposición de Barcelona}

\section{Dibujos del natural}

por

\section{Antequera Azpiri}

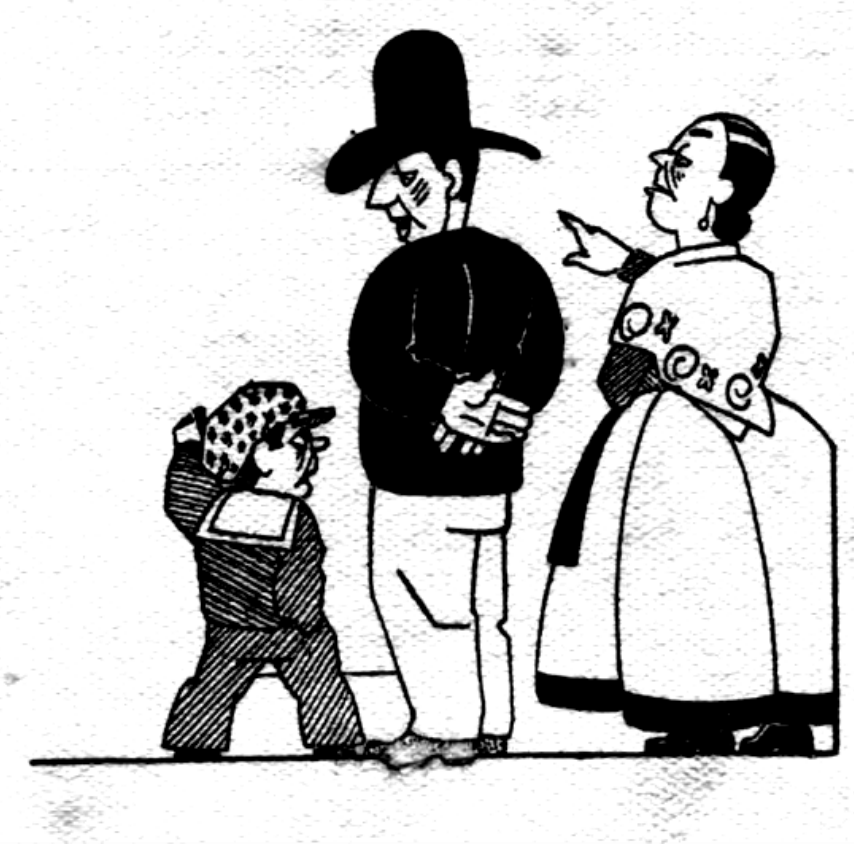




\section{El señor Cipriano, la "señá" Luteria y su hijo Cleto en la Exposición}
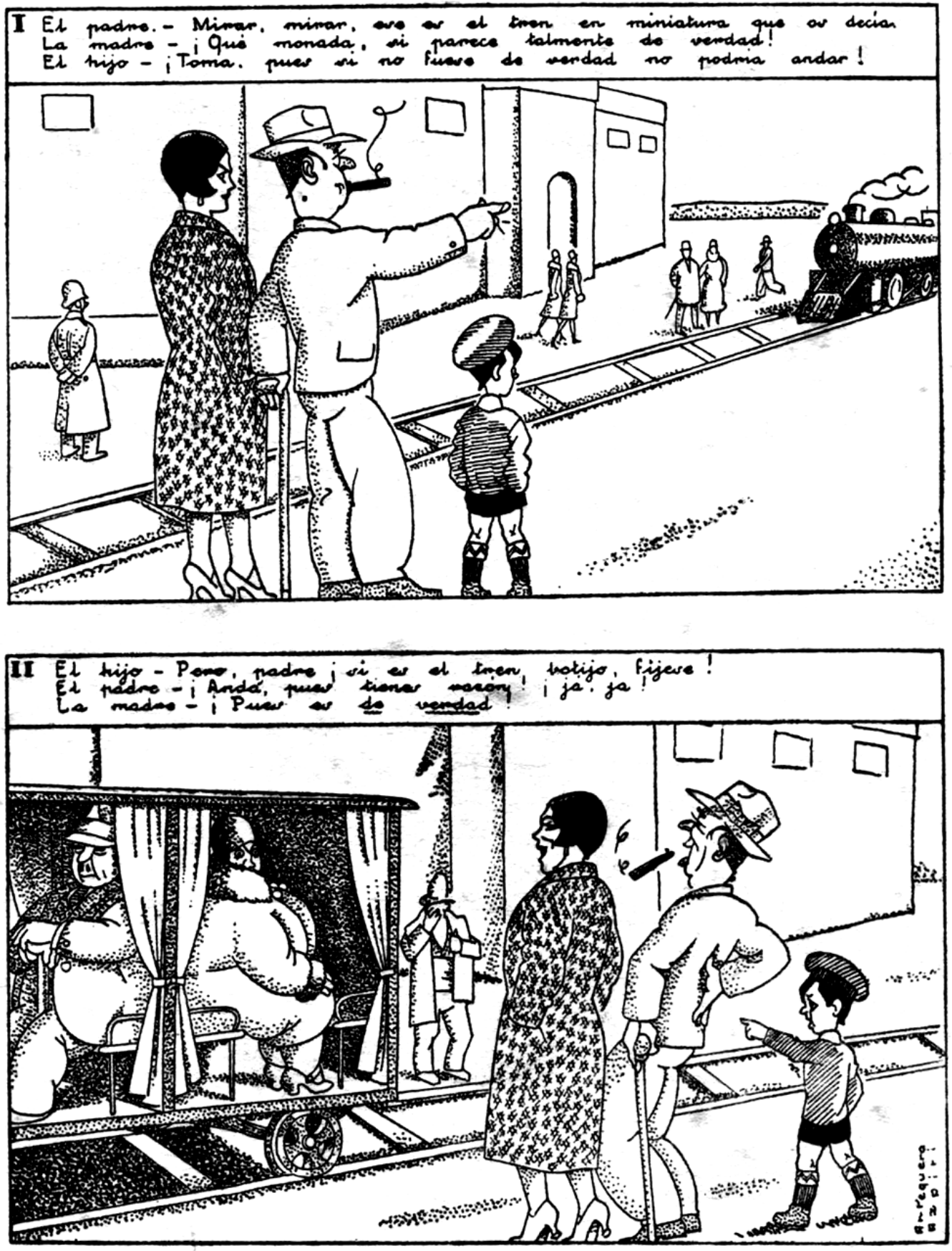


\section{Floro y familia} visitan la Exposición de Barcelona
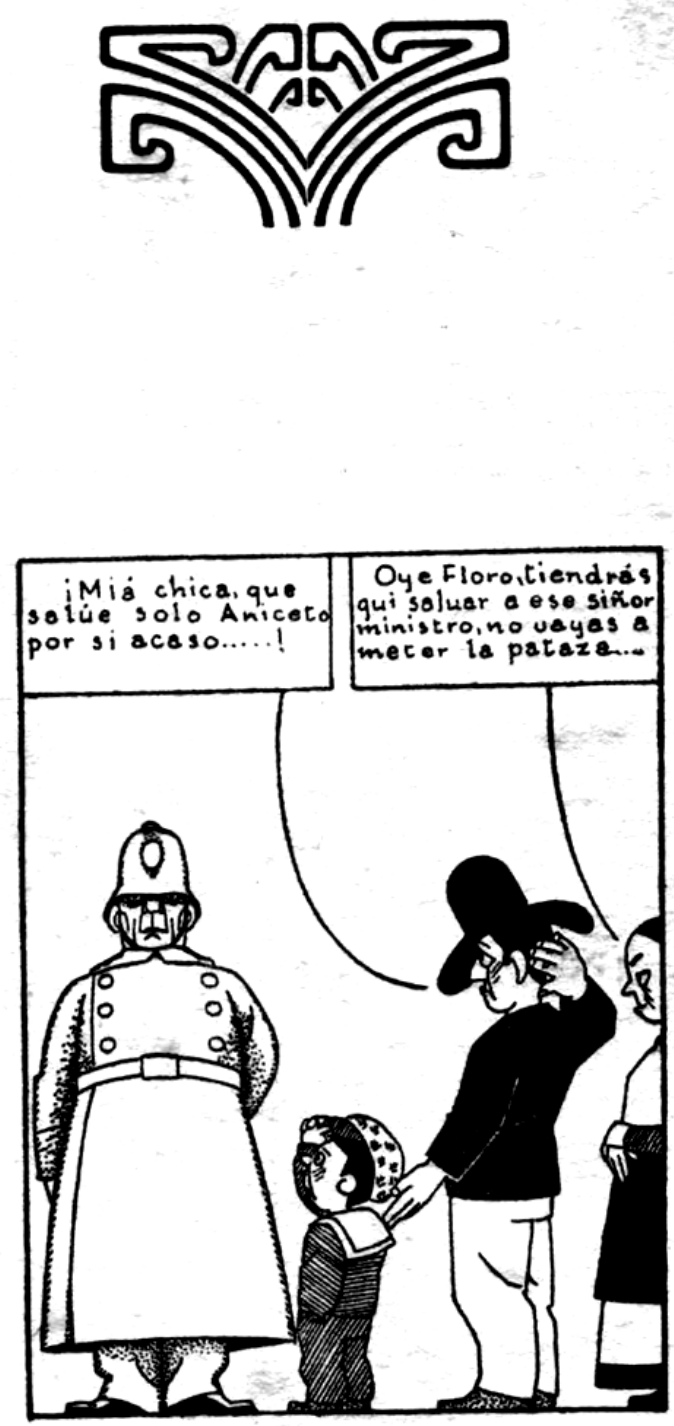
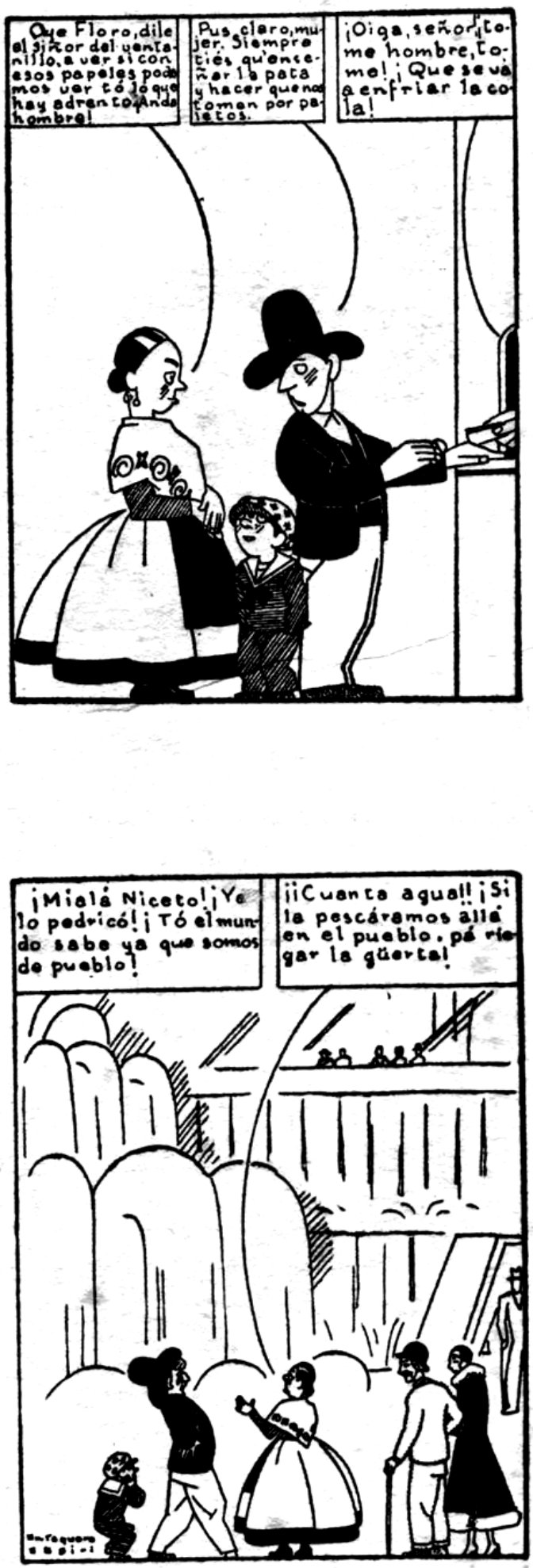


\section{Dos baturricos en Barcelona}
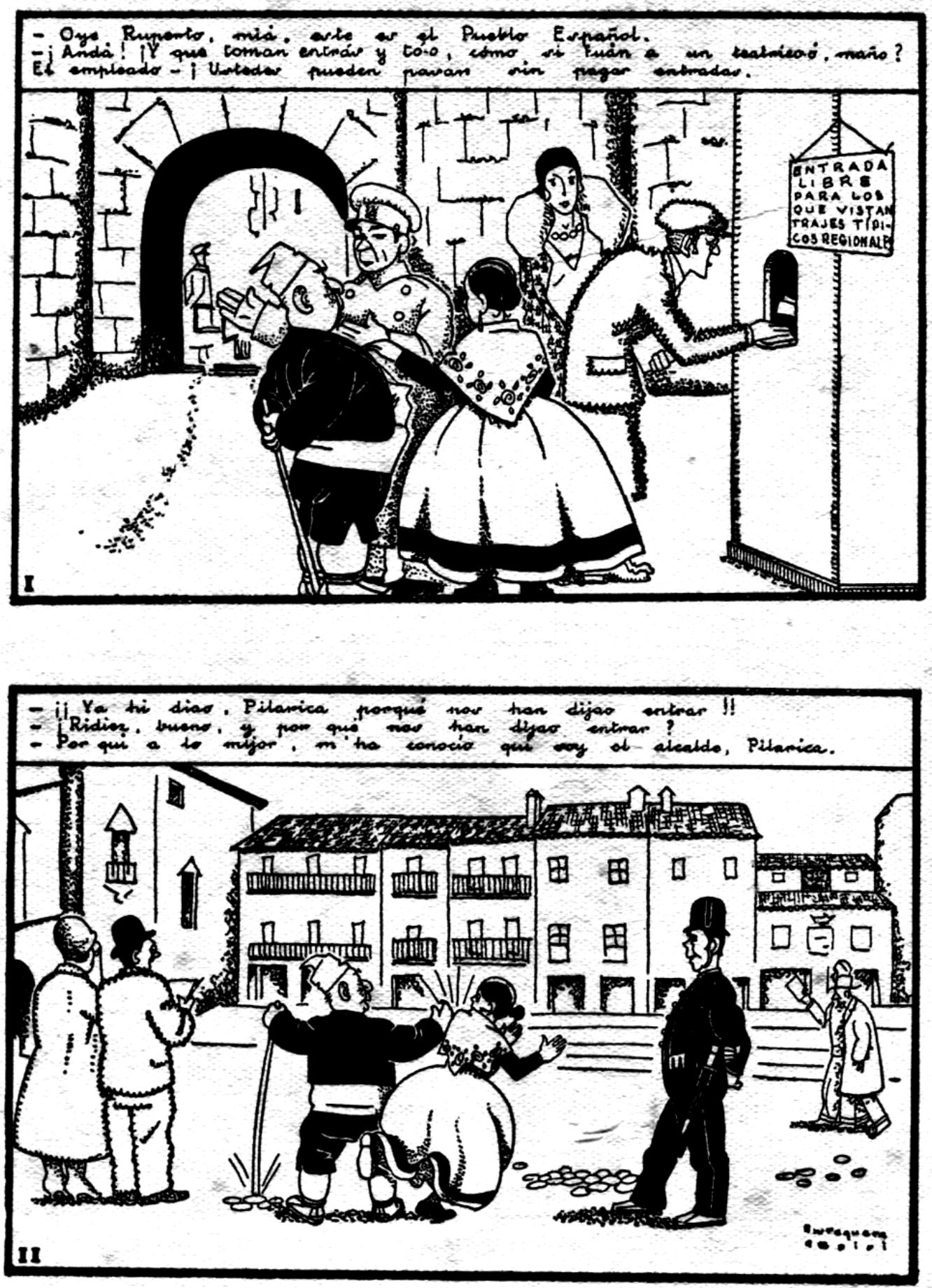


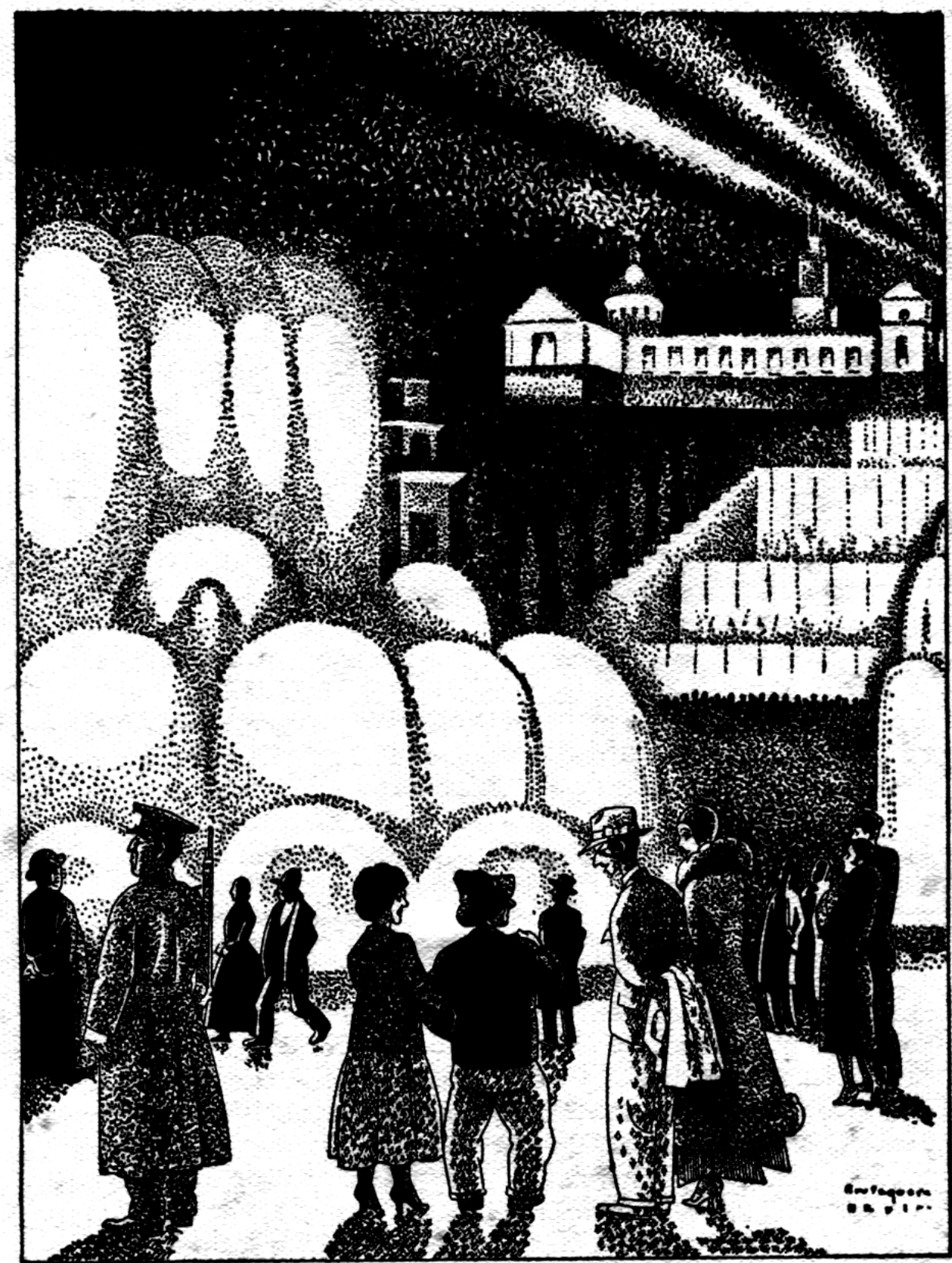

\section{Viendo las fuentes luminosas}

El caballero a su seftora. - No creo que haya derroche de agua semejante en parte alguna.

El compostelano. - $\mid \mathrm{Si}$, señor! En la mía terral

El caballero. $-¿ Y$ de dónde es usted?

El compostelano.-De Santiago de Compostela. All cae más agua que aqui.

Fig.: 129

Ilustraciones sobre dibujos al natural en la Exposición de Barcelona donde muestra de forma caricaturizada personajes, clases sociales urbanas y rurales de la España de 1929.

Biblioteca Paz. Mi Libro Ideal. Hijos de Santiago Rodríguez. 
3.5.ENRIQUE MARTÍNEZ DE TEJADA Y ECHEVARRÍA -ECHEA- (18841959).

3.5.1. Ilustración interior en blanco y negro del libro El pájaro en la nieve de la Biblioteca Rodríguez (I).

3.5.2. Ilustraciones interiores en blanco y negro del libro El pájaro en la nieve de la Biblioteca Rodríguez (II).

3.5.3. Ilustración interior a color del libro El pájaro en la nieve de la Biblioteca Rodríguez (I).

3.5.4. Ilustración interior a color del libro El pájaro en la nieve de la Biblioteca Rodríguez (II).

3.5.5. Ilustración interior a color del libro El pájaro en la nieve de la Biblioteca Rodríguez (III).

3.5.6. Ilustración interior a color del libro El pájaro en la nieve de la Biblioteca Rodríguez (IV). 
3.5.1. Ilustración interior en blanco y negro del libro El pájaro en la nieve de la Biblioteca Rodríguez (I).

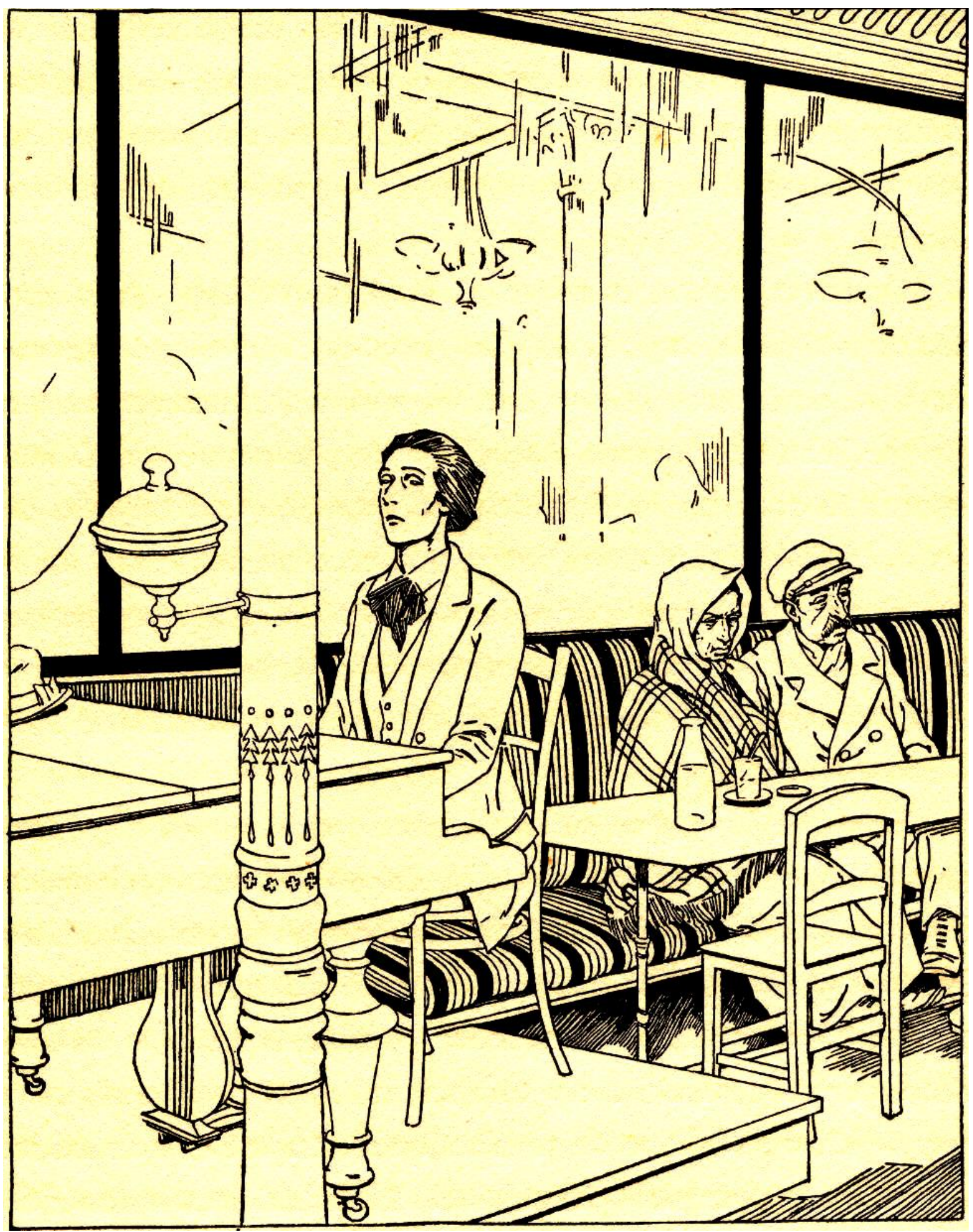

Fig.: 130

Ilustración interior del libro El pájaro en la nieve.

Biblioteca Rodríguez. Hijos de Santiago Rodríguez. 
3.5.2. Ilustraciones interiores en blanco y negro del libro El pájaro en la nieve de la Biblioteca Rodríguez (II).
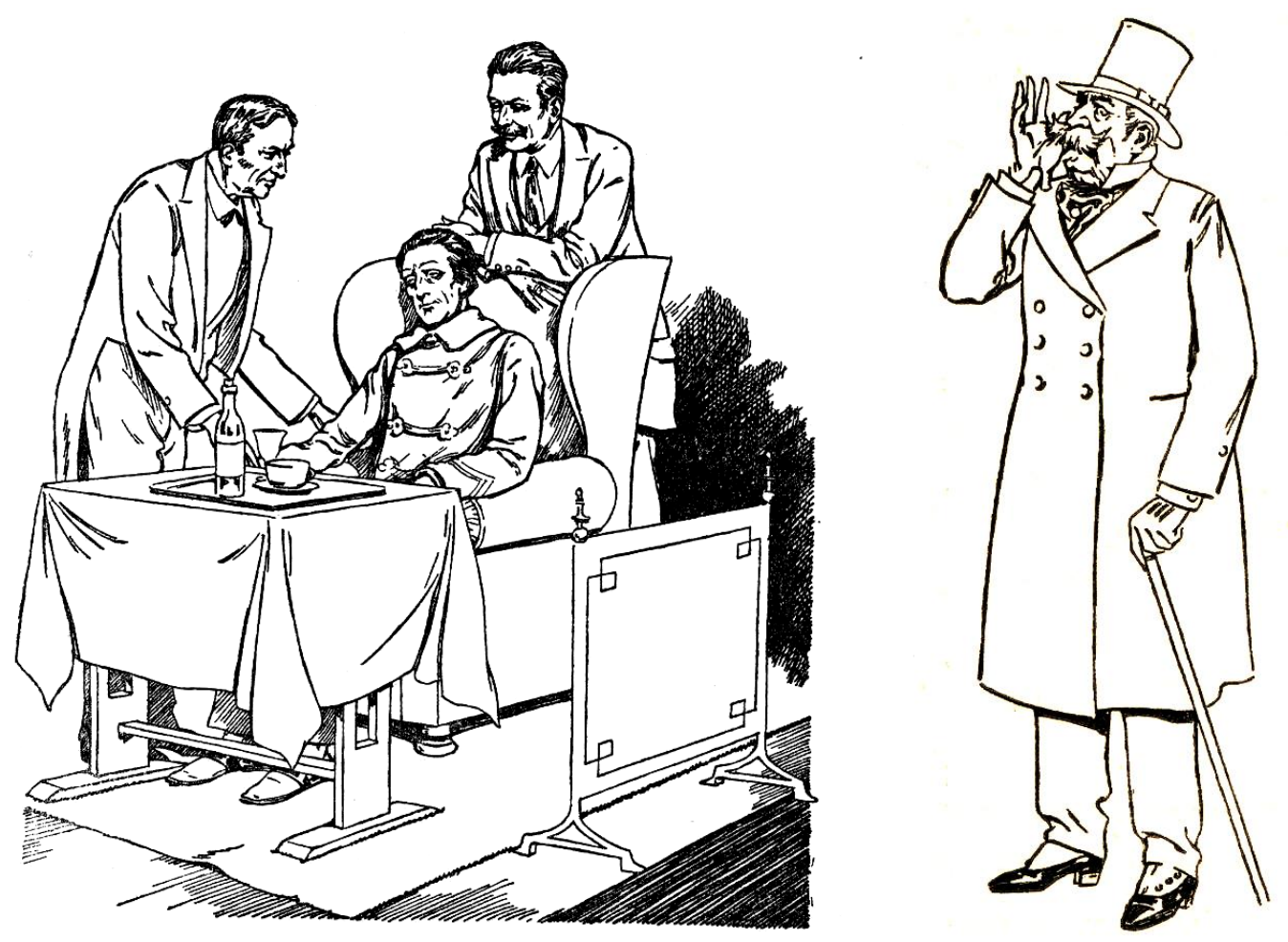

Fig.: 131

Ilustraciones interiores del libro El pájaro en la nieve.

Biblioteca Rodríguez. Hijos de Santiago Rodríguez. 
LA EDITORIAL BURGALESA HIJOS DE SANTIAGO RODRÍGUEZ (1891-1936): ANÁLISIS DE LOS LIBROS ESCOLARES

3.5.3. Ilustración interior a color del libro El pájaro en la nieve de la Biblioteca Rodríguez (I).

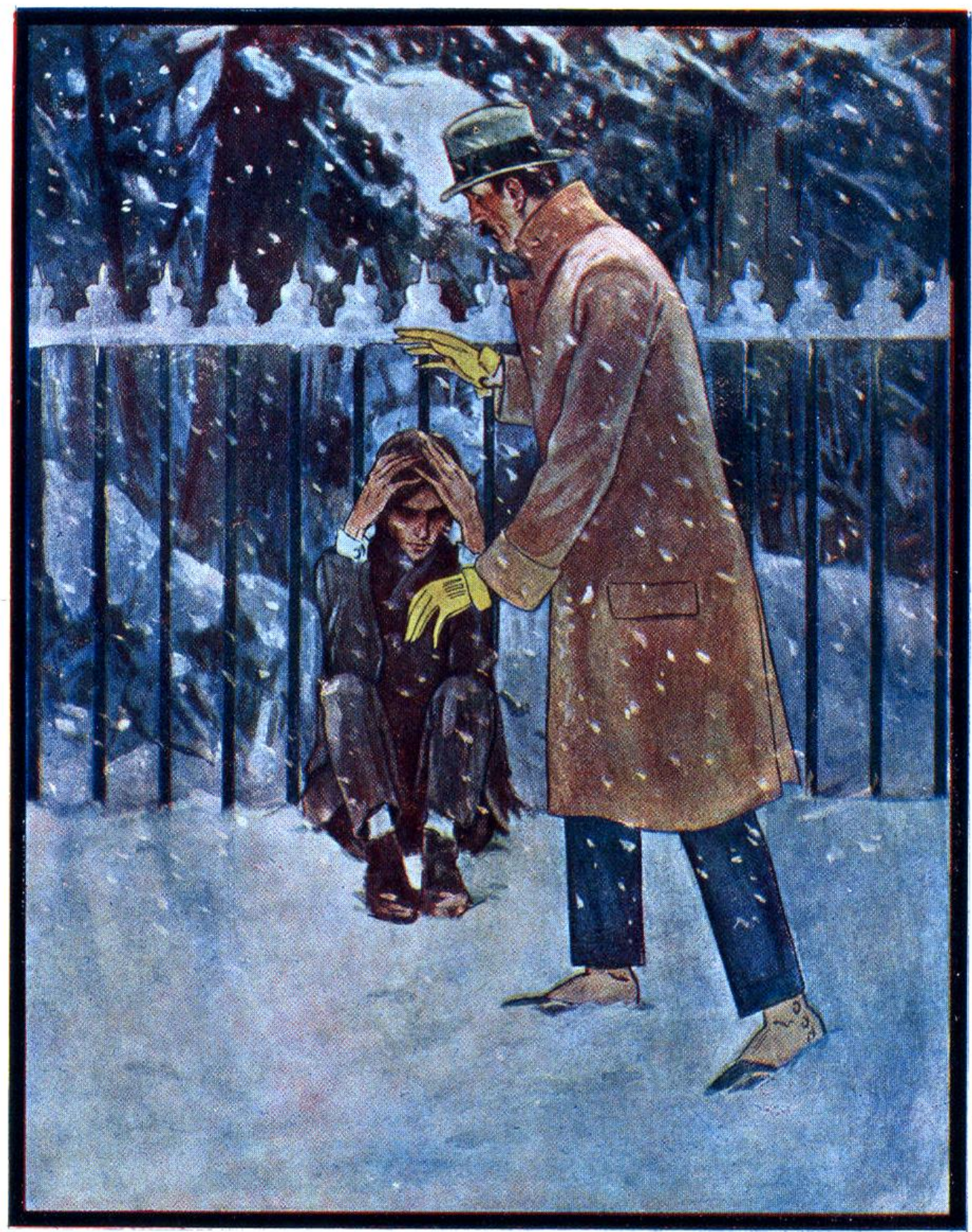

Fig.: 132

Ilustración interior del libro El pájaro en la nieve.

Biblioteca Rodríguez. Hijos de Santiago Rodríguez. 
3.5.4. Ilustración interior a color del libro El pájaro en la nieve de la Biblioteca Rodríguez (II).

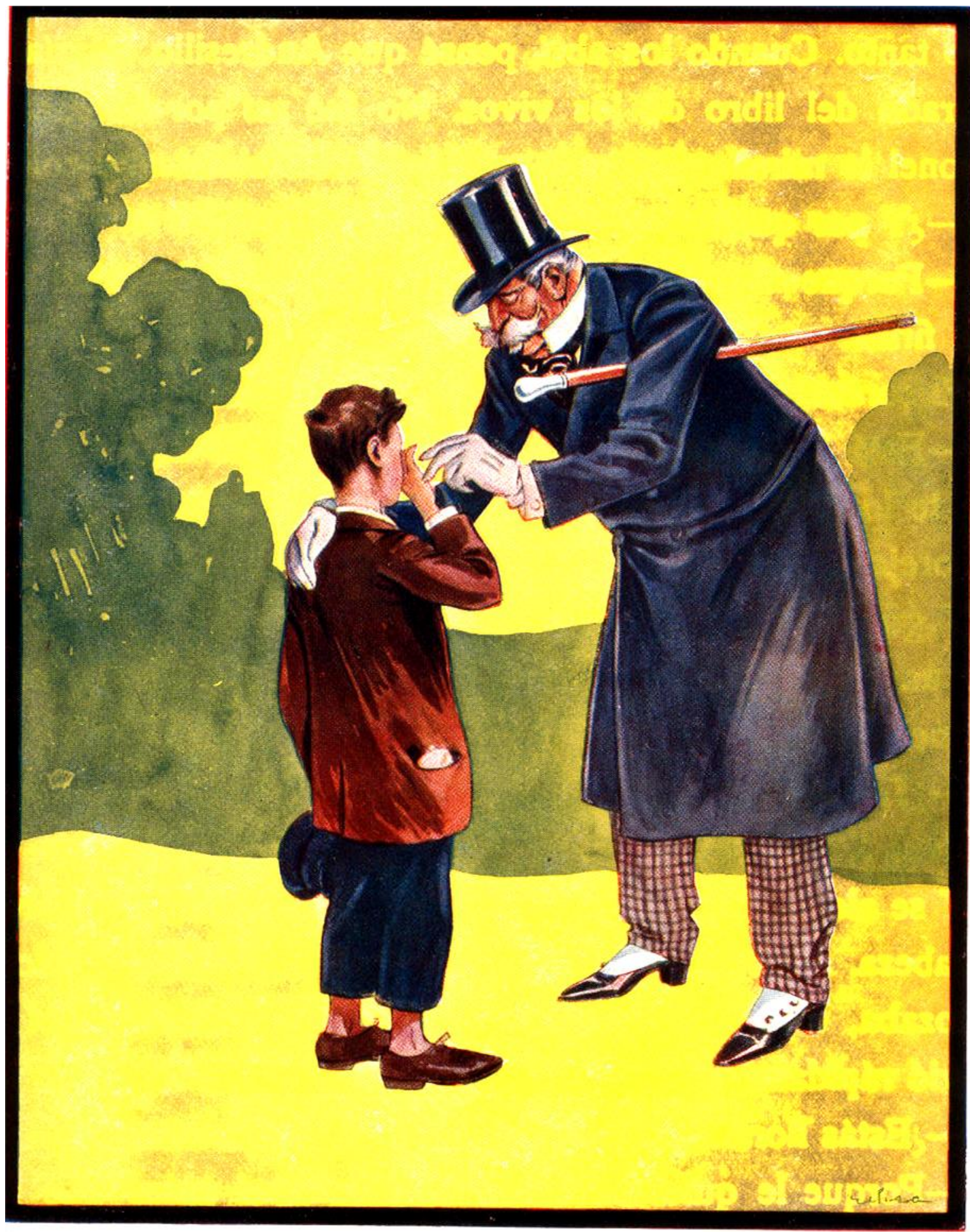

Fig.: 133

Ilustración interior del libro El pájaro en la nieve.

Biblioteca Rodríguez. 
LA EDITORIAL BURGALESA HIJOS DE SANTIAGO RODRÍGUEZ (1891-1936): ANÁLISIS DE LOS LIBROS ESCOLARES

3.5.5. Ilustración interior a color del libro El pájaro en la nieve de la Biblioteca Rodríguez (III).

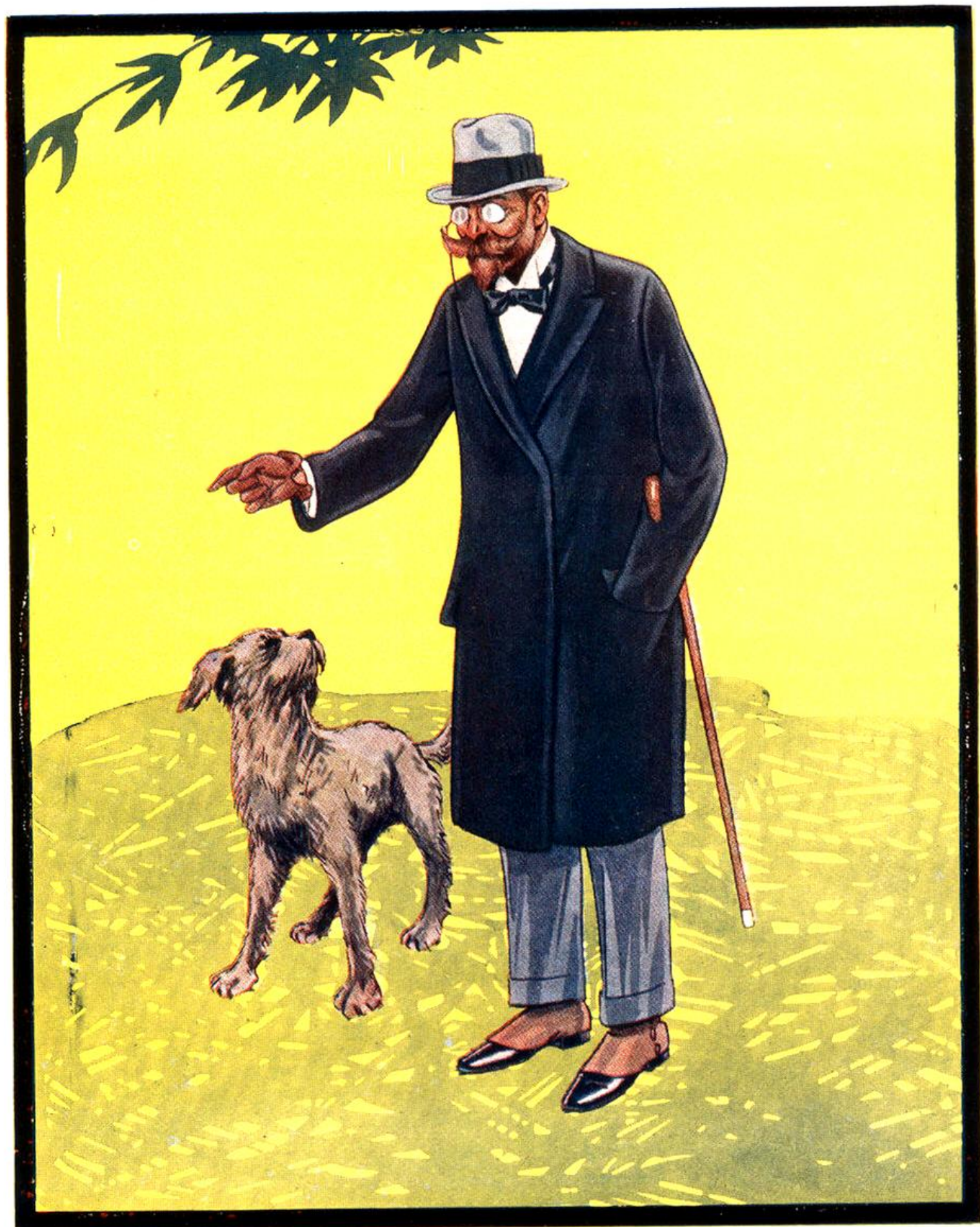

Fig.: 134

Ilustración interior del libro El pájaro en la nieve.

Biblioteca Rodríguez. 
3.5.6. Ilustración interior a color del libro El pájaro en la nieve de la Biblioteca Rodríguez (IV).

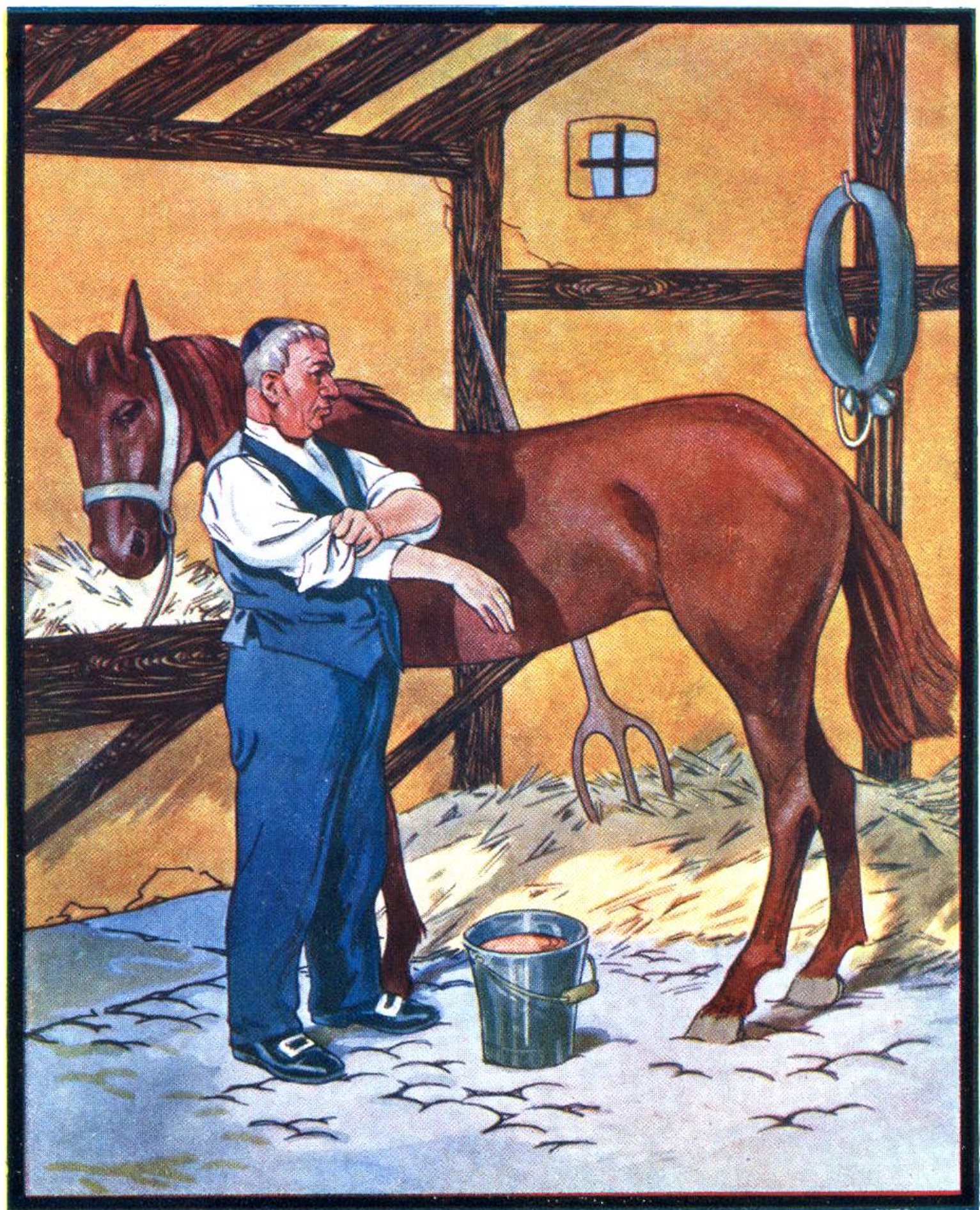

Fig.: 135

Ilustración interior del libro El pájaro en la nieve.

Biblioteca Rodríguez. 
LA EDITORIAL BURGALESA HIJOS DE SANTIAGO RODRÍGUEZ (1891-1936):

ANÁLISIS DE LOS LIBROS ESCOLARES

3.6.FRANCISCO LÓPEZ RUBIO (MOTRIL, 1895 - MADRID, 1965).

3.6.1. Ilustración de la tira cómica La caza de la pantera de Mi Libro de Año Nuevo de la Biblioteca Paz.

3.6.2. Ilustración de la tira cómica Tiempo aprovechado de Mi Libro de Año Nuevo de la Biblioteca Paz.

3.6.3. Ilustración cómica El beso de dos golosos de Mi Libro de Navidad de la Biblioteca Paz.

3.6.4. Ilustración cómica El trampolín improvisado de Mi Libro de Navidad de la Biblioteca Paz.

3.6.5. Portada de las tiras cómicas realizadas por Francisco López Rubio para Mi Libro de Reyes de la Biblioteca Paz.

3.6.6. Historieta muda Donde las dan las toman de Mi Libro de Reyes de la Biblioteca Paz.

3.6.7. Historieta muda El suicidio de D. Pero de Mi Libro de Reyes de la Biblioteca Paz.

3.6.8. Ilustración cómica Las víctimas de la ciencia de Mi Libro de Reyes de la Biblioteca Paz.

3.6.9. Ilustraciones interiores en blanco y negro del libro Cuentos de Pototo de la Biblioteca Rodríguez.

3.6.10. Ilustración a color del cuento El premio de un concurso del libro Cuentos de Pototo de la Biblioteca Rodríguez.

3.6.11. Ilustración a color del cuento El caballito mágico del libro Cuentos de Pototo de la Biblioteca Rodríguez. 
3.6.1. Ilustración de la tira cómica La caza de la pantera de Mi Libro de Año Nuevo de la Biblioteca Paz.
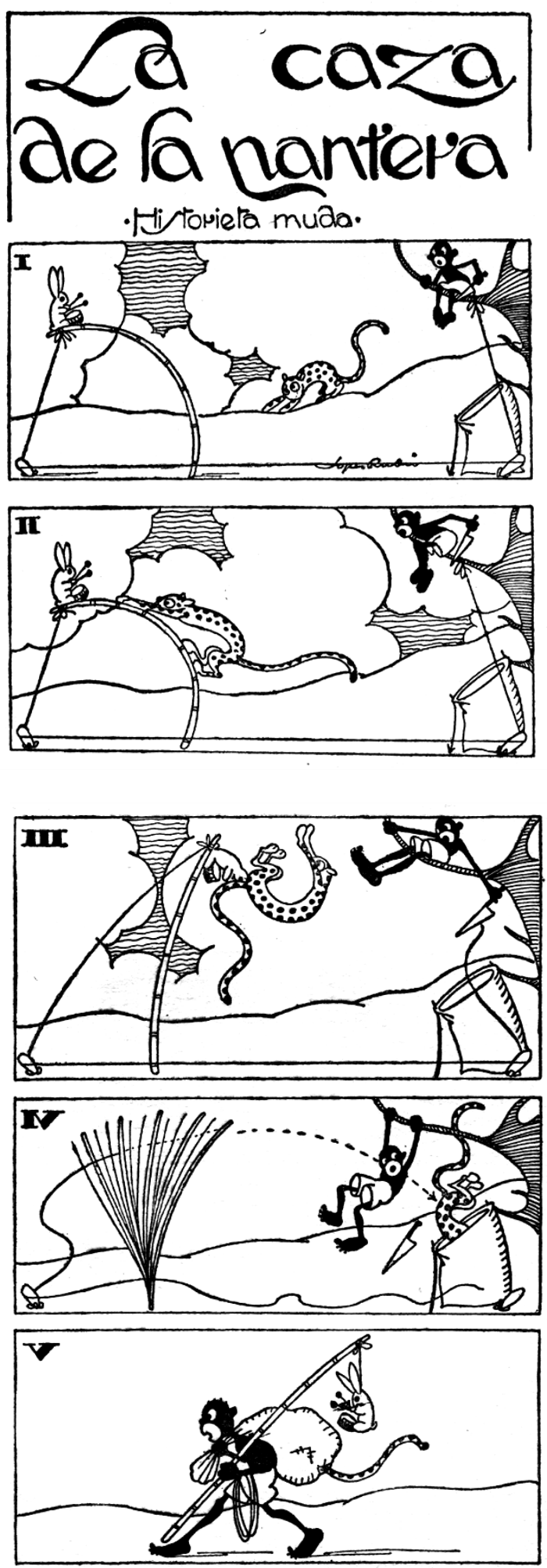

Fig.: 136

Tira cómica La caza de la pantera de Mi Libro de Año Nuevo de la Biblioteca Paz. Hijos de Santiago Rodríguez. 


\subsubsection{Ilustración de la tira cómica Tiempo aprovechado de Mi Libro de} Año Nuevo de la Biblioteca Paz.
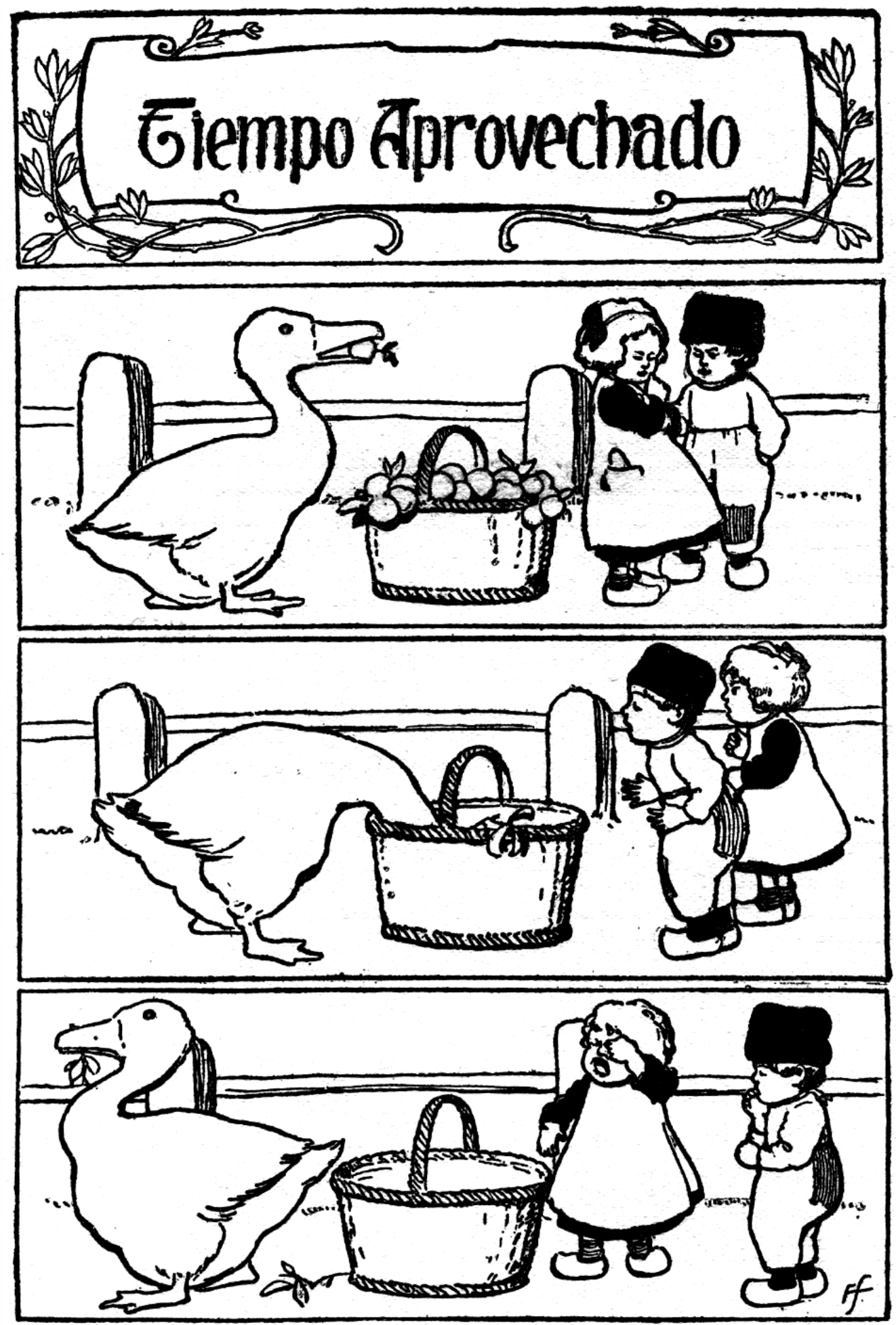

Fig.: 137

Tira cómica Tiempo aprovechado de Mi Libro de Año Nuevo de la Biblioteca Paz. 
3.6.3. Ilustración cómica El beso de dos golosos de Mi Libro de Navidad de la Biblioteca Paz.
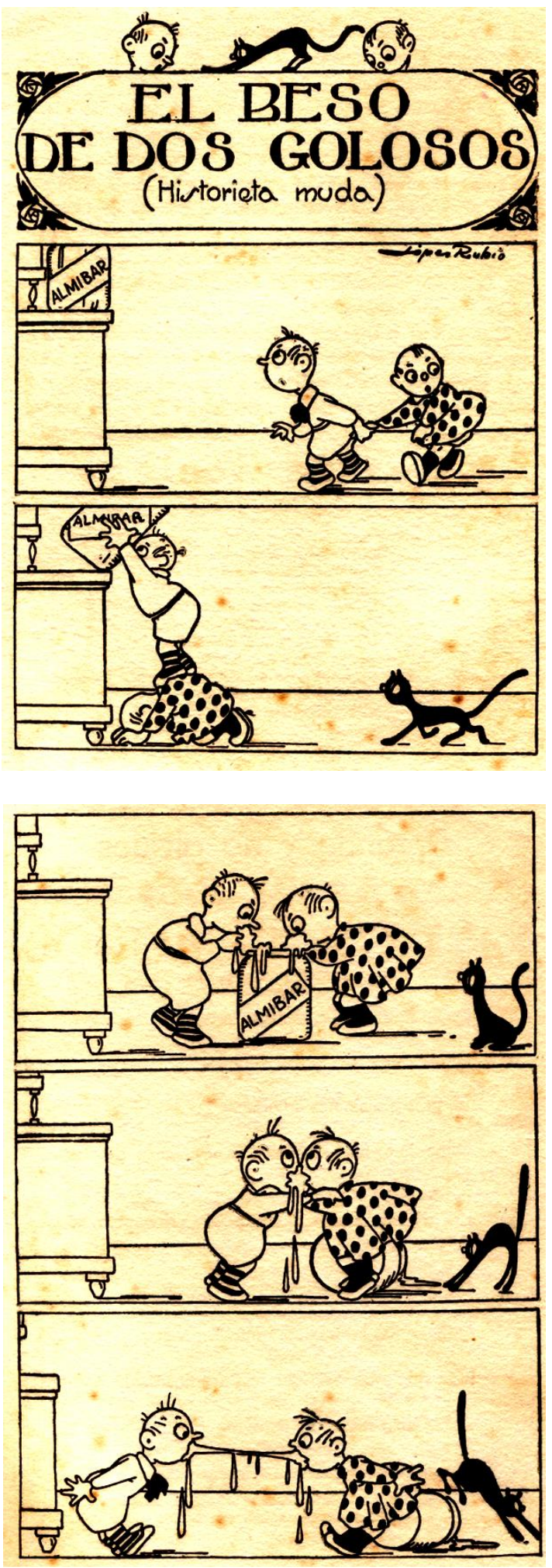

Fig.: 138

Tira cómica El beso de dos golosos de Mi Libro de Navidad de la Biblioteca Paz. Hijos de Santiago Rodríguez. 
3.6.4. Ilustración cómica El trampolín improvisado de Mi Libro de Navidad de la Biblioteca Paz.
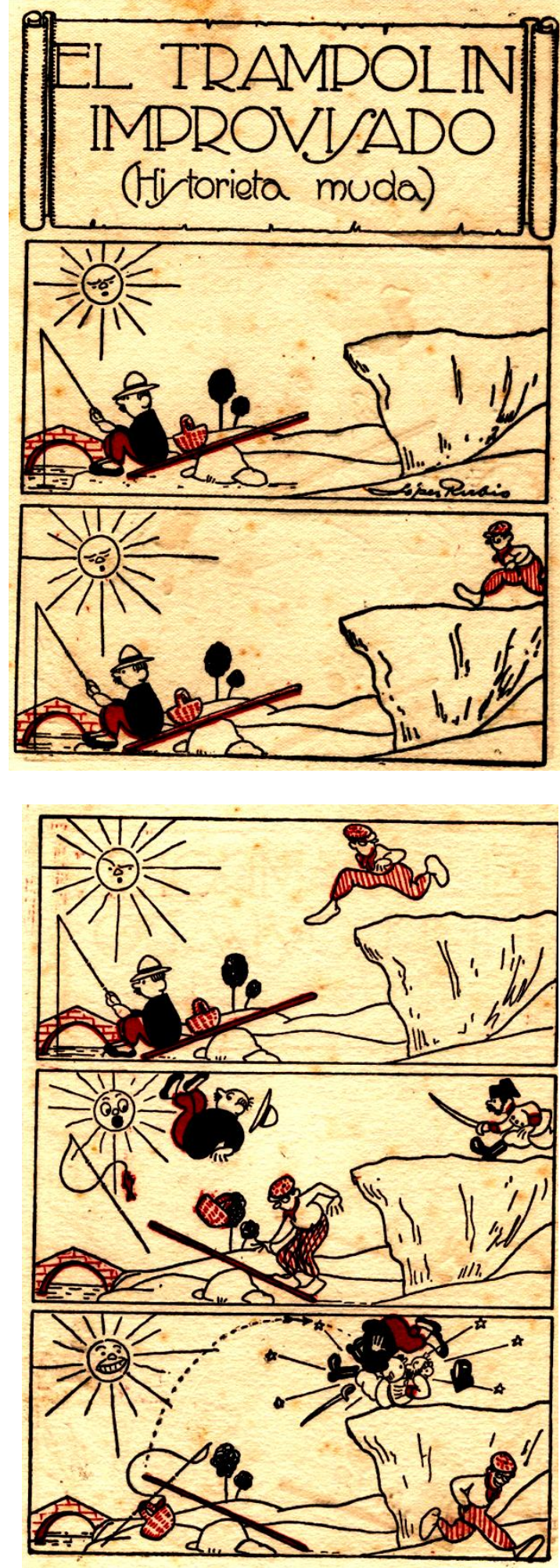

Fig.: 139

Tira cómica El trampolín improvisado de Mi Libro de Navidad de la Biblioteca Paz. Hijos de Santiago Rodríguez. 
3.6.5. Portada de las tiras cómicas realizadas por Francisco López Rubio para Mi Libro de Reyes de la Biblioteca Paz.

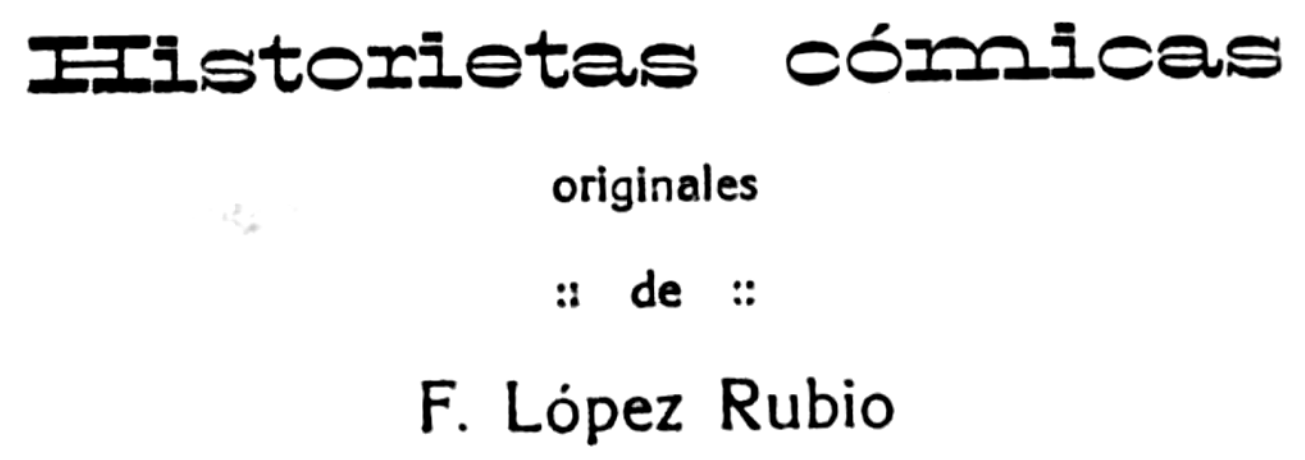

El que la hace...

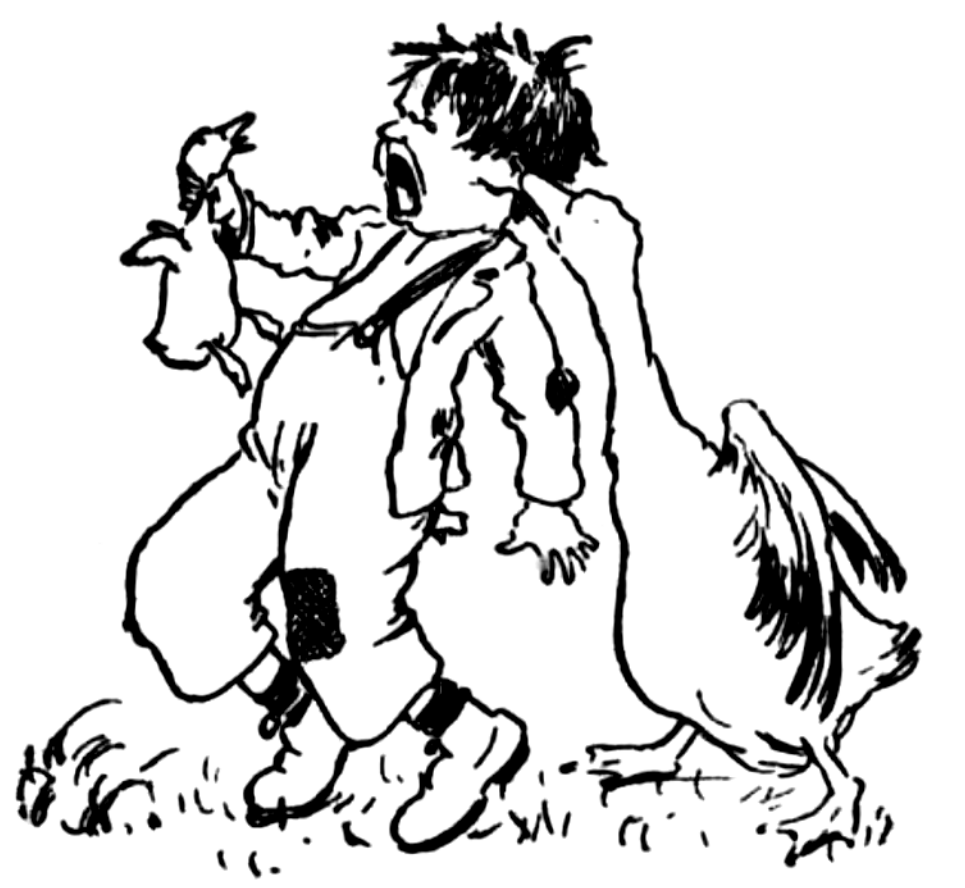

la paga.

Fig.: 140

Portada de las tiras cómicas realizadas por F. López Rubio para Mi Libro de Reyes de la Biblioteca Paz. Hijos de Santiago Rodríguez. 
3.6.6. Historieta muda Donde las dan las toman de Mi Libro de Reyes de la Biblioteca Paz.
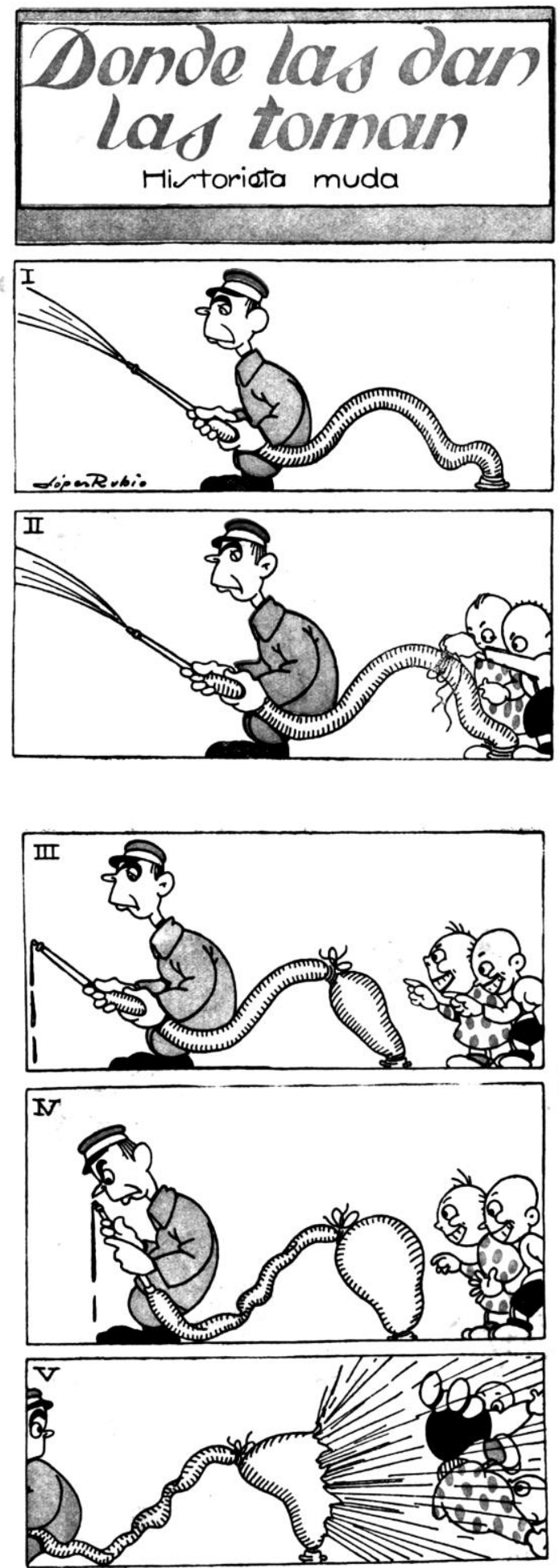

Fig141

Historieta muda Donde las dan las toma de Mi Libro de Reyes de la Biblioteca Paz. Hijos de Santiago Rodríguez. 
3.6.7. Historieta muda El suicidio de D. Pero de Mi Libro de Reyes de la Biblioteca Paz.
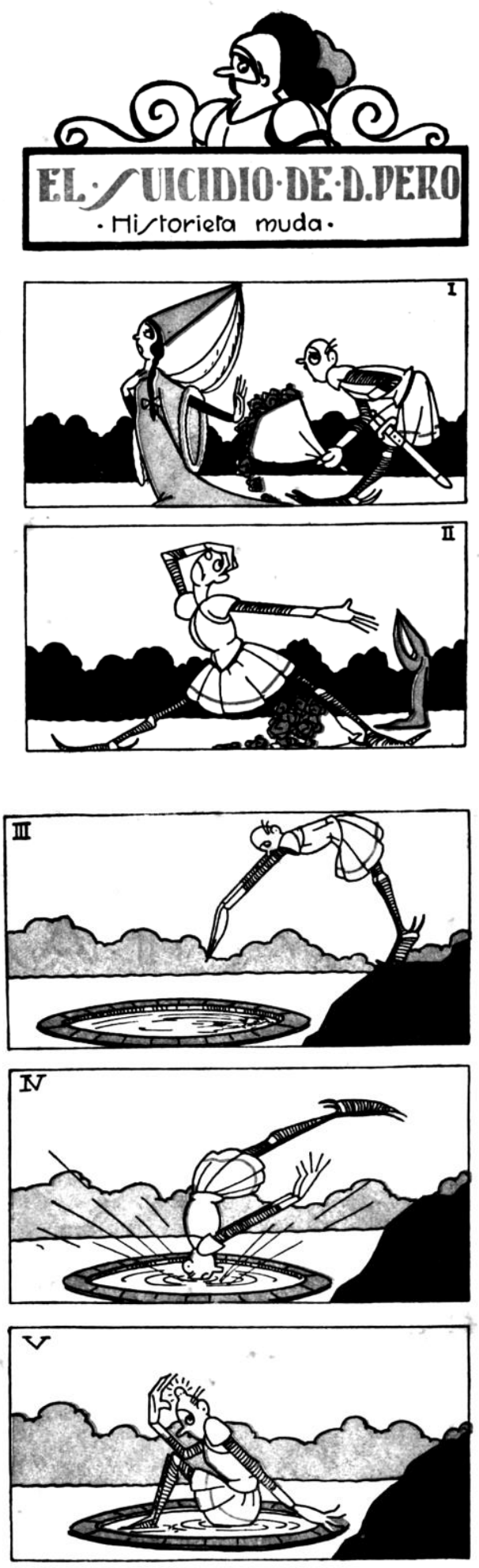

Fig.: 142

Historieta muda El suicidio de D. Pero de Mi Libro de Reyes de la Biblioteca Paz. Hijos de Santiago Rodríguez. 
LA EDITORIAL BURGALESA HIJOS DE SANTIAGO RODRÍGUEZ (1891-1936): ANÁLISIS DE LOS LIBROS ESCOLARES

3.6.8. Ilustración cómica Las víctimas de la ciencia de Mi Libro de Reyes de la Biblioteca Paz.

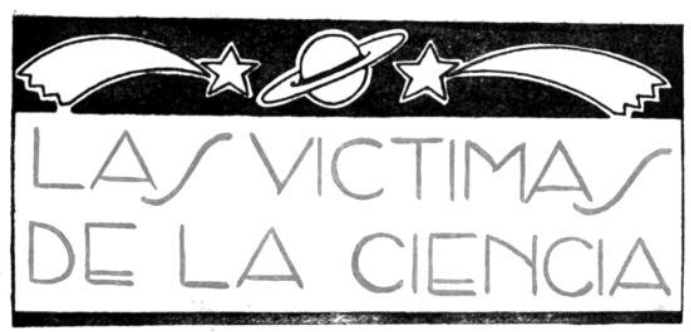

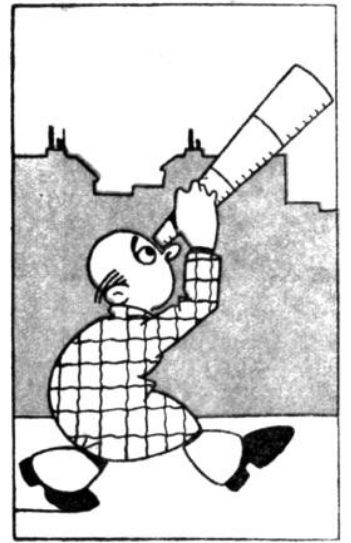

DON-TRIFON-MADADOLAN

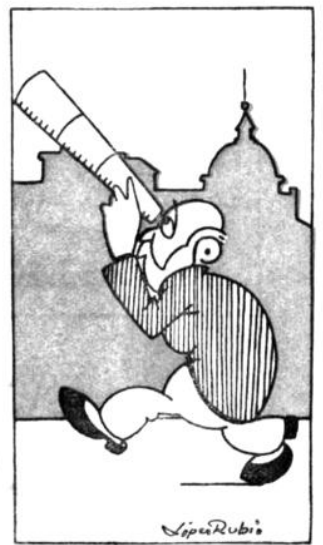

Y.DON.LUCAS.MACARRON

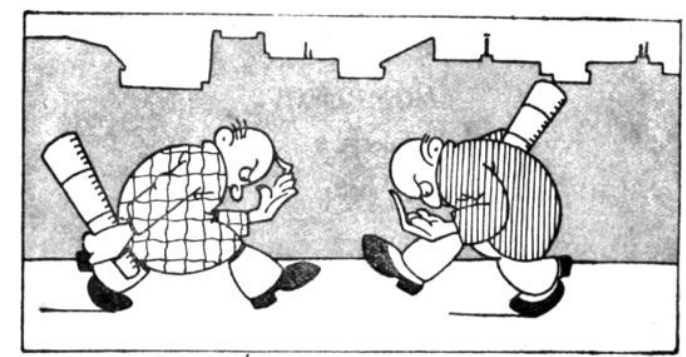

- A STRĹNDMD S.DE.AFICIDN.

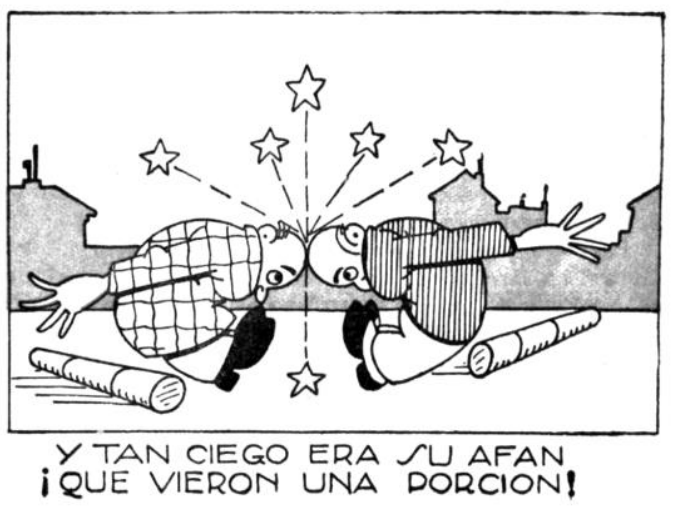

Fig.: 143

Tira cómica Las víctimas de la ciencia de Mi Libro de Reyes de la Biblioteca Paz. Hijos de Santiago Rodríguez. 
3.6.9. Ilustraciones interiores en blanco y negro del libro Cuentos de Pototo de la Biblioteca Rodríguez.
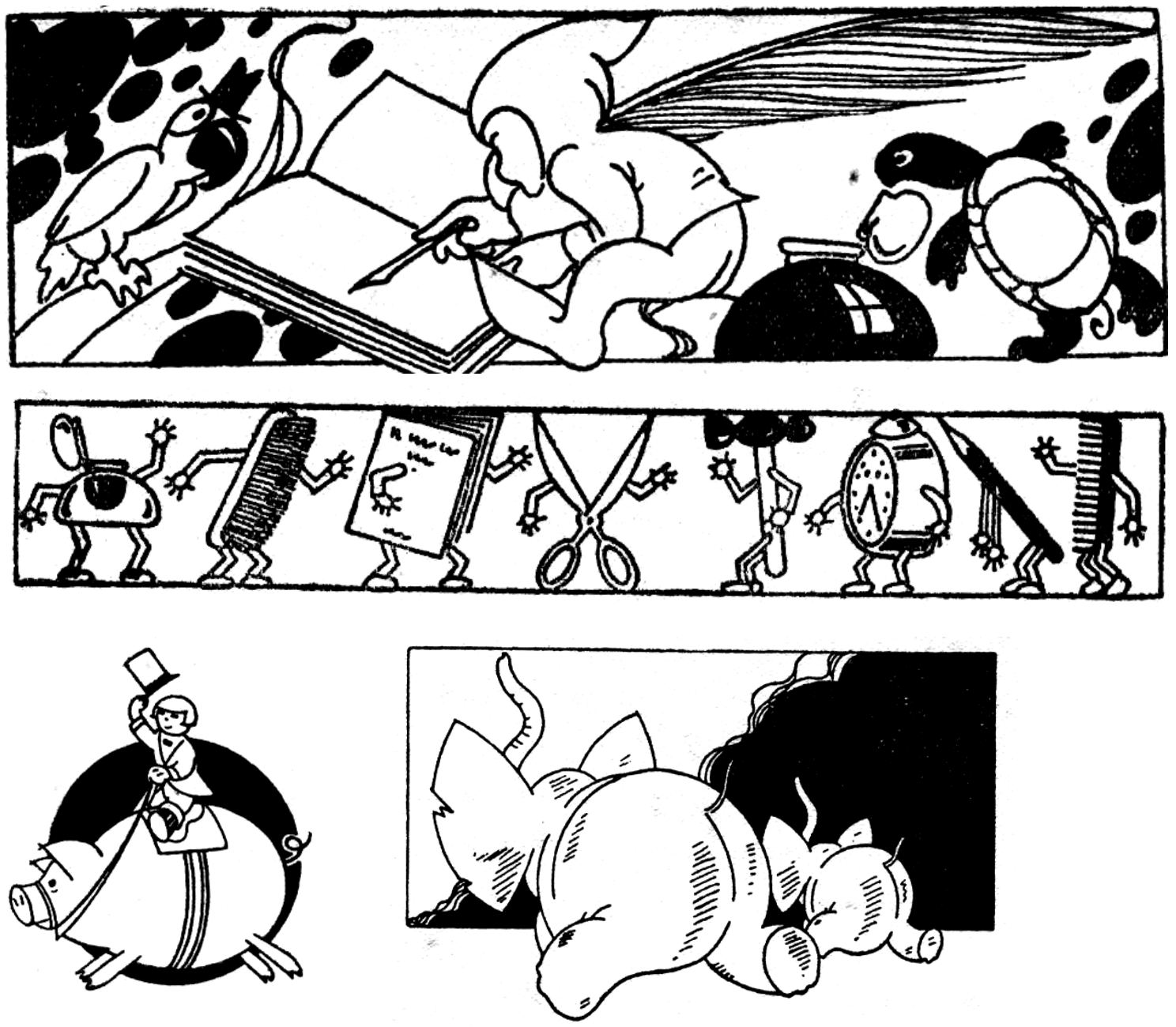

Fig.: 144

Ilustraciones interiores de Cuentos de Pototo de la Biblioteca Rodríguez.

Hijos de Santiago Rodríguez. 
LA EDITORIAL BURGALESA HIJOS DE SANTIAGO RODRÍGUEZ (1891-1936): ANÁLISIS DE LOS LIBROS ESCOLARES

3.6.10. Ilustración a color del cuento El premio de un concurso del libro Cuentos de Pototo de la Biblioteca Rodríguez.

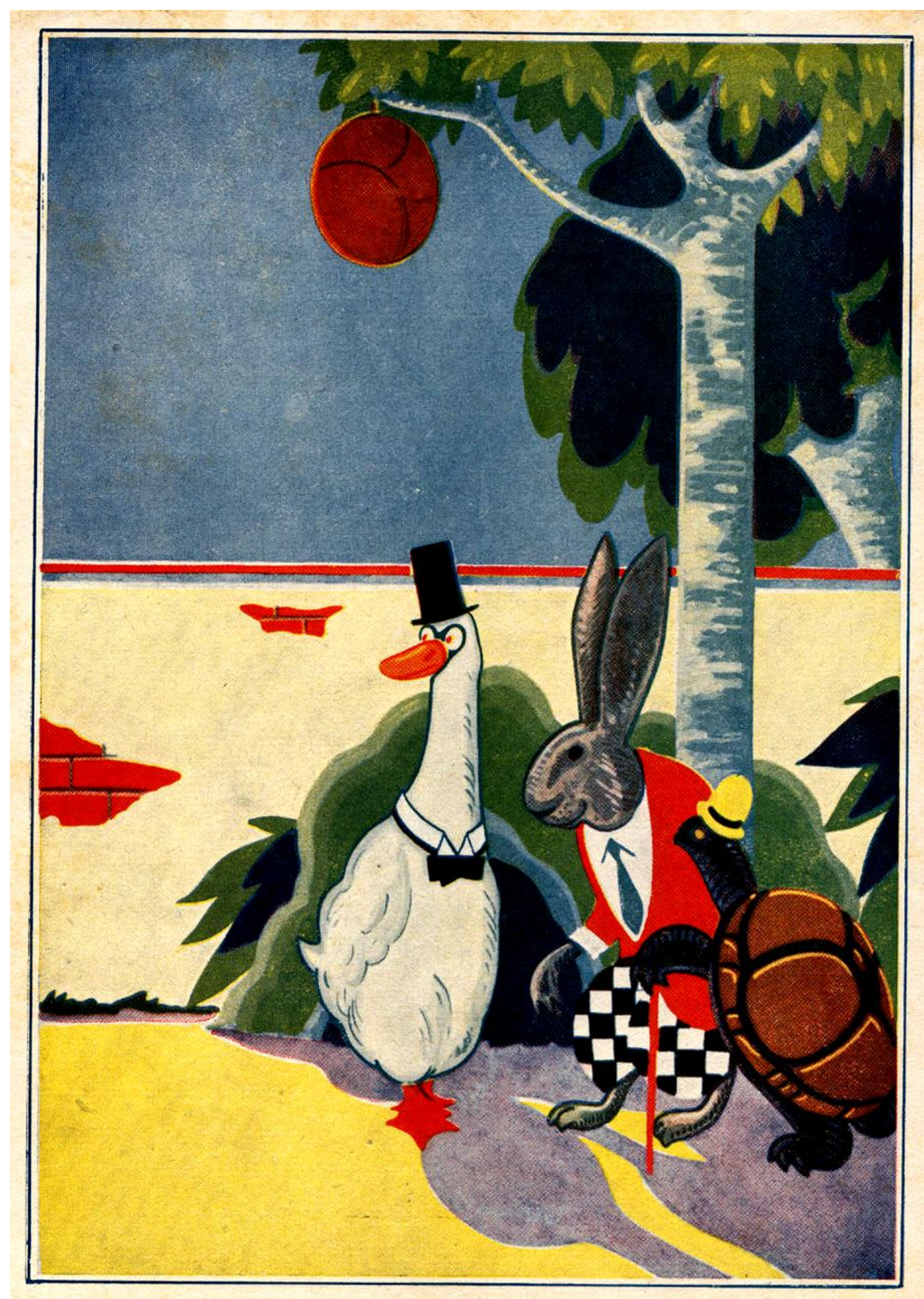

Fig.: 145

Ilustración interior del cuento El premio de un concurso del libro Cuentos de Pototo de la Biblioteca Rodríguez. Hijos de Santiago Rodríguez. 
3.6.11. Ilustración a color del cuento El caballito mágico del libro Cuentos de Pototo de la Biblioteca Rodríguez.

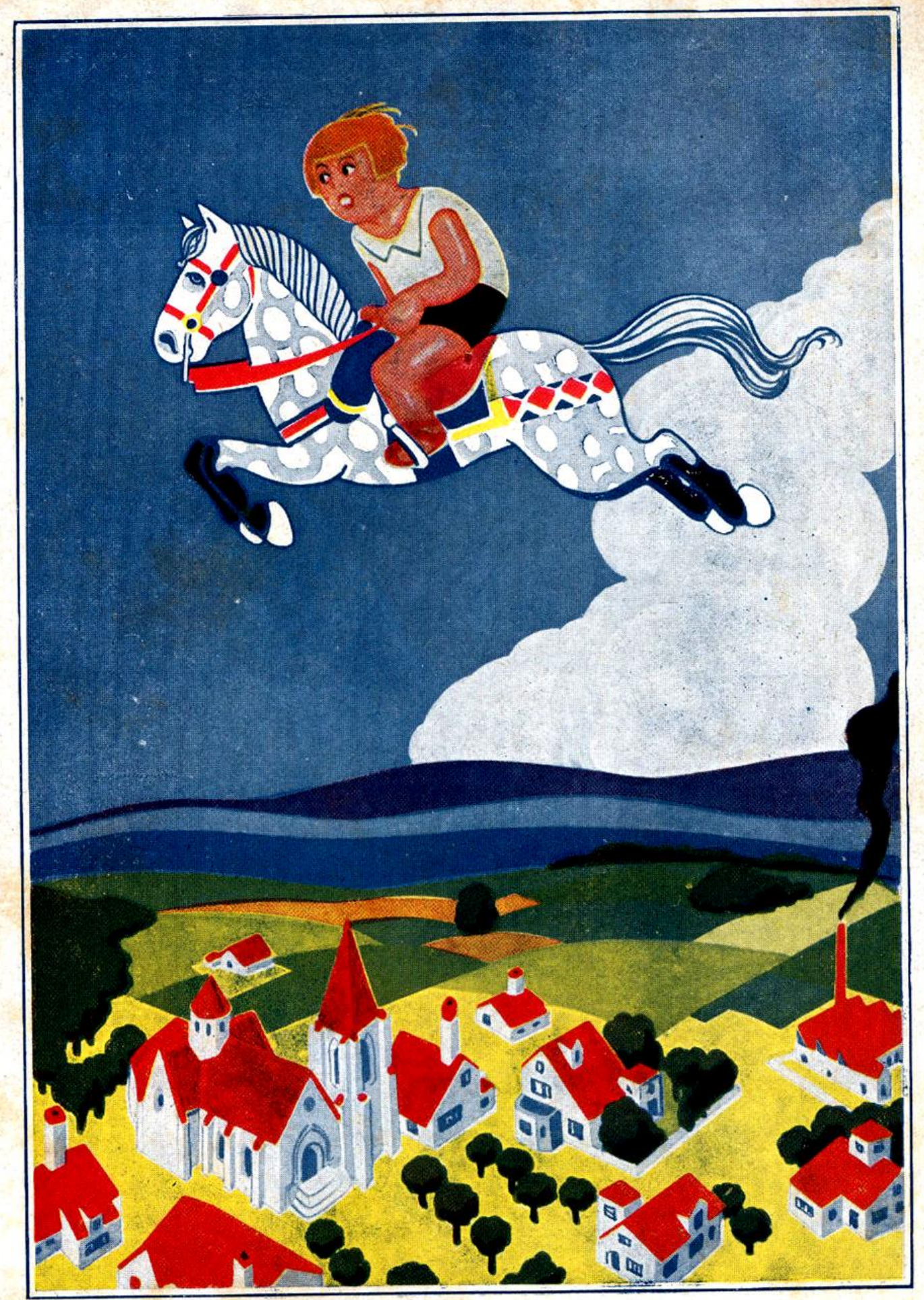

Fig.: 146

Ilustración del cuento El caballito mágico de Cuentos de Pototo de la Biblioteca Rodríguez. Hijos de Santiago Rodríguez. 
LA EDITORIAL BURGALESA HIJOS DE SANTIAGO RODRÍGUEZ (1891-1936):

ANÁLISIS DE LOS LIBROS ESCOLARES

\subsection{Rosario de Velasco (Madrid, 1904 - Barcelona, 1991).}

3.7.1. Ilustraciones interiores a color del libro Cuentos para soñar de la Biblioteca Rodríguez.

3.7.2. Ilustraciones en blanco y negro de Cuentos para soñar de la Biblioteca Rodríguez (I).

3.7.3. Ilustraciones en blanco y negro de Cuentos para soñar de la Biblioteca Rodríguez (II).

3.7.4. Ilustraciones del cuento Los dos zagales en Mi Libro Ideal dentro de la Biblioteca Paz.

3.7.5. Ilustraciones en blanco y negro del cuento El príncipe y sus compañeros de viaje cuento original de Leonardo Lázaro dentro de $\mathrm{Mi}$ Libro Ideal de la Biblioteca Paz.

3.7.6. Ilustración principal del cuento La grulla dentro de Mi Libro Ideal en la Biblioteca Paz.

3.7.7. Ilustraciones del cuento original de Leonardo Lázaro Seres abnegados de Mi Libro Ideal dentro de la Biblioteca Paz. 
3.7.1. Ilustraciones interiores a color del libro Cuentos para soñar de la Biblioteca Rodríguez.
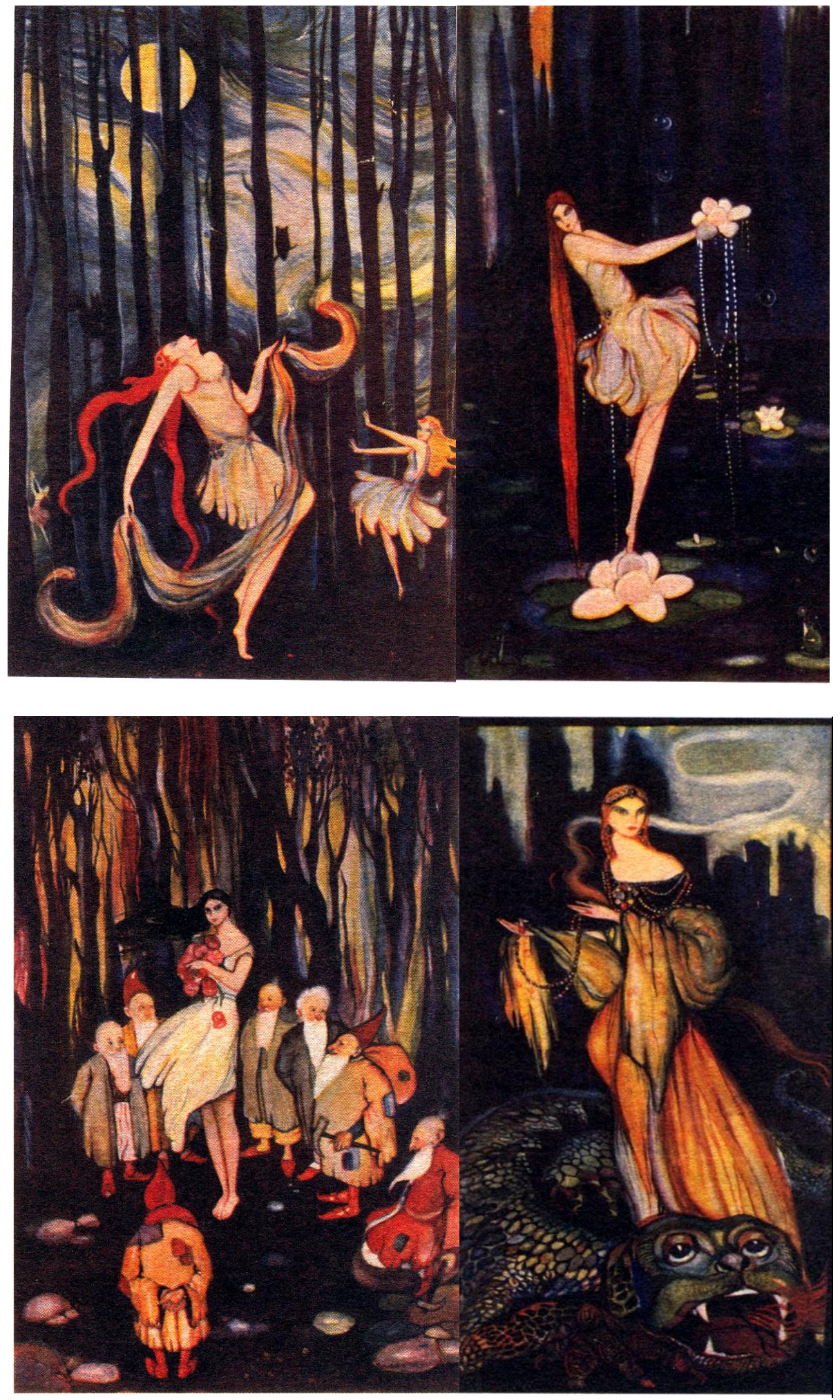

Fig.: 147

Ilustraciones interiores de Rosario de Velasco de Cuentos para soñar de la Biblioteca Rodríguez. Hijos de Santiago Rodríguez. 
3.7.2. Ilustraciones en blanco y negro de Cuentos para soñar de la Biblioteca Rodríguez (I).
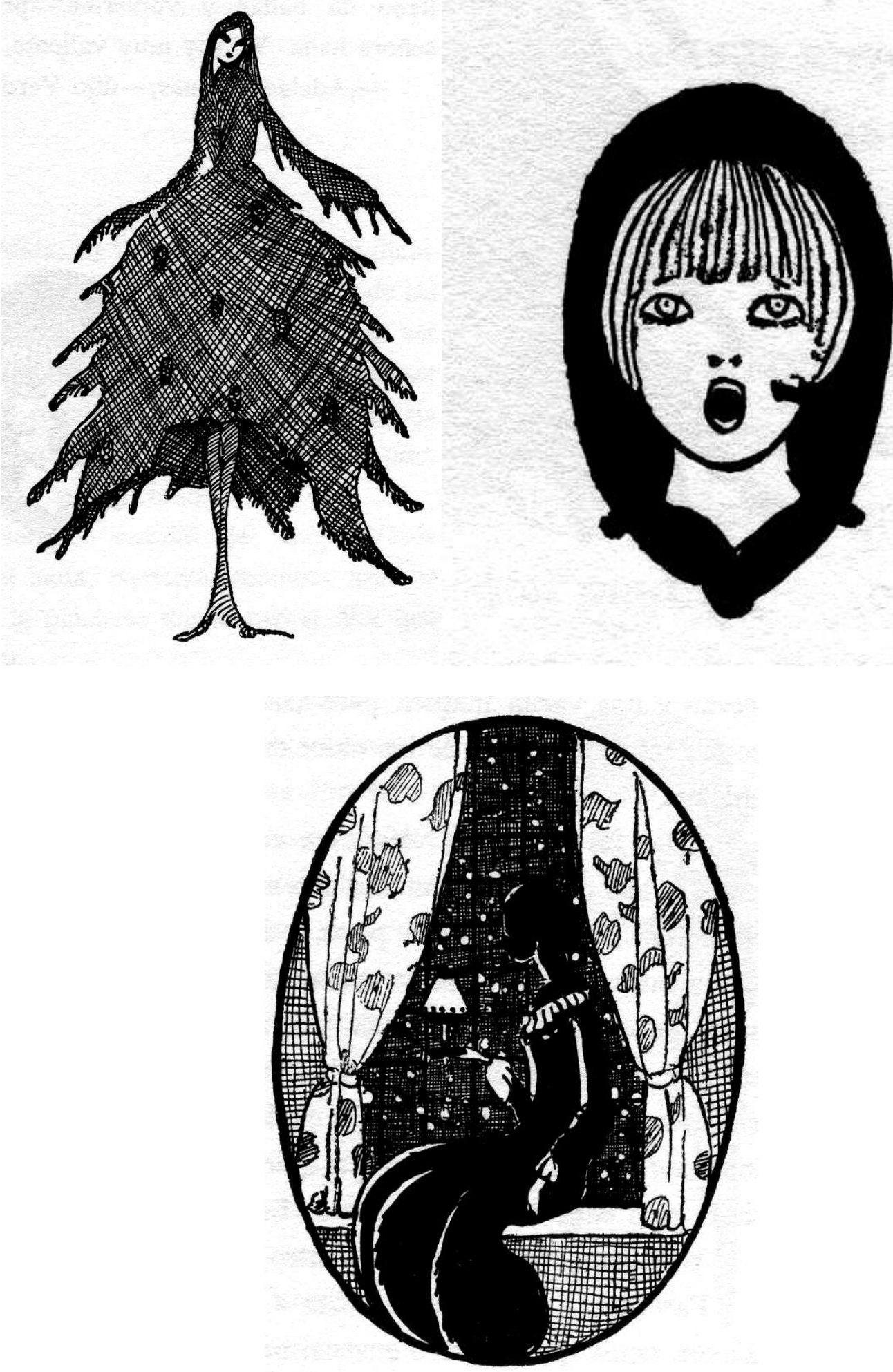

Fig.: 147

Ilustraciones interiores del libro Cuentos para soñar de la Biblioteca Rodríguez. Hijos de Santiago Rodríguez. 
3.7.3. Ilustraciones en blanco y negro de Cuentos para soñar de la Biblioteca Rodríguez (II).
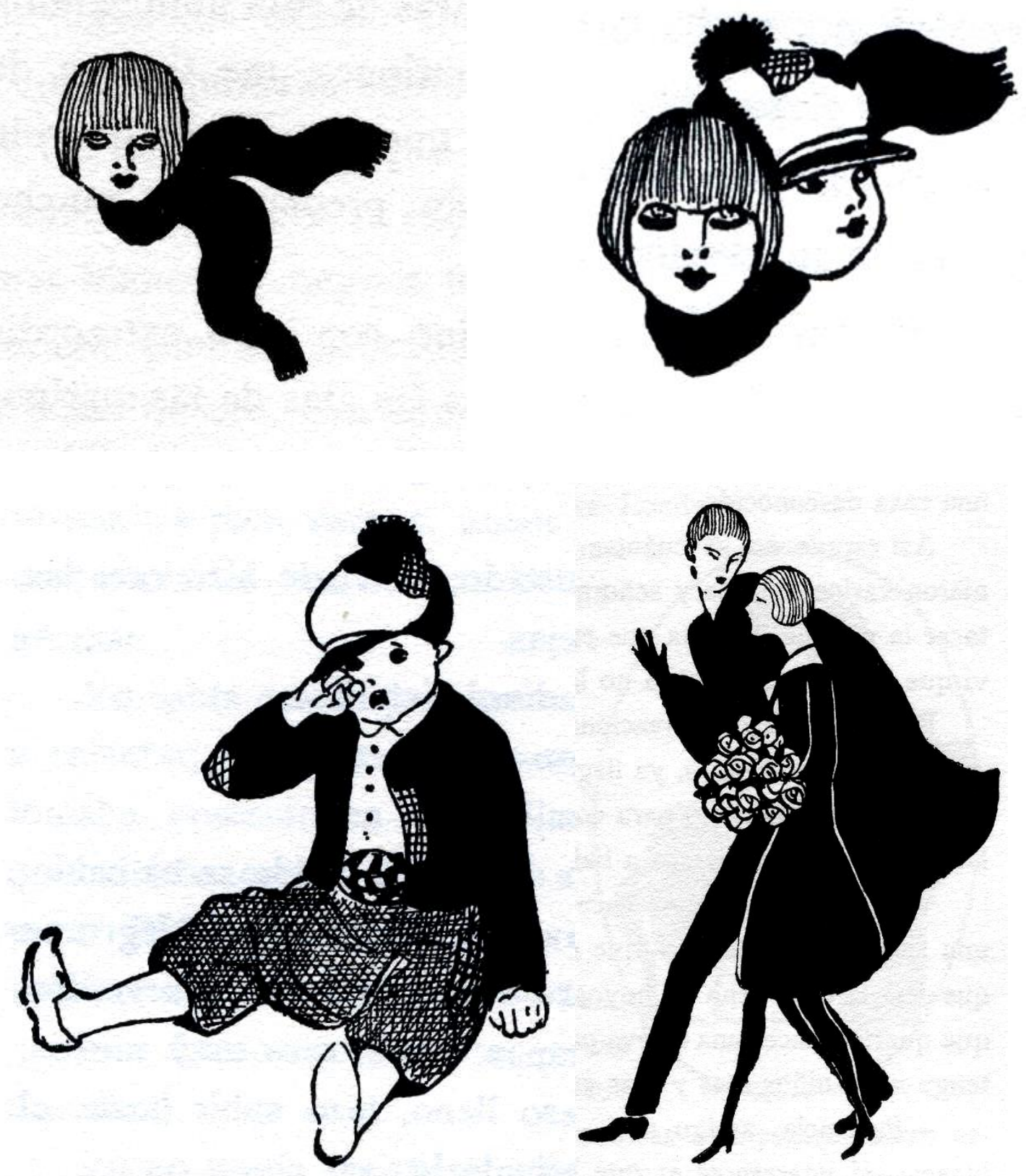

Fig.: 148

Ilustraciones interiores del libro Cuentos para soñar de la Biblioteca Rodríguez. Hijos de Santiago Rodríguez. 
3.7.4. Ilustraciones del cuento Los dos zagales en Mi Libro Ideal dentro de la Biblioteca Paz.
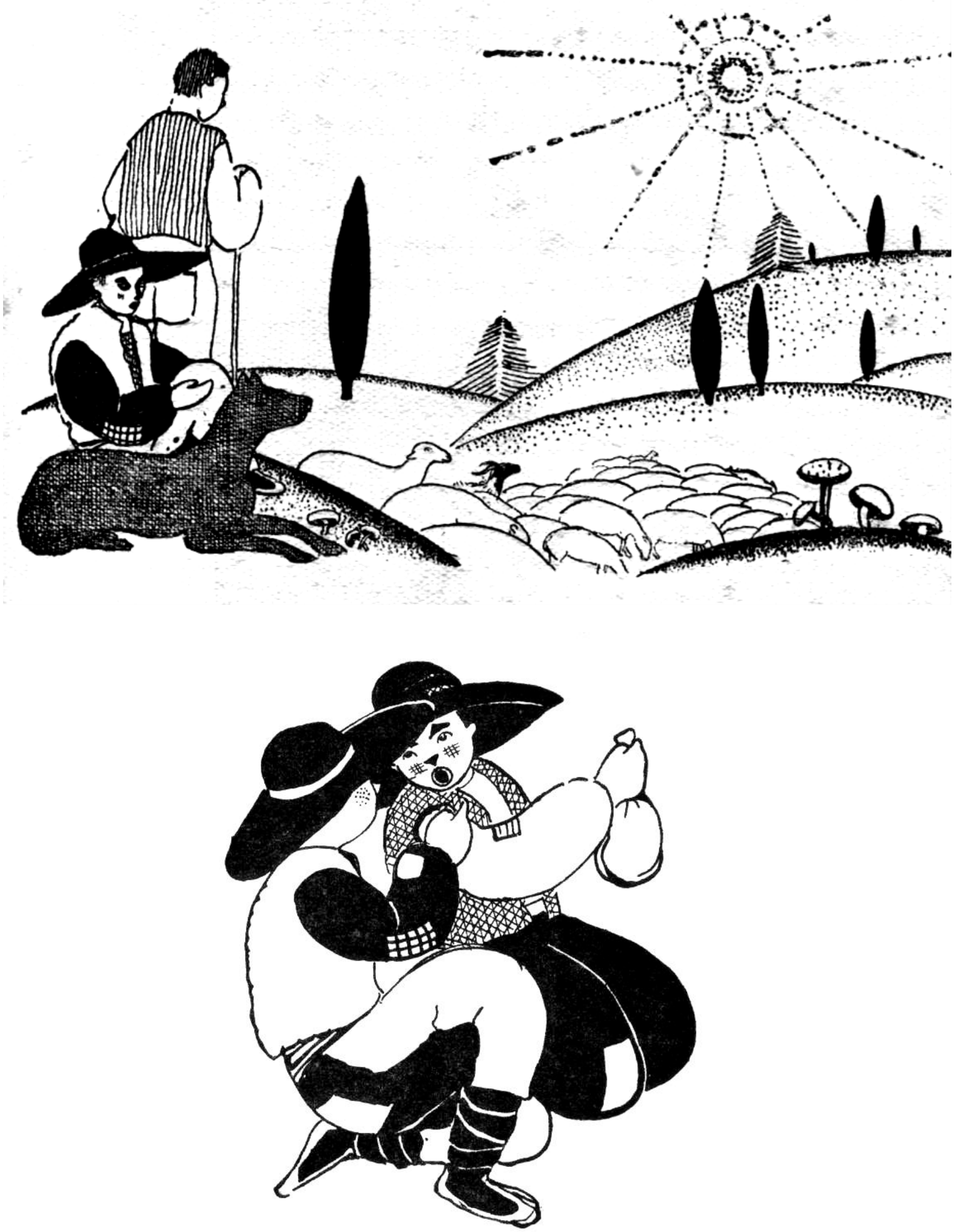

Fig.: 149

Ilustraciones en blanco y negro del cuento Los dos zagales en Mi Libro Ideal de la Biblioteca Paz. Hijos de Santiago Rodríguez. 1933. 
3.7.5. Ilustraciones en blanco y negro del cuento El príncipe y sus compañeros de viaje cuento original de Leonardo Lázaro dentro de $M i$ Libro Ideal de la Biblioteca Paz.

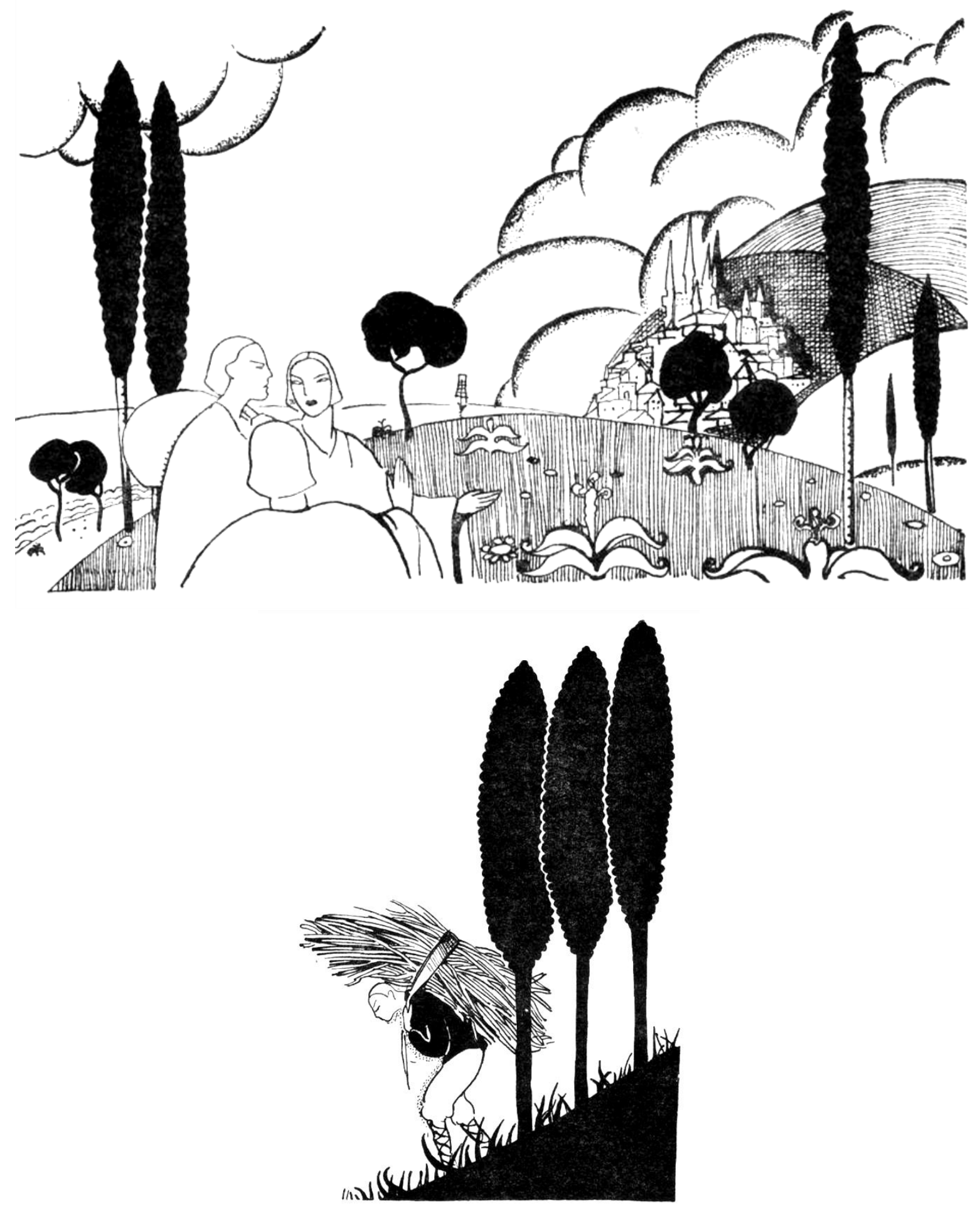

Fig.: 150

Ilustraciones del cuento El príncipe y sus compañeros de viaje en Mi Libro Ideal. Biblioteca Paz. Hijos de Santiago Rodríguez. 
3.7.6. Ilustración principal del cuento La grulla dentro de Mi Libro Ideal en la Biblioteca Paz.

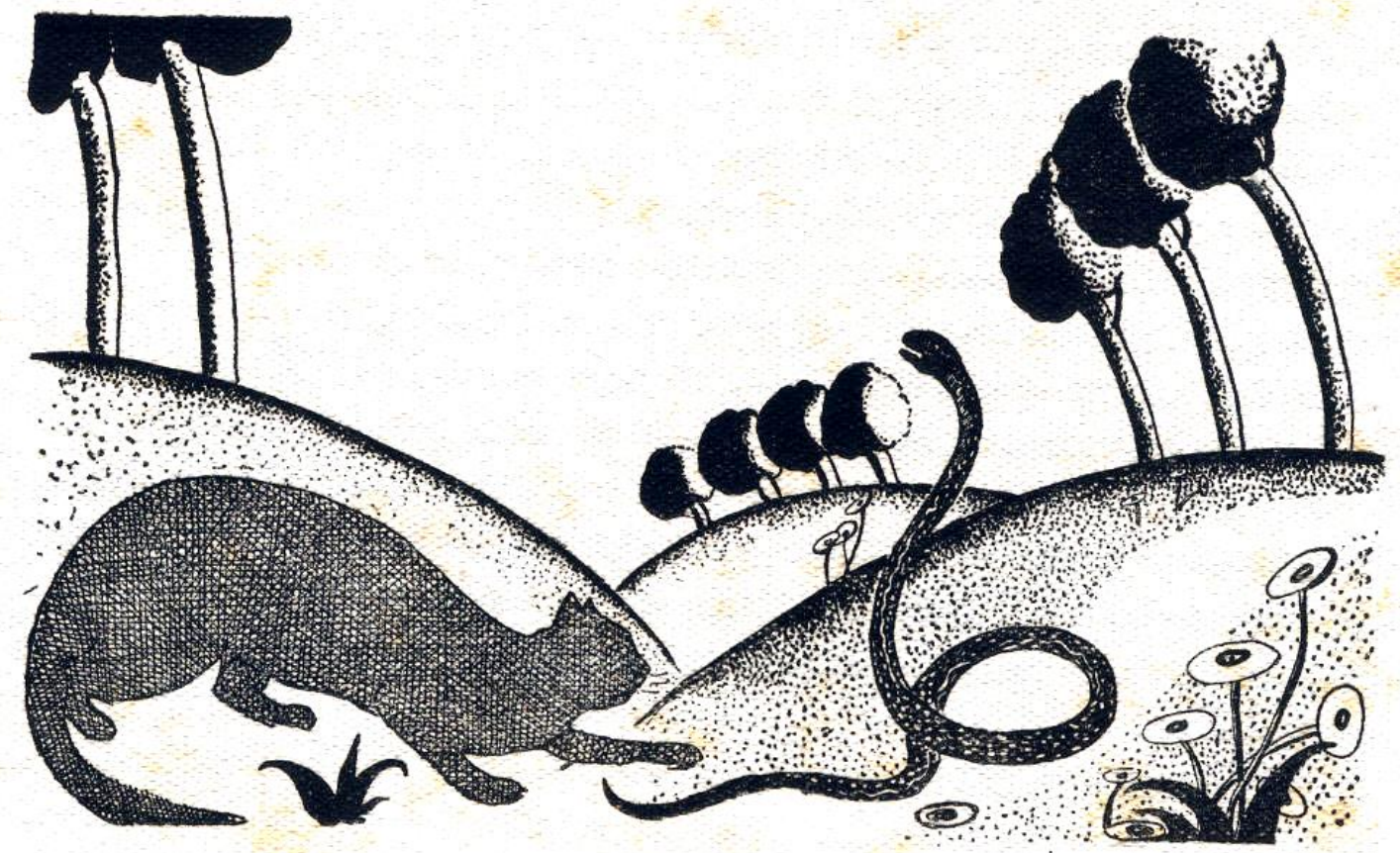

Fig.: 151

Ilustración en la cabecera del cuento La grulla escrito por Leonardo Lázaro en Mi libro Ideal de la Biblioteca Paz. Hijos de Santiago Rodríguez. 
3.7.7. Ilustraciones del cuento original de Leonardo Lázaro Seres abnegados de Mi Libro Ideal dentro de la Biblioteca Paz.
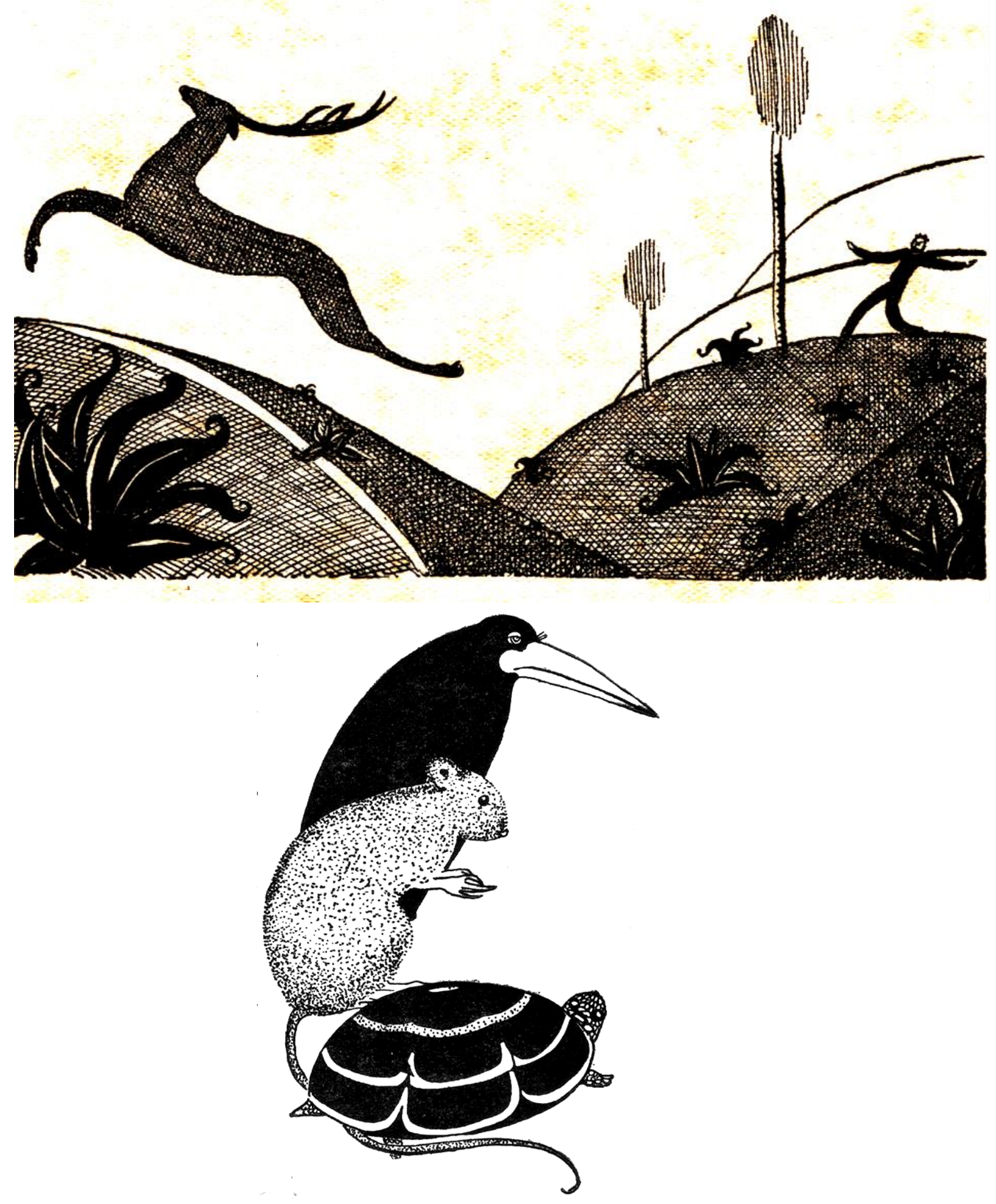

Fig.: 152

Ilustraciones sobre el cuento Seres abnegados escrito por Leonardo Lázaro en Mi Libro Ideal. Biblioteca Paz. Hijos de Santiago Rodríguez. 